
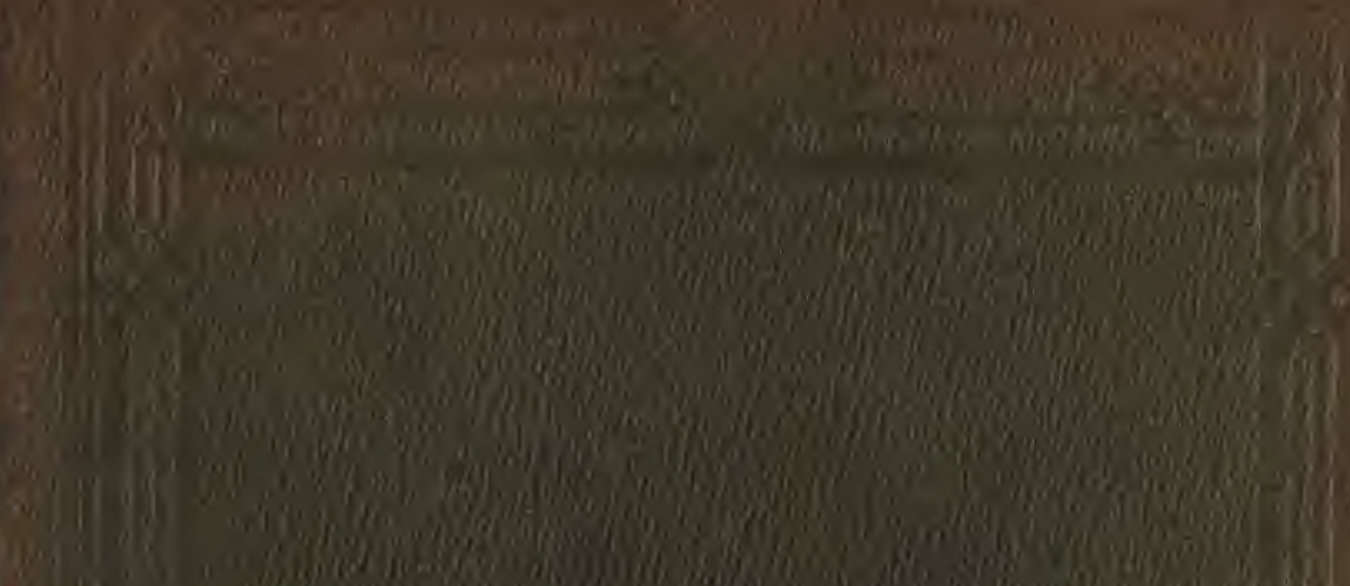

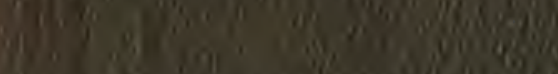

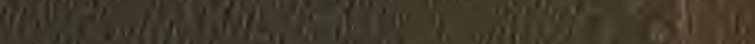

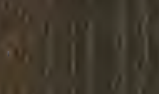

i)

17)

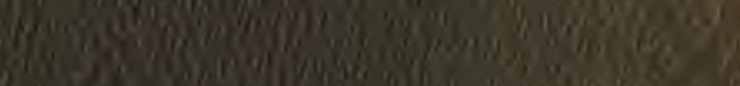

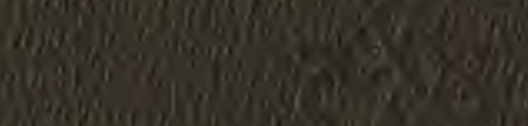

axe ing

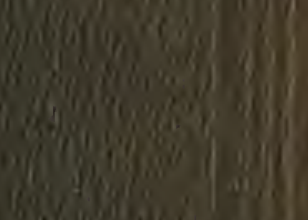
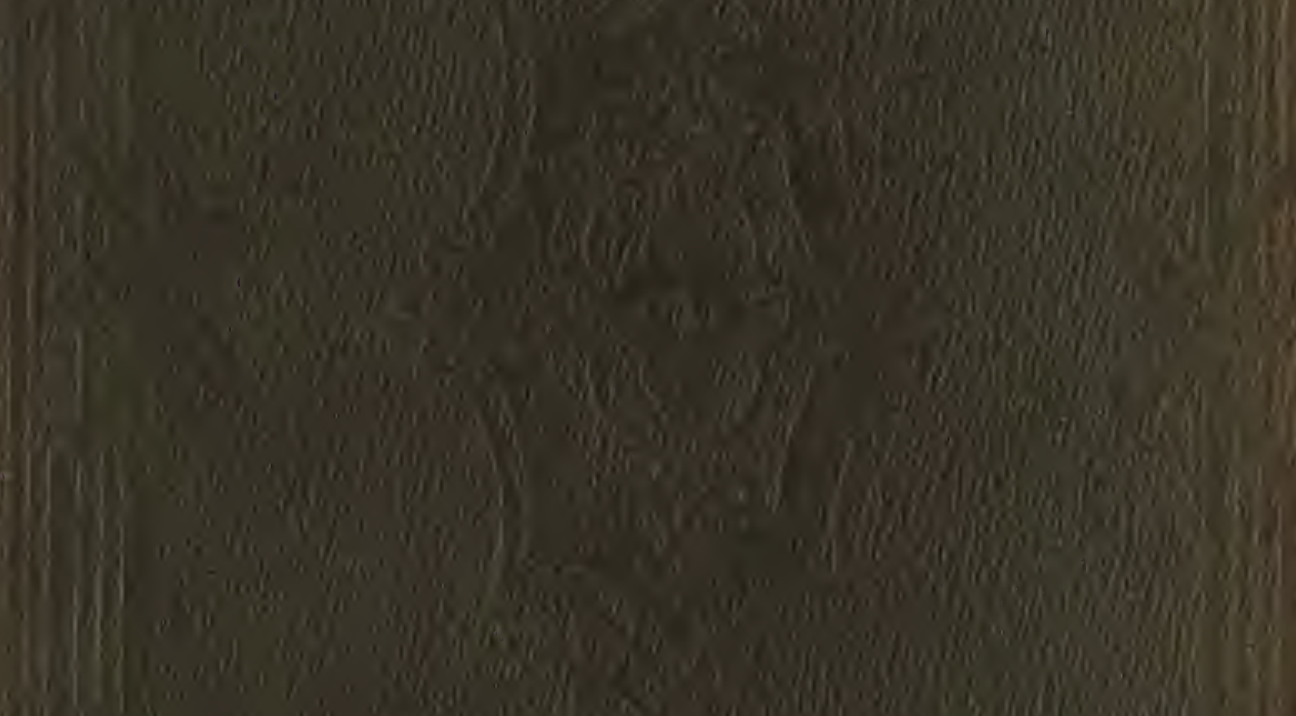

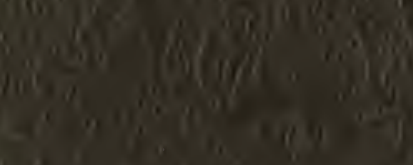

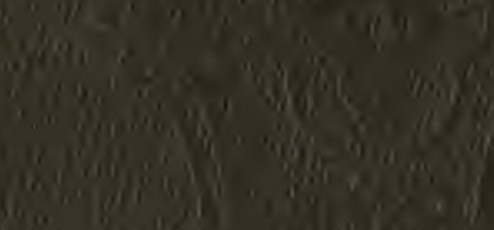

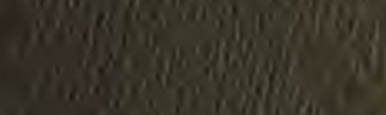

IVI

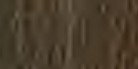

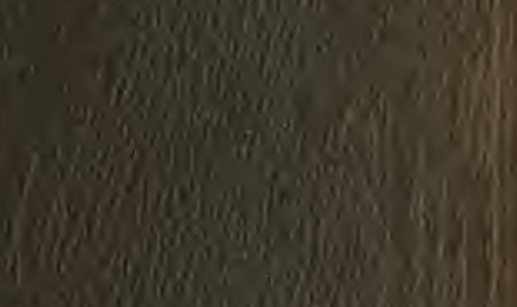

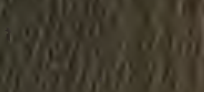

3.

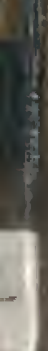

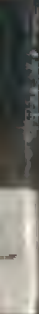

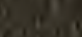

\} Q19.0.

(1) 





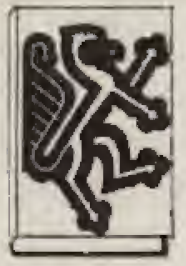

The DR. CARL ALEXANDER GIBSON-HILL COLLECTION

(born 1911: died 1963)

presented to the

NATIONAL LIBRARY OF SINGAPORE

by

MRS. LOKE YEW

in fulfilment of the intention of her son

LOKE WAN THO

(born 1915: died 1964) 
*

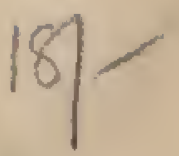

6 


\title{
NARRATIVE
}

\author{
QF rIt $\mathrm{R}$
}

\section{UNITED STATES'}

\section{EXPLORING EXPEDITION,}

\author{
IURING THE YEARS
}

$1838,1839,1840,1841,1842$.

\section{ItY}

CHARLES WILKE, U.S. N.

COMMANDER OF THE EXPEDTTON,

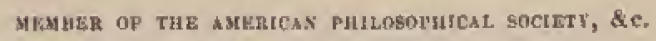

CONDENSED AND ABRIDGED.

\section{LONDON :}

WHITTAKER AND CO., AVE MARIA LANE. 
NATIONAL LIBRARY, SINGAPORE.

\section{JUN1965}

156230

R 910.4

WIL 


\section{A D V E R T I E M E N T.}

CAptaix Wilkes' Narrative of the United States' Exploring Expedition was printed at the expense of the American Government, in five imperial octavo volumes. It is a very beautifully illustrated book, but it is a dear one-too dear, indeed, for the large majority of readers interested in the subject, and too large in size for the eabin collection of many who would wish to give it a place in a seaman's library. The price of the American edition is eight guineas; the cost of the present condensation, containing the pith and marrow of the book, only half-a-guinea, or one-sixtcenth part of that sum,

In condensing Captain Wilkes' Narrative, we have endeavoured to retain, in the first place, all that is new, or likely to be of use to seamen navigating the same seas; and in the second place, to retain all that is attractive to the general render interested in the advance of Geography and Natural History. We have reduced in certain places the minute detail of the position of certain vessels composing the squadron, and omitter the large appendix of instructions to his officers, printed by Captain Wilkes in vindication of his own conduct. These instructions compose very nearly a fifth of the whole work. Freed in this way from all teclious matter, the book in its present shape will invite the perusal of many hitherto restricted by the expense of the previous publication, by its bulk, and by the minuteness of its detail.

It is much to be wished, that the United States' Government may equip before long a sceond expedition to the Antarctic Continent, to complete the discoveries made by Captain Wilkes, and detailed in the following pages. Expeditions of this description interest the worlt at large, and form in themselves a kind of debt due from the inmates of the New World to the inhabitants of the Old.

Loxms, 13:h October, 1845. 


\section{N T R O D U C T I O N*.}

TuE expedition, a narrative of the operations of which is now laid before the public, was the first, and is still the ouly one fitted out by national munificence for scientific objects, that has ever left vur shorus.

Whatever others are disposed to think, I am inclined to believe, that the originating, getting up, and getting off a first national expedition, is a work of no small diffeulty, and this is much ineroased by the jublic thinking, talking of, and intorforing too much with it. I felt this myself, slthough it dirl not cause me mucli difticulty. The very state of things that brought the expedition into general disrepute, waw of grent advantage to me, for I was left to perform my dutieg unmolested.

In the following nurrative, it may perluaps be necessury to state, that although our time was linited to a few days at sume of the plices we visited, yet the number of officers and gentlemen engaged under my consmand, enabled me to have every thing wortly of notice examined. The resalt of our observalions, I am antisfied, will give a faithful representation of the countries and ishands, during the period of our visit.

1 received every facility for obtaining information from our cousuls, as well as from missionaries and American residents abrusil. Some of them furtished mo with interesting doeuments, connected with the past and jresent state of the conntrieg where they reside, and proeured from the different governments many vistuable oflicial papers. Indecd, the facilities met with have evineed a desire in all to further the undertaking with which I was charged.

"Fo the Governor of New Suuth Wales, Sir George Gipph, my acknowledgments are particularly due, for his generous liberality in ordering me to be furnished by the Colonial Secrotary with all the docunents published, not only at the time of our visit, but ainee. "The latter have twen kindly forwarded by our consul, J. H. Williams, Esq., to whom the expedition is also greatly indebted. From alt these ducuments I have been enabled to draw much valuable infotmation, which I hopo will be interesting to the genernl render, ns well ns useful to our interestit abrond.

"The render who sluall look to this narrative for my version of the developments which were elieited by the proceedings of the courts-martinl, will be disappoiuted. I thal nake no alkusions that I can possibly avoid, to any of the subjects of a persmal character that cume before tribunals, after the return of the expedition; nor will the following nnтrative enbrice any personal nutters or difficulties that may have taken place with the oflicers, for the reason that I do not regard sich details as relevant or interesting to the genenl resder. The attenuts to throw inpeilineuts in my way were nnsuccessful, and I folly believe, that from whatever motive dncy uny linve arisen, those who enusel then aro waw desirous that they should be forgotten. My eountrymen will see that my dutieg were sufticiently arduous without having other difficulties to contend with, and 1 bave the gratification of feeling that those duties have been performed, and the rasults fairly obtained.

The perfursanes of these duties is the hest refutation that ean bo given to tho many mis-statements that have been circulated to the prejudiec of the expedition, bot which, I trust, will now be set at reat. I have never had any persoual feeling in the matter, exeept that which naturally arises from the swish to overcorne all impedimenta, of whatever tature thwy might be. I cau, therefore, have no desire but to give the true version of every circumstance of a publie nature that may concern the expeditius, and I hope that I Alanll be able to do it with impartiality and justice, touching as lightly as jossible on the faults of individuale, and bestowing praige wherever it is justly due.

I was called upon, iu a few cages, to exercise the mesus in my possession to pusisls aggreagins. Yet myy airn lins been throughout the eruise, 80 to conduct the duties devolving upon the squadron, the it would carry with it the fureo of mornl juineiple. All the regulations and operntions were nuade to tenul to this trul. I considered this as one of my tirst tutices, and in it I have been well strpported by Captain Hudson and Lieutenant-Commandant Iinggold, and by most of the oflicers of the expeditiou. I feul great sutisfnetion in linving roceived testimonials from the different missionaries, that ny cuurse las been fully appreoiated by then. Indeed, I hava renson to rojoice that I lave been enabled to carry the moml influence of our cutntry to every qunrter of the giobe where our fag bas waved, and I trust that tho expeditiosi will compare advantageously with any other that has preeded it, in its mural and eorrect deportiment.

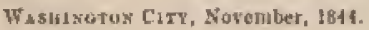

CHARLES WILKES.

- Frefixed to the entition in live rolumes, 3mperial 8wo., printed at Philndelpinin In 3845. 


\title{
LIST OF OFFICERS AND MEN
}

\author{
ATACHED TO
}

'THE UNITED STATES' EXPLORING EXPEDITION.

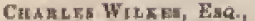
Tirosas T. Chavex, OTERTON CARR. Hozent Fa. JoHsson,

Witelay J Matar, JAXE: H. NoRTR, ET) J. I. ELeiotr, J. L. Fox J. S. WפITIt: Gzonos Mt. Totrex, Wallay REYrotud

Wilctan Max,

Joв:ти P. SAхоғон,

Grorex W. Chant

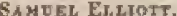

Wretu

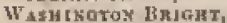
Wiclia M. Latertos. SAMUEL N. HAพTIKA, BENJ. VANDERYOUD, H, P, Rom1 K50\%

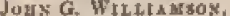
JOEFPJE DHatTox.

J. D. Bratekenringe Jaus G. Hans?

Joity W, W. Dyes.

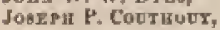

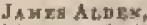
R. R. Whaser

Chates Pickenino,

\section{UNITED STATES' SHIP VINCENNES}

Commanding exploritg expeditton.

Lfeutetint. Jeff at Valpuralno, June 6th, 18:39, to take command of the Sea-Gull. Lieutenan? Trak cokninand of brig Oregon, at San Pranelaco, October, I8t1 Lieutenatst. Commanded Sea-Gull on hur southern crulse, detached at 11 onotulu, November, 1811.

Lifutenant. Joined brig Porpoise at San Franciseo, October, 191.

Leutennas. Jofped Pencock at Orange Bay, and Porpolse at Calliao

Aeting Mauter. Jolned Perpoine at Callao.

Acting Surgeon. Detnched at Sydney, March, 1810.

Puriser.

Chaplain.

Asslstant Surgeun. Joined Feacock al Jonoiulu, and Vincennes aydin at San Frabisco.

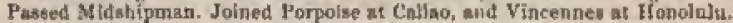

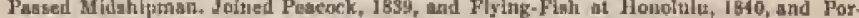

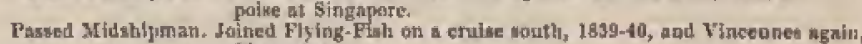

Mfay, 1840 .
Pased Mldshipman. Jolued Porpoise at Tahit, whooner Flying-Fish at San Franciseo, and Porpolige at Singapore.

Midabipmath. Jolned Peacock at Tahit, and Vincentine agein at San Franciaco.

Mldehlpirian.

Boitrofain.

Gisnner.

Carpenter.

Salimaker.

Irilot.

Jolned Relier at Callan.

Joined Retief at Callao.

Ptarwer's Stẹtward

Died, ApHI, 1812 .

Guther.

\section{SCIENTIFIC CORPS}

Naturalist.

Artlet.

Azsistant Botanikt.

Mathernatical Insirument Maker.

Assigtant Taxtelerituis.

Naturalist: Left at Sydney, and deteehed at Itonolulu, November, 1 Bto.

UNITED STATES SHIP PEACOCK.

फ RECXED JULY 16T1, 1811.

Trratak L. Judos, Era, Cammanding.

Joined Vlacepnes at Sap Franciseo.

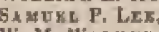

W. M. WALEE,

I.icutenust.

Delached at Orange Hay, February, 1839

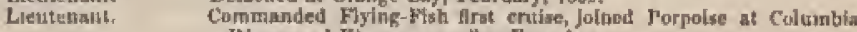
Itiver, and Vincemnes at $310 \pi$ Pranctica

Genor P. Ey Mos:

O. H. PERRT,

T

J. F. SickLE⿱宀女

WiLliar SPIKDEX.

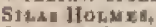

JASTISB. LEWTE.

Hex

HEXFY ELD.

Gronge W, Hantson

WTLEx IlexuY,

Wilda a 11. Hénas.

FHEDERIEK D. STOART,

THOSA G. BXLk

JOHS D. AsTERSOX

JoxAE DHEn

J. FR ETY

WILLTAM Hĭ. IsoLey,
Ltevteungt.

Lismencuant.

Acting Muster.

Surgeon.

Parmer.

lolned Vincennes at San Francitico.

Jolned Ylncennes at San Frantigco.

Joined Vifuevines al Feejee.

Joined Relief at Caltwo.

Jolued Oregen at Cotumbia Hirer.

Asbinlant Surgeon, Joinet Porpolse at Sydney, wid Oregoli at San Francikco.

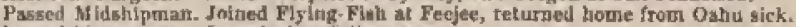

Pasted Mitglalgman, Dutacbed at Callan, I8s9.

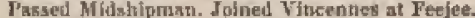

Passed Miduhiomnn, Joined Flgtng-Fish on cruiue south, Peacoek at Feejec, and Oregon at Columbia Rtver.

Mithbipman.

Mtdahipunan.

Caylatin's Clerk.

Hoats Fain,

Guniler.

Cartienter.

Sailmaket.

Purker's Stuwart.
Joined Vineennes at Callo, killeú July 24t1, 1840, at Malolo.

Joined Vincennus at Culumbia thiver

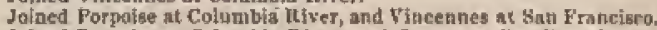
Jained Porpoise at Coltimbia River, and Oregon at sain Vranclsco.

Detasher at Callao.

Jolned Orepor at Cohumbla Bizer.

Joined porpolse at Columbla litver.

Detached int Collao. 


\section{JA M ISS D. Doxa, T. R. PraLX} logato HaLE

F. L. Dafextaht,
Minezalogist. Naturalist.

Pabologiat.

Intetpreter.
SCIENTIFIC CORPS,

Josued Vincenes at San Franelbeo.

Jolnut Vincentes at Sath Frstadeco.

Joined Vincengea nt New Zealand, Pescoek nt Elobolulu, and was Ief at Gregori to crosis the country.

Defached at Bito.

\section{UNITED STATES' SHIP RELIEF,}

A. K. Lose,

il. F. PISxะบY,

A. L. Ches. JOMEY A A. US DER FOOD GEORGE T. SixchatR,

\section{J. C. PALSER}

Atoxzo B. DAYIH,

Trowas W. Cummars, JAME G. Brotit,

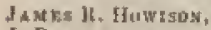
J. BLACK,

TuUSAT LEWIS,

WIILEA Rich. ALYAED $\mathrm{T}$. AUATE,

C.A TW ALADER R INGGOLD, M. G. L. Chilnoxs $\pi_{\text {, }}$ H. J. HA hT:EIK Johx B. Dat.F.

A. S. HALU,

C. E. H, Gurchou,

Sтหó, F, DLU⿻一𠃋十

Gromor W. Cozrocorsis

Tatos AS W. WaLDHOS, 0. NELOS

$A$ heas cistes.

Jond JoInts,

Wish3ait H, MORE,

Jons Frusr.

JАร PALDRACK A. BACON iraAc Pereival.

SAมUEL. It. Kx०X,

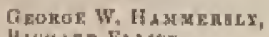

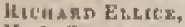

1I. A. CLEMSOY,

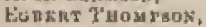

A. ML, CEAXY,

E. H. DE HAYk,

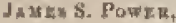

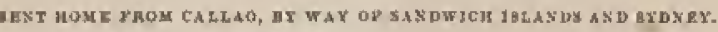

l.ieutenau-Cammantant.

Leutenathi.

Iricutenant.

I. lieutenant.

Aeting Mater.

Jolned P'eacek at Orange Bay, Flying-Fialt at Calfao, and detached at Honolutu, 1B4t

Joined Vincenines at Catian. Forpoise agrals of Jionalulu, Norenter, 1810.

Acting Surgeon. Joined Peacock at Calliso, tnu Oregon at Columbia Hrer, and Viticernea or San Fruncisco.

Passed Midahtpuath Jolnod Pedcock at Callso, and Vincennes at Columbia fijver, and Oregon at Sarh Frascised.

Passod Midshipman. Left siek at Fio.

Mivishipman. Jeined Peacoek at Rlo, wehoomer Mying-Fiah at Colimbla fiver,

anat Vincennes at Itopolulu.

Clesk. Jolned Vincenmes at callag.

Roastswain.

Gutater.

doined Pencock at Callno, and Oregon at Columbia Flver.

\section{SCIENTITLC Cothp}

Dotapilat. Joimed Poucnek at Culho, and Vincenuss at Ban Frnucisea. Aruist.

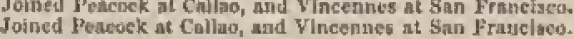

\section{UNITED STATES BRIG PORLOISE.}

Lieuteratut Commandant.

lifuterbotht. Johned Rellef at Otange Bay.

Heutenaut, Joined Etellef at Callag.

Lieutenant. Joined thether at Collac.

Acting Manter. Jolned Pencock us Callao, nnd Oregon at Columbla River.

Asslolant Surgeon. Juined Peacuek at Sydney, Hying-Finh at Columbla River, and detaclied at Houblulu, Novemher, I84h.

Pased Midshipman. Joined Ylucespes ot Orawge Hay, and ien slek at Honolulu, to A thit 1811 .

alned Peacock at Itio, YTheennes at Pecjes, and Oregon at San Francisco.

Cnptsin's Cletk.

Hoatswals, Trenched st Rio.

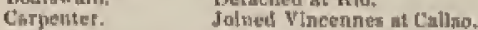

Saihmuker. Detaehed nk ctalino; jolued Rellef

Purver' Stewart.

Boats wallo.

\section{TENDEER SEA-GUIL}

Lost A BOtT MAX IsT, 1 gag.

Passed MIIdulpmat, Commandart

Pansed Midshipunan.

Pliot.

Joined Rellef at Callao

\section{TENDER FLVING.FISH,}

Cammandant.

Mitwhipman. Ac. Muster'm Mate. Mild ukilpman. Mlublipman.

Minater' Mate. Artling Master.

Purber'v Steward.

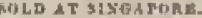

Commanding actoonez most of the crulke: Joined VLnevines at SIs

Johned Peapork at Callao, and Vincentaew at. Feclee.

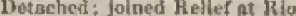

Jotned the incenue at $\mathrm{Rin}$; delachet at Callas.

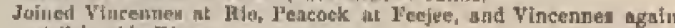
at Calumbla R!ver.

Detaclied at Houtolulu.

Jalnet Ylicfnuem at Callao, Peacock at Yeejee, und Oregon at Calutibla It iver.

Jodaed Peacock at Collan, nnd Orcgon at Culumbin Fiver. 


\section{O N T E N TS.}

CHATERK

IHG

I. Madeira , , , , . . . , , , , , , 1

II. Cape de Verdes Rio de daneiro , , , . , . , , 6

III. Rio de Janeiro . . , , , . , , , , , , , , 10

IV. The Brazils. IRio Negro, Thern del Fuego , . . . . . . . . 15

V. Terra det Fuggo. Southern Cruise . . . . . . . . . . . . 22

VI. Southern Cruise, Yalparaiso , . . . . . . . , . . 30

VII. Clíli . . . . . , . , , , , . , . 37

VIII. Peru . . + . . . . . . . . + . . . . 45

1X. Pert (continued) . . . . . . , . , . , , , 51

X. Paumotu Group . . . . . . . . . . . . . . . . . . . 62

XI. Tahiti . . . . . . . . . . 73

XI1. Tahiti and Eimeo, . . . . . . . . . . . . . . . . B0

XIII, Sampa Group. Rose Island. Tutuila . . . . . . . . . . 87

XIV. Samoan Group. Upolu. Savaij . . . . . , . . . . .94

XV. The Sumoang . . . . . . . . . . . . . , 103

XYI, New Sonth Wales. , . . . . . . . . . . . . . 116

XVII. Antaretic Cruise . . . . . . . . . . . . . . . . 129

XVIII. Antaretic Cruise. Procedings of the Vincennes . . . . . . . 139

XIX. Antaretic Cruise (continued) . . . . . . . , , , . 150

XX. Now Zealand . . . . . . . . . . . . . . . . 16io

XXI. Tongatahoo . . . . . . , . . . . . . . . - 178

XX1I. Fejoe Group. Island of Orolsu . . . . . . . . . . . , 192

XXIII. Customs of the Feejee Group. . . . . . . . . . . . . . . 202

XXIV. Feojee Group, Rewn . . . . . . . . . . . . . . . , . 215

XXV, Feejee Group (continued) . . . . . . . . . . . . . 227

XXVI. Feejec Group (eoneluded) . . . . . . . . . . . . . . . . 240

XXV1I. Hawalian Group or Sandwich Islands . . . . . . . . . . . . 251

XXYIII. Hawnian Group (continutel) , . , , + , , , , , , , , 258

XXIX. Hawiin Group (conelteded) . . . . . . . . . . . . 269

XXX. Pamotn Group and Pembyn Island . . . . . . . . . . . . 276

XXXi. Oregon . . . . . . . . . . . . . . . . 279

XXXII. De Fuea's Stmits and Loss of the Peacock . . . . . . . . . , 285

XXXIII. Cruise of the Pescock and Flying-Fish from Oahu to the Bar of the Columbia . . . . . . . . . . . . . . . 292

XXXIV, Califormis . . . . . . . . . . . . . . . 301

XXXV. San Franciseo to Mavilla . . . . . . . . . . . . . . . 307

XXXVI, Manilla ... . . . . . . . . . . 314

XXXVLI. Sooloo * . . . . . . . . . . . . . . . 327

XXXVIII, Síngmpore , . . . , . , , , , , . , , , , 338

XXXIX, Cape of Good Hope . . . . . . . . . . . . . . . . . . 346

Appendix , . . , . . . , , , , ., . , . , . . 360

Index . . . . . . . . . . . . . . . . . . . . . . . 369 

NARRATIVE

or TIII

\section{UNITED S'TATES' EXPLORING EXPEDITION.}

\section{CHAPTER I.}

\section{MADEIRA.}

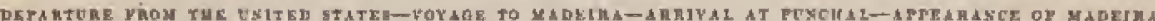

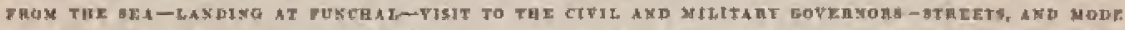

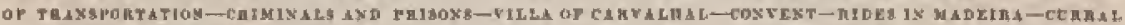

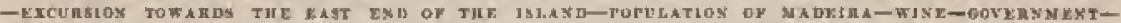

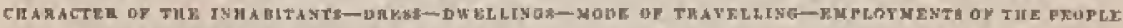

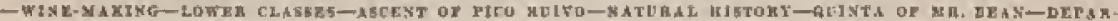
TURE FROM MADETAA.

Tist command of the Exploring Expedition devolved upon me, by urders from the J Ian. Matilon Diekersou, then seeretary of the vary, on the 20th of Mareh, 1838. On my arrival at Norfolk, I found every thing in a state of forwardness, and the squadrous in Hampton Roads, whither they had Aropped down on the 8th of August.

On the 17th of Augnes I reecived uy sailimg instructions", and finsl oriers to put to Bers tho mouent I was roudy. The sigual was accordingly made that the squadros was under sailing orders, and at 11 A.M. all hands were called to nuster, and divine service was perforned. The day was benutiful, the seis smooth, and the wirw light. I stanll never forget the impressious thist crowded on we during thut day in the hour of exvice. We were adnonisised in the discuurse to repose conlidence in the aid and protection of Him whom all bands lind been ealled to worship, astd the admouition who well enleulated to do us good.

Our squadron was composed of the following vessels, The Vincunes, $\mathrm{n}$ sluop of war of 780 tons, originnlly siugle-decked, but in cunserpuenee of the intended eruise, a light deck was put on her for the protection of the men and wo afford more room. The rccomnodations thus became those of a small frigate.

The Peseock, a sloop of war of 650 tons, originully built with a deck like that of the Vincermes Sto had made two cruises previous to her sailing in 1838 .

The Porpoise, a gun-brig of two-atud-thirty tons; the tender Sea-Gull of 110 tors; the tender Flyng. Fish of 96 tons; nul the, Relief, a new vessel, ori. ginally intended as a Btore-ship for the navy. She whe buitt for carrying, and her slow rato of sailing mude her ill mapted for the eruise.

\footnotetext{
- Daled 13ih August, 1838. Sec Appentix A.
}

Onders wore now giveu in rendezyous, in ease of separation, at Madeirn. It was son foumd, it the

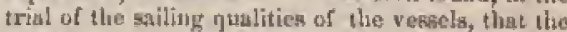
Fielief was ansuited to net with the rest willout grent deleution, aud after four dnks I determined to part conspany with lier, givitig her orders to procued to tho Cupe de Verdes.

The novelty of our situalion was quite enareh to interest ali; free communications wore had, nud cndeavours wero made to excite a generul interch in all the oljects that were pasaing nlont us. It was arnusing to bec all entering into the novel oceupation of dissecting the fists taken, and to hera scientific uames bandied about between Jack and his shipmates.

On the 25 ll of August our winde becatne farourable, and we were eviabled to lay our enurse towarls Madeira. I continued to keep the direction of the Gulf Strenm fowats the Western Islunds. We folt its inthuce until we reached the longitude of $40^{\circ} \mathrm{W}$, and found it to set for the last few doy to the northward of east. The winds bad been light and the sen smouth, indieating no other inpulse than the flow of the strean. The tornperature gradually decteased from $a 5^{\circ}$ to $75^{\circ}$.

On the night of the 26 th we parted company with the Peacock and Flying-Fish in a squall, and did not again meet then tuntil we renched Madeirn. The 5 th of Septemher, beitig near the reported shosl of St. Anne, I deternined to pases ovcr ita position.

On the fils we pased over it, the sen was smooth, the horizon clear, and the day beautiful. At 8 A.M. the look-0ut cried out, "Ruckis or a wrech on the starboard how !" which at once created an excitement on board. We stond for it. It lad at first every appearance of a rosit, then that of a wreck with the masth gone. It pivoved, howerer, to be a large tree of cotton-wood, onte 
lundred and twenty feet in length, ant fourteen feet is circumferenee nt the lieight of tive feet alsove the ruots. It liad beens a lung time in the water, was full of larnucles, and much exten by the teredo uavalis, Great yuuntiticy of tisls were ahnut it, consisting of dolphins, sluarks, Ac. We lid not, however, enceced ins taking any. In rough wenther it miglat ensily hnve been mistaken for a roek, particularly if passed in twiligld, on' nt tight.

In ensternence of the wind living from the guththard and westward, I was complelled, after makiug the: P'enk of P'jeo, to go in the nurthwart of St. Miclinel't. I nm satistied, Jowerer, it is

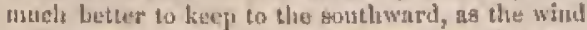
will be fonud more stondy and stronger. 13esides, the eurrent, at that sensoil of tho year, sets to alse westward nmong the islands.

As wo passed St. Mirlıat's, we amtised ourselves by a view, thruugh our glasses, of jts villas, grives, and cultivated fields.

On the night of the 13th of Septeniber we licid lıy, just after passing the north eud of St. Miclnel's, in order tu examine the position of the Tullock Reef by flaylight. Wo patseed withiu n mile and a Jalf of itt reperted position, lath saw mothing of it, althongh the sea was rumsing sufticiently hight to lave made a henvy brenk on it, if it did exist.

On the lith, is we were making sail, George Purter, one of ons matintoy-men, in loosing the tup. gallant suil, was eaturht by the buntline, anul dragged ovet the yart, where lie was seen to hang, ns it wero rquite lifeless, swinging to and fro by tho neck.

Oil the alarm being given, two men rus aluft to his assistance, It now beesine doubt ful oin deck whether they woulil not he all dragged over by the weight of his borly, until severn! ithers gavo assistance and relieved them. I enused a breathless auxiety to us sill to Beo in fellow-Leisug ill the momentary expectation that lo would be dashorl to the deck. Ho was forturntely reseued and brouglit below yet living. Hete lie spredily came to lis senses, and recollecting Itat tho drum hat foulled

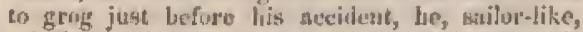
atsked for his portion of it. It was truly n provi. derutial escape. This young man died on our wny lowne, it the Chim seas, of an inllammatory feves".

On the letts we made the island of Madeirn, and having a strong westerly wind, I fletermined to pass to Funchal, on its southern side. This may be done at this season, but vessels tound to that port usually prefor going round the enstern point of the islnus. Whess off the westeri point of Madeirn wo experitneed a very long lieary swell, which gase no an opportunity of trying the veloeity of the wases, by notitus the titne the Batue wave was passing between the vessels. 'l'he result gave twoniy-dureo miles per hour, lut I was rot Hltogether Eatisfied wilh it, It wat difficule to measure the eortect angle suhtended by the Porpoise's masts for the distance, ou account of the inotion of hoth vessels. The measurument of this licight of the waven $\mathbb{I}$ fonnd still more diffieult, and the results varied too much to place confidenes in them, princifully owing weach succedling swell or wave being less than the preceding one. The different observations gave from twenty-five to fourteen feet; the width of the wave, from the stme cuuses, whs equally sariable, aud each sueeessive result varied from that which preceled it.
Before sunset we cast anchor in conjuany with the Purpoise and Sen-Gull, and were the next morning joined fy the Pentock and Flying-Fish.

Shorly after cuning to anchor, wo were boarded by the heuth ofticer, with the enptain of the prort, wine, on being rosured of mur gond health, grave na permissiun to land. The L'nited States' consul, Henry Jolsu Burdun, esq., alan erme on bonrl, and kisdly offered ats all the altention that lay is jis power:

The first appenranue of Madeisa did not como up to the ilea we liad formed of ita beantich from the glowing deseription of trawellers. It exhilited rothing to the distast view bat a bare and broken rock, of huge dimensinus, which, though grand und imposing, is peseuliarly dask atud glowny, and it was not until we had made onr way close under tio land, that we could discover the grecu patelies which aro every whero seattered over its inark red evil, eren to the tops of the highest peaks.

The mountain rerdnre wns afterwards discovered to be owing to growes of henth and tront, which grow to an extraurdiany hoight, aspising to the Btature of fortst trees. In ndditinn to tliese groves, tho termeed reclivities, covered with a luxuriath trupieal vegetation, ehaugo bn a closor apprrancls its distant harren napuet into one of extremo beaty and fertility.

The not striking preculinrity in tho mountain scenery is the jagrged outline of the ridge, the rudelyshaped lowers and sharp pyranids of rock, whied appear elevated on the tops and sides of the bighest peaks as wel] as on the lower elevations, aud the deep irecipitons gorges, which ent tlurough the lighest montontus alunost to their very hase.

Thu shores of the istand are mosty lofty eliffe, ocensionaliy faeisg the water wjth a jerpeuliculut front on or two thoussual feet in lieight. Thus cliffs aro buterrupted ly a few smal! bays, where a richly eultivated valley appronclies the water lue tween strupt precipiens, or sulrotuded liy an anphithontre of rugged hills. 'Jthese nasruw bays are the siter of the vilinges of Mndcin.

As we railet along from its western end, we necusionally saw, in these quiet and peaceful situations, small white-wniled villages, each with its littlo church nt the ontlet of the gorges. We wore par. tieularly struck with that of the Camern do Lothes, a few miles to the westwaris of Snuta Cruz hilt. This is the fargest, nat is the most interesting of any, from its tuving been the first joint seteled by Europesnss. 'ithe high precipiede were new to us Ameriesns: so different from what we rre necis. tomed so in the United Strtes. The scene was still mure strikirg, nnd otg attention was more forcibly

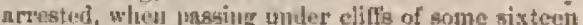
hundred feet above us. We were so near thera that the sound of the gurf was distinctly herrt. The whole eflect of the view was much lieiglatoned by th ghowing sunset in one of thu fines? climntes in the worlit.

Off the enstern eape of tho island, Inany isslated rocks were seen separuted from the lasd, with bolkt, abiupt sides and broken outhines. The character of these rocks is remarkable; they stand quite de. tached from the adjoining eliffs, and some of therm rise to a great height in a slender forni, with ex[remely rugged surfaces, u1t] broken ed ges. "T'hrough gane the waters have worn arebed ways of largo dimensions, wlich afford a prosage for the breaking 
surf, nut would secm to threaten ere long their destruction.

Similar needile-form rocks are seen off the not hy. ern Deserts, an islaud lying sone miles east of Bradeirn. Dne of them is often untatian for a ship undur sail, to whitels when first seen it hins a conbilleralule resemblance. It stamla like a slenter bioken column, several lundred feet in lieight, on a tinse scarcely largor than its sumbit.

Funchal lias a very pleasing appearauce from the sea, and ite situation, in a kind of amphithentre finmel by the motutains, adds to its beuty. The cosurast of the white brilibisgs and villas with the green tนounlnins, forาus th pieture which is tusch heightened by the bold quadrangulat Loo llook, with its embaitled summit communding the lasbour in the foreground,

The itland thronghout is rongh and mountainous, but the steeps are clothed with rich ank luxuriant verduro. I'(erraces aro visible on every side, and every spot that the iugenuity of man could mako sqailible lins been apparesstly turned to advantnge, and is diligently cultivated. These strots form an intoresting scene, particularly whet contristed with the broken and wild backgtound, with the white eottages clustered at the sea-shore, and gralually extending themselves nuwards until the eyo resis on the lighest and most atriking buildisg, that of the content of Nostra Seviurat do Monte.

fillyough the weatern half of the island runs a central ridge, alout fire thousand feet ligh, on which is an extensive planin, enlled Panl de Serra, which is mostly overytrown, und is uscu especially for breeding mules nud horats, The enstern portion of tho island, thongh quite elevated, is less so than the westeru.

The valleys uevully contain a strip of land of extreme fertility, through which winds the hed of a stremislet, that fuecumes a mutmintsin torrent in the rainy sensots, but is nearly or truite diry in summel:

The landing at Funclal is on a stony bench, and is accumpasited with gome litule diffieulity, prartly on neconum of the surf, Lase more from the notse, confusiou, and uproar marle log the thative bontmen in their effurts to drag their bont up on the bench. 'This operabion thay however understand, and are well accustoned to, and those who desire to land dry, will be wise to emploz them.

On the $17 \mathrm{hl}$, we paid our respects, with a large party of officers, to the civil governor the lasun de Lurifello, fold-masatal in the army, and adsninistrator-general of the proxineo of Madeirn and Purto Santo; nud ulso to the military governor Juse Teixeer Rebello, culunel in the nomy, and commandant of the distriet.

Ilis excelleney baron Lordello resides in the governuent house or palace, which is a large quadrangrular buildiag, vecupied in part as barracks. His suit of apartments fronts the bay, and enjoys a beautiful view of it ; they also lave the enjoyment of the iubat or sea-breeze. They aro rery large, and but meagerly furnibhed A cons the large anteroon are liung the portraits of all the civil, ceclesinstical, and irilitary go. vernoss, which form an jmposing arrzy of lurd outline, stiff figures and faces, with a vartety of arussing costume. Tluose of later years which have been liumg up, ave not calculated to give very exalted ideus of the stauding of the present Portuguese seluoul of portrait paiuting.

His excellenty the baron Lordella received us very courteously. Our audience, howover, was extruncly fortnal; tho whole furniture and appearance of the roon served to make it 50 . We all formd it diffteult to seivol ourselves to eeremonics, liaving been usfiesed as wo were tlurough diliptdated and impovetished courts anul vestihules. Ilis excellency the baron spealss English remarkably well, which I mulerstaud he lial aequired while neting as interpreter to the Jritish stiff is Portugal, Juring the Peninsular wrr. He lon been no more thau a week in slistge of the goverument, laving just arrived from Portugal. After nf few monoryllabic questions anil auswerts we tonk our leave, and he did us the honour to ser us thas the the auteroom to the hall of entrance, where we parted with many bows.

Our next visit was to the military goveruor, Sorior Rebello, who occupied a mall spartment at the opprosite end of the lutildiag. 'lyis was not largo enough to accommodate us all, and elanirs were wating for' tnany. 'The mnumer and ense of the occupatit male full amenda. Ceremony and form were laid aside : he scemed to enter warmly into our plans and plensures, and evinced a grent desise to do us serviee.

The streets of the tow are very narrow, withont sidownlks, and to our view like alley, bnt their narvuwness produces no inconvenience. They are we!l paved, and whecl-carriages are unkiowis. The only voliele, if so it may be eulled, is a sledge, of some six feet in lengtli, abunt twenty inclies wide, and only six or eight inclues high, out which are trassported the pipes of wille, T'wo strizhs of larid woud are fnstened togetiel. for runnems.

This sledge is dragged by two very smill oxen, and slips easily on the parement, which is oces. sionslly wet with a eloth. It is go dould the best mole of transportstion in Finelat, fur their wine, on account of tho great steognegs of their streets. Smalles burthens are irancportod on mes's slivulders, or in hampers and biskiets un the baeks of donkeys.

1 was anrprised to learn that all unistemeamours are refored for trial ta Pot'tugal, and thut perents Javing committed small erimes are kept for years without any disposition being made of thetu by those in muthority. 'Ithey are mnintained at the expense of the complaimant, consequently crime is scarcely molicel or complaibed if, on tho otse hand it makes the punishment very severv, sut on the other, persons ara inclinet to talie tle law into their own hands agninst petty thefts. It is impos. sible to avoid many painfal sights in passing the prisors. Caps $m$ stieks are thrust through the iron gratings, and requests are made for nlms, first is beseching tones, aud afterwarils, if nothing is given, one is pained with honring eries of execration. The occupants are in keeping with the premises, and did not fail to excite both our comnmiseration and disgust.

The rides in Madeira aro benatiful. The roads are well made, easily nud safely travelled on a Madeira pony, with a pony-loy or burroquerriv. One is at is losg to which to impute the nnost strength of mind and endurance, the pony or the boy. These boys keep eunstautly near the rider, at 12. 2 
times boluling on to the tail of the pony, then lresteswing repented blows with tleir long wticlis, and ever and mon urging him on with their singslar tones of vuice, so that lhe rider is compnelled to allow himself to be carried slong. enntertenl witls pissing safely over so novel suld (co hiss) spparently แn impassable a roadway.

On punceedisig out of Funclial, fruits, flowers, and regetables mem crowding mpan the sight ; in the lower portions, groves of orange and lemon trees are ningled with the vineyards, the trees are loaded with fruit; thrn, as nile mounts higher,

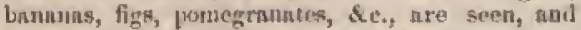
agaith, gtill higher, the fruits of the tropies are interspersed with thuse of the teniperato zone, viz, apples, currants, penrs, and penches, while the grumd is envered will melons, tumatoes, eggfiant, \&c. larther beyond, the lighest point of cultivation is reached, where the potato alone flourishes. Then the whale lower portion is aprend before the eye. Vineyrds, oceupying every spot that is susceptible of improvennent ; nnd none rides through paths hedged in with geraniums, roses, myrtlos, and hydrangeas, l'liese planta, which we had been aceugtumel to consider as the inhabitants of our parlours and grecn.houses, are lore met with in gigantic forms, and as different from our snall, sickly specimens as can well be imagined.

Every one who risitg Matein slould see the Curral. It is n very rematrabies spot, and it is difficult, if not imposible, to give an iden of its benuty and grandeut. This pilice is spprosched by the usual aseent from Fumehal, through the narrow roads, or palhs liedged with roses, fic, the view gradrally extending berseath, orer the terraced vineyarts, Just before reaching it you mount a mall ascent; you are then on tise sumbit or edge of the Curral, ant the whole scene sunldeusly butsts upors you. The eye desends to the dopth of two thousand feet, into the intmense chasm below, and wanders aver the ragged and broken ontline of the many penks that rise from its very buttom ; then upwarus, following the gany preeipitous rocks, till their summits are lost in the clots]s, which atre prasing fitfully aross it, oseasionally permitting the sumbenus to glanee to its very boton. The whole looks minre like enchnutment than reality. "Flhe shape of the Curral and its perpendieular sides give the idet ratber of a gorge than of a crater.

The islands of Madeira and Porti Sautn, utsder the vew constitution, promulgated its 1836, were jucluded in one district, ealled "Districtosadministrativo do Funclual." It contsins ten councils, in which are forty-five parishes. The pmpalatiouz, aecording to tho sensus taken in $18 \pm 36$, amounted to 115,417 souls. The English population to 108 fanisilies, numbering 324 souls,

"The reventue of the island is stated to be about 210,000 dollines per aumnt. That portion which is derived from the customs, is about ono-half, or $110, n$ on dullars. The remainder is from taxes and titueg.

There are nbout five thousand proprietors of tho ooil, of whom no more than six hurdred and fifty live on their rents; and there are about four lundred who receive goverunuent sularies.

Mendicants are numerous, asd one is much tormented with then from the very moment of landing. It is surprising to find them no invportmmate in fo tine as isinnt, and where the necesentus of life ouglit to aboumd.

Wine is the ataple conumudity : the produce durillg the year 1237 was 14,150 pjjes. The pxport the year plevitous to ons vieit mounted to fidts pipes, of which abunt 3800 pripes went to the United Staten, Tlue inluabitants of Mnteira are muchalive sund justly jealous of the reputation of their wines, which are generally the entrossing tonic of convereation. An anusing excitement existed during ous visit. A lannlon paper (The T"inses) lasd noserted, thas fureign wine has frequently been introduced into Mulcista, and nfterwirds exported as the geIItino article to the United States in partieular; ancl what gave more force to the story, it was stated as a fact, that 70 pipes had lately been entered, at the expense of 1000 dollars, and remautheured. Lvery body was up in arms, The connuercial associntion of Funchal pasked resulutions donouneing the putslieation in string term, as flesigued hy certain interested persons to injure the reputation of the wine of Madeira. So stinet are the lass to grevent frauds, that even gentuine Madeira, after being once shifped, cansot be returned to the island. I liested, however, of an attempt, nnd but onke, to smuggle ins Teneriffe nnd Faval wius, which was discovered. The easks were broken, the wine destroyed, the boats configented, and the sumuggler condenned to be transported to the coast of A frica.

The penple aro itudustrious, sober, aud civil, and showougl ignodant, I should thimk lonpty. There is litule, if any, mixed bloot amung them. They are of the nld Arnbian stock. Free negrues are seen. Jark linir, eyes, and complexion, aro most eummon; but much diversify in form aud foature, and in the colonir of the liair, exists. The chancter of the fentures of the inlabitunts is usually rather a brond face, high clicek lones, and pointed nose, full lips, good teeth, and retresting chin. T'he men are very nussudar, rather above the milable leight, strongly built, and capable of enduring great fatigue. We all agreed that the women were particularly ugly, which is to be imputed in part to the lasil laburar required of then. The two sexes do not appear to belong to the same mee.

The men of the Jower order are dressed in a lind of loose tmusers (cuecas), descending as far ns the knee, with a shirt or jacket of a gaudy colour. Both sexes wear a kind of eap (campuca), of rery small dimensinns, sied under the chin. lis ure is not resulily conceived, as it is only a fow ituches in dinmeter at its luse, and terminates in a conical top, like an inverted funnel.

'I'le womnn wear lodices, witls strort petticonts of a variety of colours, in strijes. Thicy lave ustanlly sloes and stwekings, but they genornlly go barefooted, with these articles tied is a small bundle, to be put on when they wislo to nppesar fine. The children are pourly clad, Jawe but one garment, and that dirty.

The babitations of the lower order would be called luts in our counsry. T'liey are eotnposest of walls of stone, abunt five or six leet high, with a roof rising on all sides to a centmit pole; nre thateled wicls strnw or bruors, sund contain only me reon. The only aprerturo for light nna smoke is the dour. There is but litte necetsity for ching. neys, as tire is oeldom requimal. It is said that in the northers prot of the ist:mil, some of the pea- 
sants make their liabitation in caves or excara. tions on the bill-side.

In the town of Funchal there are many elegant establiahrsents, and muels luxury among the ljigher cliusses, but the poorer elnssog ire lodged misemhy, The thouses nto generally of one story, of whirts the exterior is well kept, being nently whitewashed; but the interior is any thing buc comfortable. T"hey lave but one entrunce. The thors hre [Maved with round stones, and the walls are of rotigh stone, presenting mo better an nypearance than our wood-eellars. I'le fumiture is semity, and of the conrsest kind.

Travelling is perfortued in sednu-chairs. This mole is niways considered the safest for laties, particularly in erossing tho mountains. Hosses aim tumies are selilom used. On leavisg Fundual for the cauntry, it is one continued ascent liekween liglı stome watlin, liese forning abutments to the terraces, which are covered with vines, and afford protection from the sun. After renching the hills, one enjore a delightial view of the buanciful mondexs. The rotul-sides are lined throughout with frowers (to us those of the creen-house), among them fuchsins, digitalis, rose geraniutus, punien granatn, rosa indiea coccinea, lyydrangea liortensis, mixed with box-trees, tnyrties, sc.

The walleys are covered with the belladonn lily, and the mountain-pases camnot be compared to any thing mote appropriate than to $\&$ rich flower-garden left to grow wild. Adided to nil this, a climate wlich resembles our fincst spring weatlier.

Such of the pensantry ns do not gain a subsisteace in the viueyards have nsunlly a small pateh of ground which thay cultivate, ralsing grais, cotrs, potatoes, and the taro (arum esculentum), in quantities bntely gufficient to eko out a scanty living. The cultiwation is conmonly perfurmed by hand, althougls a plougl of vory simple construction is sometimes tused. Many of the peasantry are emplovet as carriers, and ore is much strtek by their numbers when entering lunchal early in th* morning, with sheeprakins filled with wine on theis shoulders, that look at a distance tuore like the live animal than in filled skia. These shins are ptreserved as entire as possible, even the legs of the atuimal being rotained. They nre getsernlly kept steady by a band that passes wrer the furehead, which supports a great part of the weight, Abont twonty-fivo gallons, weighing more than two hundred pounds, is a loud. They move rnpidly, and enrry this load five miles for a mere trifle. To $\mathrm{ts}$, one of the most retuarkable fentures in the population wiss to see a female trot only thus ernployed, but a stout monntain lass trudging up a steep path with ease, under a load that would have staggered one of our labourers, even for a short distruce.

The mantuet of expressing the juice I have no where seen partienlarly deserihed; and althongh a deseription of it may not add a relish to tho eup. yet it will show the manufactnre as condueted according to the old custom, at the present dny. A friend of our consul was obliging enough tu show us his works, and the machinery for expressing the juice from the grtmpe. It was in a rude sort of shed. On our gjuroach we heard a sort of song, with a continued thumping, and on entering anw six mon stnmping riulenty in a vat of six feet square by two feet dewp, tlices on euch side of a huge lever beam, their lega luare up to the thigha. On our entrance they nedonbled their excrtions till the perspintion fairly qoured froms them; the vat had been filled with gripes, and by their exertions we were enabled to see the whole process. After the grapes liad been sutheiently stamped, nod the men's legs well seraped, the puilp was Inade into tho slispe of a large bec-lsive, a rope uade of the foung twigs of the vine lueing wound around it. The lever was then nsed, which has o large stone or roek attached to it by a sejew. The juice stuws off, and is received in tubs. The produce of the press is on m Nrernge about fifty gallons dnily. Wiach gallon requires nhout ten bualuels on grapeg. The taste is very isuch like sweet cider. "The jrocess is any thing but plensing, anul cndenvours Intre been tnade by Englial residents to substituto nuchinery, but the prejudices, voxations, and difieuties experienced have caused them to give up the attempt. The general arerage is frort one to three pipes of witue per acre aumunlly.

"The somth side of Madeira, $n$ is well known, althougli not the most fertile, produces the finest wines. Every point which enn be cultivated successfinlly is aitended to, and esrth is brumght tu inerease the soil from other parts. "Jhe kinds of grapjes are various, and the wines manufacturel as numerous. The common Madeirn is outained from a mixture of Bual, Verdello, and Negro Molle g17pes; the Malmsey and Sorcial from grapes of the same name. There is a great difference in the Bphts and peedin exposure where the vino grows; and different kinds of wine nre prodnced, aceord. ing to the state of maturity to which the grape is allowed to arrivo at before heing gathered. After being expressed, it is put into coslis, uzdergoes the process of fermentstion, is clnvified with gypsum or isinglass, and a amall portion of tumudy is added, two or three gallons to the pipe.

The deportment of the lower classes is a mixture of politeness and servility. They invariably noticed us in passing by taking off the eap; and on toceiving any thing, kissed their hands, or made Eumb other regpectul salutatins.

The langurge spoken in Madeirs is. Portu. guese, lout with s rupid utteranec, or rather, elipping or abbrevinting of their words and expresbions.

Tho ignorance of the common peoplo seems great. Few ean read, and still fewer write. It is Baid they are aequainted with no more than three coins, all of which are Spanish, namely, dollars, pistareeng, and bits, and that maty kinds of Por. tuguese coing current at Lisbon will not pass in Madeim The wnst of a small deseription of money is touch felt.

I direeted a party of officers to muke an exeurgion to the top of Fico Rtivo, in order to ascertain its height, and that of the several points on their way up. They remained four hours on lhe summit, furing whicl time simultaneous observations wero male at the consul's liouse by lieutenant Carr and nuyself. 'Tluey asceruled by the Sirrits Anua road, which is the only one row gaid to lie practi. calile. Punta d'Emperia, the lighest point of eu! tivntion, was found to be four thousand obe hundred feet above the nea.

The mugnetieal observatisus for tip and intensity wero also wade, and the dongitude by chrono 
meter was fourul to be 10 sof $^{\circ} 11^{n} \mathrm{~W}$. Latibude by observation, $32^{\circ} 38^{\circ} 11^{\prime \prime} \mathrm{N}$.

The markets are well supplied witlı mest, pout$\mathrm{try}_{\mathrm{y}}$ fish, and all kinds of vegetables.

'The bat noticed by Bowdiels was the only ono of the mammalia seen in a wild state. Of birds, two eprecies of thawks, the linnet, the canary, the goldfinch, the yellow wagtail, and the swift, were atl that were seen. Sea-filh nre abumlant; but not a single trace of a fresh-water fish was sect or found in the streams Mary specimens of crustacen, insects, and thollusea wero added to our collections,

The ride to the Quintu of Mr. Fenn at Corwancha is one of the prettiest the istand affurts. It is trwarils the enst emil, and some eight or ten toiles from tho town of Fiuclad. For varicty of scenery and the beauty of its grounds it is not exceeded by any on the islarm, and it gives $a$ good idea of the effect of Englist taste when applied to tho scencry and fine climate of Madeirn. "The rond to it is the same that lass been before describen, passing through the gorges and around the different spurs, which gives great valjety to it, and presents many fint views. Having a note of introduction from our contul, we stopperd at Mr. Beail's gate, and sert the servant in, wlio returued, informing us that Mr. Bera was not at home, but a kind invitation to enter was sent to us from his lady. We did so, riding througls luedges of fuchsias and myrthes twelve foet high, when a benutiful little cottige un a sipall level spot burst suddenly upon our view, with its rerundah etntosomed in creeping vines; and from the noteg of varions kinds of birds, one could alinost have fasceied oneself in an aviary. Sereral small lakes were partially sen, their dimensions being ingoniotsly hid from view. Ont one of them was secs a tiny flect safely moored, on another waterfalls, fic, ; the banks of others were gurounded with aquatic plants, amnng which was the culla Ethiojica in full bloons. Thien agatil we were struck with the dahlias, geraniums, roses, and jasmines, and the varieties of trens and shrubs from the tropich, besides willows, onks, elng, sic, that were fumiliar to as. $A$ vjew through the trees down the gorge to the distnnt necan was beautiful, bringing before us ail the bold seenery of Madeira: truly it was an endianting spot. The grounds are extensive, und laid ont with great taste, and encli kpot appenred in keepring witla the whole. The lutl belind the house was found by the sympiesometer to he two thousand and ninetyeight feet abore the level of the sea.

After a stay of a week, we had made all our ropairs and armingemonts which wert necessary in consequence of our defective outfits, recruited the offiecrs and men, and preponred for our departure.

\section{CHAPTER II.}

\section{CAPE DE VERDES-RIO DE JANEIRO.}

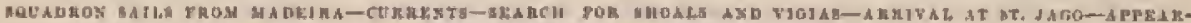

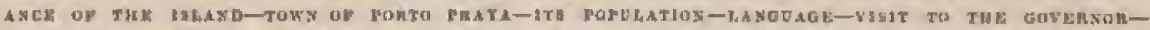

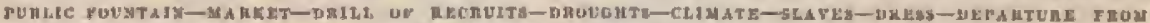

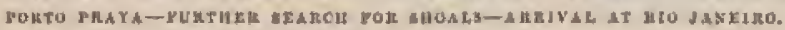

ON the 2ith of September, laring completed all that was deemed tueessary, we sailed from Mladeirn, and stood to the soulhward, istending to [mss over the locatities where shoals were supposed to exist.

After passing the Canary Inlands, we experienced a curreut setting north-enst by cast, of about onefourth of a mile an hour, until wo reached the Iatianle of Bonavista, oue of the Cape te Verdo Islatids. This somewhat surprisad me, for I had formed the iden that the sat of the current should have been in the dircetion of our course; thut many earoful observationg with the current-log, and the difference between our extronumical observations and dead reckoning, gave the same results.

It was my intention on leaving the United States to pass frolix Madeirz through the Sargasso Sen, in order to ascertain something definite in relation to this unexplured and interesting loeality, nut to gain some information rolative to the fucus nsfans, or gulf-weed, the origin of which has remained of loug in doulst. Deep sumndings in this part of the ocean $I$ deemesl wanld bo very interesting, and aftord an ojprortunity of actetling the urigit of this phut, which is apread uver the whole ocean; bat eny time did not permit me to make this deviation from our lirect course, and I hoped on my return to have ausple loisure for its explorntion.

On the 29th of September we passed into discoloured water, us green in appenrunee as that of fifty fathonss' deptll. On entering it, tho theinusneter fell one and a balf to two digrees. T"lue distance run in it was abont four hundred and fifty miles, Repented easts of the teep gea lead were bad in from two to three lumblred fathoms, but so bottom found. The water wins particularly exaJuined for animalcule, but nono wero detected. On learing it, a rise of temperature took place of two degrees; and much phogrhorescenee was scen when we lad jassod out of it.

T'le first shoal searehed for wns the Maria Rock, said to he in latiude $1 f^{\circ} 4 \bar{a}^{\prime} \mathbf{N}$, and longitule $20^{\circ} 50^{\circ} \mathrm{W}$. In its geighlourlood our pnsition was carefully ascertained. The vessela were then spreal in open orler, ant a course sailed to phas directly over the spot. The surface of the ocenn visible was not less than twenty miles in latitude, with every of portunity whieb clear weather eould afford. Good louk-uts were liept at the unst-head, and Liere was a sufticient swell to cause lreakers on nuy shoal whitio fifteen fect of the surface. We 
man over the loenlity withut perceiving any thing that indieated a shoal.

The situntion of the Bom Felix Shoal, taid down about ten lengues to the south of the above, was passed uver in the samo mumer, suluting rejuentedly for bottom with throe hundied fathons of lime, but mo appearnoce of $n$ sloal wus observed.

The reported position of the Bunctia Rock next chimed our attention, in lititude $16^{\prime} 32^{\prime} \mathrm{N}$. and longitude $20^{\circ} 57^{\prime} \mathrm{W}$. After this locality tad been well examilsed, n course was steered orer ats supposed leating from Bonarista, one of the Cape we Verdes Islunds. The ressels of the squadran sounding every haif hour during the niglit, which was clenr and bright monliglit *

On the night of the Gut of Oetober, we hove to off the island of St. Jagn. Seldorn have we seers the ser exhibit sa much plungrhorescence. Its bril liancy was so grreat, thant it might uruly be said to hare the appearance of beisur on fire. We made somo experiuluts to nscertain the depth to which these phosphoreseut animaleules extended. After many trialy, they were not found bolow eiglotens fathous. The temperature of the water at that depth was $70^{\circ}$, nt the surface $80^{\circ}$, und at one hundrem Enthoms depth $58^{\circ}$. The nienil tesupernture of the air from Madeim until our nrrival of this port, wan found to have increased from $69^{\circ}$ to $77^{\circ}$, while the ditference is the water was from $71^{\circ}$ to $81^{\circ}$.

On the motring of the pits, we ancltored in Porto Prnya bay. The islaud of St. Jaga presents a very different appearance from Madeira, particularly the sonth-eastern portion of it, though its formation is known to the similar. There are many ligh peatis and mountains in its centre, which aftord a fine tackground for the barren and uninteresting coast secuery.

The time of one artiral was just after the rainy sensum, the island consequently presented a more verdant appenmace than it does at uther seasons of the year.

Our consut, F. Gardiner, parl, enme on board, and mate us welcome to all tho island afforded. An officer was despntehed to eall upon his excellency the governor, to report our nrrival, who pruved to be a black man, Knowing that the regulations required prermission for vessels to depart, the request was nade during the interviow, which lie readily grasted at any lour wo chose.

The town of ['orto Prayn is prettily situated on an elevnted pieco of table land, and looked well from the anchorage.

The bay is ans open one, but is not expoed to the prevuiling winds. There is generally a swell setting in, which makcs the landing unpleasent nod diftieult. The only landiug -place is a small rock, somo distance from the town, and under a high bank, an which there is, or melher was, $n$ fortificution, for it it now entirvly gone to deeny.

- Sinco our examiantion, 1 have seen Ameriean conual at Porto Prsya, F. Gardlner, ear., detelling the wreck of the Britjals shlp Chariotic in 1811 , and placing

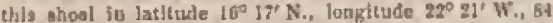
In latugitude and $15^{\prime}$ in Intltude frum the prosition 1 searched for it in: whence it appearn that it h the same reefon which the Magdelaine พลง loal. I lase no kind of dould but that they ouglt nill 10 the reforred to the Hartwell lieef. The arme gertletman was conhdeut at the pirme I saw lifn that the Mngilelaine hat heeb fosk on the reef of that name. commands the bay, and is siluated about two hamdred feut above tlic sem. Tho horizosta! stratificattion of the red and yellow-celoured snudstone shows nost conspicuonsly in this eliff, and forms one of the most rernarkible objects on this part of the jolund, It is of tertiary formation, and contrins many fussils.

On landing, a stranger is immedintely surrounded by numbers of the inhabitants, with fruit, vegetables, chickens, turkeys, and monlieys, all fressillg him with bargairs, and willing to tnke any thing for the purposo of obliging their customers. Many of them continue to follow until they meet witl some new customer.

'I'se soil, rocks, and every thing around ots the surface, show unergivocal marks of voleanie orjgin. The roek above the tertinry formation is a thich bed of cellular lava, with fitgmente of the same strews in evory direction over it $A$ thin ant port soil gives lut litule entatenance to a liglu herb. rge. Gonts and asses are found in great numbers grazing ufon it.

The walk from the landing to the town is exceedingly fatiguing, nnil the road dleep with sand. Tho first viow of the town on entering it is any thing but striking, and all the juens forned is its fovon are suon dispellerl. The hougea are whitewrslied, and in genern] appearatee resemble those inlabited by the lower orders in Madeirs, but they are mucl inferiov even to then. The uorth-cast part of the town is composed of rough sturse houses, covered wish palm leaves. The streets are wide, and in the centre is a largo publie squase, the middle of which is occupied by a small wooden monument said to to emblematieal of royalty $1 \quad \Lambda$ chapel, jail, and barracks constitute the principal public buildings. The fort, which flasks the tow1, is almost entirely in teeny. This is the ease with almost every thimy wo sats here; the pline is, indeed, little better tinu an Airican town. The houses are of stone, one story high, partly thatched, and others tiled. Their interior presents only a fow articles of sbsoluto necessity. Of eomfort and olennliness, in our senso of the words, they have no iden. The houses and strects are filthy in the extreme; and in both of them, pigs, fowls, and monkeys nppenr to elaim, und really posese, equal rights with the occupants and owner.

Tho population is made up of an intermixture of descondasits from the Portuguese, natives, nul negroes from tho adjacont conkt. The negro race scoms to predoninate, woolly hair, flat noses, nud thick lips being must frequently met with. The tumber of inhatsitants in St. Jago is albout thirty thousind. Porto Praya conthins two thousused three hundred, of which number one landred aro native Portuguese.

T'le langriago spoken is a jargon formed by o nixture of the Portuguese and ungro dialects. Most of the blachis spreale their native tongue, Mr. Hale, our plílologish, obtained bere a roenbulary of the Mandingo Janguago, and found it to agree with that gives ly Mungo l'ark.

The ofticen of this garrien were, litio the governor, al! black. The latter made a brillinnt appearnuce, dressed in a military frock cont, red Bash, two large silver epatslettes, and a military eross on his treas!. He was good-louling, althougi extremely corpulent, and Epeskis both f rensh and Spranisls well. He was very civil and attentive. 
Fruit, breal, cheese, and wibes wero handed about. Some of the wine was made ons the island of Fingo, and reatmbled the light I talian wines, 'Ihe cheese algo was made here from goats' milk, and resembled the Spanisli ctreese. After doing anngle justico to his excellency's gaod fare, we procesded to view the lions of the place.

"Ithe first and greatest of these is the fruntain, or commen whtering-place of the tuwn, abuve half a mile distant by tie path, in a valley to the weat of the town, and alraost imunedintely under it. The fountain is surrounded by $\pi$ variety of tropical srees, consisting of dates, cocon-nuts, banans, paspayas, sugar-eane, aud tamarjnds, with grapes, olauges, limes, \&c. \&c., and when brought into eomparison with the surrounding lands, msy be termed an enchanting spot; but what adds peeuliarly to its effect on a stranger, is the noveliy of the nhjects that are brought together. Over the spring is a thatehed roof, and round about it a group of the most remarkable objects in hunzat shape that can well be conceived. On one side blind begrars, dirty soldiers, and naked children; on anotlier, lepers, boys with monkers, others with fowts, half-dressed women, asses not bigger than sheep, and hogs of a mammulh breed; to say nothing of thrige with cutnneous disorders, that were undergoing nblution. All conspired to form a scene peculiar, I should think, to this semiAfrican population. Here nailors watering and washing, clatling, talking, and langhing; there a group of far wients nutives of nll sizes, shapres, aut coluurs, half clothed, with turbaned liends and handkerediefs of many and gay coloure, tied on after a different fashion from what we had been neenstomed to, the shawis being reversed, their ends hanging down behind instend of before, conphetely coveriug the brenst and one-fourtis of the face. This well barely supplies lio wants of the inhabitunts and slipping, and they are now about building a reservoir. The whole of the stone for it was prepared in Portugal, and made ready for putting up. It is to bo of marble, and the water for its supply is brought two miles in iron pipes.

A market is held daily in the morning when any ressels are in port. The square in which it is belit is quite a large one, with a cross in its centre. The market is not of much extent, but a great variety of tropical fruits, of the kirds befure ent. merated, are exposed for sale ju small quatities, as well a regetables. Throse consist of cabbageleaves, Lonns, pumpkins, squashes, corn, potatoes, yasos, murndioea, $\delta \mathrm{c}$. All theso were spretul on on the large leaves of the cocos-nut tree. No kind of meat was for sale. The ouly articles of thin deseription were clickens four or five dings old, tied up in bunches, and some eggs. In order to obtain becf, it is necessary to buy the cattle at the cattle-yard, where, on previous rotice being given, you may choose those that suit for siaughter. Thoy aro in general of smal! size, amb Jarkcoluured. 'Thuse we saw were from the interiur of the island, where they are said to thrive well.

The morning drili of the recruits which was witnessed was amusing. They wero cleanly dreased, but the rattin was freely used by the sergeant; and what aeemed cliaracteristic or in keeping with sppearnnees uround, the sergeant Iuring the drill ordered one of his men from the ranks to bring bim soune fire to light his cigar:
No trades were ohserved, and bnt one small enrpenter's shop. A few slops were supplied with cotton, hardwnre, \&c. There were likewise a nutnber of little wine shops, where they also sold fruit, which they usunlly hnve in great plenty; tut all their crojs depend much upon the rnins, and the inhabitarts have also become indifferent or carcless about raiaing more than for their own supply, from the heavy exactions of govermment made upon every thing that is cultivated. The dernand for slipping has of late years very muth decreased. The inprovenent in the supplies and comforts on bostrd of vessols on long royages, now make it untnecessary to touch in purt, as was formerly decmed unavojuable.

Porto Proya is yet risited by whale-shipg for supplies. Although the soil is poor, and tho crops very uscertain, yet the tropical fruits and some vegetables can nlways be obtained here. They are ustadly, if time is allowed, lrought from the in. terior. The inhabitants bare at times suffered almust the extremes of famine, in consequence of the dronghts that prevail for sucecssive years, and especially during the one that took place in 1832.

The exporta from these islands are salt, some ordinary wine, hictes, goats' skins, and oreliilla. The latter is a goverzment mosnpoly. Nizety thousand milrees were paid by the company for the yearly crop, and it is said at that price to yield a handsome profit.

The climate of these islauds is said to be healloy, thongh excedisgly wnrm. It is stbjeet to fevers, which generally inke place duriug the rainy montlis of July and August. There is an indistinctnes in the atruosphuere that I have not experieticed elsewhere, which causes every thiug to be ill-defined, alshugh the day way he fair. "The snme appearance whs observed after a shower of atin as befure. The temperature of the nit was foutd laere to be $77^{\circ}$, nud of the water $81^{\circ}$.

Slaves are importel fmm the coast of Africn, and settlers or leady of fanilieg are not allowed to bring with them more tlian ten slnves. There was une at the consul's, rocently imported from the Foolalı distriet in Afrien, who was puruhased by him for one hundrel and fifty dollats.

The costumes here ar'e so varions, that it senreely can be anil that any one of them is peculiar to lise igland. The men generally wenr a white slirt and trougers, with a dark veat, principally the cast-oft clothing of the whites. Others go quite naked, excepting a straw hat; others agriu are in loose shirks. The women bave a khawl fastened around then, witl osensioraliy another thrown over them, covering the mouth and bust, and eressing behind. The children for the most part go nnked.

The Relief not having artived, I leemed it an unnecessury detention to awnit lier leve. There was grent neecssity of renching Rin de Janeirn as suou na possible, in order to eomplete onr uutfits, and put the ressels in fit condition to meet the Anturetic cruising as soon as possible, I therofore determined to proceed thisher forthwith. The stose-ship did not reach Porto Praya until the 184h, after a passage from Hamption Ronds of sixty dnys. Nothing more truly illustrates the necessity of navigating in the prevailing winds, than this jassago of the Relief compared with that of the squadron. We took the route liy Mudeira, over one tlousand miles greater in distance, re- 
maing? tlere a week, and yet we nrrived at Purtu Praya eleven days sooner. 'T'he Relief, pursuing the direct route, had light bagling winds during her whole pressage. Althaugh semething is undoubtedly due to her dull sniling, yet the iliffermee is $\mathrm{c}_{\mathrm{s}}$ great to be entirely nttributed to that eause. The winds were getiernlly found by her from the northward and eastward, and soutliward and enstward, whilst we, in a higher Iatitude, had them from the sousth-west and the westwnrd.

On the 7 th of Oetober we left Porto P'mya, and stonod for Panty's Overfalle, as luid down on tho clart, in latitude $11^{\circ} \mathrm{N}$., aud lorngitude $24^{\circ} 25^{\prime} \mathrm{W}$. IVe lost tive tracle winds the day after wa luft Porto I'rayn, the Bth of October, in latitude $12^{\circ} \mathrm{N}_{2}$ and lougitude $23^{\circ} 30^{\circ} \mathrm{W}$. T'le winds then becruse varisble, and squalls of rain ensued. 'T'lwe upper clonds hat still a quick motion to the westward.

(U11 the 9h we reached the supposed position of Futty's Overfills, and were beealmed clobe in thein proximity for furty-cight lours. Nothing was seen of them. If aty had existod, we must have beell made aware of it during the tiue wo were heealmed, for we remained nearly in the anne position furty-eight hour's. Thence wo stood for Warley's Shual. "The weather had the same indistinctness that we lad first observed at Porto l'raya. It might be terned a dry haze.

The 24 th we reached the pusition assigned to Warley"s Shoul, in Jatitude $5^{\circ} 4^{\prime} \mathrm{N}$., lengltude $21^{\circ} 25^{\prime} \mathrm{W}$. Wo passed over tlie supposeil lusality, lut saw no apjearance of alixal water, or danger of any kind.

Wo now ran for the French Slınal, in latitude $4^{\circ} 5^{\prime} \mathrm{N}$., longitude $20^{\circ} 35^{\prime} \mathrm{W}$. Here the wiml inclined to the soutliward, and we proceeded as far east as longitude $13^{\circ} \mathrm{W}$., passing over the two positions laid down by the French and Jinglish hydrugraphers, but saw nothing of it.

We now tacked to the southward, to cross the equntor in longitude $17^{\circ} \mathrm{W}$. The wenther land changet, the mins whieh we had experienced at uichit ceased, and the extremely judistisct atmospluere which at tines lund previlied for the last fortaight disappeared. It is diffieult to deseritio the peculinr effect this haziness produced. It seemed to me nu effect the npposite of that of tooming, apparently diminishing all objects. A1. thougli the horizon was been, yet tha sea and sky were so blewded together, that it was diffieult for the eye to fix ugron or defiue it at any moment. It was impossible to use the dip sector. At the same time it was perfectly clenr over head, with a bright sin, and the upper cirrutus elonds, whicn seen, were in rapid motion to the westwart.

Tlo nights wore now beautiful until near morning, when it generslly clouded over, and remained overetst witly flying elonds until evening. Tho zodincal light wan vnce or twice ubserred, but the presence of these clouds for the most part provented it frum being seen.

On the $29 t h$, in latitude $3^{\circ} 40^{\prime} \mathrm{K}_{\text {, }}$, our observatinns gave a eurrent of tell miles is twenty-four liours, to the north. Until the $3 d$ of November we had light winds; the tupper stratum of clouds was Jow seen moving from the east. On the $4 I_{1}$ we laal a cry of breakors from the mast-head. We immodistely changed our conrse and rat for the appearance, but if proved on nearing it to have leees orte of the wanty oputical illusiuns secen at sen, frum the efferet of liglit and shadow.

On borrd the P'encock, on the soth of October, in Intilule $1^{\circ} 30^{\prime} \mathrm{N}_{\text {, }}$, longitude $18^{\circ} \mathrm{W}$., they witnessed a remarkable appearanee, resembling the aurora horealis, moliating front the north-west point of the horizon in different directions, and extending from south-west roumd by the norib to the enstward, at an ultisude of frum $10^{\circ}$ to $30^{\circ}$; afterwards renching to the zenith, and jassing over the nuon't disk, encireling her with a faint halo of twenty degrees in lismeter. It continued an hour, anil althongh it was bright moonlight, the phenomenon was very distinel and henutiful.

On the 5th the winds drew to the south-southenst, and wo erosed the line, ns we liad jutended, is longitude $17^{\circ} \mathrm{W}$, which enalled us to pass over aurl examise the supposed locality of the Triton Bark, in longitude $17^{3} 46^{\prime} \mathrm{W}$., latitude $32^{\prime} \mathrm{S}$.

We had now lioury deposits of dew, on several tine and eloudless evenings. Indeed the sun had scarcely get before the slip was quaite wet with it. One of the essential requisites supposed necesenry by Dr. Wells for a deposit of dew was certainly wanting in this case, vi\%. that "the temperature of tua body on which it wan deprosited should be considernbly lower than the surrounding air;"-the tesuperature of the air and ship having remained the same for several days at about $78^{3}$ : all objects, bamusuek-cloths, spars, sails, and rigging, oo far so could be ascertaiued, showed the same. And at the time when the dew wns observed to be most copious wo had a fine brecze. It liag genernlly heen supposed that dew uever falls of soundings. This al least is an old saying amosy seanen: but our observatints are at variaued with this notion; fur a far as every indication went, both by sound. ing and blue water, we certaisly had no bottom.

TJue strpposed positiun of the "Triton Shoal was now passed over, and exumincd carefully' in the Batue manner as heretofore deseribed, sonnding at the same time with two and three lundred fathoms of litse. Siotling of the kind was perceived, nor whs there any jodieations of sourdings in the digcoluratiun of the water, or asy change in its tomperature.

On the 7 th November at noon we were in longitude $18^{\circ} 20^{\prime} \mathrm{W}_{\text {, }}$ and latitade $3^{\circ} 30^{\prime} \mathrm{N}$. I then stoud for Bonvet's Sands. Isle, or its reported posicion. Wo saw nottring of it whatever. I was very desirous of continuing my nearel farther to the west, from the repurt I land secu of varions vessels having experjenced shaeks of earthqunkes, and the belief having been cotertained that shuals might lutve been formed by them. The exuatorial current having been felt, I was sware that in getting farther to the west, I should lose the ofprontunity of exaniming the locality where that distinguistied navigntor, admiral Krusenstern, supposed lie saw a volenno. I therefore gave up proceeding further to the westward in this latitude, and hauled up for its position.

It was now the 9hh of Noxember; we had delightful weather, and modirate lureezes from the buuth and east.

An amusing circutastance occurred this night, In our course we passed very near a large sail, which, frum the night being tark, the officer of the deek of the I'urpoise mistiok for the Vincennes, aldhougi sailing on a different course. He inme- 
dintely, agreetbly to lis ordern, followed the vesse.], and contimued after her until morning, when, ti his surpise, lie discovered that it was a large Dutel slip. Fortunately I had perceived the stip pass, and conjectured, when we found the Purpoise was aot in aight at dingliglit, the unturo of the mistalie. I thereforo retraced my ateps, and in nn lour or two we again came in sight of her, then tacked and proeedel on our course. On tho next day, the time being very favourable, we hore-to, to get a decp-sen sounding with the wire line, and ran out one thousand six lisndred fathoms of it. On reeling it up, the wire parted, and we lost nine hundred and sixty fathoms of line, with our sounding npparatns, inchuding one of Six's self-registering thermometers. The wire was bodly prepared and ill adapted to the puxpose.

On the lith we found ourselves nent the location of Krugenstem"s supposed shoat, ran over the position in parallel lines, and sntisfied unrselves of its nols-existence,

On the nfternoon of the 23rd of November, we took a light widd fromb the Boutls-eash, and with all sail get stood in for the mugnificest larbour of Rio Janeiro. Ous attention was drawa first to the high, funtastic, and abrupt peaks of Gavia, the Sugar Loaf, and Coreovado on our left; whilst ou our right we had the bola proint of Santa Cruz; then befure us the city of Sim Salvadot, and the towns of Sar Douningo, with Praya Grande opposite, and the islands and flee: that lay between then decking this benutiful expanse of water. "These oljects, with the pinnacles of the Organ Mountainh for a lnelground, form such a seene that it would be diffienlt to point ont in what numrev it could be improved. "Lhe life and stir crented by the number of veasels, buats, nul stentners of various forms and of all sizes josssing to and fro, gire grent animation ti the whole.
The mountuins present a very peculiur appearance. Their tops and sides lesve a rounded or worn вurface, destitute of verdure, with the exception of bere and there a yellowish putch, proultaced ly the Tillandsias, which in places covers the rocks. Tho alsuptness of the Sugar Lonf mounluin, and thone inmmediately behind Sunta Cruz, strikes the speclator very forcibly.

The slipiping do not form as in other places a dense forest of masts. There being no wharves, they are obliged to lie at auchor, exhibiting their proportions and aymmetry to grent advantage. 'They are nsually seen grouped together, with their different flagg flying, forming a picture that a painter would delight in.

Ihere is a foeling of security on eatering the harbuur of Rio, that I lave seldom experienced elsewhere, not even in our own waters. The mountains seem as it were to affurd complete proteetiun from the winds aud ocean. Wo anchured near Luxados or Hospital Joland, and found the Feacuek laxd arrived here three days before us, atud that she was proceedliug with her reprairs rapidly, The vessels being altorether mint for the southern cruise, it becnmo neecsary to etfect the reugutsite repquirs as speedily as possible.

We aro indebted to the Hon. William Hunter, oar clargés d'affuires, smil vut cunsul, William Slitcum, esf., for many kintussses and ntcentitns received during our stay at Kio. Thyough their intereession, I abtained the ure of the small ishand of Elaxadus, which was well sdaptesl to vur pllrposes. The instumuents and stores were allowed to be huded there free of inspection, and every assistance we could desire was nfforded us by the guvernment and its officens. Ilow difforent a policy and treatment from that pursued towards enptain Conk some seventy yestr befire, under an ignotull. ard jealous coloninl government!

\section{CHAPTER III.}

\section{RIO DE JANEIRO.}

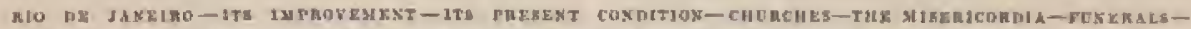

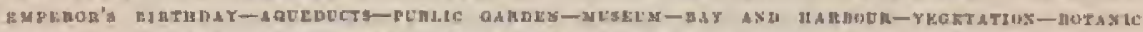

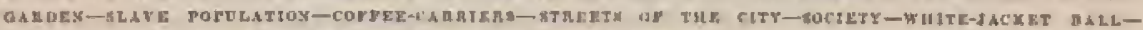

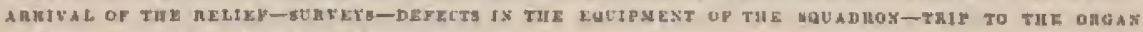
NOTHTASB-ASCENT OF TUI CORCOVAWO.

TuE city of San Salrador, better known as Riu de Jauciro, has been often duscribed. At the time of our visit, a great claago appesrod to lave taken place within a few years, as well in its outward sppeartneo as in its goverument and instilutives, thus giving to the whale a differeat aspect from that it formerly wore. Uuder jts former montureh, Don Pedm the Finst, it lad all tho aspect of a court resilence; now it is the very reverge. I shall Liverefore give my own impressioss and sketch a pieture of its atate as we found it in the latter part of the year $183 B$.

Republicas forms, hubits, and eustoms, are gradually ereeping in tuder itf new and reformed coltstitution. It is not to bo donied that the people now nppear to be nuch botter of than formerly, and more at liberty to earry on theig' lawfil pursuits. Conmerce and intercourse with foreigners are every day making liberal adranees, Every onu, on his first landing at Ritr, will be struck will tho inditeriniuate mingling of alJ elases, in every place, all appearing ou terms of tho utmost equitlity;-oltivers, soldiers, aud priests, both black nud white, mixing nud performing their respectivo duties, withont regand to enhnir or appentance. The only distinction scens to be that of freedom and shwery. There are many wesleliy free blacks, bighty respectable, who amalgamate with the white families, and are njparently geceised on a foting of perfoet equality. Thre police, ton, cunsisting of a 
mational guard, has taken masy thete forms of nilitury parade that formerly existed. An air of independence is erveping in even among the working elngses. Any littlo service that is required, and for which they are well paic, they appear to consider as a favour done you. The mecharies! arts are at least Jiajf a century behind those of our own country. The churches, which are numorous, ste falling itato decay, which gives a dilnpidated took to the eity; its religious cermonies are dis. persed will, ark to clown all, the steps of the churches are malo a market-pilace for the sale of sheep, pigeons, fruit, \&c. To judgo from nppear. ances, and the attudance on its serviecs, thero exists litula religious foeling towards tho Hontan Charelt. It is true, the same constant ringing of betls necurs that is to be henrd in all Catluolic countries, nud other outward kigns are still kejt un; but the priestheol are not regarded with such awe as they formerly were, nud soeicty seens to be breaking though the tranumeds that bive solong ellsluved the feuale portion of $\mathrm{jt}$. Religion is a mere name anteng the youth of Brazil, The aged no still observant of its ceremonies, but little or no atcention is paid to the Sabbatl, Tho Etores and the workshops are open the same as on other days. $A$ few are seen going to wosship in the snorning of tlint dity, but $n$ greater vumber attend the billiard-tables in the afternoon, sud the thentres at Iliglat,

Wo EnT Rio do Janeiro under its most farournhle aspeet, that of the liolidays, wlien thic church had put on ull her fincry and deeorations, and erery one, slave ns well as master, seculed inteut upon enjoying limself. "Tho Christmas week or holidays give a reapite from all latrour, and various are the amusements. The ehurehes are decked, aud the services extruordinary.

The neglect of the puldic walks and roads shows n want of proger attewlion, and strikeg the vikiter as different fron las tssunl order of things around a court. So for as clesuliness goes, Rin, I sm told, is not mueh inproved. It has every adrantage to make it a clean city, but the inclination appenrs to he wanting. Although the government is doing little, one sees the spirit of enterprise monong the citizchs. Many private dwellings aro being erected, and I noderstuod that mnny other improvements wore taking phace.

The houses of the city are estrongly built of stone, comemexl sycether with elay; this is lased in con. sequenee of the seurcity of lime, which is only obtained by burning sliclls fished up from the bay. The houses are plastered on the ontside, nnd havo a pretty appearance and colour. "The floors, beams, and roofs are made of the hard wool of the comntry, of great hize and strength, which are indeed necessary from the heary tile roof they have to bear. Very few of the homses have yards, cellars, or andens; consenuently the dwollers nro still greatly ineornmoded frotn the want of water-elosets, detrinental both to henlth and comfort, and not only an annoynee and inconrenience to the inhabitatsta themselves, but shared by the stranger in passing thringh the strects.

We of conrse saw all that was to be seen in Rio. The churcios elsimed our first nttention. They are richly decorated in the inferior, with massiro gold and silver ornaments. On some of the altars of the saints it is the practice to suspend the diseaned partis of the bidy in wax, in honour of the curc ouprosed to lave been effected by tho saints' intereussion. The sight of these is truly disguating, atthough they are far from being well executed.

T'he Alisericordia has now become much out of repair, and I understood had fallen off in its charitable usefulnese, but it still shows the romains of its former splendour. Few monks were seen about, and dead boulies were laid out in the Green Honse. At the time we sisited it there were eight, the greater part of whons were negroes. A monk was seen saying a lastly prayer over the bodica, whijeh wore at otree thrown into the treuch, wher they wore sprinkied with lime, placing one layer over the other, uutil the hole, aljout eix feot square and as masy deen, is filled or level with the sur. face. After one of the trenches is filled, another is dug by the side of it. Tho crowled state of this place of interment is but too evident from the number of skiulls and lones fying about, gone still with portions of flesll alhering to them,

On the Enme evening, whilst this scene was stil fresh in our minds, and as if in skrong contrnst with it, we met the funeral of a person of distiuction. A blinck bearec, oruanented with black plumeg, was drawn by mules. The driver had a cocked.hat and binck plume. Ithe coffin wan covered with $\pi$ scarlet pall oruanented with silyor. About iwenty altar-boys, in theis chureh dress, preceded the liearse, which wis surnounded by about tle rame number of black servants, in livery, all carrying lighted wax candies. Tho boily, on arriving at the imperial elenpel, wna removed inte it, and all who entered the clispel wore furmished will lighted tapers. Mnss aud llie funcmal nervice were performed by the priest, nnd some deligluful masic by a fult eloir. The body was then taken into the Campo Santo, a kind of amplithentre, with light wallis, n short diatanee from the chureli. Alunt a thousand vanlts are luilt in the wall. One of them was ogrened, the hody interred, nnd the wall hilt up again. "The centre of this eeptulelure is laid mat in a tlower-garden, and is about one lnundred feet in diameter.

Jecember $2 \mathrm{~d}$ was the birthday of the cmperrs, Don P'edro the Second, who thien was thirtees yenrs old. It was colelurated with all duo nomp. Great preparations lind been making for many da1s. He wrs to pass into the eity from St. Cliristowal, his usual residenec, in procession, and to hold a levee at the city palace. The streote were slrewn with orange and other lenves, $n$ trinmplanl areh ereated, \&e, But a description of his progress will give $\pi$ bester iden of it.

Having left St. CTristoval, lie entered the eity about noon, preceded by a large troop of hosse, He rode with his siaters, one sixteen, the atlac fourtnen yenrs of nge, in a splendid English carriage, with bronze and gold moutings, drawn by cight cream-coloured horses, gaily caparisonerl, with silver-mounted harucss, the servants in rich liveries, Three earriages, drawts by six horses ench, followed, containing officers of stato and bis householu, the whole surrounded by the emperor's garards, and alove five thousand military following. Grest cirwds of people hind assembled to nincss this pamde. As the earringes rassed under the baleonies, garjauls of thowers were throw upon them. They enterd the principal street through a trimphal arch, beautifully decorated 
with natural flowers, oil which were placed two litule boys, dressed in blue and pink, with wings to represent anguls, each Irolding in basket of fluwers, which they threw on the young monarth as lie passed. The houses in the streets llurough which the procession moveu wero bung witl satin damask draperies of the richest tints. These I understand are kept expressly tor such ocensions. At short intervaly national flags were suspended acrose the strets. The emperor moved on, receiving the Rame marks of atfection from his subjects tuitil the reached the great square and palace, witere be alighted. The trouss forming aruund the sigure soun came to order, and a genenil parse ensucd, until the firing of the fou de juie began, one of the most deafening I ever heart. He fimished thin publie exlithition by showing limself to the multitule below from the balconitey of the city palace, and was received with many eiras.

He then held his levere, which the Rer, Mr. Walah has so well described, and which closely tenembled the one at which lie was present, with this differener, that this was much more of a farce, in echuserquetice of the boyhond of the emperor. Nothing ean be more ridiculnum than to see all the dignitaries and old men, the mitred bishop, tho sage dijhlumatist, and the veteran suldict, ushered into tho presenee, and out agair, without saying a word, or turniug their backs on tho yourig mouarth. Mr. Walsts has, lowever, sajd nothing ahout the scene in the anteroom; to me it whs the most ridieulous of all. The arranging the order of entrunce to the presenee, with due form and etiquette; the examination by ench diplonatist, that lio has his dne order of precedence; lheir anxiety to gather their suites around them, not unlike a hen with her chickens, to make the fullust show; all prepares one for the riticulons scene that is to fislow. The ollust resident minister always takes the lead. At uight the eity was iltuminaterl.

Rio is now well supplied with wates', Aquedncts have been thijghed within the last two years, which bring it from the Cortovalo and Tejuen nountains, a dimtnnee of six or soven miles. There are a number of public fountuins in diflewent parts of the cicy. All the water for the supply of fanilies it trinsported ty slaves. These fumtairs lave numeruts jets, and some have pretty edifies over them. Wuring the day, there ure seldom less than fifty to one laundred, both male and fornale, water. carriers around them, filling their jars, wills which they are seen moving about poined on their lends, Near the large fountain called Hafariz, in the square of Santa Anna, are two large bnsins, ntrout fifty feet long and twenty-five wide. These are commonly fillesl with nbout two hundred negro women, who daily assemble to wash. Numlers of them are half naked, standing up to their middlo in the water, benting and thrusting the clothes they are conployed to clean againsi the adjuining wall.

Few articles are tmansporied in any other way than by sluves, and it is extremely rare to see a enrt drawn by any beast of burilen. Antiqume looking earringes and two-w/seeled calvecas ure geunrally scen,

The musum is npen twice a week: it is quite ereditable to the cily, and well worth steitig. It appears to nttract more attention frorn the infubitants of Rio tlan I strould have been led to expect.
Is is extremely rich in its native cullections and is well taken eare of.

'T'lie theatres, of which there are three, are seldom opesi on week-rlays, but always un Sunday.

Tho hay is very beataful and in anully covered with small hoats, feluect rigged, witheut decks, and gentrully about twelve tors' burlen. These bunts ure ruwed by blacks. The onn are large, the men row in a standing posture, and thus ads the weight of their budies to their strengtls. At times the bay geems alive with the nursber of these ressels, atid of small canocs, eacli nade of a situglo trunk, which are used in tislatigg. Mlany of thetwe versely are also engaged in the consting trate. Foreiguess are usually employed to tike charge of the latter, which sail under the Brazilian flag. Stenmers arm tegiuning to be used. One plies between Rio and Snitos, and during cur atny, ansolher beft the harbour for Monte Video. The greater part of the vus. seds in the bay are under fitreign flags, nnol I was such surprised to abaerve how few comparatively nere English, and trow many are from the north of Europe.

"libe hartour of Thio may be considered as nut extending forther thas Euxadug Islajd, nuove which few vessels lie. The frosh of the city is toot well alapted for wharvtes, and none consequenty exist. There a'e sonse staire, lut they are not well protected from tho sea, which at times renders liudiug alınost impossible,

In Riris, the vergetation seems to fix the attention above all uthes things, especially of thuse sitnated ns wo wero in the hatbuur, lisving it centinualty befure one's eyes,

Here, as in all tropiend elimates, the eruth of the remantk ntale by a botanist, "that every thing grows into shrubs and trees," is obvious. Herbaceons plants are mre, and anutsals may be said to be almost wanting. The frtit trees nre gunerally seen bearing fruit and flowers at tho snme time. This was the ease, as observed by one of our party, even in the cultivated apple on the Tejuca mourtains.

The botanio garden is in a flat situation, backed by a higlı rilge uf monntainuos lnud, In front is u lake of brackisl water, which forma a considerable bay, and communicutes with the rea by a nacrow inlet. The entrance to the garden has in mean appearance, and dises not correspond with the broad promemades witlin, which are planted with trees on tach side. The whule is lsid sut is the old Duteh style; seath, arbours, and houses nre cut out of arbor vitse (Thuje urientalis). In the ecintro of the garden wis at small fountain, near which grew some fine enecimens of the aplemdid bougninvilles bracteatea, in full flower. THere is also a fine collectios of orehidese, which are eultivated on deeayed trunlis of trees. 'Ithe brend-frnit trees (artwrarnas incisa and integrifolia) succeed very wwll. There were some treess of both kinds forty feot high, and the fruit of the latter as targe as an ordinary water-mulon. Several groups of banbons laad a good effect smong the wher trees, but their stems bore evilenec of a propensity to the earving of names, as a ntemento of the persons? visit. Among thru I was giad th see the mames of many Europens, which serves to prove that this Jabit loes not exikt hmoug Americans nlone. Here an attempt was made orme years since to introduce the tea-plant, with satives of Clina to cultivate it. 
The plnutation appreated to our botsuisul gentbenteu in a sickly state.

"The great ami distinctive eflaracteristic of Itio usay Le said to be its slaves assel stavery. This evil sontinually premonts itsel to the obserwer, nud he estrnot, if lie wotslal, divert lis nuterution from the many sights which keep it before his nind.

The slave population is stater at five times the tumnber of that of the wlites, and notwillestanding tho existillg danger of maritime capture, the supply still secms engal to the demand. Althungla many slavers are talsess by the Englist cruisurs, brouglit, in sod tried by the anixed cummissinn, agreeably to truaty, yet mesus are found to introduce the alnves. Two slavers were lyilig in clatroe of the Einglish sqquadron while we were thero. On brard of them, thougl quite small ressols, were two and three hundred negroes. It is dificult to imagina creatures more emaciated and miserable. Not will it fail to exeite marprise, that they should be kept thus confined by those who affect io extablish theis frecdost and ameliorate their condision. Theso vengula it is understond land sotnined their victing on the canterit coasl of $A$ irica.

Slaves aro almost the only earriers of hurdens in Rin Ianeitr. They go aimost nuked, and are exceodiugly ummeronis. They appenr to work with cheerfulues, nul go together in gangs, with a leader who earries is ratule mole wl tim, nad filled witl stonos (similar to a chilf's rulth), With this he keejus time, causing them all to mov' no a dog-trot. Easels une joins in the nonotunoms chorus, the nutes seldort varying abuve a third foun the key. The words they ume are freguently relative

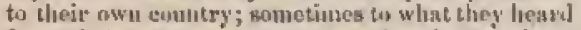
fron their master, its they sturted with their lond, but the sound is the satne.

I'hese hlaves are roquired by their nuagters to obtain a certain sum, seevrling th their abilisy, it is suid frous twenty-five to fifty cents a lay, und to phy it every aventug. The surphus hetongs to

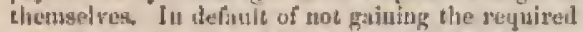
sum, crotigntion I nun tald is nlways inflicted.

It is said that the liberated negrones who own slaves aro partieulariy severe anil cruel. The usunt load carrieul ig atrout two luundred pounds weight.

Fast numbers of elaves have beres and ato etilt imported annunly into this market; and as very mnny of tho вane nution of tribe nsscucinte togelibel, they retain their own language, even after they laswe been in the cuntry for sone yenrs, It may be sees by the moat cussury examinution that they are marked in such a mauner as to morve to distingtials their diflerent mees, Sume have little of the distinctive negro elasacher, ant others more of it thas any human lueings we had soen.

The negrues of Brazil who linve been lrought froms Nortlı and Soush Afrien nre divided into (wo distinet and very dissimilar clusses. The natives of that fortion of the continent known uader the genetral mame of Upper Guinea, include the countries in the interior as far as Timbucton and Bornou, heing the whole of that region lately explored by the Euglieh exjeditions. The slaves from this quarter, though of rarious mations and lnngingew, linvo yet a geueral likenese, which stamps them as une rnce. In Brazil they aro known under the unure of Minas.

The Minis slaves are sairl to be distiuguinged froun others by their boslily and mental qualities. They are geserally above the middlo lieight, and well firroed, assd betray littlo of the levity usually ascriberl to the negro race.

In Irrazil they oecupy the highest position thnt slaves are nllowed to attain, being cujloyed as eonfidential servunts, artisme, and small traders. 'I'ley luok down upon, and refuse to liave any con nesion with, or purticipation in, the employment of the nther negroes. Many of them write and read the $A$ mbic, and all man repeat some sentences of it. The greatest number of slares who purchase tjeir freedom belong to this rwee.

There is one singularity whith seerns to be com mons to the itiliabiants of both regions, and which may be comfared with the practice of tattooing which prevails throughout the tribes of Polyuesin, viz. the eustom of cutting or branding certsin narkis upon the fnee ant body, by which the individuals of one tribe may be distinguished from those of any uther. This practice is general among all the Mitas, nnd also prevails along the Fasters or Mlozambinue coast of Southern Arrica. Among the Western or Congo tribes it toes not appear ti be unitersal. It will the meadily understoud that these marks are of great service to the slavetraders, aud all that have mucls to do will native $A$ frientus bon learn to distingnish them; and the pricu of a slave is depressed or enlanaced accurdingig.

The Minsa are held in much fenr in lirnat. They are extrumely munzeruus at Bahia; and it if malcretond that during a late insurrection, they lund fully orgaizen] thempelves, aul wore determinesl to instutute a regular system of governument. They lat gone sil far as in cireulate writings in Arabic, exlorting their fellown ia boulage to take the attempt ti teesver their liberty.

l'attooing, or marking, dues not prevail smont the sribes of lower ficion to auy great extest.

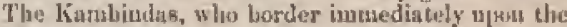
Minas, nypear to have borrowed from them the cuntum, but enplisy it ratler for the purvose of urramest than as a mode of distinguisling their origin. "The marks or figures witj, which they hrond thenselves are various, and sontitnes orumental.

The Mundjola, a sarage trilhe, Jiving in the interior, beyoud the Loungo distriet, are estermed the least valuable of all the blucks imported into Brazil, leing stupid, ferocinus, and intrnctuble. In Afrien they are stigmatized $n s$ man-eaters by the other negroes. 'Ihe Mundjola have the usunl negro features, wills somewhat of a Tartar expresเiluth.

The Benguela blncics have a muely bigher clia. raeter as slnzes then the other nations of Lower Guiner. They are rext in estimntion to the Minns, being steady, industrious, and inteltigent. They make excellent Jushandmen. They are getsernlly of good height, with features having less of thir negro stamp than those of the Congo: the forcheal tolerably high, the nose not mueli depressed, and the lips moderntely full.

Mary disgusting objects mny be seen among the sinve populntion at Jio, bint I do not recoltect lusing met with a begear. I lave understuod that they are not anflored to njpenr in the strects. This is the law in almost all citieg, but luere it is rigilly observent. 
The streets of the city generally crose tatcl oulder at right sagles, Some few of them bave kijle-walks, but they are narrow and badly pared. The gnters are in the middle of the streets, with $\mathrm{s}$ stream of water which emits a smell by no menus arreeable. Those must frequented are the hun Direitn and Ouvidor. The fottrer, enistaining the palace and catheotrol, is the brondest in the city. In the latter wre the principal shops, and it is the gryest. "Ithe atrects are paved with bhelis of stone. What gives llio its principsl charm, are its suburbe and the small quintas aroum it. Nothing ean excecil the beaty of those aruand Glaxin and Botofugo.

The amusements of riding and fisling, with water excirsions, ate frequent, and of the most agmeealule kind. Thege nnt other nlvantages of so fine a climute soon reuder a residence at Rio tuite desirable. Thure is nuch pleasant forcign socicty, compnosed of the diplnmatic corpas, nunny retired gentlemen, nnd genernlly the offiecers of the several men-of-war if different nationa.

There appear to lo but littlo intercourse between the Brazilisns and the forvign society. The female sex particularly is still nueb restricted in this respect; nnd altiough grest improvement las takel place, yet they seldum mix in social intereourse with firreigness; 1 sm told thut even among themsitves they are seldum seet exeept at ecremonions parties. They are very much as one wonld expect them to be, reserred, retiring, and wantise in education. They dress after the lirench fastion, and ato nsunlly covered with finery, often displaying splentid jewels, without taste. There is none of that ease and gaicty which exists where the for sex is cunsidered on an equality with the other, and there is a total absence of that tone which a conkcjotsmes of their value gives to society. Their ustanl place of resort duriss the afternorn and evening lo tho baleonius of their houses; some of them are oceraionally seen at clureh. It is said they soon lose their beauty, ats early nge lieing eonsidered as their urime.

Airung the many placen to which we hat the honour of an invitation was ont of their monthly bulls, the white-jacket ball, at Praya Grande; so etalled in eonserquence of a request being nade on the enrd of invitation, that the gentemen would conac in white jackets, and the ladies apreetr without bxilliants or other jewels. We gladly necepted the invitatim.

On reaching the asteroom wo were mot by the contmittee of geutlemen or manngers, and kindly greeterl withuil eeremony, naling us it onco feel nt our ease. Wo were shortly after ushered into nne of the most splendid ball-rooms I cver" saw. There were upwarils of three hundred prusent, al dressed in pure wlite, withuut any finery whatever. The rom was brilliantly lighted. We weve shown around, and introduced to is great many persons of both sexes, who all seemed bent on antusesncts. It was turly a acus sonci meeting. Seldom linve I seen so much good thiste as was dispinyed in the arrangements, or so good a tone of sucisty. A good bnud of music, all Brazilinus, played wnltzes and marchea alternately. I was told there were many distinguished persoms, seJintors, representatives of the eongress, $\delta e_{1}$, present.

The langunge generally spoken was Portuguese, though some few of the ladius, and many of the genthemen, קpoke Frencl.. I was not muchi struck with the beauty of the ladies. T'he great chatu tlirown over the whole was the umafteted manuers and mürete exhibited by the whole eompany.

On the 2jth of November tho Retief arrived, affer a prassage of one lumdred days, frum tho United States, the longest ever namle, (1n rezuisitions being made for her stores, 1 was grenty and rexatiously disappointed to reccive a report that they rentrired n survey, as $n$ ll were considered defective, including even the loend and flour. I'his report, after a careful survey by seven officers, frowed to he stuc. I had been informed before taking eommnat of the squadron that these provisions hind been inspected, and unterstool them to be in good order, and that thoy would last over a year.

We redoublet our exertinns, nud the Relief was despratched at the earliest day proskible, the lith of Decesnber, in order to enuble her to reacl Otange Harlonr, in Terra del Firego, the place I liad tixed upon as st remlezvous, aupposisg she would take at least fifteen days more thrn the other rensels to reach the plince at the same time. The boats towed hor dows the lurtour, and gave her $n$ fair start.

Our repairs in Rin were extensive, jarticularly those on the Pencoeli. Among nther things, the head of the mizzen-mast lad to be eut off eigliteen inches, in conserutesce of a defect in it, whisels it appented lasd been filled up with rope-yarzs and putty, nul painted over, at ler nutfit. Thio defects about the vessel were so glnring, that in guitsg to lise high latitudes, jt world lave bees improssible t) accure the crew from great suffering outd exjosure. Even in the state in which the squadron was now put, I lind every apprehensius of the greatest disasters. The Pescock, Jarticularly, was whelly ursenwerthy with respect to such a cruise.

My ohject in giving these details is not to isnpute blane to any one, lowever satistled I may be of the great neglect is all the oulfits, but to tet the country know what were the difficulties we harl to cueounter.

It is a arays difficult to caleulnto tyom the delays that may accur is a foreign port, particularly wluen it is necessary to enploy Eoreign workmen, Their hours, habits, and manner of souling are so different from our own, that great jatience is neruired in those who employ them. The manner in which the calkers of Rio work, would drnw crowds around them in one of our own cities; to see mary of them engnged on is sirjgle tiesm on tho ontside of the vessel, striking the milet at a signt? given by their lender or overseer with his wlistle, is amusing. They are generally blacks (prolubly slaves), and the Jeader a white man. "The Inipression tonde

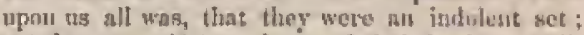
yet they nre saicl to understand their lusiness well. 1 eanzot, lowever, bes favoumble testimomy to their work; the calking of ny ship wns entainly bally dune.

The uneertainty of the length of time I should be detained, rendered it imponsitile for me to sllow long absences from the ship. I wns anxions to lare made sonie mensurements of the Orgnn moultains, and that our parties should extend thoir resenrehes beyond them to the Campos.

Dr. P'ickering and Mr. Brackenridge suceedted in usakirag the trijp to the Nrgan monntaing on a botruical exeursiun; but the vutfits and duties corn. 
nected with the ressols and ouservations, made it impossible for me to apare any ofticers to make the mensurement of their height, or to go risyelt. These gentlenten sot nut, having tnken janguge is the usual freight-bont (felueca rigged?), for Estrolla, embarking their hurses and muleg ill auother. These bonts are not decked, and are of sufficiont tonnge to matie them enfe and curve. uient freight-toats. They generally have four or five slaves witlı a padron to mannge them.

A littlo incitent that oecurred to these gentlemen will slwow the difliculties to be encountered in obtaining specimens. They lat observed for a fow days a beatiful yellow flowering tree, that was sery conspicunus in the forest. Welieving that it coulil he easily come nt, they made the attempt to roach it, but without success, finding it, instcad of bring laws, a high and inneessible tree. They then direted their steps to olhers, but were disapprinted again. Determined not to be foiled in their puratit, they argin went off in search of orhers in sight; these, to their surprise, wore on the opmonito side of a river. Nothing daurated, Mr. Brackesurilgo crossed it, thotshlh deep, nnd endenvouresl to genle the trec. What lial appreatrel neav the grousd, now prored is tree of some sixty feet its hoighth with a stuontls and sliprery bark; and he ruturzed to his eoupranion ensptyhanded. Dt. Pjokering next waklo the attempt. After crossing the strent with difficulty, he reached the lesired olyject, aud endeavoured to climb, but after reaching some forty feet, whs obliged to achnowledge himelf ranquished.

A fow days beforo our rleparture, we malo a trip to the top of the Coreovado. The raturalints who wine of our prity obsersed that nlmost a tolat change had tuken plaeo in the plants since their hask visit, atont a fortniglst before, 1 took wits mo the necensary ingtruments to metsure its height, and we all anused ourbelves witl colletring plants, insects, lixaruls, \&ce. Wo took the roml that turut oft nes Gluria, and even before we begar to emerge from the eity, severwl novel kinds of ferms wete observed growing on tho house-tops and walls. We soon entered coffee plantations, groves of bananas, tamarinds, mangroves, and orange trees. A vast vatiety of plants were jointed oul to me by Mr. Brackenridge, among them the betutiful roclyzia, with its aplendirl yellow blossoms, showirom conspicuous anowig the rest. After a fatiguing wull we reacherl the top. The last quarter of a mile, or the last rise to its funmit, enuses one to become somewliat breathlese in a lot day; bust when the top is gained, it is worth all the habour of climbing, and unply repays for the exertios.

The whole of the magnificent harbour, the city nnil envirnng, by beneath our feet. A bird'seye visw is had of every thing, grouped in the most plensing varioty; and nothing strikes one so forcibly as the white sandy bersehes of Botofogo and Praya Grande, with the beantiful blue of the aea washing on them. The many lakes, the castellated peaks, nnd the varionsly-slinped, eraggy, and troken hills, are all softened by the light and airy green vegetation, creeping up their sides so as to melt them almost into one, The day was benutifully viear, and the refreshing sea-broeze just what we conld desire. To form an iden of the benuty of Rin and its environs, it is necessnry to mount in the top of the Corcovado, or some ligh peak in its neiglibunurlood.

After finisting onr ubservations, and fully satisfying ourzelves with the beautifu! scene, we desectsded to the belle Rue, where we enjoyed is rest and luncl. We retirtzed to the eity by the way of the nquetuct late in the afterteon, all grently alelighted will our day's jaunt, whisch, beaide the amusement, liad groved a profitable one in the way of eolfectjons.

\section{CHAPTER IV.}

\section{THE BRAZILS-RIO NEGRO, TERRA DEL FUEGO.}

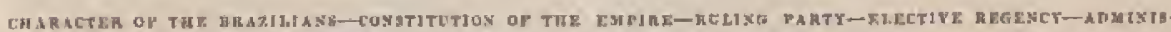

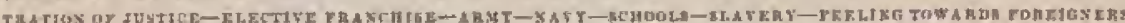

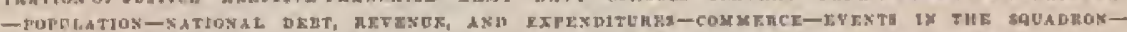

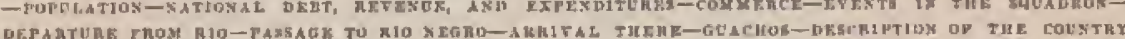

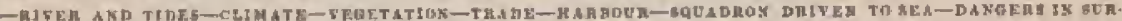
จ

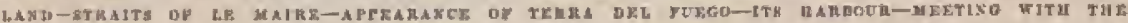

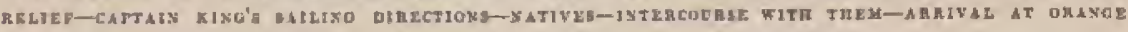
ningoun.

Doniso my stry at Rio, I had th opportunity of sening several intelligent gentlemen who had long been reshtomts of the country; I am indebted to them for much information relative to the politicnl ntate of this empire. Brazil, thongh quiet at the thme of our visit, will long be deatined to outbraks and alaruns, either from local oppression or some slight political movements. The people, for the most part, take very littlu jnterest in politics, or in the genernl welfiro of the stato. As yet, their habits make them averse to mental exertions, and they generally prefor their own ense, which precludes them from engaging in political excitement. They tre not yet sufficiently adranced in civilization and education, so far as regards the mase of the popahation, to rise from the nental dogradation which the poliey of the nother country entailed upon them.

The Brazilians, from the eliancter I have recoived of them, nwe very ceremonious and punc- 
tilioun, susceptible of flattery, s11spicions yet conrterus, selfish, ennning; sasuming frankness and generosity, timid, unsteady in purpose, and without ally large and comprehensive viewa. What is clnimed from them as a right in a buld and ecrs. fident mannor, is rendily yiklded, while often through their ignorance they beene presump* tumis.

The ponde are further advanced in morals and intelligence than their goverument, but as yot they are not sutticiently enliglitened to know thoir power. They are slow to act, and appear very pationt under oppression. Long ejdurneo of despotism has mude them so.

The now congtitution was alopted in 1825. This secured the legislatise fower from lurther interruption, and achieved a complete victory over the boyonets and tyramy of Dors l'edro, ly foreing lim, throngh the tlireats of the poople aud lis fenrs, to grant a more liberal constitution. Political frecdom secus to have made rapid advanee. ment thruugh the freedon of the press; but the alvautages of a free and frequent interchange of sentiments are almost entirely tukaswn. A lnng time will frobably clapese befure there will be any political struggle atnong ilsem. They are prosper. ing in their priwate concerns anl contented, witlout any antition to advanos themselves in political knowledge,

Every exurtion is making to give the young collpetroc a good edruation, and liss talents are well squkell of.

The alministration of justice is ennfided to two high triburals, which sre open to the public, ant where enuses are decided on appeal by $n$ majority of the jusdges.

These trilnuals are, first, the relachio, of which there are two laraches, one nt lin and the other at Bahin, each composed of eight juslges. Seenust, the supreme tribunal of justive of twelve judges. The inferior courts aro those for the trixt of eivil and criminal eases, an orphans' court, aud a court and judge of findings and losings, the last of which is not yet abolished, however obsolete it may have become. Great eorruption exists in them all, and mo class of people are so unpopular as the julges, It is gonerally believed, and the belief is acted apon, that to obtain justice, all elastes, inteluding priests and lnymen, lawyer and client, legislators and people, regent, and ministers, must sulmit to grent inposition; that it is next to impossible ta recover a debt ly law exeept through bribery. If a deltor has money or patronage, and refuses to pay, it is difficult to obtain the payment even of an ackmowledged note of liand thruagh the procens of the law, and it genelally takes yenrs to acenmplish.

It is, however, greatly to the praise of the Brizil. ians, that it is not often necensary wo huwe recourse to lis for this purpose. The grentest injuntice aceurg in the orphans" court; Lut the court of findings and losings is one of the most singular. in this respect. It takes charge of all things lost and found, making it the duty of a person fiuding any thing to deposit it with the judge. The loser, to prove property, must liswe three witnesses to Ewenc that they anw him lose it, and three others that they saw the finder pick it up, otherwise it romailu in deposit. To show the working of this system, a gentleman of liso found a lausli-nole of four hundred milrees (nhout 250 dollars). The owner went to birn and elaimed it, prosing satiefactorily to the firuder tlant the identical bank-2wote was lis, ujon whiel the firmer gave it up. The judge of findings and losings leard of the cirenmstance, sest for hinn, and asked a statenent of the case, which the finder unswepeetingly rolatod. The judge praised his lonourable conduct, asd was junetifsusly polite. Thie next day, lowever, he issued an order for the deposit of the monoy lound; and because it wns dischgarded, the fiuder, a reapcetable foreign merchisi, was arrested in the kt reet and gent in prison, to be confined with cora. пrin eximinals. The jnil(-r, hewerer, haring prisate ajurtmenta for those wlo could pay for them, he becane his guest, and was presorted from the disgust of being th close prisoner, and the companion of degraded and depraved wretelies. Piefore two cotsld regnin his biterty, he had tn pay the amoutst Found, the decision lieing the forfeiture of a like stun, tugether with the jailus's fees.

The justioes of the peace for each district are electeal hy the people, fuut at a time, to setve as masy yoars by turus, aubstituting one for the other, when sicknees or other circumstances prevent either from serving. Thry have titul judgments ju amouts not exceeding sixteen milrees. In cases of civil jrocess, liey not as mediators to etfiect a conıpromiso and reconcile diffienlties. Their prolitien] attriliutes ure to preserve the peace in ease of rint or disnrder among the prople; and they thave a right to call on the astional guard or military palice to aisl then, who muat act under their diste. tinul. There is no civil pulice, and no imprisumnent fur detr. Trial ly jury was at first linited to po. litient offenees nud viulations of the liberty of the preas, but it is now extemded to criminal enses, and in sinue instances to civil suits. Sixty persons enmpose the jury, nacl forty are necesary to try ctuses. The juiz de decrito (juitge of law) sits witls them in court, auts as president, and applies the law to the cases the jury may decide. Jury. men serve for one yenr, and are chomen in the following manter. In each district the vigairo (viear). a justice of the perce and a member of the munjeipality, select frum a list of male parishioners thinse ipualified in their judgment for juryman, and submit the nanes to the mumicipality, who, assisted by the vigairo and justice of the peace, purge the list of such as my bo considered improjer persons. It is then officially communicated by the muticipality to the justice of the prence, and posted up for public inspection in the office, and on the doors of the parish churehes throughout the district.

To entitle nny one to voto at as elcetion, he must have an income of two lnubdred milrees yer annum, from juroperty, trade, labour, or amploy ment of any kitud. The vigniro sits with tle judges at elections to decide on the qualifientions of voters. Friars or members of religious frntertities are not entitled to a vote. Free bincks have atl the civil rights, and vote at elections the prane as white men.

The attorney-general of the matinn is the ascuser in all erirainal cases. Criminuls have the right of coususel.

It may be sail that there is no standiug army in Brazil, for the few trongs do wot merit that name. A mititary staff on a large scale is supported, with a large corpss of military police, and a natimal guard. The uational goard is orgauized ly law, 
ntw in it all males frum eighteen to forty-five yenrs of age ate enrolled. 'They' aro enuipred at their own cost, the natisn furrialing arms and amrutunition only. Detachuents of this paned nre on duty duily at the palace and pubtic offices.

T'he nusy is not effuctive; they want seamen, and are not likely to have any. $A$ maxal academy is establisherl for the education of exdets or midship. men. Hero they enter at twelso years of age, re. wiving sorne of tho first rulliments of edistation, ass remain four yents. After passiag an examiuation, they are sent to sen, serve there fuur yeurs, and if foumd qualified are then promotal to second lieuturatuls.

The militury academy they cuter Iater, remain seven yenrs, passing througli varions courses of study, and if fund competest, they are male lientenaxts. Frum what I understuod, the syatem of education is very imperfect.

Sehouls for edueating the people linve been established, aud the female sex aro now allowed to loe eduested.

Agrieulture is extending; and the slare-tmde, since the treaty with Figland, lins lyeen prohilated; but "arge numbers of ghres are still easily sumgylod, by the comniraneo of the suthorities, fard althouglı many are enptured by British cruisers, vet it is said that more than one-half of the vessels esespe, nnd smuggle the slaves into the small rivers and harbours, bribing the collectons, who permit them to be landed. After lasding, the slaves are driken into the woods, where they are sacretod until they are suld to the plunters in the interior.

The slaves do not increase, as procreation is prevented as touch as possilble. The two sexes are generally lached up at night in separate apnrtinents Tho nuraiser of slaves imported into rio and Bahis previous to the probibition of the slavetuade ill 1830 , was abnot firty thousand a year for the former, und ton thomanil for the latter, as follows :-

\begin{tabular}{|c|c|c|c|c|}
\hline 1828 & • & $\begin{array}{l}\text { Rro. } \\
41,913\end{array}$ & • & 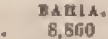 \\
\hline 182 & e & 90,615 & . & 12,808 \\
\hline 1830 & haif year & 20,777 & . & 8,588 \\
\hline
\end{tabular}

Abnut one-thitud of these were lost by death, Jenving two-thirds as an accession to the lubour of the country.

The utumber annually imported sines 1830 , enr. trary to law, is estimated at seven to ten thousnnit.

In speaking of the appretsemsion of $\mathrm{n}$ rime of the blacks in the provinees, the well-informed seemeil to entertain no kind of fear of such an event. I whe told that Iahin was the only point at which insurrections were ever lilsely to occur, and this was. from the prevalence of the Minns flases, who are very intelligent, and capsble of furming organizerl buties, which they ocensionnlly lave done. The glaves of the other provinces are of a mixed character, imeapalile of any organization, anil from laving leen taken from different trikes on the coast, they are mure or less logtile to eacli ollier, anil would be opposed th any suelt mion.

The Brazilimus lave great resnect for formigners who are not Portuguese. Tho lntter are detested. They bave a strong bias in favour of the United States and the Amerienn government generslly. They thimk the titne is approashing which will unite the people of this contineut in a distinet national policy, in contra-nligtinction to that of Furopw, and in rivalry to is. Thoy aro vain of their own country aud its institutions, and firmly beliere that a high destiny awatis Brazit. T'Jo goveruntent, in its pulitieal jelations with other countrics, is seemingly eoufhting and tiberal.

The population of the esrpire, taking the last returns of the membert of the Chimber of Deputies ns a guide, is estirnated at five millious. Ni eensits lias yet heen taken, but it is thought to exeed this number. 'The sortiny formerly exereised by tho gowerument into their domestic aftairs, it is said, enused them to eonceal flie actual number of persons it their families. Of the alrove number, about two millions are slaves, Tho populatins of Rio in 1810 was estimated at corty thussand, in 1838 it was two lrundled and fifty thoustatul.

The matiousl debt of Brazil amounts to one hundrod million nilzees, or sixty million dullury. The revenue was about sixteen suilling of dollars for 1638. It is derived priucipally frou exports aid inports.

The importa arnounted to over twenty millinjs of doliars, but the amount of exports is variously stated. Coffee is the preat staple, and more than one lundred sus twenty millions of poumds were exported in 1833. It is derived from the central provinees, and the exprosts of it lave mare than doubled willin the last ten years. The exports of the southern ptovinees are nostly confined to hides and tallow; those of the northern, to sugar, cottun, and tobreco.

The trade with the Utsited States lins greatly increased. Within the lnat few years, from one lundred and sixty to one liundred sind eversty Anerican resecla talie and luting caraoes to and from the United States, and some fureign versels are engaged in the same trate. T'he consumption of American flour in Rio and lie neighbouring enuntry has been, during the same year, about one lundred and twenty thousand barrels.

The delays in 1 io lind no offect upon the general health of the squidront, although 1 was fenrful surch might be the exse, not ouly from the lrest of the climnte, but the copius drastghts of aguardiente with which the foreigners supply the sailoto.

On the sth of Jnmunry, 1830, the Porpoise was ordered to dron down near a slaver, on board of which it was reported some of our men land been Emmgretet, to form a jart of her crew. She was Imarded, and though she captain denied thant they wure on boarl, after a searels two were fouml. One of them was a liack, wha had limself beers a slave, yet ho had been inditeed to enter for the purpose of earrying on this nefarinus trafle. Tlis wab the trig Fox, and though nadoubterly fitud for" a slaver, slie sailed under English colours. It whe giren out that ste wat hound for New Zealatul.

On the fith of January, every thing being ready, wo weiglsed nncluos, and dropped down the latrhoutr.

'There is un diflieulty, I may ould, in beating out of the larbour of Rio, with $n$ ship of any class, Altrongh vessels enil generally is the puorning, witlı tlie land-lureeze.

The winds proved light and variable during our pasange to Rio Negro, and we ocensionally expe. rienced a soutl-wsusterly current, of little strengtl. On the t8th of January, when seventy-eiglat wiles 
distant from the month of the Rio la Plata, we passed thrught the discolonred water of that river. its temperature was $4^{\circ}$ less than that of tho bus: rousnding sen.

On the 2intl we discovered the const, which is a line of low saml-hills, withont trees, and it exhibits little appesaranee of vegetation. In the evening we anchorent off the bur, in eight fislons wster, just after which we experjenced tno of the remarkatile squalls of this const, that rose from the southward and westward: it whs attented witl much lightusing and thunder; quartities of rand nut ingeets wera blawn off from the land; but lith min felt. 'The burometer indiented this squall by a de. pression of two-tentles of nn inels. The wind soou clinnged sind brought fine weather, the thicrumtsheter falling six degrees during the clinuge.

Having been hed tu believe we slould bo boarded lig pillots on our anchoring of the bar, 1 was $n$ gowil deal surpirised to find none, mad no endeavour muking to board us, although the men was quite sinuoth. The ouly appeatance of jubahitants which we cuuld gee with our telestapeg were a few borse. ineu, suspictutuly reteonnoitring th from the flagstatf on the thp of the hill. I then eoncluted tis despateh the Sur.Gull nrider licutenant-somnandant linggold into the river, fur the purjose of having conmuniention with the town, dirostug lim tis take the chamucl lowding to the nortloward and westward, as sloww by the only chart we tad, whilst I Followed in the Plying-kish, with the seientitic gentlenen; it proved to for the wrong one, and ou the tide falling the seliooners both grutuded, Our situation wits not the most ngreeathle; for, in the event of the sea rising, we stronda have been expresed to all the fury of the finte, witlcut suy eqcape fron the numerous ennilans. It Irecame nucesstry, as the lide mose, th tmake the river. 'The Ses-Gull having got oft, 1 put the seientific gentlemess ons hosrd of her, nud ortered lieutennur costmandant Ringgold to proveed ill, keprisg in what the clant peinter out as the chan. uel-way and deepest witrer. He fiualdy sucecedert in getting into the river, after lloumging henvily over a saul-bas, witl some fears on lie part of the [nssumgers, lus sithout injury to the vessed, nukl inchored, after dark, about latilf a tuilo up the river.

During this time at amusing oceurretice took phen in the rondstend. I las directed licutenantcommandant llinggold, in case of necident or re. quirimg aid, to make signal, that I might orter liunts at once to his assistance. When the night closed in, tho signal was sen; when ho ruquisite signal was made fron the Flying-Fints to the dife ferent vessels to send hents to usist. The eorn-

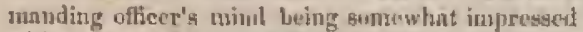
with an itles of the lostility of those on shore, lae concluded the lrate were rengirer to repel au retrek, and lasd thein fully strued; in this state they were met in a short time exerting themselves to titeir fullest strciatl at the onat, to be in timo to talic part in the expected fruy, and appeared greally disappointed when it proverl a false alarm, nnt that num was to take place.

Shortly after tho Behooner sucholed, an voice was heard from the shore, orjering a boat so be bent immetintely, whes a party landed, bat wo one was fonsul tu recoive thent. Secisur a liyhe at $n$ disfusct, they procedent tuwarty it: it prosed to be the pilot's house, a loug, low, barn-like linilding but no inlabilants were visible, and none madx their nppearance until our party land takes a survey of the premises. The futroilung was of a rule and scunty description; a tuble, trencli, two or three bunks in one cornor, and in another a number of arms, cunsisting of cutlasses, earbines, and pities, in good urder: in the atliere, various nccontrements. The two pjiots, one an Englishmath nut the otter a Frencliman, with a megro, then nade their appearance, and unravelled the ingstery, by informing thems that the ressels had been mistakess for the Fretseh squsdron, and much alaris ha! been created by otr visit; they slso faid that the gunrd of alout thirty Guachus wero in autusl near where they inmied, with lie intention of eutting our party off; but henring them apsaking Englislr, they fouml to thoir satiafaction that thoy were not Frencli. They alsu stafed that all the jiblialisants living near the montlı of the river bad fled to the town, and that most of the women aud elithlros in the tawn were laurrying off to the interius. They were likewise employed driving of the rattle, and preparing to fire the eonntry, the nsual mode of warfare, and were lejoiced to identify us as Americane,

All this aceounted for the recontuitring that we had observet, nod our ant being able to obtail at pilot. What still mure nlarmed then was the different vegselk firing whilst surveying, and our making the atterjpt to foree the jasesnge in the stuall ressels.

The explain of tho cosst-guard now nflurded all tacilities, ind a vilot for the schorner was gent bu borrd to take her up the river, nnd horses and guides were furnished for a jarty to visit tho towil.

The next murning a detachment of lneers arrived from the guvertor, with ordors not to allow uur ressela to proceed up, and that the pilot shuuld cone on shore, which effectmily put a stup to on filans; when lieutenant-commandant Ringgold decermined to go by land.

It caused mueh alarm to the pilot, whoentresteil the officers to intercede with the governor in his behalf, and for that of the captain of the constgund, strting that their lives woukl be forfeited for laving attenupted to pilot a veesel withint the govermor's orders, Aftor some delay, a party fro. ceeded to Carnen, under tho escort of Gunelins, to wuit on the governor or comnnminut. (His their way thicy met with a cordinl welcome front all they passed, is the minds of all were unw entibely re. lieved frou fear, and great deliglıt was expressed at recing the Nurth Ameriens.

I'lieso Guachos are generally well made, tall, and เมnsenar, with swartly cumplexions, biack cyex, and long hair, very largo nustachios, and remarkably ounall feet. Thejr eostume is a red striped sthit, and white drawers, large, loose, sizd frimged at the buttam of the leg, calleet cal somciltis. 'Their trousers (chiliga) consist of two yarils of searlet clulh, which is sometimas ormanented at the cumers; to form this into any lhing like an gal" ment apposed otraugo enough; yet, when it is un tho wearer, it las the apparanee of a lotir of Turkish trouscrs, The nusle in whish it is pat on

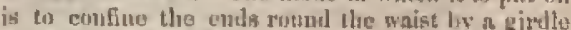
(triando), the millde of the vlotlr passing flown lectween tfus loger, while the enda falt ovelo llas 
girdle. On the heal was worn a red conical eap gurmonnted by n tissel.

Their riding bonls or leggings are nade of the litufe from the leg of a horse. "I'his is etripned off aud put on the leg while yet green, where it it sutfered in dry, and remain untîl worn ont. They fit very closely to the foot, like a stricking. The two largest toes of meh foot were uneovered, for the convelumene of putting them into the stirrup, which is mly large exough to almit them. $A$ bong knife in the girdle eompletes the dress.

The Rio Negro is anvigable for bonts to the viltage of Chichula, two liundred miles from its mouth.

The distnnee across the conntry to Buenns Ayres is but five luadred miles, yet it requires fifteen days to conmunicate with it; the governor had reeciven no advices or information for the last two mantlis from that place. The route is very un. certnin, owing to the lindes of hostile Indinue.

Gmin, fruit, and rogetables thrive well, and witl proper intlustry" might be proluced in aluusdance.

"I'to climate is delightful, and cold weather is solitom feit, although jec has ocessionally been seen a quarter of an inch in tlickness.

Bullowitand horses are the principal articles of trade; inwleerl they constitute the legal tender of the ecoutry. Thie fistaner are worth from five to ten dollawe, aceordiag to age; wild horses, twu or three dellars, nud if Lroken to the saddie, ten or fiftern.

The triff of dutieg is the sane as at Buenos Ayres, but the late reductian of thirly-three per cent. diring the blockndo did not extend to thits place.

The Intlians tint aro nceustomed to visit this phee (Carmen) fir the pupose of war or trade are of four different trilies; viz, Pampas, Ancaser, Tetutiliches or 'Telteulehes, and Chilenos, The two former oceupy the territary th the north of the Rio Negro as far as the Rin Culorado. The "Teluiliehto are from the moustains to the soutli, and the Chile. nos from the enuth-west.

During the infancy of the settlement, nud antil of hate years, these findians were extremely turtiblesome, maling degcents upon the place, and ravag ing the outponts, waylaying all who were not on lheir guard, killing them, and rotreating rapidly on their wild steeds, with their booty, to the pampas and moumlaine. The Spraniards frequently retaliated, and by the superiority of their arms and discipline, imflicted summary punishment on them. The last attrek of the Indiars was made in 18:2, when they met with suej un overwlielning defoat, that they have not ventured to nake another; yet the garrisus is always leept in nnxiety for fear of attacks.

The weapnons usual in their warfine are o long lance and the balkw, guch as is used in taking the ostrich and throwing eatte, which they use with great ilexterity. This consists of $\mathbf{n}$ thoug of hide, four feet in lesugth, with a leaden ball at eacls end, which the horacosun graspe in the middle, nuI gives the balis a rutary mution by whirling then above his lieud, then dashing on to the attrek, lie throws it shon within mage with unerring him, and seldom fails to disable his eneny. The Indians who are most feared are the Clilenis. Tho Thelui. liches, notwithstauling their immense size, are considered little better lain cossurds.
All the information gained here tended in enrlfirm the general impression thut the Teliuiliclu's or Patagonians nTo abowe the ordinary lueiglat of men, generally alyve six feet; nad the minister asserted that he had often seen them above seveu Englislı feet. We lad not any personal opportunity to verify this otatement, the Indians being only in the liabit of visiting this post onee a year, to obtain supplies, viz, in the month of Mareh, at which lime a ressel nomally visits the place.

The fow Indiang who inluabit the huts or toldos on the opposite sille of the river nre converted, and are termed Indios Mnzsos; they aje a mixture of all the tribes, and an much clunged in habits and dress from their former condition and tnode of life, that an aceurate idea could not be firined of their natural ebaracter. They were none of them abowe the middle height; their timbs were usually full and well formed; their complexion a brownish copper, with eonree straight black bair, growing very low on the forehead; this is suffered to grow long, and hangs dow on both sithes of the face, adding mueb to the witdness of their appenrance. Their forebeals are low and narrow towards the top, their eyca small, black, and deep set. Some were observed with their eyea set Chinese-like. The resemblasee whs somewhat juereased by the wilth of the face, which wa \& particular clauracteristic. The anse is usually a little flattered at the rot, and wide at the nostrils, the lips full, and the chin not prominent. The expressiuns of their countenance betoken neitluer intellect nor vivacity. The men wero genosnly decked out jn tuwdry finary, partly after the Sprnists fishion; the women had only the elsilipa to curer their naliedness.

of the Anesses very little njpears to be known; they live towists sho uotth, spenk a peculine tassgunge, nnd are infurior to live rest in stuture.

The Clillonos are durived from the western side of the continent, wad are prealatory bands of the grent A rnucunian nation.

The Peulches, inchuling the Panpas and 'T'efuiliebses, Falket, in his arcount of this country. describes as inlabiling the prortion south of the Riu de la Plata, and to the east of the Cordallems; they are seattored over the vast plains of the interior. Those to the anrth of the Rio Colomulo nte generally known under the nлme of the Pampas Indians; they call themselves Chechehets. Those as the south of that river are termed 'Tehuiliches; they inbahit the table-Int between the Cordilleras and the rlesert plains of the coast.

These people are reptesented as of girantic stature, nud it is said by the residents, that ifunse froms the gouth are generilly taller than thowe frran any other part; aud Iudians are said to fanve been met wish who are distinguished for their gigantic height and well-furned limbs; but this rests on vague authority.

The Guachos and Itadiaus are of course goon lursenen, being irained to it from their infancy. Indeed they ray be wail to live on horseback, and it is very seldow that they aro seen to walk any distumee, lowever short.

Tlueir drens, allhough anenuth and ill-arranged, is comfortable, and picturesque when they sre on hossehnek, particularly when at full speed in search of a bullock to lasso. The ease nud nonchalance with which a Guaclio mounts his steed, anranges 
hirrumlf in the sarldle, quietly t'utting off, lakso in linul, to neteet lis victim, nisd iletach it from the lierd; then the eager chins, the furious speed of the lotse, the flying dress of the Guacho, with upraised arms whirling tis lasso, the terror of the animal, the tlirow of the lesso, aud instantaseons overthow of the lualbek, all the work of all instant, excitust bath our admiracion and astonishment. Nothing can exceed the animation of both larse aud rider (11) tliess oeverasionis.

Mr. Wildrot, our purser, malo an endea vour tn puwhas some vegecablea for the crews from an estancia on the river-side, of which an old Spaniand was the owner, thus atfordiug him an opportussity of ilisposing of many of them; lout the conditions were, itsat the articiea must he on the beach in a fow linurs, whieh was ample time to have dug up mil acte, As mon, Jowerer, ats le learined theste terms, the shrugged his shoulders, and dech reat the thing improssible, took down lis guitar, sested lim. nelf its frnut of his house, and began to phay $n$ lively air, which lis two sons secomparied with their roicus.

The enast and the baths of the Rio Negro are compused uf samd-titls, of from thisty to fifty feet in theight, envered with a gentlered growth of grasg, which preventa the satul from blowing a way. These gradually rise to the height of one humberl feot, excent to the sunthwarl of the river, where the bark is perpezulieular; at this height the grourut stretelaes away in a level prairie, wittsout a single troe to broak the monutony of the seenc, and uffords a view as usiuterrunted as tho ncesn.

The twily verdure an the prative is a sunall shruh, which when the dower lirusches are trisument oft serves a useful purpuse. From an optienl illusion (the effect of refraction), they sppenr, when thus trimnted, ns lasge as su ordinary-8izenl apple-tree, anil ane is not a litule surpirised to thol them, on a ueas" s|rprosel, no higher than the surroutdiug ahrubs, four or five levet. Slurubs nre trimmed in this mamer at distanees of about thalf at vile from each other, and aro used as guide-pomes. on the [mirie. A similar ogrtical effect is spoticn of by travellers on the steppes of Russis.

Gane is most plesstiful, cunsiatiug of deer, goanacues, nutl cavias, cargnwarjes, pattrikges, bitstarils, ducks, Se. Amadillos were eommon, and the astrich was frerueutly seen; porcunines are saicl nlso to be fonnd. The cavias were eeen rumuing about in single file, witl a sort of balting gait.

The width of the river is Jess than a third of $\mathrm{a}$ mile; it has a mpid curtent, and a large body of water is earried by it to the ocono. 'I'se ordinary tile is shout eight fuet rike, aud the spring tioles fourteen leet. The curront is mastly downwart, although the tile is felt about ten miles above it moutl. T'the elub seta nff whore some tiree or four milea, and mny be known by the disoularation of the water, which just without the bar is comparatively fresh. 'The depth at ligh wher on the bat is two and a lialf fatlonos, and the bar is a etanging one.

No springa were otserved in the vicinity, of any trace of runtirs water, except in the river. The water lrom the raiss collects in the deprussions, and forms large pouds, covering acres of ground, but ouly is fow inctres in depth.

The time of uwr visit enrresponfed its Renson to our uidsummer months, and the menu temperature whs found to be $73^{\circ}$. The wiztess are represented an very nila]; mosw slines fall, but it disappents is a few hious. lee is seldowi seets, lhough frosts appenr to the frequent in the wister. Janury,

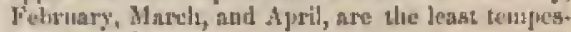

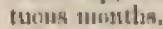

The vegetution of the uplnurks bears the marks of lung-contiumel droughts, in an alsenese of trees, Ant the roots of pituss penetrating vernitally. T'Jus Ritunted appeamnce of the sluribs, boauching from their base, theit braneliea dense, rigid, and impnesetrible, umally gruxing into spines; lle sinallucss of the leaves, and theis texture which is iry, coriaceous, and hardly deciduous; sogettrer sith the generial brown sspect of the latidseape, all denote a vegetatiun alapted to endure or escaje dretrght.

There was formerly some tnade bore with Boston and New York, in hindes, hortso, bounes, and tallow,

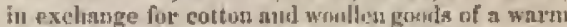
fabric, lanrdwase, erockery, hoots and shues, in fow articles of furniture, spitits, and tobacco, all of which are lartered at an enormus profit. Considerable firatititios of salt are shipped round in Duenos Ayres, Vesaels discharging ar taking in n eargo hore, pay twelvo and a haif cents per ton. Vessels stupping withont diseharging pay half duty: vessela for befreshments are pumitted to remain twenty flwe days freo of daty, after shat time they puy half uluty. This duty inelules pilotage amb ail] other cliarges; but the geverumer secms to linve the power to exact she full duty whenerer be thinks proper.

El Carmen may be termed a convict settlement; for culprits and exiles aro ant hero from Hurwow A vren. The garrison is compused of aljout two hutsdred soldiers, principally A friean and Braziling slaves brought here during the Banda Oriental war. Among thein we fiunt a person who ealled himself an American, from Thode Jsland, by name Benjamin Farden, jmior, who พas desirous of claiming our qrutcetion. Je was of small stature, uleuder moke, and a light complexion, with a nibil expreasion of countenance, nuil about luirty years of age. His story was, thai he had been by chance in Buenos Ayres at the time wlien the government was in want of troops, ant that he was seized and compelled to enlist. On inquiring, linwever, of the governor, it proved that be had lieen engaged in a riot at Buenos Ayres, in which he liad lilled two or itrre men, and committed other vutrages, for which he lamb been eondemned to death, but on the intercession of a friend, the sentence was commuted to that of exile as a soldier at this plate. Ilis further history is, tJat sot long since he forned the jilan of deserting with auother convict, by seiziug an English trafing vessed, in the absenee of the eaptrin and part of the crew, and making off with ber, which he was fully allo to acedouphish, lweing an excellest kailor. Thie night however hefore the day lixed on for the execution of this plan, he got intoxiented, discovered the whole design, atu! re. ceived the suvere punishtsemt of twelve turalred lashes, at three different times.

On the numzhing of the departure of the schooner. he efferted hils escape from the town, nud swarn off fis the schorner. He was recognised by an ollicer, who knew his leistory in prrt, mamely, that ho had becone a robber nnd a marderer, rnd liad been an nutenst from his father's luuse for fifteen yesm. 
He wag tould that he conls! that be rectived ois traxil, ant a lonat landed him again.

On the 3rd of Fubruary we got under way, and were glad to lesve an exposed and unpleasat anchorage.

On the fith and 5 th we experienced a heavy sen from the southward, with ande withl.

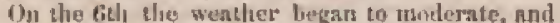
the wind to hanl to the westward, blortly afterwards we lod strong winds accors]

On the 8th we hand a sudilen foll of the barometer to 29:00 ill, but without any change in the weather except fug and inist. Ou the 1 th the wind bated to the somlly-west, when the barometer began to rise, and the weather to destr off. On the 12th slue thacrmeter again felt, and in a fow hours we hal hesvy squalls, with hail nnd min, the wether becming sensibly ealder. I'lu next morning we made Staten Land, mad sons afterwards Cape St. Diengo, Terma del Fuego, The kand was broken, ligh, and desolite. The Struits of Let Maire were befure us: we were just in time to take the tidle, and with a fair wind we Baileril rayidly thrumgh the strait, passing its whirls and eddin, now quite smenoth, but in a sloort time $t$ become vexes and frettel ly the returning tide. The squadros gliwhed along with alt its carvas spread to the breeze, senreely making a ripple under the bows. The day was a remarkably fine me for this elinate, and tho siglit beautiful, natwithatauling the desolate appearance of tho shores.

I eannot see why there should be nny objection to the [masage through the Stmits of Le Maire, ns it gives a ressel a much better chanee of making the passage round the Cape quickly, No dauger exinty here that I know of. $\Lambda$ vessel with the tide will pass thruugh in a few hours. As for the "raco and dangerans sca," I latwe fully exprevienced it it the Porpuse on the sille of Staten Lanud; and an well sutisfied that any vessel may pass eafely through it, at all times and in all weatleors, or if not biy disfoset, may wait a few hours until the sea subsides and the zido chinuges. We were only three lumra in passing through. We entered thic Stmits with studding-shils set, and left them under close-reofert toprails.

The coast of Terra del Finegis presents the samo Eeneral character thronghout, at high, hroken, ancl rogreal lank, which appears of a unifurm clevation of abont one thousaud or fifteen tundred feet, with hero aul there a jeatk or mountain covered witl suow, rising to some four or fise thotsund fuet. The whole wears a sombre and sesolate aspeet. It anay be said to be iron-bound, with many liggls and isolated rocke, thint have beeone detrehed from tho land apparently by the wear of ages. Numerous unexpecterl indontintions vecur all along the const, many of then forming harbours for gmall vessels, and some of them very safe ones.

Os Captain lïing's requort of Orunge Harbuur, I had determined to make that our place of render. vuus provious to our first nutaretic trij, and necurdingly all the vessels were ordered to proced thither. Wo lad his direetions, although wo were without the chart. I felt confident 1 might repuse full reliance in them, from his well-known ability; and I llow offer an aclanowledgment of their ralue snd genernl securucy.

The cliantule fortacel by the islands nro deep, with no anchomge except in the cuves near the rocks; but a vessel is generally safe in jonsing throngli, an there aro to dangers but those which show themselves, and wherevet melis are, kelp will he cound growing upron them. 'T'u pres through the lielp witlout previous exauination is not safe. It bordery ail the shores of the lanss and harbwurs, and effectualty points out the shonl wnter.

It was iny intentiou to pass within or to the torth of the Hermit [slands into Nлsssu Bay, but the with did not permit our doing Bo. This bay forms a large indenture in Il Terra del Fuego, a fow miles to the northward of Cape Horn; it is abont thirty miles east and wesi, by eight miles north and south, and is somewhas protected from the henry geng by the Hermit Islands. Around the bny are foumd some turr-

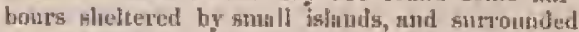
by frecipitons rocky shores, witl oecnsionully a sirall ravise forming a cove, juto which stresmus of pmre water discharge thensutves, affording a safo and convenient lunding place fur brats.

In jussing the Cape, the weatlier was delightful. We aailed within two niles of this drealed promenttory, and cutslis not but aduire its worn and wosther-benten sides, that lave so long beon insosted with all the terross that can beset sailors. Here we first encountered the long swell of the Pacitice, but there whs ecnreely a ripple on jty Eurface. Althungh the lantseape was ctavered with stow, the linwest temperature we lad yet experienced whs $40^{\circ}$ Fulirenleit.

The Purtoise, just before night, made signal that she wished to speak us, and sent on buard a tab filled with a Iarge medusa, fot examination by the naturalists. Its dimensions wero nitse feut in circunference; the brachire seven feet ing. It provel to be the nealopha meduea pelagin of Curjer.

We continned benting into the parenge between the Hernit Islants nuil Fulse Cape Horn, and found great diflienlty in pussing Point Lort, from the very strong outwarl set of the tide, which we found to run with a velocity of five miles ng hour. Wo were not able to make way agninst it, thougl the log gave that rate of sniling. After beating nbutat in this clannel $\mathrm{n}$ long snd dark nighlit, with alt hands wp, we made eail at daylight, and on the 17th of February, 1633, at half-past 6 A.s. anchinced in Orange Harbonr. Here we fuund the Relief and tenders, all well.

The Wdief had an opportunity of proving the prositians aud sailing diroetions of Captrin King, R.N., and it aifords me grent pleasure to say that all lijs observations send to sliow the accuracy of the positiong, and the enre witl whieh that officer" has compiled his sailing directions.

No sarigator frequentitig thif const or passing round Cape Hom slould bo without the aniline directions for Lust and West Patagonia, and he wiff prize them as higlsly valuable after" he has oute used them. The adiuiralle surveys nud exertions of this oflicer and those under him on this const entitle lim to the rewards of lip country, as well as the thanks of the civilized world.

The day the crew of the Reliof Imiled, no natives were scen, but many unnrks of a reocnt visit were crident ass the bonch nnit is tho deserted huts,

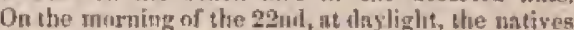
appenred on the beach, gloutiug to them so laud. 
Lieutenant-Commandant Long delayed his departure for $\Omega$ fow hours, and landed with n number of the ofticars. As the bonts aproroned the shore, the natives renewed their shouting, and adraneed towark them on their landing withont fear, exhi. biting a pleasant ais, an apparently witl every feuling of confidence: they were all unnrmed. An old man, who was the elief, enme forward to aluto them, first hy patting his own breast seweral tines, and then that of ench individual of the party, making use of the wort eu-char-lire, dwelling on tho firet syllatile, and accenting the tast, in a whining tone of voice. The menning of eu-ebar. lie it was impossille to divjnu, for it was used for every thing. After this eeremony they returned to the thicket, and bronght forth their bows and arrows. These people were admirnlble minies, and would repent all kinus of sunnds, including words, with great aceurucy: the imitation was often quite ridiculous. They were nakel, with the exeption of A gonamcos-skits, which covered then from the shoulilers to the kuces.

'The party of natives were seventeen in number, anl with if few exeeptiong Urey were nbove the European heigit. The elief, who was the oldest max anorg them, was uuler fifty years of age, and of comparatively low stature; lis son was one of the tallest, nal above six feet in ligeight. They had gond figures and pleasant-looking countenances, low fureheads, and ligh cheek-bones, will: hruad faces, the lower jart projecting; their haip was coarse, and cut ahort on the erown, laving a narvow bonter of hnir lianging down; over this they wore a kind ol ean or band of skin or woollen ysm. Tha front teeth of all of them were very much worn, more ajparent, however, in the old than in the yourg. Un one foot they wore a rualo Blín sandal,

Many of them had their faces painted in red and black stripes, with clay, soot, and ashes, Their whole appearmee, together with their inflamed and sore eyea, was filthy and disgnsting. They were thought by the ofticery more nuarly to approach to the Patigonians than any orluer matives, and were supposed to bo a sniall tribe who visit this part of Terra del Fuego in the summer months; they were entirely different from the Petcherais, whom we afterwards ssw at Orange Harbour.

None of their women or children were seen, but they were thought to be not far distant in tho woonl, as they objected to any of our poople going towarls it, and showed muel starth whes gurs. were pointed in that dircetion. 'They seomed to have a lnowledge of fire-arma, which they called EN, or Epirit; and kai-ci, which they frequently uttered will gestures, was thought to indiente their Great Spirit or God.

They had little apparent curiobity, nnd nothing seemed to astnct or cause thens surzirise; their prineipal charketeristic sevened to bo jealousy. flhougl? bley are a simple raee, lluey are mot wanting iu cuming; and it was with great difficuliy Ihat they eould be prevnited upon to part witi their bows and arrows in trade, which they how. ever dint, after waking perulissiun from thein chief: this waห ulways necesanry for them to ubtain before closinur a bargain. They have had conmmureation frequently before with lurupeans; pieces of many articles of European munufacture were soes in their possession, aucly as glasy-beals, fic. They refused tnbaceo, whimkey, biteml, or meat, nul were only flesirons of getting old irun, nails, fund pieces of honp-iren.

Their food oonsists prineipally of fisls ant sliell. fish. Their fishing apparatus is made of the dorsal fin of a fielo, tiet to a thin slip of whalebone, in the form of a barb; this serves as a good look, and with it they obtain a supply of this food. Their aring consisted nitugetlica of bows ant nrrows. The matives had the comnos dog, which they seemed to prizo muels.

Mr. Kich employed his time in hotunical researehes: the prominent plants were berberes, winterin, vaceinium, andromeda, conposituo, (sonse woody, ) eruciferve, umbellifern, se. A nutuber of these were jubl putting forti their flowering buds. Senrvy-grassed and wild celery aboundod.

On the I7th of February, an beforo stated, tho Relief was joined by the rest of the squadron.

\section{CHAPTER V.}

\section{TERRA DEL FUEGO. SOUTHERN CRUISE.}

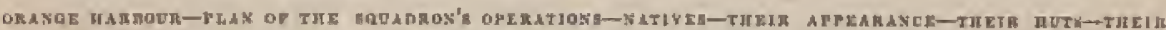

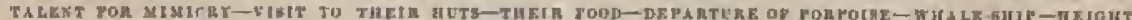

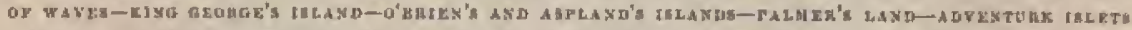

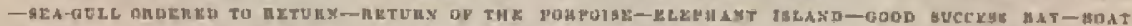

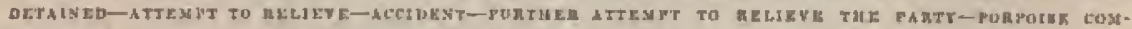

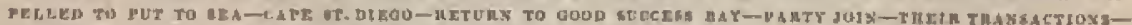

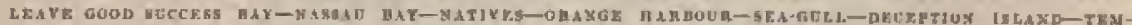

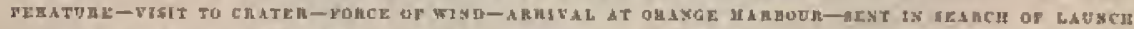

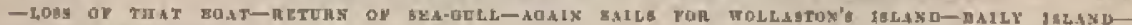

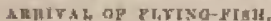

Oraver Harbouk is an the western sicle of Nassal Bay, sepusited and protected fron it by Burnt

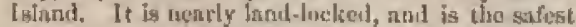
harbour on the emst. "The hills on ench side, after oeveral undulations, rise into enoical jeaks, mon tho anked rock is every where broken into s juggenl uutline, will no treeping plaris to softers or take off ita laurshuess. Every thating lans a bleak and wintry appearanee, and is in exeellent liseping with the climate; yet the scenery about it is pleas- 
ing to the eye, boumfed on all silles lyy undulating lills, whicli are covered with evergreen foliage. Distant mourtnius, some of which are cappod with sumw, sluoting up in a variety of forms, seen beyond the extensive baya, form a firo bickground. Finju the vessula, the lifils look like smonuth downs, ant if it were not for the inelonerey and fitfuluses of the weatier, they might be contellyplated with sotne plessitu.

The hills are covered with dense foreats of bextel, birch, willow, nnd winter-bark. Sumie of the former trees are forty or fifty feet brigh, lusing ull their sops bets to the nortili-east by the prevailing sontli-west winds. TJey are renuarkahly "vell us to laright, having more the look, at a distance, of heath iluan of foreat troes.

"The w/ule const has the aprearance of heigg of recht rulentic rocks, but all nur investigntions tended to prove the contrary. We no where fuund auy celtalar lava, pumite, or ubsidian, nor was there sny grauite or wther primilive ruek sters, thongls reported by Captain hing as existing. Tho roek was trachytic, or of trap formation, apparently' lanving tuntergone nore ar less action by fire.

Immediately os wur nivival nt Orange Harbour, Brtive preparations were male for a short cruise to Ihe mitaretic. Although lle season was late, I at leust nuticiguterl gotting some exprerience amoug the jes; and I supposed that the latenese of the sedsans wonld have allowed it to detneh itself from lise shores of Palmerta Lausl, and would permit hs near" an spronel, as possible to its main lody or barrier, is the vicinity of Cook's Ne Plus Ultin.

Agreenbly to my instruetions, suel disposition was tuade of the gquadron as seemed hest ealeulated to obtain the neeessary results in the different departments. Captain Hudson, with the Pencock, and the Flying.Pish, nrder Lieutenant Walker, as a tender, werte urdered to the westward, as far as the Ne Plus Ulin of Cook. I went in the Irornoise, Lieutetaut-Conmandant Rliugrold, nceorupanied by the Sea-Gull, Lieutenant Johmson, tu fras to the south, for the purposu, if rossible, of explorisg the soutli-enst kide of Palmer's Land, or, should an spportunity offer, of proceeding further" soutls. The Relief, Lientenant-Commandant Long, wist orylered into the Strats of Mingellan, thromgla the Breckuock Passage and Coekburi's Sound, with furt of the gentlumen of the scientific corps, in order to enlarge our fiedd of operations. Mr. Penle volunteered to go sontl in the Peacole.

Tho Vilwentes was safely moored in Orange Harbunr, and left under the charge of Lientenant Craven, to earry on the investigatione, survey, Se. Ste. Messis. Couthouy and Druyton, of the scientilic corps, remained in the Vineennes. Lieu. tenant Cirr was put in charge of the observatory.

In making the cluanges necessary for this cruiso to the south, I regretted extremely being compelled, from the want of juniur offusers, to snjpersede temporrutily Loth Pnssed Midslijumen Reid and Kinox in consmund of the two tenders, Tlose oflices hat not their superions in the squalron for the situstions they teeupien; but the duty I oweat she (nxpedition and eountry compelled me to do it, stnd also to refuse slieir sprilieation to be trunsferred from the tenders, for I was welt satisfied, ths long as they were on board, the resods would be woll taken care of. I had a rery lighl opinion of Mr.
Reid, from the expericuce $\mathbb{1}$ land liad of hin ; nud ns ruspeets Mr. Knox, I feel it my dinty liere to actilowledge low mueh the expodition is indebted to him fir lis services on lnard the Flying-Fish. He not only hal the alility, but the necessary jurseverance and ambition, to prertarm liss duties well. So arduous were they, lhat I was for a lime obligerl to transfer hins to my ship on aceoutit of his Jiealih. The tmoment his lrealtls persnitted it, he was again jut in comtnand of the Flying-Fisil, to the great advantage of the serviet. In accurding Hous much to his itudustry, ability, and zeal, I an well satisfied that I thut sjeak the opinjon of every officer in the squadrots.

The vessels were welt sapplied witl: fuel, provisions, sud various antikerbutios, for ten unelts. $A$ sput for the obsexvatory was fixed 11 100, and orders left for the duties to be perforned during ule alssence of the squairon.

Tyuring our atay, wo had nt varions times visits fron the antives. They were all nt first very shy, but after they fruted our friendly dispesition to. wats them, they hecame more sociable sud confiding.

Before our departure frous Orasge Hubour, a lonrk catnoe came ulosugside witl an Indian, lis squa w, and four children. The trilse to which they letonged is known by the natue of the Petcherai Incliaus, 'They were eutirely naked, with the execoption of a suall piecen of seal-skin, only sufticient to corer one shoulder, and which is gemsally worn on tho side from which the wind blows, affording them some litle shelter against its piere. ing influence.

They were not more than five feet bigh, of a light copper colour, whieh is much concented by smut and dirt, purticularly on their faces, which they mark vertienlly wilh chtureonl. I'liey lasve short frees, wurrow forcheals, and ligh checkbones, Their eyes are small and usually black, the upper eyclits in the inner corner overlapuning tho under ons, and lume a strong regemblance to those of the Chinese. Their nose is broad and that, with wide-spread rostrils, mowth large, teeth white, large, and regular. The lair is long, lauk, and black, hanging over tho fnee, aud is covered with white ashes, which gives them a hideous sppearance. The whole fnce is compressed. Their boulies sure renarkable from the great development of the chest, shouklers, and vertebral column; their artris are long, and out of proportion; their legs small and ill-made. There is in fact little difference letween the eire of the ankle and leg; and when stnncling, the skin at the knee liangs in a large loose fold. In some, the ruseles of the leg apyear almost wanting, aul possese very little gtrengtl.s. This want of development in the museles of the legs is owing to their eonstat sitting posture, both in their livts and canos. "Their skirs is sensibly colder than nurs. It is impossible to fancy any thing in huma nature nore fitllsy. They are at ill-shapen sud ugly race. They lave litsle or no idea of the rela. tive value of artieles, even of those that one would suppose were of the utmost use to them, guch as iton ard glass-ware. A glass buttle broken into pieces, jo valued as muds as a buife. Reul flannel form into striyes, ylesses theus more thas in the piese; they wound it arumbl their licats, an a kiut of turban, and it was anusing to see their satisfaction at this small requitisition. 
The children were guito stnnil, and nestlal in the bottom of the canve on sone dry grass, The woman aud eldest boy paddled the canee, the man beitsg employed to hail out the water nul attend to the fire, which is alway日 earried in the botton of the crunoc, on a few stones ased aslieg, which the water surrounds.

'Their enuous are constructed of burk, are very frail, and mened with ohreds of whalelone, senilskin, snd ewigs. They are shary ab both ends, and are kejt ju shape as well as atrengthened by a number of wtreteliers linslied to the gun wale.

T'reso Indists soldom verture uutside the kelp, by the aid of which they pull themselves along; and their paddleg are so snisl sus to be of listle use in propelling their canoes, unless it is exhm. Sume of the officers thought tluey recugnised a party on the Hentit Islands shat liad been on board ship nt Orange Harlenur. If this was the case, they must luve ventured nernss the Bay of Nasent, a dietance of scrne ten or twelve miles. This, if correst, would go to prove diat there is more intereourat among them than their frail barks would lesd we to expect.

Their huls are generally found built close to the thore, st the liead of some small bay, in a sechuled sput, and sheltered from the prevaling winds. They are built of insughs or small trees, stuek in the earth, rud brouglit together at the top, where they ne firmly bound ly burk, sedge, null twigs. Sundler branches are then interisced, forming is tolerably conplact wickcr*work, aud on this, grises, turf, and bark aro hid, making the lut quite warm, and impervious to the wind sud snow, thongli not quite so to the rain. The usunl dinuen. sions of thege lauts are seven or eight fuet in diameter, anul alout four or five foet its lieiglit. They have an uval hole to areep in nt. The fire is built in a small exensation in the midulle of the list. The floor is of elay, which has she appearance of huving theen well kneuded. The usmal accontparsinent of a hut is a conicad pile of mussel and linipet shelts opposito the door, nearly as largo as tho but itsesf.

These untives are never seen but in their huts or canoes. I'he impediments to their communieation by land are grent, growing out of the mountainous and rocky clituater of the country, intersected with irlets deep and impaceable, and in must phees bounded by abrupt precipices, together with a suil which may be termed a quagmire, on which it is dithenlt to watk. This prevails on the hills as well as in the plains nad vallogs. The inpenetrable unture of the forest, with the dense undergrowth of thorny bushes, renders it impossible for them to avercome or contend with these difficulties. They appear to five in familien, nnd not in triber, and do not seem to aeknowled ge nny ehief.

On the 11 th of March three bark eanoes arrived, containing four men, fonr women, and a girl about fixteen yenrs old, four little boys and four infants, tue of the latter about a week oild, and quite naked. 'Ihe thermometer was at $40^{\circ}$ Fahrenlieit. 'l'hey lad rude werpous, viz. silisgs to throw stones, three rude Egresis, pointed at the end with line, nand notelued on one sille with barbed teekl. Wilh this they entch their fish, which are in great quan. tities among the kelp. 'T'wo of the natives wero induced to eome on bonrd, after they had been alongside for npwards of an bour, aid reecived many presonts, fur which they gave their spears, is dog, sud aurate of their rude untive tritkets. They diil not show or express surpurise at any thing oil boaril, except when seeing one of the chrpenters engaged in boring a liole with a gerew-nuger througlı n plark, which would have been a long tusk for them. They wert yery talkative, smiling when fpoken to, and often bursting into lond laughter, but instantly setuling into lfeir uatural serious and suher east.

They were fouml to bo great minics, bntl in geature and sound, and would nepent sny worl of our lungunge, with great correctness of Jronunciation. 'Their imitations of sounds were truly astonishiug. One of then asended and descended the vetave parfectly, following the sounds of the violin correctly. It whe then found he could sound the common chords, and follow shrongh the seinitono seale, with senrely an error. They bave all tmusical voites, fipeals in the nute $G$ shorp, enuling with the semitone $A$, when asking for presents, and were contumatly siuging.

Tlueir nimicry beeane at lesgth annoying, and precluded our gretting at any of their words or ideas. It not ouly extendest tu wurls or sontus, but netions also, and was at times truly ridieulous. The usual nanner of interrogating for ranes was quik: unsuecessfil. On pointing to tho nose, fur in. stance, they did the some. Any thing they saw done they would mimic, and with in extraurdinary degree of sceuracy. On these emoes appronching the slajp, the prisicipal une of the family, or etrief, standing up in his esnoe, made a lanringte. Al though they have been hearil to shome quite loud, yot they cannot endure a noise, and when the drum beat, or a gun was fired, they invarinbly stoplpetl their ears. They alwnys speak to each other its a whisper. The tsen are excetingly joalus of thein women, aud will not alluw any one, if they eal lould it, to etaler their huts, particularly boy's.

The women were never sulfesed to eome on board. They appeared modest in the frosenee of strangers. They never move from a sitting frosture, or rather n squnt, with their hnees ehres together, raching to their chin, their feet in contact, and tunching the lower gart of the hoily. They nre extremely ugly. Jheir hands and feet were small and well-Bhaped, and from apprearance they are not nceustomed to do any lined work. They appear very fond nad seen careful of their young elildren, though on several necssions they offered them for anle for a trifle. They lave their faces stmutted all over, and it was theught, frum the hideous nypenrance of the fomnles, produced in part by their being painted and sumutted, that they had been disfygured by the men previous to coming alongride. It was rentarked tlint when ono of thens saw herself in a looking-glass, she burst into teare, as Jack thought from pure murtification.

The men nre employed in building the huts, obtaining fool, and providling for thoir other wuts. The womes were genernlly seen jadiling their valloes.

When this party of ratives left the ship and reached thes shore, the women retuained in their canoes, aud the men lyegan building their temporary huts; the little children wero seen enperiag quite naked on the beach, although the therworneter was at $40^{\circ}$. Ou the hut boing finialsed, which oecupicd 
nbout an lonut, the wosners went on mlure to take posseswioll of it. "Tliey all seened quito haply and conterited.

Before they left the ship, the gronter part of them were ilressed in old clothes, that lud heen given to them by the oflicers and men, who all showed themaelyes extremely fuxious "to make them comfortable." "This gave rise to much merrithent, as Jnck wns not disposed to allow any difficulties to interfere in the fitting. If the jackets proved too tight neross the shoulders, which they invariably were, is slit down the back ethetually remedied the defect. If a pair of trousers was found too small around the waist, she knife was agwin resorted to, mul in sume eases a fit was mode by severing the fegs. The most difticult fit, and the one which proineed the most merriment, was that of a wontan to whom an uld cont was girets. This she concluiled belunged to lier nether limbs, and no signs, lints, or shouts, eoult correct lier nistake. Her feet were thruat through the sleeves, and after hard squeez. ing she streceeded is drawing thetrin (on. Wills the skirts brought up in front, she took lier seat in the cance with great satisfaction, acuid a ronr of laugliter from all who saw her.

Towards evering, Messrs. Waldron and Drayton visited their lunts, Before they renched the shore, Ihe natives were seen making a fire on the leach, for their reception, evideutly to avoid cheir entering their lats.

On lauding, one of the men scemed anxious to talle with them. He pointed to the ship, and tried to express many things by gestures; then pointed to the sonth-cast, and thei again to the ship, after which elaxping lis hatnds, as in our mode of proyer, lis said, "Eloah, Eloah," as though he thought we lind eone from Gorl.

After a little time, they grined admitnsec to the hut. The men ereeping in first, squnted thensselves dircetly in frotst of the wumen, all bolding out the small piece of sealskin to allow the last to reach their bodies. The women were squather three deep behind the men, the oldest in front nestling the iofants.

After being in the jut, Mr. Drayton endeavonred w eall the ntwition of the man who had made sigus a hin before entering, to know whether they hind any hea of a Supreme Being. Tthe tame man then ptit his liands together, repenting as before, "Elush, Eloals." From lis namusr, it was inferred that thoy had sone iden of Goul or a Sumome Being.

Their mode of expressing friendalsip is by jumping up and down. They made Messrs. Waldron and Draytur jump with them on the beach, bofore centering the liut, took hold of their arus, facing then, und jumping two or tlirec ischey from the ground, making them keep tine to a wild music of their own.

All unr endeavours to find out how they ignited their fire proved nnavailing. It must be exeendingly difficult for them to aceomplislr, juding from the eare they take of it, alwaye carryjng if with hen in their stnoes, anil the datuger they thus run of infuring themselves by it.

"Iliseir food conkists of linupts, mussels, and other shell-fish. Qunutities of lish, and some seals, wre now and then taken among the kelp, and with berries of various kinds, and wild eclery, they do not want. They selduan cook their food much.
The thell-fial are detuched froun the sluell by lowat, nitl the fish no partly rossted in their skins, witlıout being cleaned.

When on board, one of them was indueed to sit at the dinner-tnble; after a fow lessons, he handled his kaife and fork with mueh dexterity. Ho re. fused both apirite and wibe, but was very fond of sweetened water. Salt provisions were not at nll to his liking, but rice and jlun-pudding were agretablo to his taste, and he literally erammed them into lis monath, After lais nppetite had been satiofied, he whs in grent good lumonr, singiug lis "Hey meh lek," daneing and loughing. His mimicry prevented any satisfactory infyuries being made of hin relative to a vocabulary.

Sunve of the oftivers painted the faces of these natives black, white, nind rerl: this delighted then very much, and it was ypite amusing to see the grimaces usude by thems befire a looking-glass,

One of these mativita remained cll board for up. warkls of $n$ week, and being washed and combed, he becture two ur three sladeg lighter in colour. Clothes were put on him. He wus about twentythree years of age; and was tuwell tho whule tine lie was on bosutl, fronn eating sach guantities of riee, \&e. His astonishtuent whs very great on attending divine service. T'lie monnent the elaplais begin to read from the book, his eyes were riveted upou him, where they remined fus long as lie continued to read. At the end of the week he becane dissatisfied, and was set on shore, and soon aprreared nalied signir. It was olmerved on presents being made, lhat thuse who did not receive any begmen a ont of whiuing cry, putting on the tuost duleful-louking conntenances imaginatsle.

'liey are muelt addieted to theft, if any oppor. tunity offers. "The niglit before they left the bay", they stole and cut up one of the wirul-sails, which had been serubled and liutg up on shore to dry.

Alhough we had 110 absalate proof of it, we are inclined to slie belicf that they bury their lead in caves,

There is a black-colonred moss that covers the ground in places, giving it the uppearace of having been burne. Many small pounls aro met witl, as though the pent had been dug up from the place, and the Joles filled with water. There is great plenty of scurry-grass and wild celery clubo to the beach.

At Ornige Harbour the tide was found to have fonr feet rise and fall. High water, full aul change, at 4 r.s. Ansong the Hermit lslands it seems to lye affected by the winds in the ofling. The flood sets to the east.

On the 25th of February, L389, having eompleted the artangements for tlie southern ertise, and prepared instructions for the entinuance of the dutieg of the expedition in ense of $\mathrm{my}$ being detrined among the ice, the signnl wh ordered 10 bo made for the versels to get under way, when 1 joined the Porpoise, Very junly of nuy erew were deeirous of folluwing me, and expressed regrels and disappoint. nient that the Vinoennes was not going soutl., All I could do, was tos promise them enough of antaretic cruising tho next year, and 1 believe they are now all satisfed that I kept my word. A bout 7 A.M. we left the lartour, with a light breeze from the borth, hnving the Ses-Gull, of which ressel Lieutenast Jolinson was in clarge, in com- 
puny. On passing the other vensels of the Bqualron, wo received thrce hearty cheers, whilh wero duly returised.

At the moutl of the linghour, Captnin Hudgon and the fow officers who had accountanied us, tuok their leave. I must own at that moment I felt greally depressed, for I was well tware that we had many, very unusy dangers to encounter before mecting mgain. Hut there is a feeling produced by the kind of gerviee on whicl, we were engnged, that gives a staut heart, braces it for meeting almost every emergency that may lapinen, and enuses one to luok forward with hope to overeome the diftieulties that may lie in the path. After a short uime wo saw the Pencoek and Fiyug-Fish under sail, following us.

The wind contiuned light, with fine weather, until the afternoon. Ilhe whole secnery around us was vicwed to great alvantage, truller a mild state of the atmosphere, taking away from it the usmal glnomy aspect which a sky, overcast and boisterous, gives. A dense bank of cumuli in the suuth-west foretold that we were not long to enjoy such modetrate weather. Alout 4 P.M. a heavy squall struek rta, which suen tuols us elear of the islands, on our course to the south wart.

On the acth we sliscuvered a sail, wljich proved to be the whalo-ship Aneries, frum New Zealuud, boumd to New York, and afforded as an opportunity of writing home, which we gladly availeu oursclves of. "The master" of the $A$ merien informed me that the lat experienced toustant heary winds, and las heen thirty-five duys from New Zealand; that the Alip wis very leaky, but having a full cargo of three thousatsi cight hutulrod barrels of ail, Jio was in great spirits. I have seliou seen at sea a more imeoruled atsd dincy set of mariners than his crew. Ilow they preserve any tolernbles state of health I know not; and it is not at all surprising that the ravages of seurcy shuuld he felt on board of sotue vessels belonging to the whaling fleet, if this is the usual state in which they are liept.

After delivering our lettors, we bore away to the gouth-enst, the wirat inclining to the nortli-west and blowiag heary, with a ligh and remarkably rogular sen following. This afforled me an opportunity I had long desired, fin making obsurvations to deterInime the hoight of the waves, together sith their wilth and volucity. It is olviously very diftienlt to do this with correctress. I shall therefore stato the menns which I adopted, in order that it may be perceived what relinnce is to be placed on the results,

T'le l'orpoise was directly ahend of the SeaCull, and but two waves apart; the rate of Eniling was about eight knots an hour, both vessels leisg apparently very stendy. In heaving the log, I found that the chip, in drawing in the tine, was, when ou the top of the next wave astern, distant by line three hundreal and eighty feet, equal to onesixteenth of a mile, and the seliouner being on the Mext wave, wrs twice the distance, or oude-cighth of a unile. The the vecupied fur a wave tu puss from the sebooner to the lirig was dhirteen seconds, talsing the mean of many trials, foun which none raried more tlan a second and a half. "This gavo about twenty-six and a lalf miles in an hour for their apparent progressive motion. In order to get their height, I touk the opportunity when the schouner was in the trough of the sen, ind my eye on hoard the Pospeise in the horizint, to oluserve where it eut the mnst.

"l'his gave me thirty-two feet. 'llhe waves ran bigler and nore regular un this octsision than I lave seus them at any ollur timo duriag the crusise.

Wo had many allotrosses lovering nbout, and at times resting as it were immovalle in the storun, Bome grny retrels, and Cape jigerns in rumbers. The weathor becotning thick, and the temperaturo of the water haviag fallen to $32^{\circ}, 1$ deoned it prodent wo luave-to during the darknuss.

At daylight on the lat of Marefl we hal snow in Ilurres, and the first ice-islands were uste. They excitul much curiosity, and npleared to have been a good deal worn, as tiougl the sea lad heen wash. ing over them for some time. They were of small size in comparison with thuso we sfterwarls saw, bat being ustused to the sight, wa shought blans magnificent. $A$ t noun we tuade lanul, shich proved to be Ridloy's Istand. It was high, brolien, aud rugged, with the top eovered with snow. The soctis liad o basaltic appearance, and muny were detached froms the main borly of the island, with numerous bigh pinancles, very uneh worn by the aea. The surf whs ton grent to attempt a landing for the purpose of procuring specimus. As wo closed in with the land, we lowered th boat and tried the current, which wes found setting to the north-nortlwest, two fathoms per hour.

A 6 P.м. we hal sereral ice-islands in siplst, Cape Melville benring south-by-enst (tue). Wo now had light winds from the south-soutli-west.

'The north foreland of King George's Island wa in sight, and found to bo weli placel on the ehnres. The appenrance of all this land is volearic; it is from eight liundred to onte thousand fect higlt. The upper part is covered and the valleys filled with suow of great deptit. Hefore niglit we had severul other isliuds in sight, with maty bergs ard aucl। drift-ice.

Ou the 2nd, at dnylight, we made 0 Briens and Aspland's Jalands to the enstward, with nany iceislands, some of a tabular form, and from half a mile to a mile in lengtlo. Thuough the forg and mint we got a sight of Bridgetuan's 1sland, anud stnod for it, with the intention of Jasting on it. The forg cleares off ns we appronched it, and we condd prereeive slistinctly the smulke issuing from its sides. We made it in Intitude $62^{\circ}$ o6 $\mathrm{S}$, and longitude $57^{\circ} 10^{\circ} \mathrm{W}$.

This isind is nhont gix bundred feet high, and of the slapre of a fiatened dome.

On the 3 rd we tilled away at daylight, and stood for P'almer's Laud. The birds now had rery much increntsed, Cnpe pigeons, with the gray and blick petrol, tund oecnsiunally penguins, swimuing about us in all directions, ultering their discordant sereans: they seemet astonislied at encountering so tuntamil ar oljeet as a vestel in these frozen sera. At ch 3om we rade lant, whieh J tonk to bo Mund Hope, dhe enster'u point of Pulmer's Land. I3y 8 A.ห. we hal penutrated anong the numerous iceherge, until we lound it impossible to go further. I have rarely' seon a fituer sight. 'The aca was lite. rally studted with these beautiful mases, some of pure white, others showing ail the sluades of the nghal, others emerahd green, and occnsionully here atud there sunve of a deep lilack, furzuing a otwng contrast to the puro white. Near to us, we disco. 
vored three small islets, and gave thom the nawe of the Adventuro Islets; while beyond, and alowe all, rose two high mountains, one of which was Mount Hope. I place the eastem extremity of Palmer's Lasul, or Monnt Hope, in longitude $57^{2}$ $55^{\prime}$ W, latitude 6.3 $25^{\prime}$ S.

The whule area was studded with iechergs, which it now becature neeussary to get clear of, if possible, bufore night set in.

It was a day of great excitement to all, for we luad ice of ald kinds and descriptious to encounter, from the ictherg of buge quadrangular blape, with its stmatified appearanee, to tho sunken and deceptive mass, that it was diffeult to jerecive before it was under tho bow. Our situation was critical, lut the wenther favoured us for a few hours. On elearing these dangers, we kejt of to the soutluward tund westward, amier nll enil, and at 8 P.s. we eunuted eighty large iep-islands its sight. Afterwnds it becune of thick with mist and fog as to render it necessary to lay-to till daylight, before which tine we lat a heavy snow-storm. The tetuperature of the water had fallen to $29^{\circ}$; air 28\%. At one houlred fathoms deptl wo found the former $2 !^{\circ}$. A strong gale now get in frum the sonthward and wertward. The brig's deck was corered with ice and snow, and the wenther beente excesively damp and eold. The men were suffering, not only from want of sufficiont room to aceommodate the vumbers in the reasel, but from tho iutderuney of the cluthing with which they land been supplied. Although purchasod hy tho goverument ah great expense, it was found to be entirely unworthy the service, and inferior in every way to the gamples exhibited. This was the case with all the nuticles of this description that were provided for the expedition. Not baviug been ablo to satisfy myzelf to whom the blame if to be attributed, contractors or inspectors, I lickitate to give their unterey publicity. The deception is in my opinion to be nttributed to both.

On the 5li of MLarels the yalo lind incronsed. The tender Sea-Gull being in closo company, botis vessels were in imsminent danger, At $3 \mathbf{A}, \mathbf{3}$, we narruwly escapel several teelergs, At 4 A.s. it blew a rery lienvy gale from the south-west; the temiperature of the air fell to $27^{\circ}$, amd that of the water was $2 f^{\circ}$; the ice formed rapidly on tho deck, and covered the rigging, so much as to render it lifficult to work eitlwet tho brig or schnoner; taugers laeset us in every direction, and it requiresd alt the watchfulness we were possessed of to avoid tliem.

From the state of the wenther, the lateness of the aenson, and the diffieulty of Beeing around us, tot only doring the several hours of the night, but twen in the dny-time, slse constant fogs and mist in which we had been for several houry every day envelupod, rendered onr exertions abortive, and jrecluded the possibility of doing any thing more than to attend to the sailing of the reasels. Thicse rensons deterniued me to giwo up the endearour to proceed further sonth, feeling convinced that the season for such exjilorations had gone by. therefore ordered the Sen-Gull to return to Orange Harthour, well knowing that lier situntion was muels worse than our own; directiug her to touch at Deception Island on the way, white we proceeded to the north ward to examine some of the othet islands.

When wo bore assay, I had the intention of passing forards the nssigned situation of the Aurori Isles, but I found the crew so much ell. feebled by their constant exposure, whilst some of them were affected wilh incipient seurvy, that I comeluded it was belter to return to Orange Har. bour as soon hs possible.

Wo contimned urder ensy sail, enveloped in fogg, and falling in repeatedly witl jecberges close abourl, from which at times we eseaped with ditfieulty.

On the Gth of Marcls the wind alifted to the northward, with snow.

On the 7 h, while making ald way to the northward, the fog lifter, and high land was ropurted within a short distance of us, $A$ few thonenls more, and we should lave been wreked. Tljis proved to bo Eleplinat Islnud. We funnd frotis ils position that wo had been set upwards of fifty miles to the eastward, in the last futur days, by the eurrent. We pnsmed to leeward of it. Tho sea was ton high to stempt a lating. In the aftersoon it cleared, and from our observations wo found Cape Belstiam, its eastern point, wetl placed. We passed butwern it aut Cornwallis Imlund. 'Tho Sent Roeks were also seon and observed ufrom,

Wo now stood to the nortlwarl, and on tho $16 t_{h}$ we trere off the Straits of Le Maire, where I agaits tried the deep-ses tempernture, wilh a wiro sounding-line, which parted at tlıree bundred and forty fathoms, and we lost the aptrarntus. I then made a socond experimetst, wists a line of rope four hundred fathoms in length. The ternpernturo of the surface was $44^{\circ}$, of the water below $37^{\circ}$. This was about sixty miles to the eastward of the phee whero I had sounded before, on the 15 th of ' febr. ruary, when passing around Capo Horm in the Vinemeg.

March 17th, we had light winls from the enstward, and a smooth sea, wich delightful westher. There was, however, sh benvy bank of cuntuli to the south-westward, nad after a fow hours' calm, the wind earno from that quarter, and began to blow frests, accompanied with henvy oqualls. We did not sueced that sight in renehing New Island, where it was ny interition to lave anchored and rode out the gale. Wo in congunuence found onrselves the next morning thirty miles to the enstward of our position on tho previous evenitug, hav. istg drifted at the rate of three niles an hour. Fron appearneeg I inferred that the gale laul set in for several dnys; I therefore deterinined to make for Good Success Ilay, and awnit the breaking up of the storm, being satisfied we eculd make little progress to the westward during ite cosstinuance.

We anchored in the bay early in the afternoon, when we took our bonts and wesit on sliore for n fow houry. There was but little surf when we Ltnded, Lut it rajidly jnercased, and one of tho bonts in attempting to pass through it filled, and after several ineffectual attempty, did not suceed in getting off. $\Lambda$ boat was sent to assint, lut re turnod with a report tlant no relief could be ren. derod them, and that they had determined to remain until mosnitzg.

In the morning the burf lad very musel is. creased. The sea setting in the bny ressdered our situation uneonfortable, asd somewlat daugerums, as wo were exposed to the force of it nud the wiud, which had tratled to the south-enst. 
At 1 P.x., lyeing desirms of sending protikinns to the purty ug sliore, Jientenant Hartstein was oritered to tuke elinige of two honts, to communicate with theru, and gire them supplies.

My intentina was to edfiet this ly lanving a line t]osited on slore by which ws haul the setal boat or ynwl, having jrovisions Jasl|ed in lier, tharogla the sutf by the party an shore. Instractions to this effect were given to Lientenant Hartatein, who was enjoined not to risk the lives of the nicu. We watched them attentively with mar glasses. Shortly after they Jaal anetrored their bonts untside the surf we perceived Lieutenant Hartstein nnd three mon stmping on their life-preservers, and prepuring themselves for a Innding in the buat. I fele tunder great approhensions of necident. Pheisig however, grent confidenee in that oflicer's judgment, I was thasured he would not risk the lives of the nen, and his own, on ench an ocession. It was witl groat anxiety we watched their procectings; in a few moments afterwards thoy wero separnted from the other bont, atill apjarently making preparm. thons. Jn ans instant they were burne on the crest ul" the pollew, aud immediately disnppenred. Sume few mimutes after, the boat wis seen lotton t1 anong the rollers. Prusesitly the other bont's erew wore seen pulling in haste towards a person one was picked up, then another. We louked in. teutly for the rest, but no sigus of them were seers. Wo then endeavourud to count the party un shore, and we thonght it Jad increased, but the constant linotion of the vossel bendered it impossible to keep our glissess fixed on them for a suffieient length of time to aseertairs their number. We now saw the troßt jeturning; it soon renched the vessel, aud Jieutenant Hartstein and Samuel Stretch proved to be the two that lad been saved. Bnth werc much exharsted. The persons in the boat, whilo yet at a distance from the brig, to relieve ong Inxiety, gave us the juxful intelligence that Wil. liams and Moore the renched the shore in anfety.

Lientenant Hartstein, on recovering from las axhasistion, informed me, that on arriving at the atrf and anclioring the boat, he found it inpossible tu earry intis effect the intention of getting a line ou shore. Jle then concluderl thane in the surfbuat, with ons, and a lise from the bont outside, tliey might tand il safety. Sumnel Stretch, John Willians, assd Samerel Moore, volunteered to necormpany lint. They atrapped on their life-prebitrsors, with which they were provided, and were preparing themsolwes for the trial, when a wave eurling witlout them, carried tlem forward with rapidity; in an instant the bont was thrown end over, assd they found themrelves struggling for life ia a furints surf. Had it not been for the life. jreservers, they must all lave heon drowned. The under-tow assisteri in bringing Strotel and himself out, (neither of whom conld swim, togelluer wils tore hont. Willinus nud Moore swan to the berefi.

'I'ho niglit proved dark and stormy, and the squalls were furious.

I'the morning of the 2lst dawned with mo better prosplect. All our endeavours to get a supply of previsions to the party on share by kites, de., failed, and it was now deemed atvisable for the safety of the brig, to slip our ealyes and go to sea on the malisig of the floud, which sets out of the lay. Previuts to this time, we were employed in supplying the yaw] with provisions, intendiug to len re her as a binny to nur cablo and nnedori, anil to prevent her frotn sinking, our Indin-1ubber lifespars were lashed in lser.

We dit not ngain rench finod Sucees Bay until the night of the 25 th, after fire days' absersee, when we found the party had got the prusisions, and were all well. $A t$ daylight or tho stith they catre on board. On the 27th we recusered our snchor, and on the 28th set sail for Orange Harlour.

On the exening of the arkt, laving entered Nassau liay (it lecing quite dark), as we were stanling as we supposed over for Orange Itarlsur, we lienrd the surf, and suddenly diucovered than we were cloge in and anoug the ledp; we imusediately anclored in six futhoms.

At daytiglat wo found ourselves in a sing eove of Wullaton's I I laud, and discovered that it wiss the false pack-saddle to the southward of the island which lad served to mistead us.

Wo were here visited by a canoe with six natives, two old women, two young men, smil twil clildren. The two women were paddling, nud the fire was burning in the usuad place. 'flley apfrwached the vessel, singing their rude song, is Hey meh leh," asd entinued it until they mane alongsicle. The cxpressiou of the younger ones was extretnely prepossessing, evineing nuelt intelligence and good humour. They ate binm and brend voraciously, distending their Jargo uoutlos, and binowing a strong and beautifal set of teetll. $\Lambda$ few strips of roul flatuncl thistributed among them produced grest pleasurs; they tied it froumd their hends as a gort of turban. Finwing they were fond of music, 1 Jaud the fife played, the only irsimment we enulil muster.

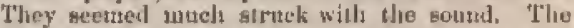
tune of "Yankeo Doolle" they did not understand; but when "Honnets of Blte" was pluyed, tlsey were all in motion keeping time in $\mathrm{jt}$. The vessel at this time was under wny, and no presesuts could persuade them to contintre any lunger with us. T'lere was some dispusition in the younger unes, bat the auluits refused to be taken where the fickles ness of their elinute might subject them to be blowu uff. We funnd them also extremely imitative, repenting over our words aul mimicking our notiuns, "lhoy" were ul] nutite maked.

I thve selchu seen so lappy a group. They were extremely lively and cherr.ul, and any thirg Lut minernte, if wo condd lave avoided contrastiog their contition sitlt our own.

The enlour of the young men was a pale, and of the old is dark cimper eulour. Their lseads were coverid with ashes, but their exterior left a glensing iumpression. Contentment was pictured in their cumstunnes ma nelions, and produced a moral effect that will long be remembered.

On the 30 th we renctued Orange Harbour. Whilo yet of the purt, we male signnl for the bosts, and were bon joined hy lliem, and leatned with much pleasure thut they were all well. The Sen-fiull juad retusmed safely. Lientenant Craven having elltertainet sotne fears of the safety of the launch, Which lad been absent on a surveying exeur. sion, had desjatehed that ressel in pursuit of her.

The Sin-Cull returned to Orango Harbour from the southerm cruise on the 22nd of Mareli, haviug, after parting company, visited, as directed, Deception Island. 
The plan of Petudulum Cave lyy lieutemat FontJaj, of the Clurstiedere, with wibls I furzished

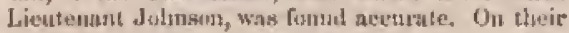
landing, the bare ground thut was seen was a lusse lilack enth. The heits of the ravines atul the leaches were of $n$ black sud reddish gravel, much rusunhling jumice-stuse in appenmec. Punguins were seen in contutles numbers, or, th lo expresses it, "covering sume husdreds of acres on the hill-kidu." It wras thes the mutting senson, and they were soen lusily oecupied in picking of cach whlicr's feathers. It was an atrusing sight to sec them assuesated in pairs, thus employed, nat the esugerness with which the Railons altucked thenr with the oan and bont-looks. They were not inclined to submit quietly to this intwusinn, and is aome instnuees readily gave battle. Their manner in ilning it was to goize the aggressor with their Lill, and beat him witls their tlippers. THwir bearing was quite couragenus, aud their retrent dignilied, as for as their risfieulous waddle world permit. They were shuwy-louking birds, with yellow topknots, and are knowa as tio aptenodytes clary'scome.

As an acemuryinent to these penguins, a small white pigeon (chironis or shealli-bili) was fonnd here, qquite tame, These wero ensily taken in numbers. They are anot wcll. fuoted, liave red legs and bills, will perfectly white though not fire plumage. They seetr to live entirely on the dung of the peuguin, and their flesth is black, coarse, nud unpilatable. Suiling up the bay, they deseried a sen-fenpard (the plioca leujardiua jam), which Lieutenant Julnsou sueceded in takitig; but by

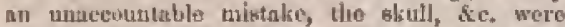
throwa overbuad. I ts dinensions were also omitted to be taken.

Finowing that Captahin Foster, in the Chanticleer, had left liese n self-registering thermonteter in 183, 1 directed Lieutenant Julumson to lowk for it, ast noto its stnudirg, Inmediately on securing Ho tender lie proceeded to senrch for it, but notwithatanding the particulnr directions, he did stut fiud it. Since my reluru home, I have received a lettor from William H. Smiley, mnster of n senliug vesgel that tuuelsed there iu Februmry, 1842, stating that lie had found the thermoneter, and enrefully moted its minituum temperature, which was $5^{\circ}$ Lrelow zero.

Lieutenant Johnson, is company with Assistant. Surgeon Whitule, visiled an wld ernter, at the hend of the bay, where a gentle aseent of about four lusulred feet brouglat them to the edgo of an mbrupt bank, some iwenty feet high, surrotinling the crater an the bay side. "I'he enter was alyout fifteen tundresl foet in diameter, from asst to weyt, bronded on the west at further side ly lofy hills, with mouy ravines, which luad apparenty been much washed by leavy raing, "This led to the belief that the water found within the crater would be fresh, but its taste, nud the incrustation of eaft found on its horders, showed that it was not so. Nenr the east end of the erater, the water boils in mnny places, sumetimes bubthing mut of the side of a bank, at others near the water's edge, with a hissing noise. The surfice water was fuund to be on a level with the waters of the bry, nad to be nilk-warm. A fow inches below, it whs pereeptibly cohder. No thermometric ofservations were ob. taised. The grund near the lkiling Springs war

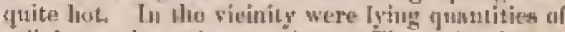
celtrilur and scoriaceous Inva. The only sign of vegetation was a liclien, growing in whill iufts, a round the sumuth of severil swall ermters, of there ou four foet in diancter. Frmm these a leated vapour is eoustauly issuigg, neeunpanied ly mueh nnise, Before they retujuct to the tender, they were overtsken ly a virlent snow-storm from the north-enst, snl witl diffieulty pesched s/10 euve witlout the boat, haviag becra conprellod to leave it at the opposite side of the bny, fir the force of lye wind was such as to render all their efforts to pull against it usolese, This wealluer continuel with much stun for tliree days, when it censet snowing, but still blew heary. "It was the intuntion of Lieuterant Johrsan to enrry arer the yawl, for the purpose of soumling in the erster, to nseer. tain its depth, and get its temperatnre, which is is to bo regretted whs not dolie. On the ITlla of Mareh they sailed from Deception 1sland, Laying left a bottle enclesing reports, tied to a Ang-rtafit. This was afterwards fousd by Coptain Smiley, whu mentiorse in his letter to me, that in Febrasary, 1842 , the whole south side of Decejtivis Jisiol apyreared as if on fire. He counted thirteen val. calres in action. He is of optuinon that the islant is undergoing many elaanges. He likewise repurts that 1"almer's Land eonsists of a number of ishande, between which lie has entered, and that the passagres are deep', narrow, and datsgervus.

The Sea-fiull, sfter a stormy paseage, reached Orange IIarbour on the 22tid, with all liands much exhnusted. She was despatelied by Lieuterant Crrven the next dlay, as before stated, in searcls of the launch, (whichs lind bers absent claven days, ) ont the route slio laat been ratered to pursue.

In paseing over frou Herroit Islawe to that of Evotit's, during a brisk gale and heavy sea, the lannch, in towing, filled, broko tedrift, and was Lost, The men liad all been proviously ordered wit of her, and moat of the articles removed. T"tie Sen-full agnin renched Orange Ilarbour on the bith.

On her arrival, finding the lanuch thad not completel the duties priated mut, I ngain despatclied the Sen-Gull tender to finish them, purticularly to examine and survey in tharbour on the east side of Wollaston'y Island. Slie aceordingly sniled the next day, and suceeded in performing the ree iquired duty, having furveyed a rery safe snd couveuient hnrtour oun the enst side, ind aseertnined that the so-called Wollatem leland forned two isfands. Lanving to the custornmost the name of Wollaston, I have given to the western the name of Baily, after Francig Baily, Etocy, the well-kuostn vice-president of the Koyal Society, as a small usemento of the obligntion tho expredition and myself ste under to him, for the great interest he touk in the equipments, and the kimdnese shown me while in Londor when procuring the justru. ments. Tha harbour that lies between these two iglands was naned after the Sen-Gull. A chint of it will be found in the Hythographieal Athos.

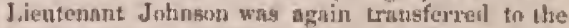
Vineennes. On the 12 th, the Fying-Fith arrived, bringing rews of the Feacock and their grpetations, which will the dotniled in the following eliajter. 


\section{CHAPTER VI.}

\section{SOUTIIERN CRUISF. VALPARAISO.}

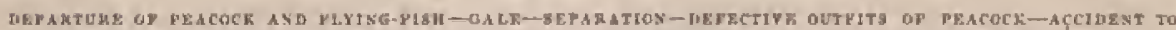
WLL\&IAN

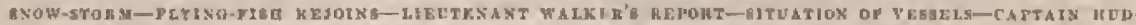

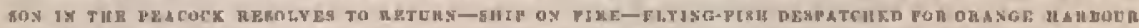

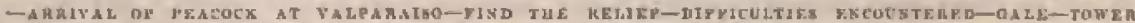

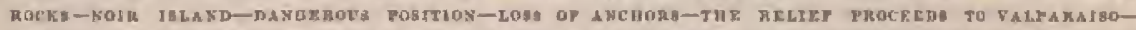

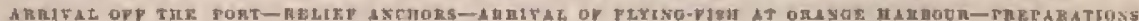

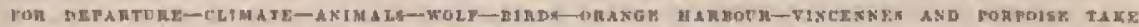

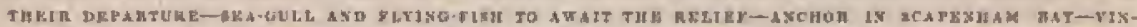

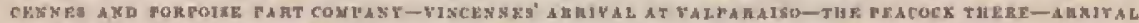

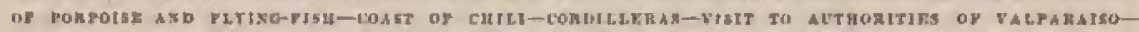

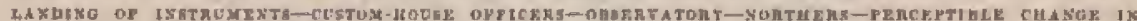

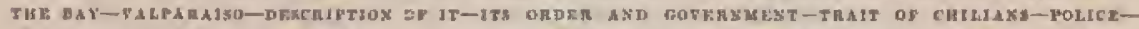

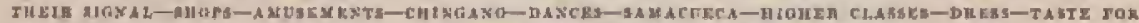

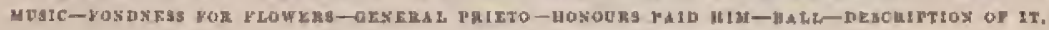

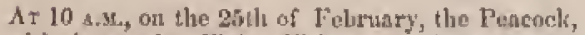
with the temier Flyiug-lish, got under way, nusl slao received parting eheers from the Vincennes atwi lelief as threy pussegl out of the lastrour. The wind, as with the Psirpoise, was light and yarinle until the afternoon, when they likes ise eneountered the heary squall from the south-west, wluich with the thick wenther intuced Captain Ifudaon to ro gain the euter anchorrge of Orange Harbour, and reiratis there during the continuance of the gale. The next morning, the wenther proving more farourable, they agnin got unter why, and stood lown the bny, widinld sail set, and a fine breege froin the nortliwarat.

Tho louvy bank of cumuli that had been perceived in the west, by noon lategn to develop itsolf, and by three o'clock they were under their Etorul-sails, The barometer, which was nt $29 \cdot 21$ ill., thegan to rise as it cume on. This gale lasted twenty-font houts, and during its contiutsace the tenles Plying-Fish was lust sight of. Captain Hudson in lis instractions to Lieutanat Walker, notified him that the Peneods sould wait twelve lours in or near the siluation where list seen; which he now did; lut mo tidings heing received of the tenter, he bore awny for their fitst rendezrous, lasing taken the precsution to fix four places of moeting.

During the last gale, from her bad and defective outfits, in resscl could be more uneomfortalile than the Puacock, and although every precaution was takon to nuke tho ports tight, yet from their worling, it was found improssible to keep them so.

Oil the 7th they again had squalle of sıow ark raill, with strong galea. On tho $9 \mathrm{th}_{\mathrm{r}}$, although the weather land nodernted, yet thu sea war very heary, and tho ship tossed and tumbled nbout in every direction. Wiltinm Stewart, captain of the mairi-trr, was this day knoclsed off the yard, and in his fall struck the nuin riggitsg, but he cantul and fell oxerbonrul, when lue was seen to lie quite jneensilile, feot up, supported by lis exploring tonts, which were supposed to have ocensioned his fall. $A$ bowline was thrown over them, and he was dex. terously drawn on board ngain. The shipy lad but little headway, תnd it wotslit laxe been impossillo to lower in brat on account of the roughness of the

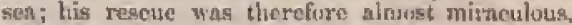
Every eare was taken if lim, but it wats govn fotusd that the vislesce of the coucusaion luad heen so greist that his lungs bad becume gorged with blood, and litte lophes were entertnisced of his recovery. After liugeriug to tho Il th, he diech. He was great $l_{y}$ regretted by botl ofticors and meth, for lie that froved himself an exedlent man, and was well endculated for the service. On the same day his body was committed to the deep, with the usunl ceremonict.

rytis day they made the first iceberg. 'The otily indication in the air or water an ajprenaching it, was a fall of two degrees in the temp-rature of the former, and ono degree is the Intter. "l'heis pmeition was in Intitude $64^{\circ} \mathrm{S}$, and Jongitude $80^{2}$ WV.

OII the 14th, Captain Hudson reinturked a grent and striking clinange in the weather since they prassed the $62^{\circ}$ of soutl Intitude, it haring become uuch more settled, and free from tho sudden soguails and constant gales they had experieneed sinee leat. ing Cape Horn, Several birds were sliot this dny, including an albatrosa and many yenguint. Potrcla and Cape pigeons were seen. "They now began to fall in with icelergo in rumbers. The tetriperature of the water and air lad fallen to $33^{\circ}$ and 32.

They encountered, during the $17 \mathrm{th}$, and part of the 18th, the loesviest grie and sen they liad experienced sinet leaving the United States. The sluip was coupletely conted with ice, even to the gumdeck. Lyery friray thrown over ber froze, and liw bows and deck were fairly packed with it. "T'lue crew suffired mucl from the gun-deck heing constiutly wet; and it being now corered with iee, the shig was damp throughout.

On tho 1Buts, tho gale continued, wilh a heavy sea, the winds prevailing more from the south and south)south-east. There were mary birls about the shif; anong them a obeath.bill, which Mr. Pealo made cvery exertion to take, but withoul sucess. $\Lambda$ blno jetrel was, hawever, enught. Severtal ieubergs 
were in sight, and at tight shy' lisd a beautifts disthlay of the aurum australik, exteruling from soutl-

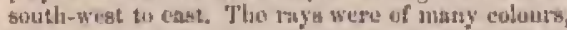
molatisg towards the sunizh, and renching an attitude of $\$ 30^{\circ}$. Several brilliant metours were also ubserved.

Hot woftee wis now gerreyl to the crew at miduight, ut at relicving of the watel, which groved excevelisgly avesptahle. The temperatne of the air lond fallen to $2 x^{\circ}$, surs of the water to $24^{\circ}$.

On the 7!th they had anther displny of the nurom, sud it exhibited a pesuliar effect. In the Butheres quarter there was an nppartance of a desose eloud, resembling a shadow cast upon the sky, nut formigg an areh, abont $10^{\circ}$ in alritude. Abure this were seca cordascations of liglat. rendering all ohjects around the ship visible. From thelifid this clond, lliverging rays frequently slost up to an altitude of from $25^{\circ}$ to $49^{\circ}$. These appear. ances contintsed until day dawned. The night was remarkably fine, and many shooting stars were obsarved. T'le batrumeter stood at 2977 ill. During the afteruoon of this day, a fog-bank was perevived ill the south-westert yuarter, and they were a short timo afterwards completely eneelnped in a fog so denee and thick, that they could twot sece twiee the length of the slip. Furtunstely, before it elosed in, they wero enabled to get good benrings of the different iceberigs in sighte, and particularly of those which elosely surrounded then.

On the 20th, they had moderate wentier, with foge. They liad now rencted the lougitude of $g^{2}$ W., latitude $6 B^{2} S_{\text {. }}$, and ubtuined a siglit of the icy barrier. The fog beenuing dense, they were ribliged to hesvo the slip to; the sea heing simuoth, they took the opportunity to scund with the deepsert line, with the apparatus for temperuture. The line beisg of copper wise, lhey suecteded in getting out eiglit hundred fnthutns of it; but when they bryath (1) reel it up, it parted, and the whole wns fust. The noise of the ses beating on the icubergot was frujuently heard close alourd, and several loud sound resembling thunder, which they imputed to the breaking issuder aud turning oper of largo ischerga

During the whole of the 21 at they conld not renture to run, in consequence of the denso fog, which Insted all day, witl the exception of ahout an lour. Mr. Peale liaring shot ane of the pervels, of the same lind as sect tho day belore, a bont was lowered to piok it up, of which advantage was taken lis try the current. It was found settiag oncthird of a mile per hour to the Lorth-west-lywest.

On the 23rd it partly cleared, and the fog having becols suceeeded by a snow+sturu, the wind hauked to the west, with a lieary batk of clouds in that fuarter. "I'be barometer showed no indiention of a galo; the wenther turuel out tlick, and prevented them from seceing uny distance. 'flicy had somo severe sgualls, accormpaned with stow. On the 21th the wind himbling to the northward and westward, trought sumw and thick wenther, with some leasy squalls. Many icehergs were net withy which were fortunately aroided. A Elarp lookont was kept for them, and the ship put in realiness to fortorm niny manosuve tlan juiglit be tesirable, sone of the icebergs were two humilest foet ntonse the surface of the water, and of a fintuclo shape. The sasow continued to fall fust, rendering the ship uncunforsthy wet.

On the 25th, the fog eostinued antil nuas meridian. Misny bircls were seen aburt the shign, ank? пraly fir-bnek whales. They obtainen a merstlin observation, the first for the Jast six ilay, and found theirselres in the Intitude of $68^{\circ} \mathrm{S}$, lungitude $a 7^{\circ} 68^{\circ} W$. Here, in the evenimg, to their grent joy, they fell in with the tender Flyiug- Fisil. On luer penr approneh, all handa wero turaed op, and gave her three laearty cheers lieutenas Walker came ost lraarl, nud reported tu Coptain Hulkon that he bad yisited all the appointed yendezrous in liopes of fulling in with the Peneock, but withnts suecesa, Javing enevustered rery sorero and boisterous weather. Dn thu loble thes left the fourth rendezvous, fraving paesed tlie 17 il in its vicinity. They then sursed lownres the gouth for Cook's No Plus Ultra, sul cmitinued their way to the southward. The wesulher was at times rery thick, the ico-islande became mimerous, and they occosionally pased a littlo Hoatimg ite. On the ifth the ice inecane atumiant, and thanted in larye masses around them. $\Lambda$ t 4 A.M. the watur was much discoloured, nat some of the ice also, having the aprearance of being but lutely dutnched from the land. Thoy obtnined a cast of the lead, but found no bottonn at one hundred fathotis $A t$ eight o'cluct the fong lifted, and discovered, to the nmazement of all, a wall of ice from fifleen to twenty feet lijirl, extending ethot and west as far as the cye could Fench, and spreading out into a rast and speniugly troumbless field to the sothtly. Their Iatitude at this timo was afrout $67^{\circ}$ s0' S., longitude $105^{\circ} \mathrm{W}$. Tho weather hecoming thick, they stoud to the north ward, and sorm wu into blue water.

On the $21 \mathrm{st}$, at $7 \mathrm{~s}, \mathrm{~m}$, they kaw the iee extunt. ing in broken ranges from soutl-luy-east to northenst, nud the sen extending rousd to the wegtwird. At cight o'vock the wrter was again much diseoloured, and masy large iechergs were around.

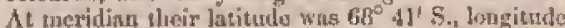
$I\left(63^{\circ} 34^{\prime} \mathrm{W}\right.$, when they again strorl to the southward, Junsiog amony the iec-islands with a fair wind, Antlering thenaselyes that they should lefore woon of the next day get further struth thin Couk hat. In this, however, they woro disappointed; for the weather beenme thick, and they wero in conseguence obliged to heave-to.

On the morning of the $23 r d$ of March, their intitnde was $70^{\circ} \mathrm{S}$, Jongitude $100^{\circ} 10^{\prime} \mathrm{W}$. The weawher froved elear. In the ufternoen they ugnin atoud to the sonthwant and eastwayl for throe humr, when they observed the appearmete of luml, and discosered lange masses of iee nut uumerous iccherrs. At midnight the susthern hurizon was beautifully illtuninated with the aurura australie.

(on the 24 th they lad a heary fall of snow; pased may iscuberys, and large quantities of floating ice; got suddenly juto large tidelds of packed and bruleen ice, extending as far as the eye could ruach, in all directions, which, with alos se. curnulation of snow, anpeared to be rapidly becoissing ealid. 'Thry lost no time is forcing their way cuit. Al] on bianed were of opinion, that withiu is short timu aflet they eleared it, it becane a firm field of ice. 'T'hut tritudu ubserved was $69^{\circ} 0 f^{\prime} \mathrm{S}$., Jungisule $\$ \ell^{\circ} 50^{\circ} \mathrm{W}$.

Haviag ims two occnsions narrowly eseaped being closed in by the iev, Lientenuat Wather lasd de- 
termined to retrrol, and was making lis way to the tortls when he fell in will the Pencuek.

The uights haviug lweene loug, witl the interruptions oceasioned by fogs asd snow-storsis, afforled but litule time for running bhe ressels among the iccbergs, whose numbers ratered the navigation extremely hazardous. Tho coudition of the P'eneock for n winter's campaigu was mike. mite, and on board the Flying-Fish there was protection in the event of leving frozen in. The positivo nature of his instructions, comblined with the report of Lieutenant Walker, convineet Cap. tain Hurlanol of the necessity of turning the Fessels" heads towards n nore temperate climate. On holding a council with lis offeers, he found them atl of the opinton that the setson for active operstions in theso latitudes lasd passed, und that it was. mirisable for the resaela to proceed without delay to the nortly.

The vessels necordingly steered to the north. warl.

Tlye weather, during the cruise Bonth, was exceerlingly unfarourable; for, with few exceptions, during their atay in the antaretic eircle, they were enveloped in dense fogs, or fonnd only oceartonnl relief from then in fulls of suow. The erew during the whole time enjoyed an unusual slegres of health, which is not at little surprising; far sinee leaving Orange Harbonr, the state of the ship had been such as to promote disense. The preenutions and endenvours to keep the men Iry entirely fniled, from the condition of the ship, heretofore refierred to.

The weather proved thick on the $28 \mathrm{th}$ and $22 \mathrm{~h} \mathrm{~h}$, and they had little opportumity of making progross to the north, ngainst the north-west winds, which were light. On this night a new danger beet them, that of heing consumed by fite I At uid night, on the agh of Marel, they were aroused by the smell of burning nut smuke, issting from the main lotu. 'The ustul orders were given relative ts the magazine. The drum beat to quarters. On openiug the main hatel, smoke issued out in volumes, and fire was diseovered muler it, pro. ceeding from a bag in full blaze. This was suon passed on deck, and the fire extingtished. It was forttuntely discovered in time, and was found to groceerd from a quantity of enffec, which had been puc below in the bag, after it liad been bumit oc roasted, tho previons afterbon.

On the Ist of $A$ [ril, in latitude $60^{\circ} 12^{\prime} \mathrm{S}$, longitude $84^{\circ} 20^{\circ} \mathrm{W} .$, Captain Hudan despatched the tender to Orange Harbour, with lis reports to ne, and contisued his route to Valparaiso. On the evening of the 19th they made the land of Chili; and on the 2 lst the Peacock arrived in Yalpartias, where to their surprise they foumd our stule-ship the Reltef, which bad arrived at Valparaiso some days previous. "lhe lost iecbergs seen weru in Intitude $62^{\circ} 30^{\circ} \mathrm{S}$. longitude $87^{\circ} 41^{\prime} \mathrm{W}$; the temperature of air $33^{\circ}$; nif water $35^{\circ}$.

The Relief left Orange Harbumr on the 26hts of Febunry, for the prirpose of visiting varions plines in the Straits of Mngeilan, to nffori an opportunity of making inveatigations, and opening a barger thald for our waturalists during the fifty or sixty days they were to be detained on the enast. Mint of the scientific gestlemeu wert accordingly trumsfertod to her; and she was orlered w enter the Brecknock Passage, and thence into Cocliburn
Sunthl, of which we had ling's raluable clart; and I thonght that the passnge into the strnit was more fessible, sud suight to sooner necomplislyed by that route than ty taking the eastern prosage, particularly as the wind was favourable. I ulas thought it would enable them to explore nure parts of the straits, and thase which had been least visiterl.

Varions difficulies prevented hev reaching the entranco to the Brecknnek Pasuge, rincipally that of keeping too far off the const on long tachs is the soutliward.

On the 17th of March, after being at sen twonty days, they approached the comst, and a gale cnsuing from the gonth-west, Lientenant-Conmundant Long, on the fullowing day, deternined to run is and anchot under Noir Island, which is spoken al by Jỉng as an excellent harbutur. The wind was hjowing a galo from the suth-west, with thick weather ant lail-squalls, Noir Island was discom vered under the lec, judged to be about twelve milas distnut, when they atererd for it. It hecoms. ing thiek, they did twe diacover the Tower Rucks until they wore almoat up with, anol just liad time to clear ihem. These roekg uresentud a suagrificent aud feraful kight, the sea brenking completely over them. I'tree anchors wero prepaued. They rounted the sonth-estst point of the island, nusl ftomd in for the bay. At aboust five o'elock slaty aushorsd in seventeen fathoms, fund the anchor tork effect.

On the moming of the $19 t h$, the lighest joint of Noir Island was seen, cenpped with snow; the wind had alated somewhat, hut not enough to permut of their landing in $n$ song little cove alictsat of thern. In the nfternoen the wind sgain iscrensed, and another anchur was let go. There wns utuch sen, and tho stip rude very unensy at her andhor. "The sea broks tremendinsty on the reef asteri, slinoting up in columas, bueh as are reen to sppear under the ceffect of mirnge. After it beene tark, the wind shifted to the southward and enstward, which brumglit the gea from that quarter, and exposed them more botls to it and the wind. The anchoss shortly after began to drag, and the vestel was urged in the direction of a roek. Fortunately the wind abated towards morning. sul canse from its old qunrter, Bonth-west, more of the land, but still blew with violence.

On the tmotning of the goth, one of their clinin cables was found to hnre purted. The cliais wns hove in witls somo difficulty, and another anchor let go. The weather towards exuning becnno agnin threntening, and produced no little anxicty. At nightinll it slifted in the same way it had dono the grevious ovening, Wlowing again leavily: I'ho Blip was feil to to constanily dmgring accunparied by that grating hind of noise of the clanis moving on the button, which is any thing but ngroeabie. 'The roek asterr, togethes" with the reet toward whish the wind and sea were both setting the ship, rendered their situation truly appalling. The prospeet of alty one surviving, ii cuse thoy lad struck, was extremely sliglit, The thiglit was clark and storuty, and the ilmgging cou-

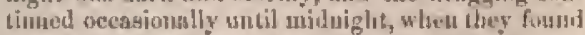
tlsey had possed turel esenped the roek, and wore near the reef. They nuw shippent a henvy sea over the bown, the shock of which was so great that it purted their cables, and theip drifting be- 
came rapicl. From the set of the current, they juat cleared the reef. When the point of the island bure cast of Bouth, they slipyed theju cables, wore round, and unde gail ; bud on the $21 \mathrm{mt}$, at daybreak, they fuund thensselves ofl Cape filoneesier.

Thy conduet of Lieutenast Commandant Long, bis officers and men, during the perilous sitnation in which the lielief was placed, deserves great praise; they did their duty in every respect. On getting to sea, Lieutenunt-Commandant Long, with is conneil of officors, opened his sosfed isstructions, which direeted him to jroceed to Valparaiso, in the eveut of not findiug mo on his return to Orange Harhour; mud concluded to mako for Valparaiso, off whicl prort he arrived on the 13tl of A pril, without anchors. It was hero that Commandant Luelie, of her Britanuic Majesty's ship Fly, in the most prompt and tunndsome mannet; degpatched a lrost with an anchor to tho assistanee of lbe Relief; nuil it affords me great pleasore to acknowledge the obligation we feel for this oppertune service. "The next day the Relief anchored in the bay of Valparaiso.

But to return to Orange Harlsour.

The Flying-Fish arrived ou the IIth April. The duties of the observatory lavisrg been cunpleted, the instrunents were embarked, and every thing inade ready for our departure. Duriug the Vinceunes" stay here of sixty days, we found the weather execedingly elungenble, Tlie wituds prorailed forty-seven days from the westward, twelve days from the nottl and eastward, and one from the south-enst. The mean tempernture was $4436^{\circ}$; maxituum $56^{3}$, mininums $32^{\circ}$. During this time there were eleven galer of wind, of from two th tiree day' $\mathrm{s}^{\prime}$ du1tatiun.

There were but few days on which mis diu not fall during some portion of the twenty-four lionss, but selelom hervily; lightning and thunder oceurred once during the time. The clitnite may be ealled extremely boistercous, although from the fact of the natives being wilhut any kind of covering, one would suppose it cannot be very variable as to temperature, throughout the yenr. The wall of clothing is not, lowever, peculiar to all the matives; those seeu at Good Success Bay were woll covered with gunnacoe skins, and are a fuer-looking and taller race of men.

Observatime of any kind are diltieuit to be had at Orange Harbuur, eitlice by day or night.

While Lientenant Carr and his party were at tho observatory, a wolf was seen, at which Midshjpman Clask fired, tout supposed he was not sloct. The next morning he was foumd dead at a short distanee from the place. Mr. Drayton made a consect drawing of him, and a number of mensurements were talien. The Inir was Jong over the whole body, and tlast about the neck and shoulders stood erect. It was a male, weighed fifteen jounds and three-quarterk, and mensured, from nose to tip of tail, three feet gix and three-fourths inclses, and stood sixteen inches and a half high; colour of back, top of lyead, and tril, gray, the latter with a tuft of black at its end; sides of lsead and outside of legs reddish browu; white between the lege and ou the belly. Dr. Fox some days nfterwards stot a fernale near the sanie place; she laul attavied one of the men, and sijued his pea-jacket.

The woif is the ouly land aniual that is a natise of the soil, and is supposed the stume as that deseribed by Captnirs king. 'Tho tutives hase many dogss.

Or land birds, we found the upland gonse, a most benulful eagle, a fow plower, and some small birits. 'llitre are great quntities of wild fiwl, geese, ducks, and the nsual sen-birds, to be seen at alt times in the harbour, where they find abundanec of ford among the kelp.

A number of burnt human bones were dng up in a eave; lust whether tho natives burn clucir dead or not, we lind no opportunity of ascertaining.

Orange Harbour is an excelleut place to oblains wood aud water. The lutter is easily procured, and of good quality. Winter.bark may be obtitined her'e in large quatilites; scursy-grass and wild celery are also plentiful around the sliores; and fish nre iis abundanee.

As a resurt for vessels in distreas or aftected witl seurry, \&c. \&e., tlyis port inny be recommended; and it is the only one on this cosst that offers a kafo and convenient habour to suply Uleit. wauts.

On the 17 th $\Lambda$ pril, the time having expired for tho return of the lulief, I conclused to lesve (bauge Harbour wish the Vincennes and Porpoise. Believing the IRelief had been detained, the Fiying. lish and Sea-Gull tenders were both left to rwait her arrival for ton days, to take the scientific genthemen on lonzt, and join us at Valparaiso, in order to preveut deterition by the slow sailing of that shij\}.

We got uniler way, but tlie wiud drnwiug ahond, with appearances of bad weather, wo nuedored in Seapeulım Bay. The weather beeoun. ing storuy, and thinking the place in which we were nuchored too much exprosed, we agnin got under way, ran back, and anchored in Orwnge I3ay.

Before lesving these desolate and stormy degions, it may be expected that I should say a fow woris relative to the passage round the Cape. There are so many opinious relntive to the luest unamer of procecdijg in this mavigation, that one in consulting them derives but litule satizfaction, an twn authorities agreeing in their views upou the subject. I an inelined to lielieve that no much depends upon the vessel, and the monnot in which slie is navigated, as the route pursued, whether the Cape is passed clase to, or given a good berth: the object of all is to pass it as quickly us possible, and taking into considerntion the difficulties to be incurred frum boisterous weather, lienvy seas, and lee, it is injossible to lay down any precise rule: that courge which aptrears must feasible at the time ought to be adopted; kepping, huwever, in vicw, that there is no danger to be apprelsended in uavigating on the western const of Term del Fuego, ns the eurrent sets along its coast, and it is perfectly safe and practicable in narigate it as far as Capo Pillar. The great difficulty exists in prasing the piteh of the Cape; there is none afterwards in gettiug to the westward. On the coast, the wim seldon bluws long from the same quarter, but veers from south-west to norih-west: the gnles generally begin at the forner quarter sad end at the latier. Previous to tho sombl-west gales, it would, therefure, in all cases, he advisable, when itujications of their oceurruce are visible, (which 
are known by the bituks of eumuli in that quarter, some twenty-four hours previously) to staml to the southward and wegtward in preference, with as much sail as well can be enrriel, that when the change occurs, yon may be realy to stand on the other tack to the northward. One thing every mavigator ought to bear in mind, that it requites all the activity and perseveranee he may be possessed of to aceomplish it quickly.

On tho 20th we trok our finnl lenve of these watery, and on the 21 st lost sight of land, passing to the morthward of the ishand of Diego Ranseres,

On the 2:3r?, during a struig gale, we parted company witls the Porpoise.

Inmeilintely after learing Orange Harbour, dysutstery made its appentunce on bonril the Viscernes, and ran through the whola ship"s company. Some of the oflicers were also affected. It proved of a very saild type, and readily yielded to mestical treatment. Upon our arrival at Valparaiso, if had ontirely disapreared. The medienl officers were unable to necount for it, the healih of the ship's company laving been very gnod duriug our stay at Orange Harbour. It was nut thought to be owing to the water, as they laud been waing it for two months without any bad eflect, bus I think must be imprated to the cold and wet we experiented in the filst part of the phasnge.

On the L5ta we made the land of Valparajo, aud before joon aucliured in the bay, where we found the Peacoek, ant receired tidiugs that the Relief had sailed with the store-ship Mariposa for Callao. The Porpoime arrived on the loth, and the Flying-Fish reached Valpuraiso on the 19 th, after having experielled extronely boisterots wentlier.

Uts appronehing the const of Chili, overy one is auxious to get a sighn of elie Corditleras. Thero are only two prodody duritig the day in which thy can be seen to advantage, viz. in the morsing beforo sumrise, and in the evening at sunset. The tirst is the most ntriking riew. The outline is at that time of a golden line, and may be ensily traced, in a long line, ruming borth not woutli. I'his gradually brighterts, and is lost the monent the sum is seent.

The evening view gives rise to disappointment. The mout ains are seen at a great distance feighty suiles in a bird's flight), reflecting the setting sun, and, in consequence, appent much lower than is anticipated.

On nur arrival at Valparaiso, I lost no time in egtablithing the observatory. The ofticers and scientific gontlensen were assigned w such duties as were deemed most degirable to insuro the results in the different departments.

'The authorities, whom 1 at ouee called upun in company with our consul, were execedingly kind and attentive, and gave every uffer of nssistiuce.

The ofticura of the customs readily gave ne permissinn to land all my instruments. Mr. Cood, an English gentteman, Kindly offered our consul to phace at my disposition an unocenpied house on the hill. Although it was gorno diatanee to monnt np, as it was quict and out of the way, I accepted the kind offer, and secupied it.

As I was desirous of atoiding all unnecessary delay, not only on atcount of the loss of time we find already met with, but bocause thro scason was appruaching when tha norther might be expected, cvery cxertinn wins made to supply nur wants, and through the kituiness and attention of nur consul, G, G. IIubson, esyn tris whs effected in tho shortegt possible time. Ilse northers are grently droaded, although 1 think without mucls crase. One of them, and the last of any force, I liad myself experienced in Juste, 1822 (wilikst in command of a mercliant vessei). In it eighteen mil of vengels wero lost. But eince that time vessels are mueh better providel with enbles and anchors, nnd what proved it diststrons storru then would uow searcely be fele. I do not deem the bay so ilangerous as it lits the tuame of being. The great difticulty of the port is its contined epace, aud in the event of a gale, the sen that sets in is so heary, that ressels are liable to cume in contact with each other, and to be mure or less injured. "The port is tho limited in extent to necommodate the trade that is earried on in it. Variuus schemes and inprovements are talked of, bat nome that are fensible. The deptls of water opposes an almost insuperablo obstacle to its improvenent by piert. The enterprise of the gaverument, sud of the inlabitnsts of Vulparnisn, is, 1 an well satiotied, expal to tuy undertaking that is practicnble.

Fron the best aceounts, I am satisfied that the harbour is filling up, from the wash off tlo hille. Although this maty secm tint a small nutgumb of deynsition, yet after a lapres of sixteen years, llie cliange was quite querceptible to me, surl the oltegt residents confirnud the fact. The auchornge of the vesuels las changed, nut what before was thought an extremely dangerous situation, is now considever tho beat in ihe eveut of bad weather. The sen is to the forred rather than the wind, for the latter feddom blows homo, becurse: the land immediately behind tho eity rises in abrupt hillH, to the theight of from eight to fifteen hundred and two thousnud feet.

Yaipaniso has greatly increased in size and consequence within the Inst few years, and has luecome the great sen-port of Chili, anis, indeed, of the whole conat. Although it Inbours under many diandvan. tages as respects itn harbour, which is inferior to others on the coast, yet it is the nearest and most cunvesicat port to Santiago, the eapital.

I have had some opportunity of knuwing Valpamiso, and contusting its present states with that of 1821 and 1822 . It who then a mere villape, colsposed, with but few exceptions, of atraggifing rat. chos. It hes now the appearance of a thicklysettled town, with a pupulation of thirty thousand, five times the number it had then. It is diviled into two parta, one of which is known hy the name of the Port, and is the old town; the otlier by that of the Amendral, necupying a level plain to the cast. Its location is liy no means snch as to show it to advantage. Tho priucipal buildings are tho custom-hunse, two churchng, and the bonses oecupying the main street. Most of the luildings are of rime story, and are built of adobes or sun-dritel brick. T'le walls of the buildings are from four to six feet thick. The resson fur this mode of build. ing is the frequent vecurrence of earthquakes. 'The atreots aro well paved. The plaza las not much to recommend it. I'lo goverument-hinuse is an inforior building. Great jmprovements sro now making, and many butidings on the eve of erection.

They are about bringing water from one of the 
neighbouring springs on the hill, which, if the supply is sufficient, wil] gise the towit muny eomforts. On the hills are ninny nest and eturfortable dwellinge, surrounded by llower-ganders, These are chistly aceupien by the familieg of $A$ merican and English merohants. Tlis is the most pleasant part of the town, and enjoys a heautiful view of the hartors. The siscent ty it is made quite sasy by a well-cunstructed road thrugh a ravise. "The height is two butadred ant ten feet above the ses. The east encl of the Almond ral is also oceupied by the wenlthy citizens, The lower chases live in tho ravines. Many of their habitations are searcely suftieient to keep them dry during the rniny sen80r2. They aro bitilt of revels, plastered widl mul, and thatcher with straw. They selilom contrin more tlan one apartment

The woll-kuswn liils to the eowth of the port, calles the "Mais and Fore "Top," are tho principal licealitieg of the grog-shops and their customers. These two hills, aud the gorge (quebrutis) hetween thern, seem to contain a large proprortion of the worthless population of both sexes. 'The femalen, Fetnatkabte fur tleir black eyea and red "bayettan," are an annoynes to the nathoricies, the trade, and commandery of vessels, and equally sn to the poor nailurs, who seldom leave this pore withuut empty pocketa and injured lienltit.

It was difticult to renlize the improvement and elinnge thut had taken pluce in she habits of the people, and the ndvancenient is civil orter nul cirilization. On my furmer visit, there was no sort of order, regulation, ar good goverument. Robbery, murder, and vices of all hinds, wero openly commitled. The exercise of arbitmry military power aluse existed. Nut ouly with the natives, but among foreiguers, gasnbling arul knavery of the lowest oriler, and all the demoralizing effeets Llat accompany tlem, prevailed.

I myself naw on my fomuer visit several dead hodies exposed in the publie snuares, victirns of the ouchillo. 'L'his was the result of a night's debauch, and the fracas attendaut apon it. No other punishunent awnited the culpris than the remorse of their own cunseience.

Now, VaJuaraiso, anil iudeed all Chili, shows a great changu for the better; order reigns throughout; crime is rnrely heard of, nul gever goes unpunished; good oriler nud deconm prevait ontwardly every where: that engine of good govornment, an active and efficient jolice, has bern established. It is atmimbly regulated, and bruuglit fully into action, not only for che protection of life and property, but in adding to the comforts of the inhabitants.

The predominant trait of the Chilians, when compared with other Soutl Antricans, is their love of cosntry and attuchment ta sheir bormes. This feeling is common to all classes. Thero is also a grent feeling of independence and equality. Public opinion has weiglat in directing the aftar of state, The people are fond of agrieultural pursuits, and the fower orters much better disponed townrds foreigners than in other parts. Schorls and colleges tare been trtablislied, and $\mathrm{A}$ desire to extend the benefits of eluentius throughout the pomplation is evinew.

The eredit of forming the prolice is given to Porthles. It consints of two distinet bolies, one ntousted, the utliur on fwot. The watchumen carry swords anly. The former patrol the atreets in horsebnck, while tho latter take their partiettlar walk rourd a Bq̨unre or 1 wo, for which they are renponsible. A nucsenge may be aent throngli them te the furthest end of the eity, and an answer roturned, in fifteen minutes, They carry a lowi and shrill whiste, the sounds of which are varied ns occusion requires, and by it a coneentration of force can lie effected in a few mements.

When they cry the lwar they all sing the same tune, but the pilch is rauged in avesiolnnee with the senpe of the voice. The manner of singing the hour, Vira Chili, Viru Chiti, las dirs amda y uerena, is plentsing.

In the morsing they ald th it a prayer, as $A \mathrm{ne}$ Marier porissima las ciuco y media.

This jorlice adds grently th the counfort ns well as to the safety of the inluabitante. To give an inetalute of its effects, apothecaries are cliosen weekly to keep tlecir shups nuen all night, and in ense of sickuess or requiring any nid, one has only to call for the righlante, who takes the recipe and paxses it to the mext, and so on to the shop, where it is ohtained, and relumed as son as possible, withut any truble whatever. They luve their particular rounds, and each doner is obliged to have is judleck. If may dower is found witliout it, they puit a lack on, for which the owner las to pay a fine of four rlollnas to the eity to lanve it removed; Ialf is the rewurd of the vigilante.

A connlaint during our stay was made by one of the officurs, of exactions made by a polticeman. It was iustarnly taken matice of, and punished. It is to be regretted that this police strould still wear the military unifonn, as it seems unbeeotaing in a republiean form of governmeut ; at least we tlought so,

The shojes are well filled wilh almost all articles of Englisly, A nerican, sud French manufacture. The markets aro well supplied. There are no market-gardens in the noighbourliowed of Valpamirs, and nearly all the vegetubles are brought frum the valley of Quillota, nourt вixtecn miles distant, on tho backs of nules, in pauniers. "The mode of bringing grass or elover to market is peculiar: it boruetimes almost covers boll horse and riter.

'l'bere are trut few amumements. $\Lambda$ mong them is a theatre, which is smull and imonvenient, and the chiagrno, both of whieh are usually open on a Sunday evening.

The Chiliass are extremely fond of the dance ealled the sambeveen. This may be called the untional dance, and is in rogue among the common Ireople. It is usually performed nt the chingano, which is a kind of implitheatre, anrzounded by tponrtments, where refreslinents, ineluding strong drinks, are sold, and is genernily well filled by both sexes, the dance is perforued on a kind of stage, under an open shed. I'ter music is a mixture of Sranish nud fodinn, nut is performed aitogether by females, on an oid-fashioned long and narrow harp, one end of which rests on the lay of the performer, and the other on the sage, ten feet off. A second girl is seen sterrily bestiug tiuse on the sounding-board of the instrument. On the right is another, strusnsming the eummon chorils on a wire-string guitar or kitty, making, at every vibration of the right hand, a full sweep across all the stringe, and rarying the ehurds. In 
addition to this, they sung a nacjonal love-song, in Spaniah, at the top of their voices, nue singing a kind of alto; the whulo producing a very strange cumbination of sounds.

The dance is performed by a young man and woman; the former is gaudily deeked in a liglat senrlet jacket, embrohlered with gold lace, white pantaloxing, rod sasil, asd pumps, with o tiny red eap; whilat that of his partner ennsists of $\Omega$ gandy [Minted nuslin dress, quite short and stiftly stareled, not a little aided by an anuple pair of hips; throwu over all is a rich-coltured Frencls shawl ; these, with well-fitterl silk stochings, complete lier stire, Tlıese last are in trutl characteristio of the Chilin worren of all claseses, mul they take tho prios to conceal them. One nut unfrequently seeg the extruraganee of silk stockings in the washerwomen at their tubs, and even with their hands in the คuds. The dress iu general fits neasty, and nurure it not distorted l,y tight lacing, or the wearitrs of eorsets. Nothing is worn on the lirsd, and the hair, parted and equally diviled from the forchend back to the neck, liangs down in two luug plaits on each shoulder to the wnist.

The stryle of dancing is somewhnt like a fatrdongo. The counde begin by facing ench other and flirting handkerchiefs over each other's heads, then approsching, slowly retreating ngair, thers quickly sliooting of to one side, prssing unler arns without touching, with great anility, ractling and beating time with enstanets. Their nuvo. ments are quite graceful, those of their feut prutty, and withal quite amoruus: the gessures nay be readily undergtood, not only by the thative rudi. thee, but by foretguers. I ennot say mueh for its moral tebdency.

"The higher clusses of females lave the name of being virtuous and watinuble in their donestic circle, but we cantuot bay that they aro benutíful. i'hey dress their huir with great care nul tuste. Their foet are suall, and they have a graeeful carriage.

The French faslion of dress prevails, and they are just beginning to wear bonnets. 'I'he al rancement of eivilization is rapid; the imitation of foreign labits and etsatoma will sons predominate over those of Chili ; and what is of nore conpequenee, some altention is being paid to their education.

A rather singular oceurrenee took place at a review of the militia on the Plainucia, one Sunday, by the presideat, who was attended by his datigliter, and a number of the most respectable fulies of the place. They marched down the line, and afterwards daneed with the officess of the field, in the presence of the suldier. All the South Americans are inveterate dancers, the Clsilians taking the lead. The uste for music is general, but although they have a number of national airs, few hnve been printed. All the pristed music in cammon use is foreign, as sre tho inetruments. Pianos are to be seen in Rlmosl every huuse.

The natives lave a fouduess for flowers, al. though they are but litule eultivated. Few gardens are yet to be seeu of any consenuetice. They re. quire constant irsigation the inost of thie verr, which anay necount for this want. There aro two in the Almendral, surrumded by higli walls, and kept in tolerable oudur ; and grent attention is paid in these to forwign ptaris.
We huppened to be at Valparaisu druing the presilent's visit, whill, ennected with the Inte victory and suctesses in J'ern, crused much rojricing ; every posible atention was shows to the ebief magistrate, hy hoth nntives and forcigners. Among oticrs, he was Lakes ou an aquntic excur sion, on bonrd of $\mathrm{n}$ smnll brignntine, deched ont with tho flags of all wations, aud was aceompranied by the civil authorities of Valparaiso, the Einglish admiral, and others. On pasting the mets-of-war, he received the ctistomary salutes from all trat our. selves. We conld not tire the guns on Hetount of our ehronometers. On his jwssing, however, the rigging was manned, nnd wo gnve him several hessty cheers, whirb, it was anid, much delighted the jresideut and lis suite, from the norelty of the consplineent.

Thiree balls were given during the stay of the squadron here, ill comsequence of the risit of tho president (Getreral P'rietu); one in honour of the recent victury of Yungal over the Peruvians; tho nthers by the eitiznos and foreigners to his excellency. As the fortuer was an extroolingry oveasion, a description of it will give some imsigli intu the manner in which they conduot these allairs in Chili. Alt three were nuanaged in a imniner that would lawo been lighly creditable in any part of the world.

Thic place selected for the great batl was between the walls of two lasge unfuished storehicuses, a space of one Jiutudred rand fifty fect long by nincty wive, over which temporary atehes were built, the whole eovered vitl an awning lined witls blue, nud studded with stars, from which were suspended sune tweuty very hondmome ehandeliers. 'l'he whole was earpeted, and the various pilars which supported the roof were decorsted with emblens of the victory and mation. At the end opposite to the entrance was is transparency of General Bulnes, the hero of Yungai, surrounded with serolls of his deeds. Along the corridors which the pinzzas formed, rauges of sofas and sethla were placed; on the walls were lung rich mirrors and paintings: the former rested ou mussive pier-tubles, jn whict buulreds of lights were seen reflectud, whilst the gracefil festoms of the mational flays and pennants formed intu uraperies, internixed with wrenths of flowers and evergreens in endless varjety, encircling kublumalic designs of the natiun's glory, pruduced an effect not easily surpassed. Whe reception-rourn of the president wha hung with searlot tupestry, decorated with paitutings, mirrom, and pier-tables, and brilliantly lighted with chanLeliers, \&c.

Thice were likewise earl-rooms, mmoking-rooms, supper-roong, and a dressing-room for the ladies, in which were a number of lanir-dressers and mantun-maliers constantly in atteniance. The wlule was well got uṕ, uniqne, and truly splendid; all Valparaiso had sent furniture of every kind, and even the elunrehes had contribnted to assiat in the great gola lette in cotmmesmoration of the national victory.

The comprny consisted of alsout firo bundred one-third of whons were females. Many enstly uniforms, of varions patterns, and not a litule fanciful, added to the brillianey of the seene.

Alout ten o'eloek, the ball was ofrened by the president, Don Jnaguim Prieto, in person, a novel sighte to us. Ife was dressed in a richly em- 
broidered enat, gold epanlettes, and field-murslal's sastl. He dauced a minuet with a lady of Vatparaiso, whom he lad especially selected, after which tho daneirg hecame generul, consisting of quadriltek, conntry-dances, and waltace, besides which they had the lascivious danees of samacueca, eachuen, and lundern. These partake sorne: what of the boleru and fandango, or Spanish and $A$ frican dance,

By way of interlude, marches and national nirs were played and smug. The ball lid not break up until eiglt o'clock next murning, at which hour the prestdent and his daughter were escorted home ly" a procession of the dancers, with the music playing tational airs, forming rathet a grntesn sic show to the by-standers, from tho interelingige of lases and outer garduests thas lind takess place.

On reaching General Prieto's quarters, they sang a vatiumbl bym, after which many were inxited in, where they agair contisued dancing until nonn.

I should not onit to mentim that ufter midnight the ladies underwent a second operution of the toilet.

The whole equalled, if it did not Eurpass, any of our own fêtes in the Uniced States; indeed alt who attenuled were much surprised, having lisle iden that Vujpuraiso could have made so briltinut aud tasteful a display of beauty aud magnificene.

\section{CHAPTER VII.}

\section{CHILI.}

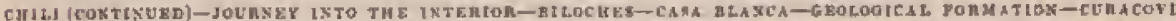

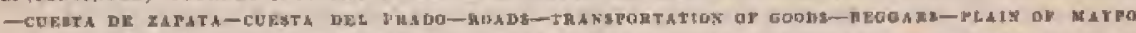

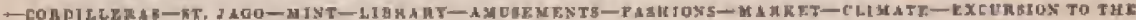

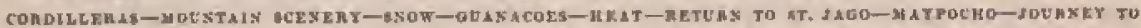

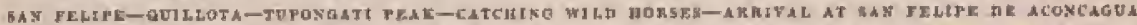

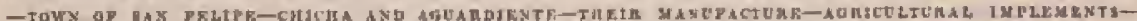

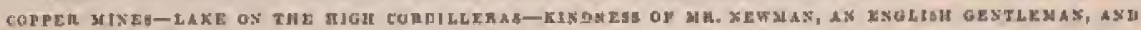
A1: LADT-POPULATIOX UY CHIL.

PRETrous to try arriral at Valpamiso, the natural. ists aut oume officers on bonrd the Pencock and Relief had suade exeursions into the isturior. On tay arrival, I altowed all those who could be spared, and were desirous of visiting Santingo, sutfieient leave to make the trip. Several set out for that city, and some with a viow of extembing their journey to the Cordilleras beyoud.

The bihacherus were enrer for apportanities to hire thejr bilindies, a relicle somewhat resciubling a double gig, which is genemlly used for travelling in Chili. Thiey hisve a most riekety and woth-out nprearance; aimost every part appears thended witls curls nade of hide. They recommodnte two passengers; and the tine required between Valparatso and the cily (Sajtingo), is nbout eighteen or twenty hours. In the stafis a horse is pot; a postilion rides one on the left, and sometines another is placed on the right, both being fistened to the velicle by lassos of raw-thide proceeding from the saddle. Each vehicle is attended by lluree bilocheros or drivers, with a drove of twelve ur fifteen horses, forming quite a cavaleade.

The bilacheros are very expert at their business. They aro exedlent riders, having been brought up to this exercise from their infnney, and undurstand managing their horses, though in a rule way. Their horseg are sanall, but spirited, and bear fatigue well. Their usual speed is about nine or ten mites an hour. Few equipages can conparo with these crnzy mathines, driven, ns they sumetimes are, uell-mell uy hill and down dnle, with all their accompaniments of lorses, grachos, Kc. ; and it affords no Errall amusemest to those on foot, to witness tho consternation of the afriglited passengers, in momeutary expectation of a breakidowth. It is a difficult matter to aequire conposure, ns seeing the ummerous tomporary lasluings, giving ecular pur of that accidenty have been frequent, however well satisfiel one may he with the skil of the comeluator. Fortunately the road is excel. lent, thongh at this sensun (May) it is divested of mucls of its beanty from the want of pegetntion. 'The interest in, liowever, carried for. wark to the lofty penks of the Andes, uf whose summits ocensional glimpses aro las ; and the eye ylances over the Burrutudiug sconery in the immediate noightourhoud, that would elsewhere the deenel grand, to rest on sonse high and towering peak. Among thesse the perk of Tupongati is the rmost nuted, ristiking, sinse the mensurement of King, as next in height to the Himmaleh mountains.

Tho first stopying-plnce is at Cass Dhanen, a small pueblo of some five huudred inhahitants, where trineliers ustally siees?. Tho accommodatiuns were good, laving been recently wuch improved. In the neightronthond is the only traet of woolland to be foumd in this part of the country. The eleration of Casa Blanea is five hundred and winety-eight fect alrove the level of tho sea.

The rond from Casa Blanea next passes throngh Curacovi, a small pueblo, where the trap rock first makes its appearance, sul then over a high ridge, culled the Cucsta des Zapata. This tertminates the first plain, ant divides it from the secund, of similar chameter, which exterds to the Cuesta del Prado, It is passed over by a zigzag rnal, and was found to be two thousanil three lundred and ninety-four feet high. On reaching the top, tho view that presents itself is extersive and magniticent.

In frut is the extensive plain of Msypo, with here and there a conical mountain stustidug alone on it. At the extremity of tle plain rise the lofty 
peaks of tho Andes, covered witl etermal snow, some reaching above the clouds. They appear het a few hours" ridta off, nlthough at a distanee of twenty leagnes. On cither side riso the high ridges of the Cuesth. Beneath lie graving grousds, extending over the phain, and coverud with lineks and herds. Vuriety and life are given to the whole by lhe view of the national rond, on which are seci numbers of vehicles, mules, \&e., thrending their way up and down the mountain-sille, laden with forvign and domestic products. This is the only roul of nny extent for whecl-carringes in thi ewintry. It is bept in good repair by conviets, who sre seen working in ehtuiss. $A$ morenlse prisun or lock-up house, sounewhat regemhling the cages used itt carnvans of wild beasts, is umed for their necommodrtion ansl sucurity at niglit.

The leary merchandise is for the nost part transported in ox-carts of enormous dimenkions. Their wheels are elansy nud withont tires, aud the whole frame is naclo strungly with timber pinned together. Their perpendicular sides aud rounded tops are wattled with cano and covered with bull'slivide $\mathrm{No}_{\mathrm{i}}$ iron is used in their structure; wooden pirta and raw-hide lashings seem to answer the purpose hetter. The yoke is set on the heads of the oxen, hehind the horns, and fastened to them. The creaking of these enrty may be benrd for miles, as tha drivers never think of greasing the axles to lessen the friction. They are generally drawn by four or eiglit oxen.

Lighter articles are transported by iuules, and immense numbery of these antumls aro sect on the road at all times.

"The unode of chnngiug horses is truly chnracteristic of the contry. The rulays are mole as suor as the shaft-horse tires; ho is quickly taken out, and one of the drove eanght with a lasso, and put in lis place, when on they go. These relays oceur every eight or ten niles; the only relief the poor horses liave it a trot out of latrness, and without a lowl. The bilacheros sollom tismotnt; all is done on lisiseback. Ou golng up hill, n thiril or eren a

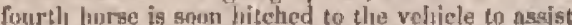
the dratght. The lurses aro all in goot contition, aus it is uot a litclo remorkable thas shey showld bo ou, fur I unlerstoul that their only food at this senaris was chopped straw. The tenmsters and gurelos thensutves are equally absteuions. They Jiro mostly upos1 brend and their fanourite chica, which is made from tho grape, and resembles cider: but after it has passed through a fermenlation, ic is quite intoxicaling. The mul fouts or ranchos, an the rond-side, are filled with lappy ats contente-1 rawes.

Bogging is common on the rowd to the city, and is quite a businces. The Luggars let thetuselres to the lighest biduere, and *alue themselves according to their deformities, At Valparniso two days are allowed in each week for begring.

The plain of Maypu, which reaches to the foot of the Cuesta del Prndo, is extrenuly lovel, and is almost thirty miles in width, extending to the foot of the Curdillestas. "Tho ruad loads nearly in a straight line over it to the city of Santiago, which is simaterl on the eastern side of the plain.

The elevatiou of Santiago ahove the sea is fifteen hunilred and niuety-one fect, upon the third step or phin from the counst. Its entrance is throurh avenues bounded by high adote walls, which shut out all the view, except the Cordilleras, which tower above and beyond it.

'Ilie mure the Curililleras are viewed, the groater spucas their nuruetion. They have at all times nn irsposing aspect from the neighbourtuod of the city. Their irregular and jagged ontline is constantly varying under the effects of light and shade. The jnys of the setting sun, with the deepening shadowis, throw the inumerable penks into tuld relief, and at thues produce yellow and red tints, which give a remurkable character to the whole seene. The resl tints are often aeconpranied witis a green lue in the sky. The city is surrounded by mnny fine orchurds, gardens, farms, and grazing grevinds. 'T'he former being enclused by light adobe walls, give it a ruther unpleasant appearance, uнtil the city is fairly entered, when the structs latve a fresh and clen look. The city is lixid out in squnres. Its otreets are well paved, and have good eidewilks. This fresh and clenu aprearned, we after. wituds understool, was owing to a law, obliging nl to whitewash their horses aud walls unce a year, a practice which gives a general uniformity, at least in colour, to the wiole, asd furms an igreeable contrast with the red-tited rovos, "I'he honseg are mostly of one story, built in the form of a hollow square, from twenty to forty feet wide, round which the rooms are siluated. Ttie roof projects on as to form a kind of pinzza or covered way. 'Ihe gnteway is usually large, ant the rooms on encl side of it are not connected with the rest of the building, but are rented as shops, Uppositu to the gateway is the centre winsow, guarded by a light and ormamental irou frane, painteul green or richly gilt. 'The court-yard is usually nently puved with small rounded jubbles from the bed of the Maypucho, arranged in fanciful forms; but in many cases tlieg are laid out in flower-gardens, where roses wid geraniums are gecen in fult bloom.

The river Mayponcho ruus through one portion of the eify, and supulies it with water. In the centre of the eity is the grent plazn, where the pulutic luildings sre situated. These are built of a cuarse kind of porjlyzry, obtainel from the menatains, arul are on a large scale. The cathedral and palnee each vecupy one sile; in the centre is a fountnin, with sevural stutueg of Italiau marble; ton snu!l however in sizo to lave any eflect is su lnrge a sionure. All these buildings are much out of repair, laving been at various tinues danaged by earthquakes.

The eathedral is very large and extensive, I to altar is lecked with a great qututity of gold nud silver. 'There are many jaintiugs and hangisgs, antury which is a Jarge nusnlrer of trophies, taket in their various wars. T'tue niches are filled with wax figures, representing suints; and there are also the remains of two martyrs of the churel, in a tolerzably good state of prescrvalion.

The place was srighally built for the vieeroy. It is now nfruropriatel to the accommodation of the fresilent, and the puldic aftices. On the sithe uphrmite to the palace is a colonnade, whisels is not yed finished, nnd will ocenyy the whote side of the syunte. Under its portico are fancy and dry-goods shupe, and between the eolunas varions trades, or lece and fringe-unakers, are at work. In the evening, this lecomes a most busy scene. Females, nith large fat baskots bufore tlsen, are vending 
shoes, fruit, and faucy articlea ; others are enployed in conking cakes, and the whole lighted up as it is with numeruas eandles, affords usuç, ainnsement to the stmuger.

The mint oceupies a shole square; it lins never yet been cumplleterl, and has also fuffered groatly from earthyukes. The operation of coluing is in the rudest in I olitest form. The rulling and cutting are done by mule-power, and the oldest kind of Ay-press, with a great serew beam, having enormons balls tht the end, is used. The dies employed are made from the male die, in the name way an swith ns, but they have not the snme facilities, and wnst the modern improvements in the process. A tuggle-jointed press whs imported from France; bul it wis soon put out of order by the workmen, been abnudoned.

The libnry is extensive, containing several thousand volumes, which formerly belonged to the Jesuits, and many eurivus matsuscripts rolating to the Indiang.

The amusements aro not very renarkable. Surtiagn, lowuver, boasts of a theatre, atw a chimgano. There appears to be little busincse loning, atul it may be called a quiet eity. The sicsta is tally in. dulged in; even she shops were slut in the afternoon, and the city is as quied as thiluight. To. wards the ceonl of the eversing, the alameda is resortod to. It is a lusutifut walk, about as mile it extent, wetl sladed, amel oceupies oze barle of tho river. It is planted with a doulde fow of proplar trees, which seem to thrive well here. Streams of witer ise constantly running on ench side of the walk. Every fow ynrds stone seats are placed, which are at times filled with a well-dressed population. "Tho almueda afforits at all times a cool and pleasant promenade.

The erenings aro grenerally pussod at tertulias, in visiting sucially, or in shopping in the colonnade. The istlubitants are much mdieted to gambling. Monte is tho garue with the higher classes, whilst that of match-penny is the favourito of the lower orders. The Chilian wosnen uro remarkable for theiv esse of tumner, kindnese, and nttentions to strugers. They are font of diversiens of any kind, lut more particularly those of daneing and musie, luth of which are rauch practisen. They seem extruvigantly fonel of music. Daucing they are taught very young. Most of them have good figures, and borme would be called pretty; but their teeth are generally defective, which chuses them bann to fook old. 'I'heir custume varie日 little frons our own, except that the farlits wear mo bonnets.

The men follow the European fastrions.

The drems of the lower order is a mixture of Spanish and Indinn. They are fond of bright colours. Over their shirt and truusers is wom a blue or brown proncha. A high-crowned and smallrimmed hat, kiut on under the ehin, over $n$ brightcoston linndkerelizef on tho hend, cumpletes their nutlit. They are a well-disposed people, and good eitizens, and have more the air of contentromt than nuy outher nation of South America.

'l'he markets are well supplied. There is ono large one neat the banks of the Maypoebo. It covers an area of four or fivo neres, and is stirrasmiled by a low building, with a tile rouf, supported by columne, under which meats of all kind are suld. The eentre is reserved for vegetables, fruits, flowers, poultry, and small-wares. The market-women are seen sented under awninga, serers, and large umbrellas, which aro usod to keep uff the sun. The place is acrupulously clean, and bas a juleasing cfect.

The average price of a horse is twelve dollnzs, but some that rre well broken are valued as hight as those in the Livited States.

The elimate of Cliti is justly celebrated throngh. out the world, and that of Santingo is deerred delightful even in Chili; the teminerature is usually lietween $60^{\circ}$ and $75^{\circ}$. "The country rousd is extremely arid, fuld were it not for its mountain stresma, which atfurd the mesns of irrigation, Clili would be a burren waste for two-thirds of the year. Rains fall mly during the winter montliw, (June to September, and aftur they lave accurred, the whole country is decked with ftowers. "The raing often last several dayg, are excessively heary, and during their cuntinuance the rivers besonite imprsealsle torrents. At Santingo, the climnte is drier and eolder, but snow rarely falls. On the asceut of tho Coldilleras, the aridity increstess with the cold. "The smow was foumd rnuch in the same state as at Terra del Finego, lying is tratches about the aummits. Even the higl peak of Thpougati жаs bare ill plues, nut to jislge from apprarsueses, it scldon ruins it the lighent regian of the Cordillems, to which cuse naxy be imputed tho absetuec of glaciers.

Several of our gentlemen made an excursion th the Curdillerss, in order to get information in their various departmenls. I regretled they were Int provided witla tho ucceskary instruments for ascertaining lheights. T'le party left Suntiago in biloches, and truvelled to the easiwurd five leagues, to the "Snow Bank" from which the eity is supplied. The ascent was grndual, but quite constant, as no intervening ravines oceurred. They then took horseg, leaving their bilodses to return. 'Their' route after tlig lay up a valloy. On the surroumding boights the guanucues were secn in guat numbers.

As they proceded they found the middle region was marked by mpiny plante, principally burnadesia. The soil was found to be a mixture of luose earth and pieces of rock. On rising higglser, the vegetation beeame almost wholly extinet. Places oceurres of an eighth of o mile in breadth destitute of verilure uf any kind. The party then ascended a ridge belonging to the unain body of die Cortillems, nud at ar elevation of about ien thun. and fect, hey resched its summit. Hero they had an extentive riew of all the line of the enrw jueatis. That of Tuponguti appeared the most consyricuous, ntthugl at a distasee of eiglity miles. The gujde asserted that he could see smuke issuing from its voleano in a fnint stresk, but it was beyond the vision of our gentlemen. The penk itself from this view of it wins quito slarp-pointed. The scene imnedistely around them was one of grndeur and desolation; mountais after mountain, separnted ly inimense chasms, w the deptls of thuteande of fect, and the sides broken in the most fantastie forng imnginable. In these lightre parts of the Cordil. lerns they foud a lurge ndmixture of the jnspery aluminous ruck, which forms the lase of the finest porthyries; also chlorite in shundance The rock likewise cuntaing fue white chslecdony in irregular straggling masses. 'Tracliytic breocia was ouserved in various places. The porphyry in 
of a dull purple culour, anther lighter than the red sandstome of the United States. No traces of col. Inlar lavn were observed, nor of other more recent volestnic prouluctiens. No linvestane was sten in the regions traversed hy our phrties; nll the lime used at Santiago is obtninel from sen-bluells ; uor wese any proper sedimentary rocks seen.

Nothing conld be more striking than the enmplete sileuce that reigned every where; not a living 山ing appenred to their view.

After spending some time on the top they begn their ducent; and after two hours" lard travelling they reached the snow line, and passed the niglit very comfortably in the open air, with their bhonkets and pillious, or sadile-eluths. Fuel for a firo they unexpectedly found in abundauce: the ntpinis anthellifora nuswering admiratly for that purpose, from the quantity of resinum matter it contuins. Noar their enmp was the bonk of snow before apmiken of, frum which the eily Jas been supplited for many years. It eovery severnl acres. "Iloc stow line litres setmed to hase remained constant, aud would have afforded a flue oppoutunity to lisve verified the rule of Humboldt, but they latd no iastruments. The beight they luad as. cended was stappused to liave been alwout eleven thusanu feet, and the Curdilleras opposite them about four thousand feet ligher. The view of the mass of the Coridilleras, in its general outline, whs not unlike these of Monc Blane and other novntuins in Switzerland.

Mr. P'salo went in senreh of the guanacoes, and succeeded in killing one, nine fert in length and four foet in lueight. They were fousd to freguent only the most inacressible sommits, and are said never to leave the vicinity of the snww. They foed apos soreasl amall thorny bushes, whieh inspar' a flavour to their flesh, arsd it sonell to thejre exeresment that may bo distinguis]ed at sonne distance from thoir places of resort. They nake a peculiar souml whea alarmed, like that of the katyolis (gryllus). 'J'his anina! is never hunted for the marlice, thoug !. its Ilexly is gond. The benzuar is often foumd in its stomnch, nut is linghly prized ammong the natives and Spaniards as a remedy fur various complaints. It is also used as a gum.

All the party sutferend grently from the heat of tho sun"s rays and the diymess of the atmonspilere. T'their taces atd linnd were blistered, and the nose awil lips mado exeecelingly sore, while the rellection of the light from the snow eaused a painful gessation to the eyes.

I'lue jext day they reached Santiago, whence they returned tu the port, ns Valpartiso is usually distinguished in the eountry,

Ovur the Maypecho at Sintiago tlore in a sulsstantial stone bridge, with five urehes. For niue juonths of almost every ytar, the borl of the streant it nearly dry. At the line of our visit il was alsout two yaris wide, ankl aeveral inclres deep; but in the winter and spring, rluring the melting of the sıอพs, it becomes quite a torrent, and from the clumuge that las been dnon in former simes, they larve taken the preeaution to wall it in on the fide of the city, towards the Cordillerws, for several tuiles, will stone and hard brick. When swollen it is a quarter of a snile wide, rapid aud deep, aud wonld cut off the conmenication with the suldouddiug country were it not for the luridge.

Messirs. Couthauy and Dana wero desirous af naking a trip to the eopper-mines of San Felipe, t) which I rendily onusested, ald gave them all the tinte possible. Altbough this was short, yet lyy their indefatigable industry, it ufforded sune interesting resulta. They left Vulpamiso on the 17th for San Felije, which is about wa hundred uilus noth of Valjaraiso. They were to bave tuken a bnrmucter with them, in case of aseending some lieights, but it was fortgotten.

'These gentfemen took a biluetwe as far as Quillota, a distance of forty miles, and proceved thence to San Felipe ou horses; for the use of which they were to give thirty dollars each, and one dollar extra for the service of the peon who aceompanied them, for seven days, The road to Quillota was found good, althongh muy lifls and valieys were met with.

For the first twenty-five miles the road passed along the sea-slore, with no elevation over two hundred feet; it wits thunglit equal to the most frequented turypikes in our awn eountry. At six miles from Valparatiso, the road is eut though a bed of sienite, remarkable for the simgular vertical dilies of granite by which it is intersected.

Ten tuiles before reaching Qnilluta, tho ruad passes over is level plain, which extesids beyond that place. The hills which buind the valley to the south, are of low elevation, until appranching Quillota, Nenr Quillota, in the south and southeastern direction, a lofty ridge rises, adjoining the campragin of Quillata, which is one of the high cones used as sea-marks for the harhour of $\mathrm{Val}$ parniso. "This is lust sight of at the town, in con. sequence of it being sliut unt by an intervening riilge. The town, or city of Quillota, mectspies the centre of the valley, tud is tweuty stles from the sea. They reached it alout ane lutu before sunset, when they stupted at Mr. Bhachard's, whu keeps a home for the accunumodatiou of foreigners.

On the $\mid 8 \mathrm{t}_{1}$ they nose at daybreak, at which time the thernometer stood at $36^{\circ}$ in the npess air, serventy feet above the seat

The towa of Quillown (aceording to Mr. Blanchard) is embrised within a circumference of three leagues. It contnins soveral churelses, of simple construction. "The "calle Jargo," tho longest street, is upwards of a tengue in length. The same authority gives its population at ten thousand juhabitanta "l'he houses are all of one story, and are built of adubes, witls thatched roofs. There is an ubundance of fine building-stune, but in this land of enrthruakes it is considered safest to use the lightest materials. Almost every louse has a vineyard attached to it, the grapes of which were of good quablity, and very abundunt. At sune plates, altlıough the vintage was lalf gathered, yet the crop still on the vines way suts us wuthld Jave been considejed elsewhero an abumdant yiejd. $A$ portion of the gringes rot upun the vines, as tho inbabitants have not the industry or inclination to manufacture them, although by proper altention they would yield a good wine. As it is, they only manufacture some into a hard and at id wine, caljed matu, or boil the juice down to the favourite drink of the lower classes, ealled chicha, which soinewhat rexembles perry or cider ill flavour. The smali qunntity that is not consumed is distilleul into aguardiente, and disposed of at $\mathrm{Val}$ parniso. Besidles grapes, considerablo quaztities of wheat and ludian cora noc cultivated. Apples, 
pears, and quinccs, are also raised. The forzuer are inferior to our uwn, tho latter much sujerior, asd in grent plenty.

Oranges were atso nlundant, but of indifferent Aavour.

Quillnta is well supplied with water from the riser Cuncon or Acuncagum, 'Flue water is led lirungh all the streets and gardens of the place. It is used for all theusehold purposes as talcen directly frum the gutters, which are the recipients of dirt of every deseription from the town. For iriukitug, it is allowed to sette in largo jare kept for the purpose.

The intereourge with strangers at Quilloth has been much less than at Valparniso or Suntingo, and sonsequently they ure less liberni, and tmore biguted. This was particularly shuwu alout four yests previous to ons visit, by their burving, it the public square, a lirge rumber of Bibles in the Spanishl language, altaig with a herp of inmorral ind indecent pamphlete, in the presenes of the civil, military, and ecelesiastical nuthorties. These Bibles lad been distributed by our countrymas, Mr. Wheslwright, who ba dute so muel by his raterprise in introducisg the conmunication by usteam along the western const of South America.

On leaving Quillotr, they went through the "Calle Largo," and took the southern sicle of tho valley, passing along the foot of the Mellacen Hill, a smooth and rounded eleration, abont tiree buntdied feet in height, and $\mathrm{n}$ mile and $\mathrm{a}$ half in cireumference, This hill is corered with in thin soil, formed from the decomposition of its own rocks, The ralley now narrows, sud in sume platees is not more than a few hundred feet in width. At aliout a leagne from Quillota, they ascended a cuesta of the Quillutn ridge, one thousand feet alove the plnin. On its top they were muels gratified with the henutiful prospeet. The fruitful plain or vega of Aconeagua, varying is width from one to six miles, extends, th the west, sotne twenty miles to the ocenn, and is lost in the other direction in the mountains; it is walered by pure streams, and cuvered with farm-houses nod thamlets, surrounded ty trees and vincyards. To the north-east are the Andes, heaped as it wero on each other, uritil the towering and distant peak of Tupongati, with its fiant fortu, crowns the whole. One fenture of the plain was peeuliar: the uwoutains seemed to sink into it as if it were the ocens iteclf. In some eases the line was so well defined, that one foot eould be plnced an the plnin, and the other on the base of a mountain rising six or seven thowand freet high. The distauce of Tupongati is about torty leagues.

Captains king and Fitzroy bnve made the lieight of this preak serezal hundred feet above Chimborwo. The surrousdiug mountains, though from ten to twelve thousud feet high, and much nearer, sink into insigmificance when compared with it. Indecu, all the ubjects nre upon such a gand Ecale, that they fail to excite the notice that they wouli] attract if situsted elsewhere.

The road over the euestr was narrow, steep, and broken. It descended into a plain, which was found well ctilikated, and watered by a branch of the Aconcagua.

The ridges on the northern side of the ralley now becane more lofty and precipitous, exhibiting the columnar structure more distinctly. Tho trap dikes were in some places four feet wide; and in otwe place, where the rock hnd heen eut fo form the road, fourteen dikes were cunted within three hundred feet On their way up the valley the peon's horse knocked up, and they were obliged to otep and hire anollier at the house of $\mathrm{a}$ farmer, called Erangelisto Celidono.

On the second cuesta they were gratified by witnersing the mode in which the Chilians capture the wild horses, A party of four or five horsonen, with abouk twenty dogs, were seen furmed in an extended crescent, driving the wald horses towards the river with sthuts, All were armed with the lasso, which was swiggiag over their lieads, to be in readiness to entrap the first that atlempted to break through the gradually coutracting segment; the dogs serving with the riders to heal the horses in. They continued to advanee, when suddenly a hurse with furions speed broke the line, passing thetr one of the horsemen, and for a moment it жыs thought lie land fexougied; the next he was jerked routud with a furce that seemed sufficient to have hroken lis neck, the horsenata luaving the mument the lasso was thrown turned round aud brnced himself for the stwek. The captured horse now began to rear and plumge furiously to effect lis escape. After becoming somewlat wom out, he was suffered to run, and again suddendy clecked. This was repeated several tines, when ancther plas was adopted. The dogs were set on him, and off he went at full rum, in the direction of another horsemnu, who threw his lasso to entangle his legs and preesjitate him to the gruund. Tlue dogs agnis roused lijm, when he agnin started, and was in like manner brought to a stand; after several triala he becme completely cxhausted and subdued, when Le stoud perfectly still, and allowed his captors to lay lands upon him. The shouts of the men, the burking of the dogs, and the seamperigg of the horses, made the whole scene extremely exciting.

After a toilsome routs of three ind $n$ lint hourn, they find thmoselves surrounded by many branches of the river, whose bunks were lut a fow inches above the water. 'The peon then achow. ledged bimself bowildered, and that lhe had missed his way. Clvssing the streamn was attended with fome danger; for owing to their rapidity and depth they were near sweeping the horses off their legs. Roturning a league or two, they fortunately met a muleteer, who put them in the road; bal their horses wete now so exhnusted, that they were compelled to seek lodgings at a runcho. After applying at several, thoy bueceded in getting a vince to lie in, afur minking many frrmises of liberal payment. A similar course, uotwithstanding a pasitive refusal or denial of having any prom visions, procured them a casucla, served in n large wonden bowl, with wooden spoons, This is a sort of Chitian chowder, witl a plentiful supply of garlic, orions, Chili pepper, $\mathcal{E} c_{\text {., }}$ and one of the farourite dishes of the cuuntry. In three days' ride they had passed overnbout sixty miles; the higheat temperature experieneed was $60^{\circ} 3^{\circ}$, the lowest 357 . At the rancho, where they stopped for the night, the temperature fell $20^{\circ} 5^{\circ}$ in tluree hours.

They passed the niglit with the usuat annoynce in most houses in Chili, for Hens were found in great nusudance. In the morning the tempernture was $355^{\circ}$, and the ground covered with hour frost. This ratrcho was supposed to be about one 
hundred feet ahove the level of the sen. The moutrtaius in the imnedinte treighbourhorl were from six to seven thousand feet ligh, exhibiting a gorgeuns appenrance as the sunbeams lighted them ux, and at times the brilliancy was oro great as to dazzle the eye. They left the rancho ut Beven o'clock, and ulthough it wes only ten miles distant, they did not reach San Felipe before eleven. 'T'te rond passed over a third enestan which exhibited a regular coltumar structure. The lidly inclining to the nortinward, open and present os vivw the brond plain of Aconcagua. San Felipe du Aancagua stanls about fifteen miles from the foot of the Andes, and the nroustains nro seen from thence in all their grandeur. "The penk of Tupougati is, however, Just siglut of as the town is apfroacled, disappearing behind the nearer snuwy peaks. This mountain is situated un the dividing or eastern ritgen of the Gordilleras, and within the United Pruvintes of La Plata.

On arriving at San Felipe they proceded at once to the house of M. Hency Newman, an Buglish gentleman resident there, and engmged its mining operations, to whom they had lettery. Mr. Newnan was uot at home, but they were hospitaLly received by his indy, a native of Chili, who treated then with grent kinslness and attention. In the absence of liet luvsband, slie made then aequainted with an American geutlenan, a Mr. Classe, rho happlened to be on a vixit there from Suttiago. He had been in Chili sinee the failure of the expedition of Currera, when lie, will several uf his companions, settled in Chili, and afterwarcts enguged in mining upurations. Ho hal several times nmassed a latge property, and as often lost it by the revolutions that had taken place in the country. Ho is now engaged in working a wilver. mine in the vicinity of Santitgo, nnd attempting the German proess of stmeting, as thete are vast quantities of ore, eontaining a large per centuge of silver, which lnve hitherto been steglected, frum the impracticability of sepnratiry the silver by tho usund mothod. There is now only one sur. vifor from aniong the thirty persorss whe settled is Chili with Mr. Chrse. From Jifs rperations to expects in a few yenrs to realizo a large fortune,

The tawn of Sinn Felipe is laill wut witl grant regularity, in the fortu of a square, surroutuled by extensive at muedar, which ane planted with Lombardy poplars. Mr. New that gave the puputation fat frum iwelve to thirteen thousind, In the centru of the twwn is a large open syunre, ore side of which is oecupied by the town-hall atwd offices eunnected with the anumicipality. Opposito aro the elureh and barracks, and tho remaining sides are cecupied with shops and private dwellings. The houses are all of ono story, and are in a guod style of builling. "The better class of houses stand some distruce back from the street, and sre de. corated tastefully with paintings in frese on the walls kases and jessamines were seen in every court-ynrd, and the gardens are well filled with พariuus fruits, apples, penches, pears, grapes, pomegrumates, oranges, lemons, and quinces; the latter aro remarkably fine, and in great pleuty. The houses, as in wher parts of Chili, linve no fireplaces, in lieu of which they use brateros, or pans of live coal, whers heat is required. Mr. Chase took them to a friend of his to see the process of manufacturing the acida and aguardiente of the coustry. The whole process is married on in a large court belind the house. The grajes are brought in large baskets, or hand-harrows, made with priles and mw hide, nud are emptied in heaps unter nn open shed. Here several small Luards are placed, on which the grapes are hid by the men, who separate them from the stalkg by milling them rapidly in their hants, the mapes fallisu along the bourds, which are inclined into a large rah where they are trudden but by men. The juice, wlich rung off through a rude gtrainer at one end, is received into large earthen jars; the pumice, or residuum, is from tisne to time tsken out of the rat, and placed on n platfurm, when more juice is expressed, by laving bonrdes and heavy stones upon it. That part which in intended for wiste proper, or the "must," is retceived, like the first, into earthen jars, where it undergoes the requisite fermentation, and reeeives a small yunntity of brandy, or the aguardiente of the enustry, to give it body. The chicha is made by boilizg dowa the clear grape-juico, after formentulin, for ecvernl hours over a slow fire A fter thin process it was put in enormous earthen jurs, coutrining sixty to ane lundred and twenty gallome, which ave covered over, and tightly luted. The yortion not required for consmmption is after wards distilled with the pumice into agrardiente of the cunntry. The stills nre of the simplest construction, being nothing more than a number of large eartien pots, holding from eighty to one humbed gallons, placed in the ground over a long narrow oven. Itistead of a worm, $n$ straiglit pipe of enprer is userl, whout twenty feet long; one of these was inserted into esch jot or jar, and to effect the condensation, a strean of water from the river was led fo ag to pass over them. All the ngricultuml implements are equally rude and primitive. The jloughs are nothing more than a erooked stick, with the share-end pointed, and fordened by eluaring. Nutwithetanding thewe disadvantages, they are entbled to mise lange erup, and bring their farms into tolerable condition.

In the evering they land the pleasure of secing Mr. Newman, who returned; aud bie reterptisu of his guests was, if possible, even morv kind tlan that of his goud lady. Learning thut our gentlemen wisled to visit sune of the mines in the nuighbourlood, lie immedistely notle mrangement to sond his agent to his uxis extabliklinetu, fire leagues lveyund Snn Fuline, nnd provided them horses nut mules, in order that the ir own might reernit fur their return journey. The tumpenature at San Felipo varicl, between noon and 10 P.at, from $63^{\circ}$ to $4 y^{\circ}$. The nighe was remarkably cher and fine.

The next moruing they sturted, witl Mr. Gearge Alderson, for tlie mines, wlith nre nent the summit of the first Corbillem, on the Mendoza road, and alout three thousand feet ahove the level of the sea. They were lore infurmed, that in cousequence of the late heary falls of snuw, the ruads were all covered and congealed, and that it extended severnl thousund feet below the limit of perpetual snow.

Tlic part of this whiley where the ranchos are situatcd in called La Yega of Jaquel. This is the principal smalting-place, the ore being bruught bero by mules from the foot of the mountain, down whose sides it is turown from the mines. The deserent is about two thousand feet, and very ateep. 
Mr. Aldoraon stuted that it took thirty Beconds for the ore to desconis. The face of tlite mountain from long usage in this wny is worn quitu smooth.

Mr. Newman had previously lost rueh projerty heve by the burnizg of his whole cutablishment, excepting two bnildiug 5, fire baving been conumunicated to the thatelied roul by the spartis from the furmte durisg a tormato that prassed over. So mpidly had the flames spread, that it was with ditheulty that Mr. Newman ond his agent saved their lives. Besides the loss of buildings, a largo quatity of machinery lately inurorted from Enghand was destroyed.

On the 2 Ist ilay, they set ont on nules for the mines, acempanied by Mr. Alderson, and reached then about ten o'elock. Their first net was to change their buots for a pair of raw-linde slones, sindt is are used by the minets, in orich to insure a safis linotiog. 'ithey now enterch the prineipal gallery, which was about sever feet high and tive broad, exenvated! for alout twenty yards lourizun tully; it shen clivides into several branches, and these again into others, frum fifteen to twenty yaris in length.

The grenteat extent of any one gailery is about thirt) feet. The mountsin las lieen penetmed lworizontally to abust four humdred feet, is the direction of morth-eatit to east-north-tast, as the veins run, and vertically to a depth of nbout one hundreal and fifty feet. Fach person was provided with $\mathrm{a}$ tallow candle stuck in the end of a spitit stick six feet long, and eantion was given not to lisse eight of the guide, for the galleries, slthongh small, are so numerous, and communiente with theh other go frequently, that a person might easily be lust.

The laldess, or rather posts, by which the deBeents are nusle are not a little daingerous.

There appouts to be little systesu in working the mines, and liule knowledge of the structure of the rock ot the conrses of the veins. Mr. Alutrsun mentioned that a few months previonsly, they lad betell working for seversl weeks extending as shalt, without meeting n particlo of ore to repany their Lbour, and they were just about giving up the search, when the maroml, or master-workman, declaring lo would have a last bow for luek, struck the rock with all his foree. This detnclsed $n$ harge fragment, and to sheir surprige ant delight laid "peert a vein wlich proved the lasgest aud rjehest that had been worled for mary yeurs, from this it would appear that the employment is attended with mucl unectainty; and after exhasting one of these tronsure depusits, there are no mentis or signs kuuwn to then by which they ena aseertain the best direction to tatie to discorer anther.

The mines, by the light of the numerous eandles, exlitiled all the shades of green, blate, yeltow, purple, lironze, fe., laviag in metillic and lustrous appenmice, 'lthe enstined nir, with the heat of 80 many candles, nrade il quite opgressire; and persons why have not often visited mines, ure subjeet to faintness and vertigo from this cause. Mr. Aldersall and Mr. Danz were buth affected by it. It was the first tine the former had ever penetrated so far, Mr. Newman and hinself being governed by the report of the innyoral, and the wre brought up in their operatiuns. The miners were not a little matonished at our gentlumen loadiug thensolves, bosides tho specimens of ores, with the piedrabruta, which they considered of 110 ₹alue, I'lse manner of falour in the mines is in as rude a state as it was found in the agricultuml branches of industry. A elumgy pick-axp, a sliart erowtar, a stone-cutter's chisel, and an oblung iron hammer of twenty-five pounds weight, were the only tools. "The hanmer is only used when the ore it too hight to be reached with the pick or crowbar. The miners, from the constant exerciso of their arras and chest, lawo them well developed, and aypear brawny figures. When the ore is too tough to be removed by the ordinary methods, they blast it off in small frage ments, not during to use large blasts, leat the rock slould eave in upon thom. Only a fow weeks previous to their visit, the mayoral, while at the furthest end of the gallery, wros alarmed by the rattling down of sume stones, and before he could rotreat, the walls caved in for several ynrds outside of where he was, leaving but a small space. It required eighteen hours of uncensing effort by nearly a hundred men to extricato him from his veriluus situntion.

The are is brought to the mouth of the mine on the baclis of men, in sacks made of $5 \mathrm{~s} w$ lide, and bolding aboat one liundred pounde. Whenerer a sufficient quantity to loal a drove of mules is extracted, if is thrown down the mountain slide, rut then carried to the furrace at Jarquel. Only seventeen minors were employed; previous to this the number employed was one hutuded. Whetkever a rielier vein was struck a larger number were conployed, whu could always be ensily obtained by forcigners, the mutives juefering to wotl for them, as they shy whatever the profics or lossces may be, they are sure of beitug regularly zkidi. The wares are small-from three to four dollars per mowtli, in addition to their food. They are allowed to draw a third of their pay on the last Suturday of every month, and full settlement is malv twice a yesir. They are supplied with clothing and other uecessuries, ont of which the ngent sualies a per centage, and which is chorged ngainst their wages.

There is one admirable regulation of the Clilian goverument, that of not permitting liquers to be brought wirlin a bengue of any mine, under a severe petsity, which is strietly enforced. The cost of itue ianistenasee of ench workman is not great; they are allowed as rations for breakfast four handfuls of dried figs, and the same of whinuts : value about three cents. Fur dinner they have bread, and fresh beef or pork. Sisall stores, as sugar and ten, they find themselves. One of the rreatese inconveniences, and which is attended with sone expense, is the supply of the miners with water, which has to be brought up the mours. taint.

The niners' huts are the last dweltings on the Crilian side of the Audes. Mr. Aluersun mentimed, that in five hours' rido from thenee, a lake way reported to exist, three lengues in cireum. ference, on the summit of a couteal mountain, which is surrounded by a beach of sand and gravel, and has no outlet. Several persons confirmed this stutement as to the uxistcnce of the lake, that it bad no visible outlet, and that the water was always at the same level. Althouglt desirous of visiting so interesting \& spot, they found they las not time left to aceomplislt it.

On the 22nd they set out on their return, after a 
good deal of delay, owing to the stupulity of their jeens, who had indulged too mueh in lis favourite chicha. Nothing, it is proper to add, could exceed the kindness and attention shown them by Mr. Newman, his lady, and Mr. Clase, Mr. Alterson, the agent, devoted himself to them for two diyy, during whiest time he left notling undone that esuld premote and furwarl the object of their visit. It affurds mo groat pleasure to bear testimnny niso to the numeruus tine specimens of corper, \&e., frum other nimes, which Mr. Newnen prosented to the Expedition, and to return him our tbasks for them, and the kind attention of his lndy.

Having hearil mued ahont the rise of the erast, from the effects of oarthquakes, I was desirous of gaining alt the information in refation to this sulyject. Frvm the residents the aceounts are so conirudictory, that no eorrect intelligence can the oh. thitued. "The decrease in the depth of the bay, I have before gaid, ean be necounted for, and un. doubtedly is owing, go far as it has taken place, to the wash of the hills; and the formation of a new street whteh has been reclaimed from the bay, has given rise to the iden, and it is pointed out as having been built upon ground left dry by the earthuguake of 1 10332. Sereml of our natumalists made a close exuminations of the const in the neighbourhood, the result of which on the minds of all wrs, that there was no pronf of elevation. I'hat thanges in the beaches, throught the agency of the heavy rullers and the northers that yearly vecur, are constuntly going on, is quite evictent ; but these, as one would naturally suppose, increase the shure only in some places, while in others they are wexring it awsy.

Earthquakes do not appenr to happen at any particular seasun. The grent one of 1730 was in Jaly ; that of $175 \mathrm{l}$, in Mny"; and those of 1822 and 1835, both of which did much damage, in February.

Slight shocke of earthquake are experienced very frequently cluroughout Chili. One during cur stay, on the 28th of May, started every one from their beds, but the slioek was not repented. No peculiar state of the wather, or ather phenomenon, seems to precede them. That of 1835 nenrly destroyed she townt of Conception, Tulcahtana, Arauco, Angeles, Coluna, Chillian, Talea, and Cauquenes. It was rery slightly folt in Valparaiso, and senrely at all further morth. T'lie sea receded in Valparniso two feet, and returned immediately. 'The ground geemed to swell under the feet. In Jurn Femandez it was very geverely felt; ard the following extract fron tho report of the then governor of this island to the supreme government is interesting: "I was walking at tho enstle of Santa Bar- bara, with the commandant of the garrieon, wlwen we suddenly obrerved that the sen had come over the mole. Fenring great damage, J hastened to have the bonts dmwn from under $n$ ahed, and pre. pared for use. At the same moment we heard a loud roaring, as of thunder, and eaw a white eolumn, like smoke, rise from the sea, a short distance from the place called " I Pumto de Bacalloro," mud then felt the enrth move. Tlie sea retired ahout two hundred feet, when it commoneed returaitag with grent violence. 'This time it earried nearly every thing with it; broke down all the housas and huts but the one recently bailt of stone and mortar to contnin provisions. Happily, this withstord its violenee, although the water noowled move than six feet nip its sides. It then retited again to its usual height. Coustant shocks were felt during the night ; and the sen, at the place before mentioned, continued throwing up water and smoke like a volesius,"

Chili ahounds with volesnic monstains, but few of thein are in an active state of eruption; which may acenut for the frequesicy of enrthquakes, The peak of 'Tupongati is the only one in activity in this section. Our travellers to the Corditleras were not forturate eunugh to get a sight of it at night.

The population of Chili may be estimated at one million two handred thasand.

Sautiago contains abont sixty thousand ishabitants, and is one of the few South American capitals, perhans the only one, that is incrensing in wealth and population. It has various private semiraries fur looth soxes, a mational institute or college, on a liberal fouting, an extensive hospitnl, a medical college, aud a military academy. The Congress meets on the Ist of June every yenr, when the President delivers his message.

Valpmaraiso numbers thirty thousand intubitsnts, and is one of the most flourishing gen-parts in the world. Its population has quintupled wjthin the lnst twenty years, and it is rnpidly advanving in overy inprovement, growing out of an incrensing foreign commerce, and the enterprise of jto juha bitants, fustered and encounged as they are by goverament.

The mining districts are to the north, aud the gtain country to the south. Extersive Hour-nills are now in work in Concession and its neighbourhood: the machinery is brought from the United States.

There is wery little vuriation in the elimate. During, what is ealled the winter the thermometer oecssionally falls for a fuw huury to $52^{\circ}$, but the menn of it throughout the year, at uid-dny, would loe $60^{\circ}$. In the evening and moming; it is at 60. 


\begin{tabular}{|c|c|c|}
\hline $\begin{array}{l}\text { Porpolse uals. - Cool indifference of a } \\
\text { muster of a Hamburgh barque, }\end{array}$ & PETLU. & $\begin{array}{l}\text { Houturgun Puesage passed. } \\
\text { Determimallut ta aend the Kelief labine. }\end{array}$ \\
\hline
\end{tabular}

CHAPTER VIII.

PERU.

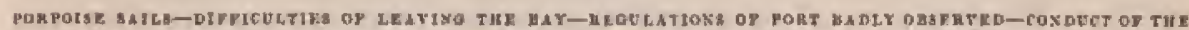
CAPTALY OY HS

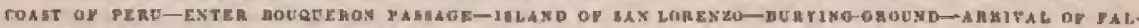

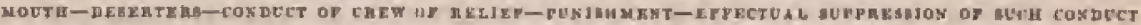

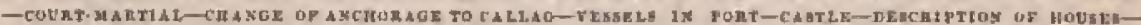

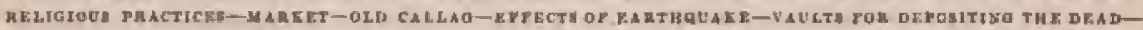

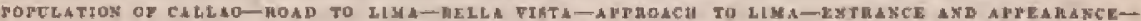

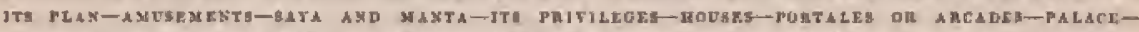

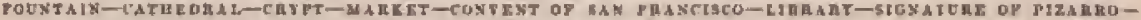
CLASEE or XATง

Ox the 3ath of May 1830, the Porpoise eniled for Callao, in surder that Bone repairs might be made on lier, which our timo here did not adruit of. At Valparaiso the weather was extremely unfavouralite for astrunemical olsservations, I lind been in great hopes of being shle to obtain a Beries of thnon euluinating stars aud occultations, but no opportmity oceurred, so that I had to content myself with shose for rating the eluronometer. and to cannect this port with Callso. Tho tongitude adupted for Fort Snn Antonio, was $71^{\circ} 39^{\prime}$ $20^{\prime \prime} \mathrm{W}_{\text {., }}$ which is the last determination of it by hing and Fitzroy".

On the thl of June we made an sttempt to get out of the thas, but were obliged ngmin to enst anehor. At this sanson of the year, light northerly wimls usually prevail, and a henry awell frequenly sets in the hay, making the rondstend very unconfortnble, and at times dangerous, The vessels are wo much erowded, and the regulations of the port are not sufficiently atremded to.

I was not a little anused with the master of a Hamburgh barque, who dropped his anchor so as to foul the berth of my slip, and when he brought uf, swung cluse alongside. He seetued perfectly satisfied with bis situation, and apparenty knew little about lia business, showing all the dogredness of hid comutrimen. The werther louking tlireatening, I sent lin word to shove, stating that in cnse of a clatuge of wind, lie would be greasly is. juted. Ho quictly replied that lis vessel was made of teak, and thut his underwriters or my government would pro lis damages, and that he could gtand a goud ideal of grinding! Witlsout more ado, I sent nin officer and nen, sind put hin at once vut of my way.

Oin the 6th, we had a breeze from the southwarl aud enstward, and intmedintely got under way with tho syumlron, and surceeded in making an offing. AB we opened the land to the sonthward, uny view and thoughts wandered in that direction, Jopiug that still, and at the last moment, the missing tender might lieave in sight. But no white speck wus seer, nor any thing ilrat could enuse a ray of hope that slie might yet the in existence; utid $\mathrm{my}$ festrs forebuded what has sinee proved too truc, - whe and lier crew bad periolsed.

On the second day after leaving Valparaiso, we had a fresh grle from the north ward, aceompanied with much seu. During the night, in thick weatle $r_{3}$ we lost sight of the Pencuck and Flying-Fish. On the 9th we got beyond the wind, which blows along the conat from the northward, and our weather ims. proved, exelianging fog, rain, mist, and contrary winds, for clear weather, and winds from the souttswest.

Ois the 20th, in the evening, we passet throuth the Boujueroi Passage, liaving gut several custs of the lead in three and a quarter fathoms water ; and by the assistanee of the lights of the other ves. sels, anchored near the rest of the squadion at San Loreuzo, after a passage of thirteen days. We found them sll well, and jroceding rajidy with their rejuirs. The Peacok and Flying-Fish nirived two day's beforo us.

On receiving the reports of the commsnders of the diffurent vessels, active operntions were at once begun to refit, replenish our stores, and comylete our dunieg, The neectisary changes in officens and men were nade, in consequcnee of my determination to send the Relief bome. This I resolved to do on several accounts. I have stated that from the first I fonud her ill-adapted to the service; ber sailing I saw wutd retard all ny operations, and be a constant mource of anxiefy to me; and I felt that I already had objects enougls without her to occupy and engross my attention. The expense was unother consideration, which I conceived mysolf ursautliorized to suljyect the government to, particularly as I found on ealculation, that for one-tenth of the sum it would cost to beep her, I could setid our stores and provisions to any part of the Pacifie.

We found it neceseary to hase the Relief smoked, in order to destroy she rats witl which she was infested, th save our storus from further damage. During this time the repaity of llue Porpuise lad been complytenl, nud the usual observitions for rating our elnonotneters, and with the magnetie inetruments, were male on shore; and such ofthers as could be spared allowed to visit Lima. The naturalists wero also busy in their several depurtments, We remined at San Iorenzo ten days, during which time its three highest points were measured with batometers at the entne time. Tlie result gnve eight hundred and ninety-six leet for the southern, nine lundred and awenty for the middle, and twelvo liumbed and eiglity-four for the northern summit. Upon the latter the clouls gentrally rest, and it is the only place on the istaud whire regetation is enabled to exist. The othera 


\section{Ialanal of Ban Loremzo, - Condurt of erew

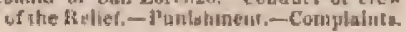

are all barren sandy hills, It is said that the only plant which has beer cultivated is the portato, aud thut only on the north perak. 'T'lis becounes possible there from the suvisture of the clouds, and their shistling it from the loot sun.

The gevlogical strueture of the island is principally cotnposed of linestone, clay, and slate, It presents a beautiful otrntification. Gypartm is found in some places between the sisala, aud crystals of seletite are nuet with in one os two loealities. Qumutites of shedl-fikl are found on the sliore, and the watem abound with exeellent tish.

The buryiagy-grotund is the only object of interest here. The graves nre envered with white shells, and a white buard, ou which is inseribed tho unme, \&e. They appear to be mustly of Englishmen and Anericatis, and it would seem that the mortality had beeu great. But when one comes to consider the large number of men-of-war wluich have been lying in the bay, and the period of time elapsed, the number of interments do not secun large.

It was with much pleasure we greeted the arrival of the Fin nouth, Captuin M'kiecver, whoue kinduess is supplying our wants, aud forwnteling our opesntiuns, we ngain experienced. The exscutial and timely aid he gave me, in exchanging the launch and first cutter of his ship', for materials to britd one, which 1 lad brought from Valparaiso for that purpose, preveluted our detention here.

The Falmouth brought from Yalparaiso tlireo deserters from the squadron, who lad been appreJended by Lieutenant Craven, and from whom I received a report, stating that two of then, Blake and Lester, land been guilty not unly of desertion, but that theil deaertions lad been attended witl very aggravated circumstunces. Just about this tine thw sturs wero deliveriug from the Relief. A ruong thesi wha a quaneity of whiskey for the other ressels. The matines who wers placed on duty over the spirit-room as gatur, with six persons employed in moving ih got drank by stealing the lijuor, and her whole crew became riotous. The deliunuents were ordered on board my ship in confinement These were court-martinl ofleucus, but tho duties of the squardron would not permit me to oriler a court tor their trial, without great Jiss of time and detriment tu the service. To lot Bnch offences pass with the cordinary punishment of twelve Lashes, would have been in tht eyes of the erew to havo overlooked their crime nltogether. I was, therefore, compelfed, is order to preserve urder and gool disciplive, to inflict what I deemed a proper pumishment, and ordered them each to receive twenty-four lashes, excepting Blako and Luster, who received thirty-six and forty-one. This was awarding to eseh abunt one-tenth of what a court-martial would have inflicted; yet it was such an example as thoroughly convineod tho men that they eonld not offend with inptumity. This was, I an well tatisfied, conwerded at the time as little or no ptusishnent for the erimes of which they had been guilty; but I felt satisfied that the prompt and decided manner in which it was administered, would linvo tho desired effect of preserving tho proper discipline, and preventing its reurrence. In this I was not disappointed. I should not have nunde this statemest, hind it not been sluat this was the sole charge, out of eleven, spread out into thirty-six specifientions, un which a court of thirtecn members, alter an invealigation of tluree weeks, could fiud I had transgressed the Jaw of the rusy in the sunllest degree. In justilicution of my cuturse on this secasion, I could not but believe that the following clnuse of my instructions from the Hon. J, K. Pataling, secretary of the navy, ought to have sufficed: "In the prosecution of these long and devious roynges, you will neeesstrily be placed in situations which cannot be anticipated, and in which sonetimes your own judgment and discresion, and at etlers necessity, unnst he your gnide." Under this I seted. I nm fully entisthed ulat in this catse cirvunstntsees tid oecur, which in the lauguage of my instruetions dii nuke "necessity my guide", and I fully beliere that in so doing I promoted the oljects of the expedition, the honour of the nary, and the glory of the country:

On the soth of June, she squadron went over to Cillaw.

'The bay of Callao is ton wall known to require much to be said of it. The clinate, combined with the prevailing winds, make it a line larbour. The islatsd of San Lorenzo protucts it on the west from the swell of the ocean, but its northern side is entirely exposed; there is no danger to be apprelentled from that quarter. A few miles to the north the influence of San Lorenzo ceases; the surf there treaks very liearily upen the boach, and prevents any lasding.

Tlie gradual inanner in which the extensive phia rises from Calla towards Lina, seetns to give a very erronems iden of the stuntion of the city. From the bay it is seen quite distinetly, about six miles dis/ant, aud does not appesur to be elevisted; yet I measured the height of Mr. Bartlett's honse shove the level of the sea ly" sympiesunuter, and found it four lundred sud twenty feet. The rise would he scureely perceptible to a stranget prussing over the road, or one who had not a proctised cye.

Since my visit to Caltino in $182 \mathrm{t}$, it had much altered, and for the better, uotwichstadiag the vicissitudes it has gone through since that time. A fine mole has been erected, surronnded by an irorr railing. On it is a guard-house, with soldiers lounging about, and some two or three on gutul.

The mole affords every convelience for lituding frrm small veesels and boats. T'ho streets of Cailno have been mado nueb wider, and the town hos a more decent appearnace. Water is conducted frum the canal to the mole, and $₫$ railway takes the yoods to the fortress, which is now enaverted into a depot. This jlace, the sen-port of Lima, nust be one of the kreat resurts of slipping, not only for its sufety, but for the convenience of providing supplies. TJie best Wea of its trade will be formued frots the number of vessels that frequeat it. I havo understuod that there is generally about the smme number as wo tound in port, namely, forty-\{wo, dine of which were ahpos of war: tive Antrican, two French, one Chilian, and thirty-five Peruvian merehntmen, large and small.

The eastle of Callno has become celebrated in history, aud las Jong been the bey of Гeru. Whicherer party had it in possession, were considered as the possessors of the country. It is now converted to a better use, viz. thine of a custonibouse, and is acarly dismantled. Only five of its guns remuin, wat of ono lundred and forty॰five, which it is suid to lave nounced. During our visit 
there the Chilian troops hat possension of the cunntry, which they had lield sinee the battle of Yungai, Mlost of the buildings are uxdergaistg repairs sizeo the late contest.

It is said that the fortress is to be demolissied, and thus the peace of Callino will in a great tneasure be secured.

The principal street of Callno runs parallel witl the bay. There are a few tuleralily well-built two story touses on the man atreet, which is paved. These houseg are brilt of alobes, and have flat roofs, which is no itronvessience here, in eonee. querse of the absence of lueary mins, The intorior of the houses is of the emmnirutest kind of work. "The partition wallo are built of eane, elosely laced tugether. T'lie houses of the sommon people are of one whory, asu] abont ten [uet high; some of tham have a grapen window, but mist of them only a dnorway sud one roum, Others nre seen shat hardly deserve the lame of lunsen, being nolling more than intul walls, witts holes covored with a Inat, nol the satme overliesd.

The ontskil'ts of Callao desorre mentioning only for their excesgivo filth; and wern it sat fin the fist? elinute it would be the lut-Ired of pestilenee, Ouw feele glad to escape from this neightourtsond.

The dotations to the elergy or priests, at two small clapeln, are collected on Saturdays fmon the inlabitants. On the evering of the kaine day, the

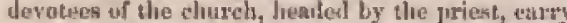
a gnadl prortahle altar through the alreets, decorated

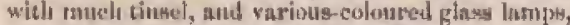
va which is a rude painting of the Virgin. As they walk, they chant their prayers.

The narket, though there is nothing else remarkatsle alout it, exlibitas mony of the peenlia custorns of the country. It is beld in a Bipare of about one and a Laalf acres. The btands for selling mest are placel indiscriminately, or without order. Beef is sold for from four to six eeuts the pound, is eut in the direction of jts fibre, and looks filthy, It is hilherd on the commons, nond the hide, hend, and loorne are left for tho lunzardh and dinge. The rest is Jrought to market on the backs of donkeys Clichens are cut up to stut purchasers. Fibls and vegolaliles are abumlatu, and of good linds, and fuod fruit may be lud if bespoken. In this case it is lirauglat frim Lins. Every sling confirus, m Inutitug, the truth of the geogrnphical adage, "It bert it scver rains," It ajpenss every whore dusty asod parclied up.

'I"he situntion of old Callo is still visible under the water, and though an interestime olject, besatures a melatudioly none, when ane thinks of the havoe a few misutes effecter. The very foundation seems to have been upturned and shaken to picees, and the whole subraerged by a mighty wave. The womder is that any otre escaped to tell the trile.

T'wo crasses mark the height to which the eea rose. The upper one, one-third of the way to Limn, indieates the extreme distanee to which the water thwed; tho lower ore marks the place whither the Spanial frigate wus carried. I very much doulut the truth of either. I can ensily conceive that a great wave sould be sutheitent to earry a large vessel from her moorings half a mile inland, but I rannot inagine how the wator sluuld have reached the beight of ore hundred and fifty feet. at least uhave the levet of the sen, ars! yet jermitted two handred inhubisants of old Cullas to have esseaped on the walls of a church which are not half that height.

Ouvide the walls of the fortress are several large raults, filled with the kleat, in all stages of decen, and nit which thp rtilures were gorging thetnselves: this was a revolting spectarle. Indeed. it is truly surprising llat the highe1 elnsses, and those in immediate ststhority, sloould not feel the necessity of appenring more eivilized in the dispssition of their dean. Many are throwa in nakel, anil covered only with a few inches of kand. Grent numbers of akeletons are still men with pieces of elnthing longing to thetn. Diggs snd vulkures in great numbers wore every whero feoling upon the dead, or atanding aloof fairly gorged with their disgusting repast. If any ling is ealculated to raske a people brutal, and to prevent the inculeation of propher feeling, it it stselt revolumg eights as these.

Callan is said to contain between two and throe thousand intubilatso, but lits number, from the appearance of the place, вeens to be overrated. Severnl jew buildings are going up, which prover, that matwitlostanding the times of revolution, they still persins in esrying on impovements. The prineipml street is atout a third of a injle in length, and in tolembly well pared, with aide-walks. Bil. liarel-sigos stare you in the fnce. 'This, ] presume, may" be get down ax lie greas amusement, to whieh may be sdded the fuvourite monte at night.

Conches, or mither omnibuses, run several times a day to Lint. The old necusuts of mobberies ou the road to Limm, aro still fresla in the mouthes of strangors. In times of revolution it was infesterl by roblers, but the ateps taken by governsment lasve eflectually put a stop to them.

On the roud to Linn is Bella Vistn; but it is is ruina, and tas been so ever sine the revolution. It was generally the outpost ur battle-ground of the twn parties, and allough the soil in the filsin which bostess the sea it extrembly fertile, consist. ing of derrmunosed rock, contuining the elements of fertility in the greatest alduzutnee, it now appehrs a neglected waste. Attention to its cultivation nat irrigation would make it n juellect gardell. On Aprurouching Linat, the gardens and fields are found to be cultivated and well irrigated. Fields of Indian cors are sces, sume fully sipe, snme ludfogrowil, and otjers just shooting ip, - a novel sight to us. This henrs testimony not only to the fineness of the climnte, but to the fertility of the soil. The gurdens near the eity are filled to frofusion with fruits of all deseriptions.

The road, on its near approach to the city, forms an avenue of about a tnile in fength. This, in its prosperous days, was the usual evetirig drive, and afforded $\mathrm{a}$ mist agrceable one. On each sille ute gardens filled with orange-trees, the fragrance of whose flowers, and the benuty and variety of tho fruit, added to its plensures, It is now going to deeny from utter negleet. It rows of willows, nnd the streams of running water on ench side, though forming its grent sttraction, will, if suffered to remain without attention, he cosnpletely destruyed. No one seems to take interest in the public works. Sis marked a difference from Clili could not but be observed.

At Limu I was struck with the eloange that had taken place since noy former visit. Every thing nuw betokens fowerty and decay; a sal clmnge 
from its former oplentur mud weathls. "l'his appearance was observed not only in the city, but also among the inlinbitants. Whole families lave been sweph off, and their furmer nttendasts, ov strangers, liare becime the pussessors of their houses and property.

The exuntry las lieen a gcese of eorumotion and revolution for the last twenty-five yours, of which Lima for a long time wrs the contre. T'loe fate of Lower Peru being entirely dependent on it, ant the fortress of Callas, the nitemute russessors have striper it and its inloabitants in every way in their power. It may with trtuth be derighated a declining city.

The negleeted walls anil ruined tenements, the want of stir and life among the penple, are sad evidences of this decay. The population is now said to be about forty-five thousand, although in former times it has been supposed to amuunt to as many as sixty-five or geventy thusand.

The aspect of the city, esplecialty a hird's-eye vitw frum the neighbutring hills, gives to the ave of the strmnger the appearance of ruins. I'liere are few buidings that laste the look of durability, and no new ates have leen put up for the las: forty years. The plan of the eity conalines more nuvan. tage than Ruy other that esuld lunve hees adopted for the bocality. The streeta are at right anglis, and all suftheiently broad. Thusu: which russ wizh the declivity of the groumd, nortl.west sund soutlyeast, hare water flowing through thrir tridlle. 'Pling nes to which these streame nre put, and tho muncrous buzzards that frequent them, give the atranger any other idea than that of eleanliness. The buzzards are protecterl by law, and rany be seen fighting for their ford in tite gntters, regardless of passers; or sitting on the topse of the houses, thirty or forty in a ruw, watching for moru food.

Great attention lıs been pail to laying out the alameda, which is on the north side of the city. Its centre is orramented witl n number of foniltaits ; its walks are well slindesl on ench side with trees; and the running water ndits to it- fresliness: all urite to form a deligheful prousenade. In tho conl' of the evenisug it is mueh frequented, sud its ktone soats are nctujnird by numbers of citizens. 'This is the lyest phee to get a yiew of the inlsabitants; and notwjtlistandiug llieir internal commo. tions, shey apmest fully to enjoy their cigaritas, which they ave combinntly moking. T'lue peenlinr dreas of the ladies is lure seen thi the beat advaltage, and, however titled it may be to cover intrigne, is nut, certainly, adnpted to the display of bennty. A more awliwird and absurd dress eannot well be conceivert. It is by no means indieative of the wenrer's mok, for frequently this disguise is ragged and tattered, and assumed under its most forbilding aspect to deceive, or earry on an intrigite, of whieh it is almost an effectual cloak.

I never could behold these dresieg withort considering them as an emblem of the wretehed conditiun of domestic society in this far-famed city.

The asyn and manto were originally intended as a retiring, mudest dress, to mark reserve, to insure seclusion, and to emable ladies to go sbroad without an eseort. The genetal term for the wearers is Tapmiln, and they were nways held sacred frum ingult. Trpala is likewise appolied to a drese which is also frequentiy seen, viz. $\mathrm{B}$ shawl wurn over the hend, so as (1) (u) ver the unse, nunth, and foreheas. None but the most insiusate friend en knuw the wertess, who frequent the sheatres in this disguise. It is to be regretted, llat it is now warn for very different purposes from ith original intertivis. Intrigucs of all kinds are asid tu be courted on unter it. It ermblyes the wearer to mix in all sucietion, fand to frequent any place of amusement, without being known, and, pven if suspected hy her hustsand or relativen, the law of cuatum would protect her from discovery. In this drees, it is said, a wife will puss her owr hushand whet she mny be walking with her lover, and the husband may nuthe love to his wife, without being aware it is she,

The kays is as sille petticoat, with mumetoss smalt vertienl flaits, contuining about thirty yards of sillk, and ensting fifty or sixty dollars, it iy drawn in close at the bottom of the duess, sil that the wenrer is olhligerd to mako very short steps (ten inches). It is a little clastie, and confurma to the shape, whether natural or artificial, from the waist down. The mante is a kind of clonk, of black silk. It is fastened to the sayn at the waiat, and brought over the head and shoulders from lovbind, cunceal. tug every thing but one eye, and one lsand, in which is uxually seen a cross, or whinge firgers are wett orrummented with jewuls. Before the mautu is arrnged, a French flaw of bright colours is thrown over the shoulders, and brought between the opeuings of the manto is front, langing down nearly" to the feet. "Jlie linse says is also much worn: this is not cuminteted at tho battom, ast in walking has a grent swing frun bide to side.

Iriso walk of the Linn ladies is graceful and pretty, and they usabaliy have small feet and hands.

The houses are buile of stm-burnt brick, entue, and small timber. All those of the bether clase have smatl baleonies to the secund story. Most of the houses are of two stories, and they generally have an ureliway from the street, secured by a strong prortal, lending into an open court. The lower, or ground-flour, is used Hs storthonses, stablea, sc. This peculats nanzer of buidding is intended ns a security against the effeets of earth. quakes, "The honsetops are a depository for alt kinds of rubbisl, and the necumulation of dust is great. The staircase lending to the upper story is gentrally landsome, and decurnted wilh freseo paintings, which nre, however, far below ruedioerity. Tlis style of building is well adspted to the clininate.

I'he priales or arcades is ane of the must attructive pluces fur the stranger. He is there sure at all honrs to sce more of life in Lima than at any other place. They aro built on two kides of the pinz. The groumbl-foner is necupied as shops, where alt kinkls of dry gandw sond funcy articles are sold. Betweers the colnums, next the pluzn, are many lace and fringe-workers; nul withont these aguin nre sundry cooks, fresco-sellers, \&c, who are frying ancoury enkes and fiah for their ens. tomers, particulnrly in the morning and late in the evening.

The arcaden are about five hundred feet long, well pared with cmall otones, interhid with the knuckle-bones of sheep, which produces a kind of musaic pavement, and makes knuwn the date of its being linid down as 1799. This phee for hours every day is the great resnrt, and one has a full insightit to every store, as they are all doom, and 
conacquently quite exposed, to their rumotest corver. The second story is oceupied as dwelling:t.

The palace of the viceroy occupies the north side of the plazs. The lower part of it is a row of smail shops, prineipally tiokers and smallwaredealors. On the enst side is the archbishop's [anlace and the cathedrat.

The foutrtain in the centre of the plazn is a fine piece of wurk, and was erected, aceording to the juscription, in 1600 , by Don Garcia Sartiento Sotonayer, the vieeroy and eaptain-genemal of the kingdom.

"El que bebe de la pila sequenda in Lima," is the usual saying.

"He that drinks of the fountain will not leave Lima."

The cathedral is a rentarkable builling, not only from its eize, hut its ornmments. Mlost of the decroracions are in bad taste, aud I shonld imagino its former riches in the metals and precious stones lave eontributed chiofly to its celebrity. Certaisly those ornaments which are loft canune be much almired.

Its great altar, contposed of silver, might as well be of lead, or pewter, for all tho show it inakes. In a chapel on one sitle of the building, there is a eollection of portmits of the archbisthops. I"Yey are good faces, welt painted, and all are there but the sne who, at the brenking sut of the resnlution, prosed faithful to lis soveteiga and the Spanish cause. They all have had the honour, except him, to be interred in niches, in the eryjt, under the great altar. Many of the enflins are npen, exposing the dried-nip remains of the saints, clothed in leather jnckets and shoes, which the sacristan nade no difficulty about disposing of for a trifle. Two ekults and a hand were abtained. There is sotne good carving about the chisir of the cathedrul.

The masket of Lima is kejul in an open squase. It is a strange plnee to visit, and the secne that is wittessed there etunnot fail to amuse the stranger. It is well supplied, and many purehasets freguent it. There are no stalls, and mats are used in their stead. The ment is lait on them in rows, and the verutables lieaped up in piles. The ment, as at Callao, is cut with the grais, and into sna!l pieces, to suit the purcliaseres; and poultry is cut up in a dimilar mauner. But wlat will most attraet $n$ stranger's notice, are the cooking estrblishments. These are in great request; stows, fries, and wha pudridus, are in constant jreparation by some traway dnme, who deals out, with tuucls gravity and a business-like nir, the small pieces to the hungry Indians who stand by waiting for their turn. The fried dishes secmed to claim their preference, if one could judge ly tho number in waiting. The expertness of tho woman who of ficinted was truly wonlerful, twisting and twirling the dough in her liand, placing it upon a stick, dipping it in the hot oil, and slipping it as soon as cooked dexterously into the dish for her curs. tomerg. Then agait was a frier of pancakes close by, equally expert. 'The variety of Jishes enoking was surprising, and those who fried fish exhibited undoubted proofs of their freshness, by consigning them to the pan before they ceased to live.

I was surprised at the variety of fish, meats, vegetabjes, and fruils; the latter particularly. These were in season, and included oranges, cheri- moyers, poungrauntes, paltas, planuisı, bamuns,

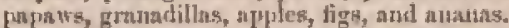

The above are the ustal artieles crowded into the market, but were I to stop here, anc-lualf wonld rost he told. All sorts of gourds, jewelry, cottons, woollens, laces, hardware, linen faluries, handkereliefs, shoes, slippers, hats, ke, nure hawked ubout hy pedlers with stentorian lungs, who, with the tottery-venders, with tickets, ink-horb, snt pen, selling the tickets in the name of the Holy Virgin and all the atints, make an uprose that one can have little ildes of, without mixing in or wit. vessing it.

The couvent of San Francisen occupies six or seven acres of ground. In its days of prosjerity it must lave been a nuagnifietrot establislument. liy chapels are very rich in gilding, earved work, \& c.. and the cloisters are ornameuted with beautiful fourntaius anu fower-gardeng. Part of it is now occupied by the soliticrs ns barracks, and theis musliets are stacked on the altar of 0120 of its elsapels. It lans long since becan striptiped of its riotuen and deserted, lut it seems one to liave fros. sesserl all that wealth, luxury, and taste could eflect or suggest. The good Fnther Anculus, who showed the builling, was blirewrl and obliging. The endlery of paijutings erontaing, it is enid, many fine Murillos. The remains of its former splentour, eren now, justifies what Father Fetillee assitrted, that there wss nothing of the kind to corrupare with it in Europe, There nre but few friars here at present, but it is said to hnre formerly maintained thve lundred, living in the grentest lnxury sul licentiousness. "The most remalkahle object in the churel, was the slixisve nad image of a black Virgin Mary, witf a wlite infant Saviour in her nruns.

The pmblic likrary is composed of rare and valunble broks, both in Fremeh and Sparish, taken from the Jesuits' enillege and conventi. They are in good order, and smong them are many manuseripts which are beavtifully illuminateal. The lilırarian, a young priest, deserves our tlasuks for Һis attention and civility.

The fublic museum hag been but lately cornmeneed. It comtaina a collection of curioils Peruvian antiquities, gome untive hixds, and the portmits of nil the vicuroys, from Pizarro down. At the entildos or city tull, are to loe serzo some of the arehiver of liusa, kejt until reently ju goont order. Many eignatures of the old riceroys and governors are curious; among others, that of Pizarzo is show.. As few of theth could write, thing adopted the rubricu, mate hy placing the fonger of the left hand and making the fourist on ench side of it, the clerk filling in the แame. I'his metion has sined been penerally aropied anuong the Suth Amerienns, in signing ofteinl doenuents, being conticlered full $\mathrm{ns}$ binding as if the name was written.

There are three classes of inhabitants, viz, whites, Indians, and negroes. The union of the two first produces the cliolo; of the two last, the zantro: and of the first and last, the mulatto. The Sipaniards, or whites, are a tall race, purticularly the females. They have brown complexions, but ocensionaly a brilliant colour, black lair and eyes. Some of them are extremely beautifol. The cholos are shorter, but well made, and liave particularly small fect and lands. All classes of people aro addieted to the smoking of cignrs, even in ear. 


50 Population of Pera.-Newspapers. PERU.
Earthquakes at Lima.

riages and at the dinner-tuble. It dich not seens to be eonsitlered his any oue as unplensant, and foreigners linve atopted ilie custom.

There does nut apjear tu exist any aceurate account of the population of Peru; lut it is gene-

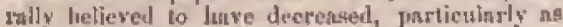
regaids the whited nut negroes. The betet informatiul gives but fittle over a million inhathitants, viz. nbout one hundred and iwenty-five tlinusnnt whitea; natives and eholos, vigtht husdred thousand; with ninety thousand negroes and ranchos, of whom about thirty-five thotasand are slaves. This does sot vary much from tho number given by the geom graphine forty yenss ago. The country appeare, from all atuonnts, not only to linwe decreased in populution, but to have diminished in wealts ant prouluetiveness. A mucl less proportion of the snil is now eulitsated than formerly usider the "elildren of thre sull."

There are lalf a dozen newspapers pullished in Lima, two of which are issued daily. They are, like the Spanish, small sheets Ther lave a good leal of currtrol over public opinion, Few or no ad. vestlisements ure snen in then. These are deemed umecesenry in Limn, and all the amosements, such as the thentre, cuckeffighting, is., aro placartied on the purtale, A light yrice is asked for the newgрарегs.

Host of the buildings in Lima have suffered more or less from eartinquakes. It was the senson of earthinkes during onr stny, and thres were felt. Some of our gentemen complained of a sickening sensation during the first. It did not, however, do much damage. The seeond tork place on the stl: of June, and was apnejbly felt ; A third was experienced on the 10th of June, with a continued shaking of the walls and flours. Tho last was reported as having been more severe to the north. trard.

With the nome of Peru the want of moikture is generally associated. The general impression is liat it never mins there. This, however, is far frum being strictly true, except in certain parts of it. Were it not, however, for irrigation by the mountain streams, a grent portion of Peru would certainly become nenrly a desert. Indeed, the upland is so now, not vielding any herbage whatever until the pastare region of the Cordilletas is renclsed. We are not to imagine, however, that the atmos. plyere is very elear, or that sunshine always jur. vails. It in extrencly difficult to get a clear day. Father Fetiillee has put upon record, more than a century ago, that the hessen were genenily obscured. I can bear testimony to the truth of this renurk, for athough a glimpere of the sun was asually had some time during the day; yet it was almomt us diffieult to get equal altítudes at Caltao dlaring our stny as it was at Terma del Fitego.

Tlie dew (ulmozu) of Lima is never ser great as to proulue running water, yet is is lowore like rain tlian a Seoteh mist.

The peetiliarity of there being no min, lias been nccounted for in severnl way, but not to me sat isfactorily. The prevailing cohi aud rlry wimls frum the routliward sweegy urer the western shoren of the continent; having a grat capacity for movalure, they absorb it as they adrance tu the nortlıwarl, from esery thing. On resteling the latitude of $12^{\circ}$ S., they cense, and having luecone arturated, now rise to a sufficient lieiglit, where thoy are condensed by the cold stratn, nand again deposited on the thountains in almost eonstant mins. This wil] secount for the nridity in the high Corvillerus of Chili, as well as fur the existence of the Desert of Atreamn, the want of rain on the coast of Upper Peru; snil at the same time, fur the moisture of the high Cordilleras of Peru, which will be shorty spoken of. It will be remenbered that our pnrtic on the Cordilleran of Chili found the aridity to increase en ascending, to the very edge of the jerpretual snow, and all the plants were of a thoruy cliarneter.

The reendes of Lirsa mention the falling of rain only four times in the eighteenth eentricy, and the oceurrence of thmoder and lightming nn equal uumlice of times. But this applics to a small part of Peru noly, numely, the country bordering the conet, some fifty or sixty miles in width nround Lima. It will be geen that our party who visited the interior when at the height of ton thousand feet, entered a regian subject to rain, nnd on the erest of the momntains the soil was liept perfectly muist by the frequent shows and rain.

Fire is not onel often, hut fon the continual dampnens there is a colit sud elnmmy feeling, that is exceetlingly uncomfortable and prejudieinl to henhth. Lima laas certainly the reputation of being a healthy place- how obsained I know not-but it certainly doey not deserve it. Tho interments bave nnnually averaged over three thongand five lundred, in a population amounting by the best accounts to no more than forty-five thousand. Many of thete dealhs are those of Etrangers, aud the clirnate has always teen fatal to the Indians.

The Rimne derives its waters exelnsively from the snows of the Cordidlerns. It is a mountain tor. rent througlout its whule cunrse. Tho quastity of water in it is stuall. The wilth at is mouth is about thirty feet, and ane foot deep. It lias not sufficient force to lreak a passage slirougl, the beach to the sea, and the water filters through the pebhly siil. 


\title{
CHAPTER IX.
}

\author{
PFRU (CONTBOED).
}

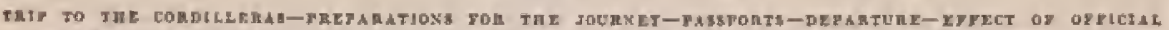

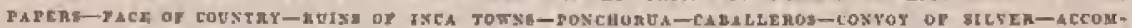

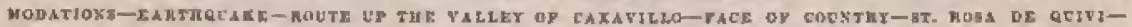

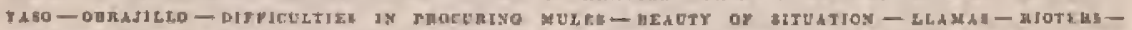

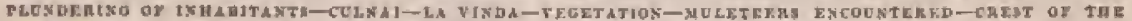

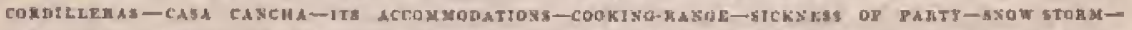

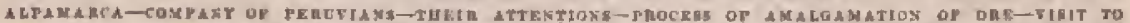

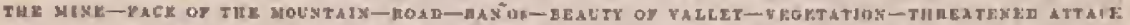

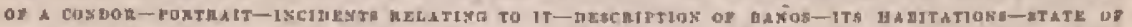

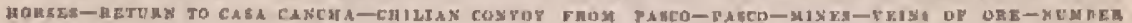

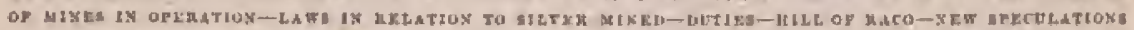

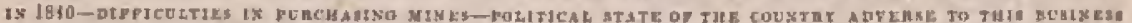

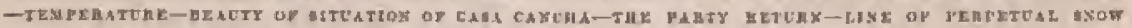

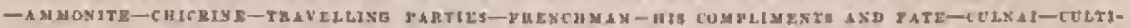

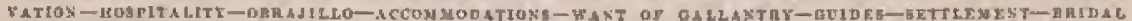

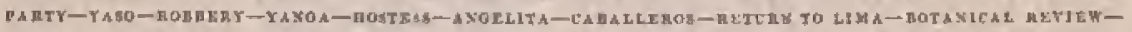

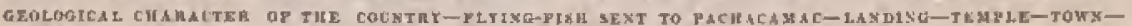

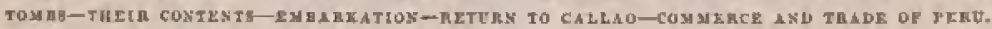

Os the arrival of the Iielief nt Callno, Messro. Picktring, Rich, Agnte, and Brackenridge, requested permission to ank a jaunt to the Curdilletras of Peril, for the purpose of making butaniesl collections. I filt much gratified thet this olject luad been elfected, nlthough I could not but regret that they were suffered to depart without the netessary instruments for obtaining the sititudes, which laad been put on board tho Relief at Orange Harbour, for that very purpose.

Mr. Rich spolie the Spanisli languago well, which afforded the party many facilities for orereoming the difficulies thint were thrown in their way.

In Lima the journey whs considered as a very serious undertaking, and likely to be attended wich much danger, from the handiti who freguent the route they intended to pass orer, - that to the mines of Pasco. 'Througli the friendly assistance of $\mathrm{Mr}$. Liggs, of the loume of Messr. Bnrtlett and $\mathrm{C}_{0}$, every thing was made easy. By his adrice, they supplied themselves, not only with blankets and horse-furniture, but with alt sorts of provisions, and partienlarly with bread, of which they took as much as they could earry, notwithstanding the country was described as well intrabited. As n prelininary step, it was necessary to proride themselves with passpotts, for which they lost no time in apjlying. After the delay of a day, the pasenorts enne in the form of a letter of pritection and res. commendation from Lafuente himself, to the locat authorities throughout all Yera, couched in the most liberni terms, and treating the affair with as much importance as if it were a national one. It is a regu. lation that the names of all who recsire passports slall be published in the ofticinl gazetto; their inter. tim, therefore, bectrrje kuown to all Lima. From the few who are gazetted, it would appear that bat a smalt number travel into the interior, or else that the regulation is not very strictly consplied with.

The injunction to render the party assistance its case of need was Fery strong, and amung otfer things specifiel to bo furuished, was clothing, which was thouglit to look somewhat oninous in this country of banditti. In spite of the pobitive terms in which the passport was expressed, it was found of little clfect in proeuring them mules or lotses; and it was not till after much trouble and disarperintment on many sides, that horses were at last obtained from the post establishment.

On the 16th May they were ready to Bet out, and were necompanied for some uilles by Mr. Ihirgs, whase frierdly advice and assistnnee they hat often, during the jant, reason to be thankful for. It snved them mueh inconvelience, and was the causo of their being proviued with many little comforta, without which they would have suffered privation.

Their proposed route was up the valley of the Rio de Caxarillo, the river next in the nortlward of the Rimac. Leaving Lima, they passed through the suburbs of San Lazaro, at the gate of which, and for the only time during tho journey, they were desired to show their passports. Sorve litule difficulty arose, and an intention wah expressed to unlond the liaggage-mule for examinatiun. Thir, however, was soon removed by the reading of tho phssport, and the exnmination ended in mnyy bowm, and the repeated exchamation, "Go ort, go on 1 God spred you !" Such was the tulismunie effect of an official document at the period of our visit.

After leaving the city, their mute lny alung the margin of the extensive plain that borders on the Eer, at the foot and over the low hills which akirt it. Mnny columne of duat and louse particles of sand were seen ribing from the heated plain, stirred by the action of the witd, forming vortices of con. aidernble dinmeter and elevation. Clouds of smolte, tor, were visible in the dialance, proceeding, according to the information of their guides, from the burning of the cane-turalies. The Peruviam willow; so much resembling the Lasmbnrly pwplar in its firm, was much adnired, fund the contrast in the landseape between the harrva clay-eoloured lills und he bright greet of the irrigated tields was very remarlable. \&. 2 
At the distance of three leagues from Liun, they passed through the ruins of an Inca town, situated (as they uniformly found then afterwards) just on the buriler of the irrigated valley. The walts of the town were rery thick, built of mud and tushurnt brick, at right angles, very much after the modern manner ; the hills also were goen covered with the ruing of Indian buildings, some of theun resembling fortitications.

They now turned up a beatiful valley, on the irrigated fieldy of w]rich were seen herds of horned cakte, horses, anul goata, $n$ proof that the irrigated land is not exclusively used for tillnge,

Ai six lengues from Lima they reached Ponchorun, the first stopring-place; but the party concluded to go a league lreyond it to Cabrileron, where blyey passed the jight. They arrived there in sufficient time to mnke a short excursion to the bauks of the Rio do Caxavillo, which appenurel a larger strean than the Rimac.

Around Caballeros are very extensive mendows and fields of clover. The posada was found oecupied by the guard and muleteers who acted as a convoy of silver from Paseo, They gnve up the only room in the house for our gentlemen, into which they were shown, and whero a gnod supper was provided for then, while the guard took wp their quarters in the yard. The netal, it was observed, was in large masses of piña, sonue of them beary enough to be a load for a mule, and an inconvenient burden to run away with.

They passed the night on the tables and rude seats, under cover, - n luxury they had not yet learned to sppreciate.

At midnight they folt the slook of an enrth. quake. A distant hollow sound was at first beard, which geemed to approach, inereasing rupidly, and before they could spring to their feet, the lonse was rolled and shaken as if it liad been on an ngitated sen. Mr. Rich says that it was with difienlty the conld hold himself on the table where be Ind been lying. The natives of the arljoining huts ran out into the rowd, uttering horrible siaricks, striking their brenste, and offering up parayers to the Iloly Virgin to proteet them. The slsock continued severe for forty seconds, but Jasted altogether about two minutes; it produeed a slight numsea, like ser-bickness, which continued for some time afterwards, and a bewildering sensntion, that rendered it diflicult to collect their jdeas to epeak. The sound resembled that produced by throwing stones over precipices, so as to roll on hollow ground beneath. This earthiquake was the most violent that hat been experieneed for mont tine, and wns folt sensibly at Lima and through all Lower Peru. No material damage was dime,-in consequerce, necording to the people of the country, of its nat getting to the surfice.

Early on the 17ith the party get out up the dry mountain valley, the soil of which is composed of stones and lonso poudery earth. This kind of ground continued for five leagues, with not a drop uf water, nor was a flant or bind collected; nothing wis seen growing but a few tillandsias. On this route they passed many crosses, marking the spots where there had been loss of lifo: a sight that was wot calculated to excite pleasiag thonghts, aud bringing to mind not only the grent number of ruurders that lad tuken place, but the daily oecur- renec of attucks upon small parties of traveljers by the desperaloes of I'err.

Immediately on the contines of this dreary wasto is Yanga, a deserted-looking place, lut liaving some good gardens and orehards, $\Delta$ t noon they renclied Santa Rosa de Quivi, a small place, when they proeured same good frit. After travalling two lengues, they at dark reached Jaso, and stoppel at the puatraster's irouse; he wa not at home, but they were permitted to sleep in the porch or veranda. Nothing edible was to bo found in the village, except a fes potatoes, after supsing on which, duey disposed theneelres on the elay and stones, with their amus ready for service, - a precaution necesuary at times, even in the muat frequented places in Peru.

Duriug the day, they had been much annoyed by eamd-tlies and Aeas; besides these, they had $n$ few musquitues, but the latter aro seldom felt in I'eru.

The serenming of partots duriug the night, had anuounced that some change had tuken place in the vexetation. In the norning they fonted this to be the ease. The land in the vicinity of the town whe cultivated, and some rood orchnrds and fields of clover were seen; the mountains, whieh had hitherto been gray with tiltnndsias, had now assumed a greenish tinge. $\Lambda$ gaves mode thejr appearance lere, and a fow mileg beyond, the hills le. caue entirely green: alf showed that a different region had been entered. The inelined roofs of the huts proved that rains were experienced, and that it was found necessary by tho imhabilants to proteet themselves from them.

Thio valley had now beeonte more contracted, and level ground was selitom seen; the mountaius increased in elevation, the roals and scenery purtaking of the ellaricter of Mateirn. Cancrides were seen springing from almost the very sunmite of the high penks; crulo were graxing, stsd oeensional cultisated patehes were mingled will the pasture-grounds ; the aid of irrigation was no hnger necessary; and the Cordiliern plants of the Flora Pevuviann, with the regetation made known by Hunboldt and Boupland, were recognised. $\Lambda$ now, after travelling six leagues, they renched Obrijillo, the rendezvous of the two celebrated Sparis] botanists, Ruiz and Pryon, authors of the F'lori Peruviana.

There are three tuwn, Obmjilio, Cunta, and San Migtuel, about a mile diatant from each other, said to contain three or four thousand inliabitauts. $\Lambda t$ Oumjillo, the general to whon they had lettery of introduction was not at hozne; some diffieulty is getting mules accurred in consequence, and it was not until mush time and patience had been exhausted, that our gentlenen understood the real difficulty, which wis, that the horses they harl brought from the low eountry, were not considered capable of standing the evid and fatigne of the molsutains, the ownery at Litua having refused to allow their mules to cross the mountains. They were askisted, liowerer, in procuring mules and guriles by the general's son.

Otsajillo, the largest of the three towns, contains nbout ono hundred cottages. It has a stone clurch, with two towers, apparently of some ase, which fronts on the rapen square. The dwellings se of one story, without Hoors, and slmost withont furniture; yet it is anid to be the residence of 
many wealthy people. How ture thia may be, it was imprssible frotn appearances to determine, for tho ligh and low, the rich and the poor, all seem to live in the same style.

I'he difficulties that oceurred in procuring mules for their journey, had delayed them so long, as to place it out of their prower to proceed befune the uext day. Tho opportumity of visiting the euvitous was taken, and a large collection of plants was ob. tained, the ammals being found in the riglit season for making collections. "THe caseade which wits secn as they approacher was visited, aud extibited a picturesque and heautiful apperance, eveu when it wus four miles distunt.

At Obrnjiliu there are many pretty gardens and fields, under a good state of ctilivation. The rondside itedf luokel like a flower-garden, and flowers of wery bue were seen on either side, calcolarins, Juluelins, $\mathrm{x}$.

Here was the first puint whore they bad met the Ulana used as a beast of larden; the lond which they carry is from seventy lo nimety punils.

On the lach, at an early lour, some ragabunds, assuming the atmo of Chilitus, weut the rounds of the sillinge, liejping themselves to every thing they desired, to the utter diming of the inhabitants, who tmale to resistance. Tho consequence was, that having nesglected to Bupply thennsives with Irend the overing before, they list the opportunity of duing it. This was is surions inconventence, for Obrajitlu supplies the upper enuntry with bread, ah Lima does the lower, and it is proenred with diffienlty, exeept at these two placer, Potrtoes ware thereforo taken as a substitute, thoagh a very its. converient one, from their great weight and bulk,

They' were on the ronto by six ofelusk, and an hour's ride brought them to a formed a very picturesque rafid, socm after which they enteren into a wild and romantic passe, leetween sterp neclivitics and precipices of immunse height.

At tell otcloek they reacled Culnui, a distance of five lengues; it eontaing about thirty collages; its height is believed to be ten thousnd feet alsove the sea, and lice cultivation censes, ending with the potato, tropreolum, oxalia, and bassolls. The second region of plants also terminates here; and now ensued the "Paramera," or pasture region of the Andes, aroided by the inhabitants of the lower districts on aceotuat of the cold. This third region gives growth to a set of plants which make a gradual transition from those of the second regron to low alpine seraggy hushes, none of which exceed two feet in height. The Paramera is remarkable for $n$ dense sward of consse grass, and low lierbaceots plants, principally of the oriler composites. The flowers of the hatter it way remarked were particularly large in proportion to tle plant. These form a rich posturnge for the flocks and berds, which are seen fecding in the rilleys and along the sides of the hills.

No endivation is attempted beyond Culnai, and but two species of Cacti were met with above this point.

I'hey had hitherto for the most part followed a norlierly direction, but now they diverged noro to the north-enst. The temperature was faling as they ascended, the air was clear and bracing, and the scenery ns they advaneed became more interesting, and екел sublime. To its wild and pre- cipitous fontures was now added the high smowy peak of La Yinda in the distanee, and some few sputs of snow were occasionally seen in places sheltered from the sun's rnys, The nute-jatlis Jad become jarrow, and when they met with mules, which was often the case, it beenme necessary to turn utsder the rocks, until the path was clear. On one oceasion, one of the prriy allowed lis niole to take tlic outside; the consequence was that a muleteer shoved nule abd rider several feat over the bank. No injury was received, and the dileuma passed off with a grood laugh at the fright.

The sagaeity of the mules on these occraions is remathule. "ilhey always endeavour to eling to the wall side, and will surceed in doist it if uot prevented by the ridler. Their enutios is grent when they ajprehend danger in pasking over steep platces; itue instant danger was anticipated, the liase and fore ficet were ased to ascerinin its extent, which done, the animals cautiously proceeded, and reached the bottom with great care and ense Lothi to the rider aud themselves.

Alwat threo o'clock ihey find gained the fourth or alpine region, where they wero met with stmrp and extting winds, accompanied with hail axd snow, that proved very uneumfortable to their sunburnt faces: this was supposed to le at घn elevation of alrout fifteen thusand feel. Our gersthemen now felt the effects of the elevation in hendaclie, biffietily of Lreathing, and excessive lassitude. The crest of the Curdillerns is at this plinee n league in width, the surface very uneven, coutaining small lakes without outlets, sunk in dowp lallows; beyoud this the streams which form the extreme gources of the Amazon were running to the enstward. After travelling two lengues on a gentle desent, they arrived at Caka Cancla about disak,

Casa Cancha consibta of three huts, and is no. thing vore than a muleteers' rendezvous; the place was in charge of two women, who in expreseton, if not in form, miglıt lave been taken for witehes. The accommodations, if they may be su cailed, were an apartmont common to all the immates, witlı no fustening to the door or wiudows, witl]out a fire, and nothing but the hard ground to lie upon.

At night the thermometer frequently falls to the freezing-point, and the climate is like that of wiuter; there is not, liowever, a stick of wood nor any resinums umbelifierie, as an the Chilian Andes, to be had, and the cooking is done with turt wien it cun be obtained, lut dry cowdung is most commonly used for this purpose. This is the only and the best estallishment the place nffords; even the first females in the country can procure no lietter nccommodations, and will ben it for the night with contentment.

$A \mathrm{~s}$ a special mark of distinction, $\mathrm{n}$ smaller apnrtment was assigned to our gentletwen, in a lint ndjoinisg that in which their supper wis cooked, of wticls they wituessed the prepuration. Tite cookjing range was of peculiar construction, ond might serve as a pattern for a modern cuivine. It oecupied one corner of the apartment, and appeared to be convenient aud well adspted to the warts of the innutes.

After a time the fore-çuarter of mutton made its appearance in the liauda of their laudlady, scorehed to a cinder. Being ungruvided with a 
knife, she began to tear it into small picees with licr fingers. Our gentlemen remonstratel, but untluing would stup her unti] unsty every morsel of it liad pasked through her dirty laands. This, adtled to her state of intuxication, cansed some of them to lose their sujper frout sheer ulisgust, thougl all agreed tiret blio earwel os toro it into pieves in in thust dexteruns manner.

After suptwer they were infurmed by their guides, in mueh eunsterntion, that $n$ bait of Chilian marauders were aptronching; the whole esinulishmone was in great uproar. The party, however, proved to be a convoy. The officer in cliarge wa civil, and engazed freely in convmration on the frending eintest luetween Chili and Peru.

Durisg the night the party were very misels tronblet wills hestache and diffleulty in breatting; liey passed an uneomfortable vight on the elay thmer. The thermoneter in the duorway stood in the morving at $33^{\circ}$.

Casa Cauchu is in a valley surronuded by lofty mountrins. Its heiglit, upoil the authority of a gentleman at Lima, is fourteen thousand tive hundred feet above the level of the sea. Pasturage in Its vichnity is gnod; wheep and cattle nte abundant: brest and potutoes ute brought over the mountains frum Ohrajiln; of these they lave oftentimes but n scanty supply, which was the ease at this period. The evening previuns to their arrivul a theft liad tuken place there, $\rightarrow$ gontleman lad lind his firearms stolen; a great loss, when one takes into eonconsideration the mature of the conutry, and the dangers to he enemuntered in travedling.

On the marning of the 20 th, with ane exception, they were all ntfocted with vomiting, hendache, and fever, nul still suffering much frum difliculty in breatling ; llic is usually felt on first visiting the colevated regiuns, nud is said to be [articularly" so at night,

The monning provel so buisteroug will frequent hait-shuwers, that they do: lesmined to renasis the day, to rest their uniles and reoruit themselye's. Thieir brealifast was mine aceeptuble thas the last jight's supper; it consisted of olla-potrida and snille.

$\Lambda$ s the wenther ailowed them to botarizo, they Bet aut in two partiea, but lad not beun oecupied over two hours, hefore tlrey were overtaken by a severe stow-stoprt, which entirely covered up al! simall plants, and male it difticule fur them to sesle the rockin,

On the 2/at, they had detertwitued in procert to Datins, which fron the description of their guides, who wete ignomant lowever of the mote beyond Caka Canclsa, they had been led to beliere was on the enstern slupe of the mountain.

They sturtet at an eturly bour, with the will] geese flying sud leeding aswund thesn, thetemining tis visit AJprnuter, which is distant frum Cara Canclia ntunut two lengues; but owing to their guides being unacquanted with the gaths, they were led ahout ansong the mountaius, and ower extensive plains, ensered with conrse herbage. A voriety of beantiful flowers were fontud, and mang dunesticated llamas were secn feeding. At eleven o'clock they stumbled, as if ly accident, on the place, enusisting of a number of lauts; une of these sliowed the weleomes sign of brenul for sale, viz., a basket stuck upon a losg prile; and they were fortunate in procuring some small rolle.
Alpamarea proved to be in the vicinity of a filver-mine, and here they found a goully conpany of Peruvian gentlemen, collected froun various quarters, and among them the geiseral to whom they liad brought ietiery to Obrajillo. They were receired with great kindness ani altention; the comyrany insisted npon their dismourting, mul gare them the cheer they hind prepareal for themselven, which was rendily partakes of. It was serveal in a large pourd-shell, and cousisted of a Sjunjsh hotela-poteli, or alln, witl enrots, protgurlic, pesper, nud small bits of mutton. It was oliserved, ata the eatabtey were disappenring, that the Spanish dorns now aud thess wonlil partake of the tiduits by reaching over their shonlders from behimul. This repast wis well timed, for onr party hat been frsting sufficiently loug to enable then to do ample juntice to it.

The l'urtyinns sent for the superintendert of the mine, and it the menn time slıwed the process of extracting the silver, which was as follows: tho ore is broken up until it resembles earth; it is then thrown intio a large routsl vat, and mixed wills merenry and water; six or eight mules are then turmed in and driven sound and round, untit the arialgam is fortued; it is then put istu a vessel, and stirred with water nritil the earth mixes witl it, and the water being poured off, leaves the smalgam, whenee the mereury is fitually exaporated.

The ore appears to be taket almost enticely from the surfince. It is foor, and the mines do not yieli much profit. There are many old woins thnt lave lepu extensively worked, but owing to their aleptlı lave been alyandured.

The supnrintondent nrrived after a while; lie proved to be an Englinh niner (Mr. 1R. Bevan), whn had been twenty yenrs in the country. He was delighted to see our party, saying ilat an Amerienn and Finglishman were all the same in Peru, and tiat lie liat not heard his own langungo spuken fur two years. He infurmed then that the olt Spraniards lind workod the mines chenper than any one las been able to do since. Tliey wura large lamlholders, and contrived to ken thenselves ill de'bs to their tenmus; this they always paid in munfactured gocth, Fery nuch in demand wills tlue Inlians who worked the mizer, thus nuaking a double profit on the wages. At the preseit titue the mines are worked by Indians of a mixed blood, sho linve a laugurge of their own. They are mueh addicted to the use of roca, (the leaf of the erythroxylun enen, whicls is mixel and masticated with quimoa,) and without a supply of this lenf they will tint work.

Mr. Bevan took the party to the mine, which is sone distance up the mumstaing. Much ditficulty whe experionced in brenthing the rarefied atmos13tere, and great fnligue in walking; so nund so, that it wha necessary to stop every fow stepls til rest; and what svas surpriking, Mr. Bevan and she Indians whon accompanied lim apyenred to be more affocted than any of the party. He nssured them it was the same even with the Indians born on the spot, showing that neither tirme now nther eircumstrnces enn adajt a constitution to this elorated region, On rencling the muth of the mine, they satw several emunciated and ghnstly-looking Indians seated near the entrance; they descended a few yards into it, bet found that timo wonld not sdmit 
of the delay neceseary to pass down to the plices where they were ab work; and wisluing to desote their attention to the interesting region of hotany is which they then wete, slaey gavo up their purpose of dereveniling.

Un tw part of their journey did they find so many remarkuble pians as on this mountain.

Towards slie midhle of the afternom they returited to the hut, when they determined to prot ceed to Bantus, Previous to leaving Alpmarare, they bad sime dillieulty with the guider, who were dissatisfied wilt their bargnin; it therefore reyuired vome management to present them from deserting ritegrether, and caubed our gentlemen some fear lest they might be compelled to returz; ; but after much disprute, the grides consented to proceed, altheugit it issust be allowed that the bargaiu was far freim thing alvantageous to thero.

Along tlie road to Banos they passed sone hight ridges, with ouow and lice coming at times dowa to the path; also lakes ill deep ruvizes, somewhat resembling small craters, which, like all the rest they liad seell, were teunnted by sumurons water-fuwl.

The crest of the $A$ mles did not apjear liere quite so briad as it had heen fuund to be four leagises to the 5outhward, but its elevatios was thought to be greater. The continuous ranges of mowy peaks in the direction of Pusco were very striking. The Indiany lave names for all the most remarkable ones, but the Spuniards embrace the whole, together with the principal one, under the nume of La Viuda.

Frum the direction of the desecut to the northward and westwarl, they began to suspreet they were descending apon tho westeru slope of the Cordilleras justead of the eastern; this proved to be the ease, which was no small disappointment, as it was their original intention to rescls the wooded distriet on the eastern! slope, termed "Montanas." In this Lney were therefore disnppointed. As they proceded the country improved, the elimste beeame tuilder, aul the soil richer"; on their way they crosed a small stream, which was said to bo the soures of the river Chancai.

At dark they renched Buñu, which is emputal to be upwarils of fivo leagues from Casa Camelia. Hañus is contsilered to be at about the name elevatirn as Culnai, but the descent is more mapt to the formes. Accorting to live custom of the country, they applied to the alealde for accomisndations, who is obliget, aceording to Inw, to firnish travellars with a house, if the town stwould prossess nome for the use of strangers, free of expense, sul to pro. vide them with a cunk; the travellers buy their owis provisions, and pay for the cooking, one real for esch dish.

Barios is celebrnted for its mineral hot-springs, from which it derives its name; they flow from the bnse of a high moututain,

The town consists of about thiriy houses and a ehureh, of which the isluabitants are very prond. It is a neat village, situated in a deep ravine, by the side of a turnbling gtrenm, bounded on both sides by isumntaisis three thousand feet ligh. The innatain sides appear so precipitous, that the remark was made by one of the party, "that he could not enceive why the cattle that were feediug on their sides did not fall off."

Along the margin of the strean, carnations, pinks, stock giltyflowers, and French marigolds are naturalized; the punles grow in inumense tum. bess in every cincle aud crevice.

The cabbages liere aro wondy aud arborescent, like the eow or trew-calınge, the irurk and hrsuches being quite hard aud cosvered with lark; they lave at a vibance sonte resumblaxte to the Brug. mansia suarenlenค.

T'lo thermometer stnod at $50^{\circ}$, and the weather', in eoupnrison with the day before, was quite milt.

"Jthe soil in tlis valley is good, and cultivated it some places with care: no fruit was observel. I'lie lurgest trees were a species of elder nad a Inddles; calceolaria, salvia, and heliutropiun ntrounded.

On the 22 ind they determined to remain at Bañns. At an etrly hour in the moming they found the village deserted, and it appeared on inquiry that all the inliahitants had gone aluroad to tend their herds. For the purpose of tuling as wide a range as possible is seareh of plants, our gentlomen separated, surse gring up, while athers descended; they ull met witl grent streess in their botanical resenrohes. Dr. Pickering attempted the aseent of one of the summits; fir nom be had reached a ligh elevation, and looking up, he espied a luage condor sur $\Gamma^{\circ}$ ing down the valley. Ho stopped to wbserve the majestic bis'd as it maifen slowly altug. To lis strurise it took a turn around him, tlien a second and $\mathrm{a}$ third, the last time llawing so near thut lie begarn to spprehera is medisated an sttack. He describes linwself as being in the warst possible condition for a fight, lis sirength theing exlunusted by climbing, and his right land laving been laned for some das's from a liurt. The inture of the grourd, too, wins any thisin but favoumble for defence; lut there was nothing left hut to prepare for a figlol, aral with this iatest be tonk a seat atrd drew his knife, At the instane, ns if intinidated by the sight of the werpon, the biril whirted off in n different direction. Dr. P'sckering confessed, linwever humiliating the achnossiedgnent, that he Was at tise time very well sutished with the cundor's determinstion to let him alone.

Dr. Pickering was enabled to rench the ridge Ilat hounded the valley, but there were masy Jizgles buyond. The view thence was magnificent, overlouking to the west eight distinet ridges betwean lim and the sen, which was senreely defined enough to be male out with any certainty. He descetuled by the same route again to the village. 'Ithe alualde diseovering that one of the party' (Mr. Agate) wus nu artist, became extrensely anxinus that le should make s sketcl of his futler-int-law, an olil revolutionary goldier, who resilded there. As the son-itr+iaw had bees so sttentive, and offered them so mouy civilities, ntong others the lous of a silver dish, sjurm, and fork, be coutd do no less than gratify these wishes. For this purpuse the old man dressed limuself in lis unifurm. "l'loe tnsk of sittiug was almost too mucli for him, and lie wris nearly overeone with the excitement and exertion. The old man wis greatly delighted with the picture, as were all those about hira, exeept the sonisj-law, who expressed great dissatisfaction that it should be without lege, it being only a tanlf.tength, anl offered a lamge price to bave them put on; but time did not admit of it.

Mr. Agate's first effort was deemed so kuccessful that his reputition was at once established at Baños, and shortly afterwards ho was called upon 
by the sacristan to engage lim to paint the four Evaungeliats for the church. Price was no vlject, provided he could du it, and they would levides cousider it as a great fis vour.

Sone of the bystanders proposed to lave the constable printed, and puinted to a strapping big neartin.

The houses liternlly contsined no furniture, and the silfer lent to our party was believed to constitute the ouly valunliles in the place. The only articles beaides that were seen were some roughlynasde worden spoons, entitien dishes, and water. jugs, a few boards male into a rough table, with a stoul or two, and a beilstead mate of eanes nnil plastured with clay. In 30 part of the Unitenl States, whether in ihe eabins of the far west, or in the punres! suburlss of uur enstern eities, are persons tu be seen lising in such a misernible mannes. The country-peojle of Peru, notwithstanding they are surrounted with every thing to make them

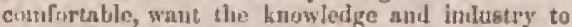
use the Bdvantagea nature lass given then.

On the 23rvl they loft Banisg on Incir returm. Notwitlstumling their horses laad hal sorje rest, their backs were in a slockiug state, hist the sonns did not secrn to be regariled math by the guides, who applied sosp to thesu ; they seoliled and blamed the Fuglish satdles, which they salled "gallnjagos turtes."

"Tho party lad determimed to make another visit to Alparraren, but the guideg would not listen to it, giring as a rensm that they shauld have their hurses stolen if they weru. While this discussion Was going on, they met a prersun who infurned then that the only perwons now there were Indialla, As their only inducement to return was the squeable company they lat Jeft, they aceeded to their guides' views, and taking mother direction, nrrived at Casa Camelia in the afteruoon. At uight some Clitian esvalry avrived, which caused great alnm amotig the oecupants of the buts and the gticles, for fear uf losing their horses, a disaster which they sajd often oceurred when sueh visiters came. The commander proved to be a geuthemanly perEofl, and rentered our farty much assistance. This party lind left Pasco, the chief minting place of Lower Ieri, in the morning, and represented it as a place of considerable trade, evntainirg many foreign resildenth, including English, Americun, Fitench, and Gorman. He stated that the quichus Innguage was spoken there, arul that the Spanisls was not eominonly unferstond.

Tho town of Pasco is at an slevation of thirteen thorarnad feet, and situated in the plain of Sin Junn, ut the head of two ravises or gullies, ont ealled Runiallsm, lending to the northward, and the otluer Huanco, to the eustwart, whero the two grent veins of Colquijiren and Parinjiren unite. These nro surposed to extund some seventy miles in length, and the town of Pasco is situaterl it their junetion. The part of the grourd that has been brokes up, and in which ores have been found, is ubunt half a mile in length in a north snd sonth direction, and shout one-fourth of a mile east and west. Within the whole of this extent ored lnave been mined of greater or less value, and the mines furmerly worked nud now deserted are said to anıonst to upwirds of a thousand.

The town of Proce is surrounded on three sides: norll-cust and south by bills of blue limestous ; on the wort the hills are of sandstone, and on the autuly-west of a blne slate. All the orea of the Cerro aro fertuginous, nut the silver nentest to the surfaco is contained in an ochreoug irun-stone. In particular spots the silver is foumd nuixed wit]। leat and copper, and at variable dupths in different lacalities the ores rest ou a berl of solid irun pyrites, which in some mines yiuld silver aud in trthers toh.

The plain of San Jinan on the nurth is divided into many mining districts, to which names are given to distingıists then more rendily. The sonthernmogt of these is ealled 'Zauricocha, and contains severnl mines, from whish great wealdh lias lien prolued since the revolution. This is the roginn from which all the richest ores have beers produced, and it has been always louked upou ns the nanat jumpurtant district in the Cerro, It is beliered that further month, between this point arm? tho hill of Uliatlim, some goud ores exist ; but no attenpe lits yet been nuals to tnine there.

In the district of Sasta Rosa, lying west of Zaurieveha, the grentest guantity of ore lans beews ruined: it his been worked down to the level of the adit; aud in seraral unines, where goot ore las been dineovered, they liavo descended to a lower level, drainge having been effected by landpumping.

On the eat of the "anricolis is the district called Arnsillapata, in which few mines sure nuw worked; the are which is produced, although abundont in particular spots, is not rich.

Intmediately within the town there are some fow mines that are good, but there has never been any extensive work curried on. It is believed that profituthe ore yet remuins to be discovered.

Cayne, atwother district lying north of Znuricoelun, is worked to sonse protit; the upper adit from the nortlo-west reaches it, and several mines in it lave been yielding goed returns.

To the nortl of Cnyge are the Chucarillo and Zaurneancha districts, the working of the mines in which had been impeded by water accumulated since the breaking otst of the revolutionary wax. The apper adic, leading from the gully of RumialJana, is caryicd above them, and they consequently derive no benefit from it.

I') the nortly of these last two distriets lies the plain of San Juan; there are a few trall veins tonning tlirough rome parts of it, but no iniportant ditcovery lias yet been made, althongh many mines linve been oprened and carried down to lepths of [rosis one limidred and twenty to one hundred and fifty feet. "The tower nelit, from the gully of Rtsinistlans, is to rua through it, and may open to the proprrietors some distoveries to recomplense them for their labours.

The whole number of mines considered rich in the different districta, may be enumerated as fol. lows :

\begin{tabular}{|c|c|c|c|c|c|c|}
\hline In Zauricocha & & & & & & \\
\hline Santa llosa & & & & & & \\
\hline Cayac :- & & & & & & \\
\hline $\begin{array}{l}\text { Chuearills } \\
\text { Zaurneancha }\end{array}$ & & & " & & t & \\
\hline
\end{tabular}

Each of these mines eomprises a space of one lunatred and eighty feet lang by ninety feet wide.

The silver ores are estimnted ly a mensure ealled a box of ore, which contains twenty-five unule-londs of ten surobas, or trenty-five pounds ench. Each box raries in wilue from six Spanish 
mares to three thoukand; the former being the lowest which, under the nost favoumble circumstanees, will pay the cost of working. The poorest is of course the most abundant.

The miner who cas mise ores in considerable qunntitics, which will give ten to twelve mares per thox, does well.

The produee of the mines since the close of the revolutionary war, has amounted to the following, viz. :

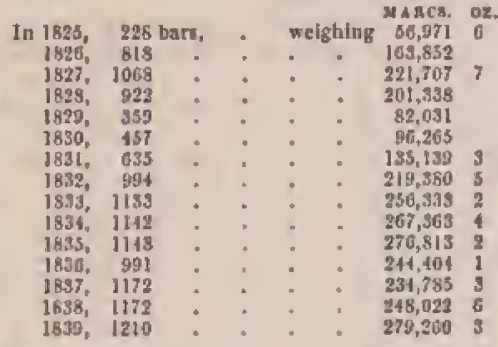

T'o this maty be added one-fifth for silver that has not paid duties.

The first adil of importance driven into the mines, was that of $\operatorname{San}$ Indas, which passed the wall of the vin of Zuuricucha, in the yenr 1794 . By monus of this ndit, very rich ores were rnised, esjecially from the king's mine. In the year 1808 , the present deep adit, from which so much wns expected, whs begun; for corering the expenses of coustructing it, the body of miners imposed a duty of one real per mare on all silver melted in the governmeat assay-office. This adit reached in 1830 the soutl-west edge of the metalliferous ground of Sinta Rosa, up to which timo the whole of its course lad been in a hard rock. An auxilury adit was then commenced, hifty-four feet atove the level of the main one, and both of these works have bees earried on until the present time. The ground alsove being better adapted for dricing in, the unper adit is in sdvance of the lower one thousaud five lundred foet, and has arrived at the district of Caync. The lower ndit kas reached the mines situated upen the rein of Znuricocha, witlsost liswing eut a single vein or deposit of oro in its transit. There are several rich nines a little in advnnee of this aclit, some of wlich have been hitherto drained by liand-pumps, and wlich nust be shortly very much benefited by it; for, slthough they extend bolow tho level of the adit, yet they witt have some fifty feet of pump-lift less. It will excite some wonder that steam is not now employed in the draining of such rajunble mines. It has, lowever, heen tried; a few jears previous to the revolution, four stenm-engines, of thirty-horse power each, were brought out from England, and three of them put up in the districts of Santa IRosa, Cayac, and Zauracaticha. That of Zauricocha was not set up, but the other three were worked with some suecess.

A level was driven from the engine-shaft of Santa Rosa into the mines of Zavrieocha, and rich ores were raised. The engine of Cayac did little more than assist thut of Zaurieocha, which, on aceount of the greater quantity of water, was barely able to do the work required of it. The experise ineurred by tho louse of Abodia in this undertaking was upwaris of six hundred thousand dollars, and at the moment when they had begun to receive a good returu for their capical, the revolution lroke out, and tho troubles ineident to it put a etop to their work, and left them with that nmount of loss. Subsequently, at the close of the war, the engine of Santa Rosa was again put in ajeration; and in parts of the years 1826 and 1827 , a considerable quantity of silver was produced hy meang of the drainage effected by it.

Some abortive attempts were nade to use the engine of Zauricochn, from 1829 to 1833 ; but since the latter period they have all been abandoned, ab unserviceable.

The establishments for grinding and amalgamating the ores are situnted at from one mile to three leagues from the mines: those nearest the tuwa are deficient in water fur soveral monthg in the yoar. The construction of nll these mills is rude, and much power is lost. A mill will grind two hundred boxes of the latrdest ore, if it have a eoustant stream of water. The amalgnmation of the ore with inercury is effected by its being trodden by lorses in cireular enclusures, containing from tire to ten boxes. The consumption of mer. eury, including mechanieal and chemical loss, is about one pound for each mare of silver prodteed.

No attempts have yet been mado at roasting any of the ores.

Conl-mines are met with in various parts of the country, nt the distance of from two to seven lengues; the price it one real for an arroba, but might be inteh reduced if the business were properly attended $t$.

Varions plana lanve been formed at Limn, and in Fingland, to purchnse and work these mines, but with what success is rery uncertain ; the attempts have generally been supposed to have resulted in a loss. Spectation is always rifo in search of these raluable ores, aud prospects of great gain are invariably held out to those who engage in them; but there is much difficulty in getting the business into suecessful operation. The great error comsuitted by all the English companieg establishod in 1825, for working mimes in Spanish America, was in gadding thenselves witl great numbers of people, engaged at hight salaries, and workmen at extravagant wages; the expenses nttending this force swallawed up ravel of the funds before any work wis begun. These included not only inspectors and mitsing-enptains, but artisans, all of whom were gent from Eungland. From a total change of life and circumstances, the mining-captains and artisnus almost invariably turned out in a short tinke drunkards, and beeame good for nothing. In somo enses miners were trouglt out, and these turmed out still more wurthless than either of the two former elasses. They, indeed, did more work than the Indians, but their wages were ligher, and the expenses for their importation in addition, made them cost much more.

A coording to the laws of Peru, the silver produeed in this department must be sent to the government assay-office, to be meited into bars, and thence to the mint at lima to bo coined. The usual price of silver as it comes from the mine, is frum seven dollars six reals, to seven dotlars seven reals per mare. If remitted to Lima on account of the nuner, it yields him about eight dullars one real per ware. 
The duties it pays aro six dulturs per bar of two liumlred and ten thares to the asay-master, one real prer mare for the public works of the Cerro, aud one reul jer unare to goverument.

The mint price is efglit dollars two maxavedis per uare of eleven penayweights fine.

Within three lengues of Pases, on an extensivo plnin, there stamls an isolated hilj of porphyry, callert Ruco, From this libl are cut the stones used in griuding the ores, which are from two and n. lialf to three 4 aras in diameter, and from eighteen to twenty-fulur inclies in thickness. The cost for dulivering then at the foot of the hill is ten dollars fol every yuarter of a vara in their dianeter, and the expense of drawing then to the mills varies from seventy to two hundred dollass, according to the dimtnuee"

In 18 o several new attempts were alrotat to be made in mining speculations,

The grest difitisulty to sucuro sticess seens to be in providiug for the proper drainaze, which the presecut aulit will not acenniplish alone, and grent adrantages miglit he derived from steam-power, properly employed, to frue the misues of water. The ownet of the mises are always detirots of inserting in the eoutracts, that they shill not have aly water to raise, as this is the most expensive purt of the process : the ore is very mpidly mitied, after the wher is dmined off. The remuneration given to the proprieksts of the steant-engines, is one-fifth of the ore raised ; this was the sim prid to the old cormpany, and the same was stipulated to ho paid to the parties who undertook tho eame wark in 1529.

Mincs are to be bought at all times, on rensonable terms; for the miners often desire to retire from business, or wish to seli fur the sake of protit, or aru not able to carry them on from wast of enpital. There is, however, one difficulty a purcliaser has to conteud with, for the nines are almost alwrys heht in small shares among a number of relatives, mniy of whom refuse to sell their smull interest. This mukes the mines lese dosirable property, as dificulties almost invariably oceur with these small proprietors.

No miner, who has worked with reasonalile prudence, stearliness, azu a sufficient eapinl, las failed to do well since the year I833. The jursduce of the mines of the Cerro frum that time, has not varied mush frotn ane year to another, as will be seeu by the table lieretafore given. The undertakinge which lave been carried on upon an extensive ocale, aro those which have prospered most. There were many diftheulties that the firmt mining cimpanies lad to enconnter, thut others need nut tguin spprohemL ; the leend interests nre better urderstood, and woulh be more respected ; is tietter hunwledge of the people prevails, and of the moiles of mining; and the people therramelves have lust some of their prejudiees agninst foneigners. Persons una now he ubtained to rasist in the direetion, ay well as to afford advice to the agents who anay bo entrusted witl the aftairs of the cumpany, so that the jrospects of auceess in the operations are decidedly more finouraisle than they were fifteen years ago. But although the actual operation of

- Most of the above facts are defired from a person who had lorig restled on the spok, and been engaged in vastous thialisg operstions. mining may be more adsantageors, yet the cuuntry in its pulitical and comraccial character has very much deteriorated, and it is to ho njwothonded that but litle enpierl will be invested in it until there is a great clisnge it jta rulers as well is in its people, sut until goverument, the laws, and goot order, hecome as well establistit as they are in Chili. All tho fritends of Pern scem, howerer, to be well antisfied, from rppearances, that the day fo not far distant when she will see the restoration of permanest tranquility.

Tu roturn, after this digression, to our party : they hal much agreeable couversation with the Chilian offiecrs, und passed a pleasant eventug. As I lave befuse spoken of the acermmodations, it is neelless to say that they wrot not improved.

On the morning of the 2 th the thermmeter stoos at $36^{\circ}$ is the hut, and an the rivulet tlore was ice olle-fuurtl of an inch thick. Mr. Brachen. tridge gatlered seeds here of a curious species of cactus, which grows plentifully all over the manntains in dense tufts ; from the quautitives of down or fire hair upon it, it las the npvearance at a distance of a white slreep, so jntuch so that a gruup of them was sometimes mistuken for a flock.

Althungli Casa Capcha was a wretelied howel, and land every thing in it to riggnst, yet the situatiun was one of great beauty. In the stream that Anwed near it were fish of from gix to eight inches in length, bus nore of these were taken, as the party was not provitled witl fishiag-tackle.

When the time came for their departure, they were glad to bid adicu to the place, nnd to begin their areent to the top of the tidge. They rude two lengues to the source of the stream, which is near the summit of the ridge At a short distance from their path was the line of perpetual snow. Tlicy found the ground hard frozen as the snow was spprosehed, and almust bare of vegetation, only a few stunted spears of grass neeurring here and there; cven this appeared to be wanting in the thare spots above the snow line. 'Tlse snow' was but a thin covering, its surface was hardened, and its Jower suargin formed a perfectly unluruken lorizontal fine aloug the face of the mountain. This was not appareuty the case on the other ridges, for the snow lay there in hollows, snd sumetimes descended, as before renarked, below the path.

It the ajpine lakes was a speeies of myrinpliyl. lum, the anme na was met with at Culiai, three thousand feet below, Dr. Pickering found at ammonite here.

Tlrey descended rnpidly on the western ileclivity ; the scenery was bonutiful, and they liad enough emphyment in cullecting speeinens. T'wo Jarge partics were mot (1) the route, the one of londer mules, the other of theveral genteel travellers, among wham wero females, accompanied by several servants well armed. In the afturnon they reached a sulitary hust, nt a place called Chicrine, situated at tho fuot of La Finda, and kept by an old worran witli one eye; she proved very much tho reverse of their liostess at Caa Canclia, being very eleanly; here they passed the niglit comfortably.

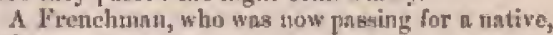
and was on his way to Pabeo with lis servant, joined them at Chierine. Being invited to portake of etpper, he accepted, nnd did ninple justice to the mesl; but when he had finishod, contrary to the usual politeness of his countrymen, he told 
thoul hu bal never cateu a wore tneal in bis life.

After this remark, a belief was etatertained that his saddle-bags cuntained elibles, and ho was accordingly plied with questions tuntil lic confessed he hat in lual of breat: this proved quite acept. able, und a triumph over their fellow-lodger, who promised them a further trent in the morning upou some tine chocolate.

On the marving of the 2sith the Frenchman departed early, and forgot all abut his fine chocointe. Tliey rogretled to hear, shortly after their arrival at Lima, that he had been rabbed and murdered on his returit.

Our party set out eatly, and after an bour's ride reaclied Culnai, where tle villagers were busy gathering in their potatoes. Thacre were also several patches of oxnlis cutata, tropedum tuberoøum, ind a species of basella. The two former when cooked are well-tasted, and all of then are much esteomed by tho natives. These patches are enclosed by low stone dikes; the plants, as they advanee, are earthed up, as we do potatoes, in the early part of the scason ; irrjgstion is necessary, as the suil is liglit and open, and consists chiofy of decryed rook and regetuble mould, Hero nomo very interesting seeda and rowts of a species of alstromeria were gatiered.

Culusi and Baños are about on the same level, ten thousand feet abuve the sea, and aro the highest mints of cultivation; they are both distant from the erest, by the rute of the water-course, ahout nine uniles.

Ur. Pickering having preceded the party on foot. reaclied Culnni after nine o'elock, when he entered a sture and was received with the utmast cor. diality; a neal was at neee prepared for him, consisting of egrs and potatoes, called chupe in the cotuntry, which was kindly tendered ; the landhord was very intulisitive, and examined lis budget, calling the attention of the by-standers to it ; his ctharge was reanonable, and the gave the doctor a heraty salutation at parting, with the "Adios per Dius."

At dark the party was reunited at Ohrajillo. Thone who nrrived first witnessed the slanghtering of a bultork in the square, on which ocension great pumbers of condors and buzzards wero collected in the air above. T"he latcer biry is seldom seen higher up thas Yuso. T'Jey stopper at the posnda, which they found occupied by the company of Chilian troups whom they had met at Casa Canclia, and in conseruence they were obliged to take wp with a filthy fut.

At Ohrajillo good crops of Iudian corn, rye, and betus nre rnised; but none of these grow $\mathrm{nl}$ a grenter ultitiate.

A fiugular and ratter ammsing eustom was witnessed iu tho morning, which does not spenk much for the pallantry of the mule propulation. $A$ town offlicer was sced strutting with a spear abont the public sugare, calling ali the women out to como athd swecp it. They soon male thoir nppearasce, anul were not loing in ereating a prodigious dust. They swept the dirt up into small heaps; thell taking their enarse stawls from their sinoulders, they spread them unm the ground, and put the dirt they lad collected into tlipm, to be earried ลพเ⿱亠䒑.

The grides now demanded n settlement, but re- quested their morney might be kept for thetn until the party rencliet Lima, as thoy certainty would be rublied if they took it themselves. This incident proves bow tittle sectrity there is in this eountry for jersons of any class having any thing valuable about thent.

The preparations that had been made in the town were for a festival, and the guides were disinclined to start for Lima. A little bribery, lowever, and reminding then that one of the grentest feasts in the Catholic Church, that of Curpus Clinati, was mear at haud, induced them to go forwarl.

On their way from Obrajillo, which they left at an early hour, they met a bridal party on horseback. The bridegroom's hat and person were decorntesl with enruntions and pinks; the bride and bridesmaid earried the same flowers, which they presented to our gentlemen in passing. After a hard day's ride they renched Taso, and took un their tquarters in the frorch of the post-house; the landlond and postmaster's absence was now accounted for, by sayjing that he had gone to cliureh, but would som lie back; ho of course did nat come, nor was lis expected by our gentlemen. They, in eonsequence, fared badly, for they had mithiug to eat. "They found here a gentlenan who bad bees rolibed the day before by threc persons in masks; they had treated lim with great politeness, orly proposing exchanges to his disadvantage; hic had nothing else to complain of ; they took his purse, watch, epurs, and a drituk of lis brandy. Much to their surprise, the guides, who had been so sertipulous nhout their money, showed no sigus of alntm. A new difficulty nrobe with them : they had been informed that is conseription was going $\mathrm{on}_{3}$ and they were afraid to proceed, lest thoy should lose their liberty; but the assurance, that they would be protected while witl tho party, attiafied them.

The frequency of murder, lighway robbery, and a constant resort to the cuchillo, lis not been exaggerated in the accounts of Lower Pern.

On the morning of the 2f th tlyey again set out, having prepared themselvey to encounter any attrck. The guides, knowing well the dangers that were to be spprehended, slowed mish solieitude nbout keeping tho company together.

They renched Yariga without accident, and find. ing the posada oceupied by a narty of moldiers, and a recruiting officer, lhey were directed to a hotse with a porch, but they found it shut up. 'T'hey, therefore, being assured that the owner would son return, deposited tho ssuldes, se, in the porch. Snon after, a woman ajpeared, and on lieitig informed of their situntion, and that they hat fasted for two days, she set ahout providing for theis supper, Aptwrently from Christian motives, for during the process she crossed herself ecverd times. She proved to he the owner of the estate, wns somewliat advanced in life, maraged ber own affirirs, and was speningly woll adajued to encounter the roughness of the cines. I'he lieiress, a litsle girl, (Augelita by unme,) came galloping on a loorse, driving the euttle before ber, with the air of a reteran, taving command over both the animnl she rode and those she inve; they were not much etruck with her benty, for her well-plastered fince, nnd witle-pureadjug aind matted hair, gave her tho sppearanee of an olf; but she was a specimen of Peruvian nobility. 
Their supper was good, and they wero permitted to lie on the clay floor in the house.

They paid the nsund price for the accommoda. tions, In the morning, betore their departure, they purchased fifty oranges for twelve and a half cents (a real), it being stipulated, lowever, that they gliould be gathered by themselves. These corved to refresli them while pasaing oper the Larren track (described in their ascent) of four leagues, They were uvertaken by their Chilinn friends, and the troop, when their ininds were relieved of the apprehensions of robberics.

Caballeros was reached at an early hour, and here they intended to stop on necount of their borses; but their Chilian friends pertunded then to purstue their journey to Lima, promising to rettder them asgistanee in ease they should yeed it. At Cabnileros they wituessed a figlt between $\mathrm{n}$ turkey and a game-coek; strife, indeed, appenrs to be a constant amusement with the Peruvians, nond scenses of this kind alune seem to interest the publie. After a long day's journey of twelve leagues, they reached Lima at eight o'dlock, very mueh fatigued, and happy to return to the comforts of civilized lifo.

The only novelty they met with during the day's ride wns a fiascho on horseback, earrying a pino board before hitm,-a proof of the scarcity of sucl articles in Peru, and the value that is set upon them.

This fourney, although attended with mueh fatigne and some disappointment, from not having accompliahed their object entirely, thut of reaching the woorled district of the enstern slope of the Andes, yet was very productive of results in the botanical department.

The great difference of elevation, and the variation in climate consenguent therens?, would lear one to expeet a grenter variety in the veyetation than was netually found. Forests were no where met with, jor were any of the palm tribe seen; very few of the many tropical plants were pelceived even on the coast. Tho atnaller shrubs wero soldon found, except in the lawer regiots, where their limit is cireutiseribed to the well. watered districh. Thickets ave very rare, and in the ligher regions appear wo be altogether wanting. The regetation of Perts, on the whale, is eharneterised by an air of tamenesa, indicating but a slight change of geasnn, and has been classed into four distinet botanical rogions, which are eavily distinguished.

Tho geological region passed over was niso one of nuch interest, snd from the observations of the gentlemen, the following information has been derived.

The geological structure, as far as their observations went, corresponds to that of Nimrth Clisti, with the exception of a narrow belt of sedimentary rocka along the sen-const, west of the granitic range, which is wanting in that country. This Let ineludes the island of San Lorenzo and others, as well as the crast itself, to the extent of from seven to ten miles from the sea-bench. These sedimentary rocks are argillaceons, distinctly stintified, and more or less slaty, the layers being in many jilaces discoloured by the red oxide of iron. In other plnces they appenred of $n$ black colour, as if in the vicinity of coal beds, of which the existenes was spoken of, but we did not discover any unequivocal traces of this subetance. Some congyicuous examples of faults were noticed by Mr. Dann along the cunst of San Lorenzo. Many minernla were also found by this gentleman ; among them gyjoun was of frequent oesurrence, as well as some fousily: for fuller information reference is made to the Geological 1keport.

The hills aud nututsing to the eastward, joining tho nbore sedinumiary roeks, aro exchasivaly of granite, which exterds in width to the distance of forty-five gengmphical miles beyond Yaro. In places it has very mucl the appearauce of a stratitied mock; it is much broken, mul variable in its claracter, so as to render it somewhat decejtive. Dr, Pjekering observes, that this peculinr clanaes or appearance is owing to the slow process of the decompositinn of the ruck in this dry climate, nud which would, in other places, subject to the ordi. nary fucturtions of scasons, bo covered with several feet of eartli. "The same reasons will necount for the duration of the Inen rillages that cover many of the litls, and which a topious shwwer would tr. tirely wash awny. The granite on its enstern gide was contso-grained, presenting more of the orilimary sppearunce of klat rock.

Immediately eastward of the granite diatrict conmene the trap rocks, consisting for the most part of jorphlyry. Dr. Pickering traced the line of jnuction for sorne miles, the hills on one side being of granite, on the other pouphyry. The eastern limit of the trap regium is supposed to be distnnt some twenty miles from the western. 'The norphyty rescmbles the Swedish, nud that in the ricinity of Boston. Many porphyry pebbles, supposed to be of this formation, were fund on the luacli at Callao, laving, it is to be presumed, heen carriel there by the action of the water-conrses.

Next comes the plntesu of the Corlillems, which is formed of sedimentary rucks; this ineludes the silver-mines, and the ligigent peaks, nad is appis. rently of the Bame nge ay the const. Mucts of the ruck it argillaceous. At Baños an argijJaceous linvestono was used for buruing, and quasstities of typsum, used for manure, was brought from the vicinity of Cas Cancha, some twenty miles to the nortil. Conglomerates provailed over a grent portion of the crest tho purty traversed. The included pobbles were olserved to the of regular shafre, mmontl and polished as if sea-washed, All the party remarked the smoothnes of the pebbles in the torrents of the Condilleras, whish had a strong resemblance to those on the sea-beacls. From the information relative to the mines in the Cerro de Pasco, it witl have been perceived that blue limestone, slate, and sandstone exist in that vichity; and at the silver-mines at Alpamarcn a compact bluish rock was observed, probnhly the limestone; it wis not, thowever, ascertained whet lier it was argillaceous or a pure limestone. Dr. Fickering remarks, that it contained numerous hard senms of opaque caleareous spar, with somewhat the lustre of "satio spar." Sandstono wjth small pebbles was not nucommon.

The bare apots of the lingher peaks did not pre. sent the rariety of eolour of the Clilinn $A$ ndea, but had a uniform dark alaty the. Many incrustations were seen forming on the rocks and plants; this was found to be gypoum.

l'revious to our departure, I folt desirous of having an excursion made to the ruing of Prehncamac; and lasing heard that the landing was 
ensy and goorl, on the inside of the island, I ment the tender Flying-Fish thither, with Dr, Pickering and Lientenant Underwond.

Pachueantac is one of the most interesting apate on this part of the emast, although it it said it will not compare wills many others in rarious parts of the cunntry, especially at Cuseo.

They lefe Callao on the afternoon of the 28th of Jume, and wero at muchor alrout midnight nhreast of the place. At daylight the sur' was found so heary is to render it danguruus to land in the whate-boat. 13y the perqeverance of the oflicurs, a taft was formed of the India-rubber tnattrusses and onrs; two balsas were alen provided, Lieutenant Underwood made the first attempt, and paddled himself into the rollers, the first one of which threw him and the halsss end over end. Shortly after, the raft was seen hottom up, the oar broken, and the fragrments aticking up in rarious directions; lut be was trissing, He sonn, howover, made his nppearance at some distnnce, nnd just as he reached the raft, a second sea bruke over him, and he again disappeared, spparently much exlinusted. When the thind roller brake over hin, he wiss contsidered for a few momenta as lost; and it whs no smull relief to sce him erswling from tho water up on the beach, a short time afterwards. The raft was now pulled back ta the tender lyy tho line. In conso. quence of the ill suctens of this expreriment, it. was determined to make a trial in the whale-bunt, which snceceded withuut accilent. Dr. Pickering and Lientemant Underwod now proceeded to the temple. At the base of the hilk, they found a fow enbins of lantians, who stuted that they had not chosen the propier pluce for landing.

The temple of Pachacamac, or enstle, as it is called ly tho Indiass, is on the summit of a hill, with three ternees; the view of it frum the north is somewint like that of the pyrnmid of Cholula, given by Humbolde, except that the flanks were perjendicular.

'The whole height of the hill is two hundred and fifty feet, that of the mason-wurk, eighty; the form is rectangular, the base being five hunired by four hundred fert. At the south-etsotern extremity, the threo distinct terraces are not so perceptible, and the dectivity is more gentle. The wralls, where grens strength was required to support tho enth, were builc of unhown squarv blocks of juek; these were casel with sar-driet brick (adobes), which were correred with a enating of elny or plaster, and stained or pairted of a reddish collour.

A minge of square brick pilasters projected from the upportront wall, facing the ses, evillently hehongiag nrigimally to the iuterior of a large apartment. These pilasters yave it the ampect of an Eigjptian structure. In no other Perurina antiqui. tieg hnre pitnsters been seell by 1t9. On one of the northern terraces were also retusius of mastments; liere the briek nppesured more frisble, owing to a gronter prophurtion of snisd; where they retnined their shape, their dimensions were nino inches in width by six inches deep, varying in height from nitse inches to two feet; and they were laid so as to break joint, though not alsay' in a worknanlike manner.

The remains of the town occupy the sane undu. lating ground, of less elevation, a quarter of a mile us the sorthward. This alen forms a rectangle, one. fifth by one-thind of a mile in size; through tho middle runs lengchwise a straight street, twenty fect in witth. The walls of some of the ruins are thirty feet high, and cross each other at right angles. The buildings were apparently connected together, except where the streets intervened. The larger areas were agnin divided by thinner partitions, and one of them was obseryed to contain four rectangular pits, the plastering of which appeared quite freah.

No traces of doors or windows towards the strects could be discovered, nor indeed, any where else. The walls were exclusively of stin-dried brick, and their direction, north-east and soutll. west, the athre as those of the temple, which frotiled the sen.

Some graves were observed to the sontlward of the temple, but the friscipal burtying-ground was between the teasple nud town. Some of the grnves were rectaugular pits, lised with a dry wall of stone, oud covered with lavers of reeds and canes, on whith the earth was filled in to the depth of a foot or more, so as to be even with the surfice. The skults brought from this ylace were of varinus eharacters; tho majority of them presented the rertical elevation, or jnised neciput, the usual ebaracteristic of the ancient Peruvians, while others land the forehead and top of the head depresend. Eight of these were obtained, and are now deposited at Washington. The bodies were found envelopenl in cloth of various qualities, and $n$ variety in ito colours still existed.

Varions utensils and other artieleg were fuund, which seened to denote the cecruption of the individunl: wooklen needlos nud weatving utensils; netting made in the nsual style; a sling; cortage of different kinds; in sort of conrse barket; fragnients of pottery, and plated stirrups. They also foumi variuts vegetable subatances: lutsks of Indian curn, with eary of two vorieties, one with the grain stighily pointed, the other the shost and black variety, which is still very commonly cultivated; cotton seeds ; small bunclies of woul; gourd-shells, witlt a square bole cut out, precisely as is done at picsent. These furnialued evilence of the style of the articles manufactured before the arrival of the Spaniards, and of the enltivation of the regetable pioducts; wlien tu these wo ard the native tuberous roots (among them the potstine) cultivated in the mountrins, sud the animals found dornesticated, viz. the lluma, dog, ayd Guinea-pig, and the knowledge of at least one metal, we mny juilge what has since been aeyured.

Tlue entarlinion of the party was attencled with risk, lut they all got on board tho Flying-Fish without accident, nind in a few hourt ther again resclied the anchorage at Callao.

The rusults of $\mathrm{my}$ intruiries into the commeree and trale of Feru, are ty no menne satisfactory. The vacillating poliey pursued townards the trado lias been most extraordinary ; and some of tloose engaged in commervin] pursuits lave frequently been enafjled, tliruugh the necessitieg of the government, to reap many advantager, Much illicit trado was carried on, cven befure the revolution, under the Spanish rule. 'The restriction laid by its authom rity en comrueree, kept the prices of juports high, whilst tho low value of exports, left to the arbitrary detnand of monopolists, prevented or diminished the means of these coumtries to pay for what they wanced frotr abroad. 
Fron this atate of things resulted the linited trate and enornous profits to a few individuals, under the colonial myitem. As surm ng the porta were opened, an expansion twok place, and the sade was entirely averilone. The market becane glutted with all kinds of foreign fibrics, and many ruinots virages were made from ignorance of the wants of the people, and their means of payment.

For the last ten gean the trade has leseu better understuot. The demand and the means of payment have been more acurntely atcertained, snd a healthy and incrassing conmerce has been carried on, ag far as the sate of the counuy and the fluetuations, whicl are inseparable from n distaut traffic, would permit. The conmuree of Peru will not bear a conpurison will that of Chili, sand while the former las ben dirnitshing, the later hos been rapidaly ineressing. $\Lambda$ pontist of the eupplies whish were turuerly sent tu Pert direct, are now ubtained in Clsili, and sent to their destinstisn in constisg vessele. 'Tlis ehange lass been brought alunt try the anwise policy pursuet by the vurious Peruvian rulers, in imposiug henvy transit duties. Tlhis is nlso in part to be attributed to the aulvantageous situntion of Falparaiso, where purchasers ne alwnys to be foum! fur articles for the leewned eunst. Thure ia little doubt it the minds of thase who are most competent to judge, that Valparaiso must beene the principal mart of foreign com. merce on the west const of Amierica.

The foreigu trade of P'ern is principally carried on by the Englisli, Anericnus, and French. Of late yenrs, a guod mony German and Spanish ves. sels also have been sent thither; nud necagiogally some of the Meditermean flags are seen on the const.
The snnual insorts into Pert fre eombined so much with thase of Chili, that it was deerned pro. per to inclute them under the one head; those of Peru smount to atrout two-fiflis of the whole. Of these ismports, part go to Guayauil ; the Interme. dins, or Soutl Peru and Belivis, take abont ono millin from Chili and Lima. 'Tho returus mado frow Peru are as follow日:-

$$
\begin{aligned}
& \text { In dollare and bullion pontas } \\
& 500,600 \\
& 3,000,000
\end{aligned}
$$

It will be pereeiset, that both in Peru and Chili, the imports and exports are nearly the name in smount ; nnd the question unturally srieses, whonce the profits on the tralle I It is readily answered lliat, as lang been almeady kaid, large givantitivs of gonde aro antuanly sulel in Chili and P'oru for Contral Amerticit, the proceds of which are ellipped thenes direct to Eurvene and the United Statse, aud du not appenr in tlic alowe note of exproits.

T'hese cousuries offer a large market for our domentic cottons; and if the prices esn be maintained, the Uuited States will supply the must of the coarser kinds used there. I have it from the best authority, that the conkumption of these gonds is now dothle what it was fire years ngo, fond it is still inereasing.

The nrticle of flour, however, lias grestly fitlen off; previous to 1830 , there were nearly thirty thotsand barrels exported to Pers from the Lnited Stites, in the laut tlire years, on!y aix thousand, and in Iฏt $\mathrm{I}$, but one thoumant, in consequetwe of Peru breig abundantly snpplied from Chili.

\section{CHAPTER X.}

\section{PALMOTU GROUP.}

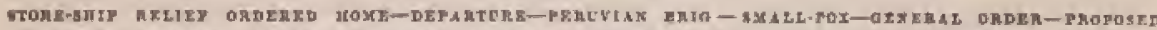

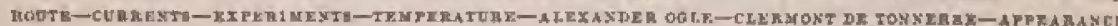

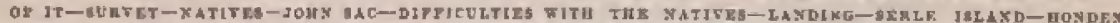

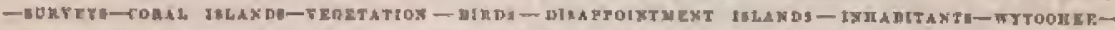

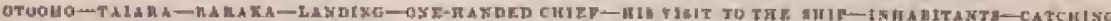

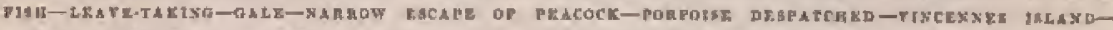

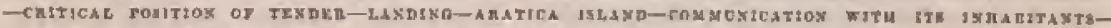

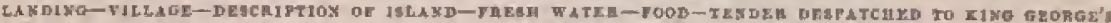

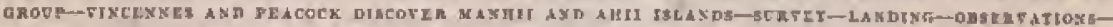

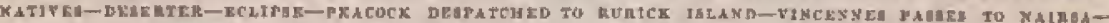

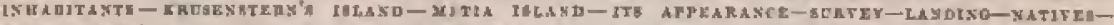

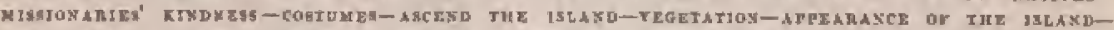

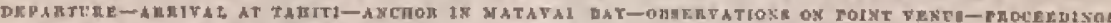

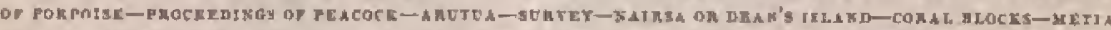

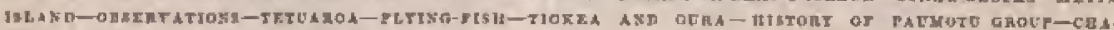

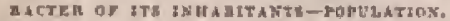

Ox the 13th July, 1839, we had finished the necencary outfits ind taken in our stores. The remainder of the latter were embarked in the store-ship Relief, which was ordered to land a prrt of thera at tho Sandwich Islands, and the rest at Syduey, New South Waleg, after which to proceed to the United States by the way of Cape Hum.

At if P.M. linving a light breeze, the sigrual was made to get under way, and we were soon standiog out of the bay under all chtraso.

The day after our aleparture, we fell in with a Pertuving trig, from San Blas, in want of water. which we suphlied. She hand fallen to leewrod of lier part, nuil her people were redneed to mudh distress fur want of that necessary article.

1 had felt much anxizty lest the small-pox should 
make its appearance among us, and looked firwari daily with approlacnsion to the lour whest the sick repurts were made, On the 14la my worst feary were realized, for the Peacock nusde signal that they lund $a$ ense of thint diseane on bonrd. It fistuwately proved af a milal type, and no other symptoms oteured that left any duult of the entire extinction of the contagion. I was, therefore, grently relieved, as day after diny elapsed, to be arkuted that"we land tut ouly eseaped so dreadlul a scourge curbelves, but that there was 110 danger of its being eunmusieated to the isluniers.

Being now about to enter thpon a new field of ubservation, in which we shuudd uecessarily come much in comsect with the natives, I issued the following genernl order; to guard agailust any miglencanours, and insure a cortect depurtment in both oflieers aud men, during our intercourse with the islanders,

\section{GEYEILL ORDER.}

The undersigned, cummanding the exploring expedition, iufurms the sflicers and crews under lais command, that as they are now alout to visit the isinndy of the Pucific, and to Jave latercourse with their inlabitints, lie wistres to ineulente on nll in the sipualron, that cutrtesy and kixdnos towards the nntives, which are well understood and fele by all classes of anankind; and trusts that neither contempt of, wor interfuretuee with, their euмcoms, Jabils, manners, and prejudices, nor ardo. gasice ower them, will be sliown liy ary one belonging tu the squndrou; bearing always in mind, that savnge tautiuns lutve but vagie ideas of the rights of property, atd sliat theft committed by them lias been the great eause of eollision between them and eivilized nntions.

He would thentore enjoin upon all, great modemation in every thing respecting theje intercusurse with them, thint nu aet of hostility will be cum. mitted, and that su nppen! will bo made rather to their gord-will than to their fents.

That the mantser of trading with them which will be established in the squndron, will be most striutly adhered to by all, and that in the event of difticulties or collision, all acts of force will be avoided, unless for aelf-protection; in short, our aim shall be pesee, good-will, and proper decorum to every class, benring constantly in mind, that the future intereourse of our cantrymen with the mutives of the istauds we may visit, will very much depend on the impression unde on their minds by us, and recollecting, that it is in the nature of the aavage long to rumember benefits, and oever to forget injuries.

it therefure bohowes us, wherever we go, to leave behind $\mathrm{us}$, whether among eivilized or savage uatious, farourable impressions, not only as respeets this national expedition, but of our flag and coutrymen. The commander-in-chief feels a confidence in retying on the offieers and crews to earry out these views, from their good and ex. emplary conduct heretofore, and trusts that he will not have to regret the confidence he reposes in them.

Any acts jneonsistent with these views, will ment swith the most exemplary punishment.

\section{(Signed) Cuskles WuкEs.}

Commanding exploring expedition.

July 13เh, 183!.

United Stales ship Vincennes.
1 had determined, on lesving Callan, to take up the examination of the Paumata group, rewm. mended to the experlition by that distinguished unvigator atd promoter of science, Admirul Krusenstern, whose notes were nuale a part of my inHtructions. I therefore steered for the ishnul of Minerva, of Clermont de Tounerre, one of she must mustern of the Paumotu group, or Cloud of Islaxds, as the name implies. I deened this to be the most interesting print at whicls to begin our surveys, nnd the resurches of our naturnlists, jur. ticularly as it was indubited, and workd thus etmbte us to trace the inlubitants from one eud of Polynesia to the other, aeruss the Pacific. At tho same time, it afforded a very' desirablo poist for magnotic observations, and a visit to jt would also enishe me to seltle a dispute between the two dis. tiuguished Ernglish and French savigntors, Cuptains Bechey and Duperrey, relative to ita geugraphlacal position. The lotagitude adopted for Cablio, from which our measurements were made, was $79^{\circ} 11^{\prime} 10^{\prime \prime} \mathrm{W}$. 'This 1 found to correspumes well with that of Valparaiso, the meridian distance between the two being $5^{\circ} 31^{\prime}$ s.t.

On the 14th we fond the current setting to the north-west-by-west three quarters of a mile per Jouนr.

The $15 t h$, nt nne hundred and twenty miles from the land, we had changed the temperature of the surface to $67^{\circ}$, being a diflerence of $7^{\circ}$. At viree hoindred fathoms depth, it was found to be $51^{\circ}$. "I'his day the current was found setting south-halfesst, hailf a mile per hour.

The lfith brought several showers of rain, the first wo had experienced sinee the Ath of June, off Valpamiso, Hero we again tried the eurreat, but foumd none. 1 now contiuned the usual experiments on the deep-sen temproture, dips, variation, currents, the risibility of a white object in water, nud the dip of the horizon, for which I must refer the render to the ubular results, only mentioning such as are geterally interesting.

On the 18 th, the surface water was $70^{\circ}$, and at two Jiundred and ninety fathoms depth $50^{\circ}$.

On the 24 th, in longitude $9 y^{\circ} 3 y^{\prime} W^{*}$, we found the current setting south-east half a mile per hour, and directly against the wind. Our latitude wris $15^{2} 35^{t}$ \$.

Until the 29th we liad modernte breezes. The current this dny was found east-north-east, onethird of a mile per hour. At $9 \mathrm{~J} . \mathrm{M}$. the wind eame from the west. This evening we luad $n$ benutiful dieplay of the zodiaca! light. It wns very bright; its altitude was $25^{\circ}$; the upper part of the cone was not well narked, and its apex was not defined ; the breadul of its baso was $30^{\circ}$. A fair breeze from the south-west continued all the next day, when we lad reached the longitude of $113^{\circ} 29$ W., and latitude $17^{\circ} 36^{\prime} \mathrm{S}$.

On the 3lst, we passed over the loenlity of no island marked on the charts of Arrowsmith. Altbough we ran over its posicion with the squadron spread so as to eover an extent of thirty-five miles in latitude, and on its parnllel for several degrees, lyjing-to at night, nothing whatever was seen to indieate land; and wo dherefore believe that it does not exint.

On the dth of August, the current was found north one-third of a mile per hour. 


\section{1-Currents, - Wints - Clermont do PAUAR'IU GROLP. Nativen on the bench.}

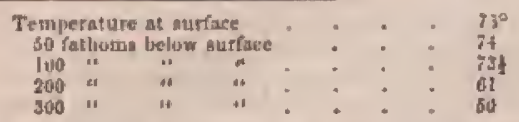

On the 5th, tle cutrent was two-thirds of a mile per hour, to the north-north-enst.

'The winds on tho parallel of $18^{\circ} \mathrm{S}$, camnot well be termed "the trades," for at this timo of the yeat they will be foumd very rariable, though prevailing generally from the entern quarter, with a long swell from the suuth-west. The upper stratum of clonds were gentrally seen thying from the sout/b-west. The deop-ses tempreralure on the bith, at throe hundred and fifty lathoms deyth, was $46^{\circ}$, surface $77^{\circ}$.

The 7 th proved a calrn and fine day, througliout which experiments were mado bourly to nscortain the depth at whiti a white object coutd be seen; the altiludo of tho sun wro taken at esch ubservation, and also the furce and direction of the curreat. The tempernture of the water at one hundred fathoms was $70^{\circ}$, whilse that of the surface was $77^{\circ}$. We were in Jongitude $125^{\circ} \mathrm{W}$, hatitude $1 B^{\circ} 14^{\prime} \mathrm{S}$

The nights of the Bth, Dth, 10th, and 11th, the meteorie showers were leuked for, the officers and naturaligts keeping watch, each gunrter uf the henvess being under vision at the sume time. the 8 il, upwarda of are Jundrent slonoting stars were seen; but the rights of the $9 t_{b}$, Inth, and 11 th, were elundy. Ors the former we hal much lightring, dlunder, and ain, with squalle from the south-west.

On the I3tly of August, at five o'clock, P.M., we made Clesmont de Tonnerre, or Minervin Ialnud, and by careful abserrations the next day, found jty south-east point to be in longitude $130^{\circ}=1^{\prime} 12^{\prime \prime}$ W., latitude $18^{\circ} 32^{\prime} 49^{\prime} \mathrm{S}$. Clemont de T'onnerre, being the first luw cornl islnnd we liad met, naturally excited a great deal of interest. Ho lad pictured thent to ourselves as being a kind of hiry-lund, and therefore looked for then with some anxiety. At first sight the island appenred nuch like a fleet of vessels at anchor, nothing but the trees being seen in the distance, and as the ship ribes and sinks with the swell of the ocenn, these nre alter. nutely seen and lost sight of. On a menrer approach, the whole white beach was distinetly" seen, constituting a sarrow bolt of land, of a light clay culour, rising up out of the deep ocoth, the surf brenkiug on its coml reefi, sumounding a lagoon of a bentutiful blue tint, and perfectly smouth. "Ilis islnd was twelve fect above the level of the scr, and six hundred feet wide tu its lagoor, and is compased of coml debris and vegetable matter. The shrubs wre few, and not more than from twelve to fifteen fect high; tho evena-nut palms and pandanus showing eonspieuously aluve them. Wo found it, by our survey, to be ten miles lung, by one and a half wide, lying in a west-morliwrest and enst-sontli-enst direction. The first, sutunding, on the enst side of the island, at three hundred feot from the reef, was obtained in unety futhorns (coral gand); at one humlred aud eighty fect, cighty-fire fathom (coral sand) ; at one hindred and thirly feet, seven fathoms (hurd coral), being at the edue of a nearly perpenticular ahelf; thence to the more the bottom was nnever, decruasing to four, three, and two fathomiss, untit s second or ipper coral shelf stose, urer which the water at high tido flowed. This extended to where the besch is composed of troken cural and shells, and arose on a gentle dechivity to ters feet high.

Tho Pencock soumled willin Iliree-r]unters of a nsile from the soutluem [roint of the island, at three hundred and fifty fathome, the lend brought up for a moment, and then agair descended to six hundrud fathorns without reaching bottom. When it was hauled $n p$, it had a small puoce of white and anotler of ret eorial attached to it. The west side of the igland is a bare recf, over which the aurf brenks violently. There is no opening or entrunce to the lagoon.

For the purpose of surveying the jaland, the Puacock aud Elying-Fish took the west side, while the Vixuenneg and Purpoise kept on the east. Hoats were lowered and sent on shore for the pur. pose of landing; soveral of the officers and naturalists sueceeded in reaching the beacls, (swimming througls the surf, ) where they remained about two hours making collectious.

I saw some natives, five men ard two women, ast endesvoured to hold communication with them. The former were armed with loug spoars. They were cantiuusly watehing our muvenents; and after the bonts bad lefi, they wore meet exanising the beach for articles that might have becn dropped. Every inducement whs helil out to them to approach my bont, Lut withont stceess; and we were obliged to return on board for the night, not having succeeded in tinisling the survey. Wishing to cumnunicate will the untises, nirl effect a lassding, wo lay-6o, nud ly susruing found that we had drifted off frots slu istand eight tuiles to the norts-west, and did not agrin rench our station uutil townrds the nfternoul. I then froceeded to the berelt, taking with me as interpreter, Jwhn Sac, a New Zealander, who spoke the Tahitiat language, determined, if possible, to enter into cummuniestion with the natives, and to land to make observations. Serenteen natives were now seen on the bench, arned with long spears and clubs, which they were brandishing with menacing attitudes, making notions for whe to retite. As I approached then with a white flag flytug, many more were secn in the bustues, probibly in all about orse humdred. I told Joln Sne to speak to them, which he did, and found he was understooul, The only answer the could get from them was, several of them erying out at the same time, "fo to your own land; this belongs to us, abd we do not want to have any thing to do with you." It was impossible so beach the bout without injury; on account of the surf and coral; ard in order to Innd it was necessary to swim a shore distance, which conld nut be donis witlsout our being attacked, and suffering injury, before we lakl established a friendly intercourse. I therefore had recourse to throwing presenta to them,-all of which they eagerly took, - assuring then that wo were frjends; but they still continut warning us off, and threntening us will their long speara. I am nather inclined now to think our interpreter was partis the cause of my not succeding in orer. coming their fearn and seruples. John Sne wats truly a eavage, althougli he had imbibed some fechings of discipline, and was generally a welldisposed fellow. He was a petty New Zealand chief at the Bay of Ialands, and had resided some time 
at Tahiti, where he sait bo was married. At thmes it was difficult to control John's tnorements. On this oecasion ho soon became provoked at the chief"s obstimacy; and the idea of their receivisig a!! our presents so greedily without even thanks in returm, excited his nntive fire; his eyes blone fiercely, and his wholo frame seemed agitaten. Half naked as he was, his tattooing conspicuous, he stood in the bow of the boat brandishing his bonthrok like a epenr, with tho dexterity of is savage. It was difficult to recognize the sailor in the fierce majestic-looking warrior beforo us. The chief and Joln kept passing words until both were becoming vociferous, the one appearing as sarage as the other. John's animuted attitudes and gestures were the admiration of all. $\Lambda \mathrm{s}$ we coald not understand him, ho may bave said many things to irritute the savage chive before he could be silenced, althuught he afterwarls declared his inmocence in thnt respect. I had been engaged for upwards of an hour endeavouring to overcome their fears, wher I was joined by severnl bonts from the other vessels, The utlicers being anxious to have communication with the natives, were desirous of lasding, and I readily gave them permission to do so withuut arms. They passed a short distance from us, hoping to effect Uneir purpose without oppositiou; but the uatives separated, in order to oppose any landing. One or two officers swam through the surf without arms, and were boldly sut upon by three of the natives, when they malo a lurried retreat. This oxidently gave the natives confideneo, and their eundnet became more violent. Mr. Couthouy requested permission to land with presents, under the protection of the bont, to shich I couserted. He swam on shore, pusing now and then, for the purpose of showing the trinkets. 'T'he ehief motioned him sway", but he landed on the rocks. The ehief retiring, appeared as if onsewhat alartned, while Mr. Couthouy advanced towards him, loviding out the presents. On beiug joined by anuther matro the dief stopred, raised his spens, and with a shout nud distortiun of countenance, made a pass at Mr. Couthouy, who at once dropped louking-glasses, trinkets, de., at his fect, and guickly made for the bont. 'The savage took tho notice of the relirs?uighed offerings, but alvanced to attack him will lis spens. When he land reached the edge of the eurf, the ehief made another tlirust at lim, but furtunately witliout injury. This [recipitaso retrent gave them still more conlidence; they now began throwing pisees of eoral, ntutnbers of which struck the men in my boat. I felt no disposition to do them harrn, and yet I had no idea of letting them see and fce! that they had driven us off without landing, well knowing, lowever, if a forcible landing took place, and they uade resistance, that injury would befal! one side, and probably both. 1, therefore, thinking that they had no idea of tire-Arma, ordered severni blank cartridges to be fired; but they took no notice of thern". According to John Sac, they hooted at these arms, calling us cowards, and daring us to come on shore. I then fired a smail cluarge of mustard-seed shot at their legs, which did

- I hase aluce undenlood, however, that the poor natlve have been fired upon by trading vessel engaged in tho penti-ilstiers, in rocte wantonness, which will occount for their hastle recepliun of us. not produee any effect. Then Mr. Peale, who was near by me, was requested to draw lis ball, and load with mustard-seed, which he did; and Lientenant North likewise fircd, which cansed the ehief and all tho rest to retreat, rubbing thoir logs. The officers were thow perinitted to land, nnder strict ujunctions, in order to swuti sll conttact with tho rastives, not to leave the hereh. So much time had been lost bufure I could get the instruments safely on sliore, that I found it too late to make the observntions 1 desired.

The natives whom we saw appeared a fine athletic race, much above the ordinnry size. "Their colnut was darker than that of our Indians, but thoir fentures regembled them. No tattooing was ubserved on the men, and the women were not sect close enough to distinguish thens. The lair of the former was long, black, asul stringlst. The chiefs had theirs draw'n lack, ant tied in a knot behiui; tho others tad theirs hauging loose. They wore a small maro made of leares, and the chiefa a pandanus leaf nround their necks, probably to distinguish their rnak. The women wure a piece of tapa as a petticoat; they were not oiled, and tho hears of somo seemed filled with ashes or lime. They spoke and understood the Talitian dialect. T'te otsly infurnation oltained from them was, that vessels had before beon there, but had gone away without landing.

Immediately on their being driven from the beach, a large columa of smoke was seen, no doubt a signal to the other inlantitants of the islant. After being on the reef balf an lyour, we joined our bonts, and returned on boari nets sunset. One canoe was reported the next morning, as having been seen frum the Peneock.

The number of intubitants that we saw certainly did not exceel one lundred and twenty.

The common house-fiy was found in great numbers at this istand. A number of fiels wore enught; some shells, and speciusens of most of the phants, were also procured.

After lying-to for the aight, we, at daylight on the 1 (tith, bore away for Serle Island, lawing first ascertained our distamee from the joint of Clermont do 'lonnerre by triangulation. Wo ther man by the patent log for Serle Island direct, by wlich meang we made the distunce between the two islands, twenty.six miles sud two-tenths, No sims of any other isiand exist between these two. This will, I think, settle tho question between Duperrey and Beeclsey. The Intter is undoubtedly wrong as respects tho longitude of Clermont do Tonnerre, which he plnees some twenty minntes tho far to the eastward, and, I doubt not, some acciclental errnr has oceurred in his observations; for I find, at Serlo Island, Duperrey, Beechey, and myself, agree within $n$ fow minutes.

Serte is a low coral island, and has a large and very segular elump of treus on its westeris end, which, at a distance, mighic be taken for a mound or lill. I ta length is seven miles, nnd its width onte and a fourth. It lies in a north-west and soutleast direction. There are but few julabitants on it. The position of its soutlieenst end is in latitude $11^{\circ} 21^{\prime} 10^{\prime \prime} \mathrm{S}$, longitude $137^{\circ} 4^{\prime} 10^{\prime \prime} \mathrm{W}$.

The vessels again separated for its survey; bonts were sent to tares the reef, and liave eummunication with the natives, if possible. Hefore uight we had completed our survey, and the boats re- 
turned. Lientenant Alden, in charge of one of therr, reported that he had had comounication with the sntiver, who wero very friendly, and ilesironts of holding intereourse with him, The rabninent severa] articles of euriosity from them. Some of them wore tattored. They were found to be armat thieves, wishing to enrty off every thing they saw, trying even tu full the conper oft the biakles of the oars, - and all chis, apparently, without any idea that it was wrong. Wlien first roen they were armed with spears, but observing thnt wo did unt attempt to hand, they sent them nway in charge of a boy, and swarn off to the lioat.

I now determined to wait nutil the next day, for the pturposc of lasving further communication wist then, and orilered every thing to he prepared for an early lasuling; but, during the night, the officer of the deck of the Porpeise ran into the Yineenzes, and did both vessels some injury, smashing the starboard quarter boat, which hroke adrift, eutting ofl our backstays, and losing some of the head-spart of the Porpoise. By this aceident we lost our position, and in the morzing found outgelves no far to the leeward, that I knew it must oceupy mueh time - which wo could not afford to lose-before we could regain tive islaul. I therefore reluctantly bore away to the nortlaward, to pass over the loenlities of one or two doubtful jislands, on our way to that of Honden.

On the 19th of August wo made Henuake, Honden, or Dug Jeland, and earno up wilts it about noon. The bonts were at once derpatelied, in order to nscertain if a landiug conld be clfected, and the shipe began the surveying wperations, The surf ars foums rery licary on the beach, lut the boats, notwithstanding, anceceded in linding. The uumber of biris seel hovering over tle isiand wis ur indieation that it was aot inhabited, which proved to be the ence. Severnl turtles were erught, and a number of specimens ohtained. Thu strrvey of the islund not having been completed, I lay hy all night, and early in the morming de. spatehed boats to complete the examinntion of it, and to effeet $\mathrm{n}$ landiras. Tho greatcst part of the day was spent on the islarud. Neav the place where we landed there has been a clinanol to tito sinull lrtgon in the centre of the is?und, sud there is nnother of a aimilar character an the opprosite side. They were both dry, and tho sen-water ent only communieste with the lagoon at very high tides.

The Landing on a coral island effectunily does awny with all preconceived notions of its beauty, and any previous ideas formed in its farour are immediately put to tlight. Thint verdure which seemed from is distant view to cartret the whole isinnd, was in reality but $\Omega$ few patelnes of wiry gmss, obstructing the walking, nnd offeriag neither fruit nor flowers to view; it grew nnang the rug. ged comi debris, with a litilo and mal vegetablo enrth.

The principal trees and slirubs are the pandanus, boerlaavin, and pisotia. It is somewhat murprising that a few trees forty or fifty feet high should liave fruml sufficient soil to protect their growth. Most of the trees, howerer, nre of stunted size, being not more thun tess to fifteen feet in height, and eightoen inches in diameser.

Tho number of birds on the island was incrodible, and they were so tame as to require to be pushed off their suests to get their eggs. The most conspicuous among them was the frigate-bird (tocligpetis aquihus): cuany of the trees were covered with their wests, corrstrueted of a few sticks. The ohl birds were seen, as they flew off, inflating their bloot-red jooselies to the nizo of a child's hend, ond lusking as if a large bladder were attached to their necks. The gamets, sooty torns, and the beal. tifts tropie-tird, wero in countlese numbers; the former gunrding their eggss, (which were laid ots tho ground without a nest,) with eare, tertaining by then, and exen suffering themselves to be eaptured witlout resintance. Their hougse eroaking wns quite denfeuing.

Some droll sights wore seen of erahs walking off with snakes, smil both ngain seized by some stout bird and borme away. Armies of gollicer or giratical crabs (paguri) were seen moving in all directions with their slvolls. We enjoyed ourselves mucls, and formd no nse for our guns, powder, and shat; na many specimens as we could desive were ubcu with the hand, both old and young. In snme caser the tropie-birds were taken off their nests, ant from others their eggs were taken withont disturbing them; indeed, I havo perer seen any burn-yard fowla linlf so tame.

The various anaker, the many-coloured fish, the great cels, enormous and roracious shnrks, sliells, large mollases, spidters, with the eurious lepidoptern, seemed tu have quiet passession, their welig stretching in every direction, and ocenaioning us muck annoyance: all gave a navelty to the sceue, that lisghly interested and delighted us. In the afternoon we returned on bosri, luaded witl apgecimcis; and the survey being conjpled, we bore away ot our conrse.

There are no eneor-rut pralons on the istand, as lans been roported by Crptaiu Fitzroy, in lis voyage; nor is there nuy fresh water to be fonmol. Some of our getutemen saw on the beach some broken oara and remains of a boat, but nothing could be isleutified.

Pandanus trees exist on the soutlı side.

On the eid of August we made the Disappoint. ment lslands of Byron: they are two in number, eallerd Wytooluee and Otooho.

On the nurning of the 24 th we were of the noitls. west end of the former ialand, which lies in latitude $14^{\circ} 9^{\prime} 30^{\prime \prime} \mathrm{S}$. longitudo $141^{\circ} 17^{\prime} \mathbf{6 0}^{\circ} \mathrm{W}$. Many nanoes came off to the ship: as they appronched the ressels, the natives were heard, while at some distunce, singing; and, as they drew nenr, the clarzour increased, accompanied wilh unch laughing, aud mnuy gesticulations; but none of them could he induced to come on bonkl, and they were not willing to frart with nny thing but some pieces of old matting. An nttempt was male to get sorme of their paddles, but they muer ridienled the idea of parting with thein.

The canoes were quite small, being only from twelve to fifteen feet long. Thoy gexserally coutained two, and sometimes three natives. Fuch eanow had an ont-rigger, and a projecting point, both before and behind, by which they get into thens from the whter. They are formed of stripa of cocos-nut wond aewed tigether. Two persons cun carry tliem. Their paddles were curved backwards.

In nrter to dispel their fears, artjeles were given them gratuitouly, and by way of showiru their gratitude, they began a monotonous song or 
chaunt. They would necasionally atop, look up, and return the laxgh of the crew by a trin; apparenty enjoying the sport as much as any of thein.

These natives are peculine, and appeared totally distiuct fmm any outhers we met with in this group", having fotrong wiry beards and nustaches, and a difrerent pliysingnomy.

I sent ore of the bonts to the slyore, with the interyreter, under Lieutemant Corse, but they refused to allow them to Innd. No netual violoneo was attempted, but Lientenant Case reparted the impracticnbility of landing without opposition, and injury to themselves and untives, they reecived seversl presents, lut they hat no fruit to give is returm, ns their cocon-rints were trbooed. T'ley gave, in exchange, sume articles, consisting of clotli, fisli-hooks, alzes, and pearl-shiells. Among the articles seen in their posession, was a fue sill poeket-hanikerelicef, ahowing that they lad had cummunication not lons since with vegsels. They refused to part with their spears or elubs. Their adzes were rudely made, but ground very sliarp; they were fornted of the tridachna $m^{\circ}$ enssis shell, lashed on a landle somewhat resembling our adzeJundlns. Knives were nlso observed in their jos. Bcesion.

Wytonlice is formel of ialets connected by a waslied coral reet, of irregular slape, witlı a lagoon havigg many knolis in it, of varions sizes, some four or five feet above the surface. Tho snuth-enst portion is the largest ant most thickly wooded, and contains the grentest nusuber of inlinitints.

After the surveying duties were over, we foum ourselves at the north-west point of the island. The matives who had refused to allow na to Intud, were now keen waving gren louglis, which is the general sign of gond-will, and a desire to lave commu. niention, and nany were seen thancing on the beach, with their spears in their hands. I pave orders to send the bonts to the shine, but on reaching it we fonnd them still sreme (u) our farding ; they, however, assisted Mr, Couthony throngh the surf to the bench; but when he liad resched it, they sur. rounded him, surl led him laseli rery gently to the water, making him distituetly understand that they would not permit him to risit thejs tuts. They were extremely desirons of obtaining hutons, pieces of iron, and eloth. We gave them several momal articles, but they could not be persunded 10 part with their aptary and clubs. The ehief, who was a very old man, was ecen lying under a pandanus tree, ciose to the betch, and on being told I wished w seo him, and make him a present, he arose: his hair was quite gray, snd he lind a long and stiff white beard ; his lers were enlarged with the elephantiasis, the swelling being of a white culour, and so large and regular that nany thought he tad on sailor's tmousers. Aburt tworty nntives were with bin on the brach. After leing shown the presents I hall for lim, he wanduced to wade into the watel ap to his neck to mecive thetn. On coming alongside the loat, he seemed somewhat uncasy, until he had gone through the coremony of rubbing noses, which 1 must exufess was any thing hut agreenble with so dirty and disestaed a person. He was extreme]y anxiots to get hold of the presents, and amused us by at once plunging them under the whter, seeming in tso mantser conecrsed about heeping thein dry. He was all ple while making \& nojse like the purring of $n$ cat. In return for my presents, he at once offered me the ahort mantle of inattisig which lie bad over this aboulders.

They understond the Talitian langnage. The clicf gave lits stame an linroken, and the uame of the jstaml as Wytoulice. He mpyesued abont biaty yenrs of age, and his weth wero all sound mid gand?

His brother whs the jriest, to whom I nlan gave some presents. 'This man had a very remartiable lead, the forchead being very ligh, and narmow simost to deformity, with a dark nnd suspicining briglit eye, His tamb were deformed, lycing desti. tute of joints, and the lower part bent at right angles. The son of the clief was a rumarkably fine-looking tal of fifteen. We saw no women, as they land all been hid. The colour of these natives was snucl darker tlan those secu before ; in some the hair was inclined to frizale, and the beard curly. All the grown men that I saw had mustaches; their features were etrnngly maked with a goad-hurnoured exjression of countenance; they wore the nano, and some lad a few festhers in theír liair.

The boats of the Peacock succeeted in landiag on the east side of the islund, where the cural peef shelves at about an angle of $10^{\circ}$, and baviag tho wind hlowing oluliquely on it, there is contunntively little surf. Sone haif a duzen natives were here seen; an oflicer a[yumacherl them making signg of friendship, which they returned. At first they seemed quite timil, meeting the adwanees mule in a manner which showed that they were atsxinus to propitiate us, but still fearful. "They were re-nssured of onr good-will by offering then some small presents, when two nld inen enme forward, holding lizeir arns upright above thrir lients, with their lands oven, and hecame desjrous of sliaking lınnds, and even oflered to rub noses. Eacl, was armed witly a stick, (fur it could not bo called a spenr, ) six or seven feet long : on some of them were fastened the jaws of the porpoise.

They appeared to be greatly astutished, and their looks bespoke amazenent at onr appesmance. Oecasionally, as if to satisfy themselves of the reality, they would put thrir hands on us. On receiring a few trifling puesents, they broke forth into the same song or clautut that was hearl on their first eoming townrds the ship. 'l'he younger ones were the first to show confidence, anil were mucls disposed to laugh and joke with the men; and some of the oflicers thought they recogtized those who had been in the earoes the day before.

On our gentlemen reriuesting to go to ilteir liuta, they seemer to be throwu into a kind of stupid wonderment, lut on being assured they hat no. thing to fear, their coustenanees brightened u[, and tisey led the way thromght the wood to an opens space, surrounded by pandants and cocon-nut trees. These natives bad evidently had communicntion witl resgels, but I very much douht if ary had landel before. They did not appenr at ail alarmed at the firing of gujs, but were much str:prised to see the birds hilled, holding up thoir lunde, and making ejaculatione. They had no iden of the principles of barter. and allowed any thisg to be tuken without opposition, reseiving any aricles in return with gratitusle anul delight. Iron was prized more than any other thing. On renching the tuts, inquiry was made of them fur their women, wlen a general hurst of hughlerer ensued, F 2 


\begin{tabular}{|c|c|c|c|}
\hline 63 & $\begin{array}{l}\text { fsland of Olonhar. } \\
\text { Natlvet averse to their landing. }\end{array}$ & I'AUMOTU GROUP. & $\begin{array}{l}\text { King" Inland discovered. } \\
\text { foraka. }\end{array}$ \\
\hline
\end{tabular}

mul they gave us to understand, that they lased pentrated our notive for Yisiting their islami"That as we inhaljited an islnul withont nuy wome11, we wanted to linve some." Notling more was sail to them on the subject. They arcompanied us to the boats, aad at parting went through tho вame ceremonies of rubbing noses, shaking hards, and mising their arms with the palms towards ts. According to the estimate I made of the iulabit. ants, the number was about ninety. From the great age of the chiefs, and the absenee of wounded or sentred individuals, I should eoneivele they lived in peace. Thoy, however, gare their neiglibours on the small island to the west (which they called Otooho) a very bad name. Water in smail quantities is to he had on the enstern sccion of the island, and a little biche de-mar might be taken nn the reefs. A small rat was vory troublesome the the natives. "Whis island has some coeon-nut, breadfruit, and pandanus trees; the pisonia, toumefortia, and the slarules that are common to the low islands, glso grow upron it.

At niglitrall the squadron was put under sloort sail, euprosing that the current by the worning would take us to the leeward near Otoolo, a distunce of ten niles. It lice west-north-west of Wytoohee, distant twelve and one-third miles, and is distimelly seen from it, like a round lenoll. T'lit: appenrnte is owing to the trees upon it, for the land is ns luw as coral islaruls usually are. We found by the motning, that the eurrent had been abont one nile per hour to the west, and therefore mach atronger than I anticipated; we were in consequence some distance to leeward of the imland. With the light wind, I knew the ship enuld not renet it befire the afternoon. I immediately sent the satumlists on boaril the tetuder Flying-Fish, and gave Lieutenant Pinckney orders to endenvour to band them, and to pars around the jsland and sarvey it; neither of which he succeded in doing. The survey was finnlly completed by the hoats of the Vineenues and Peneock. 'The naturalists tried to effect in landing, but were opposel by some dozen nntives, who were resulute in preventing them from guing beyond the water's edge; in other respects, they were disgrosed to be quite friendly.

The naturnlists in the afternoon endenvoured to effect a landing at another place, out of sight of the natives, and smceceded. Mr. Brackenridge, on landing the secoud time, ran to the thieket, in nrder to lose no time in ruking collections, and was employed in gathering specimens, whes two stout notives eanse running up, and made lim nnderstand, by very intelligithe signs, that he must return to the iroat; he preteraded mint to understand them, and endearoured to proceed, but they went hefore him, and crossed their clubs, determined that he slioutd go no farther. This enused him to laugh, in which the two natives joined. Finding there was no nlernative, he took an oblique diree. tion cowarla the boat, lioping by this meana to enlargo hia collection, which he suceeeded in doing, while the matives, ns lie descritses it, ahouldered him out of the bush, and then townrds the hoat. The rest of the party laving gone up to the luts, were nt once geized and shoved down towards the boat, and into the surf, where they presented rather a Itudicrous appearance, with tho danger of drowning on the one side, aud the natives on the other, who had them completely in their juwer, as lhey had nejther nrms nor any nther means of defence. No harn, however, was done them, but the alarm ineident to lxing threatened willi repears. The only mishap met witli was the loss, by one of the gers. tlemen, of a prir of espectacles, nid a bruise or two from the eoral, in their hurried retreat. As the Burf was heasy, life-preservers were sent to those who could not switn; and after much detention, they reached the bont in safety. Had such a eir. cumstance occurred at Clemont de Tornerre, I am satisfied that most serjous conseguences would havo resulted to us.

The superficial extent of the jsind of Otooho is nbout a square mile; it has no lagoon, is well covered with trees, and hag freals water. There were nineteen men counted, which would make the population about fifty souls. No women or children were sech.

$A t$ all the inhabited islands re found the greatest numbers of the conmon house.fly: while at Honden Island (uninhabited) none were perceived. No one can estinate the nniroyance they cause, until it bas bees experjenced.

About three quarters of an hoss nfter sunset the naturalists were again no lroard, and we bore away on ontr course to Raraka. Having beell informed that sevenal islands were supposed to he in this noiglibourlood, that were known to the nntives, but not lnid dow'n on the charts, I determined to lie-to during the night. At daylight we ngain bore axay, spreading the squadron its opes order of sailing.

On the 291l, at daylight, land was reported, and we soon ascertained that it was not laid down on the elinrts. It is low, nearly of a circtular form, and weil covered with trees and shrulk, and has a lagoon of some extent. Its centre is lin latitude $15^{\circ} 42^{\prime} 25^{\prime \prime} \mathrm{S}$, longitude $144^{\circ} 58^{\prime} 45^{\prime \prime} \mathrm{W}$. I named it King"a Island, after the man at the masthend, who first discovered it. After completing the survey of it, we landed on its lee side, where the water whs quite smoolh, and spent tlie aftemoon in exasnining $i t$. There were no natises on ic, but erery indieation that it lad been inlasbited recenuly by in party of pearl-fishers. The lagoon appeared to be well supplied with the pearl nyster. We fourd on the island two small eprings of fresh water, near its Jagoon, and is good supply of cocon-nuts. Many specimens of plants were obtained, and several interesting oljects of natuml history were added to our collections.

In the morning we bore away for Ramka, nul shortly niterwurds made it. As we approaclied it, another isind was discovered, to tlie norllwwart and westwarl, whiclı was not laid down on ary cliarts.

On Rarnka we soon discorered a party of natives, near the entrance to the lagoon, whving a Talitina flag, three horizontal stripes, red, white, nnd red. They were partly dressed, Bone in shirts, without. hats, others with vesls, and otliers again with trousers of all colours. I joined the schooner, stoul in for the mouth of the Jagnon, and laniled.

Nothing could be nore stribing than the differ. ence that prevajled bitween lhese natives those of the Disappointmest Islands, which we had just left. The half-civilization of the untives of Ra. raka was very marked, and it appeared as though we Ind issued nut of dnrkwess into lightit. They slonwed a modest disposition, sand gavo us a lenrty 
welcome. We wer not long at a loss as to what to ascribe is: the missionary had been at work here, and his exertions had been bised upons a firms foundation; the savage had been changed 60 a rensotable creature. Among the inlatitunts was a native nissionary, who had been instrumental in this work. If the missionaries had eflected nothing else, they would deserve the thanks of all those whu roam over this wido expasso of oeean, and incur its tuuy unknow's snd lidden dangers. Here all shipwrecked marinerg would be sure of kind trentment, and a share of the few consorts these people possess. No savage mistrust and fear were seen liere. The wonses and children came about us, receiving our trifles. They showed much joy and euriosity at the sight of us, and were esger to supply our wuts.

I was particularly struck with the modest and gatiet Ishaviour of the sntive nzissionary, who was a Tahitian. He kept limself alouf, whilat all the athers were crowding round to partake in tlie presents we were distributiag, and semed much gratified and astoristsed when I seleoted him out as thes recipient of a preseut similar to the one I bad gtven the chief.

All the males' heads wero shaven, sonmewhat after the fashion of a Dominican friar. This practies is said to havo been alopted by the missionaries at Tahiti, for the sake of eleanlinesg, and nlso to distingnish the Christinn from the lienthen party. "Tho womes lave theirs cut close, and sone are clotted it a pareu, consistiryg of three or four yunds of cotton, others in a Joese gown. They were any thing but good-losking ; but the men swere tall aid well made. The s'siriety of ajparel was drull enough. $d *$ for tlie children, I have seldon seen finer; all were well formed, and as eheerful as they could be. 'They were for the most pirt noked.

This was the first istand on which we observed the dnwring of Clrristianity and civilization. The native missionaries, although tlaey aro yet ignorant of most of the dutics enjuined upon a Christinn, still id much good in proparing the way. Many Jeam to read, and some even to write, under their tuitian; yet they have many impedinsents thrown it the way of their efforts by the introduction of spirits by the whitus. The old chief, and others, are much axldieted to the use of it, and the ressels resorting hore for tho pearlfisliery generally employ antive divers, and pay them for the most part iu rum or whiskey. We found here an Englishmun who had belonged to a schooner engaged in the pearl-fishery. He told no ho had been left there sick by his enptain, and had been kindly treated during his stay of three monthe on the island. I whs in hopes of obtaining some information from him, but he knew little or nothing of the langunge, atsd was, morever, a stupid fellow. I gave him a pussage to Tahiti, whither he was desirous of going, in the tender.

Having come business on board, I invited the chief to go off witl mo: he first inrugured if alt the boats and men were to stay; on my telling him they were not, he gaid lie would go on buard if I woufd nlso take his wife and ber bivther; to which I cosiscinted.

The eluef lind lost one liand, which the infortned me had been bitten off by a shark whilst employed in diving fur shells, Wre became great friemds, and he thought it necessary to bo at my sido the whole time, He was an odd old man, and proveal befure we left him that he had hecome acquaninted with some of the viees of civilization.

We all embarked, soou reached the tender, and bore away for the ethip, anse three or fuur miles distant. The old one-lianded chief now came up to me in a very mysterious manner, and untying a knot in the tnil of his shirt, (which was the only grament he wore besideg his naro, ) with oo suall difficulty, with one haud and his teeth, drew from it a small dirty pieco of litien, tied up as a bag; this he produced with great form, and evident? expected to astonish nie. The contents proved to be a few small discoloured pearls; those he begged me to aceept, but $I$ declined to receive them. Whe now reached the ship, and I ordered every thing to be slown them. Their surprise was very grent.

The natives were much amused with the ship, and surprised at tho number of men ou board. Many small prusents were given them. When they were about taking their departure, the old chice complnimen of being quite sick, and his whole ait and nutuner slıowed that the was much diseatisfied. The reason could nut be imaginet. The ressel had so littlo cuotion, it was thought it coull not originnte from sea-sicknes\%. I therefore tuld the interpteter to inquire of him what was the matter. No answer was given for tome time, but lley consulted anuch anoug themselves in a low tone. The question was repeated, when the old elief's wife answered, "that I bad not returned the prosent that hud been offered me, and liat the elief whs not plessed ; for, according to their customs, the offering a present to me etutitlet him to receive one in retmrn." $\Lambda \mathrm{s}$ very many gifts had been made him already, this amused ne not a little. On anking what it was they wanted, they at onco signified whiskey, which they said was always given then wheu tlicy went on borrd ship; nnd the elief wanted soume, for he was very sick. I accordingly ordured a bottle of water with a gill of whiskoy it it to be given them, and the moment they smelt it their manner was changed; they beetame ail animation, and left the blip in grent good Jumour. The brother was an intelligent native; he drew for me with a jiece of ehalk, on the deck, with consideruble aceuracy, all the ishands ho was sequainted with, giving their relative situntions and the native names; - that of the island we had seeu the day before, rs Tri-n-rm, and tho one $u$ which I had given the name of vincennes Isluted, as Kawalve. He informed me of three small jslands to the southward of Sacken, which were afterwards found by the Porpoise, during the cruise to this grouj on which $I$ sent her in 1840 ; his knowledge of the western part of this group was quite sxiprising. I place the entrance to the lagoon of Rnruka in longitudo $144^{\circ} 57^{\prime} 40^{\prime \prime} \mathrm{W}$., latitude $16^{\circ} 6^{\prime} 25^{\prime \prime} \mathrm{S}$

The entrance is on the north sido of the island, about one-third of its length from the western end. It is a narrow passage, but will admit at suall vessel. The eurrent runs very strong out of the lagoon, so much so, that a boat cumnot be prulled ugainst it. The water in the entrance is from tivo to eight fathoms deep, but there is no advantage in entering, as the reef is quile as steep within. A small ressel may anehor on the outside, in ten fathoms, close to the shore. This islam is nearly 
of the slape of an equilateral triangle, and its soutlers and esster's sides aro formed by a subnerged reef.' It is tifteen sniles on ench side.

1 asternpted to samest the layoou. We began at the enfrasec, but found, within a very short distarke, that the depth incrensed to thirty fathons, the water being as blue as that of the coean. So great a tepth mado it all uncertaking far beyout whot my time sllowed. The soundiug, in every case of any deptls, was comb samil.

Towarús stinset we all embarked, nud my leavo. taking with the old chief was amusing. He with all his household and retinue began to ery and whine trex me, so that I wos glad to osenge from the disjuy of so much friendship and parcutal affection.

After reaching my slip, the l'orpoiso again juined us. She had been despatehed early in the inorning towards the eastern ent of the island, to nscertain its extent, and fix its point in that directinn ; toc being able to accomplish this, LieutenantCommandant Ringgold returued for further orders. This nighit we Lay-to under the lee of Ruraka ; but as it proved dark and squtally, we stood to the norklawarl, and about one o'clock we were surprised by seeing a signa! from tho Peacock, of dituger close aboard, tunder the lee. I inmedistely tackerd, and we soon eleared it. It proved to be the reef of Kawalıe, over which the surf was breaking violeutly. The Peacock way so close to it that Captain ILulson feit linaself obliged to stand on lis course, rabser than run the risk of mimsing stays, amil continued to run alung it for soveml anilen, until, by its trending to tho westward, he was coabled to cluar the danger.

Ot the 1st of September, at anytight, we found ourselves between the two islanda, and the Peacock was out of sight; that two hours afterwards she was again seen. I made signal to the Porpoise, anil despatched lier to exnmine the surth-east side of Rarakn, nut thence to follow on to the westward as far as Krusenstern"s Islujul, passing aloug the south side of Nairsa or Dean's Islind. I thou despatched the Pequek to the nurch end, and the tender to tho soutl end of Kínwalse, to secure merridian observatiuts, whilat tho Fincenues was esuployed in surveying its eastern alores. The wind was well mapted to our object, and at aunset we met of the north erat, having cormpleted our work. The current was trier, but we found none. Tine wind wus fresh frum the enstward, witl gecasinual sijualls. On the inorning of the $2 \mathrm{~d}$, I determined to band the raturatists on the aewly-found islatud, and for this purprose snade sigual to the tonder to conv within Jail. My alip, was lying with her maiu-topsail to the mat, and forging ubead about a knot su hour. "Tho tender canse up on our lee quarter, and luffed in an awkward manner, directy neross our lows. Her mast just esenped corning in contuct with our jib-bonm. I at once ordered sll the sails of tho Vineennes to be thrown ahnck, which stopping her why, prevented the dreadful secident of ruming the temiler dowy. It was a most miraeulous mesnpe.

Wo haded on Vincenneg Isfand, and obtained the ustst ubservations. It sonth point is in latitudo $15^{\circ} 59^{\prime} 48^{\prime \prime} \mathrm{S}_{.,}$longitude $145^{\circ} y^{\prime}: 0^{\prime \prime} \mathrm{W}$. It was furmd to be sixteen miles long by ten wide ; its grentest diameter lying north and soutl. It is a nเtrow rmular ridue, ensisting of matry blocks and stabs of coral, which give a clinky souid when struck. The coral shelf seeused to dip in wao ylace at an angle of $15^{\circ}$, forming a ridge, which wha so low that the tide was begisning to thow orer it befure higla water. There is an opening into the Lagonn un the sorath-west side; ou jis soutli-easter'tu part is a highi clump of trees, boking like a kinell at a diatance. The rest of the istand is covered with a growth of hushes, ten or twelve ftect Jigh. The blooks and slabs above spokun of were very nuck water-worn, and were strewn abous on the corat shelf. This, where 1 measured it, was five liuudred foet wide, bat it is not of equal wuth in all parts. Autong the coral blocks was some sand, ast in mnny of then were foumd large specimens of the chama and other shells. I whs informerl at Itaraka that there were a few ighabitants on Viu. cermes lslaud, but none were been by us, l'hey were ssid to live on the southern end of it.

After finishing our observations wo returned on bourd, and mado sail fur Aratien or Curlshofl Island. IV arrived off it in time to secure its con. nexion witl Vineernes Island: tho distance was funud, by prtent log and astronomieal observatious, to he twenty miles to the westward. We then sterol on and off its eastem puint for the night. The next morning at daylight we begn its survey. The tender was despantehed round its nurtıeris shore, whilkt the Peacoek and Vineennes touk its southeru side, running cluse along the reef, which continued subnerged until near its Boutly-Western end, which is twetve feet high and thickly wooded. On routuling the point, we kaw a white thag waved hy several natives on tio bench. I imnedintely despatehed a bont with an officar, who bronght ofi two of alle primcipal antives, one of whom spoke a little English, and proved intelligent.

I was informed by one of them that there were about twenty natives on the island, and that they had frequent intuscouse with ressels. Water I was told was to be had on the island, and finding ourselves short, I Gespatched several boats to procure it. Aratica is cight nailes in length by fire in breadth.

The position of the west joint of the island was determiven to bo in lorsgitude $145^{\circ} 39^{\prime} 46^{\prime \prime}$ W., and latilude $15^{\circ} 20^{\circ} \mathrm{s}$.

Having obtuined all the water wo could in the aftermoun, anuminting to three hundred and ninety galluns, I directed the conrse of the sçuadron to the mortsward auk eastwarl, towards hing George's Gruul", lawisg frush breczes from the east-northenst. The next day at noon, the most southery itland was in sight, stud funding the slips coult not make it without much loss of time, I despatched the teuter to the grouj, with orders to circumnavigate and examine the islands, and then to follow ts (o) Tahiti ; whilst the Fineenses and Peacek bore awny to the westwurd, for the duubtful islund of Watcilandt. At $5 \mathrm{l}, \mathrm{s}_{\text {., }}$ it was discovered from the mastluead, and at six from the fore-yard, bearing north-west-by-north.

Wo stood on and off sll right, and at alnylight again nusle the land; wo reachorl its north point at fotw o'clock P,M, when the P'oacuek was ordered to take the enst, whilat tho Vincennes took tho west side; we contimed the survey until dark, when we touk the necessary angles to resuine the work in the morning. BLany natives were sece, sod sunke was risiug in soveral phlaces. Ou the 6uh of September, we continued our surveying operations, and shortly afterwaris juined the Peacock, Csptnin 
Hudam having cornpleted lis side of the island. The Puacotk now male the signal of Laud to the wesi ward. Wishiug to land and suako an examiustion of this islusd, as wall as to have enmmuti. eation will the natives, the boats wero luweret, und the unturalists from both vessela, sud many ollicers, landed, and ratulfed over the western part of the island for several hours. The few intives werv very friently, and isfortned ua that tle native aane of the island was Mashiz. This is, in all pro. lability, the: Waterlande of Sohouten and to Marre, sul is large and deep entrane in the south-enst end into the lagoon of Manhil Islatnd, is which the natives inforned rne reswels lad often ancliored, whilst errgaged in the preat-fishery. Soundings are not to be had with one hurdred fallioms of line, fify feet from the edge of $\mathrm{it}$.

To our surprive, one of the men of the Peacock, by the nume of Peniy, hero dessuted frosss the

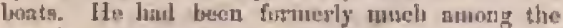
jolands, engnged in penrl-fishing, and bluke the language woll. Strict gerarels was male for lím, until the ofticer in charge of the boats beeamis ratisfied that he had ran intention of returuing. On learing of it, I was couviuced that he land eliosen this ofportunity to lesve us, particulary s as he must have beets aware that there is very frectuent communiemtion with Tahiti. The chief of this island ouforzned us that he was a relative of the one-handed clivef of linralia.

The enst ensl of the island lieg in latitude $14^{\circ} 26^{\prime \prime} 22^{\prime \prime}$ S., longitudo $146^{\circ} 4^{\circ} 20^{\prime \prime} \mathrm{W}$.

Severnl of us lind our foet severely blistered trom going hareficat on the reefs, and were made very uncomfortuble fron this cause. $\mathrm{After}$ return. ing on bourd, we bure awny to the other island, to which the natives gave the nane of Aliii. I have alson addeid that of l'eacock Island, to nurk that its correct prosition whs first estublished by the expedition. It lies west thro-fourths north per cort pass from Manhiii, and was found ly the patent log to be sight aud six-tenths miles from reef to t'eef. On corning up with it, the Vincenney and Peacock took oprosito sides, and eurveyed it ; and the next mraning partieg landed. I was hardly nble to move, on hecount of my fect, lut the desire of getcing observitions of the eclirne, urged me to make the attumfir; I only suceeeded in getting the last linsb and gont observations for litne. Aftex four o'clock, we returued on toard. This isinnd is not ishabited, and thas only n small boat-entrance into its laroun, on the weat side.

Beiug desirons of making the examination of as mary of the enral islands as possible, I vow deMratched the Pencock to the Arutua or Rurick Islaruls, with directions to exanine them, and then to proceed alung the soutlı side of Dean's Istand, whilst is the birveumes I steered for the nortl sirte of tha latter, to prase aloug it. We then [arted compary, and Dean's Islajos was made by us the next morning. After establishing our posix tion, we run aloug the northern shore, nid reaclsed its western point it $\mathrm{f} \mathrm{m}$, $\mathrm{y}$. Off this point we obtrised aighlus for our elsmometers, whiteli put it in lungitmle $147^{\circ} 58^{\prime} 34^{\prime \prime} \mathrm{W}$., latítude $15^{\circ} 5^{\prime} 15^{\prime \prime} \mathrm{S}$. During the diny we passed an entrance iuto its broou, attil suine natives same off from $n$ sminll villuge in two eanues to visit us. They acknowledged themselves subjects of qneen pounare of
Thliti, and were very desirous we should land. They brought off a few shells, and wold us they had many' fowls, pigs, taro, \&c. 'Illere are several islets in the lagnon covered with trees. Vast num. bers of inrge blocks were seen 1 yilig on its reef The sharc-reef is not nore thun two bundred feet wide, and is composed of only one siluelf. "The cur. rent was uried, but nutve was found. Wo lad the wint very fresh frou east-by-raorth all day. When off tho western point we diseovered liruenbters's Island to the went, and hauled un to pass between it and Naitrs. The prassage was found to be twedre and two-z lires miles wide, and free from nll danger. In the evening I stood for Metin Island, to the anstliward. Nairsa or Denn's Islanil was found to be sixty-fix miles in leugth.

On the morning of the yul of Septemler we were ity sight of Metia or Aumra Island, the north reud of which is it latitule $15^{\circ} 4 I^{\prime} 35^{\prime \prime} \mathrm{S}_{2}$, longitude $148^{3} 13^{\prime} 15^{\prime \prime} \mathrm{W}$. It was totally different in appearnuce frum those we lad met with, though evidently of the same fornation. It was a eorral igland uplifted, exposing its formation distinetly, and as such was very interesting. On approaching ita eastern ond, I sounded at about one trundrul atrd fifty feet from its perpendieular eliff, and found nu bottunn with une linendred and fifty fathoms of line. 'The cliff appenred worn intu caverrsa, We landed elose in its nejghbourhood, and on measuring its height, it prosed to be two hundred and firty feet.

All the aurvering boats haviug returned, we bore nway fur. Tabiti, at which island we arrived on the [0tl. At s s', $x_{1}$, Lieutenant-Cummandant Iriugrold bourled us, and brought off ${ }^{3}$ im, the pilot; he reported all well on boand the Porpoise. At sunset, we ancliored in Mutavai Bay. I hastened to ascer. tain the correctnets of our chronometers, and tie next day lnnded the iristruments on Point Venus, anel tuok observations. They gave for its longitude $14 y^{\circ} 31^{\prime} 135^{\prime \prime}$ W. Krusenstern makes it $149^{\circ} \mathrm{gy}^{\prime} 17^{\prime \prime} \mathrm{W}$.

Lieutenaunt-Commandinnt Ringgold, in the Porpoise, after parting cmplany on the 1st of Sepw tember, proeceded to the south side of Haraka, in fulfilment of his instruetions. He fownd the wholo southern part of if a bare recf, with the surf breaking violently over it. Wlien off the south point, he suade the isle of fiaciu or Sacken to the south, and that of Mabima to the enst, and conneeted them; after which he proceeded to the Hestward, [nssing Aratica (Carlshoff), and thence to Nairsa or Dean's Island, which lie made on the 5th; fixed its western end, passed along its south to its western side, and thence to hrusenstern"s Islatd, to tho wastwarl, which he circurnurigated; from thenee weut direct to Tahiti, anchored iis Papieti Harlonar on the 9th, and the next day proceded to Matavai liny, tho phace of renilexvous,

Un the $12 \mathrm{~h}$, the Pencock arrived, having pasaed to the Rurick Islands or Arutua, the north end of which lies is latitudo $15^{\circ} 15^{\prime} 00^{\prime \prime} \mathrm{S}$, longitude $146^{\circ} 51^{\prime} 00^{\prime \prime}$ W. A landing wis attenteted at Beveral places in the bonts. One of them smeceeded near a cocos-nut grove, lut the two that went to land at the village, found the Burf tow high to attempt it.

The north shore of A mutus Island was surveyed, when they bore away, and connected it with Nairs, 
or Denu's Isinnd, along which they man the whole length of its sonth side by dayliglit. The last named island is for the most part a washed reef, with no opening. The compret coral blacks showed themselres here more conspicuously and in greater iumbers thas before aeen.

After making the west ent of Nairsa, Captain Hudson sighted Kimsensterm's Island, and then stood for Metia Island, to the sonthward, on which the officers landed the next day on its western side. Their examination confirmed tho facts already given relative to its appearance.

On this island the magnetic abservations were mase, witl the Pencock's instruments. Cnjatain Hudson also sounded with the deep-sen thermometer, when within a milo of the island, in six lnutred fathoms; the teruperature at the surface of the water was $802^{\circ}$, that below, $443^{\circ}$. The next thy they made Tetuaroa, to the nortluwarl of 'l'aliti, formerly celebtated as the resort of the Tahitians, for the purpose of recovering from the bodily disenses brouglit on by their debaucheries, sc. It is a low island, about six miles long, with a few trees upon it, and a reef ofl its Boutheru end, extending hilf a mile. It is phinly to be secri from the high ridges of Taliti.

On the Ifth, the Flying-Fish arrived. Sho had visited and surveyed King Gearge's Group, which appenred well inhabited, and liave entrances to their lngoons on the west sule. The native rane of the two jslatrds is Tinken and Oura. The southwest end of 'Tioken is in latitude $14^{\circ} 3 \mathrm{~V} 12^{\prime \prime} \mathrm{S}$, longitude $145^{\circ} 9^{\prime} 30^{\prime \prime} \mathrm{W}$; Oura benrs $\mathrm{S}$. $68^{\circ} \mathrm{W}$., distant four and a half miles. Then the tender passed to Manhii and $M$ hii, round the north side of Nairsa, or Dean's Island, to Tabiti.

Little appears to be known of the listory of the Paumotu 18 lnuds, or their inlabitants, $\Lambda$ t Talriti I obtained some information from one who had heet much among the croup, and believe that it is as autlentio as can be obtained, and may bo relied on.

The Islani of Anaa or Chain Island, has been the principal seat of power, the natives of which had frequently waged war on the others, and sueceeded in conjuering all to the west of Hau or Bow Island, with which they have frequently fought.

In the reign of the first Pomare, under Tomatiti, they even, nttempted the conquest of Tahiti, and emeceded in overeoming the small peninsula of Taiarnbu. The story is, that they were about to continue their nttack on the larger istand, when Tomatiti received a written letter from Pomare, which caused hostilities to be suspended; and after further negotintion, finally led to Tomatiti's retiring from the is!nud with a large present of logs, tapa, \&c. Nothwithetanding this, the Chain Islandors remained noninatly uniler the government of 'Tahiti, and now acktowledga their dependenee on it.

Arra or Chain Islanil, is one of the smallest, yet it is the mogt thickly-peopled island of the whole group. It is said to contsin five thousand inhabitants, which large number is acconnted for by the comyuest of the other islands, and taking their inlabitants of as captives. In the list of the islands and their pojulation, it will be seen luw fow remain on tho other islands in eomparison with this number. The whole island is one coeoaatit grove, and the principal food is fislr and cocoa- nuts. The formes are esught in large quantities in the lagon. A great change has been hrought about in the character of thess islanders within the hast twenty-five years, during which tle Tahitian missionaries bave been established at Anaa. Before this period, the inhabitants were eanuibals. Since the residence of the missionaries, they lave imbibed better tastes ; nud the Christian influence has also made them more peneeful. 'This clauge wag first evineed by the treatment of their eaptives, whom they allowed to return, if they cliose, to their own island; lut very many of them had married at Anan, and beome permanent resilests there, and few lave taken advantage of the permisuion to return. Notwithstanding the mumerons population, they are said to have an abundance of food. The people of Ana still consider tho inJabitants of the eastern islands as eannibals; but their statement in this respect is little to be dejended upon, for tliey have no communication whaterer with those whom they clasg under this denomination, seldim extending Uhemselves be. yond Hau or Bow Island.

The Pannotunns are considered more warlike than the Tabitians, for which reasols Pomare I. kept a body.guard of them in preference to his own subjects. 'They liare the reputation of being an lonest and trustworthy mee.

These islanders are certainly not all from the sanse stock; and those of the Disappointment Group, whom we were much struck with at tho time of our visit, in particular differ from the others. Since we have seen all the diflerent Polynesian groups, these appear, however extrotdinary it may be, to reseuble the Feejee islanders more than any other.

By all accounts, they gqueak a different dialect from that of the Thuition nation. The difference is, however, not great, for I whs told that it required but a few weeks for any of the natives to acquire it. Mr. Hale met several Paumotuans at Mntavai Bay, and among them he found one by the name of Tuori, who contirned the accounts I have detailed alrove.

The population of this gronp I have no where seen given; I have thereforo entenvoured to obtain the most satisfactory iuformation in relation to it: the whole amounts, in round numbers, to about ten thousand, as follows:

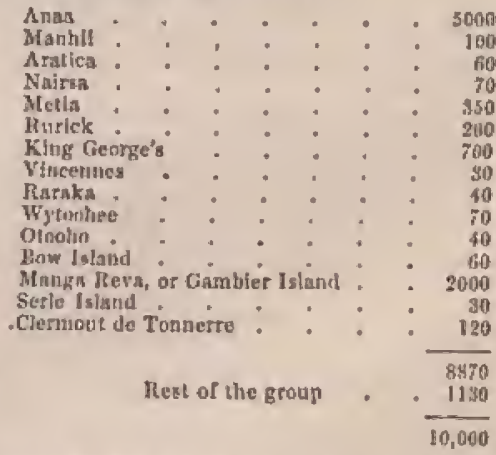

The advanement of civilization by their interconrse with the whites, together with the missionary influence, will put an end to cannibalistn, and promote peace among all the islanders of the gruup; 
not only ameliorating the condition of the natives, lut jrotecting the unforfunte mariner wlo may be wrecked within this dnugerous archipelngo.

From whrt lirs been snid of the Paumotu Grotsp, it is esident it can afford but few advantages for cornunercial euterprise; the only article which of fite years has been sought for nmong the ialanda, is the pearl oyster-sluelt, of which considerable qunntities Inve been nutained. The resaels engaged in the fistsery belong to foreigners, who reside at Talniti. The mode of takisg the oysters is by natives, who are employed as divers, for a very small compensation, It is much to be regretted, that the traders should havo reeourse to the demoralizing effects of spirits, in stimulating their exertions.

\section{CHAPTER XI.}

\section{TAHITI.}

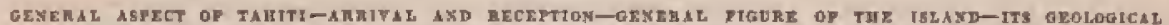

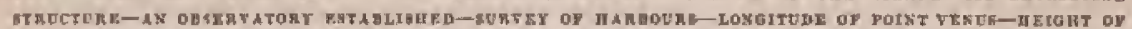

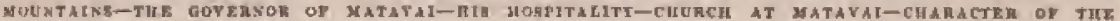

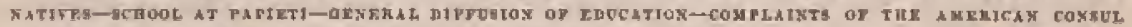

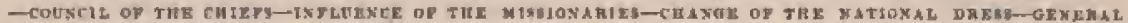

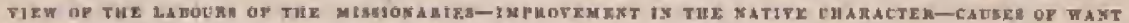

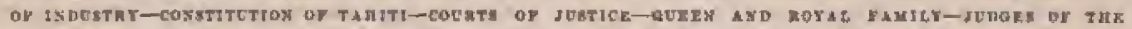

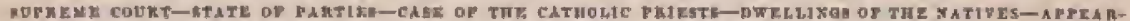

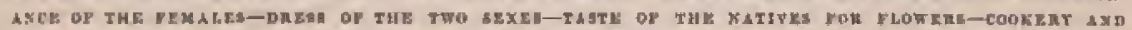

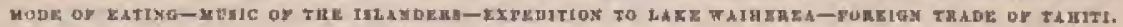

Tre beasty of the rlistant view of Tahiti las been celebrated by all navigators, but I mist confess that it diesprioisted rue. The entire outline of the island was visible for too short a time, and nt too great distunee to persnit its bonsted fentures to be distinctly seen. Uson a second and nearer view, its jagged peaks and rugged innecessiblo mountnins were visible, but we looked in rain for the verdant groves which are said by all writerg to elothe it, These inteel exist, but are confined to a unrow belt of low land, lying between the mountains and the shore, and being unseed st a listance, the general aspect of the island is that of a land rocently thrown up by voletuic actiou.

When, however, Tahiti is approached so nenr as to muke separate objects visible, the coutrast botween it and the barren coast of Peru becomes striking. Even upon the steep surface of its cliffs, vegetsition abounds; the belt of low laad is covered with the tropienl trees peculiar to l'olynesia; while the ligh peaks and walt-faced mountains in the rear are covered with vines ancl creeping plants. This verdure is gew to rise from a quiet girdle of water, which is ngatin surrounded by a line of breakess, dashing in snow-white fonm on the encircting reefs of eoral. Such objects are sufficient to forth a beautiful landseape, and my ilisnppointment probably arose in part from finding esery thing more diminutive than I land been led wo imagim! from the bighly-wrought deseriptions I had been perusing only a few days betore.

We were surronnded, even before we anchored, by cantoes of all shrpes and sizea, whose crews mate i prodigious clanour. I at onco interdicted any one who was not a chief from cosuing on boßrd; but upon thts being announced, every one elnimer to be is elief of some deseription or other. Only the great ehief, therefore, were admittod. These mame off in whale-boats, which are now muperserling the eanoe, and brought with them trifling presents of fruit. It was soon found that their errand was not ono of zaere ceremony, but wa intended to solicit the washing of ons dirty linen, a business which is anong the prerogntives of the queen and chiefs. I was informed that the queen, being enceinte, was residing on the opposite side of the island, which would prevent her from paying us a visit. I was, therefore, at liberty to chiouse a less distinguished lnundress, and apared the pain of resisting her royal solicitations for soap, an article mach needed and in gront request at Taluiti.

I was glad when the night closed in, to be rid of our numerous visitors. The pilot, who goes lyy the name of "English Jirn," was equally" so, for he chose to be considered as the only privileged person, and, besides, was looking somewhat to his own profit in the line of clotlees-washing, a business which the presence of the ehjefs threatened to intorfere with. Jim is quito a respectablowlooking tnan, dreases in tho Eurnjean fashion, and speaks English, which he has acquired on board of whaleships, twlembly well. Althougl is good pilot, so far as a linowledge of the ehoals go, he dues not undersiand what to do with a vessel in ense of difficulty. Ho told me that he had been looking out for vessels for some days, for it had thun. dered.

The two peninsulas, if they may be 80 termed, of which the ishand of Tahiti is made up, are of very different characters. The smaller one, called Tairnboo, ard usually spoken of as "the gmall islund," is said to be tho most fortile : it passesses sorne harbours, lut they are little better known thn they were balf a century ago. Both penin. sulas possess twenty-four harbours, including the goud and bad. Tahiti Proper contains the best. and therefort engrosses all the commerce. It tas in corsequence been for many years the seat of governuent.

Tho whole island is of volesnic formation, but there is wo longer any active igneous action, nor is 
there asy well-defined erater to le seen. Cornal reufs, with occrsional openings, are attached to the whores, and the larger island ('Thiti) Jas nlso a sen reef. Between the two reefy is an nlmost continurus chamel for bont anvigation, and on the northern sido they euclose many safe anid commudious larbours for shipping. On this side also vegsejs may pass from harbour to harbour, withiu the onter reef. This reef sarjes in breadth from a few yards to fifty, or even a hundred. The shore that adjoins the cural reef is formed of black voleatic sand, vecasinally mixed with comminuted shells, whieh give it a grayish hue, Basaltie ridges deach the нea at intervals, aud form projectimg points of moderato elevatiuts.

An observatory was establikhed at Point Venus, and fumisbed with both astronomic and nugnetie instruments; and as Bnou as the repairs of the versels had made such progress as to pertnit it, parties were fortned for the survey of the four priueipal barbours and the channels between then. These barbours, Matavai, Papaon, Toanon, and Papieti, ure so injortant to the many whale-shipg which visit this joland, that I felt it as imperative daty to obtain aceurate charts of them all. $A t$ the Eame time, a large purty of officess aul naturalista was oritured to cruss die ishand, to rench, if prossible, Oroltens, whe of the highest peaks, and to visit Lnke Waiheren.

1 hat been in hopes of ohtriting a full series of moun enhinating stars on Point Vetus ; but I whs disappointed, for it rained almost every uight. I was, therefore, compelled to rely for the longitude on the clironometers alone, nud restricted even in that method to observations of the sun. I was, lowever, well pleased to find that my results differed from the hest preceding authorities no more tlun I' $33^{\prime \prime \prime}$ of space. 'Tiese authorities give $144^{\circ} 29^{\prime} 43^{\prime \prime} \mathrm{W}$. for the longitude of Point Vents.

Thto mountains were obseured by clowds during the whole time of my stay, and no ungles could be tuken for the measurement of their heights, nor could the pirty I detuched fur the jurpose rench their sumuits; but tho Peacocle remained for sorre drys after iny departure, and Captain Hudrm, with his officers, sueccerded in mensuring the height of Aorni, the peals whieh is next in hes ght to OroJemn. This he fond to be six thousand une lumdred and geventy-nine feet; and as Orohons ap. freared to bo about one thousand five lusidred feet fiigher, the leight of the latter peal: may be set down us about eight thousand five hundred feet above the level of the set. From these two peaks, ridges diverge to all parts of the const, throwing off spurs ths they degcend. These ridges are procijuitous, mus for the most part narrow. In many instances their sumunit is a mere edge, making walking upen them aut only dangervus, but often impossible.

The gavomor of the district of Matavai, Trua, was the first aepuaintance of any distinction that wo mante. He lud al ready visited the Vincentes on her anchoring. He is is fire-looking man, of luxge proportions, and has a largo establislanent near Foint Venns, whetu he momoprolized nenrly all the washing, which whas performed by lais numeraus dependants. Iy this business lie derives some reantunemation for thio enst of feeding aud elothing thern, putting the gains of Uneis labour into lis own poreket. Suclt, at least, is his own reenunt of the

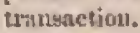

Taun'* นsเมl dress was a striped cotton sluirt, nankeen pantaloons that had once been yeliow, and a Found jucket of blue cloth. Buth shirt and pastaloons wero ton tight, and ho had neither suspendery nor stockings, although he ware shoes. In this guise be had an awkward laok, whieh he jugbubly would not have extribited in a native costune.

He was profuse in offers of haspitality at his own louse, and many of the oflicery were judueed to necept lis iuvitations. His entertainments appeas to have been of the sature general character with that to which I was treated, and which will, therefure, servo as a specimen of the ruate in which anch things are tlune by the "good socicty" of 'Taliti.

Wo reached his dwelling in time to see the preparations for the fust. These were entruster to his nuan of all work, stephen, or, as he called him, "Stiffin." "This vseful persulsage exhiluited his dexterity, not only in couking, lut in killing tho poultry. The bird selecte! whs a eock, for the Tahitians well understund the tifference in value between it and the hens; and Stephen exhibited mush alroitness in the sluying, plueking, and dressing. White this was going on, the stones for the Thlitinn osen, so ofteu described by voyagers. were heatirg, and when they had acruired the jruper tempernture, the nshes were carafully swept off,-brend-fruit, taro, and plentains, wrapped in lestres, were thes Inid on the stones, with the fowl in tho centre, and the wholo eovered tap. In about an hour tho oven wns carefully opened, the contents exposed, and found to be thoroughly cooked. The dimer was then served in an eartien dish, with a knife and fork, when, slliongh the fowl was somewhat tough, it was greatly relishod. Tho dinner hour was one o'cluel.

'Tua, acendiug to the universal opinion of the squadron, did not improve upon a closer acquaritnuce. His intrusive and greedy disposition, jot to mention lis fondness for the bottle, rendered him daily a less welcotno visitor thas at first. I undst, howover, do lin the justice to suy, that if lie were wanting in other tuats of character tbat nuglit to distinguish a clief, he did the honours of his luuse admirably, and that he must be seen in the eapacity of a lanst, if a farourzble opinion is to be formed of his charneter.

On tlec invitation of the Rev. Mr. Wilson, I visited hin at the miseion-lyouse, amd was kindly received. 'This gentenan is seventy-two years of age, and is the oldest missionary on the islund. In rpite of his atvaneed age, he still performs all the duties of lis extre. The elurch and the parsonnge are both frame houses. The former, which is neatly built, is capablo of ecrstaining a large congixgation. The Sabbath oceurred on Saturday, by our reckoning, and all labour was suepended. I thought the attendauce on worship sinalt, compared witls what I had been led to anticipate. There were less than two hundred persons present, and they did not apprear to be as attentive as they hal been representul. 'The wonen were nore tumerous than the other bex, and were dressed in a most unbecoming mumel. They wore high flating chip bonnels of their own manufucture, hose gny-culoured silk frocks, with showy ker- 
chiefs cied around their noeks. Nothing ean aprpenr more ontre than they do in these habiliments, and I wns at a loss to crnceise trow they condd, in particular, fune been induced to aulopt a eovering for the head, which atfirds ao protection from the sun, and is in eonsequence so ill-adspted to the elimnte.

A Tahitian changes his residence without difflculty ur inconvenienee; food is every where to be lasd in abundasee, and lodgings never enter into his calculation. While the squadron was at Matavai Bay, the number of those who appeared to inlanbit its elnores would hnve given a vory erroneous estimate of the usual population. They were asembled from every part of the ibland, nat the right of occupyitug each spare nook in thu livuses of the permaneut settlerg seems to be universally sulmittul. When this resource fails, they aro to be snen beneath trees, or upont the beach, within a few feet of the waler's edge, sleeping as sontuly, although without any covering, as if they wero boneuth their uwn ruofis. "

In our wholu jutereurse with the imhabitants of Trahiti, we did vot hear of a single act of theft, al. though there were inmumerable ofpurtunities for its commissinn, without the possibility of immediate detection. 'T'luey secmed always in a goot humon!, gay, liappy, and elseerful; loor did I witness a single quarrel among all fie crowde that were assembled at Puitt Venus, during our stay. They are, however, invetcrnte beggars.

At tho invitation of Mr. Pritehard, I visited tho school under his direction at P'spieti. This gentlemun was, a few ycars minee, a missionary, but now halds the station of Her Britannic Majosty's consul. He has not, bowerer, abandoned all his missionary duties.

The selaoot is hold in tho cliurch, a large frame building, mueh like a New Englund meeting-house. It has numerous wiudows, a latye gallery, and pews enpable of cuntaining a great number of people. All who wore presunt were well dressed, and the ussemblage, exeept from the eulaur of their skins, cauld hnve been, with difficulty, dintinguished from a Sunday eclool in the United Sutes.

The exhibition of the sebools did mat aurprise me so much as the fret that for matives are to be nuct with who exunnt hoth rend arid write. This was not confiued to the yourger part of the population, lut wns true everi of huse odvinced it years. I also learned that they lad achouls among themselves, and that partits were well aware of the advantages nttendant on sending their children tu them. In these schools great pains are takces to inculeate clennly and induktrious luatrits, with sound suonal and religious prineiples.

The hours of attendance ara confined to the farenoon, and duriug these the seloush aro crowded. Tise parents are unwilling that their chitdren should be confined for a longer time.

Our ennsul, Mr. Blackler, liad unade complaintg to me, as foon as 1 nrrived, of the cunduct of the queets and goverument, and rusked my juterfurence. The charger consisted in the followirg items:

1. The seizure of an dmerican whale-boat and ill-trentment of the exew.

2. Tirat fines hal boen unjustly inposed on Amcricaus seamen.

3. The refusial to appreliend deserters from
American ships, or to provide a place for their safe keteping.

4. The evasion of a jromise to provide a place for the transaction of the consular busineks.

In consergence of these complaints, I had inmediately requested that $\Omega$ council of the eliefs might be held, and the 17 th September was appointed for the purpose. On this day I ordered all the ofticers that could be sipared frim the vessels to attend. Cantain Hudson and myodf set out at un early lour, accompauied by severnl boats. We passed down tlizongh the reefs, and renched Papieti at ten o'elock, where we were joiued by our ensul, and in his counpany proeeded to the building which hous beon mentioned as the scene of the exfibition of the setiools. Here we were received by $\mathrm{Mr}$. Pritchard, who politely showed us to the seats we Wero to oecupy. Ho then called tho nirnes of the eliefs, and ench answering in his turn, took lis seat on the side of the building opposite to us.

The meeting being resdy for business, I read from a paper a list of the grievances complainet of. This was transinted sentence by sentence by a Mr. Darling, When I luad fuished, Panfai a ehief, who holits the office of chief judye, appeared to make a reply. He began by anologizing for the absence of the queen, caused by lics approsching confinemetst, atxd then reyuested a copy of the japer whieh bad been real, ju order thit it might ho considered and answred. He Btnted that it ineluderl too many points to the decided upon and answered at once, but protuised that the matter should the rxamined, and the business concluded as Equedily us possible.

I'his request was so reasonalite timt I at onee assented to it. 1 thouglat the proposed numble far better, and it was more agreeable to me than a public diseussion wonld have been, in which confusimn could hasdly be avoided. I therefore broke up the meetirag, after stating tlat I should look for a satisfactory reply un my coming in the Vineennes tis Papieti.

Mauy of the chiefs seemed disposed to act correctly and do justice, at least thoy repentedly expressed their good intentions. It who also evident. to 111e, tint their minds were grently relieved by the morletation of the domands, for they had fenred that these were to be of some extrnordinary kind, and might perluas include a clain for heary danages. Indeed, since the large contribution levied on this island by the French, the government hats entertsined spprehensions, and drends the arrival of men-of-war. These fears are taken advautage of by many ill-disposed residents, who omit no optwortunity to proctise upon their alarms, and to threater tliem with foreiga interference.

Much conplaint trns been made of the influence which the nissionaries, and Mr. Pritelard in particular, exercise over the goverument of I'aliti. They have, unquestionahly, grent influence; but I man estisfied liat thoy are justly entitled to it Indeed I camot but consider it as part of their duty, nay, the great object of their mission, to acguire and exercise a salutary control over their converls, butl of bigli aud low degree. My own abserwations sutisfied ane that this enntrol is exerted solely lise the purpose of fultilhing the latudable ub. ject for which they were sent. It is possible that 
their views of the proper method of instructing an ignoralt preople are not at all times, or in every rosprect, the unost enlightened; but no one can with propriety rguestion their pious zeal, or the lonesty of their intentions. We may perhaps lament their intolerance townrds other sects, but no ohe enu visit the islaud without perteiving on every side the most pasitive evidence of the grent benefits they have already bestowed, and are daily confering upon the inhabitants.

Alt this good hus been done in the face of many and grent dificulties. The most serious of these is the evil influence of a large portion of the ather foreign resilents. Although among these arosome who are truly respectable, the majurity is made up of runaways from the English conviet settlements, and degerters from vessels. These men, the ont. casts and refuse of every maritime nation, are addieted to every deseription of vice, and would be a pest even in a civilized community. It may onsily be conceived what an injurious influence such a band of vagabonds, without trade or oceupation by which they can support themselves, guilty of every species of profusity and crime, must exeri upon the morals of the natives, and what a barrier they must oppose to their improvement in momis and religion.

Taliti, when first viaited, was proverhial for its licentiousness, and it would be asking too much, to require that after so short an enjoyment of the ments of instruction, and in the fnee of such obstacles, its inhabitants should as a body have hecome patterns of good morals. Licentiousuess does still exist among them, but the foreiga resilevts and visitors are in a great degree the cause of its continuance, and an mbridled intercourse with them serves to perpetuate it. Severe laws have been enacted, but they cannot he put in forco in cases where one of the parties is a furcigner. I see no reason, however, why this islund eliould be pointed out as conspicuous for lieontiousness. When compared with mary party of the world that arrogkte a superior civilization, it appenrs almont in an tudvantageous light. Viee, at any rate, does not stalk abroal in the open day, as it did in some places we had lately visited ujon the American continent. It would be unfair to judge of theso natives, beforo they hat received instruction, by our rules of propriety; and now many of those who bew testimony to the laxity of their momals, visit their shores for the very purpose of enticing theru into guilt, and of riuting without fear or hinlmuce in debnueluery. Coming with sueh intentions, and finding themselves cliecked by the intluence of the missionnries, they rnil against them beeause they have put an end to the obscene dances and games of the natives, and procured the eanctment of laws foribidding illicit interenurse.

'Thu nissionaries nre far from overrating their oพn sucess in effecting an improvernent in morals, and iuculeating the obligations of religion. Sin far Froun this, I foumd that they genemily complained that sincere piety was rarely to be found among the natives. However this may bo, the externat signe of moral and religious improvement are conspicuous. Many of the natives nгe scrupulous in their attention in Cturistian duties, and mombers in communion of the church. All are strict observers of the Sabbath; indeed, nowhere is its institution more religionsly attended to thun in those Polynesian islands which are under misajonary intluence, On that disy no coune is launched upon the waters, and to person is seen abroad except while on his way to or returi from chureli. Whien thus seen, they are neatly and decently clothed, nithough in very bad taste. At church they form a respectable-looking congregation, and listen with attention to the preacher.

The success of the missionaries in introducing this strict observance of a Sablath is ascribud ly themselves in a great degree to its amalogy to the taboo-days of henthen times, and the continunnee of its sanetity is now insured by tle penalties which await an infmetion of it. The purislument for Sabtath-breaking consists in the offender being compelled to make a certain number of fathoms of road, and upon a repetition of the olfeuce, the number of fathoms is nuch inereased.

Although much las been done far the improvement of the natives, still it appears evident that much more might have been sune if the missionaries had not cunfined themselves so exclusively to teaching from the Seriptures. The natives, by all necounts, are extremely fond of story-telling, and marvellous tnles of their anecstory and nucient gods are even now a source of nmusement. The missionaries, as I sm told, possess much iufurmation in relation to the history and mythology of t/es istand, embodied in tho superbtitious tales still oecasionally current smong its inhabitants. It is to be hoperl that they will preserve a record of these, before they are obliterated by their exertions to destroy the ancient ouperstition. But they would havo sneceded enoner in endienting the practico of reciting these legrende, had they provided a sulp. stitute in works of fiction, inculcating moral and religions lessons, or teaching useful hnowledge. So also, while it was indispensable to put down those anusenents which were the means or incentives to debauchery, this measure ought to have been acompanied by the introduction of innocent modes of recreation. For waut of the first reseurce, nuch tine is now spent in unmeanisar gossip, and tle necessity for the other is often shown in a listles idleness,

No attempt has been made by the miskionaries to introduee the medinnic arts, or improvements in agrieulture, yet it cannat be doubtell, that to have taught them even the simplest of these, would have materially aidest the progress of civilization, and reacted favoumbly upori that of religion. The failure of a cotton manufuctory, with expensive machinery, which whs ereeted on the island of Eimeo, aftorls no srgument against the probable success of Jeas complex arts. The natives were not jrepared to pass at oncer froul inbits of de. sultwry exertion to the regular and stated occupation of the mill. But the spinning-wheel, the latidloom, and the plough, would nut hate rerguired auch a decided change in the number of hours of labour, and would have served as a preparation for more continnons industry. The two fornes implements liare at bength heen introdueed by other liands, and have atready treen alopted with eagerness by some of the matives.

The change of dress which has been intrudieed by the missionaries and other foreiguers, has, on the conttary, had an injurious effect on Lie industry of this preople. While they wore their native tapa, the fabric, thouglt of littlo value, gave enfigoyment 
to numbers of women; and this change of dress, intended as an advance in civilization, las liat the effect of kuperseding employments which formerly engaged their atteutions, and ocenpied their time. The idleness heneo srising, and the artifieia] wnnts thus ereated, have no little influenee in perpetuating lieestiousress among the fernales, to whom forvign fincry in a great temptation. The Eumpears dress, at least as worn ly them, is nether as beenming, nor as vell adarted to the clinate ns that wich it ham alinost sunerseded. Many of the missionaries now ree these things in their true light, and in forned me that they were emdeavouring to puraue a more enlightened course.

My experience warrants mo in eaying that the natives of Tahiti are honest, well-helured, and obliging; that no drunkenness or rioting is to be seen, except when provolied by their white visitors and inmates, and that they are obedient to the laws and to their milers. Tlant they slunuld be eompartively indolent is naturnl, is a elimate where the fruits of the earth almnst spontaneotaly supply the wants of mature, and where a mere animal existenee nay he mintained without Jabour. No people is, in truth, so independesst of the aid even of their fellows as the Tahitians. A native nuy in the morning be wholly destitute even of implements wherewith to work, nud before uightfiall he tnay be fornd clothed, louged, and lave all tho necesaries of life around him in aloudance. These lie derises from the cocon-1nst, the poorou (hiliseus tiliaceus), banans, bread-fruit, and bamboo. 'l'hat lie does not find it necesary to call upron others fur assistance, does not make him forget the duties of hospitality, but it does produce a thoughtlessnees about his own wanta, and takes away that incitement to lsbour, which is so powerful an nid in the promotion of civilization. Still, I am satisfied that the Tahitians do not avoid Inbour, when they ean work with profit to themselves. Those who were emplinyed on bonrd the squalson, where their pay was liberal and regular, performed their task faithfally and well; and they bent the same clat meter for fidelity in the whale-ships, on board of which they are jutch employed. Some of them are siow engaged in the culture of the sugareane; and $a$ single nativo plantation was mentioned to the, of which the preceding year's crop liad amounted to fivo touk. Coffer has also been planted, and suceeeds remnrkably well. Much more, too, would lave been done" in these productions had their industry been encournged by the missionnries, ns a body; but, while some of them liave done their utmost to stimulate the matives to exertion, others linve altogether discountenaneed any atterspts to introluce new articles of enlture.

One of the most important consequences of the introduction of cisilization has been the cextallishment of a settled constitution. This was framed by the missionaries in 1823 , upos the model of that of Fingland, and was revised in 1820 . The roynl authority includes the power of the volo, the nominntion of the supreme judges, and of all officers conneted with the person of the sovereign. The erown is herodicary, descending either to males or females. The legislative power is lodged in an assembly, composed of two members from each district, closen triennially by the people. This nssembiy is conrened anninaly for the purpose of remodeding existing faws, or enacting slew ones.
It has also scmi-annual meetings, and suay be conYenel moro frequently, it necessary, for the dis. cussion of questions of impartamee. All enactments of the legislature, before they become laws, are Inid before the queen for her apjrobation and signaturs, When this is affixed, they are carried into effect by the judges and the officers of the ctown. Shoulh slie refuse her siguature, they aro rovised and remodified, or laid astho altugether.

The ialand is divided jnto seven distriets, each of which las an inferior court for the trial of ordinary eases. This consists of two judges, who are not unfrequently also members of the legishature. The decision of these courts nust be founded upwn evidence, and appenl lies to tho supremo tribuual.

This supreme court is composed of soven judges, two of whom are residents of the island of Eimeo. The judges aro also executive uhicers, and noarly all are elie?s. This double eapacity gives thers great influence, and their power is sufticient to supply, in part, the iqueen's want of energy, but at the same time serves as a check aguinst any encraaclment upou the prerogatives of the sovereigu.

The powers of this court even extend to an imperchment of the royal ruler.

The mode of trial, hoth of civil and criminal cases, is by a jury, and free argument is allowed. The tostimory is not given upon onth, but the penalty for giving false evidence is tevere. The jury is conposed of six persons; and every one hass the right of boing tried by lis jeers.

The rejgning queen is named Aimata, but is more usunlly knuwn as Pomare IV. She is the fister of the late king, and grand-daughter to that Pomare 1. who acquired the sovereignty of 'Tahit soon after its discovery. She is now (1839) abmut twenty-seven years of age, and has bees twice marricd: the firgt time to Pomare, a young chief of Thalıa, from whon she was divorced; the second, to a young alitef of the island of Huaheine, by whom the has one son, the lieir of the throne. The general appellation he goes by is Pomare tawe, equisulent to king-consort.

Next in rank to the queen is her mnt, Arinpaca, the eldest sister of her mother, and at one time queeu-regent. She still poseesses great influence.

In ease of frilure of the queen's posterity, the next lueirs to the throne are the prineesses Ninito and Tait, who are the gucen's cousins, and niects to Pomane 11.

Uatn, the godfuther of the queen, nlthough not a chief ty birth, has from this connexion obtrined grent influence in the quecu's councils, and msy be terned prime ruinister.

The boves judges of the supreme tribunal are nominated by tho queen, but the nomilastion must the confirmed by the legisiature. Those who nt present hold the office are alf large handholders, and men of the highest character and intelligence to be found in the population. They are is fact the rulers of the kingdom. Five of thern, viz. Paolni, Mnre, Utami, Thati, and Tnnoni, reside on

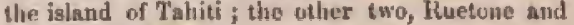
Mahine, nt Eimeo.

In spite of the small extent of the kingdom, it is not without subjects to disinct its council|r. "There are two distinet parties : the one led by the quects and the missionaries; the other, by some of the 
chicfs. The leaders of the latter aro Panfai, Hitoti, and Tiua, who aro descented from tho ancient kings dethroned ly Pomare I. These chiefa have large dumnits, and many of the matims (Inudholders) take part with them. They aro, besides, distinguished by qualities whiels give them consideration among the islanders. Pavfri, who hos more that orree been spoken of, Joolds the oftice of chief judge, nud is considered as the best statesman on the islnend. Hitoti is distinguikhed for a dignity, ugrightness, and good sense, which comsnand universub respect. Tuza possesses a litgli reputation as a brrve anil skilful warrior.

of lhese three londers, Hitoti alone is wholly free from repronch. Profai is aceused of covetous ness, and a propensity to intrigne; and T'nus, of a fundness for intoxicating drinlis.

The queen, however, enntrives to pule in all matters that rightfully belong to her; and, by the aid of the missionnrieg, maintains her ground against this strong opposition, althongh its leaders have genernlly the power to dotemnine the course of poliey to be puryased, and entire nuthority over the exceition of the laws. They are much opprosed to foreigners, and have made serenl attempts to have then bnnishes from the ishonf. Thicy are supposerl tus entertnin the slesign of sotting swide the queen, on aceount of her irregular betariour and vices; but this plan is not likely to succeed, because of the presannal popularity she enjoys, and the num. ber of adherents she possesses among the pernle. In conformity with such a design, these chiefs are snid to be continatly watching for opportusitier to increase their own power and diminish the ruya suthority. Among the necarians of which they endenvoured in avnil thenastyes, was the celobrated affair of the Roman Catholic priests, the eircumstruces of which, ns nearly gus I consld lenrn from the statements of toth partiea, are as follows :-

"Two priests of this demmination, who lasd been stalimed at the Mangn Reva, or Ganibier Group, banded on the southeri side of the island, and travelled towards Papieti, pronching the dnotrities of their ehurvts. They, lowever, found none witling to listen, and it is snid, shat no native would receive them into lyis house. On their arrival at Pnpieti, however, Pnufai, Hitoti, and sonke other eliefs, gave them enuntenatuce, nnd they were hospitably receised by Mr. Morenhout, sha neting Arweriean eonsul, who, lowever, did not lnige thern itnuler his nwn ruof, but in as adjacent lusilding. 'The people, however, excited by the preaching of the English misgionaries, bruke into the building, and enmpelled die priests to embark on bonrd a small vessel, which earriod them to Uea, or Wullis Island, about two thousand miles to the west of Tahiti.

In considering this question ealmly, nnd stripjing it of the exaggerations with which both parties have loaled it, it is diffienit to say which was most in the wrong. The Protestant religion was estalilistred by law upon the island, to the exclusion of all others, and this the priests well knew; nor ean any but zenlote, who think that those whom they style herelies are worge than infidels, excuse theire intrusiou upon missitonary ground alrendy filly and auccesfully oceupied. On the ather hatis, their precipitato expuleion, under eiretsmstanees of grent liardstip, exlibibled an unchristinn spirit, for which the resident missionaries mny justly be lield rosponsible, as they unquestionably had it in their pworer to prevent any pogitive itl treatment on the part of the natives,

The consenucnces of this expulsion of the priests remain to be related. In due course of time the Frenels frigate Venus, commanded by M. Dut Yet it Thouars, nrrived at the island, and anchored in the harbour of Papieti. The cosmunander innedintaly demnnded satisfaction for the outrage committeil on his enuntrymen the priesta, and threatened the unlese two thousand dollnas were pritl hin within twenty-four houts, he would fire 11poli sud burm the town of Papieti. The queen had no money, and was inclined, as I was tohl, to let the Frouth do their worst; hut as in this enso the loss would have fnllen whotly on tho foreign residents, the reguired вum was crilleeted from then by Mr. Pritelvard, and pnid to M. Du I'etit Thourar. A trenty was also furced upon the governumit, allowing HIl Frenclumers to visit the island freely, to enect churches, and to practise their religium. Thre the loeal Inwa were Alurognted under live threats of an irresistible forco, and the national indejuendenee virtnally surrendered.

This was a high-haubled messure on the part of the French connmander, nud one that hardly itmits of justification, partiulariy the dernand for money; for he hind himmelf been received with grent hospitality, and nut bong before nnother of his sovereigu"d frigates, the Artemise (I think), luad been maved frum wreck by the unrecompensed exurtiong of the Taloitians. The nmount demanded also was at least four timeg ns grent as the precuniary dimage incurred by the prients would be rensuably valued at. Tise Freveh enmmander, therefore, sprear, in thus bullying a defenedess people intes sho payo tment of an exorbitant irdennisy, aud into a relinquishnent of the right of admittiug or exchuding foreigners and smange religions creeds, by municipal regulation, is a light far from ad way. Ligenus.

We have seen that Panfai and his party at first countenaneed the French priests. Thim they no doubt did in the liope of introducing an influence which might be opterned to that of the Linglish mismionaries Subnquently to tlpose trnasactiona, $n \mathrm{nil}$ nfter an attempt liy two fareigness to murdurs Mis. Moreshout, they have endearoured to obeain the fonssage of a law for the expulaion of all forcigners whatsoever.

The nwersinn to the permnnent residenee of foreipners is general, and altlıough there is $\mathrm{nn}$ law forhidiling the sale of land to them, yet no offers have hitlierto been fonnd sufficient to induce the chirfa to diapose of any portion of their snil. They find in its possegsion an nektsewledged right to rank and respectability, and it spontancously yields them and their followers the menns of subsistesice. Sn puwerful is this repugnance to the almission of foreiguers to any of the privilogeng arising from a possession of Inut, that those who are nttempting to cultivate sugnr, \&c. liold their lensus by so uneertain a tenure as to prevent their making any permanene improvement.

The fertile portion of the island of Taluti lies in the ralleys, which are of omall extent, and in the plain which extruds from the gen-shore to thes spurs of the mountains. These prodnce tropical plants in grent abundance and luxurinnee, and aro jurobalily not exceedes in fertility by any portion of the earth's surface. The elimate of this region is 
warm but nut enervating, and is well adajed for the enjoymont of all the juleasures of life. To this climate the labita nud pursuits of the natives nre well adnpted, or rather they are its necessnry results, "lheir dispruaition leads them to the quict chjoyment of the beautiful seenes around them. "Their cottages are to be foumd in retired ard lovely spots, and are usually surrounded by nently-fonced enclosures, In these, which nte often of considerable extent, are to be seen growing the brest fruit, vinpple, and orange, and arnetimes extensive groves of talt cocon-nut trees. In one corner ate the patches of tnro and sweet-potatoes.

The eottages are of an oval form, nsually about fifty or sixty feet in length, and twenty in breadth. The walls are formed of bantoos set in the ground, with intervals of about an inch tretween them, for the admission of light and air. To the top of theso a plate-jiece of the hibiscus, a light nud strong wood, is lashed with sinnet. from this the rafters rise on all sides, and meot in a ridge, whieh is about half the length of the building. The rafters toveh each other, and are covered with small mats mado of the pandanus leaf, Theso aro elosely fitted tngether, and lapped over each other, forming an impervions and durable roof. The floor is the natural earth ; there are no partitions, but tapa or inatting is enployed as an pecasionsl sereen. A buildisig of this deseription may be orected for about tifty dollars.

The Tabitians use neither tables nor chairs. Their hedstends are formed of a frumework of eane, raised a short distance from the ground, upon which a few mats are laid. A pillow stufled with aromatic herbs is in general use nmong the better clasg.

1 hesitnte to spenk of the femnles of this island, for I differ from all who have gone hefure mo in relntion to their raunted beauty. I did not see among them a kingle woman whom 1 could call handsome. They have, indeed, a soft sleepinesy about the eyes, which may be fascinating to some, but I should mother aseribe the celebrity their charms have obtrined among mavigators, to their eherffulness and gaiety. Thicir figures are laad, and the greater part of them are parrot-toed. 'Tliey are exceedingly prone to pratting, or may rather be said to have a tattling disposition, for they cannot keep even their own secrets.

I liare squken of the iscongrunus character of the siress of the fertales. Among the men thit is not as atrongly marked as it is sxid formerly to have been, and they are no longer eontent with cast-off elothing. Those who can obtain it nre dressed in satlors' garls: others wear around their brodics a wrapper ealled pareu, which extends to the eslf of the leg. This is now usually made of blue cotton cloth, and with it sone wear a cutton shirt of gaudy coloum. Others luxariste in a pair of ituck trotsers, and enrry the pareu upon their shoulders,

The rppearance of the dress of the women while at elurch, has already bren spoken of. On ordinary oectsions, they wear dhe pareu alone, but when dressed, put over it a loose dress, renernbling a night-gown, buttoned at the wrists, and confined in no other plnce. Relits of their ancient dresa may still occnsionally be seen in wrenths of thowers around the hesd, and in the hair. The han is a sort of rim made of pandatus, and when it hns flowers benenth, it gives a pleasing nni rural look to the womes, to whom it nlso affirds a eunvenient shd ensily-procured protection from the sun. The wrentha are usually composed of the Cape jasmine nud rosa sinensit, the latter of which is of ten stuck through the folses of their care, and in their glosey black hnir.

The natives of both sexes sem passionately fond of thowers, but the use of these in dreas has been discouraged by their teacliers, who Jitve teught them that snch runities are unleconing to Cleristians. I am at a loss to understanl wly so imnoecut a pleasure slonald not linve been entcournged rather thas discountenaneed. In collformity with this opinion, the nbsence of flowers around the missionaries' dwellings in univessal, and camot fail to be remarked in a climnte where the plants most admired in their owa country, as exoties, are of almost kpotitnneous growth.

Cooking and eating oceapy but a small portion of their time. Their food consista principally of bread-frtit, taro, batsana, vi-apple (squontias), ornges, coeos-nuts, sugar-eane, fowls, and fisli. They ent no Ealt, but cmploy instead of it $n$ sort of sop, male of sea-water, cocon-nut milk, and the root of the ti. "Theil' mode of enting is somewhint disngrecalsle, for the bresd-f́ruik or in o is dipyed in the sop, ant then srcked into the mouth with a smacking soum, that niny be leart at somo dittanee. The ressel most commonly used in $\Omega$ cocos. nut shell. The ehildren are ferl apon poe, which is made of brend-fruit and tarn, pounded tongether with a litule sugar. The child is laid on its back, and is crammed with latls of pree of the size of $\mathrm{n}$ walnut, at whieh it shows ita dejight ly flayping its arma, kicking, and chirping like n yourng lived.

The men of Tahia care litte nbant music, but the women aprear to bo passionately fond of it, and have very correct enrm. Many of them have rich contralto voices, and ean flesectid to very low notes, while others do not diffir in this respect from the females of our awn conntry ; ocensionally me may be found that enn sound excendingly elenr and very high notes, Their voicos accurd well with ench other, and a party of four or tive will make excellent hamony.

If they ever had any native music, it has long been forgotten, and no other singisig is now henril but hymos and enilors' songs; you niserve, low. ever, in peculiar nasal sound, particularly in thobe whe indulge in the latter class of singing.

The party deefatched for the purpose of making an nttempt to reach the top of Urohenn, convisted of fifteen persorn, inclubing four natives as guides, and an American of the name of Lewis Sacket, nas interpreter. This man was from the state of New York, and was admirnbly qualified for his duties.

By the sirve of the Rev. Mr. Wilson, the purty tonk the ronte across the island which followa the Pappinn valley. The distanee on this line, to Inke Waiherea, is no more than twenty-live miles, while by that which follows the slores, it is fifty miles before the point at which the nseent begins is resclied. None of the guides were nequninted with this mute, and it was therefore neecsary tn find a person who was. For this purpose they in the firgh place proceeded towarts the eatwant from Mataval, for about five tniles, to the moul of the river Pappino, which they reached abut 
2 P.X. Here they found a guile, and wero informed that the strexm was iuweh swollen: they however determined to go forward, and were accompanied by a troop of boys and girls with flowers. Before they had procected fnr, they reached a place where it was necessury to ford the strenta, which they fonnd difficult on nocount of the rapidity, although the water was only three feet deep. Other furds of the sane desctiption vecurred every fow rods, until they at last reached one in which the water reached to their nechs. This was of course diugetous to those who eould not swim, but all croared in safety. A young native, as if in derision of the diffienlty which they appeared to experience, and of their effeminato bringing up, dashed into the flood, and was seen plunging down the raprida in sprort, and exideutly will great erjoyment, although frequendy wholly immersed in the form.

When they reached the edgo of the bake, their gnides eonstrueted a lut, in which they passed the night. The next day liseutenant Finumang nade a survey of the lake, anul sousulewl its depili from a mft. It was found to be half a mile in length, a thisd of a mile in brendth, snd in shape neasly oval. The rleptlı in the middle was ninety-six lect, whence it gradually deereases to tho edge. It hat rnined the whale of the preceding right, and the lake was observed to rise about tive leet in twenty hours. As far as could be discovered, it has wi outlet; but the natives nsert that if a bresul-fruil be tlirown into the water, it will make its appesrave at a spring, which gushes from the lill-side, about two miles nortb of Ooxigarza, and near the sen. The height of the extrace of the lake, measared by the sympienometer, is about oue thougand seven hundred feet above the lovel of the sea.

Most of the vessels that visit Thhiti are those tretonging to ons wlualing fleet: these average less than a hundred annually. From them the natives are enabled to disprose of sorne of the supplies they mise, anil in return obtain such articles as will promote their comfort and ndd to their plensure. The whale-ships, for the most part, have articles of trade which liey larter with the natives, so that littlo money is required to enrry mo their bukiness. The matives, particularly the eliefs, aro however well nequainted with the value of money.

The few other ressels that visit the islands bring tittle cargo ; if two arrive at the aame time they destroy each other's ventures by glutting tho market.

The pearl-shell fishery of the Paumotu Groun centres here, I was told it wis principaliy in the hands of the Fincheh consul. For few a years bofore our artrival, viz. from 1842 to It39, it hat been very productive. The amount obtained was abont nine hundred tons, which wa estimated to be valued at 45,000 to 50,000 dollara; the greates part of this was sent to I'muee. Of the agriculcural pruducte they have little to dispose of as yet; ueitler is the imland susceptible of any very extended operations, to induce veasels th visit it exclusively for its trade or productions. Tho three chicf articles of pruduction are sugar, cocon-nut oil, and arrow.root.

\section{CHAPTER XII.}

\section{TAHITI AND EIMEO.}

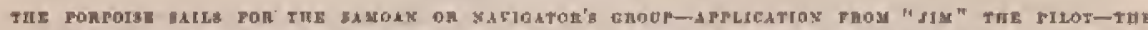

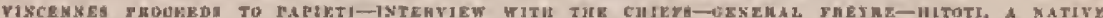

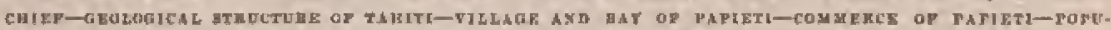

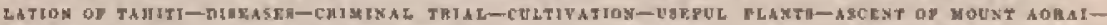

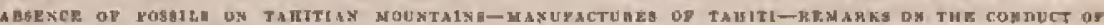

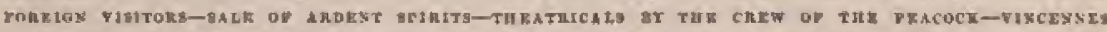

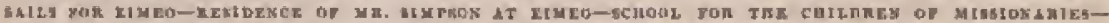

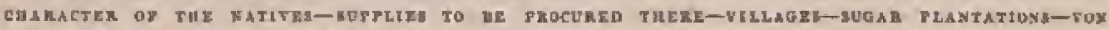

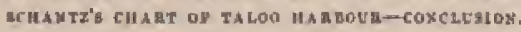

Tnz Porpoise, having been refitterl, wag pent to gen on the 20ti Sejtember, 1839, fur the purpose nf again visiting the west end of Nairst or Dean's Island, with Krusensterv's and Lazareff. She was. also orderen to pass orer the styposed locality of Recreation Island, and then to neet the Yincennes at 1hose Islaud, the easternmost of the Sanoan or Navigator's Group.

A strrmy evening laving occurred previons to our leaving Matavaj Bay, "Jim," the pilot, desired to seo whe; on his coming iuto the cabin, to my great aususement, ho urged ute to allow him to go to Papieti, where he was sure he would be wantert; and when I asked fur what purpose, he told me that the "thander and lightning would bring in ships of war:" He was dispieased when I luughed and sait, that as he was engaged on board my ship. I wushl wait until I anw the ships before I couh] give lim peruission. He then remiuded me of the night before we arrived, when there was plenty of Iloutuler ant lightning, and that ho lad told no as soon as he came on honrd that he expected us. He went on to repeat that he whos sure that they would want lim early in the morning at Pajiet, but I persisted in my rofusal; and in the moming he appeared much disconcerted to fud that there was nothing in sight out of which lo could make a ship of war.

"Ihe Vineennes moved to the harbour of Papieti on the 22nd September. At the sante time, orders were given to the Pencoek and Flying.Fish to wike on board their artieles from Point Venu, 
aud to follow an soon as they hal dowe so. The tenilur required some repairs, whitels could be dune with more safety at Prpieti. Buth vessels joined us in that linrbour on the 24th.

In proeecding to Papieti, we left Mntawni Bay ia the morning, and within $n$ few hours thad aneliored in the harbour of the former place. No soundings are un be had beyond the line of reefs, asd consequently there is nu anchorage ; the outer wall of the reef atrroumding the island is in fact perpendieular, with the exteption of some projecting patelyes in Mattwai l3ay, and to the eastward of l'vint Venus. On the latter the. Frestel frigate Artetnise struck, in 1836.

$A$ the senson of the year when we made this short'passage, there is somo danger to be appite. lyendod in entering the harbour of Papjeti, nud much cation is therefore neeussary. The tindes at this stason are irregular, and the winkls which prevail are light ; they also are nust apt to fail at the eritical moment when the rebrel is at the entrance of the narrow jussigge thirutugh the reefs, in which ease the enrrent, which rushes strongly out and sometimes across the passage, may cause the resed to drift wpon the western recf. 'the proper mode of guarding againat this, is to keep the vebisel as close as prossible to the enstern reef.

The purpase of my visit to Papieti lad originally been to go through the ceremony of reeciving tho grent clifefs on bonrd, when, according to cuscon, presents are made them; but before this was done, I determined that the business, which I lad laid beforo the eouncil, as stated in the preceding chapter, should bo adjusted. 'This was done satiafnetorily ou the gizud, when they sesented to all that buc been asked of them. I an convineed that their canduct in this matter was dictnted throughout by a sterse of what is right, and am satisfied that if grievances du exist, it is onty necessary to state them, when, if redress is wilhin then power, it will be granted.

$\Lambda$ gacenbly to my invitation, Uata, who appeared as the represpctative of the quueen, the two prineesses, Ninito and Trii, and all the head clices, visited the slip, aceomyariod by the foreign consulg. 'l'he ship wax dressed for the oecasion with fligs, and they wero received with every natk of respect. Lumelieon who preparted for them ; and when they were all scuted at it, it struek me that I lad nevur seen such a collection of corpulent perBors, Previous to eating, one of the oldest ehiefs said grace. Their appetites were good; none of the food aprearud to come amiss. They secmed heartily to enjoy thenselres, and conducted themselves with a propriety that surprised us all. "Tlıoy were cautions in partaking of tho wine which was set before them, and scemed erilently upon their good behaviour. This was the ease with the ligh chiefs, who, to the number of about fifteen, lisd been invired; but, hesides these, about an egual Itumber of others contrived to get on bont with. out invitation; the latter thrust themselres forward with eagerness to occupy places at the table, but were compelled to give place to those of higher rank. A second table was, however, prepared for them, st which they took their seath, and did amjulo justice to what was set before them.

The variety of costume which was exllibited at this banquet was amusing. The princesses were dressed is whito frocka, sloes, mil stockings, and ehip bonnets, but louked awkwardly in them, and appeared more like boys in girts" clothes than wonnen. Souse of the men wure full suits, - costs, rests, aud pantaloons, of in variely of colours;

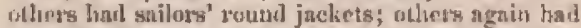
only shirts and pautalocha, all too ennll, loth in brendth nnd length. Some lind blach felt lints, of all possible fashinans, and atluers wore them of straw; sonur las slioes on their feot, others bul none.

Pwofai"s sun attraeted nttention by lis riliculous apyearance: he wore a red cluect shirt, light wlite pantalocis, that resched only half way down lis legs, coars? shoes without atnchings, nidd a shortskirted drummer's enat of blue, jlentifuily foeed with seartet. Tho latter was so sulall for hitm, that no foree would make it button upon lim. To turish all, lie laal a high-criwned conieal fell liat stuele upen the top of his hesd.

After Junchion, they repnired to the kleck, in receive the presents prepareal for then. Ithes: I has been adrisod, in older to nvoid unplensint secties, to pack in buntles, assurted to the rank of the parties. In suite of this precantion, nucls eonsultation took place among then, and a desire to exchange will one anotluer was manifested. Tlis was particalarly the erase with our old acquaintance Trash, and his friend Utore, the ex-minister and former farourite of the quen. The presents for the queen and royal family were committed to the charge of Uata, who, ins has been stated, appenred as the representative of her majesty.

Otore, who has been just named, is ouly a petty chief, but lad boen the quecn's fawourite and minister, until ho was disunissed in cunsequence of his frequent indulgenee in istoxication. He is ennsidered as the grentest orator on the islaud. He and Isus nre boon companione, and were contintally on brard the vesscle, where they so timed their visits that the hour of brealifast was sure to find them cilher actually seated at table or awaiting an invitation. Although at first weleome, tho habitual intmosion of these and others y you the messes, finally becume an annoyntec, and on board the Pencock they had at last recourse to "clearing the ship of etrangerg" during meals. Taun diul not mind this ; and when we loft Matarai, he was so kind as to renove to Papieti, in order to bo near his friends.

Among other visitors nin this aecosion, I land the honour of the company of feneral Fresre, formerty president of Chili, who has chusen I'nhiti as lis residence. It gave ue great pleasuro to become aequainted with him, partioularly as I lasl it in my power to give him recent news from his own country and Pert, which he was desirous of lear. ing. Ho rpuke musels of the deprination he surfered ly s separation from his fumily, and from the want of society, but uttored not a word of com. plnint against his enemies.

He lives in a small cottage on the bank of the hurbour of Papieti, where he is highly respected; lis manner and whole dopurtment ure gentlemarly; he is tall and robust, with a forld complexion, nid rppears about fifty-five years of age. Although his nolitical course may lave been much cunderuned, 1 ear hear testimony to the ligh estimation in which bis private character is lield in his uative country,

On arriving at Tahiti, or indeed at any of the islands, respect is natumlly due to the chiefs; this, 
I am assured, was felt by us all; but long before satiling we besame disgusted with seeing these large and noble-lnoking men passing from ship to ship, even including Paofai limself, soliciting foul linen to wash, axd performing other services tunt were not in lseeping with their rank. 'l'here is one, bowever, whom I must do justice to ${ }_{3}-$ Hitoti. He maintained the elnacter given him by Cantain Beechey, I was much pleased with his whole deportment on his visit to we, and also when 1 saw him at his own loouse; he paid but two visits to the ship, and lloge withits a day or two of our departure. That he diul not visit the vessels before, was in orter, as was supposed, to avoid the suspicion of trespassing on our libertlity ; he refused to accept any juresents, and would only drink wine when requested, performing all the little courtesies of the table witin grace and politeness.

Ou lis visit to ilie Pencock, Lieuterant Emmons and Mr. Hale being the only gentlemen on board, received him with the athentions duo to his rank; when taking lenve, he requested to know thetr names, which were given to him in English ortho. graphy ; he at orse took ont his pencil, and with grat rosuliness wrote them in the Talitian dialuct, at "Emanni" asud "Helavi l"

The genlogieal structure of the island is exclusively volentic, and the roeks are either compnet bissits, or conglomerates of bnealt and tufa, $\mathrm{al}$. though tso active volenno exists, tror any welldetimed erater, unless Lake Waiheren can be considered as one. Through these rocks olivine and pyroxene are copionsly disseminated; celfular laya was found in sorne places, bat neilter purnico uor olssidian; quartz and nica were not observed, nov' any carbonate of line, except in the form of cornl roek.

There is no conforvity between the rocks of the centre of the islund and Lhose which in most place extend hnwards for a fow miles from the const, The former are usually compact, of coltumnar structure, and exlibit no appearance of horizontal stris. tification * the latter lie in horizontal layers, composed of scoriaceous and vesicuinr lava. In both of these structurus singular thistings and contortions were alsserved. Many dikes were seen to oceur, not only in the mountains, lut near the sen-fonst ; these were from three to six feet in width.

All the rooks of the jaland appear to be under. going rnpil deconspoition. Even in places where the roek geened to lave retaived its otiginal form of starp edges and pointed pinuacles, it was foud go soft, to tho depth of a foot or more, as to crumble in the hand. The earth thus formed varies in colour from that of Indian red to a light ochrey tint; in eonsequence, many of the hills are of a red hue, and one immediately behind Papiet, takes its namo (Red Hill) from this nppearance.

This decomposed earthy matter, mixed with the abundant decayed vegetation of a tivpical climate, forms, as may be readily imagined, a soil of the preatest fertility, adapted to every kind of enltivation. On the higher grounds the soil thus conatituted has the character of a clay, and is in wet weather slippery and unctuons; in liswer positions it is mixed with lime derived from coral and sholte, which often tends tn augment its fertility.

Tron abounds thrunghout; on the mountains to ouch an extent that compasses were found of little usw from the local attraction ty which they were affeeted; and on the sliore, the gand was eornpoyed in part of iron, which conld be separated by the magnet.

Water gushes out near the const in eopious springs, but none of them were found hot, nor were any warm springs reported to exist.

I'apieti, in whose larbour we were now lying, is one of the lurgest villages on the island; being the ordinary residenee of the queen, and the abode of tho forvign contuls. T'lie foreign tresidents are also for the ruost yart collected here. Amung ail its dwellings, the ruyal residence and the huuse of Mr. Pritehard are the only ones which possess the lixury of glazed windows. The houses of the foreigners are seattered aloug the besch, or buils immediately behind it.

The bay of Papieti is the safest, and its port afforls the grestest facilities for the repair and supply of ressels, of any leelonging to the island. Fur the firat purpose a whart and warehouse have been eoustrutted, which are let to those who wish to use them. We occupied them for ten days, fur which we paid thirty dollars. The tender was hove ont at the wharf, and her equipment secured in the warehouse. A litnited sulply of ships" stures and clinudlery is ticen for sale, and may aiso he purchased from the veesels which frequent the [iurt.

The greates part of the enmmercinl husiness of Thhiti is trunsacted here, whither the ar'ticles for export from other parts of the island are brough: to be re-shipped. The number of vessels which visit this port annutnly is abous gixty, of which the largest poution are winlers; the remuluuler nee trmasent merchantmes, or regular traders frou Nes South Wales. 'The datter bring cuttun fabries, which they exchange for sugar, nolasses, arrowrot, and cocoa-nat oil. The value of the exports in this direction is supposed to be about thirty-five thotsand dollars.

The amount of American manufnctured goods imported into the isiand is estimsed at an equal sun ; they find their way lieve in trunsient sltips from the eusat of South America, and the smpplies furnished our whale-slips are generally paid in American goods.

It is almost imporsihle, in the sbsence of all gta. tisties, to arrive at any corruct statement of the amount of foreign manufnetures annually consumed tuere; but the quantity is evidently on the incresse.

By a regulation of the coloninl government of New Suth Wales, Tahitian vessels are alluwed to enter their ports on the same footing with the Einglish. Thicre are several vessels engaged in the trinde, and othera building.

'The position of this islaud, in the vicinity of the ervising-ground of our whale-ships, and the resources it posscses for supplying slipping, make it a desirable point of rendezvous.

A census recently taken, gives for the population of Taluiti nine thousand, and for that of bineo ono thousand. When this is compared with the estimates of the mavigators who first visited these islands, an enormous decrease would appear to have taken place. The first cstimntes were, Jow. ever, basokl on erroneous data, and were utquestionably far tor high; yet there is no doubt that the population luas falleri of consillerably in the interval. The decrease may be aseribed in part to 
the remains of the old eustom of infanticide, in part to new diseases introduced from abroad, and the evils entriled upon them by foreigners, and in part to the transition now going on from a savage to a civilized Jife.

Whatever may have been the case, during the first years after it was visited ly Europeans, the population for the last thirty years has been nearly stationary; the birthe and deatlis are now almost exactly in equal numbers. One of the oldest of the missionaries informed me, that although he saw nueh change in the clarmeter and habits of the people, he could perceive none in their apparent numbers.

Tohiti does not appear to be aflicted by mary diseases. Some lave been inhoultued by forvign ships, and anong nthere, the veneroal, from which the natives suffer much, being ir prossession of no metlind of arresting its rimgres, and iguorant of the proper mode of tresting it. In ennuexion with thia snbject, the wnnt of a plyysician as a part of the missionary estnblishnent struck me ns tu instance of neglect in its mangers; and 1 พณя surprised to lear that the London Snciety did not employ any medical men. From this eause, not only are the natives deprived of the benefits which might so easily have been conferred upon them, but the missionaries themselves are conpelied to pay, out of their private murkes, for medical aid, when it can be procured. They are even at times wholly without a plysician. This linppened to be the case at the time of our arrisal, when a medical practitioner who hall formerly resifed on the island had just tuken his doparture.

The effects of intoxiention from ardent spirits and ara are said to have swept off many of the inhabitunts. Sucoudury syphilis is in some enses aevere, lut their wsual vegetable diet and simple mode of living, togeller wikh frequent ablutions, tend to mitigate this disente. Its continued prevalence, as well as the severity of some of the cases, are ascribable to the inorilinste use of mercury, administered by a physicisn who was accustomed to distribute it in inordinste quantities among the nfiected, who were of course ignorant of its nature and consequences.

While lying at Pajpeti, we had an apportunity of seeing the manner in which justice is admituistered in eriminal cases. The court was held in the conncil-house, an oblong building in the native style. The alleged crime was nassult with intention of mpe. 'Ttue jullges were seated on mats, having Paofai, their chicf, a little in front of the rest; and the nudience rat or stond around. Tho culprit was a petty clief, called Ta-ma-hat, a man of huge eize, and afparently sonsewhat of a Imlly : he stool during the trial fenning against one end of the liouse, with as air of cool indifference. His aceuger was a damsel not remarkable for personal benuty ; she snt near the door annong a number of other women. The witnesses were pritiently heard, and the msitter argued, after which the six judges severally gave their opinions and made remarks on the evidence, to which Paofai listened in an attentive and dignified maaner, expressing, as occasion demanded, lis assent or disgent. Ho then pronounced the verdict of the eourt, by which the prisoner was acquitted, lut did not dismiss him withont a brief and merited admonition. It sppeared, that although not guiley of the crime alteged, he had while intoxicated addressed indecent langunge to his uteuser.

Cultivntion hus undergone a grent change within a few yenrs from the introluetion of the guava, which has overrun the lower plain ; the pasturage lis not only suffered, but to its destrustive effects are nttributed many trils. Ten years prior to our visit, about which time the guava wis introdued by the nissionarieg, the plain, from the sea to the base of the lills, was covered with verdure; and now it is overrun witl an aluost impenetrable thicket, before which all other vegetation disnppenrs, I $\mathrm{mm}$ fnelined to think, that alutrough this tree is now louked upou by the natives at in grout cusse, it will in time be beneficiul to then, and entrse them to becone industrious, when they ne obliged to got rid of it to make roou for their sugato-cane, colton, and indigo plantations; which jrulluets suceed scrustiably well, ean the raised at small cost, and will beforo many years be in great dermanid.

The cocos-tiut trees were also reprorted to hive been decreasing, but our inquiries did not confirm this statement.

The manner of ascending the trees by the na. tives las been frequently deseribed, but can soarcely be inangined until witnessed ; the feat is performed by lesping withont any cessation, even in climbing the highest tree; the body of the tree lueing rough or composed of ringr, affurds some lould for the thong which spans the tuce between the feet; nt every jump tho body is throwit entisely free from the tree.

The bread-fruit tree is also knid to have decroased, and this is no doubt the ease ; the seeds are said to be often abortive at Tahiti, for which renson the cultivation in this way las been ueglected of late, and the pianth raised in other modes have become less productive in consequence; its timlser is used for many furposes; the fruit was not in searon while we were at Thliti.

Wild sugne-cane was found in the interior, conmonly growing in tufte, but ao small in size that it was with difficulty reeognized ; the cultirated kind is derived from this, and is also of small size.

The fruits we met with were oranges, lenons, limes, shaddocks, pine-njples, papayas, bannnns, figs, vi-apples, fahies, cocon-nut, tud bread-fruit; the six first-mentioned lave been introduced since Cook"s time,

The vegetables are sweet potatoes (convolvulus), yama of simall size, taro (caladiun esculenturis), the spe (ealadium maerorhizon), turnjps, onione, and leeks; but there were no conmon potatoes cultivated. I gare Mr. Wilson some of the yellow Peruvisn potato (papas amarilas), but he informed me that nil their atiompts to raise potatoes in the low ground lind failed.

The tacen, from which arrow-ront is manufactured, grows in quantities, but we did not see it enltivated.

In the botauteal researches it wns remarlable that not a single stent of paper mulberry (broussonetia) was found, slthough fortner visicors 히ak of it as the tree from which their eluth was made.

There are a vast variety of ormamental slumbe, aud many aromatic plants, which the nalives use to perfune their coeon-nut oil.

The tutui tree (alenrites triloba), the nut of a 2 
which is used in tattooing, is very common all over the islutad.

Tobaceo is grown in small quantities.

Mr. Henry informad the that grapres succeded well on the south.east side of the islant.

T'lue price of habour is from two to four dollars a month, but for vecusional labour fifty cents a day is usually paid.

Wild hogg are said to be sumerous in the mountuin region; none of our parties, however, met any. Horses are poegessed by maty persons on the ishand, and goat were peen. Dugs and cata were abumdsnt. The island is well supplied witls cattle; sliey nre suffered to mun wild, and frertut the neighlionrtwond of the hills, whither they are obliged to go for pasturage, which is now very scaree ont the ishand, on account of the thick growth of the guava.

Afer the departure of the Vineennes, a party from the l'encuek, conmisting of Mr. Daun nnd some others, outained Jeave of absence from Captain Hudson for five days, with the degign of nscending Mount Aorai. They conmenced the ascent immedintely in the rear of Papieti, and by twon on tho secord day had renched an elevation of the thousand feet, where they stood upron a platform nlrout twelve feet aquare; thence they looked down eastward two thouannd feet into the Matavai valley; to the westward they had a gorge about a thousand feet deep rumning into 'loanos valley; to the south, the platform on which they otood was united by a narrow ridge with ILount Aorai, which was apparently only a short distance before them. In this place they were compelled to pass the right by a fog which envelojed them, through which the guides wero unwilling to lead them, refusing to proced further along the dangerous path until the cloulls should clear away,

The noxt morning was clear, and they pursued their ascending route along the edge of a ridge not more than two or three feet in width, having on ench side an abyss two thousand feet deep. Seen from this ridge, Jooking south, Mount Aorni seemed a conjeal peak, but as it was approached it jroved to be a mountain wall, whose edge sas. turned towarls them. The only nscent waa by a similar narrow path between precipices, and surpassed in steepness those they had alreasy passed. I'the width of the crest seldom exceeded two feet, and in some cascs they sat npon it as if on horseback, or were compelled to creep along it upon their hands and knees, clinging to the bushes. At last they reached the summit, where they found barely room to turn around. The ridge continued for ofily a short distance beyond them, being then cut across by the Punannis valley.

From the strmait of storai they had a mag. nificent view; to the south, it was speodily hounded by the peake of Orohena ard Pitoliti, whose steep sides rose from the ralley beneath them; to tho east, they had the rapid sucession of ridge and gorge which characterzeg Tahitinn scenery; to the west, over a similar series of jagged ridges, Eimeo and Tetuaron stood out from the harizon of the sea in bold relief; to the north, they looked down upon the plain, studded with groves of cocos-nut and ornnge, and upon the barlour with its shipping, and the encircling reef of coml.

A short distance below tho summit of Mount Aorni, a mass of turrets nnd pinnncles, which from its singnlar outline is called the crown, runs along the top of a narrow letge.

Exeept the plain of the const, no level Ind is in sight but the valley of Punatuia; this is divided from that of Matavini by a rilge of the usual edgelike form, rumninge urwards tuwards Orolicus.

Fery fow of the natives who are trow alive have been on the sumuit of Aorai; their paths in this direction, as in other places, do not lead beyour the limit of the groves of wild bamana (friluie). Begond the lreight at which these ceaso to grow, the ground is chiefly covered with a wiry gruss (gleichenia), which aprings up in many plices to the Jeeight of ten feet, and is every where alment intpenetrable. When this was not tor ligh, they broke it duwn by ensting their lusties at fuld, length upon it; and when of larger growld, they liad recourso to cutting away or breaking its stiff amd crowded stems, until they land formenl a way beneatl $\mathrm{jt}$, whence the liglit was wlunost exeluded.

The wint of water, which after a few days of dry weather is yellom found eren in the elevited valleys, was an additional discomfort. It is to be recommended to future Irnvellers in the mountaiss of Thatiti to nuke provision rgainst this incunve. mience. The party was so nueh distressed from this eause as to enjoy the dew upon the leaves as at luxury.

Mr. Dana reported that the visit to Aomi conclusively settled one questionmble point in the genlogy of the island. He foutul upon its summit meither cornls nor "gerew-shells," which rague rumours linve long located on the top of the Talittian monntains. Every one who has sisited this island has probably heard that such formations exist in theso lofty positions; hat the report rests wholly on native nuthority. Muen, the guide who accompanied the party, aud who resiles uenr oneTree Hill, insisted that ho liad sern both, and promised to show them. On renching the summit, he hegan digging, and the rest of the party atuded him. Ho anon brouglit up what he ealled coral, but which proved to be in grayish tmehytic rock; and, althongh he continued to dir for some time longer, he eould find nothing which the could venturo to exhibit as screw.shells.

In their descent from Mnunt Aorai they fol. lowed the western side of the valley of Paproa, along a narrow lodge, similar to that by which they had nscended. After proceeding for two hours they reaelsed a Bmall plnin, which speedily narrowed tis a mere edge of naked rock, with a steep inclinstion; this they were compelled to traverse on thein. hnnds and knees, taking the greatest care to avoju detaching the rock, which in many places overtung a precipice; next followed a porpendicular descent of about twersty-five feet, down which they let themselves by ropes; this difficulty overcome, the rest of the route presented no dnigerous features, and was performed in safety.

Tho manufactures of Tahiti are of bittle amount. A wong them is that of arrow-1mot from the taces pinnatifida, which employs a portion of the population. Cocon-nut oil is also rando, and preserved for use in pieces of bauboo, cut of at the joints, when the natural diaphingins form $n$ bottom, and the piece is thus a conrenient bucket. This otl is often scented with aromntic herbs, w he employed by the natives in atointing the lnir and body; it is also used for burning in lampre, and is exported in 
conshlerable yanution. The Jamps, which are always kept buruiag an their honses nt night, soc madis of the shedl of a coeos-mut. The wick is formed of wild cotton, atul is kept ungright in tho centre of the bowl by two elastic strips of cocon-nut lent' crussing pacl other at right angles.

Sugar is lwogiuniug to sttract thtention, and some attempts lave also been made in the culsure and prepuration of indigo.

Making aturw or chip lats is a farourite occupation ansong the wosnen, whose former employnent of making tapa has, as wus stated in the preceding elapiter, been moch dimiutabed by the introduction of Linsopesus fushions.

I have also thefore referred to the nliortive atteupt of the missionariog to introduce nachinery for the manufacture of eottun, which will be argain mentioned in spesting of the island of Eimes, where the experinzent was nuade.

Before closing my remarks on Taliti, I consider is my duty to sety a few words is relation to the transgression of the hresl laws liy uany of the vesself which visit it, and some of which, I regret to he enmpelled to entiss, hanr the flag of the United SIntes. I bave partienlar refierence to the licenke always allowed to the crews, and in which the ransters and officers often themselves indulgte, in tnaking brothels of their shipas. They nlso do nat sermuple to retail ardent spirits to the natives, although they well know that it is contrary to a low of the island, most strietly enforeen on shore. Such conduct not unfrequently gives rise to diff. culties very prejudicial to ithe interests of the owners; but it is still mnre diggraceful when con: sidered in its destructive effect upon the people whose hospitality tlosy are enjoying, nud as a practiea that they would nont dare to indulge in, when in the ports of nty civilized nation.

I'je influsence of the exnmple of these visitors npom the natires is ilemoralizing in the extrento, is ealculated to retard their adsaneement in civilizatinn, and throws countless diffienties and obstruetions in the way of the laudable exertions of the missionaries.

Little idea ean be formed by those wiso have not witnessed it, of the extent to which the prresice of reuding epirits is earried, not onty nt Tahiti, but throughout the Polynesian islands. I arn satialited, that if the uwners of the vesgets which indulge in it were aware of the tratlie, and had a just senso of their own interust, they wanld interdiet the sale of this perrieims article, and prohibit the earringe of it is their ships.

Captrin Hudson, who was mucls troublers with the jilicit supply of spirits to his men, mul was Isware of tho fact that the practice of vending $i$ was contrary to law, endearoured to discover the parties engnged in this trattic. He did this not unly for the suke of lis own crew, who, when questioned, sented that their intoxicstion was prodineed by gin, loughe at the mte of three dollary a bottlo, but to aid the natives in their exertions to prevent the infraction of thuis laws by the white resilitents, In pursunce of these objects, he called a mevting of the cliofs, and stated lis compinint. They forthiswitl ordered sorsth to be made fur the wifienters by the police, by which some of them woro diseoveres and immedintely fined. At the exannimatus, however, the chicofs stated to Captrin Hudsm, with what truts I do not pretend to say, that seventy easeg of win lad been landed by our own constil, from whoin they believed thant the retailem hul obtained it, while the main stoek being upor lita preraises, under the United States' fiag, whs protected from seavel.

The repairs of the l'Iying-Fish were not eonplesed before the loth Uetuber, up to which eine the Penenck wat detained, nut only in order that they might sail in company, lut because lier otficers were seill engaged in the survey of the las?boury. In the interval of leisture which wat thus nftorvid them, the erew of the Penench asked and oltained prernission to get up a sheatrical entertainment, for the anmsement of the matives and themselves. The conncil-bouse was pluet as their disposal for the purpose lay the native nuthoritites. The play chogets was Sebiller's "Robbers," the parts of which had heen rehearsed at sea, in the afternoons-a task whicl, land been the source of nuch amusement. An opportunity was now presented of getting it up well: the dresses linving been preparet, the day was appointed, and when it arrived the piecs was performed; the seting was thought liy the ofticers wery tolerablo, and fiunlly gave great delight to the natives, Itho Intter, however, were somewhat dismppointed in the early parts of the performanee, for they had expecterd an exhibition of juggliug, such ns liad been given for their entertainruent an bourl of a French frigate. Wlitle under this feeling, tsey were heard to any there was too much "parzu" (Lalk). After they legau to enter into the spirit of the performance, the murlers took their fancy; and they wer diverted with the male representatives of the femalo characters.

A number of comic songs, which formed thio relief of the more serious ptay, were exceedingly syrutauded; nmong others they laughed heartily ut "Jius Crow" sung in chniacter, and cruld not be persunded that it was a fietitious eharacter.

On the 25th September, the Fineennes eailed frum the port of Papieti for the island of Eimeo. "live distanee hetween its reef and that of 'lahiti, messnred by the patent log, is ten miles.

1 had been furnished with letters to the Rev, Mr. Simpson, who is stationed as missionary at Eimeo; when we landed, lie rnet us unon the beach, and gave us a most endial reception; wo were sorn surronnded by nearly all the matives is the place, male and femult, olis and young, whu followed us with expressions of wurder; their conduet remisded mo of the mantrer in which an Indian chief is run after in the starets of our Amerjentr eities. In spito of their excitement they were all extremoly civil, and anil they ouly wished to look at un, althrigh sorno were disposed to feel us.

Mr. Simpson led the way to his house, putsing loy a thick and well-built stone wall, the only one which I land seen used as na enchueure in these islands; on my inquiring if it was the work of nacive labour, I was informed tlace it had beet erceted by an Irishman, wha is now the overseer of Mr. Simpgon's stugar plantation. This wall enclinsea n lurte tawn, with a number of thise bread-fruit trees; wh ench side af the walk was a row of low scateiat, which were at the time in full Hoom, with flowers of usuy colours, -yollow, orange, red, snel varicgated; it the end of the walk wry a low thutehed white cottage. 
Mr. and Mis. Simposon lravo llie eare of a echool for the ctilt!ren of missionarieg and respectable white parents: these are kept estirely separate from the childrell of the natives: the reason as. wigned for this exclusireness is, that the dnnger of the fortner receiving improfrer jdens is such as to preclude their association with the latter. This tury be good poliey as far as the white childsen ste concerverl, alt|ing I doubt its having a gond effect on their minds if they are destined to spend their lives among the islands. The lashit they will thus aciutio of lontiling npm tho natives ar their inferings, eastot fail to lave at injurious intluence ou both. "The exelusireness is enrried no far, that the children of whites by native women, alobung they are unitesl in the relation of lusband and wife, are tout admitted into these schools, bocause, ลง they say, they do not wikh their children to be cuntuninated by intereourse with such in mixture of Lhod. In pursuance of the same jolicy they lave, as it is sain, prosured the enactment of $x$ lnw prolibiting martinge between whites and the natives,

This, I must say, appeared to me the worst festure I tral sfers in the uissionary establishment. It is placed here for the arowed purpose of reclaining the natives from ilolatry, and the viees which are its concomitants, In doing this, their most successfol efforts have been in the conversion and mornl improvement of the young; yet they bring up their own chihtren to luok flown upon them ns being of au inferior order. In beconing aequainted with tlis feature, I no longer wondered at the character, which I was compelled by a regord for truth to give, of the chiluden of missionary purents in 'Talitit.

The misgionaries are now aware that tlejr proper plats is to devote their line sunl attention tu the young; and in pursuance of this olject, Mr. and MIts. Howe lave lately arrised from Engfand, for the purpose of estahlishing an infunt school.

It is to be regretted that the gethouls of ranamal labuar luve, fur what reason [ could not leary, been discortinued. Some of the natises who liail been iustructed in thern ovineed a linowlerige of the trasle of the carpenter, stul firnisherl the ships witl very good hoavds sawn hy themsolves.

The matives of Eimco lave nz alvautage over those of Trahiti in heing frce frotn the inthuruec of evil examphe; many of thers sre industrious, und Jingsugs $\Omega$ propier feclisg of tho benefits they have derisel frum the missionaries, of whon they speali, whentever quoctioned, as friends.

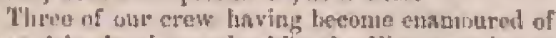
these islands, deserted while the Viacennes fay at Eimen. Tlley left the slip about ten o'clock at night, stont nffer which thejr alxsence was discovered, and ymatisg sent out in overy direction to interseet the ronds and drive them to the hills, This was effected the folluwing mostring, aud a large prorty of untives wns entoloyed to humt them up. 'T'hia task they speedily performed, nud st hast Hrovo the reserters to one of the highest ridges, in full view of the ship. Here tho rumaways ap. peared at first disposed to make fight witl stones; but when they saw tho odila agaisst them, and wituessed the alertwens of the natives in leaping from cliff to eliff, thry thought it best to give themselves up; which ibey did to shree natives, rahech oxcept the maso, atm! strmed respectively wirle a rusty sword, an old eutlase, sab a piece of iron trop. Theso bound their hames, and led them down to the shore, whusce they were brought on hoard, where the fliree tantives recejyed the resward offered for their apprehension. The clinse and enpture was an smusing sight to tJose who watcher! the proceedisgs frum the ship.

Eimen has, if possible, a moro broken surfince than 'lahisti, and' is more thrown up into soparate feaks; its sechery is wila even in compurison with that of Tabiti, and purticularly uрmu the shores, where the mountaing yire previpicusiy from the water, to the bieiglit of twenty-five humdred feet. The recf which surroundy the istand is sintilar th that of T'ahiti, and as we lave scen to be the ense there, no sommdings n ro found os the mulside of it, Binck cellular lava abounds, and bules aro found in its shathered rialget, anoung which is the noted cosse through which the gord Orou is said to have tisrown lis spear.

Wibits tre remnined at Eimen, I visited Papos or Cook's Harbour, which thes to the enat of that of Tuloo. There is $n$ marked resemblance between the two ports, exeept that the shores of Papoa are not inuite as presipitons as those of Talno, and the entranee of the former nut as practieable.

Woot and water may be lod at both harbones in abundance, but in other respects the islanil is not well adapted as a place for the supply of ships. No more than a single ship would probably be nblo to find refreshments at at time. It bs, therefure, selutom visited, and its surplus produce is carried to Tulifil for sale. Nutwitlostanding, the articles of traflic are quite as dear as at 'Thatiti.

It lass been seen that the alliwial filain at the head of the barbour of T'njoo is partly veeupied by plantations of sugar. The cane is of superior quality, nnd the elimate well adapted to its pro. suetion; the plant is inderd indigenous, and it is well known that the variety of it fontsa at Tabiti lins bees introdneed adrantageously into the Wemt Inties. At limeo the erop is liable to injury fron the ground-rat, and their are diftieulties attenting the mangenent of the crop, w lich eause the cultivators to speak despondingly. A buut utue liutdred tons, however, are mude muanaliy.

Coffec, eotton, and all oller tropisal plants, ancceed well at Eirsoo, sml the quantity of tapa manufactured is grenter in propurtiou than at Taliti.

I took the opportunity of my anchorage in the husbour of Fimeo, to verify the chart made by Captail Yon Selsantz, of the Rustinn stip America, nul frumil it aceumte. I hare added eome sound. irgs, and laid down tho topusgrapliy of the shures, ani the outline of the reefs, more minutely that he lawd attemprterl.

OII leaving Eimeo, I bade adicu to the Tahitian isflatle; but I eamot clnse the portion of the nasrative which is devoted to them, without again expressing the pleasure I and all my oflicers ilerived from our intercourge wich the bissionaries, ant our obligations fur the kindness received from shem and other residents. Anong those to whm we are iudebted, I eannot refrain from naming George Pritchard, Esq. II, B. MI. Consul, of whose strutuous exertions to advance the wislfare of the people, aud susstain the goverumentic in its eflorts: to promote their best interests, I became hy vbsurvation fally aware. It is to bo regroted that 
ไxis very netivity in thus Inloouring in many ways for the good of the commmity in which lie reaides, should be the probable cause of unkind and un- founded imputations, from those setrated, if not by motires jositively bad, at least by a less enJightened or less andent zenl.

\title{
CHAPTER XIII.
}

\author{
SAMOAN GROUP. ROSE ISLAND. TUTUILA.
}

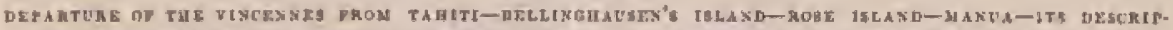

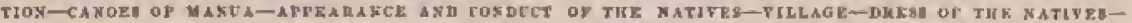

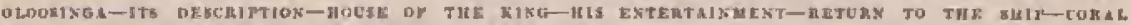

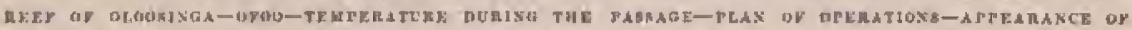

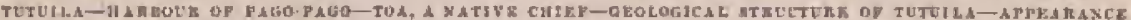

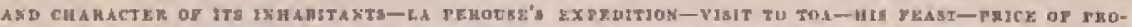

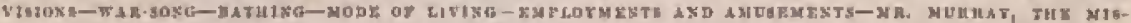
Mors A

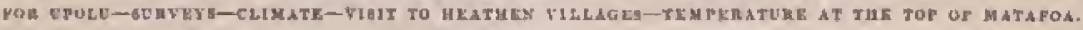

O. the 20th of September, 1339, at dnylight, laving the wind from the northward and easiward, we got under way from Tahiti, and made sail to the westward, prissing the Society Ielnud Grouj, viz. Sir Charles Saunders' Isle, Hunheine, Trhan, Horabors, Maufili, and Mnutoiti. All of these, with tho exception of the last, are high lands.

On the 30tll, we made Bellinghansen's Island, which is a low coral islaud, situilar to those whith lnve beon already described. It was uninlisbited, and is af a triangular form, with the ustal regethtion, with the exception of cocon-nut falms. We tanded upon it, and made the magtietie oxpreriments.

Birila were in great plenty, and as tame as we bad found them at other unishliabited iklands we had viriterl. No lizards of rata were observed, nor was the common $\mathrm{Hy}$ seen. The lagoon had so pasaage into it at low water, but the tide flowed hito it over the reef.

In the afternoon, we rgain made sail to the westward, for Rose Islind, and on the 6ili of Oetaber, we passerl uenu the Ineality of the Royal George Shroal, but aaw nothisg of it.

On the 7 th, which wis the day appointed for our rendezrous of Rose Island, we enme in sight of it, and at the same time degcried the Porpoise. That ressel lind passed by Nairsa or Denu's letand, and conmeeted the survey of it with that of Krusenstern's and Lazareff. Both of these were fonnd to Juve entranees into their lagonns; they are uninhabited, though occasionally visited by the natives of Nailsa island, The fosition of Recteation Island was passed over, but no signis of land discovered.

Rase Istand, the most enstern of the Samonn Group, was discovered by Freycinet, who gave it its name. It appears, at first, like a round knoll of lant, bat on a nearer afpronel, this is found to arise from a large clump of pisonia trees, similar to those furnd growing in the low archipelago. It is a low annular coral island, of small dimensions, inundated at high water, with the exception of two small banks, one of which is entirely covered by the elump of trees. Thise otler is formel of lead coml, withust ary regetation. The tide was found licre to rise about four and a half fect, the florm setting to the enstward. The brenkers on its
Feather or south-ealt side nre henry; and there is an entrance into the lagoon, having four fathoms depth of water through jt. The lagoon has from six to twelve fathoms in it. A remarkable coral formation, Jike a submergel tree, thirty foet in diameter ovnr its top, wns found in the centre of the lagoum, rising to the level of low water, and having all stound it a depth of aix fatlonss. The currents set regularly out and in to the lagoon, according to the state of the tide. In stormy wenther the sea must make a complete brench over the reet.

Sone boulders of vesicular lavn were seen $\mathrm{m}$ the eornl reef; they wene from twerty to two himdred pounds weiglat, and were found among blocks of coral conglomemte.

Hirds were sect fying wer tho island, and on landing we found then in great nututery and very tnume, The frignte-birds and loobies (sula), whose tseases had befire been obaerved on low Inslien, were here found on the tops of trees fifty fect high. The buddies laid their eggs on the parts of the island destitute of veguation. Ters were in great unmbers; their breeding-place was in n thichet on tho weather side of the island, ov that which was exposed to the wind and sen, nud was remnrkalle from the regulnrity with which the egga were placed, about slire feet spart, without any nest, snd, with bat few exceptions, ont of many thousands, cacis egg Iny separately. 'The colour of the eggos is a dirty white, mottled witl brown.

On the 7 th, we left Rose Island and stood to tho weatward, making at sunrise the island of Mnnus, which is two thousnnd five luadred feet nuove the level of the sea. It has the form of a rigular dome, rising in nost places precipitously from the water to the lieight of three or fomr lindred feet, after which its ascent appenis more gentlo and even. It is sixteen miles in circunference, is well covered with a laxuriant vegetation, and has nany coecr-nut groves on its north-west side.

On ajproaching it, Oloosinga wis in sight, and shortly after Ofoo. These two islands lie to the north-westwnrd, at the disinnce of about four miles.

The boats were lowered, and beut to trace the shores of the istand of Manum, for the purpose of surveying it; whilst the Vincennes and the Porpoise jussed on cach side. 
Thif isinul is ishabited. The priucipst settlement is on the north-west side, and there is anchor. age for a small ressel neat the shore, whure there is a eove to laud in, with lut litclo surf during the fine senson, or from April to November. It has a shore-reef of eoral, and the soundings extend off some distanee, eiglit fathoms leing fouml four lundred gatils fious the slinre.

The ennes of these islanders were the best we hasl seen. They are built of a log, laving mpan it pieces fastened together, th ratise them suticienty Jingh. They are thirty or forty feet loug, and ate parily covered it at botl euds. Srme of them are capalite of contaising twenty or twenty-five men, ald are very swift. The clitef usually sita cmosylenged on the forwand platform of teek. They linves an out-rigger, which is not so fur renoved from the cunve, and renders them mote linble to be ripset,

'The king n* chies of these islatids resirles at Olrosinga, in conseyuence of its leeing more easily defutuded.

After our party reached the sliph, wo nato soil fior Oloosinga, where I went on shore to see the king $\mathrm{m}^{\circ}$ clice, who was old and decrepit. His namo is Lalctah. His brother, and mesumptivo suecessor, was will fim, sull met me as I tumbed fiona the bont. His mode of aslutation was by taking my hand and rubbing tho back of it agningt bis uose.

The old man, I was told by the interpreter, could syutali a litulo kinglish, but $I$ could not ursdergtand lims. "I"lsis he attributed to his nge, and would not udmit tlast it was nwing to his ignorance of the language. They led the way to his liut, situated under a mural preeijuce twelve hundred feret in height.

The ishand of Oloosinga is a naryw ledge of rucks, rising nearly perpendicular ou both situs, und js threo miles in length. So precipitous is it $\mathrm{nt}$ its endre, that it is impossible to pass antound it ron the soeks. The strip of lnnd is about five huuldred yarils in width, on which breal-fruits and coconruts grow in gent profusion and sutlieient alundance fur nll the muts of the natives. 'They tofl me that this islabl had been clusen as a place of sufety, since the otier boenno unsertled jil consio fivente of the wath of the Christian and Devil's farties ; and that the island of Manua lawd for. inerly lieen the residenee of the king, but that lis foumil himsdif ussafo thert, and hat taken up lis almo at oliosingra, on its nurth-western side.

His house was eilipticrt in form, atd thirty feet fong, erected on $n$ well-flagged termace of stotve, nhront four feet absvo the ground. It was well. slatided with encon-nut and breas.fruit trees, nnd was supported atound by ten stout posts, with thee others in the centre reviching the top. "J'he rof eame down within three and a half fect of the gromond, and projecter as eaves about ciglitews inches or two feet. In the centre the hut was fifterll foet liggh nud well thatched.

'I'tu whyle How was ordered to be spread with fine mats, which were excefulty unolled, and hid over the conaser whes on the tlour. The king then sentel hinself in the centre, and desired me to take a seat between liminglf and brotiter. Shorlty afterwards two large wouden trays were brouglit itr, filled with cooket breal. fruit and covereil over with leaves. One of lhese was placed before me,

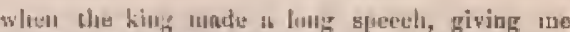
weleome and offering food to ent, I was then detired to liand sune to the king and his lorother, and to others who weru prointed wut to me. This I did, but unfortunateiy contiuued ny task, and haruded it to ono of the karukns, or common people, who were sittiug close around us ; much displessure was evinced, nceonpasnied with angry louks. I now lonked around for my men, but they were out of sight, on their return to she boat. In ordes to make the hest of my situnkin, I asked what was mennt, and feigned to be quite ignorant of lawiug given any offence. After a nimute they were apporeutly appeased, and pleasant looks wewo regtored.

They handed round a shell eontaining enena-nut oil to dip the bremd-fruit in, and nuother contrilling salt water. After wo Jad eaten, they loggan a eareful exsuraination of $\mathrm{my}$ clothes, and appewred mucl plensed with the butfons, My pocket-handlierclief was taket ont of my pocket, and spreal on the mat to he exnmined by the king. His brother took off my hat and put it in the top of his large buslyy heal. They then had ara made, of which 1 coitld not partake, nfter recing the process of making it. It is first chewed by the women and thrown into a large bowl; water is alled to it, and it is then strnined through leaves. 'Tlis was jartalien of liy than all, while they gave me a fresls coren-nut.

'They were becoming more familiar every monuent, and it was getting Inte, so I thought it time to malie a move. I therefore ruge uy, and was followed by the natives, in number upwards of a Lundred, ineluding llse king and lis brotler, to the boat. I looked earefully around for ngrms, but saww none among them. My botat was nground the king, his brother, and aeveral others gut into it, saying they must have sume prusents. They peemed clisposed tn resist, ani slowed a sutermination to contest one getting aff. I ou tho other liant wns deterinined to get rid of them, aud preacenthy if I could ; I tharefure oriered the boat's erew to ariu themselves, and drive erery one of the matives from the boat, at lhe sane sine intimnting th the king to use his authority, which I fonnd, buwever,

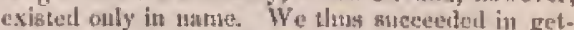
ting clest if the erowd, untit we trad no nrore than eight beft; to ench of these I fresented a small fish-howk, and cridered thent to get into the watur, which was ahout in foot deep, and go; this they disd, one by one. At last cante the king und his biother's turs, to whom I presenter, with grest cerenony, first a small not then a laige lish-liouk after which they left me, apparently is great good linmour. I was heartily glad to bo rid of atuel rapacious. troublesone feldows so easily and witltsub a light. We then pushed out bost off. When juat beyousl the reef, in taking up wur nuelror, the bont hat tho appearnee of returnitug again on slove. On seeing this, a great stuotut was set up by the with my powsler-flatk, Ho said it hart been twkes by a boy out of tho boat, and lind been dropped into the water, to be jicked up after" we had sloved off. I gave the unn a small present firs his apporent lonesty; but I am inclined tu believe it wns the feat af detection, and the belief that we laul misged the article, and were returuing fos it, llunt induced them th give it up so willingly. It was some time 
before he conld be male ta usderatand whint the reward was for, but when le found it was for lis hunesty, he laughed heartily.

"This having excited our stapicions, the bont's crew informed me lhat a canne that was paduling of had been alungside of the rig, and that they felt satisfied that the natives land taken sonvething from us. It being in our course tistards the ship, we gavo cluse, nud being faroured by the wind, goon overtouk the canoe, to the great fright of the two nativen, who were gaduliug silh all their miglıt, nnd whuse eyes were full of tevrs when overtaken. They had nothing at all in tliejr eastoe, and sffer exsmination it proved we hat lost nothimg. To consule them for this alarm, I gave thetu a fow trifles, atid they becano easy and elseerful.

The enral reef around this island was different fron any I hal litherto geen. It eonsisted of two regular shelves, the outer one frum fifty to sixty feet wille, nud slie inner in places meamuring me hundred ant forty fect, $\boldsymbol{A}$ distinet mark of thight water was sncasured along the huels, and found to be twenty feet above the ordinary sea-tide, which las Jroul furr to five feet rise.

Ofoo lies to the westward of Oloosinga. There is a passage for boats of about a fourth of a mile in width lotween them, and anchorage on the western side. Ofoo rescmbles Oloosinga; and, frnm the acenants we received, it has but few inlakitants: tlense of Oloosings lsaving made war unon them, and killed the " untives" off. There is a smalt and eomparatively low islet off ita western ntud, near which there is an andiorage. After sum. net we bore away for Tutuiln, wlitel ents been in fine reatlier from these islands.

The temperature in the psosage froth Talitit to the Somuan Islands hat increased from $77 f^{2}$ to $81.11^{\circ}$ in the air; and that of the water from $796^{\circ}$ to $\left.B\right] \cdot 6^{\circ}$.

As it was ny intention to make a thorough examisation of this gronp, I resulved, in order th nceumpish it in the least possible time, to divide the sipuadron, so as to put all the remaining islauds under expunination at the kame time. T'le islasud of 'Tutuila being the most central, and, froun the infornuntion I liad oblnined, the test position for ny astrunomical observations, I selected it for the Viucenuses. That of Upulu was reserved for the Peacoek and flying lish when they slould arrive; atm in case of their heing detained tongrer than 1 had anticipated, I stumld be ready to take up the survey of $t$ lue lattor, or assiat in enmuleting it. 'The Porpenise was ordered to examine the ikland of Strnit ; and one of the uturzalints, Dr. Piekering, was direeted to join lier, fin the purpose of exploring llo interior of the jstand during leer operstions in its vicinity.

On the 10ult of Octoluer we lat light wints, in conserguente of wlich wo idid the reach l'utuilat that duy. At daylight on the I th we were nenr its enstern eud, and off the island of Antuu.

$A$ bout eight miles to wind ward of the liarbouj of Pago-pago, we were boarded loy sevenl canow, in which were some natives, with a white una, by name William Cirny, whon I retained as interpreter during one stay lisere, and found of much use.

The island of Tutuila is light, broken, and of volemic appenrance. It is seventeen miles feng, and its greatest width is tive miles. 'The harbour' of Pagro-pago petietrates into the echutre, and al. mont divides the island into two parts. It is less Faried in surface than the Society lslands; and its Jisghest peak, that of Matrfor, was found to be 23:7 feet above the sen. The appurs and ridgeB that form the high Innd nre like these of Thatiti : precipitous, sharp-edged, and frequently rise in mural walls from the water to a lieight of three or four hundred feet, showing the bare basaltie rock. Alove this height, the surfince is cavered with a Juxuriant regetstion to the very top of the rnoustains; the cocos-nut treo sud icee-fern give the principal character to this beatiful scenery. Dead coral is seen nlong the shores, nbove lighwater mark.

The liarbour of Pago-pago is one of the most singular in all the Polvnesini isles, It is the last point nt which otw would look for a place of shelter : the const nenr it is peculiarly rugged, and las mo appearance of indesutations, and the entrance being илrow, is not easily otserved. Its shape has been compared to a variety of articles: that which it most nenrly resembles is a retort. It is surrounded on all sides by inncecsible mumb precipices, from eight landred to one thousand feet in lyeiglit. Tlie lower parts of these rocks are Lare, lut they are elothed above with Juxuriant vegetation. So impassable diù the roeky barier apjenr in al! but two places, that the laubsur was likened to the valley of Rasselas clanged into a lnke. The two brealis in the precipiee are th the lvead of the harbour and at the Pilot's Core. Tho laarlour is of ensy accesa, and its entrabe, which is abuut a thiral of a mile in width, ia well musked by ithe Tower Rack and Devil's Poiat.

As we arrived off the harbour the wiml gress Jiglıt, and finally cone out alsead, tlum cond [x+lling us to beat in to otr anchorage, under the direction of Edmund Foxall, a white pilot. He ustally comes off to ressels when witlin two or thire miles of the harbour, on a eignal being made. Wo mide nany tacks befure we reaclied our anclinmge, whicl, was in deej water, twenty-nine fathoms. About half a mile from tho estrusece of the harhour, it bents at right angles. In this position, surcounded by clifts, the firing of a gun prouluces a remarkable reverberation, resembling loud peals of cliunder.

Wo were surrounded, as sonu as we eutered, by a large number of tanues, filled wish matives, who all secmed deliglited will the ship and the number of mest on band. When we had moored, one of the prineipal elicfa, wlose name was ton, was admitter on board; ho was an athletic, museular man, of large frame, abost forty years of age, with a pleasunt expression of countenance; le manifostel gront pleasure in stelerming us. 1Je began by tolling me, shrouglt the interpreter, that lie wno n missionary; that he hat formerly been a groat thice, and shoer of suany loul acts, lout being now a missionaty, le wath reformed and stule no more. He told this with such an open expression of countunance and so much simplicity, that 1 could scareely forlear smiling. After I lasd funished asking him yuestiuns, lie enntinued eyeing ne from bead to foot, as if determining my dimensions. I told the juterpireter to ask lifm why he looked at me so intently. He rephlied, that ho had $\mathrm{n}$ eont on shore thae wha too tight for him about the arma and chest, and he believed it would fit me: if 
so, he should be glat wo excharge it for the jacket I linl on. Not being inelined to this exchange, I ortered is small lateliet to be given him. This gratified hinn much, and he irstatuly went over the slijy's side to slow it to his friends. This sume Toa is chief of the village of Fungarar, about three miles distant from she barbour, on tho north sidle of the island. Ife learns to read and write, being tanght by some of the savall chisldren, and attends rehoul regularly. Ho beesme of great use to 1 , and was a constant visitor. During one of his visits on bonrl, lye espied some red umbrellas anong the presents, and fron that time was continuality endespouring to olstain one for his wife, and brought many articles in the hope of inducing us to part with it in exchange for them.

The genlugieal elıarneter of thin islaud is simpilar to that of Manua ; it las chly a slore-reef of cort, and snundings extend sone distauce fron it. It hins many desirable ports or bays on its north side, where vessels may obtain wood, water, and supplies. The best and safest port, however, is that of Pugo-pago, on its south sille, which affords a sufe lanrbour for vessels to overlaad, aud where anpplies may be obtained in abundance.

Tutnila is thickly settled ronnd its shores, and particularly at its sonth-western end : this is lower and more essily cultiwated thnn the eastern, which is ligh and rugged. The only communiention is by the ses-shore, the hills being too precipitous atxi difticult of asecnt to pass over.

The nen of Tutuila are a remarkably tald, finelouking set, will intelligent and pleasing countenances. In comparisen with the Tahitians, they would be called sedate.

The women are far from being good-looking, with the exception of some of the younger ones. They are remarkably domestic nud virtuous, exhibiting a strange coutrast to those of Taliti. Here there is no indiscriminte intereourse, the marriage-tie is respected, and parents are ex. tremely forul of their offapring. The inhabitants are disposed to be lipspitalile to strnngers, although they expect renunertious for it. Tonvelling is generally loelievent to be safo throughont the islant if Tutuilin; and the natives, as fir as our experience gues, are not the bluod-thirsty race they lave weel reported to be. "The unfavoursblo extinute of their elaracter has, I presume, been derived from those who first knew them, and particularly from theit attack npon the expedition of La I'erouse. Of this confliet 1 obtained the following pnrticulars fron the Rev. Mr. Murray, who lud them from an old nuan, who was $n$ witnesy of the affray. The latter is the only individual now alive in the seltleusent who was present when it occurred, and his testimony was corrabornted by others who had heard of it from those who witnessed the scene.

On the morning of the massucre, the ressels stood in townrds the land. $A$ bout moon the toats went ushore, as recorded by Ia l'erouse, and while on shore, a number of canoes, belonging to the island of Upolu (to which Tutuila was at the time aubject), went from the shore, and proceeded directly to the vessels. When these estnoes sore alongside, a young man in one of them laid his hand on an jrun bolt in some part of the ship, with the intention, it is stuposed, of stealing it. He was fired upon by the French. Thu ball passed through his shoulders, and mortally wounded him. 'I'he natives, on seeing the effect of the shot on one of their uLmber, were grently enraged, and immediately left the rossels, and liastened to the shore, where they fonnd the bonts that last gone to get water. On reaching then, they began the attack, which resulted it the massere of M. De Langle, and of those who wore with him on the shore. When the natives began this ntmek, the great body of the French were absent from their basts; ane were in the buslies gathering plants, and others tulking to the femnles. On line coun. mencement of the disturbanee, they alt rusber towards their boats, and the confision becane general. The mintito circumstunees of the aftray, further than the abrve, esnnot now be ascertained from the natires. They are, lioweves, very clear in reference to the cause, and to those who were the actury in it, viz, the natives of $\mathrm{Upolu}$. The Tutuilinns anaimain thas they endearoured to save the lives of the French; and on the following day, as soon as they dared to venture from the munutrius, whither they had fled during the mnasace, they chllected the bodies, which they found in a state of uulity, dressed them in native cloth, and buried then in tho bench, as they were accustomed to bury their own cliefs. The actors $j$ the massacre proceeded at once to Upoln, which will aceornt for their lsaving been afterwards seen there, and recoguized by the French. Our inquiries relative to the spot where they had buried the bodies were not satiglackorily answered. How the eas'ponter's son egcaped is not known. Ho is said to be still living at a village on the eantern jart of the istand. 'I'here apprenrs to be mention made of a boy among the missing, in La I'erouse's necount. Levusii, n chief of the district of Faleletai, was at the masancre of the party of Lat Perouse. He wat then a lay of thirtecn years of age. Ho remembesed the vecurrence, and that threo of tho Pagat laugi were killed.

The perpetrators of the deed were sone young chiefs from the district, who were on a "malsinga" to 'l'utuila. At that time Aana distriet had the rule, ar wus the "Malo" prorty, and domineered ower the inliatriants of the other islands and distriets.

On the 17th, our frinend Toa gave us an invits. tiun to visit him at his town of Fungasar, on the north side of the island. It is situmted on the next bay to that tow eafled Massacre Bry, where Ve Langle was killed. The path across the islund is a very difficult one to tuvel; it leads up through the valley, and noross the dividing lidge, which is quite precijitous. "The min which lasd fallen macte it very slippery, und the jouruey was fatiguing to those not necustomed to this kjud of walking.

I wns much struck here with the maliness and intelligence of the antives, and with their frauk (ipen expression of countenance. The colour of their complexion is rnther darker than that of the untives of 'Tnhiti. Thic outhines of face and figure are very like those we lad left, their hair and eyes black, and their teeth good and white. Sume of them had frizzled laar, but it whs generally straight.

Just before arriving at the village, we were met by 'Toa, smd some of his relations and attendants, who welcomed us to his village, saluting me by rubbing his nowe with my liand; this is the usual custom. 
He urdered a pig, taro, breml-fruit, \&c. \&c., for our entertainureit. These wero cooked its the tniversal Polynesian mode, by lraing covered up in a hole with hot stones. We were soon told ilat Ilie fant was rearly, but having bad sone experience of their corkhing, we desired it might remain in the oven a little while louger. Their usua] custom is to take it out the moment that the taru is cooked, and from daily practice they are well neununinted wish the sine required to cook it. This is searcely sufficient to give the pig time to be warmed through, Our request prevailed, and in the course of half an bour we were summoned to the council-house or fale-tele, where strungers are always entertained. We were slown our seats, on one side of a circle, while Toa, with his family and friends, oceupied the other. 'Tho maks, except one, were not very elenn. Thue pigg, which must lave weiglted ono htundreul puutads, was brought in, and Jnid with the taro and bread-fruit on basnualeaves. A butcher's knife wis all that we possessed to earve it with. The whole village, old atril young, men, womes, asd childwen, who were waiting in suxious expectation for their share, now surrounded us, and made it unconifnrtable to ent, with so mauy luurgry expectants; I made haste, therefore, to divide it, and with it they soon dis. persed. The taro ws exceedingly well cooked, dry, and farinaceous. The bread-fruit they said was ton young, and not leing considered goou by them, they objected to giving wa any of it, but dil not hesitate to ent it themselves. A pis is a grent treat to them, for althungh they have plenty, they prefer selling to enting them.

All kinds of provisions in these islands aro enlnancing in value, and will continue to do so. It is remurkable low the priens fluctunte. On some dnyy provisions of all kinds will be exceediugly chemp, and nlmost any article will be taken in exchurge; and then ngain vothing can be found to please the natives, or induce them to trade, althugh the quantity for salo is equaliy as gront. It was not a little amusing to see the nutives sitting wholo days to olstain the price of their fowl or pig, nnd rersisting in their refusal of the offer made; and this was sometimes done by a large number nt tho Eatme tinc, all remaining true to ench other until their poe or food became exhatisted, when they woukd take the earliest opportunity of disposing of their different parcels.

In the grove nent the village wo saw boreral piles of stones. I whs told they were the graves in which they formerly buried the detul, just below the surfice. On the top were plueel stones, forming a high pile. Now they bury their dend in graves about three feet deeps, and enclose thom with the draciena, which grows rapidly, and forms a pretty and neat trellis.

Tna became quite communicative, and as lie showed mo about his village, he told ne, through the inter preter, that before the missionaries eame, the chiefs all had their "nitu" or spirits, which they worshippet, and that they felt themselves obliged to do overy thing they commanded. His aitu were fresh-water eels, which he constantly fed in the brook near the village. I visited it, and requested hin to eatch one, which he atrempted to do; but after a long soarch, turning over large stones, and exannining holes, he was unsuceessful. Ho said there wero many in li formerly, and quito tame; but sineo he had embmeed Cluristinsity, they lad all been eauglit and destroyeul. On further questioning bim, he told me that he lind himself eaten them; and that formerly if any one hat tonelied, disturbed, us attempted to entch one, he should have killed him inmedintely. He said his eels were very good to eat, and whs sorry he could not find any nor'e; and laughed very heartily when I spole to him about eating his aisu. I mention this circumstance to show the powerful efteet the Clristian religion has had turon the ancieut customs of this people.

After mueh persunsion, they were induced to sing some of their old war-songs.

$A$ translation of one of their songr was made by an interpreter, and is as follows.

$A$ ehief of Samoa atueks an enemy on nnother island and conquer, After the victors lanve emlanked safely for their island, they sing as fol. lows:-

$$
\text { "Keep ber away, and mitrd the helm." }
$$

And when they get home, the people sing,-

"Wo are clad you bave come to your is band of plenty.

We have wafted a long time for our chief and canoes."

Toa, after his unguccessful search for his favouritc eels, went into the brook for a bath, which he told me he very frequently did during the dny; and it was delightful to see the plensure ho took in it. The natives, indeed, are almost constantly in the water, and, consequently, very cleanly in their per8ons. Finding that it occupied too much of their thoughts on the Sabbath, bathing on that day has beert forluidden.

Towards evening, we took onr leare of Toa, thasking Jim warmly for his kindness; we were escorted to the outside of the viligge by his friends and relntions, whilse Toa himself necompanied us to Pago-pago.

The natives have no fixed time fo: menls, eating whenever they foel humgry. Their fond consists of park, fish, bread-fruit, cocon-nuts, bananas, \&c., but principally of taro. All of these are produced in aloundance. Water is their common drink, and, notwithstanding cocon-nuts are so abundant, the milk is soldom used: the trouble of procuring them is ton much for them. They use ara male from the piper mythistienm, and it is the only intoxicating ilrink they have *. It is never used to excess, although old and young, malo ard fomale, arte rery fond of ith The taste, to one uniccustomed to it, is not pleasant, being sornewhat similar ta that of rhubarb and magnesis. Their mode of preparing it is the same as las already been de. scribed.

They sleep on the large coarse mats with which they always cover the floms of their liouses. Over these they spread colourcd tapas, some of which are also used for nets of protection ngainst the numerous musquitoes. For a pillow they use a picce of barnboo stupported on smail legs. Their hair is frequently shorn elose, and cornt, line, or ushes sprinkled over it to destroy the vernin,

- 'The ava doen not, accoriting to the whites, Intoxicate in the ame mannor as ardent spirti, but produces a temporary pasalysie, fremers, and a confused feeling about the head, fndistlnctnes and dhiortion of vision, somewhat resembllng the effecl of oplam. 
which are generated in great numbers in their tapas and nuats.

Accorling to old Ton, a mative is in a comfurtable cordition when he has a grod house; a well-made visiting canor; a nent, landy, large, and well-formed worran for a wifo; a taro-pateli with a good fence; cocon-nut, and bread-[ruit trees, with an ressonable number of pigr.

The women are now adjuitted to the anme privileges as the men. The chitufs lare atill grent power over the people, although the influence of the missionaries lins tended greatly to diminish it. Most of the people look back to tho days when polygamy existed with regret, and eannot understand why they are restricted to one wife. They say, "Why should God be so unressonable as to require them to give up nll their wives but one for his convenieuce "' They pay just attention to their religious duties; mornimg and evening prayers are alwnys said, as is grace before their meals, and with a devotion mrely to be seen among civilized men.

Their amusements scem to be few; their books are constarstly before them, and a grent portion of their time is employed orer them. Old gray-hended men may bo seevi poriug orer the alphabet, and taught by some of the youngest of the family. The emplorment of the men is to cultivate and weed the taro, and to take care of the fences; they also make senuit for their lumses, and eanoes for fishing. The womien are engaged in making mats, and the boys and girts play, and wait upon their reniors.

Next to sttudy, fishimg is their grent emyloyment. This is performed by driving the fish towards the nets in stroal water, inliero liey are ensily eauglit. The east-net is also used.

The ouly armusement wo saw, is a game called lafo-tupe, which is plnyod with cocon-nut slivile, and resembles shufle-brard.

Mr. Murray is nu amiable as well as a troly pions man, and the untives have imitaled the example set by him. He studious!y avoida any intercourse with them in the way of trado or larter, exeept so muely as is tuecessury for the provisiou of his own family, and devotes his whole tinte to presching and teaching the Gospel. $\mathrm{He}_{\mathrm{i}}$ is one of the missionarieg engaged in translating the Bible, many parts of which are now eampleted, and extensively used by the natives, may of whon read and write well.

Their observanee of the Sabbath is very striet; and it is impossiblo to get n mative to dn nuy thing whatspever on that day, bat perform lis religious duties. They attend eluarch regularly. In-Mr. Murny's centregation there are about thirty eommumjeats, and wearly one thousand attendants un public worship. They come from nnay of the surrubuling villiges. Mr. Murray has been here about diree years, and the native preachers none or ten; ho is well neguainted with tho diffieulcies of his stution, hut seenred to feel assured that lris exertions were nbout being crowned with sucesss. He represented to ne that the latives were very tractalle, and desired execedingly to be taughis; that they had numels application, seemed to com? prehusul many things, and were certainly not sur. nasged in intelligence by aty of the natives of Polynesia.

Polygamy, which formerly was practised to a great extent, still exists anong thuse who hnve not been converted.
Circuncision is practised among tliem.

T"hey enrry their ebilalren in the same singular manner on the lip, as in the low archipelngo. 'They are enty betrollaed, without regard to age, the girt being sta, or tabnoed, until of marringenble age. During the intervening time, all kinds of native propierty nro thecumulaterl, such as inate, Sc. for the brilal day. T'wo days previous to it, the inhabitants of the district aro gatlicred together for fensting and daneing. On the third day, the bride is produced before tho assembled multitule, and the ectemony nttendant on nurriage that was custoruncy nmong the Jews performed. After the mariage liad beest consum. mated, the dowry was exhibited, and each articlo being theld up it was proclaimed by whon it was presented ; the uultitude, having consurned all the catables, and exhausted their strength in rioting and debnuchery, dispersed.

I have seldom seen a more derout or attentive collection of people than I obserwel at times in the cliurch meeting, which was held in the counctl. honge at Pago-pago; the new elusreb was undey'going alterations; for on its being completed, it was found it would not neenmmastate the cungre. gation, wlien they determined to eularge it.

Upon the colvelusion of a long nervice, they were ohserved to divide themselves into three parties; one remaining in the churel, and the other two repairing fo different buildings, The ohject of this was, that thoy miglst listen to instruetions from their native teaclzers explanatory of the sermon, and also receive exisatations to put sway all that is unbeconing to tho Cisristinn character. The affermoon is employed in further explamations nesd examinations by the missionaries, "Tlle antive missionaries lave also meetings un Fridnys.

Their mode of siuging bymrs is peculine, the whole mass juining in somo parts, with alf the lungs they could muster. 'l'his exervise appented to aflord then great delight. The congregation were mostly dressed in tajus, or clothed in nre sort of garment or othes"; lant the person who nttracted our altejition most, was the consort of Portuale. Froun being the wife of the most intluential personage, she had received more presents from us than any other; and slie endenvoured, on this occasion, to display on her person the grenter part, if not all, that she had thus acquired. These consisted of a red enlieo gown, fontr ul five petticonts of different colours, woolten socks, greets slippers, cap and bonnet, a large plaid blanket sinwl, and a pair of polar gloves, the whole surmounted Ly a fluning red silk umbrella-nud this with the therาumeter at $87^{\circ}$ ! It way difficult to lieep onr eyes oft her duxing the service, and before the end of it all her thery been nwry. The ather natives also seemed to bure the desire of exbibiting their acquisitions, though these consisted frequently of wo more than a vest, or a pair of unutaloons, with out shirt, or ocengionally of a long-skirted coat, witliout either of the furmer garments, so that a smial roll of tapa was needed to euver their nether parts.

Some untuthorized nttumfits were male to in. duce the natives to break the inissionary laws, by oflers of grent ralue in their eyes ; they were toli the nussionarics would not seo them. On under standing which, they pointed to the heavens, and replited, "There missionary see," This was wonclusive, and a just and severe ruluke. 
The Pencorek and Fy ging. lish main joinel us on the 18:h of Oetulser, in eight diys from Papieti. Orilen were at once given them to proced to Upolu, to commence the strvey of that island. they thid not satl, however, until the 20th, laving beol detained thy the winds. The larbour of Pagis. pagn, hhough easy of access, is extremely dilicult to Jeare, in conseruence of the south-east tradewinds blowing directly in, and reuderiug it neesBary to makke short tacks, Indeed, in veksol no souner yots headway on one tack, than it is fotmd necessary to thek ayain. The sea is often hesry at the moutl of the harbour, and the shure is lined witlt a narrow cornl reef all areusd it. I was gind to see the Pencock safe outside, after bentiug abut four lours.

Duriug our atay on this isiand, the whole was exnmined, the harbour surveyed, and the principal heights determined. Tidenguges were kept on the norkls and south sides, and the obeervations for magnetie dip, variation, and intengity made. Tho tentrerature duriug our stuy of fourteen days varied from $75^{\circ}$ to $\mathrm{df}^{\circ}$; the menu temperature was 80-50\%.

The elimate of Tutuila is mild and agreeable, particularly at Pago-pago, where tho temporature is lower than it is elsewhere on the island, in con-

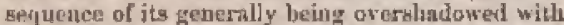
elonds that loass on Jie lighte land. There is usually a fine broeze, which sets in about ten o'elook, and cunthues until sunset. The nights being calni, much dew fills in fine wenther. We had litte fair weather daring our atay, and the prognosticatisu of the natives proved too true, rospecting the difticulty of seeing the son suil start. The wind at times was very strong, almost at gale, accosupanied ly light rain and mist I was informed that there is a good deal of min during the yenr, but selilom suel $n$ conlinuance of it ns wo experietuced. Tliwe sloes not appear to bo any particular ruiny senson, but they are linble to these high wiuls during the winter months, or from Oetuber to Marel. During eleven days of our stay, the quantity of rain that fell was 4 fo inebes.
In uur explorations, notaly all the villgges of this island were visited by some of the offieers of the squadron, and from their report they much resemble ench other. Those of Fagnitun and Lwone, on the sutuliem soast, are the largest, and are nure of the Devil's fowns than the others. One of their eustoms is tuly snvage. They seldum use pork as a fuckl, congerjuently it is a grent rarity with then; lut at intervalh of several montlis the villagers assemble at in feast, at whijelt thirty or forty logs aro killed, when they gormandize on them for four or tive days, or as long as the fioul lasts, The whole is eaten, entrails and all. Fists and taro are the primeipal food, and harge numbers of the natives any be seen fisling off the const its fine weather. The kind of fish nisually cauglat are mullet.

There is a large hind of worn which they esteem A great delieacy, fnd which is eaten with much relish. It is impossible to see them sucking down the entraila of the biche-de-mas, holithuria, and echin, without diggust, They almo ent many of the shell-fish that nie found on the shorr.

The temperature found on the top of Matafon, at the altitude of two tlousand three lundred and fifty-uine feet, was at $4 \mathrm{r} \cdot \mathrm{m}, 694^{\circ}$, whilst that on board the ship was $795^{\circ}$.

We male an endesvour here to scarch the reefs at might fur shells, with fambenux or torchlight, after the nuanter of the Chain islanders, by which moars it is said that pasny species of shells are taken, wlich are nerer scen by daylight. We cannot voucl for this heing the ease, our experinent not laving sutceeded. The lesveg of the eocanmit were eisher too green or two wet to burn. II strecess really attends this methord, it is a singular trait in the ecunomy of mollusen, which are genemilly suppoged to be partial to daylight. It was my determination to make another trinl, under moro favourable circumstanees; but from our constant oceuzation and fatizue of the crew in the laytime, we were unable to renew the experiment. 


Q4 Departure of the Fincernes frou Tutulia, SAMOAN GROUP. Native trial for matsidet.

\section{CHAPTER XIV.}

\section{SAMOAN GROUUP. UPOLU. SAVAII.}

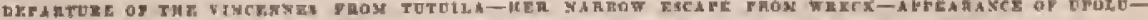

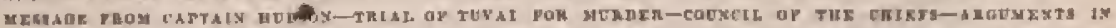

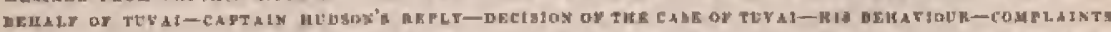

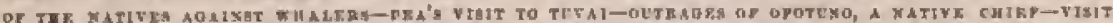

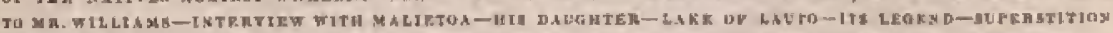

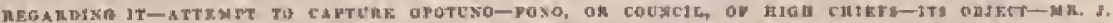

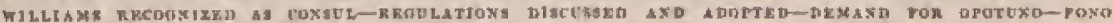

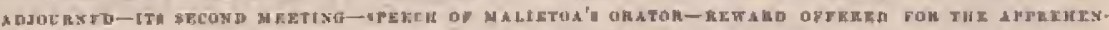

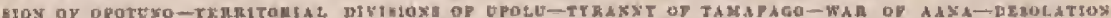

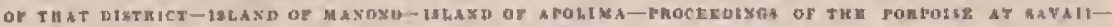

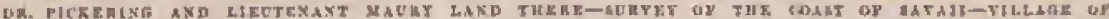

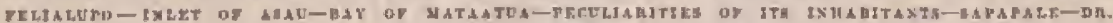

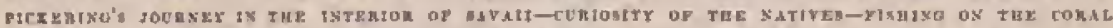

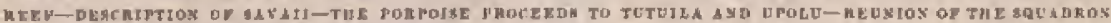

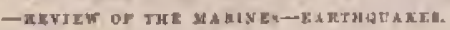

Tre surveys of the isiand of Tutuiln having been eompleted by the 23 ind November, wo nude preparntion for our departure, nth on the 25 th twe weighed anchor. In leaving the harhour we had a narrow egcape from wreck; the atmost constant sonth-enst wisd, which is fair to a resseb entering the tray, and makes jo easy of acesse, is nhead on going out, whichs renders egress rliffeult; it there. fure beeomeg neessary to make freqtent tueks, and a regsel must bo well manceuvred to escenpe ascillent, for to mise stays would be almost ecrtuin to bitisg abont slipwreck. When we beat ont, the wiul was light and it failed altageflier just ats we renched the most dangeraus purt of the chanticl; we were in consequence brought within au oar's length of the reef, on which a lesky suri was breaking. The noment was a trying one, and the event doubtful; all werto at thẹir stutions, nud not a Worl wha spoken. Of ny own fedings on the occasion I have no very precise recollectins; nerely rememboring that I felt is if I breathed more freely nftur the erisis had passed and wo were in salety.

Thes afternon was fine, and we sailed nlong the southern shore of the island, al3miring its diversifits surface, its luxuriant groves, and the siniling villages that crown its bays. Where the valley's come out from betsreell the ridges to the shore, there is usunlty a level plain extuding inwards for a cuuple of miles; these plains ore occupied for the most part by groves of eutoa-nut and bread-fruit, henenth whose shade lie the dwellings of the uativeg Many of the imhabitants woro abroad in their canoes, employed in fishing; some of them schredy seemed to notice the ship, passing them sapidly" witl BlI mail set, white others appenred to regard her with intense curiosity. In the ovening we hat muel lightaing, but no thunder.

The distance between Tutuila and Upolts, of thirty-six miles, was soon passed, and in the morrting we were delighted witfy the view of the hatter isfand as we ran down its const to the westward. It appenrs much richer and more fruitful than the other islands of this grump, aud may be described as of moderate height, rising gradually in n sucess sion of ridges from a low shinre; lyere and there brond and fertile ralleys are soen, with mumerous strenms filling from the mountring in easeades. The eastern portion of the istand is much more twggel than the western; the main ridge runs crist antl west, and ridges or sphrs rum back to it fron the northern const in $\mathrm{n}$ south-erst direction. Between thrwe faternl ridges nre brosd and fertile walleys, decrensing in width as they recede from the eanst. The glunre is lined with a carnd reef, which is unw and then interropted by channels, nud forms Nutg and convenient hnrhons:

At noon we descried the Pencoek lying in the lasrlour of A piil, afol shortly afterwarils i receised a message fron Captain Hudson, saying that my presence wan rejuired on slinre. In ifte lioge thini it was not a business of streh a nature fis to enure detention, I left the Vincennos in the offing, while I went aslone in my boat. On roneling the land, 1 futund the eliefs engaged in the trial of a rutive caller Tuvsi, who had killed an American tramed Edwatd Corenaugh, a native of New Bedfurd.

It appeared that on Captain Hudson's arrival, the murderer was poijted out to him in the village, upan whish he very properly deternined to have the offender pmished, atsl gave otders to hase him arrestes. He was in consequence beized in a houst near the water, and earried on bonrd the Poneock. Heing taken by surprise, he offered no resimance to his capture. Caplaiu Hiudson then requested a conferestee with the aeighbouriug clivefta, who in eonsequence had assembled on the 27th.

The fono, as such assomblieg are called, was held in the cnumeil-hotse, or falestele, where the chicf wero coliected. The Rev. Mr. Mills acted as interpreter on the oecasian, Captain Hudson, through him, stated that the olject of his having requested then to assemble was to britug the necused to a trial before them, in order that if bis guilt werc estallished, he might be brought to emdign pusishnent: los then puinted out to them the grilt and consequenees of the crime of muxder, and declared the course he had considered it lif duty to adopt. 'The ehiefs listened attentively to 
this adklres, and in reply, shrough the principn! one, adnitted that the mun taken was in resility the guilty persol, a faet known to every person upon the islanil. Captain Hudson then stated to them that it was absolutely necessary that Tuvai strould le promptly punished, in order that others might be deterresl from the commission of the same crine. He suggested, lowever, that in spite of tho universal belief in T'uvai's huving commithed the erime, it wos proper that he should undergo a trial, or at least an examination in order that he unight lave the privilege of being heard in this own defence.

This suggestion being approved, Tuvai was brought ois shore under a military guard, and placed in the centre of the building. Ho was an ill- Looking fellow, of alsout twenty-eighe yenrs of nge, and unanifested no fear, but looked about him with the greatest cornposure.

The trial was gimple enougl, ; lie was first asked by the chiefs whether lo was guilty of the crimse, to which he answered that he was; being next asked why he had committed it, he roplied that he tand done it in oudur to possess himBelf of the nus's property (clothes aud a kuife).

The ebiefs, smong whom wrs Hea, of $A$ pia, to whom the criminal was distuntly related, made every effort in their power to save his life; stating that ho was in darkness, and therefore tnennscious of the guilt of the action, when lie committed the murler; that as they had but just emerged from heathexism they ought not to be subjected for past netions, to laws they know not; that these laws were niade for people who ocoupied a more elevateal gtation ; that Turai was a poor man of 110 account, and was not a person of sutficient inportance to be noticed by a great jeojle like va ; that fas Snmon (the Samons fashion) did not sllow men to be put to denth in cold blowd, but that after so long a time had elapsed, as in the instance before them, it admitted of a rinsom.

Pea went wn to say, that many had acts lad been cornmitted upon natives by white men with impunity, and asted whether the Christian religion warnetioned the taking of buman life. He then appealer to our generosity to pardon the present crinte, and assured us that no such offences shontd be committed in future.

Pea had one of those countennnces which exlibits all that is passing in the mint. It was musing to see him at one time exhibjting a pictwre of whimsieal distress at the iden of being compolled to put his kinsman to denth, and inrmediately afterwarts laughing nt something ludieruns whicls had oceurred to him.

Pen was seconded in his endeavouns by Varasa, of Matono, one of the fiucst-looking of the eliefs, whose attitudes and inovements were full of grace, and lis manner exceedingly lnughty and bold.

In reply to their arguments, Captuin Hudson atated, that lowever freely other sins night be forgiven, in considerution of their late benighted state, even the darkmess of paganism could not extenuate the crime of murder. He told theu that the Scriptures said, "Whoso sheddeth nun's blood, by man shall his hlood be shed ;" that nothing hut the life of the offender could antisfy the demands of justice, nad that they must execute the criminal themselves.

This anuouncenent eatused much exciternent; the chiefs again assertad that they knew no such laws; that by the customs of Smmon, the anger of the friends and rehations of a person who had been killed wan to be appeased by a present from the criminal or his relations, and by a form of submission, which consisted in knocking their heads three times on the ground. To this it was replied, that the guilt of the prisoner had been proved and andmitter-he must die.

The chits, after mueli reluetasce, consented, but expressed great repugnance to an immediate execution. They urged in a most strenuons mnnner, that the criminal slould be carried on board slip, and executed there, or that he strould be taken to some uninbabited island and left. Tluege altertnative were refused by Captain Hudson, and the chiefs seemed in grent distress.

At this point of the diseussion, the Vineennes was mnouneed as being in sight, and the proceedinge were suspended. An ofticer wns imnediately despatehed, who, as las been already mentioned, boarded that vessel off the hurbour.

When I Jnnded, I found the assembly anxiously awuitisg the result of my arrivnl. Captain Hudson abul myself had a pritate interview, in which he detailed all the facts, and stated that it lind been liss intention to compel the ehiefs to make all the preparations for the execution, but before it was enrried into effect to cume forward and repriero the eriminal, at tho eame time requesting $\mathrm{Mr}$. Mills to make an appropirinte speech, stating the reasons for the paudon.

After $\mathrm{n}$ full discussion of the whole sulject, we came to the cutsclusion, that it would be best to transport the criminal to somo other island; for it appenred probalile that this would have a better effect than even lis execution, ns it wonld be longer remembered, while to cause him to be put to death might naturally excite a desire of revenge.

This decision was at onee communicated to the cliefs, with a statement, that in econformity with the laws of Thaiti in such enses, Turni shoulal be transported to $n$ desert island, where he would never agnin bave an opportutrity of lailing a white mar. The chiefs, although evidently relieved fron the most intense part of their distress, were still mueb affected by this decision.

The prisoner was then ordered to be taken on board the Pencook, whither ho whs followed by a crowd of natives, with many tears and lamentations, annoug whom lis wife was the most affected. Among others, Pea, the elief of Apia, to whom, as lius been stuted, the prisoner was related, was very muel, diatressed and exeited. Unable to vent his rage and troublo in any other mauser, lse คyent it upon the crowd around bint, striking in all directions with a huge stem of a cocoa-nut leaf, by which he soon dispersed them. I felt a euriosity to seo what effort the sentence would lave upon the prisoner. Death he would bave suffered without uttering a murmur; but when lse henrd he was to be taken from lits native land, his firmness was overeome, and he was observed to shed tears. He made no resistance to his being removed on bon'd ship, but after lie grot there he said he would ratioe be put to denthi nnd buried is his ow's nntive island, tlan banished to a desert one.

After this difficult businesy was arranged, they brought their own grievances before me, and particu- 
larly their complainls against the American whalers. They said that some of them lind evmded their port charges, and refused to pay for the provisione with which they had been furnished. T"o this I replied that I was ready to indemnify thesn for their losses, nnd sloould ask no other profof of them than their own statement. They nppenred struck with the urexpected liberality of this offer ; but, after consultation, as if to manifest a corresponding fecling, declined to acept it. I then informed them that theic port-clarges for the stzuadron should be paid, which gave jutteh katisfaction, particularly to old Pea, who would derise We principal benefit from them. The fono then broke up in great good humour.

Pen and some of the othet chiefs were very nnxious to hear from mo what sort of an ifland T'uพai was to be put upots. They asked many questions in relation to it, and always anong the first, whether there wotild be any cocos-nut trees, nature's first and best gift to them, uhron it. Wislling to mako the intended purishment as terrible ws possible to them, I always replied that there wotal be none whaterer.

After Tuvi was again on board slip, old Pea paid him a visit, in the cousse of which the former melted isto tears, howled bitterly, and beged that he wight be taken ou sliure to be put to death, in order that his body miglat be buried in lia native soil. It appeared from information that wo received, shat this was a part of a concerted plan to obtain a further eurnmutation of his Bentenee, and that this affecting interview was got up in order to excito our sympathice. Finding is did not produce the desined effeet, ald Pen went sunut the slip with a doleful viatge, exelaiming, "Evolvisa-ia-tu Tuหni"-lave compassion on "l'uvai.

I was in hopes to timd the surveys of Upolas nearly, if not quite fistished; but the Flying-Fish, which was to bave aided it presforming them, hat wot yet been seen or heard from. This was no small disappointmeut, as it snight compel mo to briug the Yineennes juto the harbour, and thus incur a serious telny.

Before I hat dueided upon this step, I learned that a clief of the mumo of Opoturso, whise eapture hall been coukidered sis inuportant by out government that a ship of witr that been despatelied for the express purpose, lad again lecome troublesome, and was threatening veugeance upon alt the whiteg who might fall is his power. I therefore determined to mako an altompt to obtain possession of his person by strutagen, Lest, however, such an attempt should craste distarbance in the island, or be productive of injury to the whte residents, I determined, before juting my purposse into effect, to have an interview with the Rev. MF. Williarne, the priacipal missionary in these islands, buth to constit as tu the best mode of accomplish. ing this object, and to learts what effect it would be likely to have on the operations of the missionaries". I recordingly set ont for his residence at Fasetuotni, about twenty mileg to the westward of Apia, in the loope of seeing hitn, Mrr, Cunningham, H. H. M. vice-consul, was kind enough is aceompany me.

- Mr. Wi3t.lams Is the autlior of the vell-known Polynealan Misslonary Researchen, and it wifl bo our molancholy office herenfer, to speat of his talling a martgr in hin efforta to propagato the Gospel.
We left the Pencrek at aurset, and reached Mr. Willinme's smug cottnge about mihnight. No. Ufing could be kinder than the welcume ho gave us; nud the plensure he expressed nt our visit swo made us feel at loume, He grve us supper, and provided us with connfortablo beds. Slort!y after our nrtizal, anotier party wns welcunied, consisting of thice Indies mul a gentleman of the mission, who wero in like manner provided for, withust myparent incostrenience.

Mr. William seened to me exretly what a mis. sivnary ought to bu, pious, theerful, and meek, al. thungli remolute. His whole tlonghts seemed to be directed to the welfare of those whom lie land undertnken to enlighten. His views were pointed not only so the diffusion of the Gospel, bus also to the extension of the ureful arts, and shistever could tend to elevate the condition and eradiente the vices of the natives.

After a long cossultation, Mr. Williams came to the conclusion that there was no reason for fenring that the arrest of Opoturo would be the canse of any injury to the whites or mistionaries. He said that Opotuno was a blood-thirsty fellow, and that it would be doing the itlands a great service should lie be removed; that there was not a slindow of dould that lits lind murdered twelve whites, of whom neveral were Amerienus; that he was a determined enemy to the whites, nud in the habit of eaying that he would onit no ppportunity of killing alt who might cone within his power. Mr. Williams however, dotalted the msecess of any altempt to take Opotuno, unless it was made under disguise; for upon the appronch of all menof-war, and during theis stay, he lived in the montutains of Suvnii, where it was inumessible to find him.

The situntion of Mr. Willinms's cottage is pretty; it stands within a few yods of the beacli, and is surrousded by a nicely-dressed lawn, on which nre several fine trees; tho lackgrutund is filled up witl cocos-nut, bread-fruil, and a variety of other treet Nenr by is the tisy sllip-yard of his son, Mr. Jubn Willjarus, who was tatien by his father to Englant, and there taugh all the inedianical trades. He has returned thence witlin a few montlus, with his wife, and by the nid of a few natives has already built himseif a vessel of about twenty-tive tons' burdets, which he propioses to employ in tradjug among clotse ishande.

The next dny we retnomed to A pia. On our way we stoyped at Sagana for the jurproes of visiting Malietoa, the principal clice of the Malo or cuss. quering party.

I have rarely seen a place where more atteution is paid to clennlines than at Sogasu. $A$ simular regaril to neatness prevails in the wallis around the village, and in the cultivation of the taro, melons, and bananss, which is carried on in the immediato vicinity. The patirs leading to these cultirated grounda pass through fiue shady gruves. The preservation of the broad wallse and paths appeary to be rnther an smuscment than a Inbour to tiv villagerv.

Here Mnlieton was seen in his domestic circle, witlı his wives and children around hin, I foutsd tim in a smail house, enjoying the aftertioon loreeze, with his daughter playing about him. She was about fifteen years of age, and decidedly the prettiest girl we lad seen in this group; lar name was 
Emma, and she was is intelligest as she was pretty.

The elief, whose hair was white with nge, made us warmly welcome, and wished to go oter to his isle-tele to receive us as becane cliefs, but this ] woruld not permit. His wires husied themselves in gettiug things in order, very much after the faslion of other parts of the world, whet a stsmnger arrives unexpectedly. In a few muntes the fine mats were laid, the stonly, calabashes, and struw pat away. A clenn shirt was slipped over the old man's hend while my attention wa called off to another object.

M[alieton's lonse was not larger than the other in the sillage, and exthibited no other difference from them than in containing a dais or platform, vecupying about athicd of it, and miserl about a font higher than the rust of the Hone.

When the domestic arrangements were completed, large bunches of bnumas and fresh coeonuuts wero lyrought in and presented to us. Mr. Wilson whs au excellene interpreter, and by his aid I hat a loug and agreeable talk with the old chief, who, when bis wars were tonehed apon, appeared full of fire and animation.

Messrs, Daua and Couthony visited a lalie called Lauto, whicls lies to the westward of this prass, and in the centro of an extinet erater. The eilge of the erater was found to be two thonsand five burdred and seventy feet above the sea, and the desecrit thence in the water of the lake is mo liundred and twenty feet. "Theso gentlemen suceceded in obtaining a line of sonndings ncross the lake, by cuttiug klown trees, and forming a rnlt of thetn. They found the deptil in the middle nine and a lualf fathoms, decreasing thence grodually in all directions to the shore. The form of the lake is nearly cireular, sud it has a subterranesn outlet. The hill in whiel this erater is situnted is conjeal, and there is a low knoll at sonte distanes to the south of it, which is the only other elevation in the neighbourlinod above the general height of the ridige.

The botrles of the erriter if elotled with the usual forest fulinge of these jolande, which, however, exhibits here more than uลแal beauty, being decorated with the finely-worked fronds of the arborescent ferns, in widely-spread stare, and the graeeful plumes of $n$ largo snuustain palm.

The proets of the island have appreciated the beauty of the place, and allude to the perpetinal verdure which ndorns the banks of the lake, is the following lius: :-

\section{"Lanuto'o e le tol a e latr mea." \\ "Laulo, thtouched by withered leaf."}

There is $\mathrm{n}$ legend connectod with this lnke, that has more of poetic beanty and feeling than one would have sujposed to exist among so rude a people. It is ss fullows,

Mrny generations since, during n war betweel Upulu and Savaij, a number of war-eantres from the latter island erossed over to attack Ulatamon (or, as it is now enlled, Ulumeenga), the prineipal town in the district of Ann. At the time of their appronch, two brotlıers, 'To'o and $A$ ta, cluanced to be puddling their camoes in the clanuel between the reef and the shore, and before they euuld reach the liud were attacked by a party of Savnitians.
After a valiant defence, Ata wag overpowered and Blain, wbile To'o aarzowly esenped the same fate.

Overwhelmed with sorrow at the luse of a bro. ther whom the tenderly loved, To'o retired to a ueighbouring mnustain, and burying lainself is the darkcest recesses of its forests, made them resound with his bitter lanestations. At lenguls in his wanderings lie eame to the fummit, where, stoop. ing down, he sarped out with his hunds a vast hollow, azd, leaning over its briul, suftered his tears to fall in until it was filled. F'lie lake thus fontred has ever since bortse the nppellation of LatuL-to'o,

The regard of 'Ta'o for lis brather's memory was further evineed by his adoption of Ata's name, conjoined to his own as his fanily title, and the nppellation of Toonnta, a contraction of Tu'o-maati, is retained by his desecndants, who are still clisefs of note in Dpolu, and fien whow the uadition was derived.

I'he lake of Lauto is regarderl with superstilioug dread by the natives, who heltero it to be she abode of the spirits, who, in former times, were regarded wilh great veneration, and worshipped. These were supposed to iuhabit the watere of the lake, in the shape of eels, as thick as a cocon-tutt tree, and two fathoms long. The attempt of nur gentlemen to explore it wat looked upon as suclı a profonation that their sative guides left thets, and regarled them as persons dowmed to accinlent in not to destructions. "l'he eels were represented ns so savago and fieme that they would bite a persun's leg off. So cels, however, nor any other fislı, were seen in the hake.

In the neighbourhood of the criter no rock was abserved in the place, nox any light seoria. Only a few fragments of stone were gentered nbout.

The eone of the crater of Laute is flatter than the athers of the anme chuneter that were visited, atud particularly than that of Mourst Tofua. This is the westernmost of then all, and lies belind Fasetootaj. It rises so lolclly, that it is seen distinetly from the sen. 'This, with all the other cuters, are situated urnom the central ridge, and the nost conspicuond of those whicl renain, are Sinsiuga, which lites behind Satnun and Fnliats. There is ales one upors Mount Malata, in the vear of Fangatoa, and another on the southern gide of the island, tuear Salomann.

In traversing the island of Upolu, many deep gorges were scen, in which there were waterfalls. One of these caserdes was mensured, and found to bo geren hundred and fifty feet in height, so that the whole of the water was dissipated in spray before it reached the bottom. Thuse glens are wild in the extreme, and beautiful, frum the great varinty aud peculiar character of the foliage with which they are clothed.

The soutl side of Upolu, like that of 'Tahili, in much more luxuriant than the nortlern, whici is oиring to a like catuse, namely, that it reccives more inoistnce finm the prevaiting winds.

The wild orange grows every where in great abumdance, and in some placen the rond was literally strewed with the fruit which here equals the cultivated variety in size.

In pursunance of the resolution I hal adopted, Captain Hutson bet out on the 30th of Oetuber, with the boats of his ship, for the purinose of attempting the enpture of Opotuno. This noted 
chief of tha nughbouring islnnd of Sinvait, fad, as tras besm stated, oommitled seversl murilers aral other outrages. Among nulser acta, he las takell prosessinn of two luate, gent on shore by the wlateBhip Willian Penu, Coptain Swain, of Nantuchet, killing the chice mate, and the two bont-steceres, The third offieer of the vesse! was also wounded, anil left for dead upou the beach; he wak, however, pickel up by somo fomales, who removed him to a but, where, thrwagh their kisd atteutions, lae recoverest. He rlid not, lowever, rejoin his ship, bat renained fir fome time on slse istand.

The must anrpriking part of the listory of this transaction is, that Captain Toby, of the ship Swjt, of New Bedford, afterwards purchnsed these bonts from Opotunn, althourgh he knew that clijef load abiained them by murdering this enptain's own countrymen.

Captain Hudson fell in with the Figing.Fish, on his way to Savaii, nud took har with him, to aid in earcying on the stratagen by which the watehfulmess and suspicions of the wary chief were to be Julled to rest.

On their arrivnl off the part of the island where Oprotuno asmally resides, they mado fur the shoro under pretence of surveying, nnd renched the village of Setipetea, which adjoins that where he dwels, We afterwaris learned that no surner had the boats got withis the jeef, thars tue prepared fir lis Higlat to the monutains. The gews of the capture of 'l'usi, and the re-appentrume of boats fioin a ressel (the Peacock) which hal possed about ton days before, server to put him an the alert. He lad, however, become so dnring that Jio did not at once fly, but nwaited more decided indiestions of loostility; and when Captnin Hudson, accompanied by only two men, passed througl fin villoge, having left his boats only a milo distant, he entertained the intention of shouting him. Ho had actually cocked his gun for this purpose, when one of his followery adised him not to fire, as he would bring great trouble on the istand if he slrot a clitef. When the bonts' crews afterwards ontered Oputuno"s villnge, the inloabitants showed much alurm, but the chief was mivsing. It was therofore emsiderud advisable to make no hostile demanstmtions; as to grod purpose could have been eftected by following hin th the mountains, where it would huve been impossible to apprehend lim.

The bost ilerefore returned, and although witl. out suececling in the rain object of the expedition, sonthething wus gaitued in revivitng his tpprolnensiona of being captured. His village was not destroyed, liecauso to do so would linve been mo iujury to him, but only distressing to its poor inhabitants. He wonld hase langhed at the idea of his heing puisished ty die burning of their habitations, as it is fairl tre did so when an nttempt was made, fluring a previous eruise of the Vineennes, by lier cotamander, who visited his villige, ant burned twil or thiree of his houses.

The impranity he lna hitherto mjnyed tas gerved to renulor him audseious, and it is nut Inng since be put to death an Amerienn seaman, whn Jia! been left siek in his charge.

Opoturso is detested by lis brother chiele, not only for him aggnessions upon foreigners, hat on his countrytaen also. Only a short time before nur nrrisal, he seduced ant enrried of the wife nf Varara. This aet was ecmisilered so outingenis, aud was so tiepply resented, duat we were informed n war was urly jincruted by the near relationship of these twa chliefs. The Samman regand with trorror the idea of thuse connected by ties of contвangutuily fighting agsíust ench other.

Opotunis is not anly relaterf to Yavusa, but is the sdopited sou of old Peus of Manoun, a conuexion which was not without its effect in uverting hostilities.

On the 4 th of Nowember, a furn was held, ac. cording tu the appointruent made with Malietor, in the fnle-tele of $\mathrm{A}$ pis. $\mathrm{All}$ the officers wlin could be spared from the ships were ordered to attend. Old Pea, the elief of A pia, secmed to be the mater of cermmonies on tho occasion. Clean mints wero sprend for the chices, and chairs and benches horrowed from the missionnries' louses were placed for us, ofiposite to them. All the highest chiefs of the "Malo" panty were present, except Pen of Manono, and swo minor chiefs of Savaii. Malieton presided. His whole deneanonr wis dignified, compoted, and thoughtful. His perwonal appenrance hiss already been spoken of, and the form of his head, his white hair, nut dignified bearing, again reminted [as of Genesal Jacksm, He is slender and tall, although somewhat berut by age. It was io be regretted that his dress wns ill cliosen, an I rather detracted from the respeet he would have inspired had he appeared in his native garb ; he wore puntulwons, th round jucket, and a piuk ast white striped entems shirt.

"Tona, the nephew of Malietoa, who acted as spolcesmars, and whoge contateance betukened the iutereat he felc in the business, attracted attention in the secomil regrue. Then esme Mule, the sun of Malieton, Maletatu, their general, the inost rinowned leader in the war of Asnn, and Tai-ma-lelagi, Malietoa"s brother. Thero were also present a number of ehiefs of less distinction, mong whom wha old Pea of Apia; although he was counpelled to take bis plinee, yet he did not fail to be conspicuous, nut merely by his persunal appearance, but by lis officiousness.

The proceedirugs were enducted with great ceremeny, but there was a marked lifferesice luetween this fono sud the solemuity of our Indian conneils, The Samonn assenubly" appeared more yuiesecust, the proceding exhibited more refiucineut, and the eustoms partook of an Asiatie churneter.

In all such meetings a rigil nrder of precedence, that scems well understoon by every nne, is esta. blished ; all conversation is cartiesl ou in a whisper ; no no is soen stusuling in tho presence of a supe. riur, and sitting with ontstretehed legr is considered indecarous. Artivles were never passud over n person, nul no native ever ventured to come in cunthet with a elnier.

The background on the side of the matives was flled up with inlabitatsts from difierent parta of the islant.

On the nprosile aide of the building, the oflieer of the squalron and the missionarips forned a nis. memus group. Among the batter was our friend Mr. Willians and hiн 8ou, whom I had appointed to act as eonsul until the pleasure of the goverument of the United Stuter was knowil, and whom it was intendud to pmetent in this capacity to the meeting, in order that he might be rengnized formally by the chiefs; Messra llesth, Mills, and Wilson were 
also present ; and Mr. Heath, whs was believed to bo best acyuaiuted with the Samoan langunge, was kind enough to uffieiate us sur interpreter.

The object I land in view in requesting the fono to be called, was to procture the formal enactment of laws and regulations which might secure to our whale-ships a certainty of protection and security, and at the sanc time to prevent impositions being praetiaed by them upon the native guvernment, of which, as lıs been stated, complaint hid been make. To the brench of these luws it was intended that the penalty of a fiue should be ittuched, in order to secure obedience to them.

The meeting being argunized, I in the first place presented Mr. Julu Wiltinass, as the consnl of the United States, whom the chicfs reetgrnized as Euch with great willisguess and satifraction.

We then entered upon the discussion of alie proposed regulations, which wire alopted in a form which prolaises to he tmutually benefteial, being highly advantageous to them, and at the sane time ijsuring a evotuinty of security to A merican vo Bsels that nay visit the islands they could not befure enjoy.

One of the articles referred to the redress of injuries comnnitted by the untives, and prosided for the punishnent of those who had been guily of crime, by giving then up.

Wishing to rid these islands of a pest butts to natises and foreigners, I How, as authurized by the spirit of this article, nade $a$ demand for the แuurderur Oprotumo, and stated that a compliance with this would settle nll disputes between ths. This demand produced a great sensalion annong the chicfs, and much excitement prevailed in the meeting. Salieton, is repply to it, expressed himself strongly in defestation of the elanacter of Oputumo, and stated that his capture by us wonld give litn satisfaction, but argued that the regulntions sow enneted could not apply to his past misdeeds, ard thes lie would only come within its operation should the be again guilty of like crimes. He in short pleasled that the law could have no ex prost facto luearing.

He rext argued, that the inevitable consequence of auy attempt on their part to seize Opruno, would be to involvo the whole group in a eivil war, for lse was tot oniy a powerful chief linsetr, but consueted with others atill nore so; and that a eivil war was that which lie nost desired to avoit. IJo lowever went on to say", that so for ay he was concerned, no opposition would be male to any' steps on our part to seeure one whom they knew to lie guilin of great outrages; but he could not in any wa) תssist.

In ennclusinu, he stated that the isiands load, mutil withis the few yenrs that las clapsed sines he obtained the command, been the seat of coth. timul wars; that they were now awnre of the advantages of peace, and lad a jost senee of the benefits they it conkeguence mjoyed ; nnd ileclared that he shuuld do all in his power to preserve the blessitugs of peace, and maintain the unwonted state of prosperity. For these blessings to ascribed high acknowledgments to the missionaries, saying that he huperl the Sansoan peuple would in due tinse profit by the lessons tauglit theru, furd adopt all the improvements of the Papalangis.

Few jersons have ever inspirel me with nore respect than thïs old clich, and his gentiments were clelivered by 'Toos in an impressive manuer.
It wis not my object wo dive them to extremilius, or to press for" an instunt decinion, I nloo wished th give then time to reflect upon and cansass the regrulations just atopted, and perceived that they began to be fatigued with the bugt/s of the eurferenec. I therefore propiosed thint before they gave me a final answer in relation to Opotuno, they slıould take time for consideration and reflection, for whiels purpouse I suggesteul that the meeting should be adjourned until the next any, wlsich was aceurtingly dorke.

On the Blh November we again met, whon the argumetity urged the day before wire a second time broughe forward, and the neetsaly of their taking mestures tliat should effectually prevent outrages upon the perrons and depredictions on the property of white meth, strungly set before them. They wiot theso asguments with complatuts manint the white tuen who hind exse to the istands or ben left upon then, enying that many of them were trat fellows, and had eacturd inuch truuble, I it once told then that if they worlt bring these turbulent persouss to me, 1 would take ticm away from the islande, and that the laws they lund uaw nssented to, were such Rs wuld seeure their puusklnent for any future offunces,

In this slate of the procenhing wo were faroured with a set speech from the officinl orator of Malieton, an old blinil chice, who etoud up, supporting himself by lesning with both hamds upur a long stick. In this abtitide he poured furth such a torrout of worls as few of us had ever brefore heard; and if elunuence be composed of elocution and a renty How of language, lo was fully entitled to the praise of possessing it.

As we leaned from tho tranklation of this speceh, ita abject was to urge tlwo neworsity of going (t) war, in orter to secure the muderer, Opotusto, for the purpose of delivering him up. This, however, was intended only for eflect; fur these, ns we woll knew, wero not the real sontiments entertained by Malietoa.

This speech was made up of short sud distinet sentences, was fipken in a loud roice, and colttained many repetitions.

Huwever contrary this speceh may Jave bren to the cousl deternimitinn of Matietn, it seensed to meet the popular feeling; num there is no strying what might have been the eonseguenec, lust not the miswionaries contrived to cleck the ontburst. It was now propmsed that the fonu should receire and pulilishs a docurzent, uffering a large reward for the seizure and delivery of Opotans, dead or alive. This propusition was a new fnurce of ex. estement, and old Malitur exclaimed with om. phasis, "Give mo the prapes ?-I will put it upou my lutse, where alt the world silall sce it,"

$A$ copy whe then nated ou the pillars of the eouncil-liouse, which Pea was made responsihle fir, and others were propared and distributed to the severnil chicts.

Tho neeting was then dissolved, and every one prosent evinced the greatest satisfacion liai the whole of the buaines before it had been conchuded in so satislactory n manner.

Tho island of $\mathrm{U}$ polu is dirided into three districts, viz. A tun, Tun-3Langa, aud Anna. Each of theso was formerly governed by a sejarnte and iste pendent cluief, styled Tul. Atua oecupies the easteme ent of the islanil, which exlesuls as far ก 2 
as the town of Lanli ; "lina-Masanga is the tridelle division, aud includes the towns of Simna and Safata, un the southern shlore ; Arna lies west of this, and comprisen the remuinder of the islunul. The first of these districts is of the greatest extent, the second is at present the nrost powerfut, mud the third is the most fertile. The union of tliese districts under ono general gusersument, in whisch the balaud of Savaii is also incluted, is a late event. Previous to 1830 , this island had suffered from the usurpation of in chicf of Manoro, called Tamnfago, who wras a great tyront, but wlou had corrtrived to cause his person to be considtered as sacred, and to impress on lis couturyment the ideat that it would be sacrilege to disobey, hurb, or even to touch him, After the eonquest of a rival ilis. frict in Savait, the assuned the Btyle of king of that islard, "O lo Tupu a Savaii," a titie which Malietos now enjoys, but without deriving from it nuy power.

Timafigo not buly ruled Styaii with resyl and divino altributes, but obtained a complete ascendarcy over Upoln, where he compelled all to give up their property to him, and to yietd the woutuen of all elasses to lis ifesijes.

Finally, his tyrunny nod excesses exceeder the bounds of paltence, and the people of Aam rose agailust lim, conquered, and put him to death. Frum this arose the war of Aana, which will be aggairs spoken of ; for the ehiefs of the other islands cunsidered themsetves bownd to avenge the ileails of Thmafage, The people of the other distriets of Upulu were not united its the support of their neighbours of Ama, wha laul made themselves almost unirersally odious by their liaughty temitig. The war was a bloody one, and restilcer, afler it contisunce of two of three yeus, in the entifo defent of libe people of hama, by those of Manono, who expelled them from their listriet, and forbade their return to it on pain of deacls.

This fertile region remained entirely unoceupied until the arrival of the missionaries; but when the Christian influeuces of their preaching began to be felt, the deeree that eondemiled Aana to soliturle was annulled, and the fow of its former inlabitiuts who liad escrited slanghter, were permitted to retum to their nncient humes.

Tho islatul of Manono, whose inlabitants exerted Buch an influence in the closing secnes in the war of Aana, is situsted within the atr-reef of Upolu, It contains eleven hundrel inlinbitants, and is the resillenee of the ehief Pen, who must be distisl guished from the inferior perstmage of the same name who resides at A pia. This islind is covered with forests throughout its whole extunt; its circumference is about four niles; and it is the station of one of the Euglish missionsries,

In spite of ity small extent and scanty potylation, Marono is identified with tho political history of all the other islands of the group ; for, during the reigng of the two Tauafugos, it held sujuemacy over them. The retuson of its acquiring nad exmeising this pulitical sispremacy, is prineipally to be ascribed to the pusessiun by its izhabitants of the bmall island of A pulina, which they uned as their "olo" or citadu. "To this retreat, imaceessible exeept at a single point, the iuluabitants of Manono were in tho tubit of retiling when preased by ton powerful au eseng, and when his rage had spent itself, they thense iteturiled to their homo with undiminished numbers.
This nutural formes lies between Manono and Savnii, aul soundings extend to it both from the sluses of Lpola and Sarnii. The comal reef attriched to it is bot small.

A polima, on the most cursory examination, is evidently the crnter of an extinct volenno. Perpendienlar cliffs rise from the sen around its whole cireuit, extept at a single point on its tortliern side. Here the lip of the crater is broken down, and admits the water of the sea into a small bay;, which affurds a safo harbour for bosts. The entrance to this is so narrow as to adinit no more than one boat at a time, and is dangerous whenever there is any surf. It may, thecefore, be ensily defentled. There is unly one other point on the island where it is possible to effect a landing, namely, at a strall lieight to the westward of the bay, and hero it can unly be done when the water is perfectly smooth. But an enemy landing luere woulu have malte no jrugress, for before the interior enn be renclied from this proint, the stecp and previjpitony rocks remain to be climbed.

The highest point of Apolims is on its south side, where it is four hutrdred and seventy-two feet above the sen. The perpendiculno eliffo which free the sea are of couse bare of vegetation; but with this exeeptiun the whole surfice is covered with eneon, bread-fruit, and other trees, or with plantations of taro, yame, se.

In the centre of the island is a vilhage of about twenty louses, and the permanest population con. kists of no more than about seventy-fire persons. The people are evidently jealuns of the tasides reputation of their natural fourtess, and slowed much concers when we visited it, which the wumen even manifested by slıedding tesu's.

While we were engaged at 'T'utuila and Upolu, the survey" of the island of Savaiti was performed by Lieutenant. Commnndant Ringgold, in the Purspuise, It has altendy beell mentioned that this vessut had been detached for that purpose, and that Dr. Pickering, from the Vineennes, had gone in her. 'The brig first touched at Sapapale, the residusice of the Rev. Mr. Hardie, who gave them a eordial weleome, nlthough much surprised at so tuusutul an arrival,

Mary of the natives elleeted to view the white men, if wlon so nany liad never been seet together sn the islatud. In their remarks, they, amung other thisgs, praiged our jeople for their beauly.

Dr." Pickering and Lieutemnt Manty were lanted here, to remain upou the islaud while the brig was enployed in sutreying it; the former to examine its pruductions, the latter to olserre the tides. Mr. Harilie kindly afforded them accommoditions in a new heise he lad just been erecting.

Lïunlenan-Commandant Ringgold, after landiug Dr. I'ictiering wud Lieutenaut Maury at Sapquale, proceeded anound the island for the purpose of surveying it. He begrn with the examination of the large bry of Paluale, near the criteru point of the islasd. Here there is a missionary station, under the supurintendence of MIr. M'Dunald, wlio latd resided there for abont six munths, with his wife and children. 'T'ho natives ase pesceable, but are deseribed as ingraikitive and rude. The village is [rettily situated, and is appronched through a boat-prasage in the reef.

The south bide of the islnud wns found rocky and 
jron-bound, witl a besyy surf hreaking on it "I'0warde the wrestern end of the island, the rucks aronud the points were worn into eavities, and the sen rolling into them produced innumerable sponts of wnter.

Near tho morth-westem point of Savaii is the Inrge and heautiful village of Feliulupo, with a anug little awo for boats. This place is under the cliarge of a Tonga missionary. The natives were frienfly, and tlisposed to exchange their pouttry and fruit, for tools, eloth, \&c.

The next inlet on tho north side, was that of Asau. This was supposed to be the only place where these was amy probability of tinding a harbour. But the herre of sueh riseovery was frussrated, for there is ouly a small and shallow enc tranee through the reef, aut withis the reef the shore firrus an extensive tat.

Proceeding on the survey, the brig arrived off the north proint of the island, and renclierl the bay of Matnatua, which was examined, and found to stford in good anchorage. The brig was anehored here, and the hashour surveyed. This is the only harbour in the island where a vessel can anchor with eafety, and here supplies of hngs, poultry, and regetables, may be had is aburndance; wrod and water nre nlso ensily obtained, the latter from eopions springs near the beach.

A great difference in form, physingnomy, and mannerw, from those of tho adjacent villages, was ubserved here, as well as a chauge in the character of mury urticles of mannfacture. 'Tho war-clubs and speara were of uncomumon form, atnd neatly made.

This bay is surrourded by a wlite coral bench, The matives aplenred harinless, but manifested great euringity. The somen ste more gracefully formed thas at the other islands.

The mative missionaries appesred to exereise much inflience over then, having put a stop to sually of their former evil practices.

On tho 2t:h, the brig again arrived off Sapopale, after na absence of nine days, Hero they were joined liy $\mathrm{D}_{2}$. P'ickering, and Lientestant Maury, and found the old ehief Malietoa and his son Mole, who were extremely courteous. On the former being presented with some articks, he remwrked, that "our property was very good, but oul goodwil! bettor."

Jr. Piekering engagod natives to aceompany him into the interior, and to visit the Hu or hurnt district. Preparatious for the jouruey were made in advance, and among other things, it was stipuluted that there should be only two meals $\mathrm{s}$ day, - one early in the morning, and another in the evening. I'he frest day, however, was to form an exceptinn.

$\mathrm{Mr}$. Hardio accompanied the party for a fow niles, and they soon after tikir departure met a native who was styled "llie Lord of the Furest." The party were desirous that this man should ac. company them, for his apprearance prouisied more than that of the others, and it seemed it was necessary to abtain tis permission before they could enter the forest. In times of senreity, hio domsins become of great value, in conser|uence of the quastity of wild yams they yith. This persor sgreed to accomprusy ihem, and they jroceeded along a gerod

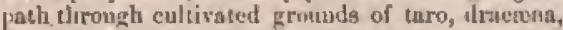
de. Mr. Hardie, before leaving the party, endenverured to inake the untives understand the nature of Dr. Piekeriug's errond ; the latter was unable to muke himsalf understood by them. They had not proceeded far before they canne to an uninhabited house, where the natives stonpred for the purpose of prepariog dimer, the cooking of which oceupied three hours! Tho day was in consequence well sdranced before they again started, and at about $4 \mathrm{l}$. M. they reached as open slied, alwout two uniles from the last stopping-place, where the natives concluded to hale for the night. The oceupints, who consisted of two clderly women and a young man, were dispossersed, and the shed wha enclosed by hanging up lenves of the lieliconia, which recomble those of the bunun. They ther prepared some excellent cocoa-nut pudding, and heated some cucos-nut milk in the shelis. This beverage is usually taken by then every morning and evening; the natives all suying grace before their menl, and pravers before they went to rest. It was late tho next morning before I r. I'ickering evuld get the party in motims, and pursting their route, they soun orertonk the Lord of the Forest, who had preceded them, and was employed in cutting a path through the woods, ulkhough that already mado mighi lave heen easily jassed through. No inducement could unke tlicu elannge their purpose, and they continued to work at theit turnpike, lopping off large branclies, bentiog down ferus, \&e. After some time, they renclied is rising ground, whicl, they fourd to be on one side of at crater, ahout a thumsand feet atuve the ses, ant seven miles inland.

Dr. Picheriog now conclundel that it was a hope. less task to attempt to penetrate into the interior witl such guides, and deturmined to return, whiti lre aecordingly did. He found the rest of his party a mile in advance of their previous eneampmeni, where they land built for themselves a fire house, and each iman lind collected wo laxige baskets of yame for frovisions. This whe their stoppingplace for the night, and among other cares for tho doctor's confort, they comstrueted for him a mative piliow, forned of a piece of bamboo, with legg lasherd to it about tbree inches high.

The nasives were in high syirits during the erenisg, talking and laughing immodertely. They streceeded in getting off hy nine o'clock the next doy, and renched the const about noun.

During the stny of Dr. Pickering and Lieutenant Maury on this island, they wero objects of great curiosity; and whenever they walked out they were followed, not only by hoye, but grown men, who dirt nut, however, ofler to moleat them in any way. Wlien they passerl through the villages, all the ithabiturts, not exceptiug the sebolars frum tho schools, cume out to look at ilı, The. The latter, however, did not abambon their lnoks, but retained them in their hands; for all, whether young, mid. dle-aged, or old, are anxious to lenrm, and their perseverance, as in other prarts of the gronty, is astonishing.

Dr. Pickering here witnesed the taking of fish in a different mode from that pructised nu the other islondse Applicestion was made to the chice and thromgl his influence a meeting of the bend men of the town was ealled, and a fishing expedition agreed upnn. The net, if it could be so called, was prepared, and in the conrse of two days every thing was realy. The net was a bind of chevaux-dt-frise, made of the lenves of the eocra-nut tree, split and 
wound round a line, and wis litule less thau Jalf It mile in length. It was inure formulable in appenrance than in reality. This net was taken out at high wnter to the cornl reef, in three pieces, then fastened together, and thus made to enclose a largo extent of water. This space was gradualty contracted by doubling up the net, wlich answored the sume purpense as the drawing of a seine. The fish did nut attempt to pass it, and were thus driven towards a certain print, where $n$ sort of stck of matting labd been placed for them to enter. As the fish wero gradually enclused by the mat, and the tide fell, the scene beesme an animated one. Men, women, and buse, to the number of two or three hundred, were eagerly engaged in pisking up or eatchug the straggless as they were reen leaping up ; the whule nrea secmed alive with fish, jumping in every direction, some over the lieads of the unives, and thu escaping, while others leaped into hand-aets. About a curve-load was eaught, com. prising thirty different kinds of fish, mome of which were six or eight pounds in weight, but the majority were sninller. The haul was considered an nnsticeessful one, which was attributed to gone zuisundirystuding and mismanagement anong the natives, by which is farge stone fell on the net, nad allused muny of tlee flsit to escape.

Savaii is the most western island of the Samom Group, and is also the lngest, being furty miles in length and twenty its brealth. It is not, however, as populous, of as importaut, as aeverisl of the others. It differs from any of the others in ita appencunce, for its shore is low, aud the ascent thence to the centre is grndual, except where the cones of $n$ fow extinet ertuters are seen. In the middle of the island a penk rises, which is almost continually enveloped in clouds, and is the highest land in the group. On aceount of these clouds, nngles could not bo unken for determining its height necurately, but it certuinly exceeds fusr thousand feet.

The interior of the island is rarely cntered, even by natixes, and has never been penetrated by sirmagers. The only settlemetis are upou the slume, along which the natives alwnys journey, and there nre no pathis acroas it.

Awother narked difference betweess Savaii and tho other large ishnds, is the want of any perimneut streams, - a cireumstance which may be esplaitues, notwitbotanding the frequency of min, by the porus inture of the rock (vesicular lava) of which it is chiclly eumposer. Water, lowever, guthes onth sear the shore in copious springs, and when henvy and continul raiss have uceurred, streans are formed ill the ravines, but these suon disa prent after the rains have teased.

Tho cornl reef nttuched to this island is interriptod to the soutli and west, where the surf beats full tpon the rucky shore. There are, in conse'juence, but fow places wliere boats can land, and ouly one hrobour for shipg, qhat of Matasua ; even this is unsafe from November to Febsury, whon the north-westerly gales prevail.

The soil is fertile, and was eomposed in every part of the istand that wns visited, of decumpased voleanic rick and regetable meull.

The Purpaise, hasing taken Dr. Pickering and Lifeuteuant MLury again on bonrd, set stil for ' $T u$ tuiln, fur the purpose of joining the Finemues, and bent tu windward along the south side of Uprolu. Duriug this passage many of the crew beenrne sick, which rudered it necessury to stup for a few days at Pagro-[ngo, in order to recruit them. Hers they ali speedily recorered, except one man, named David Blodget, who died. 'Tlue disnrder' was attibuted to the daripness of the vessed.

The delay in the arrival of the Porpoise at $\Lambda$ pia eatused me to send the Flying-Fish to Tutuila, whence they both returued to $A$ pia.

I'revious to sailing, at the pressitsg instance of the clitefs, 1 ordered the marines anil small-arm men of the squadron, in all abust one liundred and filty, to be sent on share, with their tunsic, for exercise. They had been well drilled to act on shore shomld uccasions require, atsd were provided for the ocension will blank cartridges. The natires from far and near were collevted th witness the review, and few Beence that oecurred during the yoyage wero as amusing as this. The old ind young were equally delighted, and it was ludicrues to see them enclearouring to innitate the soldiers in their marelies and countermarcher, They were not satisfied unJess the drummerg were constnntly benting, fund wero particularly delighted with the bass-drum. T'he firing occasiuned some alasm at first, but when they saw is did no harn, they beeamo reconciled to it, althongh even to the hast they would scamper off to a distance at each disclias'ge.

During vur stay in this group, we experienced two sligh shocks of enrthquakes; their veenrsence here is not unusual, but there is no account of any damage having been done, Their motion is geuemily trenulous and horizontal; one, luwever, has been experienced of a wavy deseription. They are said by the foreigters often to produce the sensition of sea-sickness.

On the 10th of Novernber the whole squalron was assemluled in the harbour of $A$ pia, after having been actively engaged sinee the Bth of October III eximining the diftcrent islands, snd making surveys of their coasts and larbours, \&c. This work whs all expeditiously and well done, witl the exception of the soutli side of the jiland of Upolu, which was imperfect ia some respects ; it was entserputitly re-siturveyed in the following year, and the eharis finished. Besides the surveys, full series of experinente were malo in magnctism, and excensive collectious obtained in untural history, butary, dic., the islands being traversed by partie日 in several directiuns for this jurpose. 


\title{
CHAPTER XV.
}

\author{
THE SAMOANS.
}

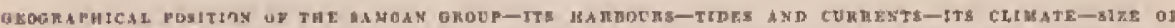

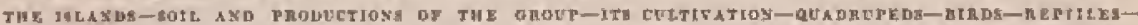

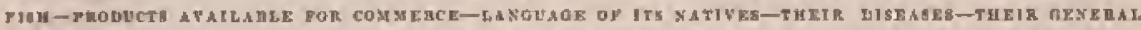

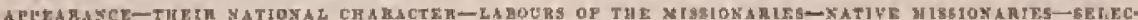

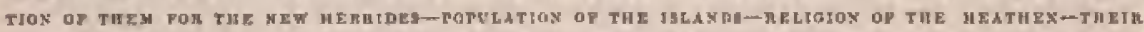

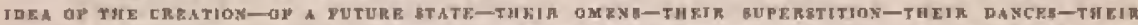

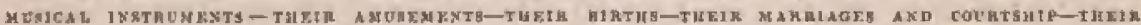

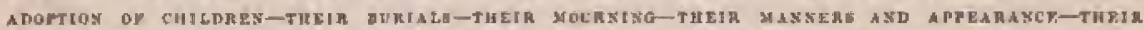

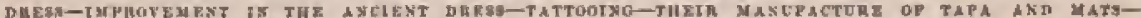

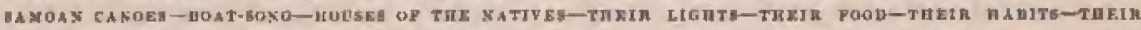

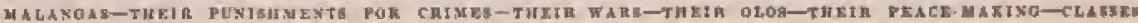

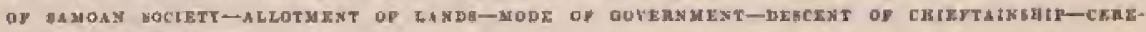
MONIEg Aт THE raxos.

Dunse the time that the sinuadron remnined in the Sanoan Grous, nll the islands of which it is nuade up were visited; nut only were the examitsations, apoken of in the swo preceding chapters, mado, but their ghores were minutely surveyed by boats i the meteorological instruments were duly registered astronomic and rangnetic observations made, and a full recold of the tides kept. We huve thus whtnined a large amount of information, which will be more easily intelligible in a condensed form, together witls a great namber of facts in relation to the aborigitasl population, which may bo made more interusting when applied to give a general view of the habits, charicter, and state of civilization among the antives, tlas if dispersed in isolated remarks in the secounts of the separate tours in which it was obtained.

Thu ginup lits between the latitudes of $13^{\circ} 30^{\prime}$

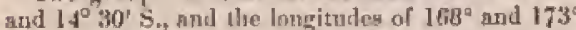
W. The islands, ns las been scen, mgree in the sencral eluarater of being of voleanic structure, and having coral reefs ; differing, huwever, in the modifications of these formatims, which have been from time to tine deseribed. The harbours aro usually gituated within the reefo, lout T'utuila is an exerpion to this rule, by the posisession of the deep linte-lucked basin of Pago-pago, This is, of all the ports, the one best adapted for the refitting of wes. gels; but A pia, in Upolu, in the latitnde of $13^{\circ} 46^{\prime}$ $566^{\prime \prime} \mathrm{S}$., and longitude $171^{\circ} 4 \mathrm{I}^{\prime} 9^{\prime \prime} \mathrm{W}$., is not so diticult of egress, asd in exmsequence of its proxinity to the fertile district of Asma, the most convenient for ressels secking only a temporary nuchorage and refrestument,

l'he approach to Pago-pago, and the other harbours of the Samoan isles, is not difficult; and as the soundings exterd in some places for a dis. tunce beyoud the reefs, vessels may drop an anehor in case of necessity.

The flood tide among these islands sets to the westward; beyond its inflnence, an the southert side of the islanda, a current generally prevails to the eastward, while it runs westwnird on their northorn side. Vesuels, therefore, when heating to windward, would find it to their advantage to kcep on the soullierts side of the grutp, whers there is not. only a favourable eurrent, but where the winds would be found more regular, and calms lese frequent.

Tidal rabervations mere male contemporaneously nt Tutuila, Upolu, and Savail; these Blsow a regular atfference of one hour in the tidal ware between 'Tutuila and Upolu; the tide at Sarail appears from the recond to have been more irregular than at the other islands, which may in part be attributerl to the extent of the red, but I Blso fear that there may hare been a want of due ntteution to the vbservations.

The climate of these islands msy be tormed variable, and there is mach bad weather, particalarty during the winter months, when long and hesvy rains, nitended at times with high winds and northerly galeg, are freruent. Destructive luurricnnes also oecur, and of these one is atill reenllected which blow down the bread-fruit trees, and destrayed many of the houses.

The air is more moist than that of the Society Islands, and the vegetation in conseruence more luxuriant. Thunder and lightning are often experienced, but during the Bammer months light withds and ealms are the prevailing elaracter of the elimite.

Somo of our gentlemen made the remark, that to judre from the time at which the bread-fruit was gatherew, there must be a grent differewee between the scasons of this island and Tahiti; for when we arrived at Tutuila, that product was ripe aud in abundance, although when we left 'Tahiti, only a few days before, it was umripe and not to be lad. The eane remark whs made in relation to the vi-apple (Apondias duleis). But, by comparing tlıe royages of Cook and Wallia, it would appear that the thine of the year at whish the brest-fruit in in senson at Tahiti is not constant, for bnth tlese navigatner found it in perfection, although they risited that islas in different mornths. If there the a difference between the time of the ripening of the lorad-fruit in the Society Islands and tlis group, the grenter moisture and ligher mean temperzture of the Samoan climnte will account for it.

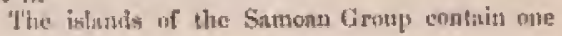


thousatud six lhundred and fifty square miles, which are divited as folluws, riz.:

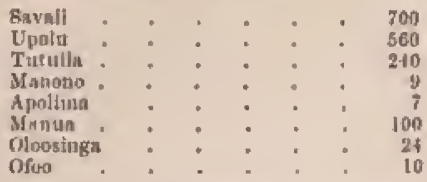

The soil of all the islannls is rich, and atrises chiefly from the decompusition of voleanie rooks, At Tutuila, it was remarked that the vegetntou was luxuriant, and the treses of linge growth. At Upolu the furests secmed more somlire than those of Brazil, although the same kind of gruwth appeared to provial.

The trees do not branch out until near the top, which renders it diflienlt to ebtain lotanicnl sjecimeras. The truuks are corered, and even the summits of the trees sometimes overgruwn, with the leaves of the seardent Hagellaria (freycinetia) a climbing piper, and other vines, as heyas, eouwolpulus, \&e. The lower part of the tranks are enveloped with ferme, of which there are many varieties, and with some species of pollos, whicl. give the whole ground a matted or woven npreasance.

The woorls in the interior of the islants are very thick, aud often conprused of large and fine trees; amung them are, treeferns, is species of banyan, pardanus, and several species of pratros. Araung other plants a spevies of cerbera was observed, with beatifal clusters of large and odorous wlite fiowers, which yiolded a quantity of white viseons sap, that our botanist, Mrr. Rieh, thought might be manufuctured into caoutchouc. On the whole, the sprecies of trees are intweh more numerous than at Tulliti, and the vegetation in consequence richer and inore varied. The wools, however, are not enlivened by showy flowers, and the few of these that are meen are of a white or grryyish hue, which is to bu ascribed to their being but littlo exposed to the mys of the san, in eonsequence of the umbrageors folinge. Many of the thowers seen on the ground were unknown to our botanist, ag were several fruits,

Among the trees which have been named, that which struck us as most remarkablo wus the species of banyan (ficus religiosa), called in these islands otwa. Sime of these were sem, whose peutant branches had takon root in the ground w the number of thousnuls, forming steme from an inch to two feet in diameter, unitiug in the main trunk more than eighty feot above the gronud, and supporting a vast sybtem of horizontal branches, spreadiug like an umbrella over the tops of the other" trees.

The bread-fruit is the most abumdent of all the trees, and grows hero to a large size; the vi-apple, the coeoa-nut, and the will orange are nlso foumd in great uumbers; ardi at Tutula a large lime-troe was eeed in full bearing, which was suid to lave bees planted bofore tle arrival of the missionaries.

Among the mast silugular of the vegetalule productions is the stinging tree, fof whish the nutives are much afraid; for if its leaves be turehol an exuption is produced, particularly if the skiss be wet. Its Jeaf is cordate, but ruito smonth.

The arborescent ferms are nut as numcrous as at
Thaiti, but grow to a larger size. The palms give a elaractes of luxurianee to the country, from the variety of their foliage. Rnttrns ninety fut in leugtli were seen ruming over the trees.

Bambous and the wild sugar-catue were very commots; the latter is used in thatching brouses: the wilu ginger also abounds.

of the wild nutmeg (myristica), two species were seen, which are small irees, and likely to bo passed without notioe, were it not for the peculing nusuner in which branehes grow out of the trunk, which is in whiris, at regulas interwals, like the white pine (pinus strobus) of our Nurthern States.

It was remarked that the chancter of the vegetation approsiched more nearly to that of the East Indies than of the Society Istrnds, nnd the leafless actacins were the type of those we nflerwnrds saw in New Holland; but there are some plants which aprear peculiar $t$ these islands.

Many of the trees we lave namesl, as wel! as other platy, are ulujects of estivation; but the grouml clenred for this purpuse does not extend fnr from the consts, wear which alt the villnges nre situated.

To clear the land, tho bark is burnt off tio trees, after which they are pertitted to stand until they becone dry, when they are eut town and used as ficel.

The enltivated plante und trees are breal-fruit (of which they litve twenty varietied), creos-ut, ti (dเacrona). baisanas, taro, paper-mulberry, taeca, from which arrow-ront is made, and of which they hare several sorts; augar-eane, which is not made into nugar, but used unly for thatehing; coffee, ava, (piper tnythisticum), sweet-pritato, pine-apple (ananu), limught by the nissionaries from the Society Islands, yams, the pajnya, and tabacco in small quantities. The agare has not been introduced; but in a fow yeary lemons and swet oranges will be produced in great quantities from treea which have recently been planted.

To the cultivatiun of the tacea tluey pry litule attention, yet the quality of the feculn (arrow-root) made from it is said to be superior.

"The misgionarics are endenvouring to teach the natives the best mode of cultirating the suggar-case and manufacturing it, nnol it is sajd that a few persons have alopted tho sew metlorls, At present they find a sabtitute for sugar in the root of the ti plant, which is laked in ovens, and yields a large quantity of ancelıarue juice resetnbling molasseg.

Great attention is paid to the enlivintion of the yam. Tlusy nre plantol in Oetuber, and are rije in Februsty and March. The vines run up the trees, and when they die, the root is lnown to bo ripe. To plant them, they are ent, like the potsto, into jieces containing eyes, which are laid in heaps and covered up until the sprout appears. The pieces are then set out at distanees of abont three feet from each other.

Henring that these wers some extensive savnn.

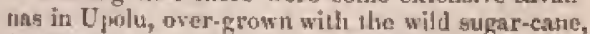
1 directed Assistnnt-Surgeon Whittlo and Mr. Conthouy to proceed to the etust end of the island, where they were said to grow. They, however, saw nothing of the kind except a few small patches of that piaut.

There are 110 truces among these islanis of nny mative quadtuped, tror any other of the matranalia, 
excont a species of bat (pteropus ruffeollis), which is very destruetive to the brend-fruit. Swine bave now become nbundant, and the missionuries have introduced entele, which are rapidly increasing, and will in a few years be in sufficient numbers for the supply of vessels. Horses lave stso been brought to the jstauds*.

The first large quadruped ever seen by these islanders was a mule. With it they were nuch astunished, and it whs corsidered so great a curivaity that it was carried uround the island of Upolis for the purpose of gratifyug the nativen witl a siglat of it. "They gave it a name, signifying - the ling thut travels over the ground.

Punltry of alt deseriptions is plentiful, and pigeons alsoush, which, however, nre coukidered sacred, and not used as as article of food. Of the latter bird (columba ocounica), between sixty ant suventy specimens of different rarietics were obtained; but it is remarkalse thas of all these, nume were the same as those fuund in the Society Ishands. There are but few birds of ganz, ane? 1tone of the hawk genus. A philomel whs pointed out by the missionaries as the principal singing bird, and the woods of T'uttila were filled witl warblers. The note of the philomel, although much praised, did not nppear agrecable to me.

The pigeon ts commonly lept as a plaything, and particularly by the cliefs ; for thin purpose they are fastened to a stick by a thread about twolve feet in length. They are taught to fly from and return to the stiek, and when well tutored to this feat, the posscast: of the bird exhibits it with much pride and sutisfuction. One of our olticers unfortunately on one occssion shot a pigeon, whicl, caused great commotion, for the birl was a king-pigeon, and to kill it was thought as great a crime as taking the life of a man. The preople were not to bo pnoified uuti] the interyreter told thens that the officer belonged to "man-of-was," which intelligence, together with a small present, satisfied them, and the matter was settled.

To justify their regard for them, we were told that when the inhabitants of Aans were driven away, about eight years since, by the people of Manono, the prigeons abandoned the distriet, but thst upon their returu to their bones, the pigeons again made their appetrance in their former abodes.

Snakes were found in Upolu, and set-sankes aro reported to have been seen off the islnnds.

Fish are taked in the neighbonring waters in grent abundance and variety. Busides other nodes of eaking them, they mre caught on the reefs by women, who place baskets near the boles where they are secustomed to take shelter. They nro also speared by torchlight, and tuken in doep water by the hook. Anomg the sea-fish mullets are very numerous, and are frequently seen leaping from the water in immense shoals.

One of the modes in which fish are eaught by the Samonns whs witnessed at Samstru. About n dozen canoes formed themelves into a ring around what appeared to be a dark cireular spot in the water, about six foet in dinmeter, and which was moving along with a slow and unequal motion. This was a shoal of the suall fish exlled lou, which is about two inches in length. The stinal being

- On Upolu lieese are now twenty bead of eartle and serea thorkes. thus surrounded, the circle of eanoes was gradually lessened, nntil the fish, findiug themselves cnelosed on all sidee, ceased to move forward. At this moment the heact-fisher, who was seen standing ap in the canoe with a net in his hand, threw it dexterunsly over the stronl, unon which all the other men dove nt onee from tho boats, and remained fur several secouds uuder the water, where they secured the sides of the net. On renppenring, all regained their canoes except four, who remained to take charge of the net, which with its prize they eonveyel to the chief.

Ihese islusds furnish abuudant supplies for the refreshment of vessels, but as yet tlieve nre few articles which ean be rendered arailable in foreign commerce. Tortoise-slield, of which a little has at times beeu prucired ni Saraif, cocon-nut vil, and arrow-root, as'e nearly all tlat can be procured in qunntities beyond the intnediate wants of the visitors. Caoutchone, gum-aralic, castor benns, orris-ront, ginger, nnd coffee, might however be casily added to the list of exports. In return for what they can furmish, the natives now look to oljects of real utility; beads, jews-Jinrps, \&e., unce so much in request, nre now searcely prized; and cotton cloth, writing-paper, and hardware, particulasly needles and other small articles of utility, are the kinds of manufactured goods which are most semingt after.

The Samoan langunge is soft and smootl, and is the only one of the Polynesian dinleets in which the sound of $\mathrm{s}$ is found. The letters that the mis. sionaries have fuund necessary to adopt in order to write it, are only fourtetu in number, viz. A $\bar{F}$ : G I L. M N O P \& $T$ U $v$. In attempting to sound the words of other languges, they use $\mathrm{L}$ instesd of $\mathrm{R}$. $s$ for II, and 8 instead of $B$. The $G$ las a rasal sonind, as in ofyg.

It has nearly the sane construction as the Talititan, neverthaless the Sxmonn is far from being underatood by the uatives of the Society Islands. The Samoans say that they never can acquire it"their jaws are too otiff." The missiunnries ulso bave great difficulty in speaking it, and are liable to make many mistakes which aplear absurd to the natives.

We hsve seen that it poseceses the sibilant sound of $\mathrm{s}$, aud every one of the words terminates with a vowel.

A separnte dialect is appropriate to the clivefs, all of whose actions, the parts of their bodies, \&c., lave different names from those of the common people.

Many of the Samoans reach the age of serenty or eighty yeass. There is, however, a great morulity among the young children, which is probably owing to their exposure to the weather. J'lose who survive, grow up robust nnd healtlys.

Among the disenses which afflict the adults, ore of the most noural is a spinal affection, which results in earies and produces humpback. This is to doubt owing to the peculiar manner in which the children are earried. Catarths and bronchial disorders, occasioned by the exposed life of the natives, are prevalent, and a white resident died of phthisis during our stay. Tho dysentery, as al epídemic, is unkuown, but sporndic cases of it ocetre, occasioned by imprudence in diet.

There is an eruptive complaint, called ilanea, which euvers many of the children under the age 
"[ tev yenrs with snres, and which seems more particularly to attack the face and stead. The mude in which it it trested i.s singular: the ehild is rutbed with the husks of the cocoa-mut, until all the scabs are removel; a soft preparation of the ureal-fruit is then aptilied, after which they aro wished. This opurtion is undergone every tinso Iley bathe, which is daily. When the bread-fruit is not in season, a decuetion of the busk uf the eucos-rut is used in ita plnce.

The eleplantiasis prevails to a groat extent smong tmen who are past the Juildle nge; mud sume of the crses are truly frightiful. There are also many instances in which women are affected by it. 14 does mo appear th eause the lenst degree of pain. Among the rensuns that have been assigued for the frequency of this disense are, the babic of enting their food without anlt, and the use of cocos-aut witer ; to which may he adkled exposure at night, and want of sutiveient exercise. The latter enuse, whether it be enpable of protucing this disease or not, unquestions bly exists ; for they are in the Jalisit of sitting for hours with their legs bent uuder them, which mnst eause a stagnation of bealohy circulation. Laziness, however, eannot be aseribed to them as a part of their untionul character, for they are disposed to exertion, snd willing to be employed. When, therefure, they liave receired sufticient instruetion, and eivilization has Laught them new wants, they will probably becomo an irdustrinus and tluriving preople.

Ophthalmia, which is suyposed to arise from the reflection of the sun from the sandy beaches near which all their villages are built, is so prevalent, that, to speak wjthiin bourds, not less tian a fifth purt of the population is affected with it ". Is most caseg it was olserved to hegin on the inner corner of the eye, whene it extends gradualy arer the pupil, until the sight is completely lost. As the disease advances, the tlickness of the film inerenses, and when it has eovered the eye, thant organ becotnes enlarged and apprears to project. From appenranees it would not be diffieslt to re. move tho film, and thus cure the disorder; bat the matives have zont male any attempt of the kind. Several eases of tolul blindness arising from this disorder were seen.

The vetierenl diseass iloes not exist at Tutuiln, and is hardly known in the other islands. This serves to prove trow grent a superiority this island] possesses over Tabiti in the chastity of its females, who is general ubserve their marriage vow with striet fidelity.

Fuvers are rave, and those of a remittent and intermiltent type are unknown; in fact, the geolorical formation of these islands is by no ments. favourable to the generation of the miasmata that enuse tliem,

No means of medical assistance are altached to the Engtish mission, and tho missionnries, therefuro, chn do but little in alleviating the malitdies of the antives. Eren their slight knowledge of remedies afrords somo alleviation, and their practice is fnr preferrble to that of the natives, who always abaniton to their fate tho日e who are very ill.

Among the few enentive mesns that the natises do employ is a sort of shamprooing. This is per.

- It is so common ab Savail, that at least one caso of blindnes, in one or botf ejes, ls to be seeu in every fanily. formed by rubbing the body and limbs with the liauds, at first gently, and gradually more and utore roughly. These manipushions are upplied ay * restorative after fatigue, atud to alleviate pain. For tha furruer purpose they are effectual, and oftell abate, if they do not remove, the latter.

Among all the I'ulynesian jalanders, the men uf Samor rank, in point of yersouml uppearance, second only to the Tongese; and many specimens uf ruanly beauty are to be sech anong thew. $A s$ sursels cannat be sail of the women, who are suther ill-formed and stout. When very young, lowever, gome of them are pretty, and their cubur is light, beiog little darker thinn tlint of a brunette or Suuth American Spaninar. The girls art lively, havo a good expression of countenance, and, whint is rare in Pulynesia, have some degree of basifulness,

The avernge lueight of the men is flve feot test inclues, and some of the clief, whuse limba are well rutuded, would be enlled fine-lnoking men in any part of the world. Their features are not in general prominent, but sro well marked and distimet, sud are all refemble to a common type. The nose is slort and wide at the hrae; the mouth Jarge and well filled with white and strung teeth, with foll and well-turned lips ; the eyes black, and often large and bright; the forchead narrow and ligh; and the cheek-bunes prominent. It was observed that some of them lad the eyo turned up at the outer comer like the Chinuse. of benrd they have but little, but their hair is strong, strighlt, and very black ; instances, however, wery observed, where it had been turned to n earroty red, by washing it with lime-water for the purpose of destroying the vermin (pediculus humanus).

When the islunds were first visited, the natives were represented as ferceius and treacherous. This aruse in at grent degree from the bloody cour. flict they had with the bosts of La Perutuse's squadron; and the opinion was kept up by the just resentment they in somid cases matufested for wrongs committed on them by lawlesg visitors. The instance of Opotuno, however, shows that this inles of their clinrneter is not entirely witlout foundation. Viewed in a more farourable light, they are, as we found them, kind, good-humoured, intelligent, fond of amusements, dexirums of plensing, and very lospritable. Both sexes ahow great kimdness and love for their chihiren, and age is so mucla respected that only old men are admitted to council. As a shade on this fieture, they are indulest, covetous, fielsle, deceitful, and little rolinnce enn be placed upon them. To illustrate these fertures of their claracter : the first question asked when a chief receives a visitor is, "What present will you take l" for they consider it incumbent uyos them to bestow some token of regard, and a ueglect to offer it would be indecorvus. This custom was alwnys complied with, when any of our officers risited them; and although it was eviluth lliey did not wish to part with any thing valuable, their elroiccst possessions were exhibited as if for the clioice of the stranger. On the refusal of their offered presents, great joy was alwayn to be observed in their countentance and manner, showing that they rejoicerl in an escape frotn loss, whilo they had at the same time performed the prescribed ritus of hospitality. This risk being wer, they were too hajly' to supply us with ecoes- 
nuts and fruits. In spite, however, of the ap. jarent libematity with which these were furvistred, they do it in expectntion of a full returu. In pur. sunuce of this lospitality, it is the eustom when a stranger passes tlirougli a village witlıul aljuwing an intention to stop, to fullow hin asd offer food.

The Sumonus sre usutlly very intjuisitive, asd it was amusing to excite their curiusily. Among other things mentioned for the purpuse was, that white men uften wore false teeth and wigs. The latter proctice in particular seented strunge to them, and they ealled it "thatching the hood." A terrestrin globe was also shwwa to some of them, whereon the position of their islands and their snusll relutive importance was puinted out. This excited great surprise, for until witlin a few years they liad no jen that there was any country except their own.

If the chiefs are libernl in their tenders of presents to their visitors, they un lise uther hand do not lresicate to ask for whaterer they soe. They may, in fact, be styled aturdy beggars. One of the most persevering in lis meudieaucy, was no less a person than Vavasu, the proud and orerbesting chief of Manono. 'They usually legan with begging from the husmblest individual, and ended with the highest; and when they had obtained all they could, would go over the side of the ship ridiculing our folly for giving so much.

Old Pes, by way of exeusing himself when charged with being a great beggar, said lie did nut keep auy thing lie got for hitnself; that it was the Sumoan fasliou always to ask for every thing lie saw. It Imattered rot if his request was refrsed, he was as content as if he obtained whist le desired, but he said be should have blaned hinsedf if he had rot asked.

The beneficiat effects of the labours of the mis. Eiousries are nure evident amoug the Snmous than at Tahiti. The spread of the Gospel thas not been opposed byevil habits of the sume invoterate character, and the natives of this group lave been more easily reclaimed from their vices than those of the Society Islands. The grentest obstacle to the success of the missionaries has arisen from the presence of a few abandoned white mesi, who attach Whemselves to the besthen clicfs. Their upposition, althongh injurious to the missionary cutse, yields little bencfit to themselves, for if every thing they acquire, the elitef under whose protecLion they are takes half; and alkhouglt no opposi. tions is ever made to their departure from the islands, they are not permitted to take any thing with them. The vices of these men excito the disgust of the nore well-disposed of the natives, who often express their astonishonent at their iguo. rance of sacred subject, and ask if it be possible that such znen enn have been brought up in a eivilized community. The first altenot to intro. duce Christianity is related to finve oceurred in the following manner. Some yenrs before the arrival of the missionuries, a ressel was wrecked upont the island of Upolu, and her cargo seized thpon by the natives, many of whom, even to the present day, regret that they did not then understand what riches were tius placed at their disposal. "Ilıeis mode of treating the prize was farcieal in the extreme: pipes were made out of candlesticks, elothing was thrown away as valueless, and uany injured thenselves with the fire-arms. The crew were welf trenteil, and fed for a long time, although the natives were greasly astonished at the quantities of jigs required for their support, and entertained fears lest they should breed a famine in the land. The captain advised lis crew to turn missionnries, and set them the example himself. Ho met with mucls suceess, and stceeded is buitling several clusehes, until, upon the arrival of the Engliwh missionariog, lie was complelled to relin. quis/d his axsumed vecupation. It is not probable that even the cajtain was deeply yersed in religinus knowledge, and rery certain that the crew could not have heen; but their success sprears to have arisun frums the great vencrntion with which white mes were at first regarded by the Smmoaus. They looked upon them as a sort of spirit, whom it was improsibile to hurt or to kill; and the ships first seen off the coust were considered as heavenly messongers, mrogunsticating some drendful calnmity. "I'he bad conduct of their nautical visitors Jins dealdoyed this reverence, and foreigners generally no lunger meet the kitul weleone they formerly received; this observation does not apply to the missionaries, who receire all the bonour that is dne tn their good intention, of which the natives are fully aware *

"The Wesleym miscionaries, and thuse of the Britibl, board, renclyed these islands about the same tinse, or the former were perhaps the firt so arrive. The influevere of the Wesleyan tenets, and the number of their followerg, increased rapidly under the superintendenec of the Rev. Mr. Turier: Diflicultics, however, arose between the two furtios of misgionaries, which were fiually adjusted between the two honrds in London, and the Wesleyans abandoned this field for that of tho Feejeo Group. This arrangement was amieably unde, and I heard of only one individual on either side who stowed an cucharitable spirit towards his folluw-labourers of the other party. In spite of the removal of the Wesleyans, there is still a large number of the natives who adhere to the tenets and forms tnught them by Mr. Turner, and still retain as strong attacliment to him.

The missinnaries were from the very first tatier under the protection of the most powerful chicfs, and lave never received either insult or injury from any of the natives. They lave establiblied seltouls in many of the villages, but lave found a diflienlty ju obtaining lative teachets.

A printing-press has also been established at Upolu, and rapid progress is making in the trntsIntion of the Seriptures, of wlich some portions aro alrendy published. Many publieations have issued from this press: nmong them I regretted to observe a surall tract containirig a violent attack upon the Roman Catholics. The sight of this surprised me, as it contradicted the opinion I laal formed, from my intoreurre with the mistionaries, of their liberality and freedom from iutolerance. The sule abject of the tract was to prepossess the minds of the nntives agatinst the missionaries of the P'npal Church, il case llyey should visit these islands. This stucli me as being at rarianee with the first principles of our religion; and I could not refmin from expressing an ofinion thnt the tract was calculated to do much harm.

The labours of the English missionaries lave

- All the antlves have sume huarituge of Cugtain Conk, derived fsoms their cumgnunication with the Friendly Islands. 
been much aided by native angistunts, who have been both inlustrions sul suecusful ; nnd unong them, thuse of Baratonga have the merit of having led the wry. "They have neted under tho direction of Mr. Williame, and tre was lout in praise of their exertioss. I witnessed a most interesting meeting of these native missinmaries, for the purpose of selecting sine from their number waceumpany $\mathrm{Mr}$. Willinng to the New Hebrides, which hing perlaps left a moro deep impression on my niud from the melanchoiy result of that attempteul missiin.

Great anxiety was exhibited by the candidates; and I have never seeu at tnore proper state of feoliug, or listened to inure correct aentinents, than were expressed on this uccasion. All nppeared devoted to their tenlling, nnd some of them were quite eloquent. After the choice was atsnounced, thoso utron whom it had falleu manifested or elseerful but not unberoming triumph, while the rejected candidates were evidently grieved and disappointod. "The former were nuw in rested with new apparel, which, althugh no more than a striped coltun shirt ", gavo then ast air of consequence among their brethren, which was amusing to us whocould draw consparisong between this siruple garment and pronder kinds of canonicals.

Eacti of the resident missinisarieg mow delivered a loug bamngue, which was replied to by" ono of the selected. The sulvjects of these diserures were, on the one hand, aulvee in reference to the duties about to be entereil upon, and on the cther a reeognition of the weight of the responsibility ineurred ly" the sucenasfiul candidates.

Most, if not nll, of those selected for the new mission wore fine-lukking men, and they were chosen ont of many applicante, for their steady liabits and strict moral conduct. The term of their engagement on the new duty was thrce years, after which they were to returt to their wires and ehildren, who were not to accompany them,

Ithe extent and inflnence of the labonrs of the missionaries may be best understowl by a compsrison between the whole population of the islands, with the nurabers of those who have embraced Christinity, and attend the schouls.

The entire populntion of the gruup is estimated at 36,600 , of whon 14,450 lare embrneed Christianity, find 12,300 attend the schools, These numbers are thus distrituted :

\begin{tabular}{|c|c|c|c|}
\hline 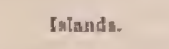 & Population. & $\begin{array}{l}\text { Profreseurs of } \\
\text { Chribtanity. }\end{array}$ & Puplis. \\
\hline 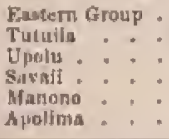 & $\begin{array}{r}2,000 \\
8,000 \\
25,000 \\
20,000 \\
1,100 \\
500\end{array}$ & $\begin{array}{r}150 \\
2,200 \\
8,000 \\
4,000 \\
100 \\
100\end{array}$ & $\begin{array}{r}150 \\
1,900 \\
6,200 \\
3,700 \\
230 \\
120\end{array}$ \\
\hline Tobal & 50,600 & $1+, 850$ & 12,300 \\
\hline
\end{tabular}

- This garment is the only remuneralion that they recvive during ench jear from the mlosionnry funds, and with it they fewl thesnselves welt requited.

I have in acknowledge the obligatlon tander whicl| I feel miscelf to the unistonaries, both individually and collectively. Fir their kindness and altention. They did all In thets power to further the objects of the expedition, and to them the squadron is malnily imdetied for a great pnrt of the Cacillitic we anloyed of becoming acquatinted with the mar ners, liabits, and cusituzin of the Sanoans.
The whote number of foreign missinuaries is eleven, of whom nne resides in Tutuila, mix in Upula, three in Snvaii, and one in Mлnota.

The number of native teachers is one hundred and thirty-cight, of whom five are in the Eastert Group, thirty-oue in 'Thuila, fifty in L polu, thirtygix in Straii, twelve in Manome, and four in Apolimis.

Bexiteg those counted as Jaring nctually enbraced Cliristianity, it is said that two-thirds of the wule population belong to the Christian purty.

of those who rttend the schools, about ten thuusand rend, and this newiy-intruduced lathit han of course made a rery great change in the luabita of a majority of the people, bue the number of heathen still left is sufficient to furnish an idea of thejr uriginal manners and customs, whicti will in a few years be either entirely lust, or so modified lyy the spread of the Gospet as to elanige their claracter entively. The rapidity witls wlich this cluange is going on, rendered it desirable to obtais as much information as pos. sible in rulation to the pristine manner of this preuple.

As respects their sncient relirion, we have obtnined the foilawiog partieutars of the heathene, They ackrowledge ono great god, whirm they call Thugalua-lagi, but pay less worship to hin than to their war-gods, Tamafaira, Sinleo, and Onafanua. The first entices then to war, the Beend leails them to it, and the third is a fermale goddess, who excourages then to fight.

Mafnie is theje god of earthiquakes, who was deemed to possese great power, but has, according to the Samoans, lost nuel of it. The wry in which they say this oceurred is as follows. One Tulatgo, who possessed a charm capable of causing the carth ta divide, coming to a well-known spot, eried, "Rock, divide! I nn Talago ; come to work !" The easth separating at his command, he weit down to eultivate Jis taro-pateh. His son, whase narne was Tiiti, became requaituted with the chrim, and watehing his father, saw him descend, and the earlh wose after him. At the same spent, Thitii suil, "Ruck, divide I I am Talago: come to work !" The rock did not upen, but on repoating the words, and stamping his foot violently, the enrth separated, and lie descended. Being a young man, lo made a grent noise nnd buste, notwithstaniling the advice of his father to be quiet, lest Mnfuie would hear him. The sun then askerl, "Who is Mafuic, that I should be afraid of Jim " Observing smokit at a distance, ho illunired tho sanse of it. Talago said, "It is Mafuie lieating his oveu." Thitii desermined to go anıl see, notwith. stanting ull the persuasions of lis father, and met Iafuic, who inciuired who he was. "Are you a plancer of tasv, a louilder, or a twister of rupes ?" "I an a twikter of ropes," sail Thitii ; "give me your arin, and I shall slowe sun," So laking the asti of Mafuit, be twisted it off in a moment. Such a pretienal illustration of lis powers soon made Maftie ery nut, "Na fia ola, ut fia ola t"-. I desire to live, I desire to live! T'itii then took pity upou linu, and lat him go. The natives, on feeling an earklıquake, exclaisn, "Thanks clıat Mafuie has but one arm 1 if he lad two, ho would sliske the earth to pieces,"

The god Salefu supports the carth. They Lave 
likewise Meswa, Frana, T'intini, Lamnmau, who are golls of lighuiug, rain, whirlwimds, \&e. These gods are suid to reside on an island to the westwatd, frum which quarter their bal wenther usually cumen,

They han, likewise, many inferior gods, who watched over particular distriets. These various

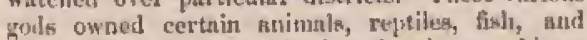
furds. II some few districts inminuste objects were worshippet, thus: a brunch of luambon, with a bumeh of coreon-nut fibres tied on the top, was wostripped in Manouo. They also had carrell blocks of wood and stone erected in memory of deud chiefs, which they worshipped.

The account they give of the crcation of their island is as follows:

Tamzalas, their grent god, who lires in the sky, Bent diwa alte bird Tuli (a kind of snipe), lis daughter, to book what was below. She reported to lier tacher that she saw nuthing bit ges. Tantrakon then rulled a stone from bearen, which bo. came the island of Savait, and another which produced Uprolu, nom the same for the others.

This did not suit "Tuli, who returned to ask for inlinbitalats. Ho gave lier ordery to plant the wild vines (fuefue), which after growing were ordered by lims to be pulled ap and thrown into twe ps, frotn wlyich worms were produced. T'lent it was desirable that they should become human. Spirits were aceordingly sent to them by Tuli, and the worms becane man and wonan.

Their notiuns of a future existence are quite vague. They helieve, however, in a happy future sute, where every thing good is providud. Some suy that it is on their own island, others on distant iblumds, and for the ciniefs at the residence of the gods on Pulotn, an islaud to the westwart. They nlso believe that the spirit goes there immediutely after death; that in these places it never rains; that they eat ambl dink there wilhout labour, sud are waited nprou by the most beautiful woinen, who are alway young, or tas a chief expressed it to one of our ufficers, "wluke breasts never laug down."

I'le spirits, according wo their belief, often conte lown to wander ahout at vight around their former dweilings; sume spirits are believed to die, while others are intnortal; sone dwell in subtermuean abodes, and are eaten by tho gods. Some person believe that after death they beeome "aitus," ot" inlerios" guels.

"I"hey butieved in unuy omens, which were carefutly watched. If the lilack stork, called matun, flew before them on is war expedition, in the direetion they were going, cluey deened it betukened success; but if in any wher direction, it was an ill viseth. If a dim moon, or very bright starlight, or cunet, were observed, it nlways indiented the death of a chief; and a minbow was a sigu of war.

The squenking of rats was all unfortunate omen. Sneezing was also considered unlucky ; if any one of it party sncezed on a jouncy, their further progrest was postponed.

I way tohl that the Sanoans have a great dread of being abroad in the dark, and thent when abliget tn pass about their villages by night, they use flambeaux made of the drienl stalks of the coeos-nat feaf to light them on theit way. This fenr is partly owing to suprerstixion, which mukes them forrin! of encountering some spirit or aitu, with which their imuginations periple the gruwes, springs, rockt, trees \& $\&$. They arte in the labit of occasionslly Jaskisag a fenet for the king's aitu, when a number of piggs are prepared, and a quantity of taro, fruit, \&c. is gathered. The portinu for the situ is placed near lis supprosed dwelling-place, and the dejerudants and others enjoy themeelves on the remainder.

They were formerly in the hahit of presenting their first fruits to the aitus aml chiefs. This ets. fom still contimues among the lonthen, but the Christinn party present theirs to the missionarices. The ceremony usually takes places iл January or February. In drinking nพa, the first cup was always presented to the gods.

Tliere is an aceoutst of a large lizard which dwells on the south sille of the island, and is worshipped as an aitu. The description gives of it malses it two fathous long und as large round us a coens-nut tree, with huge ecales, and a mouth filled with sharp teeth. It is said to dwell in a stream near Safata, into which the natires freçuently throw meat. Sotse of thets declare that they have seen him, and that lie lias dwelt there upwards of fifty years.

It is not remarkuble, however, that they should lave this tradition; and this cireumstance offurds an additional proof sliat they have had frequent interenurse with the Tunga, or l'riendly Islands, where a sinilar tradition is spoken of in Mariner's Tonga Islands.

Among their other buperstitions is that of a malignat spirit that residea in the vieinity of $A$ polima, in the shape of an enormans eel, of from six to ten fathoms long, and large in prupertion, which attacks catioes and drage them dowน.

A story is told that is said to have happened only a few years ago. While two nntives of $\mathrm{Ma}$. mम were вwimming across the chunnel in the reef, they were dr'isued in the sight of nuny whers; immediately a large cauce wny mauned, and went in quest of them; the crew of this cusoe eneoumkered the monster, and wounded it. The canoe was upset, and nithough a fow saved themselves by swimming to the shore, the grester part of them were destruyed. When nsked if it wns not a shatk, (of which they have two kinds, the tanifa, or grent white slark, and the masi, or smali blue bue, ) they replied, it wns a menstrous jersi, which is the nane applied to the muruena ur conger cel.

Their dauces and other anusentents are in a grent degree abolished, but they are still practised in the licathen villages; atul even the Christins wonen may stil! be induced to exhibit the fertner, which shey eall sira. The mode of perfornung it difters from that of the Tahitians, wut is like it, dnseivious; and neither of thew would be ealled dunces in our sense of the term. The danee is usinally perforned by young girls, who stand up before the audience, throwing their arns, legs, feet, and hands, in turmerous strange attitudes, which are any thing lut graceful. The others who are present sing amusing words, in two or three parta, while a third or fourth part is kept up in a cosrse grunt or gittural sound, in the bass clef. The words are cuopprised in short sentences, encls of which finishes sutdenly with a stuecato note, and a viulent gesture. 
The danee of the girls at Upulu consisted extirely of motions of the body, and was so indelicnte as io protuce disgust. The cliant which accomparied it was sung with a light voice, nnul three or four women were employed in benting time on the mats with short sticks, in which nust of the spectators joined with their hamils. In nil cases they kept time whl the greatest accurasy.

The Sumoar dram is made of a prart of as tree, hollowed out; Lhey louve also an instrunent formed of a loose slat fitierl into it boarel, on which they beat time with two stichs. Their thute, if it may be so called, is made of bambon, as are also their pipes, which resemble those of Pan.

The dances of the men are by no menns in. decorous. Those who perform them sary is num. ber from two to a diszen, hand the divided into two parties. These particg alerrately advasee and retreat, which gives an appenrance of aximatiou. Clapping their hands, swinging them to and fro, or elasping them over their heads, they follow ench other in a circle, leaping up and down, and turning strddonly around, keeping titne to the music. The danesg enntisue a considerable time, and end with a soddun elap of the Jands and a gimultaneaus slumst.

The song is usutly extemproranecus, relating to some recent oecurrence. The following is a trussfation of one of thens, ultained by Mr. Conthony through wa of the interyreters:

The Papalangt has come to Samon,

The Papalangi has come th Valusu,

Let un all go down to the opring

The Fapralangl is fond of the s!rs

Whers is the pig ! Where is the Iattened fow I

The Papalaragi camnot foilu in the siva.

hindle up a bright blase! Whese are the virgins

$i$ an golng to got some coeartanis.

Look at itils Samoan, how frely the annces!

These dances aro untally perforned in the faletele, where atrangew are entertained. Tho inhabitants and their gnusts oveupy different ends of the building, and alleruately keep up the daucing and singing. "Through the latter all the news is made known, occuriences related, and inçuiries made and answerted.

Besifles these dances, thero aro varioun games. One of these, ealled "lupe," is plated by two pernank, who eit mprosite esch other. One of them presents his chosed fint to his ofroncut, and then rapidly liolds up one, two, three, or all the fingers and the thumb, striking the hack of his hand or the mat at the same time. If his opponent fails of instantly holding up a like number of tingers, he loses a juint, and ten points finikl the game.

"Lafo liputa" is nimo played by iwo persons, who place abont filty beans is the mimues scantium before them; then taking up four at a time, thes throw them up in the air, and enteh them an the back of the havd; the player who eatehes a humbires] sonnent is the winner.

Tune-fun: this is played by five or six persons, It rusumbles the aport of the Chinese jugglers wilh frou balls. The tirst player sometinues takes an mary ns eight oxanges, thinowing Ituern saceexsively into the air, fund endeavutis tu keep the whole in motion at onee. They ure very dexterous at this: if they miss three times the gaine is lost.

Tui-muri afords the natives much ammement. Any' number of persous muy flay at it. 'litiey seat themselves in a cirele, and divide into two parties. Au orange is suspender from above, about two foet from the trouthd, snd each person is supplied with a small sharp-yointed atick. 'Tho orange is ewuyg routhd, nud no it passes, ench one endeavoure to pieree it, bone with great eagerues, others quite calmly, and others again with a wary conlness, all of which afiords mowh ammsement to the bystanders. The party wins who firgt suceeds in fairly hitting the orange fifty linses.

It is played for nuats, triuhets, se, lut more genenlly fur a baked firg, which is eaten when the plny is over.

Litia : this is a general spont, sometimes whole villages playing against cach other; in is is fhet an exerceige in spenr-throwing. Two parties furnish themelves wihl light sticks of the hibiseus tiliaceus, nlyout eight or ten feet long and ins thick as a finger. The bark is stripped off, which makes them tury light. The two parties arrange themselves in a lime, and strive tor throw these as far as possible; tise party which succends in throwing fifty the furthest wins the game. The usmul distunce to which tley are tlurown is about forty ynrds, and one wutald enneeive it almost impossilile for them to be thinwn su far. A grand fenst usually tor minates the sport, which the lusing party pays for.

"Isfe" is a game confined to the chisfs, who play it for pastinic, Four persons sit th the corners of $a$ mat, ten or twelve feet long, in whose eentre is placed arather of ten inches square; the persons ist opposite entrers the partuers; each party in provided with five cireular pieces of encintut shells, from two inches in dianeter to hulf a cuxon-nut. 'the first player lays his smaltest piece on the little mat, and his ongonent tries to knock it $\mathrm{nF}$, and leave his own in its place. Liach in lis turn endeavours to knoek lis opprotent's pieces off. 'The rarty which tirat sneeeds in knocking his opponent's pieces off one hunilred times, wits the gitme. The piecen of encos-tut are finely polished and earved with a wari-ty of loviees.

There is tho ceremony at birtha, or indeed any ingonvenicuee. The mother generally procects inmediately to the opring, losthes and wnshes hor infont, and se the same time her nasal occurntions are resumed. The naming of the shilal frerzuently Lahes place some tine before jta bittlı, forr sex makes tho diflurence in the nanes, which are given indieriminately to nuale. and fenales.

The mothers often suckle their chitdren until they are six yenrs old; and I was tuld of an inatance wherc n woman guve nourishment to three ehili ren of different ngex at once, tho elifest renoving the youngest sometimes by force from the mother's breast.

It is thejr practice to wash the children frequently in the fresh-water streams.

When a rative wislics to get a wife, the entsent of the chief is first obtained. Then he takes $\mathrm{n}$ hasket of bread-fruit, and ofters it to the girl of his choice. His suit is considered as ucepted if slie partales of it. He must then pay her parents a curtnin price for her, which varies with the station and ability of the pmortics. A elvief's danghter is valued high, vis. at hulf a dozen thintehets and as muny fallows of eloth.

Another mode of enrtalip is to go to the house of the istrject of attaehment or desire, and be entermined. If the family ahow a friendly feeling towrards the youmg man and eat with him, his ad- 
dresses are farourably received. The formal offer is made by a large juresent of the fastrily of the fersile, which being acespted, the natch is uale, assd if refused, the eourtship is at an end. The paresta expect thoir vildren to abide by their lecision. "l'he "Malo" party have been in the babit of tuking wives from their conquererl enerzies when they thotshth proper. At a marriago cusenuny a great feast is mode, particularly if it be a vlicer $\mathrm{s}$.

$\Lambda$ man is at liberty to repudiate his wife and marry agnin nu ceratif ennditions, but the wemnan cannut leave her louabnd without his cosisent.

$A$ daltery was formesly pursibhed vith death, and is very seldom emmitted. Arnugg single wousen, intereourse with a Snunon licfore martinge is a reproach, but not with transient forciguets.

It is a common presetive for" parents to make a prenent of their elildren to clicefs or athers, who ndopt the child as their own, and treat it ever nfter as atzel. After it is grown un, one-linlf of its earys. ings groes to its athpterl parent. "Thin custom gives the chiefs many athisted wijldren of both soxes, who continue to live with them, and are in all respects trented as their own; atsd spreads their counexisnt far and wide.

In their bariuls at Upolu, they have but little earemosiy. 'F'le borly is enveloped in many folds of tapa, and depositeal, as has already been deseribel, at 'l'utuils, with the ti planted around. No utensils, trTus, Sc., the deposited with the bodies; for, according to their belief, they liave these things providud for them in their Elysium. A fenst is made fur the attendants, consistiug of pige, taro, bread fruit, \&c.; presents are male ly nll the relatives to the fauily of the decused, atud if the family can afford it, $\Omega$ small canoe is procured for a eoffin. After tho body las tain in the grave some time, they take un the skull mul place it in a box in their trouses. The renson assighed for this is to prevent their encmics from possessing themselves of it, for it wns a custom in their wara to violate the sanctity of the grave. We heard slint a fow of the boilies of chicis had been preserved by oil and heat; and the misgionnries informed me that they lind seen the bodies of those who died thirty or forty yenrs before, preserved in this manner.

Their mode of showing their grief is to bum themaclves to blisters, (forming indelible marks, ) with little rolls of twisted tapa, which, on being lightsu, sonn produced $a$ con!. They also scrateh their bndies. The fenuley are exid (in token of affliction for deeeased frienda) to lave jricked holes in the carpse, and suckerl out the fluils. All these practices may be now said to be passing away, and aro almust obliterated.

There is already a very great difference, not only in dress but in npperarnce, between those who hase shopted Christianty, and these who adhere to beaHrenism. 'The latter have a wild look, to which their long hair, tied in a buncl behind, adds not a litte; and when gring to war they let it hang down in wild coufusion, which increnges their anvage appearance.

On the ofluer hand, the Chriatians crop their hair short, $\rightarrow$ a fastion introulued by the missionaries.

The hair of the children is cropped elose, except a loek on oach sile of the liead. The manners of the people in the Christian and hentien villages are as different as their nppearanec. In the Intter nu Echuols are secu, nur any of the incipient marks of eivilizasion. Their reception of strangers iu the Christimu villages is always kirsd and lospritalue, Althugh, as has leeen stated, a return is looked for. Annng the henthen, the manner of reception tsanot be counted ufun with eertainty, for they at athe time weleome their visitors with corliality, and at asuther are rude, insolent, and anxions io wjtain all the strangern posecss. When in good lsumour, they entertain their guests with the laseivious danes we have deserilued, performut by native girls, Their whole manter and conduct ar sin different from those of villnges willin a shore distarse of them, thint the effert produced on the later by the instrutetion of the minsionaries, ap[reare nimost miraculusus.

In the hentien villages the dress of the Samoans is tu be seen in its prinitive aimplicity. It is no more lons the titi, which is a short apron and gindle of the leaves of the ti (dractena), tied around the loitus and falling down to the thighs. The wosnen besmenr themselves with coega-nut oil mixed with turmeric, which gives them a shining yellow twt, that is congilered as a lutaty; w wets brenst is a spot of reddish browas, of a singular shape, tand of various sizes, from that of $n$ dollar to that of a dessert-plate. They do not sluw the least sign of ferminine bashfulneas, while those of the Christian villages eover their bosorns, and exhibit as much modesty as those of aIy country.

Duriug the last ten yenrs the dress of the natives has undergone much elange; the titi has been increased in length, and extends all round the body ; it las a nent axd pretty effect when first put on, hut requires renewing often, ns the leswey wilt in a few days; this garment is wrll adapted to the climnte, being enol, and the necessity of frequent clange inbures cleanliness.

The Wesleyan missionarieg from the Friendly Islanda have introduced the siapo, of Tunga, which has now come into contumon ure. It it soft, pliable, and not glazed, and is prineipally used as a twroper, after the manner of the pareu of the Taliti islanders. A piece of cottun cloth is usually worn by the chicfs as a siapo.

The maro is worn when engaged in active exereise, or in war, ns being less cumbrous. The women often wenr a benutifulfy white shnggy mat (ie sinn), hanging from the rieck to the feet. It is woven hy hand from the fine threads of the lituiscus: they also sometimes wear wrapper's of the siapo form, and the tiputa, $\mathrm{n}$ kind of poncho, of the same mnterial, after the old fashion of the Talition, which is more teeoming than the loose gown introduced into that islanil by the misaiunarics.

There is another kind of mat, of rery fine textwe, worn on great oceasions, and used in their dinces as a kind of cloak. It is ormamented with a border of red feathers. This is the most ralmable property they posese, for they cost much pains to the manufucturers, and are often a year or eigliteen montlis in their hands.

In the way of ormaments thoy use but few. The men usually wear a shell (the orula) suspended around the neck by a string.

Their hair formerly oceupied much of their attention, as it does still that of the heathen, who, as has been scell, wesr it long, and have it nicely combed and twisted $u p$ in a knot on the top of the head. The fennluts frequerity used to wear a wrenth of 
Howery, which gave them a pictnregque and pleaвuиt aрpenrance; but the 1tge of flowers as otnaments Jas been irferifuted by the missionary tenelwers,

Tattouing, if not in menlity, at lenst in appenrance, may be snid to form a part of dress. It is perfomed by persons who make it a rogninr business. The age at which it talieg fluce is froms fourteen to simliteen, and is usually consiber the initiotion to inanhood. "Tho мsual colouring natser" is obtainud from the liernel of alse cundle-mut. Tattooing is hero called ta-ta-tau, mul is tastefully drawn. The natives are very foud of it. It is expensive to the family. for the operator nlways receives a tiagl price for his labour, consistisng of the flnest runti, siapo, and other property, as agreed upot befure the uperation is begull. 'The ingtrument used is made of bone, sharp like the teeth of a comb, and requitres but a slight bluw to entar the skir. The part tattoned on lle mules is from the loius to the thighs, lut the women lave only a few lines on their hands and borlies.

"The artiches of which their dress is compoged aro manufactured by the females, who are excecdingly industrious, The cornmous cloth or qupa is malte of the imner bark of the [over-moulberry, which is cultivaled for the purpose in numeries. It is cut when

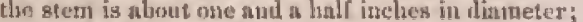
the inner bark is separated and wnshed in water, which deprives it of sntme of its rum; it is then beaten until the adhesion of the fibres furms many of tho strips into a single mass, The maillet used! for this purpose is about two inches squate, nud about fourteen inclues long, witl a bandle at wne end; two of its frees nre groved and the wher two smonth; tho bark is laid on a buard, and struck with the mallet in a dircetion at right angles wish its fibres; the groureal sides are used to sprend out the fibres, and the smonth ones to kinit them together. The gruores alsu give a thready appeat"arve to the surfice.

This method differe from that practised at Thliti, where the bark is beaten with a smaller malles, upon a spring-boned; and the tapa nade here is of inforior quality. I'he tapa is uften frinted with culans jil patterns. This is perfurmed in a roode similar to that protised in Furope before the ittruductions of copper rollers. Instend of engrayed utueks, they form talylet, about as thick as binderi' buards, of pieces of large cocan-nut leaves, by sewing them together. One side of the tablet is kept fmosth and even, and upon this cocos-nut fibrcs are sewed so as to furm the required pottern, whiel is of currse mised upon the surface of the tablut. These tablets are wet with a piece of cloch wel! sonked in the dye, after which the tapa, which fur this purpose is well bleached and beatifully whice, is laid upon then and pressed into close contuct. The dyo is made from herlos and roots, and is of various colours.

The women also njanuficture the mats, Some of these have been mentioned in describing the dress of the natives: the tinest kinds are nade of the inser hark of the paper-nulberry; those of eonuser texture of the leaves of the pandants, which nre nively scraped and blenched. The mats are nIl made by linad, and by interlacing the fibres; ane of the finent description vill require tha industrious Lislout of a year.

Amogg the mats are sonie of as fille in texture
Ant ns soft as if isinde of eotton. Thicse are barely or never tumufactured at [resent, and are solely pussensed by the elicfe, in wlose fanily they are handed down [rom fnllier to son, as heir-looms. They are considered as their chuicest freasures, and are so much coveted that wars lsave been made to obtain possession of them.

"There are seversl distinet trados among the men besides that of tattooing; mong the most esteenued is that of enuoe-building, in which there is no litule shill tisplnyed.

The usual fishing-cunoc is made of a gingle tree, with a small out-rigger to balanee it. They have no large double cantes, sueli the are seen in Tongh and leejee.

The latgest calloes are from thirty to sixty foet long, ani cauble of carrying frum ien to twelve persons. 'Tliey are formed of fieveral [icees of jlank, fasteued together with sesuit. These pieces ure of nu regular size or shaje. On the edge of ench flank is a ledize or projection, which serves to attuch the sennit, and to connect and bind it closely to the arjoining one. It is surprising to sec the Introur bestowed on uniting so suany smitl] pieces, where large and good jilanks nighic be obtainat. Before the pieces are joined, the gum from the brit of the bread-frutit tree is used to cement them clase and prevent leaknge. These conoes retain their furm much nure tuly than one would have supposed, and I saw few whose ariginal model had been inyainat by service. On the outside, the pieces are su cloegly fitted as frequently to require chise examination before the sesms can be detectod. This perlection of workmauship is astonishing to those who see the tools with which it is executed. "Tlıey are naw malte of no more thar a piece of jron tied to a stick, and used as an watze. T'Mis, with a gimlet, is all they lnve, and before they obtained these iron tools, they usod ndzes male of tuard stone or fish-toones. These canoes are built with a deck forwanl and aft. They are long snd narrow; aud their shape is elogant. Thoy are paddled by natives, who sit two abrenst, and ane gnided by n steersman. The seat of honour is on the forwaril deck, in the eentre of which is a row of pegs, to which the Jarro white orvin shell is attoched by way of ormamert. The natives find nodifliculy in occunying this place, as they ruanage to sit in alnost any jusition with ease to themselves; but a stumger who attenupty it, and is for any time conthied to otie of these places of honour, will repunt of the distinction he enjoys before muny minutes are $\|$ Fer. One of our gentlemen was trented with this distinetion, and will lung recollect the words of the song they sing.

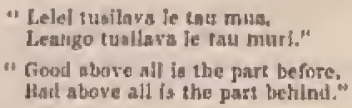

The uneasiress, from his account, does not only procecd from the kmall place left to sit upon, but also from the constatst apprehension of being pro cipitated into the sea. This fan Samoa, or Samoar fashion, is any thing but agreenble.

Having boib a jrow and stern, these canoes cannot be mancurred without tacking; consequently the out-rigger, that constitutes their safety, is, in using their sail, alternately to leeward and wind. ward, and does not, whon to leeward, add much to 
the strbility of the canne. They carry less anil than the cannes of the other natives of Polynesin: aesd to guard ngainst the danger of upsetting, the natires rig a sputit or boom (suati), projecting from the opposite side to that on which the out-rigger is fitterl. This boom is secured witl guys to the top of the mast. When the wind blows fresh, some of the ixen go ant upen it, mod thus balanese or connteract the force of the wint. Thase on the other Eide of the canne are kejt ready to go out in the out-rigger whet that becomes necessnty. 'The sail is made of a mat, of $n$ triangular stape, with its apex below: some of these are ten foet high.

None of the canoeg we kaw at the Samoan Group are calculated for long voyages. Those used in their intercourse with the Tunga Islonds nre the large double Peejec caune, of whist I slanll sjeali when I treat of thase islanders.

In theid trips from town to town, they are generally on parties of pleasure, termed sualanga, and are frequeatly to be met wilh singing their boaksongs.

These songs liase but little variety, are destitute of melody, nnil linve sminll pretensiuns to hamomy. They consist, for the must part, of two short straits, reneated afteruately, the first by n single individual, and the pecond by several. "I'heir voices nro loud, and love generally a tuor elinracler; the strains are mostly in the miuor benle, and sung in the key of two or tliret flats.

'l'He work in which the Samoans show their grentest ingenuity, is in the construction of their native louses, and particulasly of their fale-teles or council-houses, somo of which are of large dimensions. They are buitt of the wood of the breaclfruit tree, and there ane two moles in use, their nwn, and that borrowed from the Frjendly lstands. The true Saunosn house is slightly oval; those of the Friendly latands nue oblong. They may be snid to conisist of three parte, the eentre and two ends: the former is erected firkt, for this fiurposo the three contre-pusts, whicls are twenty-fire or thirly feet ligh, nre usually first raised; on tlıese rests the ridire-pole. A stuging or senffoleling is now erected, nearly in the form of the roof, which serves for laulders and to support the roof temporarity. The root is commenced at the ridge-pole, and is worked downwards. "The cross-beams are lasthed in at different leights, connecting the centro frortions of the mouf together, and are fastenced to the turgight cesstre-posts. The rafters are soade of short pieces, pluced at equal distances apart, and form the curve that is required to construet the rouf. Between the largest rafters are smaller ones, about une foot apart. Acruss the miters are placed and fastened many small rods, about an ineh in diameter. The whole is neatly thatched with the sugar-eane or pandanus-leaves, and the rafters are teiminated by a wall-piece, made of shurt pieces of wood, fastened togecher and to the ralters, so ns to form the ellipse required for the roof, The end portions, of sinnilar small pieces, are made to correspond to the requived eurvature of the roof and the ellipse of the wall-plate. Posts are nuw placed in the ground, nbout three feet apart, to receire the wall-piece, which is fastened to their tops. There is no fastering used but senuit, made of encos-iut filores. The rafters are generally made of the libiseus, which is light and strong. The eares extend about a foot beyond the posts. The smaller houses generally tave permanent sides; tho larger ones are oneji all arousd, but mats are husg up as curtains by the vecupants, and any [Hatt may be used as in door.

After the whole is fisialied, the interior hins the appoartuee of ath extensive fmmexust, from the number of cross-berms, which are nsed as depositorieg for their propesty, tapras, tnats, \&c. ; and tu some cases the farourite enme of the clitefs is placed on thein. After' a full inapection of one of these fabrica, one cantot but viesw these nutives not only as industrioug, tut as puasarsiug grent skill and ingenuity. The thatehing lasts four or five years. "There is no floor to the house, but tho ground is covered with stoncs about the size of a sinall erg. Thero is usually in paved ptatform no the ontside, about three feet wide. In some cnses this is raised a foot, and serves to keep tho loxuse dry, as the Btones allow a free prasago to water. On the parement are laid con'se mats, and the finer ones are spread above, covering about halt the nuret.

These fine mats are rolled up until required. Many baskets lang liere and there, wjul some cocoa-nut slacls to contain water, and the ava-bowl. Nats are suspended about as screens. $\Lambda t$ sight, rach sleeper is usually supplied witl a musquitocurtail, enlled tni-namu, which, forming a kind of tent, by being prased over a ridge-proh or rape, atud falling ou the ground, answers att the puryosess required

On one, and sometimes ou both sides of the centre-posit of the lonuses, is an snadl citeular hearth, enclosed by stones of larger size; this is the place for buxing the dried lenveg of tho cucon-nut, which servo them for light at night. Althong these do not give out much smolie, yet as they burn for a long sime, the loothe gradually beenmes filled with soot, fur there is no outlet abuve for its esea fiet.

As they always uso the finmineau to light them on their return from their fensts, it produces a singular and pretty effect to see an asecmbly breaking up, and the different parties winding through the growes with torches, throwing 1fue wholo into bold relief. A rude lamp is also used, mate of $n$ cocoa-mut shell, with a lithe nit in it, and a piece of vitte-gtulk for a wiek, and likeswise the nut of the aleurites trilobn, or eandle-nut, several of which ate strung on a thin stick.

Many whitewashed houses are now to be seen, for the natives have been taught the use of lime by the missionaries, and aro leginning to use it in their dwellings. All the missionaries Jouses have phastered walls, and board flwors, and are very comfortable. Tlueve is a great quatity of fine timber on these islunds, for builling purposeg. The timber of the lirend-firvit tree and hilbiscus are alone made use of ly the sutives. The missionuries have their planks or boards sawed by hamb, and gencrally ly foreiga entpenters.

The fond of the Samoans is prepared in the way practised at Tuhiti, and generally consists of bread.

- Musquitnen are exceedingly annoring to strangers, but I did not femirk thas the natives were troubled will them. Their bodles being well olled is a grent prescrvalion ogatust the bites of these linsects.

$\downarrow$ The prevalence of sore eyes is said to be owing to the smoke of thic lanaph. 
frujt, bannas, tarv, sweet-potawer, nud ynns, Fish is supplied in quantities from the roet, awd they hisu eat the large cheenut, vi-apple, and arrow-rent, tho feenla if which they begis to manufacture in gome quantities. Alshough it would senreely the sapposed necessary, where every thing is so bountifully supplied by sinture, yet they inake fruvision for times of seturcity and for their voynges of the brend-fruit, mado when green into a kind of paste, atul rolled in bantni-leaves. 'T'lis undergoes a partial fermentatiun, and is calfed mali. It is not unlike las f-baked dougl, and lans a sour urwholesome taste. They eat birds, kce, but a laxgo wood-matgot whicli is found on tho treeg is looked uposs as the most delieions foud they linve.

'lliey have much variety in their cooking, and some of their dishes are excecdingly rith and agreeable to the tuste. They practiso several turodes of couking the taro-tops; one, by tyitug them up with cocos-nut pulp and baking thots, in which state they resomble spinaels coulied wilt eremm, but are sweufer. Another dish is calleal faiai, made of tho sersped and gtrained coena-nut pulp boiled duwn th the comtisteney of castart. It is eaten buth liot and eold.

The hubits of the Samoars are regalar. They ritie sitlı the sun, and immediately take n meal. They then bathe and oil themsedves, and go to their oreuprations fur the day. "These consist in part of the eulrisation of taro anil yams; bullitig houses and eamens. Many fish; others entel birds, for which purpose they use nets affixcd to long poles. They goruerally find enought to employ the morning, in getting their daily atiply. After this is done, they lourge about, or play a their varions ganes, eat about one o'clock, and ngain at night, retiring to resc ahout nime oclock. The men do all the hard work, even to cookery.

'I"Ho woruen aro theld in much consideration among this people, sre trented with grent attention, atud last suffered to do nay thing but what riglitfully belongs to them. Thry take care of the louse, and of their children, prepare the food for coaking, do all the in-dour work, and manufincture the mats and tapa.

They are clesuly in their liabits, and bathe daily; after whieh lihey anoiu* themselves with oit nal turmeric. This enstom, I lave no doubt, tends to prescrve the heslth by prevenciug the excessive perefination which the lieat of the climate naturally brings on. It is, however, at times offensive, for the ail is apt to become rancid.

The Samoans are of a social disprasition, more go, indeed, than the other natives of the I'olynesinu islauds, and they nre fond of travelling. The reasons they lave for taking these journeys are rarious: thus, when there is a scareity of food is orse part, or a failure of the erops, they are in the habit of making a "fartaruilo," or circuit, around a portion of these islands, so that by the time they returis, (which is at the expiration of three months, ) their own taro has grown and the bread-Iruit season come nround. They are nuw in their turn prepared to afford the same hospitality and accommodation to others. The ald people nre nsually leít at the villnge to take care of it, whilat the younger portions are gone on one of these runlangas, or jounucye. During these expetítions, a sort of trade is frequently carried on. The dif- ferent partions of the inhabitants are each colebrated for a particular staple. Some excel in makiug mats; others in building canoes; the districts in which the sea-ports are, ubtill a varicty of articles from ships, which are subsequ treutly distributed over the whilo group.

It may seadily bo sulprosed that there nre many cireumstances which make this mode of cornonuneation ineonvenient, partieularly when the travelfing party is a largo one, in which case it alsolutely breeds a fumine in its progress.

1 lave before stated that every villnge has its "fale-tele," whieh is the propierty of the chief. In this llaeir "fonos" or couneils are loeld, and it is also the place where atrangers are received. 'The mote nf recoising visitors is attended with nind, cerensmy. A party enters the villnge withut inquiring where or how they are to be entertained, nul take up their quasten's is the "fule-tele." II a stiort time the elsicf and principul personages collect and risit llostragers, telling them in is set speech tho pletasure they enjoy at their arrival, and their delight to enterinis them. This is trustly satil in what they term "tala-getta" the speeclo of the lipa, and much complinentary Janguage miauts. The samons lasigunge abound in phrases adofited to this use, and wortly of a refined people.

After this interelsange of enmplineats, tho yuang women ussemble to treat the strangers to ti ava." 'This is [repared after the usual tuode, by chewing the piper unythistients. During this time the yutang men are employed collecting and cooking food. This is all dore with great despatch. The pigs are killed; the taro collected; the oven heated; and baskers made to hold she vinuds. In the fenst they aro well nseured of sharing, and sherefore linse at strong stimulus to exertion.

I'le strangers, on receiving the food, nlways return part of it to the entertainers. Thus all the vilage is oecujied with the entertainment, and a seene of frolicking ensues tuntil the strangers see fit to take their departure.

Among the henthers, dnneing during the evening always follows this fonst; but the Chriatian villages lave abolished al! dancing.

These visits aro not abwas pail or received it a spirit of hospitality. 'The slitef of a powerful district akes this mode to exact tribute from lis less powerful neighbours, and they are on such oceasions extremely overbenring and insoleut to their enterkiners.

For crines, they lave many forms of punis!ment, ameng which are: expulsion from the village in which the offender resides; exposure of thic naked body to the sus; flogging; cutting oft the ears and nose; contiscation of property; and the compuisory easting of noxious lerbs.

When as murder has been eommitterl, the frients of the prersous slain unite to avenge his dentls; nul the punishment does not fall unon the gailty party alone, but or bis friends and relatives, who with their property are made the stibjects of retaliation. If any detay in seeking redress in this manuer occurs, it is received as an intination tlat the injured party, whether the farnily, the frieuds, the village, or whole district to which the murdered persun belonged, are willing to neeept an equivalent for the wrong they bisye sustuined. The fricans of the murderer then collect what they hope may be sufficiem to avert retribution, and in 
regatiation is entered into to fix the anomut of compensution. When this is ugreed upon, it is riferent to the nearest relative of the decersed, and the jarties who present it perform nt the samo timo an act of submission, by prostrating themselves lefore him. This eloses the affir.

For some crimes nothing but the death of the offender could atone. Amung these was adultery; aul when the wires of cluief eloped with then of wnother district, it generally produced $a$ wnr. This was one of the canses of the wars waged by MaJieton.

There existed, however, means by which the condo was rendered lpas blooty, in places of refuge for offersicrs, ench as the tumbs of eliefs, which were hold snered and inviolato.

Wass were frequent among the Samonns before lise introduclion of the Guspel, and seareely a mosth passed witlout quareds heing arenged, and with blowg. The last and perhnps the monst blookly war that bns cyer occurred on these islunds, wa sbout the tine of the first risit of Mr. Witlinms, the missionary, it 1830 , when the idtabitants of ono of the finest distriets, that of Anus, in the westerm part of Upolu, were almost externimated. This war continced for eight months, and only those were saved who escaped to the ulou, or innecessille places of refuge, or were protected by the "Malo," the ruling or eumquering party.

When the unissionaries urived, in 183f, and for upwards of a year afterwnds, Asua was withont a single inlabitant; but through their influenes upan the Nalo party, it was agreed at a Inrge "founo" to restore the exiles to their lands. Ana is nemin (in 1439) the tinest part of the island, and will be in a fow yenrs quite a garden.

I'trese wars, like those of all savage people, were attended wibl great cruelty, and neither old nor youtg of edther sex wero spmed. $]_{t}$ is related that ifter the last battle of Anna, a fire wat kept burning for several days, into which lumdreds of wamen and elsildreu were cast.

T'lıcir wars were seldosn cartied on in open fight, but stratagem was resorted to, and all enemes that could be attacked were killed, whether in their houses, or when accideatally met with at thoir work in the tam-putches.

Their arms comsisted of eltab and spears, nuale of the irun-wood (casuarina), lrows and arrows, and of late yenrs, tho nusket. The man who could ward off a blow, and at the same time inflict a wound on his adversary, was considered the best warrior. Einch village hiad its separate commander, and there was no gennml, their operntions being from time to the decided in conueil. Their spenrs were pointed witls tho sting of the ryy-fisl, which, on breaking off in the body, enused certain death.

The olus, above mentioned, were nstally on the top af sume lighl ruck, or almost innicessible noumtain, where a small force could protect itseif from a lasger one. One of these olos, or strongholds, of the people of Aatn, during the late war, was on a high perpendicular ridge, which forms the western boundary of the bay of Faleletri, mat it was the scene of muny a bloudy contest. The Mannono prople, coming hy vight, would laud at the foot of the libl, amb attempt its nacent, while those nil the top would roll and hurl down stones, genernlly overcoming them with ease, and driving the invaders back with great slaughter. The Lntter, however, took a fearful and truly savage revenge for their various defeats. Laying in wait until the women carne down to fish ou the reefs, they set upon them, wnd nussacred them all. The burning of houses, tho destruetiun of tho bread-firuit, coentnut trees, taro-patclies, aud yau-grounds, \&c., were the urdinary features of these conflicts.

Upon the occurrence of a enuse of war, the parties sent to their respective frienda in the different towns to solicit their nid. Such solicitations usaaly resulted in the whole district, and munetimes the whule of the island, being engnged in a civi! war.

Or going to war, they wero accustomed to enst their lagir lonse, or to tie it up in various forms; mrut to add to the fierceness of thacir npmearanec, they wore large bunelies of falee hnir, whlich the iucreased their apparent lueiglit.

In making peace, the conquered party was rerpuirel to mako submission, by bringing loads of stones, fire-woud, and green bonghs, aud to low dawa rery abjectly in the presence of the chief. 'they were also rejuired to pay a harge aumount of thasa, mats, and ollier property.

The govergymont of the Samoans is more refined in principle thun conlu well bo expected. The ruls of heretitary elices is acknowledged, and the distinction of the several classes well defined. Great respect is paid to the chiefs, and partienlarly to tho "tupur," or lighest class. To this belong Malicton, Pea of Maroun, \&e. The secomd clase consists of the near relatives of tho first, and of others who have large posecssions; the third, of the pretty cliefs of villages; nexi come the tulafales, who are a welldeftied class between the clitefs (alii) and common people. These tulafales are proprietors of tho soil, and houscholders; they possess considerable influence, nnd act as advisers of the chiefs, and the executor of their orders. Like the chiefs, they derive their runk from deseent. There is to distinct name fur the common people as a class, but the elviefs in speaking of them always ayply some opprobrious epithet. The Bon of a low-bortn wonan by a chief ranks as a clief, althougl he bas no authority; aud the son of a nolle woman by a man of nean birth, may be either a ehief or a commoner.

'T'he lands are allntled and distinguished by know boumlarics. The natural heir of the former owner succeeds, and is the feudal elvief or leader in war, but all his dependants are free to cultivate it. Lands nay be sold, which in clone at pablic meetings, and the bargrin is nade binding by stieling their stuves into the ground, or digging in portions of it up.

The whole prower lies in the ligh chiefs of the "Malo" or conquucring party. Thiey nssemble in fono, and dofermine the gencenl laws and rules of activin. At the liead of this is Malicton, who is now considered tho heod chief of Atun, and is supposed will shortly acquire that of Tiu of Aana. Eacls of these districts formerly had a scparute clijef, burtisg the same title of Tri, but in their wars with Manono, nearly all the descendants of these princes were killed ulf. To obtain this tithe requires the consent of the chiefs of Minnono, and part of Sarait, which belongs to the roling party.

The fono may levy what contributions it pleases, 
particularly ou those they have conquered. The present "Malo" or government is lesignated "Waln-to-ton"- the geritle government.

Although there is no supreme autlority acknow ledged in any one individual, yet there are instance of elilefs of distriets assuming nod maintaining is. The date Tamalago, of whom some recount has already been given, was une of these. He assumed the attribates not only of a king, but of $\mathrm{n}$ grod, and after conquering a rival district an Savaii, he took,

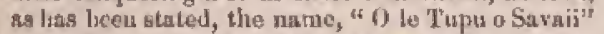
-the King of Savaii. After he was killed, Malictoa succeeded to the same tille; but it now confers no power, and is considered merely as complimentary.

Fach district and town has its own goverument. An elderly chief generally prosides, or is considered as the hend of the village, town, or district. In these primary fonos or meetings, the aflairs bre generally diseussed by the alii (chiefs) and tulafales (landjolders), and what they dewermine on is usually folluwed. The great fono, or general assembly, is selulom called, except on matters affecting the whole of the island or dis. trict. Tho subject is cnlmly debated, and most thoronghly discussed; the final decisinn, however, is not by vote, but is adopted after consultition, and is gorerned by the opinions of the most infuential chiefa. "It thus appears that these assemblies have little influenee uprom the course the chicis may have determined to pursue nad sarve chiefly to insure the united action of the district in carrying the designs of the chiefs into effect. The tulu-fano or decree, promulgated by the council, is to be obcyed, and those who fail sre purished by the Malo, being plundered by them of their lauks, \&c.
In the descent of the office of chicf, the rule of primogeniture is not strietly followed, but tho authority and title alwags remain in the samo family.

It is the eustom at the fonos to compliment the hend chiefs, asud involio blessings on them in prayers, that their lives may be prolonged and prosperous. I was informed that these nssemblies were conducted with much ecrenony, luut I was much disappointed in the one I wituessed. Tho fortns of proceeding may, however, lee different when stmugers are not present. 'I'lie fonus generally begin at an enrly bour in the moruisg, and last until late in the afternon. Une of tho most pleasing of the ceremonjes is that in which the chiefs are supplied with fuod during the time the meeting is in session. After the food is prepared and distied in fresh banana-lenves, the wives and daughters of the ehiefs attire themselves in their best dresses. They then enter the fatetele, and approach their fathers, husbands, and brothers, $\& \mathrm{c}_{.}$, before whom they stop, awaiting their instructions as to whom they sluall hat tho viands. When they liave obeyed ilieir directions, they retire. The whole rluty is endueted with tho utmost decorum, and shile it is going on, sn converantion is permitted except in a low voice. I learned from the missiomatey who had attended sone of their mettings, that the manner of speaking whs good, and the self-passessinn of the orutors remarkable. The spreakery geneanlly have persung near them who net as is sort of prompters, and re. mind them of the subjects it is desirable they should speak of. The whole proceedings aro conducted with the utmost quiet, and ao disturbance is allowed.

\section{CHAPTER XVI.}

\section{NEW SOUTH WALES.}

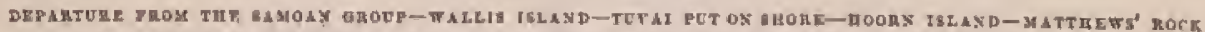

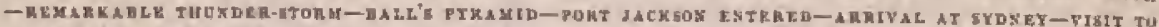

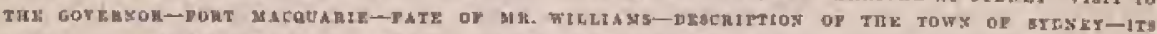

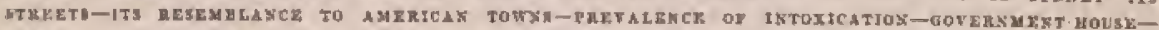

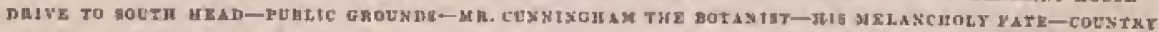

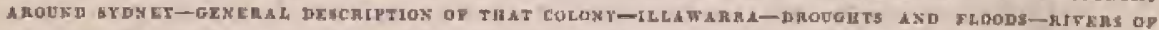
\#FW AQUTA

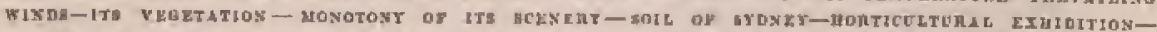

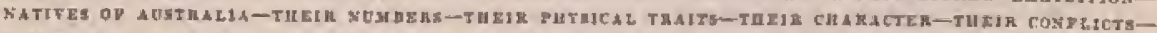

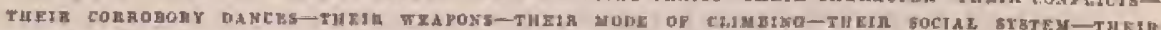

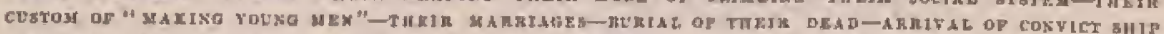

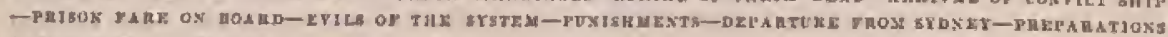
YOE ASTARCTIC CIUISE.

Ox the loth of November we weighel anchar from $A$ pin, and nude all anil to the wostwrid; and on the lith had lost sight of Savaii. Ofticers were glationed for the three following nights to look out for the periulic showers of metwors, but the nighis wero clouly, nul none wero seen.

On the 12th we made Uea or Wallis Island, and at 3 P.M. were of its southern end, which is situnted in lntitude $13^{\circ} 24^{\prime} \mathrm{S}$, longitude $176^{\circ} 9^{\prime}$ $22^{\prime \prime} \mathrm{E}$. Instead of a single island as might bo expected from the name, tluere are nine separate islands, varying in eircuib from one to ten miles, and enclosed will one extensire reef. The lanil in, in genernl, high. We made a running survey of this group.

While oft $W_{a}$ llis Island, we were boarded by a canoc, in which was a native who spoke a little English. I had thus the meuts of communicating 
with the shore, and resolved to take nulvantage of it by landing the primuner l'uvai. I conceived slat this would aceomplish all the evita 1 had in view in remaving him from his native island, particularly as the course of the wind is such, for the greater part of the yestr, as to prevent camoes proceeding from Wallis Island to the Samonu Group, and there is in erusequence no conmunication between them. His fats would of course remain a mystery to his countrytnen, and the imprissinn I faid lopred to produce on their minds wonld be eflecturlly made. My original intention had been to land lim at Hoort Ioland, which is two days" sail further to the south ; but a similar npourtanity night not perhans linvo presented itself ihere.

Haring decided on this course, 1 committed him to the chisgo of the person who had buarded us, and gave particular directions that he, with his rolls of triph, should the immediately taken and presented to the chief. The customs of the islanders pronised that this would insure lim goou urent= ment, by giving lim at once a protector; or at least that he would be only rubbed by a single person, aud not exposed to the pillage of the whole population, who would in all probability havo atripped him of his property the imstant he landed, if not rostruined by the nuthority of a chice.

Turai seemed delighted at being relensed from his confinetrent on ship.buard, and took his leave lyy alaking hands with the sentry. 'Thus, while the culprit has not been exposed to any umecesEary severity of punishment, I feel satistied that I fully necomplished my object of convineing lis countrymen that they could not lopre to cutnmit murders upon thoir white visitors will impunity.

T'liege islands appear to be well wooded, and we $8 \Omega w$ many large native louses upon then. As we drew near, we pereeived upon a roeky flat a few natives waving th white ftag. The nativo who came on bond informed me that the inlatitants nere mumerous, and that among them there were ten white men.

The entrance to the lagoon is on the south side of the Group, snd the pilot, if so he may be cilled, informed me that there was mmple mom for tho ship tis pass within tho reef. Wood, water, and refiesliments may be obtained here.

Heorn Island wo made the following day. It was discovered in 1616 by Sclwuten and Le if inire. Its lighest point is two thousand five loundred leet above the sea; on its nurthern side many rocks are visible, and the whole surfnce appenrs twold and precipitous, affording, in far as wo could prerecive, little soil for cultivation. Cocen-pnlns in considerable numbers, were, however, observed unvon a low pojnt projecting from its kunthern side. This island is inhnbites, and I have been iuformed that an unsuecegsful attempt to establish a mission upon it was made by the Calholies in 1840.

(on the 18ils we saw Mntthews' Roek, whose height we nscertnined to be IIab feet. It is of a conical shape, alsout a raile in circumference, and princinally cumposed of conglumerate, $\boldsymbol{A}$ dike of basati was absersed oceupying about a thiril of tho width of the island. In order to obtain specimens, a buat was despatched to endearour to effect a landing: the undertaking proved diffieult, but was aceomplished by Dr. Fux and Midshipunan Henry, who swam through tlie surf. They brought off some specimens of porphyritic rock, and a luw small erystals of gelonite. Patche日 were seen on the northern side of the island appearing as if covered with sulphur. As lins been so often mentioned in spenking of other uninbabited islands, great numbers of birds were seen upon and sround it. This island is in latitude $22^{\circ} 27^{\prime} \mathrm{S}_{n}$ longitude $172^{\circ} 10^{\prime} 37^{\prime \prime} \mathrm{E}$.

On the 20kl November we nade Ball's Pyrz. midl, which apjears to be a birren rowk rising nbruptly from the sea.

At sunset on the 29 ls of Nurember we made the light-house on the hesulland of Port Jackson. We lind a fair wind for entering the harbour, and ahlough the tught was dark, ankl we had no pilut, yot as it was itroportant to aroid any Inss of time, I deternined to run in. I adopted this resolution, iecnuse, although we wero all utracquainted with the clinnnel, I whs assured thut the charts in our posgession might be depended upon, and 1 stood on under a press of eail, accompanted by tho Peacock. At B s.s. we found ourselves at the entranec of tive harbour. Here a light erected on a shonl called the Sow and Pigs, since the publication of the clarta, eaured a nomentary hesitation, but it was not long before it wrs dotermined where it was plnced, and with this new aid, I decided to run up fund anchor off the Corc. In this I sueceedent, and the E'eacoek, directed by signal, followed the Viscennes. At lialf-past 10 p.y. we quietly dropped anchor of the Cove, in the midst of the shipping, without any one having the least idea of our srrival.

When the gooul people of Sydney looked nbrond in the moruing, they were mucls astonisbed to set two men-of-wat lying among their shipping, which had entered their harbour in spite of the diffieulties of the chanuel, without boing reported, and unknown to the pilots. Their sireets were speedily aljve with our ofticers and men, who were delighted at finding themselves once more in a civilized counlry, and owe where their own lnsiguage was spuketr. day.

The Porpuise and Flyisg-Fish nrrived the noxt Our consul, J. W. Williams, Esq., came enrly on bonrd to weleome us. He commusicated the its. formation that the liclief land arrived safoly, ats hasded all our stores, which were ready for us and cluse at hand; after which, and about ten days before our arrival, she hat sailed for the Lnited States.

Out arrival was duly announeed ly mo oflicer, and through him I was informed that the governor, Sir fienrge Gipps, would be liappy to receive the at eleven otelock. In eumplinnee with this intingtion, I had the honour of wating upon his ex. cellency at that hour, in comprany with Captain Hulbori, and our consul. I made my apologicy for thsing entered the larbour in so unceremulnims a manner, and stated the retsons why I could not tender tho enstomary ealutes.

The reception I met with was truly kind : every thasistance thich lay in his power was cordially uffered ; alu? I was assured that I hat only to make nuy wants known to linte thern Expplied. The use of Fort Macquaric was immedintely grinted me for an olsseryntory, a prosition which, being withis hail of my thip, gave tue grent fncilities for condueting my experiments, and at the same time superinteadiag my other dutieg. 
I thay in this phen acknowlodge the op"n-liesrted weleume we met with from all the gorermant othieerg, military and cisil, as well ns from the citizens. Uur reception was gratifying in the ex. tremse, and canums be too highly appreciated. The Australian Clulo was tlurown open to us by jts committee, and parties, bnlls, \&c., were given in our honour; in sloot, all our leisure time was fully fecupied in the receipt of these laspitable attenlions.

The dny after wo anchared at Sydney, the brig Camben niso nurived. By her wo leturned tho melancholy intelligence of the death of the Rev, Mr. Williams, from whom we had parted so short at time before at the Samman Gruup, He was then, as will be recollected, about setting furth to propagate the Gosjel among the rasiges of the New Ilebrides, and was in full health and ligh spirita, in the ardent lope of snceess in his mission. My information in respeot to this sal event, was derived from his assutinte, Mr. Cuusinghart. Tisey lad placed native missionaries at fotuma and 'Potiona. Mr. Witliams then landed at Thann, which they foumd in a high state of curltivation, and where they were hosplitabily received by the natives. Theso were Paptuns, and spoke a lati. guage much liko thnt of the Hervey islanders. At Thuma, Samoan missionaries were also left, and they thence proceeded to Erromango, Here they found a barren country and a different race of tnen, black, with woolly hair, who did not compirehend a word of nuy of the languages known to the unissionaries.

The natives, aithungh apparently sugpicions, exlibited no symptons of actual hustility. Mr. Wiltians, witls Mr. Harzis, Mr. Cuuningham, and Lie master of tho vessel, landerl, and were strolling about, stmusing themstives with picking up shells. While tlus engaged, they lind sefunted from end wher, and Messrs. Harris nud Willians were is advance of the sthers. Ou a sudden the wasshaut wag heard, and Mr, Harris was Beell rumnitng, pursued by a crowd of untires. He was son over" talien by then, and hilled. Mr. Willians thess turned and emienroured to rench tho bost, hut be liad dalayed tou long, and although he renched the water, he was followed into it and shain also,

Mr. Cususiuglum and the eaptrin eseaped, although with difficulty, and after somo finvitess attrmints to recover the bady, left the island. Mis. Cumbingham was of chinion that the attack had nat been premeditated, bit arose from a sudder desire to olstuin possession of the elothes of the persons who were on silnore; he was nlso satisfied that a single londed musiket in tho latuds of those left in the bont, would have been the means of saving these two valurble lives.

1 lial, is a convelsation sith Mr. Williams at Lpolu, expressed uy beilef that the sovage inlanitints of the New llebrides would not to anfly vivitud witbout the nesns of deferwer. He lasd it reply declared limself averso to the use of tirearmb or atny other wedapon its the propngation of the Gospel; treing of opinion that it would be smore easily and elfectually dikseminated witherst them.

The missionsry cuuse hass sustaines a grent loss in Mr. Willians's deatl; for in Jin were united a truo spirtit of enterprise and fervent real, with great persevemace and a thoraugh knowledgn of the nistive that'seler, I still think with melasseltoly pilasure of the nequaintaree I lat the good forture to form wits linu.

The town of Sydney mny, for conrenience of deseription, lo considered ss divided isto (wo) parts; the line thint soparntes them coincides nenriy willa that of Georgo Street, the brondway of Sydney. T'he old town lies on the enst side of this line, nnd oceupies the castern promontory of the Cove; it is the least reputablo part, and is mimost filled witlı grogg-shops and brothels, except at its extremo eastern guarter, where there aro a fow gentecl buildings, in agreeahle situations. The gtrcets to the soutli and west of George Street are well laid out, aud are 1apidly filling up with good touss's.

'The trouses of Sythey' are for the most part well built and commodions. On the western side of the tuwn are many' hantsome buildings and extensive public grounds; towards the eastern side is a large square, ealted Fyde Parli, ugun whicl are situated the offices of the colonial govemntment, the chureh of St. James, and the Callowic calledral.

Sylney coutains about twenty-four tlousand inhabitants, which is abuut one-fiftl part of the w hole population $(120,000)$ of the colony ; nnd about one-fourth of this number are eonviets. In truth, the fret that it is a convict settlenent may be at onee inferred from the number of police-ofticers and soldiens that sue every where seen, and is rendered certain by the appearasee of the "chatinganga." The latter reminded us, exeept in the colour of those who compused them, of the coficeearrying slaves at lio ; but the want of the cheesful geng, and the aptarent nerriment which the Brazilian slaves exhibit in the executions of their tasks, was apparant.

Whet vious from the water, Sydney appents to great aclyantage. It lits on the south eido uf the hatrbur, and covess two manrow promuntorics, separated and bounded by coves. The ground rises gradually, and thus exhibits its buildings to great advanlage, giving it the air of a hago cunmercial eity. It is elsietly built of a drab-toloured sandsume, ieserubling thint employed in tho now public buildlisngs nt Washington, int of a lichter huce. Red latick is alsu used in brilding, nnd the suburlis contain mauy nent cottnges anil couvtrysents. The entrulstone is a beutiful material, but is not very dumble. The view of the towu is liversifiod with the peculine fuliage of Australins trees, anong which tho pines of Norfolk lsland snd ALoreton biny are most conspicuchs, At the time of our arrival, tho trees wero infested with Jocusts (cicada), which made a noise absolutely denfening. T'le sound this insect produees is the samo na that made by the analngous sjectios in the Uniter States, bit is costinted here during the luat of the day, sul ten times more deafening.

Handsone equipages alwuind; and the stageconches nre mumenous. These, with the costume and domennour of the more respectuble part of the jopulatian, struck tos ns being more like what is seen in our towns than in those of Eurupe. Fivery thing laas a raw link abuut it, aut the people manifest more of the bustle asud setivity of our moneyuaking and enterprising population than are to bo seen in uld countrieg. The aequisition of wealth secmis to be the ondy ubject of all exertich liere, aud epectulation was as rifo as we lad left it is the Linited States. Cutting down hills, filling up valleys, laying out and selling lots, were actively going our. 
There are, ju truth, ruary purtictslars its which the people of Syduey resemble those of Ametica. This is obsurvatibe, antugg other things, it the intluence of the putalic press. In Australia, however, it is unote licentious than any exeept the lowest of ont seswguapens ; taking tmowarrantuble liherties with privite charncter, and is fac frum leing remotkahle for diseritunation,

Is ose particnlas, a most striking difference is to he pliserved between the secnes to he witnessed nt Syaney, and in the cities of the United States. Plhis consists in the open practice of the vice of drunkenuess, which here stalks ahrond at noonday. It is not rure at asy time, lut on lyolidas's jts pre. sulence surpases any lhing I have ever witnessed. Even persons of the fieir sex (if they may be so ealled) where there to be seen staggering along Ifo anost pulylic strects, brawling in the lrouses, or burmo of in ehnrge of the police. However lighly coloured this yicture man be thought, it is fully corrolyorated by the palice reports of the Syriney papers on Muiulay mortings. The police-offieers themselven are among the venders of the intuxicating liquid.

The favilitieg for indulgenee in this vice are to be seen every where is the form of low taverns atd grog-stiojs, which attract attention by their gaudy signs, sulnpted to the tuste uf the different ority of ctrstomers, as the "ling's Asms," the "L'uncll- Bowl," this "Slinustuck," "the "Thistte," tho "Ship." the "Jolly Snilors," Of these, two hustdred and fifty are licensed by the government, or move than one to each hundred ands. Amomg them n small slooj was pointed out which from the extent of its custum yielded the enomnous anumnt of 30 of. for" reut to its owner anzually, a sum far beyond the apparent valus of the whale joperty. The quantity of rum which is consumed in the culony uny lie estinnted from the facts, that the reveriue dexised frotn ito importation was in 1038 , 199,450 . aud that the supply aunonits nearly to eight gallons annualiy for every individual in the culony.

It is relaterl, that a lighly respectable individual transmitted complaints ngainst Goreruor Macquarie to the lrome governrment; and that, by way of unswering thest expostulatinns, the rephy of the governor was: "There are but two clnstes of persans in Now South Wales, thase whu lave been convisted, and those who ongtht to be."

'Has old rovermment-house, where I latd the lhonour of seeing Sir George Cipps, is a low, cottage-sluaped luilding, which has no pretensions to beanty, and appears to have been built at different times, having lowen enlargod os often as additional neconmotation was needed. During the snmner months the goveruor resides at the governmentluuse at Puramatta.

A new palace or goretument-liouse is at present building in the pullie grounds which lie to the enstwark of the wh one, from which a rosd extends tharvugh them towards the Sutl, Heat of Port Jackson. This road is the usual promenade and drive of the citizens of Sydney, After leaving the guverurrent domain, it enters Wonlugnoloo, a regiou covered with the country-seats and cottages of the higher classes, which altheugh originally little nore than a barren rock, has been brouglat into a bigh strte of cultivation by its oceupants. The drive in this diretion may elualenge cousparj- son for beauty witl nuy fratt of the world. Jt pre. Bents incumernble sni fincturespue views of the molite bay, and of the parmontories that jut into it, neeupied by mansions and rumanental grounds. On reaching the South Head, a view of great leanty is also seen. The point thus named, is a bold headland, about two busdred and fifty-four fect in height, on which stunds tho light-house, a fine tower, with a brillinnt revolving light.

The public grounds are is part oceupied by a botanical garden, wlich was laid out by Mr. Cutsningham, the butatuist of the colony, tu whose memory a monsment is abost to be erected in the garden, which is itself a memorial of his fine tagte, ind his suceressful cultivation of the science he mofessed. Mr. Cumnjngham periahed ly a melaneholy denth, which is still spoken of witl regtet. Ho lad, in his capreity of botanist, ncenmpanied Major Miteliell, tho survoyor-greneral of the colony, on a tons of exploration in 1835. In the pursuit of lis resenelies, he wandered from the purty, nud did not returu. As kison as the whis nissed, the native guides were keut in senreh of him, but re. turned withnut laving sneceeded in finding lis traces. Major Mitehell then instituted a fresh search, in which the tracks of Mr. Cunningluaut's linsso were [ound, and followed for ninety miles. Within this space three places were secn where lie had stopper and encataped. From the last of these, the tracks of the horse were agnin followed, untit the carcass of tho nrimal was found dead through fatigne and starvation, with tho whip tied to the brille, and all his nccontrements about him. Jetracing their steps to his last encompnent, bley ascertained, on close exsmimation, that he lind there killod his dog for food, and his footsteps wero seen as if making rapid sirides fur tho bed of a river, which lie lial followed to a pool, into which he had plunged. Further dowa the river, some sluells were found nenr the remains of st fire, which had evidently beess kindled ly a white man. Here nll further trnees of lim were lost, and the seareh abamtaned in despair.

Sotne montlis afterwarts a eccond searel was made by Lientenant Vouch. III slis course of this, some nitives were tahen near the Brogaus river, in whose yogsessien a part of Mr. Cuminglam" clothing was fomml. They stated that a white nan has cone to them in a state of great exharstion; tliat. he was litngry, and they fed him, but that doring the night they lut become afraid, the killed him. The body wns never found.

Livuteusat Vuucls infurred that Mr. Conninghntr had becomo dennged by the severity of his suffer. ings, and that this had eaved him to wander nbout at sight, which, with other Etsapicious movemente, lisd alarined the natives, who, under the influence of their terross, had murdered him.

Tluns cuded the uscful life of one who lind raised himself tu eminenec by his own exertions, and had by his virtue asxl gcientific sequircments gainet the esteem of all the pure and good of tho colony, by whom bo will be long affectionately sad homur. bly remembered.

At the end of the walk around the government domain, the following inecription is ealeulnted to excite a smile: "Be it recorded, that this roud round the insile of the government dornain, ealled Mis. Macquarie's Rosul, so called by the governor on aecount of leer having ortginally planned it, 
three miles and three liundred and serenty-seven youds in tength, was tinally cotnpleted on the 13th iby of June, 1816 ."

Govemor Maejuarie lus liternlly put his mnrk on the town of Syducy, where hardly n single street, oquare, or jublic buidding can be passenl, witlout bering his mane cut in stune.

'The asprect of the country around Sydney is sulficient to prove that Now South Wales is rery different, il its genoml fentures, from other parts of the globe. 'This is elietly owing to two eatuses: the aridity of its elimate, nud the prevalence of fisurlstone rock, 'l'lis rock may be retdily eximined at the Hends of l'ort Jnckson, and un the shores of the naty coves that surtonnd this beartiful harbour. Its colour is pule yellow or drab, and it lies in beds nearly horizontal and of rarions thiekness, whose upper surface, except where Lroken by ravines and water-eonses, forms a tablelank. The average eleration in the treighbourbood of Sydncy is from three humdred and fifty to four lundred feet. At this lorel it extends in gentle undulations to a grent distanco inland.

Tlis arid sorl yiekds but a ecanty grow th of vegetable products, which, eonsisting of Lutut pasture, and thinly-seattered trees and shrubbery, give to the whule region a look of desolation. T'lie grass does not every where concenl the lare rock, and the thins soil sipprorts only a few gum-trees (euca. Iypti), ant bushes. Throughut the wide plain there is little to relieve the eye, exeept here and there a stmall eultiratel spot.

In consequence of this midity there are nuny continuons tniles of waste Iands in New South Wales which by the inhabitants are enlled "forests." These are very different frow what we understand by the turm, iutl consist of gum-trees (oucalypti), so widely seatsered that a earriage mny be driven mpridy througis theu without meeting any olsstructim, while the folinge of these trees is so thin and apparently gn drisd up rs stareely to cast a alialc. Thus miles may" be trivered it these forests with. nut impediment. A few marslly spots are veensjunally seen, coveral with thichets of brush ; nud in other places there aro tracts so dry that even the gum-tree will not grow npon them, aud which receive the direet and sectulaing rnys of the ธแก.

The most remarkable part of New Sonth Wales is the district of Il!awatra, situated on the coast, about sixty miles to the south of Purt Jackson. This is a narrow strip, that seems to be forned by the reticat of the gandstonc cliffs from the sea, to a distance which varies from no to ten miles. The elifis or mountains sary is lieight from one thousand to two thousand feet. This region is extremely ftuitful ; its foresta aro rich with a great variely of folinge, and of ereeping plants which twine around tho tres. The great size ard rumber of the trees served to remind the gentlemen who visited it, of the regetntion of the tropical islands, luxuriant with tree-ferus, bananas, banyons, \&c. This luxuziance is in part owing to a rich and light soil, eomposed of deeonuposed brsalt and argillaceous sandstone, suixed with vegetable mould, bus more to the peculiarity of its elimate. The high cliffs which bound it to tho west, keep off tho scorching winds which reach oltser parts of the coast froms that quarter, and the moisture of the sen-breeze intercepted by theu is condensed, fulling in gcutle sliowers. For this reason, it is trot subject to the long and frequent droughts that oceur in other parts of New Sonth Walos.

These droughts are sometitnes of such long continuntre, llant we at sne time real of the whole coututry having treen burnt ny fur want of rain, a frniue threatewed, aud the shewp and eutle perish. ing in inmense utumbers.

These liave been suceeded by loug-coutinued rains, which lave rnised the rivers thirty or forty feet, fluoded tho whole exuntry, deluged the towns and villagen, and completely destroyed the crops. Such floods enrry with then houses, barns, stacks of grain, \&e., druwn the esttle, and even tho jnbalitunts are in sume eases sared only by being taken from the topes of their huses in troats.

The year of our visit, 1839 , added another itlstance to the list of disasters of the latter hind; and the jublished accounts state that twenty thonsand shcep were lost in the valley of the Hawkesbury by the flrouls. Such evils indeed appear to be of frequent occurrence, and tho settler in New South Wales has to curatend with the elements in an unusual degree.

Such disasters ane equally injurions to the husbaudman and the wool-gitower; for the rame cause that destroys the crops, nlso carries atf the stock, so that it in only tlse large capitalist who ean successfuily struggle against or overcome such at. verse circumstruces, It is some recompense for this state of thisgs, that one or two favoumble years will completely repay all former losses ; and $i$ is due to the persevernice and imlustry of the iufabitunta of New Sutuls Wales to say, that they lasve already, in spite of the dilliculties they loave had to eucumnter, male it one of the most Hourishing colnujes on the globe.

In seasons of drowght, the llocks and herds are driven into the juterior. The year of our visit (I33) wns accututed is wet one, and some parts of the Antulstune district which produced gooul crops of grain - in drior sensons would have been dry to barremuess.

In such a climate it is not striprining that there are havlly auy streans tlant merit the nnme of rivers, It is necusary to guard against being misled by the inspection of jusps of the eountryt, and fortuing from them the ides that it is weil watered. Such an impression would be erroneous, and yet the maps are not inaceurate; streams do at times exist in the places where they are laid down on the maps, but for the greate part of every yenr no more is to be seen than the beds or conuses, in which, during the season of floods, ur nfter long continued rning, absolute torrests of water flow, but which wilt within the efort space of a month again becone as string of deej pools. Were it not fur this peculiar provísion of nature, the country for the greater part of die year wonld be wilhout water, and, eonseguentily, uninhabitable.

I'he principal rivery wlich ture fouml to the east of the Blue Mountaing are, the Hunter, George, Shoallinm, and Hawhesbury. Note of these strearns aro uavigable further than the tide flows in the esturues, which sometimes extend twenty or thirty

- In tho allurlal flats along the rivers, the wheat erop is usually abotit twenty-hre lubliels to the acre. Forty ta corty-llyo bushels have bech outained, but such crops are very unasual. 
miles inland, for beyond them they are usunlly no more than twonty inches is depth, Eacl of theae streams bas numerous tributurica, which dma a largo aren of cruntry, and during heavy rains the trais branches are indelenly swelled, and cause the floorls which hnve been spoken of. To the west of the mutuntains, the water-conses are of a rory different cliaracter. The Darling, for instance, chrougli a course of seven hundresl miles, does mot receive a singly tributary, although it is sail to drain an extent of sixty thousand sinare miles. It possessem tho other ehnmetor which las been mentioned, of being frequently reduced to a mere atring of pools. The Darling, Mnrrumbilgee, nat Lachilan, unite about one lizudred ruiles from the oceasi, arut their jnitst stream is known by the rame of the Murray, which after passing through Iako $\Lambda$ lexandria, enters thu beat at Encounter Ihay. "The surfuce drained by these streasns is abrout two lumired and fifty thougand squart miles.

Another remarknte oecurvere oloservel iu these western waters, is the disappearance of a river in swampy lanuls, where, ns is sisplosed, it is swallowed up by the cavestu in the limestone roclis. This is the ease with the Macquaric, which lans its gauree Jear Bathurst.

According to all recounts, salt is very generally diflised throtghout Now South Wales, and even all Aurtralia, It las been reported as being found in masses in the sandstone, but no specimens of it were ohtained by the expedition. Senrecly a well is rlug in the interior which is not lornekish; nnd, necording to Major Mitchell, Cnptain Sturt, Oxley, and others, many of the rivers nre quite salite in parts of their courso. The northern tributarics of the Hunter nud Durling are instances of this

'The hakes are also sail to be saline, and in some instanees sufticiently strong to afford a large and profitable giedd of antt ; lut being very far in the interior, and wittont the Jueans of transportation, they are of hittle value. Alung the south enast of Australis, such lalies are leocribed as existing near the sen, and may possibly prove of sotno value to that portion of New Hollnnd.

Lead and irom laxpe been found in small quantitics; the deposits of the fotmer sre all tritling. Those of the latter afford ton impure att ore, and not in sufticient abmadnace, to the worked.

Tlie minerals stated to bo found in Anstralia, Bpecimeus of which wero procured for the expeditiun, are chulcedony, ngates, jnsper, quartz, augite, and stilbite; feldspar, arragonite, 5.7 sum, clulurite, ruica in grinite; sulplur and slum, galena snd plumbrgo, magnetic iron, iron pyrites, and basalt.

Fossils appear to be contined to partieular loealities, lyt are by no means rare.

Columans of basalt of great regularity are found on the conge of Illawarib, but the aticulations are all pline.

The water is much impregnaled with alum and iron, and its use is nvoided by the inhabitanus.

Deserts covered with salino plants are said to be frequetsty met with.

The climnte of Australia may he considered genernlly as verydry; the irregularity of the rains, and the nature of the soil, all prove that it is fo; vet the aridity is not marked, as in other countries, by $\mathbf{n}$ genemal tendency in the plants to produce tlurne, although the peculjarity of the regetation makes the dryness apparent iu other ways. From all aceonnte, New Soutl, Wales is sulject to $n$ grent atmosyheric vicissitndes as the midallo United States. For a series of years, drouglits will oceur, which in turn give place to yesus of successivo floods, and theso prevai] to ail extent that can harylly be credited, were it not that the account las been received from good auchority. As a striking instance of it, Oxley, in his exploring juturneys into the interior, in $1 B 17$, found the cuntry every where overflowed, so as to preveut him from proceseding ; while Miteltell, in 1835, in the samne districts, wns continually in elanger of perishing from thirst. The latter staten that he found unios (or fresh-water mussels) stieking in the banks of rivers and ponds alowe the level of the water; and also dead trees and saplings in similar situations.

This altertutc change must exert a great influence on the productions of the soil; the rivers cersing to flow, nnd their bets becoming as it were dey, with the exception of the pools lecetofore spoken of, must likewise hrye an influence. The prevailing westerly wirtds sweep with force over the whole country, blighting all tliey touch. The effect of these hot winds is remarkable, for they will in a few lunurs entirely destroy the crops by extracting all the moisture fium the grain, even after it is formed, and almost ready fur harvest; and the only portion that is left is that which has been sheltered by trees, liedges, or fonces. They thus destroy the prospect of the husbandman when hin eropgs are ready for the sickle. It is thumght, and I should insigitue with reason, thant were the Blue Mouninins a more lafty range, this would not be the ease, as they would have a tersdeney to eontinue the supplieg to the strenms throughout the year, by the condensation of the rapour from the sen.

These lot winds come from the direction of the Blue Mouthins, and what seems remarkable, are not fett on the other side of the mountains, or in their inmediate vicinity. Yet the extent between the const aud the montantins is not sufficient to [uroduce these winds, being only forty-five miles; and if they proceed from the interior, they must poss orer those monntains, an elevation in soule places of three thomand four hundred feet. Theis great destructiveness is molonbtedly caused by their enpacity for moistnre, althuugl few observa. tions have as yet (as far ng I was able to obtain information) heen innde upon then, execpt in relntion to the blight they oconsion. It has been found that fieldes which lave a line of woods on the side whence they blow, escape irjury. The harrest immediately on the line of the eorst does not auffer so mucl, being exempted in part from their withering influeuce by the moisture that is imbibed from the sea.

There is a portion of this country that is an exception to the general rule of axidity, nanely, the district of IIlawaria, This forms a belt of from one to ten miles wide, and has the range of the liangaroo Ilills just beluind it, of one thousand feet; these are sufficiently high at this distance from the const to condense the mointure, and atso to protect the district from the blighting effeets of the blasts from the interior.

One is cutively unprepared for the alleged facts in relation to this country; for instance, Mitchell in lis journey to the south and west, during the 
four winter tmoullos, witnessed no precipitation of molsture exeept frosts in the nornings, and the thermumeter was often helow the freczing point. Vinlent wints oecur, which have obtsingd the name of lurick-fieklers. They are nutling more than a kind of grust, peculiar to the environs of Sydney, after a sultery day. During ote of these guats litto or no rain falls, though the wind frequently appronclies a liurriense in foree. These winds get their mane foum bringing the dust frum the brickfields, formerly in the suburts of Sydney, but which nro now almost entirely built over. The temperature ituring the blow generally falls twenty sis twenty-five dugrtes, in tho space of as many minutes; the dust is very great, sut the wind so strong, is to exuse apprehension dest the houges sloulu he untoufesl, or the chimney thrown down. Our standasd barometer way earefully wntehed dnrigre the cumishg on of two of these gusts, and found to fall 0.200 in., the first time, and the second only 0 0120 in. ; lout the tenperature fell cach time abont ten degrews. They were not, lowerer, true brich-fietders, or such as a resident would so denominnto.

Snow las heen known to falt in Syctney, hut aอ raroly, that we were told some of the inhabitants were dortseful as to its satire. On the mountaing it is not ureumman, and in the winter genson is tI ways reen on those in the Xew Englund distriet, which, although three or four degrees to the northward of Sydney, enjoys a mueh eooler elimate.

I found nt Sydney a great wariety of opinions existing ntiout the elinute. During our stay, the weather wag unfavourable for alt astronomienl ob. servationg, and almost the whole timo elmuly or rniny. It was anusitug to find masy of those to whons I had the pleasure of an introduction, npelarizing for the badness of the weativer. It bivught finctibly to my recellection, the foult that Captsin Basil Hall tinds with the peojle of the United states, lut was far from being annoying to mo. I lnse but little sloubt that the elimnte is, generally speaking, a lacelthy one, and not unlike that of sune parts of our own curntry. The cotony is subject to vensional cpidemics, and from the best information I could procure, it is theught that the morkality is abonat one in forty-tluree; this may lo calied a rery small proportion, when one takes into considemation the great qutuntity of arodesth spirits that is consumed.

The general appearanee of the vegetation of New Suuth Waleg presents many pretuliatilies. The character of its prowductions is totnlly distinct from those of the other portions of the ghitre. The gum tress, Norfulk pines, anl thase of AIoreton Bny, attract attention from their seattered ajpenrance, sul greenliar foliage. Alt these lave a dark nud numbre liw. A renark male by one of un gentlenen is elaracteristic of the former, "tlat shey were glosis of trees." The lenves heing set edgewise causts this sppenange, snd in eonsenuence gire liutlo or to shade. This preculiar josition of the leat is nure conspictum in the encalypt than in other gencm, for in thera the leaves are all prendnut, while the leaves in the other genern nre tsoully upright, rigit, aw somewhat as thay bo Heen in the neacian ant other tribes. It was tubservel that both surfaces of the lesres were moteh alike, luving as it wete, two upper surfaces. Whether any pliysiological purpose has been s.5- signod for sucli an arrangement I bave not been informed.

Among the most singnlar of the productions of Australia aro the wooblu peara, as they are called. These lave a elose external resemblance to the Iruit whose narve they benr, but are ligneous within. Arrother of the fruits is a eljerry, whose stone is external, and would be sinuilsur to our fruit of that name were the lemel in its propuer falace. The pit aulieres firmly to the pulp, which is of the size of a pists]-bullet, but the fruit slirinks when ripe so that of a buck-shot. The penr grows ou a low slirul, the clustry on a large busk.

I have before remartied low fliferent the "forest," so called in New Sunth Wrles, is froun what is understood hy the torm elsewhere. The want of elose growith is not the ouly remarkable appearance, but the absence of all denyed foliage is also extracrdinary. The gruntud is clear of any fallen leaves, atud every thisig letaliens that perenuial verdure is here the oxder of thitges. Thebe two features combincel, give the forests of Aubtralia the air of a neatly-kept park. Anutral plante, (if so thicy can le called, alsonnd in the forest, requiriag, it is kaid, more tlın a simgle year to bring their seeds to maturity. There were instances we were tolid of exps of grais remuining three yeans in the gronnd. $A$ few plants forund in ether parth of ile worlat, are, it is weli knuwn, only hrought into existenee after a lapse of years, and other's give repentel crops during the same year. That these typess, so rare in other constries, shoutlil be abustant in Australia, is not remarknble, when it is considered that they are but instances of an almost complete diresyity letween the nutural history of this coutry and that of other reginns.

The remark, that the leaves of the trees nre wood, and their woonl, iron, is not inspropropiate to most of the plants of this eountry. It is not, however, to he infersed that all the jolatits are different from thene of other countries; su far from this being the case, a consideralule almixture of ordinary forms was met with. Awong these were a gleat raricty if grasses, some of which wero beforo considered 10 be peculiar to North America. Masy other fortss decidedly Norlh $A$ merienn wero also mot wils; n circumstance which, from the difference of gengraPhieal position, dislanee, and elimnte, was not to be expecterl.

All secu to have been struck with the npparent monotory of the scenery, foliage, and Ahara, although in reality the latter presents great variety. The general sentineat whs, that they were fatigued by it, which is not a little surprising, as the Austualian fhro rivals in number of species that of Brazil. This foeling way be acerunted for by the overpowering impression tliat is made by the gum trees, whose follige is of a dark sombre green. There is rlso something in the general absence of umierurusls; and the trues are so listant from ore anutlier tlint there is no need of roads, so that a earinge nany drive any where.

The trees are in general tall in juroportion to theip disncter, will an umbrella top, and lave the appearance of being thisly clad in folinge. No woudy vines are to be seen, nor any parsitic plantis. In many places a stunter growth of detuclied slarubs, called in the culony "scruls," exists, which might be termed one of their "firests" in a dwarf shape. 
It the Illuwarm dist riet a tutally distinet state of thing exists. Here is to be foumd all tho lusurinue of the tropics-bity palms, ameng them the cerryplan sustralis, witl tree-furns of two ar unure varioties, diffurent apvecies of licus, a seandent piper, aud very many vines. The fores of this distriot is thick, and alive wills nnimal life.

This district is alyout fifty miles long, and forms a sensicircular area abuut tilirty nuiles in its greatest width. The peculiarity of the situatiun of this district would tend to show what would bave been the probable state of New Holland, or rather its easte's side, if the mountains were sufticiently high to interept the moisture of the ocean, and preveut the aceess in it of the dry lot winds from the interior. IJlawarta may to termed the grmaniy of Yew Soutl. Walea ; here the erojes seldoun, if ever, fail, and are very abundast.

The soil of Sydney consists of litacti mould, mixed with a clens sulyte sand. The quartity of sam is streli, as in the dry sensons tu affect the vergetation. This annd, I underetord, is now exprifted to Einghanil at a grent profit, beiug found a valuable article in the maunfacture of phate glass. This soil, however, is made to yield a plentiful supfly of fruits and vegetables; and the display exliijuted at the borticultural exhibition wa highly ereditable, not only for the perfection to wlitech the productions had been brought, lut for their great variety. The exhibition was held in the large narket-house it Feurge Street, whicls was tastefully ilecomted for the neession witl brinclies and festonns of flower. In front of the aror was an areh fistued of beantiful flowers, wizh the motto, "Melrasee Australia I" surmousted by a erown, and the letters V. R, in yellow Howers. Behind this the hond was stationed, wlach, un our entrance, struch up Yankee I ondle. Tickets were sent to the ensill for those belonging to the squadrou. There were a great many Somth Ameriean plants in pots. A premiun was received for troprenlum pentaphylluzs, maurandya latrelayana, and for two arrevius of ealceolaria. There wero likewise anaryllig belindonna and untrellata, bouvarlia triplyylts, cober seandons, and severnl passifloras, and a variety of liyacinths, dahlias, tuberoses, \&ce, all file.

The geapes exhibited wero beautiful, ard some of thetu in very large eluaters. Neetarites, peaches, npples, prars, sunall oranges, shadiluck, pinespples, cliesnuts, tuis waluuts, wero also in abundutuce.

After viowing the fouit we exsmined the vegetabies, which consisted of potatoes, currots, turtips, yery largo pumpkins, cucumbert, eabbuges of different kinds and very fine, particularly the eurled Savoy and carly York, tomatoes, celery, squastued, vergetulile marzow, boets, capsicums, mid betrss.

After the vegretables carne speciumens of native wines, and a situer eup was given as a premitum for the best. The white wine resemblent hock in taste; the rod, claret. The climate is thought to be farcurable to the protuction of the grape. The lirst wine tnado in the eolony was by Mr. Btaxinnd, m his estato at Newington.

l'he grtudss grown in the colony are, whent, ryc, larrley, Indisur eoru, und ants, The whent yields from six to twenty-five busliels to the acre, and sume low ground as bigh as thirty-five bushels, Its weight por bushel is sixty-two pounds. The cxops of this grain are subject to great thetuations, and the most promising afpearanee sny in a single diny be entirely" destroyeul.

Tobaceo has been cultivated, and it is thonght. will suceed; but the frequent frusts reuder it a very unertain erop̣.

Cotton lass lieen nilempted, but with littlo suecess. The value of pasturage, and its profitablo yiclat in sheep-walks, will loug be a bar to the extensive cultivation of any plants that require ruteh labour in tlueir prodnetion. Our horticulturist remarks, that eherrics do not stuceed well, being affeeted by the dry cutting winds whichs occur in the blossoming season.

The ornnge, citross, and lemon trees present a scraggy and yellow dppenrance, and produce small and itsipid fruit, in conparison with cluat of the trapics. Peaches thrivo, and grow in large танntities, aud of high flawour. [Cvery farmer lzas his peach orelard; and the fruit is so plentiful that they fatten their pigs on them.

The natives of Australia are fast disappenring. The entire aboriginal population has been estinuted as high ns two laundret thousatar? ; this catimate is fonnded on the supposition that the unexplored regions of the country do not differ materially from that part of it which is known, which enunot well be the case. Other custimates, and probably much nearer the truth, aro given at from sixty to seventy. five thousasd.

'I'ise ravages of intoxication and disease, comlines with their occasional warfare, will readily account for the rapil disappensenee of the native popula. tion; and but n lew more years will suthice lor the Jow seanty pogulation to become extuct. In 1835 , the surveyor-general, Miteliell, estimated that ia nbout one-seventl of the whole colony, which the lant exnmisted, the matives alid not exeed six thousand in number; they are in tnany parts most wretched-looking leeings, and ineorrigible begrars: the momest thoy soo a stranger, he is fairly tormented to give gomethirg; $\mathrm{n}$ slilling or a sixpenee contents many, and when laid ont for rum, or bread, is slured by all present.

'l'he introduction of Furopean arts tras eausel lut listle improvensent, while the viecs which aceompany them have been the bane of the native population, which has thus acquired a fondnegs for ardent spírits and tolyaceo. The untives usually lead a wandering, ragabond life, hanging afout the louses of the settlers whero they are well trented. and doing little jubs for a slight recompense is the above articles. Their labitations are mere tenaporary sheliers, formed of boughs and bark piled up against the stump of a fallen tree, mather to strield them from the wind than for a regulnr Iubitation; the renson for this may lue, that owing to superstitious seruples they never encarnp in one spot three uights in suecession, At Illawarma, their buts were made by setting two forled sticks upright, on which another was lajd torizontally; on the latter, one end of pieces of bark, taken from the wenrest gum tree, is laid, while the other end rests upon the ground. $A$ fire is built on the npen side, which not only warms them, but keeps off the myriads of musqutitoes and other insects. $A B$ many ag ean enter such a hut, take shelter in it, lyigg upon the soft bark of tho ti tree.

The uatives of Australia differ from any other race of inet, in features, complexion, lubits, sod 
langunge. Their colour and fentures assimilate them to the Afrienn type; their long, black, silky hair laas a resemblanes to the Malays; in their lunguage they approxinate more nearly to our American Indians; while there is much in their physical traits, mammers, and eustoms, to which ni amalugy can be traced in any other peuple,

They are difficult to manaze, taking offence easily when they are ill-treated; and if any one attempts to control, thwart, or restrain their wandering habits, they at onee resort to the woods, and resune their primitive modo of life, aubsisting upon fisli, grubs, berries, agd acchsionally enjoying a feast of kaugaroo or npossumflesh. They ent the larvic of all kinds of insects with grent pusto. Those who reside upon the coast, fish with gigs or apears, which are usually three pronged; they lave no fish-hools of their

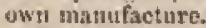

When they foel that they liave been injured by a white settler, they gratify their revenge by spenting his cattle; and it is satid unou good athority, that not a few of the whites, oven of the better class, will, when they can do so with impunity, retaliate in the blood of these wretched natixes; and it is to be regretterl that they are not very Berupulens in distinguishing the guilty from the innecent.

The natives of New South Wales are a prout, ligh-teropered race: ench man is independent of his netghbour, owning no superior, and exacting no deference; they liave not in their language any word signifying a chief or superior, flor to command ur serve. Each individual is the source of his own comforts, and the artificer of his own lousehold implements and weapons; nud but for the Jove of exmnanionship, lie might live with Lis [amily apart and isolated from the rest, without sacrificiug any alvantages whatever. They luve an air of haughtiness and iusolence arising from this independence, and nolhing will induce them to scknowletge any human being as their superior, or to show sny marks of reqpect. In illustration of this, Mr. Watson the missionary is the only white guan to whose name they prefix "Mr.," and this ite thin]:s is chielly owing the tubit seculured when ehildren under his authority. All others, of whatever rank, they address by their Christinn or surname. Tlis does not proceed from igrarance on their part, as they are known to understand the distinetions of rak among the whites, and are continually wituessing the subservience and respect oxacted among them. They appent to have ta conseiousness of independenes, which eauses them on all occrsions to treat even the highest with equality. On being asked to work, they usually reply, "White fellow work, not black fellow ;" and on entering a room they never remain strading, but immediately seat themiselves,

They have not, properly spoaking, any distrilustion into tribes. In their confliets, these spenking the same language, and who liave fought side by вide, are frequently drakn up in butile-srrny against each other, and a short time after nuy be again seen acting together. Their conflicts, for they do not deserve the name of wars, are conlucted after the followisg manner. The yunrrel or misunderstanding genernlly arises from some trivinl afthir; when the agmrieved party assembles his neighbours to consulk them relative to the couree to be pursued. T'the general upinion laving been declnred, a messenger is sunt to annourse their intention to commence bostilitics to the opposite party, and to fix a day for the combat. The Intter immediately assemble their friends, and make preparations for the np. proneling eontest. The two parties on the day assigned ruect, necompanied by the women and chilifren. The first onset is made by the oldest women (hatgs they might be terned) rituperatiun the opposite side. Then a watrior alvarees, and several throws of spears take place. These are parried with much dexterity, for all the uatives pnssess great art and skill in avoiding missiles witl their shizels. This exchange of missiles conlixues for some time, sul not unfrequetsly ends without any fatn! result. When one of either party is killed, a separntion takes place, stuceeded by nnother course of rectimiuation, after which explanatious are made, the affair terminates, and hoatility is at an end; the two parties meet atriealily, bury the dead, and join in the corrubory dance.

These danees are not only the usual clase of their combats, but are frequent in time of pence. They appear almost necessary to stir up their blood; and under the excitement they produce, the whole rature of the people seems to tro ehanged. 'T'o a epectator the effect of one of these exhibitions almost equals that of a tragic melortrame.

A suitable place for the perfismance is selected in the neightrourhool of their huts. Here a liret is built by the women and boys, whilo sueh of the men ns are to talie a share in the exhibition, usually about twenty in number, disappenr to nrrange their persons. When these preparations are completest, and the fire burns brightly, the performers are seen alvancitg in the guive of gis many slicletsus. This effeet is prodised by neans of pipe-clay, witls which they mairt brat white lines on their nrma nnd legs, rnd on the head, while others of less brenditl nre druwn across the body, to coitespond to the ribs. "The nusic consists in beating time on their shields, and singing, and to it the movements of the dancers conform. It must not be supposed that this exlubition is a dance in our sense of the ward, nor is it like any thing that we saw in the South Sen islands. It cunsists of violent and od novements of the aurns, legs, and body, contortions and violent muscular actions, nmounting almost to frefry.s. Tho performers appear more like a child's pasteboard supple-Jack than any thing huram in their novemetits.

This action contimes for a time, and then the skeletons, for so I miny teru them, for they truly resemble them, suddeuly seen to vanisll and reappear. Tlue disajprenranco is effected by merely turning mund, for the figures are painted only in frant, and sleeir dusky forms are lost by minglitg with the dark back-ground. The trees îluminated by the fire, are brunght out witl some of the figures in bollt relief, while others were indistinet and ghost-like. All concurred to gire an as' of wildness to the strange seene. As the dance proceerls, the excilement inereases, aul those whin a short time belore appeared only laif alive, become 
full of animatim, and finally were obliged to stop fron exilaustion.

Their weapons are the spear, club, or nultasulla, boomerusng, dundumel, and the bundi. T"hejr Hpens are about ten feec long, and very glender, inalo of chne ol wood tapering to a point, which is barbed. They ne light, arut one would seareely lat indiued to believe that they could be darted with any force; mor could they williout the nid of the wanimest, a struight flut stick, three feet in lentyth, terninating in a Bocket of bone or hide, into which the end of the spers is fixerl. The wanmera is grasped in the rigist lant by three fingers, tho spenr lying hetween the fore-finger and thumb. Frovions to throwing $\mathrm{jt}$, a temulous or vibratury mution is given to it, which is sapposed to add to the aceraracy of the aim; in projecting the spear, the wamnern is retained in the hasul, and the use of thits simple contrivance adds grestly tu the projectile foree given to the spenr. "l'hy are well-practised in the use of these weapons.

The nulln-nulis, or nta, is from thirty to thirty. six inclues in longth, the handle being of a size to bo conveniently grasped.

'The dundumel is $n$ wenpon used by the natives of the interior; it has a enrved fhat jundle thirty inclies in lengili, and terminates in a projection not unlike a liatehet; it is thrown from the hand before coming to clase quarters, and usually at a very short distance.

lut the most extraordinary weapon is the boomereng. This is a flat stick, three feet long and two inches wide by three-quartets of an irich thick, enrved or crooked in the centre, forming an ohtuse angle. At first sight one would conclude it was a wooden sword, very rudely and clumsily made; indeod one of the early navigators took it for such, It is an implement used both for war and in the chase. In the hands of a nativo it is a missile efticient for both, and is made to describe some most extruordinary eurves and movemenis.

As a defence, they use a shield made of the thick bark of the gum tree; this they call hiclemnrn. It is peculiar in shape, and on the const is three feet long by six or eight juelies wide, with a landle in the eentre; it is made roundiug. Those in the interior are only a three-cornetred piece of wond, with a hole on each side, through which the liand is thurst. The size of the latter is mmaller, being only isn feet long and three or fisur inches brond. It would seern almont impossible that so small a shield should be suffieient to gunrd the body of a man; and notling but their quickness of eye and hand coald make it of any value as a protection against the spest or club.

The mode in which the natives elimh trees was entsidered exirnordinary by those who witnessed it, although they hat been ncenstomed to the feuts of the Polynesians in the ascent of the coena-nut trees, The Anstralians mount a tree four or fivo feet in diameter, both with rapidity aud safety. As they climb they eut noteles above them, with a stone or metal intehet, largo enough to admit two of their toes, which are inserted in them, and support their weight until other loles are cnt.

Tho socinl system and intercourse of the Australians is regulated by custurn alone. As no system of government exists, or any neknowledgment of power to enact laws, they are solely guided hy old usage, and can give no nceount whatever of its origin. The nniversal reprobation of their associates, which follaws a brench of ancient customs, las a strong tendency to preserve $n$ striot nobservance of them. Many of these customs stiuck us as remarkable; those that bave not been actually geen by the oflicers of the expedition, linve been described by persons entitled to the fullest erefilt.

The custom (to nse the langrage of the settlers) " of making young men" is singular. When the boye reach the ago of fourteen, or tlont of puberty, the eldera of the tribe prepare to initiate their into the privileges of manhood. $A$ night or two previous, a dismal ery is heard in tho woods, which the boys are told is the Bùlu calling for them. Thereupon all the men of the tribeset off for some secluded spot, previously fixed upon, taking with them the boys or youths to be initinted. No white man is allowed to bo fresent, and the precise nature of the ceremotay is therefore unkmown; but it is eertain that the ceremonies are designed to try their courage, fortitude, and the expertness of the boys in reference to their future emplovments in the chase and in war. Tliere is probably some difference in theso cerenunies atmong the differont tribes. Tho Wellington station, or those of the interior, for instance, never knnck out a front tooth, which is always done on the coast.

From the lime the youths are initiated, they are required to yicld implicit abedienee to their elders. This is the only control that seems to prevail, and is very requisite to prescrve order and harnony in their socinl intereuturse, as well as to supply the julnee of distinctions of rank among thesu.

The youtlss are likewise restricted to articles of diet, not heing allowed to ent eggs, fish, or any of the finer hinds of opossum or langaroo. Their faro is consequently of a rery poor description, but as they grow older these restrictions me removed, although at wlat nge we have not learnt; but after Javing pased the middle age, they aro entircly at liberty to pristake of all. The purpose of this is thought to be not only to aceustom them $w$ a simplo and therdy way of living, but alen that they should provide for tlie aged, and not bo allowed to mpunoprinte all to themadves, Selfisluness is therefure yo part of their claracter, and all observerg are struck with their custum of dividing any thitug they may receive among each other, a diainterestreduess thint is seldom seet arrong eivilized untions.

'T'o protect the morals of the youths, they are fortsilden frum the time of their initintion until their marriage to spenk to or even to appsoach a funale. They must encamp at a distance from them, and if, pereliane, ono is secss in the pathway, they are obliged to make a detour in order to avoid her. Mr. Watson stated ho had been ofien put to great inconvenience in travelling through the wonds with a young native for his guide, ns be could never bo induced to ipproach an eneamjo ment wluere there were sny" women.

The ecremony of marriage is peculinr. In mest cases the partieg are betrothed at an early age, and as boun as they nrrive at the proper age, the young man clains his ' gin' or wife.

The women are considered as an article of property, and are sold or given away by the parents or relatives withont the least regard to their own wishes, $\mathrm{As}$ far as our observation weat, the women 
appear to take liale eare of thein ehiduren. Polygamy oxists, and tlsey will frequently give one of their wives to a friend who sny be in want of one; but notwithstanding this laxity they are extremely jealous, and are very prompt to resent any freedom tuken with their wives. Their quarrels for the most part aro oecasioned by the fair sex, aud being the causc, they usually are the grentest sufferers; for the waddy is applied to their heads in a most utumerciful style, and few old women aro to be seen who do not bear unquestionable murks of the hard uange they lave received. The busband who sukpeets anuther of seducing his wife, either killa one or both. Tlse nffair is taken up by the tritse, if the party belongs to another, who infliet punishment on him in the following manner.

T'he guilty party is furnished witls a shield, and mado to stand at a suitable distance, and the whote tribe enst their spens at him; his expertuess and activity often enable him to escape any serious injury, but instamees do oceur in which the party is killed. Such punishments are inflicted with great formality, upon an appointed day, fart the whole tribe nsseruble to witness it. The person most injured has the first throw, and it depends upon the feelings of the tribe respecting the affence ermmitted, whether they endeavour to do iujury to the culprit or not; nud thus it may be supposed that there is some judgment cvinced in this mode of punistment.

'l'he fullowing necount of the burial of their deal was received from the missionary who was an eyewitness to it. Ho was called out one evelung to see a nutive, who they sail was dying. On reparing to the camp, he was too lnte, for the man was already deal, and notwithstanding the sliort space of time that had elapsed, the corjuse wis atrealy wrapped up for burinl. 'The legs had treen bent at the knees and lips, and tied to the body, and the liead bent downwards towards the legs, In this position the corpse was enveloped in a blasket, and bound round with many ligntures, so as to form a shapeless Jump. There were about fifty natives present, scater within a smal! space in front. The women were mising tismal lamentrtions and cutting themselver with slarp sticks; while the men were engaged in as earnest consultation as to the phee which slould be fixed mprot for the burinl. At length it was determined to be on the banks of the Mncquaric, at no grent distanco from the misgion station. On the following day the missionury proceeded to the pinee, and fuund that the matives tuad already cleared the gruss from a space about twenty fect in diameter; in the centre of this the grave was marked ont, of an oval sliape, six feet long by three feet wide. After digging to the depth of about a foot, they left a ledge all aromed the grave of a few inches in widtl: the excavation, thus diminished in size, was contimed to the deptli of tive feet, the sides not being exactly perpendicular, bat sloping slightly inwards. the bottom of the grave whs laid $a$ bed of lenves, covered with an opossum-skin cloak, and having a stuffed hag of kangaroo-skin for a pillow; on this couch the body was laid, nisd the inplements of hunting and wat which the deceased land used during his lifetime were hild beside lim. Leaves and branclies of hushes were strewel over him, until the grave was filled up to the ledge or shelf above mestioneal. Acruss the grnve were laid strong stakes, with the eurls resting on this sliclf, and on these a lisyer of stomes, which filled the hole to the level of the soil. The excavated enrth was then put over the whute, forming a conical heaj eight or nine feet high. 'The trees on escli silde wore markel with irregalas incisions, but whather intended ns symbols, or merely to identify tho place of sepulture, was not nuderstoou. All the tino this was going on fives were kept lurniug around the place, to drive away evil tepirits, aud the wotnen and dididrent uttered load lamentations, inflictiug at the sume timo wounds ujon themselves. When the grase was completed, all the women and ehildren were ordereit away, and the nisfionary, pereciving that it was expected t]at he would do the same, retired also. His presumption was that they intended to gire utterance to theit grief, and that they were ashamed to to it in his presence, or before the women and children.

The day niter the burial the natives visited every gpot in which they recolleeted to lase been the deceased, and fumigated it, for' the purpose of driving away the evil spirits. They even went into the misionaties' houses, grently to the annoyance of the ladies.

Their style of mouruing consists in bexlaubing themselves with pipe-clay; and a more hiteous object than an old woman Uns tricked vut can Inrilly be conecived. The body and limbs aro streaked with it, and the face completely covered as with a mask, in which lives are left for the eyos, nostrils, aud montl. 'Jlie mask is gradusily removed, until the lnst that is seen of it is as sanull patels on the top of the head.

They hawe some idea of a future state, althongh some nssert that the whole mon dies, mul that nothing is left of him; while othere are of opinion that his spirit yet lives, either as a wandering glost or is a state of metamorflusis, animuting a bird or otlier crenture of a lower order than man.

During our stay at Sydney, a convict-ship arrived; and being desirous of obtaining a riew of her accommodations, and the mode of treating the conviets, I visited her. T'lis ressel was prepared expressly for the purjose. Between decks, a strong ganted barricnde, well spilied with iron, is buile neross the ship nt the steerage hulklsead. This affords the officers a fres view of all that is. going on among the prisonerg.

Bunks for sleeping are placed on ench sicle all the way to the bow, resembling these in a guard. room. Fach of these will aceommodate five persons. T'lere is no outlet but tluwugh a door in the ateerage hullihead, and this is always guarded Jy a sentry. Liglit and air are admitted therengh ine latelies, whiclı are well and stongly grated. "The gunrd is nader the cusmmand of asergennt, and is accommodsted in the stecrage, the whole being under the orders of a sturgenn, wlinse duty it is to superintend and regulato every tiong that relates to the prisonors, inspeet tho ship duily, and alminister punishment, even unto denth if neeessary. the surgeon also has control over the master of the veesel and his regulations, The uaster and mates, on receiving a certificate from the surneon, are allowed a small sum for every convict landed, in addition to their pay.

The erimunls lave prian fare, and are supplied with wooden-ware for their eating utensils, which are kept in a very nice order. The quarter-deck 
is barriesdued near the main-mant, abnit of which all the noms and accoutrements of the guard and ressel aro kept. The mater and oftheers are usuntly lodget in the poop-calin. The prisoness are hubituated to the discipline of the sling, on tonrd the lialks, hefore lenving Eughund. The usunl, and most effectual, punishment for misbehasiour is to place tho culprit in a narrow tox on theok, in which he is eonpelfed to stand erect. 'Tlis furrishment is said to bo cffectunl in reducing the smost refractory male conviets to order, but it was not found go efticacious in the femalo convict shigr ; for, when put in the box, they wotuld batw so foudly, mul use their tongueg so freely, that it was found necessnry to incresse the punislimers by plucing a cistern of water on the toj of the bux. This was turned over upon those who per. sist in using their fougues, and neted on the oecupast as a slower-bath, the conling effect of which was always and quickly effiescions in gutieling them. I Was informed that suore tlont two such sliuwers were nover required to sublus the must turbulent.

I was struek with the ruddy, hen!thy, anil athbetio looks of the young edrificts that were arriving, and frots their depurtnent and countemanees I should hardly lave been inclined to believe that they had been the porpotrators of beinous erimes,

I am not at all surprised that many of the set. thers of the colony ahould be opposed to the chinge in the assignment aysters ; for when sueh a flue buty of anen is seun, the renson is onsily under. atoou, as the posstzsion of such strong ntul liale persons to all intents asul purposes as slavis, ant at the expense of thejr uaintenatice alone, nust be very luerative to those requiring Jabourers. I on the other hand, at a lisg to eoneeive low the assigurnent systom ean be looked ujotk ill any other biglit than at a great evil, which nuant be abolished if it lee designed so make the inhabitants of New South Wales a momal community, and ti reform the convicts. It acts most unequally ou the parties, and is a barrier to tho reformution that the punisiment of transportation is intended to effeet.

The entriets on arriving nre aent tn the barracks at Sybney. The governmont selects from them weh meelanies as are required fur the public service, and then the numerous npplieanta for labourers are supplied. Those assigned to prisate employers aro sent to the interior under the cliargo of a constalile or oversecr.

They build their own luts, and the climate being very fine, requito but little shelter. The lours of libeur are from six to six, and the qual]. tity of labour exneted frum them is about two. thirds of what would be required in Eingland. 'They are trested in all respects as if they were free, and no restraint is injused, execpit that they cannot lesve their masters, who, when they have nis further use for them, return them to the government tu be reassigned.

When on ticket of lenve, they may reside in any place they elioose to select.

The conriet's time of probation depends upon the uriginal term of his sentence; lut on a commiseion of erime within the colony, it herging from Jis last conviction. For relractory eouduet, they uay he taken to the nearest magistrate, who orders purialimerst on the ontls of the nuster. The magis. triste has also power to send them to tho noarest chain.gang employed on frublie worlis. Hero they are worked it isolia, and kept on senty food for a limited period, after which they may be retumed to their masters. If bally treated, the conviet may bave the afiuir investigated, but retress comer sluwly.

Orie of the grent evilg of the system is, that many of the conviets on arriving are assigned to persons in Sydnoy and other tomma, the consc. quersee of which is that they aro exprased to the contaminations and temptations that nre likely to beset them in thone thuckly-peopled places, anil this too only a few months after their convietion in the mother country. Tlis infuenee remores nll hopes of reform, and they are usunlly soon foumd among the crimiuals of New Soutl Wales.

All persons who are landholdery mny receive conviets as assigned servants, in the proportion of one to every three hundred and twenty nerea, but no one proprictor ean have in his employ m us than seventy-fire conviets.

Written application fur labourerg is made to the Board of Assigmment, and the applicanta must biud themaclves to keep the assigned convict far at leate oxe month, and to furrish lim with foot and elothing agteenbly to the government reguhations, which are as follows, viz.

The weekly rations eonsists of twelve pounds of wheat, or nime pounds of seconds flour; or, in lieu thereof, at the diseretion of the master, three pourds of maize meal, ard nine pourds of wheat, or sereu pounds of seconds thour; with seven joutuls of beef or wutton, sal four pounds of corued pork, two ounces of salt, and two aumees of sopry.

The clothing for a yen $x$ is as followg, viz. two frocks or jackets, thitee shirts, of strong linen or cotton, two paiss of trousers, three prairs of sluess, of stout durable leather, one late or cap, and the use of a good blanket and mattress belonging to tho minster".

Cuslou, however, lan extented the shore nllow ances, as d tho quancity of luxuries added in tobaceo, sugar, teth, and grog, malieg the amount nearly double. "These additiont have becume absuIutely necessary its orier to procure work frum tho conviets, and the free supply of them is tho only way in which they ean be made to work in the harrest season. I whs infurmed tlant a settler conssilered it all-importatit to bave a large stock of these luxurieg on land at the season of pressure; for althouglt the assigned servants do sint notually refuse to work, they do so little, that, in ot'der to save his crop, the nuster must yiedd them the extra ivdulgenees.

Another evil attendant on the assignment system is the diffirence in the treatment they reseive from those to whom they are assigned. On the arrival of a convict-ship, it large number of persons whis lnve mado appiticntions to the Bond, are in wait irg ; they of course know nothing of tho elaraeter of the couvieta, and, as I learued from a gourb source, no recold is kept, or sent with the conviets thenselves. The Bonrd is entirely ignorant of their elinrueter or crimes, and thus enn exereise no discrimination in assigning the conviet. to the lnashds of a guod or of a lardi minster. 'I'he greatest villains may, therefure, fall irto hind lavds, while one who 
is comparatively innocent may suffer much more than he deserves.

The punishunent of traneportation must continuse very unequal ustil a elassification be resorted to. Many convicts, by bad treatment, are confirmed in their vices.

For any misbelunioul, they nre, na has been sech, sulject to severe castigation upou their master's making oath befure a magistrate. This tuot unfiequently drives the euljrit or convict to further crime, and in revenge for these wrongs, he either negleets his master's interest, or has been known to set fire tn lis liarvest when gathered.

'The present systen appeas fitted to entail evil and misery on the colony, and there are few disinterested men who do not view it as calculated to prevent any monal improvement. Murderg, robberies, and frads are bronglit about by it, for wlich extreme punishments are of such frenuent pecurrence that it is a matter of astonishment that a strauger sloould remark that an execution lial taken place. The day before our arriknl five criminals had been linng, and nore were to suffer in a few dinys.

These executiong take place witlout causing any tmusual excitement. T'Tere is little loubt that the conviet poptation contains among its nembers many of the most abandoned wretches, and I am also awne that the governor and council are making every exertion to put a stop to the imnin. rality and vice which so generally prevail; yet 1 an watisfied that the convicts who are assigned are, in some cases, gostled on to crime by the trentment they receive from their masters, who liold them as slaves, and degrzde them to the level of the beast with whom they are forced to labonr.

The season of our visit to Sydney was that of their summer (December), and it was somewhat diffieut for us to realize tho luxuriance of vegetatiun about us. We could hardly beeome familinr with windows and doors entirely open at Clıristmas time. Although it was properly the out-of-town senson, we found nuch gaiety existiug, and we have great pleasure in acknowledging the attentions and civilities extended to us during the whole of our atay.

The freilities for outfitg here are such as nre rot to be found elsewliere in the Paeific. Tho medsanics are good, lut as artisans are senree their wages are exorbitant, and the etsployer is, for the most part, compelled to put up with their dernands. From our experience, we inferred thoy nie not to be depended on, and requine to be welf watelied in obtain the requisite quantity of hbour from then. 'flheir rations of gtog were always a stipulation made by them, and lind to be compljed witl.

During our stay here, our men behaved well. They all received leave in their turn to visit the shore, and I felt gratificd in not having a single case reported to me of bad behavinur on shore.

As our departure drew near, one and all of us felt and expressed regret at leaving such kind frienda. In rery many places and families, we had fund ourselves at home, and were always received with that kinuness that slowed is we were welcome. The suscus, with many other things, may be reversed, yet the hospitality of old Engtand is foutud here ns whrn and frebli as ever it was in the parens land. It would be impossilute to mention all those to whom we feel indebred for varjous kindresses and attentions, or even in cite those from whom the experlition received many' neessions to its collections. Nutwithstanding I have mentioned many things that have struck us as requiring great reform, yet the whole impression left on my mind is, that it is a glorious culony, which the mother conntry, and the whole Anglo-Sixon race, may well be proud of, awd that it ought to clnim mush more attention than it apporenty does from the home goverument.

After writing our farewell Jetters, we took our Clyristmas dinner with many of otr friends, and on the morzing of the 26th December, 1839 , at six o'elock, we weiglied our anchors and stund down the bay. The day was fine, the breezo light and contrary, and we dirl not get to sea till the nfternoon. When we were abeut jassing the hends, our wortly consul and gome otliers of our countryment took their leave, and by way of dispelling the gloom that was naturally felt at parting, and to sliow the good wistses entcrtained for theit welfure, we gnve them at parting several heturty cheers, and thes bore away on our courre.

It falling calm, the Yincennes and tender were obliged to anchor between the hends. The Pencock and Porpoise suceecded in getting outside, snd when the tide made, we weighed and stood after them. On getting to sea, nithough every seareh. had been proviously made by the master-at-nirms, I learned that there were two strangera on bourd, who had contrived to evale lis watehfuhess, and on beating to quarters, and mustering tlue crew, they were among the fortheoming. Their appearance was any thing but convict.-like; but I felt after all the attentions henped upon us, it was seemingly but an ungrnteful return, to appear to lave committed an iufraction of their laws, nad this after I had received intimation lfrat an nttempt would be made, througli ns, to effect deserticu among the troops, From their appearance and carriage I thougtst they showed the drill of soldiers, and at once told them and the assembled erew, that they were mistaken if they exprected to be harboured as such, and that on my return from the south, I slould send them back to Syilney to bo delivered over. I then entered then on the rolls for provisions only, unti] I asecrtained whether they were entitled to receive couspensation; and nfter telling the men they must look forward to a harl and dnogerous cruise, and enying $\Omega$ fow words rolntive to what was expected of them by the coun. try and myself, I enjoined upon them the necessity of economy in their food nud clothing, in niding me in my endenrours to promote their health and comfort. We then piped down, and set about preparing the ship for the antaretio cruise, the events of which will be detailed in the following chapters. 


\section{CHAPTER XVIJ.}

\section{ANTARCTIC CRUISE.}

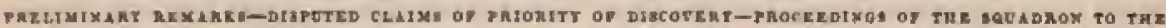

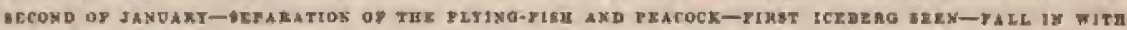

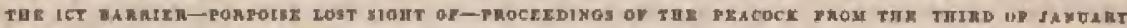

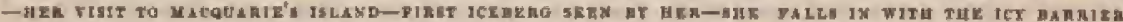

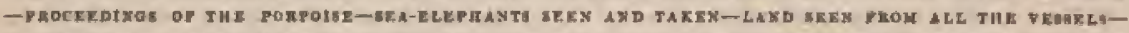

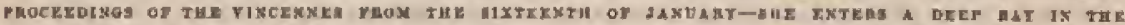

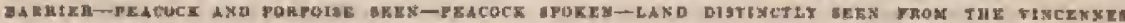

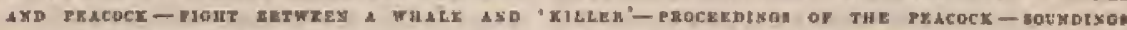

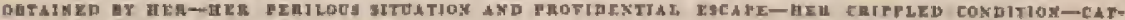

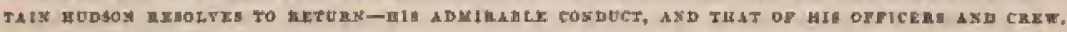

THE subjects of which I am about to trent in the fullowing ebapters are exelukively nautieal. I shall therefore adopt in treatitig them more of the form of a log-bovk, and follow the daily order of their occurrence with more strictness than I have hitherto considered necestary. 'This will be done in order to illustrate more fully the nature of the remote regions we traversed, and for tho purpose of giving a more exact relation of the iucidents of this part of our cruise,-incidents that I cunnot but hope have made this part of our labours particularly interesting to all of vur courtrymen who possess a feding of national pride.

The cretit of these discoveries hins been elaimed on the part of one fureign nation, and their extent, nay, netual existenee, called into question by anonher; both laving rival expeditions abroad, one at the same time, the other the year sueceding.

Each of these mations, with what intent I blatl not stop ta inquire, has esemed dispoed to rob us of the lonour by undermating the importance of their own rebearches, and would restrict the antarelic lnnd to the small purts they respectively Saw. However willing I might bo in a prinnte eupacity to arcid contesting thesir statements, and let truth make ita own way, I feel it due to the honour of our fing to make a proper assertion of the priority of the claim of the American expedition, and of the greater extent of its discoveries and rescarches.

Thut land does exist within the ontnretic circle is now confirmed by the united testirnory of buth French and linglish nasigators, D'Urville, the celebrated French navirator, within a few days after land was geen by the three ressela of our squadron, reports that lis bonts landed on a small poiut of rocks, at the place (its I suppose) which apperred accessible to us in Piner's Bay, whence the Vincennes was driven by a violent gale; this tre ealled Clarie Land, and testifica to his belief of the existence of a vast triet of hand, where our view of it has left no doubt of its existence. Rosa. an the otlier hand, penetrated to the latitude of $79^{\circ} \mathrm{S}$. in the succeeding year, coasted for some distance along a lofty country eosnected with our anturetic continent, and establishes beyond all cavil the correctness of our asgertion, thut we have discovered, not a range of detached islands, but a vast asturetic continent. I took care to forward to Captain lRoss a full account of the proceedingys of the arguadron. Although I lave never received any neknowledgment of their receipt from him peranally, yet I lave lieard of their having renched his hands a few monthe privr tu lis antarctic cruise. Of this, however, I do not emplain, and fed only the justifinble desire to maintain the truth in relation to a clnim that is indimputable. The following uarrative must, I feul sutiobed, leave no doubt in any uuprejudited mind of the correct. ne6s of the assertion that we have discovered a vast continerst; but I wouls ask in advance, who was there prior to 1840, citleer in this country or in Europe, that lad the lesst idea that any larye body of land existed to the south of New Holland $t$ and who is there that now doubts the fact, whether he admits it to be a vast enntinent, or corteuds that it is ouly a collection of islsnds 1

Examine all the maps and charts published un to that time, and upon them will any trnees of buch land be fonnd ! "They will not, and for the very best of renson- Done was known or even suspected to exist. Wo ourselves anticipated no such discovery the indieatiuns of it were received with doubt and hesitacion; I myself did sot venture 10 l'ecurd in my private jourtal the certaissy of lard, unil three dings after those hest nequainted with its apperance in these high latitudes wete assurved of the fnct; and finally, to remove all possibility of doubt, and to prove conclusirely that there was no deception in the case, views of the game land were tuken from the vessels in three different positions, with the bearings of its penks and promontories, by whose interection their position is nenrly as wefl establisherl as the peaks of any of the islands we eurreyed from the sea.

All doubt in relation to the reality of our dis. eovery graduslly wore nway, nnd towards the cloke of the eruise of the Vincennes along the icy barrier, the mountains of the antarctic couthent became familiar and of daily appearance, insomuch thint the $\log$-book, which is guardedly silent $\mathrm{ns}$ to the time aud date of its being first observed, suw sperks throughout of "the land."

After leaving Sydney we had, until the 3/at December, fine wenther and fuvournble winds. We wok adrantage of these, and all Enil wus crowded on the vessels of the squadron. Under such circumatnaces, the usual order of sailing, in s line ahreast, was easily maintained, and the comnunicaliuns between the vessels there frequent. 
At the above dato wo had renched the latitude of $43^{\circ} \mathrm{S}$.

During this faroumble wenther, all hnads were employed in tightening the ports, in order to secure the interior of the ressels ns much as possible from the cold and wet, which were to be apprehended is the region to which we were bousd. For this purpose, sfter ealking all the openings, the seans were covered with tnried eanvass, over which strips of sheet-lead were nailed. The sailors exhilited great interest in these preparations, and studionsly sought to make every thing snug; all useless articles wero stowed aray in the hold, for we were in truth full to overflowing.

Among other preparntions, rough easings of boards wore built nround all the histches, haying doons furnisherd with weights and pulleys, in order tu ensure that they strould not be left open. Hav. ing thus provider for the exclusion of culd air, I contented myself with preparations for keeping the interior of the vessel at a temperature no higher than $50^{\circ}$. 1 deemed this preforable to a higher temperature, in order to prevent the injurions effects which anight he produced by passisg surldenly from below to the veck. I conceiven it far more important to keep the air dry thas warm, particularly as a lower temperature wothld lave the effect of inducing the men to take exercise for the purpose of exciting their animal heat.

Aware that wartx issul dry clothing was all ubject of the first importance, inspections of the men's feot and dress were held moming and evening, in which the wenring of a suitable number of garments was ingisted upun, as well ah the grentest perronal cleauliness. With the same riews, the drying-stoves were particularly attended to; and thit every part under deck migit be effectually atsd quickly freed of moisture, additional stoves lind been procured at Sydney. Thermometers woro litun up in proper nluees, and frequestly cotsnulted, in order by following their indications to gecure all equablo temperature, and at the time to ascerkain when the use of stoves might be dispensed with, in whole or in part. The lntter was an important considention, for we were under the necessity of husbanding nur stock of fuel, by expending it only when ahsolutely necesanry.

We also took ad rantage of the fine weather to bend all our best sails, and to shift our top-galiant masts.

The 1st January, 1840, was one of those days which aro termeil, hoth at sea and on shore, a weather-breeder. The sea was sinootl and placid, but the sky was in places lowering, nod had a wintry cast, to which we had long leen gtrangers the semperature shortly began to fall, the brceze to inerease, and the wenther to become misty. In a few hours we were sailing rapidly through tho water, with a rising sea, nur by midnight it whs reported that the tedder Flying-Fish was barely visible. I shortened snil, but it was difficult in stop our way; and on the moruing of the and if January, the fog was dense, and the Percoek and Porpoise only were in sight; we hove-to, and the Peacnek and Porpoise were ordered to stand east ard west, in order to istercept tho tender, but they relurned without sucesess; we also fired guns in lopes of beimg lieard. In the ufternoun, I deemed it useless to wait any lunger for her, and that 1 must take the chanes of falling in with her at
Macquarie Island, our first appointed jilace of rendervous, $\mathrm{A}$ Fisit to which $/$ had finttered $\mathrm{my}$ solf itight hare been avoided, but which it beenme secessary now to make. We accordingly proceeded on our course for that island, with all sail set. This sepuration of the tender took place in the latitude of $48^{\circ} \mathrm{S}$. and she was not again seen until our return. The officers and crew were not slow in assigning to the Flying. Fibla a simitar fate with her unfortumate mate, ilso Sun-Gull. Men-ofwar's mets are prone co prognosticate evil, and on this ocension they were not wanting in varions Eurtnises, Woeful sccounts were soor aflost of the distress the schomer was in when last Been, and this in quite a modernte sea.

The barameter now hegan to nssume a lower range, and the temperatore to fall bolow $50^{\circ}$. On the $3 \mathrm{rd}$, the fog continuing very thich, the Peacirek got beyond hearing of our horus, bells, drums, and guns, and was parted with. 'This, however, I did not now recret 80 much, as it was of little conseguence whether we sought oue or two vessels at our reudezvous, although it might cause a longer deleation there.

The morning of the 7 th wa misty, with squally weatier. A heavy sea rising, and a otrong gale setting in, we lost sight of the Porpoise for a few hours. Being mable to see beyond an eiglath of a mile, it wna dionght inprulent to run, for fonr of passing Macunnrie Islant, and we love-to to await its modemtimg. It elesreal at noon, and we obtained an observation, by which we found nurselves in latitude $64^{\circ} 20^{\prime}$ S, and langitude $160^{\circ} 47^{\prime} \mathrm{E}$. I found that we had been carried to the enstward upwarls of twenty miles in less than eightees hours; this, witl the wind hatling ta the southweat, bromght us to leeward of the island, and the sea and wind increating, I gaw it was nseless to attempt to renelt it without great loss of time. I therefore bore off th the southwarl for our second rendezvous, Emerald lsland, or ils stuppoed loenlity.

During the thi we passed the sito of Emernid Isle, situate, as has been otated, in Intitude $57^{\circ} 15$

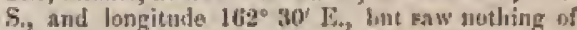
it, nor nuy indiestions of land, which $J$ therefore infer does not exist in the locality where it is laid down. We again experienced the south-rast cus. rent of ewenty miles a day. Our wariation Jiad increased to twenty-two degrees ensterly. Making our course with afl sail get, the Porptise in conspany, we passed to-dny some prices of kelj, The tempernture continued at $33^{\circ}$. Numerous Hochs of grny petrels around us.

The 10th we esconntered the first jeeberg, and the temperature of the water fell to $32^{\circ}$. We passed close to $\mathrm{it}$, and found it a mile long, and one humdred and eiglaty feet in height. We laad now renclied the latiturlo of $61^{\prime \prime} 8^{\prime} \mathrm{S}$., and longitude $162^{\circ} 32^{\prime} \mathrm{E}$. The current to-day set in the same direction as before, ubout half a mile per hour. T'he geeoul ieeberg eeon was thitty miles, nud the third abont tifty-tive miles south of the first. Thege ice-islands were ajparently much Worm by the sea foto cavities, exhibiting fissures as though they were rendy to be rent asunder, and ahowed iu npparent stmutifiention, much inclined to the horizon. The weather now beenme misty, nnd we had oceneionully a little snow. I congratulated myself that we had but few on the kicki-list, and all were in high gririts at the novelyy of the cruise. 
We coutinued ta meet icebergs of different heights, sonse of whicli, theugh jinclined to the horizon, had st plane upper surface.

$11 \mathrm{~d}$, Ille fair wind from the north-west (nceompanied with a light mist, renlering objects on the horizon indistinot) still enabled tas to pursue our course southerly, leebergs becnme so mumeruns sa to compul us oecasionaliy to clanige our eourse. They continued of the same claracter, with caverns worn in their perpendicular sides, and with flat tops, but the latter were now on a lins with the horizon. Towards $6 \mathrm{P}$. $\mathrm{k}_{\text {., }}$ we began to pereeive sinaller pieces of ice, sone of which were not more than an eighth of a mile in length, floating as it were in smnil patches. As the icebergs inereased in number, the sea became smoother, and there was no apparent motiun. Botween 8 and 9 r.M., $n$ low point of ice wns pereeired uhend, and in a short time we pasaed within it. Thero was now a large bay before us. As the vessels moved ripidy, at $\mathrm{J} 01 \mathrm{P}_{2} \mathrm{M}_{+}$we had roached its extreme liusits, and fouml our further progress entirely stapped by a cosupact barrier of ice, enclosing large square iecbergs. The burrier cumsisted of masses elosely packed, and of every variety of shape and size. We hove+to until fult daylight. The night was beautiful, and every thing seemed suml in sleep, except the somul of the distant and low rustling of the ice, that nuw nnd then mot the ear. We had now reached the Intitude of $64^{\circ} 11^{\prime} \mathrm{S}$, longitude $164^{\circ}$ $30^{\prime} \mathrm{E}_{\text {, }}$ and found our varintion twenty-two degrees easterly. One and all lelt disappointed, for we had flattered oursolves that the way was open for firctser progress to the southward, and had imbibed the impression (from the extraordinary wenther we hal had at Sydney, and the reports of iculsergs having been seen further to the northward than usual, hy all the ressels arriving) that the season would be an open one. What surprised use most was a change iu the colour of the wnter to an oliwe-green, and some faint appearanees resembliug distant lasd; but as it was twiliglit, and I did not believe the thing credible, I put no faits in these indieations, although some of the oflicers were castfident they wero not necasioned by ieebergs. The barometer stood at 29.200 in. ; the temperature of the air $33^{\circ}$, water $32^{\circ}$. We lay-to until four o'clock. A $\mathrm{B}$ it grew light, on the 12th, a fog see in so thick that we lost sight of the Porpoise, and could not hear any answer to our signals. I therefore deterunised to work along the barries to the mestward.

We were all day beating in a thick fog, witl the bartier of iee elose to us, nnil ocensionslly in tacking brought it under our lwow; at other times we were alrwost il contact with icebergs. During the whule day wo could not ase at any time further than a quarter of a mile, and seldom more than the ship's length. The fog, or rather thick mist, whs forming in ice on our rigging. From the novelty of our situation, and the excitement produced by it, we did not think of the danger.

I slunll now lenve the Viucennes and Porpoise pursuing their course to the westward with a liead wind, and bring the Peacoek up to the barrier.

Previously to parting compuny on the 3rd of January, the crew of that ship had also been engated in builsing hurricane-houres, calking, and chintzing, to secure them from the wet and cold. After parting company, Captain Hudson imme. dintely steerod for the first retadezvous, Macquaric
Island, and was mnre fortunate than we wero in reacliusg it, allfrough the Peacock had experienced the same kisd of weather that we had, asul currents senting to the eastward.

On appronehing the jaland, they discovered large patches of kelp, and anw numervis procellaria and aluntrosees nbunt the shipp. On the lotls of Janunry they made the island, anil uluarved a reef of rucks extending three-quarters of a mile off its south entl. Pasising within a slyort distance of jt, they did not observe any of the signals of the squadrou fying as they had antiedpated. T'loy, notwithstmuling, stood in, lowered a boat, and deajuateled several ufticers to put up the signal, make experiments, and cullect epuecinens. T'he boat approached an inileutation on the west side, too ofien to bo enlled a bay, and found that the sarf was running high, nted henting with grent violenee against the rocks, which, together with the kelp, rendered it dangerous to atteinjt landing. They mate for several other places which louked favourble at a distauce, but on approachitig them, they were found even less nccessible. The hoat then returned to the first place to nake mother actenut, which was attcuded with great difticuly: The boat's anchor was dropped, nul alze was backed in with great caution to the edge of the rollers; the surf was very high, sud rolled in with a noise like thunder, hreating furiously upon the rocks, so as to make the boat fuirly tremble, and threatening every moment to uverwhelm her; once or twice she was preverutel from getting brosidside-to by tratuling out towards her anchor. At length, after a dozen fruilless attempta, and awaiting a farourable opportunity, $\mathrm{Mr}$. Elt and a quarter-raster sueceeded in geting asfore, but nut without being inmersed up to their breasts. It was found im. possible to land any instrunents; and the quattermnster was despatched to erect the necessary siguals, while $\mathrm{Mr}$. Elil proceeded to visit the perguin-rookery not fut distant. On appronehing the island, it tial appeared to be enverchl with white spots : these excited conjecture; but after landing, the exlaslations rendered it wot long doubrful that it was birdline.

Mr. Fill, in his journal, gives the following account of his risit: "Althougl I had heard no aften of the grent quantity of birds on the uninlubiter istands, I was not prepared to see them in such moriads as here. The whole sides of the rugged hills were literally covered with them. Haring passed a deep fissure in the rocks, 1 ascended a crag that led to what I thought was their principal roost, and at every step my astouishment increased. Such a din of squeaking, squalling, and gabbling, I never befort lieard or dreamed could be made by aty of the featljered tribe. It whs improssible to hear one's self speak. It appenred as je every one was vying with his neiglhour to malse the greatest possiblo sooise. I goun found my preseneo particularly displeased them, for they smpped at me in all directions, catching hold of my trousers, shnking nnd pinchitng my flesl so violently as to make ne flincli nud stand upon the defensire. $\Lambda$ s we wanted a number of specimens, I commeneed lsicking them down the precipice, and knocked ot the head those which had the tentrity to attack me. After having cullected a number, nud a few eggs, I laid them nside, whilst I ascended higher on the hilf. I had not left them к. 2 
more than eighteen feet, before two albatrusses came down, and commenced picking at the dend birds I bad just killed, lut not boing able to mako any imprestion upon ilem, detiberntely piched up two of the eggs with their beaks, and in spite of my efforts to prevent it, flew away with them. I'he eggs were nbout the size of a guose's; the original colour secrmed to lave lieen white, but they wero so dirty that it was difficult to say with certainty. 'They were no doubt the eggs of the persnin, as I took them out of their nest, which was only a sinnll place semitelied in the enrth, just big enough to hald ane or two eggs, with litule or no grass, sticks, or any thing else to furns a neet of. I afterwards pieked up $n$ number of these eggs, nnd anvilier was found of the sizo of a hen's egg, white, with a Elight tinge of green, On mounting the hill stifl higher, whiseh was very stcep, minl etmposed of vulcanie rock, loose stones, and a little soil nixed with birdlime, I found that there were nore of these birds thas I anticipated. The nusta were within two feet of each otlıer, witl one or two ynung ones in each; one of the old nnes watching and sinting on the west, whilst the young were trying ineffectually to nestle themselves under the small wings of the old ones. The appenrunce of the young was not utilike that of goslitigg, being covered with a dark thick down.

"Tlese penguins are the eudyptes elirysoevme; they are from sixteen to tweesty inclies is lieight, witl white breast and nearly black latek, tho rest being of a dark duve-colour, with the exception of the head, which is adomed on each nide with four or five yellow feadiers, three or four inches long, Jouking like grnceful plumes. The birda stand ereut in rows, which gives them the aprearance of Liliputian soldiers. T'he sight was novel and beautiful, sud laad it not been for the gabble,- cmough to deafon me, - I could have stayed muets louger. It was now time to return to the brat, when it occurred to me tlat live birds would be preferable to tlye dead; so throwing the latter down, I seized one old and a couple of young ones, and with three or four egrg in my cnp, made the best of my way to the boat. It was now found impossible to hand them on bonxd, and not willing to surrender my prize, a lead-fine was tlarown me from the bont, but did not come tsear enough, and in my attempts to get it, I was overtaken by в sea, and was throw' violently against the rokks nmong the kelp, and just made out to ernw] on hnnds and lenees beyond the reach of the returning seat, somewhat bruised, wet, anil benumbed wilh the cold."

At this juncture thie qunrter-master returned with a large species of pernguin oser lis slioulders, lut without the crown of lealliers an lis head. He described a minilar rookery, and alko saw some green paruquets with a smail red spot on the liead, and an ublong slaty or purple spot at the root of the bill, and with straight beaks. Mr. Eld was too much exhausted to return with him so get specinens, ant the hour being late, it was necessary to return to the bont, wlich had been waiting for some time for tlum. Thie quarter-master succeedod in getting bis penguins to the boat, that Mr. Eld's legan foundering about, anil although their legs were tied, mantaged to get intu the water, where they were at home, and wert soon out of reach. Thie tying of the legs diuk not seem sny impediment 10 cheir exemiuns in the water, and thus several interesting specinens of natural hiswry were Inst, the trouble that it cost making thein denbly valuable. With great diflictly $\mathrm{Mr}$. Eld reached the bont; for, having again niesed his forthuld, be fell smong the kel], but ly the timely nid of those on bontul he was reseued. After nn hour's tug at their ours, thay renched the slip in senfety.

The south end of Macquarie Isinnd lies in fatitude $54^{\circ} 44^{\prime} \mathrm{S}$, and longitude $159^{\circ} 49^{\prime} \mathrm{E}$. 'The island is ligh and mucl, broken; it is apparenty covered with verdure, alitudugls a long tufted rank grnss was the only plant seen ty those who banded.

The lighest peali on the istand is fom twelve to fiftere linudred feet ligh, and as far as our observa. tions excented, it had neither tree nur shrub on it. At 6 r.m. the ship filled awny, and at eight was abreast of the Hishop and Clerk. Minetzunria Island affords no inducement for a vibit, and as far as our examination weut, lass no suitalle place for landing witl a boat. The sisly tliung I bad to regret was not being able to tnake fi a magnetic station.

On the 11 th and 12 th nothing particular oceurred on board the Pearock. All sail was set, and run. thing to the southward on lie $13 \mathrm{th}$, in latitule $61^{\circ}$ $300^{\prime}$ S., longitude $161^{\circ} 5^{\prime}$ E.e, tle firzit ice-islunds were seen. The dip was observenl with Lloyd's and Dolland's seedles, whicl made it $86^{\circ} 53^{5}$.

There was no oceasion on the nightt of the 13th to light the binutele-dampa, as newh could be read witl ease at tmilnight. On the 14th, while still making musts progress to the south, aud passing ocensionally icelergy and brast ice, the water sppeared anmewhat discoloured. Rolinsou's, Lhy d's, and Dolland's needles, gave, the same day, in the enbin, $86^{\circ} 37^{\prime}$ for the dip, and in the wardruom, $46^{\circ} 46^{\circ}$. Albatrosses, Cape pigeuns, and oher birrls atront.

On the 15th, they passed many ice-islands. The weather was thick, and suow feli at intervals; the wird continued from the westwarl. Many wilıles were secn; nlbntrosses, petrels, and Cape pigeons were frequent abut the ship. At 4 P.M. the nist raised a litlle, and to their surprise they snw a perfeet barrier of jee, extending to the south-west, with severnl large jeebergs enclused within it. Shorty after they discovered a sail, which prowed to be the Porpoise.

The Vincentues and Porpoise were left in our narrative near the fey barrier, separated by the fogs and mists that prevniled at times. The l'orpoise, on the $13 \mathrm{th}$, in latitude $65^{\circ} \mathrm{V}^{\prime} \mathrm{S}_{\text {. }}$ lamgitude $163^{\circ} \mathrm{E}$, discovered several sea-elepilanta on the ice, and sent a lont to enpture them, but without success. The current wh tried, and found to ser west one-fifth of a mile per hour. Some time afterwards, seeing some sun-elephnita near the edge of the ice, a boat was stut, and succeuded in capturing a female. From the numerous sea-elephants, and the discoloration of the water and ice, they were strongly imgrresaed with the idea of land beilig in the vicinity, but on sounding with one husdred fathoma, no buttom was found; LieutenantCommandant Ringgold felt convineed, from the ahove circumstnnees, and the report that penguins were honrd, that land was near, and thoughic be cusuld diseern to the south-cast bomething like dimtant sountaing. A nearer approach was iupussible, ag they were then in ectual contact with the jey Latrier. 
On the 14 hi, two sea-eleplinits were seen lying motionless on the iee. On letilng shot at, the muimal wonth mise its head and louk nround for an instint, surd then tusume ily forner posture. Bloats were lowered, when they were captured and brought on board: they proved to be the phrea proboseidie. Dr. Holmes examined their stotnachs, and found nothing but well-digested food, Their dimensions were as follows:-

Tutal lemgth

Length of ponterior mpiper

Hreadih

$10 \mathrm{f} .9 \mathrm{in}$.

Circumferetuce of largest part of body -6 il $\mathrm{g}$ wif

This was a young female. The other was taket afterwarls ; lie measured-

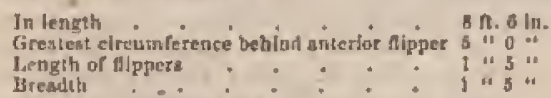

On the 15th the Pencock and Porpoise were in company: the apeeimens of sea-vephauts were put on board the Pencock; and, ster linving liad enm. numication with each other, the vessels sygain separated, stauding on opposite tacks.

On the J bith the three vessets were in Inngitud $157^{\circ} 46^{\prime} \mathrm{E}$, and all within a slurt distonce of each anviher: The water was much dikeoluured, and many albatrosses, Capo pigeons, and petrels were seen sbont the ahips. On bontrl the Yincenues, we sunnded with two hundred and thirty fathoms, and fourd no bottom: the water had the appouranee of an olive-green colour, as if but forty and fifty fathons deep. At the surface, its tempenture wis $32^{\circ}$, at the depth sounded, $31^{\circ}$. I shorsld have trieil for a deeper cast, but the line was seen to be stranded, whetl we were obliged to stop ; wo fortunately sared our apparatus, with Six's thermometers.

On this lay (16th Janunry) appenrances belieset at the time to bu land were visible finn all the three vessuls, and the conzarison of the thice atherstions, when taken in counexion with tho thore positive provols of its existonce afterwards olstrined, lias left no doubt that the appenrance was not ileceptive. From this disy, therefore, we date the diseovery which is elaimed for the squadron.

On buard the Peacock, it appetury that Parsed Midshimnen Eld and Reymolds both saw the Innd from the masthead, and reporten it to Captain Hudson: he was well satisfied on examination that the appearance was totally distinet from that of ice-islands, and a majority of the ofiecrs and men were also antisfied that if land could exist, that was it.

I mention particularly the names of these two gentlemen, because they have stated tho sonse faet under oalb, before dhe court-surtial, after our return.

On buard the Porpoise, Lieutenant-Conmandant Riuggohd states, that "lio went sluft in the afternoon, the weacher being clear and fine, the horizon good, and clouds lufty; tlat ho saw over the fieldice an ulbject, large, dark, and rounding, resernbling a musntain in the listance; the icebsigs were alt light and lyrilitut, and in great contmst." He goes on to say, ill his report, "I wacehed for an hour to see if the sun in his decline would change the colutir of the object: it remained the samo, with a white cloud above, similar to that bovering over ligh land, At sunset lite sppearntice re mained the sane. I thok the bearings accurately, intending to examine it clusely as soun as we gat a breeze. I am thorrughly of opinion it is an island surrounded by inumense fields of ice the J'encock its eight to the gouthward and eastward over the ice; the sun get at a few ninutea before ten; soon after, a light air from the Buuthward, with a fogbank arisius, whiels quickly shut out the field-ice."

In Prosed Midshipman Eld's jourual, he asserts thut he lutd been several tines to the sumsthead furing the day, to view the burrier; that it was not only a bartier of jee, but one of terra firma. Passed Midshipman lReynolds and hinnelf exelaimed, with nie neeord, that it was land. Not trusting to the naked eye, they deseended for apy. glasses, which confirmed, beyoud a doubt, their first infuression: The mountains covld be digtinetly seen, over the field-ice and bergs, streteling to the south-wert as far as any thing could be discorned. 'T'wo jeaks, in partieular, were very distinct (which I have named after tlose (wo officers), rising in a conical form ; nnd others, the lower parts of whish were quite as distinct, but whose sumnnits werte lost in light theocy clourls. l'ew clouds were to lo seen in any otlier direction, for the weather was ramarkably clear. The sus shoue brightly on ridge after ridge, whose ailles were partially bare; these connected the eminences I have just apoken of, which nust be from one to two thousand fect high. Mr. Eld further states, that on Eeporting the discovery a Captnin Hudson, the Intter replied that there whs nn doubt of it, and that he believed that inost of the scebergs then in sight were aground. At this time they were close in with the barrier, and could approach an nenrer. On this day, thie Peacoek got a cast of the deep-ser lend, with Six's thermometer attuched, to the depilh of eight hundrod and fifty fathoms, only is short distanee fivon the barrier: the tempernture of the surfwee was $31^{\circ}$, nnd at the depth sounded, $3 H^{\circ}$; curront one-fourth of a mile, north-by-uast.

"I"le log-bonk of the Purpnise lias also this notice in it: "From six to eight, calin and jleasant,took in studidint-Bails; st seven set main-topgallantsturding-aril ; disonvered what we took to be an island, bearing south-by-east, $-\mathbf{n}$ great deal of fieldice in sight: noticed peoguims arvund the brig. (Signed) J, 1. North." Dr. Hoimes, on the sinne evening, noted in his journal, n marked appeurance of land.

On honrd the Vincennes there was on the same day much excitement among the crow. All eagerly watched the flight of birds, together with the whales and penguins, and spolee of the proximity of land, which, frors the appenmece of never-failing signs, could scarcely be doubsed.

The fiold-ice is comprosed of a vast number of pieces, varying in nize, and separated from one nnotlier, the fong swell keeping the outer atres alwny in motion. The amallest picces are abnut six feot in dinueter, while the largost sometimes exceeded five or six hutudred feet. Their depth below the surfnce varjes still more, and nome appenr to be soft, whilet stherg wero hard and compact. The depth of these dnes not probably in any cose exceed twenty feet. Most of them, and particulariy the larger ones, had a movering nf about cighteen inclies of snow, Ithe wlolo at n distance appeared like s 
rast level fielu, broken un as it were by the plough, and presuting shapeless angular nasses of every posaible tigure, while here and there a table-topped iceberg was encluaul.

'This night we were beating witlı frequent tacks, in order to gain as much soutling as possible. Previous tu its becoming broud dayliglst, tho fog rendered every thing oliseure, even al a short dittnnce from the slip. I knew that we were in close proximity to icebergs and field-ice, but, frotn the report of the louk-out at sunzet, believed that there was an opening or large bay leading to the southward. The ship haul rapid way on her, and was much tossed about, when in an itstant al] was perfectly atill and quiet; the transition was so sud. den that nany were awakened by it from sound sleep, and all well knew, from the short experience we had had, that the cessation of the sound and motion usual at sen, wns a proof that we had run within a line of ice, an necurrence from which the fecling of great dauger is inseparable. The watch was ealled by the officer of the deck, to be in roadiness to execute such orders as might be necessary for the safety of the ship. Many of those from below were seen burrying up the batehes, and thowe on deck strnining their eyes to discuver the barrier in tirne to avoid aceident. The strip still moving rapidly aloug, some faint hope remained that the bay might prove a deep one, and ensble me to antisfy my snnguine hopes and belief relative to the land.

The feeling is awful and the uncertainty most trying thus to euter within the icy barrier blindfolded as it were by an impetietrable fog, and the thought constantly recurring that both ship and crew were in imminent danger; yet I was satisfied that nothing coudi be gained but ly pursuing this course. On wo kept, until it was reported to me, ly attentive listeners, that they heard the low and distant mastling of the ice: suddenly a dowen voices proclaimed the barrier to be in sight, just ahead. The ship, which a moment lefore secmed as if unpeopled, from the stillness of all on bonrd, was instantly alive with the bustle of performing the evolutions necessary to bring her to the wind, which was mofavommble to n return on the same track by which we lad entered. After a quarter of an huur, the ice was agaia made shead, and the full danger of our situation was realized. The ship was certainly embayed; and although the extent of sea-rvom to which we were linited, whs rendered invisible by the dark and murky wealher, yet that we were closely circurnseribed was evident from having made the ice so soou on either tack, and from the andible rustling around us. It requijed sevoral hours to extricate tle ship from this bay.

Few are able to estimate the feelings that sucl an nochsion causes to a commander, who las the responsibility of the safety of ship and crew ope. rating as a heavy weight upon his lieart, and producing a feeling as if os the verge of some overwhelming calamity. All tends to satisfy him that nothing could guide him in safety througl, or shich [rom destruction unse who lave been entrusted to his eluarge, but the band of an all-wise Providence.

17th. In the morning we discovered a ship apparenty within a mile of us, to which we made sigual and fired a guis, but she was shortly after. wards lost aight of. We also saw the brig th the enstward, close to the barrier of joe. In the afternuon we spoke tho Pearock: she had not seen us in the morting; and I strould be clispoed to belicre that the cause of her imago appearing $\mathrm{Bo}$ close to us in the moming was produeed by re. fraction above a low fog-bank; but the usual aceumpasituent of such phenomena, a difference of temperature below and afort, did not exist

I now desired Captain Hudson to mako the best tise of lis time in exploring, as to attenupt to keep company would only impede our progress, and without adaliug to our safety, might prevent the opportunity of examining the barrier for an opening. I was also eatisfied that the separation would be strong ineentive to exertion, by exciting rivalry among the officers and crews of the differeut vessels. This day at noon we were in tatitude $66^{\circ} 20^{\prime} \mathrm{S}$., longitude $156^{\circ} 2^{\prime} \mathrm{E}$. Many petrels, albatroses, a few whales, and a seal, were seen from the ahij!; and the water wns quity green.

18th. The weather this day was variabie, with light westerly winds; the temperature of sir and water $32^{\circ}$. Oecasional squalls of snow and nuist occurred, but it was at times clear. The water was still olive-green; and the other vessels occasionally in sight, beating to windward.

On the morning of the $19 \mathrm{th}$, we frumd ourselveg in a deep bay, and disenvered the Pexenck standing to the Boutli-west. Until eight n'eluck, A.4., we had a moderate brecze. The water was of a darker olive-green, and had a muddy appearance. Land was now certainly visible from the Viucenues, both to the south-south-enst and south-west, in the former direction most distimotly. Bolli ajyenred high. It was between eight and nine in the murning when I was fully satiffied that it was certainly luul, and my own opinton was confirmed by thint of some of the oldest and mont experienced seamen on bourd. The ofticer of the morning wateh, Lientenant $A$ ken, sent twice, and called my attention to it. We were at this time in longitude $154^{\circ} 30^{\prime}$ E., latitude $60^{\circ} 20^{\prime} \mathrm{S}$; the day whs fine, and at times quite clear, with light winds. After divine service, I still sa w the outline of the land, unchnnged in form, but not so distinet as in the morving. I3y noon, I fround we were anggirg on to the barxier; the bonts were luweled in consegnuence, and the ship towed uff. The report from atoft was, "A continued barrier of ice around the bay, and no opening to be seen, having the western point of it lenring to the northward of west of us," I stood to the westward to pass around jt, fully assured that the Poacock would explore all the outlines of the bay.

The Peacock, at ith $30 \mathrm{~m}$, according to Captain Hudson's jourmal, laving got into the drift-ice, with a barrier still aluead to the west, tneked to the south-east to work uj for an immense mass, which had every appearance of land, and whieh was believed to be euch lyy all on horrd. It was seen far beyond and towering alrove au ice-jaland that was from one bunilred and fifty to two hundred feet in heiglat. It bore frun ilsem about routh-west, and liad the nppenrance of being three throusand feet in heiglit, forming a sout of asmplitheatre, looking gray and dark, and divided into two distinet ridges or elevations throughout its cative extent, the whole being covered with snow. As there was no probability of gerting nearer to 
it in this quarter, they stood out of the bay, which was about twetity miles deep, to proceed to the westward, hoping to get an opportunity to approad the object more closely on the other aide.

He hud a bentiful and unumal sight presented to us this night: the sun and moon both sppeared above the lwrizon at tho same time, and cuch throwing its light abroud. The latter was nearly fult. The forner illuminated the jeebergs and distant consinent with his deep golden rayt; while the hatter, in the opposito horizot, tinged with silvery ligit the clouds in its immediate neighbourhuod. There now being no doubt in nry mist of the discovery of lnnd, it gave an exciting interest to the cruise, that appeared to set axide all thought of fatigue, and to make every one willing to eneounter any difliculty to effect in landing.

20th. This day, on bonrd tho Penenck they wit. neased a sen-figlit between a whale and ane of $\mathrm{i}$. many enemics. Tho sen was quite smooth, and offered the best jossible view of the whole combat First, ni a distunee from the ship, a whale was oeen flotudering its a most extraordinary way, lash ing the sinooth sea into a perfect fonm, nud en deavouring apparenty to extrieats himself from some anmoyanee. $\Lambda \mathrm{s}$ lie appronched tic ship, the struggie continuing and beconing more violent, it was perceived that a fish, appurently about tweuty feet long, lield him by the jaw, lisis contortions, strouting, and throes all betokeuing the agory of the huge monster. The whale now threw himself ac fall length from the water witl open moutl his purzuer still loanging to the jaw, the blood issuing from the wound and dyeing the sea to a distance around; but all dis flomblecings were of no avail; his pertinacinus enemy otill usintained his hold, and was ovidendy getling the advastoge of him. Much alarm seened to be folt by the souny other whales around. "These "killess," as they ne called, are of a brownislı colour on the back, and white on the belfy, with a long dorenl fin. Such was the turbulenee with which they passed, tlint n gond viow coulut not lae Jad of them to make (unt more nearly the deseription. These fish attack a whale in the snmo way as dogs lait a bull, and worry him to dentl. Tliey are armed witl strong Bharp tecth, snd geacrally seize the whale by the lower jaw. It is said thint the only part of them they ent is the tongue. The whalers give sotno marvellous aceounts of these killers and uf their irmanse strength; smong therrs, that liey bave been known to drag a wiale away from sovern. bonts which were towing it to the slip?

There was a great quantity of animalcule in the water, and sotne large squids (meduste) and quan. tities of ahrimp were frequently seen about the iceborga; theso are no doubt the attractions which bring whales to frequent these seas.

The last two days we lad very mnny beautiful snow-white fretrels about. The churneter of the ice Jnd' now becoure entirely changed. The tabularformed iceberys provailed, and there was com. paratively little fiehl-ice, Sonte of the bergs wero of magraificent dimasious, one-third of a mile in length, and frow ano lumdred and filty to two hunurend feet in height, with sides perfeetly smooth, as though they had boeu chiselled, Others again, exhibited lonty arelies of many-eoloured tints, leading into deep eaverms, open to the swell of the sen, which rushing in, produced lotud and distunt thunderings. The tliglit of birds passing in and ont of these enrems, recalled the rueollection of ruined abbeys, castles, and caves, while liero and there a bold projecting bluts, crowned with yinnacles and turrets, resembled some Gothic keep. A bitte further unwarks would be seen a rast fissure, sa if sone jowerfu? force lud rent in twnin these mighty mosses. Every noise an bon rd, even our own voices, revertyerated from the massive and pure white walle, These tabular lergs nre like massea of beantiful alataster: a verbal description of them can do little to cunvey the reality to the imaginntion of wie who has not been muong them. If an im. mense cily of ruined alabaster palnees ear be imagined, of every variety of shapo nnd tint, and composed of liuge piles of loulldiugs grouped together, with long lines or streets winding irregularly through them, some faint iden tray be formed of the grandeur and beatsty of the spectnele. The time and eircumstances under which we were viewing then, threading our way through these yast hergs, we knew not to wliat end, left an impreseion upon the of these icy and desolate regions that can never be forgotten.

22nd. It was now, during fine wenther, one contimued day; but we lind occasional snow-Enualis that produced an obseurity that was tuntalizing. The lergo wore so vast and innecessible, that there was no possibility of landing upon them.

The Peaceck and Porpoise were in sight of each wher this day. A large nutnber of whales, n1. batrobses, petrels, penguins, \&c, were seen arounil, and a flock of ducks whs also reported as having been seen from the Vineentses, as well as sosernl seals. The effect of sunrise, at a little after 2 A.nt. on the 23 rd, was glerions.

As the events which oecurred on board the Peacock during the next few days are partieulnrly interesting, I shall proeed to anrato them in detuil, learing the Vineentich and Porpoise to pursue their route along their dangerous and novel pathway.

The Peacoes stood into the bay which tho Vincennes had found closed the day uefore, and maw the satre appenrance of light laud in the distance. The water was much discoloured, and of a diark dirty green. They hove-to, for the dunble purpose of getting a cust of the lead, and of lowering the boals to earry tho instruments to a sanall icebers, on which it was possible to lnnd, for tho purpose of making magnetic obsoryations. A line of one thouennd four hundred falkoms was propared to sound, ard to the lead was altached the cylinder with Six's thermometer. The wind being fresh, several leads at different clistances were attached to the line. They were not aware that the lealline tad touched bottom, nntil they began to hatal in, when it was found that the lead bent on at fre hundred fathons was filled with blue and alnte. coloured ruud. Attached to the lead also was a piece of stone, and a fresh bruige on $\mathrm{it}$, as though the lead had struck heavily on rock.

The remainder of the lime had evidently lain on the bottom, ns the eupper eylinder was covered with rnusl, and the waler insido of it whs quite unddy. They then beat up a short distance to windward, and again sounded, when, with the Jine hangirg vertieally, bottom was reached at three luadred and twenty fathoms; the inatter 
brought up was shate-coloured mud. The temperature of the water at the eurface was $32^{\circ}$, ard at the above depth $271^{\circ}$, Jeing a decrease of $41^{\circ}$.

'The boats now' returned, and on approacling the ship the persous in them were much startled by hearing the crew eheor ship in consequence of finding soundings. This was a batural burst of joy, on abtaining this uniquestionable proof that what they asw was indeed the lats ; a circumstnice that, whilo it left no dustbt, if any had existed, in the mind of wny one on board the Peacock, that what they had previously seen was truly terra firma, furnislsed a proof that cannot be gainsaid, even by throse dispozed to dispnte the evidunce of sipht, uysupported by so decisive a favt. Mr. Fld and $\mathrm{Mr}$. Stuart, in the boats, suceeded in getting abservatious, and the mean dip by the needles was $86^{\circ} 16^{\prime}$.

Mr. Eld's hoat succeeded in taking a king-penguin of exormous size, viz. from tip of tail to the bill forty-five inches; across the fliphers thintyseven inches; and the circumference of the body thirty-theo incties, Ho was tuken after a truly axilor.like fasthion, ly knocking lim down. The bird remained quite unmoved on their approach, or mather showed a diapusition to come forward to groet them. $A$ blow with the boat-hark, however, stunned him, nut before his recovery lie whs well secured. He showed, on coming to litnself, much resentment at the trentment ho lad received, not unly by fighting, but by nu inordinate nuise. Ho wrs in due time preserved as a specimen, and now graces the cullection at Washington. In his eraw were found thirty-Lwo pelibles, from the size of a pen to that of at hiazel-nut.

2.4t. Bergs and field-ice were in Farioug directions around. They lad light buflling winds, clear and pleasant weather, wilh a smooth sea. The water was of a dark gteen colour. Standing into the bay for the purpose of mpproneling the land, they at 5 A.M. passed througls drift-ice into an open space, and when they lad agais approached the field, hove to for the purpose of suunding. Here botton was found at the depth of eight hiudred fallioms; and the matter browglut up was similar to that obtained the day before. The diatance between the points where thege two suundings were oblained was but short.

At $8^{h} 30^{\mathrm{m}}$ s.s.., while attenuting to box off the ship fruin some ice under the bow, slie made a stern.boarl, which brought the stert so foreibly in contact with another mass of ice, that it socmed from the shock, as if it were entirely stove in : the rudder was 80 muel canted from its position, as to earry away the starboard wheel-roge, and to wreuch the neck of the rudiler itself in such a manner as to render it unservicealsle, or even worse than uselegs. In hopes of lessening the difficulty, relieving-tackles were applied to the tiller, but without offech for it was discovered that the ridder had been so far twisted as to make a cunsiderable angle with the kecl, and every exertion to move it proved ineficetual.

All husds were now called, and every officer and man wus speedily at his statiun. The slip was Cound to be rapidly entering the ite, sad every effurt to direct her course by the masagencut of the sails prozed fruitless. In this Jichpless entdition acarcely a monent passed without a new slook in some quarter or other from the ice, and every blow threntened instant destruction. Tho hope was uot yet aloardetied, that some temporary expedieat might be furnd to bring the rudder again into use, until they stould bo extrieated from this perilons situation. A stage was, therefore, riggut over the sterin, for the purpose of examining intn its otate, but it was found to be so much injurel that it was imporesithle to tentedy its defects while in its place, asid preparations were fortlowith sunde for unshipjing it In the mean time the position of the vessel was every instant growing worse, surrounded as stre was liy maises of floe-ice, and driving further and further ints it, towards an its. mense kall-sided iceberg. All attcmpts to get the vessel on the other tack failed, in consequence of her being so closely encompassed, and it was therefore thought expedient to attempt to bring her bead round, by lianging her to an iceberg by the ice-anchers, nid thus complete what had been partially effected by the sails. "The anchor was nttnched, hut just at the moment the hawser was passed on board, the ship took a start so suddenly astern, that the ropre was literally dragged out of the men's liands before they could geb a turn around the bits.

"The slaip now drove stern foremost into the midst of the liuge masses of ice, striking the rudider a second time. This blow gave it the fiuishing stroke, by nearly wringing off the hend, breaking two of the pintles, and the apper und lower brace.

The wind now began to freshen, and the floe-ice to Bet upon the ship. The sails were furled, and spars rigged up and down the ship's sides as fers. ders. Aitempts were agrin made tn plant the iceanchors, for which purjose dhu buats were lowared; but the confined eppere, and the force with whieh the pieces of ice ground ayainst each other was so great, that the loats proved inearly as tinmaungeable as the ship. After much exertion, however, the iceanchors were planted, and the hawser hauled taut. Here they for a tinue enjoyed comparative seeurity, as the ressel loung by the nucliors, which were planted in a large lloe. The ice continued to close in rapidly upon them, grinding, crushing, and carrying away the fenders; and the wind, that liad changed to seaward, rose with appearances that forebmed bad wenther.

At $10^{\mathrm{h}} 30^{\mathrm{m}}$ this sccurily was at an erd ; for the anehors, in spite of the exertions of the uftieers and men who were nur them, broke lowse, and the slip was again at the mercy of liuge houtitz masses. A rapid stern-tronad was the corsequence ; and a contact with an ice-island, vast, perpendicular, and as biglı as the mastheads, appreared inevitable.

Every prasible preparation was made to meet tho expected shock. There was no noise or confusius, stud the self-joswession and admirable conduct of the comusuder inspired cuurnge and confidenee in all. Prepumtinus were ungde to coekbill the yords, nud spars were got nut.

While these prepaswtions were going forward, the imuninence of the damger leasened for aswitlo: tho aneburs again held, and there was a hoje that they uight bring the vessel up before she strucle. This hope, however, endured but for a mantut; for the atuebors, with the whole buly of ice to which they were attached, came in, asd the ship going astern, struck quartering upon a piece of sce which lay between her and the great ice-island. 
This afforded the last hope of preventing her from coming in contact with it; and this lune failed alsu ; for, grinding alnong thus iee, she went nearly stern furemast, and strack with her larbonrd guar. ter upon the jee-island with a tremendous crasll.

The first effect of this blow was to earry away the spanke-boom, the larboard etern-davit, and to crualt the gtem-luat. "The starlond steri-davit was the next to receire the Block, and as thim if connected witls the spar-deck bulwarks, tise whole of them were started; the knee, a rotten one, which bousd the davit to the taffrail, was bruken off, and with it all the stanchions to the plank-sheer, as far as the gangway.

Severe as was this shock, it liappened fortunately that it was followed by as grent a rebound. This gave the ressel a eant to starboard, and by the timely aid of the jib and other sails, carried her clear of the ice-island, and forced her into a small opening. While doisg this, and before the ressel had moved half her length, an impending nass of jee and snow fell in her wake. Had this fallen only a few secomds earlier, it must have crublyed the vessel to ntums.

It was also fortunate that the place where sive etruck the ice-islaud was neas" jes southermi end, so that there was tut $n$ short distance to be passed before slie was eutirely elear of it. "T'lis gavo more room for the drifting ice, and peruitued tho vessel to bo worked by her sails.

The relief from this pressing danger, however gratifying, gave no rssumdee of ultimate safety. The weather lud an unustrally stormy appenrance; and the destruction of the ressel seemed almost inevitable, with the loss of every life on bonrd. They had the melancholy altemative in prospect of being frozen to death orie after the other, or perishing in a body by the dissolving of the leeberg on whish they should take refuge, should the ressel sink,

When the dinner hour artived the ressel was again fast is the ice, sud nothing could for a time be done: it was therefore piped ins usual. This served to divert the minds of the men from the daugers arnund them.

When the menl whs over, the furmer manouvring whs resorted to, the yards being kept swinging to and fro, in order to keep the shiping hend in the required direction. She was labouring in the swell, with ice grinding and thumping against her on all sides; every moment somethilug either fure or aft was carried away-clnius, bolts, bubstsys, bow. sprit, slurouds; even the anchory were lifted, cuming down with a surge that carried away the eyebults and lashings, assd left them to long by the atoppers. The eut-water also was injured, and every timber scemed to grasth.

Similar dangers attended those in the boats. Passed Midshipman Eld was seut to plant the iceanchors : there was to room for the use of oars; the grinding and grating of the ice, as it rose and fell with the swell, rendered great precaution uccessary to prevent the boat from being swamped or erushed; and when it is stated the two hours of lard exertion were rmguired to plant the icearclunts, some idea of the difficulty attending this service will be lud. But this wro mot all; the diffictsly of returuing was equally greah, sat no possible way of effecting it seemed so suggest itself. The aides of the iccbergs could not be ascended, and to approash the berg on the side next the ahip was certuin destruction to the bost and crew, for the fee and water were foaming like a cauldron: and to abnuton the furmer was equally out of the question. $\Lambda$ t last a cliance uffered, althouglı alrnost a hopeluss one, by jussing between two of these trergs, that ajpreared on the uther side of a small clear sinace. The bont was upun a small piece of ice, from which, by great excrtions, she was launelsed; a fow pulls at the onrs brought them to the parange; the bergs were elosing last, and agitated lyy the swell; no sime, therelure, wa to be lost : the danger whs alrewdy grent, and in a few Becusshs it would be impossible to pare. They entered; their onrs caught, sad they got but halfway through when the ivebergs clused in upon them, and jressed the gunwales together, so as almobt to erusl the boat; the water entered her, and she was nestr ginking, whes the bery stopued, retreated, and by nuolier lawd shore they weat through, and were soun alongside the ship.

Every exertion wiss now anade to work the elijp and axoid heary thump from the ice. 'The mode resorted to, to get the ship aboul, was a novel one, namely, by urging her lee bow against $\pi$ piee of ice, which had the same eflect as giving her a lee helm; hut this was found rather too expensive a mode of effecting the olyject, and on the purspa showing an increase of witer, it was dibcontinued. The ice lind been rupidly accumulating aruutud the ship, contracting still more uarowly the space or area in which they were, and rendering their gituntion more liszardous.

At of P, M., they clewed up the tonsaits, the ship being fast in the ice, with the wind direetly in from the seaward. The jce-nnchors were now again rus out, in hopes of relieving her from some of the strain, $A$ short time afterwards the ice clearing from the stern ennbled them to unslip the rudder, which was taken on boaril in two pieces : it was imtnediately placed on the quister-deek, and all the carpenters employed on it.

It soon begant to snow vinlently, and no clear sen could be ecen from the ship in any direction. It becoming obscure, the elnmee was that they would lave to take up their last abode there. A bout six o'cluck the weather cleared a little, and the wind froshened; they parted the hawser attached to the ice-nuchor, and made sail again for the clear Bcn, which cusld now be seen from the mastheud, Towards $8 \mathrm{P} . \mathrm{M}_{-, 1}$ as if to blast the little linpe that the eontinuance of clear weather iuspired, the ship towk a wrong ennt, nud was forced into a amall opening lending further into the ice to leeward, and wwards the massive walls of the berg. Great exertions were mate, and fortunately, by the aid of the iecanchors sud anils, they suceeded in getting her round, and her liead again pointed towarls the clear sea; but they were khortly afterwarda wedged in between two large masses of ice. At midnightt the sea was observed th rise, sithinugh tho wind lasd not increased, causing nuch motion among the jee; and the stomny appremrance of the sky cun. linued, and gave promise of a gale. The only hoje left was to furce the ghip througl, and every means were empluyed to effect this object. The ice they bad now to contend with was of larger dimension, and the increased sea readered it doubly daugerous. Some of the thocks against it were so beary as to excite fers that the ship's bow would be driven in, 
and on one oceasion three of the chronometers were thrown out of their beds of eswidust upon their sides. They continued to make but littlo hendwry, and the grinding and thamping on the ship was most painful. 'The hope of extricating her lessened every moment ; for the quantity of jee hetween then and the sers was increasing, and the ship evidently tnover witl it to leeward. Few situations cotsld be more trying, but the emergency was met by Captain Hudsor with a conlness, persererance, and presence of mind, which secured the armiration of all who were present, and inspired full coufidence and a firm reliance in his ability to overcome every difticulty that liny within the power of liuman mests.

In the afternoon of the 25 th, the sea continued to increnge, and the slip frequenthy struch against the masses of ice, while every foot they forged ahead carried them secmingly into a nore precarious situntion. At about 3 P, M., they found that the gripe land been beaten off, and they were now bruising up the stem and grinding away tho bows. There appeared no other course bnt to drive her vut, which was deemed the only chance of saving the alin and erew. All the cansase that would draw was therefore set to force liev through ; snul the wind farouring then, they liad by four o'elock streceeded in passing the thick and solid ice, and ahortly afterwarils found thenselves in elene water, withowt a rudder, the gripe gote, ath, as was aiterwards found, the stem ground down to withiu an inch aud a latf of the wood-ends.

The carpenters were still employed on the rudder, and had succeeded in removing the broken pieces of the pigtles from the second and third braces on the stern-post; the upper and lower pintles were broken, leaving only two to liang the ruxlder by. The weather seened now to fivour thera, and ahout ten o'clock they had finished the rudder, which had been repaired in the best possible manner. Great credit is due to Mr. Dibble, the earpenter, (who left lis sick bed on the oceasion,) for his exertions, nttention, and perseverance. He and the carpenter's crew worked twenty-four hours without intermission. T'the ship was now hove-to, for it was apprehended that her rolling would render the task of shipping the ruddes froublesome. By meridian they were again in a situntion to make sail to extricalo themselves from a bay some thirty miles in extent, which, with the exception of the suall opening by which they had entered, was apparently elosed by the barrier.

Shortly afterwards, the wind becoming fair, they made all sail for the outlet. The weather proved fine, and the winds modernte. At midnight they found the only openisg left, which was not more than \& guarter of a mile wide; they succeeded in passing through this, by 2 4.x., in a snow-stortm, and felt grateful to God for their providentinl esenpe.

Crptain Hudson now came to the eonelusion of returuing north. "After," as he says, "tloroughly turning over in my own mind the state of the slip,with the hend of the rudder gone, hanging by two braces, and ia such a state that wo oould bardly hnpe to make it answer its purposes again, in encountering the boiaterous weather we should bave to pnss through before renching the first port,-the ship considertably strained; her starbnard gpardeck lulwarks gone as far forwarl as the gangway; the gripe off, and the sterл mutilated ;-fully satisfied from this state of things that she was perfectly useless for cruising anong icebergs, and the accompanying dangers, in thick foggy wenther, to which, in these latitudes, we ghonld be more or less anbject, and where rapid evolutions were often necesasry, in which the rudder mut perform its part; and that the ship would requiro extensive repairs before being employed in surveying operations; and foling that the season was rajudly coming ruund when our services would be requited in thas duty, I hetd $n$ council of the ward-room nfticers, and required their opisinus as to making suy fur: ther attempts to cruise in these latitules.

"There was but one opinion th to the necessity of the slip's returniug north, with the exception of Mr. Emmons and Mr. Baldwin, who thought the Fudder might stand, provided we did not get nenr the ice, or fall in with icebergs, This of course would be to effect little or nothing, and restit only in a luss of time. I necordingly pat the shiph's head north, determined to proceed at once to Syd. ney, to effect the necessary repairs, so as to be ready at the carliest possible day to join the squadron."

Such were the dangers and diffieulties from which the Pencock, by the admiruble conduet of her officers nnd erew, directed by the consumate seamanslip of luez communder, was enabled at this time to escape. There still, bowever, remnined thousands of jniles of a stormy ocean tu be encounteret, with a ship ao crippled as to be lardly capablo of working, and injured to sueh an extent is her hull as to be kept afloat with difficulty. The narrative of the events of this jerilous nsviration must, however, be postponed, until I shall have given the proceedings of tho other vessels of the squadrun, while tracing out the position of the icy barricr, and fullowing along the newly-discovered continent. 


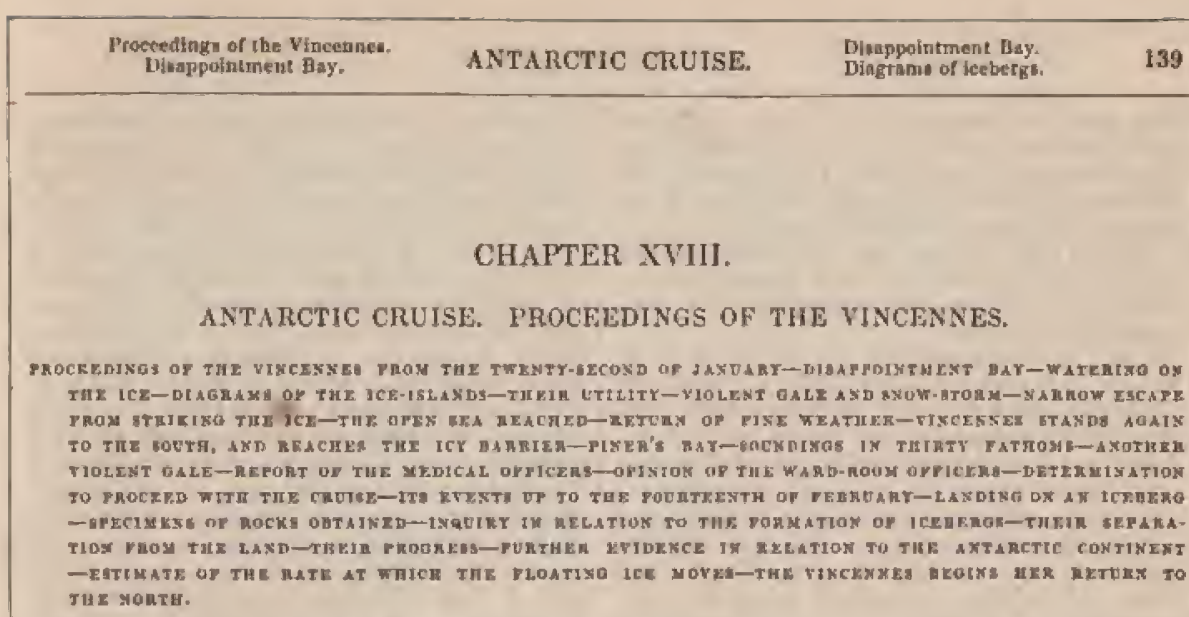

Is taking up the nurrative of the disaster sustnined by the I'eacoek, with which the preceding chapter closes, the Vincennes and Porpoise were left on the gind of Jamuary.

On that day the Vincennes passed the place through which the Pencock entered, as has beeu related, ot the $230 \mathrm{rd}$, and found mo opesing. To judge from the manner in which the ice moved luring tho tine the Peacock was enclosed in it, I an inclined to ascribe the alteruate opening atud closing of the passage into the bay, to a tide setting aloug this coast. I t support of this oprinion it is sufficient to state, that the strength of the winds experienced on board that ressel wha at no time sutticient to account for the manner in which the ice was found to move.

Atrout thirty miles to the westward of this point, the Vincennes pirssed a remarkable collection of tubular icetrergs, for whose existence $I$ enn account is no other manner than by supposing them to be attached to $\mathrm{n}$ rocky islet, whicli formed a nuclems to which they adhered. It was quite obvious that they had not been formed in the pince where they were seen, and mut, therefore, have grounded, after being adrift.

On the $23 \mathrm{rd}$ of January, after passitig around this group of iccbergs, the sea why found comparntively clear, and a large open spase showed itself to the southward. Into this apace the course of the Vinceruey was immodiately directed. While thus steering to the south, the nppenrance of land was observod on either band, both to the eastward and westwmrd.

l'ursuing this course, wo hy midright reached the arlid harrier, and all approach to the land on the enst and west was entirely cuc off by the clase packing of the icebergs. i was, therefore, reluetantly compelled to retura, not a little vexed that we were again folled in our endeswour to reneh the antarctic continert, This was a deej indentation in the coast, about twenty-five Iniles wide: we explored it to the deprth of about fifteen miles, and did not resch its termination. This bay l have called Disappointment $\mathrm{Bay}$ : it is in latitude $67^{\circ}$ $4^{\prime} 30^{\prime \prime}$ S. longitude $147^{\circ} 30^{\circ} \mathrm{E}$. The weather was remarkably fine, with a bracing nir : tho thurmometer in the ait $22^{\circ}$, in the water $31^{\circ}$.

The next hay, 24h he wiond out of the bay, and continued our conrse to the westward. About noon, to my eurprise, 1 learnt tint one of the officers, Lieutonant Underwood, luad marked on the log-slate that thore was ati opening of clear water, subtending three poists of the compass, at the botton of Disapryintment liay. Though con* fident thut this wis not the fact, in order to put this matter at rest, I at onco deternined to retura, although forty miles distant, and ordered the slipp nbout, to refute the cssertion by the oflieer's unn testinony. Tlis was most effectunlly done the next morning, g5th, when the ship renched the ilentical spot, and all were fully convineed that no opening existed. The whole bsy was enclosed by a firm bnrrier of ice, from north-north-west to eastnorth-east.

The wenther proved delight[ul, with ]ight airs from the southward, and I detertined to take this opporturity to fill up the water-tanks witl jee. The ship was hove-to, a hawsur got in rendines, the bonts lowered, and bronght ajungside of an icelierg well adapted to our purposes.

The ane opportunity was also taken to make the magnetic obserrations on the ice, and to try the local atiruction of the ship.

Many birds were seen about the ship, of whict wo were fortumate in obtaining specimens. The dny was remarkably clear, and the snme appearance of Innd was seen that had been witnessed on blue $24 t h$. We filled mineteen of our tarks with ice, after having allowed it to remain for some time on deck for the salt water to druin off in part, and it proved rery potable.

At ahout s P.M $_{4,3}$ we had completed our required store of ice, and cast off, naking snil to the northward.

In order that no further mistakes should take place as th the oprenings being passed, I iseured st! order, directing the officer of the deck on being relieved to go to the mastliead, and report to me the exact situation of the ice; and this was continued during the remaiuder of our cruise among it,

In threading our way through the many jechergg it occurred to me that they might be eonsidered as islauds, and $n$ rough enrvey made of them, by tuking their benrings at certain periods, and mnking diagrims of their positions. This was accordingly done, and every few hours they were inserted on the chart which i was construeting in my prov greas.

This I found to be very useful, and it gave me 
confidence in proceeding, for I had a tolerable chart to retreat by in easo of need, at lenst for a few linurs, during which time $\$$ hail renson to believe that there was not nuch probnbility of the jeebergs chunging their relative positinus.

'Tlie dip ubserved on the ice was $87^{\circ} 30^{\prime}$, and the variatiun $12^{\circ} 46^{\prime}$ easterly. The compasses were found to bo very sluggih, having but little borizonal directise force.

Aluut half an hour after we eat off from the iceberg, a thick snuw-storm carne up, with the wind from the soutli-east. Although there were very many ice-islands nruund us, on our way out, I felt that I understoud the ground well, haviog passed over it twice, and tnowing 1 had a space of a few miles, only thinly sprrituled with icebergs, I hove-to with shortened sail. This was the first couth-east wind we had had since being on this coast. I had been dissppointed in not finding it from thint quarter before; for I had been informed, by thnse who had navigated in high soutluern latituder, that south-enst would be the prevailing wind, and would be attended with tine weather. Now, however, with a fair wind, I was unable to run, for the weather was unfavourable.

At $6 \mathrm{~A}$.s. on the $26 \mathrm{hh}$, we again made sail, and at $b_{\text {A.x. }}$. We discovered the Porpolse, to whom we made siguals to come within hail. We fouth them all well, nut emmpared ehronometers.

As it still hlew fresh from the ocoth-east, an! the westher became a little more clear, we both bore nwny, running through touch drift-iee, at the rate of nine knota an hour. We hisd the barrier in sight; it was, however, too thick to see much beyond it. Sailing in this way I felt to he extrentely liazardous; but our time was so short for the examination of this icy const, that while the barrier was to be seen, I deenued it my duty to proceed. Wo fortunately, by good look-outs, and carefully coming the ship, were enabled to avold any beary thumps.

On the 27 th, we again luad the wind from anthsouth-west. The flue-ico had become so thick, that we found it impossible to get through it in the direction I wished to go, and we were counpellod to pass round it. The Porpoise was in sieht until noon. The weather proved beautifully clesu. A long range of tabular iechergy was in sight to the southward, indicating, as 1 have hefore observed, that the const was near. I passed though these, losing sight of the Porproise to the natkh-west about noon, whers we were in lungilude $142^{\circ} 40^{\prime} \mathrm{E}$, lntitude $65^{\circ} 54^{\prime} 21^{\prime \prime} \mathrm{S}$, varintion $5^{\circ} \theta^{\prime}$ ensterly.

On the $28 \mathrm{l}, \mathrm{I}$ found myself conpletely surrrounded by the talrular jeebergs, through which we continued to pass. 'Towards midnight the wiud shifted to the south-east, and enabled no to fraul more to the soutliward. A.C 9) A.M. we had another sight of the land ahead, and every prospect of nearing it, with a fise breeze. The sight of the icebergs around us, all of large dimensions, was beautiful. The greatest number iu siglt at owe time was moted, and found to be ruore thus a hundred, varying from a quarter of a saile to three miles in lesrgth. We took the nogst open route, and by eleven o'cluek had rut tuwarda of forty miles through them. Wo had the land now in plain view, lut the weatier soon began to thicken aud the breeze to fresher. At noun it was so thick that every thing was hidden, and no observation was obtained. The ship was hove-to, but shortly after again put under wy, making several tacks to keef iny position, which I felt was beconving a critical one, in ease a gale should ensue. I there. fore looked carufully over my clunt, and was sulprised at the vast number of ieebergs that appenred on it. At 2 р.s. the baroneter began to fall, and the weatlier to change for the worse. At $5 \mathrm{~s}, 3, \mathrm{a}$ gale was evidently toming one, so we look three recfs in the tupsails. It appeared now that certain wreck would ensue, should we remain where we were; and after much considerntion, I mnde up my mind to retrace my way, and seek the open space forty miles distant, Luking fur a landmark a remarkable berg that lad been the last entered on the chart, and which would be a guide to my course out I therefore stuod for' its position. The weather was so thick, that it was necesanry to run close to it, to be quite sure of recugnaizing it, for on this seemed to deprend our safoty. A jout the estimated time we wonld cake to prass over the distance, an icetherg was made (we were within one thousand fect of it) which, at first view, I felt confident was the one songht, but was not altugether satisfied afterwands. I therefore ngain consulted my chart, nud hecame more donatiul of it. Just at that moment I was called on deck by un officer, who informed me that there were icebergs a short distance shead! Suel proved to be the case; our prats was beset with them, and it wns evident we cunld not regsin our rouste. Ta return whs wore, Bo having but litule choive lof, 1 delermined to keep on. Tu encunater these ieobergy so soon after seeing the other, was in some respects gatinfactory, fur it removed all doubts, and slinwed mo that we were not near the track by which we entered. Nothing, therefore, was to be done bist to keep a gaod lonk-eut, nad the ahip under suffieient way to steer well. My safest plan was to keep as near our former track as possible, believisg it to be mast free of these masses.

At f r.u. it began to blow very hard, with a violent sutow-storm, cipcunuseribing out view, and rendering it impossible to sce more than two shipls-lengths aliend. The enld wns severe, and every apray that toucled the blijp was jumediately cmsverted into ice. At 9 P.M. the barvineter still falling and the gale increasing, we reduced sait to elose-rnefed fore and main-topanila, reefed foresail

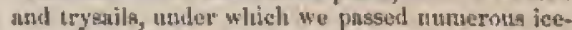

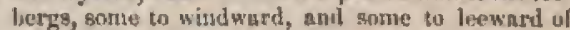
1ts. At $10^{\mathrm{h}} 30^{\mathrm{mn}}$, we futund vurselves thickly beset with them, and had many narrow esennes; the excitement became intense; it required a constust clange of belm to avoid those elose alxard; and we were compelled to press the shijp with canvas in order to escupe them, by kexping her to windwarl. We thus passed close along their wenther sides, and distimetly heard the roar of the surf dasling against tlent. We had, from time to time, glinupes of their obscure outline, appearing as though immerlately ahove us, After inany fecenpes, I found the ship so covered with ice, and the watch \$o powerless in mannging her, that a litue after midniglat, on the 29its, I had all hauds called. Searcely had they been reported on deck, whens it was made knuwn fo me that the gunner, Mr. Wilbiamson, bad fallen, bruken lis ribs, und ouberwise injured himself, on the icy deck.

The gale at thit moment was anfut. We found 
we were paseing lnage massis of drift-ice, and iceisluads became more numerous. At a little after one o"dock it was turrific, and the Bea was now so henvy, that I was obliged tu reduce sail still further: the fore aud main-topsails were clewerd up ; the lurmer was furled, but the latter being a new sail, inucli difficulty was found in securing it.

A seuman, by the unme of Bronks, in enden rouring to excente the order to furl, got on the lee yurdarn, and the sail having blawn over tho yard, provented lis return. Nut being awase of his position until it was roported to me from the forecastle, he remained there some time, On my seeing him lie appeared stift, and elinging to the yard and lift. Spilling.lines were at once rove, and au oficer with several men sont aloft to resene him, which they succeeded in doing by passing a bowline around his body and drngging him into the top. He was almost frozen to denth. Several of the best men were completely exhausted with culd, fatigue, and excitement, and were sunt below. This added to our anxielies, and but litule hope remained to nas of eseaping : I felt that ueither prudence nor foresight could nvail in protecting the ship and cresr. All that could he dine was to be prepared for any emergency, by kecping every one at lis station.

We were swiftly dnsling on, for I felt it necessary to keej the ship under rapjd way slirough the water, to ensble lier to steer and work quickly. Suddenly many vices cried out, "Iee ahead :" then, "On the wealleer bow !" and again, "On the lee luw and abean!" All hope uf esenpe seetued in a moment to ranish; retnrn we could sot, as Inrge ice-islands lind just been passed to leeward: so we dashed ou, expecting every moment the errsh. The ship, in an isatart, from having her lee guns under water, rose upriglat; and su eluse were we passing to leewari of one of these thige islands, that our trysnilk were almost thruwn uback by the eddy wind. The hetm was put up to pay the ship off, but the proxinity of diose under vur lee bade me keep my course. All whs now still excejt the distant roir of the wild atorm, that was raginu behind, before, and above Us; the sea was in great agitation, and both offieers und men were in the highest degree excited. The ship contimued her way, and as we proeected, th glimmaring of bope arose, for we accidentally lind bit upon a clear jassage between two large iceislands, which in fine weather we should not dare to liave ventured slirough. The suspense endured whilo making onr why between them was intense, but of short duration; and my gpirits rose as I heard the whistling of the gale grow louder and louder before us, as we emerged from the passage. We liad escaped an awful deach, and were again tempest-tast.

We encountered many sinilar dangers that pight. At half-past 4 A.M., I found we had reached the smald open space laid down on my chart, and at five o'clock I hove-tu the ship. I hind been under intense excitement, nnd had not been off the deek for nime boura, and was now thanlsful tes the Providence that luad guider, watched over, and preserted us. Until 7 A.M. all haurs were on tleck, when there was some appearanto of the weather mudtsrating, and they werte priped down.

'I'tis gale was from the axuly-east, from which quarter it thew durisg the whole of its ntrength ; and when is began to moderate, the wind teered to the southward. By noon we felt satiefled that the gale war over, and that we had eseaped, althouglı it whs difficult to realize a sense of security when the perila we luad jukt passond tlarough were ao fresh is onc minds, nyd others still impeniling. Towards fout o'clock it cleared off, and we saw but few iesbergs near us. Our longitude was found to be $140^{\circ}$ E. latitude $63^{\circ} .30^{\prime} \$_{1}$, nnd I agail nude sail for the ice to the solsth, to pass over the very route we lad just tmversed through su mung perila.

'The wiml hatd now hauled to the soush. weat. At $6 \mathrm{P}, \mathrm{M}$, we again begran to enter among ice-islunds. The westher apprured settled; but I tad su of ten been deceires by its ficklenees, that I felt no relinnce ought to be put in its cuntinuance. $\Lambda$ powerful indverment was held out to us, in the prosprect of getting cluse enuugh to effect a landing; snd this residered us insensible to the dnugess.

On the morning of the 30 th the sun rose in grent briltianey, and the scene was altugether untike that we had passed through only twenty-furr hours before. All was now quiet; a brisk breeze blew from the eastward, all sail was bet, and there was every prospect that we might aceomplish oul ohjeet : for the land was in sight, and the icolergs secmed flonting in quiet. We wound our way through. then in a sea so smooth that a yawl unght have passed over it in safety. No straight line cuuld lave been drawn from us in any direction, that woulal not have eut a fluzen icehergs is the same nutnber of miles, and the wordering exclamations of the officers snd crew wero oft repented,- "Huw could we have passed tlarough then muliarmed ?" and, "Wlate n lucky ship!" At eight o"cluck, we had reached the icy barrier, and huve-tu cluse to it. It wins tantalizing, with the land ins sight, to be agnin and again blocked out. Open wrter was seen nutr the land to the mouth-west of us, and a fortuous channel thmugh the broken ice to leeward, apparently leading to it. All sail was inmediately cruwded; wo passed rupidly through, and fund ourselves again in elear water, which reached to the shores: the barrier extending in a line with our course, about two miles tu wirsward, and a clear cliannel to the nurth-west, alsout two miles wide, as far as the eye could resch. Seeing this, I remarked to one of the oflicers thint it would have been a good plnce to drift in during the list gale,little thinking that in a fow slouri howrs it would serve us for that purpose, in still greater need. A brisk gale ensued, and the ship ran at the mote of nine or ten ruiles an hour; one reef was taken in the topsails, and we stood directly in for the most southerly part of the bay.

'llis bay was formed partly by rocks and partly by ice-islands. The latter were aground, and on the western side of the bny extended about five miles to the norliward of our pusition.

While we stood on in this direction the gale incressed, nnd our mom becamo so circumseribed that wo had not time on any one tack to reduce our canvas, befure it became necesary to go about. In this way we approached within half a mile of the dark volcanic rocks, which appenred on both sides of us, and saw the land gradually rising beyond the iee to the height of three thou. sand fect, and eatirely covered with snow. It could be distinctly seen extenuling to the east and west of our posjtion fully sixty milee. I make this 
bay in longitude $140^{\circ} 2^{\prime} 30^{\prime \prime} \mathrm{E}_{*}$, latitule $65^{\circ} 45^{\prime}$ $\mathrm{S}$.; and, now that all were convinced of its existence, I gave the land the name of the Antasetic Continent. Some of the affieers pointed out the appenranee of smoke, as if from a volerno, but I was of opition that this was nothing but the snow-drift, enusel by the heary sizualls. There was too much wind nt this time to tack; I therefure had recourse to lufing the vessel up in the wind, and wore her short round on lier heel. At the same time we sounded, and found a havl botom at the depth of no more than thitty fathome. I have malled this bry Piner's Bay, after the signal quarsur-master of shat name. It was impossitlo so lower a boat, or to remais longer ; indeed, I foll it inprerative on mo to cleas its confined space before the flonting ice mighlit close it up.

At $10^{\mathrm{h}} 3 \mathrm{om}^{\mathrm{m}}$ we had gone round, and in an hour more we eleared the bay. At noon the wind land increased to a gale, and by one o'elnek, P. X., we were redueed to storm-sails, with our top-dyllant yards on deck. Tho harometer laml manin dealined mpidty, proving a true indientor, brit giving little or no wrming. I'o run the gauntlet again among the licebrergs was out of the question, for a large quantity of field-ice would hase to be pased through, which must have dono us considemble damage, if it did not entirely disable us. The clear space we occupied was retnined until five or six ateluek, when 1 found the floc-ice was coming down upsin us; 1 then determined to lny the ship for a fair drift thrungh the cliannel I had obserted in the morning, and which I had every rensm to believe, frum the wind (south-cast) lylowing direetly through it, would wat be otistrueter uratil the floe-jee came down. It was $\pi$ conssolation to know that if we were eumpelled to drif, we slumula do so fater than the iee; I therelore thought it ns well to aruid it as long as possible. Anmlier ress. gon determined me to delay the drifting to the latces moment: I did not believe that the extent of the elasmel we had seen in the morning was more than ten miles in extent, and st the rate we ilpifterl, the end of it would be reached long before the gate was over. This, like the foriner gale, was an oldfaslioned snuw-storm, All the canvas we could ehow to it at one time was a cluse-reefed nuin-topsail aut fore-stortu-stayeail. It blew tremendunily, and the sea we experitencel wis a short disagreteable me, but nothing to be comparol to that which nceompanied slue first gnlo. From the blortness of the sen, I inferred thent we lad some cerment. This state of things continued fot several houts, during which we every moment expected to rench the end of unr clannisel. Since the last gate, the while erew, offleers and mesi, lias been pus in wateh and wuteh, ready for ari instantaneous mil, and preparenl for mpid movementh. The anow was of the sarne sinety or cutting eliaracter as that of the previons day, and seemed as if antmed with strarp icicles or neetles.

The 3lst hirought mo moderation of the wenther. At I A. Y., a gronp of iee-ialands was reported, and shorly niterwards field-ice chise under onr lee. We wore ship instantly; and just nwoided cursing in contuct with the latter. Sail wns immedintely made on the ship, and the scene of the formel gale again gone through, with this exception, that we were now passing to and fro amung ieeberge imme- dintely to windward of the barrier, and ench tack brought us nearer to it. Between 4 and of a. $\mathbf{x}_{\text {. }}$, our space wha becouming confinet, and there was no abatement of the gale; I therefure, st it had denred sufticiently to ennble us to seo a quarter of a mile, determined to luear up and run off nrirth. north-weat for a clear sea. In duing this we passed iecbirgs of all dimensions and heary the-ice. By $8^{\text {h }} 30^{\text {a }}$ we drat run thirty miles, when, fionding a more open sea, I judged we had partinlly clcased the ice. At noon the grale still comtisued. The lowest reading of the baruncter during this gale was $28 \cdot 59$ in.

After lusting thisty hours, the gale, at 6 F.M.g begin to notormte $\mathrm{a}$ liatle, when we again made sail tis the konthwort. I now felt inclined to scek Piner's Bay rgain, in order to effeet a landiug. This would hnre heen a great personal gratification; but the bay wns sixty miles distsun, bo that to revisit it would oecupy time that was now precions; nnd feeling salisfied that a great extout af land wholly nriknown lay to the westwurt, 1 deemed it my duty to proceed to its discurery, not doubting that if my opinions of jts existence were correct, a place equally feasitule for huding would be found Another snbject also presented itself, which, for a time, enused me some anxiety, and which I confess was not only unexpeeted by me, but direetly at varinnee with ny own ohservations on the conilition of my erow. "As I feel conrpelled to give a cotnplete detril of our proceedings, I must now revert to this subject.

The fotlowing rejort of the medical offiecrs of the ship was made to me on the day of ity date :-

\section{U. S. slsip Vincennes,}

At sea, Jahuary 31st, 1840.

SI R,-It becomes our duty, as medical officers of this ship, to report to you in writung the condition of the erew at the present time.

The number upon the list this morning is fifteen: moat of these censes are conseg uent upon the extremo hat'dahips and exposure they Jave undergone turing the lnst gales of wind, when the ship has been sur* ronnded witl ice.

This number is not large, but it is necessary to state, that the general bealth of the crew, in our opinion, is decidedly nffected, mul that under ordi. nury eirennstances the list woukd be very much increased, as the men under the present exigenwies, actuated hy a taurlahle ilesive to do their duy th the last, refrain from presenting themselves as ąyjicants for the list.

Under these circunstances, wo feet aurselves obliged to report that, in our apininn, $n$ few days inore of such exposure as they have already undergone, would reduce the nuriber of the crew by sickines to such an extent as to hnzard the safety of the slip and the lives of all on bonrd.

Very respoctfolly, your obedient servante,

$$
\text { (signed) J. L. Fox, }
$$

J. S, WutThe,

\section{To Chnrles Wilkes, Esi.}

Contmanding exploritig expedition.

Altlough my own opinion, as I have stated, differed from that expressed in the report, I deened it $m y$ iluty to ask the opinion of the ward-room wfficers, and also, in order to procure aclditional medical advice, restored to duty Acting-Surgeon 
Oplston of the ward-room aflicern,-Deter-

Gilchrist, who was under suspension. The opinion of the ward-room officers was asked in a writton circular, of which the following is a copy.

\section{U.S. ahip Vincennes,}

At Eea, Jununry 31st, 1840 .

Gevthenrs; - The receipt of the enclosed report of Dr. liux and Whittie, relative tu the health and cordition of the erew of this ship, at this time, resudery it neecesary for me to decide whether it is expedient to pusli further south in exploration umder the present cireutustances.

$A_{\varepsilon}$ you are acquatinted with all the circumstances, it it unnecessary to repent them, except to remarls, that your opiluion in requested befort I decide upon the evirse to be pursted, in sorseguence of the strong bias self-iaterest might gise we in the prosecution of our ardusus dutieb. I wish the report returned to twe, and for you to communicate your opinion in writing.

\section{I am, respectfully, \& $\mathrm{e}$,} CHATHFs WILkPs,

Contoanding exploring expredition. To the ward-room ofticers,

\section{U. S. ship Vincennes.}

Of the answers to this letter it is suficient hero to say, that a majority concurred in opinion with the report of the medienl offiecrs. Notwithetanding these opinions, I was not satisfied that there whs ruftivient cause to eliange my original des termination of passing alung to the appointed rendezvous; and after full eonsideration of tlio matter, I carne to the conclusion, at whatever hazaril to ship and erew, that it was my duty to proced, and not give up the enjise until the oliph should be torally disabled, ox it should be evident to all that it whs improssiblo to persist any longer. In loringing myself to this decision, I bolieve that 1 vieweri the cass on all sides with fairness, and aliowed usy duty to nyy country, my care for thoso whenn it lind consmitted to my elarge, and my reequnsibility to the world, each to have its due weights.

The weather now moderated, and I modered sail to be made, The 2nd of Febrancy found us about sixty miles to the westward of ['iner's Bny, steering to the southward, and as nsunl mong iceislasuss, with the land in eiglit. The land had the same lofty apperarace as before. We stond in until 3 D.M., when we were within two and a half miles of the iey eliffs by which the land was bourded on all siles. These were from one hundred and fifts to swo handred feet in height, quite perpendicular, and there was no nppentance whatcyer of rouks; all was covered with ice and snow. A short distance from us to the westward was th long range of icebergse nground, which, contrary to the usual appenzanee, lroked much weatherbeaten. We tried for soundings, but did sot get. any with ote hundred and fifly fathoms, although the water was much discoloured. The badness of the deeposea line was a great annoyunce to us, fur deeger sonndinge would prohably lawe ubuined bottom. No brenk in the icy barricr, where a foot could be set on the rucks, whs olservable from aloft. "The land still trended to the westwarl ns far as the eye couli] reach, and continued to exhibit the same character at before. Our longitude now was $137^{\circ} 2^{\prime} \mathrm{F}$, latitude $60^{\circ} 12^{\prime} \mathrm{S}$. : we foursd the maguctic declinatiou westerly.
This prored a fine day, so that we had an opportunity of airing the men's hedding, of ventilating the ship, and of gettiug rid of the ice, with whiseli wo ware much encumbered. The thermometer varied from $33^{\circ}$ to $30^{\circ}$. Our sick-list had ineronsed the last few days to twenty ; many of the men wero affected with boils, which rendered them compartively useless; and ulecrs, which wore caused by the least scruteh, were exceedingly provalent; but tleir foond was good, they liad pleuty of it, and their spirits were excellent. The Jigh land was seen this nftertions, but the barries along which we were possing prevented any nearer approach. This evening it was perceptible that the dnys were becoming thorter, which was a new surre of anxiety, for" we were oftell surrounded by tumerous ice-islauds, which the darkness renched more dangerous.

Towards ovening the weather became tinsettled, and the 3rd of Felorury was ushered in by another gale, accompanied with snow. The baroneter foll luwer than herctofore, narnely, to 28480 in.; the thermometer atood nt $33^{*}$. Before the thick bnow cano on, we lad taken the benrings of the iceislands, and finding wo had a few miles comparasively free from them, I determined to await the result of the storm, and made exery thing soug to eneounter it. The gale constinued throughout the day, and although it maderated after 5 P.M., we has some strong squilils, but nothing so violent as thase we had nheady experienced. The ship, in ermsequence of the snow, beesme mors damp and uncomfortable, and our sjck-list was increased to thirty, who were rather overeome by waut of rest and fatigue than affected by any disease. To remedy the dampness, a stovo was placed on the gun-deck, and fires kept burning in the galleys on ilio berth-deck, more for the purpose of drying the men's clothes than for warmth. We had no observations this day, but the desd-reckoning gave the longitsde $134^{\circ} \mathrm{E}$, hatitude $63^{\circ} 49^{\prime} \mathrm{S}$.

The 4 th and 5 th the weather eontinued the same. As the winds beenme lighter thick snow fell, and we were alile to see only n strort distance from the ship. We contrived by mancurring to retain our [rasition. On this lnst day we got a tolemble uhaervation, which gave our lungitude as $133^{\circ} 42^{\prime}$ F.., and latitude $64^{\circ} \mathrm{G}^{\dagger} \mathrm{S}$.

The first part of the bth the same thick wenther eontinued, but towards 4 r.x. it began to clear, when we ngais made sail, until we Baw and took the bearings of the larrier. We fonud ourselves situated copposite the part of it we bad seen three days before. It still lasd the appenraues of being attached to the Inut, and in one uninterrupted line. Wishing to examine it closely, 1 hove-to for brond daylight, Many whales, penguins, tocks of birds, wud some genls, ware roported.

On the $7 \mathrm{ll}_{1}$ we had much better weather, and continued all day ruming along the perperdicular icy barrier, about one fuundred and fifty feet in height. Beyond it the outline of the high land eould be well diatingnished. At 6 P.M, we Buddenly fusund the barjier trending to the southward, and the sea studded with jeeberg: I now trauled off until daylight in ondex to sacertain the trending of the land more exactly. I place this point, which I hare named Cape Carr, niter the first bieutenant of the Vineennes, in longitude $131^{\circ} 40^{\prime} \mathrm{E}$, and latitude $61^{\circ} 49^{\prime} \mathrm{S}$. 
On the Hth, at daylight, we again made sail to the suthward, and found at $4 \mathrm{~A}$.M. the field of ice land stopped our pmgress, and the weather was thick. Land was no longer seen to the south, a deep bay apparently makisg its. We contiuued unr courge th the westward along the barrier, until

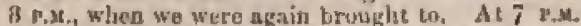
we had stmug indieations of land ; the bnrrier was of the fortner perpendicular form, and later the outlise of the continent appeared distinct though diktant. The night was tark and nnpleasint. At nom nur longitudo wis $127^{*} 7^{\prime} \mathrm{F}_{4}$, and latitude $65^{\circ} 3^{\prime} \mathrm{S}_{\text {; }}$ จ quidition $14^{\circ} 30^{\circ}$ westerly.

On the 9 h w we had the finest diy we had yet experienced on this const; the wind had veered frum the ent to sonth-west, and given us a clear, bracing, and wholesume atmosphere. 'Ithe knrries exlubited the sane appearauce as yesterday, Our forgitude was $125^{\circ} 19^{\prime} \mathrm{E}$, latitule $65^{\circ} 8^{\prime} \mathrm{S}$. variation $33^{\circ} 45^{\circ}$ westerly. The current was tried, but none found ; the pot was only visible at five fathoms; the colutur of the water a dirty green; the dip gectur gave $3^{\prime} 15^{\prime \prime}$. I never saw a clearer horizon, or une belter dofined than w'e bad to the northwark. The icy barrier was really beaucilul. At midnight we lasd a splendiul display of the nurora suatralis, exlending all aroubd tie northeru lurizon, frum west-by*nortl $w$ east-murth-enst, Befure its ampentance, a few clouds only were seen in the soutli-eust, on which the setting sun enst a red tint, that bnely rendered them visithe. The horizun, with this exeeption, appenred clenr ant well defined. Tlie spurs or brushes of light frequently reached the zeuith, eurverging to a point near it.

Although no elonda could be seen in the direc. tion of the aururn before or after ita appearante, yet when it was first seen, there nuphen red clouls, of the form of massive cutruli, tinged witls pale yellow, and behind them arose brillinut red, purple, corsuge, and yellow tints, strentwing upwards in innuiserable radiations, with all the shades that a combination of these colours could effect. In its most brilliant atate it lasted about twenty minutes. T'lie gold-leaf electrometer was tried, but without being affected : the instrument, however, was not very sensitive. Heing somewhat surprised at the Yast mass of curruli which appenred during the cuntinusnee of thes nutrora, 1 watched after its disnypearntee till diylighit, but curcld gee only a few elouds: I am therelore inclined to impute the plunomenon to some deeejtion crused lyg the light of the aururs. The apparent altitude of these clouds was $8^{\circ}$

On the 10th we were again fnvoured by the wenther; it gave us a fine sunshine, and an opportursity of riring the ship and drying the cluthes. All the sick were irmproving in health.

Ruruing cless along the barrier, wlich contiuned of the same cliaracter, although more hroken than yesterday, we saw an appearance of land, although indistinctly, to the suuthward. The water was of the sarre colour here as befure, and the wind being frum the south-southreast, we made sume progress, nud found ourwelves in Jongitude $122^{\circ} 35^{\prime} \mathrm{E}$. latitude $65^{\circ} 27^{\prime} \mathrm{S}$ : the variation had now jucreased tn $44^{\circ} 30^{\prime}$ westerly. No auroth was seen this night, although it was looked for anxiousl.

11th. The barometer had been stalionary at
29-080 in. for the last three days: it now began to fill; the temperature of the air was $31^{*}$, of the water $32^{\circ}$. The fall of the barometer was noon followed by suow and thick weather. The trending of the barrien had been sonth-west-by-west, and a good denl of flue-jee had been met with, which we ran thruugh. 'Tlie mea was quite smonth, and many icelergs wero enclosed in the barrit'r, which was very compach and eumposed of flat fields. At 10 P.M., I found it too dark to rus, and hoveto.

During the 12th we lisd plensant wenther, and at 2 A.st. filled awny. At 8 A.M., lind was reported to the koulli-west. Keeping along the barrier and inerensing our latitude, I again liad hopes of getting liear the Innd. We mussed through great quantities of large floc-ice until 1 r.as., when the sulid barrier prevented our further progress, Land was now distinetly scen, from eigliteen to twenty miles distant, bearing from sollh-suuth-enst to south-west,-a lifty mountain range, fovered with snow, thesght showiug muny ridges and indentations. I buid she ship to for three hours, in hejpes of alseovering some opening or movenent in the ice, hut none was exprerjenced, I tried the curzent, and found none, Ithe water was of a dirty darls green. We sounded with the wire-lise in two himdred and ffty fathoms, and found no bottom. The temperature at that depth was $30 \mathrm{~h}^{\circ}$, of the air $31^{\circ}$. The barrier lind in places the appearauce of being broken up, and we had ducreased our lungitude to $112^{\circ} 16^{\prime} 12^{\prime \prime} \mathrm{E}$., while our intitude was $64^{\circ} 57^{\prime} \mathrm{S}$. This puts the land in alout $65^{\circ} 29^{\prime} \mathrm{S}$, and its trending nearly enst and west. 'I'lue line of the icy barrier was genernily uniturm, alluough it was occasionalfy pjesced with deep baye. We gnw sotne iceberga with decided spoty of earth on them, which gave me hinpes of yet obtaining the object of my withes. The water was remarkably smooth during this day, and the weather clear, enabling us to see s great distance. T'wo hours after we bore away, wo left the theice, and entered a clear sen to tile westward, where we lost sight of the barrier for a time; but in bauling up to the sontl-wert, it was, by 8 8.M., within thee miles of us, when we ngain bejt off parallel to its trending. The appernsice of laud still cuntinuml. Shortly after, I hove-tn, fur the purpuse of awniting the dayliglit to costinue our obzervations of the laud, with little pruepect or probability of reaching it, from the immense quar. tity of ice which contiuned to furm an inknenetrable barrier.

13th. At 2 A.s. we made sail to the soulli-west in order to close willt the barrier, which we found retreated in that direetion, and gave us every prospect of getting nearer to jt. Our course, for the moat part, was through jcebergs of tabular form. In the afternoon we had the land ahead, and atood in for it with a light breeze until 6 f P.y., when I judged it to be ten or twelve miles distant. It was very distinct, and extended from west-south-west to south-soutli-enst. We were now in longitude $106^{\circ} 40^{\prime} \mathrm{Fos}$ and latitude $65^{\circ} 57^{\prime}$ S.; the rarition was $54^{\circ} 30^{\prime}$ westerly. The wnter was very green. Wo sounded in three hundred fatloms, and found no lottom. "The weather having an unsottled sppesrance, we stond off to seek a clearer space fur the night. The land left was high, rounded, and covered with snow, resembling 
that firgt disterered, and hat the aptontance of twing bound by perpendicular icy cliffs.

14h. At dnylight we agaiu mude anil for the land, beating in for it unti] $11 \mathrm{~A} . \mathrm{u}_{\text {.., }}$ when we found any further progress quite inpassible. I then judgeit thut it was geren or eight miles distant. The dny was rematkably elear, and the land very distinet. Hy monsurement, wo trade the extent of const of tho Antarctic Continent, wheh was then in sight, seventy-fire miles, and by approximate measurement, three thousand feet high. It was entirely covered with snow, Longitude it nom, $106^{\circ} 18^{\prime} 42^{\circ}$ E., latitade $65^{\circ} 5 f^{\prime} 10^{\prime \prime} \mathrm{S}$, variation $57^{\circ} 5^{\prime}$ westerly. On running ill, wo bad passed severnl tee. lergo greatly discoloured with enrtl, oud finding we exmal not approach the shore any nearer, 1 determined to land on tho laryest ice-island that geened accossible, to mako dip, intensity, and variation observationg. Oft coming up with it, about one and a half mile from where the barrier haul stopped as, I hove the slip to, lowered the louts, nnd fortunately effected a landing. We furtud embedust in it, in places, boulders, stones, gravel, satub, and rnud or clay. T'ho larger specitucus were of rod easulstone ond basalt. No signs of stratificatinn were to bo seen in it, lut it was in places formed of icy conglomerato (if I may use the expression), eomposed of lnrge pieces of rocks, as it were frozen together, and the ice was extrenely hard and flint-like. The largest boulder embedided in it was ahout five or gix feet is diameter, but being situated under tho shelf of the iceberg, we were not able to get at it. Muyy" specimens wero obtained, and it was amusing to see the eagerness and dusire of all hands to pustess themselve of a piece of the Antaretic Continest. These pieces were in great demand duxing the remaninder of the eruise. It tho centre of this iceberg was fount a pond of most delieious wator, over which was a seum of ice about ten inches thick. We obtained from it about five hundrel gallous. We reminised upon this icelerg several hours, and the men anused thersselvos to their lienuts content in sliking. The pond wis tlree feet deep, extending over an aren of nus nere, and entained sufficient whter for lalf-pdomen ships. The temperature of tho water was $31^{\circ}$, This island had been undonbtedly tumed party over, and had precisely the same appeamnee that the icy barrier would have exhibited if it had been turned bottom op ard subsequently much worn by storms. Therte was no doubt thit it luad been detacted from the hard, which whs about eight miles distant.

Arumd the iceberg wo found many species of zopliytes, viz. salpee, a beautiful specimen of clio helicina, sone larje pelagie, and many small ertigtacest. I male several diawing of thom. This day, notwithstanding our disappointment in being still repelled from irending on the now coutinent, was spent with mueh gratifieation, and gave us many new specimens from it.

Finding that we had reached the lonritude of $105^{\circ}$ E., before the time antieigated, risd being Aesiruns to purse tho diseuveries further west, I left $\Omega$ sigrnal ftying on this berg, with at bottle coutaining instruetions for the other venside, ditcelity them to proevel to the westward as for as incy eoukd, in the time which should remain prior to the lst of Marel. At $8 \mathrm{H}$. St, we joined tho shipg, asd bore away again to the west- ward, intending to purste the route pointed out to them.

On the 15th we passed many jeebergs much discoloured with earti, stones, \&e., notwe of which aprenred of recent formation. 'The wenther this lay beene lowering, and the brecze freals; we double-reefed the worsails, and made every thing sutug : tho wind wat from tho soutl ward. At nom this day we were in lengitule $104^{\circ}$ L. $^{*}$, latitude $64^{\circ} 6^{\prime} S$. 'Tlue sea had been remurtiably smoctl, tho Last few daye, with sko swell; and I began to cntortain the idea that we might havo a largo botly of ice to the northwnrd of us; for the josition where Cook found the barrier is 1773 whs two hundred miles further to the north. I detertained, however, to pass on in our explatntions, liopiug they might emate me to juin that of Enderly' Lsuil. I aleemed it $\pi$ grent object actunliy to prove tho continuty with it if possible; and if disappointed is this, 1 should at any rate nseurtain whether there laad been any ehasigo in the jee in this quarter, since the time of Cork, which lad been done nlready near his Ne Plus Ultra.

We had a vast number of whales about us lis day, as well nas penguitus, Cupe pigeous, white and gray, snd small and large petrels. Some senls also were sew.

1 was now linpoy to fisl the lealth of my erew liad bucume re-established, and that only a few remnined on the siel-list. This, I think was effected by constant altention to their leing waruly elothed.

The iveluergs were covered vilt pengubs. Several ofticers linded on the icebergs to get is fow as Bpecinens. On their return, sonie periguins followed them closely, purlicularly one, who at last lesped into the toot. It was sugposed thint its mate had heen anong those taken, and that it had followed on that acconnt. If this were the fact, it would show a remarkable instiuclive affection ir ulis bird.

On the I6th, the barrier of ice trended to the northwnerd, aud we wero usjligesl to haul to the unrth-eust, prosing thruugh a large number of iceislands, matry of which were stained with enrtt. In the aftermoon it large sea-elephant was dis. covered on the ice; two bonts were sent to effect his capture, and numy balls were fired into bim, but he showed the itmost indifferenee to their effect, doing nu more than to raise his head $n t$ cach shot. He contrived to esenpe by Houndering over the ied until he renched the water, in which be was guite a different heing. At about 7 r.M., Ir. Fox was desostched in a boat to visit an ice-ialand that was very much disenhured with elay in patehes. He reported that there was upens it a lingo pond of muddy water, not frozen, although the temperature on boanl was much below the freezing juint. Wa observed around tho foebergs numerous right whates, puffing in all directions. A lango qunntity of small crustacen, including

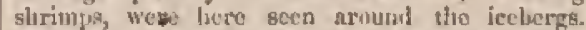
These are believel to be the eature that atimets whales to these parts; they ulso supply the numerous penguins with their foot. For several days 1 obsersed a great difference in the wind, ly day and by uight. It hud been fresh fron the lous of Beven in the mozuisg until fo F.M., when it generally becomes light on dies away altogether. 'l'odday we found ourselves in longitudo $99^{\circ} \mathrm{E}$., ant latitude 
6.4 $2 \mathrm{I}^{\prime} \mathrm{S}$. We to-day made nbservation throughout the twenty-fonr hourg with Leslie's photometer.

On the 17ih, about 10 \&.s., we diacorered the barrier extending in a line ahead, and running north asul sotith na far na the eye could rench. Appeamenes of land were alan seen to the southwest, and ita trending secemed to be to the north. warl. Wo were thus eut off from any further progress to the westwarl, and obliged to retrace wur steps. This position of the ice dissppointed me, althongh it coneurred with whint was rensonably to be expectert. We were now in longitude $97^{\circ}, 37^{\prime} \mathrm{F} .$, and latitude $64^{\circ} \mathrm{I}^{\prime} \mathrm{S}$; ; nur variation wam $6 f^{\circ} 21^{\prime}$ westerly, beisg again on the decrease. [ก-day wo hal soveral anow-\$4 [ual]s, which, instead

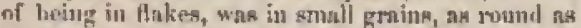
slont, surd of warjous sizes, from that of mustardsuenl to buckshot. It was remarkably dry, pure while, anul not at all like hail. We fuund the lay we hall entered was tifty or sixty miles in rlopth, nut having Jun in on iLs southern side, I determined to return along its malliern slore, which we set ahont with much anxiety, as the weather hegan to chnnge for the worwe. Our situntion was by an menus sich as I should have chosen to encounter bas wenther in, the bay being sprinkled with a great many large icebergs. Here we met with a large number of whales, whose curingity seetned atwakened by our presence, "Their proxinity, how. ever, was any thing but plmasant to uf, and their blowings regemblad that of a number of locomon tives. Their elnse ayıroach wns a convincing froof that they had snver been expresed to the pumutit of their skilful hunters. 'They were of the fin-back apecies, and of extmondinary size.

Between ten and eleven w'clwek at night it was entirely clear over hend, and we were gratified with a splendid exhibition of the aurnora nustmlis. it exceded any thing of the kind I had heretufure witnessed ; its activity wns ineraceivable, dating from the zenith to the forizon in all directions in the annat brilliant coruscations; rays procecdiag as if fivin a print in the zenith, flushed in brilliant pencilliags of Jight, like sparks of electriv flohl in Facuo, and reapprared agrals to vanish; fortsing theanselves into une body, Jike an umbrella, or fall, shus atr; agail energing to flit across the sliy will the rapidity of light, they stowed all the prismatic coluurs at once or in quick succession. So remark. able were tha phenomena that even onr satiors were conatanly exclaiming in actulsation of is brillianey. 'l'he best pass inn in whieh to view it was by fying bit upon the doek, and broking up. The elichoneter was tried, but no elfeot perceired The star Cannpus was in the zenith nt the time, and though visible throngh tle anrora, was much dimivishod in brigheness. On this niglit atso the mom ман ратtially eclipused.

Large ienhergs lad now beenme very numerous, and strengliened the halief that the Junil existing in this vieinity had taken a very decided trend to the northward. I areordingly tollewed up the purthel' barrier elosely, and passed through the thickrat of these berga, well knowing from our experience that we should liave little or no opportunity of seeing the land, unless on the inner sirle of them. It appeared as thongh they had oollectel hero from other plnees, and it is imposible to form an idea of the small space to which we were at times confined. Upwards of one lundred ice. inlands could be counted at a time without the rid of n glass, some of which were severnl miles long. We enjoyed this beantiful sight with the more pleasure, for we had become used to them, nnd knesv from experience that it was possible to navigate tfrough them withont aceident,

On the 18th, we continued beating to the engtward, and found no end to the apparenty interminable barries. We liad a smootli sea, snil bettur weather than I anticipated. At noon, wo had retraced our way about forty miles. To-day we again had snow, which fell in the form of regular six-poisted stars. The needles of which these stars were formed wers quite distinet, and of regular crystals. The temperature at the time was $24^{\circ}$. The barnmeter stood at 28.76 in., abut dlireetenths Jower than we had had it for the hast twelve days. The wind was ensterly.

iDth. During this day the barrier trenled more to the nntli-east, snd we not unfrequently cntered lays so deep as to find ourselves, on reaching the extremity, cut nff by the barrier, and compelled to return to within a few miles of the plnce where we Hail entered, I thonght at first that this miglit lave been cansed hy the tide or current, but reprented triala sforwed nane. Neither lid I detect any mution in the flosting ice except what wrs eatsed ly the wind. Our longitule to-day was $101^{\circ}$ L., Intiknde $63^{\circ} 2^{\prime} \mathrm{S}$. Somis anxiety seemed to exist among the offieers and crew lest we should find ourselves embayed or cut off from the clear pea, by a line of barrier. Thero appenred strong renson for this apprehension, so the smooth sen we had had for several days still continued; we liad been sailing as if upon a river, and the water had not assumed its blue enlour.

It was, therefure, with great pleasure that, on the 20th, a slight swell was perceived, and the barrier began to trend more to the nortlwward, ant afterwards agnin to the westward. In the moruing we found ourselyes atill furrounded by great numbers of ice-islands. After obtaining is toleratiy clear space, the day leing ralther favourable, we sounded with the deep-sea line eiglit hundred and fifty falıome. Six's thermometer gare at the ant face $31^{\circ}$, and at the depth of eight hundred and fifty fathuns $35^{\circ}$, an increase of funr degrees. The current was agrin tried, but none was found. A white object was rixible at eleven fathoms. The wrter loul now assiumed $n$ bluish cast.

We endeavoured to-day to land on an jeberg, but there was ton much sea. Shrimpls were in grest quantitieg about it, but swam two deep to be taken. The wirnd agnin bauled to the weatward, which disappointed me, as I was iu hopes of getting to the prosition where Cook saw tho ice in $17 \pi 3$, being now nearly in the same latitude. It was less thas one hundred miles to the westward of us; and little doubt enn exist that its situation has wot materially changed ia sixty-seven years.

The ohaersations of the squadron during this senson's antarctic eruise, together with thuse of the procerling yenr, would seem to confirm the ophing that very litule change takes place in the line of ien. It may be inferred that the line of perpotan! congehtion exists in a lower latitude in some prots of the southem hemisphere than in othere. The icy barrier retreats sevesal degrees to the south of the Antaretic Circle to the west of Cape Hurn, while to the eastward it in places advanees to the north- 
warl of that line, which is no dombt owing to the situntion of the Iand. From the greut quantities of jee to he found drifting in sill parts of the ocean in ligh sonthern lutitudes, I an indueed to belicve that the formation of the jee-islands is much more rapid than is generatly supposed. The manner of their formation claimed much of my attention while among them, nod I think it may be explained sntisfactarily and without difficulty. In tho tirst place, I conceive that ice requires a nucleus, whereon the fogs, snow, and rain, may congenl and accumulate; this the land affords, hecident then separates part of this mass of jee from the hud, when it drifts off, and is broken into many pieces, and part of this may again join that which is in process of formatiou.

From the accumulation of snow, such a mass spexlily assumes a that or table-topped ahaje, and continues to inereage. As there layers accumulate, the field-ice legins to sink, each storm (there of frequent occurrence) tending to give it more weight. The part which is now attached to the land remains aground, whilst that wlisels is more remote being in decp water is free to sink. The aceumulated weight on jts outer edgo produces fissures or fractures at the point where it takes the ground, which the frosts increase; thus seinatrited, the surface again becumes burizontal, and cotitinues to receive new layers from snuw, rain, nurl evel fogs, being still retained to the parent mass by the fnece of attration. The fogs bate no small influence in enntributing to the nceurnulation: some idea nay be formed of the increase from this enuse, from the fact that during a few lours the iee aceumulated to the thickness of a quarter of an inch on nur rigging and spars, though neither rain nor snow fell. It may, therefore, I think, the safely maserted that theso icelergs are at alf times on tho increase; for there are few days, necording tu our experience in this elinnte, in which some mole of precipitation does not prevail in these Jigh latitudes, where, accorditig th our observations, jee seldom melts. The tempernture of even the summer months being ravely above the freezing point, masses of a thoussnd feet in thickness miglit t'oqquire but few years to form. Ieebergs were seen in all stages of formation, from five to two tumdred feet abovo tho surface, nnil ench exposed its strntification in horizontal layers fonn six inches to four feut in thickness. When the icetuergs are fully formed, they bavo a inbular and stratified appencance, and are prexfectly wall-sided, varying from ono hundred and eighty to two hundred and ten feet in height. These were frequetstly found by us in their original situntion, attrehed to the land, and having the lorizontal stratification distinctly visible.

In some places we sniled for more than fifty milea together, along a straight and perpendicular wall, from ono hundred and fifty to two hundreat feet in height, with the land behind it. The icebergs found along the const afluat were from a quarter of a mile to five miles in length; their separation from the land may be effected by severe frost rending them asunder, after which the violest and frequent storms nay be considered a suflicient canse to overeome the attraction which holits them to the prrent mass. In their next stage they exlibis the process of deeny, being lound fifty or sixty nuiles from the tand, and for the most part with their suriaces inclined at a considerable anarlo to the loorizoth. This is cused by a change in the position of the centre of gravity, arising from the abrading actiun of the wares.

By our observations on the temperature of the

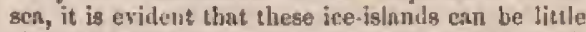
ebnaged by the melting process before they resw the latitude of $60^{\circ}$, 'The temperalure of the sea (ns observed by the ressols guing to and returning from the south), sluwed but tittle ehango ubove slis latitude, and no doult it whs at its maximum, as it was then the lieight of the summer seasum.

During their drift to the northward, on ruaching lower tatitudes, wnd as their distance from the land increnses, they are fuusd ju all stages of decay; some furming obelisks; others tuwers and Guthic arches; and all more or less perfurated : sone exhibit lufty columne, with a natural laridge resting on them of a lightmess and benuty inconccirable in any other materinh

While in this state, they raroly exhibit any signs of statification, and some appear to be formed of a solt and porots ice; vthers sre quile Lluc; otlete again show a green tint, and are of hard finty ice. Large ice-islands are seen that retain their tabular tops nearly entire until they rench a low latitude, when tleir dissolution rajidly ensues; whilbt some lave lust all resemblance to their original formation, and had evislently been overturned. The process of aetually ronding asumder was not witnessed by any of the ressels, although in the Flying.liah, when during fogs they were in close proximity to large ice-islands, they inferred from the loud crashing, and the sud. deri splashing of the sea on lier, that sucl oceurrences liad taken place. As the berga gtadually Decome worn by the alurision of the sea, they in many cases form large overlunging slielves, ubout two or three feet above the water, extending out ten or twelwe feet; tho under part of this projecting mass exhibits the aprearance of a collectiun of icicles hanging from it. The temperature of tho water when among the icubergs, was found beluw or about the freezing print.

$I$ have before spolien of the boulders embededed in the icebergs. All those that I lad nis upportunity of observing, apparuatly formed a part of the minclous, atrd were surrounded by exiremely contpact iee, so that they appear to the connected will that portion of the ive that would be the last to dissolve, and these houldery would therefore in all probnbility be carried to the farthest extent of their range before they were let loose or deposited.

The ice-islands, on being detached from theis original pluce of formation by some violent storts, are conveyed to the westward by the soutl-ent winds which are prevalent here, nut are found, the first senson after their sejutation, about seventy miles north of the barrier. This was inferred from the observations of Lotl the Vincennes and Porgroise, the greatest number having been fund about that distanee from the bartier. Tlant these were recently detached is proved by their stratifiod appearance; while those at a greater distance lad lost their primitive furm, were much work, and showed matyy more sigus of lecay. Near the extreme point of the barrier visited, in longitude $97^{\circ} \mathrm{E}$, latilude $62^{\circ} 30^{\prime} \mathrm{S}$, and where it begins to trend to the westward, rast callectious of these islands were encountered. Frum this peint they 
misst pass to the nortisward during the next season, partly intienced by the current, and partly feattered by the jrevaling winde, until they reach the sixtiels degree of Iatituic, when they encounter the ensterly and north-ensterly streamg last are known to preval, which taricy ilien rapicliy to the nourtli.

Our data for their netual drift, thongh not altogether positive, are probubly tho best than ean be finl, and will go far towards asecrtniniog the velocity of their progtess to lower latitudes; nur olegervations also furnish souse estimate of the time in whicls they are formet. On our way bouth, wo did not fall in with iee-islands until wo reseled latitude $61^{\circ} \mathrm{S}$. The Pescuck was the tirst to returw, aul nearly upon the traek ly which we lund geune sutuls; the last seen ly leer was in $65^{\circ} \mathrm{S}$. The Y'incemes, of lser returi fifty days Jater, san them in $5 l^{\circ} \mathrm{S}$. The Porpuise, abunt the sane lime, in $63^{\circ} \mathrm{S}$. The observation in the Yineenues gives a distanes of ten degrees of latitude, or six founired suiles to tho pasgerl aver in fifty days, which would give shout half is milo an hour; or, talking the I'eacoek's nbservations, a more rapid rate would be given, neariy dire-fourtles of $\mathrm{n}$ mile. Many ieebergs were net in the latitnde of $42^{\circ} \mathrm{S}$. liy outwaridound slipes to Sydney, in the month of November ; these, 1 learnefl, were much wurn, and showed lofty pintaclus, exlibiting no njpenrarsee of liaving ever been of is tabular form. These no doubt лre such ns wero detuchel turing a former season, and being disengaged from the bartier, would be naturally, early tho next season, drifted by the casterly curront as well as the westerly wind, and wonid fursue the direction they give them. They would therefore be drisen to the north-enst as far as the soull-enat winls prevail, aud when thege veer to the westwurd would receive an ensterly direction. It is where theso winds prewiil that they are most frequently found by the outward-boust ressels, - between the latitudes of $40^{\circ}$ and $50^{\circ} \mathrm{S}$.

Respecting the period of time reiniled for the furmation of these ice-islanda, nutel light caunot the expected to be thrown on the subject; but tho fuw facts derived from obsorwations lead to somo cunclusions. Many of them were mensured, and their allitude formil to be frum finy to two Inndred and fifly fect ; eighty distinet strutifications were counted in sume of the thighest, and in the amallest thirty, which sppeared to avernge a litde mure than two feet in thickssess. Supposing the average fall of surw in these liggh latitudes to be an incla a day, or thirty feet a yenr, the lurgest iceberge wulli uke more than thirty yens to form. They were seen lyy us in all the striges of their growth, nud all tore urequivoeal marks of the sanwe origiss. The distanee from the land at which they were forming, fully satisfied ne that their fresh water could ouly lie derived from the snows, Sc.

The movement of the iee along the cunst is entirely to the westwarl, aul all the liuge rarges of iec-istanuls and bergs were found is that dj. rection, while the eastern portion was comparatively free from it. A lifference whs fumd in the position of the floe-ice by the ditforent vessels, enused mather by the wind than by the tide. When the Vintemes and Porpoise passed the opening by which the Peaenel entered, it wns lound elosed, nithougli only twenty.four hours lad elajised. It las bera seen that the jee lax much movement during the time the Penenek uns heset by it, nut the bry was all but chased when she efleeted hor creape. Another instance ocenrred, where the I'orpuise, in ahout the longitude of $130^{\circ} \mathrm{E}$, fomd tho irs rracticable barrier $\mathrm{n}$ few mileg further south than tho Vintenues ditl six or soven day's after; but this fact is not to be received as warratitis any gencral conclusion, on tecount of the ocestrreice of south-east gales during the intermellinte time. Tlue trials for eurrents have, for the most purt, ollown nune to exist. The Furnoise, it is true, experienced some, bnt theso weru getwerally after a gale. If currenta do exiat, sheip tendeticy is westward, which I think the drift of the ice would elenty prove. The difference between the astromunie pasitions and those given by doadreckonings, was of no arail laere as a test", for the courses of the reasels among tlie lee were so tartuons, that the lntter could not he depenuled upon.

The wimds which prevail from the south-west to the fusth-east occusionally loting elear wenther, interrupted by flurries of Enow; the north wind is lighit, and bringes thick fugs, attended by a rise of temperature. Extremes of weallyer are experioncel in rmpid succession, and it is truly a ficlie climate.

The eqidenec that an extensive continent lies within the icy harrier, must. have aptreared in sho necount of my proceedings, hut will he, I think, more forcibly exhihited hy a comparien with tho aspect of other lands in the samo southern parnllet. Palmes's Land, for instatuee, which is in lihe manumer invested with ice, is so at certnin sersons of tho yen muly, while at others it is zuite citur, becanse strong currents merail there, whiolt sweun the ieo of to the aorth-east. Along the Antaretic Continent for the whole distanec explured, whikh is upwards of fifteen lundred niles, no open strait is fuund. The coast, where the ive permitted apuroach, was found enveloped with a perpeudieular burrier, in some cases unbruken for tifty miles. If there was only a chuin of islands, the outline of the ice would thudoubtedly be of anotlier form; nnd it is scareely to be conceived that so long a clain cunld extenul an nenrly in the sume parallel of latitule. The land has none of the alıtiptness of terminution that the islatuls of bigh southeru Jationde's exbibit; and I nm satisfied that it exists in one nuinterrupted line of coast, from Ringgold's linoll, in the east, to Fuderby's land, in the weat ; that the const (at longitude $90^{\circ} \mathrm{E}$.) trends to the sorth, and this will account for the icy larrier existing, with little alteration, where it was secu by Cook jil 1773. The rast tumber of ice-istunds conclusivcly points out that there is some extengive nuelens which retusus then in thuir position; fro I ean teo no reason why the iec slumblil not be dis. engagod from inlands, if they were such, as happens in all other enses in like latitudes. The for" mation of the enast is different from what would! probably be found nent islatuds, soundings heing obtained in comparatively shoal water; and the colour of the water also irdicates that it is not like other southern lands, ahnipt and precipitum, This enune is suthicient to retain the huga nasses of jec, by their being attached by their lower surfnecs instead of their sides only.

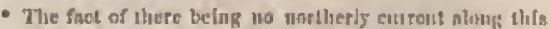

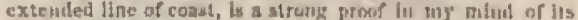
belig a contlnent, instead of a range of inlanila. 
Much inquiry aud a strong desire las been evineed by geologists, to nscertain the extent to which these ice-islanils uravel, the boulders and massos of eartl they tmusport, and the direction ther take.

From tay own obsetพntioms, and the inforzuntion I liavo collected, there appears a great difference in the movenrents of these vast masars; in some years, great numbers of them lutye floated urth from the Antnretic Cirele, and oven at times obstructed the navigation about the capen. The year IAts was remarkablo in this respect; muny vessels bound round Cape Hom frum the Pacilic, were obliged to put back to Chili, in corserguence of the dangets arising from ite; while, during the preceding and following years, littlo or none was Bews: this would fead to the belief, that great charges isnust talie place in the highen latitudes, or the prevalence of some cause to detnch the ice-ishands frons tho barricr in such great pusutities as to enver nlumst the entiro seetion of the oeen south of the latitude $50^{\circ} \mathrm{S}$. Thking the early jart of the (suttlern) spring, as the time of separation, we are elnbled to make some estimate of the velocity witl witich they move: many masters of vesselg have met then some six or seren hundred miles from the barrier, from sixty to eiglity days sfter this period, which will give a near approxianation to our results heretofore stated.

The senson of 1939 aม 1840 was considered as at open one, from the large masses of iec slat were met with it a low tatitude, by vessels that arrived from Europe at Sycluey: many of them were socu as far north as latitude $42^{3} \mathrm{~S}$.

'l'he eauses that prevail to detneh and cnrry them nor:ts are difteult to assign. I have reforred to the most probable ones that would detach them frotn the parent mass in their formation. Our frequent trisls of eurrents, as has been stated, did sot give us the nssuranco tlat any existed; but there is litsle deutut in my mind that they do prevail. I should not, however, look to is surfinee eurcent as being the motive power that earries thesa inumense uasses at the rate they move; comparatively spealing, their great bulk is below the intsuence of nuy surfinec curvent, and tio rapid trift of these masses by winds is still more ing robable; therefore 1 conceive we must Jook to an umler current as thein great propeller. In one trial of the deep-sen thermometer, we found the temperature beueath four degrees wasmer than the surfice. Off Cape Horn, the unler temperature was found hs euld as mmong the ice itself; refneated experiments linve showin the same to ocent in tho aretic regrinns. From this I wonld dow the conclusion tlint changes nte going on, and it appears to mo to be very resumabie us suppose, that at periods, currevts to and from the poles should at times exist; it is true, we nost generally find the latter to prevail, as far ng our linowledge of facts extends, but we hate not sufficient information yet to decide fuat there is not a retlow towards the pole; the very circumstance of the eurrent setting from the highter latitudes, would seews a good argunent that there nust be sume connter-current to maintain the level of the waters. 'Jhese masses, tliell, are juost prolubly carcind \&way in the seasons whes the polar streams are the strongest, ntid are lourne along lyy them at ife velueity witl which they move: that these do not occur sumually toay be infured from the absence of ice-iglands in llye Juwer latifudes; ata] that it is not from the acareity of thesn, those wla slared the daugers of tho autarctic cruike, will, I lave little doubt, be realy to teslify; for, al. thougli great numbers of them studded the acen that year, yet the narrative shows that vast numbers of them were left.

The specific gmvity of slie ice varies very much, As might naturally be expected; for while some of it is porots and of a snowy texture, ofluer istands are in great prart composed of th eompact blue fliuty ice. This difference jo occasioned by tho latter beconsing saturated with water, which afterwards freczes.

On tho ice there was usually a corering of ntout two feet of enow, which in places lind ippon it a crust of ice not strong enough to bear the weight of a man. 'T'hose ice-islandy, which after having heen once Eeen, wore again passed through immediately nfter a gale, were observed to be clanged it apperance; but sliough for forty-eight lomrs a savere storm had been experienced, they laad not undergono so grent a transforaustion as not to be recoguized. They nlso appenred to bave shifted their pasition with regard to one another, sheir former bias and trendings being liroken up.

During our stay ou the icy coast, I Bew notliug of what is terused pack-ice,-lhut is, pieces forced one upon the atler by the actius of the sen $01^{\circ}$ currents.

On the 2lst, the weather beenme unsettled, with light westerly wisud, mud we made but little progress to the vestward. I'he barrier, at 6 s.m., was secul tremling to the westwarl. In consequence of indications that threatened land weather, 1 seemed it nseless risk to remain in tho proximity of Eo many ice-islands; and a strong brecze, with squally weather, howing already set in, 1 took advantige of it, fecling satisfied that our further contiunance in this icy region would not ouly bo attended with peril to the klip, but would couse a waste of the tine which was demanded by my other duties; and having nearly thee thousasd miles to ssil to our next port (Bay of Islands), I made up my asind to turn the head of the vessel uorthwrird.

I therefure had the oftiecr and crew enlled aft, thanked them all for their exertions and good conduet during the trying secnes they had gone through, congratulated them on the success that had attended us, and informed thems that I had determined to benr un and return north.

Inving only twenty-fivo days' full allownee of water, I ordered its issuo to be reduced to half allowance.

1 luve seldom secu no many linppy faces, or wuth rejoicinge, as the announcenent of my intention to return produted. But nlthough the crew were delighlued at the terusination of this damgerous cruise, not a word of imparience or diseontent land bees hestrd during its continunee. Neither las thare been oceasion for ptuishment; and I could not but be thanklul to have been enabled to conduet tle slip thrnugh so difficult and dangerous a navigation without a siugle accident, with a erew it as good, if not in better condition than when we first reaclied the icy burries: For myself, $I$ indeed fot worse for the fivigues and mrxictics 1 land unJergone; but I was able to attend to all my duties, 
and considered myself amply repuid for my impaired liealth by the important discoveries we had made, and the suceess that had attended our exertions.
1 ghall now leare the Yincennes to pursue her route northward, and return to the Porpoise, the result of whose procetdings will be detuiled in the following clapter.

\section{CHAPTER XIX.}

\section{ANTARCTIC CRUISE-(CONTISERD).}

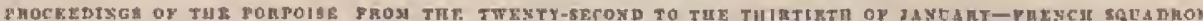

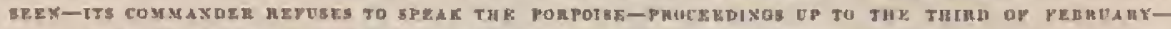

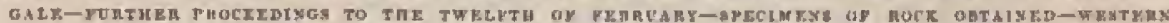

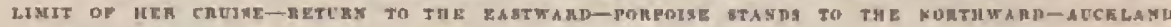

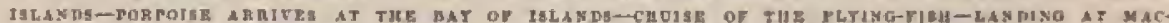

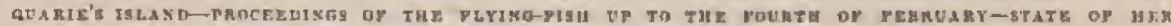

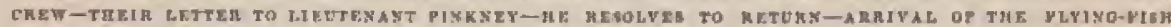

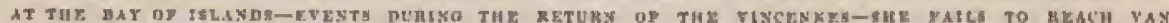

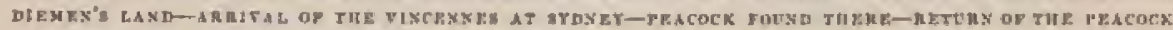

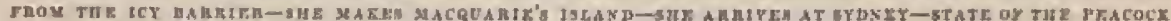

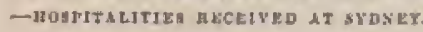

Ox the 22nd January, 1840 , the Porpoise lost sight of the Peacock, nuil comtinued beating to the soutli-west. Tlie wentlser was extrenvely cold; seawater froze on being a few minutes in the bucket on deck. Some shrimps were cauglih The water at 3 P.3. was inuch diseninured; got a east of the lead witls two hundred fathoms: no loutom; found the current south-by-east three-fourths of a mile por hour. At $4^{\text {h }}$ 39in, pased large icebergs, one of which had several dark horizuntal veins, apinrently of enrth, through it; Iarge quantities of thoe and drift-ice to the southward; the sen very smoth. A report of high Iand was made this moriutug ; in deed every thing indiented the proximity of land. The number of eals, whales, penguins, glirimps, \&ce, had very much increased. The pure white pigenns were also seen in numbers.

25rd. Countless icebergs in sight; the sea fivite smooth; not the slightest motion perceptible. At meridian, they were in latitude $66^{\circ} 44^{\prime} \mathrm{S}$, longitude $151^{\circ} 24^{\prime} \mathrm{F}$, and close to the barrier, which appeared quite impenetrable, as far as the eve could reach from aloft, to the norlh-north-west and northnorth-enst, with numberless immense ice-islands entangled and enelnsed in it in all direetions. "The position they accripied seemed an inlet of elliptical shape, with an opening to the nouth. It was reerlless to count the man seattering islands of ice distinet from the vast chain; intermingled witl field-ice, they studded the gulf Jike so many islands, of various Ehapes and dimensions. $\mathrm{Al} 2^{\mathrm{h}} 25^{\mathrm{m}} \mathrm{m}$, sail was discovered on the lee bow; kept off to communicate, snpposing it to be the vincennes or Peacock. At $2^{h} 30 \mathrm{~m}$, the Peacock was made out on the southern board, showing no disposition to comrnunicate; showed our coloura, aud hauled to the westward.

24th. The day was remarkahly fine, such as is seldom experienced in this region. The water appeared much discoloured and of a dirty olive-green colour. At meridian, they again male the fieldice, and thoked to the northward, passing through large quartities of ice-islarde; weacher boking bad, with ocensioual light snow-storms.

2oth. Part of this day was clear and pleasant, thougls snow fell at intervals; the field-ice was in sight geveral times, and many ice-islands of great size and beaty. Penguins were swimning rousd, and aiso several shoals of black-fish; a black albatross was shot; trowards night the werther became very thick; they were in longitude $1500^{\circ} \mathrm{L}$. latitude $65^{\circ} 5 b^{\prime} \mathrm{S}$.

26th. Fresh winds blowing from the enatward ; during the fitst few hours, a thick entuw-storn: at 4 A.M. it clearert ; at six otelock made a rail ; the strange sail lired a grun and made Bignal, when we bore down and spoke her; fic pruved to be the Vincennes; eumpred clironometers, nnl roceived rate; tore off to the westward under all sail ; fund the drift and lloe-ice very thick, and were with great difficulty enubled ta navigate through it ; wind fresh, with a long swell from the south-west; at $5^{\text {h }} 30 \mathrm{~m}$, the ice inereasing in quntity, found it was necessary to haul nff. Lnst sight of the Yincennes; wenther rery throatening. Tho course during the day proved in very tortuous one; maby penguins resting on the ice; their grit is an awkward kind of strut.

Received orders to-day by siftal to meet the Vincenues along the icy barrier between the 2att and $28 \mathrm{~s}$ h of next month.

27th. This day proved elenr and cold; wium? from the south-west; ice forming rapidly on the vessel ; at meridian, lost sight of the Fineennes very many ice-ialands in sight ; latitude $65^{\circ} 41^{\prime} \mathrm{S}$., longitule $142^{\circ} 31^{\prime} \mathrm{E}^{*}$ On this day, LicutenantCommandant Ringgold determined with the fair wind to juss to the extreme limit of lis orderg, ingitude $105^{\circ} \mathrm{E}$; ; being of opinion he would thereby anve time, and be enabled more eflectually to examine the barrier witls whit he thouglit would be found the prevailing wind, viz. that from the พestward ; in this, however, ho wns mistalken.

The 28th set in with a light breeze frum enstnorth-enst ; mado all sail ; at 5 A . ing rapidly, snow fniling fast, and whether becorssing thick; at six o'elock, tmade the the and driftice; slortened anil, and hauled off to the north-west, it becoming so thick as to render any ndvance ur2safe; until meridian, very strong winds from thr 
enstward, the brig under elose-reefed topsails ; at I $\mathrm{P}, \mathrm{M}$, foumd it diffieult and hazardutas to proceed, passiug within a short distance of lee-istarkds, and just secing them dimly tlirough the abseurity; at three, the levig was hive-to, nud Lieutenat-Com. mantant llinggold says, in reference to theiv situation-

"I felt great anxiety to proceed, but the course was so preritous, the extent and trond of the barrier mo uncertain, I could not reconcile it with prodence so adrnnce. "The froguent falling iss with fields of drift-jec, the numerous and often closely-grumped chain of iceliergs, wete sufficient to point aut discrefion. The lomg-extendod barrier wns encunutered in latitude $15^{\circ} 8^{3} \mathrm{~S}$.; at twelve to-dxy our position was $66^{\circ} 16^{\prime} \mathrm{S}_{0} ;$ it is easy to pereeire the poesibility of $\mathrm{n}$ trend northerly agnill, which would bave placed us in a large and dangerons gulf, with a heary galo blowing directly on, without a hopeaf ceenpe.

"At \& s. 1., blowing very heavy; the snow falling rendered visiun beyond a few yurda impossible; I lave seldom experienced a benvier blow, and towards the conclusion the squalls were severe and freqguent."

The barometer nt 3 A.M., stinod at $26-200$ in., the lowest point it reached during the gale. The temperature of the nir was $26^{\circ}$.

The sovere gale coutinued during the 29ul, with a lieawy sea, and snow falling thickly; at $\mathbf{\theta}$ A.x. the gale abated, and the clouds broke away; though the day the sun nccasionally out ; the weather ajpearcd unsetuled; the sun set red and fiery; the latitude was uberved $64^{\circ} 46^{\prime} \mathrm{S}$, longitude $137^{\circ}$ 16 I:

On the 30th they stood ngain to the south-west; at 2 4.M. sliey made the barter of ficlt-ice, extending from south-east to west, when it became necessnity to haul more to the rorth-webt; the weather beeoming thick wjth a leary fall of snow, at four actnek, the wind incrensing, compelled them to shorten sail ; at $7^{\text {Ja }} 30^{\mathrm{m}}$ the ice in fielits was dis. eurered close alxard, heading west; at this time lasuled immediately on a wind to the north-enst, fud soon prosed out of siglat of the ice and mit of danger; during the day blowing a gale of wind, and very heswy sea running, passing ocersional jeeislands; at meridian, being clear of the barrier, the hrig was hove-to under storm-sails, to await the clearing of the weather. In the afternoon the wenther showed signs of clearing; the sua coming ont, agnin made sail to approach the barrier; no jee in sight; great numbers of black petrels about.

At 4 r. \%. discorered a slip ahead, and shortly after another was made, both standing to the northward; the brig haules up to the north-west, intending to eut them off and speak them, supposing them to be the Vincennes and the Percock; shurtly afterwards they were seen to be stmngess, being smaller ships than our own; at $4^{\text {th }} 30^{\mathrm{m}}$ the Porpoise hoisted lier colours. Kunwing that nn English squudron under Captnin IRoss was expecterl in these seas, Lieutenaut-Commaniant Risuggold wouk them fur his ships, and was, as he salys, "preparing to cheer the discoverer of the North Magmetic Pole."

" $\Delta t f^{\mathrm{h}} 50 \mathrm{~m}$, being witluin a mite and a half, the strangers showed French colours : the leeward and sternmost displayed a broad pennant; concluded now that they must he the French discovery whijp under Captain D'Lrville, on a similar serviee with oursolves: dewrous of speaking and exclasuging the naual aud customury eomplimetsts iseidental in nava! life, I closed with the stmngers, desiring io jase within hail under the flag-sihip's atern. While gaining fust, and being wilhin nusket-khot, my intentions ton evident to excite $\AA$ doubl, $\mathrm{kn}$ fir from any reciproeity being evincel, 1 kaw witl surprise sail making hy bourylisg the tonin tack an bond the thag-khip. Wishout a monent's delay, 1 lanked down my colours and bore up on my course before the wiud."

It is with regret thint I mention the above transsetion, and it cannot but excite the surprise of ull that such a cold repulese should have come firum a French commander, when the offiers of that nation are usually so distinguished for their polite. nesa and attention. It was with no small excitement 1 henrd the repurt of it,- that the vessels of two friendly powers, alike engaged upon an arduous and hazardous service, in so remnte a region, sur. ronnded with every danger usivigators could be linble to, should meet ind pass wichout even the exchange of common civilitices, and exlibit notie of the kind feelings that the situation would uaturally awaken :- how could the Irench commander lnow that the brig was not in distress or in want of assistance ? By refusing to allow any communieation with him, the not only cummitied a waston violation of all proper fecling, lut a brench of the courtesy due fom one mation to another. It is difficult to imagine what could bave prontpted lim to such a course.

At 6 P.M. Uhe weather again was thick, with the wind south-easterly; ficlil-ice again in sight; it conmenced snowing, and the French ships were lost sight of. At 8 P.M. they passed in eight of large fickls of iee and ice.islands; at $10^{\mathrm{h}} 30^{\mathrm{mm}}$, the gnow falling so dense and the weather so thick, that it was impossible to see the brig's length in any direction; she was hove-to, to awnit a change of weatier.

The beginsing of the 31 st the gale continued; at 7 A.M. modernting, they agnin made snil to the westward; in half an hour discovered a higlt barrier of iee to the northwark, with jec.ishands to the southward; at 10 A.m. they found themselves in $\mu$ grent inlet formed by vast fiejds of ice, which they had entered twelve hours previsualy; the inly ofrening appenting to the eastward, they were compelied to retweo their steps, which they eflected at 8 r.y., passing some ice-ishumds which they recognized as having been acen the evenisg befure, They now found themselves out of this dangerous pusition, and passing the pwint, kept swny to the westward. Lieutenant-Commandans ringgold judged is prudent to heave-to during the vightit, on account of the darkness.

February lst. The immense perperdicular barrier encountered yesterday was nuw in sight, trending as far as the oye could rench to the westward; it was of tabular form, from one thumdred aud fifty to one buxdred nud eiglity feet in height, of solid tompact ice, rusembling a loug line of coast; wind moderate frum itse sonthi-east, - as briltinnt blink extending along and elovated above the barrior. At 4 r.st. they arrived at the end of this barrier, ntud found it trending off to the southwarl, seeming as if numbers of icheres lasd been broken from the barrier by anne miglity furee, execering in mutnbers any thing that land yer been seen, ant extending as 
for soubl as could be distinguished, intergperged with much drift and floemice. On the sunthern horizon sixty-four ice-ishands were counted, exclusive of mnny near them, and those that were not distinguishable fron tho barrier.

The current was tried here, and found sotting south-east, nearly a mile an hour. Pigeons arourd in numbers, algo whales and large flocks of ppenguins.

Tho niglits now evilently lengthened, thas adiling to the cares and anxieties attendant on this navigation. It was fortunate that the prevailing winds were from the south-chst and southwest, or coming off the ice. If they hatd blown from the northward, they would bave been attended with danger, and might lave proved fatal to the ressel.

2mi. At meridisn, in longitude $130^{\circ} 36^{\prime} \mathrm{E}$, and latitule $15^{\circ} 2 f^{\prime} S$. They were prevented from proceding futllar to the anuthwarl by the inpenctruble icy bartict. At this time they Jat one hundred lnage ice-islnuls in siglit, withont counting any of the stmaller bergo, wlitch were inzumershle; вa great mumbers of penguins and some seals (phoce proboscida). Who current was tried liere, nut found setting na yesterday, nad at the wame riste.

At 3 r.s. were abliged to retrace their steps to tho northward, the weather hecoming thick, with light snow. At eleven, eunstant and thick snowstorm, and unable to see any distance; the gale continuing, lay.lo under a close-reced maintoppatil.

3rd. A gale from south-east, heavy sea rising ; occasiomally passing ice-islands and field-icc. 'T'he gale eontinued throughout the day, but molerated tuwards midnight; the sen was henry, the wealher thick, and the trig empletely envered with ice and nnow, TJie barorneter fell to 28040 in. Temperaturo of the air $32^{\circ}$.

4th. Altlintigh the wind was modernte, yot it was so thick and fonggy as to preclude bearing ир. Towards meridian it cleared safficiently fur thera to hear up and ennlisno their exnminations. To-day the current, wus fumul west-north-west, three-iquarters of a mile per hour.

On the both they had a benutiful day, - no elimate or regios, Juleutenant-Commandsint Ringgold remartis, conld bave produced a finer: this gave them an opportunity of thorouglaly dryigg every thing and ventilating the vessel, which was much required ; standing to the northward, in apeler to niako a loug brard to the westward; the longitude $127^{\circ} \mathrm{z}^{\prime} \mathrm{E}$., hatitude $63^{\circ} \mathrm{gz^{ \prime }}$ S. ; row ire-islands in sight, and those appearerl much worn, showing marks of rapid deny, with isolated pieces, - -some struding erect, whilo others were incliner, tesernbling fringments of columns nul bruken arches, This night there wis a brilliant display of the aurom nustmalia: at cleven acluck there was perceived it the nurthern lorizons a luminus arethed cloud, at $15^{\circ}$ of n'titude, extend.

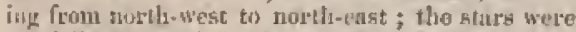
jartially obseured in the direction of the clotds; tho pale flusles or coruscation vauislung very siddenfy, were suceceded by spiral columns or btreuners, converging with great volocity townds the zenith; brilliant flashes would agnin issuo fortla from the remote parts of the clumel, suce. eceeted in quick sucession hy perpentieular rays emasuating frotn the eloud, linving the slase of a rounded column or basaltic-blaped eylinder, which in custrast with the dark cloud showed in brosd relief. As the cloud seemed to rise, the acene beenne a must interesting one, from the varied and oft-ehnnging cortuscations; fiunlly the are assumed a contrneted and elliptical form, vivid streamers bursting forth as if from a corona, converging all towards the zenith, until they were lost in the coming day. The inngnutic needle dit not slow any disturtianec. The barosneter stood stationary during its contituance. 'I'le sympiosometer indicated a slight fall. At the time there พrs no wird; the stars were brilliant, and ald risible.

6th. During this day they had light winds; pureuded their course to the wostward; wint from the southward. In the afternom they lial light flusries of snow, and at times tinil; the sen perfectly omomth, and few icebergs in sights. Longitude $125^{\circ} 32^{\prime} \mathrm{E}$. lntitude $63^{\circ} 34^{\prime} \mathrm{S}$.

During the $\mathrm{fth}$, the winds rariable; at eight tacked to the bonthwurd, in order to close in with the barrier; the wut again liauling, taeked; the number of iceberss inereasing; all those secn for the few days past have ajpenred variously shaped, much wurn not fractured, some evidenily nverturned, and immense arehes or eaves washed in them; they were totally distinet from those seen to. iny.

8th. A lurisk breeze from the soutlyward, which carried then on rapidly to the westward. At meridiun, discovered compact ficlds of ice, with many stupendous jee-islands enclosed withit it; the iee appeared more bruken than any hitherto bees, with many frngments of iccbergs resembling spires and broken culumus. Altered their course to clear the larrier, and by two o'elock they hind extriented themsolves. Penguine, whales, brown pigenon, and the black albatruss, were scen near tho liarrier. In the aftemonon the snow fell in benutiful shinisg spiculse, rescubling stars, usunlly of six, but sometimes of twelve points : they varied frou one-eighth to nne-Bixteentli of an inch in diameter.

The barticr was ocensinutly seen, and the ieeislauds began agnin to asamie a tabula fortus; towards the close of the day, very mony whales, penguins, \&ce, seen. Longitude $116^{\circ} \mathrm{L}^{\circ}$, latitude $64^{\circ} 1^{\prime} \mathrm{S}$.

Ou the $9 t_{1}$, fresh breezes from tho sauth-east; at $10 \mathrm{~A}$.m. made the barrier again, the weatlues being favoumble; at 4 t.M. standing alnig the barrier, through drift-ice, with countloss iecherges in sight; gourl observations were obtnined, placiug then in longitude $112^{\circ}+11^{\prime} \mathrm{E}$, and latisude $6.9^{\circ} 65^{\prime} \mathrm{S}$. At $10 \mathrm{~F}$. s.. souno few appearneces of the aurora nustralis il tho morthern sliy, light cornsestions atreaming uquardo, but quite faisht, and only for a very slourt period ; many stars and seremal constellations were traced withuut difliculty. 'The sea was smooth; lowered a boat to try the exrrent, but found none, The dip was få $3 y^{\circ}$.

On the morning of the 10 th the weatlon cleared off, and gave thera na frporturity of ventilatiug the vessel; closed in with the field-ice for the purpose of olitaining a suproly of water, nuil the boats were despatefied to take irs iee; the longitude was

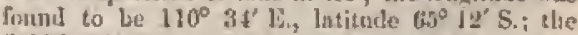
ticlalice lierc was found to be interapersed with anany large ice-ielands aud bergs. Ai live o clock 
the boats returned will iee. The enrrent was found to be setting north-north-estat, five fathons ats hour; the weather continned clear and health. ful; male tho field-ice alienl and on the lec how: shortly after, eleared it. The twilight in the southern lorizon presented a beantiful appearance, a Lriglat salmon colour ralinting from tho sun, throwing its tints orer the whole sky, tinging the few cirro-stmtas clouls that were jn the northern "uarter, and giving a soft enloar to the immense ien-islands that swere slumbering along the barries, nad risting to lond to the seene its peculinr character of silence, walitude, nud ilesriation.

'Ilise weather was clear and plustsat on tlue IIth, with a light witul from the south-enst; nany penguims anil whales were seen. The icebergs were lumerons, and sotne of gront beanty, wills almogt. regularly-turmed arelues, and of the tnost beantiful ay uq-maritue tints, Longitude was $100^{\circ} 10^{\prime} \mathrm{E}$, latitude $65^{\circ} 2 \|^{\prime} \$$.

During the morning of the 12 th, runting along high broken fields of ice, with a light breeze ftom the suuldward; weather overenst; discovered a large piece of lice of a tark brown colour thonting by, resembling a piese of dend cornl; iny-to, and sent $n$ bout $\omega$ bring it nlongside; otstained from it sevornl pieces of granite and red elay, which were fivazen in; the ice was extrentely linril and eompast, eomposed of alternate layers of jee and smow; the struta of stuw was filley with Eand. The ieubergs near at the time presented signs of having lyeen detactsed from land, being discoloured by samd dmd mud. A number of white procellarin were olstained. The ico-islands agnin sppesced in great ntimbers. At 3 1, ,. hauled эp, steering westerly into a very deep inlet or gulf, formed by exteusive fields of ice. Believing from the indicntions of the norning that tand could tout be fast off, in approaclsing the head af this inlet, several iceberge had the sppearance of boing in contact with the lnut, lansing assumed a dark colour from the elay and sand blasin upons them; the whole gruts around seemer as if in the viciungo of lntud; eounded with two lundred fathoms; no bottom: also tried the car* rest, but found none. Towards night, it becoming thick with snow, they continued under anug sail, intending to examine more elosely the barrier and inlets in the morning.

13th. At $3 \mathrm{~A}, \mathrm{~s}$, they again made sail to the westward, with wind from the east; at six o'cloek they had snow-squalls, rendering it unkafe to proceed, and impussible to make any diseovery. A few hours afterwards the weather cleared a little; male sail again to the north-west. At moridian overcast, with a stiff south-esst breeze; at 1 h 30 m, approselied to witlin pistal-shot of the harrier, olserving much of the dark dirty ice interspersed with the field-ice; kept along it very closely, trang sho barries northerly; observed ^ large black oliject an the ico; sliortened rail, and despatelied $\mathrm{n}$ boat : it proved to be a large minss of black, red, and mixed-coloured eartl, rusting upon a base of snow and iee, situated some fifty yards back from tho margin of the fiold-ice, and was found to be rous entll, mixed with granite and angdstone Penguing were also procured alive. At 3 r.at. thoy ngain fullowet the trend of the ice in a nurth-weaterly direction; a vast field, of unintermuted extent, secmed nioving along to the westwarl, the latge iechergs containisig dark and discoluaren! masqes, with frequeut etrata of the atune deserigution. 'I'ley were still at a loss to nccount for theso frequent sigus of land; dism coloured pieces of ice Eeened ningled with the general mass; they wewe uften seen aloug its mangin, and appeared as though the icebergs had been turned over, probenting collections for if from the bottom. Great numbrers of sperm whin les were seens this day. At $B$ s.M. they pnssed out inorthwardly with a light breeze and smooth son, through an extensive chain of jecbergs, which secmed grouperl uff the western point of the barrier: upwards of ono lamulred of them werc counted, several of which wero very mmels discoloured, The sunset was brilliant, bright criuson tints illuminaling the icebrga, and jowheing a beautiful effect.

On the 14th, Lientenant. Commandant Ringgold, Jaring pased in fow degrees beyoth his instruetions, that is, having reached tongitude $100^{\circ} \mathrm{F}_{\text {n }}$ atud lationde $64^{\circ} 15^{\prime}$ S. now conmenced his returs, in orider to examiue those places in the bnrrier which lo had been prevented from doing on his way west.

I5th. Continued their course to the etstward. Lientenant-Conmundant Binggold frequently refors to the lasppy and cheeriul condition of lis erew, and their freedom from all disease.

On the 18th and 17 th, they were employed in getting to the enktwrird, passing many worn and shattened berga. On the evening of the latter day, they bad another extribition of the aurora australis, extending frnm north-north-west to east; it was of a light straw colour, lut very indistinet; the lominons bank was at min elevation of $30^{\circ}$. The light in the north-west was moat distinet, radiating frum a nucleus above the borizos towards the zenith, where it formed a heautiful halo. It was not of long duration. Many ice-ialands nnd bergs in sight; unmards of two hundrel, nenrly all of a Iabular forn, - the sides of many of them heautifully excarated ty the wares, presenting itumeralye Gothic arclues, extending ofter to a eonsiderable distnuce into the body of the ice.

Their pusition on the 18th was in longitnde $114^{\circ}$

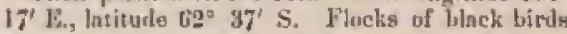
were very numerous, but not near enongly to be taken.

On the [9th nud 20th, proceeding to the rast. ward, On the 20th, they had but few jee-isinnds in sight, although they wero seventy miles furtice south than on the 18th, when the Jargest number ever seen by them at ane time was visible; having reacher tho longitude of $120^{\circ}$ E., they again steered sonth, to make the barricr. The enrrent was tried, bit none found.

'The 2 lst proved stormy, with strong brenes from tho south-enst, and much stow snd rain, which rovered the brig with iee. Field-ice was seen ahead, when they ngairs stood to the enstward, longitude being $121^{\circ} 30^{\prime} \mathrm{J}$. , latitude $65^{\circ}$ $15^{\prime} \mathrm{S}$. On this night they experienced a heary gale, during which tho barometer foll to 27.50 in., where it remained during part of the 22:su. "The squalts were very severe, aceompanied with snow, slect, hail, and heary sens; they had now reached longitude $122^{\circ} \mathrm{V}$, and latitude $04^{\circ} 9^{\prime} \mathrm{S}$.

Fubruary 22 wi, being Washington's birtlday, the culours were loistod, and the erew recejed an 
extra nllowance. Lieutenant-Commandant Ring= grold took this oectsion to express to them his sstiafaction for the manner in which they had performed their duties during the present cruise, and that their conduct would be duly represented to the comonander of tho expedition, and the governments

On the $23 n$ the weather was again thick, with snow and mist.

On the 21 th they liad reaclsed longitude $126^{\circ} \mathrm{E}$., and latitude $64^{\circ} 20^{\circ} \mathrm{S}$. On this day they again righted the barrice ; when, liaving completed what he deemed a full execution of his itustructions, Lientenant-Commandant Ringgold dotermined to put the brig's lead north, - which was necordingly done.

Strong winds and gales continued for the next three day's. On the 27th they again found themselves in enat variation, in longitude $138^{\circ} \mathrm{F}$. latitude $60^{\circ} 8^{\prime} \mathrm{S}$. The white albatross had now again beenme common.

On the 24 th, they lad a beantiful display of the aurorin mustralis; the whole southern hemisplzere was covered with arelies of a beautiful strzw colour, from which streamers radiated, both upswarda nad downwards, of nimost a lustrous white; numbers of concentric atches would ocensionally slow themselveg, of a wiath of a few feet, uniting to form a complete cannpy for a moment, and then vanish. The arches extemled from east-soutl-enst to westnorth-west; the display continued for nver two hours; the stars were seun above then. Provionf to, and during its continuance, the thermometer indicated a change of four degrees, fund the wind slifted to the sontliward.

On the lat of March, in latitude $55^{2} \mathrm{~S}_{\text {, }}$ and longitude $140^{\circ} \mathrm{E}$, they passed the lnst ice-islant.

On lihe 2nd, great numbers of pyrosomn of large size were passed.

On 1the 4th, some faint nppearances of the surora austrnlis wete seen.

On the sth, the Lord Auckland Isleg were deseried. Mr. Totten, who was offieer of the deok, was accidentally knneked overboard by the trysailboom, but was fortumately reseued withont injury. Immense numbers of albatrosses were about. The aurora was again seen $\mathrm{j}$ the fouthern liemispliere.

On the $7 t_{1}$ they anchored in the liarbour of Sarsh's Boson, iu twelve fallonis water. During their brief stay liere, all were actively employed wooding and watering, for which this hathotr affords a fine opporturity. Assistant-Surgeon Holmes made several excursions on the largest island, of whish he gives the following accouss :

"I found it very thickly covered with trees, in its legs elevated parts; as few of them were of any Bize, I found yo srmall diffienlty in peuetrating and making my way through theti ; in many places it was ahsoltutely impossible. It was only nfter n long nul fatigning walk that 1 succeeded in reaching the sumnit of that part of the island, near which the brig wns anchored, where I found the trees less numerous. A thick growth of underwood bad dwarf bushes, intermixed with forns, coneenled the surface, rendering it difticult to walk. Even on the places apyrarently most level, the ground was very urequal, and a single step would sonetines send mo searly up to the neok into a hollow filled with large fern frouda. On the highest parts, the emall level spots were covered anly with moss, and a deseription of tall grass, and in places $\mathrm{nla0}$ a kind of grain grew nbundantly. The ground was dry every where, all the water being found in the otrenms, which wore unmerous and pure. Near the summit, the ground was perforated in all direetiuns, probnbly by birds, who rear their young in these holes. Many of the tirus, principally jurncellaria, were sitting on the gronud : thry made no effort to eseape, but suffered themselyes to be taken without any altempt at resistance.

a The forest was full of small birds, of three or four different species, which were perfectly fearless; one little fellow alighted on my cap as l was kitring under a tree, and sang long and melodionsly; anuther and still snaller species, of a black colour apotted witl yellow, was numerous, and sang very sweetly; its notes were varied, but spproximated more vearly to the song of our blackbird; necasionally $\mathrm{n}$ note or two rescmibled the larks. Hawks too were numerous, and might be seen an almost ail the dead trees, ji pnirg. Along the sea-const were to be seen the marks of their ravages upon the emaller birds, 'The sen-thirds were very numerous an the opposite side of the island, sitting upon the eliffs or bovering over the islet."

On the western side of the tuckland Islnni, the under-brusl and young treeg are exceedingly thick. Dr. Holmes remarks, that it was impossible to prenetrate; that he was accupied fully an hour in making his way for a hundred yards, where to all appearanee a human step had never before uroddeu. There was not a vestige of a track; old trees wero strewn alsout irregularly, sometimes kept erect by the pressure on all sides. Some trees were secil upwards of seventy feet in height, although the genemality were only from fifteen to twenty; every parl of the island wits densoly coverel with vegetathon; the soil, from the decomposition of regetable nutter, had nequired considenble ricluness; speciwens of nll the plants were collected.

These islands have in many places the appenrance of having heen raised directly frutr the sea ; the cliffs consisted of basalt, and were generally from fifty to nisuety fect perpendiculnr.

The Aucliland islands are the resirt of wlaners, for the purpose of refting and swaiting the whaling Beason, which oceurs late in the nontlis of A pril and May. Niear the watering-place a commodius lut has been erested luy a French wlinler. Near by was another in ruins, and cluse to it the grave of a Frencli sailor, whwse name wus inscribed on a wooden cross erected over it. Sorne attempts at forming a garden were observed at ono of the points of Sumlı's Bosom, and turnips, eaboage, and potatoes were growing finely, which, if left undisturbed, will soon cover this portion of the islund; to these a few nuions were added. Besides the birda, the only living ereature seen by $\mathbf{D r}$. Holmes

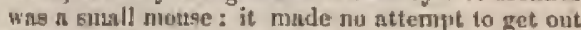
of his way, and seened to have no fear when taken; being consigned to a pocket, he som contrived to eseape. Many of the smaller islands of this group were visited ; they closily rebenuble the larger one. Penguins were ummeruus and of a varicty of colours.

These isles have a picturesque, wild, steep, and basaltic appearance: the highest peak was estimated to be eiglit hundred feet; the smaller has a less elevation: the general aspect of the land resembles the segion aruund Cape Horn, The larbour of 
Sarah's Hosoun is not the most recure; that of Lawrie's is pirntected from all winds, and has a large and fine strentmlot of water at its head. The rocks ate covered with limpots, and small fish of many varieties are caught in quantities among the liclp. The crew enjoyed themselves on ehowdera and fries. Nogecse were seen, and the only game observel were a few gmy ducks, snipes, cormormunts, and the common sling. The land biris are excellent enting, especially the hawks; and on the whole, it is a very desimble place at which to refit.

On the Ith of March tlicy had finished, and were propared for sea, but the whether was threntening and enused them to delay, The magnetic dip was found to be $73^{2} 47^{\prime} 30^{\circ} \mathrm{S}$.

A whaler, under Portuguese colours, bnt commanded by an Englishman, nrrived, and anchored in Lawrie's. Cove, to await the coming of tho whales ! The night proved stormy; the wind at $10 \mathrm{~h}$ 30 $\mathrm{nt}$ from the north-east, blowing very heavy in puffs. Towards noon it moderated, and $\mathrm{n}$ i $2 \mathrm{r}, \mathrm{M}$. they gut uuder way, with a light breeze from the nortli-west, and stood to ses.

'The latilude of Surnli's Busom is $50^{\circ} 38^{\prime} \mathrm{S}$.; the longitude $165^{\circ} 28^{\prime} \mathrm{E}$.

On the I2th jo current wns found ; latitude $49^{\circ}$ $27^{\prime}$ S. Inrgitude $168^{\circ} 13^{\prime}$ E. The wenther experieneet from this port so New Zeatand was yery Binnilar to dlat in passing from Cape Hom to Palparriso: northerly winds with nist and fog prerailing, with a hervy sen. On the 17 th they fell in with the whale-ship Mary and Martha, of Plymoutly, Coffin, naster, why inforuned them the thero were at least one lunndred whale-ships ctuising in the neighbouring seas; of these, several were seen, This will give some idea of the number of vessela enylayed, and how great a capital is engaged in this bussinese.

On the 18th they hind a gale from north-porthwest, which lasted through the daw, moderuting at sunset. 'I'hey were in lutitude $43^{\circ} 2^{\prime} \mathrm{S}$. Jongitude by chrunometer, $175^{\circ} 2 \mathrm{~A}^{\prime} \mathrm{E}$. 'The barvuneter asnk to $29 \cdot 30 \mathrm{in}$. A current was experienced setting north-west, in the direction of Couk's Straits.

On the 20th, in latitude $41^{\circ} \mathrm{S}$, longitude $177^{\circ} \mathrm{E}$, the current whs found setting north-esustby-murtb, half a mile per hour. On the 22 ud and 23rd they experienced a heavy gale from the siruth-east, when they were in longitude $179^{\circ}$ $35 \mathrm{E}_{\mathrm{u}}$ and latitude $37^{\circ} 52^{\prime} \mathrm{S}$. ; during the moru. ing of the Inter day the wind hanled to the south-sunth-weyt ; the burometer, at 3 A.s., atool at 29.10 is.; tho wonther elented, with the wind at soulili-west.

On the $261 \mathrm{~h}$, they reached and suchored in the river Kawa-liawn, in the Bay of lslands, off the Ameriean consul's, about three miles above its muuth. Many vessels were passed lying at anchor off the tawn of Koromarika. Here they found the tender Flying-Fish ; n.l well.

The eruise of the latter will now be taken tan from the lat of Junury, on which day she farted company with the Vincennes, in consequence of having curried away a galf, and being obliged to gluorten sail, in doing $w$ bieh their jib-stay got adrift, and carried away the squaresail-yard befure it could the secured. The ressel wis in the neas time expused to a heavy sets benting over her, and at midnight they were compelled to heate-to. They then steered for the first rendezrous, Macqunrie Island, whure they arrived an the I0th, in the afternom, and saw the Peacusk, but it beeoming thick, they were not seen by that ships. On the 11 th, Aeting-Master Sinchir landed for the purpose of placing a signal on the jklaud, agreeably to instructions. The Innting was fomul diffiealt and dangernus, and their deseription of the island agrees with that heretofure given of ic frota the notes of Mr. Eild, as being drenry and itrhospitable. Large numbers of pengniny, anu omall green and yollow paroquets were seen. Nenr where they landed, they saw about tweraty luge sea-elephnnts basking on the roeks, which did not scem to heed them; when disturled, they would only throw their carcasses orer, open their mouths, utter a loud growl, and go to shepr aguin ; no measurernent was taken of them, and one which was killed could not be taken in the hont. The soil wns soft and spongy, yielding to the preasure of the foet. The staft and signal being planted, they returned on board, and now passed the sierf withont difficulty.

On the 12u, they put away for the mext rendezpous, Emernil' Isle. 'I'hoy reached jto position on the 1.4th, but nothing whs seen of it; the weather was thick.

On the $16 \mathrm{th}$, they kept off to tho southward, with the wind fram the southewest, aceonspnited with sleet and smow. In Jatitude $61^{\circ} \mathrm{S}$., bongitudo $164^{\circ} \mathrm{E}$, they an the first ice. The hext day, the 19th of Junuary, the water was very much discoloured; got a cast of the lead in ninety fathoms; no bottom : passud a number of jeet)ergs that werv all flut on tho top, with perpendicular sides.

On the 2lat they made the icy barrier, in longitude $155^{\circ} 36^{\prime} \mathrm{E}$, and Intitude $65^{\circ} 20^{\circ} \mathrm{S}$. From the number of icelserge and the frequency of nnowsqualls, they found great danger in ruming througl then, although the water wns quite smooth.

On the 22ut the weatlier proved plensant, and they followed the trend of the ice. The ice-islasts stilf ahowed flat topgs and perpetwicular sides, and there were a nomber of birds, sealy, and whales around them; they were at mon in longitude $150^{\circ}$ $27^{\prime} \mathrm{E}$. On this dny they were eluse by in iechern. frou the main body of which a large mass fell with a noise like thunder; tho snuw thying into the air resembled smoke, and the swell prodtced by the immersinn of the frugment eaused the selouner to roll water in on her deek, A number of large penguins were in sight, differiug flom duny they had heretofore seen.

On the 25rd the wenther was pleasant, and they had light winds from the sunthwand and westwari. Jorgitude $187^{\circ} 4 y^{\prime} \mathrm{E}$, Intiturle $65^{\circ} 58^{\prime} \mathrm{S}$. They continued consting along the ice in seareh of an opening. At 8 P.M. they discovered sovernl duck spots, which had the appetrunee of rocks, and ou apjuroaching the tmargin of the ies, they could suake them out to be such with their glisses, but they were situated too far within the field'ice for s bont to get near them. This day being fine, an opror. tunity was aftorded of drying the deck and elothes, and searing the senms with a tot iron. The vessel had been very wet, and low decks leaked badly, notwithetanding the thurough ealking and repaits she had received at Sydirey: the crew wero almost cunstastly wet, below ns well as abuve deck.

On the 2th they were ubliged to steer again to 
the northward, in eonseqtience of making the bar. rier ahead. Sta-lions wore scon on the iee. They continted to follow the barrier, which trended worth-north-east; the corspneses were very siluggibh. On the 2fith and 27 th the weather hecame bad, with the wind to the northward and restward, nceonspanied by a hesyy fall of mow: in the everning of the Jatter dny, the wind lasuled to the southward and westward, and brought cless weather. The gets passed with clear wenther, and sereral seals were atront them.

The 2!nth was thick and snow $y$, with n north-east wind : passent through quantitice of drift-ice, atud fy $2 h^{1} 30$ it had become no thick as to render a eousinuatue of ปleir course perilous; at 7 F. M. they again made the enlis burter, when it wng bl wine

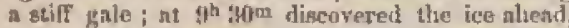
and ou both betms: wore round to the northwirl and enstward, to rotrace their steps ; it was not long before they discovered a ehain of ite-islnmis nhead, mpparentiy connected by solid jec; nbout midtitglit a pasage was discovered letween two icebergs, through swith they passed. It was now blowing a heary gale, and finring gained the open sen, they attermpted to recf the foresnil, but were tujeçual to the task (four of the men beitgg on the sick-Jist), nrid were eompelled to lay-to mnder the whole sail, which caused the ressel to hbour rery unch, as well as to beale a great denl, and endnngered her afety by makiug ber tly inta the wind, ats! get a sternboard й a ligh sen,

On the $30 \mathrm{th}_{\mathrm{b}}$ in the morning, the gale abnter, and the weather became more pleasant than they law experienced for n numbir of dnyz They hail reached the longitude of $150^{\circ} 16^{\prime} \mathrm{E}$, latitude $65^{\circ}$ $15^{\prime} \mathrm{S}$. On this day they again passed into blue water.

31st January was thick with snow; th nortli wind and henry sea.

lat of Felnuary, they were runing among ice, until they sighted the barsier, when they again laauled to the nortlwarl; n moderate gale hlowing, with thiets wenther and a lethy sen, they wero obliged to heave-tor.

Oo the 2ut and strd, they were consting the ice. In the afternon of the 3rd they arain had bat weather, which made it necesary to liring to; sur. munded by bergs nul drift-ice; the Intter, in case fof strilsing, would hase seriously injured the tender. Tho jeebergs seen un these days, had the appearanee of recent formation; the tops flat, the sides perpendieular, asd not worn by llue action of the ser.

On the ftr, the gale continmed, and the ser liad risen to an extmorlinaty luejght; the wenther wis so thjek tint an iecberg conld not he seen further llon twico the length of the resed. The tender was under too much sait, which caused lier to habour treadfully, in consequence of which she lenked in such a manner as to make it nccessary to kecp the fumps going almnst coutimualty. Wher they wete stopped for $\mathrm{s}$ short time to rest the men, the water increased so as to reach the enbin-flocis: the water enme through the mans forward in such qutuntiticg ns to wet every bed snd article of elotluing on the berth-kleck. This was a grent andition to the Inbour and diacomfort of the erow, now weduced by sielness to four men, and the strongth of these mueh impaired ly previous sickness, execssife latour, and almost culnstant ex- posure. To relieve their situntion as much as possible, I,jeutenant Pinkney ordered thorm to make tse of the eabin in conmon with the atticers. 'To ease the pitching of the versel, a quantity of coal was shiffed aft: Lut alliough this was a partin relief, yet as glve liad too truch sail on liev, whicls they had been urable to reduce at the commenecment of the gale, it was not sufficient to make her easy.

On the bth, the pale beran to abate, when tho erew, through one of their number, presented a cotnminnication to Jicutenant Pinkney, of which the following is a copy.

\section{( $\left.\cos ^{r} \mathrm{x}_{*}\right)$}

We, the umlersigned, the crew of the schouste Ftying-[Fis]1, wisl to let you know that we are in a must deplomble condition : the berl-olutles are all wet; we lave no place to lie down in; wo have not lud a dry stitch of clothes for bewers dnyt ; foul of our tumber are very sick; and we, the few rentiliste number, ean holut oue no lunger; wo bove yoa will take it into considerntion, wnd relieve us from what must terminate in our dentl.

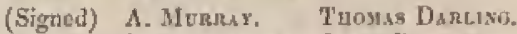
JoHs ANDERSOS. JaMes Dasiers. F. Beul... Joskilus.

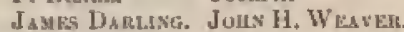

To Limexist Piskxw, U. S. Sehuaner Flying-Fish.

On the receipt of this appeal, Licutenant Pinkney addressed an order to tho ullicers, a cony of which fullows.

U. S. Selooner Flying-Fish,

Lat. $66^{\circ}$ S., loug. $143^{3}$ E., Feb. 5 th, 1840.

Gestrisus:-Y You will furtitsh me with your opinion, and the reasons which induned that opinon, of the propriety of any longer endeavouring to accomplish that part of the necontpanying order, which refers to penetrating to the south.

I am, respectfully, \&c. R. F. PINTNey, Lieutenant-Comtandant.

To Active Mastre Georia T. Sinclaik.

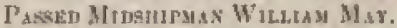

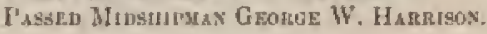

(COPY OH REPLT.)

U. S, Sehooner Firing-Fisls, Lat. $66^{\circ}$ S. long. $143^{\circ}$ Fin, Feb. 5ti, 1840.

Sirn-Agreenbly to your naler of this date, we, the undersigned ofticers, Jave to expreses our inost thorough conviction, that the endition of this vessel's enter, and the vessel, loudly demand an intmedinte retarn to midder latitudes.

The causes of this opition are these: that the crew of this ressel, consisting of fifteen persens (four officers and eleven men), even if well, are cntiroly inndequate to her eafe managenent; fut five are now confined to sick beds (one a serwant), one of them is in a very critienl state of lualth, and three others dmegirg out uyon duty, complnining, and under medical trestment. Oat of furr, anoninally performing daty, one of them, the couk, is totally unfit to a curn at the helm, and anoulier cannct lye trusted without the closest watching; inleed, $B o$ defieient in foree are wo, that in the pale of yesterdny and the day befure, nat un a previvus oceasion, whes it bicame extrenuely 
neessary to reef the foresail, the men were sor defieient in physical strength as to make it imporsible to meculuplish it.

The erew's apurtment is in the most deplumble stnte, lenkiug like a sieve, all their beds being wet, their chothes on theru being so, even to their under flannels, for one weck, and withont a dry charge on band, nud no prospect of having one: so miserable is their situatinn, that at lengtl you lave been compelled to nllot then the cabin, in commous witls us, for the purpose of cooking, cating, nut Bleeyning.

Furthernore, sir, in the gale now abating, we tind that nearly coustant application to the jump is barcly suffeient to beep the water from flooding the cabin-flond, ovidestly having started a leak; notwithstumbling this, the conklition of the crow is wure imperative, mucl more so in this, our recommetudation, for a return to the nortliward ; in fact, we wuld cheerfully cantinue to the soutliwad, if we land a proper crew.

Lastly, wuderstanding thut the crow, through one of their body, have wnited upon you, and, by written applicalium, nlso stuted their inability to live through these lasdshipts much Jonger, and begaing your return.

We are respectully, yeur obedient servats, (Sigred)

\section{Gronol: T. Sixcluth.}

W HoLTas MAY Acting Master:

Georol: W. Harmson, Passed Midahijimen.

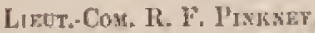

Contuatiding U. S. Sehooner Flsing-Fish.

Lieutenant P'inkney, in accordance with this ppisium, and his own conviction of the neceseity of an immodinto return to miluler latitudes, as the only means of restoring the sick, nud preserving those on duty, who were theu incmpable of man. aging the ressel without the nssistance of the officers, decmed it his duty to steer fur the nortb, whiels lie aecortingly disl.

The 6th and 7 th cuntinued tlick, with oceasional squalls, On the 5 th, the westler again broke up, when they had soreral hours of suushine, which proved of great benefit to the sick. Lieutenant Pinkrucy was enabled to come again on teck, who had searcely been able to quit his herth since lenvirg Mrequaric Js/nul, from sickness. "They larl reached the longitude of $135^{\circ} 45^{\prime} \mathrm{L}$, latitule $61^{\circ} \mathrm{S}$. At 11 p.3. the surorn was seen; it was first visible in the south-eash quartes, in spots reacmbling pole monulight, extenting to the zersitl, from whence it diverged in mys, somo of which renched the borizon, bith the grentest number terminnted at an slitude of twenty-five or thirty degrees. On the 9h, the aurors was also seen is the west, in versienl mys of pale yellow light, eon!mencing sbout five degrees above the horizon, and extending to na altilude of thirty degrees. After a short time it disapteared, and was agniu seen in the zonith, mdiating in lines to the north-enst and west, raching to within ten degrees of the horizon. The wink was from the fusthwarl. Ternperature $34^{\circ}$. The fullowing five days they lad thiek weather, and nothing ovcurred until the evenitgg of the It1l, when they agnin had a display of the aurom; the curusentions were frempent and lrilliant, but did not exhibit any dilferest form, until after mid- might, when it appeared in arches, reaching nearly to the liwizon, at from $4 a^{\circ}$ to $73^{\circ}$ of altitude, and emuposed of slort perperdieular lines, blending at one ruoneut iuto n slieet of misty light, and then breaking out into brigliter lines, some of which wero broad. It then agnin slifted to the zenith, with rndiations extending in every direetion, iu straight and wavy lines. Tho chnnges were incesFant, but not shooting.

On the morsing of the Jistl, they again had a dinfilay of the aurora. It first appested in the gnuthera heavens, at an altiqude of $45^{\circ}$, flathing to the zenill, where it disnjpeared. After milnight it was agin visible in the southers quarter, at about $30^{\circ}$ of altitudo. It finally centered in a bright spot, which changed into $a$ ereseent, witl the riunded side to the nertliwur. Froms this, fetsthery-edgerl mys of pale orange colour bmnched off in every direction, oxer which the prismatic colours secined to flit in mpid sucectsion. The rays would sontetimes fold into one nuther like a fard, and reach the lsurizon in one direetion, while in anotlier they were druwn ap to the zenitl, mgain to burst forth in repretitious, until lest ill dayfiglit. On the 19h, the aurom again appented in an arch of $15^{\circ}$ altitude.

'They passed the last jeebergs in latitude $55^{\circ} 30^{\circ}$ S., longitude $145^{\circ} 30 \mathrm{E}$

On the 22nd they spoke a French whaler from Hobart Town, who expressed nuch surprise at funding so exmall a ressel in such high latitudes. The eaptain sent a boat on boavd, and invited them to "snup" with hims.

On the 23rd they mado the southern isisnd of New Zenland. On the 1 at of Mareh they expierienced a most violent gale. The wind about noon on the agh of February hauled to the southward and castward, and by midnight it hlew a gale, hauling to the enstward, until about $8 \mathrm{P}, \mathrm{M}_{2}$, when its violence muderated. Their latitude was $40^{\circ} \mathrm{S}$. ingitudo $178^{\circ} 30^{\prime} \mathrm{E}$. For several days previons to this, a moise was heard about the heel of the maill-nast; an exanuingtion was had, and the concicaion arrived at that it worked in the step, the wedges in the partsers having been drirca without obviating it. On the 9th of March they arrived at the Kay of Islands, where they found the gentlemen who had geme there to pursue their resenrehes in natural listory waiting our artival.

The Yineenues was left on the IIst of February on her way north. On the night of the 22od, wo had a beatiful and novel appentance of the aurora australis.

Wack elouds were passing ropidly over the sky; an orunge glow of light seemed to cover the liesvens, cmanating from a point, over which Hitted mys of the prismatic colours, directed towards the borizon, lighting up both edges of the clouds, and throwing them ints lrold relief. The mys seened to dsirt simultaneously towards the lorizon, on reaching which they waild seem to be gathered, as if by magic, towarils the centre, and Glowly vanish, to reappetar agaia and folal up.

Sirong gales frum the went-north-west with smow-sogunlis continued until tlo $27 \mathrm{t}$, with thick misty weather. Numerous ice-islands were passed during this intervul. The last jeeberg geen, was it the latiunte of $53^{\circ} \mathrm{S}$., and longitude $120^{\circ} 25^{t} \mathrm{E}$., tive fentrerature of the water was $46^{\circ}$. 
On the 28 th, we found our variation $1^{\circ}$ easterly, in the longitude of $131^{\circ} 50^{\prime} \mathrm{K}$., Lutitude $30^{\circ} 30^{\circ} \mathrm{S}$.; and il attempting to got i deeps-sea sonnding of eigltt hundred and fifty futhoms, we lont our Six's therusometer lyy the wire parting. The gea was a deep blue; the fumperature $45^{\circ}$. We found a eurrent sutting west-north-west three-fourths of a linot per hour. Tho white object was seen at the depth of fifoen fithons.

On the Lat of Marcla we had reaclied the latitude of the Roynl Company's Isjes, and I eontinued to run in nearly the sanse prablel for eight degrees of longitude, without secing any nigns of the supposed land. Having asuled far to the enstward of their supposed pusition, I again lanuled to the thorthwnrd to proceed to Hubart Town, Vas Diemen's Land, to fill up our water. We now saw th sail, the first during sixty dayo, which made us feel a. if wo were returuing to a habitable part of the globe. Tlis gight we had a briliant display of the surors sustralis, resembling that secu of the 9th of February, with this difference, that it was seen to tho Bauthwenrd, oxtending from eastboutl-east to west-kouth-west.

On the 5tl of March the wind liended us off our cuurse to Hobart Town; I then deternined to prot ceed direct in Sydtey, ans this be enabled to cummuniente as speedily as possible with the United State. The consideration of getting intelligence respreting the other vessels, also led to this deterninations. I felt, in truth, forcbodings that all was not well, from not having utet any of tho vessels at the nppointerd rendezvons, along the icy barricr; and 1 was anxiuss for their safety, after the severe grale of the 28th of January.

Having resched a lower latitude, the weather had now becone pleasant, and we could dispense with our wiuter cthothing, - at rolief wlyich the whole of the crew stemed to enjoy. It was the reverse with me; I liad a feeling of exhaustion and lassitude that I eould not secoust for, and the least exertiun caused me much fatigue.

On the Dh we reached the latitude of Cone Howe, and were seventy miles to the eastwand of it We there experienced a rise in the temperature of the water: six degrees in less tinan an huur.

On the joth, whell off Cape Jersis, and about furty uiley to the enstwarl of it, we again elanged the tenspernture from $6 \phi^{\circ}$ to $73^{\circ}$, as we steered in fur the lasd to the northward, but on hauliz: to the eastward it again fell to $68^{\circ}$. $A$ strong sontherly curreut hing been fong knuwn to exist along this cunst; and I feel woll satisfied that the eluermoneter is a groul guide in making the paseage from the southward. The consting vessels, as I was infurmed at Sydney, hud frequently mado long juassiges from Vau Diemen's Land and Bonth Austrulia, whieh I linve but little doubt is owing to the prevalenee of this minos Gulf Strum, the jusition of which the use of the thermometer will densy itudivate. This current will bo tuticed purtieularly in the elaupter on eurrents; its widtl yo duubt varies with the senson.

On the Ilth of March, at uoon, we passed tho Hearls of Port Jackson, and took a pilot. Wo were, as a borly, in betker conslition than when wo left Syilney three muntlis before.

In an liuns afterwards wo dropped our nochor in Farm Cove, off Furt Mnequarie. Our reception was flattering; scarecly was our nticlior well down before many of our friends cante un band to bid us welcone; and we felt teufold that kind hospitality which on our formes risit we laad first become acçuainted witl. They appenred to rejoice in our success as if we had been their courtrytnen.

During our absenee from Sydney, many itnjrive* ments had uken place. The storelrouses fur the deposit of grain on an island in the harbour were in rapid jongres; the new govermnert-hunse nearly completed, and the fundation of an exchange laid; besides this, many improvements in town that were then in progress had been compieted; and the rnpicity with which these works had been nccomplished, strongly reminded me of similar operations at lome.

The country was looking quite green and pretty; indeed, the sail up the noble tharbonr was truly beautiful; it wore quite a different fuce from its former parched appenance, the rains having been abundant during our absence.

Observations werv olutined for the rntes of our clunnometers, and the magnetic needles agnin experimented with.

On overhauling my ship, the fure-topmast whs found to be slighily sprung-

It was with great pleasure I lenrned the anfoty of the Pencock ; for that vessel liad oceupied my thonghes mere than the others, on account of the eondition in which tho left Sydney. All on hourd of ler were well, and the ressel was undergoing repaits in Mossman's Cove, one of the many which this harbour forms. These coven may be tetrued wet-douths, affording ns they do every facility for the rejair of ressels of suny size. They aro more like artificial than untural bosins, and are secure against any wiul. There is no port in the woth that offers so many natural advantages as Port Jackson, for a greni naval power. We had many things to relate to each other ; amoug others, the purticulars of the aceident Lhat befell the Peacock, that has already been nuticed. The return of that vessel to this paint now elains our stteution.

On the 2BLi of Jumuary, their sick.jist had inereased to thirteen, moro in consequence of tho fatigue the men had uttergone, thun from any disease.

On the 29 h, they experienced strostg galea from the north-west, whish continued to increase until midnight, after whieh the wealler modemted. Tho ship duriug this gale was in latitude $61^{\circ} 30^{\prime} \mathrm{S}$., and langitude $154^{\circ} 9^{\prime} \mathrm{E}$. This gale is remarkable, in consecquence of its blowitug in a coutmry direction to dlat which the Vincennes experieneed on the sane day; while the former had it frum the torth-west, the latter had it from sonth-crest. I'heir distance apart was four loundred and fifty niled, in at north-etat direction.

On the lat of Fubruary the weather was btoraly until tuwards evenirg, when it noderated and cleared ofr, with the wind to the north-weat, aud gave then a view of the aurors anstralis lighting ap the southern portion of the trorizon. Rays were tlirvwil out in different directions, some reaching an altitude of $30^{\circ}$, others of $40^{\circ}$, whilst others again almost spanned the hearens.

On the 2nd, they hat nuother displny of the nurora, but contrary to that of the previois day, it was first soen at an altitude of $70^{\circ}$, diverying towards the horizon, from east-south-east to the soult-west-by-west, before it disajpeared. "I'he 
froint from which the rays diverged reached the zenith.

On the 4th they made Macquario Istand, and shortly after passing it, experienced another fnle from north-west to soutl-west, which caused them mueh anxiety for their rulder, which thu far hal? answered well, nithough great atteration waa necesarry to prevent girain upin it. Strung galeg yet continued. On the 5 th, they had a faint disglay of the nurora.

On the 7 th of February, the weather liad become leas boisterous, and liaving reached latitule $49^{\circ} \mathrm{S}$. Inngitude $165^{\circ} 23^{\prime} \mathrm{E}$., tho nurom nustralis again appeared. It was first scen in the north, and gradually spread its carnsentions over the whole heavens; the rays and bonms of light radiating from nearly nll points of the horizon to the zenith, where their distinetive outlines were Inst in a hright giow of light, which was encireled by suecessive flistues, resembling those of heat lightning on a sultry summer night; these formed a luminous are in the southern Bky, nbout $\mathfrak{w}^{\circ}$ in altitude, from the upper part of which, risy wore continually flashing towards the zenith; light sluswers of ynin finally filut it ont from vicw. On the same night, between one and three, the aurom burst out from the soutl-western horizon, streaming ир and concentrating in the zenilly, and attended with quiek flushe of every varioty of tint. The wind was moderate from the south. west, nud a sqgualt of linit passed at the time. In latitule $47 \mathrm{~S}$. they first encountered plinsploreseence in the water. Ot the 17th they mude the land of New South Walus, and continued to experience a variety of westher tsutil the 2 Ist, when they arrived off, and nnchored witlin, the Hends of Purt Jackson.

The next day they procenled np the harbour, and nuebred uff Sydney Cove. The ship was much shattered, bui her oftions athd crew all in good health. Here they were kindly reecived, and no time was last in proeceding to make the necesexry repairs. The cullector was kind ennugh to give them permission to land every thing that might bo necessary, when and where they plensed. The powder and fireworks were roceived into the public magazine, and when enlled for were politely gent in a gowernment loat, free of expense. The milway for merehnnt-ressels whs found too light to trust the Pencuek upon it; Mossmnn's Cove, on the north shore, wus then resorted to, not only as a eonvenient plare for making the necessry repairs, but a afforiling more sccurity for the erew agninst the crimpos atd rum-slynps.

'The day ufter my' nrrival, $\mathbf{I}$ visited the Pencock, in order to examine into lier condition, and could not withloid my rstonishment that blw lasd been al,le, after undergoing such damnge, to reach distant purt. The visible injuries lave alrendy been stated, in speaking of her secirlest. On theit arrival at syduey, it was found that luer stem bad heen chiferd to within one and a half inclieg of her nool ends, and much strained throughout. After a full examination of the circunstances, I feel it a duty I owe to Captain Hudson, as well as to his officers and crew, to state that I am well satisfied, that his coolness, decision, and seamanship, wilh the grond conduct of his officens and men in the perilous silumtion in which they were placed, are wortlyy of the lighent encomiums. The preservation of the ship and erew, and hew subseguent nnvigation to \& distant port, reflect the highest credic upon lier commander and vpon the service to which lre belongs.

Sydney whs now much erowited with peorle, and several balls were given, to which we had the honour of an invitntion. That of the St. Patrick Society was attended by the chief people in the neigitbourhond of Sydner, including the goremor and most of the officers of the enown. It was given in the new court-honse, and wat th handsome and well-conducted entertninment. "Two military bauds were in attendance; quadrilles and coumtry dances followed each wther in rapid anceession; wooms were provided for cards, refreshments, teas, lemonade, \&c.; and towards the close of tho evening, the conpany whs ushered in to an elegatst supper, which was partaken of standing.

I whs struck with the besuty and general appearance of the Indies, though 1 was informed that, many of the helles were absent. The style of the party was neither Englith nor Amerieall, but something between tlo two. I scareely need remark that we were all much gtatified and plosed. The hospitality and kindness shown us were of that kiud that made us feal truly welcome.

Our last week nt Sydney was spent in a round of pleasure, and the stention wo met with being entirely unexpected, was doully gratifying to $\mathrm{tis}$. 


\title{
CHAPTER XX.
}

\author{
NEW ZEALAND.
}

DEFATTEL F

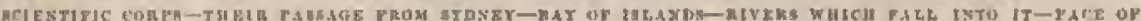

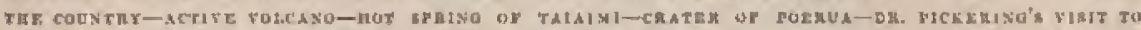

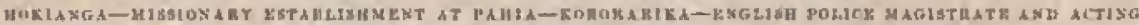

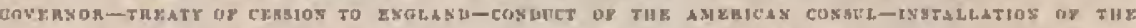

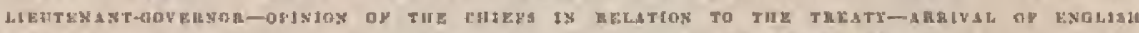

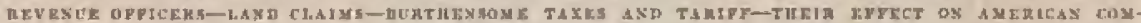

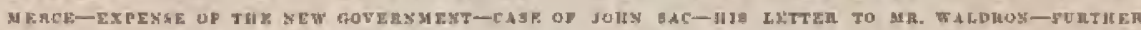

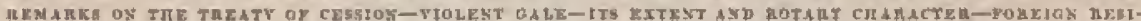

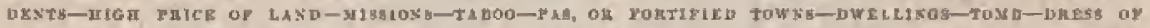

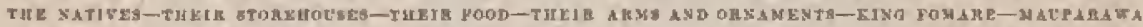

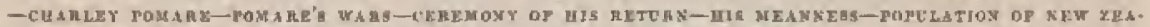

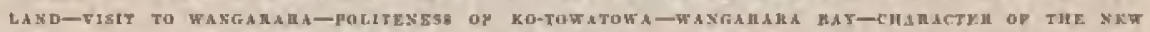

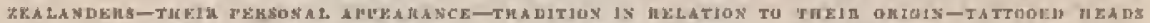

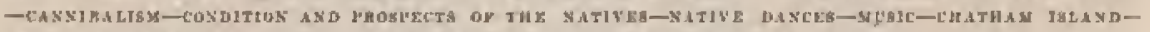

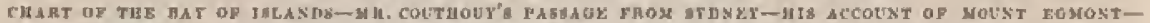

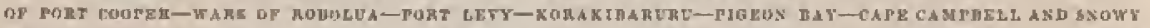

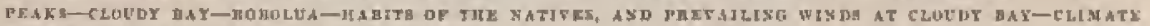

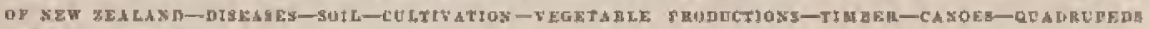

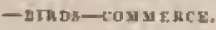

Havisi replenished our stares of provisions, we took, with musht regret, a final lenve of our frients at Syincy. The Vincemes weighed anchor, and at 3 P.3. on the lith Mareh wo discharged our pilot, stid bade adien to these hospitalule shores. The Peacock, not having completed her repairs, wns left at Sylney for a few dnys, with orkers to fullow us to Tongitabuo.

On reaching a distance of thirty mites from the coast, wo agnin found a difference ol three degrees in the temperature of the water, and experienced the effeets of a strong current wwards the south. The wind was from the unothward and eastwartil.

Ou the 23rd we sgroke the Frencls whale-slip Ville de Jurdean, in whnt of pruvisions, which we supplied her. She hal been out three yenrs, and had on board four thonanal barrels of oil. The erew was jedueed to bread and water, thd the vegsel was spuarestly in a bad condition in other resipets.

At daylight on the soth, we made Cape Brett, and after grophing otur wy through the dack, into the Bay of Islunds, anchored at in P.M. in the Kinwa-kaws river, opposite the residence of Mr. Clembn, the American enaul, Here I had the ratisfaction to fincl tho Porpoise and Jilyng-Fish, and received the reports of their crutises; they were alt well on buntd. The former vesed lad arrived a fow days, sud the latter about three weeks, before us, We were riso gratified with the receipt of letters from the United States. Every exertion was made to shorten the dumtion of our stay in New Zealand, and the necessury instruments were landed without delay.

Here also we met all the seientific gentlemen, -who, as las loen stated, liad been left nt Sydney when the oypadron axiled upon the antaretie cruise, $\longrightarrow$ anxiously awniting our arríval.
They had heen foreed to romain inative at Sydncy, in eonsequnence of a elbange in the destination of the vessed in which they had tirst taken their passages, and by this vexations delay, lowd not only been provented from pursuisig further rosearches in New South Wales, but land lost time that might linve been ndvantageously em. ployed in New Zeatand. Thoy finslly suceeded in finding an opportunity of renching the Bay of Islands, in the British brig Victorin.

After lenving Sydney in this vessel, a sea was shipped, which, besides doing nilue mischief, entered at the enlin-windows, and filled the chronometer-box witlı salt wnter; in consequence of which the master connidered it neeessary to put back, in oriter to excluange the injured time-pince for another, She accordingly incliortd again in Port Jaclison.

On the 7h Februry, they land a beantiful exhibition of the survara anstralis: the coruscations were of a straw-coloured light, renching nearly to the zenith in the southern sliy, and lasting from geven until ten o'elock. A noddy lighted on the lrig, and remaned on bond tonny days; so tame was it that it even suffered itself to be lanalled.

On the Ifoth, when they lind performed about half the pnssage, they lind nnother exlitivition of the anrorn, much lilie tho formor; after which they experieneed a gale of wiud of five days' dumtion. On the 2 ist, they were enabled again to make sail, and, on the 2sirel, they made the North Cape. $A$ gale then eane on from the enstwarl, and they had a narrow escape from shipwreck while ruming down the land. On the 2ftb, they stropper anchor at Kororarika, about thee miles ahove which ylace they found the United Stateg consul, Mr. Clenton, at Ormotu P'uint.

Prom the splemid panorama of Mr. Burforit, I lisd fietured the Bay of Istands to mygelf as a flike 
of strpassing beaty, and 1 cusl! not but fecl grntified at the ides of paying it a visit; it did nust, however, realizes my expestations. It might, with more propricty, be calded the Bay of Inlets. 'I'he best iden that can be given of itr greografthical features is, to likes it to an open trand with the fingers apread apart. The lasd is mnel indented witls bays, or frrms of the sea, running up nmong hills, which are nearly insulaterl. The distance between the two enpes (Brett and P'oint Pocoeh) is ten mitos, and there are several seonmlary bays facing this opening. Four rivers flow into them, the KawaKawi, Kíri-Kiti, Loytangi, snd Waicaddie, into which the tiule fluws a fus miles, after which threy becorte sumbl streamlets, varied by sotno waterfally. There are wasy minor indentations, which reuder it impossible to sunve any distanee without a bont ; ind it is ofven neessary to make a turn of five at six miles around nu injet or mayl in going to $a$ place, which might be reached in one-tenth of the diatance by water.

Tlae lasid has the apjearance of barren hills without accompanving valleys, and there is so little level ground that terraces are ent in the hills to builit the cottages on. The whole riew is any thing but picturesque, and there is little to meet the eve except bare hills and extensive sheets of water. Somo fine views are, however, to be met with from the elevated ridges, which nfford ocensional glimpses of the bay, with its islets.

Many of our gentlemen were struck with the resemblance of this land to that of Terra del Fuego. Black ialete and roeks, worn into varions shapes, are found, as in that country, at all the points in the lary throught which a broat can [anss.

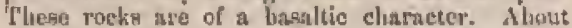
the Bay of lslands tho roek is emmet and argilInceous, showing litule or no stratifiention, and is for the most jart covered with a layer of stiff ctsy, two or three feet thick, the result of its decomposition. The lills about the Bny of Islands are generally from theo to tive huudred feet high, but some of those at the hear of the buy reach nue thousand feet. The district nhout the lany and the northern portion of the island, may be siyled volcanje ; for, in addition to rocks of undaubted rolcante origin, all the othors had in a greaten or less tegree undergone the action of fire. One naturalists wore informed that the ralley of the Thanes was. of a different cliaracter, altliough many perwong represented the whote istath as roleanic. Tho ridges in the northern part of the istand were not thought to riae mote thats $t$ wo thousand fivet. The Rev, Mr. Williams, missionary at Pahis, laas crossed the isknd from Port Nittsulson to 'Tantatsga, during which jonmey he passed a districs from which the nnow wa absent only fonr monthas in the yens. Ihis region is in the neightrourdeod of the trigh peak of Mlount Egmont, Esiil, in tlre Sydrey Almastac, hut upon what nuthority is not stated, to bo fortiteen thourand foet high. Mr. Willians deseribed tho ruste as exhiliting volennic phenomens on a large seale, smong which were guantities of purnice, extending antirely secoss the island, and an extensive plain, which liad souk fu orre place, and diselosed a bed of that substince, three or four lundred feet in thickness; he like. wise spoke of gevers or jets of boiling watur.

The ouly voleano that was kuown to be in action, was one on a enuall islarul in the Bry of l'leuty, cas the east enat.

The imbedsed minerals in the roels atrout the bay are quartz, iron, nut inon pyrites.

The hot spring of Thinimi was visited, bat it is deseritred as mather an enission of gus than af water. It is situnied in a sunall busin, asud forns a lake of three or four meres in exterat ; nets the edge of this lake, gas is constnutly bubluliag np, medally through the water, to which it gives the appearance of boiling; and gus also issues frotm the surroutding laud for' an extent of saveral hores. The water was found to be warm, but dirt not seald. The neighibourug grouml wis rlestitute of vegotation, aud appeared tas if tho striface of the earth trad been artificislly removed. Sulpluto was abundant, and there was also a slight incrustation of alum. The wnter was strongly impregnnted witl iron, was much discoloured, aud in emell and taste not unlike gyroligneous acid. $\Lambda$ gquantity of gas was brought awny, but tho bottlo met with an necident before it could be analyzed. It is not infammable, and had it been of a deleterimis sature, the fact (Jrom the quartities cmitted) could not fail to hawe been pereeived. It Jand so smell, and appeared not to differ from atmonglieric nir. Tho natives attribute medical virtues to these waters.

"Twelve or fifteen miles to the westward of the Bay of Isiands, war Thiaini, there are severul small extinct eraters, rising ahout five humblred feet above the surrounding country. Ono of them is called Poorun, and is remarkablo for the regular figure of its eone when acen fron the exstward. Its western side is cut throngli hy a deep gorge. The interior is covered with largo forest trees nnt huge blocks of Lava, while ilie exterinr is chad in ferus of low growth, Tho dimueter of the crater is about lya ff a mile. The plain which sarrounds the cone is comprosed of an nneumnouly rich stil, strewed with lavi, which slio natives collect iu lieaps, in order to chtain space for cultivation. The larn does not extent for from the cone, sud even in the intcrior, rock sebtom apyeared, but where it was gees it provel to the resicular Javn. 'I'he soil in tho ueighbrurlood of the eraters is richer, looeer, and mone fit for cultiration shan in other placer.

Dr. Pickering made a visit to Hokianga, on tlke wegtern side of the islant, and fotsud that it luod mure of the furest character thina the ceastern. H. took the direct road to Waimuti, which is thifecn miles from the Bay of I slands, Tho river Wnitanga whos very high, and one of the chicfs, $\mathrm{n}$ large and musculur mast, secmed to take particular interest in getting then acrusg srie nud dry; but notwithatanding his stature and all this care, the could not prevent a slight immersios". The ductur' arrived at Waimati at + r.s., and was kindly welcumed by Mr. Davis, the Methodist missionary, to whom ho lad a letter of introduction. It wny unt withont surprise that he found here a water-mill ill

* On the hanks of the Waitarga, the ault Inhabisants, to the aumber of iwenty, wero coliected in a cirelo, esch armed will a munkel, and kereral had been mot on the way, all armed. Thie cause of this cunsusl cocurtence nas not known. Thas are fery fond of fire-arms, nut on welcoming any one, parileulariy a clitef, alt the people of the vflinge

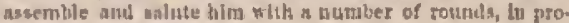
portion lo hlo rauk. 
operation, which the guides tonk enre to point out with ran little exultation. Tlis, togetler with the fences, and well-eultirated fields, were the wocks of the missionaries. He remnined with Mr. Davis for the night, who advised his proceedisag direct to Hukianga; bat the guides who had hithertn aceompanied him were ignorant of the route, and another hecumo necessury.

"Tlie next day" they passed over the fiank of Te-alworaho, is voleanic cone, and the most prominent elevation in this region. A little further on, a fine luke was pussed, about three miles in length. At nine miles from Wainati, slie woodod region was entored, which extended to Hokinnga. Just hefure crossing the Hokinnga river for the first time, the Baron de Thierry was mot with, who was exceedingly polite. The rond after this beenme diffieult, it heing necessary to cross the river repratedly, and to follow the stream for somo distлnee. "The usual mumer of erossing liere is to be carried. The guides, mnler various pretexts, prevented them from rendsing Hokianga, and they were compelled to atop fonr miles short of it, at a chief's callorl 'Toorun, of rnther doubtful clanracter.

Toorou, with hif family, lond worship both morning and areniug, os is enstomary with converted natives, ho hinuself oftutusting. The aceommotatimns were none of the hest. An open shed, with firo and hasket, were lonever suflieient to instre at good night'g rest. "Tourn was liberaily poid, and so well pleased, that he axid he was determined to carry his guests over ilwe river himself. The road was any thing but gond, being miry, and filled with roonts of trees, so that their attention was wholly engrosed in seeking a good foochold. The river was again repeatidiy crossed. On the way they met natives lnaded will baskets of nenches, the season fut" which had arrived. "They freely offered their fruit, for which tohneco was returned. Before noon, they arrived at Baron de Thierry's hotas, where they were hospilably reeeived by lis baty. This lomse is situated at the hend of tide-water on the Hokianga river, about thirty miles from its moutl, and boats enn ascend as far as this place. 'There is no rillnge at the mouth of the rivers, but many whites reside at different points on its banks. Thero is a bar between the headlands at its mouth, which will admit only of amall ressels entering.

Our trnvellers thad intended to retum the next dny, but one of their gtides, by the name of l'ooc, was missing. Ho had been allowed to take up his quarters at a short distanee, on condition of his being teady for an enrly start; on inquiry, how. ever, they were informed that looe land enid he dis not intend to go back until Mondny, which whs two ol' three dnys off. 'Tliey depinted without him, hut hefore reaching Touron's, Poos agnin joined them, huving a piece of pork, which one of lits friends laad furvished for the doetres's supper.

Mr. Davis't whs renched at dark, nul tlie anrue waru greuting expretiencel ns before. The next day they forached tho Bay of Lalutuds at I'nhia.

Paliti is the prineinal missiousury establishment of the Lipiseopal Clurch. it it plesantly situnted on the bay, opposite lioronrikn, nond is the residence of all tliose attached to the russsion, sal their printing-presses are there. It is too much exposed to ufford a gond harlsurr fur" slippring, but as it it the most. favournble side for communication with the interior, the advantages and disadvantages of its position are nearly balanced.

liororarika is still the prineipal settlement, and contains sbout twonty houses, scarcely descrving the name, and many shanties, besides tents. It is chiefly inhabited by the lowest onder of ragabonds, mostly runawny sailors and convicts, and is spproprintely named "Blackguard Beach.,"

The appointment of the police magistrntes was one of the first acts under the new order of thiugs. Mr. Robert Shortland, the first police magistrate, after the illness of Governor Hobson, styled himEelf acting gorernor, and a more ridicnlonaly prompous functionary could senrecly be imagined. He paid a visit to the ressel in which some of our getutlemen had made the parage from Sydney, and demanded the reason why the mail-bag laad not been sent to the new government postmaster. The master of the ressel replied, that he thought it his duty, not having been informed of any chase, to deliver them to the old postmaster, until he should be directed otherwise by Governor Hobson. This porrjous funetionary, in an improper tone as wel as manner, exclaimed "I wish you to know that I aim governor now !" In the words of one of the gentlemen, "land he been the viceroy of the Indics, he could not have made his inquisitions in tones of loftier supremncy."

Some of onr gentlemen nrrived tht the Bny of Islands in time to witness the ceremonies of making the trenty with the New Zealand cliofs. I mentioned, whilst at Sydney, the artival of H.B.M. frigate the Druid, with Captisin Hobson on hoard, se consul to New Zealand. It was well anderstood that he hind the appuirstment of lieutenant. goremor in his pocket, in the event of ecrtnin arrangements heing mnde. His arrival at the Bay of Islnnds, in H.B.M. ship Hernid, seemed to takc the inhabitants, forcignerg ns well as antives, by surprise. A fetr days afterwards, on the 5 th Fibrunry, a meeting wis crilled at tho dwelling of Mr. Bushy. The meeting was Jnrge, nud numerously attended by the eliefs. Many arguments and endenxours were thert to induce them to sim a treaty with Great Irritnin, all of which were but little stnderstood, oven by those who were preseth, and had some elue to the oljeet in view. Grea excitement prestiled, and niter five lours? ineffectual perstasion, the meeting broke up, every chief refusing to sign or fnyour Captain Hobson's proposition, which was in reality nothing more of lese than a cession of their lands, authority, nul persons, to Queen Victorin Among the argumenta male use of, lse stated tliat unlers they gigned the trenty, he ersuld dis nothing tnore thas act as cousul! Nothing having been eflecter, the meoting was broken up, ard the following Fridny appointed for a secoml. 'l'ohaceo and pipes were given them hefore they theparted, which restureil their gnod humorr, nod they went nway shoutity.

II the meats time, Mr.J.J. Clendon, nn Eil glishmn acting an American consul, the missinnrives, ath tmany interested persons zesiding therr, or abont becoming settlers, wetu made to underAtand that their interest would bo mueh promoted if thry should forward the views of the Britislt govenument. Every exertion พหต now nade by these parties to semove the serujhles of the chipfs, and thus to furm a party stroug enough to uver" 
reach the rest of the natives, and overcome their objections About forty ehiefs, principally minor ofles, - a very suball representation of the proprietors of the soil, -were induced to eign the treaty. The influence of Mr. Clendon, arising from liv position as the representative of the United States, was among the most efficient means by whiclı the aksent, even of this emnll party, was obtaised. The natives placed much confidence in lin, believing him to be disinterested. Ho tocnmo a witness to the document, snu informed me, when spesking of the transaction, that it was entirely through his influence tiat the treaty was signed.

The lieutemant-governor installed hisntelf, confirmed the appointmets of a lost of government officers, and the whote machistery, that liad been long prepared, wis put in suetion. Proclamations wore issued by him, extending his authority over alI the Jinglinh regidents on both fulnnds ! nut it was considered by the Euglishmen as gaod as law, though fur otherwise by the other foreigners. After this, the lieutensat-govemol proceeded to the distict of the Thameg Kiver, or Hauaki, in the Herald, for the purpose of procuring a eimilar cession of the country; but before this conhl be consummated, he was altacked sith paralysis, and the Heruld was obliged to depart for Sydney.

So far as the chiefs suderstand the agreement, they think they have not alienated any of their rights to the soil, but consider it otily as a personal grant, not transfecalble. In the interview I thal with Pomnse, I was desirous of knowing the impression it had smade upon him. I fonind he was not under the impression that ho had given up his suthority, of any portion of his land permanently; the latter the sair lie eould not do, as it helouged to all lis tribe. WVhenever this subject was bronght up, after answeriag questivns, he invariably sfolke of tho tigure lie would make in the scarlet uniform and epnulettes that Qteen Victorin was to send link, and "qhen what $\mathrm{n}$ tratdsome man ho would be !"

Those who aro not elirectly benofited by the change, cannot hut view it as a disastrous circunstance for the natives, which will seal their doom, and make them the proy of the hosts of ndrenturers who are flocking in from nil parts, some to he engaged as public ofticers, snd to fntten on the coming reve. מuts, and others as spectlators. During our stay, ts eutten arrived from Sydnoy, wilh a tumber of revenue officers, magistrateg, and other minos dignitaries.

Now Zenlan!l contimued under the nuthority of New South Wrales until Seprembor, 1R40, when it beeame a separate colfong. One of the first nets of the new gorerumeut has been, by proclamination, to require al! those who hwo acquired Innds by pur. clusse from the nutives, to exhibit their vondiers, and to olow how much land thoy had purchased, and tho priee paid. At tho same lime, a comtnitte was appointed to exnmine these clains. A few statoments made by this eommittee will slow how the triurit of speculation has been at work in New Zealans. Up tu Oetober, 1 isl, they regiorted that five lundred and ninety-one clains hud been entered by two hundred and eighty indiviluals; of these, there nne four hundred nuil thirty-live claitns, tunouting to thirteen millions nino husdreal aud twenty thousand four humbed snd riglsty-two meres. The romotining one hunilreil and tify-six clains are not definel ly ordinary landmarks, lut. are limited by legrees of latitude and Jongitude, and computed in aqgure miles imstend of acres. THw last description of claims are considered, nt a moderate caleulation, to be double the smonut of the four hundred and thirty-tive clitims, so that in round numbers, the chims alretuly selut in to the cotmmissioness may be estimated at corty millionk of acres. For four lundred claing, aftidivits lave boen made, and the total value of gooils and money paid by these elaimants is thirty-four thousand and nirlety-six perutse.

For ono hundred nud nincty-five claims, no value is stated; but if joild for in the same ratio, the nmount will the nearly furty thonksud pounds, or about one penny for threo acres. The whole surface of the two istands does not contan moro thay eiglıty thousand six tundred sinutare miles, or fifty millions of acres, and the lnrgest part of them has not yet been sold by the natives, viz, the Wrikati it istrict, Rotora and Tuบpo, in the interior, as well as the whole of the enstem coast of the nurtherm island; so that it will be difficult in first a sprace wherein to locute these esormous elaims.

Laws larve likewise been jrumulgated and imposts ifsied, harassing to foreiznors, (Amcricalls and others, ) and most destructive to their eommercial pursuits, while they ufter the rnost marked protection to those of Britisil sutjects: 'This wotald seem not a lithle unjust to those who liave boen resident, nul extensively engaged in commerce, before England took possession, and whilst New Zealand was acknowledged ns an independent stute. It hins, smong other things, becn enneted, that alt goods improrted and remaining on latss on the Ist of Jaminry, 1940, the time of British nssumption, shall pay duties; tlust all lands are to be conisidered ns belonging to the queen, even those purehased of the ehiefs prior to the tronty, while the pureloasers stall bo only entitled to ns many aeres as tho amount paid to the chichs will cover at the rnte of five shillinga per nere. Tho government in addition reserves to itself the right to such portions as it suay requile. Antry of these purchases were malo from the native chicfs, jrior to the trenty, is good fnitl, and for ars equirulent with which they wero well satisfied, nnd so expressed themselves.

The destruclive effect of these laws mi Avweriesn commorce will be great, particularly as those ejtgaged in moresutile pursits find themselves called upon to pay heavy dinties on their stocks. Muwricaus sre not permitied to loold property, nnd, in ennse. quevee, sheiv whairig estabjishments on shore must wither be broket up altogether, or transferred to other places, ut a great loss of outlay and capital. Our whalers are now prevented from resurtiug to the New Zealand ports, or fisting on the const, by the wnuage duty, port charges, sfe; are dersied the privilege of disposing of any thing in barter, and obliged to pay a diuty on American articles of from ten to fivo hiundred jer cent. The expenses of repairs have so much increased, that other places must be sought for the purpose of making them. The timber and timber-lunds are exclusiwely claimed as belonging to her majesty. Thus have nur citizens been deprived of a fishery yieking about three humdred thounnd dollars antinlly in vil.

The expenses of this usew goverument were esti- 


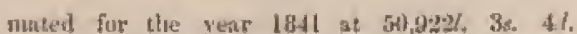
aterling, which is atrouse equal to IOL. for encl, mพ1, wonsa, and dsild ; for the whole forrign

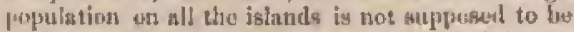
mure than five thousand, The great preeipitaney witls which the islands were taken possession of, is anid to larse been owing to the fears entertuined that the French intenled forming a colony un she kenthes's istand in liko manner.

After my artisal I gave the men liberty. Among the fitm who ubtained it was Jolur Site, a native of New Zentatid, and of the neighliourlyood of thim bay. Hig uative name was Tasti, nod he was a mity chisf. He trat been some time absest from his comutry, ard had soiled in the expedition from the Unitel States, was an excelleat sailor, a very gond fellow, and had been enthusinstic in the praise of his eountry and eountrymes. Aevording in him, there was toothing like fiex Zealiul; and under this feeling he hired a canoe to take hitu un shore, for which his countryman charged hitu three dollars, nhliongh half $\mathrm{\jmath}$ dollnr would inve been an exorbitant price. He Janiled at 'Tibley's, ant being desirnus of going to his friends, wislied to engago a cantre th take him abont ten miles up one of the rivers, the liawa-hism, where they resided, For this conveyance lu was asked $2 h$, nearly a month's pay. Yanr solw coulit not submit to this extartion, and was found sitting on a logg, greatly mortified, depressed, and ineensed nt stch treatthervt.

After Jahn returnet on bonrd, he made a propogition to Mr. Waldruts, in a later, to purchase the island which he callied Motugee, witls the territory of Muckatoo, belungiug to his futloer and fanily, and expresaing lis belief that they were alf opposed to the eneroadiments of the Englist, and were determined nut to part with their land to then.

Although the lund about the Bay of Islands is much cut up by indentations, yet. [rum this cireumEtance it afford many pretty views, which hove in some respects an nppentauce of Bul alvmice towarils civilization, that one haydly exprects to find witlan the senpe of the residerlens of these savages.

At the tine of suy visit, which was, as lans been soen, immeliatoly after Captain [Jubsou's arrival, nnul the signing of the treaty, $11^{*}$ cession, it was evident that full seven-eiglaths of the native jopuIntian hal the same feclings as aro foutulexpressed in this sute. The cireumstanem that have ocentred at New Zealinul fully prove the necessity of having American citizens as ner consuls abrund. Mr.J. R. Clemlar, our consul st Now Zealand, an independent state, and the only representative of a fureigu power, whose interest was at atake, was enusilied hy some of the nost powerful and influeurial chiefs, who had refuned tis bign the trenty or cossiun wo Grent Britaill. They cane to Mr. Clen. don for adviee, bow they slootld get, and he ad. mitted that he had alvised them to sign, telling then it wotsld the for their gord. He limkelf sigued the treaty as of witness, and did all he conth] (1) earry it iuto effect; but, in rloing thin, to salid, he lial acted an a private citisen, by requegt of

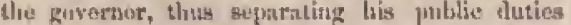
from his private acts. At the aare time he buys targe ermets of landt, fir a fos trifles, and exprects to linvo lis titles confirtues na eontul of the United States. This is not surptrising, und ary forcigner would undonbtedly bave pursued the sanc consse for lis peranal interest was very greal in laving tho British authority establislierl, whilo the inHuenee he had over the chicfo was tou great not tn attract the attention of the govesinor, and make it an tujeet to wecture lits good-will and жrvices.

The prospects of these islanders are, in miy opinion, any zlofing but plensing, and the clange by no meass enleulated to itnsure their lappriness, of fromute their welfure. It neems to liave been brought nbout hy a sage for Hpeculation, nud a Iesire to take possessiost of this eountry, in oriler to aecure it from the French. The iles that it was necessary th extend the lass of New South Waleg over the island, in order to protect the natives, and break up the nest of rogrues that find taken refuge livere, is far from being true. No such necessity existed, for there was no diffieulty in lasving any one apprehended by Bending ofticer for the pur. pose, or offering a rewart.

The New Zealnnd Land Company have been the secret spring of this transactinn, and under the sholter of certain influentinl names, the manngers Juve enntrived to blind the English mulic. It will acarcely be believed that the Niew Zenland Land Company hod disposed of several thensand shares of lun before they purehnsed an acre. Some three or four thousand emigrants, who hal purchased allotuents, deft Fingland on their way to take pmasession of them, just niter the agent. Upon their arrival they conld oltain no satisfactery information respecting their allotments, and weve left in a dostitute condition, to spend the fow enruings they had loft, and to endure alt the privations to which people landed in a new country are suhjeet.

Everi of those allotments that have been givon out, many are not susceptible of cultisation. It is searedy to be believed that the bigh names which stnud at the head of this company conld lave been iniormed of the true stnte of things; yet it is generally supposed in this purt of the world, thut it is by their exertions and influence thut the Britislı govermanent las been infuced to take fortible pussession of the territory of an indenendent atrte, which New Zenland undoubredly was. Ilow. cver this mny be, the speculators havo sueceeder in theis chject, and the eountry will now be retained by England, even if a milisary power should be necusasy. Shomld the New Zealanders resist, and thry are a warlike ruce, yet seting against European discipline, they will readily be overeome. They are rot unlike grown clilldren, and may be mace ensily ruled by kindness, and by estisfying the wants of the cliefs, than by force. The population will soon disappear before the hites, for the canses that have opernted elsewhere are to be seen in netion here, where the savage is nlreacly sinking impereeptibly lefore the ndvanees of eivili. zatiol. While philanthropy, real or pretended, is runsseking the globe to tinl subjects fur its benevolenee, it seens a little surprising tlat keareuly a voice las been raised in Parliantent ugainst this act of nsurpation.

On the 20th of Februnry, 1040, there was a vitslent gnle at the Bay uf Jslusufs, said by the missionarits to have beon the soverest they had experieneert, wills perlanps the exception of one which tuok place ghortly after their mrrirnl. Many vesgels 
suffered great damage. The Thorn, of Sig Harbers, which saifed at few alays before, bound home, was athligod to put back, and in consenquence of tlic damuge recetived, was comdemsed no unfesworthy, us พมห หtso the Tusean, an English whaler. The Larque Ninrod arrived, huving Inst Jier topmint, and enveral cousters were missing, supposed to Javo been lost. Most of the vessels lyug off liororarika dagged their anchors, but they suftered lege from not being mueh exposed; the Hartiet was driven ashore at Tipoona, a few miles to the eastward, near Point Pocock. This vessel purted her cables dariug the night, and the next moruing was fuund a completo wreck. "l'he erew barely' cacaped with their Jives, Beyitles theso disamters un the water, those on the land were also great : fences were carried away, lunses deluged, grounts over. flowed, wharves injured, and the extensive embankunent of the missimary estullishtsent at I'aluia nenrly ilenulished. The cide rose six feet turïng the night of Saturiny, beyond its usual mark, which eaused most of the dumage.

This galo was experienced at the Thames on buard H. B. M. sligs Herald, whe dausdred ark forty miles to the south; nleo by the Fying-Fish, off Conk's Straits, and thy the bark Achililes, to the nortl. Mr. Hale wns a passenger it the last-numed vessef, and twok baymetrical chiservations and notes shring the contitunatee of the gale.

Frotn the observations, it appears that the change thok fylace at the two northern and two southern pnsitions, in opposite directions, proving that the gale was a rotury one, and that its centre nust lave passed between the Bay of Islands and the river 'Thames. T'lue gruatest fores of the gale was between the hewr's of 1 anul $3 \mathrm{~A}, \mathrm{sing}$, on the lst of Mareh. At llue Bay of Islande, a calm was obs gerved by $\mathrm{Mr}$. Dawn and ofhers, which lsated fifteen minutes, rfier which the wind rapibly lousled round tw the wentward, and blew wills inerensed vinlence. On bonril the Herald, the barumekr fell to $2475 \mathrm{ins}$ and from lle fact of the gale laving been experienced filst to the nerthwarl and castward, it is certain that it eame from that quater, and passed ovir. New Zealand in is suthth-west direction : the wilth of the track was about five hundred miles.

Foreign residesita have establibhed themselves in many places, and on all the inlete ur arnis of the Bay of Islands their cuttuges aro to be seen, ocenjying the proints and esves.

Oit the north, the British rexident, Mr: Busby, lans bnilt a large anul eommuliuat coltage, and cuttumetseed luying but lis grounds in twwit lots for the future sify of Victoris, of which thore was a public sale proviuns to chr arrival, All the lots were, J believe, purchased on apeculation, for after seeing the kenlity, one must be cullyined thint it offers no advantages fur tnore than as village, if indeed for that. More to tho westward is situnted Palia, the mission establishnent. For exanmereinl jurposes, the south or Liororarika shese offers the groatest alvantages, laving the dee prest water, and leeing the most sheftered from the storny winds.

The extent to which speculntion has mised the prices of land in this neighbourhood is alsuost incredible. Mayew's Point, the tirst nbuve Kura. murita [Bay, lass on it a few storehouses, which are rented for six humfred punnds a. yeur.

Mr. Clemtort, the Ameriesus colveti, for thbunt thrue lamdert and twenty-five actwo of which buly fifty are level, lats reetived thiriy thousand pousds from the liritish povernment, reserving to hisnewl the renainder, meliuuteds nerss. He bought the whole for a uritte a few years ago. The location is a protty otze, all a liall about lliree liundred feet high, and is, perdups, the unst commanuling spout on these waterg. The lentures of his cothage atsd of the groumds about it nddes untela to its plensing appenrance.

The introduction of a Sydray police at liororarika bas been of surviee to that place, for they lase dealt in 4 sumnary manner with the vagalronds who fermerly frequenterl it.

A Roman Catholic bishop is estallished bere, who has a chupel, ant it was seid, wns making many converts; but it wha anp eipal indueenen: to conrorsion was the liberality with which he and lis associates bestowed gifts and fresents of on thuse who joined in their prayers and received the eross.

Besides the Elrisconal mission, under the Rev. Mr. Willians, forturty" a lientenant in the Britislt uavy, there is a Wesleyas missinu at Hokianga, which is highly sqraken of. Masy" requrts haro been put in cireblation by the evil disposen, in refution to these missions; but as fur at my ubservatious went, they secmed exentsiary in their duties; they were also oceupied in fartuing, in which tative las hotrers were enplayed. Mr. Williams hasing a large fimily growiug ap, many of them oblnined farus, and are now in the successful occupation of them, There is no douth the laue and cry against the father, that the nission labl olutained all the best land from the natires, arose frum this enuse. Some circumstnueus were reuarlkerl, from whieh it was evident tlint the interestr of the tantives were luoked after by the missiunaries, who protected their lands and induced them not to sell to the enigranta, who willd olhorwise lave fouzd them only too resdy to part witls thent.

It is true that tha eituation of the missionaries of the Church of Eagland is different from that of any we lat heretoforo bech, and eyually so that they do not appear in laves succested as well its muking prosel tes ns those in the ather Polynesian islands; hut i мu pressialed that they have done, and are still enden vouring to do, tmat'l good. They are, however, separnted, as it were, frum their liueks, and consequently, eannot linve that control (Wel their belavionr thint would be desirnble. Many serene, therefore, talic place at the pas or strongloolds, that miglit lie prevented if the missionaries mingled more witl their converts,

Mr. Willings was hind enengli to liave disile servite at the louse where otn uaturnlists stnyed, -Mr. 'Tibbey's. I wus not a little stropised when I lesedu tlat ML. Williang had refused any ophortunity to ous philulogitat to insjeet a gramms of the New Zealuss langunge, that was then going through the press. I mentiun the eireunstance as rematkalule, from being the only ingtance of the kind that occurred to us during the crolise ; and it canout be mosily inagined what condd lase bees the tause of lifs refusal, fur a very slurt periou after our departure it would be publisbed, amb there could linve been no fear of his being fortstulled by $u \mu$.

Atrong the uatives tive taboo is yet lnw, thougl endensulus are makiug to introduce other laws 
smong them, It was whll me, on good asthority, that there had been a trial for marder by $n$ jury of ehiefo at or near Hokianga, under sle direction of a white man, bat there wis great reason to believe thet the person did not receive that impartin] justice which a duly-organized court woult have rastured him. The evidence was sail to have been defieient, but the current helief being against him, he was notwit/standing shot.

The natives, we were told, were nat a little surprised at the summary way in which justice, or ratlier punishment, is deult out by the ruagistrate of lioromikn.

Their taluo laws are very striet, and enrefully volserved, even among those who are contidered Christians. The ehief, Tomati, refused to enter the lonse of a person whom lie tonk Mr. Hale to visit; for if he had entered, it would bave beeone tabooed; and the antive law, which does not permit any man to enter a louse in which a clisef las resided, even temporarily, would have compelled him to abandon his dwelling. Women alone atce allewed to enter the houses of clijefs. An instanco of this was witnessed at the pa of Pormare, and anotler where we attempted to purchase the prow of a casoc. This prow, which was elaborately enrved to represent some nondescript asimal, with a human head, having the tongue [n'vtruded, wa accilentilly Been in an out-of.the-winy storehonse, and was comewhat mutilated ; it had belonged to the lato chief Kiwikiwi, and was taljoned in the first legree. Orertures were ninde to the widow of hiwikiwi for its purchase. It was evidently consilered rety sacreil, for none of the natives would tonch it, or even enter the sturchouse in which it was kept. Notwithstunding all its ancrednoss, it wass sold, after a little ehaffering, for six dollars. The first price asked was two pounds, but the widow coujd not resiat the ehance of its sale. After the bargain was concluded, no native conld be found willing to ineur the penalty of the taboo, by earrying it. When the transportation was accompliebed, a new and unexpected difticulty arose : it cuuld not be carried across the water in a caune, as it was against taluoo to do it. The threat of making them refund the money, and take back the ihn or nase, so wurked upon the covatousuess of old Kinwiti, the chicf, that he eonsented to reurve it, and also prorsikerl to cone the pext dny and paint it reil, after the native fashlion. This be punctualy frerfortsed, using a kind of rod enrtl mixed with water.

The taboo is always resorted to, to pmatect their kumara-patclies, and the fenr of brenking it wns strongly shown by the intrusion of Mr. Tibbey's gonts into the kumara-patels of Pumare, nestr bis pa. No one could be fndueed to go in to drise them ont, for fear of punisliment; nind a messnge was sent to the chief to allow them to be expelted. After the perraission was given, the natives could not be induced to enter by nny nther plnee but that where the gouts ind larnken tirongh.

Tho antives, for tho most part, have their permasient residence in towns, or what are here tertned "pas," which nre generally bujlt on high promontories, or insulated liills, and fortified in a rude faslion, with th palinade of upright stakes, about ten feet lighl : the houses or huts are all built closely together.

Fomare's pa being near our anchorrure, was frefuently visited. It contained about three lut. drel lints. There was a mnin entrauee throngh the palisade, nour which are two poste, the tops of which are enrved into distorted representations of the human figure.

Within the main enclosure are other enelosures, each contuining five or six houses, with alleys of two feet wide, that traverse the town. Thicir Jouses are very simply ennstructed: four cornerposts are driven into the ground, and left from two to five feet above the surface; in the centre lino two or diree strong frosts are firmly get in the ground, to support the rilge-pole of the roof; on the posta is placed and hasticd a horizontal bean for the rafters to rest upon, and smaller poles are lashed to the josts, at one foot apart, from the ground up; on these the roofing is worked: the materiul used in thatehing is the rush (typhas latifolin), or our common cnitsil. The manner of making the roof is to tio the materials on the hori. zontal string or poles, setting the larger ends on the ground, and driving them close against each other, generally with the fist, and 80 on until all is closed in, leaving doorways under the eares, at the gable-ends; the nzppoing is then cut syutre off at the upper horizontal beam or platc-piece, and tho roof is put on, made of the ane materin], and generally thatehed with it or fern. The roofs have usunlly but little pitch, which gives a squat look to the houses. Mats are genernily hung up at the doorways, but some bare door made of pine; they are low, obliging one $\mathrm{t}$ stoop or ereer, in enter. ing. Around their houses they have usunlly pench trees growing, but nothing else is cultivated about them.

I'he furniture consists of mats, a few baskets and trinkets, an old cliest to luck them up in, an iron pot, and a doublu-barrelied guis, genemlly of the best maker.

Pomare's house was about twenty feet long by twelve broad; from five to eight feet high. The mode of construction was the same as alovo deseribed, with the exception that the raftery were ftat ani ornamented with ambesque work, drawn with snot or black pigment. The posts were likewise carved; but from the dirt and filth with which they were tovered, it was diffieult, if not impossible, w decipher them. It is sajd thas the New Zenlanders have improved in the art of building sineo they were fist visited, but they aro still is this respect far behind suy of the islanders wo have visited.

Four of our gentlemen, before my arrival, linul majd Pomare a visit, and made him some presents, which, so far from satisfying lis cupidity, only made him more covetous. On receiving a watelichain, he nstied for the watch; and could not be induced to exhibit a daxes, unless each person pro. sonted him with a shilling. This exaction was submitted to, hough they wero disgusted aud disappointed with the greedines lie manifested. The dance proved very sinilar to those seen among the Samoans and 'Tahitiane, with the same tossing of the arms and legs, and various cuntortions of the body, performed by a number of men and women. The unly music whs that of the voice, two of three singing in a high monotnuous key. The dntice was, flowerer, seen to disadvantago by cenulelightit.

On the top of the bill is a snered enclusure, or 
liningn-tabow, in which is crected the tomlis of the chiefer $\Lambda$ few days before onr visit one was interred here.

This tomb is formed of a kmall canoc, eut across through the nuddle, and the wo yarts joined face to face, forming a hollow cone, alsout seven or cight feet long. The corpso is placed inside, in a silting posture, and would remain there a your, after which the bones would be earried up the river, and as Charley Ponare expressed it, would be "thrown away any where."

The tomb is jainted red, and ormanented with festhers on each side, from tho ground to the top; it is covered with a small silien, to protest it from the weather, and enclused sil nonund with a fence. "I'lıs funcral ceretuonies were not witnegsed, but, from the deserijtion of the matives, were rery naisy, and accotmpnnied with firing of mauy gums, - th general practice on all publio oceasions. THeir faces and arms bote evitlent marks of their having beell engaged in the cerennny, being cuvered with seratehes which they had inflicted un themselves.

Tho pas of the uatives are not in reality strong places, but are litte more thin usulated and conmandiug situations. Pomare makes some slow of warlike instruments, in the formidalte array of three ten-pounders, all of them in bad contition, though looked $n$ and spoken of liy the untives witls III smald pride am tonceit. The matires, in time uf peace, do not live constantly in these pas, but are mostly occupied at their plantation-grounds; for which reason only a fow men were secn lounging about in front of their houses. Tho women were generally engagerl in making and ptaiting mats, or cooking, and the men seemed the grenter idlers.

Their untive dress consists of mats of various kitsdy, made of the native flax (phomax), whicls are braitled by hand, and are, some of them, finer than earpeling, while others sro as conrse as our corm-leaf mats. The latter were worn by the women while at work, tied around the bips, and sonetimes over the shoulders. They carry their whildren on the bnek, like ons Indisns.

'The mon were more luxurious in their dress, having fine mats, jenrly as large in size as our blankets, ingeniously ard benutifully wrought, and sometimes embroidered. Both of these kinds nre still worn, though they are gmdnally disappearing, sud the dress is becoming more Luropenu, or mather Tuhitian. The women now often wear loose slips of eutico, druwn about the neck, which ree any thing but becouning, while the men lave coarse clothing, sometimes a dirty white blanket, at ofhers, different parts of Europtan dress. The blanliet is worn in the sane manner as the mative kakalut. They uever thisk it necessary to use elothing for $n$ covering; it is worn more from pride and ostentation than any thing elso; and not unfrequenty a native may be seen decked out in a cont nnd rest without any covering on his nether limbs, and occasionully with a pea-jacket and 120 shirt. That which gives a foreigner a peeuliar disgust to the persons of the New Zealauders, is their filth, which also pervades their houses. Thay seldom, if ever, batlue themselves, or wash their elothes, which are usually worn tutil they drop off from age. They vecrsionally anoint their skins with fish-wil, and of course cannot be cxpected to kerep thenselves clean.
To their honses, the deseription of Cook still applies: they are small, low, begrined with soot, bosmeared witl grease, and are filled with filtlt. As yet, their furviture lits received no addition frum their intercourso wilh the whites, except the furge sea-chest and irun pot: the former to deposit their valuables in, and the latter for cooking. It was remarked by us all, liow few of the hrotesche figtures, so much ispolien of by voyagers, were to be seren. There nppeared to be little carving reecutly done, in comparison with former times. They are sajd to have instroved in the eonstruction of their louses; but there is still grent room for improvement, before drey ent vie with my of the other islanders we have visited. Their food consista prineipalty of the potato, fish, kumara, or sweet potato, lndian corn, and ferm-root, which is folsud througliout the cousery. The lcumarn is much smaller and inferior in quality to those grown in the other Polynesian islef. Hero it is a samalt watery root, aud is generally disliked by foreigners. It is preserved in houses constructed for tho purpose, to prevent the depredations of the rats. These are lunilt on four posts, which are serugned cxcoedingly suoutl, and are anly entered by a single slanting post. The roots are also suspended beneath these louses in large baskets.

Fish aro taken with hooks and uets, and aro dried and lnid by for use. They also eat a clam, which they call yipi. Hogs and poultry are ruised in abrudance, for their own use sud the supply of ships. They have, as I before stated, penehes, as well as many small berries, and in a few years they will have alf the fruits of the temperate zone introduced by settlers. They formerly ate their fiats rus, or cooked with the kurnara, after the Poiynesian fashion, in the ground, wilth lot stones; lut nuw they use an iron pot, in which all tleir food is boiled together. They have a great fondness for rice, wilh sugar or inolasses. They do not want for food, fur their country is well supplied with wild roots, which in case of necessity or scareity can be resorted to. They nlso make a pleasant bevernge, resembling spruce-beer, which they call weri-matori.

Tho grentest changes which have taken place in their eustoms aro the introduction of the use of fire-nrms, and tho adoption of whale-boats instead of their cannes. The latter are without an out. rigger, and differ in this respect from the loosts of nil the other Polynesinns south of the equantor. They lase also adopted the square sail (which generally consists of a blauket), in place of the triangular une common to all Pulynesia.

The ornaments of the New Zealaulers are fow; those of the men, who are chicis, generally cousists in an elaborate tattoolng, that gives a striking appearance to the face; the regularity with which it is done is wonderful. They all have their ears bored, aud bave small rings in them, made of jade or slinrk's-teeth, tipued witl sealing-wax, or emall bright-coloured fenthery. Around the necks of the chiefs and their wives is lsung their "heitiki," made of a stone of a green colour, which is theld very sncred, and which, with their "mearn,"-a short clever or club, - is handed down from father to son. The heitiki has some resemblance to at hнияа figure, sitting with crossed logs. This stone is proeured frum tho southern islund, wear the horder of a stmall lalie, which receives its mamo? 
frem the stone, being called Tewai Potmunu or the Greustosture Wnter. Frum the name of this Elutue, Curk, by mistake, gave tho name of Tavy Poesammon to the sumthern islatid. It is also supposed that Captain W'Urville's name of Itassu-uth (meatring, the fish out of Mawi), given by him to the notthern ialands, may also be the usune of some place on the uortherit side of Cook's Straits. Those who nre facriasinted witl the natives and their languago say, that they have un mative name for either of the islatds, or any part of the courtry, and lave ndopted into their language the names given by the whites, witl modifications to suit their tongue.

It was a long time before Pomare would con. senc to lis wife parting with the lneitiki whiel whe wore, and that belonging to himself (his ntur) Jie would not allow to to take oft his neek, oven tu luok at. Uur cousul interpreted for mo a singular story that the southern natives land inveuted, relative to these stones: "That they were fuund in a large fisl, somewliat resembling a shark, which they wore obliged to capture and kill for the purpose of otstaing them. Whets first taken from the stomach of the fish, the stone is suft, but from expnsire becomos lari, and nust be wrought in its soft state." This story was re. lated by Pumnre. The sinaller stones were strout three iuclies in lengits, and the larger ones about live inelnes,

I'omare is a fine-looking man, and is handsomely tattretl. He is six feet in heiglit, nut well-formed, with the exceptiun of his fete and legs. His dress was any thisg but becoming : a blanket was tiexl about his neck, and husg ungtnecfully about his frestost, leaving lits right arm free; betsenth this he wore a slirt and loose pair of denwers, deseonding to bis knees; the rest of his person and his feet wery bate. In his hand he usually curries is strort eloak of dogskin, eniled togmni, shupuni, so putulu. These short cloaks are, in shape, that unlike those of the knjglits in macient times; they are aliout three feet long, being fortued of common eloth, mat, or sewed degskin, dressed with the hair ons. Pomare's dress was surmounted by a blue naval enp, witlo a gold-lnce band. The thitooing mny give his fentures somewluat of $a$ firre asprect, and serve to disguise the expression, yet I cannot but believe that his true feelings uro developed in it. His face indientos any thing but a kingly character. Perlaps his reputatinn for businesg may have something to do with the inpression his physiognonuy firuduced. He tols no be had two wives, but it is generally believet that thirty would be nenrer the truth. The favourite une usually neompanies him; sto is higlsly spoken of for her gond sense, and Pomare is suit to phee mucli coutidence in lier judgment. She was the best-] ooting uative I вaw in New Za. land, but would not be called landsome elawwiere. The missionaries liave not yet been able to jroduce any uffect upon Pomare on' the fanily connected with lim. Ponsure's clifef wartion is Manparawn, who has been persuaded to rumain with him, although a native of Ilauki, on the river Thames.

Mnuparawa is a mach finer-lnoking man than Ponare,-in appearanee a very Heretalus; but the efficts of disaization are beginging to be perceised in this powerial cirume. He las long been in fa. vourite with the whites, who admire hin for his prowess. DIany of his followers came with lim to join lomare, of whon few are now left; for in an expedition last year he lost almust all of them: liaving landed on Aoteu or Barrier Island, he was overpowered and tually wounderl, barely escaping with life. One of tis acts of during took phes in the last feuds with the horeraritanis, by whom he wag much detested. Wishing to put a disgrace upon them and show his coutem ju, the one night torok his ennoe, and witlı six of his followers left ['ornare's pa or stronghold for linurarilia, the lienrt of his enesnies' strength. He landed there in the rnidst of his foes, whom the found fast asleep. Drawing up his ennoe on tlie beach, he wont to the linuse of a white man, whom he awoke, and ordered his to give himself and followers bome spirits, threatening him, ill euse of rofusal, with instant denth. They took their opirits quictly, desiring the man to say to the lifororarikans in the momiug, that Mauparawa tad been there in tho night, wjih some insulung message; but before lenving, it oceurred to him that the man would not hase the courage to tell of his visit: he therefore deterwined to leave lis ows ennoc, (which was very well knowu, and take a whale-bont in its stead. All of whicls was done merely to throw a slur upon his enemice, at the risk of his own life.

Another petson of some note is a cunsin of Pomare, enlled Chatley Pontare, the son of the former ruling chiel of that name. Hoin, the brother of the lking, nppears to be a stupid felluw. Charley Pomare was very talkative and intelligent, and aldhough youtig, appous well-irformed in the history of the islsud. In his necounts, he dwelts particularly on the extensive ravages comsuitted by Shougg, who I believe was caken or went to Europe, After lis return, fitsling he hat lost influence in lis tribe, in order to rcgain it, he committed some of the most barbarous cruelties that have ever disgraced these islands, and mado his unive terrible amoug the tribes. Most of these, before his wars, lual from three lundred to one thousand warriors, but only a few now remain in some of those who were formerly powerful and independent, and who being from their wenkness unable to eontend by theniselwes, hive becume incorpornted with otlicr tribes. The renson that the natives give for this diminution is, that Shougi had killes them all. His ennguesta embraced nearly all the northern part of the north island, whose warriors he then united, and leu against the people of the sonth, about Hataki, on the river Tluanes. With these ho waged a long surd bloody war, wnd extended the name of Ngapuhi, which properly belongs to the people abmut the Bay of Islanis, as far sonth as Kinpara. His death, whitely happened a fow years siluee, was a great rolicf botli to his followers and foes.

the last war took place in 18:37, alout two years before our arrival. It was, in thl probability, tho last antivo contest that will be waged. It was etured by the disapprearaneo of a woman of Otuila, whom the tribe of Korumrika were suspected ant accused of having lilled anil eaten. Formidable preparalions were made, and the allies os both sides callet in; the people of Karornritan being aided by the forees from Hokianga. The principal battly was fonght in a piece of maxshy gmound between Waikereparu and Otuilin. Here Pomate, 
Letter linown by the name of Clarley, then quite a bryy, led the forees of Otrilia, white those of liornturila mere nurshalled by $\mathrm{P}_{j}$, a grent chief of Hukinnga; and the fight was terniuated by Charley fires shooting $\mathrm{Pi}$, and then the second chiref, who was endeavourisg to save the body, with his double-tarrelled gum. The heads of tho wartions wore cut oft, and preserved as trophies, while their loulieg were left on the groumd. They were not uaten, thought the Hokinnga preople arv said to be cannibals. This latter inputation, howover, should be received with cautiun, as tho itsfurmation was derived from their enenies.

Ftom all I cotld learts, Pomare is not deemed vary courngeous, and was not himself engaged in the figlit. Ho is looked upon as quito atruricions, and as a great coward: lie is much nulieted to linuor. II will, perhaps, excite surprige to learn how he canc to exercise the influence ho dues orer thin coustrymen; it is entively owjing to his eloipuenee, by which ho is enabled to lead them any where, Wheu Charley was asked the cause of his uncle's infuence, he said that Pomare could leal the jeople wherever he chose; and to the question ต to why he himself was not king, he answered. "Oh, that is maturi" (country fashion).

Some of the gentlemen visited the pa of Pormare, for the priplose of witnessing his return from a visit to one of his allies. The canoo was seen eoning up the bay, paddled by forty-five natives, ath ot the side of the hill all the people of the pa Wure colleted, shouting, waving their gnrments, and firing muskets, to welcume their fitends. When the chief tonched the shore, a eurious secne ensued. All the boatmen seized their patddes, and rau sone distance along the beach, where they lualted, and formed themselves iuto a eomipact body, in murtin army. Those of the pa did the sarme, and were stationed in frone of the canoe; the former party then returued, ard when near, the latter made situultaneously ton or twelve lenps directly npward, waving their paddles over theis liends, and giving at ench jump a hard gnttumal susud, like hwoh. T'he two partice then changed prasitsons, when the bromen went through the eanu suotions, after whieh the whole mingled together. 'I'tuis ceremony was supposed to reprebent that used on the return of a war-party. Ponnare was found shortly afterwards sented in frout of lais house, surrounded by his people, who wore husily engaged in preparing a great fenst, for which he was giving directions, and which shortly took jlace, aceompasied by much merry-making.

The chief, Ponsare, on ono oceasjon pnid a risit to the gentlemen of the squndron at Mr. 'Tibbey's, with some fish for sale, and for which he lond been fishing severnl hours. He first nsked a shilling for them, which was landed to him, when he immedi. atoly raised his price to two shillings, and witen this was refused, he went awny in hight dudgeos, and complained to me or my arrival, that lie liat tiot been trented woll. Many instances of the anme kind occurted.

Hr. Halo indueod Hoia, Ponore's brother, to give him a list of the various clans of the great Yopaki tribe, which tunder Shougi had formerly been the terror of all New Zenlind. From this and other anthorities, the number of the tribes were given ont one luundred and firo, in which were comprised upwards of sixty thousand tighting men.
Those who aro more acquainted, and have the bist opportunties of knowing, state the population at leas that bliree hundred thousnnd; there are otlutrs who rate the popuslation from thirty to furty thou aand. A man between the two estimates would be nearer the trull. Frum the information I reecived, I an sativfted elant it canmot be great. The [population of butl। islands is eqid to amount to fiom one liundred and forty to one lundred and eighty thotsand, and the wheje of this number are on the north island, with the exceptien of three or four thousand who nre on the soutliern islatw]. It is reusurkable that erory tribe las a rame peculiar to itselt, and distinet from the district which it inlunbits: thus the matives of liuromarika are called Yaitawake; those of Hnunki (the river Thames), Ngaitawake; and with few exceptions these names begin with the aydlalle of Xiga or Ngati-most commotaly the latter. 'These names are thought to have reference to clanship. The members of ench tribe appear to be als connected by the ties of cunaanguinity.

Sume of our raturalists made a visit to a trum called Wangarnria, situnted near the const, ahout thirty miles to the southward of Cape Brott. They passed up the Waicaddie river eleven miles to Waicaddie $p_{\mathrm{n}}$. Here they found a unissionary station occupied by a Mr. Baker; but nume of the family were at home. "The old chicf of Wricadie was very indignant, nnd trented then quite uncivilly, betanse they were going to Wangarasn. After procuring a guide, they set out on foot for that place. The distunce is twelve miles, which they acconpliehed by sunset. The road lay over noustains. Tho villnge of Waragnern eansists of four or five niserable lute, or what would more pitoperly be doeignated kentsels, mude in the rudest manner, and slutehed with ferta-lenves. In order to enter these, they were abliged to crawl on their lunds and knees. Tho furniture of the clifef's house consisted of $\Omega$ few tnats, two or three fibhingnets, and an old cliest. $\Lambda$ firo was smoking in the centre to keep out the musquities, and the resem. blance to a smoke-house wus striking; or', pertinge, the latter would have suffered hy the comparison. The acconmodations in this tut were rather confined and crowded; for besides themselves, there were three runaway snilors as guests. They, therefore, gladly aceepted the invitation of the chief ho-towatown, who was on a visit here, to neconpany him to his hut, at the month of the bay. They wont with him in his fine largo canoe, nnt reachud his residence late in the evenitug, where they found themselves much nore comfortably nccommodated, having clean mats and a goud sapper of pigeons and protatnes. This was Kotowatown's principal farm. His pa is situnted a few mileg up the bay, on a rocky point, and contrins one hundrod and fifty houses. It was, at the time of their visit, nearly deserted, in consequnnce of the attention demanded by their crops; and this is the ense with nearly all the other pas at this season.

This paut of the eountry is flat, and has a good anil; snd hore Ku-towntown raises most of his potntoes and kmmaras, whieh are larger asul hetter than thuse raised at the Bay of Islands. They also raise a good supply of Indian corn, and are at no lose for fowd, which was evident from the quantities of dried ns well as fresh fish which was gevis. 
4 great differonce was perecived botween the tancives of this place and those of the Bay of Irlauds. The former lave hail littio or tut communication with forvigners, their manners are more simple, and they have little or no iden of the conventional value of money. The peorle of this place appenred more virtuous and haply, and a tumber of roung women wero seen, good-looking, sprightly, and full of animation.

'They hero siw the old clief of Wangarara, grisnd-mncle to lio-towatown. He was very fechte, with white lıir, and clad in an uld dogrskin robe. He whs observed to sit all day ota a smalf nyum of dirt aud pipi-shells; hnving lately lost a relation, lie, necordisis wo sustom, is tahoued for the seasou. He does lsot help Jinnself, and is not allowed to touch any thing with his hands; his grand-dauglter, a sfurightly girl, waits upon him; and it wos plearisg to witucss the watehfuluess she evinced in altend. ing to his wante, often filling aud lighting lis pipe, and holding it in his month whilo he smoked. Notwillstanting the promising appearnee of Kotowntown's house nud premises, it was found swirming with. fleas and other rertuin. Ko-towntorra is a member of the Episcopal Cluarch, and daily performed worship in his native tongue. After their morning meal, they began their rambleg, but had not proceeded far hefore they were met by a large pasty of natives, who kept anying to them, "walk aboul one lilling," by which they soon uruderstood that they were reifuirent to vay ono shilling for the privilege of walking on tho benth and picking wp shells; on lio-towntown's breitrg apprealed to, he sonn dispersed them. On a hilt, luenr this place, Mr. Drayton found a benutiful specimeu of bulinus Slaurgii.

Wangaram Bay is a deep indentation in the cosst, to which it runs parmalel, and is opprated from the ocean by a uarrow bele of high and rocky laud. It is said to have good anchurage for a distance of six miles from its mouth. The entrance is very deep, frec from danger, and about one nilo wile: it is a muclt safer port than the Bay of Islands. $A$ vegel might juss by its entrance withont suspecting that in harlwont uxisted. P'rovisions of all kinds are rauch cheaper and better than at the bay: aud although the natives ato nware of this diflesence, yet not beistg nble to transport their provisions there, they are content to dispune of theur for a less price.

Their kind friend Ko-towntuwn tonk them bnck (1) Wangarark, stopping on the way at his pa, wliere he presented them with guantities of preaches, which had been tabooed to bis people. At Wangarara they again fuund their guide, and the two olu ehicfs, - the ckler of whom was culled Kawan, and the other, a lithe younger, liualsena: botls of them have the charates of bejng great raseals. The contrast between then and Ka-towatowa was very much to their dispnragement. Witl some relnetanes they ordered in pot of pointoes to bu boiled; bat when night eame, they positively refusen cratrase into their luts uniess ench fave a slilling, to which Jío-towntowa storily nbjected, gaying that they were his guests, and sliould mo pay. A quarrel betweer the chiefs ensmed, sud the ouly way it was preventer from going to extrenity, was to ship the money quietly into old liawn's lnat; after which, peace was restored, and they retired for the night, where they werte effectualiy tomiseced by the flems and veruis. Ko-towatown, on taking leave of thenk, refused arsy compensation for his services; bnt a pressing invitation to pay them in risit at the bay wan aveepted.

They returned by the eame route, and by woon reached $\mathrm{W}$ aicaddie $\mathrm{P}_{\mathrm{n}}$. It contains nbout two hundred houses, and is aituated between two small fresh-wuter stmeams. "This is the most clenuly and extensive town in the neighbouthood of the Bny of Islands. Mr. Baker, of the Episcopal Missiun, hns settled lieve; lie lwas mauy neres of laud, and cumfortable dwellings, farms extensively, and las about twenty lend of cattle, with guxd pasture for them. The natives also possess some cattle. By night they reacherl their lougings.

One who lias long kuown the New Zealanders, and on whose jotdgment reliance may be placed, gives them eredit for intelligence aud generosity, aurl says that they no hospitable and coufiding to strangers, persevering where the objecl coucerua themselves, strongly attached to their children, and extremely jealons of their ennmuhial rights. A violation of the latter is panished with death, not only to the partics themselves, but sometines extended to the near relatives of the offenters. lhey are crafly, but not over-resehing is theis dealings, covetous for the progession of Hovelties, although trustworthy when any thing is placed unler their immediate clarge, bnt not otherwiso over-hollest.

A transient visiter would hurdly give tliem so ligh a clismeter, nad wonld, I thisk, have an unfuvourable opiuson of the race. Ho might, however, awatd to them intelligence; but they nppenr vitylic. tire, and, from a number of fnets, nust be truaberous. One cannot be long among them, without discuvering that they are adepts in trickery, and suspicious in their dealings. T'hese bad qualities they may lave acquirod from the number of tow whites that are among them, They seem destitute of any of the higher feeliugs, such is gratitule, tendemess, lionour, delicas, se. They are extreuty indolent nmi dirty, diagusting in theiı* lıabits, and earry on the infamous practice of taffic in womer, which even the highest chiefs are anid to be engaged in, open'y and without glıame. I'tue vice of drtukennese does not exist amung them to any degree, wud it is unt a litule astonishing tatat the bat exannple set then sliould not have been more followed. 'They are extremely proud and resentful of any insult, to arenge which the whole tribe usually unites. As an histumee of this, we may cite the conduct of Ro-towatowa, whose lospitality to one of our par. ties has been recorded. At the invitation of the geatlemen who had been iudebted w him for attenthone, he visiter them nt Tibluey"s, when an unta. ward cireunstanee oceurred, which had well-nigh ended in an open affrunt. As ploy were seated in the porth of 'Tibbey's bouse, ore of Alieis' thouglithess visiters, by way of affording arsusement to the compaus, julacel off upout ho-towatowa a boyish triek, by burning him on the unge with a cignr. "This produced grent miger in tho eluef, who would havo at once punished the rudeness, but through the timely interferenee of the bystanders, the beenne nppeased, but required sime utonement for the insult offured hin; a half-dollar was given him, but he said he would aecept only half, as he did not want to be paid for it, but merely desired a tulieu 
that it bis been atoned fur. It the opinsion of all, he rose mueh aluwo tho silly trifler who had been the prerpetrator of the jolie.

Tho astives are peculiarly sensible to any insult of this kirsl. A short time before our arrival, a mirelievous white boy, stnying with our consul, had placed $\pi$ anull brass lictle on the bead of an old chief, which caused sone amosement to tho bysinnlers. The chitef at the time did not stow any signs of being offended. He had always been well dispussed and pencenble townrds the whites, and was hnown to lave a strong partiality towards the farrily. On going to tho pa, however, he mentioned tho circumatnnee tu lis tribe, which produced a great excitement among them. They sssembled and advanced in a body to the dwelling, to require satisfaction for the aftront offered, and althongh they were told and eouvinced it was done in playfulness, they roguired atonemeut; and this being refused, they touk all the eluthes that were hanging to dry on the lines, and every thing they could find about the memisus. They even took the shows and clothes off a sick boy, whowas lying in the veranda. Their rapacity was only stopnerl by the courage of the mistress of the liotsen, who, being unable tu check their proceding by remonstrnnces, threw a billet of wood at the prineipal clpief. This bold act astonished him, and from admirntion of Jier cournge cansed them at once to desist, saying she land a big licart, which is their figurntive term for a conrngeous persont. Insults given in this accidental way, lave been known to oceasion the most deadly fends. They lave, lowever, great command of temper when insulted. As an instance of this, an anecdute was related to me of some elinefs linving become offended at dhe Ephiseopal missionaries, in consequence of some transsction respecting lands, in which they coneeived thenselven wronged. "The offendet parties proeeedeal to Paluin in order to demand redress; but on their arrival there, the missionnieg wore alosent, and thlthough the whole property was at their mercy, there being no ots on the premises but females, thev did not harm my ching, and deolined to enter into any explasuntion untif they lad seen the missionaries. Taking their sents truietly at the gate, they awaited their return, which did not take plnce for some hours after, when they dernanded an explanation of the mingused wrong, and atonement for it; and being satisfied, they departed without any inolestruion or jnjury whatever. It will, is all probability, be said shat such pationce was in cortsequence of the narties complained of being missionaties; but tlat could not well haye been the ease, for they are by uo menns popular with the natives, and the renson is, that the missionaries show very little regard for their own countrymen, which, in the eyes of a Now Zenlamler, is a great erime.

From alt I could gather, I am inclined to believe then an observant people, and that they would become an industrious one, were it less easy to provide themselves with the necessaries of life. 'They show much energy of character in liwir war. tike justetsts, on which their whole minds seem yet to dwell. The syontaneuss production of their suil furvish them so easily with nll that is required for their food and clothing, that there is no Bufficiant ineitement to industry.

The New Zealanders are above the middle size, wel] formed, and athletic; they vary in colous from a chesnut to a light eopper; they have flack hair, very thiek and eurly, which many guffer to grow long, while ottrers crop it closen. 1 saw fow with whiskers, and their boards were light. The forehoud is high, sloping baekwards; the nose frequently aquiline and prominent; the eyes are black and wioveing, but rather small; the caltuoing gives a hardness of outline to the chiefs that is not so ubscrvable in the common people; they want, however, the softness of the rest of the Polynesian family, of which they are a part, not liaving the full muscles, or soft contour of face, which we had lyitherto observed among the proups we visited. They aro as indolent as the other sognate races, Lat nore enpalte of undergoing fatigue.

Tho followisg is one of their traditions respecting their origist. The first natives came frotn Hawniki, situated towards the east, in several canves, and tho mames of sone of the pritucipal mon were, Tnuepepeke, Truewitikn, Tnumekn, Kongokako, liopaia, Kornupoku: the casoes in which they came were calfed Kotalinui, Kotenrawa, liuliorouta, Talcitina. They bettled first at Kinwia, on the western const; then near Muketu, T'uranga, and Ahuriri, at the enst cape. 'The natives, it may be as well to remark, eny' that this story is all notwense, yet the similarity of the forcgoing names with those of the people of Saraii, in the Somon Group, is striking. This, conmected with tho shory, which we slaall herenfter quote, of the introduction of the kumarn its canoes, takcell together, would appens to aftord very strong renBon for the cunjecture that they were derived from the same source. In their native traditions there appears to tra some idea of a crealion, having a general resemblance to that of the other nations of Polynesia.

The trade in mative curiosities is not quite so great as it used to be, partieuialy in tutooed hends. So great at one time was the traftie in the latter article, between New Znalasd and Sychey, that in 1831, it was prolnibited by law, Is Governol Darling's administration of the colong, the chief Shougi is supposed to linve made large sums lig it, and there are some persons who, in jart, imfute lis wars to bis desire of gain; for havisug been in England, ho became acquanted with the value set upon them, and the dennad for them. It is getrerally thought that many of the hends thus solil have been prepared by the whitc runaway convicts, who have learnt the mode of doing this from the uatives. They are still to he olytnined, though great precaution is nsed in disposing of them. A misbiumnry brig, lying at the biny of Islaukls, had masy euriosities on boarl, in the possession of the steward; and after the buying of mate, $\& e_{+}$, had bren finished, to iuvited our ofticers to step down to his little store-ruan, under the foreenstle, where the had a curiosity which could not be brought out. After this myzhrious enuticiation, they followed him to the bottom of the laulder; lie then told them be was about to put his fato into tleir lands, bolieving that they were too muel men of homutr to betray him. He then proceeded to infurm them that he had two preserved hends of New Kealand chicfs, which he would sell for ten prounds. Ht could not venture, he snid, to proilute tliem on bonrd the brig, but if they would mppoiut a glace, he would bring them. The penalty for belling thesi was fifly guinens, and he conjured them to the 
most perfect secrecy. These proved to be buatj. fil rpeciness, nud now form a prart of our collections. So effectunlly has the fine prevented shis traffic, thant it is nu extremely ditticuit matter to chbain a liead; they aro as riro now as they lase betus common heretofore; and the lase place in which it could have been expected to find them, would hare heen on bontil a missionary vessel.

Tlie New Zealanders nre still enuriluals, alubough in the districts where the missionuries reside, thry have done much to put a stop to this practice. After the arrival of our gentlemen, an instnnce occurred of a elicf having killed $\mathrm{a}$ boy about fourteen years of age, as a medicine for his son, who wh sick; and as this preserjption did not effect n cure, u girl about the same age was to be served up, but the timely interference of tho missionaries pre. vented it.

'The present eomlition of the New Zenlanders is inferior to tlint of some of the other Polynesian mation. There is, as in nther flaces, little or no vecasion for labour; the infustry of a fow weeks is all that is neoded to supply them with food for the year; their tratlic in pigs and otlier supplizes to whalers and traders is quito sufficient to procure their necessiry supply of elothing. It is snid theis mornl condition lias nucl imperved of lato, and that they are becoming sensible of the advantages of cirilized tife. In the former direction there is stitl great romu for inprovemest, and the latter, I should think, as yet far above their ideas of honesty and of the obligations they owe to those about thesn. Perhaps those who have become somewhat attaclied to the Christinn religion may be a little improved, but the only instance that we ean recall to cur recollections is that of the chief Kio-towatowa. Tlie chiefs, however, in general slow a growing iliaposition to acquire conforts about their dwellings, and in cormparison with the other natives, nre ahmost aleastly in Itseir persons. Iudusiry is also making yrogress in the cultivation of their phutations. If I could believe it possible that the dwellings of the tower elasses of the peoplt had ever leen more tilthy, or their persons less eleanly, I would moro readily credit that sume injprusement hisl taken place. Numbers are said to be nble to read and writo their own Inagaage, lasing been tanglat by the missionatries, aud cluen lave afterwarls been known to take a pride in instrueting others, and to display a greal cargerness ill the neruisition of fut. ther lonowledge; but they are far, very far behind, in the rudiments of eluention, the natives of other groups where the missimarics have been estahilished, although, ns respects natural eapacity, they may probably runk highes'.

filsere is mush that is svorthy of notice is the miqsionsy operntions licke. They geem to lanve putsued is diflerent course from ihat followed $n t$ the vilier groups, and spjuenr to begin by teaching the useful arts, and setting su example of induatry. This has given rise to momeh remark. Tho missinil.

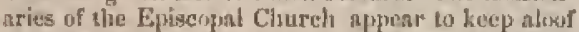
from the natives, whd an air of stiffiless tund pride, tubeciming a nissionary in meist miuls, seems to prevail. They lave a cliajel at Pahia nol owe at Tipoona, but very few persons attend; lleir native and Sunday schouls have also very few scluolars; aud they appear to he towg but litile ins suaking converta. Host of the naliwes, however, lanve morning and evening proyers, but their practives
Visit of Ponare.

and chameters slow any thing but a reform in theiv lives. Tho missionaries loold latge tracts of lamd, aul about the Iny of Ialnuds the Church mission (Episcojul) may be snid to lave the entire contur of the umperty. At the misuionary esta. blishnent as Pahin they have of pristing-press, and bave priated sume pasts of the Seripturus. 'They are now printing a Xew Zealaud gramnas. In the antive trablitiun, thure njpenrs th be sonse idea of a creation, laving a general resemblance to that of the other nations of the Palyncsinu groups. 'The first god was Maui, who fished up the earth out of the sun; afterwards a great Hoon comps, whicli cotered the lind, and then the waterg wore dried up by another god, whin set tire to the forest. From the sccounts mud olservations of all, it nay be safely nsserted that the נativen have no religion. Some few appratenty follow the fonn of it, and eall thenselves Irofessing Christians; but the majority or" preater number of the natives have none, either Christian or pagn. Whot usdergoing Iuition by the missionaries, they are said frequently to stop and ask for a present for having snid their bymn, and it is said, 1 know not with what truth, that the Catloolic missiomares liave been in the habit of giving them some snall token in the shape of crosses, which the uatives look upon as a sort of eomprensation.

At Jorornika, tha has been stated, there is a Roman Catholic chapal, and it is the residence now of the bislsop of the South Sea Cutbolie Mission. Some simgular aneclotes are related of the natives, of their first joining one denomination and then nnother, receiving little articles as prosents from cacls; indeed, it is said that there are few of them lut conceive they ought to tre paid for saying their proyers, or attendiug mass. At Hokianga there is also a Methudist or Weslegars mibsion, which is genernlly eursiderod the must nctive, aud is doing B great ileal of guod.

T'the Isative pas are generaliy scenes of revelry and debavehery. My crew soow gut tired of their visits to that of Fomne, aml cumplnined mucly of the dis-

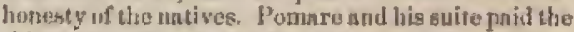
ship a visis a few dnys after our arrival, for the purpuso of ubtaining his quuta of prusents. I received fim and all his retinne with kindness, and made him several puesents, among whieh was $n$ fowling-piece; lut he had, in going round the ship, seen one of Hall's patent riftes, that loaterl at the breech; and nothing would satiofy him but to exehasge tlio gun I had given hin for tone of these. He surpsised sue by at once cumprehenting its facility of use, and jis exeellent matulncture. After a grest rical of inmortumity, I consented to the exchange, but foum that he was inclinod, after having onee succecled, to beg every thing that struck his fancy. In this he was followed by the otlier chicfs, arnong the rest by Hoin, lis lrother. To tho latter, I give an old cockod.lnt, which phessed him exceed. ingly, orud I was not a little smused to sec him wearing it, and fressed in a tight cont and vesh with hare legs, exhibiting one of the most ridiculous figures inngimble, although in lis swn opinion tho lueau ideal of degance. Ponmte went about the shij) berging for military eaps with gold banda, and was extremely importunnte until lie fotnd that nothing more cotald he obtained. I by no motus ndmined his appearame on this visil; for, although w) good jropoltions, tall, and well nowle, he is awk. 
ward and parrot-toed. His lieight and manner of walking make this defect more apparent, and ho waits itrat dignity which is sometimes scen in a savage of our country. The New Zenlanders, how. cver, atruck us as linving a closer resemblance to aur Nurtl Ameriean Indlans thats any others we had yet met with among the Palynesian nations. I whs surprised to see low little respect was paid to the orters of Pomate by his followers, and was tald that the is litclo anthority acknowledged by thene who are frec. His slaves and wives are those who nust austain the burdes of lis wrath; their lives are at lis dispossl, nnl with then his will is law; they seon, lumwover, ta tho treated kimdly. Pomare is said to be entirely turder the coutuol of his favourite wife, of whom 1 thavo heroto. fure spruken. Sho is a far more rexpectable person than her lusband, anv] was the most inteliggent. mative I mel with.

Wishing to sees their war-4lancus, I roquested Pomare to grutify us with an exhibition, which the cansented to do. 'The grvund ehosen was the hillfide of Mr. Clendon, our' ennenl's place, where between three and four hundred natives, with their wives asn ehiluren, assentsled, l'omare dividerl the men into three parties or equads, nond stationed thrse at wome distance from ench ather. Shartly after this was stume, I reciven a tuessage frum him, to say that they were all hungry, and wanted me to treat them to something to ent. This was refused antil they had finshed their dance, and much delny took plnce in cotusequence. Pomnre and his warriors were at firat immoreatle: but they in a short time determined they would wite on the litl-top, which was accordingly ordered, although I was told they were too hinigry to dance well. Here they arringed themselves in a solid enlunur, and began stanping, shouting, jumping, and sluaking their gans, clubs, and paudles in the air, with violent geaticulations, to a sort of susage time. A moro grotesque graup eannot well be imagined; dressed, hali-dressed, or entirnty naked. After much preliminary action, they nill set oft, with a frantic shout, nt hill speed in a war-eharge, which not. orily put to thight all the snimale that were fereling in the neightwourhood, lut startled she opectators. After runting about two handred and fifly yards, they fired their gune and lintled, with anutler shout. "They thun retumed in the same manner, nud stopped before uн, a truly sarage inultitude, wroughit uj to sppresst frenzy, nod extribiting all the mades practised of matmilig aw! killing their enemies, until they becane exlanusted, ant lay down on the ground like tired doge, fasit. ing for luresth. One of the elitels then took an wht bruken dragoon-8wnd, and began running to and fro before us, fouriahing it, atud at the same time delivering a speech at the top of his voice. The speech, as interpreted to me, ran thus: "You are weleome, you are our friends, and we are glad to see you;" freipuntly repented. "Aftar sliree or four liad strown otf in this way, they duternined they must have something to eat, saying lluat I lail promised them riee and sugar, anul they ouglit to linve it. Mr. Clendon, lowever, perminded them to give one of their feast-dances. The pertorthers consisted of sbout fifteen old, and as mauy young persons, whum they arranged in close corder. The young girls laid aside a part of theil dreas to exhibit heir forms to more advastige, and they commenced a kind of recitative, accompanied by III manner of gesticulations, with a sort of guttural liusk for a chorus. It was not necessary to understand thoir languago to comprebend their meaning, and it is umecessary to add, that their tastes did not appear very refined, bat were similar to what we have constuntly observed among the heathes na. tinns of Pulynesin. Their impatience nuw becnme ungoveruable, and hearing that the rice and sugar were being served out, they retreated precipitately down the hill, where they all set w most lieartily. with their wises and children, to devour the fool. This to me was the moat entertaining part of the exhibition. Thoy did not appesr selfislı tawurds each ather; the children were taken care of, atul al! semed to enjoy themselves, I received many thanks in passing among them, and their cousstenanes betakened contentment. Althugh they were clothed for the ocension in their best, thy exhibited but a squalid and dirty appearance, both in their dress and pursusa.

No native musie whs laeard hy any of our oflicers, and they seen to lave litsle or gone in their composition. In their atteuyts to sing tho Jytmas, chants, or old panlm-tunes, they entirely fitiled in produce any thing like a resemblance. "The pitch of their voices when speaking, is ligher than that of Eurupeane, (the French exeepted,) and that of the women was not a tone ubove, which gires additional comrseness in their character. I3oth sexes lave but little intonation in eonversation, and there nre un tones, heard which would indieate symipathy of feeling.

Chathin Island, which will probahly sonn be connected with the English culony of Now Zerand, is now considered as a nest of rugues, and soveml vessels have been robbed there. Iis inhabitants have a tradition that they are derived from New Zesland, whence their jurgenitors came about n cesstury since, having been driven of in their caunes by $n$ sturm, and that on landing they had chumged their langunge. "The chnnge consisted in revessiug the nrdinary construction of their phrnses, and the syllnhles of words, as, for Hare-mai, Mai. hore: and for Paika, Ka-pai. The untives of Chatlam Island are not tattnoed, do not weas cluthing, and are asid to be more intelligent than their progentors. They were eunquered a few years ago by a party of New Zealanders from l'ort Nieholson, who Jud toeen driven out by the liapiti trilies, under the celubrated Rnupuraka.

An examisation of the eliarts of the Bay of Islands was nuale, and sotwo additionul gounding added; the meridinn distunce, meastred by our chronometers from Sydney, gave the langitude of the point opposite Mr. Clendon's wharf, $174^{\circ} 7^{\prime} \mathrm{L}$. its latitude was found to be $35^{\circ} 17^{\prime} \mathrm{S}$. The dip and intensity observations were also mado lware, and will be found registered witl those results in the volume on fliysica.

Mr. Cmuthouy, who wrs left sick at Sydney, took jaksoge in a vessel to Talsiti, and passed through Conk's Straita, touching at seneral of its anchorages. Tu his ulsscryations I am indebted for the following infurmation relative to the southeru part of these islands.

The first poirt they made was the Sugar Lonf Istauls and Mount Egmont. The charts published by Clintz at Sydrey, give also the treiglit of this moustain ar furteren thousnond foet, but this whs 
beliered to be erroneous * for only a small portion of the top was coverod with anow. The day pre. Fious to their making land, they had been set to the northward by eurrent about iwenty miles in fourween hours.

They noxt prased through Cuok's Surails to Port Cooper, on the north ride of Banks' Peninsula, where they anchored. This Jnrhout is sheftured, exeept from tho northerly winds, and is much frequented by whalers, wlo renort thither to try out the whalo-blubler. The beach is is consequence Btrewn will the bones of these moneter. On going on shore, a party of thee untires and their wived were found in a state of wretelodness and degandation, - their only clothing being an old Whaket, disgustingly dirty, besmented with oil and with a rediliali eartli wlich lad been rubhed l'ou their bodies, and a coatre mat of Now Zealanil flax : they depended for subsistonce on a small potato-pateh, snil smoked fish; they lived in low luts formed of stakes, covered with mats, ant thatched with grass in the rudest mauner: their condition was but littie better than thint of the I'uegians. A fellow-passerger, who had seen the oldest man left of the tribe, stated that these were the remumits of a tribe that, but a dozen years before, could muster six hundred figlating men; they were all cut aff, ahout ten yesrs since, by tho nuted chief Robolua, residing near Couk's Straits. The old usn sppenred deeply sffected whitst dwelling on the liatory of lis people. The euphity of the whites in this ense, as in unsuy othera, had brought altont, or was the eatse of, this dendly attack ; the partieulars wetw ab fnllow.

'The master of an Euglisly ressel, by the name of Stewart, (the same person from whom the small southern island takes ita name,) was trading along the northern island, and foll in with the chidf, Roluolus, who was theu reditating an excursion to the south. Feeling confident that if he could come upon his enemies anawares their defeat was cortin, he offered Stewart to load bis vessel with Hax, if he wou!d transpurt him and his warriors to the place he wished tis attack. "I'he cuntract was readily entered into by Stowart, and the warriors were taken on lonard, suld landed on various parts of the coast, where llze inlanhitants, taken by surquise, were butehered without mercy. Not loss than fifteen lumired persons were eut off at this nad the adjoining harbour of Pott Levy, or Kickurnrapa. This Stewart is said to be still living on the northeru island of New Zenland.

Many specimens of shells were obtnined here, and a few presents, consiating of pipes and tobacco, weje נande to tlic remnant of this once powertul tribe. Two of their fullow-passengens intended to land here for the purpose of establishing them. selves, but the plince offired so little indicemert that they determined to proceed to Port Levy, a larger hirbaur to the eastward, where tho natives informed them that refreshments cotsld be trad its plenty. "The next day thoy asehored in it, and found it somewhat sibilar to Purt Conper, bue ature open. In the afternoon a party went un shore, and returned with aixty-four brace of

- I lave secr ather authoritiea, whlch kive it liebght at eiklit thousand feet. pigeona, and three black parrote. The former were in great aluundnuce and very large, sme of them weigluing twenty ounces: the culonr of their bncks was a dull slato, passing into bronze on the neck and wings; the hatd was very biack, the Irrenst white, deepresing into a reddish browa no the belty, the bill aud feet of a liriglit red. The parrots were quite black, ahout the size of a crow, and remarkalsle for two rose-coloured wattles at the lower mandible, like thio common fowl. 'They' also killed a species of piea, called cury by the thatives, about the size of a blackbiris ; it was of a dull Whack, with greenish reflectiung on the back, and on each side of the neck was a single white feather, which curled forward and upwnrd.

Here they becane nequaisted with Clsarley, or listrakitnurura, the clief proprictor of Port Cooper, Port Lory, and Pigeon Bny. Notwilhstanding these extensive possessions, meither himself nor his followers were better elad, housed, or supe. rior in any respect to those alrenly deecribet. As for Clariey himself, he apprared in a strijuer shirt, pea-jaclict, and trousers, the cast-oft elething of aome sailor. F'rom laving made the voynge to Syducy, Charley fancied he had seen the world, and took grent pains to ghnw his knowlouge and excite the selmination of those nhout hims. The captain of the vessel outained from litu alinut twenty bushels of potatoes, at the rate of a poutud of tobnceu for a hasket containing about a juek; lue besides offered to sell one-third of his domumions or estate for a new whale boat. Charley had on the usunl heitiki or neck ormament. The only nccount he could give of the loenlity of this green atone was, that it was found to the southward, in a large bed between two mountaine. Among ofluer things in Clarley"s nossession, was an enormous wax doll, dressed in the height of the Purisian fashion, which lad been presented to him lyy the ofheers of a Fretsch expedition that lind touched there, some time previously,-rather a drall occupant of a dirty New Zealanil hut.

$A$ bout Purt Levy the land rises nenrly twelve bundred feet high : the soil is every where exceedingly rieh, lout its value for agrieulusal purposes is diminished by its steepness ; it woult be impracticable to use eattle in plougling. The land in all parts of the peningula exhibited the same clraracter: $n$ suecession of steep hilts, intersucted by deep and nariow ravines, clothed with a thick forest, oxeept where they termiuate on the const, and form : tolerably level snot of a few acres in extent, uvialable for cultivation. The foreat consisted of an abundanee of fine timber, priuejpally the Kisuric pine, from one hondred and twenty to one hundred and thirty feet in height, and seven to eight feet in diameter. The forn was thick in patches, but in no greut raricty ; some scatent and purasitic planta were ruet with, and a greal number of flunishing ones observed; but Mr. Conthouy latving no means for the purjose, was not enaluled to secure any specimens. He remarked that the vegetation appeared much more luxurinat sud thersified than that of any country he had seel since leaving Brazil. The soil is a rich black leam, somposed of vegetable mould and decomposed basalt; the stmeture of the rucks decidedly columuas, exposing at tho summit of the hilis

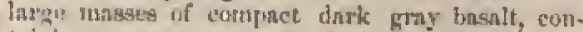
taining unnerons erystale of olivine, pyroxine, fund 
other voleanio minerab. At the base of the hilt, the roek was frequently a coarse cellular lava, nod the bevel was covired with boulders of all these varieties.

They next stonjed at Pigeon Bay, hut remained there orsly a few hours; the passeugers who were in searelj of a position ta establish themael ren, fur nd this quite as unfasourable as either of the two previous places,

In passing to the northward, towards Capo Campibell, the coast is higts and broken, with no level land in the ricinity of the Ben; but notwithstanding its abruptness, they found only fourteen fathoms of water nt a distanee of four miles from the shore, with sandy bottom. They had in fine siow of the snowy peals, enlled the "Lookers On," about twenty miles to the southward. These are suprosed ta be nenrly as high as Mount Egmont, and tower up in slintp peaks, covered with snow for fiften litsndted foet front the simmnit. The land along this part of the const is rety rugged, is npparently unsuited for any kind of cultivation, and lins IIn liarbous, Off Cape Camphell, a line of rncks was seen extending to the enstward aluot n league, which do not appenr on the charts; thoy are partly abovo and purtly below water.

They shen anchored in Cloudy Bsty, which, eontrary to the representatiou of the elingtre, proved a good anchorage. Tho wind here sweeps down the gullies in stroug squalls, but the water is at all lizues sanoth. Thero are five whaling cotablishmeuts in Clnurly Bny, eaclı employing from twenty to thirty hamds, chiefty New Zealauders. The kiul of whule taken here is urineipally the right whate, and tho cuantity of oil collected the provious year was four thousarm? five humined harrols, which wns sold on the sprot th Sydney dealers, at forty pounds the turi. In addition to this quantity, five thousand five hundred barrels were taken in the bny, by whalo-ships, prineipally Anerienus, from which some iden of its value to our eorutrynen una be formed. The establishnents on shote have connected with them stores fur supplyist ships, where articles uray bo loul at one tuudred [rer eent. advance os the Sydney prices; potrtoes ate suld ht thisty dullars the ton, aud [ork at twelve aul a latf cenls per pound; hutrds and planks may alsu be ubtained at fifty dollnws per thouand; woed and water are purobnsed of the statives for muskits, powiler and ball, blankets, pipes, and tobnevo. It is a two custonaly to make a present of Lwo muskets, or an equivalent to Robolun, the slifef, for harbour dues $A \mathrm{Mr}$, Willinm, who was oue of the esta. blishmest, furushed the above information.

Two Aneriesu whalerg were found here. A number of striefs eame off to the vessel, in the ecurse of the day; they were fleree-lnoking savages, with coarae imatted luair, tattooed visages, ats] borlies lsesueared with rets earth and oil; some of theus were clad in cosrse mats, others in Llan. kets, aud all excecilisugly fillix; mnst of them had the freitiki ornanent about their necks, nnl some in their ans, which were alan decomted with red arrd white fosthus, and the hules pistred in them wero also unale the l'eceptncle of their pipes; atherg hat uneklinees sf human tones, polished,-trophice of the enemies they losd slain.

I'heir manners were uneonth, exhibiting none of that amenity so remartialle in the natives of the utlper Pulynesinn grumps; yet thege way a rude dignity about them, that evineed a consciousness of their rank and consequence. Three or four worsen came on bonrd, lut not one of them could be called good-looking, and they appeared to care less about their appestance thas the men.

The noted Hobulua made his appearance at the lreakfast-table, unannounced and uninvited; he most unceremoniously took his seat next the captain, remarking, "Me, Robolua 1" In person, he is above the nuddle stnture, powerfully buit, and rnther ill-featured. The usual exmession of lis countenance is not bad, but when evraged, it is truly fiendish, stu his small deen-sunk eyes, which betoken cumuing, gleam witlı the feroeity of a tiger. His head is of conornous size, covered witl ling matted lair, sprinkled witl gray; his eycbrows were long and shagry; he land a has expression of the month, resulting from the leas of his teeth, a circumstance of rare necurtence among these natives. He seemed in feeble health, and his figure was slightly bent by age; he wore a filthy blanket., and over it nn old-fashioned plaid eloak, the colonss of which, like those of his under garments, were no longer distinguishable. All the chicfs wore their dress so as ti) cover their left arm, and lesve the right bnro, which Mr. Willinns said was for the jurpose of eoncealing their menta, or stone clearer, which is constnntly suspended to the left wrist, ready, at a moment's warning, for use, and which shey ulke particular catre never to expose to view. With Rotolua was his principal warrior, Orangadieti, a fine specimen of a savnge chicftain, about fifty years of age, with a noble thougli fiereo enst of countenance, nearly six amil a balf feet in height, nud as straight ns an arrow; his loug hair was tied up behinl, a la Grecture, the knot being secured by two hong black fonthers stuck throngh it; altogether he lad more the appearance of a clisef than Robolua; the latter, from the aceount Mr. Wil. liams gave of lim, owes his ascendancy more to lis powers of persunkion in conneil, and his talenth for strategy in their system of warfure, than to his warlito neliesements; and he actdom risk his person in battle. The eliefs, in their ligurative language, bny, "The hreath of Robulua can turz them roum and round, sut his tongue is more powerful than any of their westons." Ho wa uriginally a petty mugatira (latiboliter). Of late years lis fower lad very much declinel: five or kix years ngo be could number more than kix thousand wartiogr, Jut now he has not over funr fundred, His rapid rise is imputed to the intro. duetion of fire-armu, for be was long the only chicef who prosessed rily number of thera; and the deeny of his power is atcributed to the nequisition of this weaţou ly others, and the inactivity arising from his advancing nge. Several of the natives who were mot liore could reasl, and a portion of the T'estanent was seen in their prossession; two women in partieulas were desijous of showing thoir ateeomplistumests, sud rumarked that the missionary religien was tot madv fur New Zealnnders; it was too good for them. Drtukenzess and dishonesty prevall, by their own cutfession, among the white men, who are at times ontirely beyond the eontrot of their masters; they all have nalive wires, who are taken and disearded at plensure.

The whalers stated that the prevailing winds at Clondy Hay in summer and the beginning of nutumn, from November to Marel, are from the 
south-east snil nortl-west, which usually suceced each other st shout intervaly; during the rest of thre sea, winds from south mound to west are more frequent, and tring witls them wet weather.

The generwl information which we obtained, and whiel has not been iseluded in tho preceding por. tions of the ehnpter, is as follows:

The climate of New Zealand is extremely elungeable; but although it may bo considered as the cause of many disenses among the natives, it ia, perlaps, tho hest suited to a European coustitrtion of any in tho South Sess, A lagge guantity of rain falle during the year, but I was urmble to obtais sny record of its exact anuunt. The tem. perature at liororarika, during the months of February and March, varied frum $53^{\circ}$ to $78^{\circ}$, and the mean was $64.2^{\circ}$. In the sum the thermaneter ruse as lingts at $110^{\circ}$. The prineipal prevaling wiuds are fron the southeenst and west; the former are irequetuly in squalls, and attended with miz: May and $J$ ture are the rainy ununtlis.

Wartn days are often sucecerted by cold nights, which give rise to pectoral diresses aumusio the natives, many of whont are affected by phthisis, or swept off by rapid consumptions. They nre also liable to rheumatism and pleurisy. Europenn and American residente, who enjoy hetter food and chothing, and inhalit more comfortable dwellings, ure exempt from these complaints. Mcasles, honping-cough, and other epidemics, lave beeu introduced from foreign vesacls. While we lay at the liny of Islands, the isfluenza prevailed on shore sud was communicaled to our crew. The reneteal disease, propagated by their licentious habits of life, and unchecked by melicine, is rapidly reducing the numbers of the natives.

l'the greater part of the soil of the portion of New Zenlaud wbieh fell under our observation is ton aterile to lie profitahly enspluyed in agriculture. It consists, in goneral, of an obdumte pellow loam, eapable of berring little clse, after it is clened of trees and lorushworkl, than the forn (pteris esculenta). Where the soil is volcanic, lsowever, it is comparatively fertile; but this deseription of givound js mate.

Whent and other phirs are mitied, and the froits and veyebaliles of tentperate climates sucteed well. The bills are almust bare of vegetation; for after the ground is eleared, the benyy falls of rains swcep the ousil from thum into the valleys, and wear the hill-sides into gullies. In this manner patelies of gond land are formed in them, which, Lowever, rmely exced fifteen or twenty aeres in extent, The oni $y$ enntinum level tatet of as muci, as a hunded acres, is on the farm of Mr. Clendour (n) Masawa Bay. Tho sterilsty of the soil is not the only obstacle the ngrieulturist las to conterd with. The fern, of which wo hnve spoken, springs up the moment the forwst is ronuvel, nal covers the land witl a dense vegetration. PJoughing is Int auflicient to extippate it, for it will spring again frums the severed rowts, ani] clonke the grain. It cat only bo completely eradicated by removing it ly land and bursing it. The ashes are then sireal upon the ground, and are found to be a grood manure. In this manmes the sons of $\mathrm{Mr}$. Willams, the missionary at Pahin, are enden woulitag to bring a farm shoy posacss into eutivatinu. Shtives are enployed in the labour, and they linve in this wny cleared several acres.
The feth from its size and strongth, is smpposed to indiente a fertile soil ; but chis is not the fact, for I have seen nenrly a thonsand neres it a body covered with a gruwh of it six feet in leight, whero tho groumd was deejned fif for no jurpose but to furnishl brick-clay. So densely do the ferns grow, that it is impossitule to furce a way through tivem, and the only mode of traversing the cuuntry where they aboutud is by following the mative patlys; lliese pursue the high grumd ant ridges, and lave brencles which leud to the neighbouring enltivated spots. 'J'he uoment the culture of the Jnnd is neglected, the fern ngain males its npmenrance.

The clayoy soils afford orly a seanty growtl of grass, which is senreety fit fur pasture, and indeed there nppear to be so ustive grasses. In the nnre fertile soils, red claver, accordiag to Mr. Brotehen. ridge, does well; and he belioves that white clover would succeed on the hills, which are now hare. The climate is favoumble to the growth of the forejgn gruses.

After the ferz has been lumpit mid the nalee sprend, a crop of whent is raised, and the inut is laid down in gross. To give an idea of the produce of land nenr the Hay of Islands, we may eite tho instance of Captain Wright's farm, which is eligibly situated, atud is consulered as possessing a fertilo soil. He had twonty neres in whest, whrse average prosluet was only fourteen buslucls per เงcเv.

Among the foreign fruits which lave becn introdueed, are appiles, penches, and grapes. The latte grow best in the voleanic soils, but the elininte is consiflered to be too moist to permit them to attain perfection. The peaclies are fine, but the propensity of the ratives to plack them before they are ripe preventa them from attaining their full Hasour. Cape gnoseberries are plestiful, lut the comsnuн deacription of that fruit, and the currant, lanve not been introduced. Late writers have given marvellous accounts of the emwth of the fruit-1 rees of temperate climates, jn New Zenlaud; lut these may be set down as exaggenstion calculated to mislead, and intended to subservo npeculation. The suecess of Capitrin Wright, however, in mising iruit anil vegetables, has been great.

Atmong the native regetsbles is the sweet-protatn, which they eall kumara: it is plentiful.

'The mikgumaries stated that the natives lonse a remurkuble tralition in relation to this ront; numely; that it whs firgt brouglit to the islaud in canoes of a differeul construction frum their own, and corsposed of pieces of woud sewed together.

Cook left the common potato, which has been entivated ever since his vistt, and is now plentiful.

The mative liemp (phormium tenax) is a most useful plant; it grows in large quantities, and is applied by them to inary purposes, tresides being a priteipal article of loreign turte. It is an inlportsut naterial in tlie construction of their honseg, for which pur|mse it is mule into cords, that are also "mployed for other more cortumon this. It is manufactured into fine fibling-fines, which aro mथยो prized at Sydney for their strengtl and beauty.

The manufacture of the hemp is altugether performerl by the woman, who cut it, and ufter it las been itriod a litte, divide it into strips of alout an 
inch in width. The outer green fibres nro thes semped off with a piece of glass, or a slarp shell. The inner fibres boing thus exposed aro ensity separated, and the grestent enre is taken to keep all the tibres as struight ar possible, botl in this and the following operations, To this precaution the great strugth of the cordage tho natives make of it, is owing. Afier the fibres aro eeparnted, they are washed, rubbed, nnd hid is the sun to bleach.

'I'The vegetation of New Zenland is of $\mathrm{n}$ freshor and deeper green than that of New Holland, nud has sonve resemblanee to titat of Terra del Fuego. Aceording to the missionaries, the ridges, nud indeed the greater part of the northers ishand, nre destitute of trees? and the wooth, which are cotsfised to the valleys, are for the most jart in detached sjots. The western part of this islatid eontains more actual forests than the eastem.

It was remarked by cur botmists that trees of geners which is other countries grow in the more barren soils, nre found in New Zenland in those which are fertile. This is in partieulnt the cuse with the pirso tribe. It alsa appented to slyem, from the prosition of isolated trees, nnd the quan. tity of Kaurie-gum fousd imbedded in tho soit, that forests had formerly been more generalty apread aver the face of the country, than they are at present.

The gum which has jugt been fpoken of is abilt produeed by the Kutrio pine, which is the finese of the timber-trees of New Zealaud. The grentest portion of that which is shipped from the island is dog from the ground. Small quantities of the Intter deseription have beon purchased by orx countrymen, and shipped to the United States, where it was manufactured into a vamish. This was of a gond guality, and was afterwards sent ty New South Wales and New Zualnnd, whore it is sold for cojal ratuisl.

The Jiantie and Finikotia pines yield spars whicht for large ahipg are not entpassed by any in the world. The trees are geuerally large, and nre easily brought to tho const by rue ans of the numerous streans.

The natives uge these trees in building their eanoes, which are dug out of a single log. They have no out-rigger, and are in consequence liable th accident from want of stability. Great ingeauity is stown in repairing them. We saw a warcanoe which was sufliciently large to be manued by lifty men; it had a prow extended tor feet upwards, which was elaborately carved and decked with tufes of feathers. The paddleg hare spoonshaped blades, by whieh the canoes aro propelled with grent swiftress.

No nntive yuadrupeds were found wild in Now Zealand. Cnttle lane been istroduced, aud thrive. Those which are inported require to the fed, but those raised in the country cas provide fur thenselves, and grow fat by browsing.

Among tho birda nre the native aiglitingale and the tui, also knowu tunder the sobriquet of the parson-hird. The latter is a great favourite with the nutives.

I saw it only in a cage, and its note did not strike me at pleasing, but sezernl of our genticmen saw and heard it in the woods; they deseribo its note ns rather louter thnn that of the bird called by the Samonns " poe," mud it is at times Baid to utter a cry resenbling the conud of a trumpet.

The domestic fowl does not appear to have been known before alis island was visited by white men.

I ronde inquiries in rolation to the mode in whieh birds wero taken in this eanntry before the introduction of fire-nYms, but contd rot obtain any entisfuctory information. I whs inclined to thiris that the natives liad no methoul of doing this in former times.

'The grent staple articles of trade are flax, spars, and whent; potatoes and gum are also exported; but the whale-fistery is of more value at present to foreigmers than ali the prouluetions of the soil. This is esrrited on from the shores by parties of Now Zealandors and foreigners; but liney aro rapidly destroying this source of wealth, for, as hus beets stated, their eagerness for presort gain leads them to destroy the asimals whether old or young, willout discrinination.

The whaling establishments of British subjects on the const are numerous, and the nost ilisgraceful acts are perpetrated by their occupanta and by the crewt of the whale-stips, who not only use violeuce against the natives, but agningt encli other. A* New Zealand is in the immediate vicinity of the whaling-ground, it is a desinule rendezvons for our whislers; and the Amerienn whaling flect, actiredy employed on the coast in the apring of $18-40$, imountel to one hundred sail.

Many spars nte now exported to Eingland, where, however, the emalles sticks are not as much esteemed in proportion ns the larger ones. Several govornment ressel lave reently obtained spars for the royal navy at the trifling cost of a few blankets and maskets. The latter, in particular, are a great inducement to the clivefs, who are willing to devote mucl labour for tho purpose of aequiring tho means of rentering thembelves powerful. Besides gans and binkets, gunpowder, lend, coarse blue and white cottona, whiskvy, rice, sugar, and molisses are the articles ranst if request. These now bring enormaus prices, in consequence of the demand cansed by the number of immigrants; but the effect of these prices is to render labour proportionsbly dear. 


\section{CHAPTER XXI.}

\section{TONGATABOO.}

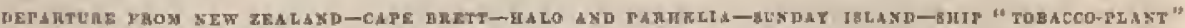

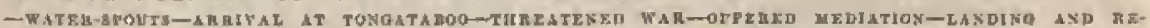

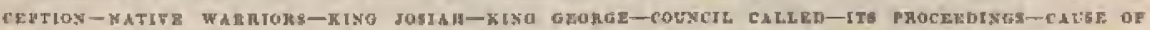

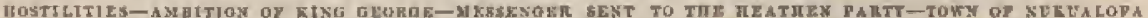

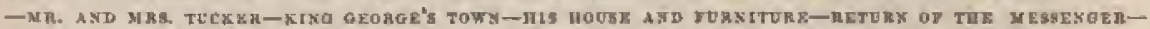

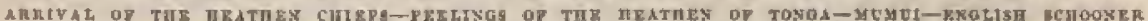

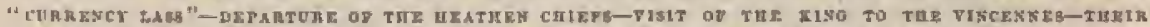

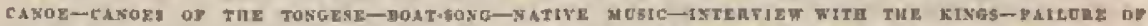

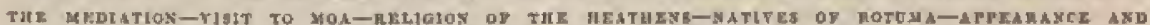

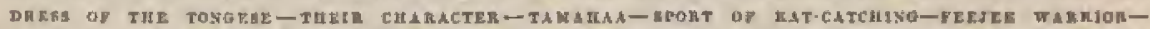

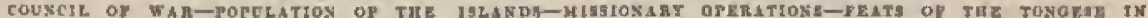

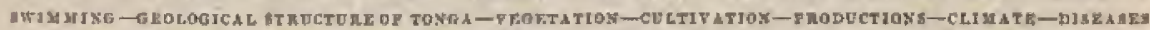

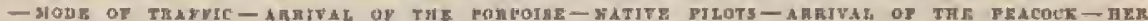

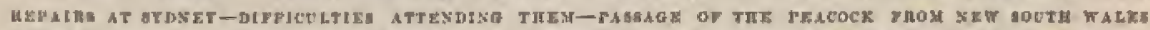

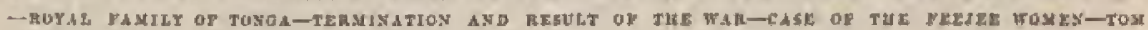

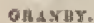

Haviva completed such repairs as were necessary, the Vineenaes, with the Porpoise nnd Flying-Fish in conpany, sailed from the Bay of Isinds on tho Gth April, 1840, for Tungatalow. I believe that no person in the squalron felt nny regret at lenving New Zealand, for there swas a want of all menus of amusement, as well na of nny ubjects in whose observation we were interested.

We had at first a light breeze from the northward and westward, followed by a ealm, alter which the wind ame round to she southward. The weather was remarkably pleasnut.

Cape Bett, suceording to our observations, is croneously placed in the clurets, which make it forty-two ninules ton far to the eastward, We experienced after miling a current of eight mites in the northward in twenty-four hours. On the 8th April, the current set nurth-ensl-by-north, half a mile per hout.

On the sch, the sen was very smooth, and the dny calm ; and wo not only triod the currest, but the distance lelow the surface at which a white object was visible. The sun's raltitudo was obBerved at the sume time.

I was desirous to pass over the positions of some of the doubtful slinals, and to werify the longitude assigned to Sunday Island (the Itanul of D'Pintrecastenux). Had this not been my design, I slrould lave preferred pursuing a more eastern route than I did, which I an satisfiel would have shortened our passage to Tongatzboo. I do not conceise, however, that there is any difticuly in reaching that island, or any risk of falling to the leewaril of it at this season of the year, for westerly winds prevail in ils neighbour'lood. We had a light witud from north-east to castnorth+east.

On the IIIn April, we lrad reached latitude $29^{\circ}$ S., longituke $178^{\circ} \mathrm{W}$, and had on that day a most benutiful halo. It was formed at firsi of the Begrrents of two great cireles, the ehords of which subtended an angle of $54^{\circ}$. These gradually ttrited, and formul a circle around the sun, whose diametor messurecl $42^{\circ}$.
The parbelia were very distinct, and hnd spurs on their outer sides; two points in the vertical plane interseeting the sun, weru very bright, but did not form partielia; tho sum's allitude was $27^{\circ}$ $20^{\prime}$ : no decided clouds were to be seen, but the whole aky was lanzy, and the wind fresh from the north-enst. About two hours after this phenonenon, muel lightuing oceurred, with torrents of rain, but no thunder, and this continued throughout the night. The barometer stood at 2909 in. ; thermometer $71^{\circ} 75$. The wenther by six in the morning las cleared, and we liad the wind light from the westward. The clouls were seen fying mpidly from the north-east.

On the 13th the wind still continued from the southward and westward, but light elouds were stiil flying from east-rorth-enst, and the sen was rough and uncomfortable. We lasd passed over the place nasigned to the Rosettr Shoal, and I believe I may safely state it does not exist in that plice.

On the 14 th we mado Sunday Intand, the Rrou! of D'Entrecasteaux. It is high and rugged, and had erery appenrnice of being valeanie; the rocks rise like brsaltic columns. The islund affords no anchorage, and the wind being light, I was not able to get near enough to send a boat to land nud procure specimens; the $8 \mathrm{e} a$, also, was wery rutagh. Sunday lsland, recording to our observations, lies in latitud $20^{\circ} 12^{\circ} \mathrm{S}_{\text {, }}$ and longitudo $17 \mathrm{f}^{\circ}$ 15 W., which agrees well with its establisher position; it is snid to be fnhabited by a few white men, and some of the ofticers reported that they saw smoke.

On the lsth, we fell in with the 'Tulaceo Plant, American whaler, Swain, master, that left the Uniterl States about the mane time we did. She lind not been rery anceeseful. A singular circumstance is cotumected with this ellip during ber cruise : H.B.M. ship Herald, Captain Nias, whom we met in Sydney, picked up, several montlss since, off Java Hend, four hundred miles frum Inond, th whale-boat, with six men, who reported to Captain Nias that they lad left the elip Tobaceo l'bant, 
which Jas been burut at sea, They were taken on board the Herald, most kinilly treated, thought and hnded in New South Wales. The crow of the Hernld presented then with 100\%, and Coplain Nias allowed them to sell their boat; besides all this, they were amply supplied with elothes. This report of the loss of the ship seemed julaced beyond contradiction, and to meet her afterwards caused us great surprise. $A$ day or two after we land lost sight of the slip, a man whom I has taken on broard as a distresset seamon, confessed that he had deserted from lier, and also informed us sliat the six men had left the ship at sen in an open buat, in consequence of the ill treatment they had received from the cantain, and the short allowance of provisions on bonrd. The manner in which they enrriel ou their deceytion upon Captain Nias, his ofticers, and erew, wns remarkable, and shows how much commiseration ald elases of men feel for those in distress, and how unwilling they are to scrutinizo a tale of sorrow, when they have the apprent eridence before them of its trutl. These men were upwards of twenty days on bond the Herald, and yet I was told that thoy were throughout consistent in their account of the alleged misfortune, and appareatly showed much proper feeling for tho fate that lad befallen their companjous.

Until the 19th wo had light breezes; in the after. noon of this day we saw the appearance of a waterspout, forming about lalf a mile from the ship; the water was seen flying up, as if from a circlo of fifty feet in diameter, throwing off jets from the circumfarence of the cirele, not unlike a willow basket in shape, and having a circular notion from riglst to left; there was a heavy blinck cloud over it, but no descending tube; nnd it did not nppeser to lave my progressive motion. Desirous of getting near, 1 kept the slsip off for it, but we had litule wind; the cloud dispersed, and the whole was dissipated before we got near to it. The electrometer showed no cluage.

The next day, the 20 th of $A$ pril, in latitude $24^{\circ}$ $26^{\prime} \mathrm{S}$, Jongitude $174^{\circ} 47^{\prime} 30^{\prime \prime} \mathrm{W}$, we took the trades from about east: passed over the position assigued to the island of Vasquer, but saw nolling of it. Some nppearance of land existing to the enstward, the Porpoise was despatclued to look for it.

Ou the 22ud, we made the island of Eoon, and thut of Tongataboo, The wind the whole day wus very variable, with squalls and heavy min; and it beilig too late to run through the foug earal that lesile in the harbour, I deemed it most prudent to haul off for the nights. A southerly eurrent drove us lurther off than I anticipated, fand we did not suecerd the next day in regainiag our position; we experiunced much lightning and rain, with the wind strong from the enstward. On the $24 t h$, at $1 \mathrm{l}, \mathrm{M} .$, we rounded the eastern end of Tongatnboo, and stool down dirough the $A$ strolatio canal. This is a dangerous rassage, and ought not to be attempted when the wind is sariahle or light; it is nine miles in length, and unswes between iwo corrl reefs, where there is no anchornge; it was at the westert end of it that tho Astrolabe was near being wrecked in 1827 . It is from thalf to one milo wide, eradually narrowing, until the small istand of Mahoga appears to elose the passage. When nearly up to this island, the pasange takes a stiort and nartow turn to the nortloward; in turuing round into this pass, I was awaro of a coral patcli, laid down by the Astrulabe, and liauled up to awoid it, by pasking to the enstward ; but the danger was nearer the reef than laid dowu, art the sun's glare being strong, we were unable to seo it, and ran directly upon it. For a moment the slip'y way was stopped, but the obatacle broke under her, nul we proeceled on to the anchorige off Nukuatofa, the residence of King Joginh, alins Tubets. In our survey of the above pnssage, no sloonl was found in the place where the ship had struck, and we had the satisfaction of knowing that we had destroyed it without isjury to the vesiel.

Tho tender had arrived before us, and I found also here the British vessel Currency Latss, This harbour, when it is reactied, is a safe one, nud is well protected by the reefs.

Nukualofa is a station of the Wesleyan Mission, the Jiends of which, Messs. Theker nnd Rabone, paid me a visit, and from them I learnt that the Christian and Devil'y parties were on the point of hostilities; that Tanfanhan or ling George, of Varno, had arrived with eight hundred warriors, for the purpose of carrying on the war, and putting an end to it.

The islnnds of Tongataboo and Eoon are the two southern islands of the Hapai Group (the Friendly lsles of Cook); the foriner in a low, level island, while that of Eoos is high. T'le highest mat of Tongataboo is only sixty feet above the level of the Bea, while that of Eooa rises about six liundred feet; the strait between them is eight miles wide. Tonga is extremely fruitful, and covered with foliage, and contains ten thousand inliabitants; while that of Eoon is roeky and barren, and contains only two lsundred irlubitutsts.

Helieving that I might exert nn influence to reconeile the parties, and through my ingtrumenthlity restore the blessings of pence, I proffered ny services to that effect, which were warnuly ac. cepted by the Reverend Mr. Tucker. I therefore sent a message to the chiefs of the Christian party, to meet me in fono in the morning, and late at night received a notice that they would be prepared to receive me. On the morning of the 24th, I landed, with all the officers that could be spared. from other duties; we werc received on the besch by Mr. Tueker, and were at once surrounded by a large number of natives. It was impossille not to be struck with the great difference luetween these people and those we had just left in New Zealand; nothing of the morose and sarage appearance su remarkable there, was seen; here all was cheer. fulness and gaiety; all appenred well-fed and wellformed, with fill faces and nuscles. The number of children particularly sttracted our notice, in striking contrust to the $\mathrm{New}$ Zealand groujs, where few but men were seen. In a few minute we heard the native drum, enlliug the warrioss and people together; we went a short distance along tho beach, passed into the fortitication, and up a gentle acelivity, on the top of which is now the Mission church, and the trouse of King Tubou. On our way up we passed by the drum, or as it is here called, tok; which is a large hollow log, not unlike a pig-trotglı, made of hard, sonornus wood; it is struck with a maliet, shaped somestiat like that used by stone-cutters; it gives a sound not $\times 2$ 
mulike a distant gong, and it is eaid may be lyerrd frum sevith to ten miles.

Frons the top of this litl (sixty feet high, and the anost elevated point on the island) there is au extensive view, nver the islard on whe hand, and on the other orer the encireling reefs nnt the deep bluosea. I felf fawilim with the secteg nround IIIe, from the description I had often rend is Mariner's 'langn I talands, ant fuet grent pleasure in euntirming the admirubles and aceurate descriptian there gives, The names we heard were familial to us, mul we found, through the natives and misaionariog, that many of the descendunts of the persosss of whom lie spenks were nresent.

I was willin the fortification of Nukualof the sceste of muly of the exploits which. Mariner relates. I was now surroumled by lnige numbers of warriurs, all grotesquely dressed and ready for the ligglıt, will clubs, speris, and muskets. In addition to the usual tapa arosnd their waist, they had Yuthuw and straw-coloured ribands, mado of the parianms-kenves, tied nround their urms above the elbows, on their legs ature anil helow the knees, ant on their botica: some latd them tied and gathered ap in knots; oshues wore them as searfs - Hamm an the riglit Bhoulder, sume an tho left, stud whers on buth slwouldert. Sorue of these sashes were beatifuly white, about three inches wide, and ruite plinble. Many of them laad fanciful lead-dresses, some with satural atul athery with artifieial tlowers nver their turbang (endlet sala); aril nearly all hail their fuces painted in tho most arnlesque snnnner, with red, yeilow, white, aud Ifack strigrem, eroksing the face in all direetionsa, Sotne were scen with a jet black face and? vermilion

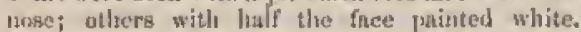
Whon a looly of some eight lutudred of tlese darts. looking, well-formed warriols, nll eager for the firlit, and going to and fro to join their several companics, is meen, it is hardly possible to describe the elleet. Tha secre whs juyst in the extreme, and entirely urexpected, for I considersd taat wo were on is inission of pence. A few mitutes' conversation with Mr. 'Tucher accounted for it all, I'the evening hefore, the "Dovil's" party, it appreared, bud atticked their yarr-grounds; some of ine ustives were wounded on louth sideg; anit Frent fear had boen entertained that they would finve fuilowest up their attack even to the town of Nukualofn; most of the warriorg bat, therefore, been under arines the whole jight.

We were led through all this confusion to the small hut of "Tubou og Ǩing Josials: heve we were prosenter to lis majesty, wish whom I sliook hands. Ho was gitting on n mat winding a ball of senuit, whiel 1 le hal been making, and at which necupatiun he continued for the most part of the tirae. He has the appearmee of boing about sixty yoars ald; his figure is tall, though mach bent

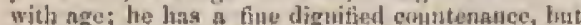
is represented as a vely inbecile old man, fit for nay thisg but to rule; as domestic and affortionate in his farnily, esring little about the aflairs of guverutment, provided he eall bave his chiddrers atal gmurlohitdren asound bim to play with, in which anugenest twe prasses the most of lis time. Sisntw were provided for 18 from the minsionnaties" Pruses, and wert plncill in the hat, whose siles lwing open, gave 14 a fall viow of nll that sha passing without. hing Jomial, with his nenromt rolatives and the highest chiefs, about ten in number, oectpicd the hut, together with tho missionarich ind anmelves. Tho warrjors were grouped almut in titute squade, in their various grotesque scentrutreuts.

Whet all was apparently ready, wo whited somo fow uninutes for King George. When he made his appenrance, I could not but admire him ; the is upwards of Bix foet in height, extremely welt pitoportioned, and uthletic; lis timbs are ronnded and fuil; his festures regular and snanly, with a five open cuntume and actsible fnce; ull which wore seen to the greatest advantage, The oniy covering ho wore was a large white tuy or gnato, girded in loose folds around his waist, and hanring to the ground, leaving his arnis and chest quite bate. He at once altracted all eyes; for, ot approaching, every moventent slowed lie was in the habit of commanding those about hin. Witly unnssuming dignity, he quitly took his seat without the hut, and as if rather prepared to be $n$ listener thrrs one who why to meet us in conneil. This was afterwards explained to me by Mr. T'ucker, who stated that King George is tat yet cunsidered a native chief of Touga, and, notwithstanding lis actual power here and at Vavan, is obliged to take his seat amoug the cunmon penple. On observing lis bituntion, and knowing him to bo the ruling thief do fitcto, 1 immediately requested that he might be admitterd to the hut; and he was neeord. ingly rerituested to enter, which lic did, and seated himself ut a respectul distanee from the king, to whom he slowed grent and murked respect.

Mr. Rabone, the Assiatant missionary, was the interpipter, and the conversation or taik that passed between us wag in an undertone, The peculiarity of figurative spoech, common to all the ishaniers, whs very marked in Fing George, afforling $n$ eosdensed, or mother concise node of expressint, that is indientive of seuse and comprehension. They lyegan by assuring me of the pleasure it gave then to see me, when they were just about going to war, and wero in mach trubblo. 1 jiroprosed nysself as a mediator between the parties, and that each proty should appoint the chiefs, to mect under my direction and protection, in order to srrango nil the difficulties between them ; that these strould meut on neutral ground, on the island of Pangai-Muntu, about laal-way between the hosthen fortress of Mon and Nukualofa. I also offired to seut offieers or go myself to the houthen fortress, to make a similar request of them. W'ith all this they aptreared plensed, but in answer to it ling George simply nsked, "Will thoy ever return ?" After a litilo conrersation, they assented to my propusitions, I then took tho oecasion to rotuke them mildly for alluwing ulyeir followers to assemble in their war-dresaes, and with so many warlike preparations on such an ocension, telling them that I thought it indieated any thing but the peacefal dispositiun, in the belief of the existence of which I had called the neeting. The affair concluded by their lenving the whole matter to my liseretion, and with an assurance thant they woth ecuform to roy decision. During the half hour Bpent in this exnference, the whole multitude outsidu seemerl as though they ware trutsfixed to the spot, awaiting in anxious expectation the result, A s king Josinh (who it seems is exccedingly prone in sonnolency) was now seen to be nodding, 1 
judged it time to move an adjoutnment, and the council was broken up.

All now lhecame bustle and apparent confusion every one was in motion; the whole village, isseluring the wonen and chitdren, earrying baskets, looem, sticks, $\delta \mathrm{c}_{\mathrm{t},}$ besides their arms nnd war instruments: all ware going to the ynm-grounds, expecting sn engagresnent with the hestlien. It lnd $n$ fine effert to seo thern passing quickly through the luenutiful cocoa+zut groves, in compmines of fifteen to twenty, in their martial costtmes, printed, belted, and turbaned, - some of the finest specimens of tho human mee that can well be imagined, aurpassing in symmetry and grace those of all the other groups we had visited. The fashion of their warike dress is elanged for every battle, in order to act as a disgruise, and prevent them from being known to the chemy, but yet they are readily distinguished by their own party.

Anxims to know the netinal eause of the war, I made every inquiry that was in my power, and satisfied myself that it was in a great tneasure $n$ religious eontest, growing nut of the zenl the missionaries have to propang te the Gospel, and convert the heathen. With this is eambined the desire of hing Gortge, or Taufalan, who is already master of Hıpai and Vavao, to proseses himself of all the islands of the group. About three yenrs prior to our visit, a war hal broken out is Tonga of a similar eharacter, and the Cliristian party being lard [nessed, pent to ask the sid of liing George, who esmo, relieved them, and thefented their enemies, Mr. Rabone, the mistionary above spuken of, was residing at Hihifo, a town or fortress on the west end of the island, where he convertud a fow of the natives, who were rerpuired to remove from the district by the ata, which is the title the governor of the district bears. They refusert, as they natserted their fauds ware all there, nod they wished to remain. About the sane time, Mr. Rabone thought proper to shant one of theil sacred pigeons, whivh incensed the poople against lim ; for if a native liad committed the sane act, Je wonld linve been clubbet, and as he himself conressed he knew their superstitioth fecling for this bird. Mr. Rnbarse, is eonsequenee of this enecurrence, was obliged to remore to Sulusiofia. Tho heathen also complained that their temples were desecrated, their enstons broken in upon, and their pleasure destroyed by the Christiat party, who endersouret to interdict their com. forts, and force laws upon then in the shape of trbous thrisuglt their king; that they even prolibited the smoking of tobacen, an innocent pleasnce, whiclo the natives lave long been meustamed to, and tnke great alelight in, but whieh is now for. bidden by royal ordinance to the Cliristian party, and any infraction of the law severely purished. "The heathen now said that they cuuld no longer errdure these scta, and were determined to resist them by retaliatiot, au! prevent the further propagations of the Cliristius religion.

The satives who had runouncel hentheniars, ntrd joined the Christian party, finding they were not pormitted to renuatu at llilifo, retired to a sbort distance from it, and built thembelses a susall fortress, wlichs the nta finally blockaded. The Cliristian party now sent for aid to Nukualofa, and haring enlisted the feelings of the mission. aries ard thoir aulherents in the cuuse, they sent a measuge for King George, who again came witl a lasge foree from flaphi and Vavan to tlueir asssistanee. On lis arrival, a long conference etsisued. in which the ata expressell hinaself desirvos of treating for peace, and proposed thet a conference should take plate in his fort.

To this King George assented, and proeerded to the small Christisn furtress in the vicinity of Hihifo, where it is said ho was met by deserter. from Hihifo, who told him loat the otrly purpose of inviting tim to a conforesete there was to assassinute him and his chices. This story was asid to hnve been cunfirmed from ntler sourec, but clip additiunal evidence seemed fax frotn buing eatis factury. King George immediately resulved to in. vest and storm the fortress of Hihifo; and, for the purpuse of dinimishing the enemy's strength, had recourse to a singulat stratagen. He direeted all of his seen who had any friende or acyutuintutuces in Hibifis, and of theso there were many, to nuvanee towards the walls, and cach one to call to his relation, friend, or acquaintance within, лtul assure him of eafecy if lee wudal desert! This had the desired effect, and a great many prorsons, forming a lerge part of the garrison, junjed extr the wall, and joined the beajegers. The remainder, buing wenlewed and dishenrtened, survenderal. 'Tlus the difliculty ended for the grnesent, the rest of the liesatren not lasing yot joined in tho affirir, ahliough it was said they were fully prepnured fur lostilitieg, ling Grorge trow ro enbarked, to re. turn home with lis wartiors, sailing fur fiunur Jonga and Honga Hapai, which is the ruttw taken in their vorages whul going back to Vavats.

The following aceount of the resulution the touk there was derived from liking Givorye, through Mr, 'finclier, and clewrly proved to my usind that lis objuce now was to enlarize bis dominione, by add. ing to them the island of Tongh. "Heve he reflected ujun tho subject of lis departuse, and the defenceless stnte of hing Jubial or Tuluon; and the wat so foreibly struck with his danger, and shat of the missionarieg, thut he resolved to returt, and remain at Xokunlofa until the hontiven werv fimally sulsiued." We, in eonserpenee, fousd bitu stablished, building and fortifying a town, and lis forees daily arriviug frust laves nnd Hapni. Indeed his whule conduct did nut lesve us aty room to doubt $\mathrm{w}$ hat lis intentions were, and that the missionarieg and ho were nutually serving ench outer's catuse. I muttioned my susgicions, pelative to lóing Geurge'y antititum, ia the missienaries, and lwow likely it would be to prevent any reeonelintion or prente with the heachen, and was much surprisen and struck with the indifference with which Mr. Rabrese spolse of the war. Ho way exilently mise inclined to have it eoutinue than desiruns thme it should bo put a stop tu ; viewing it, is fact, as at umenn of propagating the Gubrel. I regrethed to liear such sentimente, and lad little heje, nfer becosuing awaro of theto, of being instrumentat in bringing about a peace, when such tuchristiat views existed where it was least to be expected.

On consultation, Wliza Anne 'l'utrus was selected ths the must proper messengrer of pence that conld be serst, and the onily ono indeed who could go with safety. Slio is the daughter of liantu, the heathen chief of Mon, one of tlie largest heathen fortresses; is married to a chief of the Christian party. She 
is a fine intelligent-lnoking woman, with good sense and much gooil feeling, and eatered wrarsly into the armangernents. She was despatched with a written proposal for the conference, and was to return the next disy. She is called the sacred dawghter, and goes where she likes without being molested.

After the council was over, I went with Mr. Tucker to the missionary houses, passing through the town (if so it may be called), composed entirely of reed huts, of small dimensions, and enclosed with wieker-work fences. The missionary houses are on the outsirirts; the whole contritus about six lundred houses ; and on looking into a few, they did not appear to be very clearly. The houses are built after the fashion of the Samoans, only the sides are of wicker-work, made of the slender sugar-eaue. The dwellings of the missionaries are very like those of the better sort, and are within an cnclosure; and the only difference I observed was, that they bud glazed windows Liko tho others, they had no fluors, act the earth was covered with mats.

Mrs. Tucker, whom we found exceedingly intelligent, gave as a kind weleome. She lias for some time been the principal instructress of both old and young : I can myself vouch for the unexpocted proficiency of some of her scholars in speaking English. To her and her husband I feel nuch indebted for their answers to the many infuiries respecting the state of things in the island,-the employments and elaracter of the natives, their wars, manners, and customs. 'They appenred indefatigable in their exertions for what they considered the good of lhe uatives; anong other things, they have endersourel to intruduce a variety of vege. tables and fruits : cabbages, turnips, and mustard were seen; among tho fruits, were pine-apples and custard-apples, which thive well; oranges have been introduced, but do not succeed, because they are injured by an insect, which leaves its larve on the fruit, and eauses it to fill befure it reaches maturity. They are obliged to pull all their fruits before they are ripe, in consequenec of their liability to destruction by tho ants, if left to ripen on the tree.

Kïng George, or Taufaalaat, is building his town near by, juat without tho fortification of ling Josials: it is an exclosure of four hundred yards gijure; the fonee consists of close wicker-work, made of the small sugar-eane, and in order to make it strunger, several thichesses nre put toge. ther: this makes a more effective defonce than one would imagine; it is about eight feet high, and trimued off on the top, and when new has a very pretty mppearance. Tho permunency und arrasgoinent with which tho town is laid out, make Tau* fashau's intentions quite evident. The arenucs cross the square diagenally, the gates being at the cortsers, and in the centre is a large area, Jeft for a elaxpel.

The houses of King Josiah's or Tubou's town are mostly within the fortress; this is a light suud wail or embaukment, ou the top of which is a wieker-work fence; on the outside of the wall is a diteh, twelve fect wide by five feet deep. There are three principal gateways, which aro very niarrow entrinces, formed by thick cocos-nut posts, set firmly and clorely in the ground, admitting only two prersons at a tiuse; these entrances are about fifteen feet long, and in order to Becure them agninst nit attack, they are so arranged as to be filled up with enrth; they have likewise a number of hallow $\log$ buried in the wall, ant set oblijuely, serving as loop-holes, throught whicls they may have a crossfire at their enemies as they approach. These loop-holes ean only be used for mushets, snd lave been introducod since the matives bogan to use firearm, or since the time of Mariner, for be makes bo mention of them in describing the fortresses.

King George's house is near by : it was originally built at Hihifo, for a ehapel; the chief of that phace gave it to Taufashnt, and it was divided into throe parts, and brought to Nukmalofa in cusoes. On my risit tho king was not at home, but Mr. Tuclier asked me to walk in. The building is not a large one; $i t$ is divided into three apmrtments by tapa Bercens, and was partly furrished. 1 observed many decanters and tumblers on a shelf, the former well-filled to appearance with spirits and gin; but I had no opportunity of knowing actually what tho contents were. Many of the queen's waiting-maids were present, arranging the house previous to hor arrival; she wns hourly expected from Hopai, and is reported to be the rost beautiful woman in the group. The new town is rapidly progressing; great regularity exists, and every thing is so arranged that ench company of warriors with their fantlies are assigned a jarticular quarter in which to build; they have come prepared, too, for the purpose, laving brouglit many parts of their houses witl them. These louses liave a temurorary appearnnee, although they are very comfortable; nud the mpidity with which they bujld them is astunishing : tho enolosure, sud about fifty houses, were built in three days; twelve men can complete a house in a litule more than a day. The average size of the honses is fifteen by twenty feet, and about fiftuen feet high under the ridge-pole; they are of circular or elliptical form. The furniture of the natives consists of their implements of war, ava. bowl, a chest or box for their valuables, and a get of mats, some of which nre mide for the floors, and others for sereens; the lntter are about two feet in width, and are geen partly surrounding them when silting, standing ou their edges, which are supported by scrolls at each end; they are pretty, sone of them being much ormamented.

They bave great quantities of tapa cloth, in a thin sort of which they use to roll themselves nt night, is a security agninst the inusquitoes, with which their island ghounds. The new town is beautifully situnted in a bread.fruit and cocos-tut grove, which gives it perpetunl shade, whilst it is sultieiently open to admit the cool broeze.

On the 26ith, agreealily to my engagement, I movel the ship to the island of Prugai-Montw, in onler to be aear the pinco of meeting of the cull. ference between the two belligerent parties, anil to protect boch from the treachery they scemed mutually to fenr. Pangai-Moutu is about thrce and a lialf miles from Nukualota, and is now considered as tseutral grousd; the anchomge is a good and safe one. Our messenger, Anne Eliza Tubou, returued, and gave me nssurnees that the heathen were willing to moet in conforence; that they desired pence, and to be left in the quiet enjoyment of their land and their gods, and did not wish to interfere or lave any thing to do with the new religion. They again asked me, if they cane, 
would I protect them fully I In repily to this, I sent the strongest aesurances of protection to Ilrem. My lioper, however, of producing a peace and recosicilsation among them, began to decline; for it was evident that hing Genge and his advisery, and, indeed, t/se whole Clristian party, seemed to be desirous of contiuving the war, either to foree the herthen to become Cluristiane, or to earry is on to extermination, which the uumber of their warriors male them believe they liad the power to effect. I felt, in nddition, the the suissionnries were thwartiag my exertions by permitting warlike preparations during the pending of the nogrotiutions.

On the 28th, our boat returned from Mon, bringing an old blind elijef, called Mufn. "The wife of Fantu came in place of her husbaut, accompanied by fonr or five lesser chiefs, who had been deputed to altend the couneil. The wife of Fantu is a large fut woman. He bimself was willing to attend, but his chiufs and people interfered and jurevented hirn, as he was coming to the boat, fearing lest he should be detnined na $n$ linstnge; and they made such an outery (nceording to the officer) against it, that fe wres obliged to yield.

Mufa is the grnudfatler of Taufanlau, and was sapposed would lave some intluence with him. From every thing we saw, we beeame satisfied that the lieativen were desirous of making pence, at henst the people of Mon. I gave orders to provide them with every thing for their comfort, giving them fall assurizuce of my protection, and their safe return; and finding them ill at ense on board ship, I ordered a tevt to be pitched on shore for theit accommodation, aud had thern supplied with rice and molasses, as well ths the food they are in the haljit of eating, consisting of yams, taro, \&c.

Deeming it advisable that Faniu should be present himself, I ngain sent a boat for lim. The perpyle of $\mathrm{Mon}$, thougl heatliens, have mot taken nu active part in the late disturbances, which are for the most part confined to Bea and Houma ; and althougl the Moans are more strongly allied to the Intter, they have ulways lopt up an intercourse with Niukumlofn.

One can rendity enter into the feelings of the heathen, who are intubitants of the encred Tonga, and have always been looked up to by the inbinitsunts of the resi of the group, who were obliged to carry thither offerings, \& $\mathrm{c}_{\text {, }}$ to the gods, as superior to thernselves, when they see an attempt made to subjugate them, by these whom they linve always looked upon with contempt, and to force upon them a new religion, and a change in every thing they have hitherto looket upon ns enered. Such feelings are ennugh to make them war againet any innovation in their social polity and laws; and nfter hariug been acknowledged from time immemorial ins pre-entinent throughout the whole group, including Wallis, Hoors, 'I'raitor's and Keppel's Islands, it is not surprising that they should bo fotnd the active enemics of religious encroachments. Their rexation is augmented by the disappointment they experienced in the last election of the king of "longa (Tui lianakabulo); Tubou, thlthougl the biather of his predecessor, was chosen by them in preforence to Mumuj, the son, becsuse they believed him to be farounblile to their side, and opposed to the Cliriatian party; Mumui, on the other baud, was brought ny' by the missionnries, speaks English tolerably well, aud is tho mission. arjes' principal school-teacher. Mr. Tueker informed mo that Mumui is now considered as the son of Tubots, and will be entitled to the succession, for which both Fantu and Taufunhan, are likewise eandidates, on the death of 'T'ulsot.

The singular custom is sail to prevail in 'I'onga, that none of the royal family ever receive a title of office; for by so iloing, I was told, eliey would virtually renounce tiveix right to the lingdom. The Tui lismakabolo has the power of rescinding titles. In one viow, the government may be cons. sidered a kind of family compact, for the persons bolding titleg nud offiecs address one nnother by the wames of father, son, wnele, and grandlather, without referenee whatever to their real degree of reliationship,

Tlıe titles generally consist of the name of the tistrict over which the chicf rutcs, and of which they receive the revenues, with "tui," " Bynonymous with lart, befure it. This, however, is not always the ease, for there nre others who have distinet titles, as Lavalk, the king of Hea, one of the bitterest opponents of the Ciristians, asul who is determined to die rnther than submit to them; and Ats, Trknfamn, and Vacn, the grent ehief of Houma. 'l'he latter was deposed a short time since, yet still retains his tille among the hesthen.

Shadrach, or Murnui, as he is also called, is a good sample of the Tongese. I sw him at Mr. Tucker's, where he was introduced to me; and i must confess mysolf not is little surprised to hear hitn address me in tolerably good English, akking me the news, and what occurrences had taken place in Enrope. It appenred ridieulons to be questioned by a half-naked savage upon such sulyjects; but I must do him the justice to say he Beemed quite familiar with sone of the events that trave taken place during the last fifteen or twenty yenrs. He is one of the missionaries' most zealous converts, and I beliove to Mra. Tueker is due the credit of teacling him; he las, 1 understood, sole charge of their lirge sehool of three hundred scholass, and it, in order and regularity, equals, if it does not exced, any in our own country. Mrs. Tureker thinks this is partly to be ascribed to his being a high elief, whom they are brought un to have a great respect for. Mumui's countenatice shows much intelligence, but his figuro is rather out of proportion: his age is under thirty.

On the 27 th, I risited Nulualofa, on business respecting the English schooner Currency Lass, Captain Wilson, which ressel was found here. The inaster reported that two of his men had heen seized by King George, and imprisoned, until a ramsom was paid, nud the four Fejee women be lad on board were delivered up. On inquiry, it proved that two of the erew of the Curresicy Lase, with the knowledge of the commander and owner (who was present), had takcu the Feejee womer on bonrl at Vavao, knowing it to be againat the laws of that island; they thence snited for Tonga. On their leaving Yavno, a canoe was immediately degpatelyed to Tonga, to inform King George of the oceurrunce, and it arrived before the vessel. Kking George, ou her arrival, immediately seat on board for the purpose of a searcli; but the women were concenterl below, and they were believed not to bo on board. It however becane known, in some 
way, that they were theve, and when four of the vessel's crew were sent on shore to mend tho ensks to receive oil, King Gcorge seized thens, wnd tied tren to trees. He then seit word, that the woren mist be given up, and that the owner must pny a ransom of muskets for the men. I found 110 difficulty in arranging the business, King Georgo was very frank und straightforward about it, and told the fnets rery much us they aro above related. On my pointing out to him that he had taken the wrung cunrse, and whs purishing the innocent men of the crew, he sail he had no means of telling who were tho guilty, bat that if he lad cloue any thing wrong he was williug to make amends, I thought that the conduct of the Currency Lass had beets inproger, and the decision being left to me, I determined that the men should be set at liberty, the women given up, and the rsuskets paid; that ling George should return the water-enshs, and pay for those tliat had been injured. I took oecasion, Jowever, to impress upon King George the necessity of not being so precipitate in punislung the innocent for the grilty. The men of the Currency Lass who hat recived bat trentment nt his handa, received a recompuse, and so the aftir was ended.

On the morning of the $29 t h$, it was reported to me that MItafa, the old blind chief, and his compro nion, hal decamped, withont giving any notice of their intention, and after enting their fill of the good things set before them, lresides carrying off the remains of their fenst. This movement, I afterwards learnt, was owing to their laving received intelligence of the people of Ben havisg made another attuck upons tlie yam-grounds of the Christians, and carried off a large quantity; and they were fenrful lest some rotaliatory mensures should be taken to intercept them.

This day the kings visited me, with a number of their chiof and people in a large canoe, and made a fine appenrance on approaching tho ship; it whs the largest wo saw during the vojage: it wits one hundred feet in length, and of the donble kind, which consists of two eanoes of different size jained together by a teck thrown acrose them lwels; on this deck a small house is contructed, whiclt serves for a eabin to keep off the weallea"; above the house was a sinall platform, eight feet squnre, witl a railing on each side; the mast, which ig nhout thirty feet long, is supported by grys, laving a long yard attached to it, with its mat-sail of huge dimensions furled.

In all canoes, lyoth double and single, fmall latchways are left at both ends, with ligh combings, and when under way, a mon is always seen in encl baling out the water. Their mode of propel. ling the cantoe by seulling is peculiar to the Tongese and Feejees; the scullor, instend of using tho oar as we do, stands behind $\mathrm{it}$, and holds it perpendicularly. The on has a broad blade, and is ten feet in length: the sculler thus has the whole weight of his body to assist his strength in using it: it is confined in a hole in the platform. There is generally oue of theso oturs at ench cud, anis they are enabled ta propel one of these large crnoes between two an! three miles an lour by sueans of them.

l'he 'lowgese nav great adepts in managing their canoes when newer sail; and they sail much more Bwiftly on a wind than befare it. As this canoe is of Fecjec origin, l shal! defer describing it until a stuceeding chanter.
The canoe of thrse chiefs was scen adrancing olowly over the calm ses by the effurts of its seullers, and was filled with men, keeping perfeet time and making excellent nussic.

They sing any worls, but generally such as are applicnble to the missinn of busines or pleasure they may be on; and afthought the air aod bass are hear'd most distinctly, the four parts are all sung in the most perfect harmony. From the fact that the tenors and basses sing parts of a bar, alteruating witlı each other, and come in perfectly, it would seen that they cultivnte mnusic in their own rude way, producing a wild but agrenble effect. To this the scullers keep time.

This music has a great resemblance to that of the Samon Group, and it is the custom in botlo to sing it while at work. It may therefore be inferred that it is native, for the Tongese never had foreign music of any kind taught them. The mnissiowaries themselves do not sing, and deciared they were not able to tell Old 11 undred from God save the ling, if the sume words were alapted to both I Tile femalez of this island, generally, have very musienl roices, wlose pitch is the same as that of European women; the voiees of the men are a full octnve below, round and full; all are very apt in learning a tune. Mr. Drayton remarks that he did not lear a single strain in the minor mood in singing, nor even it their ratural sounds in speaking. Missie might be culivated among this people with grent success, from the evident delight they tako in musical sounds, nud their strong desire to learn; but they could with dificulty be prexailed upon to sing, for the state of the country, and the fear of the missionaries, or the order of the king, prevented it.

Finding me engaged on the island of Pangai. Moutu, at the olservatory, the natives passed to the shore. I received them in nyy tent, and the first words spoken were to infomn me that they had come to the conferenee; and they asked where their adveranties were. Being well aware that they liad avoided coming the day before, and liwh gone out to nuake battle, insteand of coming as apjointed to the meeting, and that they knew the chicfs of Mon had returned, I took eare to let them know that I was not to be imposed upon by such a trick. When they sas they could not doceive me, they becmed disposed to laugh it off: but fuding that their chiefs and warriors (upwarts of one lundred) were all armed, I took care to retort upon then for their wast of coufidence, aus to tell them huw unlike it was to their pufession of Christianity, and thine they must show a proper disposition, before the white penple would givo them any credit for being Cloristians. I then took the two kings with me on board the shig?, leaving their cnnoe to follow. Shortly after we had emlarked, ling Gecrge's followers, finding a conne on the beach owired by liree ratives of listuma, who reside at Moa, stale the paddles out of it, turned it sver, nnd set it aldift, On making it knowu to king Geosge, liowever, lie promised recompense, but would ant punish or seek to find out the perpetrutors of the deed. I felt provoled that the kitug should not have had more control over them, He in truth seems to excreise very listle power over his preogle. The kings were slown over the ship, nnt several guus were fired, which they pretented to wouder at very mnch. 
They remained on boarl upwards of an hour, and took lunch with tne. I was much funused with their condinet; they ate lieartily of every thing on the table, asid fiually crammed themselves with alnonds and raikins, with a most unkirrbly nppetite. They then requested lenve to tuke some to their wives, wlich they tied up in the corner of their topns. Beforo they lett the ship, I presented ling Georye (in the name of the govern. nont) wirls a handgomo fowling-piece, and King Josiah with a red silk umbrella, which highly do. lighted him. Their majesties wero both maked, except the tape woutrd around their waists; and it was a exrious sight to seo them endeavouring to juitate us in tho use of knives and forks. They left the ship highly delighted with their presents and visit, embarked in their canoe, and proceeded to Nuknalofa, all joining again in the strme chorus. The canno was biearly level with the water, and appresred liko a flosting mass of human beingh.

Thus ended ny hojes of effecting the desired reconciliation between the two parties. The heathen are represented by the Christian pnrty and missionaries as a set of cruel savages, great liars, treacherons, and ovil-disposed; nud this character secms to be given to then only because they will not listen to the preaching; and it is alleger they must therefore be trented with severity, and com: pelles to yield. Under these feclings it was in vain to expect to produce a reconciliation; and had I been aware of them, I should not have attempted the task. I must here record, that in all that met our observations, the impression was, that the lreathen were well-disposed and kind, and were desirous of putting ans end to the difficulties.

Several of dio oltieers visitud Mon. In order to reacls it, it is neecessary to pass in boals through a large shallow lagoon, and it nust be crossed nearly at high water, or the channel will be fnuml very tortunus. The town or village is situnted a little abore the general level; it is surrounded by a diteh, which has little depth, as the coral rock is soor renched, and is not cut into. The intrench. ment is cormposed of earth and logs, over which is a wicker fence, like that su Nukualofa; at the gates the ditch is interrupted, so is to form entrances, which are narrow and low. On the iuside $n$ gunrd-house wich a sertinel was found; within the intrenclument was $\mathrm{n}$ hish and well-built fenee, sud inside agaiu were serphrate enclosures. They were led to the house of Fastu, the principa! chief, who treatted them with civility and kindness; they fonmd him to possess buth dignity and politeness. In his house were severn! Tonga drums, which were offered as seats. "Tllse natives were in great numbera, of all ages and sexes, A brisk trade was carried on for the supplies we needed; aud althugh Fantu took no nctive part, yet tho whosle was evidently under his supervigion.

'The missionaries were kind enough to give me the fullowing ontline of the lrelief of the lietthen belonging to this graup of islands. They worship many gods, who are believed to possess unlimited power over then, and are called the gods of Bulatu or Atur faka Bulotu, whom they beliere immortal; nome of these goda are of this world, assd are called Atua.

They believe that all evil is inflicted by eertain gods, called Atua Basuu; that the sjurits of all chiefs go to Bulotu; hut that thuse of poor penple remain in this world, to feed tpon ants and lizards; that the island of Bulntu is not distant, nithough they do not astempt to fix its loenlity; that both gods and godderses have visited Touga within thirty years past, when they drank nva in theis temples, and were married to Tonga chiefs; that itse ligher gods or those of I3ulotu do not consider lying, theft, adultery, murder, \&c., as crimes, but as things of this worlh, which nre left for the inferior gods to deal with, and do not con. cern their more olevated natures. The only crime agninst the higher gods is sncrilege, eommitted sowards their tetuples, or an improper use of the offerings. 'T'lsey eall their oldest god Maui, and say that he drew the world or islands out of the sea with a hook and line: the first he drew up lie named $\mathrm{Ata}$, wlifel is referred to Pylstart; the next was Tonga, wilh all its group of ialande; then Lo. fanga and the other Hapai islands; and bat, the Vayno Group. After lie had finished his wark, be eatne ant fixed his residence at T'ongn. In those days the sky was so near the earth that meal wejo obliged to crawl. One day Maui is represented as having tmet an old woman with water in a coconnut shetl, of whom the begged some drink, which slio refused until ho promined to send the sky tup higl, which he did, by pustring it uj, and there it has remained ever since. 'To Maui is ascribed the origin of that most nseful tree calied ton, the irunwood (casuarina), which in time reached the sky, and enabled the god called Ftumatubua in descend, Maul had two sons, the eldest called Mnui Atalonga, and the ronager Kijikiji, but by whom is not known. Kijikiji obtained some tire from the eartl, and taught them to cook their food, which they found was good, and from that day foon luas been cooked which before was ented raw. Iu order to jreserve the fro, lijjikiji commanded it to go into ecrtnin trees, whence it is now obtained by friction. They further sny, that during the tizse old Maui was on the earth, the only light was like that of the moon, and that neitler dny nor niglat existed; that Maui and his two sons live under the earth, where he sleeps smost of lits time; that when he iums himself over, he proilucess enrihqualies, which they call " mofuocke." Masii is not now worshipped by any tribe, nor is he loved or feared.

Tangaloa, their second god, is thought to be nearly as old as Mnui, and equal to him in dignity. He resides in the skieg, which the Tongese believe to lie very numerons. Hiktsleo is the got of spirita, and is the thind in sriter of time; the awells in a cave in the islatrd. Bulutu is most remaskathe for a long tail, wlich prevents hirn from goimg further froms the eave in which he resides than if length will admit of. In this eave lie has feusts, and lives with his wives, hy whom lie has many childreu; he lase atsoluto power over all, and all are forced to go to hint; ho is a being withoue love or goodness; to him the apirits of the chicfs and matraboles go, becoming his servants, nnd are foreed to do fis will, and to serve for what purpose he jleases; he even nace them to make fenees of, es" an bars to lis gates; and they hare the biden that his loouse and all things in it are made of the spirils of people, where chey continue to sorve withont end. They never jray to Bulotu, except when some eacri. lege lus been commuitted to the offerings bley make him; rud on this oceasiun they always 
make a human sacritice, They also jnvole him when the Tui Tongh is sick; and it depends on the reigning 'Tut hanahabolu whother or not a humas sncrifice is offered. None but gods aro ever permitted to come from Bulotu. This god has lits spirit-tomple, where all their valuable presents to the goils are deposited. I was ghown by the missioniries some Inrge whale's teeth thin were prettily earved, which had been found in the teraple lately destroyed hy the Christian jarty.

We saw here three natives of the island of $\mathrm{Ro}$ tuma, who had been sone time at Tongn: one of them was said to be a elsief of high rank; nnother, an old man, a chief also, mind a kind of Meator to the former, who spoke a little English, and was quite blitd, haring become so sinee he laad left his own island. The old man seemed to leel great solicitude about his charge, and expressed a wish to get away from Tonga. The reason lie gave me for this desire was, "there wh too much fight here; it would be bad for the young chicf, who was to be a king." He told me also there lnd been no war on bis island for mnny yenrs. It is genernlly known by the whalerg and others, thint at Rotuma, the people are the most percenble of any of theso Polynesian islanders; and the whalers have been in the habit of resorting thither, becsuse they experieneed littlo difficulty, and aro in no danger of being molested by the natives. He mentioned that many of his islanders were now abrond, on bonsd of whale-slips, where they earned good wages, and afterwards returned to the island with soine property : he said that Rotuma contnined very may people. He who was designated as the high elice, was a pleasing, handsome young man, and appenred modest and gentle in his deportment. Some thought he resembled in physiognony on Amerienn Indians, but I did not myself remark it.

The nntires of Tonga, in habits, customs, looks, and general appearnuce, are so like the Samoans, that we were grently struck with the resemblance; indeed, in writing of Samon, I mentioned that many thinge lanvo been derived from Tonga, partienlarly their tapa envering from the waist downwards, ealled siapo. The two races also agree in having nu covering for the head, and the females resemble each other. The missionstries, throngh the king's ordinance, lave caused the females to clothe themselves up to the neck with the pareu; but this is only conformed to before the missionaries, for we as frequently saw it worn in the native faslitin.

In colour the Tongese are a littlo lighter than tho Sumons, and tho young children are almost if not quite whitc. As they grow up, they aro left, both males and females, to run about in $\Omega$ state of nature, with their hair cropped close, except a small curly luck over esch ear. This is a practice which has before been spoken of, as prevalent among the Samnans. Indeed, the similarity between the nppenrance of the ehildren in the two grvupg is sueh, that they might bo mistaken for each other. A larger proportion of fine-looking people is seldom to be seen in ary portion of the globe; they aro a shade lighter than any of the other islunders; their countenances are generally of the Luropean enst; they are tall and well made, and their muscles are well developed. We had an opportunity of contrasting tlseir physical chameters with those of several other untives, and particulurly with a natipe of Erromago, The features of the latter were more nearly allied to those of the negro than any we lial yet seen. Ilis hair was woolty, his face prominent, and his lips thick. His nose, however, was not remarkably brond; his eyes were small, deeply sunk, and had a lively expression; his eountenance was pleasing and intelligent, and his cheeks thin; his limbs wete slender, and the calf of his leg high".

Wealso found some of the Fecjee islanders here: the intereourse between Tonga and the windward islands of the Feejee Group, is frequent. This intercourse is sail to be tho cause of the warlike liabits which tho 'Tongese have aeguired. Tho people of Feejee appear to disadsantage when conirasted with those of Tonga; for the latter have much larger frames, their culour is several sludes lighter, and their hair straight and tine, while that of the Feejee is frizzled.

The women of the Tonga Group are equally remarkiable for their personal beauty.

The native of Touga, from the missionaries? accounts, are industrious and ingenious; much attachment exists between husband and wife, and they nre very fond of their children. We were surprised at their numbers, which give a striking air of cheerfulness and gaiety to the scene, when they are scen in groups, playing, and practising many kinds of jugglery.

$\Lambda$ far as we observed, the Tongese nre very fond of amusements, and snoking tobaceo is absolutely a passion witls them; this is raised by themselves: the leaf is eut up very fine, and then rolled within a fine pandanus-lent, forming a eigar. "Tlu Christian party aro not allowed to smoke, although they uso large quastities of ava, made of the piper mythistieum, which has more intoxienting and deleterions effects than tobacev, So singular an interdiction of the one, witli the free use of the other, induced me to ask Mr. 'Tucker the renson of it, and why, if they had only the power to present the use of nne, they did not prulnibit the most pernieious? The only answer I got was, that it would be a pity to brenk up their ava circles. I believe that few rise frrm then without being sumewhat stupified, but it does not amount to actunl intoxicntion. The manner in which these natives use tobaceo is one of the must plensing of their socint customs, and sloows an rbsence of all selfishness; it is the Bause as at the Samonn Group, where the person who lights a pipe seldoin gets more than two whiffs of its contents, as it is immedintely passed around.

As a people they nay be tertied warlike; and war-eonncils, making speecles, and drinking ava, niny be erlfed the business of their lives.

The women are said to be virtuous; their emplogzuents are to make tapa, mats, baskets, \&ce, and do the house-work. 'The men culivate the grousul, and fislı. The females are more in the liabit of using lime-water and lime on their hair thau thuse we lisve seen elsewhere. This appliention tums it red, but its chief use is to promote cleanliness. Of the ingenuity of the men we saw many proufs, in their mnnuacture of boxes, baskets, and mininture canocs.

- Amang other jeculiarities of Ith mative of Erromago, It was stated ty the low whites, that instead of wrapphing hiniself up in tapa at night, ltke the T'ongese, he was in the habit of lusrying lifenself In the sand In order to avoid the musululioes. 
The last day I visited Nukunlola, Mr. Tucker was kind enough to take me to see Tamahan, the aunt of Tui Tonga, who is consilered of livine origin, for which reason great respect and honours are paid lier. It is said that she bas grent influence with the lienthen, nithough being a corvert, she is favourable to the Christinn side. $A \mathrm{~s} n$ token of the great reapect with which she is regarded, it was remarked that the natives never turn the back upon her until at thirty or forty lect distance, and never ent in her pressice. Slie is old enongh to remenber the arrival of Cook when she was a chill. Wo fotnd her sitting in her house, with a ehild who eould just walk (both enclosed in a rolled sereen, before described), whom she was feeding with cocon-rut pulp. We shook hands and sat some time with her, making many inģuiries ahout the former persons of the island, which the entertaining volumes of Dr. Martin, relating the adventures of Mariner, had made me aequainted with. She seenved to know Togi Uummen, the name by which Marisser was known, and also most of the people mentioned in Mariner's necount.

On a visit to the missionsries, I found Tubou or King Josiah, who had been sitting for his picture, and had fallen fast asleep. Wishing to get some information from him, I felt desirous of waking thim up, and for that purpose asked him some ques. tions about the kingly sport of rat-lınting, described in Mariner's Tonga Isiands, aud whether be could not indulge me with an exlibition of a hunt. His eyes at ofice brightened, and he becnme aroused to great agimation, as though his former fents and pleasure in this sport were vividly before him. He regretted that the present state of the island, and the all-engrossing war, occuphied too much of their uttention to nllow them to eugnge irs any such percefut occupation, He was represented to be a great sportsman, and the animation with which he fipole gave evident proof of it. He said that the game or sport was now seldom practised; that the rats had in consequence much increased, and were a grent annoyance to the cultivator; - but the war seemed to engross all the powerg of his feeble mind. He told me that the henthen in all had fifteen hundred warriors; that they usually made war by attacking the taro and yam-grounds; these they plunder and destroy, which ultimately produecs is famine, not oniy to their cnemies but to themselves. Ho seemed to rejoice that the beathen had made the first attack, as they would thereby, nccording to their belief, be conquered. He told me lse much desired pence and quietness, and wns willing to do uny thing to bring it about: aud as far as ho was personally concerned, I believe ho was in earnest, for every one seemed to give lim the eredit of being an imbecile, sleepy fellow, and paid lim litto or no respect.

During this visit I nlso saw a noted Feejee warrior, who hat been nlsent from Tonga many yenrs, and on his return had been engaged in these wars; he was deseribed as a rery wicked fellow, and if so, I can only say that lis louks did not belie him: a worse or more brutal-lowking man I hnve seldom seen, I understooul that his arrival lind been looked for with much impatience by the heathen, as affording them sdditional strength in a noted leader; loue to the surprise of all, ho joined himscif to hing George, and desires to become a Cluristinu; he was received as atch, nud was now employed fighting against the heathen.

On the evening of the dny on which King George risited the ship, be beld a couneil, in which ho addressed his eliefs and warriors on the necessity of carrying on the war with vigour; and mensure were taker to prosecute it accorditsgly. The meeting took pluce in the mulai opposite his house, while he sat in tho doorway with his two children, with the clurch-people forming a cirele around bim. At this meeting was geen the noted chicf and Feejee wartior who bas already been spoken of, fully armed, in the background. After the council had debated and talked over the sulject fully, king George gnve sotne commands, which severnl messengers were sent to exeeute, and the council was dismissed in a truly primitive style and Inngonge: "Let every man go and cook his yams."

After the assemblage was dismissed, the king and chiefs remained some time in consultation. In this conncil, an attack upon the lieathen towns was armaged. The next moruing, smoke wa secn aseending from some of the heathen rillages, and word was brought to me afterwards, that king George, baving sallied forth with eight husdred warriors at midnight, had burned two of the heathen towng. Although be liad ordered sewen lundred more warriore to follow him at daylight, he did not pursue the beallen, who fled before him. On his return in the evering he held an ara fenst in honour of his success; at this meeting, Lavalia and $\Lambda$ ta, or the eliefs who held theec titles, were formally degmded from their uffices by the king, - atroke of policy that is thonght will hare much influence in alienating this people, as it has usually had that effect. 1, Jowever, very much question its suecess in the present instance, when the parties bave such a deadly aninosity townrds ench other; for the very nuthority by which the act of degradation is performed, has abandoned the religion by which the act was sanctioned.

Tho population of the Tongu Islands, ns now given by the missionarice, is 18,500 , viz..:

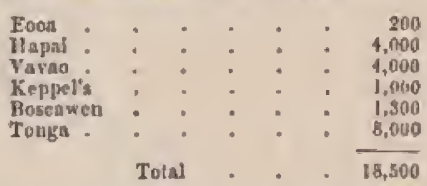

At present the number on Tonga is increased by about one thousand.

About four thousnnd five hundred of the matives are Christians, of whom two tlousand five hundred are church members.

The jurisdietion of Tui linnalatolo, or Lord of Kinaknbolo, used to extend to Uea or Wallis Island, and several of the smaller islands in the neighbourlwod.

This group of islnuds is divided into three missionary stations, viz. :

Tonghestroo, commenced lo :
Hapal
Yavao

The missionaries reside at each of these stationg. The smaller istands are under the care of uative teachers, and aro visited occasiunally by the missionaries to marry and baptize, \&e. There is a printing-press established at Fava, which bas 
been in operation since 1832. Many of the women can sew, and a great number of the nutives thve lenrmed to real and write; a few of then huve been tanght the rules of arithmetic, and the prineiples of gengraphy. A very great inprovernent lins taken place in the mornls of the Christian part of the community; but the attachment of the people to their ancient usnges is so stroug, and the islaud so littlo visited by eivilized natiuts, that they bave not hal that stimulus to improsement wlich others bave derived from such advantages.

While I bear witness to the aridunts labours and woll-conducted apgerations of these nissiounries, I camot heln romnrking that T was disapminten! in firding religious intolernne existing among them. It was to be expected, that mpong a elass so devoted, axd undergoing so many privutions dangers, and sacrifices for the carise they are engaged in, charity would not linve been wantisg ; and that they would towe exteraded a friendly hasal to all, of whatever persuasion, who came within their spluere of duty, especinlly those engaged in similar duties with themselveg; but an instance of intoloranee esmo to ny knowledge here, that I regretted to hear of. On boand "The Currency Lass" were two Catholie nissionaries, who had been in this small ressel of one humstred and twenty tons for five monthe, and three wecks of that time they wero in this harlonus, without laving recelved even an invitation to visit the shore from the Wesloyas missionaries, nor were any eivilitios whatever offered or paid to tlım. I can easily conceive why ohjections sloulul he tundo to their preaching or remaining to promagate their creed in a fiell? that whs already oveupivid; but to withliold from them the common courtesies of life, in the present state of tho world, surprised me not a little; and I an satistied that tho example set in this ense by the missionaries has eaused misch remark among the nitives themselves upon this want of Lnapitality. 'R'hey camnot mulerstand the dogmas of the different sects of Cliristians, so that they naturally look unon them all as missionarios of this snme fith, and cantot see why they shonli] treal ench other with less enurtesy thin is extenulei? to those who are nat wigsionaries. Their ideas of eneming only extend to those who fight, which they well kuow all miesionaries refuse to do. Were miksionaries aware of the unfawourable intression produed on the minds of most of the matires hy fucls intolerance, it would never be practised, particularly ns it is enlenlated tu excite prrejudices in atringens who viait their difrerent mission station, which sut unfrequently so blinls them that they go away with unfavourable impressions. Every endeavour is frequenty made by those whites who are resident near thern to store up and repreat these fucts, witl exaggerations, which go far to damp the ardour of liose who are inferested in forwarditz the great esuse in which they are engaged. For nlt these eonsiderations, they ought to avoid, by every moane, falling short of ilint highmituled liberality that is expected from them.

The Tongese are remarkable for their feats in swimming, and are very daring when eniling theis" canneg. All instanes whs bold mo that occurred in $18: 9$, the year hefore our visit, whish is louted tspor ns $n$ well-establiatreal fuct in this gtonp. Two canoes left Hapni for Vavan; on their way, the wind arose and blew a strong gale from the notth direetly agairat them; one of them was driven back

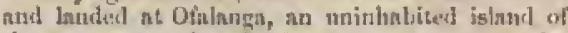
the eroup, ocenaionaliy visited by tha natives, for

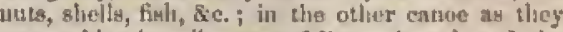
wero taking in sail, $n$ man fell overbonrd, and the wind and sea being strong and high, it was found impossible to save lim without risking the lives of all on bonrd, aul he was given up; this was about four w'elock, sud the ennoe was jnst in sight uf lasul. Tlie mats accordingly turned his face towards Hapai, and resulved to rench it if posatible; ho kuew the wind was north, and directed his cuurse lyy fecling the witud in his right and left ear, intendiing to swim before it; lye contuued swimming and resting by floating upon the water, until the monen rose; he then stcered his coume by that lutuitury, and thus continued tutil momilng, when ho was near land, and nimost willin reacls of the eartal recf. When he lad thus nearly easoped drowning, he was on the proint of beernaing the prey of a hugo slank, wloge jaws he awoided by reaching the cornl shelf; he thon landed upon the istand, whicls proved to lie Ofalanga, where the first canoe had been driven; the crew found him on she hesch senseless, and attendel to him; lie soon was brought to, and ahortly afterwards reeovered lifs strength. This man's nnmo is Theopltitus Tolus; he is a uative of Honno on lise islmond of Hapai. "Tho eanoe from whieh he was lost returued to Hunso before Theoplsilug did, aus when lie reached his hone, he found his friends but pased through the abuat ceremonies of his fuseral.

The island of Tougataboo is of eorsl formation, and with extengive cormal reefs to the northwaril of it; it bns a sludlow lagoon, which extench shout ten miles into the interion. The soil is deeper than ufrou ary islasid of cural formation we linve yes risited; it is nearly a dend lovel, witl blse exception of a few hillneta, ilsirty or forty feet high; the soil is a rich and fertile vegetable mould, and it is not composed of sand, at in the other consl islatuds. 'The vegetation, probahly for this retaon, does tut altogether regemble that found on those islanda The luxuriance of tise folinge is not surpassed. Sume few ervecimens of purnice lase been furnd on

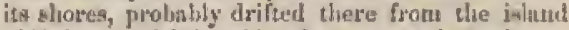
of Tofona, which is saicl to have an notive vulesno. Tofona is the ligheat island of the group, nthl text iII Jeight is bon, There is a marked differenee in the aprentante of the sislauds of Enoa anl 'T'unga; on the [usmers of which there is comparatively liulo vegelation.

On 'longa, sichough the regotation equala any within the trupies, I was struck with the exaggerated aecuunts of the cultivation of tho island; for, so far from finding it a perfect ganlen, exhilsiting the greatust care in its cnltivation, it 1912 appenreul tn be entirely noglected. 'the ynu-grotunds are more in the interion of the ialnnif, nut in eonsequence at the war, there wns gn safety in pansiug lieyund the limits of the maty sylich jossesert the nortl gart of tho taland, or that in the vieisity of Nukualufin.

The nntives cullivate yama, sweet-potatues, ba11uts, coeon-nuts, breat-fruil, sugnr catse, shadilock, lines, and the ti (spoudina suleis); the prutdann is musth whtendul to, and is one of their nuost usefol trecs, and of it all their nants are mailo; a little corni is grown, and they have the papas ampalc (एapsya), and water-melon. The missionaries 
lave introduced the sweet orange from Tahiti, and a species of clictimuyer (annona); many other thisign lave, as I learsed, beon atempied, but havo hitherto failed. I pregented he miesionaries with a suriety of buth fruil nnil vegetshlo secils, sud trust tist they will atreseerf sund bo of mivantage to future visitens; the satives, I was tohl, undenstum the different kinds, diseriminnting among them in thets planting.

The botany of this islaud resemhlog that of the Samotan firup. A specica of nutmeng was formel trere, differing from either of the Samonn ones: the trees were very full of fruit, and much larger; ose of them was observed a foot not a lanlf in dimeter, and upwards of forty feet in height, There was a umuber of ornamiental slumbs, $A$ deseription of elimbing plante, which it was fonnd a difficult mitter to trice mong the varieties of forest trees, gave a peculint climteter to some parts of this overymown islast.

T'lou elinate of Tusiga is humid nmel the heat oppressive, riking frequently to $\$ 3^{\circ}$ in the slawe; unuh mals fally; the mean temperuture during our atay was $7 y^{\circ} 25^{\circ}$. The tonde-winds are by no meins constume, nnd westerly wints necasiunally blow in every season, which, from their variable ehanctes; lave obtuined the name with the natives of "forlish winulu."

We lad th regret the stato the island was in, as it provented our making that full examinstion of th that I taxl intended and hoped; we saw enough, however, to eatisfy onrselves that Tongataloo is not the eultivatud gurien it has becn represented to be. The tieus tree figured in the voyago of the Astrolabe, whase trunk is there stated to be one hundred feet is circumference, was visited. We were surprised to find it had no proper trunk, but only a mass of intertwincd rubls, thtough which it is jospilste to see in many directions, rising to a leighe of eiglty or nimety feet, when it throws arvunh $j$ th great and widc-uprending branches. 'T'wo other sjeteres of fients wete fouth, otse wits labiate branches and horizontal spreading amms, the other witl a trutik about nine feet in slismeter.

The climate eannot be cousideted ralubrions : very leavy dews fald at night, and so constitution ear endure frequent exposure at this time; the uratsitions from heat to eold rre sudden and great, and the nights ture often Bo chilly as to trake blankets necessary.

Hurricants are frequent in this grotap, scarcely at Besson prassing withont sone oecurrence of the kind: the monihe of February and Narch are those in which they oceur; but they lanve also tuken place in Norember atu December. The missionatios as yet lave mado no serjes of observations, wor kepil any kind of meteoculegical diary; bat in nnswer to my imaguirieg I obtained the information, thro tise storms begin at the north-west, thenee veer to the enstward, and end in soutli-enat, The wind contisues to itrerense until it becomes a hurricato: Jwouses are levelled, and trees torn up by the routs; vessels ate driven un ulıote; canocs lost or driven lisndreds of miles away to other islsnds. In these starms the wind is frequently observed to chnngo almost immedintely from one point to its opposite; tund in the sause group of iglatufe, trees have fallet, during the Eame gate, somo to the seuth and others to the nortl. They are Incal in theis effects, and fall cliefly upon Hapai and
Farao; if the fury of the storm be felt at Varno, Thong generally excapus, and rice rered; but Hapis is moro or less the sufferes in both eases, situnted as it is between the two places. $A$ very severo hurricane was felt at Lefook, Hapai, in 1834. Thest lutricanes vary in duration from eighten to thirty-six hours; nfter a restructive orse, a famine generally ensues, in which numbers of the natizes die: it dustroys all their emps. 'The nativerg give the namo to those which are nosh severe, "Afa hign faji," or the burrieane thut throws down the barama-trees.

Linrthquakes are frequently fels here, thourgh there is no knowledge of any destruclive eflects frum them.

"The disenses of this elimate sre infinenza, colds, cotghs, and consumptixns; glandular swelings, some cruptive complaints, fevers, nud some slight irregulns jntermitients are experienced; lout to judge from the munber of old persons, lengevity is by no mensis uncommon. Thlie vencreal disenso lins not unde the same devastation hero as elsewhere; probably beenure, as reapeets morals nut virtue, these natives are the oprosite to those of Thatiti.

Desirous of olataining sorne of their nrme, implements, and bther curiosities, Mr. Waldron, Mr. Hale, and Mr. Varderford, went to Nukualofa to make purchases, taking with them a inrgo assortment of artieles for the fair. The difficulties to be encountered in making purcluases of the natives is senreely to be imagined; no farall amount of pntience is required to go through the cluafiering that is necessury to secure the article desived ; for if their price is at once seeted to, they consider their bargain is a bad one. No inducenent is sufficient for them to purt witl geveral nrtieles of a kind at unet ; each raust be disposed of sepmrately, and on nll a like chatforing motst be gone through with. The natives, before they bring artieles for sale, fix their minds upon something they desire to obtain, and if that is not to be had, they take their things away agrain, it nutters not whether the article is erjuivalent in value or not. Mr. Yanderford, who has been hero severnl times since 1810 , told mo "lie hud never fuund tho 'fonga peoplo such anney fellows."

During our atay here, we were much ineommoted by the musquitoes. I never anw them more troublesone; and for three or four nights tho ofticers and men obtained no sleep, which, added to the excesgive lieat, was orerpowering, after the fatigues of $n$ day spent in survoying. I never saw the men look as much fatigued when the day davaed; some of them dechrerl that the musquitoes had bitten through every thing lout their bnots and huts; they even bought shelter in tho tops and eross-trees, hoping thus to eseape the attucks of these tormentors; the ship was so filled with thern, that she was (not unaptly) bikened to a musienl-box. Their attaks burle definnes to nil defences in the way of muspititoe-nets; night observations became almost impracticable in consequence of this intolerable annoyance, snd I felt quite desiruts for the time of our departure from the island to arrive.

On the Ist of May, our observationg and sturveying duties being completed, the instruments were embarked, and the boats lioisted in. A new difficulty now arose; for I was informed that 
the natire pilots had received a mesage from the king, forbidding them to take the ships through the reefs; and although we needed their services but little, yet 1 lhought it was a circumstance that repuired some investigation. I lowever gave orderg to weigh anchor; but, while in the act of doing so, the Porpoise was reported as in sight: I thereforo awaited her joining company. She Jad been detained in eonsequence of light, varinble wimds; lad seen nothing of Yasquez Islasd, but liad sighited Pylstart's Island.

We found that the crew of the Porpoise had heen, as well as ourselves, affected by the epidemic influenza, and that one case (alat of David Bateman the mnrine) was somewhat gerious; we therefore received him on bonrd the Vinecnnes, for his better sccommodation.

In the afternoon we mn down to the anchorage, off Niukualofa, when the Porpoise and Flying-Fish both went ashiore on the reef, in eonsequence of the sun preventing it from being seen; they got off soon after without any damage. On anchoring, I despatched an officer on shore, fo inquire into the reason of the order sent the pilnts; word was immedintely returned, on the part of the kings, that they knew nothing of the business; and they diselaimed any interference with them at all. On further investigntion, the report was found to have grown out of the jealousy between two pilots, Tahiti Jim and Isac : the former being the favourite of King George, whilst the latter was attached to King Josiah. Imate laving come on board first, was accepted as pilot; but Tahiti Jim being shrewd and cunuing, (of which we hal Juch experiesice afterwards, ) did not like the ides of laate, whin, ns he told me, was no pilot, reaping all the reward; he accordingly intimated to him, that unless he promised to shrse the profits with him, he should report him to King George; and that if lie got the ship nstsore the cagtain would lang him. This so alarmed Isasc, that being unwilling to fall under the displensure of the king, and equally so to divide his prolits, coneocted the story that lie whs ordered by the king ant to take the vessel to ses. I rather suspected Tahiti Jim of delivering atch a messnge; finding, however, since the arrival of the Porpoise, that there was now a prospect of protit for botli, they becnme reconeiled. 'This affair lueing sottled, and having finished my orders for the Pencock, and bent them to the missionnries, we love up our anclions, and made sail. Before we had got withont the reef, a sail was descried, which proved to be the Peacock. After passing congrntulations, by cheering, I mado signal to anchor, which was done, anear the outer reefs, in ten fathoms water. We were now once mors together, and only is few dnys bolind the time allot ted for renching the Feejee Group, and begiuning operations there.

The Peacock, as we have seen, was left at Sydney to complete her repairs; these detnined her until the 30 th of March, for it was found extremely diffcult to obtain mechanies; and all who wero err. pluyed, exeopt two, were a lazy and drustien set: they all belong to the "Trudes" Union;" and to such an extreme is the action of this association encried, that thoy invarinbly support the most worthless, and make commen cause with them. Employers are completely under their control, and there is no manner of redress for idleness or bad work. If the employer eomplains, they alt leave work, refusing to do any thing more, and soon compel him to reengage them through necessity.

The repnirs were made, as has been atsted, in Moseman's Cove, on the north shore of the harbonr of Sydney, one of the many natural docks that nature lans proviled for this lasbour. The ship was laid aground, so as to expose her whole fore. foot, during tho ebls tide. The damage which she had sualained lins been before spoken of; the stem was literully worth to withis an inch and $\mathrm{a}$ half of the wood-ends. After repairing this, by seraping the stem and patting on a new cut-water, they raude use of a diving appuratus to place the new braces, and mend the copper that was liroken.

Although they were removed some distance from Sydney and its rile grog-shops, despite the utmost enution to 1 revent the erew from procuring spirits, it was found that a plan had been formed to aupply them with it. In a hut near by, lived an I rishnar, familiarly enlled Paddy, who acted as a kind of suttler, in supplying the meases of the officers and men with fresh bread and milk, and also doing the washing. After a few riays it was discovered that the men wero obtaining some extrm allowance of spirits, and suspicions naturnlly cuough fell on Paddy as the couse of this irregularity, and its conseguent disturbanees. Orders were tlierefore giren to seareh him, on his next visit to the shiy; this fully contirmed the suspicion, and his presence on bonul was at once interdicted.

Padily had no iden of being thas defented in reaping lis luarvest from the thip's company: ho therefore enlisted in his service a man, if possible, of a worse character than limself, whom he kept constantly supplied with rum, brandy; and gin from Sydney, and made it known to the erew that lo was rearly to furnish lis former customers. The mes sonn mnnnged, under various pretexts, to visit his hut, and supply thenselves at the expense of their clothing, or sotne other equivalent. This new arrangement stseceded for $\Omega$ time, but was at length detucted, and the nnisance wholly stupped; steps were also taken for the punishment of the offenders, by making a complaint against them, which eaued the apprehension of Paddy and his partner, and he was required to pay a fine of $30 \%$, or be imprisoned for six months.

Paddy was not the only annoyanee they had to encounter. Another was the poisonous sunkes that infest the seeluded nooks of Mossinas's Bay, munbers of which were daily seen near the ship; among them was one resembiling the diamond-snake, of a light silvery colour, about eighteen inches in length, and as thick as the fitue finger: these aro very numerons, and it is very desirnble to avoid coming in contaet with them, for their bite has ofter provod fatal. Instances are known in Sydney of persons who haro been bitten, and huve died in a few hours. An eminent physician of Sydney, on being asked the treatment in case of a bite, repilied: "to bandage the affected port as soon as possible, cut it out, and as suon as preparations ean be made, amputate the limb l" These venomons snakes frequently cinwl into houses near the woods, and persons have been thitten whilst sitting at their doors in the evening. $A$ lady, lixirg on the north shore, near the residence of the American consul, was sitting playing on the piano, when hearing some rustling noise, suddenly looked around, aml discovered a diamond-stnake only a short dis- 
tance from her; she sereaned aloud, anid jumped on the music-stool; a serrant soon came to the retene, and killed the intruder. Instanees oecur reprentedly of these annkes infesting the hauses, nud so common are they, that if a person is stung, it is at onee supposed to be by a snake. The offects of the bite, if not fatal, are said to produce partinl blinuness.

On the 3oth of March they left Sydney, and passed the Heads of Port Jackson on the Bame aftermon. They had at first light winde, and annde lust titulo progress. When about seventy miles from the const, in latitude $331^{\circ} \mathrm{S}$., they experienced a clange of four degrees in the temperature of the sea; aud on the $9_{\text {ril }}$ of $A$ pril, they found they hal been set thirty miles to the southward during the day. On the 5 th, the temperature agrin fell to $72^{\circ}$, with an casterly current. Several Euglish vessels were seen cruising for whales in latitude $26^{\circ} \mathrm{S}_{m}$ longitude $157^{\circ} \mathrm{E}$. The winds coutinued contrary and light. On the $9 t h$, in longitude $159^{\circ} 43^{\prime}$ E., latilude $26^{\circ} \mathrm{S}_{\text {. }}$ an opportudity oceurred for trying tho decp-sen temperature. At eight hundred and thirty futhoms below the surface, the tempersture had decreased to $46^{\circ}$, that of the surface being $76^{3}$; and the carrent was found setting oas-by-south tualf a nile per hour.

The eurrent was now found aeting to the soithsonth-west, at the rate of half a mile per lionr.

On the IBrh they again attempled to get a deepsea cast, and liad rineteen humbred fathoms of line out; in haling in the line it parted, and nearly seventeen humdred fallioms of it were lost, besitleg the only self-registering thermometer we Jand left in the fiquairou, which put a stop to our experiments. They lad now several days of light. variable winds, with ocensional rain and much lightning and thunder. The islats of Eroos was minde an the 30th of April, and on the lst of May they pased througli the ruefs and joined the squadron.

The present Fing Josiah is one of the sons of Mursui, who was reigning in Cook's time. Tluree of King Josizln's bruthers have preceded him ng rulers of Tonga: these were Tugo Aho, Tubou Ton, and Tubon Maloki. The first reigned but a short time, being put to dentl, by Tubou Ninha, a brotler of the colobrated Finau. Tubou Ninha was afterwards murdered by Tubon Toa, who reignet over the Hapai Islands, Tubou Maloki receiving the title of Kiug of Tongan, or rather Tui Fianatinibolo, or Lord of Kianakabulo, wlite that of Vavin was governed by the younger Finnu, adopted sou of Finas Ulukalalu. This was the state of the islaud at the time of Mnriner'z, or Togi Uummen's risit, A fow manthe after lis departure, linas giod a matural dentl, and was suceveded by his uncle, Finnu Feejee, taring 'Fon Onno to assiat litn. Finnu Feejee was truodered by Mala A piapria, who succecded lim; but bis ambition of oltaining kingly power wis not long satistied, before he was put to denlla by Paunga, a high elsief. The son of Finar Eluknlalu, named Tuabiji, suceceded, but died within a few years, and did not bear a gond elaracter. His dominions were immediately geized upon by Trufnalsau, the present King George, then king of Hapai, the son of Tubou Ton, and grandson of Mumus; and there is now a prospect of thit beconing king of the whole groups. The Tui liarakabolo, Tubou Maloki, was sue- ceeded by the present King Josinh, or Tubou. Hefore the deall of Tubou Maloki, his power had beeme very limited, Tongn itself being distracted by many eisil broils; neither has his successor, liing Josiah, more energy. His domain may now he said to be cireumseribed to the town of Nukunlofn; and if it had not been for the timely nid of Tavfantian, he would in all probnbility cre now have been driven from his kinglom. The son of Tubon Maloki, Mumui, before spoken of, is most thought of as his successor, though agminst auch is powerful competitor as King George he does not stand much chance.

Since lenving the island, in the month of August, whilst onployed in the nejghbouring group (the Feejece), we leszuel that the war in Tonga hat terminated very differently from what lud been antieipated, - in the complete runt of the Christian party, $\mathrm{king}$ George and all his warriors being compelled to fly the fisnad. On the arrival of Coptnin Croker, of H.B.M. sloop Parourite, be warmly interested himbelf in the advancement of the nissionary eause, and deternined to engage in regotintions with the lwesthen; but finding that many diffieulties impeded his pluns, he unfortunately determined to bring matter at onee to an issuc, and demanded that the terms lio dictated should be neceded to by the lonthen within a few hours. To enforee live demand, he landed a large part of lis crew, with oftecrs, and proceeded to the fortress of Bea; only an honr was given its defonders to decide. I nun informed that it has since beell tunlerstood that if a longer time lanil been grmited, they would have neveded to his densurul. Ho was punctunl to his time, and on the ehiefs refusing to surrenter, he made an attack upon the fortress. On lis advasuing near tho gate, he, with many of his oflieers and men, were shot duwn; the survivors suffered a total defeat, aud were obliged to retreat forthwith. The henthen now beane the assailnute, and the Cliristian party, together with the missionaries, were forced to embark, and afterwards landed at Varao; King George was obliged to retire, and Nukualofa was invested by the heathen. Thus ended this religious war, and I cannot but believe that the pre. cipitate zeal of the missionaries was the cause of so disastrous a result. That the lientles wero well disposed to make peace, J am well assured; a little patience and forbenrance, and at the same time encouraging intercourse with their towns and setting then a good example, would lare gradually aud suroly trought atrout the desireil resulta; while to force them to become converts, was a mode of proceeding ealenlated only to excito their ennity and opposition.

The night previous to our eniling, May $3 r d$, two of the Ferjee wamen who thad been smuggled from Favao by Captain Wilson, parddled off is a canoe to the Pencock, entrenting to be received an hoart and conveyed to their own coustry, and with the view of Becuring their object, it was found they lusd thrown away their paddles. The request was deniet, sut Captain Hudson bad new ones at once made for them; they were compelled to enter their eanoe again, and paldled off. They then visited the tender Flying-Fish, and in order to wrevent their being turned off in the same way, they set their coune alrifl. Af it was late at night, they were retnined on board, and sent w the Fincenes 
enty in the manring. Well nuderstnnding, from the interview I had with king George in relation to The Curroncy Lass, his feclings on the subject, (for the abduetion of these very women from the islund of Vavno had been the enuse of the difliculty, I immediately ordered them to be Insded. I did this because I was not willing to liave an appenrariee of inconsistency in the minds of these nuciven, in first blamiug condnet 1 thought unwarrantable in Captain Wilson, and then doing the same act myself. Had I taken any other course, it woubd no doubt have jrovoked nggression upon the first Anerienn vessel that visited any of the ports of this group. My emnmiseration and that of many of the ofticers was exeited at the sight of these poor defenceless erestures, who were desirous to return to their native island, and who had made Buch strenuous elforts to recomplisll their wighes; turt my pubtic duty was too well defirced for me to nllow their tears and entreaties to prevail over higher considerations.

The intercourse between the Feejee and Tonga islanders, has been of late years frequent; tho latter are more inclined to lave their homes than the former, and when a Tongese has once visited the Peejee Group and returns safely, he is looked upon as is traveller. In Tonga thoy consider and look up ta the Peojec islanders as more polished, and likcir oprinions are viewed with much respect; this one not only observes in their conversation, but they slow it in adopting their manners and customs, and the nttention and deference they pay to the opinions of thoso who have visited or belong to that group; from them they ubtain their eanos, and lnve lented the art of sailimg and navignting them; and from the situation of their islands, being more exposed to at surgh ocean, they are probably now better and more adventurong uavigators. This intorcourse is kept up mote partien. Jarly with the rasteri islarta of tho liecjees: at Laliomba we found many of them residing. When
Conk visited this group, little was known of the Fecjees. Thirty jears afterwarile, during the time Mariter resided an the Tonga Islands, the intercourse and information liad become greater and more acenrate; and at tho period of nur risit, we henrd of many things that were passing in that group ns familiar topies; and we found among them many Torsgese who were enjoying the hospitality of their western nejglihours, The prevailing winds aro in fnvour of the intercourse on the side of the Tongese, which may in some measure account for it; nnd the faronr with which they have always been received, and tho flutteriag nechnuts throwe who returned lave given of their reception, may in some mensire nceount for the desire thry always evince to pay the beejee Group a visit. In a rery few yeurs, through the intereourse that will be bunght about by the missionries, there will bo as much passing to and fro between them, as there is now mmong the several islands of ejther groul, which will have a great tendency to advance the eivilization of both.

Previous to my departure, a sailor by the name of Tom Granby desired to have a paseage to the Feejees, and although I entertnined always rnuch suspicion of the ragribonds who frequent the dirferent islands, Tom'e countenance was so very prepossessing, and his modesty as to his caprabilities as $n$ pilot such as to satisfy me that he was not one of the runawnys or convicts; lie was, besidet, as he informed me, a resident of the isinnt of ovolsu. I had already made up my mind that this island should be the first place the squadron stoould go to, on account of ils central position, which, if the harbour proved cosvenienst, offered the best point whence to superintend the duties and to fix my observatony at: 'lon was therefore taken on board, and remained with us duritsg the whale time we were in the Fegjee Group, and I was well satisfed with lim; in short, he did not belie lise counteunuee.

\section{CHAPTER XXII.}

\section{FEEJEE GROUP. ISLAND OF OVOLAU.}

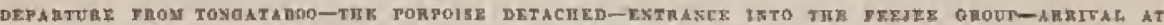

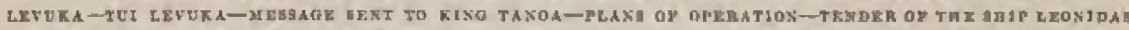

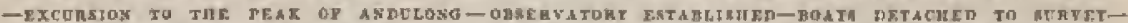

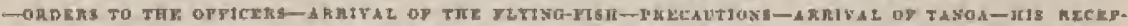

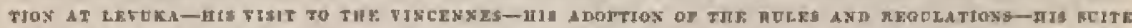

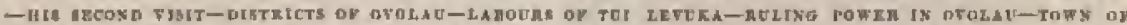

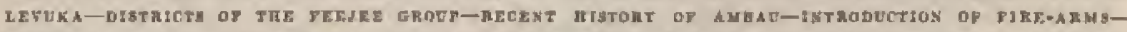

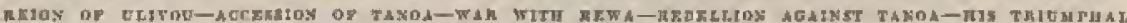

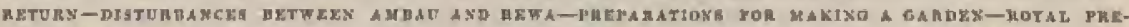

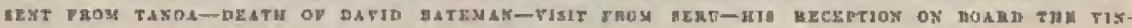
CESSES- VISIT FHOA PADDY COXXEL-HIS NISTORY.

At daylight on the th of May, 1850 , the squadron got under way from the lasbour of Siukualofin, anit passing without the reefs through a narrow passage, safely bore of to the westward under all sail, having the wind from east-north-east. At meridian we laxd the islands of Honga Tonga and Honga Hapai to the north of us; these are both high, and are distant from Tongs twenty-seven miles. On the 5th wo lind a sight of Turtle Island, nat determined it to be in longitude $175^{\circ} 3 \mathrm{Y} \mathrm{W}$, latitude $19^{\circ} 43^{\prime} \mathrm{S} . "$; it has the appeatance of a sinall

- Sibsequent observations by the I'orpoise, place it frt longrituce $178^{\circ} 3 \hat{n}^{\prime}$ is $\mathrm{W}$. latitude $19^{\circ}, 60^{\prime} \mathrm{S}$. 
rusuded knolt. The wind was blowing fresh from the eouth-enst, and after dark I determined to leare-to to await daylight, off the southern and eastern islands of the Feejee Group; this was dove in order to set the Porpoise at lier work Since leaving longa, we lave found uleers prevalent amoug our unen, from the bites they liad receired; they were inflammatory and difficult to cure, pro raifing anong those apparently most healthy;. Just at dawn we mado an island, and at the sanse time a largo saudbank, about half n mile from us; lisul darkness continued fonlf an bour longer, we should have probably been wreeked ppron the latter, ni I did not believe snyscll within fave miles of it. Our unexpected vieinity to it was causud by a strosg current to the norihward.

A 6 a.3. we begnn our observations, snd at eight I made signal to the Porpoise to part exmpany.

We continued onr course with the Pencock and Flying-Fish in enmpany, I hat compiled a chart of the compatratively unknown Bea we were about to traverse; but the weather wag threatening, and from the specimen we had latd in the morring of ite dangers, I thought it would be prudent to liaul off, which I did, at 2 p.M. At five, land was ropoitted aliend, and on the lee bow; it proved to be the island of Tutoin. which I now fond wrs thirty miles out of the positiou assigned it ly former navi. gators. I at once canse to the deterinisation of running iuto the group, fecling assured we shouid Hsus ave much tine, and prolsalsly find stmonther water; the dangers we lad to enteounter in eillyer way wore athout equal. It was now hlowing a fresh gale, which obliged us to take three reefs in the topsails; it is by no mesns a plessunt buasiness to be ruming over unkwown ground, in a dark night, before a brisligale, at the rate of sevely or eight miles an hour. The sea was ursusually plooptorrescent, and the sight was disagreenble with rain aud mists. The Peacoek and Flying- Tish followed 119. The morroing proved fine, hnd at daylight we were within a short distance of the Hinrse-bline Reef, uskanown to suy of us but Tom, who thought we must be at lenst twenty niles [rom it. Hes found ourselves in lie midst of a number of bentuful islands, viz." Guro, Vumun-levu, aryd Somน-somn on our right; Nairai, Ambatiki, ant Mutuku, on the left; whilst Ovolau, Wakaia, and Mokungai, were in front; they wore all girt by white encircling reefs. So beatiful was their aspect, that I could searcely bring my mind to the realizing sense of the well-known fact, that they were the atute of a savage, ferocious, and treacherous race of camibals.

Each islnod lifal its own peculiar beanty, but the cye as well as mind felt more satisfaction in resting upun Ovolau, which as we approached, had moro of the appesrance of civilization about it than the othess; it is also the highest, wost broken, and mont pieturesque. In consequence of light wishds, we lid not succeed in renchug the harbour of Levuka that eveuing, amd pased the night under wry, between Orolau and Waknia. At diaylight on tive Sth of May, we were off the port, mul unade all sail for it. At nine o'clock, being off the entrance, I twok the precaution, as the breaze was light, to hoist the

- In the orthography of the names of the Frejee Grous?, I have followed the promuctation, and nat the true cunetruction of the langringe.
Loats out (hnwing to pates through a pasaga only eight husured feet in width $)$, and sent them alpend to tow. At first it is not a little alarming to npuroseb tliese entrances with a light wisul, and often with a strung eurrent selting in or umt; 1 ht ship rolling and tossing with tho swell as alie nents the reefs, the deep-blue water of the veeall eurling into white foam on thetn, witl no botton until the entance is gajned, when a heautiful and tranquil basis oprens to the view.

The remarkable peculinrity of these coral liarbouss, if so I may call them, is that in ginumg thetn, it is hut an instnut from the time the een is left until security is fortud equal to that of sul artificial dock; this is particulatly the caso with the larlyour of Levukn. The shore wis lined with natives, watching our prongress with their usunl euriusity; sul it was amusing to hesr the shouts of applause that emanated from the crowds nn shire, when they witnesed the men, dreseed all in white, running up the rigging to furl the saila,

In jassing to tho anchnrage, we Raw a tiny bont, in which was David Whiply", one of the priucipal white resildents hese, with une of his naked children. This mail ran away from a ship, commanuled by Iris brother, that was thaling in this group, in eonsequence of tho ill-tretanent lie received on board; he now lus been eighteen years on this ixlasd, and is the prineipsl mas among the whites. He is considered a roynl Imessmiger, or Maticum Ambat, and is muel Inoked uy to by the ehiefs. He speals their language well $;$ is a prudunt trunt. worthy person, and understands the charater of the nalives perfectly: his worth snd excellent clarneter 1 hat loug toond of $\bullet$. He immedintely eame on board to weleome 155 , and after we hari anclingei near the town, lı brought off Tui Levuka, Lite chief of the Levulia town. This diguitury was a stout, weld-anade man, strong and athletie, entirely uaked, with the excephlion of a aennty muro, with long euds of white tapa lassging down before atad behind, and a turban of whito flecey tapa, not uslike tissuc-japer, around lis hend, of enormons size. These turbans designate the chiefs, and frequenty have a small wreath of flowers ower thum, His face was a shining black, loving bees patinted for the oceusion; his countenamec Jitad a gond expreswion, and he seemed, after a fow manents, to be quite at bis ease. As is customary, I nt once gave hin n present of two whale's tecth and two fatlinms of wed cotton cloth, with which be was well satisfied, clnpping his hands several times, which is their mode of expressing thanks Ifie hnir was criaped, with a small wholulane stick or needle, twelve or fourteen inches in leugth, stuck inte it an one side; ha did unt leave me long in doubt as to the tree to wlyich the latter is put, fur it was continually in requisition to Bcrateh his liend, the vernin being not a little troublesome. He was very deairong of doing every thing for mo, and said that aly grmund I wished to oceupy, was It the service of the countrymen of his friend Whiphy.

Ovolat is the principal residence of the white men in the group, to whose general deportmust and gond conduet I must limar testimnny; I turet will wone better dispoed throughout the vorago

- Ile lask, inte nur return, been appoltrier rice conatal for the Feelet Girnup. 
than were found there. I at once engaged them tis become out interpreters during the time we stayed, which afforded us many advantages in communicating with the natives.

A bont thrte hourf after the Vincennes ancliored, the Peacoch entererl; but there wns no news or sign of the Flying-Fisll, nol land alse been seen while the Peacocti was is the ofting. I felt much messiness about her, mare so on necount of the inexperieneed oflicer who luad her in tempornry charge.

I directed tho chief, Tui Levuka, to send a message immediately to Amban, to inform ling Tanon nf my alrival, and desire him to visit me. This was at once assuming nurlority over him, and after the fashion (as I understoorl) of the cunntry ; but it was doubted by sorue whether he would come, ns lie was old, nnd a powerful chief. I thouthlt the expreriment was worlt trving, as, in caso he abeyed, it wimld be considered that he acknowledged tne as his superion, which I thotght tright be bencficial in ense of ally difientty ocentring during our stay ; I lelievel, mareover, that it wonkt ant grently to the respect which tho nit tives would lould us in.

The town of Levulia contains alont forty hotses; it is situsted on the enst side of the jstund of Orolats, in a quiet ard penceful valley, strrourded by a dense grove of enetra-nut nfld litearj fruit treers, with a fine stream of fresh and pure water nunting tlurusgh it th the leach; high, broken, volesuic peaks rises to the west, forming the buckgroumh.

I'le frames of elue liouses ate built of the treadfruit tree, and are filled in witls reeds, whilat the ruof is covered with a thatch of the wild sugarcanc. 'Tluey are usually oblong jim rlape, and frum tweaty to twenty-five feet in leugth by tifteen is brendih.

The most conspieuons вnก' remarkable artucture is the bure, or spirit-house, which is luilt on a raised and walleil mound: lits proportions sire excectingly uncunth, being nearly twice as ligh as it is broad at its lase, and forming to situgular, silarp-peaked ruof; the fisce of timber serving for the ridge-pule, projects thre or four foet at ench euil, is covered with numbers of white shells (ovula cypres), nnit lins two long poles or" spears crossing it at right angles, At the lermination of the thutehing, the roofs of all the house's are ahout a fout thick, anul project eighteen inelzes or I wo feet, forming eaves, which secure them from the wot. For the most part they hrve two dootr, and a fireplace in the eentre, composed of a few stomes. I'he furuture coumists of a few toxes, muta, beveral lnrge elny jars, and many drinking ressels, the mantufncture of pottery being extensively carried on lyy them. The slerpung-julace is genernily seteened off, and inised ubout a font above the other prort of the lfoor.

Haviug setted ilefinitively the moric of oneration I intended to pursue in sarveying the group, I was desirus of fixing somo of the matu points in my own minul, as well as in that of the officers, ami therefore ordered a large party from each shin to be prepured to accompary me on the following momi. ing, to one of the high preaks of the ighari, ealled Andulong, taking with us the barumeteris, fic., for mensuring its nltitude. I likewise issued an orler, directing offiecrs who left the ship for any puspose to bo armed; being well nutisfied that every pre- cation ought to be taken, in order to prevent surprise in nny shape; I also inipressed upon all the necessity of citcumspection, ant of keeping them. selves on their guard, which, as 1 learti from the few incidents related to ne hy Whippy and others, was highly neetsary ; orders were also given to prepnre the buata of both ships for surveying duties.

I understond that about forty whites had taken up their residence here; but we only found twelve, who were slt married to native worren, and generally had large families.

We fornd lying at anclior here a smali sloup, about the size of a long-boat, called "Who'd liave thunghis it t"* a tender to the sluip Leunidus, Captain Eagleston, whos was at suother islaud euring the lichede-mar ; sto was is charge of his first oflieer, Mr. Winn, who las bees shout trading for tortuise-shell at the different islands. He gepurted to me tlant one of lis men liad leen entices from the bont, and lind been nurdered, and probubly eaten : this was sail tu have oceurred neap Muthunts, on the north silte of Yanua-levu. It nppenrend that Mr. Winn, with mily four or five men, lat lecu trading in this small bont, for vessed she could not be called, arunid the gronu; they land with them a small shiff or pult, ctipatile of halditug otsly one tuan. In this nime of the crew hast been sent on shore, for the purpinge of ascertaining whetluer the latives had any thing to dispowe of. On litg landing, he was led up from the beach, and never returned. 'This incilust elahed our atiention afterwards, and nur procedings in relation to it will be spoken of in their proper plince.

Un the morsiug of the Dth, the wealler proved fine, and at half-past fievess we all werat un sliore with our instruments. Otders were left nitl, the ship to fire guos, on a signal being given frnti the trop of Audulngg. I put up both of the barometers, sul mato several comparisons, and then left onc under chargo of an ofticer to make lable-haurly olservatious. We set off for the peak of Andisleng, apperently but a short lour's walls. Our party cuasisted of abuut twenty-five oflicery and the naturalists, all intent upoint their different branclus of duty. Being estirely unused to so fatiguing a chimb, sonse gave un, and were obliged to reluris; the strungest of yo fond no little exertion necestary to aretcome the diffeulties which beset our path : every sow and then a perpendi. cular rive of fiftere or twenty fect wng to be ascendut, then a narrow rillge to be erosed, and ugain It descent into a deep ravine; the wlole was clothed witls rines at intervals, and the walking was very precurions, from the nambers of roots and slimery tnud we encuntered ; water contiumaliy bubbled neross our path fonm numerous rills that were hurrying beadlong down the ravines. The last part of the uswent was Elarp and steep, having precipiees of several hussdreds of fect un enclis side of 11*. On forsing up the path, I tatw our nntire guides each pull a leaf when they eame to n spot, and throw it down; on incuiry, Whippy told me it whe the place where a Iman had been clubbed: this was considered ag an offoring of regpect to litu, aul, if not performed, they have a motion Wrey wil! sown be killed themselves. Judging from the number of places in which theso nioneruents were made, many victims lave suffered in this 
way. The path we followed orer the tmountain wis the ligh road to the interior towns, and the inbabitants of these nountains have the chnracter nmong the earuibal poprelntion of the eost, of being very savage! Just before nonon, we reached the top of Andulong, nul suceseded in getting the meridian altilude. Tho gevere that nuw presented itself was truly beantiful ; the pricturenque ralleya of the island of Ovulam lay in full view beneath us, exhibiting here and there sunts of culivated ground, witla growes of cocon-nuts and bread-fruit; the towns porched upon apparently inacoussible spots, overhouking their small domains; the sereral pesks rising arouna, all eut atd broken in the mist grotesque forms, only one of which, that of Dille. uxolate, overtopped the ane on which wo were, being about two hundred foet thiglier; around th in the distnace, we Inal the variuts isliuds of the group, and the fantastic needle-shinperl peaks of Vanua-lowu wero distinetly seru, allbough at the distance of sixty miles. T'lue detached reefis could be staced for milen, lyy the water breaking on them, until they were lost in the laze. The rquadrum lay quietly beuseath us, and every danger that eould in any way aflect the safuty of in ressel was as this. tinetly marked as thougli it had been already put upun our charts, Each offieor was now directed to ohaerve a series of angles between all the points, freaks, and islatids, aud to enter the uames of them: these were obtainesl thrught the interyreters. The lincunoter was set up, and observations usade. 'The signal was now given, upros whicls guns were fired from the ressel, while w' noted the tine that elnped betweens sceing the thash and liearisg the sound. Thu angles of depremion were alow Luken of ail objects. "l'he restils of these different methods gare the altitude of $A$ uduleng two thousand and beventy fect.

We remained on the summit until nenr gurset, and abtained much knowledge reintive to the situation of all the islnuls aud reefs that lay around us, which I futsud of muels service in this proggtess of out work.

During our slay on Andulang, a native eane up, who appeared to be under the intltence of grent fur; he aeported that one of the officess had fallen unwn, and that sonnthisg was the malter with hitr. On being asked why lie left lim, lie told us thot the eloief laad said $\vec{G}-\mathrm{a} d-\mathrm{n}$, and that he was afraill that ho would lifl him. Lieutenant Ennons went down with hirn, atud after a olort descent, he funnd Mr. Edd lying quite exhnusud near tho path, and it wus with difficuly loo was cuabled to reselı the towns.

T'ho descent grovied more toilsone and dangerous than the aseent; the slipperiness of the puth frechuensly brought us in enntact witl sharp roveks. I hive selitom witnessed a party so helpliss as

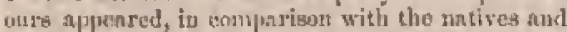
whito jerideuts, who ynu aver the rocks like goals. Datkiness overtwok us hefure wo reached the town; muny of the natires, however, brought tordien of dried cocon-mut leaves to livith is on uur way, and we renched our respeetive elijps without aceident, thungls tnucls fatigued. Many' new specinens were sulded to our collections, and 1 believe all felt gra. tified in lasing had an ogpurtunity of viewing from ne elerred is point this labyristle of isinuds, reefs, and sunl.en sloosts.

The islaud of Ovolau is ejght miles in lengtli, north and soubl, by seven in tarendib, east and west; it is of vuleanic formzation, aud its rucks aro cemposed of a conglonernto or judding-stono; it is hight azad rouged throughunt. The valleys extend only in short distance into the interjor, ond lesve but little level ground; they are, lwwever, exceedingly fertile, with a deep and rich soil, mu are well cultivated. Its harluutrs are all furmed by the reefs, and were it not for these, there woulil be lut few in the group; that of Levulia is safe, laas good lisilding-ground, and is ensy of necess.

On the l0th, the Flying-l'isht wag stilt missing.

Feoliug satislied that Onolux was the most suitable pluee for my juspoke, I selected a sice for my olservatory on is mojecting insulatert print, albout thirty feet abuve the beach, on which was subticient rom to accominodute ontr tents und liouses I slso obtained in few acres of gruund from the elifef, for the purpose of mianting a garden, which was well feneed in, and placed under the direetion of aur lorticutturiat, Mr. Brnckesırilge.

On tla $11 \mathrm{tl}$, she instrumenth, tents, \&e., were lamled and put up. '['/1日e surprise of the natives was extremely great to find it village or tow ll, hs they culled it, orected in a few hours, and every thing in arder: the guards on pust to prevent thil iutrusiun must exeited thejr eurjogity.

All the seevesnry nitrnngenenty laving been macle, the dautuch and first eutter of the Viueenme, under Lientemants Mlden, linux, Midsbipman Iterury, and Assistant-Surgeon Whitule, were de-

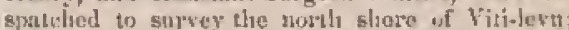
the lanush sund lirst wutter of the Pencocli, utuler

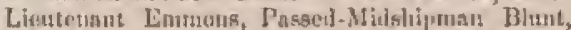
sund Mr. Dyes, fu examine nut] nurvey the siuth alore, visithe Yiwn, Aubu, mul lews, the missionary posts: Clagulais Elliott wam of the latter party, that fie miglit be enabled (1) gasther information frotn these tebtablisliments; pot wh, who acted as interpieters, wete ecit will botl. Orders, of which the fullowing is an extrnet, were issuel so the offecers in writing, in relatioss to lle sutives, pminting out to them the necessity of watedifut. 11ees.

- You will observe the following instructions very partieularly, and in no cese depart from them, usuless it is for the preservation of jour jurty.

" lst. You will nvoid laudimg any where un the

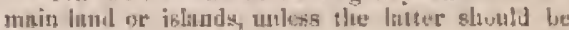
uninterbiten.

"2at. Every preenution must be obsurved in treating with these mativen, and an untive mast be suffored to come alongside or ness your bats, without yon* Loajoling-inettings bejing u[1; all trading nust be carjied on uver the sterth of your boat, aud your artns and howikxery ready to repel attack.

"Yol. Yon will nrond any disputes with them, and never be off your guard, or free from sngpicion; they are in no case to be tristed.

4if 4 h. lour two honts must never le separated nt night, but anchened so cluse together as pusssilble.

"You will alwaye keep the honts witlin signal distanee of each uiber, neparating then in castem of extrerue vecessity only for a short time."

Tha Flying-Fisil now matie her appenranee, to nuy great relief. Her lebys had boen owiay to lier Luving run fon tho shis, the night nfter sho n 2 


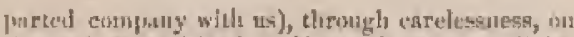
the reef ofl the islard of Nuirai, in lire nuonlight, w ith the reef full in viow; lwe she reumined some hours, laving had a narrow esenpe from totnl wreek; she, liowever, only loat a part of her fulse keel. Lisentenant Carr, the firat-lieutenant of the Yincennes, was inmedintely put ju command of her. The Peacock and Flying-Fiah were now ordered to prepare for sea with all despatel.

I tnust eusferes I folt grent mnxiefy for the safety of our parties in the lonts, $\Delta$ and $i$ sued the foregoing ordels very partieularly, in order to aroid sll misпрpreltention, and to leave as little as prasible to the discretion of the officers who had charke of the bonts. They were all well artuel, and lie lonts were provided with tronrding-nettings; for I felt Eatisfied that any inattention or want of care would inevitably lead to the destruction, if wot of the whole, at least some of the party: the aceilent that had receutly occurred to the tersder of the I.emidas, showed that the least degree of corntidence reposed in the tatires was attended with great risk, and that an treacherong a people were not to be trusted uarer nuy circumstanees. A departure from these instructions, anil an vumles confulence, reaulting from having for a Jong time eserped the matry dungers encountered, was, I regret to say, the eause of the losk we met witli before leaving this gromp, and tauglit, when tos tate, tho necessity of obeying stricly the orders of their commnnting offieer, whether absent or present.

On the 12th, whilst magaed at the observatory, the carne of Tamoa, the king of Ambau, was dis. envered rounding the southeris puint of the islasut: it bad a maguilicent appearanes, with its immense sait of white mants ; the pennnnts streaning from its yard, denoted it at once as belouging to surne great elief. It was a fit acconnpanisment to the nugnifient secnery arutud, and advaned raphilly anil gracefully along; it wam a cingle cunoe, one lıüdred foet in length, with an outrigger of large size, ormanented will a great umber (two thousand five hundred) of the cyprea ovula sheils ; ita velocity was almost inconcerwale, and erary one was struck will the selrojtmess with which is was marnged and landed on tive luench *

Tranos disemhatkerl, aceomprnied loy his nttendants, whor se generally 'l'tugn men, forty of whom had the lirection and sailing of his canoen. Shortly after honding, he was met by Mir. Vanderford, who had formerly been shipwreekel here, and who thal lived under his protection for ten months. Thu meeting was a curious anc : the old elioe walked up to him, and strod lonking, first on one gite and then on the other, without noticiug lim, and pretending that he dint sot see him ; Mr. Vamlerford then walked un $t$ lisin, clapped him on the lask, and ealied him by name, when they thoth began Inughing henrtily. Mr. Vauderfurd spoke macir of the kindness of T"anon to hum during lhis resilenee sumeng the reople of Ambru: it is true, that he nobbed him of every thing lut his skin, but then he protected him frum the nttacks of otlerk. Shortly afterwada a larige double canne arrived,

- I was told that Tanon frequently amunes lifmolf, whea asiling, by running town camoes, learink thase who belong in them to zecoye? their eanue and prmerty the beab way they ran. entirely nanned by 'louga penple, unles their twu chicfs, Lajikn and Tulou Tutni, whos wre buth of them, with about five tumbed of their fullowers, paying Tatroa a visit at Ambau; they were the sons of Tubou Nintr, and neplews of the celebrated Finau. Tubou Totai tokl me that he nnd his hrothers hat beet resiling severnl years in the Fecjees; that they were empilnyed building eanues on some of the eastern islamlk, and that it genemaly touk them seven years from the tisne they left Tonga, to finikh then and returu.

Truna tunk up lyis abode in the mbure, ar couneil-liouse, which is the ylace where all straugers are entertained. Here lie seated laimself, with his principal attenlants about him, when his oratr, or prime minister, made a complimentary oratical, at the ent of which a clapping of liantes took plase; to this oration one of the primeipal soswspepte replied. This is the usunl mode of conducting the ccremony : the guest, the moment he arrives, gives a endensed account of all his doings sinee they last sas encli other, ending with many complimenta is which the host replies in equally finttering tertas, wishoug him all kinds of lappriness und prosprerity. This ceremony being orer, Thuna despatched David Whipps on binnd to inform mo of his arrival, w/rct 1 immediately sent bieutenant Carr to eall upon lime and inform him that tuy loat would be at the slone in the morniag for lium. Foud was tion bronght by the Levukians, necurdiug to their native custum: it consistent uf two large haskets contaiuing cach a roasted pig, yanis, taro, bread-fruit, de, whiels were plined before the company; this present was necrmpanied by another Epeech, to which the prime minister again replied; then came clapping of hands, nut the fenet eutod with ata drinling.

On the foslthwing morning, when the bout lundenl, the thrce clices wore waiting on the trakl, and all eame on bonrd, the large earioe following the batt; every thing was prepred to give then a most marked reception, excepling the salute. 'Tanos was the first to motmat the side of the sluph, where I was ready to receive hill, with the officers at the gankway, When he renelsed the deck, he was evidently much astonished, partientarly when lo anw the marines, with eleir muskets, prerenting arms, and 8o many" oftiecrs. "The novel siglit, to him, of $19 y$ large Newfoundand dog, Sydncy, who did not altntaether like the satle appearance of his majesty, the noise of the drum and hoatswain"s pipe, eombined to enuse him some alarm, and he evineed a disposi. tion to rotirs, kcering limself close to the ship's side. He was, after the fashion of his group, almost naked, lsaving a gonall muro pased a round his loing, with long cinds to it, and a harge turban of

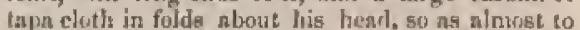
hide the expression of this comuteunce; his face wis bedaubed with oil nnd jvory-blact, as were also his lang kiearil and mustacheg, the natural hte of which I understood was quite grny. From his begrimed frok he has obtrined the sobriquen of "Old sinuff", among the whites; he is nbout sixty-fivo yents old, tall, slender, and rather beut by age; on his breast, hanging from this seck, he wore au ornament matlo of rother-of-perrl, tortoise-shelt, and ivory, not very nently put togetlier, and as large as a dimner. plate (called diva ndina) ; on his arms he bad shell arullets (called ygato), siate of tho trochus-shell, by grinding then down to the furm of rings; lis countenumee was indicative of intelligente nud 
shrewduess, as far as it conla be scen; his mind is nald to be quite netive; the is nhout five feet ten inches in beight, and of smill frame; his fentures nre rather inclined to the Europenn mould, and tot the least allied to the negrn; his lasir is erispy; he speals through his nose, wr ratler ns if he lond lost lis palate; his londy is, like that of all his people, remarkably bairy. After presentimg lius to the oflieers, arut reeeiving the rest of his suite, I lod him to the nfter jart of the deck, where unats were laid down, and we all sarated ousclyes to hold a council; for I whs auxious to finish first the husiness for which I had particularly souglat tho interview; this was to procure the adoption of rules and regulations for the intercourse with foreign vesecls, similar to those established in the Samoan Gronp the yenr ureereding. David Whippy became my intarpreter, but 'Tanos lad too much dignity ahout him to receive the interpretation thruugh Wlippy alone, although the understool all that he said perfectly, for Whippy speaks their language well ; but he had his "speedi-explaining eounsel]or," Malani-vanua Vakstuduna, or prime minister, who was a renarkably grod-looking, inwelligent man. Whipey gave his uane as KioroLumrasnlu, and anil that he lad great indluence with the king. It was amusilug to ree their mode of conducting the business, and to understant that "l'anna's diguity would be offersed by loblding discourse with otu friend Whippy as interpreter; not, however, ( $n$ s it was explained to me by Tubul Totni,) from any objection Jie liad to Whijpy, but it would be derogatory to his rask and station.

On the production of the rules and regulations, 'T'snoa secmed rattier confuren, and at fiıt nispeared dull nnd stupid; this I imputes to his ava ilrinking, in which they lund al! indulged to excess the nirlit before. He did not seern to compreliend the object of them, or as the interpretes expreased it, "could not eake the iden." This is not to be wondered at, when it is considered that this was the first net of the kind he harl been called npon to dn. Tubon Totai being a traveller of rome note, cendily understood their meaning, and through his explanations 'Tnnos soon comprehended the object, and listened with attention (his whole suite sitting around) th the reading of them, sentenee by sentence; after which he made signs of understunding them, sud gave his approval and consent to luving them established, and the next day signed them, by making his mark. That which he was ti keop I had solled up and put into a bright roums tin cotse, which ho secused to regard with gresi pride.

Altiough I did sw anticipate much irumedinte goud from these regulitiong, yet I was well satisfied they would be of use in rutraining the natives as well as masters of slipes, and in securiug a better understanding betwoen them; at any rate it was a beginting, and would make then feel we were desirus of duing then justice. I talked to him much, through the inlurpreter, of the neessity of prolecting the whites, sud of gunislisg thuse who mulest and take frrmen then their guods is case of staipwreck. He listewed to ne very patiestly, and said, "lac had always done so: that my advice was very" gond, but he did not need it; that I must give plenty of it to his son Sert, god talk liarel tu lim; thrt tie would in a sloort time be king, and neeled 13."
We now proceederd to show them the ship. Tarnot expressed great astonishment at the wheel, und the ninnser of steering our large canoe or man. of-war. I told hin I was going to nrder some guns to he fired with balls, when he immediately expressed his joy al it, saying that Jie thought I was offended with hirs, from iny not firing when he eame on Lratal. On my tellirg lim it was nat 80, lut that he must consiles it more homourable to hitu to fire halls, the was well satistied. It was amusing to seo the curiosicy exeited among them all, whon they understuod the large puns were to be firod. On tlue firing taking jilaer, luey all made nn exelamation of surprise and setonislimentfollowed with a cluck of the tongue in a high key, purting their finguse to the mostit, asd frattug it after the fashion of elvildren, or one of our own Indians in giving the war-whonj. Tanoa would jot at first look it the ball flying along and tlirnw. ing up the water. When the seend was fired, he ultered the snme matks of surprige as the rest; and after the third, be begged that no more sliould be fired, as he was amply satisfied will the honnur, and the nuise alurust distracted lin. As they went about the ship, when they saw any thing that pleased them, tlogy would say-vi naka, vi uaka. In expressing their matisfaction for unany thiuga, they repeat the words vi uaka several times very quickly.

- Suitable presents were now distributed to Tunoa and suite, consisting of shinwls, axes, necordions, jlane-jruns, whinles' tectli, and a variety of other nrticles, atnong which was a box of Windsor sonp, tobnceo, a musliet, watch, \&o. These were received with clapping of liands, their modo of roturuing thanks. It was my intention to bave lat the foskt of rice-bread and nolases on hoard, but I found their number's so treat clunt I determined on sending it on sliore, and only trented them to some weak whiskey and water in lien of aqn, with which they were nuch plinsed. The marines were put through their exereises, narehed and connter. natrelsed to the mueic of the drtum and fife, which detighted them extremely. After being three honrs on bonrd, hearing thint the provisions for the feast had been gent on shore, they desired to degart, and were again landed. The Tongese sang their Irost-song at they fonlled his canoe; but this custrm, aceording to Whippy, is not jurnetised by the Feejees.

1 lave ucarcely geen a fincr-looking set of men thun conposed the suito of Tunon. There was a great contrast betweon the Tungese and Feejees; itse forner being light mulattoes, while tho latter were quite bluck: their wlule unke seemed to point out a different origin. The T"ongese have outl juints, nut well-developed nod rourkled nusetes, while the Feejees' limbs are latre and museular; the latter rre slender in body, and aptyarently inured to had fare and living. The difference in wanuer xas equally' great: fu the Tongese there wats a native grnec, eumbined will fine forms, and an expression and carriage as if eduented ; whilst there was an air of power and independence in the Feejees, that male them clain nttentiun. Tlusy at unce etrike otie ns peculins, and unlike the Poly usekian natives, having a great deul of activity Lutle of minal and trody; this may be owing, is a great mensure, to their conatant wars, mal the rweessity of their ljcing contisually on the nlert, to 
prevent surpriae. It was pleasant to look upon the Tungeae, but I felt more interest in the Feejees; the cuntrast was somewhat like that observable between at weil-bred gentleunan and a boor.

After the king got on shore, they hul much taik at the mbure-house, upou all thy had seen, aud amoug rithet tlzingu, lie renuarked, "that my men nitglit be goo] warrors, but they walked very much like Mnseovy dneks," a bird of which they have numabers.

Tuna sent me word he would liko to come and see things withoul cerenumy, to which I restily consenteil. The next day he eame on boaril, as he said, to look and sce for himself; the stayed somo haurs. When he enterer the catin, I was pouring out sone mereury for my artificint horizon, of which 1 gave him soveral glubules in his londi. He complained of their being hor, nod amused limadf for a long time in trying to pinch them up, whish of course lie formd it irypossible to do, and showed some vexation on being follod, nipping his fisgers trogether with great vehemenee to eatelis the metrs. His actions resembled thuse of a monkey he kent lorking at lis fingers, anil seemed ssto. nished that they were not wet, and could isut the made to urderstatyd how it cunlis wet a button, (which I silvered for him.) and not lis fingers. He talkerl a great denl of tho regulatious be land signed. I was desirous of knuwing whether bo fully understond them, which I found ho did. - I then asked him if it would not he better for his sul Sern to sign then also, as he is understond to tro the acting chief ; be anid "nn," that lis signing was quite suthicient, and unde them binding on al] the dependencies of Ambru. Ho tesired me, when his son Suru paisl ne a visit, to talk harrl til him, and give lim plenty of good advice, for lie was a young tann, and frisky ; but ho himself was whl, and saw things tliat were goot and bat. He sand Seru would visit me in a fow days, when he retursed, as they conld not both leuve Ambau at the same time.

The observatory ituties wero now commeneed, and Lieutonant Perry and Mr. Eld were ordered to assist me. I trad, while thus emplnyed, smple time to get information from David Whippy, who secmed not only to have acquired the langunge perfectly, but also a goor knowledge of the customs, manners, and habits of the natives.

Ovulus is divided into four districts, viz. Levukn on the east, Fokambon on the south-west, Barita on the south-east, and Vaki Levuka on the nurthwest; besides these, there is the intering or momtailious region, collod by the natives hivini. Luruka is motri to the ehiefs of Ambau ; FokasnInsu and Darita are ygali to the same power, but Vaki Levuka is ygali to Levuka, whilst ure mountniusus regions are independent and predatory, The term mbati signifies allies, or being under provection, though nut actually subjoet to it. Y'gali expresses that they are subjects, asd compelled to pay tribute yearly, or obliged to satisfy the demands of the ehiefs, whenerer inade upmil them.

Tui levula is the principal ebief of Ovotan; his anthority extench over eiglit towns on the cast side. He is very friendly to the whites, and is represented by them to be a kind-hested arul larnest eluicf: he is between forty and fifty yenrs of age, and has a pleasing enurtennec ; he rules lis viflago witl great popularity. It was amusing to see his hewilderment in attending to the rarious duties and offices he had to perform, in providing tino large supplies of fond, coneisting of yans, taro, se., that wero required for our usa ; he was, how. ever, very industrions, atud by the ais of Whipps", got through very well, llough witl much fear snd trembling, lest he sluould be lach neconntable for any theft or lepredations committel on our proporily, or accilent to our men, is the various oeclspatiuns tint were all going forward at the same titue, eotsisting of watering, woolling, digging gardens, making enclnsures, huilding, as he kaid, trwis, holling markets, and tradiug alt day lobig for spears, clubs, whells, \&c. ; lie lisd great fenrs, ton, of exciting the jenlouky of the Ambals chiefs, who he judged woulit not like to see tlae alvantages he was reaping from our lengthenenl stay, which would iaturally enough bring their displeasure upon hin. I found litn of great nse, and was iu the halit of receiving from fim almost daily, visits the tho observatury, sa that when Whippy was at $n$ loss for any information relative to the islands, T'ui Leruka wns slways at hand to supply it.

The rest of the island is under the $A$ mban chliefs, or as they express it, ygali to Ansbu, execptiag the tmountaineers, who are ensily brumglit ovir to fight ou any sile, and are, from all geconts, fruc farages. Tui Levuka has never theen propesly installeil iuto office, althougi fromt bis eunruge and talent as a leader, he is highly respected. The cireunstance which lias prevented this ceremony from taking place was, that the Ambau chicos succted bul ly sttatagem in getting posatssion of Orolau about fifteen yearg ago, or in 1825 , before wlyich time it had belonged to Vernta, witl wheh $A$ mbau was at wnr. The Verata chices liad been always in the habit of installing the cliefn, but since they have lost Ovulail, they reluso to perform the rite, and the Ambau chiefs will not exereise it, on acenutit of religions tread, nrid the fear of offenditug their gorts.

Theislands of Wakaia and Mokungai, wear that of Orolau, nre suder" 'Tui Levuka ; they have but few iubalitanss. Tui Levula's eldest yon is the chiof of Wakain.

The town of Leruka is nuch larger than ont wauld itnmgine on secing it fromt the water. Many of the honses are situated on the side of the hili Its natural position is pretty: it has a fine broti running through it, coning from the gorge in the mountuin, the water of which is nucle great use of for irrignting the taro-pafches, which, with their yam-grounds, claim the principal attentios of the inhalitunts: the matives constantly bathe in it, and are remarkably cleanly in their persons; the evident plenstre they take in the bats is even shared by those who see then sporting in the water.

The Feejeo Group is composed of seven districts, and is under as many frincipal chiefs, viz. :
1st. Ambsu.
2nil. Hewa,
Ird. Yerala.
4th. Mulluuath.
sth. Sotnu-somu.
6th. Ninitasirt.
7th. Mluma.

All the minor chiefs on the different islanis are more or less connected or subject to one of these, and as the one party or the other prevnils in their ware, they eliange masters. Wur is the constant occuration of the natives, and engrosses all their time and thouglits. 
Ambau is now the most powerfal of these dis. tricts, although it is it itself but a small island on the cosst, and connected witl Vitilevu; but it is the resilence of most of the grent cluiels, and, as I lave before observed, Turns, the most powerfin. clatef of all the islands, lives there. The original inlanbisnts of Anbaus were called Kả Levuka, and alte of 'Tongh desecent. During the absence of most of the natives oul in tradiug royage to Lakemba, tho natives of Moturiki, a neiglibosiring island, made a descent upou Arubu, and took possossion of it, ever since which the liai Levuka liave remained a broken panple: they still retain their originul nasuc, but ate now only wasdering tralers; they larve no fixed planee of residener, and are sonnewhat of the chnsuster of the Jews. They reside principally at Laliemba, Somu-8nmu, Vum, aral oecessionally at ather istands. Most of the exchange trade is in their hands; their hereditary elsiof rides at Lakemba; they are juucl respected, and when they visit $A$ nabu, they are trented with the lyest of every thing, ju aeknowledgmest of their uriginal riplit to the soil. At Ambau there are tow two claseses, one known by the natue of his Anban, or original penple of Anilsau, nath the other as lini Lasikan, who were introducel from a Emul] island near liantayn, nome sixty years sinee, to fisls for the chicfs; these are considered as inferior to Kni Ambau, lut are not exnctly slaves. About eight years thefore our arrival, disseusions aroso between these two clnsses, which resulted in Tranos's being expelled, and obliged to seck refuge in anotles part of his dominions.

Accrrling to Whipys, at the commencement of the vresent centwry, Banivj ruled at $A$ nobur ; he wns suceeded by his son Uliwn. At this time Verata was the princinal city of the Feejees, and its elices held the rule: tlis city or town is about eiglut uniles from Ambau, on Vilileru; the islands of Ovolau, Goro, Ambatilit, Angau, and others were subject io it, as was also Rewa. The introduction of fire-arms brought about a great elsange of power; this happered in the yent 1309 . The brig Bliza was wrecked on the reef nff Nairai, and had hoth guns and powder on board. Naitaj was at this time a deprendency of Aulunu, and many of the erew, in order to preserve their lives, showed tho vatives the use of (to them) the jow instrument. Among the crew was a Swede, called Charley Snvare, who acted a very conspicuons part in the group for some few years. Tliese men joined the Anbutu people, instrueted them in the use of the musket, and assisted then in theit wars. The clitef of Ambau was at that time Ulirou, who gladly arailed himself of their services, granting them many privileges; amoug others, it is said tuat Clarley Savare laad a liundred wives! Taking adsnntage of all the means lut now possessed to extent his own power mud reduce that of Verata, lie finally succeeded, eilher by fighting or intrigue, in cutting off all its dependencies, lenving the clice of Verua conly his town to rule over.

In the carly part of Ulivou's reign a cursspiracy brolie out against him, but lo discoverced it, and was able to expel the rebels from Amban. Tliey fled to Rewa, where they made some show of resistance; lie Jowever overeame them. They then took refuge on Goro, where he again sought them, pursued them to Snmu-somu, and ilrove shetn thence. Their next step was to go to Laliemba, in order to collect a large flent of enuoes and riclies, for the purjuse of gaining allies un Vitilesu; but they were agail purtued, and being met with at sea, were compliletely destroyed. I'his fully estatbliahed Utivou's authurity, astl the latter part of his reign whs unnurked by nus disturlumees of rebellion against lifs rule. He died in Ifi2n. Tanoa, his bruther, the present king, was at this tine at Lalicurbar, (nz one of the eastern islands, engaged, according to Whippy, in building a large canoe, which he naned Nidnutivio (the vin-leaf), a large phant of the arums species. When the news reached him the innsediately cmbarked for $\Lambda \mathrm{n}$ lan, susd on his arrival found nll the chicfs lisposed to make lim king. It is said sliat he at first refuseld the dignity, lest "they should malie a fool of him ;" but lyy promises and persut. sinu tie was induced to accede. l'jefarations wero aceordingly male to install him. This ecremony is verformed by tho Levuka penple, the origina inlalitante of $\mathrm{Ambau}$, uniting with those of fiumba, inimbiting a town near Kinmba Point, the most ensterm proint of Witilevn, and about ten miles esat of Ambau. As sonn as the clivefa of Ambau Jave elected a king, they make a grand ara party, and the first cup is liainded to the newhy-clected chief, who receives the title of Funiralu. Some time niter this, the Kumba and Levula jenple are called in to make the installation, and confer the title of rovalty. It is related, that while the preparations for this ceremuny were going on, the chiefs of Ambau were restless, and determined to make war upกu Rewa, n place always in rivalry; alsout fifteen miles disiant from Amluan, to the souti. Tanea, liowever, was well disposel townrds the people of this district, being a Vasu of Rewa. There are tlaree winds of Vnsus, Yasu-togai, Visulevu, and Vasu. The first is the lighlest title, and is derived from the mother being qucen of Ambu. Vastaleve is where the mother is matried to one of the great clicefs of Rewn, Somu-somu, ur Minthuata, and the name of "Vasu extends jot cinly" to the minor chiefs, but also down to the commou penple. It confers riglits and priviteges of great extent, and is exclusively derived from the mother being a ligh chicf or wifo of some of the reiguing kings. It gives the person at right to seize ution and appropriate tu his own use any thing helongitı to sa inhabitant of his mother's native place, and even the privilege of talking things from the sovereign litmeclf, and this withont resistnnce, dispule, os hesitation, however much furized or valuale the article nay be. In the conrse of this markative, some inatanecs of the exercise of this power will he related. Tamon thereforo nael alt his efforts to prevent an outbreak, but witlsuut success, and he was compelled to carry on the war. He, however, secretly gave enenuragement, and, it is said, even assistance, to the opposte party; this beconing kmown, produced nuseht difficuley and discontent among the Ambar chices and jeople. Notwitbstanding this, he at longth contrived to brimg alont a truce, aud isvited many of the Jewa chiefs and reople to visit him, whons he received with great distisctiou. This inceneed Jis new subjects very much: and on his prosentisg to the late cuemy lis new and large canoe, Ndranuivio, their indignation was freatly increased, and causod some of ibeun even to criter into a plot to murder him. Annong the conspirators were tise head chiefs, Seru 
"Limon, Komaivunindava, Mars, and Dahrdan, of Auldan, Nigindrakete, chiof of Nikelo, ant Misomalıs, of Viwn. Thnos, ou being ndvised of this, tork uis menns to frusteato their plans openly, but appears to have been sonewhat on his guard.

In the third year of his reign, whilist on a visit to Ovolus to attend to his plantation of yutns, the rebellinn broke out, of which, lie was snon advised, and fled to Goro, where his encmies followed him; but he continued his Hight to Sumu-gomu, the poople of which hal been always his friends and supporters. Hlere he found protection, bis defenters being two numerous for his enemies. The einspirators tried, however, to urge upon thesn the propiriety of giving up their king, saying that they only degired he should retura anil reign aver them; but the peuple of Somn-gomn deemed lis too shallow a pretence to bo listened to. After Tianon's expulsion, the reluels installed his brother Komainsknrinakula as king. Tanon renuiated under the protection of the chief of Somu-somu fin throe years, in gratitude for which lo made over to him all the wibutsard istauds, viz. Lakemba, Naian, sc. During all this period, Taros was carrying on a sort of warfare against the rebela, with slie nid of the iatives of the eastern group and llose of Fewa, who rembined faisliful to him, eneouraging thet all th his power, collectiug lis reveutue fron the forneer, which he distributed hountifully smong his mdherentos, and buyitz over others to lis interests.

As Trum was almat to sail for Lakembn, word wha bronglit to him, tlat his neplicw, enlled Nona, regiding on Naiat, $n$ neiglbouring island, had been bribed by the eliefs to put hisi to desth. He therefore, on his way, stopped at Nainu, and when his neplicw appronched tim under the gasise of friendship, Tamna at onee enused him, witl all his family and adherents, to be sumen and put to death.

'L'anna, funding lis strength incrensing, concluded (1) prosectste the war with more activity. In order to do 50, after haring first collected ali his means, lie remosed to Rewin, where he estahlislied him. self, and began his secret intrigues to undermine and dissipate his enemies' forects. Ho was so suceessful in this, tint in a shat time the lad guimed nocer all 2lieir allies, as well as the towns on the mains land or large isfand in the vieinity, nnd oveu many of the cliters at Amhau. The latter olyject wris iffueted through the is lluence of lis son, Butu Sern, who had been suffered to remain thero during the whole war, although not withont frequent ntfemfits treing nunde on his life, which ho escnped from through lis nacensing vigitace and that of his whlherents. During the latter part of the time, he was constsully in communication witl his futher, who kept him well supplied witl the articles in which the riches of the natives consist: theso were liberally distribnted among the Lasiknus, of frahermen, and gained the most of tije class over to jis interests. Alt things being turranged, on a certrins day the aignal way given, and most of the allize declared cot Tamos. Whilst the rebel chiefs were in consternation at this nnoxpected ewent, the Lasilsmus rose tund atlacken them. A severe contest enatzed; hut it is anin the fishermen, having built a wrall rividing their part of the town from tlunt of the

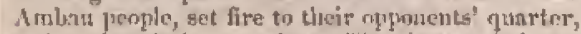
thul reducod it tu ashes 'Tho latter fled for refuge to the main land, across tha shallow istlumus, but found themectres licre opposed by the ling with his army, whos slatghtered all those whio hall esenped from Ambatt. This done, Tanon entered $A$ mbnu in triumall, and receiving the submission of all the neightoturing towns, resumed the gorernment, after tu absence of five yenrs. This recovery of his kingdorn touk place in 1937. Being thus re-established, Tanon, in order eflec. tually to destruy his enenies, sent messenges to the different towns, with presents, to induce the iulabilarts of the places whither the rebels had filed to put them to desth. In this he soun suctceoded, and their fortuer fricuds were thus madr the ingtruments of their punishment. Thaon laving succecded in estallishing lie rulr, put a stop to all furtier sisughter; but all the principal chices who lad oppost him, except Masomalna, of Viwa, liat been slain. 'Tanoa's aullurity was now neknowledged in all bis former dominions; but this has not jut an end to the petry wark. The three ehiof cities, Antbat, Rewa, and Naitasiri, are frequently at war, notwilhstandiug they are all three elowely connected by alimanees with each other. Here, in fact, is the great seat of power in the group, llouglr it varies occasiunally. These three places form, as it were, a triangle, the two furner being on the torth nud south consts, while that of Nistasiri is situated iuland, on the Wailevu, or I'eale's rivor. These diasurbances most frequently vecur letwern $A$ mbau and Tewa. Truon takes no part in throse euntests, but whict the thinks the belligerents have foughts lusg enough he senula the Rewa people word to "come and beg pardon," after the Feejee euston, which they invariably do, even thungl they may lave bees vietnrinus.

Mr. Brakkeuridge, "นr lrortieulturint, was soon lutsily engaged in preparing the garden for our seeds. I lind been suxious that this shotzld be done as suon as pussible, in order that we might have $n$ chance of seeing it in a prosperous state before we left the island; and I feet mueb indebted to him for the zenl lie manifested, A bout twenty matives were enployed in putting up the fence, the chite linving agreed with each of them to ntake two fathoms of it. Some were empluyed in eterting away the weeds, amb athers in bringing reeds and stalies down from the momitains. Mr. Brackenridge marked out the line for the fence, but they could not the indued to follow it, or ulserve my regularity, each individual making his allotted part accotding to bis own fancy; these sopurate portious were ufterwards joiner sogether, forming a zigzag work. The purts of the enchlo. sure ware tient ingether by a sprecies of dolichos, crossed, braced, nand wattled like loaskct-work, the whole making a tight fence, which answered the purqnose welt entrigh.

The digging of the ground was performed witl st long prointed pole, which tley thrust into the gromed with both hands, and by swinging on the upper enul, they contrived to mise up large pieces of the soil, which was gute bard. Nfter this, two sailors with spotes smothed it. The centre of the gardeu liad been a repository for their dead, where many stones had once been placed, which tad becomic scnttererl. These the natives were told to throw in a pile in the eentre. They wiest fin digging for somo time, jrobably witlout an idea 
that any ore had been Luried there, but as they approached the pile they sinultiueotsly came to a stop, and began to murnur atnong thenselves, using the words mate wate. No inducenent ersuld persunde them to juoced, until it was explained to them by David Whipry, that there was no desire to dig its the directiou of the grave, which was to be left encred. With this intimation they seenred well satisfied, and went on digging merrily, A large quantity of sects, of varions kinds of regetablea and fivits, were planted, For the fencing and digging of the garden I gave, lyy ngreenent, a trade musket, and I believe this incluted the purchase of the grumind!

The day niter Thnob's visit, I received [rom fim a ruyal present of ten loogs, a quantily of yums, taru, fruit, \& e.

Our stay at Ovolau continued for six weehs. Among the incisleuts which vecurred during this tirne were the following :

On the 17th May, David Dateman dicd. He land teen a marine on board the Porpoise, and had been transferred to the Vincennes nt Tonga. A [nst. mortem examination slowed that the right long was almost.wholly destroyed by disense, alud chere was about is pint of purulont matter in the pleura.

On the 19th, Serm, the son of Tamon, arrived from Arubnu, fur the purjuse of visiting nc. I imonediately senc him and his suito an invitation in meet mo at the olservatory on the following Iny, with which la complienl. Suru is extremely gusd-foolting, buing tal!, woll-mude, nnd athletic. He exlibits much intelligence buth in his exures sisn of cotntenallee and maners. His features and figure rememble those if a liusopent, und he is graceful and easy in his exrriage. 'llhe instruments at the observatory exciled his wonder and curiosity. $\mathrm{He}_{\mathrm{e}}$ in common with the ather natives, believed that they were intended for the purpose of Jooking at the Crrent špirit, and in conmequence paid them the gratest respect and rever*nee, This upinion saved us much troulle, for they lid not presume to npproach the instruments; and nlchough sume of them were alwayg to be found witlout the boundary which had been traced to limit their aprroach, they never intruded within it. 'Tlucy alwnys liehared civilly, and said they only earne to snrth-saru (lonk-nu)

I afterwards took Seru on boaril the Vineennes, where, as his father lad reeonntuetded, I gave hita Inlenty of goord advice, to which be semed to jay great attention, I Jat been tolu that he would probably exhibit hauteur and an arrogant bearing, but he manifested nothing of the liud He aph peared rather, as I lial heen told by his father I would find him, "young and frislsy". He wos received with the sane nitentions that land been paid to his father. Tire firing of the guns seemed to take his fancy muels, and he wis desirous that 1 should gratily him by continuing to fire them Innger ; but I was not isclined to nake the housans paid to him greater than those rendered to his fatleer, knowiug how olwervant they are of all forms. The whole party, hinmelf included, showed more pleasuro and were much more libernl, in their exclatsations of vi makn? vi makn! not whon! using then wore energetienlly thau the kirg's party, nu inighlit bo inalurally expected from a younger set of untives. Seru is yuite isgenious; lue took the nusket given hin th pieces as quichly, and used it with as nuch ndroitriess as if he luad been a gunsmith. His ambati (priust) was wilh hitn, and the party all appenret] greatly dediglobed will the ship. On the whole I wis much pleased witl him during lis vinit; Bhotsly afterwarda, he, laswever, visited the slaip during my alsessee, and displayed $n$ very different lestring, so mutheh so as to reguire to be elieclied. I beaned a cireumstance which would serve to prove tlat the reputation he bears is pretty well fourked. He on one vecasion had sent word to ntio of the silunds (Goro, I helieve), for tho elife to have a quantity of coeon-nut oil ready for him by a certain time. Towards the expiration of the specified intervnl, Seru went to the ishand ant] found it was not realy. The old chief of the island pleaded the infinsulbility of complinuce, from want of time, snd promised to have it reasy a. som ns possible. Seru tolu thin lue was a great liar, and without further worde, struck litn on the hent and lifled him an the sper. T'lis is only one of masy instances of the exercise of arbitury authority over their vassuls.

One day, while at the observatnry, I was grently strprised at secing one whom 1 took to be a Feejeeman enter my tent, a circumstance so inconsistent. witls the respect to our prescribed limit, of wich I lanvo spoken. His culour, liowever, struck the as lighter than that of any uative I lad yet seen. He was a ehort wriblied old may, but appeared to prossess great vigour aud netivity. He lind a beard that renclied to his middle, and but littlo hair, of a reddish grey colour, on his head. Ho gave me no time fir inquiry, but at once addressed tone in bruad Irieh, with a rich Milesian brogue. In a few minutes lie made me acguainted with his atory, which, by lis own account, wiss as followg.

Ilis nume was Paddy Consel, but the natives ealled hins Berry; lo was born in the couny of Clare in Ireland; had run sway from sebuml when ho was a littlo felluw, and after wandering about as a vagaboud, was juressed into the arrily in the first Irisli rebellion. $A t$ the timo the French laniled in Ireland, the regiment to which the was attuclied nunclied at once agninst the eneny, and suon artived ou the field of lattle, where they wero bruught to the cluarge. The first thing lie kwew or lashd, the drums struek up a White boys' turse, and his whole regiment went over and joined tho Frenel, witl, the exception of the offieers, who had tu fig, They were then marclied ngainst the British, and were soon defented by Lord Cornwallis; it was a linsd fight, anul Paddy found himself musng the slain. When he thoughi the battle was over, and night earve on, lae errwled of and renched home. He was them tatien wh and tried for lis life, but was aequittel; l he was, howerer, remajnded to prison, and busierl lituself in effecting the escerpe of some of lis commades. On this being divenvered, he was corthed in the black loole, and soon after sent to Cork, to be jut ons board a convist-bip bound to New South Wales. When be arrived there, Jis nume was not found on the books of the prisoners, consequenlly lie lind been transproted by mistalie, mad was, therefure, set nt |ithesty. He shen worked about for several years, and collected a mmall sum of money, bus unfortirrattely fell into bad company, got drunk, and lost it all. IJust ahout this time Coptain Sartori, of the ship General Wellesley, arrived at Syduey. Having 
last a great part of bis erew by sickness and desertion, he desired to procure hands for his ship, which was gtill at Sandalwond Bay, and obtained thirty-five men, one of whom was Paddy Conmel. At the time chey were ready to dejart, in Freneh privatec, Le Gloriant, Cajtain Iubardien, put into Syduey, when Captain Sartori engaged a passige fir himself and his men to the Peyjers. On ther way they touched at Norfolk Islumd, where the ship stmel; and onumaged lier heel so much that they wore obliged to put into the Bay of lohinds for repairs. Inaddy asserts that a diftienity lad mentred liero between Captain Sartori and lis ruen uhut tluir provisions, whisls was snicalbly settled. 'The Gloriant finally sailed from New Zeahun! for Tumgatabin, where they arrived just after the capturo of a vessel, which he supposod to lan ween the Port au Prince, ns they Jad obtnined many articles from the natives, which had avident] helouger to some large ressol. Here they resuairsed same montha, aud then sailed for Sandalwand Bay, where the mell, on aceunt of sheir former quarrel witlı Cajtain Sartori, refused to gu osi boarl the Genernl Wellesles: some of thein shipped on board zlie Glorinnt, and others, with Paldy, determinud to rensin on thoro witl the natives. He added, that Gaptain Sartori was kiul to Jim, atrl at parting lard given hitn a pistol, etstlass, and ath old good-for-nutling wasdiet; these, with his sea-chest and a fow clunlies, were all that he possesencl. He had now lived forty yesurs anong these savnge日. After lieariug his whole ftury, i told him I dis nat belicre a word of it; to which he answered, that the main part of it was true, lut he might have made somo nistalies, ns lie had been sor touch in the hatit of lying to the Feejecans, that he lardly now knew when the told the truth, adding that he lasd no desire to tell ary thing but the truths.

P'uddy turued out to he a very amusing fellow, and possessed an acenrate knowiledge of the Fee. jee chancter. Some of lue whitus toll me that he was more tlisn half Feejee; indeed he seemed to delight in stowing how nearly he was allied to then in feeling and propensities; ant, like them, secmed to fix his attention won itifles. He gavo me a drolt aceount of his daily emplorments, which it would te inapproprinte to give there, anor furished by telling me the only wimlt he las ihen, was to get for lis litte loy; ou whom be donled, a small hateliet, and the only articles be had to offer fur it were a few old liens. On my asking him if the did not cultivate the ground, he snill at once no, lie found it untelt ensice to get lis living ly trilling

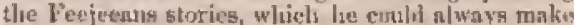
good enough for tlicion ; thesen, ant the enre of lis two litule buys, and his hens, nud his figs, when he lind any, gave hin anple employment nud plenty of foosl. He latd lived suth at Rewa, amel uutil lately had been $n$ resident at Levuka, bat lat, in conserquenou of his intrignes, been expelled by the wibite residents, to the isilurel of Ambatili. It appeared that they had naminomsly cume to the conelusion that if he did not nemove, they would he obliged to puz him to dentl, for their own salety. 1 could not induce Whippy or 'Tom ta give me the cireunminnces that ocensioned this detertsination, and F'suldy would not communiente more than that his resirfeuce ot Ambatiki was a forced one, and that it was an though he was livigg out of the world, renring pige, fowls, ant children. of the last description of live slock he had forty-eiglit, and loperd that lo might live to see fifig born to him. He had had one hundred wives.

\section{CHAPTER XXIII.}

\section{CUSTOMS OF THE FEEJEE GROUP.}

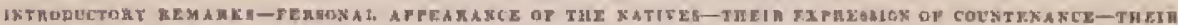

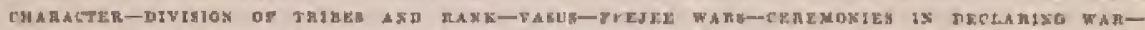

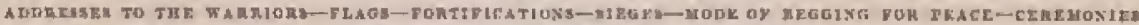

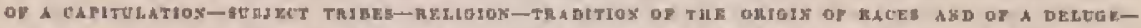

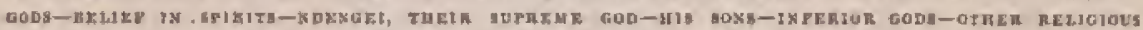

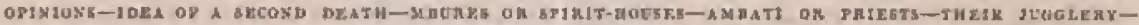

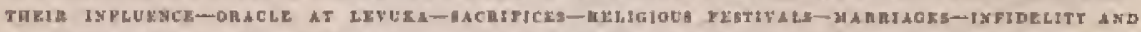

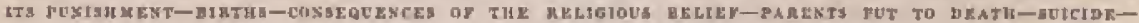

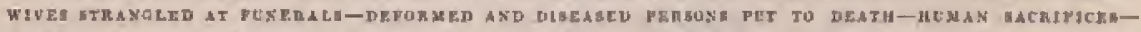

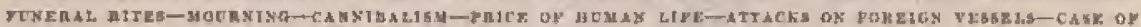

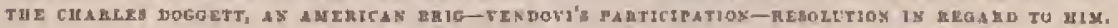

Bafose proceeding to the sinrration of the operntions of the squadron in the Feejec Group, it would appenr expedient ta giwe some ncenum of the pecople who inliabit the islands of which it is corn. posed. A reader unacquainted with their minnmes and customs cas hardly appreciato the difficulics with which the performance of our rituties was attenrled, or the olustacles which impedod our progress. Our information, in relation to the almost und nown rinee which ceenpies the Feejee Group, was olitained from personsl observation, form the statements of the nutiven thenselves, and from white residetits. I sho derived much information from the missionarics, who, infueneed by motires of religion, lave undertakes the arduous, and as yet naprofitable task, of introdlicing the light of civilization and the illumination of the Gospel into this benighterl region.

Aithough, ns we shall see, the natives of Feejee have made considerable progress is serveral of the 
useful arts, chey are, in cmany regpets, the mont barlarans and anvage race now existing urwon the globe. The intercourse they lave had with whito then has produced some effert on their politirs! condition, but does not appear to have had the least inllanee in mitigating the barbarous ferocity of their character. In this group, therefure, may be seen the savnge in his state of nature; and is cimparison of lias daracter with shat of the ratives of the grums in which the Ginspel has becn profitably preached, will enable our renders to form $a$ tretter estimate of the value of missionary Iahours than ean well be seuzuired in any otliex manumer.

The Fecjesan aro genemally above the mialle height, nnd extibis a great variely of higure. Among them tho elicefo are tall, well-mate, and mnacular; white the lower orden manifist the mearreness arising from laborious hervieg and scusty nurishment. 'I'heir complexion fies, in general, hetwoen that of the blsck and copper. colutred ment, altiough instaness of buth extremes are ta be met with, thus ipulienting a deseent from two different stocks, One of these, :lie eopper. culoured, is ne doulit the same as that whence the Tnagese al'e derived.

None of them equal the natives of T'onga in beats of person. The frees of the greater inmber ure tong, with a large moutl, good and well-set teeth, and a well-formed nuse. [nstances, howercr, are by no mentas me, of narmow and ligh forehends, thik noses, and thick lips, with a broad short chin; still they inve rnthing abont them of the negro type. Eves the firzaled spperamed of the Lair, which is alıast miversal, and which at first sight seerns a distinet natural elometeristic, I was, nfter a long aequaintance with their habits, inelined to uscrilze in artifieinl caureg. Besides the long buslyy beurds anil mustacheg, which are always woru by the elicefo, they have a grent quantity of lnair nn their bodies. This, with the peculiar jivn. pration between their thighs and the ealves of their legs, brings then nesrer to the whites vllan any of the Polynesian races visited by ns.

The eyes of the lieejeetus are usually fine, being black and penetrating. Some, however, have them red and bloudshot, which may probably be ascribed to awa drinking.

The expression of their countenances is usually restless aud watchful; they are observing and quick in their movenuents,

The binir of the boya is croppet close, while that of the young girls is allowed to grow, In the Intter it is to bo sos maturally arranged in tight crik-rerew loeks, many inelses in length, which falt it all directions froun ilee crown of the head. The natuml culour of the hair of the girls can liardly be ascertaised, for they aro in the habit of acting uphn it by lime and pigments, which niake it white, red, brown, or black, acenrding to the taste of tho individual.

When the boye grow up, their hair is nolonger cropled, and grent paing is taken to spread it out into a mop-like furm. The chiefs, in particular, pay great attontion to the dreseisig of their heads, arul for this purpose all of them lave barbers, whoso sole oeeupation is the eare of their masters" lieada. The duty of these functionaries is held th be of so sacred a nature, that their hands are tabooed from all other employment, and they are not, even pernitted to feed themselves ${ }^{\circ}$. Tis dress the hend of a chief oceupief several hututs, and the hnir is nade to spiread out frum tho heaul, an every sille, to a distance that is often eight inches. The beard, which is aluo carefully nursed, of tes reaches the breast and when a Veujeen has these im. portant parts of lis person well dressed, lio exhithita a degree of conceit that is not a litule aนกนหing.

In the process of dressing tho hair, it is well anninted with oil, mixed with a earhonnecou black, uncil it is enmplecely anturatedt. The barber then takes the hair-pin, which is a long and stender rod, made of tortoise-shell or bone, anil proceeds to twitch almost exery seynrate hair. This exusca it to frizzle and etand ercet. The bush of hair is thes trimmed enooth, lyy singeing it, until it has the appenrance of an immense wig. When this has been fiuiphed, a picee of tapra, so fluo ns th resemble tistuc-paper, is wound in light folds mound it, to gruteet the hair from dew or dust. This covering, which has the look of a turban, is ealled sak, nud none but elicfo are allowed to wear it; any attenpt to assume this head-dress by n kiaisi, or eomınu person, would bo imsuediately puished with death. The sala, when taken earo of, will last three week or a mouth, and the hair is wot dressed exeept when it is romoved; but the ligh chicf and dandies seldom allow a day tu pass withnut changiug the sala, and laving their laair put in order.

The Feejecans are extrenvely changerable in their disyosition. They ne fond of joking, indalge in laughter, and will at one moment appear to give themselves ap to merriment, from which they in an instant pass to demon-like nuger, which they evince by looks which cannut be misumderstood by thase who are the subjects of it, and partieularly if in the prower of the enrnged native. 'Iheir anger seldon fiuda vent in worrts, hut has the character of sultenuess. A chit, when offented, sehtom spenks n word, but puts stichs in the ground, to keep the causo of his anger constantly in this recollection. Tho objects of it now understand that it is lime to Rppesse hin by pronitiatory offeringe, if they would a $y$ wid the bat entsequences. When these luve heen tendered to the satisinetion of tho offended dignitary, he pulls up the sticks as a signal that he is pacitied.

Aecording to Whippy, whin had an excellent opportunity of julging, the Feejeens are addicted fo stealing, are treaclicrous in tha extreme, and, witl all their ferocity, cowarls. The most univerExl trait of their character is their inelination to lying. They tell a falseliond in preference, whon the truth would tretter answer their purpose; and in consersing will them, the truth ean bo only obtained by cantioning then not to taik like a Feejeo man, or, in other words, not tu tell any lies.

Adrouit lying is regardet as an accornplishment, and one who in expert at it is suve of a comfortablo subsistence and a friendly reception wherever ho goes, 'llıeir own weakness in this respect does nut render then suspicious, and nothing but what is

- These barbers are called s-vu+nl-vlu. They we attached to the houselabid of the cliefs In numines of from two to dozer.

t The ofl Is procured by scraping and squeezing a nut called malketu; the binck in prepared from the landl sout. 
greatly exaggerated is likely to be believed. Iu illustration of the latter Irati, I was told by Paddy Connel, that he nover told them the truth whel he wislied to be believerl, for of it they were nlways

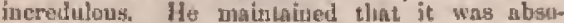
Jutely necessary to tell them lics in order wo receive eredence.

Covetuasness is prohably one of the strongest fescures of the Fecjeean elanater, and is the its. centive to mata crimeg. 1 have, however, been assured, that $n$ white man might tuavel with safety from rone end of at island to the vther, prowided lie Lad Jothing slont him to excite their desire of nequisition. This may be tue, but it is impossible to say that even the most valueless article of our muntsiactures nught nut be coveted by llem. With all this risk of boing put to denth, lospitable enteruimment and reception in their huuseg ia almost etrtxin; and while in them, perfect security may be relied 0us. The same native who within a few ynrds of his house would murder a coming or deparbing guest for sake of a lnife or a hatchet, will defend him at the risk of lis own life as $800 \mathrm{~m}$ as he has passed his threshold.

T'he people of the Ferjec Grustp are divided intu a number of triber, indefiendent and often liestile to each other. In ench tribe greac and matkerl distinctions of rank exist. The classes which aro readily distinguiblet are ns fullows: 1. kings; 2. chiefs; 3. warrions; 4. landholders (matanivarua); 5. slaver (kai-gi). 'l'tse last lave nomimnlly litte istifunce; lut in this grouy, as in other countries, the mere furce of numbers is sullicient to counter. balance or overcome the foree of the prescriptire rights uf the hight' and less numerous classes. "This las been the ease at Ambau, where the people at no distant period ruse igainst and drove out their kings.

A mong the most singular of the Ferjee customs, anl of whose origin it is diflicult to form a rational oppinios, is that which gives certniu rights to a nember of another tribe, who is called Fasu (ueplew). To give sun iden of the charncter of thin right, and the manner in which it is excreised, 1 shall cite the ease of Innoa. He, slthomght the most powerful chief in the grotup, ferly enupellet to eouply with, and acknowler]ges Thokannutus (better linown to fureignere as Mr. P'litlijs) hs Yasu-tugat of Ambiu, whu has in cotsengenee the right of sending thither for any thing ho may want, and even from 'Tanoa himself, On 'Tunon's first visit to ne, among other presunts, 1 gave him one of IIalt's patent rilles, "Whis Thoknuauto heard of, and de. sorrmined to have $i t$, and 'Tumou had no other mode of preserving it than by seudiug it away from Amlan. When Rivaletta, Tranon's youngest son, visited me one day at the observatory, lie liad the rifte with him, and told une that his father had jut it into lhis latads, in order that it might rot be de. nuasded.

Afterwads, when Thokanauto himalf paid me a sisit, he lad in his possession one of the wntehes that had been given to Sern, sund told me openly that the would have the misket also. While nit Levuta, he appropriated to himself a ennce and its contents, lenring the owner to tind his way back to Ambau as he could. The latter made tro complaint, and seemed to cumsider the net as one of courge.

When the Vasu-hugai or Vasu-levu of a hwo or district sisity it, ho is received with honchrs even greater than thooe puil to the chief who rules ores it. All bow in abedienee to his will, and he is re. ceived with elapping of hauts and the salutation, "O sa vi nakia lake mat raka turanga Ratu Vasulevu," (Hail! good is the cunning hither of our noble Lord Nephew).

When the Vasu-Jesu of Mhengs goes thither, honours almust divine nre rudered lint, for he is anpposed in be deteender] in a direst line from gods. Mtenga formerly played a very conspicuous part in the affuias of the gram, bot uf hate years it luppened to got into difficulties with liewa, in eonsequence of which Ngaraningiou attacked it, esnquered its inlubitants, and nustacred many of then, Sinee that tine it has had little or no folitical inflnence.

The hostile feclinga of tho different tribes makes wur the prireipal employment of the malos throughout the group; nnd where there is so strong $\boldsymbol{n}$ disposition to atuek their neightwours, plnusible reasons for beginning Justilities are not difficult to find. The wars of the Feejeeang ustally arise from gome aceidental aftrout or misunderstanding, of whish the most powerful yarty takes advantage to extend his dominions or increase lis weaklt. "This is soanetimes neenomplished by a mere thent, by which the weaker party is tetrified into submission to the demand for serritory or property.

When threats fail, a formal dechration of war is made by an ufficer, retembling in his fusctione the heralds (feeiales) of the ltotumn. Every tuwn has one of these, who is licld in much respect, and whose words are always tuken as true. When be repairs to the luwn of itue adverse party, where lie is always received wich greas attention, he carries witl hiun an ass root, which he presurts 10 the chiefs, satying, "Korni sat tata, sta kalu" (I bid you goodbye, it is war). The usual answer is, " $\mathrm{Sn}$ if mak, sis lake tulo hi " (It is well, return lome). Preparations are then made on both sides, and when they menu to linve a fair open fight, a mossenger is sent from oue farty to ask tho other, what towu they interd to attuck first. The reply is somelimes true, but is somelimes intended merely an a eover for their renl istentions. In the latter case, lowever, it rarely suceeds; in the furmer, both parties repair to the nppointed junce.

ln jreparing for war, and during its coulimuance, they abstsin from the conypury of women; und there were instances rulated to me, where thit aly. stinence lind cuntiuued for eeveral years.

When a borly snade up of several tribes liss nppromehed rear the encry, the vunivalu, or genersi, makes a speedi to chich suparate tribe. In this to does all in his power ly praises, taunts, or exhortations, as lie thinks best ruited to the purpose, to exeite them tis deeds of bravery. To orte ho will talk in the following nunner :

"You kay you ate a bravo peigle. You have mnde the great prumises, now se will seo how you will keen them. To ne you louk nore like slaves Usan fightiug men."

Or tins: "Here nre these stmugers como to fight willi us. Let us sice who nire the best men."

T'o another tribe he will say, "Whero do you come from ${ }^{\prime \prime}$ Some one of the tribe starts up, ind striking the ground will bis club, replies lw natming its julse of residence. The vunivalu then con. 
tinues, "Ah! I have heard of you; you boast yourselves to he brave men; we shall see what you are; 1 doubt whether you will do much. Yon seen to he more like men fit to plant and dig yams than to fight,"

After lie has thus gone througli bis fores, be cries ont: "Attend I" On this the whole elnp their lands. Ho then telfs them to prepare for battle, to which they answer, "Mana ndinn" (it is true).

In some parts of the grunp the forces are max. shalled in bands, each of which has a banner or flag, under which it fights. The staff of these flags (druatian) is about twenty feet in length, and the thigy themelves, which ne of corresponding dinensions are toade of tлp. $A$ s an instance, the forces of Rewa are arranged in four bands, viz. :- $\rightarrow$

1. 'The Faleveln, or king's own people, who are highest in runk, and held in the grentest estimation.

2. The Niaku ne tumbun, the people of the vunivalu, ot fighting elief.

3. The Kai Rewn, or landlobliers of Rewn.

4. The liai Ratn, wluch is composed of the offspring of shicfs by common women.

The fings are distingujahed from ench other by markings: that of the Valevelu has four or fire vertical black atripes, shout a foot wide, with equal spaces of white lefi betwean them; the rest of the tlay is white.

In the flag of the runivalu the black and white stripes are horizontal.

The flag of the liat Rewa is all white.

Tho Ini Ratu tse, at flags, merely strips of tapa, or artay themselves utuler the flag of a clivel. Encts of the first sliree bands is kejt cistinet, and tiglts under its own flag, in tho place which the commander appoint, The flag of the latter is always longest, and in raised lighest, whether he be king or ouly vunivalu. To curry $n$ flag is conkidered as a post of the greatest distinction, and is confinet to the bravest and most active of the tribe.

A town, when berieged, Jns rlso its signa! of pride. This consists of a sort of kite, of a cirenlar shape, thade of palm-lesves, and decorated with ribands of white and coluured tapa. When an enemy approaches the town, if the wind be favour. shle, the kite is raised by means of a very longe cord. The cord is passed through a loble masle near the top of a pole thirty or forty feet in lieight, whifely is elected in a consyicums frat of the tow\%. The cord is then strown backwarls and forwards through the fwole, in such a manner as to be kept flortiti as a aigual of dofiance, immediately nver the approaching enemy. The attacking party, cxeited by this, rusll forward wit? their flag, and plant it as neav the watls ns possible. If the garrison be sufficicatly stmong they will aalfy nut and endeavour to talie the Arg; for it is conisidered in $n$ grent triumph to capture a fiag, and a foul disgrace to lose nne.

Whel fags are taken, they are always lung up ne troplies in the ubure; and in that of Lewuka I saw inany snatl ones suspended, which, as I was informed by Whippy, had been tukets frem mourtaineers of lise interine of the island.

'I'he sowns are usunlly fortified with a strning

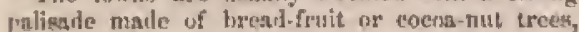

arvond which is a ditch partly filled with water. There are usually two entrances, in which are gates, so narrow as to ndmit only one peram at a time. The villnge of Waitom, about. two miles to the north of Levaks, is justly consideren by the nativen as a place of great Btrength. Thiक was visited by Messrs. Hale and Sandford, who give tho fublowing description of it. It is sitnated upon a litl, ตni ean be approsehed only by a narruw rath along the sloping edge of a rocky ridge, $A t$ the extremity of this path is a level spree of about an acre in extent, which is surrounded by a stowe wall, and filled with houscy. In the centre is a rock, aboul twenty foct high, nut one lundred feet scquase. 'The top of this is reached by a satural sinirease, formed by the roots of a banyan trece, which insert themselves in the erevices of the mek. The tree itself, with its numerous trunks, spreads ont atsd overshadows the whole of the rock. A house stunds in the nialdle of the rock. This contains two Feejee drums, which, when struck, attract crowds of natives tingether.

Sume of the primcipal towns are gine furtified at alf. This is the case with Anbau, Motlowatr, and 1Rewa. The fortifieations of which we have sproten, whether palisades and diteh or stono walls, are eunatructed with great ingenuity, partienlarly the holds to which they retire when hard pressed. For thege a rock or hill, as inaccessilble ag pussible, is chosen, with a small level space on the top. Arnund this space a palisade is constructed of upright posts of cocon-nut tree, alsout nisse inches in diancter, and about two feet apart. To the outside of these wieker-work is fastened will strung Inslıings of sounit. Over esth entrance is is $\mu \mathrm{ro}$. jeeting platform, about wine fent square, for tho purpose of guarding tho approach by litroliug gpears and shooting nrrows. The gates or entrances are shut by sliding bary from the inside, atu] are defended on ench side by struclures of stmng wicker-work, resembling bnstions, whie's are placed abnut fifteen feet apart. Whien there is a ditch, the bridge across it is complosed of two unrow logs. The whole srrangement nfturde an excellent defenco against any weapong uset ly the natives of these islande, and even against nusketry.

Sieges of these furtified places selchom continue tong ; for if the nttadking party be nut speedily successful, the want of provisions, of which there is seldum a sujply fur more than two or three days, compels them to retire. Although such Rsagults sre of short duration, the war often continues fur a long time withnut any decisive resulth

If we of the partieg desires pence, it sends an ambassador, who carries a whale's tooth, as a token of submission. The victorions party often requires the ennquered to yield the right of soil, in which case the litter bring wilh them a basket of the eartly from their distriet. The acceptance of this is the signat of perese, but fivm that timo the conquered become liable to the jayment of a yearly tribute. In stdition to this burlen, the moro jutwerful tribes often scal word to their dependencips thint they have not receired a jresent for a long time; ond if the intimation has nu effect, the messige is speedily followed by an artuet force, by which the rectisant tribe or tow is sonetimes eutirdy desiroyed. The bearer of such a mesonge enrries with hin a piece of tova, whluch is 
given to the ehief of the town in council, who eallses it to he brewed, after which the message is delivered. But when an errant is sent to Ambur, or nny superior cliwe the messenger always cniries with him a gift of provisiuns and other valuubles.

If a town is enmpelled to entreat to be permitted to enpitulate, for the purpose of snving the lives of its peaple, its chicis ald principal inhabitants are required so crawl townits their enquerurs upon their hands and kuses, ouing for pardou and imploring merey. The daughiters of the cliefs nris also bromght forward and offered to the victors, while foum the lower elass vietims ure selected to be sacrificed to the gods. Liven such hard conditions do nnt always sultice, but a whole population is sorselimes butehered in eold Lhood, or renlticel to a condition of sinvery. Tin avoid stucls temilule consedyrtinces, most if lise weak tribes seck mecurity by establisbing themselves ons high and almost inacoessible rocks. Some of these sre 80 gleep that it would be lourdly ponssible for any bat one of the ratives ta elimb ithem; yet oven their women may be theu dimbing their rocky and almost perpendicular wisls, to heiglits of fifry or sixty feet, and citrrying loads of water, yans, dic.

Tribes that to unt posgess such forthcsses, are comprelked to take refuge under the protection of some powerful chicf, in consideration of which they are lround to aid their protectors in ease of wur. 'I'ley are sumnonet to do this by a mes. senger, who carrias a whale's touth, and sumetimes directs the number of men they are to send. A refusal would bring war upon thembelves, and is therefure seldom vostured. 'I'here is, however, a recellt ingtance its which such nid was refused with impunity by T'ni Levolk, whe was persuated luy the white residests " tu disobey in sunmons serit from Ambat Having done this, the people of Levuka felt it necensary to prejure for defence, by rupuiring their storie walls and provisionting theil strunghold in the motutains. They thus stood upon their guard for a long time, but were not attacked.

The religion of the Fucjeens, and the practives which are fownded upen it, ofifler materially from linse of the lighter-culoured Pulynasian perople.

The traditiun givent by the untives of the origan of the vatioun races is singular, and not very flattering to thenselsets. Alf ure said to havo been burn of one pair of fisst parents. The lieejes was first born, hut neted wickedly and was black: he therefare receired bat liulo clothing. 'Tungo was next born; ho neted less wickerly, was whiter, and had more clotles given hitn. Whito suen, or Papalangis, cunse last; they acted well, were white, aud lawd plenty of stothes.

They have a tradition of a grent flood or deluge, which they call Wrlavu-levt. Their neentunt of it is as fullows: after the islands had been peopled by the first man and woman, in grest rain took place, hy which they were finally suldwerged; but, before the

- Thal in not the only Instanee in whlchl lite white rest. depte lisve exercised a enlutary influence. It is fortutate for the natres that thase wha have oettled mmong them have been prinelpally of meh a character as han tended to thatr Improveneat. There me, hawever, solut extephiosne,

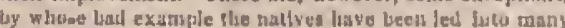
excedsci. linghest placeg wive euvered loy the watels, two large double eanoes unde tlieir aprearauce; in one of these was Rokora, the gad of carpetitis, in the otlier Rokola, lis head warkman, who piched up some of the penple, atul kept them on board unsil the waters had subsided, after which they wero again tanded on the island. It is reported slant in forner times ennoes were always kept in resdiness Against anotlier inusdation.

The persons thus soved, eight in number, were Inaded at Mbenga, whero the lighest of their goods is eaid to tave marle lib firat appearance. By virtue of this tradition, the ehiefs of Minengs trlie rank before all olbers, and liave always neted a consipjeuous part amouy the Peeject. 'I'luey stylo themselves Ngali-duvi-ki-langi (sulject to heaveu alone).

The Partheon of the Fecjes Group contains many dutieg. The first of iliere in rank is Nulengei. He is worslipped iu the form of a large serpertit, alleged to dwell in a district under thes muldority of Ambau, which is colled Nakauvaudra, and is situated nenr the wexteru end of Yitilestu. To this deity, they belinve that the spirit gness inmediately after denth, for purifleation or to receive senterse. From his tribunal the spirit is supposed to return and remain about the mbure or teinple of its former abode.

All ippirita, however, nre not believed to be permitted to reacls the judgurent-sent of Ndesgei, for upon the road it is supposed that an enormous giant, armed with a large axe, stands constantly on the watch. With this wespon. be endearours tu wousud alt who attempt to jase him. Those who are wounded dare not presest themselves tu Nidengei, and uro obliged to wauder about in the nourstains. Whether the spririt he wounded or not, depends not upan the cunstuet in life, but they uscribe an esenpe from the blow wholly to good luek.

Stories nre prevalent of prerous who huvo succeeded in passizg the monster without injury. One of these, which was told mo by a whito pilot, will suffice to sliow the clinacter of this superstitiun.

A powerfial elifof, who had died and been interred with all due eeremony, finding that he land to pass this giant, who, in the legewl, is stationed in the Motariki Clasmol, landed his gan, whiel had been buried with hin, and prepared for the enemanter. The giant seeing the danger that threatened hill, was on the louk-out to divige the ball, whiselt he did when the jiece was distharged. Of this the nthief took advantage to rush by him before he could re. cover himself, rescherl the judgment-seat of Nidengei, asul now enjoys etelostial happiness !

Besides the entire form of n serpert. Ndengei is sometimes represecuted as laving ority the liend and Lalf the bady of the figure of that reptite, white the remaining portiou of his form is a stone, signifient of eletral durntios?.

No one pretends to know the origiu of Xidengei, hut many assert that he bas been seen by wot'tals. Thus, he is reported to have appeared under the form of a nun, dresaed in masi (wlyite tapa), nfter the fashion of the aatives, on the bench, near Ragiragi. Thence ho proceedicd to Mbenga, where, although it did sot please him, on account of its rueky shores, he made himself manifest, ind thenec went to liastavu. Not liking the hatter plice, he went to Jiewa, where le towk ug lis alwate. Herw he was joitud hy another pworiul god, called 
Warun, to whom after a time he consented tu resign this locality, on coudition of receiving the clivicest parts of all kinds of food, as the liends of the turtle and pig, - which are still letel sacred. Under this agreement he deternined to proceed to Verata, where he has resided ever siluce, and by lim Verata is believod to have been rendered inspregualse.

Next in rank, in their mythology, atand two sons of Neneoi, "whinirumbe sad Tui Iakemba". These not as trediatore betweon their father and inferior Bpirits, 'They are said to be stationed, in the form of unen, at the duor of their father'y cabin, where they receise and transmit to hisu the pruyers and supplitstions of departed souls.

T'le grandehiloresn of Nengei ure third in rank. They we innumerable, nud ench thas a peculisto duty to perform, of witich the most usust is that of presiding over islands nnd districts.

A fourth eluss is supprosed to be made up of more distant relatives of Ndengej, I"hese preside over separate tribes, by whose jriests they are cousullud. T'hey have no jurisdiction beyasd theis own tribe, and pussess no power but what is deputen to theus liy muperior dejices.

In molitious on these benignant beings, they believe in mulicious atul mischievons gods. Thesse reside in their Hades, which they eall Mbuln (underneatla the world). Thore ruigns a crtul ty ratit, will grim aspect, whom they uame Lotlis. Snnuinlo (uestroger of gouls) is lis collengue, and sits on the Lriuk of a luge fiery caveru, into wlisel he precipitates departed spirita.

These notiuns, althougth the most prevalent, are not universal. Thus: the got of Muthunta is called Rutiuadina. He is considered as the sum of Ndengei. Here also Itokora, the god of carpenters, is hell in honour; and they worehip also Rokavom, the grml of fisliermen.

The peupla of Lakemba believe that departed Bouls proted to Namukaliwa, a place in the vieinity of the sen. Here they for a time excrutse the kame employments as wilen in this life, aftor whisch they die ngain, asad go to Mtbulu, whero they are met by Samuialo. This deity is empowerel to seize nisd hurl into the fiery gulf all those whon be dislikes. On Kantasu thty adrait of na god appristed to receive departed souls, hut suppuse that these go down inlo the wea, where they are examined by the great spirit, who retaits those the likes, und sends back the others to their native islambl, to dwell among their friends. Another belicf is, that the departed kpirit govs beforo the god Taseta, who, is it aprroaclirs, darts a spear al it. If the spitit exhibits any signs of fear, it ineurs the diapleasuze of the gorl, but if it advanees witls cont mage, it is received with favour.

On Vanun-levo it is lielieved that slie souls of their decusend friends go to Dimba-dimba, a point of land which forma Ambnu Bay. Hore tlicy nre fupposed to pass down into the sen, where they are talies into two canose by Itukarona and Ruliom, and ferried across intu the duminions of Nidengei. When it blows lard, nid there sre storms of thunder, lightring, nul rail, the natives say that the cances are gretting realy.

Some few of the natires worbip an evil spirit, whom they call Rukn latiu dun (the one-toothed

- Some cay he has bul one mon, called Maubu the breats. (ruli).
Lorrl). He is represented under the form of man, having wings insteml of arms and as provided with clnws to seize his vietins. His tooth is deseribed ns being large enough to reach above the top of his hesd; it is alleged he flies through the tir emitting spachs of fire. He is said to ruast in the nil the wicked who appertain to him. Tloose who do not

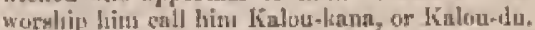

At Rewa, it is believed that the Epirits first repait to the rusideuce of Nihngal, who allots some of them to the devils for fuod, and hends the rest awny to Mukilot, a sual] island off Rewa, where they remain until an appoiuted dny, after which they are all doemed to anuihilatiou. The judgments thus passed by Nidengei, scen to bu ascribed ratleer to lis eaprice than to any desert of the departut Boul.

'Thils iles of a secont death is illustrated by the followiog aneedute, reluted by Mr. Vanderford. This uflices resided, for several sunths after his shipwreck, witlı Tauon, king of Amban. During this time there was a great feast, at which many cliks were present, who remnitsed to slewp. Before the slose of the exching amusements, one of then Irad recounted the circumbtances of his killing a noigtbouring chief. During the nigltt he liad orearion to feave the house, and bia sujerstition led him to believe that lo saw tho ghost of his vietim, at which los threw his elnb, and, as be nsserted, killed it. Returuing to the house, ho aroused the king nard all the other inmater, to whom lie related what he had done. The oceurgence was considered by all as highly important, and formed the subjest of due detiberation. In the moming the club way found, when it way taken, wits great pomp and parsito, to the mbure, whero it was deposited es a memoria!. All seerued to consider the killing of the spirit as a total amnihita. tion of the persull.

Amang other furrus of tlis surerstition regarding spirits, is thut of transmignation. Those who lubld it, think tlant spirits wander about the villages in various shapes, and can make thembelves visible or imvisible at pleasure: that there are particular places to which they rewort, and in passing these they are sccustomed to nuke a propitiatory offering of foot or eloth. This form of superatition is the esuss: of an arersion to go abroad at uight, and particularly when it is dark.

It is also a teneral belkef, that the spirit of a celebrated olijef may, after death, tuler into sutne young man of the tribe, anil atsinnto him to deeds of valour. Persuns thiss distinguished are pointed out as highly favoured; ill corsectuence, they reveiva grent respuet, and their opjinions aro treated wilt. mueh couthisertion, besicles which, they lave many pessunal privileges.

In general, the passage froun life to death is considered ns ons froms pain ter lapjiness, and I was informed, that vine out of tell look forward w it with anxietr, in urder en esespe front the isfirmilies of old sge, (n) the sufferings of divense.

The deities whom we have named are served by priests, called ambati, who aro worshipped in huildings denominnted mlure, or spirit-houses. Of guch huildings each town las nt least one, and often severul, which serve also for entertaining strangers, as well as for holding cowncils and other public metings. In these mbures, images are found; but these, although much esteened is orus- 
ments, and held snered, nre not worshipped as inols. They are only produced on grent occasions, such as festivals, \&c.

The ambrti, or priests, lave great influcnee over the people, who consult then on ail ocrasions, but are generally fount acting in concert with the eliefs, thus forming a mion of power which rules the islands. Faclı chief has his ambati, who attents his wherever he goes. The people nre gronsly superstitious, and ilscre nre fow of their vecuphations in which the ambati is not more or less concerned. He is lielil sacred withis lis own district, being considered as the representntive of the kallow, or spirit. Mr. Hunt informed me, that the antives seldom separate the ilea of the gorl from that of his prient, who is viewed will almost divine reverence. $\mathrm{My}$ own abservations, however, led to the conclusion, that it is more especially the ease nt Somu-somu, where $\mathrm{Mr}_{\mathrm{r}}$. Hunt resides, and where the nutives are more savage, if possible, in their custurng, thun those of the other islands. If intercourse with white men hins produced no other effect, it has lesened their reverence for the priesthood; for wherever they bave foreign visiters, there may be seen a marked change in this respect.

The office of nmbati is nsually heredisary, hut in some cuses may lue consiklered as melf-chosen. TPlun, when a priest dies without malo heirs, some one, who is ambitious to succeed him, and desirous of leading an idle life, will strive for the sucession. To accomptislt this end, he will cnnningly assume a mystericus air, spenhing incoherently, and pretending that cuming erents have tieen foretold lim hy the kalon, whom lis clains to have seen and talked with. If he should lave made a prediction in relation to a subject in which tho people take ant anxious interest, nud witls which the event laspjens to corresfund, the belief that his pretensions are well formiled is adopted. Before he is acknowledged as ambati, he, however, is made to undergo a further trial, and is required to show publicly that the kalou is entering into him. The proof of this is considered to lie in certain alviverings, which appenr to be involuntary, and in the per. formance of which none tut an expert jnggler could suceed.

1 lad an opportunity, whilo a! Levuka, of secing a performance of this desertption. Whippy gave me notice of it, lawing ascertained that the offering which precedes the consultation was in preparation, This oftering consisted of $\mathrm{n}$ hog, $\mathbf{n}$ basket of yams, and a quantity of banarias. In this case the ambati had recoived notice that he was to he consulted, and *na attached to the persun of Seru, (Tnuon's Anon,) for whose Iurposes the proplsetic intervention was needed.

On such ocensions the clicefs dress in the morning in their gala halite, and proceed with much ceremony to tho mburo, where the priest is. On some ocasions, previous notice is given him; at other times ho has no warning of their coming, unti] he receives the offiring.

The amunt of this offering depends upon the inclination of the party who makes it. The chiefs and people seat themsives promiscuously in a Bemicircle, the open side of which is occupied by the person who prepares the ara. This mode of sitting is intended as an act of humiliation on the purt of the chiels, which is considered ns neceptable to the gods." When atl is prepared, the prineipal ehief, if the occasion he a great one, presents a wilale's tooth. The priest recejves diis in lis luands, and eontemplates it steadily, witls dewticabl cyes, remaining perfectly quiet for aome time. In a few пiumes distortions login to be visible ill his face, indienting, as they smprose, that the gorl is entering into his body. J lis limbs next slww a violent muscular netium, which inereases notil lis whole frame sppentr conrulard, and trembles as if under the influence of an agne fit; his eyclualls roll, and are distended; the blood seeme rashing with viutence to and from his head; tears stalt from lis eyes; his brenst heaves; his lipss grow livid, and his utterance confused. In short, lits whole appenmuce is that of a manine. Finnlly, a profuse persfinistion streans frum every pore, hy which lie is relieved, and the symploms gradually alonte; after this, he again sinks into in attitude of quiet, gazing about him from side to side, until suddenly striling the ground with a club, lo thus annosner that the god Jias degarted from lim. Whatever the priest. utters while thus excited, is received ons on direet response of the god's to the proyers of those who made the offering. The provisions of which the offering is composed are now sllared out, nul ava prepared. Tlese are caten aud drunk in silence. The priest partakes of the fenst, and always eats voraciousiy, supplying, as it were, the exlusustion ho has pre? vioushy undergone. It is seldom, lowever, that bis muscles resame at once a quieserit state, aud tlies more usually contimus to twiteh and tremble for some time afterwaridu.

When the eandidate for the office of ambati las gone successfully through ench, n ceremeny, and the resplanse lie gives as from the god is admited to be eurrect, he is considerul an juulified to le a priest, and takes possession of the mbure. It is, however, casily to be seen, that it is the chief wloo in fact makes tle appointment. The indivitual chisen is always on good terms with lino, and is but his tool. The purposes of butis aro acconplished by a good undersianding between then. There can be no doubl thint thuse who excrcise the aftiee of ambati, and go through the actins just mentioned, are cousumnate jugglers; but they aften becone so mush affected by their ons effurts, that the motinns of the muscles becone in reality involuntary, and they liave every appensalee of being affected by a siplerwatural igesiey.

By the dexterity will which the ambati perform their juggling perfurnances, they acquire grat influcuce over the common people; lut, ns bifore remarked, they ate nerely the instruments of the clivess. Whes the latter are about guing to baltle, or engaging in nuy other important enterprise, thes desire the priest to Jet the sjuirit enter him forll. with, tuaking him, $n$ t tle samo time, $\pi$ present. The priest speedily legins to slunke and sliver, and ere long conmunieates the will of the got, wluth filwas fallice with the wishes of the elvief. It aometines bappens that the priest fails is exciting limself to convulsive action; Lut this, ammog a pecople 80 wrapt in stoperstition, exu always be ingeniously nccounted for: the most trual mode of excusing the failure, is to say that the halou is dissatisfied with the oflering.

I'he chiefo themselves sumitted, nud Whippy informod me, that they lave little resuect for the Inwer of the prients, and use them merely to govirn tlie people. The ambati are gentrally the 
most shrewd and intelligent metuluers of the cornturnity, aut the ressons for their intinate mitus with the chiefs are obviuus; without the influenes of the supenstition of which they are the ingents, the elvief would be wobles soceessully to rule; while withuut support fruzu the authurity of the elidef, the molmti could seareely practise thoir munameries willıut detection.

"Che priests, when their serviees nre not wanted hy thw shiefs, are sometimes driven to straits for fond, II such cases they lave reveurse to the feras of the people, and anumg uther modtes of intinidntion, threaten to eat them if their dewands are not eormpliet with. To give foree to the nenuwe, they pretenul to have had comnunication with the gorl in dreans, and assetsuble the people to henr the messuge of the deity. This message is alwnys portettous of evil; the simple native nre thus induced to make propiliatory offerings, which the priest aptplies to lis uwn use.

The priest at Leruka pretends to receive oracles from a miliature inture, an engitie of superstition, which he keeps belind a sereen in the spirit house, It is about four feet high; the base is ahout fifteen inelee square; it is hollow within, las an ent on one side of it, and a moutli and nose oll the other.

This orncle is eovered with acarlet and white soeds, about the mize of n large pea, which are stuck upon it in funtastic figures with gum. To the priest this is a labour-sssing machine; for on ordisuary ocensions, instesd of going slrwough the performanee we have deseribed, he merely whis. fress in the ear of the model, and pretends to reeeive an answer. by antylying his own ear to its month.

T'he occasions on which the priests are required to bluke, are usually of the following kinds: to implise good cropa of yamis and taro; on going to batte; for propitious voyages; for rain; for starms, to drive boats and shipg sshore, in order that the natives muy seize the property they are freighted with; and for tho destruction of their enemies

When the proyers offered are fur a delivemec from famine, the pricst directs the penple to return w) their louses, in the mame of Aidugei, who then at his instance is expected to turn limaself over, in which ease an eartliqutike cusues, which is to be fullawed by a season of fertility.

When it is determined to wfter a sacrifice, the people are assembled and uddressed by a chief. A the is then fixed for the cermony, until which tinte n taboo is tail upon pigs, turtles, \&e. On the appointed day, each inan brings his quota of provisione, and a whale's tooth if he have one. The clinef, accumpuried by the uthers, sppronclies the inture, and while he offers up his puryers, the people present their gifts. The hatter then seturn to their houses, and the offering is distributed by the priest.

When a elsief wishes to sappliente a god for the recosery of a sick frieud, the returu of a canoe, or any viluer desired nbject, he takes a rowh of ara and as whale's touth to the nibure, and offers then to the priest. "Ihe latter takes the whale"s tonth in his hands, and then gues through the operation of sliaking, \&.e., as has nlready heen described.

Besides the occrsional exusultation of the gouls through the sthisti, there rre stated religious festi. vals. One of these, wlinel is suid to be unly prac- timed in districta subject to 'T'ui Levuka, takes place in the inents of Noveasher, and lasts fonr fass. At its commenvemelit an inliuential nat uilvanua (landholder) procecds juat at sunset to the outside of the koro, or town, where, in a haml vuice, he invokes tho stivit of the sky, praying for gooul crops asd other Lilessings. This is followed by a goneral beating of sticks annl druus, and blowing of conelas, which lasta fur lundf an lonur. During the four lays, she theu live in the mbure, when thry foust upwon the balola", a curious speeics of withwater wortı, which makes its appeaknice at this season, fior one diny, whito tive woirsen and boys renatis slut up in the lonses, No labour is permitteul, no work carried un; and so strictly is this rule observed, that not even a leaf is plucked; sud the offal is not retrioved from the housey. At daylight on the expiration of the fourth uight, the whole town is in an uproar, and men and boys scamper nbout, kmoking with clubs and sticks at the dwors of the fortses, erying out, "Situnribn." This coucludes the ceremony, and the usunl routine of affaic goes on thenceforth as usual.

At Ambau a grand featiral takes place at the ingathesing of the fruits. This is called Ratami mbulu (the spirit below or in the earth). On this occasion a great feast is licld, and the king, chiefs, and people walk in procession, with great pomp and ceremony, to Viwn, wluere they pay homage to the spirit. I was unable to ubtnin further detnils of this festirnl, but its olifect was explained to be a return of thanks for the fruits of the earth.

The mariages of the Feejeesus are sanctiuned by religiotus ceremonies, and, among the bifiph chiefs, are attended with muclı form and parade. As at all other eeremonien, ava drinking forms an essential part. The ambati, of priest, takes a ount, loving the bridegrooms on his right and the bride on the left band. He then inwohes the protection of tive gud or spirit upan the brite, after which he leards her to the bridegroum, and joins their bands, witls injunctions to love, honour, and obey, to be faithfol and die with each other.

During this ceremnny, the girls are engaged in elewing the sva, on which the priest directs the water to be pured, nud cries out, "Ai sevu." He then calls ypon all the gods of the town or island. He takes care to make no ounistion, lest the negleeted deity shonld infliet injury on the eouple he has unites. Ho eoncludee the ceremony by ealling out "umus" (it is finished); to which the people respond "udina" (it is trie).

Fur the murriage of $n$ woman, the consent of her finther, mother, and brother is required, and must be asked by the intended husband. Even if the father aud mother assent, the refusal of the brother will prevent the marriage; lunt, with lis coneurtence, it mury take place, oven if loth father ant minther oppose. In asking a woman in unarriage, rolls of tapa, whales' weth, [novisions, der, are fometines prescuted to the [parents, The sceeptanee of' these significe that the auit is favourably recoived; thejr rejection is a reftusal of the suit.

If the proposals of the young man nre received, he gives nutice of it to lis owi relations, who take

- The baloin is olsiafnet al Wokala, and Io eater both

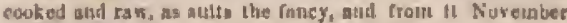
recelvea lip nume. 
presents to his betrothed. Her own relations, by why of dewry, give her a stone-chopuner (matrwiwí) and two tapha-stick (ciki), after which the surringe ruay take place

Amang the common penple the marriage rites are less coremonious tuan strose of the chiefs. The priest of the tribe cumes to the house, when he is presented with a wlate's tootl and a lowl of ava, and muling a sevu-sevu ( $p$ rsyer), invokes lasppiness yion the union. The bride's nent relations then present her with a largo poticiont (licentib), and the more distant relatives make gifts of tapas, mats, and provisions.

Every man may liave ns many wives as he can maintais, and the chicfs have many betsothed to them at an early age, for the purpose of extunding their political connexions by bonds which, according to their customs, cuntunt be orerlonked.

The dntughters of chiefs are usually betrothed early in life. If the bridegroom refumes to earry tlie contract into effect, it is conkidered as a great insult, and he may lay his account to have a contest with her relutiony and friends. If the betrothed lusbland die before the girl grows up, his sext bruther succeeds to his rights in thig respect. Many of the anarriages in high life are the result of mutual attachment, and are preceded by a cuntohip, presenta, \&c. The partiey may be frequenly secn, as nmong us, walking armi-it-arus after they are engaged. Foreed marriages sometines occur, althongh they are by no means frequent in this class; in such instances suicile is ocensionally the cumsequence, A case of this sort hat occurred previuns to our arrival, when a danghter of the chice of Ovolas killed herself by jumping off a precipice behind the town, because she had been forced to marry a brother of Tanoa. The females of the lower classes have no such delicate scruples. Among them, marriages are mere matters of bargain, and wives are purchased and looked apon n\& property in most parts of the group. The usual price is a whale's tooth, or a musket; and this once raid, the husband lias an entire right to the person of the wife, whom he may even kill and eat if he feel so disposed. Young women, until ptrrehased, belong to the chief of the village, who maty dispose of them an the thinks best. Elopementa, however, sometimes take place, when a marriage is opposed from difterence of rank or other cause, when the parties flee to some neighbouring ehief, whom they engage to intercede and bring alout a reconcilistions.

Wirea are faithful to their husbands rather from fear than from affection. If letected in infidelity, the womnn is not unfrequently knocked on the head, or made a slave for life. The man may also be treated in the samo manner; but this muristsmeat may also conrist in what is called sushti. This is a forfeiture of his lants, which is signified by sticking reods into the ground. Thecte sre bound togetier by knots, so ns to form triprods. If the offender wishes to regain his dands, ho jumst purchnse alie good-will of the offended party by presents. In some cases, the friends of the injured party seize the wife of the uffender, and give her to the aggrieved husband. There are nlso other modes in which a husband revenges limself for the infidelity of bis wife, which do not admit of de. seription.

We have seen that the extent to which polygamy is earried is limited only by the will of the mnn atud bis means of maintaining his wives, The latter are almost completely alaves, and usually, by the strict discipline of the husbund, live peaceably together. The totusehold is under the charge of the prineipal wife, nal the others are required to gield to her culatrol. If thoy misbehave, they nre tied tx, prut in irons, or thagged.

The birth of tha fint child is celelmated by a ferat on the matal day; nuother feast tnkes place four days afterwards, and mother in ten dnys, when unitabte presents are made to the young conple.

Parturition is not usullly severe, ond some womes have been known to go to wark within an hour nfter delivery. Others, however, resmaiu under the nurse's care for months, It is the prevailing opinion that hard work make the delivery more easy. After elilubirth the women usually remain quiet, and live upon a diet composed of young taru-toph, for from four to eight dnyz, after which they bathe constantly.

Milwifery is a distinet profession, exereised by women in all the towna, and they are kajd to be very skilful, performing operations which are among us considered as surgical. Abartion is prevalent, and nenriy half of those conceired are supposed to be destmyed in this numner, usunliy by the cortamand of this father, at whuse itiatanoe the wife takes herbs which are known to produce this feffect. If this do not suceed, the sccuuctseur is employed to strangle the child, and bring it fortlı dead.

$\Lambda$ child is rubbed with turmeric as Eoon as $i t$ is born, which they consider strengthening. It is named immedintely, by some relative ur friend. If, througl, nerglect or nceintent, a name should not be furthwith given, the child would be concidered as an outcast, and be destroyed by the nother.

Giris reach the age of puberty when about fourteen yeurs old, and boys when from seventeen to eighteen. "This period in a girl's life is duly celebraled by her; for which purpose she requests the loan of a honse from a friend, and inkes jussession of it, in comprny with \& number of young girla. The townspeoplla supuly them with purvvisions for ten days, doring which they anuint themsulves with turmeric and oil. At the expiration of this time, they all go out to fish, and are furnished by the men with provisitus,

The only general fact to be tlerived from the various opinions in relation to the spirits of the deald, which lave been alated ia the way we received thers, is, flast a belief in a future siato is univerally outertained by the Feejeuts. Ju some parts of the group, this loar taken lie fol. lowing form, which, if not derived from intereourse with the whitee, is at Jeast more cunzsisteut with revealed truth than any of thase previously recorded. Those who hold this oginion, eny that alt the souts of the departed will remain in their appointed place, until the world is destroyed by fire and a new one created; that in the Intter all Ujings will be renovated, and to it they will again be gent in dwell thereoll.

This belief in a future state, guided by no just notions of religions or moral obligation, is the source of many abliorrent practices A mong these are the custom of putting their purents to death when they are adraneed in years; suicide; the 
iminulation of wives at the funetsl of their hugbands, and human suerifiess.

It is among the most usual oecurrences, that a father or s mother will notify their chiluren that it is time for them to dice, or that is soon shall give notice to Jis parents that lhey are becoming i burden to him. In either case, the ralatives and friends nro callected, and informed of the fnet. A consultution is then held, which generally results in the conctusion, that the request is ty be connulied with, is which ense they fix upun at tay for the purpose, uriless it strould be duve by the party whose fate is undex deliberation. The day is usually chosen at a line when yams or turo aro ripe, in order to fumish materinls for a groat fenst, onlled mburua. Tho aged pergon is then asked, whether he will prefer to bo strangled before his burinl, or buried alive. When the nppointed duy arrives, the relatives and friends bring thpos, untr, and vil, as prosents. They are reedved as at oilier funeral feasts, and all motsen together meil the time fon the ceremony arrives. The aged petson then proceets to poim wht the place where the grave is to bo dug; and while some are digging it, the others put on a new maro and turbara, When the grave is dug, wilich is about four foet deep, the persum is assisted into it, while the relatives and fricnds begin their Jamentatious, and proceed to weep and cut themselves as they lo at other funerals. All thov proveed to take a jarting kiss, aiter which the living hodly is covered 4], fiss with inats and taju wrapped around the liend, and then with stieks and earth, which are trodden down, When this hay beet done, all rocire, and aro tabored, as will be stuted in describing shoir ortinary funerals. The succeeding night the sou goes privalely to the grave, and lays uprou it a piece of awa-root, which is called the reí-talia or fareuell.

Mr. Hunt, one of the missionaries, had been $\boldsymbol{\Omega}$ witness of several of these ncts. On one occasion, ho was called upon by a young man, who desired clant he would pray to this spirit for his mother, who was dearl. Mr. Hunt was at first in hopes that tlis would atford him an opportunity of forwarding their great cause. Oh inquiry, tlye young man told him tiat his bruthers and himalf wero just going to bury luer. Mr. Hunt accompnuied the young man, telling lim ho would follow in the procession, aud do as he desired him, supposing, of course, the corpee would he brought along; but he now met the procession, when the young man said that this was the funezal, and pointed out his mother, who was walking aloug with them, as gay and lively as ary of thinse jresent, and npparently as much pleased. Mr. Hunt exjresed lis surpirise to the young mati, and asked how he enuld deceive tim so Iutuch by soying his nother was dead, when ahe war alive and well. Ito said, in reply, that they liad mado lier rleath.[erst, and were now Foine to bury her; that she was old; that his bro. ther and limaelf that thught she had livod lung enongh, and it was time to bury her, to which she had willingly assented, and they were alout it now. He hal come to Mr. Hunt to ask his pravers, as thry did those of the priest. He adeled, thin it was rroin bove for lis mother that lie had done so; shat, in eonaequence of the same lowt, they were mow going to buty lier, and liat tone hat themselves couid or ought to do so sacted an office Mr. Hut did all in lis power to prevent so dis-
Inlienl au aes: but the only reply he recuived was that slyo was their mother, and they were her children, atid they ouglit to put her to denth. On reaching the fruve, the mothex sat down, whets they all, includiug chiluren, grandchildren, relattions, and friends, took th uffeciomate leave of ber; a rope, made of twisted tapa, was then passed twiees around her neck by lier sone, who tomk hold of it, aruf sirangled her; nfter which alhe was yut intu lier grave, with the usual eerenonies. They returtied to feast and inourn, afler which she wiss entirely forgotten as thuugh she las not existed.

Mr. Hunt, after giving ne this ntsedote, sur. prised ne by expressing lis opiuim that the Feejeeans were a kind and affectionate people to their parents, adding, that lice was assured by many of them thint they considered this custoun as so great a pronf of affection that noue but ebilatren eould be found is perform it. The sate opition was ex. [pressed by all the other white renidents.

A sluort time helore our arrival, an ald man at Levulis did sonetling to vex one of his grandcliidren, who in consequence 1 hrew stones at him. The valy action the old man toak in the ense was to walk away, abying that ho had now lived lang enongl, when his grandelilidren eonlil stone him with impunsy. He then reyuested bis eliblen and frieuds to bury him, to whislo they consented. A fenst was marle, he was drused is lim best rapa, and his face blackened. He was then phaced sittimg in lis grave, with his heuri abont two feet beluw the surface. Tupa and mats were thrown upon him, and the earth pressed down; duritg which he was heard to complaits that they hurt hitu, and to beg that they would not prese so hard.

Self-immolation is by no mens raro, aud they helieve that as they leave this lift, so will thoy remain ever after. This forms a powerful motive to cecape from decrepitude, or froa a crippled eondition, by a voluntnry death.

Wives are often strangled, or buried aljye, at the funcrat of their Lusbands, and genernily at their own instance. Cares of this sort linve fres quently been witnessed ly the white residenta. On ore oceasin Whippy drove away the murderers, rescued the woman, and caltied hex to his own house, where sha was resukcitated. So fnr, however, from feeling grateful for her preservation, glue loaded him with abuse, snd ever aftorws rannifebted the most dendly lintred towards lium. That women should desire to acconpany their lusbanis in death is by no means strange, when it is considered that it is one of the articles of their belief, that in this way alome ean they reach tho reulms of hiss, and she whn neets her death with the greatest Jerotedness, will becume the favourite wife in the nbode of spirits;

The sacrifice is ant, however, always voluntary; but when a womats refuses to be strangled, het relations often conpel her to submit. This they do frum interested motives; fur, by her death, Jer conmoxion becotne entitled to the properly of her hustand. Eves a delay is made a matter of reproach, Thus, nt the cuneral of the late king, Ulivm, which was witnesged by Mr. Cargill, lis five wives and B daughter were strangled. The prineipal wife delayed the ceremory, by taking leave of these arumbl her: whereupou $\mathrm{T}$ asea, the present king, clijd her. The viction was his uwu 
aurt, and he assisted in putting the rope around her neck, and strangling her, is aervice he is sail to have rentered on a former ocension to his own mother.

Not ouly do masy of the natives desire thoir friends to put them to deuth to escape decrepitude, or immolstu: themselves with a similar view, bue farnilies Iuve suela a repugrunce to laving deformed or mainned persous amnug them, that those who biswe met wilh such mimfortumes are almost always destroyed. An instance of this sort was $r$ lated to me, when $n$ boy whose ley hal been bitten off by a shark was strangled, altlough he had leen taken enro of by one of the white residenta, and there was every prosisect of lis recovory. No other reasola was assigned by the perpetrators of the deed, than that if he had lived he would have been a diagrace to his family, in consequence of lis having only one leg.

When a native, whether man, woman, or child, is sick of a lingering disense, thoir relnuves will eithor wring their hesds off, or strangle thent. $\mathrm{Mr}$. Hunt stated that this was a frequent custom, and eited a case where be lund with difliculty anved a serwant of lig own from such a fate, who afterwards recovered his honlt].

Formal laman sacrilices are frequent. The victims are ususlly taken from a distant tribe, and when not supplied by war or violuce, they are at times obtained by isegotiation. After being selected for this purpose, they are often kept for a time to be fattersed. When ibout to be sacrificed, they are compelled to sit upon the ground, wilh their feet ulrawn under their thigh, and their artus placed close before them. In this posture lhey ure bound so tightly that they cannot stir, or move a joint. They are then plineed in the usual oven, เม็กn hot stones, and eovered with leaveg and earth, where they are ronsted slive. When the hody is conked, it is taken from the oven and the face painted black, as is done by the natives on festal oecasions. It is thet carried to the mbure, where it is offered tu the gods, and is afterwards removed to be cut up and distributed, to bo eaten by the people.

Wonen are not allowed to enter the mbure, or to eat human flesh.

Humnn stcrifices are a preliminary to almost all their undertakings. When a now mbure is built, a party goes out and seizes the first person they meet, whom they sacrifice to the gods; when is large ennoe is husuched, the first person, man or Foman, whom they encumter, is laid lould of and carried home for a feast.

When 'T'anion launclies a eanpe, ten or more men are slaughtered on the deck, in order that it mry be washed with human blood.

Human sacrifices are also amoug the rites performed at the funcrals of chiefs, when slaves are in gome instances put to death. Their bodies are first plneed in the grave, and upou them those of tho elief and his wives are hid.

The ceremonies attendaat on the death and burial of a grest chief, were deseribed to me by persons who had witnessed them. When his last moments are approaclaing, his friends place in his hands two wlinle's teeth, which it is supposed he will noed to throw at a tree that stands on the rosd to the regions of the dead. As soon as the last struggle is over, the friends and atteudants fill the air with theis lamentations Two priest then take in each of their hands a reed abotit eighteen inches long, on which the lenves at the esud are left, and with tlese they indicate two persons for grave-diggers, and mark out the place for the grave. The spot usually selected is as near as possible to the banks of it strenm. The grave-diggers are provided with mangrove-staves (tiri) for their worl;, and take their positions, one at the hesd, the other at the foot of the grave, having eacl one of the priests on his right hawd. At a given sigual, the jabourers, making lluee feints before they strike, stick their staves intor the ground, while the priests twice exclange reeds, reperting Fejeo, Thonga : Feejee, Tonga. "The diggers work in a sitting josture, and thus dir a pit sufficiently inrge to contain the body. The first enrth which is retnoved is considered as acred, and Jaid mide.

The persons who lave dug the grave nlso wash and prepare the budy for internent, and they are the only persmis who cals souch the corpso without being hid urider a tabus for teu montlus. The Jooly after being washed is laid on a enuch of cloth and mats, and carefully wiped. I $I$ is then drissed and decorated as the leceased was in life, when preparing for a great assembly of chirfs: it is first anointed with oil, and then the neet, breast, and arms, duwn to the elbows, are daubed witls biack pigment; a white bandnge of ustive clotl in bousd around the head, and tited orer the temple is a graceful knot; a elub is placed in the liand, and hivil aeross the lireast, to indicate in the aexe world that the deceased was a chiof aut warrior. The borly is then laicl ona a hier, and the cluiefs of tha subject trilses nssemble; ench tribe presents a whales booth, and the clief or spokesmnn says: "This is our offering to the dead; wo ane puor nod cannot find riclses." All now elap their hamds, and the king or a chief of rauk replies: " $\mathrm{A}$ mumundi ni mate" (the cusl of dentlı); to which nill the people present respond, "O dims" (it is true). The fermale friends then appruach and kiss the eorpse, and if any of lis wives wish to die and be buried with him, she runs to her brother or nearest rolative and exclaima, "I wish to die, that I may accompany ny lusbliand to the land where lis spirit lats gone! love me, stnd miske lraste to strangle me, tliat I may overtake him !" Her friesde applaud her purpose, nnd being dressed, and decorated in lier best elathes, she sents herself on a mat, reclining her head on the lap of a wontan; another holds her nostrils, that she may unt hreathe shruugh them ; a cord, made by twisting fine tapa (masi), ia then put around her neek, and drawn tight by four or five strong merr, so that the struggle is soon over. The cord it left tight, ant tied in a bow-knot, until the friends of the husbund present a whale's tooth, saying, "This is the untying of the cord of strangling." The cord is then loosed, but is not removed from the neck of the corpse.

When the grave is finished, the principnl work. man takes the four reeds used by the priests, and pasases them backwards and forwards across each other; he then lines tlo pit or gruve with fine mats, and lays two of the leaves nt the head and two at the toot of the grave; on these the curpise of the ehief is placed, with two of his wires, one on encls side, hnving their right and left hande, reaprectively, laid ou his breast; the buties are then 
wrapped together in folis of native elotll; the grave is thess filled in, and the sacred enthl is lajd on, and a stone over it. All the nen who lave had any thing to do with the dead bndy take off their mano or masi, and ruts themselves all over with the leaves of a plant they call tionikonia. A friend of the parties takes new tana, nud clothes them, for they nre not allowed to tuteh any ling, being taboned persons. At the end of ten days, the hend chief of the tribe provides a great feast (nburua), at which time the tabooed men agnin serub themselves, and are newly dressed. After Ite feast, ava is prepared and set before the priegt, who goes through many incantations, bhiveribgs, and shakings, and prays for long life and abundance of elifidren. The soul of the deceased is now enabled to quit tho body and go to its destination, During these ten days, all the women in the town prowide themselves with long whips, knotted with shells; these they use upon the men, inflicting bloody wounds, whicl the men retnrt by flirting from a piece of split bamboo little liard balls of elity.

When the tabroed person becomes tired of remuining so restricted, they send to the head chief, and infirm hisn, and he replies that he will remove the taboo whenever they please; they then send him presents of pigs and other jrovisions, which lie slusres amm the people. The tnbooed persons then go into an streans and wash themselves, which act they call vuluvulu; they then catch some arimal, a pig or turtle, on wilich they wipe thoir liands: it then becomes ascred to the elisef, the trboso is nuw romoved, and the men are free to work, feed thembelves, and live with their wives. The taboo usually insts from two to ten monchs in the ease of clutefs, according to their rank; in the case of a petty clice, the taboo would not exceel a mouth, and for a commos persos, not inote than four days. It is generally resorted to by the lazy and idle; for during slis time they are not only provided with food, lus are actually fed by attend. ants, or cat their food from the ground. On the death of a clicef, a tuboo is laid upou the cucuauuts, piga, sc., of a whole district.

Truking off a tabor is attembled with certain ceremonies. It can be done by none but a elief of high rnnk. Presents are brought to the priest, พเมd a picee of ara, which is brewed and drutk; he thes unkes a prnyer (seru-seru), and tho cervmony is finished.

In laying a taboo, a stone about two feet in length is set up before the mbtre, and printed red; ava is chewed; after which slie priest makes a prayer, and inveles maledictions on the heads of those who shall lyouk it. Trees that are tabood have bands of cocon-nut or pandanus-leaves tied around them, and a stick is set in a lieap of enrth near by, Wo had an iustance of this at the time of ur arriwal, when we found all the cocon-nuts tnluned. We in conserzuence could obtain none, until I spokse to the chicfs of $A m b a u$, who renoved the taboo.

I'u the funeral ceremonies we lave degeribed, others are added, in Bome parts of the group, and there are differences in sume of the details of the rites. Tlus, at Muthunta, the body of a chief is thuslly tricen th the roynl mbure, ots the island of that finme, to be interwil. The corpuse, insteal of leing dressed in lige labiliments of life, is wiapped in white mats, and borme on a wide plusk. On its arrival at the anbure, it is rcceived by the priest, wisy pronounces an eulogium on tiis claracter, after which the yutung men form thenselves into two ravis, between which, and aruund the corpse, the rest of the people pass severnl times.

All the boys who have arrived at is suitable age are now eireumeised, and many boys suffer the less of their littlo fingers. The foreskins and fingers are placed in the grave of the chief. When this part of the ceremony is over, young brendfruit trees are presented by the relatives of the chief to the boys, whose connexions are bourd to cultivite them until the boys are able to do it thicinselves*

'The strangulation of the ehief's wires follows; and this is succeeded by a farther eulogium of the decensed, and a lament for the luss his people have sustriner. The whole is concluded by a great feast of hogs, taro, yams, and bauknas.

The funerals of prersobis of lower rats are of course far less ceremonious. The body is wrmped in tapa or mats, nnd sometimes spriukled witJ tumeric, and is buried in a sitsing posture, just below the surface of the ground. Even in this class the wife generally insists un being strangled. Instances are now, lowever, beytinning to oceur, in which this custom is not persisted in, a cireum. stance which seems to show that the dawn of eivilization is brealing upon them.

On the day of the denti, a ferst ealled mburua is always provided; anotiner four days after, called bonira; and a third at the cud of teu days, which is ealled buniviti.

The usual outward sign of mourning is to crop the hair or beard, or very ravely buth. Indeed, they are too vain of tliese appendages to part with then แn trilling occasions; and ns the hair, if cut off, takes a long time to grow again, they use a wig us n substitute. Sumc of these wigs are brautifully mado, and even moro exnes imitations of uature than those of uur best purruguiers.

Another mark of solrow is to eut off the joints wif the emrit toe and little finger; and this is not done onty as a mark of grief or s token of uffection, but the dismentuered joints are frequently seut to farwilies which are considered wenthy, and who are able to rewurd this toles of symapaliy in their Inss, which they never fail to ilo.

Wnmen in mourning tnuru their skin into blis. ters, as is the practice also in other groups visited by us. I'he ingtruncut weed for tho purpose is a piceo of tapa twisted into a small roll and ignited. Marks thus produced may be seen on their arins, shuulders, neck, and breast. Ithis custom is culled loloe mate.

The eating of human flesh is not confined to cases of sacrifice for religious purposes, but is practised from labit and taste. The existence of cunnitalism, independent of suprerstitious notionk, has been duubted by many. "l'tere can be no question that, nllbough it may have originated as a sacred rite, it is continued in the Fejee Group for the mere pleasure of eating luman flesh as a food. Their fondnees for it wil! be understoul from the custom they barce of sending portions of

- Tlis custom has an important Infuence in kecplng yp stock of this Imumrent suree of food, and lnay lave originated witlit that vick. 
it to their friends at a distance, as an scepptable present, and the gift is eaten, even if deconymasition bave lregun before it is received. So highly dis they esteem this food, that the greatest praige they cin bestow on a delietcy is to say that it is as tender as a dead man.

Even their sacrifices are made more frequent, not merely to gratify feelings of revenge, but to intinlge thuir taste for this lsorrid foud. In resprect to this proprensity, they affect on disguise; I hise anyself frequently sproken with them concerlus it, and received bat one answer, both from chie[s and combunon people, thas it was visalia (gomd).

Thu bolies of enemies slain in battle nre always eaten. Whipyy told no that he saw, un one oecaвiou, upwards of twenty men cooked; and several of the white residents stated that they have seen bodies brought from such a distance as to bo green from putruscence, and to lure the flesh dropping froin the bones, which were, dotwithstnding, enten witl greediness nad apporent plensure.

War, trowever, does not furnish enough of this fuod to satisfy their apretite for it. Stratagem and violence are resorted to for obtaining it. While we were at Leruka, as n munher of worren belonging to the village were engaged in picking up shells and fishing, a earno betunging to tho Lasiknus, or fishermen, in passing by the reef, seized sud carried of two of them, as it was be lieved, for eamibal purposes. When I heard the story I could ust at first believe it; but it was confirmed by Thi Levukn, who said that the Isasikaus frequently stule women from the reefs for the purjosse of eating thenr.

All doubt, luwever, was removed, when Mr. Ed, while statianed at the observatory, beeane as eye-witness of an attempt of the kind. 'The daughter of the Vi Tonga *hief, with some of her compasions, was engaged in fishing on the reel in a stmall canne, By some accident the cance was swamped, which rendered them a prize to whoever should capture then. A canoo from Ambau lad watched the proor ereatises like a liawk, atsd, as gonon the the medent baprened, pounced upon thern. The men in the enuoe suceedted in eajuring the elizef'y duughtes', and finreed her into the versel. When near the shore, however, sho eontrived to make laer escapre by jumping overtoasd, and renclied the slure before they could overtake her. Clubs aud spenrs were tlrown at her, with no other effect than a shiglt acracch under the arm, and a bruise on her.shoulder. On the beach she was received by her friends, who stond ready to protect her, upon which the Ambau people gave up the pursuil.

The camibal propensity is not limited to enemies or persous of a different tribe, but they will banquet on the flesla of their dearest friends; now it is even relnted, that in times of searcity, fumilies will nulke at exettange of children for this horrid purpose.

T'the Hesh of women is preferred to clat of men, and they consider the flesh of the arus above the celbow, and of the thigh, as the choicest parts. The womeu are not allowed to est it openty, but it is said that the wives of ehicfs do partake of it in

- Vi Tonga lo a town frumedlately below the point on which the observatory wan placed. private. It is also forbidules to the kai-bi, or common penple, unless there be a great qtiantity, but they lave an oppurtunity of pieking the botres,

As a further instance of these cannibal propengities, and to show that the macrifice of human life to gratify their passions aud apretites is of ulnost daily occurrence, a feast frequently takes place anong the eliefs, to which each is required to bring a pigg. On these oecasions Tanon, from pride aud istentatinn, alway furnishes a human body.

$A$ whale's tooti is about the price of a lumen life, even when the party slatn is of muk, as will twe shown by the following anecdotes. IRivaletta, the youngest won of Tanoa, while pasing atung the worth eus of Ovolau in lis canoe, descried a fishing party. He al once determined to possess limself of whint they had taken, and for this purpose dashed in among them, nnd fired his musket. The shot killed a young man, who proved to be a nephliew of Thi Ievuka, the chief of Ovolum, and was reongnisel by some of Rivaletta's followers. 'Tllis disenvery diul not prevent their earrying the body to Antun to be feasted tupon; but in ordor to provent it from being known there, the face was disfigured by broiling it in the tire in the canoe. Tann, limwever, soos became surare of the fnet, and forthwitls gent a winle's terotlı to 'Tui Luvuka, as the value of his Jass, trgether with a number of Jitule fingers, eut from the people of Ambuu, as a propitintury offering. The memuneration was received by Tui l.evuka as euffieient, an! no more notice was taken of the matter.

Before we left the group, an inferior chief ras nway with one of the wives of Tui Levulin. The latter immedintely despatehed his son to the town where the etief residted, for the purpose of killing the uffender, which was effected, and the wonas brought back. Tui Levukn therenjwets sent a whate's tootla and sume tapa to the prineifal chice of the tnwts, anul the nffuir was ended.

When they set so little value on the lives of their own comerymen, it is not to be expected that they should nuth regard those of foreigners. It is neenfassy, therefure, while holding intereourso witl thern, to be contimually guarded ngainst their nurderous desigus, which they are always meditating for the sake of the property about the person, wr to obtnin the body for food. Several recent iustanees are ralated, where crews of vessels risiting these islands have been put to death. One of these, in particular, beeame known to me, and led to certivin proceedings on try part, which will form an important part of the following chapter.

The vessed in question was the Anerican brig, Charles Doggett, Captain Bachelor. I had heand of the attack upon her, and after Paddy Connel paid me lis first visic, of which I have before spoken, I learned that he had been on board the brig at the time, and had a full knowledge of all who were concerved in tho transaction. I therefore, on his next visit, questioned fin iu relation to the affair, and obtained the following particulars.

In the montli of August, 1834, Padij, with some other men, was engaged by Captsin Bachelor to assist in gettiug a cargo of biche de mar. The brig then went to lewa, where the captain made a cor. tract with Vendovi, is chief of that islaul, ard Yamu of Kantavu, for further nssistanee in atcaining his object. Here the enduct of Vendovi, Thukananto 
and other chieth, led to the suajeicm thint nomo mischief was intented; Paldy heard rumours of the grent value of the articles on bonrd the brig, accompanied by hints that the erew was but sanall, and predictions that it would not he well with her. He also found that a disire was erinced that he should not go further in the ressel. In consequenee, Paddy, while on the way to Kantaru. mentioned his suspicions to Captain Bnchelor, nnd advised him to be on his gund. When they arrived at Kantarn, they proceded to a mall island near ith eastern end, where the biche de nur house พas erected, and a ehief of the islnnd was, as nвนal, tabien on buard as a hostage. 'The day after he eame on board, he feigned gicliness, and was, in cunsequence, permitted to go on shore. He departed with such unusual exhibitions of friendly disposition, ns nerved to eontirm Padily's previous suspicions; hut lie felt assured that all would be safo Eo long as the crptain renained on board.

On the following moruitig (Stmday), Vendor: eame oft, raying that the young chief was very sick, and he wanfed the captain to come to the biche de mar lonse, where he stid he was, to give him nome medicine. In this house eight of the met were employed, of whom two were Sandwich Islanders. The eaptain was preparing to go ashlore witl the medicine, when Paddy stepped af to him, and told him that to go on sloore was as much as Jib life was worth, for be was sure that the natives intended to kill him, and to the all their lives, T'le enptain in consequence renunined on honrd, but tho mate went on slure, and took wills him the bottle of medicine. Vendovi went in the boat, and landed with the mate, but could not concesl his disatppoin tment that the eaptain did not come rlso. Padrly now whs convinced, from the arragements that lind beon made to get the people and boats ansy from the brig, that the intended migchief was about to be consummated. He therefore kept a wharp look-out apon the shore, and sonon saw the tregitusing of an nftray, the mate, Mr. Chitman, hilled, and the Iniluling in flutmes. The others were also slain, with the exeeption of James Ilousman, who had been engaged st the game time with Iadly, sul who swam off, and was taken on board. Those in the brig opened a tire from the grem guns, but without effeet.

On the following day Padly was employed to bargain with the nutives for the bodies, seven of which were brought down to the sloore inuch ma. tilated, in contiderntion of $\mathrm{n}$ musket The eighth, a negro, had been cooked and enten. Captain Bachelor had the bodies aewed up in caurass, nud tlirown overbont, in the usual manner. They however floated aguin, and fell into the hands of the earages, who, as he afterwards understood, deswoureal them alt.' 'They' comptained, however, that they did not like them, and particularly the negro, whose flesh they said tasted sirong of tobateson. The brig then went to Ovolnu, where Prady left her.

In addition, Padrly told me that he was sa $i$ tied that all the eliefs of Rewa had loeen privy to the plor, partieularly the brolliers of Vendovi, and that the wholo plan had been arranged before slıe brig left that island. Vendovi, however, was the person who bad netually perpetmited the outrage.

Hnving leard this statement, I determined to capture Yendori, and atked Padoly if he would curry a letter immedintely to Captain Hudnon, who wat then with the Pencock at Rewa. After some lesitation he agreed $w_{0}$ do it, if I would give him a musket. I aeenrdingly prepared instructions directing Captain Hudson to make Fendovi prisoser, and despatelied Paddy next morning in a caute for Rewa.

\title{
CHAPTER XXIV.
}

\author{
THE FEEJEE GROUP.-REWA.
}

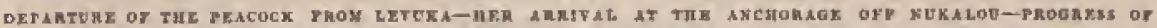

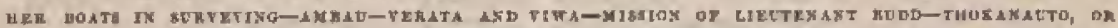

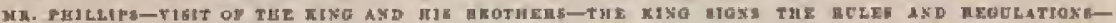

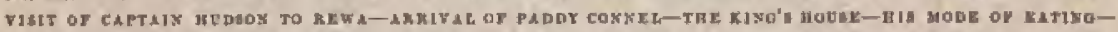

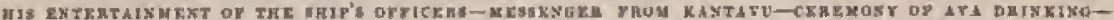

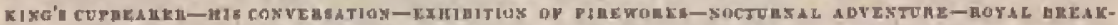

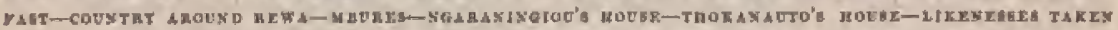

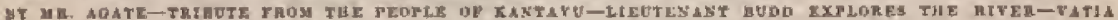

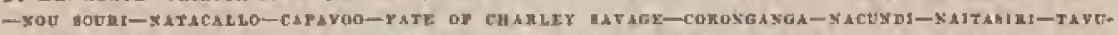

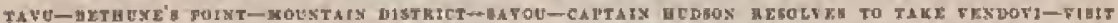

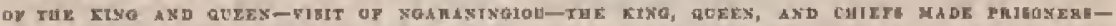

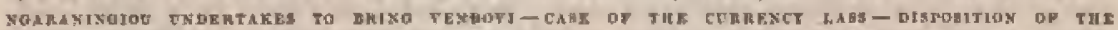

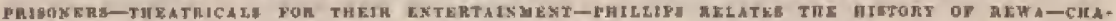

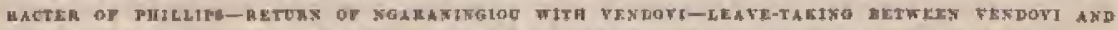

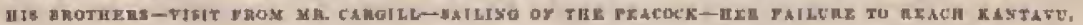

WuEx the Peacoch left the barbour of Levukg for lkewa, it was for the purpose of visiting that town and indweing the king of Itewn so xign the Feejec regulations, and also to enrry on the surveys in that quarter. The Peacoek left Leruka on the I5th May, and reached Kewn at nom tho next day.
The harbour of Rewa is formed by two santl islands, called Nukalou and Mukalon, with their attached coral reefs, and has three prasages into it. The two southert ones are safe, thongh narrow, but the northern one ia much obstructed with coral Jumpe. The port is a secure one, and the anchor- 
nge, which is off the island of Nulkalon, is about three miles from the mouth of Wailern, or Peale's river, and six from the town of lkews, which is situated on a low piece of land, whieh the river, jassing on each side of it, has furned into an islaul. I'Te east point of Vitileru is low, and is divided by sovoral small and miniportant streans, which we had not time to examine; there is, also, at high water, a passage for enoes through one of thern to Anbau, which lies ten miles to the nurthward.

The launch and firat culter of the Peacoek, under Lieutenant Limmorns and Prosed.Midwliumun Blurst, were found here, liaving alvanced thus far in their surveying operations. They had pased around the biy of Ambau, stopled at the towsin, wtol net witls ratluer an unfriendly reecption there; the ethefs refused to give them any water unlest paitl for, on account, ns they said, of our trademaster llot paying a higher price for the yams they caries him. For this renson the chiefs were in a bad homour, and had refused a supjly of wafer to the bonts.

Amban is a singular-looking place. It oceupies a smalt islaud, which is entirely eorered with louses, antong which the mbure stunds consynicuous. I'ine appronch to the town is much obstrueted ly roefs of eural; and tho water being shullow, is impuscable for an artued ressel. The island is con. nected with the main land or inge islaud, by a long fiat of combl, which is fordable, ever al high watwr, and is in places quite bare at low water. One is at a loss to conceive how this phice could hove acruiced its strength and impertance. I an ratler jnelined to impute it to the enterprise of its first settlers, and the ascendancy given it lyy the tecidental aid that lass been afforted its chivifs ly the whites, who enum: aszung them and joined their side. It was, probably, at first, the retrent of the tishurmen; and from their enterprise, the difficulties they had to encouster, and the powerful enpnexions thoy have formed with the other towns stud districts, it is likely thet their rule will cmutinute until the people sladl have becone eivilized, whell, from the want of internal resoures, the terror of jts name will jass away, nnd it must fall to the rusk of a place of scevndary im[xartauce.

At present it is in the ascendancy, and its chiefo have a bigh estimate of thoir own importanes. Thuts, while 1 was at Levuka, I was much asouscel by a question put me by Seru, "Why I had not gino with my ship to Ambau ? why como to Levuka, where there were no gentlenen, nune hut common people (kni-si) I atl the gentlemen livent at A milau."

The towns of Vornta and Viwa are willin a short distance of Arubau, and have buth becul its rivals. Al each of these some fenrfill outruge lras been prerpetrated upon trailing vessots, for which the gutily lasvo been but partially punislied. The chice of Viwa, I tunderstoont, lial made it lis boast that the French hat only burneal a few of his mul huts, whieh he enulu shortly build again; that it would give as very few days of labour tis hig alaves; and that he would cut of the next reasel that eane, if he las an oppurtunity. Ho thinks that it was is very clueap purelnase to get so misel property for Bo lietle damage. The Amban perfite also epoke vatuntingly of lasing given the
Fremel perabission to destroy $V^{\prime}$ iwh as it was nothing, and sacisfied the I'apalangis ; bat they did rut intend that any property or lives should be lost, for they had sent to inform the Viws people that the attack was to be make, and even Jiclyed them to remove all tycir valunbles. Viwa is ow so large a town as Ambnu, but is built on a Jarger island, and affurdy more conveniences for a poit.

The whole hay of Ambau in well shielded by extcnsive coutal sen-reels. Hete sho launeh and first cutter again left the l'eacock, on their way to she ishand of Mbenga, to the mestward.

Captain Hudson, after muchoring, sent Licutenant Budd tu the town of Rewa fur the purpoee of connumicating with the king and clsiefn, and of obtaining the services of Thukamato (Mr. Plijlips) us interpreter and pilot. Lieuteunut Budd observed much apvirent fear among the clitefs and preople. The king, Kania, ou the approach of the bonts, had gome to hiide lingelf in the outskirts of the town, but Mr. Phillipss whe jet on the way eoming fruwards them, and after much thesitation determined to accompany Mr. Budd on board the ship. The natives appenred to entertain the sane fonrs as their clisef.

Philipg is about thirty yearg of nge, of middle size, active, and well-made; he is more intelligent than tle natives gonernlly, and his appearance less Eavage; he spenits Linglish tolernbly well, though it is not diffieult to perceivo whence he las obtained

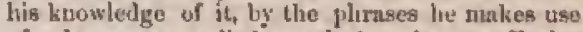
of It was jot a litle comieal to liear a Fecjee nian talk of "New York lizghtindors," "s Bastun dauulies, "Baltinore snobtowus," On ns:urnnces being given to the natives that wo were their friends, they beeame more reconciled, and after a time the king, Kania, of Tui Ndraketi, was found, and invitations delivered to lim to fry $n$ visit to the ship. Lieutemant Budd then crossed the river to the missionarites' housta, where he saw their wives, and fonnd Mr. Jagger, who is ane of the mission. The Rev. Mr. Cargill hat visited the ship shortly after the Peacncli anchored; his eanoo was matmed by Tomga men. He was on his way to a tuwn fifteer miles distant, where the ehief and $a$ few of the people bad just embraced Chriss. tianity. He was invited to preach wn buard the next diny ; he complied, and delivered an excellest diseonrse.

On the morrsing of the $[8 \mathrm{th}$, Mt) nduy, the king and lis brother, Ngarningiou, visited the ship. The king eame in $n$ esuloe of beatiful construction, abour forty feet in length, propelles by jaddles, whiels the king alone is alluwed to use. Ngaraningjou was in a mol, hrger cartoe, hav ing a largo mast and enil, and the clice?'s petrunt flying from the yard, but sculls were used.

Captain Hulson now sespatelied Licutenant Budd snd Passol-Midslipuniul Davis, witl twn buats, up the river. Mr. Peak, one of the naturnlists, west with this experlition, nnd Mtr. Phillips's Bervices werto engaged to nceorm [atuy aud proteet the bouts in the exploration of the river.

Tho slip lad been jrepared for the ding's visit; he was received with due coromuny, and was led aft, and sented on the quarter-deck. I'ui Nilinketi is about furty years of age, and is n talt, thic-looking man, with a Inunly expreasien 
of eountesance, and much dignity. His intellect is nut as gisick as that of his brother, Mr. Philljps; and his matmer was cold and repulsive. He was without any attendants of high rank. Ngaraningivt shortly afterwards made his appeamnee, nccornpanied by six chiels, and a retinue of thirty or forty men, forming a singular contrast to the un. assuming appeartince of the suite of the king. Anuther of the purty was a chief of high rank, ealled Vunivalu, "Root of war :" he is a tescen." rant of the royal family tluat were detlironed by lianir. His position gives him grent influence, and, is case of war, the operations are ennfided to him. This chief bears, among the foreiguers, the litle of gofernor,

Ngarausugion is equally tall with his oldeat brother, the king, and betier and more gracefully formenl. He may bo considered a gornl specimen of a Feejee man of high rusk nul fashion; iadeed, his deportment struek the afficers as quite distin. guished: he lus, withal, the appearance of a rove, nnd his conthet does not belie the indications, and hy is considered by all, both natives and white residents, as a daugecons man. "The young chiefs who werv his companions, resembled him in chnrncter and mantuers. They were all shown over the ship, anal every thing exlibited that it was thought could interest them; the small-arm men were excreised, the only music on board, the drum and fife, were played. These, together with the fring off the guns, shotted, did not fnil to druw forth their usual expressions of wonder and aurprise, "whoo-00 l" the same that was uttered by Thuois's party, on board the Vineennes. After partaking of some refreshuments with Cuptain Hudson, the rules and regulations, similnr to those subseribed by Tanna, were carefully isterpreted to them by Mr. Cargill, and willingly subecribed by the king and eliels, with the strongest assurances, on their part, that they should be earried into eftect, and most strictly abserved. Suitalile pre sents were then distributed to the king and elntef, and they left the ship, apparently highly delighted with their visit.

The surveying operations were nnw prosecuterl, and the paturalists, with as many ufticers as could the npared, visited Rewn. Captain IImdson describer the passago up to Rewa as turtumus and dillicult, eveo for a bort, on account of the many sand-banks and shoals. Severnl of the geutlemen tumbriced with Mr. Cargill in his eanoe, which bat a high platform, undertieath which was a enrt of euddy, with seals. It was a tolernbly cumfortable conveyance in fise weather; but it wan their misforture to experience a heavy rais, and all were well wetted. The winl being contrary, they wero abliged to seult tho whole distanee, and thoy deseribe the canoe as laving an uncomfortable rocking motion.

Cuptrin Hudson visited the missionaries, and found them most miserably acenumolnted, in a sinall rickety house on the left batzk of the triver, onposite the town of Rewa, the diwelling-honse that they hal oecupied laving been blown down in the tromendous atorn * which happened on the 25 th of Fobruary, 1840.

- Thin storm spyears to have heer enineidens with, if rout part of, the gale that occurred at New Zealand on the lot of March.
A fier Captain Hudson thd spent sone time with the missionaries, my messenger, I'adily Connel, made his appentance and delivered him iny letters. Padjy had a very awkward mishap in rounding Kamba I'oint, for lais canoe land enpsized, and he liad been ubliged to swim for his life. He had thought, as he said, that some ill Juck would overtake him, and had, therefore, tied my letter in the handkerehicf on his head. By this means he kept it dry, und he believed the important paper, as lie called it, had kept his from drowning.

Although it lind rained hard, Cuptain Hudson resolved tu fulfil his promise ta the king, of ahuwing him some fireworks, and the gunner hat been oidered up with rockets, fireworks, $\&$ c., for that purpose. He, thereforu, jroveded ncruss the river to she king's lsouse, where he found a large collection of mntives. The house is large, and in sliape not unlike a Dutch barn : it is sixiy feet in length nul thirty in width; the eaves were six feet from the grours, and alung esch stde there were three inrge posts, two feet in diameter and six feet high, set firmly into the ground; on these were lnjd the horizontal beams and plates to receive the lower ends of the infters; the rafters rise to a ridge-pole, thirty feet from the ground, which is supported by three posts in the eentre of the builuing; they were of uniform size, abont three inclies in dinmeter, and eightecn inclues apart. The uaunl thick thateh was in tlis ease very neatly male. The sides of the house were of sminll upriglit reeds, set elosely together. All the fastenings were of sennit, made from the husk of the coron-ant. Some attenipts at ornament were olsserved, the doorposts being covered with reeds wound around with Beurit, which had a pretty effect. Thiere are two loorways, one on each side : theae are only about three feet in height, and are closed by hanging mats. At the inside of the principal door are two small cannons, pointed acinss it, which, in the eyos of the king, give it a formidable mpjearance. A sort of dais wrs mised at one ent, a few inches: this was corered with mats for the king and his wives, while at the other end mats were lail for lis attendants ; above was a shelf for bis property, or riches, consisting of mals, capa, enrthenware, apears, and clubs. On one side of the lrouse, us is ustal among the Feejeenus, the cooking-place is excavated, a foot deep and aboul eightic feet squnre; Iljis was furnished with three large earthen pots, of native manufacture, and two liuge iron ketties, obtsined from some wlunling ship, such as are used for trying out oil. These were cranmed with fuod.

Some of our gentlemen entered $n$ slyort time previous to Captain Hudson' $\mathrm{k}$ arrival, and fonth! the king taking a neal, with lis principal wife besisle hitn stretclied out ou a mnt. All those around him were sitting after the matmex of thes nntives, for nome presume to stursd or lie down in the presence of the king. Whell he had finished encing and pustied the food from lim, a genernl clapying of liands took place, nfter which water was brouglin und the cuj held to his mmuth until he hat done drinking, when clapying of lands again etisued. This was reprealed whenever the hing finished doing nuy thing-n piece of etiquette nlways observed will great atrietness.

On state oectsions this ceremony in ensrien muel, farlser: the king's food at sucts tines is prosed 
around a large circle, until it renclies his principal wife, who feeds him witl her handz. Many of the chiefs always riequire the awa-eup to be held to their mouths. Notwithstanding all this oere. mony, the chiefs, and the people kitting arvutid them, join faniliarty in the conversntion, and ajfear otherwise perfectly at their ease.

The king at onee ordered provisions for lis guests, for whom sents were provided on a serchest. The priveigsal articlo of food wns the salt beef he lad received as a present from the slip, and which he named bula-mn-knu. The origin of this anme is not a little singular, and is due to nur countryman, Captain Kagleatun, who has been for several years truding among this group. Wisling to cunfer a henefit on these natives, he took on board a bull snd cow at Tutiti, and brought them to Rewn, where he presentel them to the king. On being rsked the name of them, he said thing were culled "bull and cow," which words the natives at once arlopted as a silugle tertn to derbig. uate buth, aud thenceforward these suimals have been knowi as bula-ma-kau, T'he beof was found to the more satroury chan on board shij, perthaps from being twice briled. "I'lue king was asked to jnin them, which he did, altlrough he had just fiuished a limarty mest. After the menl was over, a suall earthen firiger-bowl was brought to the king to wnsll Jis Janids, and as the attendant did not acem to be prepared to extend the like ourtesy to our gentlemen, a desire for a sinilar utensil was expressed and eonplied with, although spparently with snme reluetance. In like manner, when the jar of water was brouglit to the king, one of the party seized upon it and drank, and the rest followed suit, to the evident distress of the attendant. It was afterwarda understood that bis anxiety arose from the ressel being tabnoed, as every thing belonging or appropriated to the use of the king is. 'The Papalangi ehief are exempted frota these restrictions.

When the meal was fnished, the whole company seated thenselves in a Bemicircle. 'Ihe house was now converted into nu autience-bull, and the riff. cers and stewnids of the king entered to render their report of the day respecting the manngement of his luainess. A claief had just arrived to pry lis respects to the king, ind was drensed in a piece of new enpa, which was wrapped nround his boly in numerous folds. When he had seated himself, the unrolked it, and tore it into strips of three fathous in length, which he diatributed to the chiefs around him, who inmediately substituted it for their own dresses. 'This chicf was the messenger announcing a tribute from Kantavu, and be land cone to receive the commands of the king relative to its preantation, which was fixed upon to take place the sext tay.

Ava was cliewing when Captain Indson and his party entered. They were kindly reecived by tho hing, who sented them nenr him. There is a peculine ceremong observed smong this people in mixing their swa. It laving been first chewed by acteral young persous, on the pouring in of the water, they all, following the ambnti, raise a kiud of howl, and say, " $\Lambda$ i seru." The perple present were surauged in a semicircle, having the chief operntur in the centre, with an inmense wooden bowl before jim. The latter, immedintely nfter the water is poured in, begins to striu the liquid through the wonly fibres of the vau, aud at the same time simgs. He is aceompanied in his song by thuse present, who likerise initate all hiH motions with the upper part of their bodies while in a sitting posture. The motiuns keep time to the song. "lihe king joined occasionally in the song; and when any in. purtant stage of the operation was arrived at, the roug censed, and a clapping of hands ensued. As each cup was filled $\omega$ be served out, the ambati sitting near uttered the sante wild how! as before. The first eup is filled from another, that answers botls for dipper and funnel, laving a hole in it, over whlelt he who brews the nva places lais finger when dipping, and then wjthdmwing it, lets the liquid run wut is a stream. 'They are very particular to see that min one touches the king's eup except the eujs-benter.

On the jresent neension, a worthless Englishman by the uane of Janes Housman, called Jisu or Jimmy, ofticiated. Few would lanve distiugtsished him from a native, so elosely was he assimilnted to them in jdeas and feelings, as well as in lais erouching before the clisefs, lis mode of sitting, and slorenly walli, On tho king's finishing drinking, there was a gencral clnpping of hands; hut when the lower order of chiefs were served, this was nut observed, and in lieu of it, there was a general exclamation of "Sa madat" (it is empty). After ava the king rinses his mouth, lights lis eigar, or pịe, and lolle on lijs mat. It was laughable to see the king's harber take his aya; as he is not allowed to touch any thing witl his liants, it leecones necessary that the eup stusll be luedd for lim lig another person, who alno feeds him. One of the iffliers gare him a cigar, shiclı was lighted and put io his mouth, and when he wisherl to renowe it, be did it its a very ingenjous manter by twistiug a small twig around it.

The king made many inquiries, spoke of his riches, his pateat rifle, and the feast he intended to give; bat he wanted a double-barrelled gun. Ho likewise spoke of being desirous of seniling his two little girls (the only clibilren lie lias) to the mismionary schrol, but their attendants (lhey lave male nurses) were such thieves they would stenl every thing they condd lay itueir hands on from the mis. sicmaries, and in this way would give him a great deal of trouble. Cajtain Hudion inusueed him to promise to build the isisstonaries confortalile houses, as soon as the wanther became goxd, and he had recejved his tritute from linntavu. He struko kindly of the missiunaries, aud seemed well satiafied that their object was to do bimself and his people gruml. The king ordered lis hotsachold to thant a kind of song, for the umusement of his grests, the subject of which was the advontures of a chief on a voynge, nfter leaving his wife, and her resolution to destruy herself in consequence of lis failing to refurn.

A bout aine o'clock the fireworks were exhibited. Wheu the first rocket was sent aff, the natives exhi. bited fear and excitement; the king seized Canaain Hludson by the laand and trembled like a leaf. When the rockets hurst, and displayed their many stars, they all seemed electrified. 'The effect produced lyy the blue-lights on the dark groups of naked figures, smazed and bewildered as they were, was quite striking, particularly at the epectacle was accompanied by the uneouth sounds of many conchs, and hy the yell of the savages, to drive away the 
spirits they supponsed to be lec loose and Aying in the air. Paddy Connol, alins Berry, told them thint uothing trut the unwillingness we hid to do them injury prevented ua from menting then to Ambau, ten miles distant, and he said these was nn doubt that they believed that it could be done. 'This exhibition excited the wouder and nunazement of all tho country round, and induced them to bedioge that these flying spirits were collected for the ile. struction of Ilews, and thst they themselves would be the next ta suffer.

After the fireworks they all retired, Captain Hudson taking up his abode with the king, and continuing to talk-with lim until a late hour. When they rotired to their sleepiug apartments, lie found his places of rest was divided by tapa-elortha and seresus from the rest of the ajartiments of the houre, and well furuished with musquito netting. Ere he got to sleep, he was survurtised tu fiur his เmirquito-net moviag, and utill sore so when he sow the figure of a womass, one of the king's own sives, of whom the lina a large number, endenvuring to become his bedfollow. Jhis was to bim an ursexpected adventure, and su lumonr of which he wam not ambitious. He therefore called foudly for Puldy Connel and Jimny, the king's borly-servant and enp-bearer, and through then very politely dedint the hoswour; but the Indy positively refused to go away, saying that she had been sent by tha king, and must sleep there; that she darst not go awny, for the king would dub her! She was told that she must go, that the matter wowlt be armuged with the king in the morning, and slue need have no fears ahout it. She then Jeft the musquitonet, althongh with evident alsm as to the consequences, and would go no further. Seeing this Captnin Hudson sent Jinumy to the king, to say he did unt wish a bedfellow; to which the monareli replied it was sell, and directed the woman to withdivtw, which olıt did as goon as gatisfied that it was the hinc's command. 'This circumstnnee, together with the continued trampling of the mice, with which the palnee is operrum, drove sway sny thing like sleep; and Captrin Hudson, in self-defence, was abliged to pass the remainder of the night with Puddy and Jinmy over the fire.

As soon as the dry dawned, his mnjesty, who is an mrly riser, ealled for his ava, and her majesty called out luatily for Jimmy to light a cigar anil bring it to her in bed, for stre is as fond of cigars as her royal epouse. After the hing had drunk his ava and sooked his cigar, they had breakfast of baked pig, tiro, and yams. The repast whs sprend upon a mat; nfter which Captain Hudson, accompanied by the king and Poddy Connet, crossed the river, to the missionaries, where they partook of a second breakfast, the king belaving bimself with great decorum at the table; and Paddy, too, took his acend luneh behind the door, wills great emjoymeut. The king ronewed bia promises to buila their houses, ns foon as the westher became fine, and said that then he would not leave them nutil they were finistied. This engngenent, I an happy to sny, the fully performed. After brenkfnst, they again eruased the river to Rewa, and the weasher lowing cleared up, the towin presented an entirely different nppearnee. THie seenery around Rewa is fine. There are in its neighbourbood many creek, not utsilie narrow cannls, bordered on each aikle with ricls and beantiful vegetation, resemuling that of Oriental regions. Dr. Pickering and Mr. Rich threaded tnany miles of there creeks, in the canoe of Mr. Cargill, who was kind enough to lend it to them. During this exeursinn they landed and went to a village, where they saw a well-planted ball-alley, kept in good order, level and clean. Turo and sugar-chne were found to be extronsively eultivated. Afler wading neruss severnl erecks, they finally renclied an uncleared wood, consiating of large trass of Inocarpus, Iarringtonis, and Uvaria, whli palms and pandaus, reseubling the vegetation of Ovolat. The coustry spluentred very wet, and was full of mund-lonles and small creeke, which rendered walking jrksome. Tlicy returned to Rewa by dark, and the next day jurocedterl in all. other direction, whets a F'ergee dandy nffered th he their guide, and was extremely attentive to them throughout their excursion, He refused all conpentalion, until a litcle girl, who was near, seejug a Jew's-harp, requested to have it. He then necepted it, and gnve it to her. T'his act, tugether with his civil and attentive hehavions, produced a farusrable impression uposs thetr.

The town of Rewn, though in a low situation, has a picturesine though singular appenrance. It txtends alrout a mile along the river, and contains from five to six hundred houses of all sizes, from the lofty mbutes with their sointed roofs, and the barn-like edifices of the chiefs, to the rickety shan. tees of the kai-gis, and the diminutive ynm-honses, perched on four posts, to protect the yams from the depredations of the rats. It is every where intersected by aarrow lanes, elosely shut in with high reerl fences.

The party visited the mast eonspicuous houses of the place. The first which they gaw whs the mbure, situated on the spot where the king's father was murdered; the mound on which it is built is an artifieial one, ten feet ligh. The mbure is alout twelve feet square, and its sides or walls only four foet high; while its bigh-pitehed roof risteg to the beight of about thirty feet. The walle and roof of the mbure are constructed of cunes about the size of a finger, and ench one is wound round with sennit as thick as a cod-line, male from the cocon-nut busk. At a liulo distance, the whole house looked as though it wns built of brated cord, and presented a singular and curious apperance, crenting a farourmble jdes of the skill as well as labour expended in its construction.

The next building visited was that of the king's women. This is one bundred and eighty feet in length, twenly-four feet wide, and thirty feet bigh. Here were a number of women engaged in naking mats, tapa, and haskets. Tluy were gay and merry, though tusily engaged at their work.

Another large epirit-liutse was next visited, in which the mnuntaiseers congregate; and on their exit frou it they saw a bull near the donr, which the natives, in essaying to follow the party, had tu encrunter. It was not a little amusing to see then enilting at the beast to drive him oft.

Nigarnningiou's dwelling was then visited. This is enueidered the most elegrant house in the Feejeer. It is very elabnrately ornamented with sessit and braid. Order and decorum reign tiroughust, for Ngamangion is extremely diguified and yeserved in his domicile, and is reputed to be somewhat of a tyrant. He will not suffer nny of the natives to approach and gaze in at his doors, which is a 
common practice with them; and whess, on one occasion, a stranger took the liberty to peep in at his door, he is snid to lanve askit him if his head was made of jons that he dared thus to presume.

Thoknuanto's house was aceupied by several of our getslemen daring their stay. It is rquite a large eslabliahment, and was une of the nuisiest that can well be imagined; for Ptillips limself being absent with the bonts, his wife did not pos. sess the requisite authority to thaintain oreler. On the first night of their loolging there, about fifty pretsons, men, women, and children, were collected, fenstiug, drisking fwa, nud maintaining a prodigi* culs racket. They were apparently engaged it detriling and iliscussing the ovents that had taket plise on buard slip, and tho marrative was eonstantly interrupted by jukes, laughtur, expressions of astonishurzent, and arguments letoding to wharp words, Intil the shrill voice of the young miatress of the mansion was heanl in earnesi ex pustulation 'The elorinence of Phitlips's orator, nnd his mauy bartrers, was not to be so easily repressed; and nftor a few moments? silence, an alterestion arose, that graduslly grew into a ginarel and termiznted in a furitrus fight, in which one of the combatrnts was thrown againgt the musquito-bar serving as a sereen tn our gertlemen, breaking down one end of it. J'lıey now sought their atma, and plateen themselves un tlieir guard for self-pritection, not knnwing whac Feejee ferocity and trenchery might bring abont. Tho hoskess ni last interferml with none effect, and put down the enmmotion, and the house was quieted for the nights, exeepting the rats and mice, which during the noturual hours touk full passersion. Little can one imagine the soise of these mi races; Whittington's eat here would indeed be wortl her golden jurice.

Mr. A gate umde giond lose of his short stay at Rewa. While waudering about, he was mot by is yrieat, who cames to lim and taigrified by gigns he wished lin to sketeh sormething, and at tho same time priuting to a house. Mr. Agate followod him in. There were a large number of retuiners present, and shartly after his entratco a wan was aroused from his imath who suil he wislıed lis likoness taken. His heal was dressed in the must elatonrate anl extravagant fashion of Rewa, and from the number of lis retainess he appeared to ho a high elipe. A lay or two after lie proved to be the notorions Vend ovi, brother to the king, and the pursum whan we desired to capture. He had his faces smeared with oil and lamp-black.

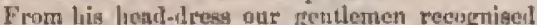
him as the individual who lad been their guilde in one of the short excursions they had made in the neighbourhond, and with whon they had been so mucl pleased when they offored lini a reward for his services.

Ms. Agate nleo ulutnined good likenesses of the king and queen.

Whilst ho was employed in oketelning these, he witnessed the delivery of their tribute by the people of lintavu. When the kitug was seated in state, with this principal ullicers around him, the chiefs of Katsts:u rpprenred, cach encireled with many fulds of tapa and mats. After leaving their clutir, Ac., near the door, they ontered, crouching upon their liands and foech and thas pased round the sumicircle to their appointed pitaces. Their chief conlinued to proved towards the king, and wher nour, presented Jin Innjesty with a whale's turith. neatly slung in the maturer of a powder-thozu. The king, on receiving it, nnswered, "Linding," The chief then retired, and was followed by andiner, who, after disburdening himself of the taju in which he was enveloper, gave place to anduther, and so on to the last. Ench offering whs acknowledged by the king in the same tone of voice and manicr. "When ail had been receirmd, they rotired in the same order they had entered, anil the king took expecinl care to place the new aequisitions among his valuatules. This was understond to be the tribute for a yenr.

These presents are ususally received in the sinuare before the king's house, and a datco genernlly fol. lows. But owing to the heary rains, which had conrerter not only this apont, but the whole of Rewa, intu a mud-puldle, they were deprived of an npprtunity of witnessing one of these tribute dances; a deprivation which they much regretted, for foreignery seldom have an opportunity of seeing them.

Tho expedition under Lientenant Budd, that went to explore the river, hal now relurned, after having proceeded forty-firo miles above Kewa, which is ten miles farther than it hat beer befors areended. The party entsisted of Licutenant Budil, Pscsed-Midstipiman Davis, anil MIr. Peale, with two boats. Thuy leit the slifi at cue o'clock, und in consequence of rain touk refuge in an mbure at the town of $\mathrm{V}$ atia. There they found a large yututity of urans, chllected by a tax on eneh male, of as spear, club, \&c. l'hege bring kept in n cunseerated place, the wownds juade by them are consilered as always fatul, while the satne kind of injury by a new or uneunsemated spear would heal. Thisy had here an npportunity of seeing the reverence paid to Plitlips, who is a very high shief. Whenever the ratives saw him, they iavariably dropped on their linins until he passed; when lis spoke to thens, they slapped the palms of their lands together; and in lis presence nono presurned to walk uprightit.

In the villago they anw quantitics of the cyrenus and lingula shells, the tenants of which tad been eaten by the inlrabitants. They found sulssepreatly an their trip, that the furmer inade excellent sunp. This village is carnous for its pottery, ardl some earthen jars were seen that would huld a barrel of water. The elay of which they aro made is yellus: and is dug out of the banks of thertvor. The mosle of modelling these vesacls is deserilsed in nnother place. 'Tlie pots are very light, and of mang tanci. rul shapes; but they are guite fragile.

They reached Rewn before dark, and took up their Jodgings in Pbillips's bouse, which is one of the largest in Rewa, sud built in the pame mantse as the king's, Soreens of obnamented tapa were used to divinle it. into npartments, aud the floor was neatly covered wilh mats. The forntiture cousisted of a liand-orgau, table, lenches, several aru-chests, and a closet. To crown all, the supper-table was laid with a cloth, dishes, plates, kniver, and forks, aud they were waited on by hig white steward (an Italian), who was left here sick by The Cur. reney Lass under his charge. He hna also a white enrpenter.

The night wn passed uncomfortably, in conse. quence of the matsy noisy natives who nstembled to lripk ara. 'l'heava-Jowl of Iluillips was three feet 
in diancer. In drinking the ara, the fisst cup whe Itanded to thillips, and as there was nure in it than he ehose to driak, the rouainder was poured back inta the bowl. The ecreissony of elnģjing of linads was then performed. Instead, however, of lieir serving tult more avn from the bowl, the whole was throwrt masy, fir it is the eustom that when nuy is ponted truck from the clicf's cap, none must drink from the ressel. Mnre ava was therufure [repared, which they sat driuking nearly all night. The usual savage hospitality was oflered ench of them, and they kept their armus aul aceoutrements in readiness.

'l'he next morning they proceeded up the river, the banks of which were from eight to ten feet alnove the water, sud covered with a thick growth. of reeds. Hevond then ane well-eultivated fiedds of tum, vams, and lansins, ns before described; ail giving evideues of the overfluwing of the hasnks. folets were contimnlly pased, and nany towns containing from two of three inudred to a thousnnd inluabitnuts. Numerous creeks disemboguod an hoth sider.

"lie town of Xiou Souri was next passenl. Here the chicf Cormulsalaxoo sen! presents to them-he is the cousin of Plitlips-and afterwards nccompawied them up the riser in a cunse.

About seven milea up trom Rewn is a ereek leading to $A \mathrm{mball}$, wlich ia pasablo for canoeg at bigh trater. The town of Natacallo is bere situated, and the first rise of hill talies pliee. 'This is one of their great battle-grounds, atud was, necording to Phillips, the scene of many of lis deculs, whieh he recounted.

About a mile above this there is a hav whish extends nearly acrugs the river. The channel lics elose to the Jifls, which are two lundred foet in Jeiglst. Below this bar the banks of the river are all alluvial. Thero is lere an elbow in the riwer, alove which is tho tuwn of Capusvo, of funr hundrerl inlabitanta, which was the seene of one of the blowily attacks of the Aubau people under the notorions Charley Savage. It is asicl that lie was afterwarkls killed near Il hun or Sundalwow Bay, and to greas was the enmity of the natives towards lyiu, that lee was not only saton, lut liis boues were ground to pasder and druak in llieir ava. Phillips mentioned tlat a daughter of this notorions viltain is now nnaried to one of the kiug's brothers, at Rewa. Stapping in the evening for the men's supper, they saw naany fine shadinck treeg in full fruit along the banks, and MIr. P'eale shot a beauliful partoh, witls very gay blue and red plumage; he also nbtained two dueks. Phillipa mas the low islauds bave bees formed in the river by the fretguest floods from the mountains "since he has haul achichers." His nge is supposed to be thirty-five year.

Pho uative lonses hercalouts are construeted with a solit basement Burrutanded with piless, to prevent their heing waslied awsy on the occurretice of the Ploculs.

At night they stupped at the town of Corongruma, alinut eighteen miles above the nouth of the rivel. Here they took posesessiun of the thlure, nnd with the assistunce of Mr. Phillips's white stewnrl, they unada themselves quite entufortable. The same deferentee and respect were paid plillips laere as they had before observest; lout, nostwitlostanding this, Lieutersat Buth and party took every prevaution to prevest surpurise, to convince the matives that their walchlulnesh was never asteep.

T'lus banks showed a rito and fall of the water during the night. It was full tide about elever o'cleck at night; accurding to PJitliz̧ts, tho tido Howed somo miles above this place. "The current of the river was found by the tronts to be about a mile and a loalf the hour.

Having passed a comfortable night, (more by reason of their uwn futigue than the coinforts if the mhure.) notwitlistanding the muscyutiog and bats, which were loth very numerous, they left tho town of Coronganga at an early hour in tho morning. The best prosible understanding exister between themselves and the rutives, sud they dis. tributed presents to tho chiefs, for which the Intter expressed many thanks,

Shortly after having Curonganga, they passed the town of Nacundi, ecrntaining about six bundred inliabiantw. The sownery hero was beatiful, being eunbultished by maxy elumps of mule trees, resembling our vaks in thiejr wide-spreating branches, covered with vines, and interspersed with ferns and tall graceful paluns, The banka were here twelve feet ligh, and steep. From appenrance the country in Ijickly populatod, gotwitlistanding the destruetive ware which lave been waged with the people of $\Lambda$ mbatu. All the inhabitants were ob. served to be eltstered in the villages, for the purposs of mulual protection; and the same reasur causes them tn eluose as their sites for building, either sume insecessilile point, or a place llat affords Pacility for fortification.

Five miles above Corongauga, the enutry changes ita charneter; the river pasees by clifty of sutudstane five liumlred feet in bejglit, whose strat tifiestion dips tun degrees to the eastward. linnges of tills now rear themselves to a goodly lieight, and exterud sonte miles bask into the juterior.

They next jagsed the town of Naitasiri, wliere one of the brothers of Phillips, ealled Sarou, is ahief. Naitasiri is the enpital of this diatrict, and in uext in prower to Rewa, on the islend of Vitilevu. Phillipa was not disposed to land liere; for a misunderstanding land vecurted between hisn and lis brother, in consequenee of Savolt lusing taken elsurge, for Phillipis, of sotne two lundted hogh, of which, when demanded after a short time, only ten or fifters were to be found, Savou haviug either enten or given away the remainder. Cornubalaron went on shore in lin cance, and tonk Savou on board, who spoke as he passed Phillips, bitt the latter would not eusdescend to return his salutation.

As they passed further up the river, they were preceded by Savon, and when oppesite the town of Tavri-tavu, a canoe cume off witls a pregent of baked Laro and yams, frotm Sivou to Phillips and Lientenart Budd. This was eunsidered aв a penceoffering, and appestred to be acepulyle, at least to the vanity of Plislijos.

In the vicinity of this village there was much gugar-cane growing. Iust abowo it is an ellow in the river, the point formed by which was that renched by Captsin Betlume, of H.B.M. sloop of war Conway. This Lieutenhnt Ruckd colled Bethune's Puint. "'they shottly afterwards passed the gtnall town of Viti, yIfrosite $u$ whieh is in clill" four hundred foet in height, ovrgrown with shrub- 
bery; and near this many otreanlets enter the river. Juat after pasaing this flace, the guides poisted out a creck tisit led to Ambats. Thlo eountry appeared here more thichly peopled thau that below; onny more natives wero seurs, and the whole surface was well cultivated. There wh great astonisliment eviuced at the appenranes of our bonts, and it is believed our peuple were the fitst whites who hat been thus far in the interior.

The motntain district was renched at thirty-six miles frum the mouth of the river, and the ridges wero frum twelve to fiftess huidred foet high. The Wailevu, which I have naned Peale's River, here makes a turn to the westward of four uiles, to a point where it divides into two brunches. That on which they were eonses from the moutstnins direct, while the other, taking a conrse to the soutli, is said to disembogue at the town of Indiubi, on the south shore, about ten mile fo the nestward of the harbour of IRewa, and opposite to the islaud of Mbeuga. Having reachod the unountains, they could proceed no further in tho bons, and began to retrace their route. Near the place where they turned btack, there was a remarkiable waterfall of several bunilred feet leap.

The untives stute that this river flows from a targe lake in the centre of Vitilevin, and that, by akeending the heights abore Itagi-ragi, the water tany bu neet *

On their retura they were again presented by Sarou with a low of couked provisions, and a fine red-striped variety of sugar-cane. Savou seemed to be very desirons of mollifying Phillips's muger. They were well drenched with rain all the afternoon, and rewhed their old quarters at Curonganga just at dark. T"hey had a disagreenble night. The next morring they set out enriy, and reached Howa in the afternoen, withont accident. Their royal guidh presented every one of the party with soniething is a token uf remembranee, even to each of the bunt's crew.

Phillips returnes on board ship with them, where a Jnadsome present awaited him, for lis good and haspitsble conduet.

The number uf imlentitants esmprised in the towns and villages on this river is, from the eonpatation given by Phitlipe, aluout six or seven thowsard.

The party having now returned, alt the offieurs were orlered on board.

Captain Hudson't next step was to cndeavour to eapture Veridovi. From informution he obtained, it was believen that this chief intended to visit the ship the next dsy, to rcceive the presents which, as was given out, awaited his coming. Captain Hudson world then have had an opportunity to detain lim without any diffieulty or diaturbance whatever. They all, therefore, loft Rewa for the ship, and on the way down the river, stopsed at the small village of Vatia to purchase sume earthenwure; this is a village of pottern. They wero at once sarsuunded by several hondreds of the inlabitauts, ail pressing their waree on them, of which they bought soveral sjecinens, but not enough to satiofy the venders, who, whes they fisund that the officers did not intend to purchine more, hooted and shouted masy offerivive epithets, that only becnme known through the iweerpreter's repurt.

- This I rery mueh doubs, an from the lopography of the bisland If dues not seem probable.
At an early hour un tho 21st, the king and queen, one of their eliildren, nut Syaratingiou, toguther with the man of Yunivalu, canie un bosarl. As MIr. I'billips was already theje, all the rayal fanily, excepting Veudovi, were, by their own net, within our frower, and it was eatid the was also to conve in the afteramon. There was an evitunt constrant in the namer of the visiters, which whs apparent from their not expressiog the naus astonishtunent at every thing liey saw. 'T'heir little daughter, of five or six years of ago, had a eprightly cunntenance, sud, ns is usual, her hend was exveloped in twisted locks. Ono of the ullicers presented luer with a sash, which he tied on, and the bystatiders wero nuch anuse to to see the queen rearlaiging it after the loejee fistiun.

'l'he inteen was ubserved to lave puid more attertions than is trual tos the deceney of her dress, being envelupasl in the pareu, after the Tunur fashion. She is $n$ fine-losking womnn, with an intelligent couvtenauce. The kirg woro lis natro, accompanied with tho aenro, which is the jastie they give to the Jong traits of trya stached to it, thit are worn by ehiefs to deaste their ravk, Thus sesvo of the kiing trailed severnt feet on the ground.

The perans who attracted the most attention was Ngaraulinginu, with his attendant eliefs. In truth, lie caune in fine otyle, noving towards the ship in his henutiful ennou, wills its long stresmery flecnuting the rank of the owner) slontity in the brecze. When be came on loard, it was at rnce seen that he lind decked himse'f specially for the ocersion. His face was painted red ard black, whieh, if possilule, improved lis appearatice as a surage chief. He wos, by far, the finest-looking person amung the whule assembled group. His hinir was frizzled cut with great care ; around lits ueck bo wore a necklnce of aluells, with nemnlets of the truchus; and his thighs were encircled with a black cons. The usunl seavo was worn by lim, and over it a flounce of black fringe, which subles] much to the effect of the whole, and grve him I/so look of being partly dreased. Livery exurtion being made to enterisin them, the cunstraint they werc under was som dinsiqualed, and never did theople sem to enjoy themselves more.

Ii was hotred by Cuptuin Hudson, until afternoon, that Ventovi would tmako his aryenrance; but futur o'eluck came, and no chief. Captain Hudson then cuncluded that he wat not coning, and that it would be imporsible to take him, unless by force. He therefore determined to try the expestient of retaining those be lad on boand until Fendovi should be fortheoming. He orierud the drums to bent to qunters, and placed a seutimel st the enbin-doos, ordering at the same time thit all their canoeg should be retained alungside. The king and chiefs were immedincely informed, thrungh the interpreter, that they were nsimones, and that the object was to obtain Yeudoxi, the munderer of the crew of the Churles Doguet, some eight years before. It may readily be inngined that this announcement threw them all into great constermation, while it was, at the sume time, n matter of surprise to alf the officers of the ship. The poor queen was apjareistly the most alarmed, and maxiously inquirert of Phillips if they were all to be gut to death. Philljps was eranliy frightened 
with the rest, and it was observed that his nerves werve 80 much affected fur Bome time afturwards that he was unable to light a cigar that was given hiun, nud could not speak distinety. Captain Hud. son renibled them, that they had visited the ship of their own aceord, sud withunt my protutise of safeguard from lim; that lis object was to obtatin Fendovi, and that ali hopes of obtaining him witisout this decisive measure land frifed; that he meant then no harm, but it was his iutention to detain them until Vendovi was brought off. The canves wero likewise Beerred, and orders giren to allow nous to leave the ship. Tho whole party thus mado prisoners consisted of serenty or eiglity natives.

The king and chisef, when they had revorered themrelves a little, ackisusledged flat our demand was a just one; that Vendovi deserved to be punished; that he was a dangerous charneter snong themsetves; and that they would be glad to soe him remuved. At the sarre time, they said they thought the eapture of Vendovi impossille, and gave many reasots for this opinion. They expressed great fears for the missionaries and their fimilies, when the people of Rewa should licar of their detention. Cautnin Hudson had assured lime self previonsly of the perfect safety of the thissivmaries and their fanilies, and well know that this was a ruse un the jart of the king to induce birn to clinuge bis furpose.

'They' suon found him fully determined in his purpose. It was shorlly arringer? that, witl? his

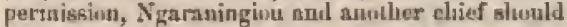
go quietly to Jewa, take Vendovi by surpqrise, luefore tre had time wo escape, and bring him on hoard alive if prossible, In order to insure protection to the missionaries and their establiwlimenta, they were particularly told that the missionaries had nothing to do wilh tlie business, and did not know uf it, as was evident from Mr. Iaggor tis ving ro. turted to Rewa before they wore detained, and that overy influence mast lie exorted to protect them frum haru, or the prisoners might expect the unast exemplary puishiment.

T'le selection of Nyaranirggiun as the emisibary to enpture the thorderer whs well-timed, as Vendowi has always been his rival, and the temptation to get rid of so poworiul an adversary was an opportunity not to be lost by a Feejee man, althungh tist idversary was a brother. He was soon under way in lis double canoe, which, with its enormous sail spreas to a strumg breeze, was speedily out of siglst.

The king, at Captain Hudson's request, informed hin people that nono trust attentipt to leave the ship, ur they would be thed at; that they must remanis on toard until furtlies urders; and that, in the meas time, they would be asppolied with fort. One attempt was maile by a sinall ennoe to leave the whip, but on seeing the preparations for firing st it, the persuns in it quickly returned.

After the departure of Ngaraningion, the king, queen, and ehief became more reconciled to their position. They tallied unch sbout Vendovi and Lhe amumder he had eommitterl on the erew of the Charres Doggeth, and said that he had also killed lis eldeat lirother.

The king, during the evening, spoke much of his being a friend in the white men, nsserted that hu had always been so, and alduced, as an instance of it, lis conduct in the ense of The Currency Lass, an English trading achonner, of Sydney, Now Suth Waleg. He saill that this ressel, in going out of the harbutur, lad got on shore near the anchorage; that his people liad asementsled rount about her for plunder, lut that lie went on buard himself, and kept all his subjects off that were not required to assiat. He tald Captain Wilson and the owner, Mr. Hotghton, who was ons lymrd, that if she got off he slimulil expect a present, which they rendily consented to give; but if slie broke, and got water in her huld, the vessel and property thust bo his. This, he said, they also angeed to. II is people, wishing her to go to pieces, male serernl atempits to remove the nnehors, but lie stopped them, and alrowe them away ; and the ouly thing lye dit, with the thrae of getting the vessel limself, white he was assistisg the captain tu get her of, was to semd up some of lis elicts to Jiewn, to give a present to the subati, at the mlunse, to offer up prayers to the Grent Spirit, that he would causo her to get water in. Sonselhing went wanng will the spirit, and the vessel got elear. Tho exly thing the owper gave lim was a whale's touth and a sanall louking glass !

When the twering set in, the natives (kni-sis) were all trouglit on buard fur the rightit, and placed forward on the gun-deck. Here they were supptied with plenty of lased bread and molasses, which they enjoyed excediugly, nnd afterwarls peiforment several danees, The performers arranged shetnselves in two ranks, und went tlirough various nuvements, with clieja trudies, heads, arms, ant fect, keoping time to a soug in a hight monotonous key, in which the whule joined, the ranks oeeasionally changing places, thuse in the rear ocespying the front, and the others retiring tehind.

The inferior chief were provided with stil under the Jalf-deck; the king, yueen, and slieis little daugliter were acemmodated by Capluin Hulson in his eabin. The kiug thaving expressed a desire to have his evering duasght of ava, same of the piper mythisticum, from which it is made, was forlunately foum among the botanical ufrecimens which had been collected, and a harge and well-polished dish-eover was converted issto an ava-bowl. The aya was aecordingly brewed, ats? all the ustanl ceremonies gone through wilh, oven to tho king's havitig his own eup-bearer, Jimsny Honkman, whe was one of the party.

After the ava was over, theatrieals were resorted to for the amusument of their majeatiet. This was n business in which many of the crew of the Peacock were proficients. baving been in the habit of amusing themselves is this way. Jim Crow was the first pieec, and well personated, both in appearance und soung, by oliver, the ship"s tailor. This representation did nut fail to amuse the sudience excoedingly; and grently artonished their majesties, Jim Crow's appeasance, on the back of a jackass, was truly emienl: the ass was enacted by two men in a kneeling posture, with their posteriors in contact; the bouty of the anitmal was formed of cholhing; four iron belaying-pius served it fur leet; a slipip's swab for its tsil, and a pair of old flooes fur its ears, witl a blanket as a covering. The walking of the mimic quadruped about the deck, with its consical-looking rider, and the andjence, half civilized, half gavage, gave the whole 
serene a very remarkable effect. 'I'lue hing confessed thit if lye has been nloste, loe would be much frightencel at the enrvetting and braying of the besast before him. The quseen, on its lieing explained to her that what she saw was only two meu, expressed the greatest astonishment in her enger, incresjulous lisk. "The darice of "Jvba" earne off well, through the exertinns of Howart and Shepherd, tut the braying fus of Godwin, with the Jim Crow of Otiver, will Inug be rennembered! Ly their savage as well ob eivilized spectntors.

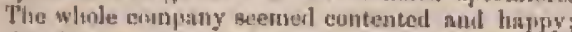
the king last his extra bowl of asm, the rqueen aid chiefs their tea sul supper ; and alt enjoyed their eigars, of which thicy smoked a grent number. On Craptiain Hudson expresesing to she king his lonpe that the quren luad got over her fears, snd inguiriug if alue was tired, loe replied, "Why aloguld stle be tunbleil ! is sho not with me! Whlien 1 die, nust nut she die also f" Thereby intirsating that were the in peril, she would be equally so, whether present or alssent. The theatrienle having been ended, they all retired to rest.

One could not but perceive the great difference between the Tungese and Forject who prissed the uight on buard. "Tlue fozner are generally Christians, or missionaries' penple; they were orderiy and respectable, and before going to rest, quictly and very deroutly met mol lad their evening prayer; whish, contrasted with the conduct of the others, hat a pleasing effect.

Mr. Phillipis, in reenmpense for his attention to Lieutenaat 13udl nad Mr. Penle, was well provided for by the oftieers; nud, at varions tines, impartel information resfrecting the history of Rewa, his owr In family, and other\%, that inny be looked upou ar quite unthentic; and I lave littlo doubt that it will prove interesting to the resuder.

By the aid of the whites, f'annbiswalu, tather of Камis, was estalylished as king, upon the dethronetzent of the reigning farnily, of whom Vunivalu, the governor, is a ilescenlant. Rews at this time was of lithe consequence, comprising only the small tuwn of Nirnketi, frou which the king now derives his title.

Tumbinvalu goverued with great fimuness and wisdom. During his reign, al] criminnls met witl exemplary punisinent. According to the Fecjen euatom, he had many trives, the clifef among whom wis a descemant of the family of Mtbatitombj, who reigned at Ambau before Barniva, the father of T'mon, succested in gaining the hingdon, A]. thougls considerest the rueon, and holling tive tible of Ramdini-Nidnketi, she was not the lighest in rank. There was alsu anong the wives of Taqubiavalu a siater of Tanca, mamed Salaiwai, who was younger, and in conseqnenee lad not the station to which lier rank entitled her to.

Plitlips gives Taubiavuln the eredit of having had a hundred children by lis mumemus wives and concubires, a statement of which those best nequainted with Feejer hiatory to not doubt the eorrectness, Of this large progeny, the children hy the two abnve-mentiossed females are alone entitled to my mnk. By the queen, Rumdini-Ndraketi, the had fut sons, named Madonovi, Kanin, Valiveaka, asd Ngarningiou. By Salaiwai, he had only two, Sers and Thokatanto (Mr. Phillips). Of tho gix, Kania, Ngaraningiou, and 'J'hokusasto are still living.
Tambiaralu tal a long and prosperaus reign, and under him lewn nxsumed a rank armong the chial cities of the Veejees, having sequired muel territory, nnt among the rest, the islaul of Kialtavu. His oldest son, liomitamano, was the child of a liuntasu woman of rank; to was, ill colsequuence, a vasu of the most important jossessions of liewa, and hol many connexions and friends thrunghout the conntry; he had so ingratiated lim. self with the eliefs and people, that he could hatve zonste linuself king on the death of his fatler Rambini-Nurnketi, the rueer, who jo ropresented as a most artiol as well as unsernyulous soman,

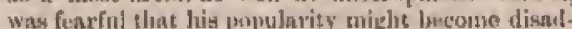
vantageots to her ehildren, and sho determined tis huve him removed. She mansed to instil into the king's mind sitspicions that liornitumano intended to seize uprou the sucessaion, w/sich determinet him to put this son to dench. Jiomitamato receiverl a lint of his intentions, and was nble w evale every attempt. On some ocensions he was obliged to flee to distant places, oned to $\mathrm{Kh}$, tho wester's end of Fitilevu, nual nnother time tu Mbenga, wliero lie remained until a kind of reoneilintion took place, when he was induced w return. He liad not been long in liewa, before the queen recommenced licr machinations for his destruction, mul his father ulso resumed his designe azninat lims.

Kuraitamano was doubtiul whether ngain to resort to flight or reunin, when sume chiefs who were hostile to the king, represented to the young elief that the only methot to secure lis own safety effectually was to put his father to denth, assuring Jim they wotld stand by him in the struggle. By their persuasions he was induced to aceede to their desigus, At night he get fire to a canue-liouse, and comisug into liss father's idwelling, he npprouched the place where the was sleeping, and cried out, "Dn you lie lrere asleep when your city is buruing!" Tambiatah immedistely atarted up and mn caut Jioraitanano following closely after him, watched an ncension, sumek lim with his elub on the lanek of his leasl, and killeyl him on the spot; after which he retired to his owis house, trunting to the promises of his friends and adherents, that they would protect and defend him. But the queen was tnore than sn equal for his cuntuitsg, aud her hatred causer her to gu th the greatest lengtlis in wreaking ber vengeance wpon lim. She lial the body lirought to the home, where, observitug that the exterual injury to the head was slighr, ohe conceived the singular plan of making the deed of the nssassin and his friends recoil upon their own lseads. She, therefore, at unce mised a cry that the trowly showed signs of life, and that her husband was not dead. She then had the bolly enveyed th the inther end of his house, arder the plea that lie required in bo remuved from the noist; urul 120 one was wufferet] to appronch the body lut bearself and a Tonga wa. man, who was ber confidant. She somil aptead the report that the king land recovered his senseg, but was very wenk, and ealled tapon severa] chiefs in the king'y sume, sayng that liu requirul the instant leath of Koraitamano, The chiefs comvened a meeting to consider the course that ought to be pursued, but could conse to no decisian, it consefuence of the general opinion that the conduct of Roraitanuano was justifinble; although, on the other hand, they feared the wrath of the bing, in exse the 
hhould recover, partientarly those who had advised and wished to upholil liomitamano. The queen becoming sware of their hesitation, on the following morning took sume winles' teeth and odyer valuables, and presenterl them herself to the eliefs, saying they were sent by the king to purehase the death of his son. Fearing to hold out any longer, they west to Koraitamano and announeed to him the futal mandate, an! he was immediately killed. They then proceeded to the king's louse to reprort that the doed was done, and on approaching the cotreh of the king, the putrescent odour which purceeded from the corpine at nnce disclosed to tliem the deception that had been practised. It was, bowever, ton date to anend the matter, nnd Mndo. mori, the eldest sun of the rueen, nuw suceveded Jis futher witlusu: apposition. One of the first sets of Madonovi waн so louild an mbure over the Hot where his father was murdered. His buceession deprived Seru and Thokanauto (Phillips) of their riglit to the throne, and of course excited their thostility to the reigning chief, who was by no means so popular as his facher, and dicl not govern tu the salisfaction of lis subjects. Seru, who wr. the oldest of the two maleontenta, was a very tall and renuarkably handsome man, and haul grent intuence rmong the people, which exeited the jealousy of the king. Such was his strungth that it is saitl he couli knock down a full-grown hog by a blow on the forethend, and would break a cocoa-nut by striking it on his ellow.

Mutial words of defiance lind passed between the two brothers, and they were living in daily expectation of some encouncer that worde bring on serinus disturlanees. Inring the height of this feeting, they met on the rosd, where the scene that was enueted was quite remarkalote, and the uarration of it by I'hillips equually so.

Seris had one of the slbort missile clubs (uln) in his givdle, which Feejee men usually wear stucls in behind. As Marinnovi npprosehed, Seru placed bis back agninst the feuce, without any design. The king had three sluaddock (nulitivi) in his band, of which, as he came up to Stru, he lield one up and called ons in aprort, that he meast to throw it at him. The thruglat then eame into Seru's mind that if the king slurew and hit him the would let him pass, but that if to missed he would iske the opprortunity to put him tis denth. He, therefore, replied to his bruther in the same joenso ununner, "L'lirow, but if you mias, I'll try." "The king threw, but missed. He the drew nesurer, and loolding up annther of the shaddocks, eried out, "This time I will liat you," "To whinh Suru replied, "Take eare; if you miss, then I'll try." "flice king threw again, but Seru, by a quick movement, wroided tho missile. Madonavi then ad. vanced to within two or three yards of Seru, saying, "This time I think I shall hit you." Sertu made limself ready to aroid it, and witl। his hands bulind him, said, "if you miss, then I take my turn." The king threw the third time and misaed, for Setu stooped, and the sliadduck prosed over his shoulder. Seru then drew bimself up, flenrished his elub in the air, and exclaimed in tomes of exulting mockery, "Aha, I think you did not see this !" With that he buried lis weapon with so desdly an nim chat it crusled the skull of the king, and killed his on the spot.

As scon as thip event becnue known, the queen with her otluer sors flet to Ambau, leaving the guj reme power in the hands of Seru, whu, low. ever, did wot take the title of Nidraketi, but adnpted that of 'Ini Sawau, after the chief town of Mltenga, on which he had made war and captured, and by which title be was thenceforth known. He was not, lowever, long left to enjoy lis nuthority. Thie exiled family made several unstrcessaful atienpts to destroy him, and at last indueed Vendovi, by a large bribe, to undertake his destructinu. Venduvi mauraged to get to Rewa unobserved, nad locking in at the door of 'Tlmkannuto's house, «ax 'J'ui Sawnu lying on his mat eating. He immediately levelled his mushet and shot him. Four balls passed thrumgh his lirenst, but such who the strength of his constitution, that ho survivol for eiglat days. This oceurred in the year 1807 .

When it beearse kwown at Amban that this frntricide lad heen cumnithed, the queen arud her sons roturned to Rewa, and Kania assumed the direction of the goverument, to the exelusion of Thokinnanto.

Plse charneter of Phillips, who enils himself the white man's friend, it rather equivoenl. He is said while young to have been fed mostly on litminn fiesh. Whet I saw him on bonrd my slip at Leruka, I told him I had henrd that he liked this foud, and I thought the lse slowwed nuwel shame at heing considered a cannibal by us. IJis youthful practices, which lie talu an though mome eredit wero due to limself for a elange in lity latter conduct, will tend to ahow how early these uatives enploy themselves in intlicting pain on ench otler. One of these was to set a shapppointed stick in the ground, eover it with enrth, and then challenge another boy to jump with lim, Hu would then leap in sttch a mumer that the boy on folluwing lis exsmple would alight upors the prointed stick, and run it through lis fort. He is said also to bo fiequently etruloyed ly the hing as nn instruncnt of his vengeanne. The missions relate that ho was usee sent to kill an native hy tho king"s arder, upon whids lie wert to the person's house, and tuld litm that "The king has sent the to kill you;" to which he replied, "It ta grood only that I should die." Phillips struck, but only stumed him, after which he returnem, and tolid the king lo had uot succederd in hilling lim. When the man recuvered, Phillips was again sent inck, and wueceded in giving lim his deathblew, which he recelved with olue same rusignntion ns befure. Notwithstanding lis losd traits, he is certainly one of the most intelligent natives that I lunve met will in all Polyuesin. He possesses mnch informstiou respecting bis own people, and would, if the king allowed $j$, be the moans of cflectiug many infqruvenents, He has already introduced some into his own establishment, and is very desirous of learnisg, but he unfortumately has not suffieient knowledge to distinguish hetween goud atud evil. He visits all the ressels that touch at this gl'ouy, and says that he passes most of his time uil board of them. He proluees many reeomrnendations frum their commanders, which, bexides recommending him, give the very saluary precation of s]ways being on their gurad while among these satives.

I'he prisoners on board the Pencock were early in motion on the following morning, looking anxi. ously for the return of Ngarnninglou; atd ruasy 
speculations were thrown out ns to whetler he wonld succeed in his errand, or connive at the escape of Vendori. The hatred he was knowu to bear Veudovi, was in farour of his return with lim, eillier dead or alive. These surmises were shortly put to rest, by the appesrance of the large cauno emerging from the numth of the river, which drew all to watch its approach, It soon camo alangsile, thil Vendovi wros reeoguised as a prisoner on board. The mude of his capture was singular, nud slows the foree of the customs to which all ranks of this people give implicil obedicne. Ngarnuingion, on arriving at Rewn, went at whee to Venturit's botise, and took him by surprise. Guing in, he took lis onat by him, lainl his liand on his arm, nnd trild hisis that he was wanted, and that the king had sent for him to go on bond the man-of-war. He immediatedy assented, und whs preparing to come at once, but Ngaraningiou said, "Not till to-morrow." "They passed the evening and niglit tugether, and in the morning embarkeal to come on board.

Vendovi was at once brought on bonrd and delivered to Captain Hulson, who forthwith exa. mined him before the king and chiefs, and in the presenee of the ofticers of the slap, assembled in the calin. Vendovi nckunwledged las guilt is causing the muruler of part of the crew of the Charles Doggett, and andinted that he had lield the mate by the arms while the natives killed litn with clulss, Ciptain Hudson now explaised why Jo has thought proper to retain the king and the others as prisoners, saying that the eourse the aftair had taken had asved them mucla trouble, and probably fighting, for he would lave thouglit it ineumbent upon him to burn Rewa, if Vendovi had not been taken. The king replied, that Captain Hudson had done right; that he would like to go to America himself, they had all been treated so well; that we were now all grod friends, and that the slould ever continue to be a good friend to alf white men. Vendovi was now put in irons, nnd the otherg were told that the slip would go so Kantavu, to punish any other elief's that had jarticipated is the act, and burn their town, They were assured of our smicalie disposition towarls them so long as they cundueterl themselves wall; and in order to itupress this fally upon them, after their own fashion, presents were made them, which were received grutefully.

When the leare-taking cane, Phillips appeared the most dejected of, nil. This scmed strange after the part Vendovi land taken in the musder of his brother, of one whom he represented as having been very kind to lijm ay a protector, and with whan he lived when the fatal shot was fired by Vendovi. Phillips expressed himself in this way, "That as long as Serti lived he eould be saucy, bit after his death he was all alone, just like a stick." This kind of ofposite conduct is cunformulule to the uसunl prolicy of this people, and is characterisic. Yendovi, at this time, was the only one of his brothers who frvoured the party of Phillips, and was among his strongest adhererits. I could mention many other instanees of the same iuconsis. tency of conduet on the part of chiefs.

All the party wero now mush affeeted. Kania, the king, seated himself on the right side of Vendovi, tuking hold of his arm, while Navuminlu placed limself on the left. Plillips walked ap and down in front. All shed tears, and sobbed aloud whito conversing in braken sentences with their brother. The natires shed tenrs alsu, and nono but Ngaranisgiou resnained unmoved. The king kissed the prisoner's forelead, touched noses, anc turned awny. The inferior chiefs npproached und kissed his hands, whilst the common people eraw led up to hism and kissed lis feet. One young man who belonged to the houschold of Vendori was tho last to quit him; he wished to remain with lyis master, but was lot pertuitted. In biddsug fanewell to the chief, he embraced his knees, kissed lis hands and feet, and received a parting lyessing from Vendovi, who placed both his manaeled trands on his head. The young man then retreaced bnckwards townda the Ludder, sigling and sol). bing as though his heart would break. The last request the king made to Captrin Indson wan, that hir own barber, Oaliu Sam (a Sandwich islander), might accompany Vendavi. 'This was readily assented to, as lie would be a useful man on board ship, laving sailed in a whaler, and Jaring some Jinowledge of the Euglish language.

Mr. Cargill, the missionary, came ors buard the Pencock sluartly after the royal party had left lier, and informed Cuptain IIudson, that the night before, the chief who had been sent for his protection had visited him, and snid that lie should keep guard over liun and his house, nud not suffer any one to cross the river from Rewa. Mr. Cargill anid there had been no himd of disturbance, the chief haring remained at lis house until the king returned, and he felt mueh indebted to Captain Hudson for the lively interest he lasil taken in his affairs. He did not feel tat apprehensive of danger to themselves, and there was no kind of necessity for the detention of the ship on that accuunt. At noon Mr. Cargill took lis lenve. When I saw him, a few weaks afterwards, he spoke in very high terms of the conduet of Captain Hudson, and the manner in which he had coudueted the whole business at Rewn. He also told me that the chiefs often spoke of it, and were fully sensilsle that it was just that Vendovi shord be punished. Mr. Cargill apulce much of the rast benefit that would result from our visit, not only to the frading vessols and whites generally, but also to the natives, as well as the advautage it would be to the missiovary cause.

The surveys of the liarhour having been all completed and joined with the survey of the river, made ly Licutcrant Budd and Passed-Midshipman Davis,-botl of whom deserve much eredit for tho manner in which their operations were condrueted, not only as regards the duties performed, but the caro and attention they paid to the party en/rusted to their charge,- preparations were now male for sailing; but, owing to the wind being ahead, they were not able to pass the reefs until the morning of the 23rd; in the mean time, Oalus Sanu was received on board as Vetadovi's barluer. When they got to sen, Captain Hudson again exanined Vendosi, before several of the oflicers, respecting the lisantaru murder, and the part lie had himself taken in it. He stated, that he was sent by Ngaraningiou to pilot the brig to Kinstavu; and that a ehief of that place, crlled Thehau, who is nuw dead, was to take the vessel Cor $\mathrm{Ngarnu}$ ingiou. Thebau was to make what he could for himself, and was the leader of the cotsiriacy to murder the crew. Teu of the 
crow ware killed, eight of them in the biche de mar house, and the mate and boy nenr the boat, The people of the towns of Xumbuwallo, Lueti, and Roro, lasd cut large vines to pass under the cable, for the purpose of hauling the reanel on shore during the night. He nliso stated that a black man had been roasted and eaten by the natives, but that he himself did not partake. Nine bodies were givea up to Paddy Connel, and were taken on hoard, sewed up in crurnss, and munk nlongside. Tho bodies afterwards floated on shore, and wcre eaten by the natives. His statement, therefore, conformed to that of Paddy in all important particulars.

Vendoni likewise mentimed another act of his, as follows. About two yenrs before, the mate of the whale-ghip Nimrorl, of Sydney, New South Wales, fanded at Kantaru to purchase provisions. Vendovi sas some harga whales' teeth in possession of the mate, in order to obtain whicls, he made him and the boat's crew prisoners. Ho then told the mate to write to his centain to ranson lim and lís men, and that he must have fify whales' teerli, forr axes, two jlates, a case of pipes, a bundle of fish-looks, an iron pot, and a late of cloth. These were all sent bim, and they were released, he giving tho mate a present of a head of tortoise-shell.

Captain Hudbon, having thus successfully accomplished the enpturo of Vendovi, steered for Kantarn, in order, if possible, to bring to punisllment more of the offorders; but the wind fell light, and he found that the ship had drifted, during the night, to the eastward of the Astrolabe Reef, and conssequenty would be conprelled, in proereding to liantnvu, to retrace his ruute. This would buve occupied rauch tirne, and the prospect of gaining their port woulu! have bees faint. He therefore deternined, ns the alloted time for jnit: ing the bosts hat nearly expired, to bear up for the wast end of Vitilevi; where I shall now lesve him, and return to Levuks, to the rest of the squadron.

\section{CHAPTER XXV.}

\section{FEEJEE GROUP-(COSTINUED).}

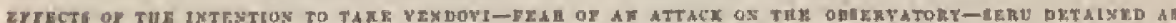

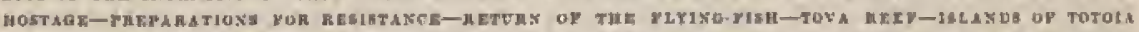

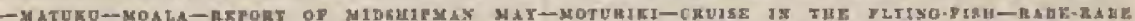

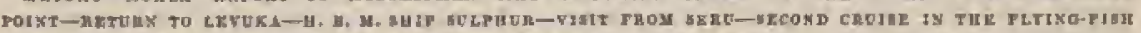

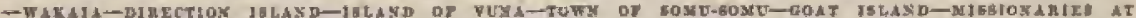

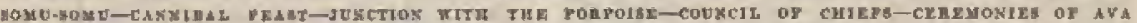

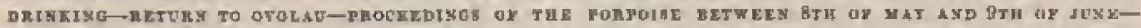

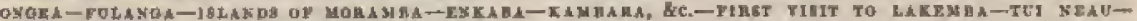

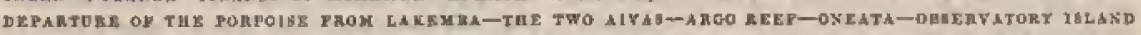

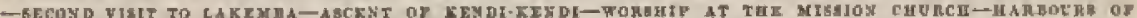

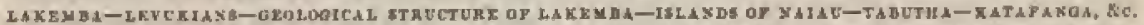

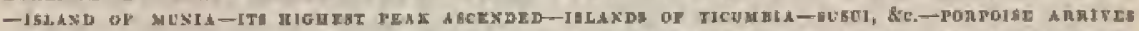

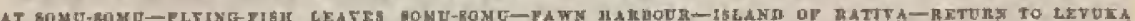

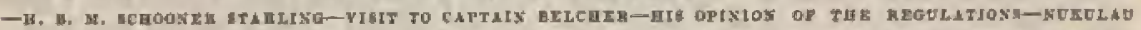

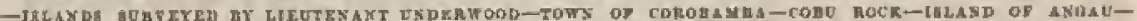

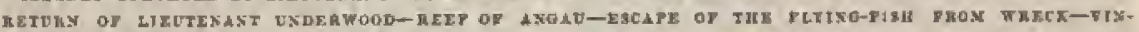

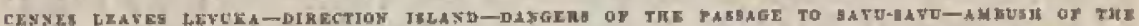

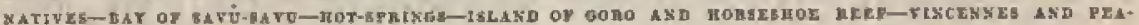
cock Asctson 3\% hAXDA1, wOOD DAT.

Imazdatery after despatehing Paddy Connel on his errand to Captain IIudeon, Whippy canve to me. He had brard, on board the ship, sone intimation of the purjort of the meesage sent to lkewn by Connel, and he advined me to be on my guard fut the first novement after Veudovi's enpture. He thought that an endervour would be made by the peoplo of $A$ mbau to surprise the observatory, and to talie me prisoner, (fur the paryose of ransoming Vendovi,) for they are closely allied to those of Rewa. $\Lambda$ sour distance from $\Lambda$ mban was no moro than a few hourg' travel, it would be ensy fur Tanoa, or his enen Seru, to fall upon us with a thousand men, before we could bnve any notice whateper of their appronch. After hearing all he had to say upon the subject, I sent him for Tui Levula, who came to my tent. His anuzement was grent when lie was told what was in jurugres, and he seened to be almost beside limuself for a few moments. When lie was sufficiendity recovered, I told him that I put implicit confidesce in lim; that if he suffered me to be surprised by any foroe, on him and his people would rest the responsibility, and that I looked to him to give me the esrliest untice of any attempt to attuck me. This he accordingly promisted, and, at the sanse time, he tolu Whippy, the most probable persons from whom any attuck would come would be the mountaineers, who were all now under the influevce of Ambau, and would be onsily induced to attuck u*. A slousand of thern, according to his opinion, miglst be upon us in $\mathrm{s}$ few hours; but we liad litile to fear before dawn of day, for that was the only time at whicl they mnde an attack, choosing the time of the beond or sonmalest sleep. He then went of to send out lis scouts and spies, in urder to bring the the enrlicst information.

Seru was on hoard the slip wben I heard these Q 2 
things, I, therefore, sent off word that he should be kept on boaril as a kind of hostage, and ordered forty men to reinforce the observatory, after dark, for the ship was not near enotigh to use our guns in Jefending it. The night, however, was quiet, ard there were no signs of the matives moving nbout on shore. Indeed they aro extremely averse to ge out after dark, from a fear of meeting kalous, or spirits. Seru was amused with rockets, se., on bonrd, and parsed his time to his satisfuetion.

On the 21 st, the ship was moved up abreast the obaervatory poist, in order to protect it, and moored so that tuer vans might rake each side of the point in case of an attack. The knoll on which 1 had rectid the observatom was a strong position, and we now set to work to niake it more so, by elearing it of all the rublisis and brushwood that might afford coper to sssailnuts. Signals wers arranged with the ship in ense of attick, to direct the fire of the guns, and all thitugs made realy tn gire any Justile force a warm reeption. Alout eight o'clock in the erening, Whippy told me that a report had renched Tui Levtuk that there was troutle at lewr, and that the king and chiefs were prisoners; but to this we gave no credit at the time, In the moming, however, I learned through him, that one old chief had got isflurmation that Vendovi was a prisoner, and that the king and queen would be relensed; in fact, nearly the whole story that has been related in the preceling chapter, reached Levuka before the day on which it oecutred had passed. On inquiring of Tui Levuka, throngh Whippy, aiter I had heas'd the particulars, and learned how nerrly they corresponted with the report, how he obtained lis information, lis nnewer was, "Did you not tell me to bring you the ensliest. news, and have my spies out ?" The news must Jare been brought a distance of twenty miles in less than six luurs, for 1 can scarcely beliseve that any native could poesibly lave invented the story, or could have surmiged what was to take place.

Early on the morring of the 22nd, Seru left the ship and proceeded to Ambau, although I hud been informed that it was his intention to go to the dif ferent islands, to bring us hogs and yams. Tui Levukn ealled my attention to this, and also to the finet that a megeenger hind brought Seru intelligence of what had happened at Rewh during the stay of the Peacock there, and of the sailing of that ship with Vendovi on board.

During this time miny things eceurred to keep us on the alert. On the night of the 25rd, the noual number of men wero landed at tho observatory, and in the niglit a musket was accidentally fired, which, of course, created some stir, but it proved a false alarm; it, however, served to keep up our vigilance in case of attack.

On the 2fith the Flying-Fish retnrned, entering through the reefo after dark. Lieutenant Carr had executed the greater part of the duties poiuted out in his ingtructions.

Lieutenant Carr reached Lakemba on the morning of the 17th; and on leaving Lakemba, proeecded with the tender to Vanua-vatu, where they began their Burveye. "The tender's boats were launclied, and the island whs circummavigated. It rises gradually, on all sides, to the lipiglit of several hundred feet, and is covered with fnliage; it is six nitles in circumference, and is encircled ly a reef, through which there are two entrances for boats, but neither of them is sufliciently wide for the catrance of a ressel. This island is not inhabited, but the natives resort there for the purpose of fisting.

Lieutenant Carr next surveyed the 'lova Reef, which was found abuut equidistant from Totola, Moala, and Vasua-ratu. He repregents il as oun of the most dangerous outlying reefs in the group: it is a mile in diameter, and nearly circular: the two former islands are in sight from it, but the linter, being low, was not seen. At low water this reef is yuile dry, and it then formb a suug basin, into which there is a shallow passage for bonts. The soundings within the reef were found extremely irreguiar, varying from two to fourten feet. At high water the reef is entirely covered, and the aea breaks on it at all times.

The next island that elaimed Lieutenant Carr's attention was Totois. Here he discovered a pabeage leading through the reef, iuto which he went with the tender, and anchored in fifteen fathoms, half a mile distant from the shore. They found there a canoe from Vavao, manned by Toungeso. Totoia is high and mucl, broken; it resembles the rest of the group in its voleanic formntion; it is covered with luxuriant foliage, and lins many fertile rulleys. Lieutenant Carr thinks that this harbour can be useful only as a temporary refuge. It is filled with broken patches, has very irregular soundings, from three to thirty fathoms, and the passages betwers these patches are quite narrow and cortuous. The weatler setting in bad, they were obliged to torego the examinations of a small part of the boutlicin portion of the reef for openings: it is believed, however, hat noto exist.

Matuku was the next island. Of this they hegan the survey on the south-enstern side, whence shey passed round the southern strote. On the westeru side they discovered an opening through the reef, through which they passed, and anchored in one of tho best harbours in the group. "This I have called Carr's Harbour. Its entrance is, perhass, too uarrow for a ship to bent is, which the prevalence of easterly wiuds would generally require to be dont: but the channel to it is quite cless of patches, aul the passage throurh the reef is a good one, though long. Within the reef there is a circulnr busin of large extent, in nll [arts of which a stip mny select ber bertly witl hood bottom. Wood and water aro to be had here in plenty. The natives resemblet those of the olfirs islands, and are consillered as prosessing ekill in the use of their aring.

Muala was next visited. It is a high volennic island. There is an opening througis the reef, on the west side, that leads to an inferior herbour, which the bonts surveycd. Thoy found hore a whito man, calling himself Cliariey, who was of snme use to them in pointing out the localities. Lieutenant Carr sent him, the next morning, with the boats, to examine a supposed tarbour, into which, in cousequence of the lighe winds, the ten. der was unablo to enter. The reef on the north sidh of Mouls resembles that of 'Tatoin being a collection of sunken and detrehed patches. The reef on the north-east mukes off to the distance of two and a half miles. After passing it, there is a deep indentation in the island, with a truad passage through the reef, leading to a safe nnd very fire harbour, and, what is unusual, the p̧assage is sufti- 
ciently widu fur a wessel to beat out. 'Tlis, however, would seldom be necessary, as there are Beveral passages through the roef to the wnstward, which are safe with a leading wind.

"This island affords wood, water, and some provjsione, and has about aeven hundred inhabituts.

Lieutennnt Carr, finding that his time was almast expired, deternined to proceed wo Orolan, by passing close to the Mothea. Reef, off the souther'i puint of Nniri. On the 25th, the tunder anchorer] nt Levuka, On receiving Lientenast Carr'g repurt, I irumedintely despatched lim to survoy tho passuge round the westeru side of Ovolau. The casteris frortion, together with the lasrbour of Levuka, lad alieady been completed by the Vincennes. Lieutenant Carr lad, in the performance of this duty, renclsed the island of Moturikl, when the time allotted for the purpose lad expired. He accorifingly left the two bosts under Lieutennt Underworal, to exraplete the remaining part of the wutk, winiel ocerpict them two days, during which time, it appears, frorn Passed-Midshipman May's aceount, they tiad anothor narrow esenpe from dis. Buter, under the fullowing circumstnnes. The night the Lonts Jeft the terder, they imprudently thruded or the island of Moturiki, where tlicy ntslonded their boats, allowing the natives to help them up, and then reanoved all the things out of them up to the mhure, although there was reason to apprehend, from their couluet, that mischief was unetitated. 'They demed it neessury to havo sentincts posted, and all the men remaitsed with their arns by their side. The natives before ten o'elock law disporsed, excejt ten or firteers, who were seemingly on the wateh. I'these were diseovered passing ju soune club, whicla were secroly laid by a log. Ljentenant Underwood then determined to compel them all to guit the hotse, which they did, going out in rather a sulky manuer. The moment the side thorted the huats, jt was thought necessary to load them and shove off. They then anchored, and passed the remainder of the night il them. The uext night, for greater safety, they souglit shelter from the rain and wet under the roeks, which enused them mueh diftieulty in lighting their fires. T'his wne not avereome until their old native guide took the tinder, and ascending a tall eceon-nut tree to the fronds, quickly returned witls a blazing torch. Having fintshet the survey of that part of the Moturiki Passage assigned them, they returued to the ship at Levuka.

The island of Mloturiki is almost in conlatet with that of Orolau to the south of it. The same reef extends around bath of them, and there is no passage hetween them, except for bonta and eanoes. $A$ large square castellated rock lies nidway between them, called Laudolib, of which there is $\mathrm{s}$ tradition, that Ndengei was bringing it to block up the big passage of Mnturiki, which, according to the natives, lends to his dominions, but being overtaken by daylight, the dropped it where it now lies.

Moturiki is three miles long, and one brosd; it is not so much broken as Ovolat, though it rises in ita centre, forming a bigh rilge. There are two small fshads, named Geluvia and Thangala, to the south of it, and between these and Moturiki is the entrance to the bay of Ambau, termed tho Mo. turiki Passage : this is about two miles long, and is a unile in widtl towards its eastern end; the tide flows strongly thaugh it, and the trove sets th the westward.

The tender having returned to Ovolat, I made preţarations to leavo that place.

Not being able to spare the services of Lieutenant Carr as first lieutenant, I transferred him to the Viucennes, and urdered lieutenant Case to the tender. Lientesnnt Carr was jmt in cbarge of the observatory, whilo Lieutennat Alden in the lnunch, and $\mathrm{Mr}$. Kinox in the first cutter, were relieved by Lieutenant Perry aud Mr. De Haven. Both bonts received new crews, and proceeded to gurvey the recfo ly Prssage Island, and thence to Varua levu. I embarked in the tender on the 3rit of June, and by night ancliured ofl Mibun or Snndalwood Bay, where I had nppointed to meot the Pencock. Wo burmt bluo-lights and sent of rockets, but received no answer, and in the noming found tho slip had not arrived.

Levuka was reached at 2 A.M.; here I found H.13.M. selouner Starling, Lieutenant liellet, cunsort of the Sislyhur, Captain Belcher, on a similar anty with ourbelves. Lieutemant Fellet informed me that the Sulphur, in going into Rews, had struck on some enral Junips in tlie jorth passage, and lost lier rudder; ansl bhe object of Lientenant Fiellet's risit was to ubtrin nid, or new pintleg for that ship. As those of the Vincennes were thought to be too large, I at once ordered a loat wo be mnuned, and soute under charges of Lientenant [thderwoud to Mbun Bay (seventy willes), to the Peacuck, for the purpose of olutaining thase belunging to that alip. It afforded ne great phensure to be of service to nny of Her Mrjesty's sliphs, aud knowing low important it was to have prouplo and efficient aid, there was no deliny. I had the plensure of a few hours" conrersition with Ifeutenant Kellet, but as my appointment with the Porpoise rendered it necessary that I should mect her at the town of Sumu-80nu, un the island of Vuna, I was Boou wbliged to leave Levoki for the eastern prat of the group. It the nean time, I olstained my returz merjdian distnees and the night observations.

Beforo 1 left Loruka, Suru, Tanoa's eldest son, paid us another visit, and brought some hogrs and other prorisions, as a present. On this occusism, his conduet towards Mr. Vauderford was swot witht it should have been, for he approplrinted some of that offiees's property to himself. I regret I did not learn this until some time afterwarls, for I lud no opportusity of speaking to Seru ngain; but 1 sent him word slost his cossduct was not approved of and he anust mat take such a liberty again.

Orders were left with Lieutenant Carr to despatch Lieutenant Underwood and Passed-Midshipman Sundford, with two linats, to survey the islands of Ambntiki, Nairai, and Angu, all of which nre in sight from Ovoluu.

At five o'elock the next morning wo wero under way, in the tender, wilh two buals if the Vineennes in eornous, and erossed over to Wrknia, where I loft Passed-Mildhinnten Knox and May to Enrvey that islnst and Mtokungai, with their mefs. Here 1 fixed o station, and olserred, with the theodulite, ou the distant sigials. I then made an endenvour to get out of the reef, lut the wenther looking bat, I put back and anehored in a suug buy, which I laad entled Flyug-Fish Rarbour. This is on the west sille of the island of Wakisir, and has two pas. sages theough the reef to it. 
The next morning we again got under way, and stood for Nemena, or Direction Island, where we audiured, after passing thrutsgla a zarrow passage iu its outlying refe. Dimetion Island forms two high reuglar hills, covered with a dense foliage. It is not indalliterl, being only occasionally resorted to for turties by the uatives.

On the $7 \mathrm{~h}$, we were engaged in tho surveg of the inland and reef, with tle buats, while 1 fixel a slation an its western eummit, where I paesed the dny observing for longitude and hatitude and angles, on all the points, peaks, und signals, in sight.

In the erening, we sniled for Vuas Island. The wind was very light, and we did not make much progress, but spent the greatest part of the next doy jus getting up with the island. Not wishing to lo detained, I took my gig and pulled for Somusomil.

Sornu-вom, although one of the elief towns of Fecjee, aeknowledges a sort of subjection to $\mathrm{Am}$. bau. The cause of this is found in an ancient tradition of a contest between their respective futelar spirits, in which the spirit of Somu-komu was orercome, and compelled to perform the tama or salute due to as superior, to the god of Amban.

The town of Somn-gomu contains a bout two hundred louses, which are more straggling than any I had yet seen. It is partly built below a bluff, which affurds a very safe retreat and strong defance to its inlubitants, and is diviled, therefore, into al tower and upper town. The old mbure nenr the missionaries' house is nearly gono to decay. Here was found the only carved image I baw in the group; it was a synall figure cut out of solid wood, and she missiunnries did not seem to think that it was regarded by the periple witl any reverence. The priest appears to havo taken up his nbode with the old king, and was apparently held in great reverence.

The town is siturted on the north-weat side of the island of Vunn, which is separated from the island of Vanua-levu, or the large land, by a strait five miles wide in its narrowest part, which I lave called the Strait of Somu-Bomu. The island of Vuna rises gradually to a central ridge, the heiglit of which, by beveral measurenteuts, was found to be two thomsand and fifty-two feet. 'The summit is generylly covered with clouds. From its graduna rise, and its surface being smoother, it is susceptible of a mueh higher statio of cothivition than the other islands; the soil is a rich redclish loan, and it appears to be considered as the most fruitful of the islankls. At the same time, its inhabitara are ncknowledged by all to be the most savage. Canuibalism prevails hern to a greater extent than any where else.

Tho length of Puna is twenty-five miles, and its breatth five miles. Althonght bliere is a navigablo presage botween Vum and Corolib, yet it is naclo somewlat intrionte by sunken coral knolls aud banks of sand. These shouls extend' tso miles feyond the islawd, into the strait. The tides nor strong, but set through the strait. Calus and light winds prevail, is consequence of $\mathrm{its}$ being under the lee of the high land of Vuns, which makes the presage through it tedious and uncertain.

Corolib, or Goat Islanil, I made one of my stntions, as it commanded most of those we had been at; nind I obtained the necessury abservationa to secure its position.
I dined and spent the afternoon with the misBionaries ass] their lndies, and henrd a recital of souse of the trials they have heen suljectod to. I carnot but feel astoniabed that they enu endure to live among such a liorile of sarages. Their house is a tolerably comfurtsble one, and they lasve a few T'ungege around them as serwants, some of whom are converted; but all the rest of the inhabitnnts are cantibals. Mr. Hunt was lifind enough to rive the an acentrit of some of the secnes they had to witness, which will conrey an idea of what their situation is, and what they have hal to undergo.

Mr. and Mrr. Hunt, and Mr. and Mrs. Lythe, arrived at Somu-sonum in Angust, 1839, and consequently at the time of our visit they had been there nearly a year.

On the ilth of Fobrunry, 1840 , one of thein servants informed thens that the king had sent for two dead men from Lauthala, a town or koro not far from Somu-somu. On inquiring the resson, he knew of nowe but that the king was angry; this was sufficient to know, and in some degree pre. pared them for what they shortly afterwark had to witness. They now found that their serrant was only purtly informed, for, instend of two men, they soon observed eleven brought in, and knew that a feast was to take place, Messrs. Hunt and Lythe went to the old king, to urge him to desist from so barbarous and horrid a repast, and warned him that the time would come when he would be punished fur it. The king referred him to his son, but the savage propensities of the latter rendered it impossible to turn him from his barbarons purposes.

On the day of the feast the shutters of their house were closed, in order to keep out the disgusting smell that would ensue, but Mr. Hunt took his station just within his fence, and witnessed the whole that followg. The vietims were irrgged nlong the ground with ropes nround their necks, by these merciless cannibuls, and laid, as a present to the king, in the front of the missionaries' lotise, which is directly opposite the king's square, or public flace of the town. "l'he enuse of the mnssaere was, that the people of Lanthala liad killed a man belonging to the king's tcoro, who was doing some business for the king; and, notwithstanding the people of Laithala are related to the king, it was considered an unpardonable oftence, and an order wis given to attack their town. The party that weut for this purpose eame upon the unsus. peeting village when (according to thentselves) they were neither prepared for defence nor flight, or, as they described it to Mr. Hunt, "at the tirne the cock crows, they open their eyes and raise their heads from sleep, they rushed in upon them, and eltubed them to death," witlout any regard to rank, nge, or sex. Alt slinred the same fate, whether innoent or guilty. A large number were enten on the spot. No reprort mathes this less than thirty, but others speak of as many as three hun. dred. Of these it is not my intention to speak, but only of what was done with the eleven presented to the king and spirit.

The ntmost order was preserved on this ocen. sion, as at their other feasts, the people appronching the residence of the king with every mark of reapect and reverence, at the beat of the drum. When human bodies are to be shared, the king himself makes a speech, as be did on this occasion. 
In it he oresented the dend to his son, and int. mated that the gods of Feejee should be propitinted, that they might lave rain, sc. 'The son then ruse and publicly accepted the gift, after which the herald pronotineed aloud the names of tho chiefs who wero to lave the bodies. The lifferent chiefs take the bodien allotted to thon away to their mbures, there to be devoured.

The chicf of Lauthala was given to their prits. cipal god, whase temple is near the nissionaries' licuse. He was cut up and cooked two or thiree yarils from their fence, and Mr. Hunt stood in his yard and kaw the operation. He was mucl struck with the skilh and despatch with which these prectieed estunibais performed their work While it was going on, the old priest was sitting in the door of his temple giving ordere, anl anxiously looking for his shate, All this, Mr. Hunt said, was done with the most perfect insersibility. He could not perceive the lesust sign of revenge on the part of those who ate them, and only one body was given to the injured purty. Sono of those who joined in the feast reknowledged that the people of Lanthala were their relations, and he fully believes that thoy cooled and ate them, becanse they wore commanded to do so. Tho coolness, Mr. Hunt further rumarked, with which all this was done, proved to lim that there was a total want of feeting and natural sffection armong them.

After ull the purts but the liend had been consumed, and the fenst was endel, the king's son bnoclied at the missionaries' door, (mhicls was opened by Mr. Hunt, ) and demunled why their windows were closed ! Mr. Hunt told him to kecp out the sight as well as the smell of tho bodjes that were cooking. The earage instantly rejoined, in the presence of the missonaries' wives, that if it lapperted agail, tro would krock them on the liend and eat them.

The missionaries were of opinion, that after these feasts, the elitefs becone more ferncious, and are uften very troublewutne. In the present case, they attempted to bring ncensations against the missionaries, that they might hare a pretext fur plundering them, but the only fasit they enuld find to complaju of wna, that they did not receive presents. The missionaries' conduct was firm and decided, telling them if they desired the property, they must take it by force. This the aatives seemed afraid to do, and after they were fully convineed they could not intimidnte them, showed a desire to become friend. The misminnaries then took then a progent, which they were glad to accept, and gave one in rotum, as a make-peace, eince which time they lave lived in pence.

On the afterion of the $9 t h$, the Porpoise joined me liere, sgreenbly to nppointment.

Ou the loth, I endenvoured to get tho chiefs on board the I'orpoise to sign the treaty, or regulations, which the ehtefs of $\Lambda$ mban and lewn lat done. For this purpose I gave them an invitution to come on boarl; but no inducement could persuade them to pluce themselves in aur nower, for fets of a like detentions with Vendavi. Finding that they were deturnined to persist in their refusal to come on bosmd, I asked that a council of chicfs should be held on shore. To this the king ngreed, and issued his ouders for the tneeting. It touk place in lis house, which is built much nfter the fushion of an noure, though of larger dimentions; it bad four apertures for doors; the fire-place was in one corner, and part of the honse was curtained off with tapa, A large number of junk-bottles were bung from a beam, both for use and to display lis wealth, for they aro very nuch valued. The king also possessed a chair, two ohesta, and several unuskets. The former he seened tw take much pleasure in sitting in, having discovered, as lie told the interpreter, that they were very cunfortable for an old man, We had a full meeting, and I wתs much struck with the number of fine-luoking men who were present. Their complexions were dark, and they resembled one another moie thau auy collection of matives I hal before sect in tho group.

Thie two sons of the king were present. Tui Illa-jita, who is the notual king, is hold much in awe by the people. The regulations, after a full explanation of their objects, were signed, or rather they make their snark, for the first time, on paper. Tho old king has alway's lreen friendly to the whites, but lis son is conkidered quite unfriendly towards them; and it is thomghth, by the missionaries, that were it not fur the vid man, and the fear of punishment by a man-of-war, tlecy would nint be safe.

Messra. Hunt and Lythe acted as interpreters on this Decasinn, but not until after the one: I liad chosen wag ung ble to make them understand. "This was intehrional on my nart, for 1 did not wish tho king and natives to think that the mirsionuries hod had any part in the proceeding; and they did not undertake the office until the king and chiefs dosired their asgistanee. Besides the signing, we had the clnpping of hands and thighs, snd the three audible grunts of extisfaction from the audience. The meeting broke up witl $\mathrm{n}$ distribution. of presents, and anl, I believe, weut away eatisfied.

The ceremony attending the ava drinking of the king, at Sumu-somu, is peculitur. Enrly its the tnorning, the first thing heard is the king'a herald, or oratic, erying out, in front of his house, "Yangonn ei ava," sumewhat like a muezzin in Turkey, though not from the housetop. Tu thin the people ruswer, from alt parts of the koro, "mutus" (prepare ava). "The principal men and chiefs innediatcly assemblo together from all quarters, bringing Their awa-bowl and ava-root to the mbure, where they sent themselves to talasoa, or to converse on the affirs of the dny, while the younger proced to jrepare the ava. "Tliose wlo prepare the ava are required to have elean aud undecayed teeth, and are not allowed en swallow any of the juice, on pain of punishmeut. As som as the nva-root is chowed, it is thrown into the avn-bowl, where water is purted on it with great formality. The king's herula, with a pentiar drawling whine, then cries, "Seru-rui-n-na" (make the offering). A fter this, a cousiderable time is spent in straining the ava through cocon-nut lusks; and when this is dote, the herald repeats, witl still more ceremuny, his command, "Sovu-rui-a-4n." When he las chanted it several times, the other chiefs jois him, and \&lıy nll sing, "Mana endina sendina le." A person is then commanted to get up and take the king lis ava, after which the finging ngain goen on. Tise orator then invokes their principa! gord, Tara-Sava, and they repeat lise namea of their departed friende, atking then to wateh over and 


\section{$\pm 2: 3-3$ \\ Heturn to Ovolat. - Prisecedings of the Perpoline.-labas of rulaiga. \\ PEFJEE GROUP. \\ Jalnoul of Morambn. \\ Islanilg risleted by clie Porpaise.}

be griscicus to them. They then pray for mitr, for the lifo of the king, the arrival of wangara Pagalangi (foreign ships), that they may lave richeg and live to enjoy them. This prayer is followed by a most enrriest response, "Mawa entina" (amen, amen). They then repeat several times, "Mnna endina sendina le." Every time d lis in repented they mise their voives, until thoy rench the highest piteln, and conchude with "0-ya-ye," which they utter in a tone resenbling $\mathrm{n}$ lorrid Bcteam. Tlis screech goes the rounds, being repented by all the reople of the koro, until it reaches is farthest limits, and, when it eenses, the king drinks his ava. All the clitefs clap their hasds, with great regularity, while he is driaking, and, after he has finishul lis nva, the cluiefs arink theirs, withont sny more ceremony. The busilless of the dny is then begun. The peoples never do nny thing in the morning before the king lans drunk his ava. Even a foreiguer will not venture to work or make it uoise bufore that ceremouy is over, ol Juring the prepartion of it, if he wislies to be on good terms with the king and peuple.

The fender liaving rettrned with the boats of the Porpoise from surveying the straits opposito Gont Island, wo receired on luon'd Tubou Totai aud Coroduwdow, together with their suites; and I was happy to be able to give the Rev. Mrs. Hunt a pussange tin Rewa, whither I intended proceeding our nay return to Levuka. Mrt. Huat was going for the purpose of offering to take the elarge of the elihitreu of the Rov, Mr. Cargill, who had met with the inelancholy luss of his wife shortly after the ['eacoels land left Rewa. From this gentleman I

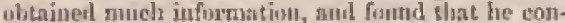
firued a great deal of that whisel I linwe alrealy given. He was obliging enough to act na my ityterpureter on utuny oevusions afterwatds.

'lle Porpoise partel enmpany with the Vincotises on the 8th May, off the islund of liulanga. From this time, until Jure 9uh, wher I net her at Souแ-8onn, Lieutemant-Coumandaut Ringgold Iral beos engaged in the survey of the eastern islarsits of tho group. It is sow time that I should revert to the operations in which he lad bers engaged.

the survey utuler Lieutenant-Commanilant Ringrold wiss begran at the south-enst island, called Ongen. There are, in fact, two islands inclosed in the same ruef, called Ongen-form ant Ongen-ribi. $A$ good entranee was found or the north-west sido of the reof, and a harliour, to shich the name of l'ort Refuge was given; but there is litcle or no induecusents to enter it, for the islands are lanrect, and no water is to be feund. A few wretclsed Jahabitants aro on them.

Thires miles to tho somthward nod eastwryd of Ongra is a dangerous recf cuml sand-hank, called Ningu Dngen.

Fulatuga was the next examined. This is a fine islant, surruunded by the usmal coral reef, which bas an entrunec through it on the norliy-east side (suitable fur stnall vessels), thut expaulo into a large basin, with many islets nud reefs, where large quantities of biche-de-mar huvo been gnthered. The bats cireumanvigated this island, and their cress wete on shore all night, in conse. quence of having heen obliged to return to the place where they first began theic work, and of blose bxing no prosibility of pasaing over the reef

to enable them to join the luigg beture the night cluated in. They wero kimlly traterl.

Duriug the night n lteavy 6 qquall was experienced from the north-north-west, with vivid lightning and rain; lut the following day proved fine. In the mostning the bonts rejoined the brig, ant brought off a native who gave lis mame as Tiann, and through $\mathrm{Jim}$, the interpreter, they gathered the information that the island is subject to Tui Nean, king of Inkemba. He also gave the names of all the istands in siglth He knew our flag, and spoke of vessels often visiting this island.

The buats left the brig in the afternoon, under the pilotage of 'Tinut, finished the survoy' of the inland, and made the west bluff of Fulanga, by triangulation, one bumdred and fifty feet high. They then returzed, bringing on bont a elvier of the islond, whose name was Songi, and the native missionasy from "Tonga, called Tuia. Neither of them lind any covering but the maro. They re mained on bonal sill uights.

This islutul is one of those on which fine timber grows, and is, therefore, regorted to ly the Yavalo and Friendly islanders for building enumes. Three of these were seen in the proeess of eonstruetion, under a long shed, one of which, bu mensurement, was found to be one lnusutred and two feet long, seven feet widle, and five feret deeps, of a beatifich model; the other two wero someshnt smaller. The builders said that they wete constrtseling them for a Yarno elief, called Salomon, fur the Tonga war. The work was performed unler a contract, and the price isgreed on wns to be paill in whales' tecth, axes, gutis, $\delta e^{\circ}$. Salumon was at the villnge, and went off with Livotenant-Commanelant Ringgold to the lrig, for the purpose of necompanyiug him to the other islands. He was a remarkably hardsome man, and resembled the Tonga ahiefs more than the other Feyje:

Learisug Fulanga Licuterant-Commandant Ring. gold bore asay for Kinmbara, laving firet surveyed the smalt islatit of Mornmba, which is halt n milo in diameter. It is well wouded, and is surromilerl by a recf, but offers no fucilities to vessels.

Enkaba, which is two miles long by one wide, is inhahited, well wooded, and has $\mathrm{n}$ breach in the reef, first no hasbour.

Iinmhara was the next island in course. It is of a rectangular farm, is about three miles and $\mathrm{n}$ half long and two wide, and is the westemmost of what I have turmed the Fasterz Gromp. It is fertile and well wooded; its timber is esteemed abowe that of all the other islands of the gronp for ennuc-Iuilding; and coeon-nut groves alound along its sliorss. The islnat is not entirely surrounded by the reef, which ia wanting on the north-west side. On examination it proved to have no assehor. nge for large vessels, but small onces ant bats may find protection. This island may bo known by a remarkable well-shaped peak on its north-west side, which is a good landmark. It is coveret with rich verdure, and was foum to be threo lundred and fifty feet liigh.

Talousielli is a small unintabited islnnd on the westers side of Kambnra.

Namuka, which was the next to clain attention, has a very extensive reef surronnding it, and offers no anchornge. There are but few natives up̧on it. 
Augasa and threo smaller islanda nre enclosed in one extensive reef, along with several ormall unjuhalited isteta. Angasa is the largest and most eastern of them, It ja easily distinguishet, and is remarkiblo for long regular ridges, thint extend throught the contre, and appenr as thougls they had been artifieislty formed.

Vharua is a small desolate island encompassed by an extensive reef.

Th the north of there wore fnund two suall jslands, Komn-levu and Kumu-riki, enclosed in the matne revf, Ilscough which there is a passage on the Joull-east side. Gnoil anchornge was fotand brere, except in north-east winds.

Motha lies to the enstward of Konno. It is one of the most picturesque islands in the grouj, with sn undulating surface; its liil|s were more free of wood than these they had belore surveyed; it is abrut two miles in diameter, snd is surrosunded by an extensive reof, through which thero is only a boat-entmace on the north shore. Karoni, which is of small gize, lies within the samo reef, towards ils smutheril end. Motha forms the southern side of what I have calied the Onentr Cliaunel ; is a geod latuImark to run for in makisg the group, leing ligh and surroumbel witls aloping sides. It soil is rich. Its population consists of a few nutives. F'liere are three detached reefs to the castwaril, and within a fow miles of it.

Onetata lies north of Motlia, and forms the nortlerti side of the Onenta Chantuel. It is of good height, and snay readily be known by Observatury Iske to the nurth-enst, two hundred and fifty feet iu height, with three lofty trees on its apex. "The reef arvulud Oneats is also extensive; it has two good entrinees on the nortli-enst side, and three on the west.

Nut being able to pass through tle reef of Oneata, Licutenant-Commandant Ringgold bore awn to the norlt-west for Lakemba, which is twelve miles distant. At nine o'clock on the 15tl the Poypunse whs off its south side, and as the boats wero prepariug to land, a camoe wis seen leaving the bench, having on loard the missionnry, the Reverend Mr. Calvert, belonging to the Weslevan Society. Ho had been on the island more ihan a year, nud succeded the Re*. Messis. Cargitl, Cross, and Jagger, who had removed to the larger and more impuriant ialands of the group. Liesstonant-Commnulant Ringrold and some of the officers returned with him th the island, where they were kindly entertained by him and his lady. Mr. Calvert did not express limself favoumbly regard. ing the untives, describiug them as eruel and bloodthirsty, and said it was the prevailing custum to destroy all shipwrecked persons. Camuibalism, however, is now extinct on this island.

'T'he king of Lakembs, Tui Nenu, was found seated in a Inrge eanoo-hnuse, near the landing, with a numerisus retimue of almost naked nutives ahout him. He is a corpulent, nasty-looking fellow, anl has the ummilizated habits of $n$ savage. He is srid to have one hundred wives! He exercises lespotic power over all tho surrounding islands, las the elnracter of heirg a cruel tyrant, and lives in the midst of all kindl of exceseses. The settloment is dirty and badly built, but has some largo honloes,

Mr. Calvert was landed in the evening, and the next mornisg, the Itth, the brig resaned the sur- veying duties, the ishands of Komo, Ularua, and the Airas, (buth the high and low, Oneata, and Motlas, all in the neiglaburliood of Lakenbu, were obscrved on and explored.

At uight these was a violent squall, acenmpanied with lightning and min. Annong these islands and пumerous reefs, strch ศqunlia becume very dingerous, but fortunately they are not of long dipratiot.

The two Aivar are both urishalited; they lie between Lakemina and Oneata, nnd aro surzonnded by an extensive reef, with the exception of a large opening in the north-enst side, which affords anelionge, exposed, lsowever, to the north-enst wints.

On the I7th they were engaged in exploring the grent Argo Reef. Its native name is Bucatatanon, and it is one of the most extensive and dangerous in the group. Its Englisl, mane is derived from the Joss (on its south-east end) of the linglish brig Argo, which hapjened in the yenr 1806 .

The outlyiug reefs oft Angasa and Motha, were also examined anil survoyel. Licutenati-Cornman. clant Ikinggold then proceeded towards Onealn. Here they found excellent nuelormge, under $\mathrm{Ob}$ scrvatory Isle, near a setulement on Lle nurth-enst side of the islankl. $A$ seesond nuchorage is to be frind off the west side of the island, near a large sandy bay. No water is to be liad here, except from we'ls, but there is abnndance of fruit, regetsbles, nird poultry. The population is two hundred. Two T'uhitian missionaries were found here, and about one-half of the people are Clnistians.

The Talation missionarieg prepossessed all in their favour by their puict and orterly belıviour. They have many recommendations from the former visiters to the island. They have heen on Oneata upwnrds of twenty years, having been placed there, ts they said, hy Mr. SWillians, who was the pioneer for so muly years in the mise gionary field, in which service lae lost his valuable life.

Observatory Island was made one of the magnetic stations, and Lieutemant-Cornmandant Ringgold nlso obtained there a full set of observations for latitude and azimuth, sights fur clironometers, and a round of angles on all the islands and reefs in sight. The wenther being unfaroumble, they did not suceeed in finishing the survey of Onenta and its reefs until the 23!. Tiana, the pitot whom they took on bonrd at Fulangat, was licre parted witl. He had proved very serviceable, and possessed much knowledge of this part of the group. Lieutenant-Commandant Ringguld gave lim his discharge with many presents, null a certificate of lig gori eondnet and abilities as n pilot.

The uflicers frequently visited the shore. The natives secmed to vie with each other as to wio should apprens most in the Europeas garb. The native missionarien, and some others, wore ruftled shirts marked $\mathbf{I}$, Dilton. Thuse, with a straw laat, constituted their only elothing, except the maro.

Thu southern side of Onenta is a mase of lavn. gomewhat resembling the clinkers of the Sandwich Islands. This roek is comparatively recent, hasing undergone but $n$ slight decomposition. Deop chasma were oecasionally met with. The whole is partially covered with vines and ereeners, athd the abore was lined with maugroves. 
On the 22d, they sailed, and continued the surveys to the eastward, towards the Boentatanoa, or Argo Reef. Hesides the brig Argo, another vessel, by the name of the Harriet, is saill to have been lost here. Aecording to Thaki's report, all hands from one of these vessels were killed, while only a few from the other egeaped. He rememhers the oteurrence, but it was a long time ago. This extensive reef was exsmined, when Lieutenant-Commandaut Ringgold, having heard of the arrival of the Flying. Fisls, with a pilot and des. patelies, returued to Lakemba.

It is remarkable that, up to this time, in all their trials of the eurrejt, they had found it setting to the enstward about half a mile per lour, varying in direction frum east-noruly-enst to eastNunthinast. This fact is confirmed by the infornu. tion obtajned from the Intives, that eanoes which nre wrecked to the westwurd aro always drifted tpon these islands.

On the 28ith, Mr. Totten and Dr. Holmes were despatcher on shore, to ascend Kindi-kendi, the highest peak of the island af Lakemba, for the pulpuse of making observations and getting its hoight by syrnpiesometer. The altitude was thus found to be seven hundred and fourteen feet. The ascent was not difticult, for a regular path led to the highest proint. The ruing of a town were found on it, called Tumboa, from which the Totiga chiefs of the fanily of 'Tubou Tutai are supposed to bave derived their name.

Mr. Calvert and his lady received them most kindly at the missios, as they had already done the other offieers. The house and out-buildings are comfortable, and the churel, which stands near the mission-lwouse, is a good building, eighty feet hng by thirty-two wide, nat twenty-five feet higl, The latter is convenient and approprinte to its purpose, and its flowr is corered with muts. $\Lambda \mathrm{t}$ 4 p.s. the hollow ling drum was beaten for prayera, which the officers atterded with Mr. Calvert. There were only fifteen persons present. A Tungn man ofteiated, as Mr. Calvert was fatigued with lis mornimg jaunt; and the serviees consisted of singing and prayer. There are about fifty resident Christrans, nearly all of whom are Tongese, of whom about one-stird of the population is composed; and they have litemlly taken posscssion of tho islnut, for they never work, but subsist on the Jabour of the Fecjee population, who bold them in much awe. The diflerence between the two mees was as striking here as at Ovolau. Hothenism is fast passing nway at Lakemba, and jts absturd rites are held in yidicule by most of those who are atill considered as lienthens. The influenee of the priest is diminishert, and the temple or mbure has fallen into decay.

Lakemba is the largest islnul in the eastern grvoup. It is five miles in dinnter ; its shape is neally jound, witls an extensive encircling reef. There is an opening on its enstery side, sullicient for large vessels, but dangerons, from the sumber of comal patehes which situl $\mathrm{j}$. The town is of the south side, and contains about two-thirds of the population of the island (one thousand preple).

Thie people of this islanil seenzed to be far from healthy; pulmonary disenses were comruon, and often fatal, and an unsightiy scrofulous aftection appeared to he quite prevalent.

The survey of Lakemba gave its length fire miles enst and west, by three sorth and south. The reef extends fix triles frum the island, in an east-north-east direction; in it there are two openings, ouse un tlie sauth-east side, and one opposite to the town on tho south or south-West side. Into the latter a vessel of one or two liundred tons may enter; lut after getting in, the space is very confincd, and it would be necessary to mor head And stern.

This island is the primeipal lacntion of the people I have heretofore deseribed, under the nawe of Levulisus, ns the first settlers of Ambru. They live in a villago which js dennmisated Levukn, and lave the character, at Lakemba, of being a wandering, faillikss tribe, addieted, occasionally, to piney. This is not considered the cuse alse. where, for the Feejee men, in general, look whon them is a useful elass, and thruugh them they carry on the trole lietween the different islands. It is not surprising that they should besr a bad uame among the Tonga men, for I heard that they were the means of cheeking the depredntions of those of that rnee who now hold possession of the istand of Lakemba, and exert a great influence on the south-enst islands of this gronp, which they find essential for their purposes of ubtaining war. canoes.

Lakemba wa found, like the rest of this group, to tye of rulemic formation, The Boil is similar to that of Vanun, composed of a dark red Joam. The islaud, in point of fertility, will compare with any of the others, and exceeds all thise of the goutlieast in size and productiveness. It has rich valleys, or rather ravines, gradualty rising and eothtracting until they reach the lills Extensive groves of encoa-lats cover its shoreg and low Lands, and add much to its beanty.

The Porpoise, having taken Tubou Totai on board, proceeded to tho island of Naian. This is a bigh island, and rises in perpendicular elifls from the sea to the lieight of two hundred and seventy. five feet. It has only a small reef attached to it on one side, the ollier side being free, It affers no facilities for the visit of ressols. Nainu contains a jopulation of two hundred inhabitants, who are perched upon inacessible pealks, in order to proteet themselves from depredations.

T'rabutha is thirty miles north of Lakemba. It lans a remarkable pent, which rises on its nortli-west end, fand is the Cap fslund of the clanrts, A reef surrounds it, in which there are two boat-entrances on the south-west and north-west aides. 'There are on it abunt anety jntalitants : it has no water except from wells. 'Tubou 'T'utai says that this islant belongs to him, the haxing received it as a present from the king of Ialsumba. There sere two small reefs, called Mamouko, to the soutli-weat of it, which can bo ciosely aupronched, and laswe n passage hetween them. 'Illey nue tliree uniles from the island, sonth-sonth-west (unt).

To the enstward of 'Tabutha lice the amall island of Am. This is a very prolty island, and tas taree reefs in its neightourdinut, - ane lying northenst meven miles; another, east-half-south two and o half miles; the third, soutli-half-east two and a lıalf uiles. Tlus smalt island is only indunbited during the turtle season, which beging in October and ends in Februnry.

Chichin lies twenty miles to the north-west of Nain. It is nearly circular, is three miles in 
diameter, and a shore-reef extends around it, with no opening lat for eanocs. Some of its points are three hundred feet light. It is in places thichly wourled, and has about tliree liundred inbabitants. There is a small reef to tho scruth-west, with a passage between it and the inland. The soil is rich, and every thing is prolneed it abundarce, Extensive coear-nut grores clothe is low points.

Mango is another sunall island, eighteen miles to the north-north-east of Chichia $I t$ is remnrlable for an open stace near is centre, which nppesuss us if it hal been artificially clented. It is surrounded by a reef, which has a break on the northWest side, but affords no protection for ressels. The southern part of the reef extends off about a mile, and has two small islets in it. It affords no sheiter, and there is no water except from wells. Its Ghape is an oval, whoso longest diameter is three miles, and its shortest two. There is a distinet reef, which lies north-west-by-nortlı, four rniles from it.

Vekai, Fintafinga, and the rcef of Malevuvu, all three lying north of Tabutha, were next exarnined.

Velat is six miles from Trbutha. It is a low islet, with an extensive reef lying on its northwest side, and is resorted to during the turtlo seasru.

Kntafanga is alsos small isle, inhabited only during the turtle geasoll. Its reef is inuch more extensive, being four and a half uniles from east to west, and lias a small openirg, which would admit a vessel drawing ten feet of water, were it rot impeded by some dangerous comal knulls. There are huts on its north-east point; and abundanee of sugar-csne, fruit, and regetables, may lie procured. Both the last-named islands are volennic, and specimens of tava were obtained frows then. The latter island is one bundred and fifty feet in height.

The reef of Malevuvu is two and a half miles long, and is awash, with the sen breaking over it. It is aeven miles north-by-enst from Katafnnga. Lieutenant-Commandant Ringgold having nnderstuod from Tukou that the reef around Munia enclosed, besides that island, six others, and that there was a wide ant safe pasage through the reef, deteruined, on conuing up witls it, to enter, which he did on its south-enst side. The islatuds, seven in number, were all of considernble size: Vasun. valavo, the largest of them, proved to be of a sirpentine slape, and fourtcen miles in length; eacls island had its separnte reef around its sloore, and the whole were eneloed by a very extensive reef, sonewhat of the shaje of a triangle, whose sides are twenty-fuur miles in length. The large istand is in no place nore than two miles wide; it is situated along the westorn side of the triangle, and contains many line lnys and safe anebromges. The other islands are enlled Munia, Susui, Malatta, T'icumbir, and Osubu, Lieutennat-Commandant Ringgold gave to the chaster the name of the ExpHorimg Isles.

Buats were dropped to survey the entrance, whilgt the brig proceeded to her first anchorage under the istand of Munia, to which the name of Discovery Harbour was given. This anchorago was a good one, in eiglit and a half fathoms water, with fine sandy bottom.

The chief of this island had but one eye. He appeared somewhat under the intluence of fear, but made some presents of hanamas and cocon-nute, anul complained mueh of his porerty.

The next day the boats were prepared for surreying. The lausch and another bost, under Lieutenants Jobuson and Maury, were sent to circumnavigate the large ishatu. "Parties were also despatched to get wood sud water. Mr. Totten and Dr. Holmes ascended the lighliest peale of Manin, talled Tulnniculo, the messurement of which, lyy aympiesometer, gave one thounand and fifty-fotu feet above the level of the sen. This penk is comprosed of volcasic tunsses, witl high, crugry, and uverlunging clifts. The ascent proved diftscuit, for the path phssed over steep litlis and along the edges of tho rocks, and it was in places 80 narrow that only one person could pass at a sime. A few men might defend the ascent against nI army. Upon she summit they fornd the ruins of a small village; some of the lut were, however, kept in repair, as refuge in limes of danger. The view from the top they describe as beautiful, many of the other ialands being in sight. The natives who recompanied them, to carry the instruments, sc., helıved well, and were amply rewarded. All the natives yet seen by the Porpoise were exceedingly fond of tobacco, thery small piece of which is tul ample reward for a long service. Some thefts were cominitted from the boats by the natives who as. sisted in bringing the water, but on speaking to the clijef they were quickly returned. He at the same time pointed out the thieves, and requested they might be killed.

The island of Munia contains about eighty inhobitants, and the settlement is on the western side, where water may be ubtained in small quantities.

Tieumbia lies five miles to the north-east of Munia, It bears a close resemblance to Munia, but is much smaller; the intabitants are about seventy in number. This island affords but little water.

Susui lies next to Vanua-valavo, and between it and Munin, It is divided into three parts, of which the easternmost is low, and covered with thick shrubbery and groves of coeon-nuls; the western portion riseg in broken basaltic peaks, geveral liundred feet high, and is tlickly wooded. On this istand are severnl villages, and the number of intubitants is one bundred and fifty. The ground is much better cultivated than is usual, the patehes of taro and yaus being kept remarkably neat. Good water may bo ulstained on the sorth.west side, running from the cliff. On the nortli-west side, Lieutenant-Cotntnandant Ringgold discovered a beatiful harbour, secure from all winds, whence an extensive valley runs back, thickly corcrted with bananas, cocon-nuts, \&c., with a small stream runaing through it.

Malutta is the next island. It lies near Susui, and is of emaller size than it. It is divided from Vauma-valavo by a marrow passage. The southert part of the latter island is ealled Lomo-lomo; its inrthern is ealled Ava; it has a good larbour on its east side, opposite Susui, protected by a small islet. On the west side of the island are two openings in the reef, a spacious harbour, and large stieam of water. 'T'lie population of Vanua-valavo? is five huwdred. There is a large villnge at the head of the bay.

Aris is a stmall island to the north-east of Vanuaralavo. It bas a few natives resituing upon it. 
On the sonthern side of the great reef, are two Emall uninhabited islands.

These exploring islsuds are well situnted for the resurt of vessels. "Tho ameliorages are very safe and easily renched. They affird an abundanee of fruit and vegetables. There are five openings in the lange reef, two at the cast end, two nin the west, ars one on the north side; all eafe, Vessels wisling to anchor on the western side inust enter now of the weatern pasargen, as the nen $r$ approneh of Fonum-sniarn to the large reef does not admit of a parage for vessels between them.

On the 8th, the Porpoise sailed from the Exphoring Isles, and continued the surveys of $0 \mathrm{kimbo}$ and Nitumba, witl the surrounding reefs, both attached and separatc. The former is made up of three small isles, enelosed in the same reef, funr trites enst and west, by three iniles north and अuth, which are seven miles to tho north of the north-west point of Fanun-valavn. The detacled reefs are from one to four miles in tength; they are awnsh and dangerous. Okinbo is elesolate, and aflords nothing but curtles in the serson, und some biele de mar.

Naitumba is high and rugged; it is of a circular form, one mile and a laalf in diameter. The reef does not extend beyond lasif a milo from it, and has no openitugas, It has fow isloahitants.

The time having now nrived for our meeting at Somm-sonu, Lieutenaut.Commundmat Ringgold bure up for that place, passing thrungh Tasman's Straits, which lie between the julnuiss of Kannia and Vura. Batl of these hrse many reefs projecting from their shores. This passngo should nat bo atternpted exeept in favourable weather, and the best time it during the morvisg hours, when the sun is to tho enstwund of the meridian. The currents are strumg, nul calms the very frequent under the highlanda of linunia and Lasuthala. In passing through these strutts, although they had a eareful look-out at the mast-liead they wero cluse to a coral knoll before it was seen, and passed withitn a fow feet of it. It had no more tlan eight feet of water on it. At noon they rounded the north point of Vuna, entering tho Sirnits of Somusomu, and at two o'cloek r.w. they reached the anchornge aff the town of Somi-Bomu.

Having thinshed all my business at Somu-Bomn of the ioth of June, at ten o'clock nt zight, I determined, notwithstanding the inteness of the hour, to gat under wny with the Flying-Fish, in order that I might take np the survey of the south side of Vamua-levu, beginning at Tolsanova Point. carly the next morning. We recortlingly weighed auchor, and atood ont of the Straits of Somu-romm.

In rontuding Goat Island we did not give it a sufficient berth, and grounded on a surken pateh of coml, an accident which hurt tho feelings of pror Tom the pilot more than it injured the tender. We remsined on this shonl about an hour, and after getting off we drifted through the struit, and by daylight fund onrselves in a prosition w begiu the survey.

At an early hour, Lientenant Case, Passed-Midshipman Harrison, and myself, took our bonts ant entered the reef. Mr. Sinclair was left in tho tender, with orders to foltow the reef close almard, and directions to enter Fawn Hartrowr; but Javing in our progress along the reef dissovered an onening, I made gignal for tho tender to enter. This entrance apnearg to le unkrinwn, and leads to a harbour which 1 ealled Baino, after a town that Tulou informed me was near by. It offers good ancliorage, being protected by the corni reef, which extende off some distanee. After the tender had fired guns for fixing our tase line, $\mathfrak{n}$ signal was minde for lier to get under way and proced to Fawn Harbonr four miles to leeward, and anchor at surset. We joined her there, linving hrought up onr work. 'This has heen ealled Fnwo Harbour after the namet of nn Amerienn brig, which was wreeker on the reef. In attempting to beat out, she missed stays and went ashore.

In the mornitng early we surveyed this small hartmur; and the two chiefs having returned on boarl, we started on onz surveys of the conft. The tendur at the cummencement grve us our base by sound, and we proceerled on our snrvey, leaving her to get under wisy, with orders to anchor at Savu-savil. We continued our work sill day, and passed only one rpeting in the reef, which is near the small islet of Rativn, and ofters little accommodation for nny clase of vessels.

In the nftermonn I observed for chrntmometer sights on the sma?l island of Rativn. "Two miles boyond this, the reef joined the shore. Mtr. Sinclair having conjectured thint I had received erroneous information respecting the distsnce to Sart-sav1, returned to this point to pick us up before dark, and finding an opening in the reef sufficient for small vessels, we took silvantage of it to join the tender. I at first intended to nneinor in this little harbour for the night; but when 1 reflected low necesary it was for mo tn return to ILesuka, I determined, after getting on board, to take advantage of the strong breeze, and push direct for Orolau, and at ten o'clock the next morning anchored at Leruka, where I found all well.

T'lie Starling had sailed for Rewa with the rudder-pintles of the Peacock, which Licutenank Underwood had succeeded in getting; and having heard that Captain Beleher was btill at Rewn, I deterunined to visit it, for the double purpose of secing if we could afford him nny further facility, atrd getting obserwations fur latitude and metidin distance, ns wel] as effecting a corurarison with my intensity needles.

Having cransferred Lieutenant Case to the Vincennes, Assistant-Surgeon Fox and Midshipman Henry joined the tender, and at noon we were again under way for lkewa, where we ancliorel at 9 r.m. I had the pleasure of funding Captain Beleler there. He was on the eve of sailing, having nearly completed the repairs of lis ship, and was nuking lis last series of observations.

The Starling had sniled for Mbenga a fow dayg before, whither the Sulphur who to go to join lier. Captain Jeleher sasled the next vening; and the following day tlie tender was tauled in close to the bench of the ialnnd of Nukalau, in orler to protect the spot where we were observing throughont the day, and guard against surprise upon us by the chiefa of Rewa, which place was but a few miles froul 11 .

I was not a little amused at Captain Butcher's account of the cffect of the regulations as operating upon his vegsel. The chiefs reuguired him to pay port-cliargen, and in default thereof refused to give lim any supplies. In drawing up the Fules and Regulations for the trade, it had never oc- 
curred to me to mention men-of-war as being free, feuling assured that they would all very rendily give five times the anount of the articles required in pressents. But it nppears that Cap̧tsin Belcher dil not think proper to make the custonuny prescnl, and the chicfs refused to allow any supplies to go to hir vessel until he should enmply with the rulus. This incensed the captsin, and catured him to take offence at the missionaries, who ho supprosed prevented the supplies from being sent. I well know, however, that they were guiltless. He likewise broke out into strong intectives agninst the elicfin, declaring that it was impossible they could unilerstand the rules, \&c., although the whole proceeding stuwed they were not anly conversant with thejr nueaning, but also with the power they had in their laadg of compelling the visiter to pay.

Nukalau is a Jnw, asiuly island, wel] covered witls word. On the easterm side it lins an extensive cond recf; but the western is elenr, and may be appronched clusely. Thete is a pool of water un the island, but as one could water a ship thure without the risk of cansing sickness on bont'd,

In tha morming, before daylight, we got under way, on our return to Ovolau. The day having proved ealm, we were at sunget yet onme distance from the island. I concluded, therefore, to lay under Amlatiki for the night, and by 10 A.M. on the 18th, we again anchorell at Levaka.

Lientenant Underwood and Passed-Midshipman Sandford I found had returned from the survey of the islaude of Angav, Nairai, and Ambatiki, to the eastwayd of Ovoliu, Daviul Whippy, the Maticum A mbau, had been sent with them as an interpreter, anil to hold proper authority over the untives.

The firat island which had occupied their attenttion was Ambatiki. It ja in shape nearly an equilateral triangle, surrounded by a reef, which offers no protection for ressels, nnd only pasagges for bonts. The island is seven humdred and fifty feat ligh, of a dome shape, aml contains five lsundred inliabitnnts, nll suljoet (or ygali) to Ambau. I'he people were civil, and gave them taro and yams is plenty, but would rot part witlı any pigs. T'lee renson given for" this was, their fen* of Tatioa. They live in villages, and seor thriving. The island lins rery little wood on it. "The reefs extesd ane-third of a mile from its shore.

Nairil was the next istand visited by them. They first anchored on the west end of the Ororuga Reef, that extenis off from the middle of Nairai, fivo miles in is vesterly direction. There is a passege between this and the Mothea, or Eliza Reof, stretching off from the island towarls the goutl; and there are also a good passage and harbour between the reef and the fshnd. The Cotu Rock is a good mark for tho former passage, when it bears easth It lieg a mile south of the south puint of Nuirri.

The bonts anchored in the harbour of Venemole, which may be known by two small inlets, joined to Nairai by the reef, which forms a protection aganinst the north winds; and veseels of any draght of water may anchor lyere in fifteen fathorns, with good bottom, from a qunrter to half a mile from the alore. Somewhat farther to the soutliward is a three-fathotn bark, which is the only danger that exists inside the reof townrds the Colut Rock or south-west passage. A bout a mile to the north is
Venemole Bay, It is eireular, with a uarrow entrasce, affurding, scemingly, a good harbour; but, on examination, this entrance proved to be quite shaltuw. The bay lad the appearance of having been an old erater; at low water, it may almost be said to become a lake. Tho officers were much struck with the benuty of the bay. It conkaing a village of the same name, and also another, called Tulailai; but both aro small. The nstives were quite peaceable.

They atwehored at night off the town of Tonloa, which lies in a bight at the north end of the island, and proved the largest fown on tho island. Here" David Whippy, acting as the "Mratieum hmban," olitained for them all kinds of provisions, and, by his exertions all night in superintending the cooking, they were prevented from being delayed the wext day. Whippy told ne that this isholud held a mediun between mbati and yrali to Ambau, being not exnetly in that state of servitude that the last would imply, nor yet as free as the first.

Nisirai is fumous for its mnnufactures of mats, baskets, \&c., a largo trade in which is carried on throughout the group by exclianges.

The reef extends fiom the island four miles northward, and, where it ends, turns for a short distance to the westward. There are a few patches of rack on its westers side, but sone fartluer from it than half a mile. This is the reef on which the Flying-Fish struck on enterisg the group, and where she cante near bejag lost. It does not join the islnnd, but is connected will the Mothen, or Elizn Reef; and there is, between it and the island, a good ship channel, leading to the large bay of Coubaruba. On the eastern side of thi. bay, there is safo anchorage, in thirteen fathous water, with a white sandy bottom. The reef, extending ns it does to the enutliward for a long dis. trase, protects it frosu the sea in luat direction. A brond pasange leads from Corubamba to the sonthward, and then passes botween Colsu and Nairai to the south-west piass through the reef. The only danger is a swall coral pateli, lyitig east-south-enst, a mile frum the south ond of the island, and a nile north of Cobu Rock.

The town of Corobambar lies at the bottom of tho bay, and is next in size to Toaloa. The Cobu Rook is a singular one. It is innecussible on three sides, of roleanic formation, and is enclosed by the Mothea Reef, which here spreads to the wjdth of alout three miles, and exterds four miles farther south, where it forms a rounded point. The enstern side it an unbroken reef, but the western is somewhat irregular and broken, with mnny openiags for bonts.

Lieutenant Underwood ascended the Colun Rock, for the purpose of obtriting angles; $\mathrm{nd}$, after observing these with lis instrument, furuing to take the conipass's bearing, diseovered a remarkable effect of local attraction. So great was this, as to cause a deviation of thirteen and a quarter points; Nauni, which was directly to the nortli, bearing, by compass, southeast-by-80uth che quarter south, while, what was quite remarkable, at the foot of the rock, near the water, the same compass gave the bearing Dorth, agreeing with that taken from the upposite bearing on Point Musilana.

They next fixed the southern point of Mothea Reef. T'his lins obtuined the name of the Elizn 
Reef, from the loss of the brig of that mame in 160?. On that ocension a large anount of dollars fell into the linnds of the natives, who fisher them un from the water. They were afterwards truled off to the whites, some of whom tolu me they yet occasionally saw a native wearing one as a kind of medal : but none fell under our notice. This accident brought the notorious ruseal Chnsley Savage among them.

They now steered for the north-enst point of Angau, whence the reef extends off one mile and a hall, and has no teep water inside of it. It was, therefore, diffienlt to find a plince whero they conld mehor the boals, fut at lust they found anehorago off the tuwn of Vione, which is concented frum view hy the mangrove bushes that linc the shores of this lstand for several miles. Angau is nuch targer and higher than either $\Lambda$ mbutiki or Nuirat.

The reef entinues round the east aide, close to the island. There are several openings in jt, but nowe that offer a tit place for a vessel to nnchor. As the south sile is approached, tho reef extends off sevoral miles, sud the water upon it is go shonl diat even the bats were forcod to keep on the outside, mad, for want of an opening, were obliged to anchor without the reef. In the morning they crossed the reof at tigh water, and soon got into deep water. The survey of the sonthert side proved there was safo anclunage, the holding-ground being good in twenty fathong water in the bay, and ofposito the town of Lakemba; but diring a southerly blow, a vessel would be mach exposed to the wiud and sen. There aro severul openinga and clear passages through the reef on the north-west side, nul elear wnter round to the south, bat the bights to the north are full of coral patches.

Having completed thie Eurveys, agreenbly to his instructions, Lieutenant Underwood returned by the way of Ambatiki, and reached Levuka after an absence of nine dryg. The men had been at their oars pulling almust constantly for the period of eight days, sleeping in the boats, and seldom allowed to land.

Mr. linox and Colvocoresia were sent with the tender to complete the aurveys of Walkain, Mokungai, and M[ekundrangh. Ail tiree contain few inhabitants, and lave been the seene of the horrid tragedies often cornmitted by the stronger on the weak tribes of this group. There is a remarkable ahelf formed near the centre of the island of Wakain, which goes by the tame of the Clitet's or Clicftuin's Leap. Near this there is now a smal town.

Muknngai foll under the displessure of the Ambau chiels, and the whole population was exterminated after a bloody battle on the beach of ita little harbour, Some of the whites witnessed tlis thingaetion, and bear testimony to the bloody scerre, and the cannibul foasting for days after, even on those badies that were far gone to dectry. They are both, as I liave before said, under the rule of the chief of Levuka.

Wakaia now containa only about thirty inluabitants, whilst Mokungni lias only one or two families.

Thege islards are in sight from Ovolau, frosn which they are separated by a strait of ten miles in width. Although several miles apart, they are situated within the same reef. 'Thero are several openings leading through the raef near Wakain, on its enstern side, but they cannot be recommenied except for amnll veseils. I pased througls one of them, bot cound it much blocked up with coral knolls. The entrance on the south-weat side, tending to Flying-Eish Harlmur, is quite narrow. On the west eide of MInkungai there is aiso a small harbour, formed partly by reefs and partly by the little isiand of Mektudman.

Finding, on examinstion, that there was a reef that hal not been surveveth, orders were sent for the tenser to return to Levuka, which slie did on the following day, and on the next I sent her, with Lientenunt Uuderwood, to examine the reef of Angau. This reef is called Mumbolithe, and is situated fourteen miles to the sonth of Loho Hill, the south-east point of $A$ ugau; it is oval in straje, and three-fourtlis of a mile in length; the oes breaks on it at all tines.

In returuing from this service, when off Nairai, they had a narrow escapo from stipwreck, being nearly on the reef, in a dark nimht, before it was discovered. Any other vessel of the squadron but the P'lying. Fish would probably luve becn lost; but lor admirable qualities were well proved in the explortion of this dangerous and unkiown group.

On the 27 th, the instruments were all embarked, and the return of the tender enabled us to put th ser in the Vincennes on the 28 th of June. Intend ing to visit the hot springs of Sivu-\$ava on Vanualevu, we left Levuka in the moning, and stood over towards the end of the Waliaja Reef, with the view of passing round it. It being Sumday, the Rev. Mr. Hunt, who was a passenger on bonrd with me, yolunteered to officiate for us, which was gladly accepted. After service, I found tho wind would not permit my wenthering the point of the reef; so I bore up to pass tlirough the Mokungai Passage, with a strong breeze. After getting thruugh (which we had some difficulty in doing, in consequence of the strong abb tide setting to the southward and westward), I stood on towards Direction or Nemena Island, intending, as the wind was beconning light, to enter through the narrow pase sage in the reef, and anchor under it, rather thas remain aurrounded by reefs during the night.

The next day completed my olservations, and finished the suryey of Nemena, or Dircetion Isle. In the afternoon we got under way, ind stowat over to the nortlaward for Savu-gavu on the isinnd of Vanua-levu, Tlıe wind was quite light when se passent out of the reef, on the opposite side to that where we had entered it. I hud proviously sent two boats to exampine the passuge, and anclior in the decpest water. Wo approncind the pasage with a light air, having all sail set, but had rery little headway. The water was perfeetly elear, and the roeks, and fish, with the hottom and keel of the eluip, were plainly visible. When we got in the parsage, the oflicer in the hoat tohl me that the keel looked an if it was in contact with the cornl; the lead, lowever, gave three fathoms, one and a half feet to spare. It was a little exciting fur twenty mitutes, lint we did not touch. If we liad, the ship, in all probability, wotsld have been a wreck: for as the tide was falling, she would have liung on the coral shelf, and been but partly snpported by it. This is the great danger altendant on the nnvigation of this group, as indeed of alt coral islands. 
We wero becalmed during the whole night; and the uext morning, finding the calm still eontimued, I touk to my buat, direeting Lieatenant Cart to steer in for the bay when he got a brecze, eupposing it would sot in st the ordinary time, eleven a'cluck. I Innded on a small islet, alsout six miles from the plice where I left the ship, and near tho mouth of the bny. To reach the islet we putlod in over the reef, which had on it nbont four feet of waler. The islet was composed of scoriaceous lava, much worts, sud about twelwe feet alvovo the corrd shelf. Here I estalilished myself, and was busy sceuring nuy observations, when I discovered that my bost was aground, and that the tide was. still falling. Tho islet as well ns tho revi beeame dry. It whs not long before we observed the shadow of nntives projecting from a rock about fifty yards from 118 , who it now syprared were wateling us closely; and not long after not less than fifty shadows were seen in different direetions. I nt once ordered all the arms and ammunition to be brought up on the top, ard made our situation as defensible as possible, for I lud little doubt if they saw that we were unprepared they would attack us. The firing of ono or two grus, and the sliow that we wero all on our guam, at once esused a change in their intentions towards us, which they manifested by bringing articley of trade.

In the afternoon we agaits got under way, and procested fartloer up the bay, anchoring of Waicama, or the hot eprings, in twenty-eight fathoms water. The bay of Snru-savu is a fine shect of deep wnter, ten miles in leugth, east and west, by five miles in brealth, from north to south; it is surrounded by very bigh and broken land, rising in many places into lofty needle-shnped penks; it is protected by the extensive reef neaching from Saru-saru Point on the east, to Kombelau on the west, excepting a large opening of about a mile in width, two miles diatant from Savu-sawu I'oint. On anchoring I despatelied two boats, under Iicutenants Case and Underwood, to join the surveys wo had nade in the tender, as far as Rativa Ikland; they departed the same evening nn this duty. The projection of land forming Savu-sarn Point is much lower than that on the other sides of the bay.

I visited the hot springs, which are situated opposite a mall islnnd, round which a narrow nrm of the bay passes, furrsing a smull harbour; a considerable stream of fresh water enters the bay, about a mile above the gituation of the springs. On lanling, we found the beach absolntely steam. ing, nnd warts wnter oozing throngh the sand and gravel; in some places it was too hat to be borne by the feet.

The liot springs are five in number; they are Aituated at nome dialance from the beach, and are nimo fect above the level of high water; they oceupy a basin forty feet in dismeter, almout halfway butween the brse of the hill and the beach. A inull brook of fresh water, three feet wide by two deep, passes so close to the basin, lint one hand mny he put into a scalding spring, and the olluer in water of the temperature of $75^{\circ}$. "That of the spring stands at $200^{\circ}$ to $210^{\circ}$. The waters foin below, and the united streans stand at $145^{\circ}$, which diminish in temperature until they onter the sen. In the lower part of the bed of the united stream, excavations luave been made, where the natives lathe. The rock in the neighbourhood is conngact coral and rolernic brecein, although it is $\mathrm{n} n$ where to be seen exposed within $\mathrm{a}$ third of a mile of the spring. The ground about the spring is a deep brown and black mould, covered with conrse native grass, ( $\mathrm{n}$ epecies of scirpus, ) which is thickly matted. There is no smels of eulphur, exeept whon the hend is brought as close as possible to the water; but ft has a strong saline taste. No gas appenred to be disengaged. The basin is in a mixture of blue and brown clay, and little grass grows in it.

These eprines are used by the natives to boil their fond, which is done ly putting the taro on ynms into the sprimg, and covering then trp with haves atud grase, Although the wnter searcely had suy apprearince of boiling before, rapid subullition ensueg. It girgles up to a leiglit of eight or ten inches, with the anme noise as is made by th cauldron when over the fire, Taro, yams, \&u, that were put in, were well done in about fiftech minutes. The mouths of the springs are from eighteen inches to two feet in diameter, and have apparently been excarated by the natives for thejr own purposes. The nccount they give of them k4, that they lawe always been in the same state sinco the epirit first took up his nbode there. They are convineed thant he still ragides there, and the natives say that one spring is kept pure for lini, which they du not use.

On the 3rot of July the tender eame in and anchosed, laving suceeeded in accumplishing the survey of both the island of Gore and the Horse. shoe Reef. The former is considered by the natives oue of the mont fruitul islanuls of the group ; it is a high island, though not so much brolien as the others, and, from appearance, would be susceptible of cultipation to jts very top. It is surnotunded by a reef, which is, for the most part, as shore-reef, ind affords no linrbour; there is, lowever, aneliorage on the north-west side. The istand is nine and a hulf miles long, by four miles wide. The produce of Goro is oil atd tortuise-shell, and exceeds in quantity that of any other island of the group; its population is two thousand.

The Iforseshoe Reef liss between Goro, Nairai, and Wakaia ; it is an extremely dargerous nne. The nawe is derived from its shape, and its opening is on the north side; it is even with the water, which after stormy wenther may be seen bresking on it, from the heights of Ovolau; it is one mile in dianeter; there are no other dangers nearer to it than the worth reef of Naini.

The bay of Saru-savu may be known by a remarkable saddle*shapel peak, lying just behind it; there are several other high peaks, that show the interior to be very rugged nud high. Some of these peaks reach the altitude of four thousand feet.

At daylight on the $5 t^{\prime}$, the Vincernes got under way to proceed to Mbua or Sandalwood Bay, with a moderate snd favoumble breeze. I determined to take the outside passage off Kombelnu Point, although that usually pujsucd, which is elose to the land, is considered the safest. There is a reef of Konbelau Island, fire miles in tength by two in width; and beyond, and between it and the great Passage Island Reef, there is a passage supposed to be full of shoale. I had reason to believe, however, frum the examination of Lieutennnt Perry 
and SIr. De Haven, that there would the no diffculty in taking the ship through, wlieh I aceordingly did. This clannel has shosls it it, some with but a few feet of water over them, while others luve sufficient for any class of vessels. The least water wo had was jine fathom, I believe we were enabled to locate all the slooale in it, and I think it a safo pasage. With the bun in the enst, and steering towards the west, the dangera are distinetly visible.

Beyond Buis Point the parsage becomes still more intricate, nnd opposite Rabe-rabe Island it is quite narrow, though there in stmple whter for any tessel. We, however, went briskly on, having a fine breeze from the enatward. After getting sigint of the Lecumba I'oint Reef, there is but a uarrow clianuel into the bay, which we reached at hulf-past 3 P.se. The Peacock lind just arrived from the north side of Vanua-leru, and auchored.

Mbun or Sandalwoorl Bay, though much filled with large reefo, offers ample space for anchorage.
The Indling-ground is excellent, and the water not too deep. The bay is of the figures of $\mathrm{n}$ large seg ment of a circle, exix miles in dinmeter, and is forment by Leoumba Point on the east and that of Dinbarlimba on the west. The land immediately surrounding it is low, but a few miles back it rises in high and picturesqua penks, That of Corobato jo distinguighed from the Vitilewu shore, and has an altitude of two thousus feet. The shores of tive bay are lined witls mangroves, and have, generally, extensive mud-fiats. There are few facilities liere for obtaining either wool or water, ns the andtorage is a lang dintanee frum the whore. Several emall strenns enter the bny in its upper part, Howing from aptne distnnce in the interios. This was the prineipul pluce where the sandniwood was formerly obtalned, but it hins for some years pat been exlrausted. I stal! defer speaking of this district until I have given an account of the operations of the Peacock.

\section{CHAPTER XXVI.}

\section{FEENEE GROUP-(cosclenED).}

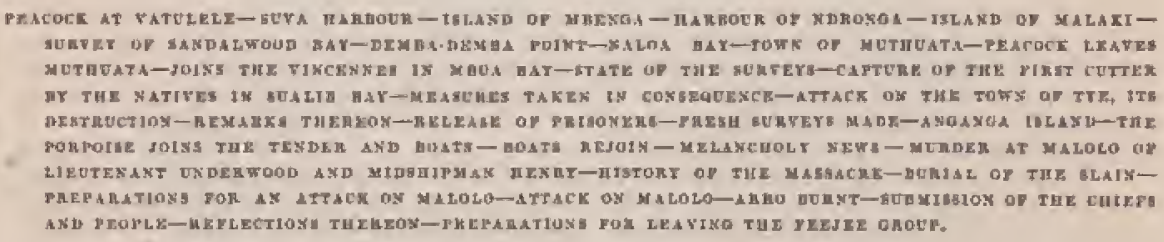

Ox the 2fiti of May, the Peacoek was off Vatulele. Leaving Mbenga to the nortli, Kantaru on the south, and passing through the sea of liantavu, they hisd survesed the suthir-wert side of Vatulele, and afterwards atood fon the opening in the reef off the west end of Fitileru, through which they passed after sumset, muhoring ant the inside of the reef of Naxula, in thirten fnthoms water, This is the limit of the king of Rews's authority.

On the morining of the 27 th, they coasted along the land inside of the reef. Tho shores of Vitileve are bere low ; but the land within a shurt dintsince rises to the lieight of one thousand feet, ntw has a brown and barien appearance. It is destitute of treck, except on the low points nlong the slowes which aro evered with mangrove (rhizuplura) and cocon-rit groves.

Troward sunset the ressel mo upon a coral lump, which gave her a conaiderable jar; but, on geteing out a kedige, they rely soon linuled off, when Ciptwin Hudson anchored for the night.

In the evening, partly as a sigmal for the absent bonts that were appuinted to nrect the ship here, and partly for effect on the antives, they fired an evening gun, burnt a blue-light, and set off threo mekets, or as the nntives term them, "fiery spirits, These brought forth many silsuts from the lani], which were nudibly heard on heard, although the wescel was at a great distance from the shore. These signals were soon snswered by is rocket from the boats, which joined the ship early tho next morning.

Lieuterant Fmmons, his officers, and bonts' crewe, were all well. No accilent hal occurred to thein, and he reported that he had finished his work. After lesving the ghip at Rewa, he passed wutside the roef for soveral miles, until he came to a narrow and deep pasage through the ref, which lest to a gpacious harbour, on which lies the village of Sura. Thu natives of this village told Mt. Emmons' interpreter, that they were subjects of the king of Rewa, and that they had lately become Cliristinns. This is the village where the Feverend Mr. Cargill had been the Sundny preeeding, and ita inlubitants were the furst progelytes the had.

Suva Harbour wan surveyed and found to be an excellemt one, free from stuals, well shettered, and with good holling-ground, easy of ingress aud egress, with an abundance of wood and water. It lies ten miles west of Rewa Roads.

On the 20th, the boals atood over for Mbengn. They found the eurrent setting very strong to the eastward, which mado a disagreenblo short sea, oblinging them to keep two hands bniling to prevent the Lois from swainping. Towards night they 
entered the reef that surrotnds Mhesiga through a shalluw passage, and anclused ofl' a deep harbour, where they remained for the night.

Mtbenga, like all the large islanda of this group, is basaltic. Its shupe is an oval, five miles long by three wide.

Thu bonts now visited Bird Island, lying in the passage botween Mbenga Keef and Vitilevu. The reef oft this purt of Vitilevu nearly joins that of Mbenga. 'Two miles beyond this, Lieutenant Enmons entered a well-sheltered harbour, where the bonty stayed over-night. About three miles to the westward of it, they found another sintilarly situated, after which they continued to pruceed down the coast, along the reef, willout meeting any Jarbour titulil after dark, when they stuceeded in getting into the exposed one of Ndronga.

Thie larbour (if so it may be called) of Nironga, affords no protection against the southwest winds, and is only suitable for strall vessels. The Bnchumge is in fivo futhoms wator. The reef frou this point westward increases in distance from the shore from one to two miles.

Five miles beyoud this harbour they came to the Mabulo Istand Passage, where the great seareef from the westward joins, lonving two entrances, the Inrgest of which I lave named the Malolo Passage. That to the eastward, which I ealled the Nivula Passage, they mased tliroagh and snelsored at night under the town of Navula.

On the 2rith, Lieutenant Emmons gained Ba, the point where his work was to terminnte, and be juined by that of the other parties. On the sath they wient alongside of the Peacock, after lanving been in the boats geventeen days.

The Puacoek now took the launcb and cutter in tow, and began benting up for the purpose of reaching the Malaki Island's, in order to take a departure from Ambon Bay.

On the 2nd of June, they reached and landed on the island of Malaki, which is a high islet, divided from the lnrge islant by a narrow strait, near which is the town of Rnke-rake, which is also subject to Amball.

Malaki has the appearance of having onee lieen well eulivated. This island is eiglat liundred feet high, and on the top are the remuins of a furtifica. tion of atone, whose walls are four feet high, surrousded by a muat several feet deep, and sen feet พide.

On the Bith June, Captain Hudson ret about the survey of Sundalwood Bay. Ile then, with the tnaturalists and many of the ufficen, visited the thore. 'There are thee rivern that How into the bay; the midlle one of these they entered. It has two entrnnces for troats. It is bordered on each aidu by extensive trud-flath, which are bare at Jow water for a considernble distance. Parts of these flats are covered by thick magrove-bushes, among which rnany womed and chilliren were seen catching a large kind of crab, whilst llocks of paroquets were flying around them. This river is about two hundred feet wide, and very tortuous.

The town, named Vaturita, is situated about a mile up the river. The entranee to it is through a flollow way, to pass through which it was almost necessary to crue|t.

Abut one-fourth of a rmile from Vaturus is another town, called Matainole, which also belongs to
I'ui Mora, and is in all resjects similar to the other.

In the afterrom of the 10:h, Cnptain Hodron got under way, although nearly alt the officens and nell were still at work on the survey, and anchored the ship off the northern puint of Mbua Bay. This point is ealled Dirnba-dimbn, and is eunsidered by the uatives as sncred gromud; it is kept strictly frum sny kind of disturhanee, for it is supposed to be inlabited tiy the spirits of the departed, and to be the place where they embark for the regisns of Ndengei. It is a most benntiful spot, and in strong contrist with the surrumblitug country, which is is many places devoid of trucs, while here they flourists as nature has planted them.

On the 12th, Captnin Eigleston of the Lconidas cane on hoard, mad piloted them to Naloa Bay.

On the 17th of June, the Peacock left the bry of Nalua, in company with the Leonidas; and on tho aftertiona of the igth, anchored of the town of Mutlusata.

The tuwn of Mutlunats congists of ahout one liundred louses, built clusely together, and is situtited in an open valley close to ligh-water mark. It is very much exposed and quite defenedess; has but fow trees fibout it, but is one of the best-built towns in the Feejees. The style of building resenbles that of Rewa. T'lse king's name is Ndrandranda; his tille, 'lui Muthuata. He is old and quite infirm, the result of au sttack of elephnntiasis in one of his legs, which renders it diflicult for him to walk.

Tui Muthusta has from eighty to one hundred towns under lis control; and his territory ex. tends fron Unda Point to the island of Tavea, in Naloa Bay. Many of these towns are of suall extert, and contrin but fow inhabitants ; and I found that so estimate the population by the report of the chijefs themselves, would give errumeons resulti. Feejee men lie with grent plausibility, and particularly if it is to swell their own isplortance.

On the 28th, Passed-Milktipman Harzison arrived in the schouner hini-riti, with the supply of yams, and ray orders to the Poacock to join me at Mbua Bay on the 4 th of July.

On the $5 . L_{1}$, thie Pencock anchored in Mbua Bay, about an bour before the Vincenues reached it, all well and in good spirits.

Upan the junction of the Peacoek with the Vin. cennes in Mibua Bay, I find it in my power to exarnine and collate all the work that we had thus fur accornulished. After doing this, I found that so much yet remained to be done before a thorough survey of the Feejee Group could be completed, that I must either leave this important duty unfinished, or devote more time to it than lnad originally been contemplated. I deemed this to be among the most important of the objects of the expedition; and cotuidering that the seas around these iglands abound in dangers whose position lad up to this time been entirely unknown, I resolved not only to complete the murreys, but not to leare the group until I had entirely satistied myself of the accuracy of the work.

In furtherance of the lnst object, I set all who had been employed in the servicte to work in plotting and calculating their Eurveys, while the features of the region were yet fresh in their metnerices. 
bis a lew dush, at this tima, every onte was empluyed who could work, in repririmg tlie bonts, preparatory to the further exasuination which i contemplatel making or the howriy-expected ar. rival of the Porpoise.

Ou the afternonon of the 12 th, Lieutenant Perry arrived in the launel, bringing with him Mr. Knox and the crew of the first cutter. That bust had been coptured by tlue tustives, at Sualib Bay, about twenty-five miles to windward, on the same island. In this bay" the launch and first cutter lad taken refuge doriag the bad weather, although it offers indifferent necommotation. After being there two ur three days, they attempted to lreat out, when the cuttur, in tryisg tis go about, nenr the reef, missed stays nud was thrown on it. At the time this oceurred, it wag low water. Tho natives, who it whs supposed by the party, lind antieipated tho accident, find followed along the $r$ ef, and, ns soon as it haptrened, crowded down, all well frmed with clubs, fpreats, storses, \&e, Mt. linox, firding it impossible to get tlie boat off, thought of looking intr lis menus of delence, and found himself com. pletely in the power of the natives, for all his arms and momumition were soglied with solt wnter. Licutenant Perry, finding that the Inumeh could not make headway against tho wind and sen, had anchured at loug gum-sliot from the sput where the cutter had gorie on shote. As foon as ho saw what was going forwaid, he mened a fire on the natives, but without effect; for they, notwithetanding, collected around Mr. Knox"s party, and gave them to understand chat they must alvandon the hout and go on board the launch. Having no clioice left, he took out all the arms and the chronumerera, nul, keepirg the natifee at bay, by prinling the guns at them and tureats of killing them, the erew renched the hunch in sufety. The natives towk posgession of the first cutter, dragged her over the reef, and stripped her of every thitig. 'They then appeared to be engerly watching the launeh, at which they ocensionally firevd their muskets, witl which tloy aro better proviled on this islasd than elsewhere. Thes did not prove good saarksmen, lowever, for they did so damage.

Two natives, from anuther part of the eliser, now suam off to the Inusel, with offers of assiatance to Lieutonant Perry; but he supjosed ulat this was done to spy out his weakmesg, and leam bow to take advantage of it. He, therefore, at once seized and retairsed them. They jirowed to be a great chicf and an inferior one. After he had obtained posession of these men, the satives on shore gave him no further trouble, but remtined Jurking about the mangroves.

The next morning, the wenther having moderuted, he was cuabled to get out of the bay, nnd reselyed the ship at the above date.

Inmediately on recejving the report, I ordered the iwo prisoners to be put finto irons, and the schooster and eight bosits, four from each slipip, to be ready for service at sunset. "Pwenty aditional men and oflicers were put on bownd the tender. Captain Hulson and myself both accompanied the party, which left the ships at she appointed time. Our firet rendezvous was ibout twelve miles from the ship, and it wus my intention to reach Sunlib by daylight the next moming.

The cutter, we found, on our arrival nt Sunlib Bny, had been drawn ap to a eonsiderable distanee, and the tite being low, there was a wide moth-fat between her nud tho place where we Iny at nachor, through which a smbll tortuous ereek led up to lier.

The natives of the two towns on each side of the bay, one called Tye and the other Sualib, seeured both to be active in proparing to give us a wart l'eeption, Our inlerpreler gave me reasm to expeet that we should not get the bont without a starp fight, and that slie would be perliajo destroyed by fire betore we strould bo alule to save ther. As it would, in all probability, have been attended with losas of life to nuke the attempt at low water, I delermined to awnit until tho tisle rose, and in tite mean time to nttempt to procure her restoration by megotiation. I therefore sent Whippy and Tum so lobld a parley, and to state to Ihe natises, that if they reatoret the bont and every thing belonging to ler, I would, for this tine, forgive them.

My conditions not being complied with, I determinet to make an exnmple of these natives, and to show them that they coulil no fruger hupe to eommit nets of this description without reeciving punikfunent.

We moved on for this purrose in an imposing atruy, keeping ourselves well prepared for an nttack, to which we were necessnrily exposed on our approncli. A very few man eould have done Hs much mischief, had they been tolerable marks. men and stood their ground.

To approach the village we had to puss hetween Jong lines of mangrove bustien, ard I was assurced by Whipty, who had beet before on a war.party with a formidable force agningt these nativer and been benten alf, that we should Jave sometling more than a mere show of tresistanete to cneounter. Under this expectation we proceded forwards; but all was silont, and no innpediment whs oflered to our course.

Whey near the beach the bonts were anchored, and the ofticers and men jumped overbont, and waded in about two feet water to the shore. Every thing was eouducted with plie most perfect order; the three dirising landed; Coptrin Hudson, with two, proceeded to burn and destroy the bown, nud the thitr remained on the beach as a reserve to jurtect the boat, for I was apprehensive that ar attack iniglit be math on thein by those on the other side of the bay, a great mary of whom were visible, arued, and aptarently ready for a fight. "The precaution I lad taken to let them know, through Whipyy, that I held their chiefs as hostages, and that their safety depended upon the good condiset of the townspeuple, I felt was some security, but I had made up my mind not to trust the natives in auy way. I therefore kept a large foted liuder my own cliarge to repel any attack on the boats, and act as a reserve should it become necessary.

The wwrs was soon fired, but the anxiety of some of the sailors to make a blaze, induced thern to fire one or two of the tlick thntched roofs to wind ward, while the rest of the party had gone to begin the work of testruction to lecward. The whole villnge was in consequence soon wrapped in sheets of llanic, and many of tho met were exposed to tanger ou their return, from the intense lieat of the burning buildinge. So elose was the resemblance of the noise mado by tho bursting of tho bamboo eanes, 
(of which material the houses are for the ruost part built, to a ruming firo of musketry, that every one believed that $\mathrm{n}$ general fight was taking place in the parta distant ant opposite to litm.

About an hour snfficed to reduce the whole to ashes, leaving the village a heap of amokirs ruins. We then returned to our bosts in the same good order in which we landed.

The town of Tye contained about sixty dwellings, built of bamboo, besides a number of yam-houses, wherein they lad gathered their erops. The upper and outer yams were well ronsted, but the hent from the light material was of short duration, so tlant few in reality were lost. Another small collection of ymm-houses, alout a quarter of $\mathrm{n}$ mile distant, was also burnt.

Few things were found in the town, for the natives bal removed all the articles that could be earried away. Three or four weeks of labout would, thereforo, suffice to rebuitid their liouses, and restore them to the aame state as before the burning.

There พns no oppoeition made to this attack; nl the Feejee men had retired out of gun-shlot, and were only now and then seen from belimd the bushes, or on tome cringgy peak on the sides of the neighbouring liills, frum wlich they were ocension. ally dislouged by our rockets. This firework produced consternation, and dispersen them in every direction. As the buats were pulling of from the shore, a few balls foll nenr us, but did no darnage.

The inflictions of this punishment I deemed necessary; it was efficiently and promptly done, and, wichout the sacrifice of any lives, tanght these savages a balutary lesson.

In the first etitter was private and public property to the value of above one thousand dullarg, which was all lost.

By reference to my instructiona, it will be seen that cases of theft were expressly mentioned as oceasions that might require punishment to bo inflicted on the natives; yot this transaction formed the gist of one of the eliarges preferred agninst mo lyy the administration, on my return to the United States.

"Tho conduct of the offeers and men on this ocension shuwed a promptness and energy that were lighly creditable, and gave me the assurance that they were as much to bo depended upon in dangers of this description, as I had hitherto found them in others.

The next day having become gatisfied that the Sualib chiefs who had been detrined by Lieutenan Perry had renlly ment to act a frieduly part, I deternined, for the purpose of making the evutrust ng stiong as possiblo between those who had offered aid and those who had stolen the cutter, to reward the former for their good intentions.

The next morming, ald hands were called on deck, and the prisoners brouglit to tho gangway in irons, expecting that their time was now come, and exhilsiting great fear, both in their countenances and trembling limbs. Through David Whippy, I then told them, that although appearances were at lirst against them, I had satisfied uyself that they iutended to act a friendly part in assisting the launck, and as they had taken no share in the robbery and capture of the boat, and the people of their town had done nothing to molest us, instead of purishing them, I should reward them with presents, and send them buck safoly to their town. The joy that was defricterl on their countenances at this cliange can readily bo imagined. Their irons were then removed, and the presents given.

After thasking the nflicess and men for their good ennduet in this affir, we piped down, nud our several oceupations were resumed.

On the 16th of July, the tender and lonts troing prepured, I ordered the following officers upon at expedition : Assistant-Surgeon Fox, Acting-Mnster Siluclnir, I'assed-Midshipman Litd, and Mr. Agnte, to accompany me in the tender; Lieutennnt Alden and Midshiprian Henry in the first, and Lientenant Underwood in the second eutter of the Vincennes; Licutenant Enmmng and Midslipman Clark in the first cutter of the Pencock. The boats being fulty manised and arused, left the versele in the afternoon, for the island of Anganga.

Ordes were left witl Captaiu Hudson to resurvey the bay of Mbua, (for I was not satisfied with the survey that had been made, ) isscluding the outlying reef, and after having completed this duty, to pro. ceed with the Peacoels round to Muthunta, and then return for the Viucennes. It was my intenLion to circumnnvigato the wholo group of islands, cerrying meridiun distances from island to island, and likewise to complete and connect by triangulation all the parts that reruired further examination. I proprosed to return to Muthumla by the north ath east side of Vartus-jeru.

Ilaving batisfied Inyself with observations on Lakemba Point, I set out in the tender at eight o'clock, r.xt., in order to join the boats early the next morning at Anganga İłand, about thirty suiles from Mbun bay, At 6 A.s. we anchored near the west end of Auganga lslatal, where the boats soon after joined ue, Angauga Ioland is high, and rery much broken; it is not inlanbited, aud offers nothing but turtles in the senson.

At noon I was rejoiced to discover the Porpoise in sight. She lad been looked for during borme days, and I could not but feel anxious, knowing tho dangers with which the service I had sent her on was surrounded. Ot her coming uj, 1 ordered signal to be made for her to nachor neur us, and in the afternoon we juined company.

Here I pursued my obseryations, and while I was congmutulating myself that I had now finished my last atation of the survey, and that my meridian distauces and latitudes were all complete, it was rejorted to me that the three boats were in sight, coming down before the breeze. So unusual an oceurrence at once male me auspect that Botine accident bad occurred; and on the first sight I got of them, I found that their colours were half-most and union down. I need not describe the dread that came over me. We reached the tender only a few moments before them, and when they ar. rived, I learnod that a hurrid massacre had but a short hour before taken place, and asw the mutilated and bleeding bodies of Lieutenant Joseph A. Underwood and my nephow, Midshipman Wilkes Hestry.

The bonte were taken in tow, when we stood for Malolo, and as the right elosed in, anchored in jts eastern bay.

It would not be easy to describe my foolings at this time; the melanclioly event of which 1 became aware in its full extent by the return of the boats $\mathrm{x} 2$ 
muler Lisutemant Alden, took place just as, after werks of intenso anxiefy for the sifety of those unter my courazand, exposed in open bnats to the perils of the sea, and in small detachuments to the insidimas attacks of savages, instignter not merely by eupidity, but by the horrible instinct of cannilint appocite,-I has myself closed the operations of the survey, and awaited only my jumetion with the bonts to be satisfied that all our perils were at an eud. One of the victims wns my own near relation, confuferl to my ene by a widowed mother; I had therefore moro than the ordinary degree of sorrow, which the lose of proniating and efticient officers nut entuse ill the breat of every commalder, to opprest me.

It wns lweyond every thing else important, that in the desire of inflieting punishtment, 1 should nvoid, of fir as grossible, the risk of losing other valuable lives, "The two chief ressels of my squadron were at a distance, and I knew that the natives of Malulu were not only guarded in their towns by fortificatious, impregtable in their own mode of warfare, but were furristres] with fire-sus and ammunition. To burn the dwelliugs of these fitntnesses, us I had done at Tre, if an adequnte punishment for mere thr.fts, would have been no sufficient penalty for the present heinous offence, nor watslil it have serwed to deter the people of Malolo from similar acts for the future.

My firnt duty was to receive tho report of the officer in cmmiand of the buats, and to mnke such further iuguiry into the circumstances of the trans. action, as should antisfy me that the lilowdy deed lind not been provoked on the past of the vietims. The resul ts of this inquiry were as follow.

On the 22nd July, the first cutter of the Vir centres, Lieuteusut Alden und Midahipman Henry, and the Leopard, Licuteannt Unhlerwond, left the station at Eld Island, and proeceded along the right sidu of Waia, for the purpose of fulfilling my orders to survey the small islands lying nuth of Malolo. This done, they had instructions to join the tenuer or Porpioise on the western side of that island, and survey such islañds as they might fall in wilb oul the way, After passing Wain, tho thoate anchored for the niglit wader one of the small islouds.

The next day, they were employed in the survey of the small jolunds, and in the eventing anchored in the bay on the east side of Malolo, formed by it and Mnlolo-lai-lai, or Little Malolo.

On reaching this place, Licutemnt $A$ iden, being desirous of aseertaining if the Porpyise was at the anchorage on the west side, directed Lientenant Underwond to land near the south end of Malulo, and to ascend a emall eminence to get a view uf that anchurage. Lieutenant Alden, it Bppears, cautioned Lieuterant Linderwood to go woll turmed and to be on his guard with the natives, as on lis former visit, nbout six weeks before, he lud been led to doubt their friendly disposition, nnd, in consequence, had avoided haviag any conmunication with them. He also directed Líeutenant Uaderwood to retmon befure sunsot.

Lientennnt Underwood handed and weut up the bill with one of his meu. After a few minutes, Jieutenant Alden observed sone suspicious movements among the natives nens the point, and, in cousequence, hoisted a signal of recall. Lieutenant [nderwood was boon seen returning to the boat with his man and a native. Bufore leavisg the beach, he bad 6onre talk sith the natives.

On jwining Lieutenant Alden, he reported that there was no vesse] in sight, sut nentioned that on his wry up the thill, be sudilenly taume upon a thative carrying an armful of clubs, who, tho monent he perceived him, tlirew down his lond and attempted flight, but Lieutenut Underwod detrined and made hin go thefore them to the bont. When they renched the beach, a party of natives joined, and appeared to lim much diseoncerted at finding the lad a prisoner, and without armis,

They passed the night at amelur in this bay, and on the ruorning of the 24 th discovered the tender at anchor to the enstward. At nine o'elock Lieutetunnt Emmons joined them in the Peacock's first eutter, laving prissed the righit at one of the small sand-islands in the neighbourlsood. Lientenant Emowns fund them waiting breakfast for hin. They ankicipated that he had some more provisions for them, as be had recently parted with the tender, and hoped to procure some yams, pigs, Sic, from him, or from the tender herseif, whicl would in all probability resch Mnlolo during the day.

When Lieutenant Limmans arrived, several of the natives, some of whim were artnel, were on the beach where the hoats' erews lasd couked their breakfast,

Many inducements were uffered to them for pigs, yatus, \&es, with very little sueces, ench offerisg gome exeuse, and urging the necessity of the bouts going to lloeir town for euch thangs.

Just after they land finished their loreakfast, the elicf spokesman of the village came, wading out near the bonts, and invitenl them, in the name of the chisef, tn their towil, where ho said the chief lad secured fuur large tongs as a probent for thom.

It appears that Lieutennt Underwood now volunteered to go to the town for proviejons, taking with him John Sae (the New Zealander heretofore mentioued) as interyreter, from Lieutenant $A \mid d e n$ 's boat. He, in connequence, shoved off, Jeaving the other boat to follow him as soon as tho tide would allow it to crose the meef between the jislarus. Lieutenant Emmons then pushed lis host for the shore, and landed, with three amed men, nn Malolo-Jaj-Ini, in order to oblain some angles from the top of a hill. On lis apuroaching the beach, the natives waded off to his boat, but he ordered them off, and direeterl the officer with him, Mid= shipman Clark, to keep lis Lont aflont, and not sufier them to appronch her during his absenee, T'his order was strichly sttended to, and although a similar attempt was agnin mate, the natives when ordered off retired as before.

Lieutenant Underwood'H hont drew too much water to get neross the reef, and grumnded, upon whicl a number of natives cullected around her, and joining with the bint's crew, arsisted to drag lier over the reef. At this tine the natives got a knowledge of the ficeblenesg of the armament of Lieutenant Underwool's bont. 'To my surprisa I have since lenrned that Lieutenaut Underwood had Jeft the greater part of the armament with which he had been furnished on bonrd the brig eome few days before. Seven riffes liad been put on loned that vessel, under the filea that it would lighten the bout, nud no more than three out of 
the teat he took with him frum the Vingentues remtined.

On lasding they found no mure than two piga tied to n tree for sale, instead of the four they lind been promised its prosents. These the natives declined selling until the clicf, who was out upon the reef fislting, stuould rettrin. A nressonger was sent fur him, and he oron made bis appesirance, bus condueted himself lavightily, and refused to part with his hogs except for in musket, jowder, and ball, whioh being against orders was rofused.

Lieutenant Alden entertained some unessiness at the number of natives that had erowded around the Leopard, and proceeded to join ler, but was detained near the reef abnut twenty minutes befouse the tide woukd allow the lowat to puss over, the first cutter drawing nore water than the Leoparil. On entering the bay, he fund the Leopard at nuchor about two thousand foet from the shore, in just suffiejent water to enable his tron to get alongride. Ho wss informed br the bont"s crew that Lieutenaut Underwond lud gone ot shore, lenving a hustage in the Leopard, whon Lieutennat Aludes immediately took into his own bost. Lieutenant Underwond was accompanied the slore by J. Ciark, armed with a rille and shentli-huife; $J$. Dunnek and J. M'Kesn, amned will cutlnsses; Willian Ieicester, win lind the irade-lox, unarned; John Sac, interpreter, nnarmed; Jerone $D_{\text {avis }}$ and Rwhert f urman, unarmed. The rest of his mets remained iu tho boat, armed with cutlasses and two rilleg.

Lieutenant Underwood was now seen on the besch, enilearouring to trade with a party of about fifteen natives, whence he sent oft Robert Furman, a coloured boy, to Lieutenant Alden, to say that the natives wotild stot trade, exeept for powiler, shot, and muskets. Furtann wha sent tack by Lieutenast Alten to gay, that he would not conserit to any such exchange while tho sehoner wns within reach ; that they euuld be supplied by lier, and that he must hurry off, as he thought he lad been long enough absent (having renuased on shore about an hour) to purehase all they required, if the natives were disposed to trade.

After this, Midshipman Henry asked, aud Lieutenant Alden gave him permission to Jand in the cunoe, and come off with Lieutennt Lnderwood. A fow moments after, a small emoe crume mongside Lieuterant Alden's boat, and exclanged somo words with the hostage, who displayed a little Anxiety to retusn with them to the shore. As the canoe shoved off, he altempted to lenvo the boat, when Jieuterant Alden took him by the arm and directed lim to sit down, giring him to understand liat he must keep quict. Lieuterant limmuns now joined, and the Leopard was ordered to drup in as near' to the party on shore ns possible. The tide had by tlije time risen sulfieiently to allow her to go must of the way ou the reef. After mother half lrour lad expired, Jerome Daพ is, nese of the boat"s erew, eame off with a message from Lientenant Underwnol, that with another batchet be could purchuse all be toquired.

The Jiatchet whs giren to Davis, who was dirceted to eay to Lieutennnt Undorwood that Lieutenant Alden desired to see him without delity, and that the should come of as soun as possiblo with what lie hind.

While Lientenart Alden was relating the cir- eurnaturees of the lioutage's desire to eserpe to Lieutennt Emmons, from the starboard side of the bont, the hoalage jumped arerboard from the larbosird quarter, and nude for the slore, in two and n lıalf feet water, looking over his shuulder, so $r 3$ to dodge at the flast if fired nt. He took a direc. tion difierent from that of the party un the bench, to divide the attention of those in the bonts. Liewtenane Alden imunediately levelled his mukliet at the hostage, who slackewed bis pace for a moment, and then cuntinued to retrest.

Midshjpman Clark, who was ready to fire, was directed to fire ower lis liend, which did not stop him.

J. Clark testifies that Lieutennut Underwond, M'Kean, nud histuself, were standing nesu the bench, waiting the return of Davis, when they naw the chief eseape from the hoat, ant heard the report of the jutsiset. The old chief, who was standing noar, immediately eried out that his son wrs killed, and ordered the untives to make fight. Upon this two of them seized upon Clark's rifte, and tried to take it from him. One of these he stabled it the ireast with bis slienth-knife; tho other Mr. Underwond struck un the luwil with the butt-end of his pistol, upon which both relini tsished their bold. Lieuterant Usuerwood then ordered the men to keep close torether, nthd they endis. roured to make their way to the hoat, facing the natives, Lientenant Underwood also ealled uprn Midshipman Henry to assist in covering the retreat of the men to the bats, to wlich Mr. Henry z'cpliet, that he had just receised a blow from the club of a native, and would first have n enck at him. He theu pusued dhe mulive s few stepg, ard cut hin down with his bowio-kuife pigtol, and hat again reaclicd the water's edge, when he was struck with in short elub on the bnek of the liend, juat as ho fired his pintol and shot a native. The blow stumned tint, atul he fell with his fnce in the water, when lie wos inatantly murrounded by the natives, who stripped him. T'he natives now rushed unt from the mangrove-lushes in great numbers, some of them endenvouring to gei between Lieutenint Umierwood and the water, while others ernwded upon his party, throwing their short-handled clubs and nsing their Epenrs. Lieu. tenant Underwood, having received a spear-wound, fired, and ordered the men to do the atame; nud after be had fired his becond pistol, was kneveled down by the blnw of a elub. Clnrk at the exune timo was stmuck, and hal no firtlier recolleetiurs.

J. Durmek kays that he was at some distance from Lieutennn Underwowd at the time the attack wan made; and the first insimntion he land of it, was Lieutenant Lixlerwood's order to keep tugether sud go down to the hont. While obeying the order, he anw the natives seize upon Clark's rifte, and strike Licutenant Underwenhl; lut nfter Llis lie had as much as be eould du to avoid the clubs and spenrs hurled at hinsulf. He says that Mr. Menry whs nenr him, nnd up to his knees in water, when he received the blow from the slart club which knocked him down lifolese, with lis face in the water. He did sint seve the hootage escape, nor liear the gui fired.

M'Kean states that he was stundire by the side of Lifentenant Underwood at the tine they were awniting the return of Davis; that suddenly there 
was a uovement among the natives, and the canse of it was disenvered to be the esenpo of the Jostage. Mr. Underwood, anticipating trouble, imuediately ordered the men to asaermble and nruke fur the boat.

John Sac's story corrohorates that of M'Keat. Ho says, that upon henrits the gun, and geeing the hostage escaping, the chief eried out that bis son was killer, and gave the war-ery.

On sering the ntlick, Lieutenants Emmons and Alden puslied for the shore, with both boats, The former had alrendy started to endenvour to retakio the bowtnge. The bonts commenced firing as they sailed in on some natives who appented to be woling out to meet them. $A 8$ soon as the bonts tork the trothom, all jumped out except two bostkecpers, and wadod in, occasionally hring at the antives, who now retreated, carrying off their dend and wounded, and soon disnpyearod among tho mangrove-lushes.

Before renching the beach, J. G. Clavks was met bndly worsuder, and was taken at once tuthe honts. On the bench lay Lieutenant Uaderwerod, partly stripperd, and Midshipman Henry, quite naked, with a tmive close by the latter, badly wonnded, who was at once des intelued.

The [sarty, picking up the bodies, bore them to tho boats, On the first inspection, some frint hrpes were entertained that Midshijman Heny wis not dead; but a second examination dissipated this illen.

The bonts now laulerl off, arkl made Bail to join the tender, where they had seen her in the morning at anclior.

Every attention whs paid to the wonnded and dend by the officers that aftection and regard cossld dietate; and I could not hust foel a melancholy satisfaction in having it in luy fower to pay them the Inst sad duties, nul that itheir bodies bad been resered from the shambles of these othous cannibals. Yot, when I thouglit that even the gravo might not he hell sncred from their trellish arpetites, $I$ folt much coneerin relative to the disposition of the bodies. I thouglit of committing them to the open sen; but ono of the sectuded siturl-istands wo bad passed the day before oceurred to mo as a pluce far enough removed from these condor-eyed savages to permit them to be entombed in the earth, without risk of exluutuation, althung thero was to doubt that our movements were dosely watehed from the highest perks, On consultation with the ofticere, they concurred with my views on this point.

There being no doubt, from the reports of all parties jresent, that this nutrago was entirely un. provoked, I had no hesitntion in deternitzing to infliet the punishment it merited, and this, not by the burning of the towns alone, but in the bloord of the plotters and netors in the massicre.

The two first cutters of tho Vincennes and Pencoek wero therefore directed to take up stations to prevent the escape of nuy persona from the island, and before daylight Prssed-Midshipman Pld wis despsatehed on the same service with the leopard.

'The tender got under way at the sane time, and proceeded towards the spot I had chosen for the phace of burial.

The sun rose elearly, and nothing could look more beantiful and greaceful than did the little group of islands, as we paseed them in steecssion on our melnmeholy errand. At tho last and largest, atrout ten miles from Malolo, we eatne to auchor. Dr. Fux and Mr. Agate wert on sliore to seloct a place, arul dig a common gravo for both tho vic. tims. A bout nine o'clock they came oft, and reported to me that all was ready. T'lie bodies were תnw plaecl in my gig, side by side, wrapped in their coututry"s Hing, and I pulled on-sliore, followed by Mr. Sinclair and the officers in the tonder's boat.

Mnly twenty sailorg, (all dresaed in white,) with myself un! ofticers, landed to pay this last nuark of affection anul respect to those whin had gone through so many toils, and sluared so many dangors with un, nud of whom we had been so muddenly bereared. The quiet of the scene, the solemity of tha ocengion, and tho smallness of the number who assisted, were nll ealeulated to prodice an unhroken silence. The bodies wete quietly taken up and bome along to the centro of the jsland, where stood a grove of ficus trees, whore linbs were ontwined in all directions by running vines, It waa a lonely and snitable apot that luad been chosen, is n shaule so rlesse that senre a tay of the sur could pencelrate it.

The grave was dug deep in the pure white sand, and eufficiently wide for the twu corveseg, Mr. A rate read the funcral selvice so calnuly and yet with such feeling, that none who were present will forget the impression of that sal half hour. After the bodies had been closed in, lluree volleys were fired over the grave. We then used every precaution to ernse all marks than might indicate wheve these mifortunnte gentlenuen were interred. I felt as if to refrain from marking the spot where they were Inid, deprived us of one of the consolations that alleviate the loss of $n$ relative and friend, but was relieved when it occititrd to me to fix a more enduring mark on that pluce, by naming the isisad after iny nephew, "Heury," nnil the pretty cluster of which it forms one, "Underwond Group."

Places remote from the grave were now more disturbed by fontsteps and digging than the grave itself, and our tracks were olliternted from the saud, leaves being thrown alsnut to obscure all indications that miglit lend the wary savage to the resting-plnce of the dead.

Wo wandered about the treach a short time, after which we embarked and weighed our anchor in return to Maldo. Shortly after, we discovered tho Porpoise entering the Malolo Pasage, with whon we soon juined company, and ancliored again in the bay un the enst side of Malolo before dark.

Preparntions were now actively commenced to punish the netors in this foul deed; the nrms were prepared, and the parties duly orgawized in the cuurse of the niglit.

Upon the ishind of Maluln there are two towns, Sualib and Arro. The former was on the southwest side, and the residenee of the prineipal actors in the mussaere. Unow this I intended to intlict the heaviest blow. The latter, whose inhabitants had also tuken a jart in the tragedy, and whose unprovoked hostility had been exhibited by their firing upon the boais from the mangrore-bushes, I determined to burn to the ground. It was also necesenry to be prepared upon the water to prevent any attempt at escape, or the more desperate effort to eapture the vesenels, necessarily left nniler a feeble gunrd. Thie two lntter objects were con- 
neeted, and for this purpose I kept under ny own immedinte commond, my gig, the tirst enthers of the Fincenres and Peacock, nuder' Lieutenants Allen and Emrnons, and the kender's bont, under Mirshiptnas Clavk.

T'bo party which was to land aud attack Sualib, wrs placed under the orders of Lieutemant-Commandant tinggold. It wns composed of seventy oflieers and mell, of the crews of the Porpoise and tender, with a fow men from the boats, and was armaged in threo divisions, under LieutenantCornisandant Ringgold himbelf, Lieutenstrts John. solt and Maury, To the parly were also attached Lieutenant North, I'assed-Midshipmen Siuclair aud Eld, with Assistaut-Surgeon Holmes aud Mr. Agate.

The party laul orders after landing to move upon Suulit, destroying all the plantations they slould neet on their way, sparing none except womba nod children. They wero then to mareh reross the islanil to Arro, nind join me for the purpose of revembarling. Actiug-Master T'utten, who was too tumwll to assist in active aperations on shore, whs left in charge of the brig, with such of the erew as were on the sick-list, and had orders to prevent the matives escaping across the channel to Mialulo-lai-Jaj,

Nine o'clock in the morning was the hour appointed for -landing Lieuteuant-Cornmandant Ringgold's foree, which ws eflected in good order, and the patty being arrauged is its three divifions, tnarched uff. Before the disembarkntion was effected, two nalives mileavuned to pass over to Malulu-lni-lni, but a weil-directed shot from Mr. l'ottell cumpellal them to return.

Aн sюon as Lieuteunat-Commonndant Ringguld's purty lial moved off, two eanoes were seen turn. ing the point of Malolo-lai-lai. I gave immediate orders to chase and istercept them, when, if they were frum any other island, they were to be directed to returz on their course, but if belonging to Malulo, they were to be eaptured. All the boats puilted ont, and Lieutenant Emmons, who took the lent, succedted in cutting them off from the shore. Through Oahu San, lis interpreter; be found that they belonged to Maloto, nud the men in Licutonarit Emmons's hont were so much excited that they at once fred several muskets into the eanoes, by which sone of the persons it thern were struck; the rest inmediately jumped overboard, and swam in varous directibus. By this time I lad spproacliel near enough to order the firitag to eease, and quarter to be given. 'The swimmers werv then picked up. Among them were found one of the chicfs of Arro, the town we were about to attuck, with a wiman, a girl, and an infant. I directed the three last to be set on shore and liberated, telling then we did not war sgainst women and chihmen. The men I sent on board the brig, to be put is irons, and had the canoes towed alongside of her.

As soon as we retsutied the town of Arro, per. ceiving no natives to oppose иง, 1 despateled Lieutenat Esmtnons to pull tuwarts the approaching canoes and intereept them, while witis the rest of the bonts' crews the town of Arro was burut. In doing this we net with no hindrane, fur al. though the place was Jarge, evitiently populous, and well fortified with a diteh and fence, it was found deserted. Many of the male ishlabitante, as
I afterwarly learned, las gone to Sualib, to aid in the defence of that wwi, shisle others had necom. panied the women and clildren to the muuntains, whither ail their moreuble property had also ween carried.

Having completed the destruction of Arro, I procected in tho gig towards the north-west point of the island, for the purpose of joining Lientenant Emmuns, on rrunding which, I observed the stroke of the burniag of Sualib. As I pulled around the island, I saw many of the natives on the higheat peaks, whither they had retrented for safety, and others upon the beach, who, on seeing the bont, fled towards the mountains. In pursuit of these, the "fiery spirits" were freqzuently sent, to their grent slarm. When 1 had proceeted fur enough to get a view of the bay in front of Sualib, neitlier boat nor cantes were ji sight, and 1 turned back, to rejostl the other bonts off Arro.

On renching them, Licutenant Alden reported that he had executed the orlers, and land, at high water, towed off of degtroyed all the cumus. During my slssence, an old Inax had venturod down to the beach, with two otliets is his colisjany, and made sigus that he wislied to speak with them. They held a parloy with lim, througls the interpreter, and learned thut he was the clitef of Arro. He told them that he was houseless, liad lost his property, his sont, and many of his preople; loo declares that his viltage lual nothing to do with the kitling of the Papalangis, ard offering pige, ste., an presents, begged thant we would not punish him any farthes:

Lieuternant-Cosnmaudant Ringgold, with his party, reached Arro just at sunset. His three divisions were separatel immediately after they landed, in order to cover more space, and rinore effectually to destroy the plantutioss. The division under Lieutennit Minury was the first to appronch Sinalib. As som as the uatives got sighit of it, they set up shouth of rlefiance. No sigus of fear were exlibitel, tut, on tlic contrary, every prout of a determinnion to resist.

Lieutemant-Commandnat kiaggold in $n$ short time cume ug with his division, and on examining the defences of the towr, thonglat it expedient to await the arrival of Lieutcmant Johnson. Ujun the laster oflicer esmuing tup, which was shortly after, the three parties descended the hitl, and appronclued the ditel of the town. The natives buldly sallied out to nuect them, with a discharge of arrows, and exhibited the utmost entidence. They in truth beliered heis town to be inpregniLle, for it liad billorto withstood every attuck rasde by Feejec warrios's. Its defences evinced no little shill in engineoring: o ditell twelve foet wide snd futl of tond and water, smrousded the whole; next eame a strotig palisale, built of cocoanut tunks, placed four or five feet apart, anung which whs liere nud there a living tree; this palisale was anited by o fence of wicker-worli, about tul feet high, so strong and deuso as to defy all attempts to penetinte or evell see through it; inside of the palisude was a second ditelt, reecutly excarated, the earts thrown up from which formed a parapet about four feet in thickness, and ns many in lreight. In the diteh tho dufenders shetterud themselves, and ouly exposed their theads when they rose to slinot through the looplinoles hefe in the palisade. As the whole party continued to aj- 
proncls the fortifination, our wen epread out go ar to nuthank the skirmishers, and by a few rockets and a slower of balls showed them that they hat different enemics fron Feejee men to teal with. "lhis compelled them to retire within the fortifiention, and alnandon all on its ontside to destruction. W'lien the skirmisher had retired into the for. tress, all united in Inud shouts of lako-mai (come on 1), flourishing their spears and elubs.

Our [arty having appronched within about seventy fect of the stockacle, opened its fire on the fortification. Now was sech, what many of those present had not before believed, the expertness with which these people dodge a khot at the flash of a guts. Those who wore the most incredulous befine, wero now satisfed that they could do this effectually.

1'ot about fifteen minutes nn obstinate resistaneo was kept up with tasusketry and armows In this the women and children wero as astively engaged as the tmen, and all made a prudigious clamour. After the nhove time, the noise diminislied, the defence slackened, and mary were seen to make thir esenpe from in gate which was istentionally left unattacked, enrrying the dend and wounded on their bncks. A rocket, of which severnl had alrendy bren tried withun visible effect, now struck one of the thatched roufs; a native ajorung up to tear it olf, but that moment was bis last, and the rouf inmediately burst into flames. Upors this Lieutesiant-Commandant Ringgohd recolled several afticers who were desirous of otorming the town through it small gate, an atempt which, even if nuccessful, must have been attended with lose of life on our part, and which the success of the mochet practice rendered unuecensary. To force the gate woull have been a difficult operation, lad it been dofender with the least pertiuacity, for it was congtructed in the manner of a fisli-weir. The natirem, as has been secen, lad, in addition to their arrows, clulss, spears, and nuskets; but the latter wore so mokilfully handled an tis do little damage, for they, as I had before been informed was their practice, put elurges into them secording to the wize of the person they inteuled w stroot at. I'hey believe that it requires a larger lond to bill a large man than it does to kill a sull one. The bows and arrows were for the most part naed by the wonien.

the moment the flames were found to be apreading, a scene of cnnfusion ensted that bafles deecription. The shumb of men were intexmingled with the crics and slurieks of the women and children, the roaring of thie fire, the bursting of the bambous, and an oecrsional volley of maskotry.

'The heat bevame so intersse, that LieuteuantComrandane Ringgold drew off the divisions to a cocnt-nut grinve in the neighbourthoul, where the witited until the enofiagration shumbl have exliausted its fury. After the lapse of ary hour, the whole towis was reduced to ashus, and a few of the officers and men were able, although with diffienlty, to enter within its ditcls. It was evident that largo quantitieg of water and provisione (pigne, \&c.) liad been stored nip, in the anticipation of $\mathrm{n}$ lung singe. Numerrss elubs, spess, bows and arrows, with several muskets, were picked up, together with fish-nets, taja, ke., and the cap of Lieutenant Underworad. Only four boulies were foutud, among whum was that of a clisld, which had been seen during the conflagration, apparentiy deserted, and in a state of danger, from which our men would gladly have relieved it, had it heen possible.

Our party austnined tut little injury. Only ono man was struck by a ball, which, liuwever, did no olher harrn than to tear his jacliet. Severat were woundel by arrows, but only Samucl Stretch, quirter-gunner, so sererely as to eaușu any solicitude.

After the destruction of the town, the third divisions, under Lieutensint Maury, wng ordered to return to the brig, atong the bench of the western side of the island. Tlis ruute wis chosen for the anke of the wnmded man, who was nmalle to travel over the hills, The firet nnd second divisions marched across the island to the town of Arro. The officerz deseribe the scche tluat lay before them, when they hol reactied the highest part of the ground the lay in their route, as extremely benutiful. In the ralley below them, and on the dedivities of the hills, were to be seen yam and taro-patelres fiept in the tseates order, with the small yan-houses (lololo) in the midst, surrounded by froves of tall cocon-trees, and platutations of bananns. All looked quiet and penceful, in strong contrass to the exciting contest in which they lut just been engnged, and the claracter of the ruthless and murderous race who bad been tho vecupants of the Bmiliug valley.

Lieutenant-Comunundait Thinggral, with these livisions, reachen the leach of Arro at smmset, when a part of the nuess were ernbarked in the canoes nul hosts, Licuterant Ahlen was at once despatched round the island in the cutter, for the purpere of rondering assistance to Lieutennat Maury, lut lie arrived too late to be of service.

White these transactions were taking place on the island, the water also becare the scene of a conflict. Lieutenati Limmons, who had been despatelued to interoept the five canoes, reported to be scess from the ridge, pulled round the island with. out discovering them. Whilo triaking this cireuit, the full is with the party under Lieutetsant North, ant tomok the wounded man into the hont, leuviug one of his eight in his place. He then pulter to tho brig, where he refreshed his tuen, and in the afternoon proceeded round Malolo-laifai to sesrch for the canocs, supposing they might hare cscaped and been dravn up in the mangruve-bughes. He soon, however, diseovered the enemy foling along on the outer ref towarils Malolo-lailni. They were somewhat separnted when first seen, but as he approach ed, the wenthermost mnde anil to leeward to join their companions, and when they had accomplished this, all struck their sails and advanced to attack him, mлnow ring together. In ench canoe there were about eight warriors, having a kimd of breastwork to protect them frons the slint, while Licute. nant Fmmons's bont's crew consisted only of seven. After a slort hut severe contegt, only one of the canoes escaped; the others were all captured, tngether with their warriors. Lieutennnt Emmons reached the brig, with three of his prizes, a little before midnight.

Shortly after daylight, a few natives were seet on the beach orngesite to the tender. 1 lind been hoping throughout the sight that soune overture would lou made, and at onee took my gig, with the interpreter, and pulled for then. $A$ a we apprabched the edge of the reef, which was now bare, it being 
low water, all the men retired, loaving a young native woman standing, with the different articles near her belonging to Lieutenant Underwood and Midglupman Henry. She held s white eock in her arms, which she whs desirous of my nccepting; but, believing is to be an emblem of pence with this penple, (which I found afterwaris was the ense, ) I refused it, but took the other articles. I declined the pacifio offering, because I had no ides of making peace with them until it should be sued fir after thejr own faslion. I had obtained a sutficient knowledge of their mntmets and eustoms to know that it was usual for then, when defented, and nt the mercy of their enemies, to beg pardon and sue for mercy, hefore the whole of the attack. ing party, in order that all might be witnesses. I also knew that they never acknowledged thenselres conquered unless this was done, and would construe my failing to require it of them into an adrnission that I lund not bueceded in overcoming them. Many noessages were, indeed, dutivered to me by this girl from the chiofs, expressive of their sorrow for liaving attacked and killed our little eliefs; but, in Ferjee language, this nurounted to nobling; and 1 was detcrmiucl to receive from them in furtual ncknowledgment of defeat, accord. ing to llueir own nude, before I Innde peace with them, however anxiuns I was to avold any more bloodshed. I therefore sent the chicfs and peoplo a message that they must come and beg parion and sue for merey, before all our warrviors, on a hill that I pointer out, on the south end of the island, saying thent I sloould land there in a littlo while to receive them, and that if they did not como they must be respoukible tor the consequences.

At about eight o'clock I west on bonrd the Porpoise, where I had in confinement is elief of Arro and sone of his followers, in ouder that the fears of the preople of the islarul might not itwluee them to neglect the npportunity of asking for peace, and knowiog that this chidf would have great influence in bringiog alout the result I desired. I tant an interview with hum in the eabin. The thrst question I put to bim startled hisu taot is litule: it was, whether the cauld trust his life in the hands of any of his people that were on board with hirn; for it was ny intention to send a messenger from amosig those natives on hoard to the chiefs and penple of tho island, anil if lie did not exeente it and return at the appointed time, I strould slinot him. His eyes grew very linge, he hesitated, nut thon spoke very juickly. At inst he said, "Yes;" lut that lie would like the two younger lroyg to be sent, as they wene the best and most trustworthy. My object was now fully explained to him; and after he "thornughly understood the penalty both to hinself and the people of the island, he entored wartuly into my riews, as be perceired that by so doing ho would at once regain his own liberty, and save his island from furlher devagtation.

The boys, who were retpectively about fifteen and seventien years of ago, were tifen called into tho cubin. I took two leeds, and repented, thrungh the inturpretes, the messenges, which the ehief twok great prins to rnake thera understand. They wore to this effect: that the whule of the nalives of the island should come to me by the time the sun was overhend, to beg pardon and sue for mercy; and that if they did not do so, they must expect to be exterminated. This being fully understood by the hoyg, they were landed, the chicf having pteviously assured them that bis life depended on their good conduct and laste in executing their charge.

Every thing was now prepared, agreeably to the orders of the night hefore, and the whole fures was landed; but instend of moving on to mnke farther devastation and destruction, we ascended the esstern knoll. This ir covered with a beautiful copse of casuntina trees, resembling somewhat the pines of ous own contutry. Here we took our station, and remained fron absut ten in the morning till four o'cloek is the sftermoon.

The day was perfertly serene, and the island, which, but a few hours luefure, had been one of the loveliest sputs it creatinn, was now entircly taid waste, showing the place of the massacre, the ruined town, and the devnstated plantations. The eye wantered orer the treary wisto to the beat1tiful expanse of waters beyonal aud arunad, with the homg lines of white sjarkling reefs, until it rested, far in the listance, an the ennall green spat where wo lind performed the last rites to our mur. dered companions. A gentle breeze, which was blowing through the casuariua trees, gave out the monving sound that is uttered by the pines of our own country, produciug a feeling of depression insopsmble from the occasion, and binging rividly to my thoughts the sar impression which this melancholy and dreadful oceurrence would bring upnn shose who were far away.

Townrls four o'elnek, the sound of distnnt wailings was heard, which gradually drew nearer and nearer. At the same time, the natives were seen passing over the hills towards us, giving an effect to the whole scene which will be Jong burme in my menory. They at length reached the fout of the bill, but wonld come no farther, until asmared that their petition would be recuived. On reeeiving this assurasee, they wound upward, and in a sluurt time sbout forty men appeared, crouching on thoir hands and knees, und vecasiunally stopping to uttor piteous monss and wailingr. When within thirty feet of tsa, they stopjet, nud an ald man, their leader, in the must piteuns manser, begged pardon, supplicating forgivenesth, and pledging that they would never du the like again to a white inan. He said, that they acknowledged themselves eonquered, and that the island belonged to us; that they wore our slivea, and wotild do whatever I desined; thint they had lost every thing; that the two great elivef of the islatid, and all their best warriors, had been killed, all their provisions deatroyed, and tseir houres bumeds. They neknowledged $\mathrm{a}$ loss of fifty-seven killed. WVlietliet the twenty-five that wore opposed to Lieutenant Emmons were includod in this numler, I know not, but. I nm rather incliued to helieve that they were; fir accuusts subsequently reeeived, give the antne number. Thoy dectared that they were nuw eonvineerl that lhey nefer eould mnke war against the white men (l'iphaluıgis); nad that they had brought two of the chief" 8 dhughters as a present for the great chicf. During the whole time thast the old man was spreaking, they ult remained bent down witl ctheir lesads to the [risund.

I asked them many questions, and, among ethers, what had induced thens to murder the little chiefs. They acknowledged that the ofticers had done them nu harm, and confessed that they hat been killed 
without the slightest cause. They stated that all the murderers were sinin, and that the act was planned and executed by the people of Suslib, none of whors were then present, or could be found ; and anid that the persons prosent were the only ones uninjured. Somo of the officers believed that they recognised several of them as having been in the fight. I then, through the interproter, dwelt unon the atrocity of their erime, and pointed out to thom how justly we wero offended with them, and how mueh they deserved the punishment they lad received. I told them they might enicider themselves fortumato that we dit not exterminato then; and farther assured them, that if ever a like act was comnitted, or any nggrestion on the whites again took place, the most terrilyle punishment would await them; that wo did not wish to ilo them any harm, bat came among them as friends, and wished to be treated as guch ; that they must now see the folly of opposing us, in they had loat their best warriorg, while we hal not last one; that we never fought againat women or elnitdren, and never received any gifto or presenty; that I granted them pardan, but they must do as I was about to direet them.

I then told them, that to-morrow, very early, they nust all eome to the tow'll of Arro tmarmed, and bring back every article they lad taken from the officers, with what provisiuns they could gather, nnd that they would be employer to bring water for the vessels. This was according 10 their custons, that the conquered should ilo work for the victors.

'Ihey readily nssented to all these demands, but snil that many of the articles belonging to the little chicfs must have heen destroyed by tire, and that they knew not where to obtain them, or where to find any thing to ent. I knew that the last assertion was false, na $I$ had seen many plantations on the nortli-west side of the jsinnd which had not suffered, and renained untouched. I therefore told them they muat conply with nll they had been ordered to do.

T'liey wark then dismissed, and instantly ranislıed from before us. Orders were mow given to embark, unil wo renehed the vessels at sunget.

I hal grent renson to be satisfied with the result of this dny's proceedings; for I fult, that nfter administering to the sa vages a very severe puntsh. ment, I had probathy effected the desirmble end of preventing ary further bloodshed.

Early on the morning of the $28 \mathrm{lh}$, the tender and brig got under way, and anchored of the town of Arro, where the nntives, to the number of reventy, cano down to the beach, with every appearance of lumility, to carry intu effect the terms wo had unate with them. The water-bags and breakers were given to them to fill and bring to the beach for the bonts. They found this very haril work, nul often exprossed thenselves to the interyneters, who were with the ofticera attending to the duty, that it would have becn as well for Lliern to have been killod in battle as to die of hard work. They solled thus unsil nearly sumset, anul procured about three thousand gallons of water fur 118. They also brought twelve good -sized pigs for the crewe, sume yams and alout tlaree thousand coeos-tuts.

Among the articles restored, was the silver watch of Lientemant Uinderwnixs, nlunost entirely melted up, and a prece of the eye-glnss of Midshipmnn Henry.

When I went on shore, I saw the chicf and about twenty of the whit men, who were not ablo to take part in the work. I had a long talk with them, through tho interpreter, and explained to then that they had frought this trouble tipon themgelvee. I yointed out, particularly, that the blow had fallen upon tho tawn of $\Lambda \mathrm{rro}$, ns well as upon that of Sualib, bechuse its inlabitunte bad fired at the boats from the nangrove-bushes, which whas wrong ; and if it orecurteil again, or they ever molested the Papalatagis, they would meet witl exemplary punishment. They als listened with great attention, and said it should never oceur agnis; and that when any Papalangis came to their island, they would to every thing for them, and treat them as friends and children.

At evening, I had the ehief who was our prisouer brought up and liberated. He had now, from the death of the one nt Sualib, beeome the highest atief of the island. I gave him giond advice, and asenred him, chat if he altowed nay white man to bo injured, lie would sooner or later be punished. Ho promised me, that as long no bo lived they shonlil aiways be trented as friends and elildren ; that lie would be the first to befriend thern; that ho now considered the ishaud as belonging to the Papalnngis ; that he had noted all that I had said; thut it was goord, and he would be very careful to observe it; that he would, if lhe had no canoe, swin off to the white people's ships to do then all the service in his power; nad that his peofnle should do so atso. He was then, with the natives who had been captured, put on sljore. When they landed, the while populution woro heard erying and wailing orer hisn at his retum.

'The above are all the importunt facts relative to this tragieal affair, both to the natives and ourselves. I feel little dieposed to cast blame any where, but it must be apparent that if the precantions directod in the orders given for the eunduet of the ufficers on boat duty had been adliered to, this misfortune would not bave ocenrred. It is therefure to be regretted, thnt a striet regard had not been paid to theere orders, and thet eare and watchifulness to preserve and keep ail on theip guard had not been eorstantly manifested. It is difficult to inagine how anme of the officers blonld, in spite of all warnings, have indulged an overconsfidence in the pereenble disposition and good intertions of the matives; and it is atill nure surprising that this should have been the ense with Lieutenant Alden, who had charge of the party for the time being, and whe had fregnently expressed himself satisfiet, nnd had also warned others, that the natives of Malolo were not to be tusted. This opinim was wot sulopted by him without good grounds; for to lis former visit, abrut six weeks befure, they had shown a disfrosition to cut off the taunch and first cutter, of which lo was then in charge. Thore was no absulute necessity for ohtnining provisiuns, and still less for tis nilowing Lientenant Undorwood to remain an hour nnd a lialf on shore, elatfuring for two or three pigs, whets they knew the tender was in sight, and that ahe would reseh the place of rendezrous before night.

The whole of this afflicting tragedy I cannot but believe grew oul of a wath of proper caro and 
wateldiulness over the hostage, after he hul showth a diapnosition to escape, and is heedlessnegs thrt it. is impossible to look at without astorishment. The horstage certainly would never have stlempted to cacaje, had there been a proper guard kept over him while in the bost; and from the evidence of all those who were on shore, it nppeare certais that no disturbance took pluce until the escape was maile.

I am well aware, that nll the officors and mon present were not at the time satisfied with the punishrnen inflieted. Many of them even thouglat ilat ald in any way concerned in the rutuder unght to hive been put to death.

But I felt then as I do now, that the punishment whs suflieient and effectual, while it was aceomnanied, ns far as it could be, with merey. Some, no donbt, will look upon it as unnecessarily severe; thit if they duly considered the wanton murders that hare been committed on the whites in this group of islands, merely to gratify the desire of plunder or the lorril appetite for cannibal rejusts, they would seareely think the punislument to severe.

The warriors of this island were looked upon as a nest of pirnles even by tho rest of the group, and lad their great crime been suffered to go unpunished, would in all probability have bewomo more fearless and daring 1 tht ever.

The blow I isthicted not only required to be done promply and effectually, as a punishment for the inurder of my officers, lint was richly deserved for other vutrages. It coull not have fallen upor ang place where it would have produced as much effect, in inpressing the whole gruup with a full sense of our power and determination to punish sucli aggressions,

Such has been its effect on the people of Maloln, that they have since been found the most cisil, larmless, and well-disposed natives of the group.

Natwitlistanding that the prinion of all the officurs who were present and cognizant of nll the facts wus, that I had not gone far coough in the prunishnent I lasd intlicted, I fonnd myself charged on sny retarn by the administration, as guilty of uxuder, nnd of acting on this ocension in a crucl, mereiless, and tymurical manner. To make ont the latter clarge, it was allegut thint I had made the natives actually crawl to triy feet to beg partinn. The part of the whole aftaix for which I take some eredit to myrelf is, shat when I judgrod it had become necessary to punish, it was in like mannex abligntory on nie to study how it carald be dono most effectunily ; and from the kuowledge I lanul abtained of the curstums of the natives, during the time I had been engaged in the group, I was enabled to perform this painful though necesenry duty, in a manner that mate it vently more effectunl, by requiring of them their own forms of submission, and their ow1 nuodes of neknowledging defent.

AlJ the facts of the crae are before my countrymen, and they will be nble to judge whether I Hhould, for my conduet in the punishment of this atrocious massacre, lisve been srmigned on a clarge of murder, and of acting in a cruel, merciless, and tyrannical nunner, and this witlout any previous inguiry into the facts or motives that led to my actions, and merely on the report of a few diseontented oflicers of the squadron, whom the gond of the service compelled twe to send back to the Uniced States, Nor were these grave charges made known to me until two days before the court was convened for my trial upon them.

Tho revuion of the several vessels of the aquadrou did not give rise to the feeling of pleasure which had altended such meetings on other oecasions. A deep gloow on the eonirary was spread over the miruls of all by the melancitroly fate of Lheir commdes, who hat been tho vietims of the butehery at Malolo, In bonour of their memories a funeral sermou was prenclied, on the loth of August, by the clipulain, before the ssembled officers and crews.

Ou the 10th of Aagust, in the afternoon, the squadron beat down to Mali, and ail the neeessary preparations were made for going to sea the next day.

On taking our final departure from these islands, all of us felt great pleasute; Vendovi alune manifested his feeling by shedding toars at the last view of his native land.

\section{CHAPTER̃ XXVII.}

\section{HAWAIIAN GROUP, OR SANDWICH ISLANDS.}

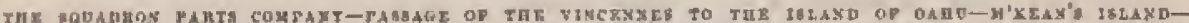

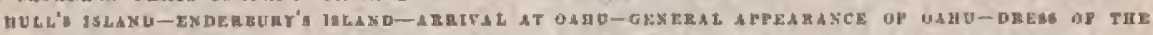

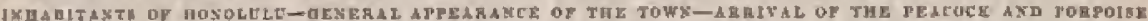

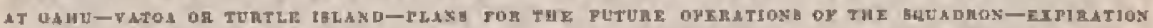
DУ TIL MXX's รנज

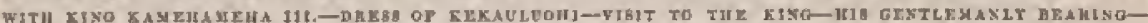

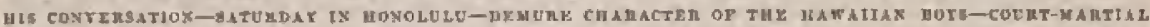

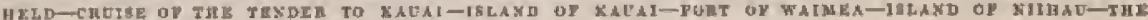

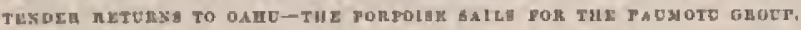

I sow made signal to the Purpoige to part cumpany, and despatched the tonder to run alung the sea.reof ns far ns Round lshand, before shaping lier course for chatu in the Sandwich Islands.

All the necessary arrangements wilh Captain
Indsos being complete by this time, I determined that the vessele should part company. Our pasenge to Oahu, I thouglit, would probabiy be expedited by this course, - a matter of some importanee, in congequence of the low state of our stock oi 
provisiuns. By pursuing separate tracka, there wunld, moreover, I conccived, he a botter opportunity of searching for sorne duubtfn! islands, and of obtaining information in rolatian to the currents and wimls. The ressels therefore parted cumpany on the evening of the I tels of August.

On the 15th, the winds inclined more to the south; and on the $l 6 t h$, an hoard the Yincennes, we lad variable wiuds, veuring to the northwatd. I thusefore tucketl to the enstward, in order to take adfantage of the change of wind in making easting.

On the 18 th, the weather was fine and the wind still light; tropic-bitds and tem wera scen, nud a constaut look-ont was kejt, in the expectation of ecoing land. 'This was the second anniverary' of our sailing from the Unterl States.

On the 19th, we made an island in the neighbourloond of the position ussigned to lieming" ar Condner's Islanl. Its true place is in latitude $4^{\circ} 37^{\prime} 42^{\prime \prime} \mathrm{S}$, longitude $174^{\circ} 40^{\prime} 18^{\prime \prime} \mathrm{W}$. This is a low coral taland, having a shallow lagoon in the ceutre, into which there is no navigable pasage; but the reef on the western side is so low that the tide can flow into the lagoum. Believing this to be the island discovered by Cuptain Gardner, I have setained lis name.

At ten ou the morning of the 19th, breakers were diseuvered from the rnathead, and hy mon a sualt island was geen, to which 1 gave the name of the man who first saw it,-M'kenn's Island. In the afternoon, boats were despateloed to survey it.

M'Kenn's Istand is composed of coral sand and blocks, and is three-fourths of a milo long, by half a mile wide. It rises twenty-five feet abovo the level of the sen, and has upon it no vegetation except a scanty growtl of coar'se grass. The surf was too lieavy to permit a landing.

Our observations place $\mathrm{Al}^{\mathrm{t}}$ Kean's Island in longitude $174^{\circ} 17^{\prime} 26^{\prime \prime} \mathrm{W}$, and latitude $3^{\circ} 35^{\prime} 10^{\prime \prime}$ S., and it lies about north-north-enat sixty usiles from that of Kemins.

On the 2filt we made land, which proved to he a lagoon fislaut, about sixty miles to the westwark, of the position of Sydnej Islard. At ten otclock, being nenr it, the bouts were lowered and sent round one side of the island, while the Elsip prosceeded round the other.

This islaud was not found on any clant; I therefore called it Hull's Islant, in lwaour of that distinguished officer of otr navy. It has no doubt been frequenty taken for Syduey latand. Its north-west point lies in lougitude $172^{\circ} 20^{\circ} 52^{\prime \prime} \mathrm{W}$., and latitude $4^{\circ} 29^{\prime} 49^{\prime \prime} \mathrm{S}$.

Endurlury"s Jaland, in latitude $3^{2} 8^{2} 5$, langitude $171^{\circ} B^{\prime} 30^{\circ} \mathrm{W}$., in a coral istaud, with a dry lagoon, thee miles long, by two and a laslf wide. Flie southern end is the widest, nnd on it are two clumps of stunted slırubs and plauts, cunsisting of cordia, tournefortia, portulaca, boerhavia, ic. "The uortheri end is "Ilnost bare of vegetation, with the exception of a small runuing viue (convolvulus maritima).

Missing Birute's Islund, and feeling that it was neceseary for us to be making nur why to the Sundwich Islands, on account of the shortness of our provisions, I tacked bo the nostliward, after lnving spent thirteen dinys in this viciuity*

On the $23 d$ of Septerniber we undo the island of
Orhu, and stond in for lint those who Jrad been there before, and ponfused to lave a knowledge of the laml, said wis the situation of Horolulu. They all knew its locenlity to be under our lee, and i ordered the course necordiugly; On appronching the land there was no town to bo seen, and every oue then knew that a mistake had becen made, of which no oue was willing to assune the blnme. Instead of boing off Honoluln, we were nnder the higls land of Muuma Jiasla, ert the west side of Oahu, near the small village of Wainat.

The appearance of Oahu is ly no monrs inviting; it han a grotater resemlalance to the descrt const of Peru than any other of the Polyueaian islands we lad visited, ind has an litule appearance of cultivation, The eountry would be termed at first sight barren and rocky, The land in places in very nuch broken, and rises into high ridges, here ind there divided by deep and nnrrow ravises, with litule vegetation, except on the mountain ranges. From the published deseriptions of the Hnwstian Jalands, I wus prepared to wee them, and particularly Oaluu, a prerfect garden. I was isclined to jmpote uy disipjointment to our approach being made on its lee side, which is nas. tasun]; lunt I regret to any that any side of it, when seets from the sea, is very far frum laving an inviting apponance.

I now made a tack off, asw by fonir o'cluck we saw the town of Honolulu, which is very conspicuous from the sea, and has more the appearnuce of a civilized land, wilh its churehes and spires, tlan any other inland in Polynesia.

On the mornisg of the 24th we came to anchor in the ruado, and found the tender had arrived a few dnye before us, all well.

On landing, a great uprose prevalled, and groups pursented thetuselven to view, no molley that it would be difficult to degeribe their uress or appearance. There are, irdeed, few plnces where so grent a diversity in ilress and langtuage exists na at Ilonolulu, The majority were in well-warn Furopean clothing, put oly in the most fancifol manner; but upon the whole, I shonli say that the crowd were seantily evered, some being lanlr. dressed, many shirtiess, none fully clothed, ard numbers of them with nothing on but the maro. I had bech led to expect a greater appearance of cisilization. The women were all clad in lung loose garments, like bntluing-dresses, and many of them were gporting in the water as if it had leen their native elersent. Some of these natives ware the simple tapa, thrown over their shoulders, which gave them a much more resprectable appearante than thoso who were elotlied in enst-off garments.

Every thing is eartly-colotur, with the execptiun of a few green blinds. The streets, if so they may he called, have no regularity as to width, and are arkle-deep in light Just and sand. Little pains are taken to lieep then elean [rom offul; and, in sorne pluces, offensive sink.holes strike the sensen, in which are secn wallowing some old and corpulent hogs, One of these, which was pointed aut to us as belonging to the king, was tahoord, and conseupuently a privileged personage. The walk on shore, however, nfter so long a confinement to the ship, was ngreeable.

On the 30th of September, the Pencock renched Onlis, all woll. On parting tompany wish the 
Vincennes, Capitain Hutson passed over the positiin assigthed to a reef, hy Captain Swain, in longitude $176^{\circ} 56^{\prime}$ W. latitude $9^{\circ} 55^{\prime}$ S., without seeing any thing of it, and continuing to the muttliward, erussed the line on the 27 th of August.

Tho Purpoise arrived at Oahu on the oth of Oetober, all well.

Vaton, or Turtle Island, as determined by the Porroise, lies in latitude $19^{\circ} 50^{\prime} \mathrm{S}$., longitude $170^{\circ}$ $37^{\prime} 45^{\prime \prime}$ W. It was fuund to he throe miles lang, by one and a quarter mile wide. The reef extends all around the island, and is from one and a half to two miles wile. The island contrins about fifty inhabitants, who lasve native missionaries, and are Christians : they have but a scanty supply of fool, and no water is to be obtained.

We mot with a warm reception at the Hawaina Islands. The govennor, Kekuanon, kindly ylaced at ruy disposal the large stone hususe belonging to Reknuluolvi, in the squure where the tomb in which the royal fnmily are iuterred is situated. The tomb was at that time undergoing some repairs. The stato coffin, which are richly ormamented with scarlet and gold cloth, and in two of which the hodlice of the late king, Liho-liho, and his wife were brought from Englnm\}, in the frigate Blonde, were doposited in the liwnse I was to oecupy. The governor liad them at once removed to the tomb, and in two disy I was confortably estrlulished, and engnged in putting up my irstraments, and getting ready to earry on our shoro duties.

It will now be necessary for me to euter into some particulars relative to the future operntious of the sryuadron, in order to show the difficulties that had to be encountered at this part of the eruise. Before reaching Onhu, I was eorvineed that it woul] be altogethor too late to attempt any thing on the north-west coast of America this year, and to winter there would have rendered us Jiable to contract disenses to which the men would have been tuo prone, after the hard service they lind secn in the tropies; besides, I wus averse to phssing our time in comparative inactivity, and I wished to make the most of the force that lial been intrustell to my charge. As my instructions had not contemplated such an event, I was beft to my own jurlyment and resources, to elooose the course which would prove the most beneficial to our commerce, and to science; I had aleo to take into account what we could accomplials in sorme other direction, prior to the end of April, when the season would becone fawourable for our operations on the north-west const, and in the Columbia River.

On our way from the Feejees, various hints were thowil out thint the times of the crew lind expired, and that they would not resthip. I understood their disposition, however, and had little spprehension of their heing led astrny by those who were dis. posed to create diffentios among them. Their tine, in their opinion, would expire on the lst of November; in my mind this construction was at least doubtful, the wording of the articles being, that "they shipped for three years from the lst of November, 1837, to return with the vessele to a port of safety in the United States." "The latter clause certainly contemplated the possibility of the expiration of the tinte prior to their return, and therefore the engagement was not limited w three ymars; num did it allow of my diseluarging any of thou by paying them off in full, or of my erippling or retarding the duties of the expedition. Many of the men spoke very sensilily on the suljeet, and expressed a desire to finish tho cruise, which they would bo glad to do by restipning, a conrse lyy which they would become entilled to one-fourth more pay ; others again seemed desirots of prot dueing diseord, in which they were encouraged by the inprudent language of a few of the ofticem, whether with the intention of producing discontent, I know not. This injiseretion, howerer, Was prompity arrested on jts beconing known to the.

$\Lambda_{\mathrm{B}}$ I was obliged to make a deviation from the original cruise pointed out in $\mathrm{my}$ instructions, which wonld extend its durntion, I thought it lut just that new articles should be opened; and in order that all should be placed on an equal forting, I included the crew of the Porpoise, as well as all those who had joined the squatiron previous to our last southern eruise. A Inrge majority of tho erew re-entered for eighteen months, on doing which they received three monthe" pay and a week's liberty. The few who declined, told me, that it was not from any dislike they lat to the ship or service, but laving families at home, they wished $t$, avoid a longer separation frmm them. About fifteen of them took passage in vessels that were bound to the United Stateg.

The charncter of sailors was uddly exhibited on this ocension; the man who, before arriving, had protested most strensously linat he would not reship, was the first to place his name on the roll, as I liad predicted he would be; their conduct enused much sumusement, ard showed how little sailory know their own mitsd. Captain Hudsun addressed his crew, confidently expecting that every man would volunteer to reship, and on his desiring all to pass to the other side who did not wish to reship, the whole crew passed over; yet within eightand-forty hours they had all re-entered, with the exception of three or four, who held out for a time, to show, ns thoy said, their indeper. dence.

It now becume necessary in supply the places of those who had left the equadron, and thus to complete our effective complement. Instead, howerer, of resorting to picking up the worthless, dissipated, and worn-out ragabonds of all nations, who have been wandering from island to island for yearg, without any object or employment, I concluded to take a number of Kankas, and enter them upon such terms that I could at any moment discharge them.

The authorities of Oahu were spplied to through our consul, and readily agreed to the men being employed, provided they were returted to the ialand agreenbly to their own laws. Articles of agreenent were consequently entered into to this effeet, by which I bound the goverument of the United States to return them after their services were no longer noeded; and a stipulntion was made that the rations of spirits should not bo drawn by them. I was thus assured of laving at least sober men. Word was sent to the different parts of the ialand for those who were disposed to enter, to assemble on a given dny at the fort, under the autliority of the governor. Upwards of five huudred men assenubled in consequence, out of 
whom Captain Hudan and myself ctose about fifty, all able-bodied and active joung men, is perfect heaith.

The nuthority for thas completing our enmylement of hands is conzined in the Act of Congress of Mareh the 3rd, 1813; the niuth seerion of which provides as follows: "That nothing in this aet contrined shall be construes to prohibit any commander or master, of a publie or private ressel of the United States, whilst in a foreign country or place, from receiving any Americal seamer, in conformity to law, or suyjtying any defreieney of manen on basrd steh rased, by ernploying Americnn scamen or subjucts of ewch forcign ecintry, the cmplayment of whom slasll wot lie prohilited by the law's thereuf." Yet, notwithutanding my neting under thig ninth section, on my return hume it was alleged that I had riolnted the first section of this sane act, and it was nuade one of the charges agaiust me by the Secretary of the Navy. The whole act is to be funt in Story's Laws of the United States, vol. ii. 1. 302.

It was highly necessnry for the service I was engaged in, to enlist these men for a time; it was done according to law; all the circunistnnces were daly reported to the government in my next slespatclies, and my conduct was not oljected to umtil tho charges were made out against me.

I was nuw euabled to eomplete my plaus of operntion, and every exertion was made forthwith to pot the resgels in condition for servies, half of the crews heing retained on board to proceed with the outfits, while the rest were on liberty.

'I'he services on which I proposed to emplogy the vesseles of the squasiron, were as follows, viz, :

Cruptain Hudsun, it the Peneock, accompanied by the tender, was to be instructed to return to the Samonn Group, and re-examine the ourveys malo by the Flying-Fisls sun boats, of the south side of Upoh, in which 1 liad detected oxersights, and auspected negleet; to seek for several small anil donthtful islanile, ssid $w$ be uuder the equator $x_{7}$ anil to visit the little-known grouph of Eulice and Kringamill; to inquire into the fate of Captain Dowath, commanding al Amoriena schnoner engaged in the whale-fisliery at the Peseadores; and to seck redress for the eapture of the $A$ merien brig Waverley, owned by Messrs. Picreo and Con, of Oahu, ot Strong's Island.

Having by the arrival of the Porpolse learred the news of the murder of Gideon Smith at Upoln, I induted in my ortlers to Captain Hudson, the duty of investigating the circtzmstances of the crime, and muishing the offenders. He was likewise instructed to reek for the nagnetic equator in longitude $160^{\circ} \mathrm{W}$, and to follow it down to the westwaril. These duties aceomplished, I direoted him, after visiting Ascension Island, to join me at the Columbin Fiver, towards the end of tho corning month of April.

These instructious covered a wide field, which had, as far as I could lenru, been but little explored, and which our whalitsg fleet is continanlly traversing. To exatuino it could aot fail to bo bighly useful to those engaged in that importunt branch of industry.

I designed to employ the Porpoise in a more close exanination of soune islusds in the Paumotu Group or Low Archijgelago, whleh it had not been in my nower to aceomplist during our visit of the previous year. She was alyo to leare a party, witl the boring apparatus, upan one of the istanils, an soon the the rebed the group, to rentuin there for about six weelis, or to long as the ressel was engaged in the examination of the other islande. This exaniuation being completed, LienteunntConmandant lRinggiold was disected to touch at Taliti, and thence, after aurveying Punrlyzt and Flint's Ialands, to return to Oaliu before the lat of April.

Witl the Fincennes, it was ny intention to proceed to Hawaii, there to ascessl to the top of Mauna Loa ; to make tho pendulusu ubservatinns on the summit and at tho baso of that mountain; to examine the ernters ard late eruptions; and after performing these duties, if the nllowed, to proceed to the Marquesas Islands, and thenes to puss wlong the magnotic equator to the meridian of the Hawaina Islands, whither it was my intention to retura before the Ist of A pril, to meet the Purpoise, and proceed, in company with her, to the north-west const. I deemed the time frum tle 2ith of Novernher woull be nmply suf. ficient, with proper athention, to ensble ns to prerform these duties, and also affurd smflicient re. Inxnting to the officers and men, frum llueir long confinemeut on lorard slijp.

The temler was overhauled in a few dayn, when Passed-Midshipann finox was again jut ill clarge of her, and the raturalists sent on an exeurainn to liauai. Alter their returu, I again ilespateded those who were attnclued to the Peacock in her to Hawail, being desirous that they should have an opportunity of risiting as mucli of these islands ass ponsible.

The king, Kamelanmelın 111 , who had given orders that he shuuld be sent for as suon as the Yincenues arrived, reached Honolulu on the 20 h September, from Mani. The next day I waited upon lirm, accompanied by our consul, Mr. Brinsmade, and by rasiy of the oficers and naturalists, at his quarters near the fort. $\Lambda$ soldier dressed in a searlet uniform stood as guard at the door. We were tahered into the audinence-chaniber, and presented to the king, whom we found seated in the midst of his retinue The apartnent was composed of two large. roons wilh low eélings, communienting by folding doors. On the right of tho king was Kekauluolii, n daugtuter of Kinmelamelia I. who acts as prine wiulater; and there were also present, among others, Keliuanusa, the governor of Onluu, Mr. Richards, who is the king' 9 interpreter and auviser, Handilio, Joln Young, and the oflicers of the body-guard.

The king was dressed in a blue cont, white pantaloons, and vest. Wo afterwards understood that he had prepared himscif to receire us in full cosstume, but on seeing ts appronching in undress unifomn, he had taken off his robes of state.

The appearance of the ling is prepossessing : he is muther robust, nbove the willale beight, has a good expression of countesanee, and pleasing manners.

The person who attracted our nttentiun mest, was Kékaluohi. This lady is upwatds of six feet in heiglit; her frane is execedingly large and woll covered with fat. She was dreesed in yellow silk, with enormonsly large gignt sleeves, and wore on her heal a tiurs of bonutiful yellow fenthers inter- 
spressed with a few of a scarlet colour $\bullet$. Aluve the feathers apueared a large tortoise-ghell counb, that confined lier staight black hair. Her'sluulalers were covered with a richly-etulmoidered shawl of seatlet ctrąn, She sat in a large armb-elonir, over whijel was thrown as rotse made of the same kind of yellow feathers ns deched her tiara. Hor feet were encased is white cotton stockings snd mert's shoes. She was altagether one of the most remorkable-dooking persunages I have ever seen.

The gavernor was landsornely dressed it $n$ uriform of blue and gold.

The conversation was earriel shs with ense through the interpretation of Ml. Theluards, aund left upon our uninds a faveruble impression of the intelligence of the roynl fumily of these islunds. One thing was certain, numely, tlunt, in regard to personal size, they aro unsurpassed by any family tluat las ever enue under my nutice.

On the 2 nd Oetnher, I received $n$ visit from Mr. Richarils, who cormunuiented to the the desire of the king thint I shonld visit him. In conformity witls this request, I called upom him, sceompanied by Captain Hudson. Although I had departed, after niy first visit, highsly preprossensed in his favomr, l was not prepared to find him tho ensy and centlemanly in his manners as he now appeared. He was alone wlien he received us, and in a few minutes we foum that he was able to express himself very intelligibly in English, and mas rutuck in coroprelrending what wus said to him.

He was fund at one end of the lagge grase-home built for him by the Gosernor Keluanan. This buildiug is about sixty feet long by forty foet wide, and contains only one roon, which nuy, however, be divided by moveable screens into several npart ments. The floor was covered with mats. 'The whole was well adapted to the heat of the climate, and the smell of the sweet-beented grass was ngrecnule and refresting.

He roceived us in a friendly manner. Frota the representatious that lind heen made to me, I lad been lorl to beliere thint the king was not only duil of apprehension, but had lituledisposition to crigage in or talk of the uffitis of goverument; I found him, on the contrary, exhibiting an intimate ncguaintance with them. He entered fully and frankly in the diseussion of nl] the matters in relation to which disputes had arisen between hin and fureigu nations; and I, on the other hand, was desirous to elicit his views with regard to the diffieulties be lad for the lnat year or two enenuntered, and leasn the feelings he hol experieneed in the arduous situations in which he liad been placed.

He spolie of the manzer in which foreigners lad obtuded themselves into the affiairs of his govemment, sa that no one of its acts was perrnitted to pass widlout his being ealled, in a rude and unciri? manner, to nceount for it. He stated, that he found great difficulty in acting correctly ; for foreigners, whom he and his chiefs lad sreated with every possible attentir'n, lad, from interested motives,

- These fontheri are among the most celebrated proditefions of thewe istanda, and some ldes of their cost may te formest, when it fo ataied thal eacls bird yields only a few, wot that mone itonsand are reguired to form a bead-drese. The birds (triellthreptes pactfica) are taken by means of brdtime, rnate from the pisorila, atud the catching of them is practined a a trade by the mounialieers. The wearing of thuse fenthers is a 45 mbol of hlgh rank. urgend measures upon lian which lie knew to be wrung, and lad, in many cases, isbued the conftdenee he land placed in them. He expressed the strongest dasire to dis rigkth, and to protect his people from evil influences and the eneronchments of Ilesigning persons, by whulesome laws and rugulations.

He said his consent had been extorted by threats, to measures of which he disnpproved, and that Lhere has been instunees when lre had been called upon to perform nlloged juromises which the bad never givell, for there were some of the foreigners who miscepresented eresy thing that took place in their interviewa with him.

I nh once pointed out a simple remedy for this, namely, that lie mlinuld hereafter twasact all lowithess in wriking, aud have no verbnl commuticatiun with peingle of this stamp, or indeed with uny one; telling hin tlat byt keeping their letters, ans cupies of his own, he would niways be in possession of evidence of what had passerl. I thatured him that I eonsidered his goverument to have nade sufficient progress iowards a position among civilized mations in authorize him to require that ofticial busituess slould be carried on in this manner, and expressed nuy belief, that should he adopt this method, the "bullies" of whom he had spoken would give him no further trouble.

1 now found that his principal ohject in requesting an interviow with tne was, sloxt he might renew and amplify his treaty with the United States, for which purpose the thouglit it probnble that 1 might have luad instructions. When he foumd that this whs not the case, and thas I had no ofticial communiention for hirn, lae was evidently dienppointed; for he appeared most desirous to enter into a close friendship with the Lnited States, and spoke in the lighest terms of the kind nunner in which the hal ever been treated by our consul Mr. Brimsinade, and tho commanders of the United States' ressels of war that had visited his islande. In conelusian, he intimated his hopes that the Upited States would acknowledge his peoplo as a nation, and enter into a new treaty with him as its ruler.

All this wns well and intelligently expressed by him, but the main subject of the conversation, which lasted for three hours, was his regret that lie had ever permitted fureigners to interfere with his lawg nnd municipal regulutions, and had not rather allowed them to do their worst, The only justification the could offer to himself for his subnission was, that by yielding lie had saved much trouble and distress to others.

Snturday in Honohulu is a gala day, and all agres of botli sexes devote themselves to amusement. Towards the afternoon, they may be seen wonding their way tuwards the east end of the town in every variety of coatume, and barne slong in every possible mauner. All who have health enougl must engage in this dny's sport, and every horse is it requisition. The bational taste, if I may oo spenk, is riding horses; nind the more break. neck and furious the auimal is, the better. Nicety of equigment is not thought of: any thing answers for a saddle and bridle, and as for stirrups, they are considered quite unnecessary. By four o' elock tho crowd is well collected, and feats of horgemanship are practised, consisting generally is those in. voluntary tumblings that inexpert ridere are wont to indulge in. The great gathering is on the eastern 
plain, flin row to whish is well wyered with dust. The wholv louks, when due erowil has poseession of it, not unlike a rag fair, the predominant colour being yellow. They are generally well belinved, and the only eufferers are the jowr horses, who are kept runuing, not races ouly, but for the amusemont of the riders, whose great delight is to ride at full upeed. At tisntes there nre ruces, in which case the erowd is increased by the suldition of the foreigners, many of whon are in a state of intoxien tion. The upruar is proportionably grest, and the natives are less curnspicunns, their places being veeupied by shuse whose morals and enjoyments are far from being as imocent. When his majesty and suite are present, much more order and decorum are oberved, and the whole affords a pleasing and arnusing sight. The returning throug is leaded by the king and his party, after whom follow the crowd in a somewhat uproaijous style; those on horges indiseriminately nixed, racing and ballowing; the fair riders being bume aloug, amidst elouds of dust so thick, that were it not for the rustling of flowing ailks and tapas, one would be at a loss to know their sex. By tho evening, all is again quiet, the streets are iearly deserted, and Sunday is whered in witl a decorum and quietness that would satisfy the most serupulous I'uritan.

I wns nuchs struck with the absence of sports among the boya and ehildren. On inuuiry, I learned, that it liad, after mature deliberntion and experience, been considered advisable by the misvionaries to deprive them of nll their heathenish enjoynents, rather than allow them to occupy their minds with suy thing that might recall old sssuciations. The consequences is, thint the Huwailan boys are staid and demure, having the quiet looks of old men. I cannot donbe that they posscss the naturnl tendency of youth towards frolicksone relaxations; but the fear of offending keeps a constant restraint over them. It might ve well, perhaps, to introduce osmo innocent anusements; and inteed I believe this has been attemplted, for I oecasionally saw then flying kites.

Among our other duties at this time, a courtmartial beeame necentary. The tervices we were engaged in had rendered it impossible to convene one prior to our arrival here; and if it ball not been for the inperative necessity of making an exanule in the ease of two marines on board the Peacock, I shoula bare been inclined still to defer it from want of time - Besides the two marines, there was an unruly fellow by the name of Sweeny, an Englishnnan, who had been ahipned in the tender at New Zesalamd, and was at times so rintous on board myship, that I determined to try lim also. A court composed of the oldest officers of the equadron senteneed them "to be flogged at such time and place as the commander of the squadson might think pruper." Understanding from our conkal that the sailors of the whaling Heet, as is most generally the case, were disposed to be disorderly, and my interference having been several times asked for, 1 thought it a good oppor. turity to show the erews of all these vessels that authority to punish offences existed. I therefore ordered the sentence of the enurt to be put intu execution publicly, after the usual mamer in such cases; a part of the ptunishment to be inflicted at ench vessel, diminishing very much its extent in the cuses of the two mariner. At the time of the infliction of the punishtuent 1 reecived a letter from the must respectabli portion of the crew, requesting Swemy's discliarge, and stating thut lse was a trcublosome cluarseter. To inaure his digmisal, they uffered to pay all the debts lie might owo to the government As lit had no clam on the squadron or fing, which, I was afterwarils tolil, lie lat fregtiently cursed, and as the luad been only six months in the squadmon (having joined it with seare a allirt to his huck), I resolved to eumply witls the men's request, and sent him out of the squadron at once, with lis bag and hatnmock, far better ofl than when the juinod us. T'be slip became orderly again, having got rid of one of the greatest of the many raseals who are found ronming ubout I'ulynesia.

This act, together with the legal punishment of the marines for refusing to do duty, when their time of service had not expired, was nuther of tho unusy complaints brouglit against me vu my returt.

The men's time of liberty lisving expined, they were again received on board, heartily sick of their frulic. They wero remarkably orderly and weilbehaved wbile on shore; and Indeed the police is so efficient that it would lave been impossible for then to be riotous, if so disporort, without finding theuselves frisonely in the fort. I must here do Governor Kekunanon the justice to say, that he performs the part of a most excelient and energetic mngiatrute, nud whil he iusists ou ethers conforming to the laws, the is tqually mindful of thern himself. His fuult, if he errs, lies in carry. ing them into uffect too iquikly and withuut sullicient exnmisnation.

Desirous of having as thorough an examinations made of all the islanis of the group an possible, and the repairs of the tender being completed, I put Mr. Knox in elinrge of her, and sent her with neveral of tho naturalists to the island of Kauni, with instructions to land them, on their return, un the west side of Uahu, for its examination.

On landing at Kulna, they entered an extensive Jevel plaiu, bounded by a ridge of mountains, bud cultivated in sugar-eane and imulberries. Cajtain Stetson has an establishment here built of alobes, but these are sot found to be adapted to the climate. The environs of Koloa nfford some pasturage; the soil is good, though dry and very stimy; the grass and foliage, however, looked luxuriant About two niles from Kóloa, Coptsin Stetson has his sill estrublishmeut, consigting of mulberry-grounds, cueoonery, \&ce.

Agreeably to instruetions, the naturnlists dividesd thengelves into three parties - one, consisting of Dr. Pickering and Mr. Brackenridge, was to cross over the centre of the island, from Waimes to Halelea, observing the botany of the high ground; another, comprising Mesera. Peale and Rich, was to proceed nlong the coast on its eastern side; and the third party, Messis. Dana and Agate, iulended to pursue np intervnediate course, to view the acenery, geological formation, sic. The scheoner' was in the mear time to make gome examinations of the roadstedds and small harbours of the island.

Thero wero two old craters near tho beach, which were risited. Only a few trees were ab. served. On the luw wet grounds are tato-patches 
and fish-prondf. Among the few interesting plants were species of daplune, a cleome, suld soute Ridas. The garden of Captuin Stetson coutained вeveral armamental phants, Lrouglit from St. Contlanrinc's, Brazil. The garden land a pretty nppearance, being enclused with $\mathrm{B}$ hedge of $t i$ phants (drecsena), set closely together, about five feet in lieight, topped with thin, wide-spreading leaves, while the walkg were bordered with psilotum instent of box.

The mulberry trees do not produce woll here, being subject to blight, aud requiring great attention. This is thouglit to be owing to the dryness of the strong trade-winds that constarty bluw, and which have parted with their anuisture in passing over the high lands of Onhu, lying directly to wind ward.

The silk is reeled by native wnmen. The вpecinems seen appeared of gool qunlity', lat were not recled sufticiently fine, or with tlat attentian to economy which is nevessary to its profitable cultivation.

The sugnr-mills of Lacli and Co, are said to be doing a gond business. They are turued by whter. The sugar is of a fair qunlity, and has been sold is the Unjted States at a protit. T'he untives are induced to rajec the sugar-cane, which is sometimes ground, or manufietured, on shares, and is also bought. "The latoms of the uatives, in raising the cane, costs twelve and a hnif cents fier dny. T'his, however, is paid in paper eurreney, issued hy Ladu and $C_{0}$., redecmabie nt their" store ; consequently the price of the labour is no nore than eix and quarter cents ; for the sale of goods is really made in these islands under a profit of one hundred prer cent. The want of a native currency is beginuing to be minch folt, loth hy the gorernment mind people; a faet that will tend to show the advance thoy have made and are making in civilization,

Dr. Piekering and Mr, Brackenridge set oat on foot, the day after the tender arrived, along the southern const, for Wrimen, distant eigliteen miles, in order to thke the western route acrues the island. The whole distnnee between lioloa and Wainen was found to bo a series of sunburnt bills and barren plains, sloping gradually from the lake of the mountains to the ocenr, and now and then intergected witl ravjues, or, ss they are called in the Hawnilan Islands, "gulches," Only a few conrse grasses aro met witl, quite unfit for pasture.

At Waimen, the furt built by the Russians, under their absurd trude-master, Dr, Sehool, is still in existonce. His ambition wauld have made him the mopritun of the whole island, although his only business was to take posscssion of the remains of the wreck of a slip belonging ta tho Russinu Company, that bad been lost in the bay. Several Russian vessela werw afterwards sent there, which Sehoof took elarge of, by displacing their masters. It is said he made presents to linmehaneha I., and received in returis a grant of land from him; somo nccounts onv, the wlule island! It is guite certain, however, that hamehamelan's ferars were excited by the ruports that were circulated from time to time, tlint the Russinus, thrungh 13r. Schoof's operations, intended to get stach a foothold as to subvert his authority, and keop pos- session of the island. With his usmbl promptness, he, in conserpence, ordered the governor, finumus alli, at onee to send thern al] awny, This was effected witlout any disturbanee, nud all the Rusains embarked in a brig, in which they proceeded to Halelea, to jois other Russion ressels that were lying shere, and all departed together. $A$ an any intention of taking forcible possession, or calonizing the island, was shortly ufterwnrts tenied, in the most positive manuer, by the Russians, it is probable that the whole was the work of a wain and ambitious man, who had surdenly foumd himself elevated above his own sphere. That he either wanted the inelinntion or the colirige to earry out his coneeptions, if he lind any, is unat. fest, from his immediate acquiescence to the order of the chive to quit the island. He is now known at the jshnds under the appellation of the Rustinn Disctor, aithongh by tirtl a German. The Ruseian Stone Furt, as it is now enlled, is garrisuned by a guned of natives.

Waimen offers the bost anchorige at this island, except in the montho of Januny and Febsuary, when the trades are interrupted, and the wind blows strong from the soutl-west, and dircelly on Bliore.

About a mile west of Whimen is the sprat where the first English boat landed from Cuolis expedition. The village of Waimea eakes its name from the river, which rises in the momntains, and after is course of suout fifteen niles, enters the sua there. It is navigable three-fourthe of a nile from its month, in boats. The whter is used for irrigating the valley, and might also be appropriated to thanufacturing purpobes, as there are many excellent mill-sents, and a stendy supprly of waler for such purposes.

The island of Nithau was not visited by auy one belonging to the equadron; but it seems praprer that in giving an account of the Hastainan lalands, it should bo spoken of. It is situnted sixteen miles south-west of Kianai, and is eighteen miles long lyy eiglut broad. There is an nuchorage on its western kide, but no harlınur. Ita castern side is rocky and untit for cultiwation; the inbabitants therefore reside on its westerid elile, on the sensliure, and are for tho rnost part miserably poor. 'Illey cultivate, prineipally, yame nal sweet-potatoes, the former of which succed much better here than at any of the other folands. Water is very searce, and they suffer ocensionally froti droughts, from which eatuse they are not able to miso the taro. This island is celebrated for the beautiful mats mannfactured by its womed. It is alsu said to bo a favourable glace for the manufacture of salt. The number of inhabitants is dio tlionssand.

On the 3 rd of November, the tender reached Rawailos, in Waialua district, and the naturnlists were landed on the western side of Oalun. It wa near this place that Mr. Gooch, who accumpanied Vancouver, was killed by the natives. Here the party again divided, to explore the island of Oalıu, on their way to Honolulu.

On the ifth, the Porpoise, under LieutenantCommatiast Itinggohl, sailed to the Low Areltipelagin, or Paumotu Grotsp, with instructions to return to the Larbout of Honolula by the I5th of March. 


\section{CHAPTER XXVIII.}

\section{HAWAITAN GROUP, OR SANDWICH ISLANDS-(CONTINUEN).}

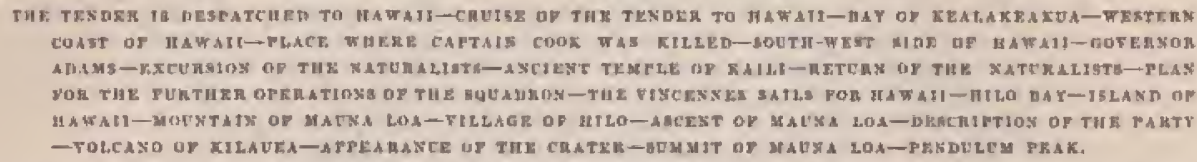

Suontwy after vur artival, orders were given to be rendy for sea by the llth of Novernber, at which time it was my desire that we should ngaiu bo on active duty. Finding, after the return of the terwier from Knuai, that the Vincennes and Pereock would necessarily be detained beyond this time to cuns. plete their repairs, and wishing to affurl the naturalists belonging to the Pesteock an olryortunity of visiting Hawaij, I gave Messrs. Peale, Rich, and Dann orders to rejoin the tender on the loth of November, I also gave Mr. Jinox instructions to proceed direct to Kealakenkua Bay, to land them there, and to be agatio reaty w receive them in an week afterwards at Hilo Hay, on the opposite side of the istaul. The party woukl thas be emabled to erose the island, which 1 had no hopes of being able to acconplish with the muturalists attached to the Vincentres, as I believed we wlould all buve enought to ocenpy us fully in the contemplated trip to the top of the moutitain, nnd the exsmitration of the voleanic eruptions. On the same evening at 10 P.s., they went to sea, sweeping out of the harbour, and proceeding on their trip.

In the mean time our preparstions for duty were actively progressing. The Forpuise aniled on the I 6 th of November, under orders for the Psumotu Group.

Prepantions were making on bnard the Fineennes for our trip to the monntain. Dr. Judd, of the mission, at my solicitution, ennsented to accompany me, aq did also Mr. Brinsmale, our consul.

On the $24 \mathrm{th}$, all wero ordered to join the ships. The tender, agreeably to hex otders, roturned on the $28 \mathrm{th}$, and the launcls of the Pestenck being rendy, wrs tnken on bossy on the 29th of November.

Before trking wp the eruises of the ships, how. ever, I shall give an account of the tonder's trip to Hawnii.

Detained by culms and light winds, they did not reach the bay of Kenlakeakua until ten o'clock at night, whon, having obtained the guidance of some Gshermen, they anchored in the dnrk,

This hay derives its name (path of the gods) from a slide in the hill, which is still risible, which the gouls are said to liave used in order to cruss the bay quickly. It is of no great extent, and opens between two low and barren hills, on each of which a town is situnted.

Between them a high perpendieular bluff rises directly from the water, in which are seen nume. rous cares : in these the natives formerly buried their dead, and still rise ocensiontilly for the same purpose. "These eares nppear ingecessible, and are the resort of wast numbers of birds.
On this 14th (Satutilny), they landed at Napolo, and wer: kinly received by Mir. Forbes, tho resident missinnary for the district of Kealskeakua. They wero grently disappointed wiven they found it would be irmpossible to proceed on their tour that day, and that their departuro would have to be dofeired unti] Mondiny, as it would be impossible to prepare the food necesenry for the jourtiey in a day, and the next being Sunday, no natives could be persuacled to fravel until Monday. On the niglats of their stay with Mr. Forbes, they ilintiuctly aaw the hearens lighted ap by the fires of the voleano of Kilauea Fele, although at the distance of forty miles, This misgion atation is on the west side of Ilawai, ant on the south side of the bay of Kenlahenkua.

Almost the whole const of this district, extending forty miles, is one line of lava. This frequently lite in large masses for miles in extent, and is in olher places partially broken, oxhibititg perpendicular cliffs, agniust which the sen dashes with fury. This formation extenda half a milo into the interior, and as the distance from the sea increases, the soil becomes richer and more productive. The face of the cointry, even within this rocky larrier, is rough, and eovered with blocks and beds of lnva, more of less decomposed. The lnnd in places renches the altitude of two thonsand feet, and at a distance uf two milez from the enst begins to bo well covered with woods of variuns kinds of trees, which are rendeved almost impassalte by nu urudergtowth of vines and ferns. In these wowls there are many eleared sjots, which hare the appearance of haring been formetly eultivated, or havisg been burnt ly the descending streans of lava. Iu sume places, these strijs of wood descemi to within a mile of the shore, having escaped destuction. These are in no place parallel to the shore, but lie always in the direetion which the streams of lava would take in descending from the mountains.

Our gentlemen, during their detention, crossed over to the nortb shore of the bay of Kealakoskua, to vigit the place where Captrin Cook was killed. The natives pointed out the spot where he fell, which was on a rock, the most convenient for landing of any in the vicinity, as it is somewhat protected from the swell hy a point of lnva rocks. Witluit a few yards there is a stump of a cocon-nut treo, at the font of which he is said to lare breathed hig hat. The top of this tree bad been eut off and carried to Englaud by H. B. M. Bhip Imogene. It is now treasured up in the musentm of Greentsich Hospital, which I caunot but feel was an approphriate disposition of it, enleulated to recall his memory to the 
minds of the thousands who riew it, and inspire in them the feeling of proper pride, in finding that the conntry npprociates so remote an emblesn of their distinguished countryman,

On the stump of the tree is inscribed:

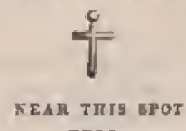

FELL

CAPTAK JAMHS COOK, R.N, THE

REYOWY CIACUMBATLATOR, พrI0

DIGCOTENED TIIELE IBLAXDA, A. D. $17 \% 8$.

HIS MAJESTY'B aHIT JMOARER,

octoner 17тн, 1637.

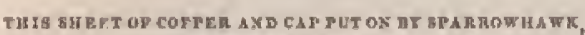

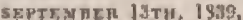

IY ONDER TO PRESENTJ. TUTS MONCMEST TO THE mesort of coux.

I could have wished that the first inscription, relating solely to Cook, was the only one; the other, it seerns to me, was not worthy of being associnted with any thing connected with so grent a name; and good taste and proper feeling I think would bavo slurunk from inseribing it as well as the following on nrother part, "Gice this a cont of tar."

Tho south-west sille of IIawnit is termed the district of hona, and includes liealakenkua aud kiailan. The town of liailau is the residence of huakini, better know'n among foreigners by the name of Govemor Adams, who is governor of Hawait.

This district lies to the north of Kealakeakun, and begins about tire miles from Napolo. It is similar to it in character, but the lava is of nore recent formation, the eruptions from Hualalai having flowed down and covered nenrly the whole northerm portion. This ermption lın̨pened ahout thirty years since, in 1809 and 1810 . Hualalni is between acren and eight thousand feet in beight, and rises abruptly on its west side.

Rain sellom fnils on the coast, exeept in strowers, and a miny day onee in the year is looked upon as somethiug remarkable. This, together with the abscrnce of all dew, prevents the existence of much eultivation; it afforis, nevertheles, a coarse vegetation, sufficient to pasture a few hundred goats; but, a mile back from the shore, the surface is covered will herbnge, which maintaing enttle, \&e; and $t w n$ miles in the interior there is suffieient moisture to keep un a eanstant verdure.

The dwellings of the natives are $\mathrm{a}$ litte improved, and Governor Adanis has the best-built atone house in the Hnwaitin Isinnds. Ile ling also a cotton factory construeted of stome, and by his influewe there has been erected a largo stone chureh and a sehool-house. Ho also gives much attention to the schools, and has twenty-tbree in his district for ailutt seholnrs, who are six or seven hundred in number; and thirteen for children, with about five hundred pupils: all of these are tnught by natives. To these is to be added a school for girls, tauglit by the locies of the mission, numbering fifty-five scholars.

Goveruor Adams, like all individuals of bis class who are desirous of inproving lis countrymen, is represented by the low foreigners to be of a miserly and gramping disposition, aud they say that lie las sequired large stores of wealth, which lie linards up. He is certainly much respected by all thope not engaged in trade, and spoken highly of by the natives over whom he rutes. He is asmitter, howexer, by both foreigners and nativeg, to be one of the most shrewd and intelligent of the nation, and hesirous of turning all things to account, compreting even with foreigners. I lud not the pleasure of meeting with him, of which $\mathbf{J}$ whs desirous; for, owing to our unexpected detention at Onlww, we dic not reach Hilo so soon as we had intended, and he was obliged to return to his lome on the opposito side of the ishnd. Being a man of large dimensions, as the chiofs usunlly are, he was deterred from per. forming so toilsomo a jonrney again during our stay.

On Mondny, our gentlenien formed themselves into two parties, and started on horseback for Lheir jourmey, One party consisted of Messre. Peale, Rich, ankl Hall, will eiglat Ḱnnaks ant two gnides; Mr. Dana and Mitshipmna Hadson, with Rauakas and guides, formed the other, which took the ronte along the sea-shlore towarls the soutls, well provided with provisions, and a supply of various articles for their joursey.

After $n$ dny's travel, they renched the site of the ancient temple of liaili. These ruins lie nhout equally distant from three mountnins, Mauna lien, Mauna Lna, and Hunlalä. This temple is said to have been built by Umi, who, witl lis wife $P_{a} m$, is suppoed to have inlmbited it, when he was ling of the island. 'The three nortiern pyanids forming the front were originally erected by Uni, to represent the distriets of the islnul he then governed and as he conquered wither districts, he ubliged ereh of them to build a pyramid on the side of the temple. The main building is ninety-two feet long, by seventy-one feet ten incher wide; tho walls are six fect nine inclies ligh, aeven feot thijek at the top, and nexrly perpendicular. Tho twilding is anid to lave been covered with idole, and offerings were requitred to be lrought from a great distance, consisting generally of provisions. Thlere are now no trinces left of these idols The situation of the temple is at an elevarion of five thousand feet above tho sen.

At Hilo on the 23rd, the natumlists embarked on board the Flying-Fish, which sailed for Onhu, and reached Hovulula on the 28th of November.

"Tie squaujron was now on the eve of aniling. having on hourd stores and provisions for a loug cruise. An this winter's crusing was particularly intended to exannine the portinn of neear that was not iscluderl in my instructions, I shall, beforo narrating the dotails of the proecerliugs of the spuadron, give, in a genernl view, the intended operntions.

The muvements of the struadron were, at this time, particularly directed to the examination of parts of the becan possessing grent interest in t/3eir connexion witlı that important frruch of national industry, the whale-fishery ; and the eonrse 1 jroposed to alopt will be understeod from the following statement of the objects I now had in view.

The Purpoise had previously been sent towarils the Paumotu Group, or Dangerbus Arebipelage, lying to the eastward of Tahiti, to exansine some islands that were reported as doubtful, and others s 2 
whose position wero not well ascertained. Slse was alsi ti lesve a prarty on osie of them, to boro through the enrnl rock, the expedition lasing been providel with an spparatus for that purpose. Thence she was to proceed to Trluti, and from Tahiti townds Penrlign and Flint's Island; oss return to Oatu by the end of Mareh, 1641.

The Peacoek, with the Flying-Fish as tender, I designed shoulil viait and exanine the location of several of the douhtful ishnds, passing alorg the naguetic equatir westward from the meridian of $160^{\circ} \mathrm{W}$; R Renee to $n$ small group of islands in lougitude $174^{\circ} \mathrm{W}$, which I hind partly examined in the Viuceune, and lund found some new islouds among them; these I lat ealled the Phocnix Group. Thence the Pencuck was to proceed to setreh for the Gento Hermusas of Quiros, or the islands reported to me at Upols, when I was there in 1839, as existing to the [aorth-enst; thence to Upola, to re-suryey the soutl sithe of the island, not having been alsle to satisly myself with the former surrey of it. From Upolu the Pencock ant Flying-1'tah ltad directions to sail to Ascension Islund, nnol from thence to the north-west const of Americn, to rendezvous with the rest of the squadron at the Columbin IRiver, in the latter end of April.

The Porpoise sailed on the $16 \mathrm{th}$ November, 1840 , and the Pencock and Flying-Fish on the 2nd of December.

The Vincernes aniled for the harbour of Honnlulu for Hawnil on the Ard Decernber with Mr. Brinsmade our worthy cansul and Dr. G. P. Judid on board.

During our progress to Wniaken, or Hilo Bay, we had light variable winds, with henvy dews nt night. On the 8th we made Mrura Kea, then about fifty miles distant, subtending an angle of two degrees: it was cappod with вnow, $\Lambda$ s we spproached the island, we had, also, a riew of Maus Lon, with the eloud resting over the voleano of Kilatica, the seene of our future adventurea.

Hilo Bay is indifferenty protectert from the sen, and is almost an open roadstead. It has, howerer, an extensire sunken coml reef to senwnrd, which is too shoul to allow of the pasage of ressels orter, and affords some protection agnisst the rolling sen ; a vessel therefore usuilly lus quiet, unless it is blowing strong outside. Thero is no danger in enteriug the bay; all that is required is to avoid the west point of the reef, and on passing it to lnaul to the southwarl. We found the best anchnoage on the east side of the bay, where Cocon-nut Island and the most enstern point are in range.

In sailing towarila Hilo Bay, Hawnit has but few of the chancters that indicate a volennie origin. In this respect it rosembles Sisvait, in the Samoan Group ; and tho resemblance las been the cause of what is in fact tho stme name Javirtg been given to both. The two works differ no more in apelling and sound, than bas arigen from the long separation of two fumilieg of the same race and langunge. Many of the pnints and hetullauds present a like similnrity in name, and strengthen the convietion of the common origin of the in. habitants of the two groups.

To one unaequainted with the groat height of the mosntain of Hawaii, this islnad might appoar of cotnparatively sinall clevation, for its surfice rises gradually fron the sen, usiform and unbro-
Ken; no abrupt spurs or anguliur peaks are to bo oeen, and the whole is nppareutly clothed with a luxuriaut vegetation.

The scene which the island presents as viewed from the anehorage in Hilo Bay, is both nuyel and splendid: the shores are atudded with extensive groves of cocos-ntt and brend-fruit trees, interspersed with plantations of sugar-cane; through these, numerous strenrna are seen hurrying to the ocenu; to this sucuecels a befe of some miles in width, free from woorls, but slothed in veriture; beyond is it wider belt of forest, whose troes, as tluey rife higher and higher from the sen, clange their elarmetere from the vegetation of the tropies to that of polar regions; and above all tower the snow-capped summits of the mountuins.

Frum this point of view, Manna liea, distant ahout thirty-live milis, has the nopearance of leing by muels the lighest mountain on the island; while Nauna Lon, distant sixty miles, nul roundod at its summit to the alıape of a regular dome, re. quires an eflurt of reason to satisfy the ubserver that if really las as great an elevation. $\Lambda$ convietinn that this is the ense may be renclied by tracing with the eye slie edge of the forest that encireles botl mountaiss, and noting bow large a portion of the done of Mnuma Loa rises atove the wowly negion.

No sunw was visible to the naked eye on Mrana Lon, but with a telesenpe it whs sects seattered here and there en its rounders summit. The apypenrarye of this mountain is so deceptire, that one would not strppose it in lave laalf its real altitude ; and it might easily bo passed unnutieed, so utıretending is ita nspect. From Hilo, Mann Los lookg as if one might walk over its amooth surface will.1out difficulty; there is, ind eed, so much optical deception in respect to this mountain, that it served to give us all grent encourngerment, and wo set about making onr preparations with $\mathrm{n}$ determination to steceed in the attempt to reach its highest aummit, The position of the erater of kilauea whs denoted by the silvery clond which hangs over it by day; whioh, as evening closed in, was, by the glare of the fires burning benealh, made visible througliout the niglat.

$\mathrm{My}$ time was now netively errployed in estal, lishing the observatory at Wainkea Point, for rating the chrononeters, and in arranging the irstruments to earry on simultaneons abservations with our mountnin party. I lud also a house buils after the nntive fashion, in onder that some of the oflicers might be engaged upon the churts.

Waiaker Point is situated on the opposite sille of the bay from Hilo. 'The distance between them is a litulo more than a mile, anil the path leada along a sandy beach, on which the surf coutinually breaks, and at times with grent violence.

Hito is a straggling village, and is rendered nlarost invisible by the luxuriant growth of the sugar-cane, which tho uatives plant around their hotsses. A good road bas been unde througlt it for the extent of a mile, at one end of which the mission establishment is situsted. This cunsists of several houses, most of which are of modern style, covered with zine and shingles. One of them, however, thie resillenee of the Rev, Mr. Conn, was very differently built, and derived importance in our eyes, from its recalling the nssocintiuns of home. It was an olh-fashioned, prim, red 
Yarkee horss, witl white sills and casennents, an! double rowg of small windswg. No une couhl nistake the hirthplace of the sachisent, and althought thirty degrees nearer the equator than the climate whence its molel was draw it as well adapted to ito new as to ita original station.

On mir way to Mauna Loa we passed the lifll deseribed by Lord Byrou's party, which it would have been diffieult to recognise lind it not been puinted out, on nccount of its gradual rise. Tllis bitl affurdod a minguiticent view of Lilo Bay, and of the surrounding eountry below us.

Six miles flom Hilo we entered the first wood, nnil at 6 P.x. we passed, at eight miles distance, the classm that divides the Jilo from the Pun district. As the darkness set in, we began tio experience the diffienlties we had antieipated: the bustlo and noise becsme every moment more rudi. ble alning the whote lino as the niglit advaneed: what adjed not a little to our diseomfort, was the bad! rond we now had to encourster, rendered worse as each native passed ots in the tracks of thase proceding him, until at last it becarde in places quite wiry.

We conlinued on, however, until we found most of the natives had eome to a stand, and were lying aboust ninoug tha grass by the rondside siear a few grass-houmes. One of these was lired for our ne. commodation and to protect us from the benry slew, to which the rutives seerned accustomed: here we proposed to slay until the moon nrose, and in the interim to get what litulo rest we eould.

After it beenme sufficiently light we again set out with a purt of our host. "The clond of the volcano of Kilanen luy before ns like a pillar of fire, to gujde us on our way.

It will acarecly be prosible to from a full ichen of our company: that of my Lord Byron is deseribed as a surt of triumplial procession; unrs was very different from this, and was more allied to a May. diky morning in Now lork, $0^{*}$ a vast caruvan, consisting, as it did, of two hundred bearers of burlens, forty logss, a bullock and bullock-humter, fifty bearers of poe (native fuod), twerty-five with salahaslses, of different sizes and slapes, from two feet to six inches in diameter. Snme of the bearers lad large and sinall prnels of the portable house on their breks; oltwers, frying-pans or kettles; and others, teuts or knausacks. Then there were lame lasses, which, instend of carrying their rilers, were led by them; besides a large number of hangers-on, in the shaje of mothers, wives, null ehildren, equalling in number the bearess, all grambling und eomplainizg of their loads; su that wherever and whenever we stopped, confusion and noise ensued. I felt haply in not ustderatanding the language, and of course was deaf to their comphints. 1t was rery evident that the lomils were unequally divided; and I must do the tastives the justice to say, they land resson to cornplnis, aot of us, lut of esch other. It was impossible for the thing to bo remedied at once, although it was not a little provoking to sec several tatives staggering under thejr losds, while oue or two would be skipring along with a few ponnds' weight only.

Lensing Olat, at a height of eleven humdred snd thirty-eight feet above the level of the sea, we had tho distiftet path to follow; for the whole surface became a mass of lava, whieh retained all its metallic Justre, and appenred as if it lad but just rut over the ground-so small was the netion of decomposition. There were only a few stunted buslies on our track; but some dense patches of wood were observed on the right. "Ihe day wis wartu, with a bright sur; and when we passed pouls of water standing in the lavu rock, as we frequently did, the natives would rush into them Ithe oserheated dogs, and seemed to enjoy the temporary coolness brought about by the evaporz. tion.

At 3 p.y. wo reached Kapuauti, which consists of a few houses, and is about fifteen miles from Olan. The temperature, on out irtival, was foumd to be $80^{\circ}$ in the shinde, while in the sun it stood at 84"; the whole extent nround wns thack lava; indeed there was no place $w$ here we coukl pitch a tent of six feet by ciglit, anol as it lowked like rain we concluted to oecupy one of the houses that was oftered to us; but it Laught its a lessun we rement. bered for some time, for all atr blankets and eluthes becrme infested with fleas, and thoso of the anost vorncions kind.

T"le height we lnd now attained was two thousand one hundred nid oighty-four feet; tho thermotuetar, $72^{\circ}$; the lowest tempernture in the night, $58^{\circ}$.

At d s.y. we left Kapumuhi, ot whant our company ealled "Fles Hall," after hovisug passed a most comfortless night. Nothing could be more anuoying thar the swarins of fless itrat attacked ns, and I beliore all the native houses are thus unpleasantly infested. In about three hours we renched the Okea tree, known as the boundary of the territory of Pele, or the gnddess of the volenno. In bygone dayg no matire dared venture beyond it without an offering to Pele, under penalty of her vengennec.

Som after wo left Kapuanhi, we met with soil formed upon the lava by voleanic ashes; tho bushes becante thicker and more thrifty, rising into smali trees; quastities of strawberry-vines were perceived, but the natires senrehed in vain for some straggling fruit. The time for its bear. jug lad passed, but they are said to be found in great abundance, nud of very fine flarour, at the yroper senson. Oken was the principal wood, and there was some koa (aucin). A curious plant, was pointed ont, the sap of wlich blisters the skin, and with which the inliabitants produce a sort of tat. tooing in large and small round lumps. I bid not Jearu how durable they were. This plant is ealled uหru+ลa-laili.

Just as we reached the grent plain of the vol. cano, we approached the southern linit of the wood, and, on turning its cormer, Matua Lon burst upors us is all its graudeur. The day was extremely fise, the atmosphero pure and clear, except a few flying clouda, nnt this immense dome rose bufore us from a plaill some twenty miles in brendth. I hod not, unkil then, formed any ade. quate idea of its magnitude and height. The whole dome appesred of a bronze colour, and its uninterrupted smooth outline was relieved against the deep bluse of is tropical sky. Masses of eloude were flasting around it, throwing their slindows distinctly ou its sides, to which they rave oceasional relief and variety. There was a bluish loaze resting on the plain, that apparently gave it great 
distance, though this was partially counteracted by the distinetivences of the dome. I now, for the first linue, felt the rangnitrde of the trok 1 had undertaken.

So strilting was the mountain, that I was surprised and disanpointed when ealled upon by my friend, Dr. Jutd, to look at the volcuno of Kitauea; for I suw nothing before us but a huge pit, black, ill-louking, and tolally differest from wliat I had nenticipated. There were no jets of fire, no eruptions of hented stones, tho cones, nothing but a depression, that, in the tridst of the sast plnin by which it is surruanded, appeared small and insig. nificsust.

We lsurried to the edge of the envity, in order to get is view of its interior, and as we approached, vapour issuing from numerous eracks slowed that we were pussing over ground beneath which fire was raging. The rublhing of the wind past us was ns if it were drawn inwards to support the cuss. lustion of some mighty conftagration.

When the edge is reached, the extent of the exvity beconses apparent, and its depth became gensible by comparisou with the figures of some of our party who had already descended. The rastness tlus made sensible transtixes the mind with astonishment, aurl every instaut the in uression of grandenr and maguitude increnses To give an illea of its capacity, the eity of New York might be placed withis it, and when it ite bottons would be laardly moticed, for it is three tand a talf miles long, two and a lwif wide, and over a thousand feet deep. A black ledge surrounds it at the depth of six hundred and sixty feet, and thenee to the button is three hundred and ejphty-four feet. The bottom looks, in the daytime, like a lieap of smouldering ruins. The desecut to the ledge appears to the sight a eloort and ensy tnsli, but it takes an hour to aceurnplish.

We pilched our tents in full view of the rolcaro, and ant on its northern bank for a loug time in silence. Wo succeeded in renching the second Icdige, though the way to it is steep, rugged, and uneertaits. At the edge of the pool, or lnke of fire, the light was so strong that it enabled me to rend the smatlest print. This poot is fifteen hundred long by one thousand feet wide, nod of an oval figure.

I was stratek with the nbsence of any noise, except a low murmuring, like that which is lieard from the butling of a thick liryuid. The lnke was apparently risiog, and wanted but a few feet of overflowing its banks. When I began to reflect upon the position we were in, its insecurity, and the rast and leep fires beneath, with the high basaltis: walls encompassing it difficult to eompreheud how such a reberwoir ean thus be pent un, and be riewed in such cluse proximity, without aecideut or tanger. The whole party was perfectly silent, and tho countennace of encli individual expressed the fecling of awe and wonder which I felt in so grestl a degree nyssetf, ant which the seene was so well enleulated to excite.

No ons can see all this and yet doulst the theory of the ignemus fluidity of the centre of the enrth. All cornlanstible causes that we are nequainted with are totally inalequate to produce such an effect. "The whole seerned boiling up like in fountain, difforing only in density and colour.
We returned to our tents towarels midnight, much faigued, but found sleep impossible after the excitement of such a scene.

The day we remained at the roleano was employed by she natives in preparing their food, by boiling it in the crevices on the plains from which the stenm issues; into theso they put the turo, \&c., and clase the lole up with fern-leaves, and in a short time the food wag well cooked. All the water for drinking is oltuined bere by the condensation of the stream, whicl gathers in small pools, and aftords a suprily of sweet and soft water. From the numbers in the enmp who used it, this supply became rather seanty, but it did not entirely give out.

The crater, at night, was extretnely beatiful, and we sat for a long time watching its clunging and glowing pool. The shadows thrown by the walls of the crater seemed to reach the heavens, and gave it the appenrance of being elothed in a dark cloud; but on looking at it more attentively, and shutting off the glare of the crater, the stars were pereeived shining brightly.

About four o'tlock it loud report was heard from the direction of the boiling Jake, which proved to lave been caused by a large projecting point of the black ledge near the lake having fallen in arse disapueared.

The lowest tempernture, during the night, was $46^{\circ}$. There was a light wind and no dew.

At darn on the morntug of the $18 \mathrm{th}$, the signal called us to make preparntious for our journey, and as al tlings lind now been noxe systemnticaly arranged, we anticipated loss diffieulty in our onward jourmey. Tho natives seemed to be all in good spirits, and moved with altcrity.

Our exmp hitherto (as all cumps are) hind been beset with langers-on, in the shape of wires, mothers, and children, who were not only much in the way of those to whom they belonged, but were great consumers of the fuod the natives lad supe plied themselves with for the journey. As we already entertained apprehensions of in scarcity, prompt mensures were takien by Dr. Jndd to get rid of our troublesome guests, which we suceceded in doing though not without some difficulty, and a low monotonsus growling, that indicated mueh displensure on the part of the fair bex.

The divisions now set oft, and our host was lega mob-like, partly owing to the improssibility of going in sryuads, the paths having become more contracted.

The water thint I have mentioned as being found in the small pools, the produet of condensation, was extrausted before we left the crater. This wrs. in cunsernenue of the natives inving filled thejr enlabashes; and we had partieulnrly instructed our servants atd the sailors to do the kame. The former provided thenselves; liut the latter, enulor-like, preferred to take their clannee of meeting with it on the rond, rather than earty a load for theis future eupply. I diacovered, after we started, that they were unprovided, but was informed thut there was, within ahout two miles, an old canoe which would be found full of whter. On our arrival at it, we found that the natives, who had preceded us, after supplying thenselves had emptied out the rest.

Our route was taken at first and for a fow miles in a due west line, for the top of Mruna $\mathrm{L}$ oa, over 
the extenive plain surfounding the vuleno; it then deriated to the southward, over an aneient tava-bed, very much brokell, that appeared nover to have beon traversed before. We now hecame for the first time neqquainted with elinkers. T'o describe these, it is merely neessanry to say, they are like the scoria from a foundry, only instead of being the size of the firt, they are from one to ter feet square, and armed on all sides with sharp points; they are for the most purt loose, and what uakies them still more dangerous, is that a grent deal of the vitreous lava is among them. 'There never was mote difticult or unpleasaut ground to Iravel over.

Our guile Puhano of Puna, who we understood had necompaniet Loughes nnd Lowenstern on their ascents, now took tho lend, but it soots nppeared that he lonew little of the route. I thero. fore, in compnsy with Mr. Bringatunde, trok the lead, compass in hath ; and after walking over the brolien and turn-up ground, we turned again towarrls the bill-side, and began a mpld nscent through a beit of long grase, where the rnek was envered with whitu clay, and seldom to le seen. This part appested ta bave sufferod much from drouglit; for in passing along we came to severnl narrow and dry water-eourses, but met with no water.

At two o'clock wo lind nearly reached the upper limit of tho woods, and as the clouds began to phss over, and obscure the path, we determined to halt and encamp. We made berenal fires along the route, is order to guide those behind, and as fh mark for the stragglers; bushes were ulso hroken off, and their tops litid in tho direction we were going, by the natives; and 1 likewise lind the trees blaced, as a further indieation, well known to our uyen. Chronometer sights were taken here, and the altitude by barometer wa fire thumsaud nitd eighty-six foet.

During the day, the renson that had indueed the natives to cmpty the water out from the eanoe, beenme evintern in their anxiety to sell us water. My friend the consul had hired an enpecial bearer for lis ealabasts of water, determining thast he would have a sufficient supply. By our watching and cautiuning the ohl mat who liat it in charge, be tecanie somewlint alarmed and unateridy, as i thought also from fatigue. Whon he had arrived wislin a stwrt distanes of the camp, lie stombled on a smooth place, fell, and broke the calabash into tumtretous pieces. Those who were coning uj, sceing the aceident, rushed to purtake of its contents, but the fluid quickly dissppenred in the loose and absorbent lava. Thio was a dreadful blow to iny friend's feelings, and produced much laughter annong us, in which the consul himsolf nt letzith joumed; although I must cunfess I was sonewlat of his opinion, that it had been done designedly, either to secure tho sale of thut belonging to whers, or to get rid of tho loai, which had been a great annogrance and trouble to the bearer all day, and for which ho lind already been paid.

At sunrise on the 19th, we lad the temperature ne $48^{\circ}$.

As the ascent was now becoming laborious, we sclected and left the things we had no immedinte uso for, to follow us by easy stages. We then took a diagonal direction through the remaining portion of the woods. By one o'clock we had lost all signa of trees, and were surruunded by low scraggy buslies: the cliange of vegetation became evidut, wot unly in species, laut in fize; we alan passed through extensive patches thine had been destroyed by fire. Soudalwood wis seen, not as a tree, but a low dlirub.

During the day we had passed extensive caves, in all of which I lind senrch mide for wnter. These often lend a long distance under grouml, sut some of the men pinssed in at one elil and out at another.

Intetuling to stop on Sunday not far above these eaves, enlabash top's were left in one or two where water was found to be dropning, in topes by this means to procure a small supyly; but on returning the next rlny, it was found that very littlo had ac. cumulated.

Between two and threo o'clock, we again became enveloped in clouds, and it was necesenry for us to rerlouble our precantions against losing the truck. Fires were agnin resorted to, which at short distnnces condd be seen in the intervals of mist.

Deeming it advisable to make an enrly trath, we stapped shortly after three o'clock, to nllow all the langgage to cone up. Notwithstauding the size of our party, there was no pereeptible tratet left or any thing by which to be guided, but the smoko of the fres, or oceasionally a broken shrub, the a finger-post. All the ground was hard metalliclooking lava, and around nothing but a dreary waste. The voice too beeame finter, as the atmosphere grew more rarefied, Our encampment was called the Sunday Station, on account of our having remaned quietly liew on that day. The altitude given hy the barometer was six thousand sud seventy. one feet, nt which we found onselves above the re. gion of elouds, and could look down upon them.

$\Lambda$ night, on pulling of my clothes, I noticed the quastity of clectrical fluid elicited, which continued for sone time to affect the objects about me, particulurly a large guanco-robo I had to sleep ili.

This aftertoon, we found that it would be jurpos. sible to irive the bullock any further ; for the aninal began to aufler from fatigte and the want of water, our stuply of which was nlmost exJausted t he wns nccordingly killed. The natives were uow howking water about the camp at laalf $\mathrm{n}$ dollns the quart. I nm not aware than they sold any at that extravagant prive; but I saw soine of them in possession of handkerchiefs and old slirts, which I understoud lasd been given for it.

Ragsdale, one of our guides, who bal been deapalched to Papapala from the crater to jurchase Jrovision, now joined tha, with two more guides. He brouglit information liat he had obtained forty gonts, and tlunt we should recejve full supplies, This was encouragiug news, for I felt somewhat doubtful from the first in relying on the nntiver, and their bedarour at Kilatuen was not caleulated to rnise iny optrion of thert. I foulut also, as we ascended the mountrin, that eren light londs liad become heavy, and those of any weight, insupportable ; that our time was rapilly possing, and we land $\mathrm{n}$ long way yet before we resched the summit; and that the native food was nearly exlasusted, whilo the supply for our own men was rapidly cousuning.

The two guides that Ragsdale brought with him, were perfectly fatniliar with the mountain, One 
of thern was a celebrated bird-enteher, entled Keaweetau, who had been the guile of Lowermtern, and knew where water wa to be obtained; hut it was ten niles distarst. He eaid, that if he wns furnished witl entabashes and matives to carry them, he would be able to liring us a supily by the afternum, if he left befure the day dawned; and that it would be swo dnys bofore we could get toly suow, even if it were founl on the mountain. It bad never crosed my anitu, that there wns any probability of this latter resource fuiling us; I had in truth relied ungon it with confidence, and coneluded that in the event of nnly one snow-storm we should lo enabled to find some place for a deposit, to save enough sater for all our wants,

We now numbered nearly three hundred persors in camp, with hut a few small calabashes euntaining five or six gallums of water; sud all, moro or less, foli the effects of the rnretied air.

OHd heaweelu told us that wo had taken the wrung road to the motsntain, and that Puluno was not at all acquainted with the right road, - a faet we had long befure discovered; that if we had cume by way of Papapala, he would linve been able to eondict us by a route we should have found water every few miles.

The 20th, being Sunday, was a day of rest: the nutives requested that it might be $80^{\circ}$ and I readily yjoldod to their wishes. I was anxious, however, to saccertail the state of the mountain, and whetlier there was any snow to be lad on its top, for I now felt satisfied that the want of water would prove the greatest difficulty I should have to cneounter, in remaining there as long as I interideil.

Lieutenant Budd recoived orilers to set out with a few attondants nt daylight ; but after making his preparatians, and laving all thisge ready, the uatives refused to nccompany him on nccount of ith being Simulay, as they said. I ntu, howover, inclined to believe that fear had something to do with it, for they never knew of atyy olle having gone up this motutain before, nud thonght me mad for taking so much troublo to seend it They said that I must be in pursuit of gold aud silver, or aomething to sell for money, us I sever would take so much iroulste, and spend so unuch money, unless it wero to aejuire great riches.

In the evening we were nutel gratified at re. ceiving fifteen gallons of water, which the natives had brought ters miles in open-mouthed ressels, over the rough mountain roade: this they do by placisig some forn-leares on the top of tho water, when it earrios ng well as a solid, and will benr much agitation without spilling. Though a very small supply for our necessities, it was a preat sntisfuction to kuow that it wns now within rench of us. Bartially relieved from this pressing thifieulty, onr attention was turned to the fucl, and I at once saw the recessity of providing some ments fol procuring a supply, as we were now at one of the last joints whero it whe to be obtained. We were certuinly two, if not three days' journey from the summit, and an aseent of ejght thousand feet was still to be accomplished.

On Monday, 21st, we set out at at early hour. 'T'he ascent now became much steeper than any we land hitherto experienced, for the whole face of the mountain evnsisted of ome mass of lava, that hud appurently flowed over in all directions from the summit. The sun shne brightily, and his rays seened to fall witlı incronsed power on the black lava. No wind was stirring, and the exhaustion canseguent on the rarefied air we were breathing made the labour of elimbing very fatiguing; many suffered from nausen and headache, and the desire fur water redoubled in both whites and natives. For water they could no longer find a substitnte in berries, as they had previously done, for that fruit had disappeared, and the only regetation left was a fow tofts of gTrss.

$A$ bout noon, Dr. Judd solunteered to proceed with the gruide to ascertrin if there whs any snow, and at wliat distauce. It was agreed that we should continue to movo on in the sanue direction, and encanip when we found we could get no higher, Most of the party were naw lying about on the rocks, with thic noonday sun pouring on them ; a dispositiun to sleep, nnd a sensation and listlessness similar to that producel by sea-sickness, seemed to jurvail. I felt the former strongly myself, and enjoyed as sound au hour's sleep on the laard lava as I lawe over tad. The lurritens had become intolerably leary, nnd nll eomplained of their jnability to carry them. The use of the sextant lind beeme still more fatiguing than the day before, causing me much prin to hold it. From what I myself experienced, I was satiofied that every one's streugth had decreased nearly one-half.

We managed, aiftor au hour's rest, to go on two miles fumter, and then cueanjed. No jiace of fered where we eoull drive a preg for the telats, and loose blooks of lava were resorted to, to eonfine the cords. The principal induceneut for stopping at this spot was the discovery of $n$ large tunnel, or eave, in which the men conlil be accommodated, and whtich was at a suffieient distnnee from the Sunday Station for a day's journey. This station was afterwards known as the Recruiting Station, beeatse all the sick aud wounded from the higher stations were sent liere as to as trospital.

Long nfter we harl finished our arrangements tox tho right, and even after it had beeme dark, wo lonked in vain for Dr. Jadd and his companion. Wo therefore liglsted our fireg as a signal to him, and were soon rejoiced to sec lim safely buek. He trought with him a small snow-bsil, and the agreenble intelligence that we should find abundance of sunw on the top of the mountain, provided we reached it next day; for lie tok us it was melting fast. He had trnvelled for more than four hours and a half before lo reached the snow, and lokl been an lour and a half returning down hill, on a run. Tho point where he rret the snow appeared to him to be nbout equidistant from our present camp and the sunsmit of the mountatn.

I now feth that the troubles of my scientific operations were beginniug, for I found that one of the iron eross-bus of the lower part of the peddulum-frunse, which lad boen entrusted to a native to earry, had bees lroken into two pieces. 'lo provide, however, fur mishaps of this deseription, I land brouglat the armonrer of the Vincen. ues with me. There would lanve been na dificulty in his mending it under favourable circumstances; but, fearing that in our present position he might not streceed, I at onee despatehed a messenger to the ship, with orders to ture a new one nade and forwarded as opeedily as possible.

Although it was somewhat encouraging to know 
that snow hal been found, yet we were apprehensive it might disappear before wo could reatel it. On holding a consultation, it was thought boes that all thrse who were not absolutely needed for the intended operations an the monntain should nake a liasty trip to the top, or terminal crater, and then return to the coast; for our provisions, as well as water, were so low, as in all probability to reduece us to a very short allowance. Jt was, therefore, determined, that the consul, Mr. Binchenridge, Mr. Drayton, aud Mr. Elliott, should each be supplied wills a dny's allowance, and go on an an early hour to the summit, unencimbered, in order tn salisfy themselves with $n$ sight of it, ruturn before night to the Recruiting Station, and thenee proceed duwn the isumntain. I resulvesl to go on wills a few of the instruments, to choose an tneanjument on the sumunit.

All the partien set out at an exry lour on their asvernl arfelis amul duties. My party consisted of the gutde, Keawechu, twelve Kanakns, nsu seven of our own men, inclusing the sergeant. At abont twelve n'clock we renched a tipot where the gride pointed out a few bilf-burnt sticks, as the place where Lowenstern hat eorked his dinner. As the two himakas who hail eluarge of the bundles of wond lat entrived to lighten their lands very numch by drojping part of it by the way, I gave them orders to take the wood he lud left to cook our supper.

Mr. Brnckenridge prssed me on lis wny from the crater. From him I ascertained we were yet three and a half miles from the terminal point." I gave him instructions to repair to the lower conniry, as there whs nothing for him to do in this barren region.

l'he witul blew a strong gale from the south-west, and was piereingly eold : the thermometer, at : r. M., showed $25^{\circ}$. For some time previous, 1 had been obliged to keep the Kanalas liefore nue, to frevent Liem from throwing their hrads down and deserting; but 1 found trems unable to go any furthes; being nenrly naked, they were suffering much. Seeking a place of shelter under a high bank of elinkers, partly protected frosin the wind, I allowerl them to deposit their londa, and gave them permission to return, upon which they scemed actually to rarish; I never snw such ngility displayed by them before.

As roull as the matives who were on the road an w those from the upper party coning down, they eonld mo longer be indnced to face the cobd, and ail deserted nt unce. Tlae mountails becane in consequence a scene of confusion; being strewn with insimunents, bost 5 , pieces of the portable honse, tenta, calabaslies, \&c., which the natives had diviplped.

I now fund myself with the guide and nime men, with nothing for a covering but the smal! tent used for the instruments, and the coning on of $\mathrm{a}$ Bnowstorm mado it very necessary to have something to protect 119. The shermometer had gone down to $18^{\circ}$, and most of the men were much affected with the mountair-siclneas, with healnche and fever, and were unable to do any thing. I felt quite unwoll myself from the sune eause, laving a violent throbbing of the temples and a sliortuess of breath, that were both painful and distressing. With the few men that remained able to work, I began luilding a circular wall of the clinkers, to enable us to fyread what little ennvass we had, over it; nll the blankets we coulil epare were hung inside, which I lieped wauld lieep us from being frozen. After succeeding in this, which occupied us till dark, we made a fire to prepare our seanly supper, and some ten for the sicti. I now discovered that three of the men were alsent; and on inquiry, found that they had gone slown, in hopes of finding my tent, which they supprosed had been left about in mile beluw. One tany judge of my uncasiness, as it was pitely datk, and there was no trace whaterer of $n$ tuack, or my thing ly which they conkl find their way baek, over many dangerous chinsins, I land bnrely wourl ennugh to lient the water for the sick, and no more than a piece or two of candle, willous any lanteri, and therefore no obvious means of makiug a sigual. However, as necessity is the mother of invention, I turned my clothes out of tho culabash, and fasteniag a piece uf a cotton shirt over it, made qquite a tespectable lantern; this was placed nn the timst conspictous point. After the light had been extinguished soveral tims, and $\mathrm{n}$ scries of diffienltieg encountered in relighting it, we succeeded in cogtablishisg our lightlunise; and though a feeble one, it hal the desired effect. The men, when they first saw it, had alrenty stmyed of the trnck; fatd had it not been for the lantern, would nut have been able to join us again, They eame back, ernwling on their hands and knees; and lasd travelled thus for most of the distance. The wholo sime they liad beon alisent, was two hours and a lati. Aithough I felt rery much displeased with their departure willont permission, I coukl not find fault with them, -80 much wa 1 rejoiced to see them in siffty; and when I knew they lond incurred all this fatigue and risk to make me more comfurtable.

The snow now begnn to fall fast. My steward, from his thoughtinlness, land an ample supply of tea, which he hal carried its his knspusack to she it from being plandered; and cousequently we had euongh to sujply all.

The supper being ended, we stowed ourselves away within the circular pen; and while the mon leyt passing their jokes about its comforts, the wint blew a perfect lurricane witlont. The spiritg of tline whe were sick began to revive; and although there was acarcely a foot of level rock, nil were goon fast asleep. I had litte inelination indeed to rest; for difficulties seemed to incrense upon me.

At nbout four o'clock in the moruing, the snow lind aecumulated in such quatities on our eatswass roof, that it broke in upous us, bringing down also some of the stones. This was a dikagreable accident ; nut after cscaping from benenth the ruin, it berame necessary to take the covering off and elear the snow nut of the pen, which was nearly fult. 'This was the work of nearly an hour of unpleasant labour; but it was much more exyily aceonulistied, than getting onrselves warm again. I need seareely say, I passed a most uncomfortable night.

When dnyliglit came, the storm had somewhat ahated in viulence, and 1 despatched the men for the tents and wood, s part of which had been dropped by one of the natives within half a mile of our position. $A$ man sonn returned with the wnod, and anotter bronght forward a calabash, in which we fortumately found some provisions, 
and we soon lind what we little expected, something to eat, aud what the men ealled a comfortalule breakfast.

It whs very plensant to find the sick ones revivisg, and good-Jumots and cheorfulness so preilomixnnt amoug flom that they scomed ready for farther exertions. We had now all that was necessary to pust on to the summit. I left a Alag nn a tocky peak thear $b y ;$ and this was afterwards called the Flag Station.

About eleven o'clock two set out, and were obliged to cross at muss of cliukers, which our guile had hitherto eudenvoured 10 avoid. When, after two hrues" laborions walking, we reached the top ot terminal erater, it still continued snowing in gqualls, with a keen gouth-west winl driving in out faces; the ground being covered a Coot deep with snow, rendered it more danger. ous and irksome to pass over such loose snd detacherl miseres.

From intelligence that had been brought me by the gentleunen who laad gone before nul taken a basty took into the cruter, it whs througlit the the deseout into it would prose casy, and that I might encam on its floor ; but I found nfter tinvelling a long distance over the rugged surfaec, that it was impansible to succeed in making a deseent. I was, therefore, compelled to return, aut chouse the sinuotliest place for our encamjument 1 enuld find. It was after four o'elock, and bat litule time was left for the men to return. As soon ns they laad pitched the tent, within atont sisty feet of the ledge of the erater, using large blocks of lava to conffice jts corils, I sent them off under etange of the guide to the Flag Station, and remained with my ervants only:

By six o'stnek I thumght that we land made onr. selves comfortable for the right, nnd that the storm hisl so fur moderated that is would no trouble us; but a short hour proved the contrary. Our fite was dispersed, candlus blown out, and the tent rocking and flapping as if it wotsld ga to preces, or bo torm asunder from its fnstenings, and disopjess befure the howling blast. I now folt that whint wo last passed through on the previous night was comfort in comparison to this, The tent, howover, contisued to gtand, although it had many linles torm in it, and the ridge-pole had chaferl throngh its top.

It wns iruly refreshing, after the night we laad passed, to wee the sm rising clear. It seemed quite stnalt, and was mucl affected by horizontal refrnction, as it appenred above the sea, forming a homg horizontal ellipse of two and a falr dinweters, first enlarging on one side and then on another. After it hind reached the lieight of two diameters above the horizon, the ellizkte gratually inelined on the right, and in a few moments afterwards its longer $\mathrm{nx}$ is becane rertionl, and it then enlarged at the botton, somewhat in the form of an egg.

$M 1 y$ servants fruitlesisly attempted to make a fire; after they had exhausted all their matehea withous strecess, we ench took turns to ignite a stick nfter the native fashion, but with no more sucecss ; the nearest approximntion to it was plenty of smoke. After making many vain attempta, snd having had but little mleep, we took to our blinkets agnin, to nurait the exming of Eome of the pnoty from below.

At atrout eleven o'clock on the 23rd, Drs. Judd and Pieliering pulled open the tent, and found us all three wratued up in our blarkets. They had pnssed the night nt the Fhag Station.

The newa Dr. Judd brouglit was far from encouraging, nearly all the mives had degerted the boxes; many of thera had not even reached tho Recruitiog Station, Ragsdale and his forty gonts lad not arrised; nor were there any tidings of the party from the ahip. Tho natives hearing of our distresser, and probably exaggerating them, had refused to furnish any thing ualess at exorbitant prices. The ofticers hal rery properly rejected the whole that was offered; for, although our al lospalsee was stuall, we truated that the provisions from the olitp would artive in a disy or two at farthest.

After getting a fire lighted, and something to cuc, Drs. Indtl, Pichering, and myself, set out to recosnoitre the cmer for $a$ more suitable pliteo in which to establish the tents; but, after mucli Bearch, wo found none that offered sn many freilities as lint I land necideritally chosers tho first uight. Dr. Prikering jaxted from us, and was the first to make a descent into the criter.

Nothing enn exceed the derastation of the monntain: the whole area of it is one mass of lnsa, that has at one time been thrown out in $n$ thihl state frum its terminal crater. There is no eand or other rock; Jothing but lava, on whicherer side the eye is turned. To npprearnee it is of difierent ages, some of very miciont dnte, though as yet not decomprosed, and the alteritations of hent and cotd, with rain atol $8 n o w$, secm to have tunited in vain for ils destruetion. In some places, it is quite smooti, og similnr to what lons nhready been deseribed ns the pahoihoi, of" "satin atream ;" sgain, it appears in the form of elinkers, which nre seldom found in heaps, but lio extended in beds for miles in length, somelimes a uile wide, and oceasionally mised from ten to twenty feet above the surface of the surenundiag lava.

The place where these elinkers nnpear to me to have been formed is in tho erater itself; there they hrve been broker up by contending forces, and afterwarils cjected with the more fltid lavn, and borne upon its surface down the murntrin side, mutil they herame arrested in their course by the acetrmulating weight, or stopped by the excessire friction that the ronss had to avereome. In this way the beds, or rather stresms, nf them might liave been formed, which would necumulate for miles, and eontinue to inereaso as the crater discharged this deseription of Ecoria. What strengthened my opinion in this respect was, that there were, appsrently, Btressus of palsoilioj coming out from anderuenth the masses of clizkers wherever they had stuppred.

'lihis thy we reecived thews of the arrival of Lieutenant Alden at the fiecruiting Station, with the detachment from the ship; luxt ho land brought 3io provisions, and nune lad yet reached the station. This arrival, therefore, instead of supplying our wants rather increared them.

The omall transit was brought up this dsy, and, to add to my vexations, ou opening it I found the level broken. I did not stop to incunire by what neciclent this had happened, but within ten minutes dearntched an order to the ship for another, which was distant aixty niles.

In the evening, nt $6 \mathrm{r}, \mathrm{u}_{\text {, }}$, tho thermoneter stood at $2 y^{\circ}$, and duritrg tho uight it fell to $22^{\circ}$. 
Christmastalny get in quite stormy, with suow atuo a gale from the sonth-west; it was very cold, atwh the only way we had of keeping warm was to wrap ourselves up with blankets nul furs. WVe had just wood enough to heat a litule chocolate.

The amall instruments having arrived, I began some of the observations.

While the rest were employed in making our tents as tight as possible, in the one Dr. Judd and myself oceupied we discorered a great deposit of moisture, which, on examination, was found to be caused by steam issuing through a etruk in tho lava. On placing a therrnometer in it, it rose to $63^{2}$. The tent was forty feet from the edgo of the precipice of the crnter, and it was not surprising that the steam should find its way up from the fire benenth. $\Lambda$ s it somawlint ninnyed us, wo pounded arut filled the sean full of liroken pieces of lava. This eireumstance led to the diseovery of a smull pioce of roosg, the only living thiskg, either auinal or regetable, that was found within tix miles distanco, or within four thousund feet of the beight of the teruiual crater. This moss was hero neurishod by the stenn that escaped, which supplied it will warmth and moibture.

Tluis day we made many experiments on the temperature of boiling water: the mean of the observations gave the boiling temperature at $1 \% t^{\circ}$, being five hundred and sixty feot to ereh degree of temperature. At the voleaus of lílanea, I had found it less than fivo hundred and fifty feet to each degree; while the result of earoful experiments at the Sunday Station gave tire liurdred and fifty-five feet to tho degree, and at the Recruiting Station, ftre hundred and fifty-eight feet.

We also employod ourselves in buldting a ligh stone wall around a space large enough to contain the louses and tents, when they should all arrive, having found the neecssity of it to protect ourselves from the violent winds. Besides this, each tent was to be surrounded by a separte wall, up as thights the eaves, when conuleted.

Sorste of the boxes now began to make their nppearance, by the aid of the sailon from the ship; but the provisions had not arrived, and the allowance was ngain reduced. Most of the men were reported as without ahocs, having word ont those tivey lef the ship with; aud being barefonted, could not move over the slrarp vitreous lava. Many of then were likewise sain to bo ill with the mountain-sickness. Wood was brought up, and water aent duwn to the lower station, ill exelange.

The winul lad been freah throughout the day; but towarda night it began to inerense, and by eiglat o'clock we had another violent gale fron the sontli-west. I do not think I crel passed anch a niglit: it blow a perfoet lumricane for several hours, causing an incesanat slammita, langing, and flapping of the tenta, as though lundreds of persinns were beating them with clubs. These noises, adted to the low ling of the wish over the crater, rawlered the linurg of darkness truly awful.

The two other teuts were blown duwn, but mine strod firm. T'le men ling under the fallen tents, and were made far moro eomforlable after the aceident It was imprasiblo to staul against the gusts; and we watelied all night, for no one could sleep. The thermometer fell to $17^{\circ}$ inside the tent; and water in the bags, under my gillow, froze Alsust three o'elocli, the wind begrat to modemte; and at sunrise, we found the ternperature at $20^{\circ}$.

From the news received on the 25 th, respecting the condition of the nem, I determined to see thers myself. I)r. Juld and I therefore set out on the moruing of the 26th; and when ahout two miles from the summit, we met Lieuternnt Alden, Dr. Pickering, and Mr. Eld, who were cotning up to see me, to Juport the condition of the men. T'he account they gave of them was any thing but eheering. On the arrival of Lieutenant A]den, I lind directed that he should take an intermediate post between Lieutenant Budd's Recruiting Station and the summit crater, if order that the men belonging to one station might be able to bring up their losds and retum before night. This, lientenant Alden informed me, he had done: his station was at tho height of eloven thousand eight hundred feet.

I now saw more strongly the necessity of my guing dowa, in order to Iscertain the exact situstun of things, give the men encouragenent, ant renew the spirit with which thay had left the ship, as volunteers. I Lave nlways found that sailors are easily cacoumged; and by putting a light heart and cheerful face upan the times, they quiskly resssumo their good ajurit; nnd this I found to be the erse in the proant irstarice.

Wo parted; Lieutenant Alden, Dr. Pjckering, and Mr. Eld going up to she terminat crater, while Dr. Judd and myself contimued to descend for nbout four miles. Thiere we found $\mathrm{a}$ large number of men in a comporary tent, lying on the panels of the portable housea : some of them were suffering from mountain-sichness, others vomiting; some had nttacks of diarrtroen, others had not got over their foreed march, and showed me their bleeding feet and shoeless condition; sll were looking half-sarage, with overgrown beards, dirty and ragged cluthes, - so totally different from their trim and neat nppenrance on bonrd ship, that I was shocked at the chango produced in so short a time.

Whitst Dr. Ind admisistered to the sick, I apoke to those who ware well, and succeeded in animating them: they all assured me they were "good plick," and such I afterwards found them. They act about mending their slwes and making sandals; and by the next day, many were transporting small loads up the mowntain side.

At about four o'clock we reached the Recruiting Station, having encountered the boxes and varions articles, together witl pieces of the portable house, rtrewed along the way. These laad been left by the natives, who deserted en mase when those who had left me the first night exme down giring exaggemted accounts of the cold, and other difficulties of the journey. I found Livutenant Budd quite well, and only a fow of the men that were with him sick: they hand litth or no provisions.

The difference of tempreruture between the altiturde of fourteen thousand and nine thousand feet was vory apparent: we could now enjoy sitting in the open air without fecling cold; it was as if we hud passed at once from winter to spring. Although, ten days before, I had looked ugnon this spot as particularly barren, being destitute of vegetation and without water, yet, by comparison with the upper station which we had just left, every thing now appuared comfortable. It had been chosen, as I lave said before, for" a very remarkablo cave, 


268 Summll of Mauna Laa. HAWAIIAN GROLP, OR Yiew trom the sumnde of Mauna Loc.

which had now become our loospital, and which was found dry, wasn, and large enosgh to have secommodated the whole party. All the sick wore immediately transported here, and placed under the auperintendence of Dr. Judd and his ussistants. The nien hero lad proeured n large turtle-shell from the natives, nud in cummemoration of their jaunt, engraved on it nll their natres, and nailed it to a staif which they erected at she mouth of the eave.

We passed the night with Lieutenant Budd, nul although the lava huor of the tent was a rough bed, we selitam enjoyed so sotnd is sleep.

After arranging every thing relatise to the provisions, when they shontl arrive, and risiting the sick with Dr. Judd, I determined to return to the top. The doctor remained for a day or two, to arrunge matters with the natires at the lower station, so as to lave our supplies more regularly forwarled. 'Taking with me James G. Clarke, a senman, J again started for the sumnit, heavily laden with provisisns, In order to provent any accident by losing the direetion, omsll flags were placed, us wo went up, within sight of each other. We reached the obserrntory at the terminal crnter ut four o'clock, after a hard walk of gix lonre, We land now three stations, viz.; the Rexruiting Station, Lientenant Alalma's, and the Flag Station, uniler the aergeant of marines. Tliese masle it a more easy task to get the losds up, slikongh it wonld require a longer time.

I fonsul they lad luilt some part of the wall arouml our eneampment on tles summit, and beimg apprelieusive that we wero again to linve bad wertluer, we all joined to gecure tho tents more efrectually against lise antieipated atorn.

The culd, this day, to our fuelings wns intense, nflhough the tenperature wns not lower than $26^{\circ}$. All out exertione is earrying stane for the wall, and violent exercise, conld not keep th wajrm. Dr. Pickering came in, towards dark, half frozen, baving nade the eireuit of the three ernters, which had ocetried him nenrly all day.

THzo two chmometers, will the pendulum clock, and sume of the pendulum apparatus, linit reaches] the top during the day"; and I was rejoiced to fiud, ofl exsminntion and comparisnn with the one I hatd, that two difference of mo hard ret tnken place,

On the 28th the day dawned with fine wenttier, aml comtinued benutifully clear. We wero employerl in taking observations, and the transit was set firuly, to get the passage of the stars: a wall wra alyo built around dhe ubservatory, to protect it fmm the wind.

On the 29ulı we were busy palting up the pers. dulum apparntus, $A$ short time after goon, Dr. Judd ngair joined us with the joyful news that the party from the ship land arrived, witls sixty days" provisions for as many men. I now feit that through our own perseverance we shoull] suceed in abtaining nur wishes, for with this supply we could remain gulficiontly long to effect my object in visiting the mountsin.

At uight, on the $30 \mathrm{dh}$, we hand a risit from the old guide, Kenweehu, the bird-enteher, who gave แa the name of the terminal crnter, as Moku-n. weo-kreo, and of that south of it as Pohakuolianalei. Aecording to his statement, Moku-a-weu-weo emitted firc not long after Couk's visit, and again five years sinee, on the nortis side.
We now erected our pendulum-house, and Treble, the armourer, suceneded in rendering tho bar of the pendulum-irame as good as it was origirially.

The view from the western side of the dinno of Marma Lon was, na we saw it, gurpnssingly grand. In the distatice, the jeland of Mati euserged from and bruke the line of the deep blue horizon, white ita Lower sids wns dinmed by a whitish haze, that scemed to tnite it to the island of Hawaii. "The same haze enveloped the bills of Kiolsala can nux right, and the western extremity of Hawaï. Nuare to us was Ilualalaj, the third great suotin. tain of Hawril, up whose bides a compuset masa of white flecry clouds was impelled by the sea breve. T's onr right rose in bold relief Maunn Ken, covered witl its snowy mantle; and at our feet whs spread out, between the three great moun. tains, the black plain of lasn, overhung ly a dusky pall of clonds. All these features were su bletuled thto each other by the misl, as to exhilit a torse of harmony that could hardly be coneeived, consider. ing the variety of the forms, chnrneters, and distances of the ohjects, amt which seesued to blesd earth, sen, aul sky into one. I can never hopo agnin ta witnegs so subline a scene, to gaze wh which exeited ancin feclings that I felt relicved whes 1 turned from it to engage in the duties that lati ealleil me to the spot.

It whs not without one nerwous excitenent that I placed my instrument on the highest puint of Mnuna Lnn, wilhin a few feet of its crater, and turned it ufon Mauns Kea, to treasure the difference in the height of these twin gianty of the Pacific.

The very ides of stanting on the summit of one of tho lighest peaks in the midse of this rast ocean, in cluse proximity to a precipice of profound depth, overlanging an immense crater "outrageous a a sen," witl molten rork, would latre leen exciting even to a strong man; but the acnation was overpoweriug to one already exhanated by breathing the rarefied air, and toiling over the lava which this limge caldron must have vomited forth in qunntities sufficiont to furm a dome sixty miles in diameter, atul tenrly three miles in leeight.

I was still in doukt which mountrin [ shou]d find the highest; for although provious measurements tand given it in fapour of Mana kea, yet I lind Cousu Mauna Toa nbout threo hundred feet higher dins it had buen reported to he. Double the zenith angle was soon obtained, and decided it in favour of Mruta Ken, and subseguert calculation gave one ense of it us ono hundred and ninety-three feet atumve the flace where I stond. Alihough twin mountains, they are of very different ehuracter. Mauma Ken is a rast monnd topperl with cones, aine in umuber, whilst Mauns Loa is th smontli dome. Da the former the frosts of winter prevail, while the latter has internal fires, nud occosionally vomits forth its lava to the very proint where the other begins to rise, covering its broad flanks with layers of rocks.

When day broke, on the 13th Janusy, all was Justle on the aumuit of Matma Lon. Every one was engaged in taking down aud packirg up the instruments and equipuge, londed with which the native labowrers scampered off. Some of them, indeed, unable to bear the cold any longer, and hoping to obtain londo afterwards, withdrew without burdens, 
At nine otelock, Dr, Judd, nyyself, and six of the crew of the Yincesmes, bade adien to the wnlted ril, lage we hat built. The nen slinwed their delight at quitting this barren and desolate spot by three hearty elueers.

Previons to our departure, I had the worda "Pendulum Peak, January, 1841," eut in the hava witlin our village. J. G. Clarke, one of the seanen belonging to the Pineennes, why made these marks came to me aud desired, on the part of the men, that 1 would allow them to ndd to it U. S. Ex. Ex., in orderthat there might be no mistake as to who lind been thero; to this I readily gavo my consent. This was the same man who had been wommled at Mnlinto, and one of the best and most useful we hat with ng; in hirnself he muited many employments, as a seaman, drumuer, fifer, cook, and stome-cutter; knew a little of pligsic, aning a good sallor'b song, and was withal a proet!

The wirut when we set out, blew very strong front the soutl-weat, nnd thurries of strow wero passing by every few minules. In two lours we reached the lkecruiling Station, where twe fonnd Lieutenunt Ahten aud many linukas on thejr way up. After a rest of two hours, and cibtnining new slioes, we weit on and renclied the Sunday Station at live o'clack, scurtely nble to drug one font after the otlier. Ilere we were sron envolofied in mist, and foumd the soft and delightitul temperature of spring. I cannot venture to deseribe the effect this produced ous us after ota three weeks' sojourn on the cold, bleak, and barren summit. I fejt [or the first time is my lifo frity broken town, nud almost past the soothing effects of the tommi-lonimi, which the uatives at onco offered 15 a relief to me: it may be called a lesacr shampooing, and consiata, as practised in tho Sandwich Islaude, of a gentle kueading of the linuls, which las a great teadency to restine the circulation, and reln $\mathrm{x}$ the muscles and joints. The natives uge it for rheumatim, hendarle, and all kinds of pains. It requires same skill to do it well, and there is the greatest diffur. enee in the perfumance between persons wlo sro practised in it and those who aro not. The cluiefs gefierally lave two persono employed at the sarue time. We soon had $n$ good fire made before our Hawaitan hut; its warmth, together with an exeellent sapper, made us comfortnble, and we were soom asleetr on the dried grrasis.

The next morting, when I awoke, all nature seened to the mlire: the songs of the bimls, the elieerful voices of the nativen, were delightful; the green foliage gave every thing an air of spring. We were so stiff as acurcely 10 be able to move, which was all that now remined to renind us of the secrese we had left, nud tive fatiguts we had undergone. When we again set ofr, it was amusing to ace the whole parly moving along with their atift and nehing limba, trying to appestr lut litto fatigued. At twelvo welock wo reached the station where wo had absudoned our chnirs, and I never was Inore relieved llinn whon I reaclied mine, for I was qiuite umnble so walk any further. Here, also, we were met by the natives with fruit; indeed, every atep we took beemed to be restoring us to the comforts of life.

\section{CHAPTER XXIX.}

\section{HAWAIIAN GROUP, OR SANDWICH ISLANDS-(CONCILUED).}

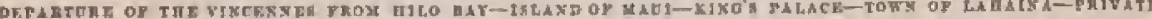
A

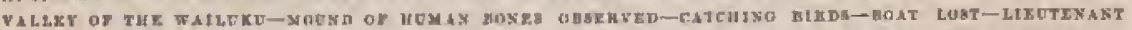

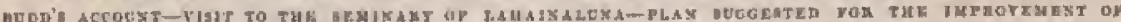

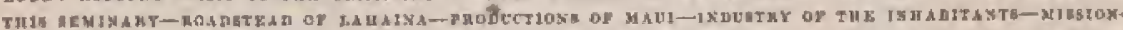

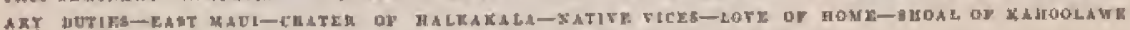

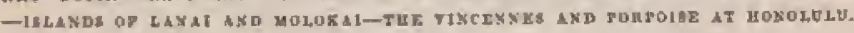

Br the 15th of February, 1B4l, I found that my long detention at Itilo would pilate it ont of my power to visit the Marquess. Islande, as I lad intended. I therefore deternined, before return. ing to Onhu, to paes a short time at Maui ; and ns we had exlinuated the field of resental on Hawaii, I gave arder to Measra. Pickering, Dimyton, and Brnekenrilge, to take pasage thither iil a small vegset, in order that they might have a longer time to explore that islard. Dr. Judd took passage in the parne vessel, to return to Oahu. On the bilt of March, we sueceeded in getting to sea.

The longitude of Traiaken Bay was found to be $156^{\circ} 3^{\prime} \mathrm{W}$., latitude $19^{\circ} 43^{\prime} 5 \mathrm{l}^{\prime \prime} \mathrm{N}$.

The afterinon was fine and tho snowy peak of

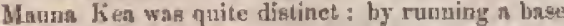
line with the protent log, and obtaining the requisite angles, we made its height thirteen thousand six hundred and fifty-six fect.
At triduight, being nefoly ap with Kahnolawe, we bove-to, to await daylight, as I wished to look for a shosi that wag supposed to exist off its southeru end. I ponsed within two and a hall miles of that goint, and bad nothing less than goven and a yuarter fathoms water. By half-past nine we hal entirely lost the trudes, owing to the tiots land, amul, after being beenimed for an hour, we trok a light ech-brecze Irom the south-wost, which sluwly bruoght us to nn anchurnge in Latraina Roads, abrenst of the king's palace.

Tho island of Maui is disiled intu twa oval. shaped peninsulas, connected by a low isthmu, only a few feet higher than the beach. Alstongh on i first view the peninsuls resetnble ench other, on closer exaruination they are fousd to be rery different. Enst Mavi is the largest of the two, and rises in one unbroken montain ten thousand fiet in elevation, which fnlls nlmost perpendieularly 
towards the вen. West Mari hns many sharp peaks and ridges, which are divided by deep valleys, and which in lesecnding townrds the sen open out and form sloping julains on the north snd south sides of considerable extent:- The highest peak of West Maui was found, by triangulation, to be six thousand one humblred and turirty feet.

An oflicer was at once despateled to wait upon the king, who signtified his'desire to sce mo in the aftertoon. I aceordingly had the homour of waiting in him, and was received with great warmth and kindness. I paid lim a long visit, in which the ennversation tumed principally on the business of lis islands.

The king's palnce is built of cornl rock, and is anly half finisherl: it nlready secmis to be its a somewhat dilajidated stnte, nud exhibits poverty ruther than regal niagriticence. I could wos bui feel that too little attention had been given to bis household by those who have hind the management of his affiairs. I regretted to see that any change, except for the better, lad leet effected in the native style of accomnodation. His present residence is neither calculated to maintain the respect of his subjects, nor to enhance his importance in the byes of foreigners. I sm wedl aware that ims. provements are going on nesr to and connected with the aituation his house oceupies, but I beliove that these could all have been longt sinco finished, had yroper exertions been made.

The town of Lalsaina is buils along the beach for a distance of three-quarters of a mile: it is principally tomposel of grass-houses, situnted as near the beacls as possible: it lins one principal street, with a few othurs running it riglit angles. After the king's palace, the fort is the most conspicnous object: its form is qualratogulnr, the lungest side facing the sea : it is of little aceount, lwowever, as a defenes, serving chiefly to confine unruly suljects arwh sailors in. The area within is about one acre, and the walla are twenty feet ligh. By the observations which I made lere, it is situnted in longitude $15 t^{\circ} 41^{\prime} \mathrm{W}$, hatitude $20^{\circ} 51^{\prime} 6 t^{\prime \prime} \mathrm{N}$.

1 had the pleasure of receiving his majesty on bonrd, with suitable bonours, aceompanied hy hio suite. Thloy mude a very reapectable appenrunce; and altiough what I liad alrendy soen of the king lund greatly prepossessed the in his favour, a risit which 1 paid him before my departure tended greatly to inerease tho interest 1 felt for hit wel. fare. Instead of heing reecived in the ditapiclated and half-finished palace, I was ushered over a mon?l causeway to a stsort distance lehind it, into lis private apartmente, and intridnced to his wife, whis lad been very unwell. She is not acknow. lesiged as queen. She is the daughter of an inferior chitef on tho island of Hawaii, and the pretiest woman on the island. The king, it is believed, married her from affection, and agninst the wishes of his chiefs, nfter they had prohilited lis marriage witl, his sister Nalienaena. In order to prevernt any dispute in the suecession to the llorone, it was formerly deemed necessary that the king should take all the women of the highest rank ss live wives, and all the ehildren born of them were declared and considered as lis heirs.

The present kiug is said to be the natural son of Karmebamelsa I., and became, from political causes, lieir to the clirone.

Alter crosaing the causeway we reached a srial! island: on this was a griss-house of modemte dimenaions, surrounded by hibiscus trees, which grow quite tow, and made a bower almust inpervious to the sur's rays. At the entrance of the bouse I was met by lis majesty, dressed in a roundabout of blue eloth, and white pantaloons. He led the way into the bower, in the centre of which his wife was lying in a elean white hammoele, suspeniled between the trees. Every thing about her was pleasant-lwoking, betokening care and attention to her comfort, and a degree of refinement I little expeeted to see. Althungh nnwell, she showed many marks of besuty, ant I was much struck with her appenrnnee.

The king told me tlieso were lheir private apartments, whore they could remain undisturbed and free from intrusion. They prased most of their time togelicer, and he pointed out a amall liut of ti-leaves that he lad constricted for her, in which she bad been lying of new-mown grass. The king pointed out the improvements he has in entenplation, but complnined that he had not momey to eatry them on. Although his ineome is very considerable, in tnpas and native prodnee, aud would lare constitnted great wealth in former times, ye from the deprecintion in the value of these articleg, it is now of litcle value. He has so many hangersou, that it takes n large amounc to mipply, ninitnthis, and clothe them, even in the ordinary gar. menta of the ishud. These eircumstunces leave the king quito as paor as nuy of his subjects.

The litle domestic scene I lad witnessed gare me great plensure, the more so from theing çuite unexpected; and I found afterwards that very few are ever admitted to this sanetun sanctorum. I take pleasure in mentioning it, as I had not before given his majesty eredit fur the domestic virtnes, which I am now satisfied lie prossesses to a grent degree, both from the tenor of his cunversation and Uhe plensing picture he exhibited in the last interview I had with him.

His wife is mucl fairer than the natives asually, and she has not so corarse atrd disproportionate a figure as seems charneteristic of the fenrales of distinction in theso is]nuds. Her fentures, however, were decirledly of the untive cluaracter. The tone of voice wns pleasing and lalylike.

Wisloing to inspect the female seruinary of Wailuku, which I thad heard much syoken of, I west over to it, in company witl Mr. Drayten. One of the ehiofs was obliging enough to inrnish me with a linso for the occasion.

The seminary of Wailuku consista of an extensive ringe of corrl and adobe buildings, benutifully situated on an inclined plane, with figh and massive precipices behuthd, in a fluurishing village, which Alows more of sybtemutic improvenent nad organized exertion thans any place I lave met with in the Iswailan islands. Thie fields, also, are betier feneed, and the crops mnare diligently attenderl to. We were kindly received by the Rev. Mr. Grevenc, his lady, aud Mise Opden, who have tlıe ehnrge of the establishment, which consists of eighty sebolnts, botween the agea of twelve and eightien years. Every opportunity was afforded me of inspecting the establishment, and while I found moch to commend, there were muny things I could have desired tis see clianged.

In the first place, I was much struek with the appeacance of a want of eleanlincss in the dresses 
of the scholars, contrasting so unfarourably with the neatness and cleanliness of the rest of the establishment. Neither can it be expected that lley shauld imbibe cleanly latits, or bo able to freserve them, when they are allowed to went their elatises unchanged from the beginning to the end of the week. The dress consists of the usual loose gown adopted in the islands, and in which these children are allowed to sleep. Ou Suturday they wasly, and on Sunday make tleir appearance in a white cotton smock, shawl, aud bonset, the luster of their own manufacture. Their dormitory is a long ndube building, with wulle two feet thick, diviled into eornpartments twelve feet by ten, eacls of which accommodater three scholar. More than hatf of this squace is accupied by sheir bed, which is mode of mats lais on a bank of ti-leaves, or sugar-esne, about two fect thick, wilh a small pillow of about tiglıt inclies soluare. What elothes they had woro bung u[, in the corners, and a seanty sujply they appeared to be. Folles of tapa were faid on the mats, which serve to eover them at night. Tho only ventilation was through a simall syindow and the top part of the partition-wall, which was left open. I pasned into several of these small rooms, all of which load a musty smell, ns of leenyed or mouldy vegetable matter. It was no longer a subject of surpriso to me that the establishruent had obtained the namo of being usihenlthy, or that several of the girls had diod ?

While Mr. Greene gives the scholnrs instruction in the various departinents of education, Miss Ogden teaches them all kinds of useful employ. ments, stch as spinuing, weaving, knitting, sewing, quilting, millinery, sc. She has, also, the euperintendenec of their entillg mpartment, and no place could be better ammonired than this part of the estublishment: every thing lins a useful pur. pose, and one readily soes the practical operation of all that is doing. I had the pleasure of seeing the scinolurs at their meals, where all was regulated and weut accoriling to rule: those who were aypointed to " wash qp" kept their places while the rest left the table. I"hey made a better appenrance at their moraing menl than they had done on the day of our arrival, wouring now nea white capes; but I still esw the same frock.s. I do not, however, wish to give the iden that they are not in realiry clean: they are so beyond a doulst, as I understood they loathed almost every day; but they did sut book tidy. Miss Ogden took lier place at a small table, whenee she was easbleil to overtsuts the whole. Their frod is that of the eountry, consisting principally of gone and fiab, and they ure oceasionally indulgerl with mularsete.

Dithis and walkingogrounils are prepared for them, whero they enn take exereize. The a vowed object of this establiahment is to educate the daughters of Hnwnii as wives for the young men who are educated at Lihhniualuma. They are fed and elothed by the Missionary Society, and it is proposed that they shall remain at the establishment until they be marvied.

One courtship lins already taken place by letters; and I was informed these were the first lowelotters that had ever been written in this group. I was

- I have alnce understood that this defeet has beer remedied, the seholars having been grorlded will bedsteanls and beddiag, and that no edses of sickness hare alnoe oc eurred. extremely degirous of obtanining the originala or copies, but was not successful. The cortempondence appears to have been carried on under the eye of the missionaries, and the expressions they contained were very common-place.

This whole establishment does great credit to those who are engaged in rearing it up, on account of the method and perseverence with which it is carried on. It is extromely gratifying to see efforts of this kind nado, but 1 eaunot help dumbt. ing the policy of not allowing any of the burden of it fall upon the natives themselves (the parents). The only argument adranced in justification of this course, was the rather unsatiafhetory one, that these people cannot naderstand and appreeiate sufficiently the advantages, to be persunded to contribute to the edueation of their ehildren.. As far as my own observations went, I believe this to be an crror: As long as the children are educated and maintained gratis, tho natives will never make any exertions to furuish the means. Somo of the natives said to me, on my making inquiry why their children were not at the seminary, that they could not get then there, for all thuse admitted were selected by the missiunaries, and there are go other means of tnition; they also adled, that they would be willing to contribute a few dollars for the education of their children, if allowed.

Thte greatest objection to the syrtem of this sebool, in noy opinion, is that the ptupils are not thken at an earlior nge, and lofore their habits are ju any way formed, and that it is attempted to educate then exelusively for civilized lifo as it now is. Taken at ton nilvineed an nge, they linvo senreely an opportunity of forgetting the life of ense they led while in their savage state; nod tum Jyeir early impressions remaining btill uneradiented, they return almost as sodn ns they leave the sehool to their savage state, fonding it more easy than to keep ap their partially cirilized labits; wheress, if they were taken very young, and put under a course of discipline that would make their improvement permancont, and were, besider, isught the way of maintaining theluselves as they now are, by useful emplingmest, they would not be so likely to relape into their former liabits, or adont those of their jarents. I lave litle doubt, that such a course wonld be a great means of reforming many of thejr parents, as far as they are susceptible of reformstion; for the relation between prrents and children is allogether different witl, shem from what it is among us, parents being invariably under the control of the children, after the latter have grown up.

The plas of tuking the cluildren, as is done, from the dregs of the watives, is, I think, another mistake. The bigher orders in a tronurehiul systom of gavernutent ouglit to be unore earefully instrueted thin the others. This principle is admitted by the establishment of the chiefs' seliool at Howolulu, and I see no reason why it should noe equally mpply to the children of the petty shiefs, or second class. I atm, indecd, satisfied that greater surastages would be derived from euch a course, and the sehool would, in this way, beeome more propular. Pawents of this rank would, also, be enabled to assist in ita maintemanee, and tho buwer orders, ns elsewhere, would juitate the lisgher.

1 must do full justice to the good fare and kind 
attentions of Mrs Greene; and from the appenrance of the supper-tuble, I could reaclily have believerl myself in New Englnnd itustend of the Hawailan Islauds.

Eurly the next morning, Mr. Drnyton and myself wert to breakfast with $\mathrm{Mr}$. Brily and lis wife. He is the assistant missionary at this station, and auperintends the school for boys. It being Saturday, and $\mathrm{n}$ lıoliday, we had not the pleasure of seeing the echolats.

Mr. Baily had provided bountifully for us, and thete was anuple evidence here that this was a land of plenty, to all thuse who exereised ordinary industry,

After breakfast, Mt. Greene wns obliging enongh to secompany us to sec the angar-mills and taro-plantations, in the valley of the Wriluku. The sugar.manufnetory is an experiment of the king, and is now under the superintestence of a Clinese, $\mathbf{3}$ o sorte twkwald nistake in making the agrcement, his majesty's interests were entirely lost sight of, and it is said that lie will lose money, although his agenta liave a prospect of considerable gain. The iron-work of the mill was imported from the United Stateg, nnt is turned by water. power. The water-wheel is batly constructed : it is a Lreast-wheol, witli great Joss of power.

There appears bat littlo economy about the establishment : as an instance of this, instend of drying and preparing the cane for fuel, they uso woud altogether, which is rery scarce, ind costs nuch to transport it. The sugar appears to be of good çuality, and with proper altentivn, the munufueture enuld no doubt be made profitable. I unalerstood from the Chinese who had charge, that the sugnt condl be solu at four cents per pound, and that with a proper economy as w fuel, night be reduced to lialf that sum.

Botls the king and eliefs linve a desire to enconrage the arts and agriculture. Unfortusately, however, after they have incurred expenses, they are obliged to give the sole dircetion into the hand of those who have nothing but their own interests in view. The congequence is, that in all these undertukings the king and chiefs have finnd themselwes deeoived, by listening to foreignors by whom they lave been defaruded.

We now rode down the valley among the taropatches, and over to the Sand-Iills; where was a mound of human bones, - a perfect Golgotha, There appenrs to be no tradition respecting this accumulation of mortal relicg. By some it is suppused to have been a burying place after a battle, for the place where they were found wats linown to be a battle-ground. Hloody contests, inleed, nust have taken place here, if we are to judge from the number of skeletrons which aro exposed. Some of these are in a state of perfect preservatiun, and I regretted not being able to tmansport vne to the slip.

Noar slis glace we anw several boys anxinusly watehing some objeet, and on getting nenr them, found they were emplowed in critching birds. This Wus dune by baiting sniall sticks, to which a string was tied, anil the other end of the string fastened tn s suall Btone: the bird swallows the stick along with the bait, and in attemptisig to Ay off, it pierees lis throat, and ho is thus secured.

After riding around these plains we returned to Wailukn, where we partook of a sumptuous lunel, and parted under a feeling of obligation for the kind attentions we had receired, and the tokens of remembmuce from the selsolnis. Wo reached Lalatina before dark, after a fatiguilig ride.

On our why I heard a rumour thint one of the bonts hart been lost, whivh made me anxious to get on board as soon as possible. I lad been flater. ing myself that from dangers of this hind we sere, nat lenst for the present, exenyt; lut the report proved too true. Previous to kearing Lahaitra I had despatched Lieatennat Budd, with PassetMidslipmenan May, in clunge of two Loats, and it was to one of these thint the accident ocenrred. Lieuterant Budd gave the following account of it.

At ten v'clock, wn the Sth of March, they left the shiy, when it was blowiug a moderate breere, and steered for the south point of linbulnwe. After they had proceeded some distance in their way, it fell ealsn for a short time, and then the trade-wind set in strong from the nurthward and eastward, and sonn increased to a stiff gale, the aea rising to $a$ clnngerous lweight for the bouts. Just after doubling the point of Kahoolawe, I'assed. Midshipman May, in the Leopard, hailed Licuterant Buld, to report tlat lijs boat was sinking; and funr of the men were perceived to be bnling. Lienternat Budd pulled alongside, and seeing the tuat was settling, ordered the anchor to be droppert, Host of the erew coutinued to bale with tweir lats, whilst the rest passed mut tho nost innortaut articles. A portion of the Loppard's crew, who could not swim, were now ordered to get into the Greyhound; Lieutenamt Budd intending ta land them and retura for those ou the wreck. The men who were thus left said that the bont was drifting to sea, and wished to be taken oft; but this wonld lave endangered the lives of all. Iassed-Mid. stupman May, pereeiving their unwillingmess to remain, jumped overhonrd and joined them: lis example eneournged them to do their best. Lientemant Burdd sueceeded in as slort $n$ time as posstble in landing the men and muicles from his loat. and then returned. He found the boat sinking fast, and the offiecr and men supporting themselves with the ons. The bont was now turning over and over ns every wave struck her. Mr. Mny sind the rest of the men were taken on bontel, and they then roturned to the slinre, all mueb exhausted. Lieutevant Budk, seeing that the sido of the bont had been stove in by a heary sen, and the impossibility of eaving or being able to repair tlic boat, left lyer to her fate, and tonok such nensures ns the found necessary for the comfort of his men. Lientenant Build deserves much credit for his presenee of mind in preserving the lives of the suen entrusted to him, as well as protecting then afterwards fram unneceskary exposure.

Kaboulawe, the islaud they wero now on, lios to the west of the soulh end of Maui, and is fuurteen miles long by five milns wide. It is uninhabited, except by a few poor fishermen, and is used as a place of exile: at this time, there was one state prisoner contued on it, Licutentant Buda re. turned to the ship on the 15 th.

I visited, in company with some of the officers, the seminary of Latuainaluna, situated on the hill behind the fown, arul about two miles diatast from it. The rond thither was partly made by the pupils of the semisary. We found the students at work along this road, making stone walls. Mnny of them were large boys ot young men. Their 
numle of working was not systematic, aut every otwe appeared to be toing whint lie thuught best: they dicl nut appear to be identified with their work, but seemed tnore like a mbble, Wo were received by the Rev. Mr. Anilrewa, who was kind enougls to show us the whole establishment.

On our approncl, we noticed an mir of neglect, ant particularly in the out-buildings. The garten also was in bad order; indeed, lwothing suoceets well in it, beenuse its situatinn is too ligh for irrigation, which in this climnte is absolutely necessary. The soil is composed of a red clay, which in dry wenther forms a fine dust, covering erery thing, and whieh the daily winuls eontinually raise into clouls. These circurnstances present air obstacle to one of the great objects of the institution, while the scarcity of water prevents the inculestion of halsits of personul cleanliness, of whicls the natives stand in great need.

In all the departnents of this establishment I saw nothisg but ill-directed meass, and a whste of funts thint miglit lave been avoided by proper forethourht, and a fult exsminntion of the subject by pratienl men. T'he setwoul hns phased its meridista, and is twow fast going to decry, a fact. which must strilce erery one on a casual visit. I'he discipline of the seliolars is loose and irregular; they are their own rulers, and make their own lawa: in this respect it tasy be called a republican school. The seluatar act by committees, sud withont the knowletige or consent of their tenchers, in every thing that concerns themselves and their apartmenty, As may be supposed, they are left to settle their owu disputes, and hittle disciphino of any kind exists.

It is easy to point ont the defects in an establistument, lut mueh mort diffieuft to suggest a remedy. "The difticulty is, perbspos, not easily" overeome, but I will nffer one or two plus, which appenrel to me to be feasible, and ealculated to give the nntives a turn towards becoming a justom! as well as au agcicultural people. The pupils should be tauglit the care of calte and the superintendence of flocks, to which purtuit the greater part of the taud of these islands is well adapted. A sufficient inducement might be held out for exertion, by giving them a portius of the inerease of the floeks, that would recompense them for Itseir eare, without inerensing the experses of the society. Above all things, in theit' mantani-labour selools the higher branches should not be trught before the pupila are all well grounded in the luwer unes; for instance, I can conceive of nothiug nore absurd and useless than spending the time of both teachers and schulars in studying Grect, as was proposed. Fortumately for the students, however, they couhl not proceed for want of books. I would not be nuderstoud as throwing any blane on the nissiunaries: thes: aro many ervors commitced and expenseg incurred in eutulueting a miksion, slat ought to he louked at with tnueb charity by Luose who are visiters, as well as by the socitty at home, Even a slight knuwledge of lie situation of things will show how difticult it is for the Bonrl of Missions to judge of the expenses incurred in carrying on their opnerations, and how unwise it is for the managers at home to control their agents, except by sume zeneral rules applicable to their duries. The enployment of persons in whom they have confidence is the best and only security; and if those whs are insested with the fouwer shothli make n wrong ese of it, tho remedy is to rerrute the?m.

Muel discontent has been caned, nud the usefulness of the nissionarien irrpniret, ty the cutstrol which the Bunard of Missions exereises over their conduct. Tho restrictions on the liberty of lise press, anil the extravagasce complinimed of, is not justly clargeable to the evivention; for, eon. stituted as the board is, it is implostible it should be otlerwise, and the effect naturnlly arises from tmplinying an irrespousible body. I nim well satis. fted that harn results to the caume from want of full confidence being extended to thosi who are engaged in these duties.

Lahaina being the great resort of our whalers in these islands, a surrey was made of tho roadsteanl. The chicf resson for resorting to this jalace is, flut tlacir erews are thure easily hey in order, and tave not that temptation to visit the slore that is expericneed at Hunnlulu; besiles, provisions nre in grentur julenty, parlicularly jotatocs, whisel me raisert in aluundance on tho highinuds of Maut.

Lalunina contsine about three tlowsand inhalitants. More order xeigns here than in any other town of the same size I lave seen in Polynesis. This is to be attributed to the intluence exerted by the anthorities, and to the absenee of foreigners, uhd thwir attendant grog obhorn.

The district of Wailuku is composed nf valley and upland. The soil in the furmer is extrenuly rich aus well watered; the uphanil, thlso, produces gaol cropss when suffleient juoisture ein be lad. Potatucs, curn, sugar-cane, aud sweet-potatoes, are the chief prouluets of the wiulward side of the island.

In some places there are extensive woods, the treeg in which aro of large size; but the timber is of litile value, being eitlucr suft and spongy, or hard nnd difficule to work. of the former binds the natives make tlieir canoes.

The district of Kula, on Fast Mani, althougl extremely rougli and rocky, has a loany, rieh, mat productive soil : it produces the fiuess I rish potstoes, turnips, comi, tuelous, and whest. The latter, of an excellent qunlity, is fouts growing wild. It was introduced nbutit twonty years hefore our vikit, planterl, and tot the lenst altention paid to it ; instead, however, of "runaing sht," it lass increased. At Malaca Bay there is gond anclior. age for vessels of any size, and a fine fisllery.

The isthmus is too dry to ba fit for enltivntian: it is in extent abut twenty by fifteen miles. During nine montis of the yen it is a fine grazing coututry, and feeds large herds of enttle, that are nustly wwill loy foreigners.

The pruduction on Mau are the same ns thone of the other islunds: to these may be added a few fruits, as grapes, \& c., but these are not raised in large quantities.

III industry and enterprise, the natives of this island have made but slow priygress, though there is abundant evidence that they possess both, if properly developed. This is blown in their at temptes at cultivation.

Buth at Wiluku and at Jamakualna, the natives have shown much jerseverance atd enterprise in erecting ftone churches. These are built by untive workmen, and their dimensions are one lundred feot in length, hy fifty feet is wialdi. Fur 
the construetion of tlut at Huruakualon, they were obliged to bring the stoves, lime, and sand, on their backs, to the place of building. The lime and sand were brought from a distance of two or throe miles, and the timber was drigged from four to six miles. In putting on the roof, it fell in twice, nfter nearly nll the timbers were up, and broke them to pieces; but they persevered until they land completed the edifice, which will contsin about one thousand people. The whole nmonnt of money laid out was sixteen dollars! At Wailuku the building-gtone used was vesieular lnva.

The fullowing may give some idea of the duties of a unissionary at these islands. T'heir labuurs on the Sabbutls are, a sermon at surise, Sabbathschool at cight o'clock, bermon again at eleven o'clock, Bible-class at une, and lecturo at four. On week-days, going to adjacent villages, lectures, schnols, and visiting the poor and needy, besides acting as physicin for a whole distriet, which alone is a work of no trifling labour.

In Wrilukw, the population is thought to be Hecrensing at the rate of about one humlred and thirty nnually, but no alequate causes are assigned for this diminution. The climate of Mati is lenlthy, and no diseases prevail. Intanticido may be anid not to exist.

I have hefore staterl, that Messrs. Pickering, Drnyton, and Brackenridge were ordered to visit Maui. They lad a long and tedious passage, and instead of reaching Maui in a few hưrs, as they had expected, they were several disys, owing to a strong nouth-west gale blowing. By this they were obliged to take shelter under the lee on the unrth side of Mani, where Dr. Judd and Mr. Drayton lauded, for the purpose of passing overland to Lahaina.

The north coast of East Maui is a succession of deep ravines, whicl gradually diminisls in breadth as they aseend, and are finally lost on the flanks of the suoustains: travelliug along the coast, is consequence, beennes almost impossible. Cascades are seen falling in these ravines several hundred feet in leeight, having little volume of water however.

The face of Mauna Haleakala is somewhat like that of Mauna Ken: it is destitute of trees to the height of absut two thousand feet; then sueceeds a belt of forest, to the height of six thousnnd foet, and again, the summit, which is clelt by a deep gorge, is bare.

During their stay under the lee of the island, the king's schooner sought refuge there alks, Inaving been driven fron the roads of Labaina, where it is impossible to lie during the prevalence of south-west gales, as vessels are then exposod both to the gen and wind.

The party who landed, and the schooner, nrrived about the same time at Labaina, where our gentlemen wero very hindly received by the king and missionaries, THzey forthwith made preparations for a tour to Last Mauj. The Rev. Mr. Andrews, his sol, and four students of the semisnary, joined the party, together witl six lisnakas to estry their food. 'The Kanakas were engaged at twenty-five cents a day, and twenty-five cents mure was allowed for their food. The party first passed to Wriluku, where it was further increased by the accession of Mr. Baily.

Crops of Irish potatoes are very productive here; and corn is abundait a thousand feet higher up the mountain.

The next day, the party net out at an early hour, in hopes of resching the sunmit, bit it began to rain violently, in consequence of which they tomok sloblter in a large cave, at an altitude of eight thousand and ninety feet. Here many interesting plants were found, nmong which were two species of pelargonium, one with dark crimson, the other with lilac tlowers; the argyruziphium began to disappear as they ascended, and itg place was taken up by the silky gpecies, which is unly found at high altitudes. From the cave to the summit they found shrubly plauts, consisting of epacris, vaccinum, cdwardsia, composita, and various rubinceous plants.

Ont their arrival at the edge of the crater, on the summit, the clouds were driving witl great velocity through it, and completely concenled its extent. The beight, ag ascertained by the barometer, was ten thousand two lnndred feet. The driving of the sleet befure the strong gnle boun affected the missionaries and native students, the latter of whom, for the hirst time, felt the effects of culd. The limitline of woods. wra ascertained to be at six thonsand tive bundred feet.

The crater of Haleaknla, if so it may be called, is a deep gorge, open at the north and east, furming a kind of elbow: the bottom of it, as ascersained by the barometer, was two thousand seven humbred and eighty-thrce feet below the summit peak, ant two thiusand and ninety-three feet helow the wall. Although its sides are steen, yet a descent is practicable at nlmost any part of it. The inside of the crater was entirely bare of vegetation, and from its botton arose sume large hills of seoria and sasd: Bome of the latter are of an ochre-red colour at the summit, with small cratery in the centre. All bore the ajpearance of volcanic action, but the natives lave no tradition of an eruption. It was said, however, that in former times the dread goddess Pele had her habitation here, but was driven out by the sea, and then took up lier abode on Hawaii, where slie has ever since remained. Can this tegend refer to a time when the voleanoes of Mani were in activity ?

Of the origin of the nnme Mauna Haleakala, or the Ilouse of the Sun, I could not obtain any information. Sorne of the residents thought it might be derived from the sun rising from over it to the people of West Maui, which it does at sume seasons of the year.

Our gentlemen made excursinns to the crnter, and descended into it. The break to the north appears to have been oceasioned thy the violence of volcanic action within. T'hero does noc appear any true lava stream ont the north, but there is a cleft or valley which has a steep flescent: here the soil was found to be of a epongy nature, and many intertsting plants were fuund, among the most remarkable of which was the aborescent geraminum.

The floor of the erater, in the north luranch, is extrumely rough, and about two miles wide at the apex, which extends to the sea. In the minues there is much conspact argillaceous rock, similar to what had been óbserved cu Mauna Ken, retaining, like it, pools of water. The rock, in general, was much Joss absorbent than on the roouratains of Hawaii.

Mr. Draytou made an accurate drawing or plan of the crater, the distanees on which are estimnted, 
lut the many cruss bearings serve to make its relative proportions correct. Perhaps the best idler that eat be given of the size of this eavity, is by the time requisite to make a desecnt into it, being one hour, although the depth is only two thousand feet. The distanee from the middle wo cither opening was upwarls of five miles; that to tho eastward พas filled with a line of bills of scoria, some of them five ot six hundred feet higli; under them was lying a lava strean, that, to apries rance, wus nearly loorizontal, sn gradual was jtg fall.

On their returu to Lahaina, Dr. Pickering and Mr. Brackenridge wok the route through the Wailuku Pasa, as it is called, which with its rocky preaks shouting npwards several hundred feet direetly above shem, reminied them of the deep gorges of Madeita. Some fine plants were eol. leeted, and unexpectedly among the most conspieuous was a woody lobelia, which gave its clanneter to the vegetation. The route did not prove so much shorter as was anticipated, owing to the obliquexdirection of the valley.

It may now perhape bo as well to say a fow words respectiug the operation of foreign opinions upon the natives, who are more prone to take knowledge and adviee from the books that aro cireulated among them, than strungers nre inelined to beliove. Their gambling propensities appear to hase been very difficult tir overeome; yet, from the simple sentence, "Do not gamble" haring been printed in the first books circulated among them, that expresssion has become almost proverbial, and many have in consergtuence been restrained from jorblging in gaming to excess, while sonse have abaudoned the practice altogether.

From the ingquiries I made on the subject of their viees, I am satisfied that these have been much overnted by hoth residents and missionaries, and I fully believe that these natives are as susceptible of correct impressions as any other people.

They appeared to me to be wanting in that nationsl pride which was found a produninant trait in the gronps we had previously visitod. They spenk less of their country than other Polynesians; but Mr. Riehards and $\mathrm{Dr}$. Judd both sasured me that khey felt a ecrtain degree of pride in their re. spective isfunde. $\Lambda \mathrm{s}$ an instanee of this, it was stated to me that the goverument proposing to make the island of Kahoolawe a pluce for conviets, wished to induce the people of the island to guit it; but no persunsiou could prevail on then to da so; and it is said that this feeling has existed to stuch an extent there, that the young women have refused to enarry, unless under a plerlge shat they shall not be required to remove. The people of Hawai consider themadves auperior to thinse of the other iklands; rext to them rank the ratives of Mauj and Onhu, while Kanai is looked upon as the most inferior. It was likewise thentioned that some individuals have come forward to ask to excluange plots that had been assigned to them, for those on which their fathers had residod, or where they were bort.

I was much amused to hear that when one of the teachers of the semuinary gave out to the elass as a theme, "Whether it was right for parents to give away their clikdren t" all belotiging to it took the aftimnative side! It is not to be supposed that their ressons were very strong, but it was said the principal one urged was the difticulty of travedling witl thers, and proeuring fued; this fractice having prevailed from time inmemorial, they no doubt endeavoured to find reasons tu justify it.

In the opinion of a native, the most distant relationship or connexion, justifies him in calling on and receiving entertainment. They not only consider that they have a right tn partake of the hospitality, but spesk of it us a great cosvenience; so that in eloosing a wife or busband, me who lass ruany relations is a more desirable mateh on this secount than one who has few. This custon alko cnuses move intercourse between the islnuds than would otherwise take place, and their snull vessels seldom pass from one to the other, without being well filled with passengers.

Among the visits I paid at Lahaina, was one to tlie regent Kekaulnohi, who receives visiters during certnin hours of the day. She lives in a grass-hut nenr the water, and has severnl chiofs in actend. ance on her : she appcars to be a good-natured and eortented person, and has adopted some foreign custons in her way of living. She is not spolsen of as being equal to her sister, Kanhumanu or Kinau.

It has been mentioned, that on our passage from Hilo we liad rot found the stroal sail to exist off Kahoolawe. Reeciving authentic infumation that it really existed, I determined to send two boats, uraler the command of Lieutenant Ludd and PassedMidshipman May, to seck for and examine it. The king, learning my intentions, volunteered to send his yacht along with them. The ynclit and boats set out on this expedition, on the $17 \mathrm{th}$ of March, witls a pilot who know tho grvumd.

On the mame day wo tuok leave of our kint friends, and at noon got under way and stood for Kahoolawe, to piek tip the boats under Lieutenant Budd. Owing to tlse light wind, we did not succeed in reaching the point till late, where we found the king's selwoner and the two boats about to enter upon the examimation. We, therefore, lowered all the boats and sent them to search for the slusal. It was soon found, and proved to be much nearer the point of the island thn was anticipated. It lies a snile and a laslf off the print, and has one and at Jalf fathoms of water on it. We fixed learings, by noting which, it may be aroided. Vessels may pass within two miles of the point with anfoty; but as it is difficult to estinate the distance, it will be better to pass the point at three milog distance, as nothing is lest by so doing. It is renarkable, that this is the only shoal around the Hawaitn Islands that is hidden from the nuvigator; and even this is situated so near the laud that it ean senreely be dewmed datigerous.

At nime o'ctock, we thok up the honts and bore away for Onhu. Passing to the Bouthward of Lanai, though at the distance of twenty miles, we felt the effects of its highlands upon the winds.

Lanai in a dome-shinped island, and appears to have been frequently rent, large fissurea being apparent on its sides. It is exclusively of volcutic formation.

ARer passing Lanai, I hauled up for Molokni, intending, ns the day was far adranced, to lio under the lee of that istand for the night. Molokai is about forty miles long and nise miles in wirth. One-third of the island, towards the western end, is a barren waste, nut susceptible of cultivation, ex- 
cept in the miny scason; it has in consequence few inhahitunts, who are engaged mostly it fisłing. The ensterts two-thirds are almost one entire mmintain, rising gradually from the south, until it attaius an elevation of two thousand five hundted feet; while on the north, it is almost perpendieular.

On the sontl side, it has a narrow strip of land, not exceeding one-fnarth of a mile in whikls, the suil of which is very rich, and which contains the greater part of the population. Owing to the want of noisture, hnwever, few planta will thrive even here; resont is thercfore had to the uplnuly, which noe furnd to be susceptible of the higliest degree of cultivation.

The amount of arable land, or that sukceptibte of cultivation, is believed by the missionn rieg to be one-\{ourth; but I should be inclined to reduce it tu one-eighth, from the report of olturs, and my own observations. Only about one-tenth of this is cultirnted.

The population of the island was repnrted ne fire thousand, in 1840; eight years prior, is 1832, it was six thousand: during this tinie, five hundred marriage日 took place. The data has shown, that the births much execed the denths; and the decrense is attributed to emigration, which las becn going on for some time. The inhabitatsts are all poor, nud their pustor, the Rov. Mr. Hitclicock, tusserts, that there are not ten individtals on the island who have entufortable clothing, and sufticient firod; and lie adils, thint theto has been no injurovement in their dwelling for the tast ten years.

The schools on this island nre littie more than n name; fur they have ueither regular tenclyers nor achool-houses, One thousand scholars are anid to be embodied in them.

The island luns been oceupied as a missifunary striton stince 1832, abl the church contnins about three hunitred nombers.

There are geveral sumall harbotirs within the reef, on the south side, at Kalunaha, the missiorary station, which are capable of affording shelter for vessels of from sixty to eighty tons.

On the 18th, we suchored off Honolulu, at an early hour, alliough too late to enter. The appesrnnco of the ialand was auch more fertile, now that the winter had passed. There being no letters from home, was a disaprointment to us all. Wo were sgain warmaly welersased by our friends and eotsutromen.

On the 10th, we went in and anchored in the outer harbour, where on the $23 \mathrm{rd}$ wo were joined by tho Porpoise.

\section{CHAPTER XXX.}

\section{PAUMOTU GROUP AND PENRHYN ISIAND.}

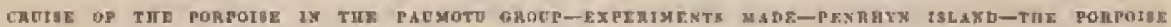

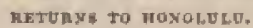

ТлЕ disposition that was intended tn be made of the P'orpoive during the winter nonths, las been melltioned in a preceeling eliniter; an aceount of her proceedings in the prosecution of the dutice assignerl ta her, will now be given.

On the 15th November, 18te, as has been lefore stated, she left Oalu. In addition to her erew, a number of liaralias were shippued for the purpose of beitug employed, under the direction of an officer, on onia of the cotal islands, to bore through the corsil rack.

"ltho first shoal senrehed for was that of Manuel 1hulriguer : its supposed locality, in longitude $163^{\circ}$ $54^{\circ} W_{-,}$and latitule $10^{\circ} 68^{\prime} \mathrm{N}_{2,}$ war passed orer, Ami no indieations whatever of if were seen.

On the llth Deceuslyer, they made the island of Marliti, of the Paumotr Group, and shartly nfter, thite of Ahii, or Peneotk lalnd,

On the 13th, they misdo Llie Rurick Clinin.

On the 15th they reached Aratica, or Curshofi Isinnd, on which Lieutenant-Commoudaut Ringgold lin! detertsined to land the party intended in experineut in boring, consisting of fifteen men, ander Lieutenant Johnson, among whon were nine linuakas and three seamen, the nrmutrer with bis furge", atud a carpenter. Lietstennat Jolnsson wss put in charge of the party to cotudut the experiinents.

By the 18th, they bal succeded in completing all the arrangernents, when the brig left them to pursuo her eruise for thirty or fiaty days th the wind ward jurt of the gromp?

On the ifth, they mande Vinconnes and Raratin Islnumls.

Ons tho 20th, they made Snken Island, which proved low, with but a few trees on it: the grester part of the istand is a necf.

The next day they were wp with the three small islancls to the Bouthward of Saker, which they liarl been directed tis look for and survey. LientestantComminulant Ringgold found and surveyed then, ant designated the eluster as the Sen-Gull Gronp; while to the three islauda he gave the names of Fassed-Midshipmant Reid and Bacon, antl QuarterMarter Clute. Reid Island proved to be inhabited, and the brig was boarded from it by two canoess. These contained funl matives, besides a toothless uld man ealling himsedf a missionary, who readily consented tis remain for the uight on bonrd. The Tahitians on board had to difficulty in understanding them.

On the 22ud, severnl of the oflicers visited Reid Jeland. Its population consisted of about twontyfive men, women, and children, among whom was the danghter of the old chief, considered by our officers as a very bentifisl pirl, with fue figure, exprescive eotutenance, and long silky hair: sho was sprightly, but I rogret wo eny, tas conered with vermin. This oliduren were fat and clubby",

Lieutensut-Cornnumdant Ringgold, having finish- 
ed all the necessary observations, proceeded, on the 23rk, in senret of some islands to the eastwarl, On the 26 th they made the island of Ruroia, or Barclay to Tolly, and passed close to it. The position assigted tis it on the churts proved to be entrect.

On the 27 th, they made Takurea, or Wolconoky, with Raroin in sight to the sontluward: there is a massage hetween them acven miles wide. The former, Wulconsky, is of an oblong shane, ten miles in circumferenee : its north end is high and thickly wooled with coeon-nut groves and other trees: its eastern boundury is pnrtly a submerted reef. There is no opening to its lagonis. It was found to be incorrectly plneed on the eharts.

"The search nftex Camboy's and Merril Islands proved unsurecesful. The position ascigned to then, longitude $141^{\circ} \mathrm{W}_{\text {, latitude }} 10^{\circ} 13^{\prime} \mathrm{S}$. having been cruised over without any appearance whutever of land.

On the sth January, 1841 , they passed nenr Thweree, or Resolution Istand, but found there was too much surf to land upon it. There were about twenty inlabitants, who, on the approneh of the brig, eamo ruming to the bescli will encos-nuts to birter. 'They appeared to be stout men, and were thought to reseublo the natives seen at Clermont de Tomnerre.

Tawereo consists of two small is/es, together about four miles in circumference : it has three clumipe of encos-nut trees upen it, but of itg south nnt west sides the greater portion is a bare reef. After surveying it, they bore un, for the two groupg, and the saute fifteraoon passed through the ehtanel between then, which is a mile wide, with no soum iugs. Tho southern islund was surveyed: it has a bare reef on its bouth-enst aud west sides, with a cocos-nut grove on the soutl end. Na entrance exists to the lagoon, and no matives were seen. The southern portion of the norlhers isle is a bnre reef, with some high clumps of trocs ou the eastern side.

Cin the Gib, Nukutipipi or Margaret's Is]and was made. It proved to lse a small round lagoot ishand, two railes in circusterence, high and wellwooded on the north side, with in tlat smbnerged reef on the south-east and enst gidue. After completing the observations, they stoon for Teliu or the Four Crown of Quiros, the island to the westward: it lias now five clumps of treer. It had no opening to its lagoon, nor could a landing be effected. No trices of inhabitants were seen on either of the islands.

On the J0th, Licutenant-Corumandant Ringgold made what they supposed to be the island of Arch. angel, but very much out of pluce. It is a sual lagoon island, of oblong shape, Jying uorth.west and south-enst; woolerl on the torth-east and east with a stunted gruwth of trees. No cueoa.nut trees wero seen, and the mstern portion of the trees appeared as if burnt. A reef extends off the northWest and gouth-west sideg, with a leery gurf, and there is a subuerged reef on the south and west fides. No mening exists, and a landing cannot be effected without imminent danger to tlit boats. It native sume is Herctua.

"The supposen location of Arehangel was then senrehed for, but no signs of lasnd found. Turubuil 1sland way also louked for without success.

On the 12th, they make the island of San Pablo,

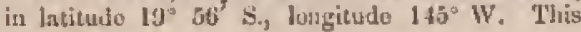

island is higher tlan those just mentowed: it has several cacon-fut groves, and ntives were secll on the island. No opening was observed into its lagoon.

After searehing around this locality for ather islands, the I'orpoiso steered to the northward, for the island of Aratica (Curlshofs). On the 15th they made the istund of Tahnnes : jts south end is a bare reef, but there are trees on the east and west sides, Fireg were scen after dark on the island. This, like all the other islands, has small islets around it, connected by low coral reefis, and waslied by the ses in sereml places.

Passing in sight of Saken, Rurnka, and Taiarn, they mado Arntica on the 18th, where they fund the party all well, and at once began to embark them, which was cumpleted on the listh. The Por. poise then bore away for Tahiti, two hundred and fifty miles distant, whicl they ande on the 21st, nud the same day they anchored in Matuvai Bay.

At the time the brig left lim, Lieutennnt Johnson lad eucceeded in thaking a beginning with the apparatus. Cunsidering the novelty of the businesa, and that all were unacquainted with the uses of the different parts of the machinery, $J$ was aware of the difficulty of the task that would be improsed upon the officer who directed the operation. I bad therefore designated Lieuteunat Johuson for this business, who, on decount of his jugenuity, persererance, and mechanieal contrivance, was considered by me as nust suitable for this daty. The undertaking proved fully as laborions as I liad aciticipated, and Liculenant Johngan's exertions werc worthy of better stecesis. The principal difficulties he had to encounter were the looseness of the soud, and the falling in of the ommal stones. Every mears were devised to overcome these impediments, but in the sttempts the pipes became cluked, broke, anil were thrown out of the perpendicular. When the impedimente in one place were found to be too great to be overcome, it was nlandoned, and the work began anew. The greatost depth to which he suceeeded in reaching was twenty-one fect: ten to eleven feot were geswrally reeonplished without much diffieuly; but after that depth was arrived at, they frequently did not succeed in gething down beyond one foot per iny.

The coral shelf, compased of conglomerates aud compact coral rock, secoms to have afforded an im. pediment to further progress. After the breaking of pizes and augert, and the nccurrence of variuus other accidents, principally from the impossibility of mintaining a yerpendieular ; Lieutenant Johnson begnn from his acquired exprerience to hoje for sucecss $\mathrm{n}$ day or two previuus to the arrival of tho brig, when the whole was abandmed by order of Lifusenant-Commondant Riruggold, and every thisg "mbarked, I $\mathrm{nm}$ well entistied that there is no iusulverable difficulty in buring into coral islands : but ju the jresent case the season of tho year was somowhat agsinst them, as it caused them to uncounter much nore water in the soil thas they would otherwise have met with. The proper season for such nn attempt would the the dry one. Much rail foll during their stuy ; and altbough no terinus sickness oecurred, yet many felt unwell.

These experiments turned ont very much as I anticipated, viz. that we should fiud but litue 
enral sand, and an сес⿰⿻上丨⿶凵人al stratum of eoral rock. Since my returts, I have aecen the results of a similar experiment made by Captain Belcher, on anotluer island, (Hau or Bow [Bland, in the same group. They are ldentical with ours.

Among nther duties askigned Lieutenant Jolinson were tithal uhservationa, wlich wero contisured uniuterruptully, from the 19hl of December, 1940 , till his departure from the island; buk unfortunatcly, the tide-stafi was placed in the lagoon, a place not free frum objections, becange the tide there has but a amall rise and fall, and is much influenced by the wind, that blows the water over the reef, giving less tide and a longer outflowing there; but the flood wat distinctly yeen, by Llextonant Johnson, during a fiohing excursion at the entrance of the lagoon, to flow in rapidly; and the higls tide was correct, for the water on the reef was two feet or more in depth. The record of these observations gives the high water at the full and clinnge of the moon at six o'clock: the rise and fall in the lagoon eight inches, and two tides in twentyfun howrs. During our visit to this island I had observed a fall of upwards of two feet, and have to regret that the tide-staff was placed in so unfortubate a josition.

Lieutenant-Conmandant Ringgold now left $\mathrm{Ta}$ biti. On the Bth of February, they made Flint"s Islnes, situated in longitude $15 \mathrm{l}^{\circ} 43^{\prime} \mathrm{W}$, and latiturde $11^{\circ} 25^{\prime} 43^{\prime \prime} \mathrm{s}$. It it of small eize, being only one mile and $\mathrm{s}$ half in length, from north-irortts. west to south-south-east, and thickly wooded: high brenkers extended off its point for some distance, and the burf was so lights that it way deemed impuasible to laud willı a boat. No inlınhitsnts were seen.

'The next istand searched for was one reported to have been seen by Captain Cash, It was discovered on the 8 th, and proved to be a low sandy islet with a lagnon. It is well wooded, lialf a mile in dinmeter, of owal slape, wilh heavy breakers surroundiug it. Landing w'as reported to be impussible, and no attempt was nade. After determinimg its position to be in latitude $10^{\circ} 5^{3} \mathrm{~S}$, and lougitude $152^{\circ} 22^{\prime \prime} 30^{\prime \prime} \mathrm{W}$, they bore away for the position of Penrtiyn Islnnd. Lieutenant.ComImandant Ringgold believed the island hast spoken of to be Staver's Ialand, and by this name it is designated on our charts At uight the water was very pirsphtioreacent: its temperature $78^{\circ}$.

Tlie Purpoige next prosed over the supposed site of 'Tuinhoven Is/and, without Beeing any signs of land, and thence porth-west across two pusitions assigned to Penrliyn's, exanining particulurly that given by Captain Casb, in latitude $9^{\circ} 58^{\prime} \mathrm{S}_{\text {., }}$ and ingitude $158^{\circ} 14^{\prime} \mathrm{W}$, No island, however, was seen. Proceediug further to the north-west, they, on the 15th, discovered land, which proved to bo Penrhyn Jalund, about thirly miles west of its plnce on Arrowsmith's Chart. It was of the usual coral formution, low, and densely covered with trees, anong which the cocosenut was the most conapicunus.

The ressel stood off and on all tight, and on the 16 th, at suntise, catocs were discovered apparouch- ing the brig, in great numbers, many of them large. At seven u'clock, two eame alongside, sul others soon followed them. As the rumbers of the vixitery increased, they became more bold, and elamiered up the sides, uttering loud and aavage yells. They were the wildest and most savage-looking beings that hal been roet with, rociferuting in a trightful manzer, and accompanying their exclarations with the mont violest contortions and gesticulations: they seemed fratic with excitement. These natives were quito naked, except a few who had on a small maro of cocoa-kut leares,

I'enrhyn Island sus by estimnte fifty feet lizhl, and was found to be mino miles loug, north-northeast and south-south-west, and abcut five miles wide, with an extensive Ingoon, hnving in it many coral patches: there is a bont-entrance into it. On the north-west side there appears to be a continuous village, witl cocoa nut groves througlout its whole extent, and the island is evidently very thickly peopled: the fenocity of the savnges precluded the possibility of attempting a landing.

Lieutenant-Commandant Ringgohd induced one of the natives to come on brard for a hatehet, and directed him to draw the shape of the island with a piece of chalk; but he proved so wild and was so mueh amazed, that he did nothing but leap about, constantly uttering exclamations.

It was now decmed inspossible to extend the cruise to the Isles of Danger, ngreenbly to tho instructions, on account of wari of time sud Bearcity of provisions. This I regret, as 1 was very devirous that these islands, pointed out by Admiral krusenstera, should be examined. This cruise would also have embraed the westera positiuns of Flint's nnd other islands, as laid down on Arrowsmith's Chart. Compelfed to forego this part of his intended task, he stood to the northward; and on the evering of the 24th of March, anchored off Honolulu, ifter an absence of four months and nine days, only oight of which were passed in port.

The results of this cruine of the Porpoise werc antisfnetory to me, although it had boen found impossible to earry out all the duties embrneod in her instructions. The perfurmanee of thuse that were aceoruplished was atcended with mueh fatigue from the asverse state of the weather, an obstaclo 1 was somewhat apprchensive of, lut not to the extent that they exflerienced. Ifad 1 been at liberty, or had time allowed, I should have gladly chosen another season for it. With suitable wenther, there would have been ample time w accomplish the whole.

From the report of Lieutenant-Commindent Ringgold, relative to tho Porpoise, and on exrmination of her bottom, the copper was found so far gone as to make it neceseary to re-eupper her This cause of detention was unlooked for, and I had lieen in hopes to give lier crew a short relaxation; hut there was no opportunity for it. The nocessity of a Epreedy departare admitter of no delay. Slo was accordingly haled into the wharf, the work set spcedily about, sund tho brig again prepared for sea. 


\section{CHAPTER XXXI.}

\section{OREGON.}

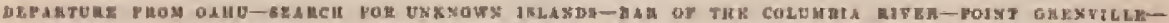

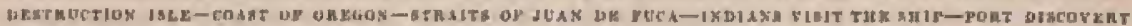

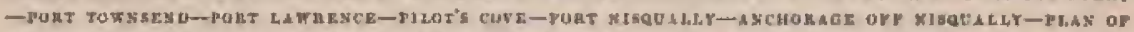

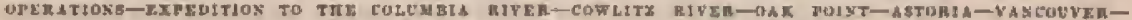

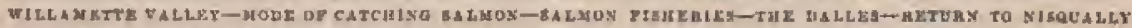
- MHOAEGS OP THK JUREYNG RARTIE.

Os the Bth April, 1841, we had completed our repairs, and mado arrangements for the transquertastion of our slores to the Columbin River. "The Purpoise was ordered to leare the hartuour in the afternoon, and anchor near the Yincennes in the outer roads. Towarils suuset we took lenve of our kind and numertus friends, and the same night at $11^{\text {th }} 30^{\mathrm{ma}}$, the gignn] was numle for getting under wn y. We soon afterwards made Esil, and steered to the westward, in order to pass between the islauds of Orshu nnd Kiari.

In proeeeding to the north, I was desirous to pass over a portion of the sea that lad not been examiued by preceding uavigators, particularly as it is eonfidently believed by nany persons in the Hawailan Islande, that land existed in the neighbourhood where we now were. I was, therefore, anxious to make search for it in such places as had not been explored by others, and I had procuted a chart, showing the tracks of Portlock and others. This genreh wus maxle as elosely as time and opportunity permitted, but ineffectually. I am, however, far from antisfed tlat land miay not exist in this quarter, for wo in fact did little in the way of exploration, in consequence of the foggy arit hazy weather which linited our yiew.

The part of the Nortiern Pacifie which lice between the latitudes of $33^{\circ}$ and $43^{\circ} \mathrm{N}$, and longitudes of $140^{\circ}$ and $150^{\circ} \mathrm{W}$, is particularly subject to forg and thick weather, and there are few places where indieations of land are stronger: thus, numerous birds were seen, of apecies foutud only in the ricinity of land. I therefore feel satisfied that although we fajed from want of sufficient time for a thorongh senrch, land will he found at sone future day within the space just defined.

On the 28th of April, at 6 t.s. we made Cnpe Disaypointment, which wo sion eame ap with. A heavy sen, caused by the strong winds that hat prevailed for several days, was rontuing. I, not withglanding, stoud for the bar of the Culumbia river, after traking every preparation to cross it; but on appronching nearer, I found breakers extending from Cape Disappointment to Point Adams, in one unbroken line.

I nm at a Juss to conceive low any doubt should over linve existed, that here was the mouth of the mighty rivor, whose existence was reported so long before the actual place of its dischnrge was knowa, or how the inquiring mind and talent of obarrvation of Vancouver could have alluwed him to hesiute, when bo must have seen the evidence of $n$ powerful flpod of fresh water contending with tho tides of the ocenn, in a bar turbulent with bretkers, in turbid waters extending several miles beyoud the line of the shore, and in the marked line of separntion betweeu the sea and river water. Such appenrances must be constunt, and if seen, the inferences could bardly be questionable, that the grent river of the west poured itsolf into the weean at this point

Mere description enn give little iden of the ter. rors of the lar of the Columbin: all who lane seen it Jave spoken of the wildness of the scene, and the incessast roar of the waters, representing it se oue of the most ferrful siglits that can portsibly meet the eye of the anilor. The difliculty of its ehannel, the distance of the leading sailing marks, their kneertatinty th one unacquaisted wath them, the want of knowledge of the strength and direchion of the currents, with the necessity of ap. proaching cluse to uneen dangers, the transition from cleur to tarbid water, all cause doubt and mistrust.

Under such feelings I must confess that I fol mysetf labouring; and slthough I had on bont a person from the Sandwich Islinds who professed to be a Columbia river pilut, I found him at a lass to designate the true passage, and unable to tell whether we were in a right way or not. I therefore, at once, determined to haul oft with the tide, which was running ebb with great mpidity, and which soon carrited us back into the bluo water of the ocean, to wait there until the sea on the bar had in some mensure subsided.

The land netr the mouth of the river is well marked, and eannot readily be mistaken, and on the summit of the two capes are several lofty spruce and pine troes, which the officers of the IIudson Bay Company have caused to be trimmed of branches nesirly to their tops. These serve as conspieuous tratks, but our pilot was ignornat of their relation to the channel.

Our pasage from Oahu had been no more than twenty-two days, which is unusully short. The tirst fyart of it, until we passed in latitude $28^{\circ} \mathrm{N}$, beyond the influence of the trades and variables, had been attended with light and contrary winds.

During the night, I took into consideration the loss of time that must arise from awaiting an opportunity to cross the bar, and after due reflec. tion came to the conclusion that it would be better to proceed at once to the Stratis of Juan de Fucs, and there begin my work on this coast. At day. light, therefore, I spoke the Porpoise, and immediately bore away to the northward. Signal wata ther made to her to follow. Both vessels then 
proceeded at the rate of eight or ten miles an liour.

Tho wenther was rery thiek, and the wind soutlsoutli-west. At ten o'elock the Porpoise was elose inder our lee-guniter. I wa inyself below, when I was informed by the officer of the deck that we hul entened distrirbed water. A number of birds were around the vessels, and a cast of the lead kavo fifteen fathoms. By the time I renclied the ilinck, land was seen through the linze, close abourd. The ship was at once brought by the witsd and all the atudding-sails taken its.

The wather before long cleared up suffictently to give us a view of the land, which proved to be Poirt Grenville of Vancouver, and Destruction Iale, The latter is easily known by oome rentarkable performlions tlirough a rock near it.

On the 30th, I was in hopes that the wind would cortisue fair, and enalle us to larve reached Neal Harbout tre night; but as we approaclsed Cape Flattery and opented the Stmits of Fura, it becane cuntrary. We were thercfore comprolled to pass the night, which proved dark and miny, under wry. Wo had but litste knowledge of the dangers that miglt surround us; but our frequent tacks throughout the lijelst showed us that but few existed at the snusitl of the strails.

The eosat of Oregot, to the south of Capre Flattery, is rocky, much broken, and afturils no larlours, exeept for rery stmall yesselo. It may therefore be considered at extretnely dangerous, atud particularly un aveount of its outh fur l'ucks, The soundings on this const, however, I afterwards discovered, nay serve as as sure isdication by which danger unzy he aroided, ansl safety may be inaured by not npprunching the cuast into soumlings of lest than seventy fathoune.

On the murning of the Ist of May, we fundul ourselves well into the straits; and is I proposed to defer" the survey of this part of them until my retur'l, we liastened to reacls Furt Discovery, where we anchored at lull. past 6 P.M, on the 2ud of May; juat forty-nime yenrs after Vuncouver, pursuing

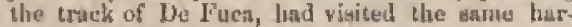
bour.

The Straits of Junn do Fues may be safely mavgated. Flis wind will for the greater pari of the year be fatud to blow direckly through dow, and generally outs arts: this witnd is at tines rery viofent. The sluares of the strnit are bold, and anelorago in to be foush in but few glaces, Wo could uot obtain bothen in thome placets with sixty fathams of line, eren within a buat's leagth of the Hiore.

Tho south slinre is conprosed of perpendicular sastly elifin, that run back juts higls sull rugged prealis, and is covered with a foreat uf varius sfeeies of pines, that rises almost 10 the lighest proists of the range of mumtains. The highest points thomsclves are covered witl anow; and among them Mutsnt Otymins was consjicuuns, ribing to an alkitude of eighe thousand une liundred and thirty-eigint feet.

The north shore is rocky, nut composed, Bs far as we could "xanjitue it, if conglomerate, and in some few places of a roldith granite.

In the moming we were bonrled by a large cantre, with Indians who sproke a fus words of Finglist. The principul mus of the party was dressed in a cunase evat of red chuth, with the
Hudson Bay Company's buttons, and corcluroy truntsers. He had neither shirt, signes, not loat, although the rain was falling fast. Tha others were linbited in blankets or skins, nnd wore conich grass hats, resembling in shaje those of the Cluiuese.

The first inquiry was, whether we were Bosturs or Jing George's ships, by which terms they distinguiali Ameriears and Engitish.

They brought with them for ale some fish and a few furs. On the hatter they appeared to set $n$ Jigh value, and were not a litule disappointed when they learsed that we had no desire to purchase them. They readily parted with their fine fish for a few fish-hooks and a little tobneco.

It was anusing to us, who bad no very exnlted opinion of the Feejecars, th obsurve the contempt our prisoner Vendovi entertaitsed fur these Indians, which was such that he would hardly deigu to look at them.

Iate in the afteranon, we reached and werthered the low sand-point, called by Vanecurer Now Dungeness, and stood over for lis Protection lsland. We passed witlin lesg than a cyunter of a mile of the point, where we lad three nnd a half fathoms water.

After pussing that igland, an extensive bay opened, on whose shoreg we atw the long poles mentioned by Vaneuuver, and represented in his buok. "The use of these he was tuahle to discurer, but the Indians iulormed us that they were for the purpore of suspendisg wets for taking the wild-fowl that frequent these stores ill grear numbers, On these poles the nets are set ug at night, at which lime the reese search these ground for food : firus are then lighted, which alusin the birds, and cause them to thy against the neta, by which they are thrown uph the ground, where, befure they liaro time to recover themselres, they are eaught and killed".

The deseription of Vnucouver is so exactly applicable to the present state of this port, that it was diflicule to believe that almost half a centnry had elauked ninee it was written. The benutiful wonds and lawns of Protection Istand, in particular, exist uncliauged, The lawns still produce the same berutiful flowers and slirule, and although chosely surrounderd by desise wools, do not seem to have beenl encroached upon by their loxurint growth, aldiough there in no apparent reason why it slould not long ere this lave overruts them.

Ous auchorage in Port Diseurery wha elose to the shore, in twenty-seven fathoms water. It is a wellprotected harbour, and sery conveniont of neceas, but the depll of water and the high precipitous bank would almost preclude its being made the seat of a settlement.

The same of Port Diseovery was given by Vancomer. It is eight miles long, two miles in average width, and its points, which terminate in low sandy grojectiona, interluek ench other. 'The shores are supgivier? with large quantities of sliell-fish. Proteetinn Island envers it completely to the uorth, and would ronder it easily defonkive against the most formidutule attack. The only objection to is as a harbutr is that already spolien of, the grent depth of the water, which in the middle in no where less than forty ur fifty fathons, and is often a: muth in sixtoen fathom close to the shore.

The Indians whom w'e funnl dwelling here nre of 
the Clalam tribe. They oecupy a few miseralule lodjes an one of the points, asid are a mont fittly mce, so much so inlled that to enter their lixdges is alssalutely disgusting. They atw no thore than a few nudely-cut slabs, covered is part by coarse mats,

We remained at Port Discovery until 6th Mny, during which time we were employed in surreying the tuarhour and explering the country. Our britanists lund a large and interesting ficld opened to then, and there are ferw places where the variety sund lienuty of the flom are so great as they are liere. The soil consists of a light-trown loam, but its general clinetes aromul Port Discovery is a thin, black, vegetabls mould, willn a substratun of earnd and grmvel.

Suon after atr arrival at Part Discavery, I despatehed an Imilian with a lotker to the fort of the Indson Bas Company at Xiscually, at the upper exh of Fuget Sumd, to request that a pilat might be sent me. My interview witl the native whou I employed for this purpose was aruusing. He njtreareul of a gay and lively diaposition: the first thing lie lid, when brumght into the cabin, whs to show me a cruss and repent his ave, which ho did with great rendiness aud appurent devotion; but he burst into loud lauglater as soon as lie had finished repeating it. He and I made many eflorts to understand ench other, but willont much success, except si) far as the transunision of the letter to Fort Nisqually, and the reward he was to receire on lis return.

On the bith of Miny, funding that the inessenger whom I had despatclied to Fort Nisipully did not return, I determined to proceod tuwards thar place widhout further delay. Wo cherefore got under way at balf-phst ten, and bent ent of Port Discovery: we then stond towards Point Wilsots fof Yancouver), which forms one side of the entrance into Armiralty Inlet. Turning the fraint, wo eotured the inlet, and soon snchored in ['urt Towusend, on its northern shle, in ten fathous water.

Port 'Towusend is a fine sheet of water, three uniles and $\mathrm{n}$ ruarter in length, by one mile and tloree-y atarters in width. Opposite tn our anchoruge is au extensive tnble-land, [ree frotn wood, and whicls wouln! afford a good wite for a town.

The bay is free from dangery, and is well protreted frinus the quartery whence tormy wiluls bluw. It lias anchurage of a convenient dejuth; nud there is abundance of frealt water to be lind. In the nftermoon, wo landed and exanined the table-land stid bay.

On the 7 th, we land courpleted the survoy; lout the wird coning up from tho southward and eastward, which why contrary to our intendied course, wo deternined to remain. $\Lambda t$ uonly, there was a fayourable clange, when both vessets moved up about eight milee, and anchored in whint I called Port Lamrence. "This is just at the entrance of Huwd" Canal, and grve us a view both of it and Admiralty lulet. The weather was unplessunt, and the only duty that could be performed whs that of dredging

On the morning of the Bth, we mude the surroy of Port Lawrence, beginning at daylight. . This being completed, 1 took advantage of the tide making to got usder way with a fresh breeze, and passed with both vessets as far as a small core on the west side of the inlet opposite to the south end of Whidby's. Jolnnd. Here we anclowed before sunset, and I named it I'ilot's Cove, from the circumstance of having been liere juined by the firat officer of the Iludsou Bay Company's steamer, cansmanded by Captain M'Nicl, who on learing of our nrrival, kindly sent him down to pilot up the ship.

We wero under way soon sfter daylight, taking advantago of the tide, and continuod beating as loug as it lasted. This was abount two hours, by which time we reached another small cuve. This was uamed Apple-Tree Cove, from the nambers of that tree which were in blossum around its shores. This cove answerg well all the purposes of a temporary anchornge, Before the tido began to mnke in our farour, we again salled, and at dark nnehored under the west shore, near a fine bay; which the next day was surveyed, aml named Port M[adison, This is an exceslent liathour, affording every possible convenience for shipping.

The wind proved fair the same afternoon, and we pnssed up Ailnimalty Inlet, taking the passage to the right of Vaslow"s Island, and finnily, townors evening, anchored just below the narrowy leallug into Puget Sound, within a few yards of the shore ant under a tigh perpondicular bank, ins sixteun fathomis.

The shores of all these inlets and bays are rejuarkably bold; so much so, that in maxy places. a shitiv's bides would strike the sliore before the keel would touch the ground.

On the 11th of Mar, we agaill weighed utr anchors, but lud great difficulty it getting beyoud the reach of the edidy winds ocensiuned by the bigh banks. The secuery abotat this pass becomes very fine: ors all sides are high projecting blutts of sund. stone, rising almost perpendieularly from the water with a great variety of blurubs along their bnse. T'he tide, which rung through the junrows with greas relocity, causes mauy ed dies and whirlpouls, through which a silip is carried with extraordinary mugidity, while the darger scems to be immineni. Tho I'orposse sucteoled in enteriug the narrow: first, and in a few minutes was lost sight of ; tho Vincenures entered, atul seemed at first to be hnrry. ing to destruction, with Jier saila quits aback. We were estried anward wholly by the force of the tive, and lant backed and filled only once befure we funud ourselves in ar spacious is sound as the nue wo luw just left. This narrow juss meems an if intended by its ualural facilities to aflurd every menus for ith perfect defenee.

'T'welve nilles more bronght us to the anchoizge off Nisqually, whero hoth rensits dropperl theis machors alsut eighe cielock. Here wo foutul an Einglish atemoer usdergening requirs. Suon after we anchored, I land the plensure of $a$ visit from Mit. Anderson, who is in elange of the fort, and? Captail M'Niel. They gare me a warm welcume, and offered every sisgistance in their power to aij me in my operntions.

Nothing cran exeed tho beauty of these waters, and their safety : not a slonal exists within the Straits of Junu de Fuca, Aimiralty Inlet, Puget Sound, or Hood's Cannl, that ean in any way interrupe their navigation by a seventy-four gun ship. I venture nothing in Enying, there is no ecuntry in the world that possesses waters equal to kluese. 
$282 \quad \begin{gathered}\text { Anchorage ofr Nikqually. } \\ \text { Plan of operations. }\end{gathered}$
.

The aneljorage of Niscually is very contrincted, in consequence of the rapid shelving of the bask, that soun drops off into deep water. The shore rises abruptly to a leiglit of about two hundred feet, and on the top of the ascent is an extended plain, covered with pine, oak, and ash. Fort Nisqually, with its out-buildings and enclosure, stands. back about half a mile from the edge of the table. land.

I now put tny plans into operation. The Purpoise, with two of the Vineenues' boats, under Lieutennnt-Commandant IRinggold, were directed ta tako up the survey of Admiralty Inlet. The latuch, first cutter, and two boats of the Vincenues, wore placed under the commund of Lieutesiant Case, to survey Hood's Canal. The land party iatended to explore the jnterior, was placed under the command of Lieutenant Johnson of the Porpoise. Eighty days wero allowed for the operations of this party, which it was intended should cross the Cascade Range of mountnins, towards the Columbin, and on to Fort Colville, and south to Lapwai (the mission station on the Kooskooskee river), thence to Wallawall $\mathrm{n}$, and returning by the way of the Yakima river, repass tho mountains to Nisqually. Dr. Pickering and Mr. Brackenridge were of this party.

The other land party consisted of Messts. Drayton and Waldron of the Yincennes, myself, and two servants. Our intended route lay neross the cuuntry to the Culumbia river. First, I proposed to risit Astoria, then Fort Vancouver, and the Willamette rettlemest, and to proceed up tie river as far as Wallawnlla. From Astoria I proposed to send parties frum the Pereock into the interior, and to set on foot the survey of the Culumbin siver, by meanis of her bonts,

The establishment of an obserwatory slso clained roy altention: a suitalle site was found on the top of the hill, within hail of the ship. Here the instruments and clocks were landed, and put up in a mall clesring, whence the treeg had been cut in order to supply the steamer with fuel.

All these preparations oceupiod us until the 15 th, when the brig wns reported as rendy, and satled the anme day.

In returing the risits of Mr. Anderson and Captain M'Niel, I had an opportunity of examining Fort Nisqually. It is constructed of piekets, erclosing a space about two lutudred feet squitre, with four comer bastions. Within this enclosure me the agents' stores, and about half a dozen housses, huilt of logs, and roofed with barlt. Thi. fort was vonsidered quite large when it was first established, but since it las become an agrieultural post as well as a trading one, it is found to be too small. Its locality is also ill ehosen, on necount of the difliculty of obtaining water, which has to be brought frum a distance of nearly a mile. I was informed that there was now little necesgity for any sort of protection against the Indinns, who are but few in number, and rery peaceably disposed. Mr. Anderson nnd Captnin M'Niel both reside in the fort with their families: bnth are married to half-breeds, and have several fine clithlron.

Ilaring seen the other parties all off, or ready to start, our party for the Columbia rivor also set out. It was as strange earalcade, for most of us were but sorry horsemen, and we hal every variety of accoutrements, frow the saddle and bridle to the
Expedtion to the Columbla. Cowlitz river. bare back and halter. We were eight in number: Messrs. Dnyton, Waldron, and mybelf, two servants, two Indians, and a Canadian guide, witi four pack-horses. All the horses and the guide were kindly furnished us by the gentlemen at the fort, to carry us as far ns Cowlitz Farms, about sixty miles distant, where we intended taking eanoes.

The direction of our route was nearly south over the plain, passing occasionally a pretty lawn, and groves of ank and ash trees. At the distance of nine miles wo reached the river Nisqually, whose chansel is sunk three hundred feet bolow the plain, between alinost perpendicular banks. The ravine is about half a mile wide, and is filled with a large growth of timber, whieh is occasionally unooted by the torrents that pass down, on the meling of the snows of the nountains. T'he usun bed of the stream is about one hundred yards wide, with is ripid current: its course in this place was nortl. north-west, and its average depth at the ford about three feet.

After crossing Shute's river, in all respects similar to the Nisqually, wo cacamped, just beforo night, having travelled about twenty-two miles. Our tents were pitched, and fires made; but on examining our alforcas (or dule-bag), wo were reminded that we were but noviecs in steh travelling, for we found that all our small stores had been destroyed in fording the streans, the sugar leing turned into syrup, \&e. This was a mishap over which we had a hearty lnugh; it reudered the part that was saver doubly precious, and mado us enjoy our evening meal.

In the morning, when we resumed our jonmey, the park scenery increased in beauty, and it was almost impossible to restizo that we were in a Bavage and wild country, and that nature, not nrt, had perfected tho lanilscape. Beautiful lakes, witl greensward growing to the water edge, with deer feeding fenrlessly on their margin, sud overy tint of flower, many of which were not new to our gardens at home, strewn in profusion around; we could hardly, in galloping along, but expect to see some beautiful mansion, as a fit accompaniment to such seenery:

The Cowlizz river, the enst fork of which we prssed at a short distance from our encampment, takes its rise in the Casende Range, ueax Mount Rainier, and has many short turns in it. Its banks, until it appronches the Columbin, nre tolerably lights.

When I examined the Cowlitz in the month of Sepuember following, I found it exbibiting a very different character. $A$ few miles above its month there was not water enough to fluat eren a boat, and it wh besider filled with rapids. It is tot navigable for barges more than three mouths in a yeur. The distunce we passed down the Cowlitz did not exceed twenty-six aniles, although we had been told that it was inore than forty.

On entering the Columbia our Indians required some rest, and said they were lungry; we therefore coseluded to stop for a short time on its banks. If I were to judge of the whole Cuwlitz tribe from the specimens we had with us, I should eny they were the merriest set of fellows I ever saw, foll of fm, and laughing all day long: I became at lnst wearied with their incessant gaiety.

The Culumbia, wlere the Cowlitz joins it, is a 
brosd fluwing stream, ald was at this times nuch swollen. We had, affer entering it, about furty miles yet to make, and it was past noon; but we glided briskly on with the eurrest, altheugh it was by no theans so raptid as I land expected to liave found it.

About ten miles lower duwn, we pased Oak Point, where the river turns nearly at right angles, taking its course nlong a barrier of trap rocks, which it here neets on ils west side, and which rises eight hundred fect perpendieularly above its surface. On the other gide of the river is one of the remarkable prairies of the country, coveried witld tall waving grass, and studded with many oaks, from which the point takes its nane. What adds additional interest and beauty to the scene is Mutnt St. Helen's, which man be seen frum the sea when eighty ailes distant: its beight 1 made nine thousand tive hundred and lifty feet.

In this part of the river, which I named St. Heles's Reach, we met the brig that hat brought our stores from Onhu. The master infurmed me that he hat landed them at dotoris, and placed them under the care of Mr. Birnie, wha liad clumge of the Companty's fort. By sunset we had renched Terninution Island, and lind yet swenty miles to nakke in a very llark night. Wo had already passed the only place where we could have eneaniped, and the natives slowed extreme rolue. tance to go on. They soon desired to return; saying that the night was very dark, and that the bay would be dangerous. This request was overmled, however, and we contisned our course, though under apprehension of disaster.

1 now began to lave misgivings that we should pasa Astoria, and comraeneed firing muskets, the ustal signal of an mirival. They wero immedintely atswered by others just behind sts, asd the lond elamour of sbout forty yelpirig dogs. These sounds, although discurdant, gavo us the delightful assurance that we had reached our destination, and might uow mako our escape from the confirted and itkswme position we had been in a wholo day. Mr. Birnie, the agent of the Hutson Bay Cumpany, met us at the landing, with lanterns aud every assistance, and gave us a truly Seoteh weleome. Wo soon found ourselves in his quarters, where in a strert line a fire was burning brighely, and his huspitable board spresd with guod cheer, although it was past midnight. After partakisg of the sup. per, blankets wero fumished us, and we were made excuedingly comfortable for the night.

In the morning we had a view of the Bomewhat famous Astorin, which is any thing but what I sisurld wish to deserife. Inalf a dozen log houses, with as many sheds and $\Omega$ pig-sty or two, are afl that it eru bonst of, and even these appens to be rapidly going to decay.

The Company pay little regard to it, and the idea of holding or improving it as a prost, has long sinee been given up. The head-quarters of their operations lave been removed to Vancouver, eighty uiles further up the river, gince which Astoria hus merely been held for the convenience of their vessels. It bonsts of but one field, and that was in potaloes, which I can, however, vouch for as being very fine. In former times it had its gardens, forts, and banqueting balls; and from all aecounts, when it was the bend-quarters of the North. west Compuny, during their rivalalip with the Hudson
Buy Cumpaly, there was as jovial a set residiab licre, as ever were net togetlier.

Ia point of beasty of situntion, few phlaces will vie with Astoria. It is situsted on the bouth side of the Columbia river, eleven miles from Cape Disapmointruent, as the crow thes. From Astoria there is a fine view of the high promontory of Cape Disappointment, and the ocen bounding it un the weat; the Chimok Hills and Point Ellice, with its rugged peak, an the uorth; Tougue Point and Kntalamet Range on the east; and a high backgrumnd, bristling with lofty pines, to the south. The ground rises from the river gradually to the tap of a ridge five hundred feet in elevation. This was originally covered with a thick forest of pissea: that part reclained by the first ocenpants is agaju growing up in brusliwood. From all parts of the ground the brond surfice of the river is in views The stillness is remarkable, and maken it evidust that one is yet far removed frum civilized life : the distant though distinet roar of the ocean is the ouly sonnd that is heard : this, huwever, is almost ineessant; for the strens, though rushing onwards in silence to meet tho ocean, keeps up an eterta? war with it on the bar, producing at times scenes of extruordinary grandeur.

The Colambia, opposite to Astorin, is four miles wide, but in the middle of the river is an extensive cand-bar, with only a few feet water on it, and at extreme low tides it is bare: the chamel is very narrow on each side, and diflicult to navigate. At Astoria there is onfy space for a dozen ressels to the at anchor, and it would therefore be difficult to accommodate any extensive trade. The point of land extends about half a mile below its site, where Young's rivet joins the Columbia, and forms a bry.

Our guide, Plumondon, an expert trapper, informed me that the country lying north of the Columbia, between the Cowlitz nud Cape Disap. pointment, is generally ruugh and rugged, with numemus strenus of water, and in many places a riel soil : it is extremely well timbered, and is eapable, whell clearud, of growing grain, and other agricultural produce.

I wituessed the Columbia at its grentent and Jeast heights, and no idea $\tan$ be formed of it unless sceth at bouh these epochs. The llool is a very graud sight from the banks of the river at Vancouver, ns it passes swiftly by, bearing along the gignutic forest trees, whose immetsse trunks apjuear as mero ehips. They frequently ludge for a time, in which case others are speedily caught by them, which, obstruating the flow of the water, form rmpids, until by a sudden rush the whole is borne off to the ocean, and in time lodged by the currents on sone remote and savage island, to supply the natives with eanves. I also witnessed the underunining of laxge treeg on the banks, and occusional strips of soil: thus does the river yearly make inroads on its banks, and changes in its channels.

From the circumstance of this annual inunda. linn of the river prairies, they will alway be unfit for trusb:uudry, yet they are ndmirably adapted for graxing, except during the periods of high water. Thero is no preeaution that ean prevent the inrond of the water. At Vancouver they were at the expesse of throwing up a long embankment of earth, but without tho desired offect. It has been 
fontud that the crop of grnin suffers in proportion tn the quantity of the stalk immersed ! unlese the whent is completely covered, a partial liarvest may the expeeted.

The maters of the Columbia have no fertilizing qualities, which is remarkable when the extent of its cuurse is considered: on the contrary, it is said, from experisnce, to deteriurate and exhaust the soil. It is, when taken up, quite elear, althongh it lins a turbid look ns it flows by. Quantities of fine sand are however borne along, nud being deposited in the eddies, rapidly form hanks, which alter the clsansel in places to is great degree.

The situation of Vancourer in farourable for ngricultural prornoses, and it may be sajd to be tlon heal of unvigation for sen-going vessels, A vessel of futurteen foet druft of wuter, may rench it in the lewest state of the river. The Culumbit at this point makes a corsidemblo angle, and is divided by two islands, which oxtend upwards aloout throe uniles, to where the npuer branch of the Willatuette joiss it. The slores of these islands are covered with tures, consisting of ash, puplars, pines, and onks, while the centro is genernlly prairie, and lower than the banks: they are prin. cipally cousposed of sand. During the rise of the river in May and June, the jsiands are covered with wates, that filters through tho bsnks that are unt overflowed. This influx renders them unfit for grain crops, as the coldness of the water inrariably destroys every culturnted plant it touches.

The Cumpsny's establishment at Vancouver is upon an extensive senle, and is worthy of the vast interest of which it is the eentro. The regidents mess ut eeveral tables: one for the chief factor and his clerks: one for their wives (it being andinst the regulations of the Company for their oflicers and wives to tnke their meals together); anotler for the missionaries; and nnother for the siek and tho Cathulic missiunaries. All is arrnuged in the best arder, and I should think with giveat veonomy. Every thing tuay be lad within the fort: thoy batw an extensive agnotrecary shop, a bakery, blacksuntlus' and coopers' shops, tralle. ofllees for buying, others for solling, noluers agnin for keepirng aceounts and transacting business; shop for retnil, where English manufnetured noticles may bo purchnsed at as low a prive, if nut chuaper, than in the United Staten, cunsisting of cottur and woollen goods, peady-mate eluthing, shij)-

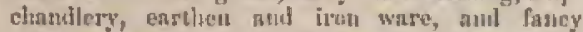
artives ; in short, every thing, sat of every kind asul deatription, ineluding ull sorts of groceries, nt all advance of eighty $j^{\text {th's }}$ cent. on the Losudon prime enst. This is the establisterl priee at Yonecuver, but at the oltier posts it is oue hundred prer cent., to cover the extrm expenses of transportation. Alt these articlea are of good quality, nud suitable for the servants, Beulers, and sisiters. Of the quantity su hand, some idea may he formed from the fact that all the ponts west of the Ftocky Mountaius get their annusl supplies from this depòt.

I"le Willamette river is gonernlly whout onefunth of a raile wide. For the distance of four miles from its entrance into the Columbin its banks are low, and during the rise of the latter nre overHowed, its wnters being backed into the Willamette. There is little currest to contend with in this river during this geason. After pussing this low grouad, the banks become lifgh and precipituas, and are in onfy a few places ausceptible of cultivation.

At the tirse of our visit to the falls of Willanette, the salmon-fishery whs at its height, and was to ns a noved as well an an amusing scenc. The salmon lens the fall; snd it would be inconceivable, if not actually witnessed, how they can foree themselves t.j, and after a leap of from ten to twelve feet retain strength enough to stem the force of the water atuove. Abaut one in ten of those who jumped, would sac. eeed in gusting by: They are seen to dnrt out of the fonm beneatli and reach stout two-thirds of the lieight, at a single bound : thooe that thus prased the apex of the running water, suceed; but ull that fell Bhorth were tluraws bsek agrill into the foam. I never saw so muny fish collected together befure; and the Indians are constantly einployed in takitug them. They rig out two stout poles, long enough to project over the fonning cauldron, and ecture their larger conds to the rows. On the outur enil they make a platform for the finherman to staud on, who is perehed on it with a prole thirly feet long in hand, to which the net is fastoned by a hoop four feet in dinmeter: the net is made to slide on the hoop, so as to close its mouth when the fish is tnkell. The musle of using the net is peculiar: they throw it is to the foarn as far up the streum na they can ronch, and it being then quickly enrried down, the fisl who are running up in a cuntrny direction are caught. Sometimes twenty large fish are taken lyg a single person in an hour; and it is unly surprising that twive as maty should wot le eaught.

The river the falls is tliree humrlred and fifty yards wide, and its greatest fall twonty.five feet. When the water is not very high, tho rapits begin some distuice nbove the falls. Sorne of the Indiuns aro in the habit of consing down in crnoes to the brink of the falls, where they secure themselves by thrusting down poles in the crevices of the rock. There thiey take many fish, that have succeeded in passing the lower fall, with a hook fastessed to the end of a pale. These are esteemed to be of the besl thavour, as they are the strongest arul fallest. It is said frum these places the fish ean be suen very distinctly pussiag up, and are taken very ropidly; but few Indiaus are willing or expose theragelves to the risk of fishing there. Tlas number of Indians at the Willamette Falls during the fistring gfason, is abotst serenty, includimg nil ages and rexes: there are athers who visit the fitls in canocs for fish, which at times will raise the number to not far from one hundred. Tlyobe fish which are unable to get up, remnin some time at the falls, very much exhausted, and fitally resort to the smaller streans belisw.

[n eonserpuence of the interruption of the navigation of its rivers in the dry sesson, the Willanette Valley will never becone a large gettlement,

Thie sulmou-fishery may be classed as one of tho grent soures of wenitls, fint it afforts a large ariount of food at a very low price, nnd of the rery best quality: it dows not extend ahove the falls, I fruthd it. improssible to olutain any data to fonud a calculation of the quantity taken, but it eamost be short of eight lundred barrels; nul slis after the Indian manner of eatehing thess, bs before de. serilsed. The finest of the salmon aro those caught nenrest the sea.

The settlers and Indians told are that the salmon as they pass up the river become pexter, tuid when 
they reach the tributares of the upper Columbia, they are excecilingly exhansted, and have thuir boulies and heads much disfigured and cut, and their tails and fins worn out by eontact with the rocks. Mary of the salmon in consequence die : these tho Jndians no in the lnabit of drying for finol, by hanging them on the limbs of trees. This is to preservo them from the walres, nnd to be used in time of neet, when they are devouted, though roten and fult of maggots. "l'he figh of the upper walere are said to be hardly edilile, and, compared with those canght at the mouth of the Columbia, are sotally different in flavour. The latter are she richest and tous delicinu fish I erer rocillect to have tasted: if any thing, they were too fal to eat, and one can perceive a differenoe even in those taken at the Willarnette Fulla, which, however, are the best kind for kalting. There are four different kinds of salmon, which frequent this river in differwat montls: the latest nppens in Qctober, and is the only kind that frequents the Cowlitz river. The finest sort is a dark silvery fish, of large eizs, three or fuur feet lowg, and weigliing forty or fifty pounds.

Otre of the most remarkuble places upon the Columbin is called the Dnlles. The river is lere compressed into n narrow eliannel, three hundred fect wide, and Jail a milo long; the walls are perpenlicular, fint at tho top, atud cmuposed of basalt; the river forms an elbow, being sitnited in an amphithentre, extending severnl mites to the thirth.west, and closed is by a ligh bakalkie wall. Frour appearatices, one is led to conclude that in forner times the river made a straight ecurse orer the whole; but, laving the chanael deeper, is now confined withis the present limits. Mr. Irnytint, on incrivy of an old Indian, thrusgh Mr. Ogalmu, lenrned that he believed thit in the time of bis fortather they west up straight in theit chmos.

The somentry about the Dalles is broken, and the missionsies reprort that this in the crme for ande milets aruund. There are, however, nlso sotro plaina atad tnble-Jasida, which are considered as very valuable, being well whtcred with aprings asul small streatus; exceltent for gmoing, and well oupplied will rimber-aak and pine. The soil varies in quality, and portion of it are very rich. Garden vegetatiles suceoed, but requuire irrigntiun. l'otatoes alqo must be watered, by whicl mode of culture they muceed weil. Curn and pase can be raised in suffieient quantities. Wheat produces aloout twenty-fivo bushcls to the acre: this is not, lowever, on the best Jasd, They sow in Ociober and March, and harrest keging tomards the cnd of June.

I now returned to Nisgunlly, and found that news had been received from the various surveying and exploring parties, all of wheh it was reported were advancing mpielly in the execution of their duties,

\section{CHAPTER XXXI.}

\section{DE FUCA'S STRAITS AND LOSS OF THF PEACOCK.}

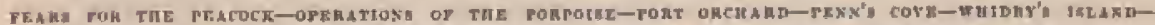

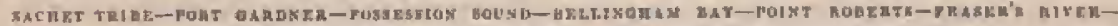

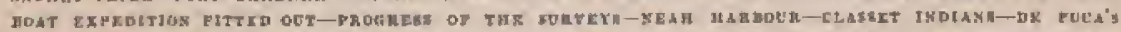

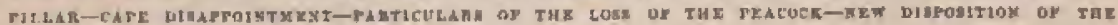

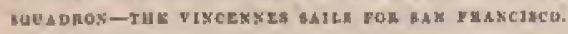

It would twe diffienlt to gire the render an illon of tho anxieties that beset me when I joined bhe Vincennes once more on the lfith June, 184l. Day after dny laad passed in the anxious expectation of receiving news of the Peacock and Flying. Fish, until a conviction became general, with hoth offcers nud erew, that some serious accident hand oseirfter? th one or brth of them, among the dangerous coral reefs and islunds they lad been sent to explore. 'They were now three months Later than the time appointed for their arrival at the Columlin river.

For my own part, after reviewing the whole of the duties masigned to Captain fluctson in my inhtructions, and aguin estimsting the time necseary to futfil them, I could not but apprehcad, from the length to whioh his voyage was protracted, that disaster had weeurred. In this state of feeling, the officers of tho Vincennes slawed a highly con. mesidable spirit, and aware that additional Labours wete thus to be thrown tipon them, stmined every tserve to avoid any further loks of time. The ofij. cers of the Forpoise, as I was informed by Lieu- tenant - Commandant Ringgold, matifested an equally praisewortly spirit.

With the aid of both wind and tide, we suceeeded in getting tlirongh the pasa at the Narrows before dark, nnd when this was effected, I anchored under Vashon's Island for the viaght.

The next day we made but little progrese, owing to light xinds, sarl as stroug tide agaimst us.

On the goli we came to suchor in New Dungeness Roads, where we were joined by the Porjoise agreable to instructions. I shall therefore revert to the surveying oprerations of the erew of that resagl.

On the 15tl of May, the Porpoise left Nisqually, and anchored the firat night near the point where the surveys were to begin, but outside of the Nar. rows.

The first bay at the bottom of Admiralty Sound was teruwed Commencement Bay. Into this, the Puyallup falls, a small river, ten or twelve miles from Nisgunlly. Commeneement Bay affords aneluorage, rud a supply of wood and water moy be obtained. Thic Puyallup forms a dela, aud 
none of the branches isto which it is divided are large enough for the entrance of a boat. The Inding were at this senenn of the year to be found on almost all the points.

The Porpoise was engaged until the 20th in surveying Adnimity Sound to the end of Vashon's [aland, and on the afternoun of the day anchored in the Port Orehard of Vineouver.

Port Orchard is one of the must heautiful of the many fino harbours on these inlaud water, and is perfectly protected frutu the winds. The only danger is a reet of rocks, which is nearly in the middle of the entrance. The sheet of water is very extengive, and is sumounded by a Jarke growth of trees, with here and there a small prairio eovered by $A$ rerlant greensward, and with its honeysuckleg and roses juxt in bloous, resembling n well-kept inwn. The soil is stperior th that of most places around the sound, and is capable of yielding almost any kind of production. The woorls reemed alive with (mi) uirrels, while tracks on the shore mil through the forest sluowed that the Insger class of animnls also wero in the labit of fresuenting then.

The next nine dnys wore employed in surveying Port Orchard, which consist of two inoer mid un outer harbours. T'lie former, although the entrance is by a strait not more than two himulred yards wjde, in from two to six miles in width, and extends fur a distance of fifteen miles. The water was found deep enough for the largest class of resscls, with a bold shore and good anchorage. Lieutenant-Commandant Ringgold made a set of magnetic ubservations here.

Уesr the anchorage wero secn three canoes, propped on trees, contsining the bodies of Indiaus. These were visited by Dr. Holmes, who procured a Flathead skull. The bodies were found wrapped firmly in matting, beneath which was a white blanket, closely fastened round the body, and unfler this a covering of blue cotton. Nesx by, on stages, were boxes hlout three fect square, supposed to entain the articles which are deposited by the Indians near the bodies of the dead, and which were not dieturbet.

Mary Judians, who were alt cheerful and welt disposen, visited the port during the eontinumee of the kurvey.

Purt Orehnrd was funml to emmonicate, on the north, with Port Mndikon. Lieutenant Maury, with the basts, surveyed this pansage, and found that it had $n$ depth of four and a half fnthoms water at low tide.

Near this jusage is a place where the Romat Catholie missionaries lave establistued a gtation for teaching the surrominging tribes. $A$ large crose is erested, and a builing one hundred and seventytwo feet long hy seventy-two wide, which was fonnd to coutain many rude images. Many of the nntives are capable of saying their jrayers and telling their bends, anul fome were net with who eoult sing sume Catholic hymm in their owa languago.

Tho Inlinns frequenting this port called thentselves of the Je-nch-tac tribe.

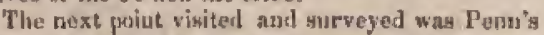
Cove, between Whidby's Island and the mails. This island eoutuns many small villages, nud appears to be muro thickly peopled than other parts of the sound. It is in possessican of the Sachet Iribe, who bave here a permanenf settlement, cun- sisting of Jarge and well-built lodges of timber and phanks, similar to those alreacly described un the Columbis and etrewhere. "The chief possessed a chest of valuables, marefully preserved in a corner, the contents of which were ahown by him with no small pride, and corsisisted of a long roll of paper, on which were many representations of European houses and elurebes, togather with rude akcetches of the heavenly bodtes, and a mop of America. These bad been given to him and explained by the Roman Cathoilic priest, aut loo seenned to understand the explanntion. This whole tribe are Catholice, nnd have much affection and reverence for their iustructors.

The Sachet tribe aro obliged to provide for their defenees agatinst the nore northers tribes, by whom they are frequently attucked, for the purpose of earrying them off as slaves, For protection against thege attacks they have large enclosures, four turldred feet long, and capable of containing many farnilies, which are constructed of pickets made of thick planks, about thirty foet high. "The pickets are firmly fixed into the ground, the epaces between them being only sufficient to point a nusket through. The apprearnnce of one of these onelosures in formidable, and they may be termed impregmable to any Indian foree; for, in the opinion of the officers, it would have required artillery to make a brench in them. The interior of the enclosure is divided into lodges, and has all the ispect of a fortress.

Near the larbour of Port Gardner, a fine streatn empties itself into Possession Sound, by four mouths. The water was not found to be kufticiently deep in any of these to admit boats at low water. in consequence of a bar or flat extending across the mouths

Here they were surrounded by many canosa, containing Indians from the various tribes to the southward, whom they had befure seen. The dress of the Sachet does not vary much from that of the other triber, and generally consists of a single blanket, fastenued with a wooden pin sround the neck and shonlders. Those who are not able to purchase blankets wear lentherı hunting-shirts, friaged in part with beads or sliclss, nud very few are seen with leggings. The women ornanent themselves with amall brass bells, or other triukets. The cartilage of the nose is alsu perforated, and pieces of potished bone or wool passed through it. Although the dress of these nativey would seem to offer some concealment to the body, fow are seen that wenr it with any kird of decency. Their persons ars usually very filthy, and they misy be snid to be at all times conted with ditt. They aro fond of wenting bross rings on their wriats and fingers, and a few are seen to be tatooed who have some lines upon the arrns and face. They disfigure their bodies by the manner in which they daub themselves with red ochre, mixed with salmon-oil, which, besides being disgusting in appentance, is extremely so is smeli.

The brig moved on the 18th Jine, to the northern ontlet of Possession Sound, through Deception Prssage. This was not lolieved by Vun. couver to afford a paseage for vessels; but. althuugh narrow, it is fensible for those of small size. The tides rush with relocity through it, and there are some rocks in the pasange. 'Tlio Indians lakd moved from their village to tempourary huts on 
the beach, where they secmed to etijoy thernselves.

Lieutenarat - Commandant Ringgold, being informed by the Indiuns that a passage existed to the north into Bellingham Bay, boats were sent to explore it. The information proved to be correct; but tho water was so shoal, that it is, at lowest point, almost a mud-flat; and the channel, beaides, is tortupus. This duty being completed, the Porpuise, on the 26th, wns moved through the passage, and anchored under one of the small isles at the entrance.

The Indians from various parts of $\Lambda$ dmiralty Inlet, were constautly around the luig, endeavouring to derive some advantage in the way of trade. Thing were found to oceupy variouts points, ench tribe keeping distinet. Their nanes were, the Scocornish, Suquamish, Clalaum, and Sichets, who live in linrmony with each other, although they do not acruple to call one another "peshac," or bad; but this enithet is invariably given to those of a diflerent tribe by all the Orogon Indians, Tho term, however, is applier with greater force to the move northern tribes, who frequently undertake incursions on them, in strong maraduing parties, for the purpose of obtaining slaves : they are, in consequence, helil in great drend. During the stay of the brig, an alarm oceurred, which produced much consternation among them. Miny sought shelter in the wonds; others went off to their strongholds, and some women sought shelter alongside the brig in their canoes.

These Indinus suffer little inconrenience in their changes of residence; for, having but $f \mathrm{w}$ chattels, they can remove at a few romonts' notice; and niter landiug at an entirely strange pluce, they are at home the mament their fires are lighted.

The 4th of July was spent near Point Roberts; and on the 5 th, the brig renched the mothth of Fraser's river, which is about a mile wide, with a serpentine channel, leading through an extensive mud-flut. Fort Langley, of the Hudson Bay Com. pany, is situated about twenty miles from the mouth. The country immediately around is low, and has a rich allurial soil. It is inhabited by the Naniteh tribe, who accompanted the brig thither from Birch Bay, The mouth of Fraser's river was found to be six miles north of latiture $49^{\circ} \mathrm{N}$.

Lieutenant-Commnndant Ringgoll, on the 20th, received further instructions from no to push the nurvey to the north; but being short of bread, lie had sent Passer-Midshipmsn Sand ford to obtain a supply, which was at once despatehed in the launch, although I expeeted to meet the brig at Now Dungeness ill a few days.

On the 20th, as hefure mentioned, the brig joined the Vituceunes at Now Dungeness.

I had treen in hopes that, after the severe tour of surreying duty for the last three months, I slould be able to give the crewe some relaxation; but I found this impossible, for the duties were necessarily much increased by the absenco of the Peacock and Flying-Fish, and the necessity of finishing as much of the northern snrvey as possible, ns well as obtaining accurate informintion in relation to the pusitions, \&c. I deemed it of too much importance to allow a day to go by unimproved. Orjers were therefore given to the bonts under Lieutenant Case to proceed to Port 'Townsend, to fill up the surveys and connect them with Hood's Canal and those of Whidby"s Islund.

Another division of boats, with those of the Porpoise, were employed in surveying New Dangeness Bay, and connecting it with I'rotection Island, while I was oecupied in getting a series of observa. tions for latitudo and longitude, dip and intensity, at the low sand point which forms the bay. Onders were also prepared for the Porpoime to proceed to Port 'Townsend; thenco to Fraser's river, visiting Fort Langley: and then through Juhtason's Strnita, and round the north end of Fineouver" Island, to Nootka Sound.

A large boat expedition was also fitted out, of which I took charge in perwon, to proceed across the Struits of De Fuea, to cormplete the survey of the Canal de Arro, with the adjecent bay's and har. bours, and thence to the mouth of Fraser's river, where I anticipated fnlling in with the Purpoise again.

On the morning of the 25th, tho brig parted company, and in tho afternoun I bet out, with seven boats, to cross the atrait. The wind had been blowing strong, but I dill not anticipate moch sea or danger. It proved otherwise, however, for the tide was found to be running strong ebh against the wind, producing a very high sea, which mado the passigo at times perilous. We, however, crossed this distance of twenty miles witlout any other accident than the loss of a mast belonging to one of the boats, and reacher the opposite shore in safety, thengh completely wet from the quantity of water we had shipped. The boats arswered all purposes uncomminty well; and many who had believed them unsafc, were now sntisfied that they were admimbly adapted for all wenthers. Largo fires and dry elothes soon restored the men to their wonted good spirits.

On the 2Gth, we began the survey of this labyrinth of islands, which was continued ste next day, 27 th, on the afternoon of which I was joined by Passed-Midshipman Mny, with letters from the ship and despatches from Niaguslly, informing me of the loss of the Pencock, on the bar of the Columbin, but that all hands were saved. This new, although bad, was a great relief to me; for I had feared not only the loss of the vessele, but had serious apprehensions for the lives of the persons on board. $A$ henvy losd that had long hung over my mind was removed.

All my plans for the employment of the squadron were now at once to be changed; for it beeame necessary for me to proceed without delay to afford relief to our shipwrecked companions. I therefore immediately sent orders to the Porpoise, conntermanding her previous instructions, and ordering ler to repair forthwith to join the Vincentses at New Dungeness, On the 28 th, the duties of our survey were again resumed, and a finish made of those of the Canal de Arro. This was effected Aluough the strenuous exertions of both officers ntul men, and the same night wo reacherl the Vincenves.

Although we had completed all that was essential for the navigation of the Canal de Arro, I regretted that I had been deprived of the opportunity of examining the anuth-east end of Vancouver Istand, which ["have reason to helieve offerg many file harbours. Threo days more would have enabled me to aceotnplish this portion to my satisfaction. 
On the 29th, the brig again joined ns, and Mtr. T. W. Wuldron was at onee etut with despatehes to Nianually, to pus nerose the emantry to the Cowlitz, and thence dowa the Columbia to Astoria. finng the despatctes was an order to all the wardrooin nflicers of the Peacock, to report to me in writing the circimastances that led to tho loss of that ship :

On the 31st, towards noon, the wind and tide permitting, we got muder way, and stond down the Straits of De Fuen; but owing to the light winds, we mado little progress of the northern side of these straits it had been my intention to make a very particular exanination, after completing the sutriey of the Canal de Arro. I have understood that there is a fine harbour nenr the eastern end of the istand, where a [rost has becu lately entablished hy the Hulleon Bay Company; thet of San Junn, Hear the methl of the strrita, the Porpolse sas ordired to survey on the 2 nd of August, while the Vincenne was engnget in the survey of Nent Hnrbour, Jying on the suuth sille of the strnits, just withiu Cape Flattery, Port San Juan was foand to aftoril little sitwlter, heing exposed to the soutlywest winds, and the licavy swell of the ocesn ; and is reported as being unafe, except for temporary anchorage.

Neah Hartour is but a small indentation in the const, which is partly sheltered on tlac north-east by Nenh loland. It is the position where the Spaniards attempited to extablish thomselver in 1572 , and which they ealled Port Nunez Grona. The romaiss of au old fort aro still to be perceived, and sono brisks were found that wero swpposed to hayo belosiged to it. Water is to be obtainel here in some quanlity, and a small vessel woryt f have no difficulty in getting enough. It offers a tolernbly anfo anchorage, though somewhat exposod to the north-weat gales; yec by anchuring well in, which a small vessel may do, prutection even from these gnles miglit be hail.

The ship, on suchoring, whe gurrounded by mony eanues of the Classet Indians, who istliabit tie country around Cape [Flattery. They wero well dispoged to triklo, and were greutly surprised that wo large a ship strould wait no furn, which were of several kinds : the ena-otter was that most prized, and held at very exorbitant prices, more than they could the bought for in the United States. George, the chief of the Talonche tribe, as be terms hinself, was on buard nll day. He apeaks a few worts of English, anu! is a fine-looking man. It was dilttcutit to make him or any of his troople uswlerstand the use of a man-of-war, the number of people on board, and the care that was taken to keep then from comirig an loard. Ife showel it by continuslly asking, "What for" so big ship " "What for so many mans !"-all probably proceeding froin lis disappointruent in not heing able to sell his filins.

'The Classet tribe of Indians is one of the moat numerous on the cuast that I had an apportunity of seeing, aml seesns the most intelligent. These Indians wore sruall pieces of an iridescent musset. shell, nttrehed to the eartilage of their nose, which was, in some, of the size of a ten cents picce, and triangnlar in shape. It is generally kept in motion

- These will be fotand pribluhed In Dacument Ko. 127 .

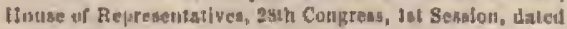
loth Aprll, IHH. by their breathing. "I'hey hat seldtum any ctothirsy exeepting a blauket; but a fow who havo entrived to make fricnds with the visiters, lave obtaimed some old slothes; while others seem to be in the pay of the Hudan Bay Comprany. The prineipal articles of trade are tobneco, prowider ("paulales"), and ieaden balis. These are preferrel to moft other merchandise, althaugh more ean the olstained for spirits than for any other article. This showe very conchnsively, to my mind, the sort of trade that was earried on when the Boston ships cutered into rivalry with the North-west Company for the pur. chnse of furs.

On the s'rt, we were engaged in the survey of the harbour, besides obtnining fifteen hundred gallons of wntel. Its posstion (tho north print of Nenh Island) was foutud to bre in Intitule $48^{\circ} 24^{\prime} 40^{\prime \prime} \mathrm{X}$. longilude $124^{\circ} 36^{\prime} 4 h^{\prime \prime}$ V.; variation $21^{\circ} 8^{\prime} 14^{\prime \prime}$ ertuterly.

Wd had as mnity as forty cannes alongkide on the 31 d, with various urtieles for anle, iscludisur fists, venison, \&c. Some of the canoes lad al many on twenty persons in them. They were generally a stout, athletie rree; nnd it was observed that blue worsen were much better looking than those of the other tribes, Some of then, indeed, laad quite fair complexions ars rosy coftecks. 'l'hey aro nut as much exposed to the wenther ss those we hind proviously seen, being provided witlt a canical lut, made of grass, and plaitesl so tight ns to be impervious to water, which hoth protects them frots the rain and atm.

It is said that this tribe can muster one thou. ancul warriose, nod they lave the reputution of being treacherous and warlike. Msny of them were fautastieally painted, that i, bestneared with oil, soot, and red pitut. Their dress consists of a native Llanket, made of dog'a hnir interapersed with fenthers: this is much more highly valued than the trouglit oncs, but is rarely to be ubtaiued. Tlie elamour ande by our numerous vigiters along. site was very gresi, and their offers of erticles were without nuch regard to the priority of rank, station, or any thing else.

Al2 P.s. we gat under way, with the Porpuise in company, and suceeded in maling an olfing befure the fug cuveloped un, Thege fogra are one of the grentest andoyndes to vessels arriving on this crant; for, in tine weatler, they ane expreienced almost drily, coning up with the sea-brueze, continuing throngliout ihe night, and until the sun las sufficiant pow the next day to dissipate them.

In leaving $\mathrm{D}_{4}$ Fues's Straita, I unximsly watehed for Do Fuen's l'illar, and suon obtained a siglit of it.

The morring of the ath August the Porpoise was direnvered astern, which relieved me frum any apprchensinn of detention.

The sounlings were somewhnt peculiar; for is was found that in our progress down the coast, they iscreased almost regularly until ninoty fathoms was renched; but, a ehort distance beyond that depth, surd at about fitteen miles from the const, the bnnk suddenly fell off, and no botton was to be obtained witl a line of two bundrol and two hundred and fifty fathoms long.

On the Eith, at daytight, Cape Disappointment was in sight; and at ten o'elock we were near the cupe. The Flying-Fish joined us at soon; when Captris Hudson etane on board, and frots hin I 
Jearued the particulars of the loss of the Peacurk.

It will be necesenry in the first place to state, that at Oalu, Sandwieh Islauds, previous to the departure of the sptudwh on their several ertises, I had farnished the Pescock, Porpoise, and tewler, with diretions for their passing lag las of the Culumbis river, which I obtsined front Captain Spalding, of the ship Lausanne, is ressel of tive or six hundred tons' burten, which had just returned from the Columbia, whithor sho had talien a num. ber of missionarics and their stores. "Thome n. peared to be carofully dmwn up, and Captain Spalling informed me that they couli be depended upon. The fact tlant so large a ship lad been navigated by them, and the rejort of the master, that he believed them correct, left me wo reason to doubt their probuble aceuracy; althungh at the time I had sume triggivinga about them, ns they were entirely dependent on compass bearings, ald those of objects at great distances. "They were, however, the only directions for passing this chargorous bar whicli were to be had, and were then believed to be the only correet ones in existerse. It was supposed, indeed, that they had becr communicatrod to the Fludsors Bay Company by the officers of 1I.B.M. surveying vessuls Sulphur aud Starling; but of this 1 liwl no jositive evidunce; for, nthough I met those vessels at tho Feejee Istands, I received no communication fron them on this subject.

The Peacock male Capre Dikappointment on the afternoon of the 17 th of July, and throughout the night experietuced figlst nirs aud ealms, neounphnjed by a dense fog.

On the morting of the 18th, between seven nud eiglit oicluck, the fog clenred off, with the wind from the soulhward and eastwayl. Cape Dispppointment was then about nine miles diatant. $A$ t nine they bounded in forty fathoms water; at ten, fifteen: they had but fourteen fathoms when they tucked off shore. It beíng Sunday, Captain Hudsoty, as usual, perforned divine service, which being finisbed at $17 \mathrm{~s} 5 \mathrm{~m}$, they again tacked to sumbl in. The tender at this timo was several miles to lec. ward.

At meridian, the wind came out frotn the sontlward am! westward, with the werther a little clomiy; suon after which time the slip was off the tintratice, and all hanls were called to work her into port. Lieutenunt Einmons was now sent alort, on the furetopsail-yard, while Captain Hudsan attunded personnlly to the piloting of the silnit, agreeAbly to the directions before Epolets of, which lie loeld in his hast. The sthip was, aceotring to Captain Hadeon's report, running a nort's-cust-quarterenst course, laesding for Cope Disarpointuneut, until the proper beating of Chinonk Puiut east-Inntheast was reached, whin they discowered the sea breaking miend of ticnt. He now betiored himself too far to the southward, wore blip, and ras off a short distnue, unti] clenr of the breakers, after which they again stood in, whero the passage ap. peared elear and smooth, huth from helow and aloft. In less than five minutes, the ship touelsed. Lieutenash Emuons, who was on tho look-tout aloft, together with Ioieutenaut Perry, who also was similarly engaged, both seate that they were of opinion that the ouly juce whero the chamud existed was where the water dil not lireak, and agreeing as it did so nearly with the sailing directions, Captain Hudson did wat hesitate to attempt to procesd through the smoother part.

I am well aware that many opiujons lave been, and probally still are entertained, relative to the prudence of venturing with the ship belore the chanmel had been explored and exnumed by tho tender and bonts. This is but unturn! to ono 111 aefuninted with the bas of the Colmulia river and it dangers. After laving paid much attention to this subject, and having been engaged there with the tender and boats in the survey, I feet myself entitled to give an opjinion as to the course pursued by Captain Hudsons, and thisk it altngether correct, on every gromm of exprediency, as well as the only juroper vine for lim to lave followed under these eireumstances, It will be reoollected unt ho lad been detatined nearly three months beyond hia azprointel time, and that he was well aware that this would occusion sutuch ineourenience to thes progreses of unr duljes; Jis anxiety to prevent any furcher delay, even of a few hours, can readily be imagined. 'T'lie time wns, to all appearance, propitions, and tresitntion then might hare rendered it impossilye to lave entered for a weuk. I'lie tender going it alsead would lave been litule or no security, for she would, undushtedly; have jursued the same cumrse, and have beet, in all yrobability, lost; and thus the Pencoes would lave been obliged at last to truat to the knuwled ge of those os Lond of her. As resprects the examination of the bar in boats, this is a thing nexc to imposaible; for the tides are so strong as to be beyoud the power of onrs to contend with. To wat utul a thorough knwwledge could be had of the bar from survey, would lave been equally impossillo nt that time: all were uninformed, ot incuphble of juiging of the sceurney of the directions; but, so far as nppearances went, thoy seemed to the trie, and they are buch as I should eren now give, so far his conjpass bensings are concerned. But thero is one diffieulty that will ever exist in passing over the bar, and this, nothing but an intimate aequaintnnee with the locality will remove, I allute to the cross-tides, which are changing every half-hour. These tides are at times so rapid, that it is impossible to stecr a thip by her compuss, or maintain her position; and no sililing directiots can possibly embrace the various effects produed by them uqun a vessed. A singular fact in illustrution of this remarl is, that the safese time to cross the bar is when buth the tide and wint are adverse; and this is the only port, within my knowledge, where this is the case. Captain Hudam, in veuturing the attenpt to enter the Columbia, unanifested tho strumgent denire to mecomplish his oriders and forward the objects of the expedition. Disregating the well-lnown perils of the navigntion, he did not lyesitnte, when fol lis judgment the time was propitions, to bueur the dangers of the bar, mather than suljeet the servieu to a further delay, wlich anight have proved us disas. trous to the expetition as the lins of the vessel.

There nre wo pilots for the entrance of the Culumbia river, or rnther, wone that could bo refied upon. Feither old Rambey nor George deBerve the name, nor were these any other pereons kwown, who hnd any pretcusiuns to be cunsidered 4s pilute.

Having set this matter at rest, I thall proceod to give the details of the loss of the peacosk. 
On the ohip striking, the lielm was inmedintely put a-lee, and every practical effort was made to bring her by the wind, and laul off." "Thege efforts were not sticessful, and the ship, which hugg by the keed, begras to thump heavily. Every sea forced lour furtier upon the stoosl, nitud as sho lad now become completely unmanngeable, the sails were furled. The gtream calle and nuchor were got realy, and the first cutter was hoisted out. Licutensint Emmons was sent to sound around the ship in rarious directions, in one of the waist boats.

At this time, the wind hrying veered to the nartluward and westwatd, was freshening; the ais was haxy and a fog was forming "; the elib tide had begun to rus strong, and meeting, nat only the ocenn wares, but au opposing wind, in as short tinse formen breakers which complotely enveluped the ship. These brenkers soon atove in the fitet eutter, and reudered her raelcsa. Susels was the fury of the sea, that it was with grent difficulty Lieutenant Emnonis reached the ahip, and the boat wns secured.

With every sen the ship lifted and strucli hervily, and mueh solicitude was therefore fett leat it should be irrpmoticsblo to get the laurch aflont; but no boat could lave lived alongride of the resel fur more than a few taoments.

Thu Jighter spars were now sent down, and the pumps were rigged; every exertion was made to save the masts and lower yards, by which the lanuch might be livisted out ns soon as the nea would perinit it.

Captain Hudgon, finding that the slupip was leaking bajly, ordered the watclies in gangs to the pumps, which wero thencefurward kept in action until the vessel was aluandoned. Fivery passible exertion was male to bring the ship's hear to the een, but withont much effeet, for the rudder wns soon disabled in consequence of the iron tiller being bioskon off. Tluo muder was thus jeft to thresh alout with such vialence as to threnten to tear away the stern-frame.

At last, by heaving the shot overboard, and starting the water, the ship was so mueh lighecned that, by means of the lastoont atichor, which had been east free of the ship, she was hove round with lier head to tho sen. At low water, which oecurrend about dark, there wns only nine feet depth of water alougaide. At $\mathrm{g}^{\mathrm{h}} 4 \mathrm{j}^{\mathrm{m}}$ the chain-cable parted, the ship was again thrown broadside to the sen, and begara agnin to striko heavily.

At $11^{\mathrm{h}} 3 \mathrm{H}^{\mathrm{m}} \mathrm{h}$ it was high water; nt I r.M. tho sea was trupidly inerensing; and at $2 \mathrm{~A}$, $\mathrm{M}_{\text {, }}$ the brenkens were making a contiuned brencl, over tho vassel, by which tlie bulwarks were stovo ist, and the spar-deck fiooded. 'The water wa linee-deep on the gun-dect, and the slot-lockens were buried in it. The night passed heavily, with litulo hope of the ship"s loolding together tilt mornilig. At lnst the day dawned, and with the coming light, and at the extreme fall of the tide, the gea providentinily abated.

At six o'clock in the morning, a large canoe boarded the vessel, manned by a erew of Chinook Indians, and having on board old Ramsey, the pilot, witl a coloured boy belonging to the Vin-

- During the summer, this wind, haze, anul fog oceur almost every day tu the afternoon. connes, of the name of Jolu Dean. The latter, who lind been left by mo with Mr. Waldron at Astorin, lial persunded Ratmsey and the Indians to entme off, for the purpose of remteriag ansistance. The launels and bonts were also twisted out, a few provisions put in them, nnd a part of the men and offiecrs embarked, with as litule delay as ponsiblo, and just as 1]iey stood, for fear of overlondiug the bonts, and thus causing the loss of all. In these, Lientenant Perry, with Purber Spieden, the sick, the naturalists, and the charts, books, and ship's papers, were scut off, to be landed in Baker's J3ay. The bosts landed all not neeessary to row them, in safoty ; ant sueceeded in making a secont trip, in which all who had remained on hoard were taken to the Bhore, except Cinptain Hudson, Lieutenant Walker, the boatswnin, the earpenter, and nibout thirty men.

Towarth noon, the breakers again increased; and the sen was making a breach in all directions over the stup, which was filling fast, the wuter having risen above the level of the berth-deck. The nusts were eut awny, aud the ressel lay a complete wreck, with totlying stasding but the stump of the mirzen-mast.

Lieutennit Enmons, who had charge of the boats, was, fluring this time, using every possible exertion to mako a third trip, but without sucess: and the crews of the busts were the anxious witnesses of the condition of the slipt, without being able to relieve those on board from this perilons situnlion. They persevered, lowerer, in their fruitless and laliorious endesvours, until one of the lonts, in elasge of $\mathrm{Mr}$. Lewis, the ganner, was tlsrown eul over cod, and with her crew engulfed. Lieutenant De Haren was fortunately close at hnud, and succedexl in anving those on bonrd; all of whom were iujured, and one of thein surerely, by the breaking of lis hiph-bne.

The intense exciteruent, bntls of those in the resel and in the bonts at this monent, may be rendily imaginet. The aecileut was seen froni the ship: Captain Hudson was totisfied that any immediate attompt to relieve lins and his companinns must be fruitless; and that the only clance that remained, was to preserve the bonts for a future ocession.

In therefore ordered the ensigts to lie hoisted on the stump of the mizzen-mast, ns a signal for tho boats to return to the land; which was obeyed by them, altinough with the foeling thist they were abandoning their commander and those with him to their fate. Those on bosad, on the other hand, were relensed from their anxiety for the bonts, on which alone they could depend for being relieved, if the wreck should remain tugether for a few hours. of this, lowwerer, the jrospect was for from promising, amil tho stumgrle between tho waterg of the great river and those of the mighty ocean, when every sume seemed to forebode the utter dissolution of the fabric of the ship.

The light articles wcre now removed to the spardeck, to give them a chance of resching the blore by the action of the wares and winds, should the shipg go to pieces.

In the midst of this trying secue, the ordinary routine of ship's duty was earried on, even to the piping to dinner. It is needlex for time to say any thing in praise of the conduct of Captain Hudsor, aud 1 have simply to refer to tho letters I received 
from the officers and naturalisto, in reply to a call I made upon then, for the aspeet in which the transactions presented thewselves ta thuse yresent; and more pirticulnrly to those of the latter gentemert, who, as spectaturs, had ar opportunity of witnessing the whole procedingr.

By three o elock, Liententut Eramons, with the boats, was again ajproaching the stip; fut the sea was still too rough to venture nea her, und it was not till five o'clock tlas lie sacceded in gettisg alongside, when the remnining men were distributed among the boats, and emlarked in good order, Captain Hulson being the last to leave the ship. After a pull of two miles, they landed in Baker's Bay, when Captain Hudson was reeeived by tho other officers and men with three hearty cheess, the spontaneous expression of their admiration and gratitule for tho courago and eonduet he had exlyibited in lis effurto fur the preservation of the slip, and in finally preserving the lives of ull.

"The exertions of the oflicers and men were not yet at an end; for some fnint hopes wete entertained that a portion of the juoperty might still be saved from the wreck, as a relief in their state of utter destitution; and, in consequence, the boats were despatehed the next morniug at daybreak to the bar. But nothing was there to be seen of the Peacock, except the eas of her bowspuit; for her upper deck had been separated, and the pieces seatlerel for many miles along the coast.

Captrin Hudson passed the lighest enenminus on his ofticers and crew, for the faitliful natuer in which they continued to perfora their duties and carry out his orders to the rery last,

I nim astisfied that every thing that seamanship could devise to save the vessel, was resorted to; and I am quite confifont that when the facts are all known sull fully weighed by the comranity, the conduct of Captain Hudson, and that of his officers aud erew, in this perilous and trying seene, will be consitered as reduunding to the erelit of the service.

Mr. Bimie, the agent of the Hudson Bay Company at Astorin, Messrs. Frvst aud Koen, the unissionariss, witl several residents, csme prompely to the aid of the shipwrecked erew, with provisions, tents, cooking utenkils, and clothing, all vying with each other in affording assistance.

When all hopes of getting any thing from the wreck were at an end, Captain Hludsum sent the crow to Astorin, in the bouts, with orders to furts an eneampment there, where they found an ample stpply of provisions in the stores that lind treen sent from the Sandwich Islands, and were supplied with elothing by the kindness of Dr. M'Laughlin and the otlicers of the Hudson Bay Company:

As goon as I learned the exact state of athairs in the river, I deternined to make such disposition of the sefundron as would be most adrantigeots, in the performance, utider tho new eireumatinnees, of the duties which remained to be accomplished.

With this jutent, I rearlved to slift my pentant to the I'urpoise, and with-that vessel, the I'yzugFish, and the bonts of the I'encock, tu survey the Culumbia to its extreme navignble poirt. Thiss force would be tanply suftivient to perforzu this survey in the shortest possible time, and yet cuable me to despateh a party, as I ham before intended, throngh the southert scetion of the Oregon ter. ritory to San Francisco. The Vincenses, to which I ordered Liontenant-Conunazdant Rinugold, I lesolved to bend to Sun Franciseo, to mako a survey of the Sncramento rixer, while I was engaged upioun that of the Colambia.

In conformity with this plan, I directed the Finconnes to be off and on at the motith of the river, while I proceeded in with the Horpoise to make the necessary changes and transfers. Taking Mr. linox, and Ramsoy the pilot, on bourl the latter vesel, we pasaed the line and stood townrds Asturia, but were compelled by the tide to antelior before reaching that place. On the morning of the 7 th, we anchored in frunt of Astoria, where all the necessary arrangenents were courinted; ast] Lientennat-Cummaradant Ringgold, on the mext day, proceded in the Flying-Fish, with the transferred officers, to join tle Viucenues. $A 8$ goon 4 this way effected, that ressel bore away for San Franciseo, and the tendes returtsel to the jister.

As it became absolutely necessary to conomize our time as much as possihle, every disposition was now unde of the men rud bonts. I noen, however, found that, although I had sent an number of mento the Fineennes, there would bo miny thit eould not be well necommodated in the smaller vessel, and I was desirons of procuring some extm necommodation. Fortunately, the American brig, the Thomas H. I'erking, Captain Varney, was lying at Astoria; mad a reasonablo agrecneut wns entered iuto for her purchase. DL. M' Laughlia, who had entered into n eliarter party, realily agreed to sarrenter it for a small consideration, if the goods he had on board were delivered at Vaucouver. This there was no diflienlty in, as it was found necessay to make some nlturntious in hur aceommodations, and it would be necessary to resort to Vancouvet" fol many articles; and thieso repairs conld be easily effected during the time we were eagaged in the survey of the river, and better at Yancouver than elsewtiere. It was, therufore, detersuined to proceed up with both reasels, at the time of making the survey.

It jo now proper that I should return to the regrular order of events, and take up the narration of the interestiry eruise of the Pencoek, the thforeseen and disastrous termimation of which has just been related. 


\section{CHAPTER XXXII.}

\section{CRUISE OF THE PFACOCK AND FLYING.FISH FROM OAHU TO THE BAR OF THE COLUMBIA.}

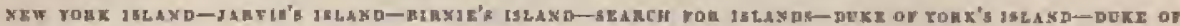

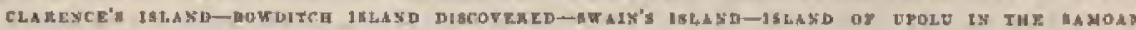

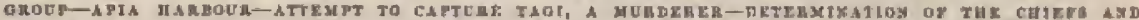

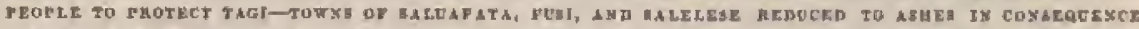

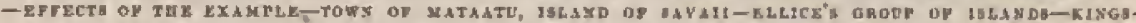

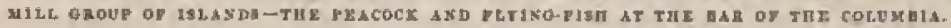

The Feacoes and Flying. Fish lett Oahu on the and Deconber, $1 B 40$, and stecred of to the south. whrd until they resiched the latitude of $5^{0} \mathrm{~N}$, and longitude $160^{\circ} \mathrm{W}$, a position in which it was thought that an island existerl. 'This position was carefully examived, until they were sntisfied that there was no land at or near the locality. They then zteered for Washington Island, known on the chart of Arrowsmith as New Yurk Islnnd, whicl was foumd and surreyed. Its position is in latitude $4^{\circ} 4 I^{\prime} 35^{\prime \prime} \mathrm{N}$., and longitude $160^{\circ} 15^{\prime} 37^{\prime \prime} \mathrm{W}$. It is three and a quarter miles long by one and a fourth wide, and is entirely covered with coconnut and other trees, exhibiting a most luxuriant growth. There is a reel off its eastern point, which extends for baif a mile. At the western end, a coral ledge extends two miles in a nortly. west-by-weat direction, on which the water appears much discoloured, but the sea was not seen to break upon it, exeept close to the point of the island. The island is clevated shout ten feet above the sea. The surf proved too henvy to allow of their landing, and the island affords no anchor. age.

The positions in this neighbourhoorl, where five islands have beun reported to exist, were dili. gently searched for eight days; but jo land was seen, and Captain Hudson beenme antisfied that none but Washington Island is to be found.

On the goth December, they made Jarvis's Island, in latitude $22^{\prime} 33^{\prime \prime} \mathrm{S}$, and longitude $152^{\circ}$ $54^{\prime}$ II" W. This is a small coral island, triangular in shape, a mile und three-fourths in length east and west, and a mile wide north and soutl. It exhibits tho appenrance of a white sand-beach, ten or twelve feet above the sea, without a tree or shrub, and but a few patehes of grase. The sea breaks violently around its shores, but no recf extends to any distance from the ioland, which way be closely appronetied. A few sea-birds were seen alout the ishand. No landing could be attempted, the surf being too henvy. Captain Hudson considers this $n$ dangerous islaml for navigators.

The Peacock and Flying-Fish, for the next fifteen days, were engaged in searching for Brwoks's Island, Clark'e Reef, and varions shoals; but without Euceess, and, after examining the neighbouring sen, left the Jocality, fully satiefied that if any islands or shoals had existed, in or near the pluces assigned to them, they nust liave been seen.

On the Tth January, 1841, they made Enderbury's Island, of the Plionix Group.
On the 11 th, they made and surveyed Birnie's Island, which lies soutli-west from Enderbury's, in latitude $5^{\circ} 34^{\prime} 15^{\prime \prime}$ S., longitude $171^{\circ} 33^{\prime}$ W. It has an elevation of tio more than six fect above the sea; is about one mile long and a quarter of a mile wide, trending about north-west and southeast. It is but a strip of coral, apparently uplifted, and is exceedingly dangerous for resseln, as it cannot be seen from a distance, and a vessel, in thick wenthes, would senrcely linve time to avoid it after it was clincoveretl.

A number of islands and reefs, reported to exist, were searched for in this neighbourbond, viz. Mary Baleont's, Brothers', Robertgon's, Phonix, Harjer's, and others, laid down, but jot named, all of which aro believed to have no existence whatever.

On the 17th January they made Hull's Island. Captain Hudsm, believing this to be Sydney Island, ran off forty.five miles to the westward, fur Hull's lejand, but, of course, saw nuthing of it, as it lies that distance to the eastward, in the same latitude.

The position of an island supposed to exist in

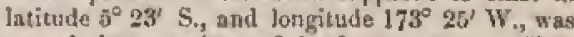
passed, but no signs of land were seen. They then ran over the supposed place of Pletctier's Islard, in latisude $7^{\circ} 2^{\prime} \mathrm{S}_{\text {, }}$ longinude $173^{\circ} 22^{\prime} \mathrm{W}_{4}$ without seeing ary sboal, islatu, or reef.

The next day they procected to the Duke of York's Islamd, which they made on the 25th, in latilude $8^{\circ} 36^{\prime} \mathrm{S}_{\text {, }}$, bugitude $172^{\circ} 23^{\prime} 52^{\prime \prime}$ W. This is a bigon island, of conul furnution : its lengtl east nnd west is three usiles, and ita width two and a haif tuiles, north and soutl. There is no passage into the lagun ; the sea breaks on the reef with violence; but at high water a loost may pass over without difficulty, if proper care is taken. The islets that have been furmed on the reef are eiglin or ten foet alsove the water, and are covered with cocoa-nut and pandanus trees,

As they spproached the island, three donble canoes were seen coming towarls the slip, but with grent enution; the mizen-topsail was lacked to allow them to cone up, which they did, singring and shoutitu, making matsy gestrres, and waving piees of matting. A white hlug wro wared in re. turn, and various articles exhibited to induce them to conso alongside, which they at last did; but no inducement could prevail on then to come on board.

The boats wero now lowered, and a large party proceeded to land at the nearest point. The hand- 
ing was effected on the coral slself with some difficulty, and they fund the natives, who lud cone nlongwide, ready to receive them, with every sign of friendship. They had appareutly reeovered from dheir alnum, and met the offieers liefore they reached the bench, greeting them by rubbing noses aud Ihıwing their arms around their necks. Their exeitement seemed to be so great that it was diffieult for them to contime still for a momeut, dis. tracted by the numerons novel things around thems. Some of them, however, were exceedingly sliy, and would rat suffer themselves to be appronched; others had greater confidence, but at the same time sliowed a respectinl festr; while a few put their armus round the oflicers' neeks, and exhibited a boldness deroid of dretul of aty kintl.

Their village, to which sur purty went, was ors the inter or liagoon fide ol the island, and ecustained abont thirty honses, which were raised about a fimot above the surrounding earlt: they were of oblong shape, about fifteen feet light to the ridge-pole, slopisg gradunlly, and of $n$ eonvex form to withit twa nr thiree feet of the gruund ; the joof was supported an high posts, whilat the lower purt rested on short ones, tliree feet willin the eaves, having a stming piete extending arouud, on which the rafters are tive; the gatsle-ends were overtopped by the rouf, and seemed necessary to protevt theu from the weather. Below tho enves, the whole was open fron the ground to the roof. The thatching, made of mandauns-hunves, wis of grent thickness, nild put on loosely. The interior of the houses wins rery elean, but there was wo furviture except a few gourds, snd a reelinitig stons, eut from a solid block of wood, having two legs at oue ent, whiets inclined it at an rnglo of nearly forty-five degrees: to show the manmer of lying in it, they initated a cereless and comfortablo luntge, which they evidently considered it luxury. It was conjectured that they had removed their parious luusehold utensils ton secret place.

The mast remarkable construetious of the islandery near the willage, were tlure small qunys, five or six fect wide, and two feet above the whter, fortuing slipe abrut teu feet wide: at the end of ench of these was a small bouse, lyilt of pandanus-lenves, partly on pries in the wnter. Thuse appenred to be pluees for securing their eanoes, and for the purpose of keeping their fisluing implenents. Thrce canoes were seen lyiug a short slistance off in the lignom, filled with tho women and children. This was a preeaution adopted to enuble them to eseape if it becune necessury; yet they did not seem to apprehend any hostility. No kind of war inple. Inenta was observed amoug them, nud likeir bodies exhibited no marks of strifo witl ench other.

This island was diseovered by Byron, is 3765 , who reported it as destitute of inliahitants. The natives gave the mane of their island as Oatafu, and aeksowledged themselves the sulijects of a chief who lived ou a neightouring island, utled Fakaro, pointing to a southerly dircelion. With this exception, they did not appear to pussess the knowledge of any other islands but their own.

On the 26 th, the ressels sailed for the Dulre of Clareuce Island, but owing to the tmafarourable state of the wenther, they did not resch it uatil the 28th, thought unly a few miles distant, when it wa surveyed, ond fond to be seven and : wo-tentha miles long, in a sorth and Eouth direction, and five miles wide from east to west. It is of a triangular Blanje, with the apex to the arorth. It has a Ingoon similur to thet of the Duke of York's, will islets in it; the north-west side is a bure reet, or wash, on which the sen lirenks henvily. After the survey whs effected, Captain Hodson foumd it impossiblo to Jand to lold communication witl the native. but lans to doube of its leeilly inhnbited, as is wrs spuken of by the inhatitants of the Dulie of lork's lelarud as belonging to the samo people, and whs called by them Nakumun. Nu opening was perceived into the lagoon, and there were many cucosnut and other trees on the island.

On the 29th, at git $30 \mathrm{~m}$ Aos., whilst Lieutemant Emmons had the deck, the night being very dark, and the weather clear, he heard the distant sound of surf; soon afterwarda the wind changed, when land whs discorered cluse to the vessel, bearing north-east. They made signal to the tender, and hove-to till daylight, when the largest island they had get secn was within two miles of the shipi.

'This proved to he at new discovery, ns it was not to be found on any chart. The jiland, which I have natred Bowditeh, agreeably to live wisl of Captain Itudson, was of cornl formation, and its shaje is that of a tringle, with the npex to the sotsth. From north to sonth it is eight miles long, and its width from its west point, four miles, on its south-west and north poisita the land is of emssiderable eleration, and the more elevated parts are ecinneeted by an extensire coral rcef, that is awnsh. On the cast side tho fand is mure contijuotss, and on tlire parta there an extensive groves of cocon-nut trees and shrulatery. There is no entrance for a ressel to the lagonis, which, from the appearance of the water, has but litule depth.

At daylight, eighteen ennoes, with four or five persons in each, were seen off the enil of the island, npparently on a fishing excursion: they disregarded the vessels altogether, and contimued their occupntion, without taking any notice of them, and as if utwilling to lose the opportunity of taking the fisl. The fish seensed to be extrenely numerous, if the actions of the birds were to be taken ns an indieasion, for immetse numbers of them were seen dnrting isto and rising from the sen every noment.

As the latives refused to come near the slip, Captain Hudsoll ordered swo bon1s to be sent to open a consumintion wịth them. They were tuking fieh after the manwer of the Samoans, by troiling in lise, it being fastened by a pole eight or ton feet long to the stern of the cmnes, and clevated ahove the sarface to a sufficient height to allow the fisli-liovk, which was made of stiell or bone, to drag alone the surface of the water; ns their canoes were gurupelled, the fish, attracted by the glintening of the hook, eagerly caught at it, and were taken.

The Jatives were at first very shy of the boats; but the Hawaiinn who were in them soon induced them to spproach, and enter into trade, and firally enticel them alongside the ships. On coming near, they began a song or ehant, holding up their paddles and mats, and shouting " hafilou tamatau." They regembled tlie natives of Oatafu, or Duke of York's Island, wore the sarze kind of mate, eye-shades, and orvaments, and some were 
tattooed after the same manner. They were at finely formed, and masly iı appenrninec, with plensing countennees that expressed good-nature.

They seemed enger enongh for tude, and soon disposed of nit they tad to exchange; n few presesits weie also made then, but all indueements failed to entice them on bonrd. They appeared very ehecrful, faughing leartily at any thing that struck them as ridicnlous.

I'hree bonts, witls acvernl of the officers, landed $m n$ the snutli-west point of the island, whither funr fit five cannus aecompanied thens. The islet was found corered witls cocon-sut tuees, but there were no trouses upon it. T'ley called it Fukaro, which wis the antue as the natives of Ontafu liad desig. nated as the island where their great chicf lived.

Captain Hudson now determined to benr away for the situation of the island of the Gente Hermosns of Quiros.

The position of this island is in longitudo $170^{\circ}$

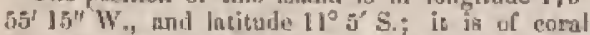
formation, but has no lagross; it is nearly round, and forr mileg nud tlares-lerthe in cireumference; it mny be classed with the ligh coral islands, and is elevated from fifteen to twenty-tive fert above tho level of the sea; it is well wooded witls coentmuts, ptsdants, and other trees and slurubs. Tho ses breaks eorstantly on nll parts, nud no safo landing exists. Its situation differs from the position lail dossu for time of Quiros. Captniil Ifulsinl therofore called it Swrin's Island, after the master of a whaler, who had informen laim of its existence. When wiltin a nile of tho island, no bottom conh be had with two hundred fathoms of line. This isniated spot gave no other evidence of its ever laving becn inhatuled, execpt tho groves of cocon-nut trees.

After sururing observations for its position, tho ressuls bore aray for Upolu, witl the westerly breeze, which had coutiuusl for the last eight days, asd been almost constunt. This will serve to show that there is wo leal difficnlty in the pepulation of Pulyuesia migrnting from west to enst during this seasun of the year, when the trade-winds are simost entircly isperrupterl.

Lintil the 4th of Fobming they last bad weather, and henvy strualts, accompauicd with thunder and lightring.

On the sth of February, the mountains of Savaii wore thinly visible, nithugh they were between fifty and sixty miles oft. (O) the fith, they were off the fistand of "Upolu, when Captain Htadsun, to lose no time, lespatelsed the tender, with two bonts, to sirrey the sotth sitle of the islath, while the launel, with the first outter, whs to be rent round its east enl, in order to complete tlue work in the leart possible time. In the sfterwonis, the Pencock anchned iı $A$ jia Harluets:。

At A jia, among tlicir ald nequajntanecs, they encmuntered Peat, the ruling chief of the plnee, whose begging jroprensities still existed in all their force. His form whs equally rotund, and his devire of theing of sorvice quite as great. Reprort spoke of him as having becorne very religious of late, hat lis covetonstwas lud not diminislwal in conserjucnec, at leakt in the opinion of our ollicess. He was gemetnfly full of buaines, surng lais friends and relativet, all of whou he considers more or less as lis dipendante. Ile was very anxinus to ho informed wht had hecome of his relutive, Tuvai, the murilerer, whom we hal carried away from these islands on our former visit.

On the 2Ist, while at anchor, Captain Hudson bearing that the noted Sangapulutale, principal chiof of the towns of Saluafata, Fusi, and Salelese, who hail protected nad rofused to give up the nturderer of Gideos Sinith, wh at one of the towns near by on a visit, deterznined, if possible, to sireprise and take him prisoner, to be lneld until such time as the murlerer were given up. Fur this jurpose the visited the town before dayliglat of the 22nd, will a few offieers and men, but witlout success.

Previous to this time, Captrin Huden land loat intereourse with this chief through our consul, Mr. Williams; and land clesunderl of lim the promish. ment or defivery of the murlerer, Tagi. In the course of the commanications, Sangapolutale acknowledged thent the murderes ought to he purislled or given up; said he once wnited to kill him limself; but being a petty ehief, the was bneked and protected by the chicis and the peoplo of the three towns before naned, who were promiaed, in ense of necessity, nassistance from some of the neighbouring chiefs, as welt as others on the opposite sitle of the islanil. Ite further saik, that he wns desiruns of giving him up, $a$ few montlis before, to the commanuter of tho lnrprise. It was distinetly stated to Sungapolutale, tlat the nuurderer. must bo either punislied or gisen up, in ennfornity to the regulations adopted in their fono, composed of all the prineipal elicfs in the islant, and than if neither of these stipulations were complied with, Captain Hudson would be compelled to omploy the force under thim in burring the towns that concealed and protected the sunrderer, nud act llair own lawa and us at defiance.

Three dnys were given hitn frum the time of the interview, to eomply witls the deirand. He pronised to do what lie eould, lunt he was fearful of the result, ath lis persple womted to fight, and laal been promised sid from many juartess.

On the third dny, his messeuters arrived at A joia, and bronght word thet the chiefs and peopte wore determined that the murderer should jint be giren up or punished; thint they defied the Papafingis and their power; and that, if Captain Hudson chose to come and take him, they woth give him a fight. The nessenger further" stated, that they weil knew he wnuld be denarded aceording to their own regulations, but shey would take eare he slsould rot be punished or given wp, for they were prepared to resiat any attemjt that wonld be made. Mrny other insulting messuges were recived; anmong then, one from the murlerer and his friende, that when " Jie could kill a few more white men, he would be given tu,."

Sinch were their threats and hoasting: their eonduet was enrformathle to them, as represented by nur consul, the missionaries, nnd Mr. Cunninglum, H. B. M. vice-consul. Captnin Hudion notw saw the necessity of taking somo steps that would eleck this eriminal and aulacions spirit, and prove to the natives that we had the powes to punish these aggregsions on our cilizons.

On the 24th, the Peacocti anclinred in the har. hour of Saluafinta. Preparations wete ulercforo made for swinging the bronitside to the town, and the necessaty arrangerucnts for lasding enrupleted. Captain Hudson, hosever, still thought it proper to 
wait a fow luour, in the hope of receiving some comanuication from the natives, and that they would at the last moment agree to give up or pusialt the murderer. But no overtures whateser being made, at nine a'cloek the boats were manned, and iny on their oars, ready for the signal to proeced. A tire was now upened from the ship, the bnlls being elcrated after which the boats pushed for the rhore, the party laxded, ant the town of Saluafnta, which eunsisted of aluout seventy-five houses, was reduced to nsthes. The towns of Fusi and Sulelese, of some fifty more, shnred the enme fnte. The party then returned to the ship, without any aecident to them. selves or the natives, hnving met with no opposition whntever, notwithstanding the grent bonstings and bratsodo messnges which hat been sent by the chicfs and inhabitants.

This act was performed witl great reluctance, and not until thie most perfeot ennviction of jtg being absolutely necessary to necuro the safety of the erews of such of our whaling flect as tomch st this island, as well as to restore the respect due to our flag and those who sail unuler it, and to correct the orruneous opiniom, that our forbearance was the result of fear of their prowess and numbers. In their transactions, and outrages commilted on strangers, they lat extribited of fenrlessuess and spirit of daring that it was time to put a stop to. iby this attack upon them, they becane fully gensiWhe thant they were not our egुuals in war, nor eapable of resisting attack that might be mate on them; they lave jar ennseqnence becone much move lumble, so that the general opinion throtrghout the istauds is, that hercafter they must couform to the regutations they male on nur former visit, ant maistain them with strict integrity towards foreiguers.

Since this transaction, I have receired letters from tho islaud of Upolu, which inform me that this well-slesersed punislinient las lusd a nust liappy effert, and has put a termination to evils that had formerly been of commun oceurrence.

They now lefi Salunfath, and on the evening of the $5 \mathrm{~h}$, anchored in the rondsteal of Mataatu, ialnthd of Savaii.

The town of Matantu is benutifully situnted on a bay, which is no more than a mere indentation of the const. It is surrounded by extensive eucon-mut groves, behinul which the lumseb are funilt, in mumber sbout four lanndred. Tise cown contains abent. two thousand inlubitunls, suvet of whom are still hentheris.

On the fith of March, they sailed from the roas. stead of Matantu, for the islands known on the clant of Arrowsmith as Ellice's Croup.

At noon, on the 14th, they mude tand, and by $2 \mathrm{~J} . \mathrm{M}_{\text {. }}$ they were close to what proved to be an extensive ring of small jslets, situnted on a eoral reef surrounding a lagom. These are co far separisted as to give the iden of distinct islands, wbicl has probahly led to their having the nome of "group." These islets are well covered with encoa-nut and other trees, which give them a sufficient elevation to be seen at ten or twelve miles distance. Tho roef which links these islets is awash, ower which the sea lureaks with riolence. There are two openings in its west side, and an island off its sonth-west point, at the distanee of a mile, five niles in leugth by two in widtb. The island is thirteen miles long, in a north-by-eagt aru? sonth-by-west direction, and sever miles and twoteriths east and west.

When the versels bad appronched within a short distince of the largest islaud, two cannes were secn eoning towarls the ship, only one of which erne near. In it were fivo unen; and from the familiar manner in which they eamo alongside, it was oxi. dent they lind had frequent conmunication with vessels. They refused to come on bonrt, but exlithited rnyous articles of triffic.

They had no other weapons but spenrs and kniwes, and secmed to be equipped for $\pi$ fishing party, from tho implements they had with them. Some rolls of ennit were bought, and large wonden shark-hooke. Their spears were only poles of coconnut wond, pointed at one cnul; sind their knives mode of small sharks' teetl, inserted into a stick with gum and fone sernit, and are about a foot long.

It was soon found that they understood the Samonn language, and opoke a jurely Polynesian dialeet. The Samoan native easity eonversed with them. They gave the mame of the island as Fanafute. They secemed perfectly familiar wilh white men, and when the guns were fired for a base by sount, they showed no kind of alarm.

The island was surveyerl, and was found to be in latitude $8^{\circ} 30^{\prime} 43^{\prime \prime} \mathrm{S}$, longitude $179^{\circ} 13^{\prime} 30^{\prime \prime} \mathrm{E}$. There appenrs to be good inseliorage widhin the lngoon; an ahtumlanee of wood is to bo lad, but it is believed linere is no adequate bupply of fresh wates.

From what was ascertnined, the populntion was pat down at two liundred and fify souls.

The vestols left Ellice's Group the same evering, ptoceeded miler easy sail, and at daylight made tho Depreygter Islanda, distant three and a lialf miles to the north-west.

Thicy surveyed this islnnil; and on the same day Trney's Ishard, whose native name is Oastupu, was in sight to the eastward. The obserwationa placerl it in latitude $7^{\circ} 38^{\prime} \mathrm{S}$, and longitude $171^{\circ} 43^{\circ} 35^{\prime \prime}$ L. It is well covered with trees, and to all appearanee as extensive as Dejeyster Island.

Depeyster Island is ealled by the natives Nuku-

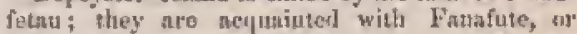
Elliee's Island, and also with Oaitupu, or 'T'tacy's Istund. On being asked if these were all the islands they knew of, shey said, pointing tu the enst, that beyond Onitupu there were three istuads, called Oatafu, Nukunouo, and Falinafo, which it witl he recollected are those of the Union Group. $\mathrm{Mr}$. Hale pressed the inquiry, if this were all; and with some liesitation they ndded the nane of Olnosinga, which is cose of the small eststern islands of tho Samous Group; but what scemed sirauge, they did not understumil the namus of Ssmoa. Un mentioning Tonga and Hastai, the names appenred fo he recognised.

The ressels left Nukufetan the same evening: nnd steered away to the northward. In hatitude $6^{\circ} 10^{\prime} \mathrm{S}$, and langitude $177^{\circ} 41^{\prime} \mathrm{K}$, they passed a smalt island which lass un lagrocu, and does not apjear to be named on any of tho clarts. This they gaw at some distance, sind altwwugh it ajpears to have tieen seon before, yet as the elarts onily designate it as an juland, I have bestowed upon it the name of Speiden, after the purser of the Peacock, one of the most. valuable officers of the expeditiun. 
On the 2Ath they fell in with another islatsd, in latitude $6^{\circ} 19^{\prime} \mathrm{S}$., longitude $176^{\circ} 23^{\prime} 16^{\prime \prime} \mathrm{E}$. 'This discovery I have enlled 13udson, after Captain Hudsoun. It was surveyed and found to be hit one mile aud fourotentls long, north and south, anil tnine-tenths of a mile wide, east and west. This islanl is juhahited, a few natives being seen on the beach, and several huuses uniter cocoa-nut trees un its weat side. It is of coral furtnation, has nn lagoon, and can be seen about eight or ten miles.

On the wsth they passed the small island of St. Auguatine, whose position as ascertaiued was in Iatiturle $5^{\circ} 35^{\prime} \mathrm{S}$., ant longitude $176^{\circ} 6^{\prime} \mathrm{E}$. It appenred well wouded.

Until she 3rd of April, they contimued to mil to the northward, without meeting with any islards. On that disy they malo Drunmosid's Istand of the elurts, one of the Kingsnill Group, where tlicy encounterted the regular north-enst trades. This islaud is ealled Taputeonea by the natives; it is situated in latitude $1^{\circ} 20^{\circ} \mathrm{S}_{4}$, and inngitude $174^{\circ}$ 57 E. It is of coral formation, is thity w whes long in a nurth-west and south-tast direction, and varies in widtl from a half to tliree-quarters of a mile. This, however, anly inscludes the higl portinns, or that which is abnve the ocenn level a few feet. it is thinly covereil with cocos-nut and pandanus-trees, and not a patch of grass is to be seew, or any gort of shrubbery or undengrowth. To the leeward, or on its west side, the reefs and aandbunks extond off some distance, graulually increasing from the north-west point to the south-east, where they are ns much as six and a half miles in witll. 'This reet is interrupted in places, nut there is good anchornge off the town of Utiron, towneds the north-west end, near a small andbank, which is usunlly bare.

'The natives did all in their power to pilfer from the party that landed; if their attention were diverted for a moment, the bands of a native wero foit at their pockets. When detected, they would hold up their hands, with open palms, and laugl. This londdness was moro especially confined to a few, and one in particular, a young chice, who was a tall, gond-luoking prerson, with a wain and impudent expression of eountenance. It is imposible to give a correct ides of the annoynnces that onr gentlenen were subjected to from the ruleness of gonne, che excess of civility of others, and the constant watchfulnegs that became necessary to avoid the pickpockets. An old man was about smearing himvelf is cueon-nut oil, with a cup full of salve, in which he wonld dip his fogrers, and enteavons to rub them in their faces. This afforded much anusement to the party, wlaile the natives scemed nstunished that the attempt was repulsed; for there was little doubt of jts being intended as is great compliment thus to anoint their gnests.

On the sfternoon of the $7 \mathrm{l}_{1}$, a large party visited the town of Utiran, equally well nimed as the day tefore, and with fresh instructions nrd catstions that no one sliould give cause of offenco, nut if any thing was offered for sale, to pay libernlly for it. These preeautious were enjoined, in corse? uence of the belief that the natives were a trenteterous and dangerous set of fellows. An opportunity lad been taken, liefore a large number, to slinw them that the cuirass, \&o, was not ureouf agrainst our weaports at any distauce; for which purpase one of the conts of mail was hoisted up at the yarilarm, and fired at: the holes were then exhibited, Lut did not seem to produce mueh effect upon them. They manifested a decided disposition for wartike purstits, and ferocity was the must predominant trait in their character.

After they land loeen an frour and a half on ahore, Captain Houlson ardereat all the officers and honts' crews duwn to tlie licach, faring a onllision, and being satisfiel that it was quite cime to deprart. As they were assembling for the purpese of em. barking, a noise was heard, resenbling a sudden assault, from some of the liouses nen: by, sud on mnstering the men, John Andersoll, s seaman, whs missing. Lientenant Walker md Passed-Midshipman Davis were seat, ench with a few men, in the direction whenee the rejort proceeded, but they saw nothing of him, and all was quiet at the enclosure. Ithe natives began tow to assemble in large nursbers, artued, and things losked somewhat serious; for, as Passed-Milshipman Davis returned to the beach, he was stoner, and ono of the men received a severe blow. This was low. ever borne without retnrn, (/I inquiry, it was found that Anderson had been met but in few moments before the party was mnstered. Ho was armed with a musket, pistol, and eutlass, and was esteened one of the most correct and prudent men in the slip. The boats were now shoved off a short discance from the beach, and beyond the reach of the uative arms, when bevesal muskets were firel to motify him, amo his mame repentedly ealled, which could lave been heard in any part of the village; but no Anderson appeared. Captain Hulson finaliy came to the conclusion that he had either been onticed away by the women, or that the natives bad detained him, in the hopes of receiving a mnsom for his release, and that he would eitler return in one of the canoes to the ship, or be given up ots a lewand being offered. Under these impressions, he ordered the buats to return to the slip.

The next day passed wilhont any intelligence of poor Andersoly, nad Captajn Hudson made up his mind tlant Anderson had been treacherously mur. dered. Ile llaerefore believed it to be a paramnunt duty to punish them, wot only for this netfidious set, but to secure their good contuet hereafter, in ease of other vessels toucluing at this island.

In eonseqgnenee of this detcrmituation, the boats were prepare! for lauking, and $\mathrm{Mr}$. Kinox wag ordered to anchor the teniler in a position near the slıore npposite the town, in oriler to protect them.

The expedition consisted of seven thats; in them were cubarket nbout eiglity oftieers and men. Abont aine a'elnek they aproronched the town of Ctiron. The first ubject that attracted attention พAR a colum of smoke arising from tho small building that stood on piles in front of the town hefore spoken of. On arriving near the beach, the three dirisions formed in a line abrenst, acenrding to the directions. Lientennt Walker, with Mr. Hale, (who acted ns interpreter,) now showed the white flag, and pulled in toward the bench in front, in order to hold n parley, make further inquiries relative to Anderson, aurl endersonir to have him given up, if alive. There were about five hundred natives, well armed, on the beach, and others were contantly coming in from nit sides: they khouted and shook their wenpons with threat- 
ening gestures. Mnny of them, however, scemed undeciderl how to act; and their whole apperance, though formidsble enougl, was yot quite ltadicrous in the cyes of the men, equipped as the savages were in their cumbrons conts of mail and figh-skin helmets.

As the bont appronched, several of the natives anvaneed towarda it, preceded hy a chief fully equipped in armour, and holding in spear in his right hand, Mr. Halo then explnined tho object they luad in view, and showed the large quantity of tobaceo which they had brought for a musom. The chief appeared to underratad, and poinled to the shore, naking signs at the same time for them to cone in. The savages who attended the chief lind now increased in numbers, and were vose to the boat, while the whole body was advuncing stowly forwards. Finding that it was not only useless but dangerous to continue the parley, the loost was pulled back into line.

Having thus failed to procure the desired end, the most lsumane nuaner of effecting their pusishment wits eoticeived to be at onee to show them the power of our artme, and sacrifice some of the most prominent among the sarages. Lieutenant Walker, therefore, requested Mr. Penle, the best shot of the party, to give them a troof of it, nud thus prevent the further effusion of bloct. This was accordingly done by singling out one of the forenost, nud a rocket was alsu diselinrged, which took its flight towards the grent budy of them. The latter missile eaused great eonfusion, nnd many of them turtred to seek tho shore, but their terror did not last long. and they made another stand, brnidishing their spentr and wenpons as if lwent upron a trial of Htrength with their mponents; the falling of their clicfo was disregarded, nud few seoned to consider the effects produced, except those w lo were wounded. A general rolley sown folluwed, which caused them all to retreat, some in great haste, whilo others moved nore blowly townrds the shore, seeming to be but little impressed as to the charncter of our arus. Tle wounded and dead were all carried off. The bonts now pushed in for the beach, and by the time they lind renched it, there was not a native of the whole host to be seen.

The tliree divisions then landerl, and the first and second proceeded to fire the mariapa and town, while the third remnined to guard the bonts. The whole was 80013 in a blaze, and but a short time enfficed to reduce it to ashes. The natives wero still to be seen in small parties, out of reach of the guns, among the cocoa-nut groves. After the work if destruction had been effeeted, the divisions again returned to the boats. The place now exhihited a very differetat picture from that it had presented only a slunt hour before. The blackened sites wero all that remained of the former dwellings, the council-house was entirely in aslies, the fences were torn down, and the cocon-nut trees leafless.

The tide lanxing fallen, three bodics were found, one of whom was the young chief who had been so troublesome and insolent to otr gentlemen, and when it was belicred had been actire in the murder of poor A uderson.

While the party were getting roady to embark, $n$ small party of natives were seen coming towards shem from Eta; these were all unarmed, and had cocoa-nut lenves and mats ticl round their necks: they lind come to aseure our party of their good- will, and their joy at the destruction of Utiroa One old man in particular repeated frequently his nssuranees, witl much laughter and many grimaces. No snoner had they ascertained that the intentions towards them were not hustile, than they began to pillago the burising town.

The tumber of liouses destroyed was suppused to the about three hundred, benides upwards of a dozen large cannes. The hass of life was twelve on thie part of the natives: there was no one injured on our side.

Irron the fact that the natives had left every thing in their dwellinge, it was elear that they diu not anticizate the fate that was to befall them; that they were in loupes of being nble to cut off our houts, and perhapes flattered themselves with the prospect of an indiscriminate plunder. This would bo in perfect accordnnce with their custums and cotsstant praclice of attempting tu cut off all ressels or boatg that may visit their islands. Although I lave no rensou to come to this conclusion from our own knowledgo respecting this island, yet from all the accounts of those whin have resided bome time among like gavages, their first idea is always to capture or poseess thenuselves of the vessel or any of the boats. We thave seen that this is put in practice snnong the lieejees and nthers, who regard all resacls wreeked as sent to them as a gift from the goils.

The cliaracter of these islanders is the most savage of any that we met with; their ferocity led to the belief that they were cantribals, although no pusitive proofs were seen of it. They are under no eontrol whatever, and possess little uf the charne. teristic hospitality usmally found in anvage nations. It was observed also that thejr treatment of each other exhibited a great want of feeling, and in many instances, passieus and propensitieg indicative of the lowest etate of barbariam. Their young girls were offered to be disposed of, by their finthers and brothers, alongxide the ship, npenly, and withont concealment; and to drive a bargain for them, was une of the prineipal objects of their visits to the ship.

$\mathrm{It}$ is to be hoped that the punishment inflieted on Utroa for the murder of Andersan will be long remembered, and prove a ealualary lesson to the nu. merous and thickly-peopled towns of Taputeouea, or Drummond's Isinds.

On the anme evening, (the $9 h_{1}$ ) they weighed anchor, and on the next dny ruale Bishopis or Sydenhan Island, which they sturveyed the following day.

Off the morth point of Bishop's Island, there is a slooal extending one nud a lialf mile to the nortlward and westward, the water on which is discoloured, and where the Peacuch found nine falhoms. The native name for Bisliop's or Sydenham Istand, is Nanouti; it lies in latieude $36^{t} \mathrm{~S}_{\text {, }}$ and Jongitnde $175^{\circ} 24^{\prime} \mathrm{L}_{\text {; }}$ i it is of cortl formation, and a mere ledge of Jnad, like Drummond 's Island, with a ingoon, reef, and bauk, on its lee or south-west side. The survey made it nineteen miles letug, trending north-west and sncth-eant, and its widthl, juschuling lagoon and reef, eight and a half miles. On the south-west and sorth-west portions of it, there is a corml bank, from one to ore and a balf mile heyond the reef, on which there is ten fathoms water. At the distanee of four miles from the unrt]-west end of the istand, they found soundings in two hundred and sixty-five fithmms. 
At daylight on the 11 th, they made Henderville Island, called by tive natives Nanouki.

Hetiderville Island was determined to be in lati tude $11^{\prime} \mathrm{N}_{\text {., }}$ and longitude $173^{\prime \prime} 39^{\prime} 20^{\prime \prime} \mathrm{E}$. This island is six and $\AA$ tialf miles long, east nnd west, and five and a latif miles wide at the east end, diminishing to two miles at the west end: it is of coral formation. There are two towus on the west end, and sereral on the enst and sonth-enst parts, and it is thickly jubnbited. The natives who came on bonrd said that tha two ende of the island were at war wilh each other. They are yery much the same in mupenrance ras the natives of Drummond ${ }^{\prime} \mathrm{H}$ Island; were mked, nnd spoke the eame dinlect. T'lieso natives knew of the islands in their immediate vicinity, as well as the direction of Taputeouca, or Drwmmond"s Island, and gave them the name of being inhabited by a sarage and hostile people.

Hall's Island, ealled by the natives Mainna, is of coral formation; the thorth-east and south-enst parts are continuous land, whilst to the south-west and north-west it eonsists of a reef and bnnk, it sone plnces awash, with a sand-jit in its lagoon. The western sides of the islatd are therefore very datagerous, and should be spuroached with eastion, ns the sed selom brenks on thert, and the discolnration of the water is not at all times io be observed. The survey malces this island nine tniles long, in in north-enst and south-west direction, and six miles in widt $h_{1}$ ir a south-enst and north-west direction : it is situated in latitule $56^{\prime} 45^{\prime \prime} \mathrm{N} .$, and longitude $173^{\circ} 4^{\prime} 15^{\prime \prime}$ k. Du its west side, ou sotne of the lonkis, there is nuchorage in frosn ten to fifteen futhoms of water.

On tive morning of the $15 \mathrm{th}$, they made the istund of Aparnama, the Hopper 1sland of Duper. rey, wud the Simpson's Island of the clumes of Arrowsnith. It is about five fert ahove the surface of the ocent is ten miles long, north.west and south-east, ancl five miles in width, worth ars! south. The lnud is continuons an the north and east sides, excentiug two small strips of bnte reel. Thero is anclusage cas tho wost sifte in an opening between the reef and the north-west paint of the island, which is about two miles wide. The sonnd. ings vary from two to five fathoms: Acrosss it, in sutne places, the bottom is livken curml; in others, it is ectrnl surut. The extrance to the lagonn, although feasilule, slioulal not be attemptod through this paserge; but there is a gnod passegge into it un the south-east side of the islaut, which is a mile wille. $A$ emall quantivy of ficsh water may be land by digging on the benclies: awont and refreslynuents are not proturalite fur blippeng. This islant is situated in latiturte $27^{\prime} 21^{\prime \prime} \mathrm{N}$, ard longitude $173^{\circ} 57^{\prime} 30^{\circ \prime} \mathrm{E}_{\text {. : }}$ it has heretofore been reprenentod as two islunds on the charth, ealled on one Simpsora's, and tho other Hopuler and Harbottle; but there is only whe, joined by the same reef.

On the Ititi, while engaged in the surrey of liuria or Wondle's I thasul, sorre sanocs came off to the ship, when the sativeg cance on loard witl]. out hesiatiots,corrmaniestiou with ships, and their confitence of gosil trentment. It was soon reforted, that a white иนแน พละ enming off; and, as it all such enses, he was looked for and watched wich grent interest, and varions surnisus were male relative to his origin and listory. They were not long lefe in doubt, fur before he reached the deck, lis voice besproke him nn Irishnan. He was dressed in a pair of duck trousers and red flnouel shirt, and announced ljinself as "John Kinthy, $n$ itesserter from the English whale-ship Adriral Cachlsurn." He suid he land been on the island for three yenrs; that he wus living with the daughter of the princjpal elive ; nud solicited a passage to sonte civilized place.

'The princinal clief of the island, with his daughter, whom Kirby had for a wifo, caure on bourd with lim. They both seemed deenly af fected, when they harned that ho had received pheraniesion to remain on boari, and was abous to lenvo them; auld both cudeavoured to dissuade him frons going.

His wifo showed much conecri, and withed to aecompany hisn: the old chier, her father, endenvoured to persunde him ta tafo lur. Findion slue coulit not prevail, slic requested as a parting grift, an old jack-knife, the nuly property he had left to give. Several preseuts were made to her by the offiecs rul men, which reconeiled her soinew hat to her lot. The natives all left the ship tnuch grmeified, excepting Kirby's wife, who cuntimued to be soruewhat downeartur.

Kirby proved an inteiligent man: he moderstond the lawgunge, and was well acquatinted with the clinracle'r, manus:s, and customs of the islauders, among whom he had lived from the 1 th of Febranry, 1938, to the 15til of April, 184t. His presence in the slip uffurded Capitrin Hudson an opportunity, not only of eornnunicsting whth the natives more ficely, lut of obtaining mueh intereating information relative to this group.

Kiaria or Woodle's Island las four towns on it, which kirby egtimater to euntsin between four and five thousand izhabitants. Its gengraphieal position is is latimule $14^{\circ} 30^{\prime \prime} \mathrm{N}$, longitude $173^{2} 27^{\prime} \mathrm{E}$ : its greatebt length in five miler, north-west and south-enst, and its greatert widch, which is at the south-east end, is two and a half miles. Tho romainder is very narrow, and almost divided towards the centre. The north.west portion has two smal. lagontas, two or threo humdred ynrds from the besch; the water in them is not so ealt as the oeenu. In one of them, the bottom coneists of red mud on one side, while it is $n$ white clay on the other. They are nesed as fish-ponds by the chiefs. There is a reef extending to the north-west nearly three miles.

Kirby stntes, that on the firat night of his landing, they stripped him of every thing but an ols] pair of trousers, after which ho was eonducted to a great conclare of untives, asymbled around a largo fire, which the then trelieved was intended to roast him. He had fortunntely gone on Bhore in the highest chief"s cturec, ant placed bimself under bis protection, ns well os he knew Jow, After sosne censiderable talk, instead of being roasted, he was furnished with a wife, and taken to reside with his friend, the prineipal chief, who, with the rest of Lhe natives, ever afer treated lim kindly. After in few mothts residence in the fannily of the chief, lie gave his own daughter to Kirby for a wife. The result of this was nuch jealousy and envy between his first wifo, of cornnon origin, zutl his lakt, of lighs rank, ustil the fortner was ousterl axud sent havk th her parenta, leaving the chief"s daugh, ter in quiet prosegsion of the house. 
During Kirby's residence on the joland, several English, and one Ametiean whaler, land been off the island, on which oecasions he land been ernployed as pilot and interpreter. 'T/10 nutives were constnntly asking bim, after theis dejurture, why he "did not fool the vessety and rim them on shore, that they might plunder them." One of tlie abovo rossels left two pigs, twa goals, and a pair of Mus. cary ducks; but no sooner had the ressel left, than they killed them all, for some superstitious fars, ant threw them into the sea, notwithstandiug all Kirby's remonstmnces mul entreaties to hare them spared, and allow him to ent them.

Kirby says that the uatives, Jhough not profesacd cannibnls, Bometimes eat human Hesh; but their food is generally fish, Tliey do not eat fowls, and will not raise pigs, on neemnt of their filth. 'Their trencle is extracted fixum the epathes of the cucun. nut trees, an operntion which, if frerpently re. peated, destroys the tree. They are very foud of cock-fighting.

The eonduet of forvigncrs who visib these istantls is sometimes of $n$ most outrageous clintacter. Some cour or five months before the leacock's visit, lifrby states that mie Letsonhs, master of the whale-ship Oifley, of London, and whose wnto was n Amerien, uamed Lako, Inmiod sis yourig gin's un this island, whum he liad obtuined at Peru, ers Francis ishal. After laving kogt them on honm eeveral ilays, he brouglit them here to save himself the trouble of bonting his vessel up to the islond to which they balongen.

These young girls were extremely good-Inoking, and are now slaves to the ehicf of this island, and made to labour and satisly his lusts. They were lantet on Kuris, il despite of theil entreatiog and tenrs. These people are in the habit of killing all stmngers from islarris not connected with their immedinte group; but the lives of tlıese girle were spared, and they were retaimed in hondage. Two of them were bringht off to the slsip, who eutrented most enrnestly to be kept on board, aud to be earried to their harno.

The publislıed charts of these istands were found so inncerate, as to bo a cause of alunger milict than of safoty; for in then the islands are multiplied, and every lummock or detached islet on the samo reef is represented as soparate, and n bame assigned it. Thus a echususion exists, that jt is almost impossible to unravel, How so mony erors enuld bo committed, eas whly be aceounted for ly the fact that tlose who had the mblication of the elinrts formerly were getwerally iguorant, and did not take that care to sift and examine the information that was essential to aceuracy.

Several islands are laid down lowe on the dif. fetent charts, but those ouly really exist which are named "Tarawn, or Kinox İland; Apia, nr" Clinrlotte Island; and Maraki, or Matthew's Island,

Tarnwa, or Knox Island, is in length twenty miles, trending north-west and south-east, and lies in latiude $1^{\circ} 29^{\prime} \mathrm{X}$, and longitude $173^{\circ} 5^{\prime} \mathrm{E}$. The Iand is continuous and wnoded, with the exception of four gaps, where the reef is bare. The south side is twolve miles long, nnd trends nearly eart and west. On this patt, nont the vestern end, are three hummocks (which appear like istands in the dis. tance), and severni small Eand-banks, which are conneeted by the same reef. I'his islnud lats $\mathrm{its}$ lagoon, but it has the sppentrance of an extenbive bay, in conaequence of the reef ou tho west side being a zunken one, on which is fund five fathoms of water.

Apin, or Clundotto Island, consists of strings of comal islets, situated within n reef, which is aix and sever foer alwve the water. 'The reef lıas a bluff fromt, and is much woru by the sen. 'There is no corrl sand. Apia was found to be in lacitule $1^{\circ} 52^{\prime} \mathrm{N}$. and $173^{\circ}$ $2^{\prime} \mathrm{J}_{\mathrm{A}}$ It is a lagoon istaind. I ts lengtla in the dircetion. of north-enst and gouth.west in sixten miles, and its average breadily five. On the east side of the island the land is eovered with coeon-rut nul pardnnus groves, wish some undergrowth. The northwest anil west sile is a continnous reef, foux or five feet abore the water's alge, on which ne many islets. A bout the centre of the reef, on the southwest side, is a ship's clanuel into the lagoou, which is lonlf a mila wido. Near jto entrance is a small islet, which atambs alone, and is a good romk for the entrance. There is no istand in the lagoon, ns shown on the French ehurts of Duperrey.

It was ascertained that their knowledge of other islanis only extended to Tarawa, or finux's Is]und, and twn others. W'o orre of these they peinted in a direction west of norkb, and enlled it Maraki, Mathew's Lsland: mul the other Taritnzi and Mahiln, which tlsey said were two day's" eail, and which whs believed to bet P'ict's I aland.

The next island that daimed their attention wro Mataki, or Matthew's Islaur. It is muelı smaller ttar the two last, and situated in intitude $2^{4} \mathrm{~N}$, nod longicude $173^{\circ} 23^{\circ} 30^{n} \mathrm{E}$. It is a lagmon istand, witheat entrances, and of comal formation. It is but five miles long, north-by-east and south-lyywast, nud two and a lanlf wide at jts base, being of trinngular shupe. It appens to be densely penpled.

On the 27th, the Peacoek left Matthew's Island to look for I'itt's Island, which they made on the 2Bti, nt 9 A.M. There are two islnnds known under this name: the largest is called ly the nntives Thrituri, and the smallest, Makin. The Intistule of the sotthern point of Taritari is $3^{\circ} \mathrm{W}$ N., longitude $172^{\circ} 48^{\prime} \mathrm{E}$. 'This island is of the figure of a tringle, with its apex ta the sontl, nnd its sides are about funrteen miles in length. The Bontil-erst side is a continuous grove of cacun-nut and pandunus, with fomo undergrowtl ; ors the other two sides jo a reef, which is awash, excepting the north-wegt point, in which there is a small inlet.

Makin is of much smaller dimensions, being but six miles losg : it mries in width from half a mile to a mile. Jts northern point lics in latitude $3^{2}$ $20^{\circ} 43^{\prime \prime} \mathrm{X}^{\prime}$, and longitude $172^{\circ} 57^{\prime} \mathrm{E}$. This small island is the seat of goxertment, and the natives now unite both names under the one of Mativi.

It was goon evident that the island was thickly inlubited; for wlsen the ship reached the lee sinte, in the afternoon, about twenty canoes came off; contrining from five to ten natives in ench, and in one of them was a whice man, who was clothed it mats. The ship was immedistely lowe-to to take him on board, and he gare his naune na Robert Wood (alias Grey), a Seotehmua by birth, who was left by lis own wish on the islaud, seven years before, by the linglish whaling lirig Jumie, of Lomilon, eailing frou Sydney. Ha was umler so great excitencut ts to rotwler his nterance quito unintelligible at times, nnd souse amusing scenes 


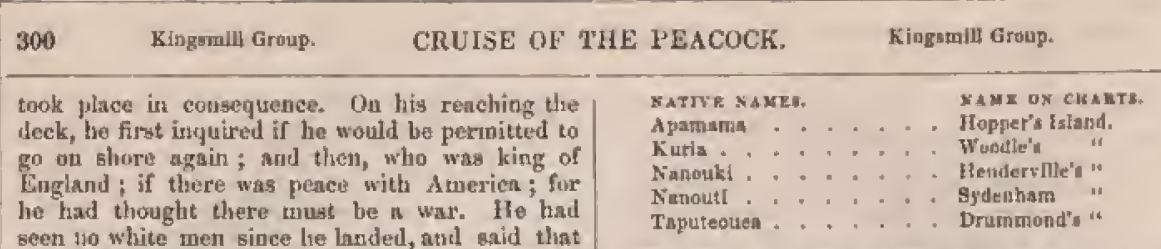
wo white men since he landed, atul gaid that he has becone old and grayleaded. To prove the latter nssertion tse pulled of his apulogy for $\Omega$ hat, aud displayed a most Juxurisnt growth of jethlack linir.

He lad not been on tnard long befuro he asked for a passage to some civilized land; and when he: was informed that his wishes wonld be gratified, lie seemed for a time besillo himself fron excess of joy. His feelings were evineed in his endenvours to interpret the questions to the natives; he almost invariably repreated to them what was gatid to him in English, in the same lauguage; and gave back their answers or expressions in the ieland dialeet. "This tral a droll effect, and he had frêquently to be reminded that he was an iuterpreter.

Woud says, that the natives hal always trealed bin kituly; and for the first few months after lis arrival annong then, they carried him nbout on their shoulders (ho was the first white man that maty of them lad ever secti), and almost deitied lim. They lavo no wars, and very fow sims, and seldom quarrel, except atrout their wonen, The punishment of denth is inflicted on those who infringe the seraglio of the chits.

Wher the vessels liad made sail, in oreler to loave the istzud, and it was supposed that all the uatires hal left the ship, nne was found hanging to the man-ropes near the water. Wood, on questioning the uative, found that ho was a petty clitef, who wisled to aceonpany the alipp, and lad taken this rueans of doing it, hoping not to be perceived sintil he was out of sight of lis island. He said he way ton frow a chief to have any wiven, aod there. fore wislued to lenve his islutu, and be landed ot some other, where he could obtain fome. Captait Hudgon had a boat loweresl at nftee, ly which lie was put on board a canot, that took him to the shore,

The Küngmill Group consists of tifteen islande, of which the geographical positions have been alrendy given in speaking of them separately.

They are as follow, viz.:

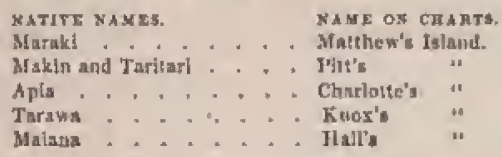

The above are all those that were viaited by the Peacock : the natives, lowever, gave the namea of others, which are anid to be in the neighbourhood, to the number of eix.

\begin{tabular}{|c|c|c|c|c|c|c|c|c|c|}
\hline Pens & & & & & & & & Francis Iol & tan \\
\hline Nokunau & & & - & & - & . & & lyzon's & " \\
\hline Arural & 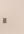 & , & . & . & 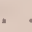 & • & 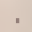 & Hurd's & *s \\
\hline J'smans & . & . & . & - & - & + & & Pliwbe & th \\
\hline Ononta & & . & . & . & . & . & . & Rotsher' & $"$ \\
\hline
\end{tabular}

Tho first of these fire sre known on the maps, but the two last are not. There is one which the natives of $\Lambda$ pis designated by Thrawari-Makin, but I and inclined to believe it whs intended for I'itt's Islind,

The population of the arour from tho best data which was obtruined, is about sixty tlousand bouls. At Drummond's Island, where there was the best opportunity of a personal examination, the estimates were above ten Houssud: this is eonsiderod the most populous isinnd of the whole group. On A pamana, Kirby saw collected from six to seven thougand warivure, belonging to it, Nanouki, and Kuria : the joint population of these three islanda may therefore be reckoned at twenty-eiglit thousand $\mathrm{j}$ it would seem reasonable to estimate the remaining twelve islands, whicls have been observed to be thickly inhabited, at the same number.

On completing the survey of the Fingsmill Group, Captain Hudson found it necearary to place his crew, and that of the tender, upon a reduced allownee of provisions anil water. He then kteered nway to the sorthward, tlirough the Mulgrave Islauds; awl on the morning of the 3rd of May, they made Pedder lsland of Artowsmith. The ressets prassed along its west side, and through the Fordyce Passage, between it and Arrowsmith"s Island. Daniel Islatid was also geen from aloft to tho eastward. These islands are all of cornl formation, with lagoons, and are infabited. The sontheast eud of Arrowamith's Jaland was found to be in latitude $7^{\circ} 5^{\prime \prime} \mathrm{N}_{*}$, longitudo $171^{\circ} 28^{\prime} 64^{\prime \prime} \mathrm{E}$. It is twersty mites long.

Oy the 17th of July, the Peacock and FlyngFish arrived at the bar of the Columbia River. I have already detailed of the former vessel. 


\section{CHAPTER XXXIV.}

\section{CALIFORNIA.}

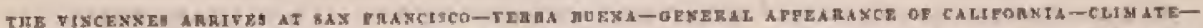

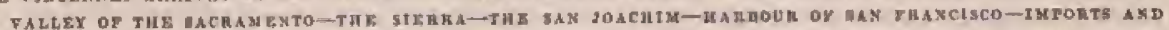

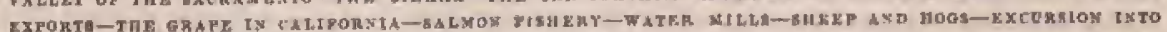

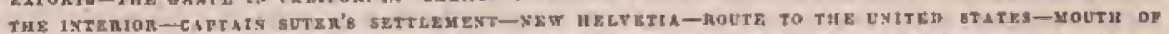

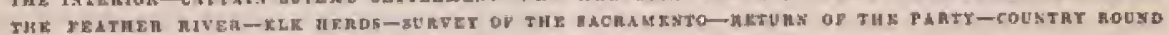
THE BAY OP BAN TADLO-CITY OP ZOSOSA-GESERAL VALLEJO.

Tre Yincennes arriwed at San Francisco on the 14th of August, 1841, and anchored off Yerba Buena. As sool as the ship anchored, an officer was despatelied on shore to call upon the authorities; but none of any deseription were to be found. The only magistrate, an alcalde, was absent. Tho frenuency of revolutions in this eountry bad caused a great clange since the visit of Captain Beecliey.

On the 17th, after consultation with the captain of the port, a Mr. Richardson, the ship was maved to the north shoro, at Squsalito, or Whaler's Harbour. Wnter, which it was impossible to obtain at Yerba Buena, on account of the drunght that had prevniled for several months, is here to be had from a small spring. Afrer the ship was moored, the bonts were hoisted out, and fitted for survering duties up the river Sacramento.

On approaching the conts in the neighbourhood of San Francisco, the conntry has by no mests an inviting aspect. To the north, it rises in a lofty rauge, whose highest point is known ns tho Table Ifill, anul forms an iron-bourd const from Pursto de los Reyes to the mouth of the larthuur.

To the soutly, there is an extended sandy beach, behind which rise the sand-hills of San Brumo, to a moderate height. There are no symptome of cultivation, tor is the land on either side fit for it for in the forner direction it is moustainous, in the latter sandy, and in both harren. The entrance to the harbonr is striking : bold and rocky slonres confine the rush of the tide, which bore us on and thruggh a narrow pasage into a large estuary : in this, severa] istands and rucks lie senttered around: some of the istands are cluthed with vegetation to their very tols ; others are barren and coveted with guano, liaving as immense number of sesfowls hovering over, around, and alighting upron them. T'le distant shores of the bay extend north and sonth far beyond the risilule borizon, exhibiting one of the most spacious, and nt the same time safest ports in the world. To the east rises a lofty inland muge, known by the name of La Sierm, britlint with all the benutiful tiats that the atmospluere in this elimato produceg.

Yerba Buens is the usunl thongh by no means the best anchorage. The tuwn, as is stated, is not calculated to produce a farourable impression on a atrauger. It buildings may be eounted, and consists of a large frame lujildiug, occupied by the agent of the Hudson Bay Company, a store, kept by Mr. Spears, an American, a billiard-roou and bar, a ponp cabin of a ship, occupied as a dwelling by Captain Ilinekley, a blacksmith's shop, and some out. buildings. These, though few in number, are also far between. With these, I muat not forget to enumersto an old dilapialated adobe buildiug, which has $\mathrm{n}$ conspicuous pusition on the top of the hill overlooking the anchornge. When to this we add a sterifo soil and hills of bare roch, it will be seen that Yerha Buena and the country around it are any thing but bonntiful. This deseription holds good when the tide is high, but at fow water it has for a foreground an extensive mud-flat, which does not add to the beatity of the view.

After passing through the entrance, wo were acarcely ablo to diatinguish the presidio; and had it not been for its solitary flag-staff, we could not have agcertnined jts situation. From this staff no flag fluated; the building was deserted, the wall lasi fallen to decay, the guns were disnomnted, and every thing arousid it lay in quiet We wero not eren saluted by the stentorian lungs of some soldier, so eustomary in Spanish places, even after ali political power as well as military and civil rule has fled. I afterwards learned thist the presidio was still a garrison in name, and that it had not been wholly abandoned: but the rernns of the troops stritioned there consisted of no more than an officer and one soldier. At Yertus Buena there was a simuilar ahsence of all authority"

At the time of our visit, the country altogether presented rather a singular appearance. Inatead of a lively green hue, it las geurrally o tint of a light stritw-enfour, showing at extreme want of moisture. The drought had comtinued for eleves moutlis; the enttle were dying in the fields; and the first view of California was not caleulaterl to make a favoursble impression either of its beauty or fertility.

There is, perhapa, no other eotuntry where there is such a diversity of fentures, soil, and elimate, as California. The surface exhibits the varieties of Infty ranges of mountains, confined valleys, aud extensive plains. On the const, a range of high land extends in length from Cnpe Menducino to lasitude $32^{\circ} \mathrm{N}_{n}$ and in breadtls into the juterior from ters to iwenty miles.

The valley of San Juan, of no great extent, lies between these hills and the Siern, which is a luw runge of mountains. East of the Sierra is the broad valley of the Sacramento, which is prolonged to the south it that of Huena Venturn, as far as Mount San Bernardino, undex the thirty-fourth parallel. Beyond this valley is the Californian 
Range, which is a continuation of the Cascade Range of Oregon, and whose southern summits are enpo ped with snow. 'This rauge gradually decrenses in height, until it declines into lislis of moderate elevation, 'To the east of the Californinn Mountains are the vast sandy plaing, of which we know but little, except that they form a wile tractless waste, destitute of overy thing that can fit it for the habitation of mur or henst.

The soil is as variable as the face of the country. On the const range of hillu there is litule to itsvite the ngrieulturist, exeept in sone vules of no great exteut. 'Tluese lills are, however, adnimbly adupted for raising herds and flocks, ntul no at present the feeding grounds of numerous deer, elk, \&c., to which the sliort sweet grass and wild oats that ure sprend over them, afford a plentiful supply of food. No attempts have been mode to eallivate the northern part of this section, tror is it susceptible of being the seat of any large agriculturn? operations.

The valley of the Sacramento, and that of San Juan, are the most fruitful parts of California, particularly the latter, which is espable of producing wheat, Indlian corri, rye, oats, \&ce, with all the fruits of the temperate and many of the tropienl climnteg. It likewise offers fine pasture-grounds for crttle. This region comprises a level ploin, from fffeen to twenty miles in willth, extending from the bay of Sam Eranciseo, beynnd the mission of that nume, north and south. This may be termed the garden of Cnlifornin; but although several small streams and lakes serve to water it, yet in dry seasons or drouglits, not only the erops but the berbage also auffers extremely, and the cattle are deprived of food.

The Sierra aftords little senpe for cultivation, being much broken, barren, and snndy. It is in pleces covered with cedar, pine, and onk; hut it offers few inducements to the settler. The grent salley of Buen Ventura next steceeds, which, although it offera more prospects of protitable eultivation, is by all accounte far inferior to that of San Jusn. "It lies nearly parnllel to the Intter, and is watered by the San Jonchim river and its brunches.

In this valley the Californian Intians principally dwell. The Sin Joachin receives its waters from the many strenms that issue from the Californian range of mountains. These are well wonded, their base being covered with oaks, to which succeeds the red Californin cetlar (schubertia abertina), and after it, in a still higher region, pines, ustil

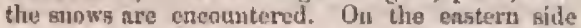
of this mnge, there is found rery litule timber, and in crmsetjuence of the want of moisture, trees do not flourish, even on the west side. The isslanit plain, eonstituting s large part of Upper Califorsist, is, according to all accountu, an arid waste; the few rivers that exist being periodical, and losing themselves in the sandy soil.

In elimate, Califortuia variea as much if not even more then in untuml features and soil. On the const muge, it has as high a mean tempernture in winter as in summer. The latter is in fact the coldest part of the year, owing to tho constrnt prevalence of the north-west winds, which blaw with the remularity of a monsonn, and are exceedingly cold, damp, and uncomfortable, rentering fire ofien necessnry for confort in midsummer. This is, howeter, but boldom resorted to, and mnny persuns have informed me that they lave suffered more from cold at Munterey, than in places of a much higher latitude. Tlo cliuste thirty miles from the coast undorgoes a great etanage, and in no part of the world is there to be fomml a finer or more enuable one than in the valley of San Juan. It more resembles that of Audrlusin, in Spain, than any other, and wone esin be more salubrions. The cold winds of the const lave become warned, ard have lost their force and violence, though they retsin their freshusess nod purity. "This strip of country is that in which the far-famed missions hrsve been established; and the accounts of these have led many to belicve tlast the whole of Upper California was well adapted for agricultural uses. This is not the ease, for the small district nlrearly pointed out is the only section of country whero these advantares are to be foumd. This valley extends beyond the pueblo of San Jusn, or to the enstward of Monterey: it is of nis great exteut, being about twenty miles long by iwelve wide.

The Sierm, which separntes the valley of San Juan fron slint of Buena Ventura, is about one thousand five hundret feet high, batren and sandy. Sines corer its simmit, and the clinate is exceed. ingly dry and arid, though cooled by the fresil wind thant passes beyond them. Next comes the ceneral valley of Buena Ventura, which is a cous. tinustion of the Sacrumento, and tlurough wlich the San Jonchin flows. Being confined within the two ranges of mountains, and not having the same eauseg opernting to modify the temperature as the smaller valiey of San Junin, the heats of its sum. mer are oppressive, the thernumeter ranging, it is said, higher than within the torrid zone, and the heat continusing withent cessation.

Although the Californian llavge is covered with snow in elose proximity to this valley, it seents to have but little effect in modifying the climate, which is represented as iropical throughout the year. This valley extends no far south as the San Bernardino Mouritain. The resideuts in California say that they have never known tlie wind to blow from the north-east witlin thirty miles of the const.

The Saerumento is the largest river it Califor. nia. One of its brarches, Destruction river, takes jts risa near Mount Shaste, aud was exnmined throughoul tha whole of its course by our land party, until it joined the Sacrunento: the lntter is thouglat by some to pass eltrough the mountnios and join l'itt's river. Pitt's river js anid to talie it rise to the north-enst of the Shaste Mountaiu, and from the information tiat I received, extouds Its far as Pilt's Lake, under the forty-sereond parallel. I lave reason to doulut whether the length of its course is so grent, and beliove that the Sacramento has its Bource in the eaterts spurs of the Shasto Muuntrin.

The first lirancls of any size in descending the Snernmento is that called Fenther river, which joins it below the Prairic Butes, coming from the north-east. This braneh takea its riso in tho $\mathrm{Cali}$ formis Mountains, near their northerı end, and has is course of nbout forty miles. The Ameriean river is $\mathrm{n}$ small branch that joins the Sacrmento at New Helvetia. After receiving this strenm, the Sacramento is joined by the San Jonelinin, which courses from the south, nnd helow their con- 
fluence enters the bays of Sin Pablo and Sin Erancigeo.

I'he Sacmmento is navigable for bonts to the distnuee of one hundred and fifty milest, and for vessels an far as New Helretin. The nuper portion of it, near the Prairie Butes, overftows ils bnnlis, and submerges the whole of the Sucrumento Palley as ine down ne the San Jondim. This imusulation is probably caused by the united effects of the Sacrautento and the Feather rivers, as there is not in its bed sufficient room to discharge so large a qunntity of water.

Ûpper Califurnia may boast of one of the finest, if not the very best lartiour in tive world, - that of San Frnneisco, Fow are nore extcusive or could be is readily defended as it; while the combined tleets of all the nawa] penwers of Europe might thoor in it. This is, however, the only really good harbour which thit country possesses; for the oshers so called may be frequented only during the fise seakon, being nothing more than rondstends, affording little safety nud but few supplies to vessels.

The principal articles imported are cotton eloths, velvet, silks, brandies, wines, teas, dc. ; in return for which they receive lides and tallow, skins, whent, and salmon. The attention of the inlanbitants thas been principally directed to the mising of entule, arvd the greater part of the wealth of Californis may be considered as eonsisting of lire stock. The exportations, on the aremge of years, is ahout one hundred and fffty thonsant hiles, and two handred thousand arrobns of tallow. From four to five humdrel sea-otter slins are brouglat in by the Anorienn liunters, and sro valued at thirty sollas ench. The beaver" slius are comparatively few. Whent has been exported to the Russian ports, to tho amount of twelve thousand bushels.

I'lie yidat of whent is remarkable, and in some places, where the land is well situated, very large roturns are received. Mr. Spears, of Yerba Buena, infurnod mo that ho lind delirered to an active Avierien farmer thirty bushels of whent for seed, at a tine when it was difficult to proeure it, tuder an agrecment that he should have the refuan of the crop at the nuarket price. In the July following, Jo delivered him three thousand bushels, and on its deliwery, he fotnd that the farmer had resorved six lundrod bushels for lituself; and this, witlont estimating the loss from Ind renping and trending out with loorses, would give one hundred and twenty for one. This is not considered a fitir eriterion or sverage, as the land พns remarknble for its richness and whs well nttended to; tut $\mathrm{Mr}$. Spenrs and sevelal others nssured the that the averago would be as ligh as eighty buslsels yielded for one planted.

Indinn corn yiekls weil, as aiso potntocs, leans, and peas. The cultivntion of regetubles is incressing ropidly, and supplies in these lntter arricles may be had in alutsdance and of the finest quality.

The country appears to bo well adapted for grapes. Those that tince beeu tried at the missions yield most abundantly; and about (wo hundred ensks, each of eighteen galluns, of bminly, and the ame quantity of wine, are snade. Tlie cultivation of the grape increnses yearly, but is not sufficient for the supply of the country; as lnrgo quantities of foreign wines aud liquors are int- parted, which pay an enermons duty; and although Califurnia may not bosat of its dense population, every intelligene person I met with agreed that it consumed more spirits in proportion than any otler part of the work. The wiss of the country which I tasted is miserable stuff, and would geareely he taken for the juice of the grape.

The salmors-fighery, if nttended to, would be a souree of considemble profit, yet I was toll that the Californinns never seem dieposed to atters pt to take them. The general opirion is, that they are too indolent to bestir themselves, and they naturally choose the emplozment which gives theiz the least trouble. A bove every thing, the rearing of eattle requires the lenst labour in this country, for it is only necessary to provido keepers and have their enttle markel. This done, they can support themselves by the inerense of the stock. At the missions, the manulneture of various conrse articles lant been undertaken by the nissionaries as a step in the education of the neophytes, Among these were blarkets and wearing npharel sufficient to supply all the Indians; but with the decline of these establishmente, the manulactures lave in great part been discontiuned. Soap of a good quality is manufacfurct in considerable quantities, and it is thought that it might be exprorted at a profit, if the proper arraggenjents were mado to use the grease that is now throwil awny. Tho neceesary alkali is very nbundant. Leather of an excellent quality is also made and well tanned, but in such small quantities as to be hardly sufficient to supply the wants of the country.

There are in California only two or three watormills for grinding flour, and these are owned by foreigtsers. The mills in genernl used in the cotnitry, are composed of no moxe than two burr-stones. To the umper stone a cross-beam is secured, to whieh mule-power is mpplied. In most of the estancias thore is to be found a mill in an apurtment adjoiniug the kitchen, if not in it. The whole is as primitive as well ean be, although I lave no doubt it answers all the wants of this rudo and indolent penple.

1.rom all accounte, besides cattle, the country is well ainpted for the raising of Eloep, which simply require watching, as they cau find plenty of uutritious fooud the whole yenr ruund; but there has been no attention paid to this sort of stock, nnd the wool is of very ordisary guality. The mutton is thoughe to be if very the fisrour.

Hugs are raised in some parts, and might be fed to great adrantage on the neortis which are aluundant un the hills, where the lnul is not susceptible of cultiration, l'ork may bo packed at turee dollare the hundred-weight. What adds to the facility of doing this business, is the fact that large quantities of sait collect in the jonds in the dry season, which may be obtained for the expense of earting it.

As respects trade, it may be said there is scarcely nny, for it is so interrupted, and so mueli under the influence of the governor and the oflicers of the eustoms, that those attempting to enrry on sny under the forms asual clsewhere, would probably find it a losing business. Foreignens, however, contrive to evade this by keeping their veasels at arschor, and seling a large portion of their cargoes from on bonrd. Great jartiality is shown to those of them who lave \& full understanding with his 
excellency the governor; and from what I was given to understand, if this be not secured, the traders are liable to exactions and vexations without number.

On the s0th of A sgust, Lieutenant-Commandant Ringgold left the Vincenues with six boats, accotnpasied by Dr. Pickerisg, Lieutenants Alden and Budd, Passed-Midahipman Sandford, Midahipmen Hanumersly and Elliou, asd Gunner Williamson, with provivion for thirty days, accompanied by an Indin pilot. They first passed the islands of Angelus and Molate, next the points of Sau Pedro and San Pablo, and then entered the bay of San Pablo.

San Pallo Bay is of a form nearly circular, and ten niles in dismeter; many small streams enter it on alt sides, fron the neiglibouring hills. On the east aido of this bay, the river Sacramento emptien into it througlt tho Straits of Kinquitues.

Ihe party took the suthth-east arm of the Sacramesto, and proceeded up the streatm for the distance of three miles, where they enearnped, without water, that of the river being still brackiph. The soil was hard, from being sunlurnt, and tise foot-niarks of the cattle, which had been made during the last rainy senson, still remaitred.

In the morning, they discovered that they had taken the wrong brunch of tho river, for this led imuediately into the San Jonchin. 'They, in consequenee, returued to the extrance, whera they began their survey. On the 23rd, they reached the residence of Caytain Suter, and enesmped on the opposite bank.

Captria Suter is a Swiss by birth, and informed them that he lad been a lieuteasnt in the Swiss guards during the time of Charles $\mathrm{X}$. Soon after the revulution of July, he enme to the United States, and passed several years in the state of Missouri. He has but recently removed to Califortia, where he has obtrined froul the govermment A eonditional grant of thirty leagues square, bounded by the Sacramesto on the west, and extending ars far up the river is the Prairie Butes. The swot lie has ehosen for the erection of his dwelling and fortification, he has called New Helvetia; it is situnted on the summit of a small knoll, rising from the level prairie, two miles frum the east bant of the Sacramento, and fifty miles from its mouth. New Helretia is bounded on the north by the Ameriean Fork, a snall serpentine strenm, which has a cuurse of but a few miles. This river, having a bar near its mouth, no vessels larger than boats can enter it. At this place the Sncrumento is eight hundred foet wide, and this may be termed the head of its nuvigation during the ary Betson, or the stage of low water.

When Captrin Suter first seltlel trere in 1n30, lie was surrounded by some of the most lostile tribes of Indians on the river; but by his energy and management, with the aid of a suall party of trappers, las thus far preversted opposition to his plans. Ho has even suceceded in wiming the goutwill of the livdians, who are now labouring for him in building houses, und a line of wall, to protect him against the inroads or attacks that he appre. hends, more from the present authorities of the land, than from the tribes alout him, who are nuw working in his employ. He lolds, by appointment of the government, the oflice of administrador, and has, according to his own belikf, suprome power in lis own district, condemuing, nequitting, and puuishing, as well as marrying and burying those who nro under him. He treats the Indiais very kindly, and pays them well for their services in tmpping and working for him. His object is to stinch them, as muels as possible, to his interests, that in ease of need he unay rely upon their cliefo for assistance.

Coptain Suter has commenced extensivo operations in faming; but in the yesr of our visit tho drought had affected him, as well as others, ard ruined all his crops. About forty Indians were at work for him, whots he had tauglit to malie adubes. The ngreement for their servicus is ustally made with their cliefs, and in this why as many as are wanted are readily obtained. These chiefs have far more auchority over their tribes than those wo lam seen to the nurth; and in the opinion of an in. telligent $A$ inerican, they have more power over and are more respected by their tribes than those of nuy other Sorth Anerican lndians. Connected with the establislument, Captain Suter has erected a distillery, in which ho makes a kind of piseo from the wild grape of the country.

New Helvetia was found to be in latitude $3 a^{\circ}$ $33^{\prime} 43^{\prime \prime} \mathrm{N}$, and longitude $121^{\circ} 40^{\prime} 3^{\prime \prime} \mathrm{W}$.

The best ronte from New Helretia to the United Stateg is to follow the Sau Jonehin for sixty miles, thenee easterly, through a gap in the Suowy Mountains, by a govid bestets rond; thence the course is uorth-easterly to Mary's river, which thows soutlieast and has no outlet, but loges itself in a lake; thence continuing in the same direction, the I'ortneuf river, in the $\mathrm{U}_{\mathrm{Pper}}$ Shoshone, is reached; and thenee to Fort Hall. Aecording to Dr. Marsh, (an American of much intelligence, resident at the mouth of the Snn Jonchin, to whom we are indebted for much information of the cuuntry, there is plenty of fresh water and proturage all the way, and no proper lesert between the Californtats Izange nuit the Colorade.

On the $25 t h$, the bunts left New Helvetia. It was dissovered, previuns to startiug, that four men lasd deserted from their party. This is a common cireumstance is this port, and very few ressels visil it without losing some portion of their crews. The rlissilute hatits of the people form streh strong temptations for sailors, that few can resist them. A mumber of nen who were destrters were continually arousd us. Amosig others, the eergeant and marine guard tlat Jad deterted frun H.B.M. ship Sulplutr were the most trisublesome. Their appestr. ance did not prove that they had clanged their aituation for the better.

T'⿺ miles up the river, a saud-bar occurred, over which it was found that the laureh could not pass, Licuteunnt-Commandnnt Risuggold thereforo eft her at this place, tuncer claarge of Mr. Wiltinme, taking sutticient provisions in the boats. The oaks beeame mure seat tered, and the soil thickly covered with vegetatiun, althumgh parehed up by continued drought.

On the 2fith, they renched the moutli of Feather river, which is fifteen miles above New Helvetia. it appeared nearly as broad as the main strenm, but there is $\mathrm{a}$ bar extending the whole distance neross it, on which the bonts grounded. On the jeint of the fork, the ground was strewed with the bkulls and bones of an Indian tribe, all of whom are snid to have died, within a lew years, of the 
tertinn fover, and to liave nearly become extinct in cotsenuence.

Gane is represented to lase decrensed in this vicinity, from the murnbers destroyel by the partjes of the Hudson 13y Company, who innually frequent these grounds. Largo flocks of eurless were then around; and the Californa quanil, which disappeared ainee leaving tho const, was agaits seen. the trees that line the lanks coneist of the cattenwund, ke. Single onks, with short gruss beneult them, are serittered over the plun.

As tlsey advanced, gasne becamo mare plentiful, and elks were fonnd in nbundance: Bome were of Jarge size, and nt this season of the yenr, the rutting, they are seen genemily in prirs; lut at other times, the fentales aro in linge herds. They nre fine-looking animals, with very large antlers, nud seemed, in the first instance, devoid of fear. "The herdts are usually thirty to furty is number, and are chictly composed of fenales and their young. The fisther of the tlock is alway conspicuous, and with lis horng scemed to over'shadow and protect the family.

The tula or bulruslt was founl in grent quantities, growing ont the bauks. The Indians use its roots as food, tither raw, or mixed wilh the grass need, which forms the principal artiche of their food. This root is likewise enten by the grisly bear.

At the eneamping $p$ lace was a grove of popiars of large size, some of which were seventy feut high, and two and a lual' feet in dismeter. I'He leal re. sernbled that of the Amerienn aspen. At night they had a slighe thunder-khower. The wolves and bens had entered the camp during the night, aithought there was a watch kept at each end of it. The lowlimg of the wolves was almosh constant.

On the 27 th, the eurent in the Sucramesto last trecone truch more rapid, and the suags more frequeut; its basks were on an swernge about twenty feet rhove the water, though there was every aptrarance on them of their laving been overflowed.

On the 29th, they for the first time met Indiane, who appeared quito sby, concealing themselves belind trees, As they incrensed in numbers, however, they beenme mure contident, and invited the party to laud. 'Towardo noon the character of the country began to clauge, aud trees of a Inrger size than before were secn, growing rout from tho baulis. A little after noon, they met with the remnins of a fisln-weir. Some Indians were scen along the bauks, amied with bown, nrrows, and lanees: none lut males nppenred; they, lowever, made no liostile desmonstration.

Gime ant fur-bearing animals had lseome more numerous, and anong then were the lyux and fox. the later is the specieg whose fur briugs a high furice in Clina, where as much as twenty dollaus is paid for it skin. This fox is snid to have one pectslinrity, tamely, thnt when chased it will nseend trees. Benrs were also in grent numbers. It is reported that they will sonetines attack ant eat the Indians.

The Indians olsserved by the party were generally line robust mers, of low stature, and badly formed but the chicf, five or six in tumber, were fully cqual in size to the whites, though inferior in stature and good-lcoking as compared with the generality of the Polynesians. T'ley had a strong resemblance to the latter, except that the nose wro not so flat aut their culour rather darker. Although the men go malied, the women are satid to wear the maro. The tualea setmed to be execelingly jenlous, on account, it is said, of the unprinejpled conduet of the whites who have oreasionally prissent among them. Their linir is not worn sh lnge as it is by tho nurtheru Indiass, and is much blicker. They laat heards and whiskers au inch or two long, very Eoft aul fine.

On the morning when the party were brenking up ennp to emslinlti, an Indian boldly seized the lrowie-kinfe-pistul of Dr. J'ickering, and masu at ance for the wods. Ho had choseu his time well, for no arms were at hand. Sovernl of the men pursised hini, but by his nlertness he eluded alf jursuit; and having gained the buthes, escaped with lais prize.

Tluis aet, enmmitted in open disylight, and at the risk of life, shows huw strong is their propensity to steal. Alf the other Indiaus present soms understood the difheulty, and at once took their departore. The clife wh not present ; thogo who were conecrned in the theft had not been before seen, and it was conjectured belonged to one of the ratu. elicrias higher up tho river. $\Lambda$ short listnuec nbowe the piace where this occurret, they met the clief, to whom the theft was mado known, and who promised to restore the stolen article.

At noon they passed the Prairie Butes, which aro a collection of isolnted hills, rising from the level plisill, as if out of the son. Indians were sent on the west bank of the river, with a number of women in conspany, who seened well disposed to enter into connmusication, as they mutioned the party to Jamd.

In the afternoon they encrmped on the swest bark, at a considerable distance above the Butes. 'The river was hero only two handred feet wides, and its banks but fifteen feet high. The trees rul the slores lind now beeone quite thick, and grew with great luxuriance; so misch so, that were the sight confined to the river banks, it niglit be supposed that the country was one continued forest, jastend of an open proirie.

"the Indians who visited them $n$ this enmp, were less tinid, and a much fincr-lanking ect of men than thoso before seen. I'hey allowsal the officer and men to examine their bows and arrows, nnd appensed to hare confidence in our good feeling towards them. The old clief weleomed the party granted them permission to enesmup on the bask, and thers departing with all his tribe, nothing more was seen of hin until late the next morning.

On the 3lat, they again proceeded, and passed several Imdian villages. Bofore nom, thoy artived at a substantially-built fisl-weir, of with the Indians loggan to take a part down, hut LicutennmtConutandast Riaggold deeming that this was the termitution of his explonatiun, motioned to them to desist.

Ttue river was examined for two or thece miles alove, and found to be filkd with rapids, and inเsumerullo difliculties caused by snags aud samulLars. Here Lieutemant-Cumtnandnat Kingerold nsenrtained his position to be in latitude $39^{\circ} 13 y^{\prime} 39^{\prime \prime}$ $\mathrm{N}_{\text {, }}$ longitude $122^{\circ} 12^{\prime} 17^{\prime \prime} \mathrm{W}_{\text {, }}$, which, joined to the work of the land pinty, gives the exploration of the whole extent of the Sncrnmento river, from its sonvee to the sea, a distance of two hundred miles. 'The first fork, or the junction of Pitc's with that of 
Destruction river or ereek, is in latitude $40^{\circ} 47^{\prime} \mathrm{N}$, longitude $122^{\circ} 34^{\prime} \mathrm{W}$.

At the plnee where the survey ended, the river wan wwo humlred feet wide, its banks being fwosty feet nhove she river; bat it was evident that its perpendicular rise exceoded this, ns there was every appearassee of its overtlswing them; ant, accoiding to the testiung of the Indians, the whole country was atsnually iuutwated.

On the afternoon of the 91 st of August, the party turned to go lowa the stresm, nat with the aid of the carrest ande rapid progress, Townrda sunset they chtered the sinall atrean ealted Bute, on whose banks they encamped. Here they were much disturbed, both with lears and musquitues.

On the lst of September, they made an enry start, and about nool retched the village where the theft of Dr. Pickering's pistol had been committed.

It was with sone difficulty that the Indians wore persuaded to approselı; but a fine-looking savage, more buld than the rest, at last ventured ta dos so, and gave the informution that the Indian who hat committed the theft resiled nt the village up stream.

The wenton therefore not bsing fortheoming, Lieutennnt-Commnndant Ringguld determined to seize this man ns a hostrge for the retwrn of the nrticle. He was necordingly sceured, him arme pinioned belind him, and leil down to the bont, when two men were orllered to tiv his legs; while they were in the net of doing thit, he extricated himiself, and jumped oxerboard. The guns were at ance levelled, and half-a-dozen triggers ready to be pulled ; but Lieutennat-Commandant Rinugold very properly stopped them from firing, and endenvours were made to recspture him, but without effect. 'These eflorts hinving failed, they trok to their brats, and pulled down the strenm. The Indians who were on the banks, to the number of twa hinsdred and fifty, made no dounonstrations of linatility.

On the Hrd, they continued the survey, unti? they were below Feather river, when tho provssions were 80 nearly cxhaustod that LieutenntCommandaut Ringguld foumd that it would be im. possible for lim to exannine that stream. Tho residents and trappers informed me that they hnd followed it to its source. From them I lenmed that it takes $j$ ts rise in the Californinn Range, from which it pursues a south-weat course, until it falls into the Sarramento river. If is about forty miles in longth, It is believet that the Spaninrts, when they first explured this country; designated the Fenther river as the Sacrumento, and gave to the true sacramento the rame of the Jesu Marin. In no other way, at least, enu the error which has ocetrred, in rolation to the Jesu Maris, be explsined; and on this supposition, the necounts of it hecone intelligible.

In the neightourhood of the Sneramento, there are sometimes to be found small Inkes or bayous, which geen to be tilled at high water, but becone stagtinnt during the try sesison. These the elk and deet frequent in large numbers. Their ory or whistle is at times very surill, and uny bo lientrd for a great distance.

At the jumetioss of the Fenther river with the Sacramento, the latter increases in wilth to nearly Alouble. It was found just below the junetion to bo from twelve to fifteen hundred feet brond, forming a sort of bay, but it soon agnin contracts. They encamped about ted mites below the confluence of these streams.

On the tili, they had returmed to Captain Suter's quarters, where they stayed till the fith, when the survey being finished down to this point, they descented the river, on their returti to the ship. On the oth, they had artived at the mosth of the river, and the Straits of Kaquines. On the Oth, at midnight, they reached the Vincennes, after at alusence of twenty dnys.

On the opposite side of the bay of San Pablo, or to the west, are some of the fincst traets of country in California. One of these is calted the Yalley of Nappa, another that of Zonoma, sul a third, San Rrficel, In Zonoms jas situated the town of the same nume, the residence of Genernl Vallejo, and the mission of San Rafuel. The fertile counury ex. lendtheross to Ross and Bodega, the two Russian settlementa before spoken of. Zonomn is the seat of grovernment, and is situated in an extenxive plain, with some ligh hills for its southern boundiny. The plain is covered with tine onlis, atal there is a never-failing stream of water prosking thrnagh it. 'Jhere js besides an inlet from the lay, which allowa a boat navigation to it of abotat twelve miles.

Upon paper, Zonoma is a large city, and laid out accurding to the most approved plan. In renlity, however, it consists of mily the following brildings: General Vallejo's louse, built of allobes, of two stories, which fronts on the public square, and is said to be one of the best houses in Califor. nin. On the right of this is the residence of the general's brother, Snivadore, and to the left, the barracks for the accommodation of the gunsd for the general, consisting of about twonsy fusileers. Not far removed is the old dilapidated missionIsouse of San Francisco Solano, searedy tennntable, though a small part of it is inlonbited still ty the Padre Kilans, who contiuues, notwithstanding the poverty of his mission, to entertain the stranger, and show him all the loogitality he can.

Besides the luilditugs just enumeruted, thero were in the conrse of construction, in 18.11 , a neat little chaf̧el, anal a small building for a billiardroum. There are also three or four more houses and huts which are tenanted ; atud at some future day it may honst of some farther adtitions.

General Vallejo war one of those who figured in the revolution of 1836 , and was then mppointed Commandant-General of Alta-Califortin. $\mathrm{He}_{\mathrm{e}}$ is now the owner of lange estutes; and laving chosen this part of the country for his residence, he is free from the opposition und brotls that are continually" growing out of the petty eoncerns of the entam-bonse fund its duties. He is not overseruzulous in demanding duties of the ressels entering the port of San Frnneigen; and nutil the Jins heell secu and eonsulted, a vesbel trading here is liable to an turlefinite nuours of dutins. A prottions of the paynent addes to his wealth, and liow much goes to the govemment is not knowu; enough, I was told, it some enses, to sare appentances, and no more. The foreigners who trale here are very attentive to him; and it might be supposed, before making inquiry juto the cause, that he is $\boldsymbol{n}$ grent favourite with them, The highest oflicia! urotection is necessary for all those who wish to prosper in their trade to this port, and to prevent exactions from suburdinates, 


\title{
CHAPTER XXXV.
}

\section{SAX FRANCISCO TO MANILLA.}

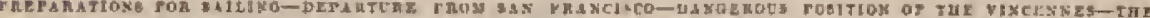

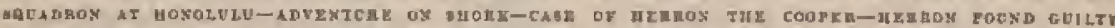

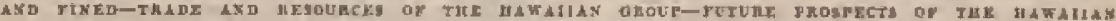

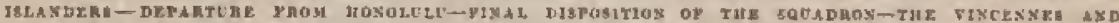

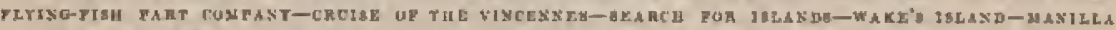

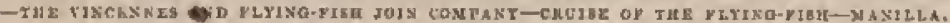

By the 28th of Oetober, 1841, all the exploring partios had returned to San Francisco. The duties of the observatory and surveys were completed, the instruments embsrked, and preparations made to sail with the first fair wind.

The brig bouglit to stipply the loss of the Pea. cock, wrecked ots the bar of the Columbia, I tow new-1ismed tise Oregon, and gave the commind of it to Lieutensut CarT, first lieuteunst of the Virs. cennes. It was with no little regret that I parted with Lieutennat Carr, the executive offieer of my shiz for upwards of two yesrs, during which timie bis duties had been al ali times responaible, arduous, asd valuable to the expedition. My regret at partirg with him gave way, however, to the pleasure of assigning lim in stutions to which his conduct bad so justly entitled lim, and which he wna to well quilified to fill.

To complete our suphilies for the return vayage, it was expedient that we should again visit the Hawainu Group: this was rendered absolutely necesary, in order to procuro clothing for those who had lost every thing by the wreck of the Peacock; for deficiency in that imporinut wrticle might, land we pursued the direct route to the China Sear, hare subjected tine men, who had alrendy undergone so much exposure, to the at tache of disense.

This necessity, added to the other delays the unfortunate lenes of the Peacock had caused, was a sonrce of profound regret, as it preventel me from availing myself of the permission granted is my instructions, to enter tle Sea of Jajan, through the Simits of Snngar. I gave up this plan, ta which I had lonked forward as one of the most interesting ynrts of our eruise, will great reluetunce; but the reason was rapidly passing, and to undertake this remote expedition wonld render it impossible to accomplish the other objects marked out for me previous to iny return to the United States. We might not, perhaps, lave succeeded in enteriag into communicatins witl the inliabitants of that interesting and little-kuows country ; but we might certainly, by landing on some of the islarut adjecont to its coast, bave obiained much isteresting information, arnd silded greatly to the cullectinus of our seientific departmonts.

On the lst of Novenber, we had $n$ wind that enabled us to make sail, alllough it wrat linte in the dny before it was sufficiently strong, and by that time the ebb tide was far spent, To avoid axy farther loss of timne, 1 determined to anake the attempt. Sigual was nccordingly made; and the ressels were in a few minutes unuler way, nand stand- jug out of the hurbour. It mav, indecd, he said, that it is practicable to enter and depart from this port whenever the tide is faroutable. We continued benting rut to gain an offing vitil towards sunset, when it fell calm, and the tite failed us. The Viueemes was, therefore, compelled to anchor is six and three-fourthe futloms water, three iniles frotu tre land; and signal wing made to the two brigs, which were alrotut threo miles outside of our josition, to do the anme.

On eur coming to anchor, there whs scarcely nuy swell, and the slip Iny almost ss still so if she bad been within the harbour. The sun set elear, and every thing betukened a calm ath quiet jighth.

At about 10 P.M. the swell begrin to increase, without any apparent cause, and so rapidly as to awaken my anxiety; but heing in such decp water, I thought tlat the vesseI was sufficiontly distust from the bar not to be exposed to any brealiers, As the flood continued to make, the swell in. creased, and by midntight we were enveloped in fun, without a brenth of air, and the ships rode orer the rollers, that were now lecoming very loavy, aud caused her to pitch viulently. There was, huw. ever, no brenk to then; but as anple scope of cable had been given, the ship occnsionally swang broadsite to, when the hexty pitching was cluanged to rolling go deep as to endanger our mastas. At 2 A.N, a brenker wat licharl outside of us, prossing in with the rone of a surf, siter which they became conglant, and ratly awful. The ship might now be enid to be rilling in breakers of gigantic size; they rushed onwards witl, sulh a tremendous rosr and violenee, that ns ench wave was heard approaching, it beenme a souree of appreliension uatil it luad safely pagsod. Such was itg force that whet it struck the ship, the chain calsle would surge, the ring-stoppess part, and sone few fathoung of the cable escape. As the time of ligh water approacherl, the ruar of these immense breakers was constaut. The ghip was as if tempest-tost, and our siluation became at each monert one of greater solicitude, The actuat danger of wreek wns not falesd great, for in the evout of parting our cathle, the tide would have carried us towurds the harbons, and into deeper water, where the rollere would hine coased to brenk; and there wus no grent danger that we would drift on the bar, whitels was n mile or two to the northward of our position.

1 Jooked forward witlıanxiely for tlie time of bigh water, as the periud whess wis should be relieved from our unpleasant situation, not ouly by the x 2 
clange in the course of the tide, but also by the cessation of the brenkers.

0 ur situation afforded the an opportunity of mensuring the reloeity of the waves as they passed the ship; and though the distance was shurt, yet the observations were tsumerous, hul gave the velocity at from fifteen to eigliseen miles an hour ; their estimated height was over thirty feet their width, fron eight humbred to one thousnnd feet.

At half rpast three, one of there immense breakers struck the ship broad on the bow, and broke with its full foree on bonerd: the cablo surged: the stoppers were carried away; and the whole spar-duck swept fore and nit; the bonts and boomis broke ndrift, the former were atove, and the Intter thrown with rinlence to one side.

Unfortumately, Josenb Allshouse, a marine, who whs in the act of ascendisg tite lader at the time, was struck by one of tho apers, and so much injured that lie died a few hours afterwards.

It was not until between seven and eight o'clock that the slif conld be relieved from this situntion: at that time a light air from the land sprung tap, of which advartage was at once taken to weigh our anefior. Tho rollers, liwwover, laad by this tinte ecased to lireak, the sea began to fall, und a few bours afterwards regained its former plncid ast duiet state. The fog was still dense wher we reached deen wuter, where we agtin dropped anchor; but shortly after the weather clenred us, and we had communication with the Por poise and Oregon; they linving reached deeper water, had fortunately not experienced any of tho rollers.

We now got under way, and stood for the bny of Monterey, from whenee I sent the Purpquise with despatches for the Uniled Strtes, ordering her to land them; and in cuse she did nut meet the Vincennes, to make the best of lier way to tho Sandwich Islands.

The next lay being foggy, I bore nway in enmpany with the Oregons.

On the sth, the weather contisuning thick and foggy, with atrong breezes from the northward and weatward, I mado all sail and parted companny.

The wind on the $7 \mathrm{th}$, when we had renched tho latitude of $27^{\circ} \mathrm{N}$, began to incline to the north eust, and the tempetuture beeame mild.

On the 13th, I shaped our conse to run over one of the positions of Copper's Istatu, supposed to exist in longitude $151^{\circ} 36^{\prime} W^{\circ}$, and latitude $25^{\circ}$ $48^{\prime} \mathrm{N}$. On this aftermon of the 14th, we wuro within five miles of its assigned place, and the Wetther was perfectly fine, with is elear horizon, but there was no afjenrance of land.

On the morning of the 16 th, whe marle the igland of Mani, atrd on the 17th, at daylight, the ishand of Onhu, anchoring at $10 \mathrm{s.3}$. off ilse town of HonoJulu. The Porpoise came in at $2 \mathrm{P}+\mathrm{Min}$, and the Flying. Fish at tive o'clock of the anne day. The following day the trode-wind was ton strong to ad. mit of the Vinconnes entering the inner harbour but the Porpoiso and tender were enabled to do $\mathrm{sa}$. The Oregon joined us it the aftornoon, and on the next day at an enrly hour the squadron was again moored in the larbour of Honolulu.
Our reception was even kinder than before; and every facility that wo could alesire wis offered for artvancing our duties and procuring the necessary stores and clothing that our shipwreeked ofticers and mes requitud.

Honolulu shawed signs of improvement, but I regretted to pereeive slast during the year the morals of the place seemed to lnave declined. The number of grog-sliops had apparently increnset, and the sailoss doncing-halts, with their music, were allowed moro license than at our first visit. Yet, as far ns the prompt execution of the lisw went, I did not find the authoritieg defiejent. Indeed, at times, Governnr Riekunnon is rather too precipitato in his decisions, of which the soon hat in instance.

During our stay of ten days, she crews were allowed, in turn, recreatinn on slore. Among the number was Lewis Herron, the conper, In the course of his liberty, he was desirous of entering one of the saifor's bonrding-lonenes, at the door of which his progress was arrested by a coleured nuan, who was on guard with an old cutlase, and who threatened Herron with viulence if he at wempted to enter. Tlis, Herron, tlough usully a very quiet and orvlerly man, at once resented; fand the altereation firally come to an angry dispute as to who was the better man. Herron, determined to prove tha he was, laid hold of the sentry, orertlirew him, took the rusty cuthasy awny, and struck him with it so as to give the num a sliglit seruteh on the leg. Herron now brnudished bis weapon in victory; but being told by the byotnnders that it was unlawful to carry weapons, he determined to take it himbelf to the governor at the fort, and de. liver it up. On his way thither, nnd just before be arrived, he was met by some soldiers, who at onee seized and carried him before the governar, with the sword in his hand, which he had refnsed to give up to any one else.

The goveruor had a kind of trial held by litmself, and not necording to law, (which provides for trin by jury,) to which ho summoned the very man who las exused the quarrel, as a witness, without any formality or onth, nud senteneed Herron to fifty dollars fino, aud to recoive one hundred lashes; whilo the person who had been guilty of using the arms, received but a nominal fine. One of the oftieers hearing of the circumstanes in the afternon, went to see Herron, lieard his story, and thell gaw the governor, who promised that the man sliould have another lenting or trial the next monuing, at nise o'eloek, and that he should stot be prinished until I was informed of it. In the nuoming, however, to my great susprise, I heard that, iy the goventor's orders, and in lija presence, Herroit had, at eight o'chsek, nn hour before the time lit new trial was to take place, received twenty-eight Jashes. On lenrniug this circurnstance, an officer wat at once gent to wait upon the govermor, to re. quest an explanation of the proceedings, ant that Herron might be given up, and held subjoet to the governor's order, for a proper trial. On reccivitug the ofticer, Guvernor Kekunzaon declated that is was a misunderstanding relative to his laring promised a new trial, and declined giving up the nian. In consegtuenee of this, I at ouce sent a message to demand him, and to state that if the wag not sur. rendered, I should bo vbliged to take him, for I would not suffer him to remain any longer in the 
kepping of persons who would inflict punisfrwent with so mueh precipilation. Tlis enused lis debivery. Shurtly after, I received a letter, telling me that the corporeal part of his ptunishuneut was remitted, but demanding the fine, I took this oc. casion to write the governor a letter, poincing out wlterein he lind erred, in order that he might not full into a similar erros.

The next day I was notiffed that he would be again tried hefore n legal trilmanal, viz. the goveruor gnd the United States" concul. "The day hifer, he was necurdingly sent on shore to undergo a trial, which he himself wislsed, fur the purpose of jroving whetier he was guilty and subject to the tine. Tho trial of Herron wotk place in tlie grass. house of the king; the seene was chatacteristic, and will show the manner of conducting trinls in the Hawaiian Islands, Govertnor Kekunnaon, the American cotsul, Captnin Hudaon, Dr. Juid of the American Mission, who acted as interpreter, and severnl officers belonging to the spundron, ns well $n s$ those of the government pulice, numerous residents, of all colvurs and classes, the prisoner, his friends and accusers, were present. At one tablo the governor and Or. Judn were sented, at another the consul and Captsin Hudson, while the prisoner and witnesses, with tho spectatons, were staurding is groups around. The eourt was opened in due form, nud Dr. Juild stated the judictment, to which Herron plended not guilty; every thing wns enducted witli dne solemnity: the orth was then meninistered by the Americn consul, to the wit messer on loth sides. Dr. Judd examined and interpreted the whole. During this proceeding all

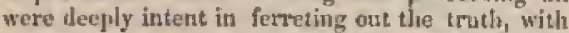
the exceftion of his excellency the gowernor, who whs occupied most of the time in searching his little white pet $\log$, that was lying on the table luefore lim, fot Heas. Tho whole trinl was, lowever, fairly conducted, and resulted in proving that Henton was guilty. Herron was fined fifty dollart, which wos paid, and the husiness ended.

I was satisfied, however, that the governor had in this erse neted with uubeconing faste and inconsiderateness, aud at the sane timo was wantiog in delieacy to hir beat friends, for we, of all nations, are the most inelined to respect liag laws und upholi his authority, I enllod upon lin before my departure to take leave, when he admitted that the course he had fursused was un unnsual one, when foreignerg were concerned; but from the explanations he made, I was satisfied his intertion sas to do right, but like many uthers whes rested with authority, he was nos indined to delay netion on a case he considered no elenr as this. It proved a good lesson for him, and I do not believe he will err in the same way again.

The tralle of the Hawain Group is, at present, confined within very narrow limits, Tho islands protuce but litle, and their consumption of foreign proiduts is neeserarily small. "I'se eapaluilitieg of the islanda have gererally been undertated, for their soil and climnte are suitalile for raising all tropieal productions in considernble gunantitice, and at a moderste cost. But very litte investment of capital las yet taken place, and the business that has andued the establishment of several commercial houses lias been more that of transit than for the purpose of supplying the consurnptiot of the islnnds, or obtaining their exports. $\Lambda$ talle of statisties, which was published in a newspaper at Ouluu, and compiled by iutelligent merchants thero, gives tlie anumut of importa netually landed at four hubdred and fifty-five thousind dollars, while the exports of native produce nre ne tore than ninetyeight thousand dullars. From this great difference beween the infrorts and exjorts, it would sppear that masy of these articles nunk have been reshipped to ather ports, or are still on lasus?. The latter I believe to be the ease. The trate on the north-west const, furnerty su much resorted to by our vessels, is eutirely broken up by the Rusaians, who have interdieted the taking of fure on the oonst of their torritory, and obtain hieir supplies exeltssively from the Hudmom Bay Corrpary, ar by the later, who bave adented the prineiple of under. selling all compretitors, and have therety caused a monopoly, which offectunlly shuts ont all small traders. Sosue articles of Chinese man facturo are sent from the Sundwich Jslands to Mexieo, but to no great amout. There are, compuratively, few trankient versels that ealt at these islands on their way to China, and the whole trude seenis now earlfinel to but a few vessels. One-linlf of tho iraports is bet down as receivod from the United States.

Atthogls the Sandwich Islands are not so frtritful ag many of tho other islands of Polyneria, yet their gengraphical silnation lins rendered them bitherto by far ste nost important group in the I'neific Ovesun.

'l'luey are the favourite and most convenient regort fur those whale-ships whose eruising-ground is the North Pacific; and the nmourst of property engnged in this business, visiting the ports of the Sundwicls Islands annually, is equal to three mil. lions of dollars. To the supply of this fleet, the Introur of the iuhabiennts lias priucipally been disected.

The ehiefs have ceased to look to their groves of sandalwood as a Bource of profit, and have legun the cultirntion of sugar, which, togother with silk, now attrnet much attentioss; but uncil some capital be invested in these cultures, and the busineas be botter understool, these articles ennnot be risised to nily largo aunount; yet the provisions and supplies to ships, suffice to aftord all the necessary comforts to the inlabitants of this group.

Fortunately fur the Sandwich Ialands, lhey have no port that is defensible agninst a strong araval force, and therolore their consequence will be comparatively small in a politieal point of view. No foreign power, in fact, centd well loold them, with. out great exprense and difliculty. Honolulu is the port where ressels ent best receive repairs, but it can only be used ly the amaller class. By these cireunstances, the ireutral positiou of this group I think is insured; and this is most desirnule for its peace and lappiness. This fact seems fo use to be incilly acknowledged by the anaritine powers, as no attemp̧t lus ab yet been tunde to tako possexsious of them, rud they will, in all probstility, be long left in the enjoytment of their neutrality, which king Kamelsamela 111 , is now endenvouristy to estublikl through a fortnal reenguition of his kingdosu by the United Stutes, England, and France, by negotiations that are now pending. Such recognition will render them Ines lisble, if not nlto gether excmpt from aggressions. Tlese islands sem isteruled for pencefil oceupations alone; their products, situation, and inhubitants, require and 
wish it. The power on which they mast become deprodent hereafter, is that which is to be establinhed in Oregon anil Califiornin; amk, adapted as they are to suppiy all the products of the trupies, they will beonne a valtuble apprendage to those siates: lut I deem the illea entertained by many, who suppose they ever ean become so powerful an to emmmand those states, to bo a mistake. So far ns the eonsurnption of $\pi$ small amotut of mannfac-

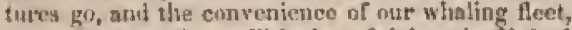
but sto farther, llaey will be beneficial to the United Stater. In this relution, the clinmeter of the govertument becomes a source of solicitude to us. It is the interest of the Uniter States that they stronld инantain the neutrality that they seck to establish, askl shoukl not be permitter to fall into the hands of any other power.

I wu ratlier disposed to think, that, in the progrens of civilizntion in the South Sena, this group will the considered of less importance tlan it now

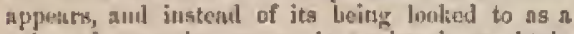
point of attraction, or a place wherein to obtain infortuntion and supplies, it will bo only visited by wlıalew fur rectuiting. Tlieir growtly lras already mrrivat at the grealest extent fo which it can ever rencls. A direct eommutestion with Oregun sud Califortia will do awny with the neecsaity of intercontse throtigh the islahis; they inusi, consequently, bo left to their own lexources to maintain trnde; and when Califormin and the Oregon territory can atturil the whulers chlual alvancages, which, when settled, they will du in a fow yeats, live advaistages derived from this source will be willulinun. Un. fortumbly for these ishorls, a thetitious importance lsas been ascriberl to their geogrmplitul prosition, in the belicf tlut muelı politieal areenduney in the Pacilie must necrue tw the notion which may pusaess them; this stnte of opinion las been brought about by the exertions of the $A$ merican miasionaries, whit linve been the nterns of raising the natives so rapidy jo the seale of civilization, and from whoso success our countrymen lave acquired mach influence. 'This ascendancy, howevel, has lieen partly the means of provoking a sectarian war, which hins brought ubout much trouble, and heell the cause of greart distress buth to the hing and people. These troubles have parabably been of some adrantage to the people, and alforded the menns of increasing their wealth, ard cansing a denand for their prodaets, which, though trifling as to amount, yet in mels a small comumunity lins beent sensibly feit, and lats eubleil them to obtain many advaunges they eotild not have land otlerwise. I have somne doubt whotler the Hawaitan Islanis can ever become an independent sation ly the exertion of their own people, since they lare unwisely invited foreigners to reside among Ulem, and given them equal rights and privileges with natives. Endeavours are now making to introduce foreign labourers and capital, which, althotigh proceeding froms a disposition to adrance and develop the resources of the islands, will have a tendency to injure the nstive lnbouring population. The jntroduction of foreign lahour will necessarily bring with it foreign thabits and custom, which the natises are, ewen now, tro prone to imitate $;$ and the exnmples that are set before them are getserally, if not alwnys, of the worst deseription.

The inducoments lield out to the ling and chiefs to make large grints of land to foreigners, lave been great; but such grants can never be cnrried into effect without endangering tlie very existence of the govermment and people. In all eases tlint cane within my knowledge on the ialands, the object of the majority of forkigu residents was solely to inerense their own wealth; and on the aceumulation of a sufficient amount, they withdraw from the islanth, taking their eapital with them; atul this will alwayg be the ease. Su far, therefore, as their influence goes, instend of enriching the islanders, their excrtions have in some rlegrec lanil a conlrary effect, nnd the result does not justify those engnged in mereantile pursuits, in attributing the advancernent of the islands to thernselves; on the contrury, they leave vary little but evi] habits and vices beldind them. Fow foreigners lave made any permanent insprovements, and when they have, they pass into the hands of others, to the exclusion of the aatives, who are louked upon ard treated as slaves.

It is impossible for $\mathrm{a}$ disinterested person to reside any time among these natives, without itubibing a strong interest in the progress of their institntions, and the developtnent of their govermment. In the Jawainas aro seen many things to condemn; but they lave, on the other Jiund, many gond qualities, which their religions instructurg nre endenvonting by every mens in their power to fualer and develop. In tuking lenve of them, I cannot recall a single instareo in which they did not venduet themselves towards th with a full belief that they were acting right; anil I feel rejuiced to say, that during ull our intereourse with then, no incident occurred to mar the harmony which existed on our first arrival. $1 \mathrm{sm}$, ind ceed, fally persuaden? that with proper attention and forbenrinee wo difticnlties will ovel" occur. One thing, howerer, ought always to be borme in mind on visiung this island, viz. that ton much eredit must not bio given to those who will nn your first arrival endenvour to impress on you their ow and of thwo who have been their benefactrirs, and are constant in their exertions to promote the welfite of those they live among. The natives and the latter eluss are fnt better able to judge what the islands require or stand in need of than any ensunl visiter, or he who nay be a sojourner only for a few weelis.

I sliall alwayn think with pleasure and antisfaction of the many friends we left in the Hawaiian Group; and I nm fully satisfied, tlat, with fow exceptions, and those growing out of a mistaken zeal, our country lias just reason to be proud of the advance these istanders lase made willin the last twenty-five years in civilization, morals, nud religion; in advaice that lase been almost wholly the work of our citizens, eilher nt home or abrond, the one in fumighing the means, the oulher in giving the instrnction.

The expredition hat become so much identified with the history of these islands during our stay, that we were made familiar with all the village seanulat. Few who live in such small places are aware how unfavourable an inpression they make ирмn visiters, and tho bad light in which they nppear, by this hathit of talking of each other; wlut. ever may be the terms on which thoy associnte to. gether, or however discordant the materials of which the eociety is composed, they would do well to avoid showing their uncharitable fcelings, or 
making use of detrnetion to create a bing against others.

On the afternoun of the 27th November, we re.

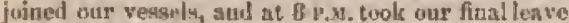
of the Hawuitun Iblanda.

At midnight, signal was made to heare-to, in order that I miglit finish the instructious for the different vessels. Althnugh it was out of ny pawer to visit Japan, I lasd determined if possible to atscertain the character of the currents off that istant. I therefore directed the Porpoise and Oregon to follow out, and explore the shomls and reefs extending is a west-morth-west direction from the $\mathrm{Ha}$. wailan Islatde, and proceed nutil they fell in with the eurreut or stream thint is suppused by some to art nlung the consts of Japan, nul reacmble the Gulf Stream off our own soust. This dome, they were oriered to pmoeed Inrough the China Seas, to Simgapore, in the Straits of Malineca.

With the Fincennes and teulor it was my intention tu proeed to Strong's and Ascension Jalambs, which the Peacock hal been unable to reach in lier eruise, examiniug every slonal that might lio in my way, and thence to Manilla. 1 proposed on learing that yort to explore and survey the Sooloo Archipelago, then proceeding ta Singapoive to meet the brigs, filt up witl provisions, and thenee anil for the United States, where it was incumbent on me to arrive by the 31at of May following. This, agreeably to my promise to niy crew a yenr previous, left me just six mouths to porform the duty, of which nt lestst one hundred and forty dnys were required for the actual pusesage.

We parted eominany from the brigg the next day at noon, and bore away under all anil to the sonthward and wertward. At 4 p.s., the Flying-Fish made the signal "in want of assistntsee;" and on coming within hail, reprorted tlast her mainmnst was sprung. Carpenters were at once sent on board, who reported that the mast was quite sonnd : the resels were reduced to easy snil for the night in order to keep in eompany, ns I intended in the morning, when the soa slould have decreased, to have a farther examination of it.

1 land now the prosprect of another obstacle, in the delays this vessel inust accesion me with a sprung nuat, if such should prove to be the ense, which I could, however, scarcely bring nuseself to believe. In priler to secure mu exanimstion of the Sooloo Sen, whell was a prat of my uriginal instructions, I gavo Mr. linox onders to net liy him. self, in casc 1 should find it necesenty to push at onee to Manilla and awoid detention, directiog lim to touch at Strang's and Aseengios Islands, and to part company if her spars were sound. Tluis I wins glad to fird whs the case, and on the $30 \mathrm{th}$, we parted company in the Intitude of Maloon's Island, the Viuennes steering a west courso through the night under ensy sail. At daylight sail was again sande, and by nows we found the ship, by good observations, in Intitulo $19^{\circ} 19^{\prime} \mathrm{K}$, limgilude $165^{\circ}$ $25^{\prime}$ W. "The supposed position of the ishrod being in latituile $19^{\circ} 20^{\prime} \mathrm{N}_{1}$, aud longitude $165^{\circ} 20^{\prime} \mathrm{W}^{\circ}$, we hat consequently passed direcly over the pince, with the weather so clear as to reuler all objects within a radius of fifteen miles perfectly distinet, and with two look-outs at the mastliead, yet no signs of land were visible. I continued in its latitudo until we had passod serenty miles to the westward, when we steered for another island, Jaid dowa in
Arrowemilli's clints in langitude $166^{\circ} 48^{\prime} \mathrm{W}_{\text {, }}$ and latitute $19^{\circ} 17^{\prime} \mathrm{N}$, On its parallel, we ran for sixty mileg east and west of the assigned place; but in tike manner, there was nothing jorceived that indiented any proximity to land.

On tho 3ed of Deecmber, we ran oper the locality of a siloal, iying tn $170^{\circ} 30^{\prime} \mathrm{W}$, and latitude $-16^{\circ}$ $20^{\prime}$ N. This was likesise seareher for, over space of sixty miles crst nul west of its supposed luesality.

Jane's Island, surpensud to be in longitude $173^{\circ}$ $15^{\prime} \mathrm{W}$., latitude $16^{3} 10^{\prime} \mathrm{X}$., was next searehed for. In doing this, I was greatly Hurprised to find that we bad entered a strong eurrent metting to the northwhrd and westrand. Our difference of latitude showed 24, and wo were at once compelied to taul isp to the sonthward, to retsch the sunposed linculity of the island. We pussed nbout five miles to the westward of its place, bue no sigu of land was seen. This was the first day since leaving Onliu, liat we were able to write with any degree of curnfort, the Bess laving besone perfectly smooth.

I was ut first disposed to doulte the accuracy of the observations for latitule, lunt the next day (5tl, Decemlier) proved then to be correct, mearly the sante difference having necurred.

On the 6th, we rehched the pusition of Gaspar Istanil, in Intitude $16^{\circ} \mathcal{N}_{*}$, and ths the different Inenlitieg assigned ik variesl eonsideruthy in longitude, I deterrained to run on jts parrilel until I had passed then all.

On the 7th, we dropped a day, passing into east Jongitude. Our winds had heconte light, varying from the enst to the south-west quarters, and it was generally enlm throughout the night, 80 that we narlo littlo progress.

On the 10 : $h_{1}$, the current was found setting westsouth-west three-quarter of a mile, both by the difference of the observations, and tlie current-log. The pot, at this time, was seen at thirty-two fatloums depth, several fathums lower than at any previous observation. The temperatnre of the water was $81^{\circ}$, the day fine, and beantifully elear.

We eontimed on the parallel of latitude $15^{\circ} \mathrm{N}$. nntil the lfth, when we found onsyelves in the longitude of $174^{\circ} 50^{\prime}$ Fo, having passed over all the lneslities assigned the islnut, hetween lntugitude $175^{\circ} \mathrm{W}$, and $174^{\circ} 20^{\prime} \mathrm{E}$. I ans fully antisfied that it does not exist withis thene meyidinus,

Having been thus retarded, the fenr I entertained of meeting with light, nud in all probalility, weblurly wimls, determined me to forego my visit to Strong's and Aseeneion 1slands, and baul to the northward, to lnok for some of the many shonls laid down on the track nsunlly pursued liy ships bound tu the Clina Scas.

After this determination was made, I hauled up for an hiland gaid to exist in longitude $171^{\circ}+2^{\prime \prime} \mathrm{E}$. and latitude $16^{\circ} \mathrm{N}$. On the night of the 15 th we have-10, in order to rum over the loenlity by daylight. This position was pasaed over, ond forty miles to the westward of it explored, but nothing intienting a proximily tu land was seen. The stpposed site of Curnwallis Islunul, in longitude $169^{\circ}$ $33^{\circ} \mathrm{E}$, and latitude $16^{\circ} 5 \mathrm{l}^{\prime} \mathrm{N}$, was in like manner passed over.

Wake's Island next claimet my attention. On the lgth we renctied its purallel, and love-to til dnylight of the 20th, when we siscovered it, bear. ing west-by-north, about niue niles distant. The 
wind wns light from the north-north-enst. After breakftust, several boats were sent to survey thrs islasul. Wake" Island is a linw cornt onte, of triangulur furm, and eiglit feet sbove the surface. It has h large langon in the eentre, which was wel] filled witls tish of a variety of apecies; among these were some fue mullet. There is no fresh water ou the imland, and nesither pandanus nor cacos-nut trees. It lase upron it the slurubs whit'l are usually found on the liw ialnnals of the Pacific, the most. xhundaut of which was the tourzefortia, Mr. Venle found here the short-tailexl albatross, and proverted an egg from its nest. The birds were quite tame, although they were not so numerous as we liad before met with on uninhabited islands.

The time of low water tnok place at one o'clock, and the mon entered its last quartos" on the sane day: the tidu was setting along the shore of the island with much strength to the westward; tho rige and full was three fect. From appenrances, the island must be at times subrierged, ot the ben makts a onuplete lireach over it; the apprenunace of the coral blocks and of all the vegetation leads to this conchasion, for they have a rery deeided in. clituniou to the eastwail, showirtg gles that the violent winds or rush of the water, when the island is ousered, ate from the westwart. The reaf atoum this islaul is very small in extent.

The position of Wakn's lslard was found by my obsersations of equal altitudes on shore to bo in longitude $166^{\circ} 31^{\prime} 30^{\prime \prime} \mathrm{E}$, and latitudo $19^{\circ} 10^{\prime}$ $34^{\prime \prime} \mathrm{s}$

By four o'clock, r.x., all the boats had returned on board, when we flled nway and proceeded on oute conse to the westward. Althought these coral islands resetnlle one another very strongly, yet they affordecl us gone recreation for a fow hours, and much satisfaction in obtainiug serjes of obserFatiuns in magnetism. Our visit to Wajees Island gave ив an opportunity of adding to our collections in natural listory.

In the evening we steered to pass over the positiots of Haleyon Islant,-longitude $163^{\circ} 30^{\circ}$ E., latitude $19^{\circ} 13^{\prime} \mathrm{X}_{\text {. }}$; aud on the $27 \mathrm{ch}$, we passed immedintely over its locality, and had run on its supprosed parallal fifty miles on each side of it, but nothing wns seen of it. We nuw folt the current to the south-east twetwo miles in the twenty-fors hours.

Folger"s Islund nest elumed my attertion: it is said to lie in longitude $155^{\circ} 19^{\circ}$ E., latitude $18^{\circ}$ $21^{\prime}$ N. This position was passed over, but the inguiry rosulted as the athera had, in a fruitless senreh.

I now bore awny for Grignt, the narthernmost of the inlustuted Ladrone or Marian Islouds, which we made on the 29th December, at 7 A.3., bearing south-sonth-wegt. As we aptronched these isliunds, we had experieficed a strong eurrent to the northward ant westward; and the wind had also veered to the southward nud westward.

At midnight, we discovered the island of As. surnption, beraring ynthleast-by-east.

The island of Grigan appenrs to be nhout eight miles in width, seen [rom the nortli, and] las the form of a dotne. Its lieight, by a very unkatisfactory observation, wns two thoussund three bundred feet. It was my intention to stop nnd tnake it a magnetic station; but tho weather appeared so thick as to thretaten delay; and this I could ill afford, so I gave up the ides.

There is said to be wo other settlement than one small village, on the south.west side of Grigan, where a few individunls ifwell, and I mulerstuod that they were licadiol by an American; its shores are alumost perpendicular, und it has no curnl reefs to form lartrours; so that in this respect it id not so much favoured as tho southern isles of the same group. The passage between Grigan and $\Lambda$ ssumptinn is free from dangers, and I an well satisfted that no shonl exists where Freycinet has laid fown the Mruigs, for we passed direetly aver the locality, and saw nothing of the kind. The Mangs were seen in their true position, to the northward of Assumption.

The wird was light and variable. On tho lat of Janunry, 1842, it changed th the soutl-west; with this elinugo of wind we experienced a fall both of the thermoneter and barometer, and exeessive dampness; wo trad some lighturng, and at midnight a violeut sqquall with rain burst upon us, atiended by a shift of wind to the northward and westward, which afterwards bauled to the northward and eastwat. A slight current was felt settitry to the enstward.

Wo now steered for the most enstern position assimed to Copper's Islnud, and un the 4th, ran orer the position in longitude $131^{\circ} 54^{\prime} \mathrm{E}$, and latitude $20^{\circ} \mathrm{L} \mathrm{L}^{\prime} \mathrm{N}$. 'The $\mathrm{Abajos}$ Shosl of $\mathrm{Arrow}$ omith las no existence; its position was passed over in broad dryliglit.

On the oth, we felt a current to the west of fifteen miles. The variations of the compuss were uow to the westward; nuch phosphoreseence in the water; its temperaturu was $75^{\circ}$. The slight enrrent contirned until the Bth, when we made tive islunds of Sabtring and Batan on the starbosard oide. and the Richmotd Roeks on the harboard, steering a westerly course through the Balingtang Struits. The weather being remarkally the, we land excelfent obscrvations on tyunst besring. The longitude of the west point of Snbtang is $121^{\circ} 50^{\prime}$ $30^{\prime}$ F.+ the Intitude is in $20^{\circ} 18^{\prime} \mathrm{N}$, instend of $20^{\circ} 11^{\prime} \mathrm{N}$. In the strait we lind strong ripples, rusd oecasionally fett the infuenes of the eurent, as we pasaed thirough then,

We had now left the P'Beific Ocentr, and I could not but rejoice that we bad all the resulty of our cruiso up to this time gquite safe.

Sabtang and Batan are of broken surface, shoot. ing up into mnny remarkable juaks, to the elevation of a thousand feet. These are both inhabited, and aftiord one or two anchorages.

In the route from (halu, we hud experienced $n$ set tu the westward of four liundred miles by current; the grenter part of this was felt before reaching the meriditur of the Ladrone Islands.

I nuw stowd to the south ward along the island of Luzun, to pass just clear of Capo Bolinao, On the Hh, we continued to have very strong winds. $A$ rery heavy sea arose, without apparent canse; the progressing motion of the wnves in passing the ghip was twenty-two miles per hour; their width, as near as it could be ascertained, wins one hundred and furty yards.

At cumbet of the 10th, we were off Cape Caţones, and numerous lights were seen mn sliore. The breeze failed us nfter midnight, and ju the morning we found that we had drifted some thisty tsiles 
to the leeward of Cape Miravales, having Cape Capones due north, lhe eurrent laving set to the sonthward. As the breeze wat adverse to our entrance into the bay, we contiued benting until the afternoon, when the sen-lirese gnve us the hope of renching the anchorage; but it was so feetle, that wo nade no way, and the night was agair passed under mail.

"live next ilay, the 12 th, whs also prosed in working up for the eity of Manilh. For thie delay I had eomething to console me in the arrival of the Flying-Fish, which ressel was discovered at $3^{\mathrm{h}} 30^{\mathrm{m}}$ r.x. beating in. Signal was mado for her to join company.

On arriving at the island of Corregidor, we were bonrded by a governnient galloy, pulling sixteen oncs, and haring a large liriss twelve-pround fiece mounted on the bow. Theso vessels, 1 understood, are intendod prineipally to pursue the pirates of Stroloo, who not unfrequently make excursions amoug the islands, attacking the villnges, and enrrying off the inhabitants as slares. They are manned by the natives of this island, who are represented as actire and expert sailoss, although they nre, generally, of amall size.

After dark, we anehored abont eight miles from the city, in the middle of the broad and beautiful expanse of its bny, which is nearly cireular, with an almost unifurm depth of water. I learned, whilst at Mamilia, that sinee the settlement of Emmpeans, the bay las tilled up in places very considerably, from the wash of the liflls. The lands in the ricinity are high and mountninoug, and are clothed with the regetation of the tropies. After dark, the many lights that were seen in the direction of the city gave the bay an animated appearaneo, and bespoke our being near a large anil setive population.

Mr. Knox repurted to me that after his separation, on the 30 h of November, he stood for the position of Cortuwallis Island, as laid down by Arzowssuith in longitude $169^{\circ} 31^{\prime} \mathrm{W}$., latitude $16^{\circ}$ $50^{\prime} \mathrm{N}$, without seeing any indiention of land. T'weuty-two miles to the sosth-by-east of this position, he discovered a reef, which surrounded an exteusive lagoun, extending north-oast and sotathwest ten miles, and in the opposite direction five miles. On the north-west side of this reef there ale two low islets: the one to the westwarl wh covered with bushes, but no trees; the other was no more thinn a sand-bank. This reef lies deep. The longitude of the wreternmost islet was foumd to be $160^{\circ} 45^{\prime} 36^{n} \mathrm{~W}$, and latitude $16^{\circ} 48^{2} \mathrm{~N}$. He then bore away fur Snn Pedro of Arrowsmith, in langitude $179^{\circ} \mathrm{W}$, nnd latitude $11^{\circ} 17^{\prime} \mathrm{N}_{\text {a, and on }}$ the Fils of Decemlies sailed over it and on its parnlle! forty miles both enst and west, but gnw no indieations of land whatever.

The Mulyrave Islatads were steered for, and two small islevide made on the loth, in the position of longitude $172^{\circ}$ ' $33^{\prime \prime} \mathrm{E}_{\text {, n }}$ and latitude $5^{\circ} 59^{\prime} 15^{\prime \prime}$ N., which eorresponds with the chart of Arrowamith. They are low islets, extending two miles from north to south, and one and a linif from east to west. They are connected by a reef, which sturounds a ligons. Natives were neen upron them, but no communication was had witls them.

Bapham's, a lngoon islanul, wat made on the $17 \mathrm{~h}$ : it was found to be correctly located ; it is alwo iniabited.

Hunter's Island was made the eame evening. and was examined the next dny; is is one and three-quarters of a mile ling, north and south, and two-thirds of a mile east atud west; it in iterated in the centre, and has no Ingoon; its jusition was ascertnined to be in longitude $169^{\circ} \mathrm{B}^{\prime} 46^{\prime \prime} \mathrm{E}$, and latitude $5^{\circ} 42^{\prime} \mathrm{N}$.

Baring's lsland was next passed in $168^{\circ} 26^{\prime} 24^{\prime \prime}$ E., Jatitude $5^{\circ} 34^{\prime} 42^{\prime \prime} \mathrm{N}$. The eurrent experienced off these islands was from fifteen to twenty-five miles easterly.

It hnsing been strongly enjoined upon $\mathrm{Mr}$. Kinox not to be behiud the time designated for his arrival at Manilla, he found, on his reaching the equntar, that but twenty-two days of his time remained: hasing already experienced light winds atul cultus, he saw that it would be impossible to range through the Cnroline Group and visit Aacension and Strong" Istands : he therelore determined to luanl again to the northward, and passed severnl of the groups in a ligher latitude.

On the 26th, he passed over the siturtion ascribed to Firoilip Island, in latitude $10^{\circ} 45^{\prime} \mathrm{N}$, longitude $140^{\circ} 27^{7} \mathbf{E}$., wiltheut nay indientions of land. He then sought Feis Island, whose position was eronged on the 271 ), but saw no land.

Tlio easteru extremity of M'Kenzie's Group wns made on the 29 th, in lititude $10^{\circ} 7^{\prime} 63^{\prime \prime} N$., Jougitude $139^{\circ} 4^{\prime} 58^{\prime \prime} \mathrm{E}$. To the north ward and west. ward of it, a supposed shoal was paseed over, but none was found.

M'kenzie's Group is of greater extent than is represented on the maps. It is composed of $\mathrm{a}$ great uany islets, with passnges between them, some of them into the lagoon, through one of which the selioner entered, with not less than seven fathoms water on the bar. This group is thiekly inhalited, and some of the natives bonrled the sctronner. They resembled the Caroline Islanders, but land their teath much discoloured, apparently from the use of the betel-nut. From tlien some fish and cocos-nuts were procured. They were geen to be in pospession of iron utensils, and nppeared to have before had communication with veracls.

Mr. Knox now steered for the Strzits of Bernadino, and made Cape Espiritu Santo, on the night of the $4 \mathrm{th}$ of Jasuary. Owing to the want of observations for two days before lie was in danger of being shipwrecked. Un the IIth, he lad passed tarungh the stmits, and anelored under Cape St. Jago, wheneo he got under wny, and renehed Manilla, ns before stated.

I now felt myself secure against fartlıer detention, and hoped to expedite my dutich, so ay to resch Siugnpore in tlue time desiguated in my instructions. 


\title{
CHAPTER XXXVI.
}

\section{MIANILLA.}

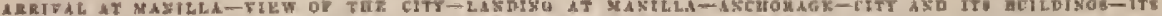

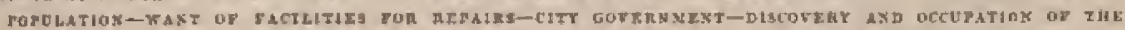

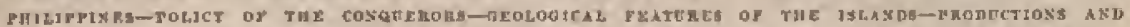

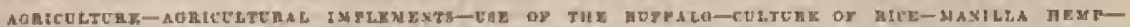

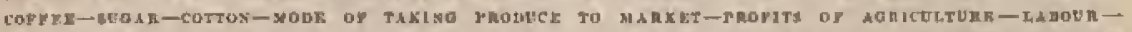

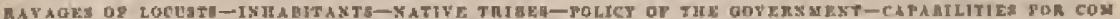

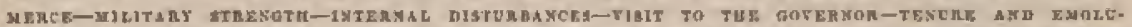

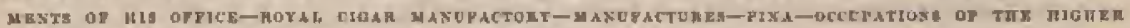

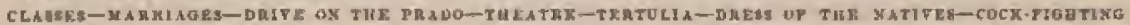

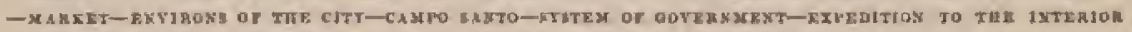

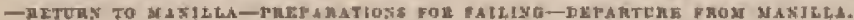

At daylight on the 13th of January, 1042, we were agmin tzoler way", with a bight air, and at nine o'cluck reached the roadetead, whore wo nnehored in six fathorng wrater, with good holding-ground.

A number of vessels were lying in the roads, anong which were several imericans londing with hemp. There was also a large English Kant lndiaman, manned by Jasears, whose noige rendered her more like a Hoating Bedlam than any thing else to which I ean liken it.

The view of the city and comnlry around Manilla partakes both of a Spanish ard an Oriental etratncter. The sombre and heary-looking churches, with their awkworl towers; the long lines of hatteries mounted with heavy ealunon; the massive linuses, with ranges of talconies; and the light and siry cottage, elevated on posts, siluated in the luxuriant gruves of tropical trees, -all excite a desire to becone better acgianinted with the counlry.

Mavilia is situated on an extensive ploin, Ftrullally swelling into distant hills, beyoul which, again, mouutains rise in the backgruund, to the heiglit of several thousaud feet. The litter are apportently clollied with regetstion to their surnmits. The cits is in strong cuntrast to this luxu. riant senery, bearing evident marks of decny, particularly in the chinehes, whose steeples and tile ronlis lare a dilapidated look. The site of the city rous not appear to have heen well ehosen, it linving nprarentiy been seleeted emtirely for the conveniuce of conmerce, and the ermmuncrion that the outlet of the lake affords for the batteaux that transport the produce from the shores of tho Laguna do Bay to the city.

There are many arus or branches to this stream, which lave beeli converted into carials; and almost any part of Manilln may now be reached in a bancen.

In the aftermonn, in company with Captain Hurlson, i paid my fiest visjt to Matilla. The anchor. age considered safest for large ships is nearly three miles from the shore, but andler vessels inay lie much newrer, and even enter the canal; a facility of which a nuralief of these take advantage, to accomplish any reparairs they may have ocension to nake.

The canal, howeres, is gosernily filted with coasting ressels, battenux from the lake, and lighter for the discharye of the ressels Jying in the roads. The bay of Manilla is safe, excepting during the chnnge of the minnsuons, when it is subject to the typlanons of the China Sens, within whoge range it lies. These bluw at times with much force, and canse grent dannge. Foreign veasels have, lowever, liept this anchnrage, and rode out these sturrns in erfety; but native as well as Symish vessels seek th these times the port of Cavite, abent three lengues to tho south-west, at the entrance of the bny, which is perfectly secure. Here the government doekyord is situated, and this harbour is consegurently the resort of the few gunbonts and galleys that are slationed here.

The entrnnce to the earal or river Pasig is three hundred feet wide, and is encloser between two well-consturucted piers, which extend for some distance into the bay. On the ent af one of these is tive lichthouse, and on the other a gunrd-house. The walls of these piers are about four feet above ordinary high water, and include the natural clanunel of the river, whose currents sets out with sone force, particulurly when the elb is making in the bay.

The suburbs, or Binosdo quarter, contain more inhabitants than the city itself, and is the com. mercind town. They have all tho stir and life ineident to a large population netively engaged in trade, snd in this respect the contrast will the eity proper is grent.

The city of Mnnilla is built in the forn of a large segment of a cirele, having the chord of the megment on tho river: the whole is strungly fortificd with walls and ditches. The houses ure substantially built after the fashion of the mother country. Within the walls are the governor's palace, custom-house, treasury, adniralty, several clurelres, convents, and charitable institutions, a university, and the barracks fir the troopls; it nlso contains some public squares, on one of which is a bronze statue of Ctrarles IV.

The city is properly deened the court residenee of these islands; and all those attached to the goverument, or who wisl, to be considered na of the ligher circle, reside liere; but foreigners are nut perwiltud to do $\mathrm{Bo}$. The houses in the city ure generally of stone, plastered, and white or yellow waslied on the outside. 'They are only two stories bigh, and in eonsequence eiver is 
Jarge space, being built around a patio or court. yard.

The ground-floors are occupied as storehonsen, stables, ind for purtery' Loylges. The sccond story is devoted to the dising-lialls atod slepeing apartments, kitcliens, bisth-mons, \&e, Tho bed-rooms lave the windows dowis to the floor, openisg on wide haleonies, with blinds or shuters. 'I'/lese blinds aro construeted will sliding frames, having small scyurres of two inclies filled in with a thin somi-tratspmrent shell, a species of placuna; the frouts of sone of the homses have a large number of these snnll lights, where the femsles of the family may enjoy thensolves unpercovised.

After entering the cathal, wo very boon found ourdelveg among a mutley and strange population. On lauding, tho attertion is drawn to the rast number of small sualls and shope with wich the streuts are lined on each side, and to the crowds of people passing to and fro, all intent upon their several vecupatious. The artisans in Manila are almost wholly Chinese; and all trates are local, so chat in each quarter of tho Binondo suburb the privilege of exclusive ocenpartey is clnimed by some particular kinds of shops. In prasing up the Esculta (which is the longest and inain street in this district), the cabinet-makers, seen busily nt work in their shops, anc frrst met will; gext to these coma the tinkers and blachsmiths; then the shornukers, clothiers, tistumongers, haberiashers, \&c. These are flanked by outdoor occupations and in each quarter are numeruns curks, frying cales, stewing, $\mathbf{c} c_{,}$, in noveable kitehens; while there and there are to be seen betel-nut sellers, cither moving ahout to obtain eustomers, or takitsg a stand in some great tlyorughfare. The moring thivang, composed of carriers, waiturs, messengers, Ae., pass quietly and wichont my noise: they are goremlly eeen with the Chineso unbrella, piinted of many culuurs, sereening themselves from the sut. T'lie whole jopulacion wear slippers, and move along with a slip-sliod gait.

The Chinese are apparently far more numerous than the Mralays, and tho two races differ as much in cliaracter Rs in appearance; orve is all activity, while the other is disposed to aroid all exertiou. They preservo their distinelive clunacter throughout, nixing but rery linte with encl other, and the removed as far as posaible in their civilities; she former, from their industry and purseverenee, hive slmust nomppolized all the luemtive employmerts among tho luwer orders, excepting the sefl. ing of fish and betel-nut, and articles manufictried in the prorinces.

On shore, we were kindly received by $\mathbf{M r}$. Moure, who at once male us feel at home. The change of fueliug that takes place in a transfer Iroms shipboard in a hot climute, after a long cruise, to spacious and nity apartments, surrounded by every luxury that kind atteutions ean give, can be scarcely inagined by those who lave not experienced it.

As we needed somse repairs and sapplies, to atterd to these was my first oceupation. Among the former, we yequired a leavy piuce of blacksmith. work, to prepare wlich, we were obligerl to serul our armouress on slare. The only thing they could proxeure was a place for a forge; but coal, and every thing else, we had to supply from the ship. I mentios these things to slow that those in want of repairs пust not calcutate upon their being done at Marsilia with despateh, if they car be accom. plislıed it all.

The eity goverument of Manilla was establisted on the 2ith of June, 1571 , and the tithe imder which it in designated is, "The celebrated and for ever royal city of Masilia." In 1595, the charter was confirmed by royal authority; usud all the prerogatives prossessed by other cities in the kingslom were couferred upon it in 1638. The nernbers of the cily comneil, by autherity of the king, were constituted a souncil of advisement with the governor and captain-gencral. 'f'les city magistrates were also placed in rank uext the judges; and in 1646 the jurisdiction of the city way extended over a ridius of fire leagues. In 1818, the number of the council were increased and urdered to assume tho title of "excellency." Manilla has been ore of the most constantly loyal cities of the Sprnish kingdom, and is, in consequestee, considered to merit these additional royul favours to its inha. bitants.

In 1834, the Royal Tribumal of Commereo was instituted, to supersede the old comsulate, which had heer astablistied since 1772. The Royal Tribunal of Cammerce acts under the new emmercial code, and possesses the eame privilegey of arbitration as the old consulate. It eonsists of $n$ prior, two consula, arsd four deputics, elected by the profession. The three first exercise consular jurisdiction, the other four suprerintend the encouragement of commerec. The "Junta de Comercio" (chntulet of conmerec) was formed in 1835. This juntis consists of the Tribunal of Conmerce, with fisur merchants, who are sclected thy the governnent, two of whom aro removed smtsually. The prior of the Tribural presides at the Junta, whose meetings are required to be held twice a month, or oftencr if necessary, and upon days in which the Tribunal is not in Bession. "The twa courts being under the same influences, and laving the same ofticers, little bencfit is to be derived from their double action, and great complaints are made of the manner in which business is conducted in thern.

of all her foreign posscssions, the Philippines have cost Spain the lenst blood sund labour. The lonour of theit discovery belougs to Mageltraens, whose name is assoeviated with the struits at the soutluer extremity of the American continent, but which has no memorial in these islands. Now that the glory which he gained by being the first to pentriate from the Atumtic to the Preific, has becn in some mensure obhiternter by the distse of those straits by mavigators, if would seem due to lis memory that some aprot surong these islands should be bet apart to comnenosute the name of him who made them known to Europe. I'lis would be but conmon justice to the discuserer of a region which lass been $a$ source of to mucl honour and profit to the Spaninh nation, whon opened the vast expanse of the Paeific to the lieets of Eurupe, and who died fighting to seeuro the benetits of his enterprise to hit king and country.

Mngelhnens was kilted at the island of Matan on the 26th of A pril, 1521; and Duarte, the second in command, wio succeeded lim, imprndently nceepting an isvitation from the elhief of Febri in n feast, was, with twenty companions, massacred. of all the Spaninrds present, only one escaped. 
After these and varions other misfortunes, only one ressel of the squadron, lase Fictoria, returned to Spain. Don Junn Sebrstian del Catso, her commander, was compliuncuted by lis overeign by a grant for his nrms of $n$ globe, with the pruud inscription, cummemorative of lis being the first circumnavigator,

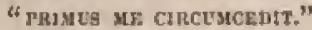

Two years afterwards, a second expedition was fittel out, under the command of Loaisa, who died after they had passed through the Suraits of Magelhaens, when they had been a yenr on their voyage. The command then felf upun Sebastinn, who dicd in four days after his predecessor. Salayar succeeden to the command, and renched the Ladrone IElauds, but shortly after learing there he died nlso. They eame in sight of Mindanan, but contmry winds obliged them to go to the Molneess. When arrived at the Portugucse settlements, contentions and jenlousies arose, and finally alt the expedition was dispersed, and the fate of all but ono of the ressels has become doubtial. None but the snual] tender returned, which, after encountering grent difficulties, reached New Spain.

Tho third expedition was fitted out by Cortes, then viceroy of Mexico, and the enmmand of it given to Survedra. This aniled from the port of Silguattaujo, on the 31 st of October, 1528, and stopped the the Ladrone Islands, of which it took posscession for the crown of Spain. It afterwards went to Mindanso, and then purzued its royago to Timor, where part of the expedition of Lontse was found remaining. From Timor they mnde two attempts to return to New Spain, both of which friled. The climate suon brought on disease, which enrried off a great number, and among them Sarvedra. Thus the whole expedition was broken up, and the survivorg found their way to the Portuguese settlements.

The fourth expedition was sent from New Spain when under the goverument of Don Autanio de Mendoza, for the purpose of establishing a trade with the new jalands, and it received orders not w visit the Moluceas. This expedition sniled in 1542 , under the command of Villabobos. It renehed the Philippine Istands without accident, and Villalobos gave them that name after Phillp II., then prince of Asturias. Notwitlatanding his positive instructions to the enntrary, he was obliged to visit the Moluesa, and met the eame treatment from the Purtuguese that had heen given to all whom they believed had any intention to interfere in their spice trade. The squadron tonched at $A \mathrm{mbulma}$, where Villabolos died, an event which eaused the brenling up of the expertition; and the few Spaniards that remained embarked in the Portuguese vesselg to retut? home.

The fifth and lagt expedition was ordered lyy Philin IJ, to be sent frum Mexiew, when urales the govemment of Don Luis de Velaseo, for the find conquest and setllement of the Philippises. With this expedition was sent Andrea Urianetn, a friar, whose reputation stood very high as a cos mographer: he hat belnaged to the ill-fated expedition of Lonisa. This was the largest that had yet been fitted out for this purpose, numbering fire vessels and nbout four hundred men. The eommand of it was intrugted to Segaspi, under whom it sailed from tho port of Natividad, on the 21st of
Nivember, 156t, and upon whom was cunferred tho title of governur and rilelasitalo of the con. quered landis, with the fullest powers. On the 13th of Feliruary, 1505, he arrived at the island of 'T'andayn, nne of the Plitiptines: from itsenco he went to Leyte; there he obtained the sou of a powerful chief as a guide, through whom he estabilished peace with soveral of the native rulers, whu thereafter aided the expredition with all the means in their power. At Buhol they built the first church. There he met and male peace with a chice of Luzon, with whom he went to that island.

He now (April, 1565) took possession of all the islawd in the mame of the crown of Span, and liecane their first governor. In this conquest, motives different fom those which governed then on the American continent, secmed to have in. flueneed the Sraniards. Instead of earrying on a cruel war against the ratives, they here pursued the policy of encournging and fostering their industry. Whether they felt that this policy was necessary for the suecess of their undertaking, or were influenced by the religiuns fathers who wero with then, is uncertain ; but their mensures seem to have been dictated by a desire to promote penco and secure the welfare of the inhahitants. There mny be snother causo for this course of action, namely, the absence of the precious metals, which held out no indueement to those slirsting f $r$ inordinate gain. 'Tlis may hare had its weight in exempting the expedition in its outfit from the prosence of those araticiout epiajts which had ac. companied other Spnuish expeditions, and been the means of marking their progress with excessive tyramny, blaokished, and violence. It is evident to one who visite the Philippines that bome other power besides the sword lins been at wark in them; the natives are amalgnmated with the Spaniards, and all seen disposed to cultivate the land and foster civilization. None of the feeling that grows out of eougucses is to be observed in these islands; the two ruces are identified now in labits, manners and religion, and their interests are 80 clusely altied that they feel their mutual dependence uyon ench other.

The establishmest of the new constitution in Spain in the yent 1825, has bad a wonderlul efleet upon these colonies, whoso resources lanve withil the last ten yenrs been developed, and improvements pushed forward with a rapid step. Greater knowledge and more liberal views in the rulers are aloue wauting te cause a still mote rajud advance In the eareer of juosierity.

As our visit was to Luzon, wo maturally obtained more personal information respecting it than the ather islande. We learned that the northern peninists * was composed of granite and recent. voleanic rocks, together with secoudary aud tertiary depusits, while the southern penirsula is almost whully voleanic. The northers contains many valuable mincs of gold, lead, copper, and tron, besile: conl,

So far as our information and observations went, the whule of the Philjppine Islaude are of similar geological forruation. In some of the islands the volesnic ruck prevails, while in others conl and the

- It in called so in conscquenee of the latand belng nesrig diviled in the parathel of $14^{\circ} \mathrm{N}$., by two bays. 
metalliferous depusits predominate. Un some of then the coab-beds furm part of the eliffa alung the shore; on others, copper is fund in at chlorito and talcose slate. 'The latter is more particularly the care with Luzon, and the same formation extends to Mindaro. Muelt inous oceurs on the monntains. Thus, among the Thigala natives, who aro yet unsubdued by the Spranimde, and who inhabit these monntrins, it is found by them of mo pure a quality that it is manufactured iuto sworda and clearers. These are, ocensinually, obtained by the Spaniarda in their excursions into the interiur against these Lands.

The country sound Manilla is composed of tufis of a light grny colour, which being soft and masily worked, is enployed as the comnon building materint in the city. It contsine, sonetimes, scurin azuł pudice, in preces of various sizes, besilleg, nectsionsliy, jopressions of plants, with petrifienl wnous. 'I'hese are confued to recent species, ald inchude paltns, \&c.

This tufic formos one of the remarknble fentures of the voleanoes of the Philippine Islands, sluwwing a stmng entrast betweers them and those of the Pacifie islos, which laswe ejected litulo else than lava noul securis.

Few purtions of the globe secm to to so much the seat of irtermal fires, or to exhibit the effects of vulcanic action so strongly as the Plilippines. During our visit, it was not known that any of the voleanues were in setion; but many of them were smoking, marlieularly that in the distriet of Albay, ealled Isarue. Its latest cruption was in the year 1839: Int this did little damage conspared with that of 1814, which covered goveral villages, and the contstry for a great distance arvund, with awhes. This mountain is siturated to the southenst of Mauilla one hundred and tifty miles, and is suid to be a verfect cone, will a crater at its ז

It does nut appenr that the islands are much affeeted by earthquakes, allhuoglı some lave oceasimally vecurred that have done daninge to the churches at Muillin.

The conl which wo have spoken of jo deemed of value; it has a.strung resemblanee to she bitumimus canl of our own country, possesses a bright Instre, atw nppentra very free from all woody lex. ture when fraclured. If is fouml associated wilh sarststone, which contains many fossils. Lend and copger me reqorted na bejug very abumdaut; gypsum and limestone necur in some districts. From this, it will be seen that these istands have every thing in the mineral way to constitute them desirable possessions.

Wibla snch mineral resonrees, and a soil capsble of producing the most waried regetation of the tropics, a liberul pulicy is all that the country lacks. The produets of the Philippine Islands consist af sumar, eoffee, hemp, iutigo, rice, tortoise-shell, hides, elony, saffron-wood, sulphur, cotton, coedage, silk, pepper, cueon, wax, and tusny other articles, In their agricultural operations the people aro industrious, although mucls labuur is lost by the use of defective implements. The plough, of very simple construetion, has been adopted from the Chinese; it has no coulter, the share is flat, and being turned partly to one side, answers, in a certain degreo, the prirpose of a muuld-hoard. This rude implement is sufficient for the rich suils, where the tillage depends ehiefly upon tho harow, in eonstructing which is thorny species of bamboo is used. The harrow is formed of five or six pieces of this muterisl, on which the thorns are left, firmily fastened together. It answers jts purpuse well, and is seltiom out of order. A wrought-iron harrow, that was introduced by the Jesuits, is ubed lor elearing the ground moro effectually, and moro particularly for tho purpose of extirpating a troublesomo grass, litat is know' by the namo of eogon (a specice of andropogon), of which it is very diffieult to ril the fields. "The bolo or lang-linife, a basket, and hoe, complete the list of inplements, and answer all the furposes of our spades, de.

The bulthlo was used until within $₫$ few years exelusively in their agricultural operntions, and they have lately taken to the nse of the ox; lut horses are never uact. The buffulo, from the slowness of his motions, and his exceding reat. lessness under the licat of the climate, is ill alajted to agriculural Iatour; but the natives are very partial to them, notwithstanding they oceasion them much lalsour and troublo in bathing then during the grent hent. This is absolutely neces. sary, or the anima! becomes so fretful as to tho unfit for use. If it were not for this, the bufthlo would, notwithstanding his sluw yace, be most effective in agricultum! operations; lie requires litthe food, and that of the eonrsest kirul; lis strength surpasses that of the stoutest $0 \mathrm{x}$, and he is admirably adapted for the rice or paddy fields. They aro very docile when used by the natives, nud even elildren can mauage them; lut it is said they bave a great ancipallyy to the whites, nut all strangers. The usunl mode of guiding them is by a small cord attached to the cartilage of the trose. The yoke rests on the neck before the stroulders, and is of simple construction. To this is attached whatever it my be necessary to draw, elther by traces, slinfte, or other fastenings. Frequently this animal may be seen with large bundles of brmboo lashed to then on excli side. Huftrloes are to be met with an the luke with no nore than their noses ansl eyes out of the water, and nre not visible until they are approached within a fow foet, when they cause atamn to the prasengers by raising their large furms cluse to the bont. It is sail that they resort $\omega$ lie lake to feed on $n$ farourite grasg that growg on its bottom in sluallow water, and whicl, they dive for. Their flesti is not enten, except that of the young ones, fur it is longh and tastelesa. The ruilk is nutritious, and of a clabracter between that of the gont and cow.

Rice is, perlapes, of their agricultural products, the artiele upon which the inhabitants of the Philippise lulunds most dopend for fows and profit; of this tlicy have several different varieties, which the gntives distinguish by their size and the shap̧e of the grain: the birmanbang, lanuyo, analagegnuit, bontot-entayo, dumali, quimanda, bolulars, nnil tangi. The thee first are aquatic; the five latter upland rnrieties. They cach hawe their paculinr uses. The dumali is the early rnricty; it ripens in tluree mosthe from planting, from which circumstance it derives its name: it is raised exclusively on the mplands. Although mulh esteemed, it is not extensively eultivated, an the birds and insects destmy a large part of the erop.

The mnlagequit is very much prized, and used 
for making aweet and fancy dishes; it becomes exceedingly glutinous, for which reason it is used in making whitewash, witich it is said to cause to become of a brilliant white, and to witlstand the weather. This varjety is not, however, believed to be whotesone. There is also a variety of this last species which is used as food for horses, and aupposed to be a remelly and proventive against worms

The rice grounds or fields are laid out in squares, and surrounded by embarkments, to retain the water of the rains or streans After the rains linve fallen in sufficient quantities to saturate the ground, a seed-berl is generally planted in one corner of the ficld, in which the rice is sown bromkenst, about the month of June. The lieary rains take plaee in Avgust, when the fields are ploughed, and aro soon filled with water. The young pinnts are about tling time taken from tho geed-bed, their tops and roots trimmed, and then planted in the field by making Inoles in the grotud with the fingers, and placing four or five sprouts in enell of them; in this tedions labour the poor women are employed, whilat the males are lounging in their houses or in the slinde of the trees.

The harvest for the aguatic riee begins in December. It is reaped with suall sickies, preculiux to the country, enlled yntap; to the bnek of these a small stick is fostened, by which they are treld, and the stalk is forced upon it and eut. The spilses of rico are eut with this implement, oue by one. In this operation, med, women, and children all take part.

The uplant rice requires much more eare and Isbour in its cultivation. The land must be plonghed three or four times, and all the turf and lumps well broken up by the hnrrow.

During its growth it requires to he sweeded two or threo times, to keep the weeds from choking the crop, The seed is sown broaleat in May. This kind of rice is harvested in November, and to collect the crop is atill wore tedims than it the other case, for it is alwnys gathered earlier, and never reaped, in consequence of the grain not adhering to the ear. If it were gathered in any other wry, tho lose by transportation on the backs of buflaloes and horses, withont any covering to the shenf, would bo co great as to dissipate $n$ great portion of the crop.

It appears almost incredible that any people can remain in ignorance of a way of preveutiug go extravagant and wagteful a mode of harvesting. The goverument las been requested to prolibit it on account of tho great expeuse it gives rise to; but whether any stepos have ever been aken in the watter, I did not learv. It is said that not unfrequently a third pout of the crop is lost, is consequetrea of the sestreity of labourery; while those who are disengaged wili refuse to work, uulese they receive one-third, and even one-half of the erop, to be delivered free of expense nt their honses, This the planters are often obliged to give, or lose the whole crop. Nay, unlese the harrost is a goot one, reapers are rery unsilling to engage to take it even on these terms, and the entire crop is lost The labourers, during the time of harvest, sre aup. ported by the planter, who is during that time ex. posed to great vexution, if not losses. The renperg are for the most part composed of the idle and vicious part of the population, who go abroad over the country to eagage themselves in this employruent, which affords a livelihood to the porores classes; for the different periods at which the varieties of rice aro plauted and harvested, gives them work during a large portivin of the year.

After the rice is harvested, there are different modes of treating it. Sowe of the proprietors take it loome, where it is thrown into lueaps, and left Intil it is desirable to separate it from the straw, whes it is trodden out by men and women with their bare feet. For this operation, they usually receive another ffth of the rice.

Others stack it in a wet and green state, which subjects it to heat, from which eatse tho grnin contracts a dark celour, and an tujpleasant taste and smell. The uatives, lowever, inpute these defects to the wetness of the serason.

The erop of both the low and upland rice, is usuaily from thirty to fifty for one: this is on ofd land; Lut on that which is newly eleared, or which has never been cultivated, the yteld is fir beyond this. In some soils of the latter deseription, it is said the for a chum (sevets cubic inches) planted, the yield bas been a caban. The former ho the wohundred-and-eighth part of the lutter. This is mot the only ardvantage gainerl in planting rich lands, but the saving of labotr to equally great; for al! that is retpuired is to make a lonle with the fingers, sund plnce thuee or four gratus in it. The uplarul rice requires but litule water, and is never icrigated.

The cultivator in the Philippine Islands is al. ways enabled to secure filenty of rannure; for vegetation is so luxmriant thut by pulling the weeds and laying them with earth, a gorsd stock is quickly obtnined with which to cuver his fields. Thus, nlthough the growth is an mik as to enuse bim lnbour, yet in this hot elimate its decry is equally rapid, which teuds to make his labours more saccessful.

Among the important productions of these ishads, I lave mentioned liemp, ahthough the article enlled Mavilla hemp nust not be miderstand to be derived frum the plant whicls produces the common hemp (eanaljis), being obtained from n Hpecies of plantin (musa textilio), called in the Fhilippincs "abace." "This is a native of these islands, and was fomerly believed to be foumd only on Miudanao; but this is ant the case, for it is chltisated on the south part of Juzon, and all the islntkis south of it. It grows on high ground, in rich soil, atad is propagated by seeds. It resem. bles tho other plants of the tribe of plantring, but its fruit is much smaller, ulthougl edible. The fibre is derived from the stem, and the plant nttains the lieight of fifteen or twenty feet. 'The usual mode of preparing the bemp is to eut off the stem thear the grousd, lefore the time or jist when the fruit is ripe. The sters is then eight or ten feet long below the lenves, where it is again cut. The outer conting of the lierbaceong stem is thes stripper olf, until the fibres or cellular parts nre secn, when it unlergoes the process of rotting, and nfter being well dried in hotses and sheds, is prepsued for market by tasorting it, a task which is performed by the women and children. That which in in. tended for eloth is suaked for an lour or two in weak lime-water prepared from mea-shells, agsin dried, and put up in busilles. From all the diatricts in which it grows, it is sent to Mnuilla, which 
is the only port whence it ean legally be exported. It nrrives in largo bundles, nnd is pueked there, by menns of a screw-press, in comprnet bales, for shipping, secured by rattal, each weighing two pieuls.

I'ke best Mrunilla hemp aught to be white, dry, and of a ling and fine fibre. This is known at Manilla by the name of Jupis; the second quality they eall bandala.

'I'te expurtation has much increased within the lnat lew yens, in eonsequence of the demand for it in the United States; and the whole crop is now monopolized by the two American houses of Sturges \& $\mathrm{C}_{0}$, and 'T'. N. Pealo \& Co, of Manilla, who buy all of good quality that comes to market. This is divided between the two houses, and the price they ray is from four to five dollars the pieul. The entiro quantity raised in 1840 was eighty-three thousand seven hundred and nirety piculs ; in 184 , eighty-seren thoursnd.

The quantity exported to the United States in 1940, was sixty-eighe thomand two hundred and eighty pieuls, and in 1841, only sixty-two thousnnd seven lunderl pieute; its value in Manilh is abmut three liundred thousand dollarg. Twenty thousand piculs go to Europe. 'T'here nro no duties on its exportatiou.

That which is brought to the United States is prisicipally maunfactured in or near Boston, and is the eordage lawwn as "white rope." The curtage manufacured at Matulla if, huwever, very superior to the rope made with us, although thio liemp is of the infervor kind. $\Lambda$ large quantity is also marufhetured into mats.

In the opinion of our butanist, it is not probable that tho plint could be introdued with suceess into our country, for in the Philippines it is not found north of latitude $14^{\circ} \mathrm{N}$.

The euffec-plant is well adapted to these islande. $\Lambda$ fow plants were introduced intw the gardens of Munilla, about tifty years ago, ainee which time it lias been spread all over the island, as is supposed Ly tho civet-cats, which, after swallowing the seeds, carry them to a distanco before they are voidor.

The coffee of commerco is obtained here from tho wild plant, and is of an cxcellent quality. Upwards of three thousand five hutadred piculs are now exported, of which one-sixth goes to the United States.

'The sughr-cane thrives well hore. It is planted after the French fastion, by stiching the piece diagonally into the ground. Sume, finding the cane has suffered in times of dmorlst, have adopted other mortes. It comes to perfection in a year, and they schlom have two crops frum the parse picee of latud, unless the senson is very favoursthe,

There are many kinis of eane cultivated, lut thast grewn in the ralley of Pamjnanga is thought to be the best. It is a small red sariety, from fuur to fire feet high, and not thicker than the thumb. 'I'he mannfacture of the sugar is rulely conducted; and the whole business, I was cold, was it the lands of a few enpitalists, who, by making advanees, secure the whole crop forn thnse who sre employed to brisg it to market. It is generally brought in moulds, of the usual conical shape, enlled pilones, which are delivered to the purcliaser from November to June, and contnin each nbout one lundred and fifty ponnde. On their receipt, they are placed in large storehouses, where the inmiliar aperation of claying is performed. The estimnte for tho qunntity of sugar from these pilones after this process is shout one hundred pounds; it depends upon the eare taken in the process,

of cotton they mise a considerable quartity, which is of a fine quality, and principally of the yellow nankeen. In the provitice of Yloens it is cultivated most extensively. The modo of cleaning it of its seed is wery rude, by means of a hnndmill, and the expense of eleaning a picul (one hutIred and forty pounds) is from five to severs dollars. There hive, as far as 1 have anderslood, been no endenvourg to introduce any cotton-gins from our country.

It will be morely necessary to give the prices at which labourers are paid, to show how low tho compensation is, in comparison with those in our own country. In the vieinity of Manilla, twelve and a half cents per day if the ususl wagee; this in the prorinces falls to six and nine cents. A man with two bulfaloes is paid about thirty centg. "The amount of lakour performed by tho latter in a day would be the plougling of a soane, about two. tentha of an sere. The most profituble way of employing labourers is by the task, when, it is said, the natives work well, and are industrious.

The manner in which tlie sugar and other groduce is brought to mnrket at Manilla is pectliar, snul deserves to be mentioned. In some of the villages, the chief men unite to braild a vesse?, genersily a pirogae, in which they embark their produce, under the conduct of a few persons, who go to unvigate it, and dispose of the cargo. In due time thoy sake their voyage, and when the accounts are settled, the returns are distriluted to enel according to his share. Festivities are then held, the saiuts thanked for their kindness, nnd blessings iuvoked for nuwther year. After this is over, the ressel is taken esrefully to pieces, and distributed anong the owuers, to be preserved fur tlze next eenson.

The profits in the crops, according to cstimates, vary frum sixty to one hundred per cent.; but ft was thought, ns a genernl average, that this wns, notwithstarding the great productiveness of the suil, far beyond the tisual profits aceruing from agricultural operationg. In some prosinees this estimnte would lould gond, and grobably be ex. coeded.

Indigo would probably be a luerative emp, for tluat rnised here is said to be of a quality equal to the best, and the enop is not subject to bo many uneertainties as in Iudia: the enpital and attention requiged in vuts, Se., prevent it from being rnised in any qumitities, Among the produclions, the lantuso and rattan ought to eluim a particular wotice from thejr grent utility: they enter into alunost every thing. Of tho former their houses are built, including frames, foors, sides, and roof; fences are nuale of the same material, ns well as cyery article of genera! howseluuld use, including baskets for oil and water. The rattan is a general substitute for ropes of all deserjptions, and the two combined are used in construeting rafts for ernssing ferries.

1 lave thus given a general outline of the eapabilities of this country fur agricultural operations, 
in some of the mast important articles of commeree; by which it wilit be seen tlant the Philippine Islands are one of the most faroured parts of tho stobe.

The crops froquently suffer from the ravges of the locusts, which swcep all beforc them. Fortunately for tha pooret classos, their attucks ialie place after the rice has been harrested; lust the enne is sometimes entirely cut off, The anthoritics of Manilla, in the vain hope of stopping their devas:tations, employ persons to gather them and throw them into the sets. I understood on one ocension they had spent eiglity thousand dollars in tlis way, but all to little purpose. It is said that the erops rarely suffer from dronghts, but on the contrary the rains are thought to fall too often, and th flood the rice fielis; these, hawever, yield a novel crop, and are very ndwantageons to the poor, riz.: a great quantity of fish, which are called dalag, and are a species of blumrsius; they are 80 plentiful, that they nre enuglit with baskets: these fish weigh from a half to two pourals, and some are said to be eigliteen inches long: but this is not all; they are said, after a deep inundation, to be found even in the vaults of churelies.

Thw Philippines are divided into thirty+one pro. vinces, sixteen of which rure on the island of Lazon, and the renuander comprise the other islands of the group ant the Ladrones.

The population of the whole group is above three millions, ineluding all tribes of natives, mestizoes, and whites. The latter-uamed class are but few in number, not exceediug three thowsand. The nuestizoea wers supposed to be alwot fifteen or twenty thouand; they are distinguighed as Spanish and Indian mestizoes, "Plse Chinese have of late yenry inereased to a largo number, and it is said that there aro forty thousand of them in and around Mranila alone. Oue-half of the whole population belonga to Luzon. The istand next to it in the number of inhabitants is Punay, which containg nbout three humlred und thirty thoussnd. "Then come Zebu, Miminnoa, Leyte, Samar, and Negros, varying from the atone nusubers dourn to tifty thousand. The population is increasing, and it is thought thnt it doubles itself in seventy years. This rate of increnso appenrs probable, from a comparison of the present propulation witl the est imate made at the beginning of the present century, which shows a growti in the forty years of about one million four humdred thousnnil.

The native propulation is compsed of a number of distinet tribes, the principal of which in Luzan are Pangaritan, Y'locos, Cagayan, Tagala, and Parpangan.

Tlie Irogetes, who diwell in the mountains, are the only natives. who lave not been suljected by the Spaniards. The other tribes hove beeome identitiert witl their rulerg in religion, and it is thought that by this circumstance alone hns Spain been ablo to maintain the aseendaney with so small A number, over such a Immerous, ivtelligent, aud energetie race as they are represented to be. 'Fhis is, lowever, more easily aceounted for, frum the Spnniards foatering and kepping alive tho jealousy and hatred that existed at the time of the discovery between the different trihes.

It seems almont incredible that Spain alıuld have so long persisted in the policy of allowing no more than one galleon to pass augunlly between her colo. nies, and equally go that the uations of Furope shuuli hnve lieen si long deceived in regard to the riches and wealth that Spain was monopolizing in itse Philippines. The cajeture of Marilis, in 1762 by the English, first gave s clear idea of the value of this remote and litule-known sppendage of the empirc.

The Philippines, coneidered in their capacity for commere, are ceriainly nmors the most fivvurel portions of the glube, nad there is but one cireumstanee that teuds in the least degree to lesten their apparent advaninge; this is the prevalesce of syphosis in the China seas, which are oecrsionally felt with foree to the north of latitude $10^{\circ} \mathrm{N}$. Suth of that parallel, they have never ben knows to prevail, and seldom so far; but from their unfiling oceurremce yenrly is some part of the Clinn stas, they are looked for with more or legis dread, and cause each season a tempurnry interuption in al the trade that passeg along the cunst of thesc islands,

The army is now composed entirely of native troops, who number about six thousand men, and the regiments are never suffered to serve in the provinces in which they are recruited, but those from the north are sent to the suuth, and vice versa. Thery they are employed to leep up a cuntinual watch on ench other; nnd, speaking ditferent dintects, they never becume identified.

They are, indeed, never allowed to remsin long enough in ane region, to imbitre any feclings in unison with those of its intabitants. The bostility is so great amosg the regiments, that mutinies have occurred, and contests arisen which have produced even Uloodshed, which it was cutircly out of tho power of the officer to provent. In eases of this kind, summary purishment is resurted to.

Although the Spaniards, as fro as is known abrond, live in peace and ytuict, this is fur from being the case; for rebellion and revols artong the troups and tribes are not unfrejuent in the provinees. Duriag the time of our visit one of these took place, but it wns impossible tu learn any tlying concerning it that conld be relied uposs, for ai converation regpecting such occurrences is interdieted by the government. The diffeulty to which I refer who brid to have originated "from the jrenching of a fantic priest, who inliamed them to such a degree that thoy orerthrew the troups and beeame temporarily nasters of the enantiy. Irompt metsures wore immetintely taken, srid orders issued to give tho rebels no quarter; the regiments most hostile to chose engaged in the revolk wero ordered to the spot; they spared no ouse; the priest aud lis companions were thken, put to death, and sceording to report, in a wanner $B$ m cruel as to be a dibgrnce to the records of tho nineteenth extury. Although I stioulil lope the accounta 1 hented of these transactions were incor. reet, yet the detestation these nots were held iI, would give some colour to the staternents.

The fow gazcttes that are published at Banilla are entirely under the control of tho govermuent: nnd a rebident of that eity must nake sp lis mind to remain in ignorance of the slings that are passing around him, or beliove just what the antluorities will allow to be told, whether truth or fminelsoud. 'The growernment of the Jhilippines is enifhaticully an iron rule: how long it car contisue 80 , is doubt. [ul. 
()ne of my fust duries was to make an ofheial call upon his Excellency Don Mnrcelino Uruß, who is the sixty-first goremor of the Philippine Istsmis. Aceording to the estatished etiquette, Mr. Moore, the vice consul, annomeed our desire to do so, rud requested to be informed of the time when we would bo received. This was aceordingly named, and at the aptroluted liour wo proceeded to the palace in the eity proper. On our atrival, we wero announeed nad Jed up a flight of steps, atmplo and spacioum, bat by no mesns of euch splendous as would indiente the residence of vice-royally. 'T'be suito of roorus into whicl we ware ushored were 80 dark that it was difheulf to see. I Inide outy however, that they were panelled, and by no means richly furmished. His exeellency entered from a aide-door, and led us through two or three apartments into his private audience-room, an apart. ment not quite so dark as those we had come from: rour being condueted to this, I was told afterwardw, was to be consideret an especial turk of reapect to my country. His reception of us wa friendly. The gowernor has much more the appearance of an Irishman than of a Spaniard, being tall, portly, of a tlorid complesion. Ho is apparcntly more thau sixty years of age. Mu was drossed in a full sait of binck, with a siar on his breast.

Mr. Moore acted as interpreter, and the governot readily aceeded to my request to be allowed to send in party into the interior for a few days; a formissinn which I almost despaired of receivitsg, for I knew that lie hal refused a like application some fow manth beforc. The refussl, huwever, I think was in part owing to the eliaracter of tho applicants, and the doubtfil object they had in view, I imputa the permisgion wo receired fo the influence of our consul, together with Mr. Starges, whose agreenble manners, conciliatory tone, and ligh standing with the autliorities, will, I nm gatisfied, insure us at all times every reasonable advasutage or facility.

The term of the governor in oflice is three yearm, and the present incumbent was installed in "IBAl. This length of time is thought to be sufficient for muy one of them to make a fortume. The office is held by the appointment of the ministry in Siain, and with it nre conuected prortuisites that are shared, ic is said, by thuse who coufer them.

Dusing our stay ah Manilla, our sime was oceupied in seeing sights, shopping, ritirng, and anusing unrselves with gaxing on the throng incessantly passing through the Escolta of the Binosido suburb, or more properly, the conmereial town of Muilin.

Among, the lions of the place, the great royal cigar mnnufacturies elnim eepecial notice from their extent and the many persony employed. "There are two of theso establishments, ono situated in the Binondo quarter, and tho other un the great square or Prado; its the former, which was risited by us, shere are two buildiugs of two stories ligh, besides aeveral storwhouses, enclosed by a wall, with two large gateways, nt which sentinels are always posted. The principal wnrkshop is in the second story, which in divided into oix apartments, in which eight thourand females are employed, "Throughowt the whole cxtent, tables are arranged, about sixteen inches high, wen feet long and three fet wide, at each of which fifteen women are seated, laving smull piles of tobaceo before them.
The tribleg are set closswise from tho wall, leaving \& space in the middlo of the rooul free. The Inbuur of a fumale produces about two landrod eigars a day; and the working hours are from 6 A.M. till 6 P.M., with a recess of two luuts, frum eleven till one o'clock. The whole establishment is kept very nent aud clent, and every thing appears to he car ried on in the tuost systematie and workmanlike manner. Atuong such numbers, it has been found necessary to institute a search on their lesving the establithaent to provent enbezaternent and this is regular']y made twice a day, withont distinction of sex. It is a strange sichlt to witness the incress and egress of these loordes of femnles; and probnbly the world eantiot elsewliere exlibit so large n uniuber of egly women. Their nges vary frum fifteers to forty-five. "The sum paid them for' wnges is very tritling. The whole number of persons employed in the manufuctories is about fifteen thousand; this includes the officers, clerks, urerseers, Sc.

As nearly as 1 could nscertain, the revenue derived from these establishments is half a million of dullary.

The matives of the Philippines are itudustrioum. They manufacture s. amount of goods sullieient to supply their own wants, pirticularly from Panky and Flocos. These tor the most part consist of cotton and silk, and a jeculiar articlo ealled pina. The lates is matufinctured from a species of bromelis (pine-mple), atul comes principally from the istand of Pansy. The finest kinds of pina nre execedingly beautiful, and surpass any otlıer malorial in its erenness and betury of texture. Ita colour is yellowish, and the erabroidery is fully equal to the material. It is much sotight ifter by all strangers, and considered as wh of the curiosities of this group. Various reports tave been stated of the mode of its msmufacture, and anong others that it was woven under water, whicls I fouth, spon inquiry, to be quite erroneous. The web of the pins is so fine, that they are obliged to prevent all eur. rents of air from passing lirough the rootus where it if mantifactured, for which purpose there nre ganze serecens iu die windows. After the article is brought to Manilla, it is duen embroidered by girls; this hat operntion ndds grently to its valuo.

Гhis mantufictory his work engaged for nino months of yen in advance. The fabric is extrenuely expersive, and none but the wealthy can aflord it It is also much soughe after by foreigners, Even orders for Queen Fictorin nnd many of the English nobility were then in hand; at least 1 so henrd at Mavilla. Those who are netually present bare, aotwithstandirg, the privilegre of selecting what they wish to purchuse; for, wills the inhabitants here, as elsuwhere, ready money las ton much attraction for them to forego tho templation.

Time in Manilla seens to hang hesvity on the hands of some of its inluabitants; their amuse. Inents are few, nnd the clinate ill adapted to ex. ertion. The gentlemen of the higher classes pars theis morning in the trausactiou of a little public Imsinesg, Inunging atout and smokjng. In the afterwoon, they sleep, and ride on the Irado; and in the evening, visit their friends, or atiend a ter. tulin. The ladies are to be pitied; for they pase three-fourths of their tirte in dishbille, with their maids around them, sleeprug, dressing, iolling, and 
combing their trair. In this why the whole mont ing is lounged away : they ueither read, write, nor work. In dress they getuerally imitate the Europeans, except that they seldon wear stockings, and go with their arms lare. In the afternoon they ride on the Prado in state, and in the evening acompary their husbands. Chocolate is taken early in the morning, breakfust at eleven, nnd dinver and supper are included in one meal.

Mothers provide for the marringe of their daughters; utd I was told that such a thing as a gentlenans proposing to any one but the mother, or a young lady engaging herself, is uriknown and unheard of. The negotiation is all carried forward by the mother, and the daughter is given to any suitor sle mny deem a desirable mateh. The young ladies are atid to be equally disinclined to a chice themseiver, and if proposaly were made to them, the suitor would he at once referred to the mother. Among the lower orders it is no unconmon thing for the parties to be living without the cercmony of marriage, until they have a family; and no sdimn whatever is attached to such a connexion. They are looked upon as man and wife, though they do not live together; and they rarely fail to solemnize their union when they have nccumulated sufficient property to procure the requisite articles for housckeeping.

Otar afternoons were spent in drives on the Prado, where all the fashion and rank of Manilla are to bo met, and where it is exceedingly agreeable to partake of the fresh and pure air after a heated day in the eity. The extreme ond of the Prado lies along the shore of the bay of Manilln, luaving the rondstend and ships on one side, and the city proper with its fortifications and moats on the other. 'This drive usually lages for an hour, and alt sorts of veluicles are shown ofi, from the governor's coach and six, surroundod by his tancers, to the sorry chaise and limping nag. The ctrriage most used is a four-wheeled biloclie, with in grig tor, quite low, and drawn by two horses, on one of which is a postilion; these vebicles are exceedinity comfortable for two persons. The lorses aro small, but epirited, and nre said to be able to undergo grent fatigue, al though their appearance does not promise it. This drive is enlivened by the music of the different regiments, who are nt this time to bo seen manceurring on the Prado. The soldiers trave a very neat and clean appearance; great attention is paid to them, and the whole are well appoituted. The force stationed in Mnnilla is six thousand, sad the army in the Philippines amounts to twenty thonsind men. The ofticers are all Spatiards, generally the relations and friends of those in the administration of the government. The pay of the soldiers is four dol. lary a month, and a ration, which is equal to six ceute a dny. As troops, I whs told they aequitted themselves well. Thle Prado is laid out in many avenues, leading in various directions to the suburbs, and these are planted with wild almond trees, which afford a pleasant shade. It is well keph, and creditable to the city.

In prssing the crowds of earringes very little display of fenjale beauty is ohserred, and although wel]-dressed above, one cannot. but rescrt to their wearing no stockings benenth.

On the Prado is a small thentre, but so inferior that the building searee deserves tho name: the acting was equally bad. This amusement meets with little excourngement in Masilla, ard. I was told, was diacountenancel by the governor.

I had the pleasnre during our atay of attending a tertulia in the city. The company was not a large ove, comprising some thirty or lorty ladies ani about sixiy gentlemen. It resembled those of the mother courstry. Daneing was introrluced at an early hour, and continued till a few minutes before olewen o'clock, at which time tho gates of the city sre alway's sliut. It was antusing to see the sudder breakiug up of the party, most of the guests residjing out of the city. The ealling for carriages, shas is, Junts, sce, produced for a few miuutes great confusion, every one being desirous of getting off at the earliest moneut possible, for fear of being too lnte. This regulation, by which the gates are closed at an early nn hour, does not uppear necessary, and only gerves to intertupt the communication between the foreign and Spnnish society, ns tho former is obliged, as before observed, to live ontside of the city proper. This want of free intercounse is to be regretted, as it prevents that kind of friendshin by which many of their jealousiea and prejudices might be remored.

The society at this tertulia was essy, and so far as the enjoyment of daneing went, plensant; but there was no converation. The refreshments consisted of a few dulees, lemonade, and strong drisks in an ante-room. The house appeared very spacious and well adapted for extertanments, but ouly one of the rooms was welt lighted. From the novelty of the scene, and the attentions of the gentle. man of the house, wo pased a pleasant evening.

The natives and mestizoes attracted much of my attention at Manilla. Their tress is peculiar: over a pair of striped trousers of varinus colouss, the men usually wear a fine grass-eloth stirt, a lnrge straw hat, and around the head or ueck a marnycolonred gilk handkerchicf. They often wear slippers as well as shoes, The Chinese dress, as they have done for centuries, in lrose white shirts and trousers. One peculiarity of the common mon i their passion for cock-fighting; and they cary these fowts wherever they go, after a peculiar fastion under their arm.

Cock-figliting is lieensed lyy the goverument, and great care is uken in the breeding of gamo fowls, which are very large and heavy birds. They are armed with a curved double-edged gaff. The exhibitions are usually crowded with half-breeds or mestizaes, who are generally more addicted to gambling than either the higher or lower clasges of Spariands, It would not be an unst desigantion to eall the middling class cook-fighters, for their whole lives seem to he taken np with the breeding and fighting of these birds. On the exit from a cockpit, I was mach amused wilt the mode of giving the return check, which wus done by a starap on the naked arm, and preeludes the possibility of its transfer to mother person. The dress of the lower order of females is somewhat civilized, yet it bore so strong a restemblanes to that of the Polynesians as to recall the latter to our recollec. tion. A long piece of coloured cotton is wound ronnd the body, like the pareu, and tueked in at the side : this covers the nether limbs; and a jacket fitting close to the body is worn, without \& glirt. In some, this jucket is ornamented witls work around the neck; it has no collar, and in many 
cases no slecves, nnd over this a riehly embroidered eape. The feet are covered with slippers, with wooden solea, which are kept on by the little toe, vnly four thes entering the sliprer, and the litule one being on the viside. The etfect of both costumes is picturesque.

The nurket is a never-failing place of amusement to a foreigner, for there a crowd of the com. nun people is always to be secll, and their mote of conduching business ma be observed. The canals here aftord great facitities for bringing vegetslules and produee to market in a fresh state. Thie vegetables are chiefly brought from the shores of the Lagunn de Bay, through the river Pasig. 'The meat appeared inferior, and ha in alt spanisli pinces the art of butchering is not understood. The poultry, however, surpasses that of any other place I bave seen, particularly in ducks, the breeding of which is pursued to a great extent. E'stablishments for breeding these birda are liere enrried on in a systematic manner, and are a great euriosity. They consist of many amall enclosures, each about twenty feet by forty or fifty, made of bambon, which are placed on the hank of the river, and partly covered with water, In whe corner of the enclosure is a small louse, where the eggs are hatchad by artifcial heat, produced ly rice-chaff in a state of fer. mentation, It is not meommon to see six or eight hundred ducklings all of the sane nge. There are neveral hundteds of these enclotures, and the numlier of ducks of all ages may be computed at mitlions. The manuer in which they are schooled to talke exercise, and to go in and out of the water, sud to retum to their house, nimost execeils belief. Tlie keepers or tenders are of the Trgala tribe, who live near the enclosanes, and lave them at all times under their eyo. The old birds are not suffered to cinroach the yourg, and ail of nue age aro hept together. They are fed upon rice nud a smalt specien of shell-fish that is found in the river, nnd is pectiliar to it. From the extent of these establishments we inferred that ducks were the favourite article of food at Manilln, and the consumption of them must be immense. The markets are well supplied with chickens, pigreons, young partridges, which are brought in alive, and turkeys. $A$ nomg strunge nrticles that we saw fin sale, wero cakes of coarulated blood. The markets aro well stoeked with a warjety of fish, taken both in the Lnguna and bay of Manilia, affording a supply of both the fresh and salt-water species, and many smaller hinds thast are dried and smoked. Vegetables are in great plenty, and consist of pumpkins, lettuce, onions, radishes, very long squashes, \&e.; of fruits, they have nelous, chicos, durikns, marbolas, and ornnges.

The country around Manilla, though no more than ars extended plain for some miles, is one of great interest and benuty, and affords many ngreeathe rides on the roods to Sants Auna and Maraquino. Most of the country-sente are situnted on the river Pasig; they may indeed be called palaces, from their extent and nupearnnee. They are built upon a grand seale, nat after the ltalinn style, witls terraces, supported by strong abutments, decked with vases of plants. The grounds are ormamented with the luxuriant, lofty, aud graceful trees of the tropies; these are tolerably well bept. Here and there fine large stone churches, with their towers and steeples, are to be seen, the whole giving the impression of n wealthy nobility, atd a happy and flourialing peasuntry.

In one of pur rides we made a visit to the Campe Santo or cemetery, about four miles from Manilla, It is small, but has many handsome trees alvont it anvong them was an agati, full of lange white flowers, showing most eonspicuously. The whule flave is as unlike a depository of tho desd as it wel] enn be. Its form is cireulur, having a small elsapel, in the form of a rotunda, directly opposite the gate, or entrance. The walls are nbout twenty feet high, with three tiers of niches, in whiel the bodic: alde enclused with quichlime. Here they are allowed to remain fur three vears, or until such titne as the siches may bo required for further use, Niches juny be purelinsed, lowever, and permruently closed up; but in the whole cemetery there were but five thus secured. This would seem to indicate an indifference on the part of the living, for their depatted relatives or friends: at least sucl was my impression at the time. The centre of the enclosure is laid out as a flower-garden and shrul?leery, and all the buildings nre wished a deep buftcolour, with white cornices; these colours, when contrasted with the green foliage, givo nn effect that is not unpleasing. In the chanet are two tombs, the one fur the bishop, and the other for the governor. The former, I believe, is occupied, and will continue to be so, until anotler shall feilow him; lut the latter is empty, for since the ereetion of the cemetery, none of the gowernors linve died. In the rear of the chanel is another small conctery, called Lars Angelos; and, further behind, the Osero. "The former is sinular to the one is froul, but straller, nad appropriated exelusively to difldren: the latter is an open sjace, where the bones of alt those who linve been removed from the niches, after three yenre, are cast out, and now lio in a cons. fused heap, with portions of flesh aud hair adhering to them, No porson is allowed to be riceeived hero for interment, until the fees aro first paid to the priest, thowerer respectable tho parties many be; and all those who pay the fece, and are of the true faith, enn be interred. I was told of a curpse of a very respectable person being refused admittance, for the warat of the priest'y pass, to show that the claim had been untisfied, and the coffin atomped in the rood until it wis obtamed. We ourselves wit. newsed a similar refusat. A servant entered with a dead child, borme on a tray, which ho presented to the encristan to have interred; the latter aked him for the pase, which not being prodtreed, he was dismissed, nor was be suffered to leave his burden until this requisite could he procured from the priest, who lised opposite. The price of interment was three dollars, lut whether this included the purchaso of the niche, or its rent for three years ouly, I did not learn.

The government of the Phitippines is in the hands of a gevernor-general, who has the titles of viceroy, commander-itr-clief, sub-delegnte, judge of the revenue from the post-office, comnander of the troops, captain-genemi, and commander of the naral forees. His duties embrace every thing that relates to the security and defenee of the country. As advisers, he bos a council calted the Audiencia.

The islanda are divided into provinces, each of which has a military officer with the title of governor, approinted by the governor-general, They set as chief magistrates, have jurisdiction over all dis- 
putes of minor importauce, have the command of the troops in time of war, end are colleators of the royal revenues, for the acurity of which they give bonds, which must be npproved of hy the comptroller-general of the trensury. The provines of Cavite is alone excmpt from this rule, and the collection of tribute is there confided to a police magistrate.

Each province is again sululivided into pueblos, containing a greater or less number of inbabitants, each of whicla lans again its ruler, ealled a gobernadurcillo, who has in like manner other officers under him to act as prolice magistrates. "The num. ber of the latter hre very great, ench of them Javing his approprinte dutiea. These enusist in tho supervision of the grain fields, eocon-nut groves, betel-nut plantations, and in the preservation of the general order and pestee of the town. So numerous are theso petty officers, that there is seareely a family of any consequenee, that has not a nember who holls some kind of office under government. This policy, in caso of disturbances, at once unites a large and influential body nn the side of the government, that is maintrined at litslo expense. The grobermadoreilla exereiseg the municipal autherity, and is enpecially charged to aid the parish priest in every thing appertaining to religions observanceg, \&c.

$\Lambda$ a soon as we could proctre the necessary pass. prorts, which were obligingly furatshed by the governor to "Don Russel Stirges y quatro Auglo Americanos," our party left Mauilla for a sliort jaunt to the rnontains. It was cunsidered as a mark of great favour on the part of his excellency to grunt this indulgenee, particularly as he liad a few montlys prior denied it to a party of French officers. I was told that he preferred to make it a domestic eoncern, by issuing the paseport in the arame of a resident, in order that eomplinnee in this care might unt give umbrage to the French. It was generally believed that the cause of the refusal in the former iustance was the imprudent manner in which the French offieery went hbout taking plans and sketches, at the corners of streets, Sic., which in the minds of an unenliglueved and iguorant coloninl governmeut, of course excited suspieion. Nothing ean be sio tidiculous as this system of paskports; for if ote was so disposed, a phan, and the most minute information of every thing liat conceras the defences of places, can always the obtained at little cost now-andays; for sueh is the skitl of engineers, that a plan is easily made of places, merely by a sight of them. We wero not, linwever, disposed to question the propriety of the governor's conduct in the former case, and I folt abundantly obliged to him for a permission that would add to our stoch of informalion.

It was deemed at first impogible for the party to divide, as they lasd but one paspport, and some difficulties were anticipnted from the number being double that stated in the passport. The party corssiated of Messrs. Sturges, Pickering, KId, Rich, Dana, ani Brackeuridge. Mr. Sturges, however, $\mathrm{saw}$ no diffieulty in dividing the party after they Jad passed beyoud the precinet of the city, taking the precantion, at the same time, not to appear tngether beyond the number designated on the paper.

On the 14th, they left Manilln, and procecded in carriages to Santa Anm, on the Pasig, in order th avoit the delay that would mene if they fullowed tho windings of the river in $\mathrm{a}$ banca, and againat the current.

At Santa Anna they funul their baneas waiting for theis, and embarked. Here the acene was rendered animated by numerous boats of all de. seriptions, from the parno to the small canoe of a single log.

There is a targe population that lise wholly on the water: for the padrones of the paruos lave usually their fnmilies with them, which from the great variety of nges and sexen, give a rery differeut and much nure bustling appenrance to the crowd of boats, than watdl be the case if they only contained those who are employed to navigate them. At times the parmos and barsens, of all sizes, together with the enabara and pativns (duck establishments), beenme jumbled together, and create a confusion apd noise such as is seldom met witl in any other enuntry.

The potivas are under the care of the original inhabitants, to whom exclusively the stperintendence of the ducklings seems to be committed. The pens are made of bamboo, and are not over $u$ font lighl. The birds were all in admirable urder, and made no attempt to escape over the low barrier, although so slight that it was thought by some of onr gestlenven it would not hno sufficed to eoutine A merican dueks, although their wings might have been eut. The made of giving them exercise was by causing them to run round in a ring. The good understanding existing between the keepers and their ehnrge was striking, particularly whes the former were engaged in cleassing the pens, and assisting the current to earry uff the impnrities, In the course of their sxil, it was estimnted that hundreds of thousunds of ducks of all ages were seen.

The women who were seen were usually engaged in fishing with a hook and line, and were genernlly stauding in the water, or in ennoes. The surndoss were here also in use. 'The run of the fisll is gemerally coneentrated hy a chevaux-de-frise to guide them towards the nety and localities where the fishers place themselves.

At five oclock they resched the Laguna de Bay, where thry toole in a new erew, with mast and sail. This is enlled twenty-five miles from Manilla hy the river: the distnnee in a bird's flight is nut over twelve. 'The whole distance is densely penpled, and well cultivated. The crops eonsist of indigo, riee, \&e., with gruves of the betel, prim, cocon-nut, and quantities of fruit trees.

The shores of the lake are slielwing, and afford grood situntions for plncing fish-weirs, which aro here establishod on an extensive seale. These weirs are formed of slips of bambou, atud ure to be seeu running in every direction to the distance of two or three miles. They may be said to invest entirely the shores of the lake for severnal miles from its outlet, and without a pilat it would be difficult to find the way through them. At right, when heron and tern were seen ronsting on the top of each slat, these weirs prosented rutlies" a curions spectacle.

The Lagun do Bay is said to be ahout ten leagues in length by three in width, and trends in a north-north-west and south-gouth-cnst direction. 
After dark, the bancas separated. Mr- Sturges, with Dr. Pjekering and Mr. IId, proceseded to visit the mountain of Mrijnijai, while Messrs. Rich, Buna, and Brackenridge, west towards slic Wolcuno de 'I'ual. The lntter party trok the passpurt, while the former rolied ajom certain letters of introduction for protection, in ense of diffienlty.

Mr. Sturges, with his party, directed his course to the east side of the lake, townrds a point called Jalujalu, which they reached about tlireo o'clock in the morning, and stopped for the crew to cook some rice, se. At 8 A. st, they reached Santa Cruz, situated about half a mile up a sma!' strenmlet, ealled Puxnnan. At this plawe they foumd bon Escudero, to whom they had a letter of introduction, and who bolds a civil appointment. They were very kindly received by this gentlemnn nnd his browil laty, with their interesting family. He at ance orderied linoseg for them to proceed to the mission of Maijajaj, and etutertained them with a sumptuous breakfast.

They were not prepared to set out hefore noon, until which time tiry strolled strout the town of Santa Cruz, the inhabitats 5 of which are Tagalas. There are only two ohd spaninds in the place. The frovince in which Sants Ctuz is situated, contrins about fire thutsand inluabitunts, of whom eiglateen hundred pay tribute.

The people have the chameter of being orderly, and govern themkelres without the sid of the military. The principal article of eulture is the cocos-nut tree, which is seen in large groves. The trunks of these were untched, as sas supposed, for Ine purpose of elimbing thetu. From the npatie a kind of spirit is mantafactured, which is fully a strong as vur whiskey.

About nows they left Don Eseuderis's, snd took at road leadling fo the sontliward ond enstward, through a luxuriant and lysantiful country, well eultivated, and ornamented with lofty cocon-nut tuees, betel palmis, ama tamnn groves. Severnl beatiful valleys were passed, will strcamiets rushing through them.

Majjaijai is situated about one thoumand feet nbove the Laguna de Bay, but the rise is so gradina] that it was alnust imperceplible. 'The country has every where the aprenunce of being densely peopled ; but to more than ure village was passed between Santa Cruz and the missioti. They had letters to F. Antonio Romana y Aranda, padre of the mision, who received then kindly, and entertained them most hospitably. Wher he was told of their intentiun to visit the mountain, he anid it was imposkible with such weather, pointing to the black clouds that then euveloped its summit ; and be endeavoured to persunde the gentlenen to dosiat from what appeared to ham a mad attempt; but finditug them resolved to make the triad, he nided in making all the necessary pre. parations, thuogh he had no loelief in their success.

On the morning of the 27 th, after wasa, Mr. Eld and Dr. Piekering set out, but Mr. Sturges preferred to keep the good padre company until their return. The padre had provided them with guides, liorses, iwenty natives, and provisions for three dinys. He land been litnself on the eame laborious journey, some six montls before, and? knew its fatigues; although it turned ont afterwards that his expelition was prerformenl in fine werther, and that he had been borne un a liter by natives the whole way.

The first part of the roal was wet and uniry, and discourtuging enugh. The sxil was excecdingly rich, producing eropical plants in great profusion, in the rüdst of whith were seen the neat bambor cottages, syitlı thwir industrious and elenuly-lonking inlabitants. When they reached the font of the mouthain, they found it was impossible to ride farther, and wero obliged to tako to walking, which was, Jowever, lese of a landehip than ridiug thes little rats of horses, covereul with in ud and dirt, which were at first deemed useless; lut the manner in which they ascended and maintained lisemselver on the slippery banks, surpassed any thing they had before witressed in horseflest. T"he first purt of the ascent of the mountain was gradual, but over a miry path, which was extremely sliptery; and bad it not been for the sticks muck down by the party of the padre in their formet ascent, they would have found it extrenely dittenlt to over. conse : to mako it more disagreeable, it rained all the time.

It touk about two hentrs to reach the steep aneent. The last portion of their route had been dirough an usinlabitud region, with some openings in the woods, affording pasture grounds to a few small herds of buffulo. In three hours they renched the half-ray house, by a rery eteep and legular ascent. Hers the natives insisted upon stupping to cook their lirnakfast, as they lias not yot partakes of any thing through the dar. "l'se natives now endenvoured to persusde thom it was impraeticable to go ayy farther, or it. least to reach the top of the motutain and return hefore night. Our genthemen Jost their patience at the delay, and after an lour"s endurnuce of it, reaslved to set out alone. Six of the nacives foltnwed them, ant by half-past three they reached the fummit, where they found it cold and unemfortable. The ascent liad beetı difficult, and was prineifyally aceontplished by entehisg loold of slurubs ind the roots of trees. The summit is comparatively bare, amil not more than fity fect in width. The side opprisite to that by which they monuted was perpejdicular, but owing to the thick fog they eanld not see the depth to which the pureeipiee destented.

The observations with the barometers were speedily taker, which gave the height of Hamajou as six thousand fivo hundred feet. The trees on the summit were twenty or thirty feet high, wnd a Epecies of fir was very cummou. Gaultheria, attached to the trunks of trees, rhododendrons, and frolygonume, also shounded. The rocks were 80 ecrered with soil that it was diffeult to ascertain their clunacter ; Dr. Piekering is of opinion, however, that they gro not volesnic. The hosae on the stmmit aftorded then little or no shelter; being a mere shed, open on all sides, they found it untenantable, and deterniued to retum 18 soou as their obecrvations were finished, to the half-way house, which they reached before dark.

The uight was pussed uncomfortably, and in the morning they made an enrly start down the mountain to reach the native village at its foot, where they were refreshed with a cuj of chocolate, cakes, atmi some dulces, aceording to the custom of the country. At ten o'clock they reached the mission, where they were received by the pudre and Mr. Siurges. The former was greatly astonished to 
hear that they had really been to the summit, and had accomplished in twenty-four lours what he liad deemed a hhour of thee dsys. Ho quichly atteruled to their wanta, the first ainung which was dry clothing; umi as theip baygage had unfortunately beess loft at Santa Cruz, the warelsobe of the rotund padre was placed at their disposal, Altrough the fit was rather uncouth on tho spare forms of our gentlemen, yet his clothey served the jurpose tolerably well, and were thankfully male use of. During their nusence, Mr. Sturges had been muels amused with the diseipline tro find witnessed at the hands of the Chureh, which here seen to be the ouly visible ruling power, "Two ynung malives had made complaint to the padre that a ecrtain dansel liad entered into vows or etlgagetwents to marry toth: she was accordingly brought up before the padre, Mr. Sturges being presunt. The judre tirsh lectured her most seriously upon the enosmity of her erime, then inflicted several blows on the palm of her outstretched hand, again renewing the lecture, and finally concluding witl another whipping. The girl was pretty, and exeited the interest of our friend, who looked on with much desire to interfere, and save the damsel from the conjoreal puit ishment, rendered more aggnvated by the dispassionnte and cool manser" in which it and the lecture were ndministered. In the conversation which ensured, the foulre said he had more euses of the violation of the marriage row, aud of infudelity, than any other elsss of erimes.

After in henrty brenkfast, or ratier dinner, and expressing their thanks to the paulre, they rocto back to Santa Cruz, whero they arrived at an early hour, nud at of P.M. they embarked in their bancens for Mamilln.

In the morning they found themselves, after a comfortable night, at Banos. Hero they tork chocolnte with the parlre, to whom Mr. Sturges had a letter, who infurmed them that the other party lad left the place the evening before for Mritila

This party land proceeded to the town of Baia, where they arrived at daylight on the $15 \mathrm{th}$. Buia is quite in pretty place, and well situated; the loustes are elesall and comfortuble, and it possessed a weremble etone cliturch, with towers and bella, On infiuiring for tlo padre, they found that he was absent, and it was in consequente impuesible for Uless to procure liorses to proeced to the Volcano de 'Tas. They therefore concluded to walk in the trot springs at Barios, about five uniles chistunc. Along the rond they collected a number of eurious plants. Rice is much eultivated, and fielis of it extend to some disturyce on each side of the rond. Buffalnes were seen feeding and wallowing in the ditches.

At Bsinos the hot springs are numerous, the wator irsuing from the rock orer a contiderable surfuee. The quantity of water discharged by them is inrge, and the whole is collected and con. ducted to the bathing-houses. The temperature of the water at the mouth of tire culvert was $180^{\circ}$.

The old batly-trouse is a kingular-looking place, being brilt on the lill-kide, in the old Spanish style. It is beantifully situnted, and overlooks the baths and Jake. The bath are of stone, and consist of two large rooms, in each of which is th niche, through which the hot water prosses. 'This build- ing is now in ruing, the roof and floors basing fillen in.

Bnios is a Bmall village, but contains $\mathrm{n}$ reapectable-looking stone clutrch, and two or three houses of the same material. Here the party found a diffieulty in getting on, for the alcalde could not speak Spanioh, and they wero oliluged to use ast interpreter, in order to cummunicate with lim. Notwithstanding this, he is a ningtsurate, whines duty it is to administer laws written in that lau. gunge. Finding they coukl not sueced even here in procuring guides or lorses, they deternined to remain and explore Moust Maquiling, the lieight of which is three thousand four liundred and fifty feet, and in the mean time to semd for their bancas.

The next day they set out on their journey to that mountain, ind the first part of their path lay over a gentle ascent, through eultivated gruunds. Next succeederl an almost perpendicular hill, baro of trees, and overgrown with a tall grass, which it was difficult to pass through,

Such had been the time taken up, that the party found it impussible to reach the Enmmit aud return before darti. They thereforw begith to colleet specimens: and arter laxing obtained a full load, they returned late in the afternonn to Butios.

The mountain is composed of traclytic rocks and tufa, which are oceasivunily sees to brenk through the rich and deep suil, showing themselves here and there, in the deep valleys which former voleanic action has crested, and which have destroyel the regular outline of the cone-slinged mountnin. The sufa is getietslly found to form the gently-sloping pluins tlint surround these nowntains, and hя in all probalility been ajected fron. them. Small eraters, of some two hundred feet in height, are senttered orer the plains. The tufa is likewise exposed to view on the shores of the lake; but elsewhere, except on a few baro hills, it is entirely envered with the dense and luxurinnt foliage- The tufa is generally of a soft character, crumbling its tho fingers, and in it are found cotrese and fixo fragments of scoria pumice, \&e. The layers are from a few inches to five feet in thickness.

In the country around Bapios, there sre severa! voleanic hills, auil on the sides of Mnunt Maruiling are nppearances of parasitic cones, similar to those abserved at the Hawniinn Islandz; but time and the folinge lanve so diaguised them, that it is difficult to determine exactly their true chameter.

1 regretted exceedingly that the party that net out for the Lake re. Taal was not able to reach it, as, from the accounts ] laad, it mast be one of the most interesting portions of the country. It lies vearly south-west from Manilia, and necupies an area of about one hundred and twenty squaro miles. The Voleatio de 'l'anl is sitonted on an jslarm near the eentre of $\mathrm{jt}$, and is now in netion. The cone which rises from its centre is remarkably regulnr, and consists for the most part of einders and securin. It has been found to be nine lumireal feet in elevaton abono the lake. The crnter lus a diuneter of two miles, nnd its depth is equal to the elevation: the walls of the crater are nenrly perpendieular, so much so that the duscent carmot be nudo without the assistance of ropes. At the bottom there are two small cones, Much steam issuts from the 
пuny fissures, accompanied by sulphurous acid gas. The waters of the lake are impregnated with sulphur, and there are said to bo also lnrge beds of sulphur. In the opinion of those who have visited this spot, the whole lake once formed an innuense erater; and this does not appear very improbable, if we are to credit the accounts we received of the mainy chaters on this itland that are now filled with water; for instance, in the neighbonrhood of Sinn Pablo there are said to be eight or nime.

The hot springs of Baños are numterous, and in their vicinity large quantitica of stenm are seen to isene from the shore of the lake. There are about a doren which give out is copious supply of water. Tho principal one has been onelosed, nud made to flow through at stone aqueduct, which discharges a considerable stream. The tompernture of the water as it leaves the aqueduct is $178^{\circ}$. The vil. lagers use it fur cooking and wasling: the signs of the former employment aro evident enough from the quantities of fenthers from the poultry that lare been acalded and plucked prejaratory to cooking. The batlus are formed by a small circular buildiug gix feet in diameter, erented over the point. of discharge for the purpose of securing stenmbath: the temperature of these is $160^{\circ}$ and $140^{\circ}$. A change of temperatare is said to have occurred in the latter.

The rocks in the vicinity are all tufh, and some of the springs break out close to the cold water of the lnke. Near the aqueduct, a stone wall surrounds owe of the prinuipal outiets. Two-thirds of the area thus enolosed is occupied by a pond of warm water, and the other third is divided into two stone reservoirs, built for bnths. These batlis lind at one time a high reputation, and were a very fasinionable resort for the saciety of Marvilta; but their celobrity gradunlly diminislied, and the whole premises have gone out of repair, and aro fist fall. ing to ruin.

On Mount Mrquiling, wild buffaloes, hogs, a small species of deer, atd monkeys, are found. Birds are also very numemus, and nmong them is the hurn-bill: the noise inade by this bird resumbles a loud barking; report apeaks of them as an excellent bird for the table. Our gentlemen reached their lodging-place as the night elosed in, and the next day again embarked fir Manilla, re. gretting that time would not permit them to make another visit to en interesting a field of research. They found the lake go rough that they were combpelled to return, und remain until eight o'clock. This, however, gareonr botanists another opportunity of making collections, among which were beantiful specimens of volkameria splentens, with elegant acarlet thowerg, and a brugnangia, which expanded its beautiful silvery flowers after eunset. On the shores a number of birds were fecting, includisg pelicans, with their luge bills, the diver, with its long-hrched neek, herons, guils, eagles, and snow-white cranes, with ducks and other mmall aquatic flocks. Towards night these were joined by large bats, that were seen winging their way towards the plantations of fruit. These, with quantitieg of insecto, gave a wivid jden of the wonderful myrinds of amimated things that are constantly brought into being in these tropical and luxuriant climates.

Sailing all night in a rough sea, they were much incommodted by the water, which was shipped into the banen which kept them coustautly bailing out; they reached the river Pasig at daylight, and agsin prased the dack establishments, and the numerous bonts and baneas on their way to the markets of Manilla. Both the parties reached the consul's the same day, higluly ploased with their resprec. tive jaunts,

On the morning of the 21st of January, we took leave of our friends, and got under way. We then, with a strong northerly wind, and a native pilot on board, made all sail to the sonth for the Strits of Mindoro.

\section{CHAPTER XXXVII.}

SOOLOO.

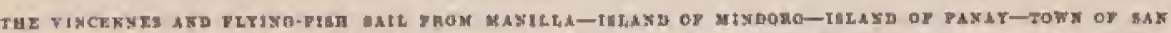

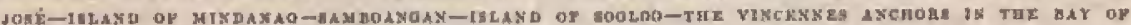

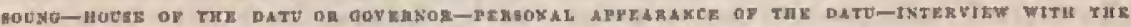

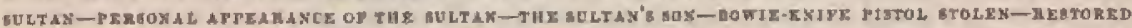

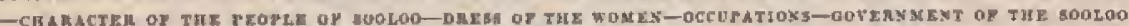

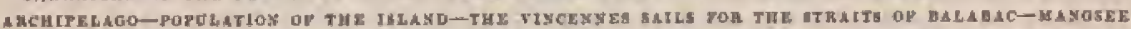

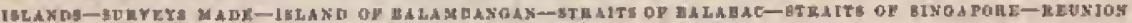

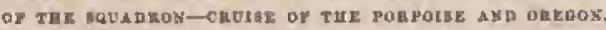

ON the evening of the 21 st of Jnuary, the Vincennes, with the tender in company, left the bay of Mrnilla. I then sent for Mr. Kuox, who conmanjer the latter, aud gave hin directions to keep elosely in company with tho Vincenres, and at the same time pointerl sut to him places of rendezvous where the ressels might again meet in ease asy Inaroidable circumstance caused their separation. [ was more partiedar in giving him instructions to avoid losing sight of the Vincenpes, as I was aware that my proposed surveys might bo impeded or frusirated altogether, were I deprived of the assistance of the vessel under his cominand.

On the 2 ind, we passed the entrinee of the Straits of San Bernadino. It would have been my most direct route to follow these straits until I had prosed Mindoro, nud it is, I atn satisfied, the safest course, unless the winds nre fair, for the direct passage. My object, however, was to examine the ground for the benefit of others, and the Apo 
Slant, which lies nbout mid-clannel between Palawalt and Mimioro, chimed my first attention. Tho tentet whs despurehed to survey it, while I proceeded in the Vincennes to examine the more immediate entrance to the Sooloo Ser, off the soutswerst end of Mindoro.

Calnvite Peak is the unrtl proint of Mindoro, and onr observations made it two thousund feet high. This peak is of the shape of at dome, and apjuents remarkably regular when geen from its westem side. On approsuching Mindoro, we, as is tranal, under high islunds, lost the steady breeze, and the wind beenme light for the rest of the day. Mindoro is a benutiful island, and is evidently vol. canic; it appenrs as if thrown up in confused nusses: it is not much settled, as the more southers ishands are preferred to it as in residenec.

On the 2:12d, we uscertained the elevation of the highest peak of the island by tringulation to be three thoustud oue hunilred and twenty-six feet. 'The easternmost island of the Palawan Group, Busvagan, was at the time just in sight from the deek, to the sontli-west.

It lind been rmy intention to anchor st Ambolou Island; but the wind died away before we renehed it, and I determined to starid ofl and on all night.

On the $2 A \mathrm{~h}$, I begnn to experience the truth of what Captain Haleon had asserted, namely, that the existing churts were entirely worthless, and I also found that my native pilot was of no more value than they were: he had ovidently passed the place before; but whelluer the size of the vessel, so nuch greater thon any ho laad eniled in, confused lim, or whether it was from his inahility to nuderstarsil and to malo hionsolf understood by us, lie was of no use whatever, and we had the misfortune of ruuning into slıonl water, barely escaping the bottom. These dingers were usunliy quickly prassed, and we soon found ourselves again tlosting in thirty or forty fathons water.

We eontinued beating to windward, in hopes of being joined by the Flying-Fish, snd I resolved to finish the survey towards the island of Semarara. We found every thing in a different position from that assigned it by any of the cliarts with which we were furnisherl.

Towards eveting, I agairs man donn to the sonth-west print of the island of Mindoro, and sett is Jetter on shore to the pueblo, with dipections to have it put on board the tender, when she should arrive. We theu logan to beat round Semarara, in order to pass over towards Pnnay.

The southern part of Mindoro is much ligher than the northern, but appears to be equally rough. It is, however, susceptible of cultivation, and there are many villages along its shores.

Semnrara is moderately ligh, and about fifteen miles in circumference; it is inbnuited, and like Mindoro, muels wooded. Aceurding to the native pilot, its slıores aro free from shosals. It was not until the next day thnt we succeded in reaching Punay. I determined to pass the night off Point Potal, tho north end of Pany, as I helieved the sea is its neighbourhood to he free of ahoals, and wished to resume our ronning survey early in the morting.

At daylight on the 27 th we continned the survey down the const of I'nnay, and sueceeded in correcting many errors in the existing charts (both English and Sparish). The ebannel along this side is from twelve to twenty miles wide, and suilable for berting in; little current is believed to exist; and the tides, as fir as aur observations wellt, seom to be regular and of littlo strength.

The islnnd of Panay is high and broken, particularly on the south end; its shores are thiekly settled and well cultirated. Indigo and sugar-tane claim ruvels of the attention of the inlabitants. The Indians are the principal culisators. They pay to government a chpitation tax of seven risla. Its population is estimated at threo hundred thousand, which I think is rather short of the actual number.

On all tho hills there are telegmplts of rude construetion, to give infurmation of the approseh of piratical prahus from Sooloo, which fornerly were in the lubit of making attacks upon the defenceless inhabiants, and carrying them off into slavery. Of late yeurs they have cunsed these depredations, for the Spaniards lave resorted to a new mode of warfare, Insteat of pursuing and punishing the offenders, they now intercept all their supplies, both of necessaries and Juxuries; and the fear of this has had the effect to deter pirates from their usual attucks.

We remained off San Peltro for the nigbt, in hopes of falling in with the Flying-Fish in the mornisg.

On the moming of the $28 t_{1}$, the Flying-Fish wns discovered plainly in sight. I jmmediately stood for her, fired in gun and mado signal. At sevell a'elock, nnother gun wis fired, lut the ressel still stool off, aud was seen to nuke sail to the westwarl without paying any regard whatever to either, nul being favoured by o brecze while tho Vireetwes was bechlmed, she stole off and was soon out of sight*,

After breakfast we opened the lay of Antique, on which is situated the town of San Jorre. As this bay apparently offered allehorage for ressojs bound up this coast, I determined to survey it; and for this purpose the hoats were hoisted out and pre. pared for surveying. Lieutenant Budi was despatcheil to risit the pueblo enlled San Jose.

On reaching the bay, the bonts were sent to different points of it, whid when they were in station, the ship fired guns to furnish bases by the sourd, and angles were simultaneoukly mensured. The bosts made soundings on thiejr returs to the ship, and thus completed this duty, so that in su hour or two afterwards the bay was correctly represented on paper. Tt offers no more than a teminomary anchonage for vessels, and unless the shore is closely appronched, the water is almost too deep fur the purpose.

At San Jose a Spanish governor resiltes, who proeides over the two preblos of San Pedro arid San Jnse, and does the duty also of alenlde. Lieutenant Budal did not see him, as he was alsent, but his lady did the housurs. Lieutenant Budd represented the pueblo as eleanly and orderly. About fiften sulliers were seen, whin complose the governor's gunrd, and more were sail to be stationed at San Pridro. A small fort of eight guns commands the rondstead. The beach

- On my arrivel at Singaprore, this circumstance was investigated ly a court of inquiry. The result showed that Mr. Knox had no knowledge of the Vlucenue having beets seen: got the officer of the witch had not reported to libm the face 
Fas fonnd to bo of fithe voleanic and, comjosed chietly of oxido of iron, and cormminuted shells; there is here also st narrow shore reel of eornl. The plain bondering the sen is eovered with a dense growll of cocunt-1ut trees. In the fine nersun the bay it secure, bue we were informed that in westerly and south-westerly grles heavy sens set in, and vensels are nut able to lio at atheher. Suveral small ressels wete lying in a emall river about one and a linalf mile to the southasard of the point on which the for" is sitaated. The eatruice to this river is very narrow and tortuous,

Panny is ono of the largest islands of the group. We had an opportunity of measuring the hoight of some of its western peaks or lighlinits, none of which exceel throe thoumand feet. The interior and enstern side have many lofty summits, which are tanil to rench an altitude of seven thoustud five hundred feet; but these, as we prssed, weru cuveloped in clouds, or sliut out from viow by the nearer highlsuds. Thus gemeral features of the islumal are like tljose of Luzou and Mindoro. The higher land whs bare of trees, and had it unt been for the numeruns fertile valleya lying between the slarp and rugged spurs, it would lave land a sterile appenrance.

The bay of Anlique is in latitude $10^{\circ} 40^{\prime} \mathrm{N}$, Jungitude $121^{\circ} 59^{\circ} 30^{\prime \prime} \mathrm{E}$.

Ii was my intention to remais lot two or three days at a convenient anchorage to enalolo us to mike shurt exeursions into the interior; but the vexatious mismanagement of the tender now made it incumbent that I should rake every possible use of the time to eotuplete the operations connected with the hydrography of this sea; for I perceived that the duties which I intended shonld be perforned by her, would now devolve upon the brats, and necessarily expore both ofticers and men to the hazard of conlracting disense. I regretted giving tp this design, not only on my own acconnt and that of the expedition, but because of the gratifieation it would have afforded personally to the nuturalists.

Tlie town of San Jué has shout thirty bambno honses, sone of which are filled in with elay or mortar, and plastered over, both inside and out. Few of then are more than a single story in height, That of the governor is of the same material, and overtops the rest; it in whitewnshed, and has a neat and cleanly arpenrance. In tho vicinity of the town are several beautiful valley, wlich run into the mounting from the plain that borders the bay. The linding is on a bambo bridge, whish has been erected over an extensive mud-flat, that is exposed at low water, and prevents any nearer approasd of bonts. This bridge is alsout seven laundred feet is length; and a novel plan loas been alopted to preserve it from being carried away. Tlio stems of bamboo not being sufliciently large and heary to maintain the superstructure in the soft mud, a beaffind is construeted just under the ton, which is londed with blocls of large stone, and the outer piles are secured to anchurs or rocks, with grass rope. The rondway or top is ten feet wide, covered with split bamboo, woven tugether, aud has rails on ench sile, to assiat the passunger. This is absolutely necessary for snfoty ; and even with this aid, ote unaccustomed to it inust be prose sessed of to little bodily strungth to puss over this smooth, slippery; and springy bridgo, without aceident.

Two pirogues were at anchor in tlie bay', and on the shore was the frange of a veatel which had evidently been a long while on the stocks, fur the weeds and bushes nenr the ked wero six or eight feet high, and a portion of the timbers were decayed. Cnrts and sleds drawn by bufialoes were in use, and every' thing gave it the appearneo of a thriving viliage, Although 1 have mentioned the presence of soldiest, it was observed on tanting that no guard was atationed about or even at the fort; but shortly afterwards a soldier was seen laurrying towards the latter, in the act of ilrussing lingself in this regimentalt, and another running by his side, with his eartridge-box snd musket. In a litule while one was passing up and down on his post, as though he was as permanent there us the fort itself.

After evmpleting these duties, the light airs detained us the remainder of the day under Panay, in sight of the bay. On the 29th, at noon, we hoid beer wafted by it for enough in the ofting to obtain the essterly breeze, which soon beeane strong, with an overcast sky, and enrried us rapidly on our cousse; my time would not pertnit my heaving. to. We kept on our course for Mlindnnzo during the whole night, and were constantly engaged in sulunding, with nuy patent lead, with from thirty to forty fathoms east, to jrevent our passing over this part of the sen eatiraly unexaminod.

At dnylight on the 3lst, we had the island of Mandanno before us, but did not roneh its western erpe until $8 \mathrm{r}$. like those to the north of it, but, unlike them, its mountaing are covered with forests to their very tops, and there were no distinct cones of minor dimensions, as we had observed on the others. If they do exist, they were hidden by the dense forest.

I had determined to anchor at Caldera, a smalt port on the south-west side of Mindanas, atrout wen miles distrut from Sarnbuangan, where the goverunr resides. The latter is a considerable place, but the anchornge in its ruadstead is said to be bad, and the currents that run through the Straits of Bnsilian aro represented to be strong. Caldera, on the other hand, has a good, though small anchorage, which is free from the currents of the gtraits. It is therefore an excellent stopping-plnee, in ease of the tide proving unlavourable. On une of its points sunds a small fort, whish, on our arrival, lıisted Spanish cutoura.

At six o'clock we earne to mnchor at Caldera, in seven fathons water. There were few indications of inhabitants, exeept at and near the fort. An officer was despntehed to the fort, to report the ship. It was found to be oceupied by a fow soldiers under the command of a licutenant.

The furt is about seventy feet aquare, and is built of Jarge blucks of red coral, which evidently lave not been taken from the vicinity of the place, as was stnted by the officers of the fort; for, alchough our partieg wandered slong the altuvial bearh for two or three miles in encli directlon, no sigus of coral were abserved. Many fragments of red, gray, and juuplo basalt and jorplyry were met with along the bench ; trleose rock and glate, syentite, hornblend, quartz, both cornpact and slaty, with ehalcedony, were found in pieces and large 
pebbles. Those who were engaged in dredging reported the bottom as being of coral, in from four to six or eight fathoms; but this was of a different kind from that of which the fort was constructed.

The furt was built in the year 1784, prineipally for protection against the Sooluo piratea, who were in the habit of visiting tho gettlements, and carrying off the inlabitants as slaves, to obtain ransom for them. This and other of the mane description, were therefore constructed as plinees of refuge for the imhabitants, as well as to afford protection to versels.

Depredntions are still committed, which render it neecesary to keep up a small force. One or two huts which were secn is the noighbourhood of the bay, are built on posts twenty feet from the ground, and into them they ascend by ladders, which are hauled up after the oceupants bave entered.

These, it is said, are the sleeping-buts, and are so built for the purpose of preventing surprise at night. Before our arrival we lad beard that the villages were all so constructed, luts a visit to one soon showed that this was untrue. The natives seen at the village were thought to be of a decidediy lighter colour and a somewhint lifferent expression from the Malays. They were found to be very eivil, and more polished in mamers than our genkemen expected. Ots asking for a urink of water, it was brought in a glass tumbler on a china plate. An uld woman, to willom they had presented some trifles, took the trouble to meet them in another path on their return, and insisted on their ncceptirng a basket of potatoes. Some of the houses contained several families, and many of them had no other means of entrance than a notehed post stuck up to the door.

The forests of Mindanno contain a great variety of trees, some of which are of large size, rising to the height of wne hundred and one humdred and fifty feet. Sume of their trunks sure shaped like buttresses, firmilar to those before spoken of at Manills, from which they obtained bromul slabs for the tops of tables. Tlie trunks were observed to shoot up remarkably straight. Our botanical gon. tlemen, though plensed with the excursion, were disappointed at not being able tu procure specimens from the lofty trees ; and the day was less prodice. tive in this respect than they had anticipated. Lnage woody vines were common, which enveloped the trunks of trees in their fukls, and ascending to their tons, prevented the collection of the most desirable specimens.

The paths leading to the interior were nartuw and much ubstrueted: one fine stresm was erosserl. Many buffaloes wero observed wallowing in the mire, and the woods swarmed with monkeys and numbery of birds, smong then the horu-bills : these kept up a continual chatter, and made a variety of loud aoises. The forests lere are entirely different from any we lud seen elsewhere tad the stories of their leing the abode of large lroas and proisonons snakes, make the effect stifl greacer on those who visil them for the fine time. Our parties, however, saw nothing of these reptiles, nor nny thing to warrant a belief that ettel exist. Yot the officer at the fort related to me many stake stories that secmed to have some foundation; and by inquirieg made elswwhere, 1 lenrned that they were at least warrznted by some frets, though probnbly not to the extent that he represetuted.

Truces of deer and wild hog wero seon, and many birds were obtained, as well as land aud sen shells. Among the latter was the malleus vulgarie, which is used as food by the natives. The soil on this part of the island is a stiff clay, and the plants it produces are mostly woody; those of an herbaceous character were scarce, and only a few orchidcous epiphyter and forns were seon. Around the dwellings in the villages were a variety of vegetables and fruits, consisting of sugar-cane, sweetpotato, gourds, pumpkins, neprers, riee, water and uusk melons, all tine and of largo size.

The officer at the fort was a licutenant of infuntry; one of that rank is stationed here for a month, after which he, with the gurrison, consisting of three soldiers, are relieved, from Samboangan, where the Spaniards have three companies.

Sambonngas is a convict settlement, to which the natire rogues, principally thieves, are sent. The Spanish criminals are sent to Spain.

The inhabitants of the island of Mimdanao who are under the subjection of Spain, are about ten thousand in number, of whons five or six thousand ase at or in the neighbourhood of Sambonngan. The original inhabitants, who dwell in the mountains and on the east coast, are said to be quite black, and are reprosented to be a very eruel and bad set; they have bitherto bid defiance to all attempts to subjugate them. When the Spaniards make excursions into the interior, which is selitom, they alwaym go in largo parties on account of the wild beasts, serpents, and hostilo natives ; nevertheless, the latter frequently attack and drive them back.

The little fort is considered ns in sufficient protection for the fishermen and amalt ressels against tio pirntes, who inbabit the islam of Bagillan, which is in sight from Mindanao, and forms tho swuthern side of the strnity of the same Harue, It is said that ahout seven hundred inhabit it. The name of Moor is given by the Spaninds to all those who profess the Mahomedan religion, and by such all the islands to the west of Mindanno, and known muler the name of the Soolow Arotipelngo, are inlabited.

The dny we spent at Caldera was employed in surveying the bay, and in obtaining observations for iis geographical position, and for magnetism. The flood tide sets to the northward and west ward, through the straits, and the ebb to the enstward, In the bay we found it to rin two miles an hour by the log, but it must be muds more rapid in the utraits.

At daylight on the 1st of February, wo got under way to stand over for the Sangboys, a cmall islarnt with two starp hills on jt. One and a half mito from the bay we parsed over a bark, the least whter on which was ten fathoms null a andidy bottom, and on whteh \& ressel might anchor. The wind atortly after failed us, and we drifted with the tide for sume hours, in full view of the island of Mirndanto, which is hold and picturesque. We had thus a good opportunity of mensuring sorne of its mountain mages, which we mado alout the thou. sand feet high.

In the afternoon, a light breeze camo from the 
soull 1 -west, and before sunget I found that we were again on soundings. As soon as we liad a east of wenty fathoms, I anchored for the night, judging it much better than to be drifting about wichout any knowledge of the locality and currents to which we wero subjected.

On the morning of the 2nd, we got under way to proceed to the weatward. As the bottom was unequal, I determined to pass through the broadest channel, alchusgli it had the sppearanee of boing the shoalest, and oent two boats aheal to sound, In this way we passed through, continuing our surveying operntions, and at the same time made an attompt to dredge; but the gronend was too uncten for the latter purpose, and little of value was obtrinerl.

Shartly after passing the Sangboys, wo had the island of Sooloo in siglt, for which I now steered direct. As sunset we found ourselves within five or six miles of Soung Harbour ; but there was not sufficient light to risk the dangers that might be in our course, nor wind enough to cormmand the shiz; amit having no bottom where we were, I determined again to run out to sea, and auchor on the first bank I should nueet. At half-just eiglit o'clock, wo struck sounling in twenty-six facloums, and anchored.

At dnylight we deterunined our position lyy angles, and fouad it to correspond with part of the route we had passed over the day before, and that we were about fifteen miles from the large ishnd of Sooloo. Weighing anchor, we were shortly wafted by the westerly tide and a light air towards that beatrtiful jaland, which lay in the tridst of its little arclipiplago; and as we wero brought nearer and nearer, we came to the conclusion that in our many wanderings we had seen nothing to be compared to this enchanting spot. It appessed to be well eultivnted, with gentle slopes rising here and there ints eminences from one to two thousand feet high. One or two of these might be dignified with the name of mountains, and were sufficiently ligh to arrest the pussing clonds; on the nfternoon of our arrival we lind a singular examplo in the dissipation of a thunder-storm.

Although much of the island was under cultivatimn, yet it had all the freshness of a forest rugion. The many smokes on the hills, buildings of Inrge size, cottiges, and eultivated fpots, togetlier with the moving crowds on the land, the prahus, canoes, and fisling-boats on the water, gave the whole a civilized appearance, Our own veesel lay, almost without a riphle at her side, on the glassy enirfine of the sea, emrried onwrds to our destined suchorage by the fluwing tide, and scarce as sound was heard except the splashing of the lesd as it sought the bottom. The effect of this was destroved in part by the knowledge that this beautiful nrchipelago was the abode of $\mathrm{n}$ cruel and bartarous race of pirate. Iowards annset we had nenrly renched the bay of Soung, when we were met by the opposing tide, which frustrnted all otrr endeatours to rench it, and I was compelled to auchor, lest we should agnin be swept to seat.

The next morning at eight $0^{\prime}$ elock wo got under way, and were towed by our boats into the bay of Soung, where we anchured off the town in nine fathoms water. While in the aet of doing $\mathrm{so}$, and after our intentions had lecome too evident to admit of a doubt, the suitan gracionsly sent off a message giving us permission to enter lis port.

Lieutenant Budd was immediately despatelsed with the interpreter to eall upon the datu snulu or governor, and to Jearn at what hour wo conld sec the sultan. When the officer reached the town, all were fonnd asleep; and after remaining four hours waiting, the ouly answer ho could get out of the datu mulu was, that he supposed that tho sultan would be awatie at three o'cluck, when he thought I could set him.

At the appointed time, Captain Hudsen and myself went on shore to wait upon the sultan, On our approach to the town, we found that a great propostion of it was buili over the water on piles, and only eonnected with the slore by narrow bridges of bamboo. The style of building in Sootoo does not differ inaterially from that of the Malsye. The houses are railuer larger, and they surpass the others in filth.

We passed for some distanco between the brilges to the landing, and on our way saw oeveral piratical prahus apprently laid up. Twenty of these were counted, of abuut thirty tons burden, evidently built for sea-vessels, and capable of mounting one or two Jong guss. We landed at a small strenmlet, and walked a short diatance to the datu's housc, which is of largo dimentsions and rudely built on piles, which raise it about six feet nhove the ground, and into wtuich we were invited. The house of the datu eontains ove room, part of which is sereened off to furm the apartment of his wife, Nearly in the centre is a raised dnis, tight or ten feet sịuare, under whiclı are stowed all his ralu. ables, packed in chests and Clinese trunks. Upon this dnis are placed mats for sleeping, with eushious, pillows, dic.; and over it is a sort of canopy, hung around with fine ehint; or muslit.

The dais was occupied by the datu, who is, next to the sultan, the greatest man of this island. He at once cane from it to receive us, and lad chirs provided for us near his sunctum. After we were sented, he again retired to his lounge. The datt is small in person, and emsinted in form, but has a quick eye and an intelligent coutenance. He lives, as he told me, with all his goods aronnd him, and they formed $n$ collection anch as I could scarcely imagine it possible to bring together in much a place. The interior put me in mind of a barn inhabited by a comyany of strolling players. On ope side were hung up a collection of various finds of gay dresses, here drums and gongs, there swords, lanterws, spears, muskets, and smail cannon; on another side were shields, bueklers, masks, saws, anil wheele, witl helts, bands, and long rubes. The whole was a strange nixture of tragedy and faree; and the group of natives were not far removed in afpenance from the supernumeraries that a Turkish tragedy might bave brought together in the green-room of a thentre. $A$ set of more cowardly-looking miscreants I never ş They appeared ready either to trade with us, pick our poekets, or cut our tbronts, as an opportumity might ofler.

The wife's apartment was not remarksble for its cornforts, although the datu spoke of it with rsuch eonsideration, and evidently held bis better half in high estimation. He was also prond of his aix children, the youngest of whom he brought uut in its nurse's arms, and exhibited with much prido 
and satisfactinn. He pnrticulntly drew my attention to its liule highly-wrought and splendidlymounted kris, which was stuck through its girdle, as an emblem of his rauk. He was in renlity n fine-looking child. The kitchen was behiud the house, and ocenpied but a small space, for they have little in the way of food that requires much preparation. The house of the datu might justly be termed nasty.

We now learned the reason why the sultan could not be seen: it wis Frixlay, tho Matromedan Salibath, and he had been at the roosque from an early hour. Lioutenant Budd lasd been detained, because it was not known when the would finish his proyers; and the ceremonies of the day were more important tlan usual, on aecount of its peculiar sanctity in their ealendar.

Word had been sent of to the slip that the sultan was rendy to l'eceive me, lut the messenger passed us while on our way to the slrore. After we firl been seated for a while, the datu asked if we were ready to accompany him to see the sultan; but intimsted that no ono but Captain Hodson and myself could be permisted to set cyes on him. Being informed that we were, he at onee, and in our presence, slipped on bis silken trousers, and a new jacket, covered wilh belt-buttons; pat on hia slippers, strapped himself round with a fung silken uet Bash, into which lie stuck his liris, aul, with umbrella in hank, sail he was ready. He nuw led the way out of lis louse, lenving the motley gronp bethind, and we took the path to the interior of the tuwn, towardis the sultan's. The datu and I walkel hand in band, on a rosdwry about ten feet wide, with a sinall stream running on each side. Gaptain Hudson and the interpreter came next, and a gund of six trusty slaves brought up the ren:.

When we reached the outskirts of the town, about half a mile from the datu's, we came to the sultan's residence, where he was prepared to receive us in state. His house is constructed in tle game anunner as that of the datu, but is of larger dimensions, and the piles nre rather higher. Instead of steps, wo found a ladder, rudely construeted of bamboo, and very crazy. This พas so stcep that it was necesarsy to 1150 the Jands in mounting it, 1 anderstood that the ladder was always remioved in the night, for the anke of Becurity. We entered at once into the presence. sintuler, where the whole divan, if snch it may be enllexl, sat in arm-chairs, ocenpying the bult of a large round table, covered with a white cuttun cloth. On the oppusite side of the tuble, seats were placed for us. On our npprotuch, the sultan sud all lis council rose, and motioned us to our seats. When we had zaken them, the part of the roon behind tas was literally crammed with wellnrned merz. A few minules were passed in sitence, during which time we hall an opportunity of looking at each other, ard around the lath in which we were seated. The latter wrs of very common wurkmanship, and exhibited no signs of orjontal magnificence. Orerlıead hung a printed cotton cloth, forming a kind of tester, whieh covered about half of the apartment. In other pilaces the roof and rafues were visible. A part of tho house was rongtsly partitioned off, to the lieiglit of nine or ten fect enelosing, as I was afterwards told, the sultan's sleepiug apartment, and tlat appropsiated to his wife and ber attendants.
The sultan is of the middle height, spare and thin; he was dressed in a white cotton shire, lonse trousery of the same mnterial, and slippers; he lad no stockings: the bottom of his trutsers was worked in senflops with blue silk, and this was the only orument I saw about lim. On lis head lit wore a small coloured cotton handkerchief, wound into a turban, that just covered the top of his head. His eyes were blnudshot, sund had an uneasy wild look, showing that low was under the effects of opiun, of which they all smuke large guanticies. His teeth were as blick as abony, which, with bis bright cherry-coloured lipis ${ }^{\circ}$, contrasted with lis swarthy skin, gave him any thing but a pleasant look.

On the left hand of the sultan sat his two mons, while bis right was vecupied by lis councillors; just behind Jint snt the carrier of his betel-mit casket. The casket was of filigree sidver, about the size of a small tea-caddy, of oblong shape, and rounded at the top. It hal three divisions, one for the leaf, another fur the nut, and a third fur the lime. Next to this oflicial was the pipe-berrer, who did not nppear to bo held in suel estimation as the former.

1 opened the conversation by desiring that tho datu would explain the nuture of our visit, and tell the sultan that I had come to mako the treaty which he had some time before desired to form with the United States + .

'The sultan replied, that such was still his desire; upon which I told him, I would draw one up for hism that ance day. While I was explaining to lim the terms, a brass eandlestiek wis brought in with a lighted tallow candle, of a very dark colour, and rude atrape, that showod lout lictlo art in the mnutheture. "Ithis was placed in the conere of the talsle, with a plate of Minilla cigars. None of them, however, were offerod to ns, nor any kind of refreshment.

Our visit lasted nearly an hour. When we aruse to take our leave, the sultan and his divn did the same, and we made our exit with luw bows on each side.

1 Joaked upon it as a matter of daily oceurrence for all those who came to the island to risit the sultan; but the dntu mulu took grent pains to nalie mo believe that in great farong had been granted in allowing ts a sight of his ruler. Ont the orher lumil, I dwelt upm the condesecnsion it was on my part to visit him, and I refuted to admit that I wa under any gratitude or sbligation for the sight of His Majesty the Sultan Moliummed Damaliel Kisand, but stid that he might feel grateful to me if he signed the treaty I would prepare for him.

On our return from the sultan's to the datu mulu's house, we found even a greator crowd tlatn before. The dntu. huwever, coutrived to get us seats. TJe altraction which drew it, togetler was to Jook at Mr. Agate, who was talijug a sketeh of Mohamulued Polalu, the sthlar's son, nnd next heir to the throue. I had hoped to prueure one of

- Chewing the betel-nut and pepper-Jens also produce thli eltect, and la carried to is great extent among these istanders.

4 The suliar, on the vints of nie of our mercharn-vesyels, had informed the supercanco that he wished to encourage our trale, and to see the ressels of the United States coming cu lis port. 
the sultan, fut this was declared to be imposible. The son, however, has all the characteristies of the Sooloon, and the likencss was thought an excellent one. Mohanumed Polalu is about twenty-three years of agc, of a tall slender figure, with a long face, hersy and dull eyes, as though lic was constantly uster the influence of opium. So much, indeed, was he addieted to the use of this drug. even according to the dafu mulu's aceounts, that his strength and constitution were rery much imspuired, As he is kept particularly under the gunsdianship of the datu, tho latter has a strong interest in preserving this influence over him, and seens on this account to afford him every opportunity of indulging in this deplorable habit.

During our visit, the effects of th pipe of this drug was seen upon lisn * for but a short time after he had reclined hinself on the datu's cuuch and cushion, and taken a few whifts, the was entirely overeome, stupid, and listless. I laad never seen any one tho young, beariug such evident marks of the effects of this deleterions drug. When but purtially recowered fonm its effects he callet for lis betel-Iut, to revive lim by its exciting effects. This whs carefully cliewed by his attendant to a proper consistency, moulded in a ball about the size of a walnut, and then slipped into the munth of the heir-aprorent.

One of the requests 1 had muse of the sultan was, that the officers miglat lase guidies to pass over the island. This was at once said to be too dnngerous to be aftempted, as the datus of the interios and southern touns would in all probability attack the partieg. I understood what this mesut, and replied that I was quite willing to take the responsibility, and that the party should be well amed. To this the sultan replied, that he would nut risk his own men. This I saw was a mete evasion, but it was difficult and would be dangerous for our gentlemen to proceed slone, and I therefore said no more. On our return to the dstu's, I gave them permission to get as far from the beach as they could, lut I was afterwards informed by them that in endesvouring to penetrate into the wouds, they were always stopped by armed men. This was also the case when they nppronelued particular parts of the towi, lut they were not molested at long as their rambles were confined to the bench. At the datu'y we were treated to ehocolate snd negus in gilt-cuged tumblerg, with small stale enkes, which had been brought from Manilla.

After we bad set some time I was julormed that Mr. Dana missed his lowie-knife pistol, which he had for a moment laid down on a chest. I at once came to the conclusion that it had been stolon, nni ns the theft had oecurred in the datu's louse, I Heternined to hold lin responsible for it, and gave him at once tu understand that I sloould do so, informing him that the pistul must be returned before the next morring, or lic tuust take the consequenees. This threw lim into some cunsternation, and by my manner he felt thac I was serious.

The theft was so barefaced an affisir, that I made up my ninn! to ingist on its restorntion. At the getting of the watch in the evening, it bal been our practice on bonrd the Vincennes to fire a small hrass howitzer. This frequently; in tho calm evenings, produced a great reverberation, aur rolled nlong the water to the surrounding islands with considerable noise. Instesd of it, on this evening, I ordered one of the long guns to be fired, believing that the sound and reverberation alone would suffice to intimidate such rohbers. One was aecordingly fired in the direction of the town, which tairly shook the island, as thoy said, and it was not long before wo saw that the rogues were fully nroused, for the elatter of gongs int voices thut camse over the water, and the motion of ligtits, convineed the thant the pistol would be forthcoming in the morning. In this 1 was not mistakon, for at early daylight I was awalkened by a special messenger from the datu to tell me that the ristol was found, and would be brought off without delay; that he had been searehing for it all night, and had at last succeeded in finding it, as well as the thief, on whom he intended to inflict the bastinado. Aceordingly, in $\pi$ short time the pistol was delivened on board, and every expression of friendship and good-will given, with the strongest assurances that nothing of the lind slould happen again.

Few if any of the Sooloos can writo or read, though mary talk Spunish. Their nocounts stre all kept by the slaves, Those who can read and writo are, in consequence, highly prized. All the aceounts of the datu of Soung ate kept in Dutch, by a young Malay from Ternate, who writes a good lind, and streaks Englist, and whom we found exceedingly useful to in. He is the slave of the datu, who employs him for this purpose only. He told wo he was captured in a brig by the pirates of Basiltan, and sold here as a sinre, where he is likely to rewnin fur life, althrugh lie says the datu has pro. mised to give him his freodom after ten years.

Horses, cows, and buffalues are the bensts of burden, and a fooloo may usunlly be seen riding either one or the other, armed cap-a-pie, witt kris, spear, and target, or shield.

They use sadules cut out of solid wood, and many ride with their stirrups so short that they briag the bnees very bigh, and the riders look more like weil-gruwn monkeys than motrated men. The cuws and buftnloes are guided by a piece of thong, throngh the cartilage of the nose. 13y law, no swine are allowed to be kept on the ishnd, assd if they are bought, they are immediately killed. The Clinese nre obliged to raise and kill clueir pigs very secretl, when they desire that species of food; for, notwithstanding the law and the prejudices of tho inhabitnuts, the former continue to keep swine.

The inhabitants of Sooloo are a tall, thin, and effeuninate-lonking race: I do not recollect to have geen one corguteut person among them. Their faces are peculiar for length, particularly in the lower jaw and chin, with ligh clieek-boues, sunkey, lack-lustre eyes, and narrow foreheads. Their lieals are thinly covered with hair, which aprears to be kept elusely cropped. I was told that they pluck ont their beards, and dye their teeth black with antimony, and some file them.

T'heir eyebrows appenr to be sluaven, formisg a very regular and high arch, which they estecm a ereat beatuty.

The dress of the common people is very like tlat of the Cliuese, with loose and full sleeves, without buttong. The materials of which it is made are grass-cloths, silks, sutins, of white cotton, from 
China, I ghould judge from the appearance of their persons, that they ought to be termed, so far as ablutions go, at eleasy people. Their is no outwarl respect or obeisance shown by the alnve to his master, nur is the presence of the datu, or even of the sultan himself, held in any awe. All appenr upon an equality, and thero does not seen to be any controlling power; yet it may he at onee perceived that thoy ure suspicious and jealous of strangers.

The Sonlons, although they are ready to do any thing for the sake of plunder, even to the taking of life, yet are not disposed to honrd their ill-gotten wealth, and, with all their fnulte, cannot be termed avaricions.

They have but few qualities to redeem their trenchery, cruclty, and revengeful dispositions ; and one of the principal causes of their being so predominunt, or even of their existence, is thejr inordinate lust for power. When they possess this, it is accompanied by a haughty, conserpuential, mo ostentatious bravery. No greater affront ean be offered to a Sooloo, than to underrate his dignity and ufficial consequence. Such nn insalt is seldom forgiven, and never forgotten. From one who has made numerous voyages to these islands, I have obtained mauy of the above facts, and ny own observation assures me that this viow of their character is a eorrect one. I would, however, add another trait, which is common anong them, and that is cowardice, which is obvious, in spite of their boasted prowess and daring. 'This trait of etharacter is universally nseribed to them among the Spaniards in the Philippines, who ought to be well acquainted with them.

The dress of the women is not unlike that of the men in appearnace. They wear close inckets of various colours when they go abroad, and tho samo loose breeclies as the men, but over tirem they usually have a large wripper (sarong), not unlike the pareu of the Polynesian islanders, which is put round them like a petticont, or thrown over the shoulders. Their hair is drawn to the back of the hend, and around the forehend it is shaven in the form of a regutar arch, to correspond with the cyebrows, Those that I anw at the su]tan's were like the Maliays, and had light complexions, with very black teeth. The dati thusught them very handsome, and on our return he asked mo if I had seen the sultan's beauties. The femaleg of Sooloo have the reputation of ruling their lords, and posesess mnch weight in the government by the influence they exert over their husbunds.

It may be owing to this that there is little jealonsy of their wives, who are said to hold their virtues in no very great estimatiou, In their houses they are but seantily clathed, though women of mak have alwnys a large number of rings on their fingers, some of which aro of great value, as well as enr-1iugs of fine gold. They wear no stockings, but hnve on Chinese slippers, or Spanish shoes. They are as capable of governing as their lusbandis, and in many cases more 80 , as they rasuciste with the slaves, from whon they obtain some knowlyelge of Christendom, and of the habits and custons of other nations, which they study to imitate in exery way.

The mode in which the Sooloos employ their time may be exemplified by giving that of the datu; for all, whether free or slave, endeavour to imitate the bigher rank as far as in in their nower. The datus selitam rise before eleven o'elnek, unless they lase some particular business ; and the datu mulu complained of being sleepy is eonsentsence of the early jour at which we had disturbed him.

On rising, they linve clincolate served in gilt glaksware, with some light bisenit, and sweetrnests imported from Chima or Mauilla, of which thes informed me they laid in large supplies. They then lounge about their houses, transacting a little business, and plnying at various gaules, or, in the trading season, go to the meeting of the Rumn Becharr.

At surset they take their prineipal meal, conBisting of stews of fish, poultry, beef, eggr, and rice, propared somewhint after tho Chinese and Spanish modes, mixed up with that of the Mlalay. Althnugh Mislems, they da not forego the use of wine, and some are said to indulge in it to a grent extent. After snnseh when the air has beevme somewhat eooled by the refreshing breezes, they sally forth attended by their retriners to take a walk, or proceed to the bazaars to purchase goods, or to sell or to barter away their articles of produce. They thers pay vists to their friends, when they are in the labit of having frequent convirial parties, talking over their hargains, smoking cigars, drinking wine and liquenrs, tea, colfee, and chinenInte, and indulging in their favourite piye of opinm. At times they are entertained with inusic, both vocal and instrumental, by their dependants. Of this nat they appear to be rery fond, and there art many musieal instruments amoug them. A datu, indeed, would be lorked upron ns unedueated if he could not play on some instrument.

It is considered polite that when refreshments are handed they should be partaken of. Throw offered us by the datu were sucl an are usual, but every thing was stale. Of fruit they ure said to be very fonl, and ears afford to indulgo thenselves in any kinds. Witls all these articles to cloy the appetite, only one set menl a day is taken; though the poorer elasses, fishermen and Iabourers, partake of two.

The government of the Sooloo Arehipelngo is $\mathrm{n}$ kind of oligarchy, and the supreme authority is vested in the sultan and the Ruma Bechara or trading council. This consists of about twenty chiefs, either datus, or their next in mak, calleil orangs, who are governors of towns or detaclied provinces. The intluence of the individunl chiefs depends chietly upon the number of their retainers or slares, and the foree they can bring into their service when they require it. These are purchased from the pirates, who bring them to Sooloo and its dependencies for sale. Tho slaves are employed in a variety of ways, as in tmding ponhus, in the peasl and biche-de-mar fisheries, and in the search after the cdible birds'-nesis.

$A$ few are engaged in agrieufture, and those who are at all elueated are employed th elerks. These slaves are not denied the right of holding projerty, which they enjoy during their lives, but at their death it reverts to the nasster. Some of them arp quite rieh, and what ma appenr strange, the glaves of Sooloo are invariably better off than the untitled freenen, who are at all times the prey of the hereditary datus, even of those who hold no official stations. By all accounts these constitute a large proportion of the poptalion, and it being 
treason for any low-born freeman to jnjure or mal. treat a dato, the latter, who nre of a laughty, over. bearing, and tyrannical disposition, selilom keep themsolves within bounds in their treatment of their inferiors. The consequence $\mathrm{ik}$, the lower elass of freemen are obliged to put themselves umber the protection of some particular datı, which guards them from the encroachment of others The clinef to whom they thus attseh thensolves, is indueed to treat them well, in order to retain their services, and attach them to his person, that he may, in case of need, be enubled to defend himself from depredations, and the violenee of his neighbours.

Such is the absence of legal restraint, that all find it necessary to go abroad nirned, and nceompraied by a trusty set of followers, who are also armed. This is the case both hy day and night, and, according to the datu's account, frequent affrnys take place it the open streets, which not unfrequently end in bloodslied.

Caution is newer hid aside, the only law that exists being that of foree; but the weak contrive to balane the nower of the strong by uniting. They hare mot only contentions and strife smong thernselves, but it was atated at Manilla that the mountaineers of Sooloo, who are said to be Christians, occasionally make inroads upon them. $\Lambda \mathrm{t}$ Sooloo, howorer, it did not appear that they were nnder mueb apprehension of these attreks. The only fear I heard expressed was by the sultan, in my interview with hin ; and the cause of this, as I have already stated, was probably a desire to find an exeuse for not affording us facilities to go into the interior. Within twenty years, however, the roigning sultan has been obliged to retire swithin his forts, in the town of Sooloo, which I Jave befure adverted to.

These people are hostile to the Sooloos of the coast and tow $1 \mathrm{n}$, who take every opportunity to rob them of their eattle and property, for which the mounthinovrs seck retalintion when they bave an opportunity. From the manner in which the datu spoke of them, they are not much regaried. Through another souree I lenut that the mountaineers were Papuna, and the original inlabitants of the isinnds, wio pay tribute to the sultan, and have acknowledged his authority, ever since they were converted to Islatnism. Before that time they were considered extremely ferocious, and whenever it was practicable they wero destroyed. Others opent of an original race of Dyacks it the interior, but there is one circumstnnee to satisfy me that there is no confidence to be placed in this accourst, namely, that the island is not of bufficient extent to aceunimoulate so numerous a population as some ascribe to $\mathrm{jt}$.

The forts corsist of a double row of piles, filled in with coral blocke That siturted on the east side of the small strosm mny be said to mount a fow guns, but these are nlogether inellicient; and in anchluer, on the west side, which is rnther a rude embankment than a fort, there are some twelve or fifteen pieces of lnrge calibre; but I doubt very much if they had been fired off for years, and mary of the houses built upon the water would require to be pulled down before these guns cuuld be brought to bear upon any thing on the side of the bay, supposing them to be in a good condition; a little farther to the east of the town, I was in- formed they had a kind of stockade, but none of ta wore pernitted to see it.

According to our estimates, and the information we received while at Soolvo, the island itself does not contain moro than thirty thoueand inhabitants, of whicly the town of Soung may have six or seven thousand. The whole group rasy number sbout one lundred and thirty thonsand. I am aware, however, that it is diffieult to estimste the population of a half-civilized people, who insariably oxaggerate their own strength ; and visiters are likewise prone to da the game thing. The Chinege comprise about an eighth of the populntion of the town, and are generally of the lower class. They are constantly busy at their trades, and iatent upon making money.

At Sourag, biatiness seems active, and all, slaves as wel! as masters, seem to engage in it. "The nbsonce of a strong government leaves all at liberty to act for themselves, and the Ruma Bechara gives unlimited frecdom to trade. These circumstances promote the industry of the community, and even that of the sinve, for he too, as before observed, liss a life interest in what he earns.

Soung being the residence of the sultan, as well as the grand depot for all piratical goods, is probably more of a mart than any of the surxounding towns. In the months of Mareh and April it is visited by severa! Chincse junks, who remain trading until the beginning of the month of August. If delinyed after that time, they ean senreely return in safety, being unable to contend with the boisterous weather and head winds that then provail in the Chinese sens. These junks are aaid to cone chicfly from Anoy, where the cottons, \&c., best suited for the Sooloos, are made. Their eargoes consist of a variety of auticles of Chinese mranufacture and produee, such as sillk, satin goods, eottuns, red and checked, grass-cloth elothing, handkerehiefs, entlery, guns, anmunition, opium, lumber, chins and glass-ware, rice, sugar, oil, lard, and butter. In roturn for this merchandise they obtsin canjphor, birds'-nests, ruttans, biche-de-mas, pearls and penrl-ghells, cocon, tortoise-shell, and wax ; but there is no great quantity of these aricles to be obtained, perflaps not more than two or three enrgoes during the season. The trade reguires great knowledge of the articles purchased, for the Chineso and Sooloos are both such adepis in fraud, that great eution and eircumspeetion are necessary.

Soung Rosd offets good anchorage; and supplies of all kinds may be had in abundance. Beef is cheap, and wegetables and fruits at all seasons plenty. Our observations placed tho town in latitude $6^{2} 1^{\prime} \mathrm{N}$, longitude $120^{\circ} 55^{\prime} 51^{\prime \prime} \mathrm{E}$.

On the bth, having conclated the treatr and the other business that had taken mo to Snoloo, we took our departure for the Straits of Balabnc, the western entrnee into this sea, witl a fine breeze to the eastwarly. By puon we lasd renched the group of Pangootnarang, consisting of five tmall islands. All of these are low, covered with trees, and without lagoons. They presented a grest contrast to Souloo, which was seen behiud us in the distance. The absence of the swell of the ocean in sailing through this ses is striking, and gives the idea of navigating an extensive bay, on whose luxuriant islands no surf breaks. There are, how. eves, sources of danger that incite the navigator to 
watehfulness anil constant anxiety; the hidden shoals and reefs, and the sweep of the tide, which leave him to control over his vesse].

Through the night, which was exceedingly dark, wo sounded every twenty mimutes, but found no bottons; and at daylight on the $7 \mathrm{th}$, we male the islands of Cagayan Soolon, in latitude $7^{\circ} 3^{\prime} 30^{\prime \prime} \mathrm{N}$, longitude $118^{\circ} 37^{\prime} \mathrm{E}$. The tide or current was prasing the islands fo the west-8outh-west, threequarters of a mile per hour; we had soundings of seventy-five fathoms. Cagayan Sooloo bas a pleasant nppearance from the sen, and may be termed n high islatsd. It is less covered with undergrowth and mangrove-busheg than the neiglibour ing islands, and the roefs are compuratively small. It has fallen off is importance; and by comparing former accounts with those I received, and from its present aspect, it would seem that it has doerensed both in population and products, Its eaves formerly aupplied a large quatity of edible birds'nests; large numbers of eattle were to be found upon it; and iks cultivation was carried on to some extent. These nrticles of commerce nre not so much attended to at the present time, and the biche-de-mar and tortoiso-slsell, formerly brouglat hither, are now carried to other places. There is a small anchorage on the west side, but we did not visit it. There are no dangors near these small islands that anay uot be guarded against, Our survey exteuded nonly to their size and fituation, as I decmed it ony duty to devote all the remainder of the time 1 hind to spare to the Straits of $\mathrm{Bn}$ Inbac.

At 9 A.M, of the Buth, we mado the Mangree Islands ahead of us, and likewise Balabne to the north, and Balambargan to the south. Several sand-bank and extensive reef's were also seen between them. On seeing the ground sn which we had to operate, of which the published chirts rive no idea whatever, I determined to proeed, and take a central position with the khip under the Mnngsee Istands; but in order not to lose time, I hoisted ont and dropned two boats, under Lieutcnant l'erry, to survey the first and-bank we carne to, which lies a few miles to the eastward of these islands, with orders to effect this duty and join me at the anchorage, or find a shelter under the lee of the isinnds.

At half-past 2 P.Y. we anchored near the recf, in thirty-six futhoms water. I thought myself fortunte in getting bottun, as the reefs on closing with them seemed to iudierte but little apperance of it.

'The rest of the day was spent in preparing the boats for uur operations. I now felt the want of tho tender. Although, in the absence of this ves. sel, great exposure was necessary to effect this survey, I fund both oflicers and wen eheerful and willing. The parties were organized, -the firgt to proceed to the north, towards Balabac lslaud, to Burvey the intermediate shonla and reefs, under Lieutenant Emmons sud Mr. Totten; the second to the south, under Lieuteuants Perry anil Budd; and Mr. Hammersly for the survey of the shuals of Balambangan and Banguey, and their roefs. The examination of the Mangsee Islands, and the reefs aujacent, with the astronomical and magnetic observations, \& $c_{2}$, devolved on myself and those who rensined on board the ship.

The weather was watehed witl anxiety, and turned out disngrcenble, henry showers and strong winds prevailing; notwithstanding, the bonts were despratched, after being as well protected against it as possible. We flattered onrselves that these extensire reefs would produce a fine harvest of shells; but, although every exortion was made in the search, we did not add as many to nur collections as we nuticipated. Some Innd-shells, how. ever, were found that we little expected to meet with, for many of the tren were covered with them, and on entting them down, large quantitien were ensily obtained. Mr. Penle shot soveral birds, among which was a Nicubar pigeon; smo interesting pinnts and comb were alsu added. On the island a large quantity of drifh-wool was found, which with that which is growing affords amplo supplies of fuel for ships. No fresh water is to be had, excent by digging, the isfund being but a few feet above high-water mark.

Althougl the tirse was somewhat unfatourable, Lieutenant Emmons and party executed their orders wthin the time designatell, nnd met with no other obstructions than the inclenency of the weather. This was not, however, the case with Lieutenant Perry, who, nenr os aniall bencls on the island of Balambangan, encountered some Suoloos, who were slisponed to attack him. The satives, no doubt, were under the injuression that the buats were from some shipwrecked vessel. They were all well amied, atul appurently prepared to tako advantage of the party if possible; but, hy the prodence and forbenrance of this officer, collision was avoidel, and his party saved from an attack.

The islnnd of Balambaugnn was obtained from the Soulons for a settlement and phace of deposit. by the East Indin Company, who took possersion of it in 1773 . Its situation off the northers ead of Borneo, near the fertile distriet of that ialand, its central position, and its two fine prorts, offered great aulvantages for commeree, and for its becom. ing a grent entrepoit for the riches of this archipelago. Troops, and stores of all kinds, were sent from India; numbers of Chinese and Malays were indinced to settle; and Mr. Herbert, one of the council of Bencoolen, was appointed governor. It had been supposed to be a healthy place, as the ialsnd was elevated, and therefore probably free from malaria; but in 1775 the mative troops from India becane much redued from eickness, and the post eonsequtent/y much weakened. This, with the absence of the cruisers from the harbour, afforded a favourable opportunity for its caplure; and the wealth that it was supposed to contain ereated an inducement that proved too great for the hordes of marruding pirates to resist. Cloosing their time, they rushed upon the sentries, put them to dealls, took possession of the guns, and turned them against the garrigon, only a few of whom made their escape on board of a small vessel. The booty in goods and valuables was said to hawe been very large, amounting to neariy four lundred thousani] founds aterling.

As the prineipal objects of rny visit were to ascertain tho disposition and resources of the Souluos for trale, and to examine the stmits lending into the Sooloo beas, in order to facilitate the communication with Cluina, by aroiding un the one land the eastern route, and on the other the dingers of the Palnwan Passage, it may be as well to givo the result of the latter inquiry. 
The difficultice in the Palawar Pasenge arising firutn lieavy seas and fresh gales do not exist in the Soolino Sin, nor nre the sliodls so numerous or so dangervus. Is the place of storms and rought water, sroouth sens are found, and for most of the time moderate breezes, which do rut subjeet a veranel to the wear and tear experienced in benting up against a monson.

The Sumits of Balnbue may be ensily reached, eicher from Singapore, or by beating up along the sestern shore of liorsten. When the straits sto reached, in vessel by chonsing her time may easily' Ithes slirough them by inylight, evell by heating when the wind is alsesd. Onee through, the way is elenr; will the excegtion of a few cornl lumjis; the

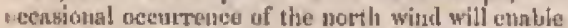
4h vessel to pass directly to the shores of the island uf Pans $A$ fuir wind will or dinarily grevail along that islingd, anh, as I lave already mentioned, it may he appronelied elosely. The pasange throrigh th the enstwart of Mindoro Island may lae taken in preference to that on the west side tlarumgh the Mindory Stmil, nud thus all the reefe and shonts will be avoided. Thernee. the western toust of L,uzon will be followed to the north, sit in the old route.

1 do not think it necensary to print out any par. lieular route through the Sooloo Sen, as ressels niust he guided chiefly as the winds blow, hut I would generally avoid approaching the Snotwo Islands, ns the currents are torore rupivi, and bet mather tu the sollthward. W'herever theto is anchorage, it would be advisnble to anchor ne night, as much time might thus be saved, and a knowledge of the eurrents or sets of the tides olutined. Perluaps it wotld be ne well to enution those who aro venturesome, that it is necessnry to keep a good look-out, and those who ane timid, that there does sot appenr to be much dinger frum the piratical prahus, anless a vessel gets on shore: in that esce it will not be loug before they will be seen collecting in the linvizon hu large numbers. T'u conclude, I an satistied that under ondiuary circunstances, tn pass throngh the Soolon Sen will shorten by several Anys the passage to Manilla or Conton, and lie a great Eaving of exprense in the wear and teax of a fhip and her eanvass.

On the 13th, we passed near the location of the Viper Shonl, but saw nothing of it. It is, there. firce, marked doubtful on tho ehart. As I had but little time to spare, the lnok-outs were doubled, and we pursuct our course throughout the night, sound. ing as we weut evary fifteen milutes; but nuthing I11et our view.

(in the 18 th, we made Pulo Aor and Pulo Pedang, and arriving off the Strats of Singajore I hove-to, to Awrit drylight. In the moming at dawn, we found ourvelves in close company with a Chinese jurk. The 19th, until late in ihe afternoon, we were in the Simgapore Straits, making but slow frogregs towards this emporium of the east. The number of native as well as foreign vessola which we phesed, proved that wo were approsuching some

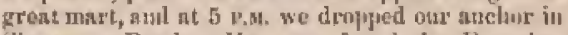
Singapor'e Ruads. Hete we frums the Porjuise, Oregron, nud Flying. lish, all well: the two former had arrived on the 22ud of Jamary, nenty a nonth before, and the fatter three day previously. Hefwe

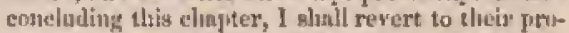
ceedings sinee our bejatration off the Sandwich Islands.

The instructions to the brits have been hereto. fore given; lut it may not be nusss to repent here that the ubject is detseling them was, that they miglit expline the line of reefn und islnnds knowit to exist to the nortliward mol westwry of the Hawaitan Grouj, and thence continue their courso towards the ecast of Japan. Hat they etfected the latter ubject, it would lave given important re. sults in relation to the furce of the currets and the termpernture of the water. It was desirable, if possible, to ascertnin with eertaitity the existenet on the const of Japhn of a currant sinilar to the Gulf Stresan, to which ny attention land been particularly drawil.

The first Inthd they made was on tito lat of December, 1841, and was Necker Island. I3irdk, pspeciatly the white tert, linl been seen in mumbers prior to its announcement. Necker lslatid is appurently a mase of volennic rocks, about three hundred foet high, and is destitute of nny kind of vegetntion, but covered with gonno. It is surroninded by a reef, tluree miles from which annulings were obtrined, in twonty fathoms water. "The furious furf that was benting on all sides of thes island, precluded all frossibility of a lnoding leing made. By the connocted observations of the ressets, it lies in longitnde $164^{\circ} 3 \bar{j}^{-} \mathrm{W}^{\prime}$, and latitude $23^{\circ} 44^{\prime} \mathrm{N}$

'the Freneh-Figate Shoal whs seen nu tiv 3ril; the weather jroved basl, aml thoy were unable fo execute the work of examinisng this revf. 'I'he Eest was braking furiously upon it.

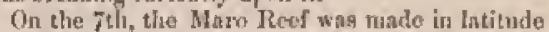
$25^{\circ} 24^{\prime} 2 y^{\prime \prime} \mathrm{N}$, longitude $170^{\circ} 43^{\prime} 24^{\prime \prime}$ W. Buttom was found at a distance of fum miles from the recf, with forty-five fathens of line. On the 8 th, they pussed aver the gite of Neva Isle, as hid demm by Arrowsulth, but no indientions of iand were secn.

On the 11 th, Lieuteant-Commandant Ringgold determined, on necount of the condition of the brigs, and the eontinumee of bad wenther, it whs impossible tu keep their course to the northwnd and westwnrd towards the eanst of Japan: he therefire latuled to the southwarl, which was much to be regretterl, and followed so very nearly in the enme track as that pursued ly the Vincenues, towurds the China seas, that nothing now wns clicitud by thent.

After a passage of fifty-six dinys from the Sandwich lslands, they drolped their ancliors in Singapore on the ighl of datuary, 1642 , all weil. 


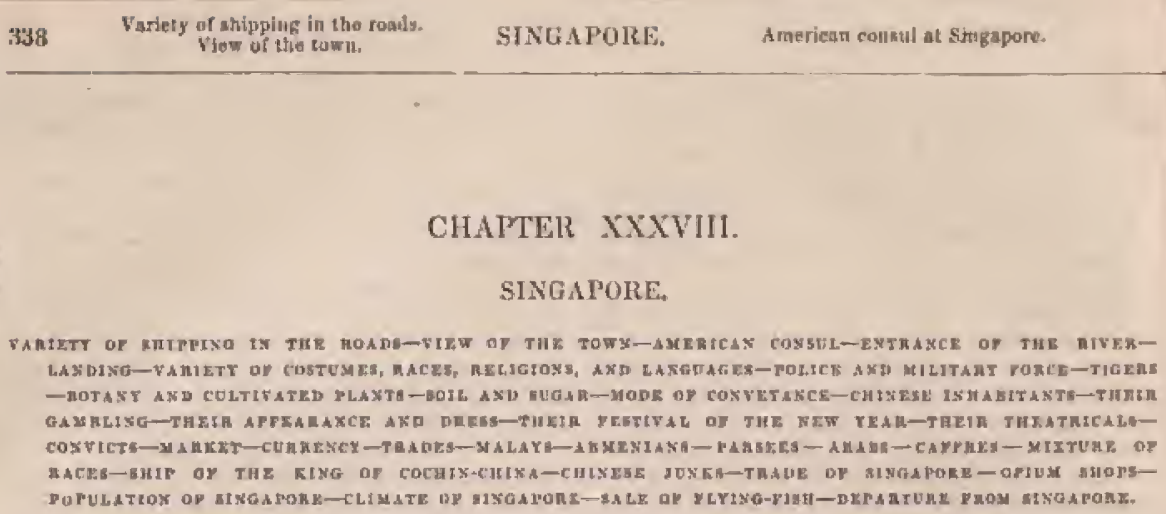

W $\mathrm{k}$ found at Singapore a collection of ahipping, of various sizes, from the tiny cockboat to the stately and well-formed Indiaun, from the vist. hulk-like junk to the light and skipping saupan". Not only were a great part of the vessels of a novel description, but their national flugs were equally strange. Many of the latter were now seon by us for the first time, and were diaplayed its visious ways; some Hew at ench masthead, others floated from horizontal yards, while tlie more cirilized nations wero distinguished by onsigtı peniest from the perak.

The variety in the style of paint and ormament was equally great. The Chinese junks exhibited their arched sides painted in curved streals of red, yellow, and white ; the Sinmese ships, half European in stracture and model, showed huge carved sterns; soul these were contrasted with the long, low, and dark hulls of the prahus and the opiumsmuggler. The two lattor classes perhaps excited the greatest nttention, in consequence of the war they are continually eurrying on against the groperty and lives, as welt no the morsls and laws, of the natives of the surrounding conntrics.

It is difficult to estimate the arerage number of vesaels that are to be seen in the raads of Singapore; for on somo days they appear crowded, while on others they are compatatively empty, While many vessels are tontimully arriving and departing, the Chinese junks alone appens as fixtures; more than fifty of them were eounted, with sails unbent, yayds housed, and rudders untung, in which state they resemble floating shopg, where in wo offered for salo assoriments of every article produced or manufactured in the Celestial Frupire; samples of which, by way of sign, are to be seen hanging about thern in alh directioue. These junks make no more than one voynge a rear, perfortuing their parsage in either direction during the favouring monsoon.

Unlike other ports, the water presents at first many objects to attract the attention, that the land and town remain unnoticed until the curiosity in relation to those which are afloat in satisfied. On tursing to view the town, its siturtion appests to be low, as well as that of the jigland on which it is built. The highent point of the Intter is not more than five hundred feet above the level of the sea, and even this elevation is distant, so that there is

- The ampan fin a liglit and eary-puliting bont, tamed at Singaporo to carry passengers to and from the hhpping in the rasds. mothing to dender the scenery picturesyne, nor has it tuuelt of the character that is stylet Oriental. The distant jungle, bowever, relieved by the white portious of buildings in the Europenn style, furnishes a landacape pleasing to the eye. These buildings seen to be upon the very beach, while a lill in the rear is crowned by the dwelling of the governor, near which is the the-ataff. The intervening space is filled with buildings, whose style holda an intermediate place between that of Europe and that of the Chinese and Malays, neither of which predominaten so much as to give its distinctive chatracter to the seene.

The utranger, after anchoring in the ronds, is not long befure he discovere the point at which the river dischnrges itself; fort ane continued streatm of bonts, sampans, and prahus, is scen teruling to a. point in the beach, where the entrance is partly concealed from vinw; neither eran tho lye long ignorant how large a concourse of various ruces is hero nssembled. Onr ship was crowded from an early hour with trilors, shoemakers, washerwomen, and venders of enriosities. The latter brought stsells, birds of paradise, nonkeyg, parrots, cumls, and mats, Without board there wero innumerable bunsbonts, bringing for salo freah bread, egrss, milk, chickens, and ducks, both alive and cooked, fish, fruit, anil regetables. All sued pitcously for per. mission to eome alongside, and made a prorligivus clatter. The fentures, dress, and language of the venders were as various as the articles they bad to sold; and they agreed only in the common cha meter of a dark skin. The epecinen thus presented of the population of Singapore prepnred 11 for the sight of the motley group we were to meet on shore.

At Singapore I had the plensure of renewing my aequaintance with Mr. Baleatier, our wortlyy consul. To him, his lady, and his son, we are under many ahligations for their kind treatment and attention. Mr. Balestier is so well known sumong men of science in the United States, jt would be needless for me to aay thet from lim I derived much interesting information relatiwe to the place, its com-

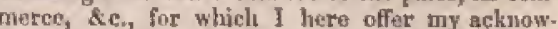
ledgmenta. Ho was exteusively engaged in the eultivation of sugar, on a plantation of one thonsind neres, within two mites of Singapore, nenrly half of which was under eutiration. This extent of ground he lass by lias exertions reelaimed from the jungle, and it bids fair to repay the labour and expense he has incurred in clearing and bringing it into cultivation. He is the first 
prexwon who has attempted the cultivntion of sugar at Singapore, and fur his suecess he was a warded the gold nedal of the Calcutis Agricultural Society.

As we passed tlırough the vessels with which the roads wore crowded on our way to the sliore, tho bum of voices was plainly audilite, particularly from the Cininese juaks, which seemed not unlike a human live. On reaching tho rnouth of tho river, as was to be expected, the crowd thickened, and the why became moro and more ubstrueted, until wo were faisly jammed among the sampars, with their crowded population. The river does not exeeed two bundred and fifty feet in width. It is shallow at its mouth, and passes through the centre, or rather divides tho old fron the new town; these are convected by a wouden brilge. As far up as the lridge, which is about onethird of a mile frous the entrance, the river is of various wijths, and its banks havo becn careftilly built up with stone, havitug stepg uccasionally fur the convenience of landiug frum the honts. A large population is on the river, dwelling in the eampans, which are all crowded with men, womers, atsd children, the latter nuked, ant froliching in aud out of the water at pleasure. Theas boats are nunged in rows on each side of the pansage townrds the bridge, and are confined by stakes stuck in the bottom. $A s$ ma be well inagined, thete sre frentuent acoidento and sisadventures, that enll for the exertise of the luugs of this crowdel multutude, yet during the many opportunities I had of viewing them, both by day and niglit, I have seldom seen a set of people apprurently so contented,

We landed at the luridge, near which is the nffice of onr cunsul, in a layge yuadrangular building, one side of which finces the river. "I'tue terms of old and new Lawa promise a difference of architecture as well as inluabitants, which they amply fulfil. The former vecupies the south-west or lefthand side of the river, and exlibits alung the quay a fine row of stuceoed or climanued warehouses The lower story of the grenter prart of theno is an areade supported by pillars at shart distances, 'Thoy are only two stories high, devoid of strebitectural ornament, but are convenient buildings for the trade. On the right are to be seen the puildings apprupriated to the government officos, 'These are aituated on an extengire parade-ground, studded with a few fino trees. The houses having extensive porticnes, and being adorned with tlowers in large vases, bave sather su elogant appenrnnee, but this is in part dissipated on a nearer approach. 'They are usually enclosed with low malls, surmounted by iron railings, within which are small flower-gardens, that do not, however, disjlay much Laste.

The bridge which connects the two towns is ly far the must attractive place in Singapore, for the constant passing and repassing aernss this thoroughtare makes it particularly amming to a stranger. 'The consul's roorus were su siluated at in enmmand a free view of Llis moving panorama. The aumber of Asiatie nations that frequent Singapore is aaid to be twexty-four, consisting of Chimese, Hirslous, Malays, Jews, Arunenians, Parsets, Bugists, besides Europeans. The raricty of costumo exlabited may therefore be ensily imsgined, and afforded opportunities for inquiry as well as amuse- ment. The bridge was particularly thronged duriug the first day of our visit, for it was n holiday, both witl the Chinese and Mahomedans of Hindonstan.

The trudes, as is usnal in the East, are carricd on is the streuts, and earpenters, blacksmithe, tinness, buteliers, lakers, tailors, barbers, crockery and opium sellerg, aut colfin-makers, are to bo met. itl sucecsion. Moncy'-changers are to be fouml here aud there, and largo well-8upplied shops aro not wanting, although their narrow sund contracted fronts give no reason to atuticifato their existence. That of Whangroa, our eomprador, was ono of the largest, and it ginve a better idea of Nonlis ark than of my thing else, presenting a mixture of living arimials, with every thing that is required for the artilicial wants of the shipling. In front wero all the varjeties of whip stures that Chinn sud Europe could furnish ; and in the rear wero poultry, pigs, slieep, and pigeuns, in pens aud eages, with various parrots, eocliatoos, and monkeys, while guantities of geese and ducks were accomnodated beneath with pools of water. Jetween the lire-stock and the gracerice were large quantitieg of vegetableg and fruit, besides lots of brend, flour, ank dough ready for the oven. The noise ocensionel by the cackiling, bellowing, crowing, and blenting, with the accumulation of fillh, surprised Hs well as disguster] ; for although it was reached at exry tivle by the wrter, yet there was ample neeessity for thit use of frooms ant shovels. The Clinese, thrugls elesuly in their pussons, are far frum being Bo in their general thatits, if we may judge fronı those that I have met in the places we have visited.

On landiug, that which impresses a stranger most strongly, is the great varioty both of costume aud of mee. Alnost every person that is enenunterul appenrs different from his predlecesaur, bo that it is some time before it can be doeided which nation sredominates; but ots reaching the old town, this is no longer doubtful, for the Clinese are souts found to he the most numveruus.

The variety of recligions aects also soons become evident. All have their places of worship, and enjoy the free exereise of their religion, so that in phssing aroumd, the musque of the Malomedan, the temple of the Clinese, and the churclies of rarious Cliristian sects, aro net with in their turn.

The number of rpoken langunges is such as to reeall the idea of Babel, and is excite a degire to lenrn the cause of such a collection of nations. "This is partly to bo fout in the firvorable commercial site of Singapore, on the gruat highway between the chstern und western nutiuns, und in the protection afforded to all by its beimg tancer a European power, but chielly in the fact of fis being a free port, in erery mense uf the word. Ali are allowed to visit it without any question being askod: pirates of nny nation may refit here, and nu doube frergently do, without any motestation, so long as they keej the peace.

I was uuch struck with the apparent absente of either police or military foree; but after some inquiry, I was satisfied, by the noler and general quite of tho mulcitude, that there must be a coutrolliur nower within resch, and found the policemen under the semblanee of Persinns, ensily distinguieluable by their neat and cleanly aprearamce. "They wro genernlly better dreswed than the body of the 
inhabitants, and are to be known by their red and black sashes, and turbuned hends. Without the precinets of the tawn, a regiment of Sepoys, six hurndred strong, and olficered by Luropeans, is statinned. These aro to be secul liabited like Finglish soldiers, in elcuse-loodied red coata, than which at more innpproprote dress in such a climate as this ean searcely be imagined.

The islund of Singmpore is composed of red clay, sandstone, and in sume places grmnite. The lneality of the town aptears to hnve been a salt-maral, with a narrow strip of rocks and sand nenr the bencl. In consequence of its rapid incrense, they are begimning now to fill up the low ground witl the surplus earth taken from the surrounding hills.

The highest point of Singapore is enlled Tuhuit Timn, and does not exceed, it is said, five hundred feet in elevation. Although this heiglıt is but seven miles distant from the town, I was told it has never yet leen visited by a buropenn and sel. dom by nutives, on aceount of the obstructed nature of the intervening country; there are a few small fishing or piratieal establislments (the two names are synongmous here, for when the people are not engrged in the one, they are in the other), on the north and west end of the island. The length of the island is twenty-seven miles, and its greatest breadth is fiftern. It is divitod from the perinsula by the old atrait of Singapare, so long followed by navigators, for reasons it is now diffieult to surnise, when the short, wide, and Bnfo channel was open tu them, which is now allogether used.

The botany of Singapare is far from being thoroughly known, notwithstanding 80 many scientifie expeditions have visited it; nor is it lifiely to become so very soon, infested as the woorls are with tigers. It is remarianble that before the island was inhabited, tigers did not exist in it, although there wero great numbers of them in the peninsula opposite; and it is said that they haves ouly mate their appearance here within the last six or seven years. Indeed, one of the rensons assigned for its selection, was the absence of this ferocions animal, and of the wild elephant. It is to bo presumed, thercfore, that the tigers come in seasch of food, by swimming over the narow straits. Some fifty persons have been killed by them within the last two years, within two miles of the eentro of the town, and two bundred in all are reported as having beeome victins to these heasts. Criminaly and thioves were formerly in the habit of escnping to the wools or jungle, but of late years this lias not been attempted by them.

The government, in eonsequence of the attacks of tigers becoming so frequent, and of the jungle hoing so much infested by them, offured n premium of one huudred dollars for every tiger's head that should be brought in. This indueed large parties to hunt thern; hut since the government have reduced the reward to fifty dolines, this daring business lias not been followed; not, bowever, from any scareity of the animals, for they now frequently geize men working in the inmediate vicinity, but becanse the sum is ton amall to be an equivaleut for the risk and trouble.

The soil of the istand is a stiff yellow loam, in which the autrneg, coffec, black pepper, chncolate, and gambogo (garcinis), grow to a great extent. Tho threo first appear to be particularly well ndapted to the climate and soil. The cultivation of sugar is attended with snecess. Captain Seatt is phanting the durian, whieb, independently of its fruit, yelds a timber highly valued for ship-building. "This gentleman has left numerous forest trees atanding on his plantation, many of wlich sro of large dimensions, being full one hundred fect il lieight, These consisted chiefly of species of querev6, wyrtaces, nuelastomaces, and rubiacese. The undergrowth is alnost impenetrable, on account of the vast number of creeping plants which intertwine and clasp around the trees. Two species of nepenthe (pitcher-plasts) were found in the swamp, which were preserved and brought to the United Stntes.

Fruit semed to be very abundant, and it is anid, that there are one bundred and twenty kinds tlint can be served ss a dessert: nmong these are pinte-apples, mangosteens, melons, bananas, ormuges, sic. The pine-ajples are remarkably fine, nnd not in the least acid; in proof of whicli, they do not turn the knife black in euting them, and to eat them in considered wholesome at all hours. The season for this fruit was just coming in at the time of our arrival, and large bost-londs were senl lying at the quay. They are usually planted nlong the rondside, aud though, when small, rather stiff-looking, yet when full-grown auml in hearing, they are a pretty object. Of all tho plants we saw, the nutmeg requires and receives the greatest care. The trees are planted in orchards, and while young lase a surt of arbour erecterl over them, to protect them from the vertical ruys of the sun.

The garnbeer (nauclea) also claims much of the attention of tho cultivator: it is B low-sized tree, or bush, of uo benty. Its bark is used for tanning, and it is anid to be the most powerful astringent known for this purpose. It is to be seen in the shops in the form of a powder, of a roddish brown colour. We did not lenrn how this wns prepared, or how it was used: it appears, however, to be in great demand. It is oecasionslly used by the Chinese, with their betel-nut, of which there is $n$ grent consumption here, nlilinugh it is not sold in the strects, as at Masilin; but quantities of the nuts wre seen for sale in the market. From the teaves also a powerful astriugent is obtained by boiling.

The gamboge tree is also cultivated here, but mure extensively on the shores of the strnits thm at Singapore, and is a very considerable article of traile.

The rite outsile of the town to the hills is pleasant, passing through phatations loaded with fruit, and the nir at an enrly hour of the morting is filled with a spicy frogrance. The vivid green of the woods and grass is also remarlanble, and con. tinueg throughout the wlinle year, for searcely a dny passes but a refreshing shower falls. The roads are tlus kept free from dust, and at all times in good order. The usual mode of conveyance is in a palaugquin, which is capable of containing two persons. The couley, or Hindoo who attends his horse, usually runs by the side of the patanquir, and seldom tives, 'litic charge for one of these conveyances is a dollar, whether for a wholo or a part of a day, and a douceur is paid to tho conley according to the time he has leen employm. The palanquin is a very conrenicnt vehicle, and its usc 
is absolutely neeessary during the hent of the day, to shield the stranger frons the buming rnys of the suil. These conotey's will run wll day through it without any incolsvenience, They are primejpally from the neighlourhood of Madras, and are generally about the midille siza, thin, and nuseular.

Wo found, on our arrival, the whiche of this motley population engaged in a festivul. With the Clinese it was that of the New Year, and with the Hindoo Mussulman the feart ealled "Marmuma," or the seareh for and finding of the grandehildreu of Moltaned. The Chinese, on such ocensions, give themselves up entirely to ganbling; nni the first day and night I was on shure, this part of the town might be eunsidered as a vast gumbling-shop. During this holiday they are allowed to ganible as much as they please, bnt what restrielion is put upron the open indulgence of gaming at uther times, I did not learn, but from appeasmess I shond suppuse it was uot very Bevere.

The exteat to which garning was carrieil by the Ctrinese cuuld not fail to astonish any ond who had not been brunght up to it. It was extrametinary to see all engagenl in such an exoiting vice; ma to watcls the different individusls was tumusing Ganting whs going on in every shop, and fregutently in each particular corner, under the enlonsades, in the bazaras, and at the comer of alnust every street a sariety of games were playing. Of severa of theso I had no kuowled ge; some were performed with carts, and others with dise. The stnlie seomet generally to bo in simall eopper coin, calleri pice, about five husdred to the dollar, each of which is valued at three cowries; but althougl this was the usual betting coin, the stake was sometimes silver, and at times to a consitlexul, le amount Those who have not seen the Chiuese play, hase never witnessed tho spirit of ganbling at its height their whale sul is staked with their money, however strall it mus" be in amount, and they nppenred to the to go as eamestly to work as if it laxd bees for the safiety of their lives sud fortunes.

Alawost every ane las formed to himaself an idea of a Chinese; but to be well known, he requires to be seen on tris own soil, or where he is in inter. course with lis eountrymen. The different individusls of this race seented to us to have a strong resemblance to each other, and although this may its part bo owing to similarity of dress, it is also the to their trodily conformation. The flat chest, in particular, is poeuliar, at least to the lubouring class. All of them seem active and attentive to their business, of whatever lind it may be, and as far is ontward expression and netion go, an harmless as lambse It is oumewhat reurarkiblule, that the very sign which was put upon then by their Tartar conquerors to mark them as a subdued race, should now lavo becono their mutional bonst; for nothing seerns to claim a Chinannu's attention so much as his long queue, and the lisuger and blacker it is the more it appears to elaim his admirution. Wo frequently saw it tonching the very beels, and tied at the end nestly witl a bit of riband. On rreat oceasinns this langs down to its full length; but at other tines, being somewhat in the way, it is wound up ont the back of the head. I have luetrd it asserted, that the Chinese nover becone bald or gray; but this apinian seemed to be ermoneots, fron what 1 gaw iu this sunll cummunity.
The Clinese is at all limes to be found industriously employed, exeept when gambling; and were it not for this Jatter propunity, and his desire of elreating foreigners, has jurblably as fow vices as exist in any uther race. Wherever he is fotmil, prace and quictness seem to dwell; ho moves, rand las been moving for ages in the saune path, aud prefers all his own ways to those of the rest of the world. We gaw the Chinese in some pleasing lights, and were rumch struch, on these festival occrsions, by their attention towards their children. and the fondaegs and invariable hindnegs with which they wete treated.

Before ceasing to squeak of Ite Clinese, I shall give a brief description of their mode of colebruting the New Year, although it was diffieult w $[n]$ low it, and still more so to moterstand its full useaning. The ceremonies consisted cliselly of proeessions, both by night and day, in which the whole Chinese populutiou seented to be engaged. Tho grand one bure a sort of silken temple, which was carrier on tho slioulders of several men, with banners before and behind it, having Chinese chat racters on them, and of the moet gaudy colours. These were preceded by music, if such it could be called, eonsisting of cymbals and gongs, on which every performer strove to strike with his utmost force, and, if possible, oftener than his neighbour. Noise they at leist erented in perfeetion. This procension wats ocensionally joined by amaller ones, and the whole seemed to afturd both to the erowd and actors as much anusement ns it did to us, to whon it was altogether new. During the vight, and particularly on that of the 21 of of Febriary, lise last day of theil year, the illuminated proces. sions were curtious, as well as amusing, and wero execedingly numerous. Sume of them wero to be seen in erery strent at the same time, and no swoner lund one pused clasu whers were seen to follow, all husrying along as if there were some goal tis be reached. The jllumination ['tuceeder frotn lanterus of all colours, sires, and shapres. W'

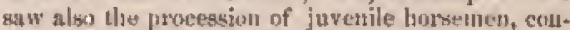
sisting alingether of ehildrets, Einch of them bore the fore and hind parts of a hosse in sueb a manner that the cliblu represented the rider. These mimic portions of the quadruped were made of paper, and illuminated. The elfect was that of a mininture regiment of cavalry. Others were represented as if on the baclis of fish, that seerned to swim along in the errowd. Some of the children were not mone than two years of aye, and the oldest not more than five or six. They were all fututatically drossed, and some among them in Luropean costume, which had a grotesque effect among the ruore appropriate dressea of the east. They niere ded about preeded by antsic, such as it was, of gongg and cymbals; and all passed by ous a dog-trot. Tuwards this elese of the evening, some of the children frad attendanta or each side, who enrried the peror litch fatigued creatures along, many of whom were tienrly, if not yuile asleep. Whemever this procession latterl, the Chintse would load them with eakes and dulees, and sluwed a hiudness sud attention truly pleasing. The most extraordinary exhibition uf the evering sas an immense illuminated sea-serpent, which wo all thurght fully equalled, in size and moxement, the famous New lingland one, and agreed in other respeets uhlerably well with its deserijption, for he had at intervals large buusps of the shape of an small 
casts. Theac were in fuct lnteras, eupported by poleg, arsd eonnected tugether by white cottuin is gauze, which was here and there coloured. "The head of the inonater wns of large dimensions, witl a wifle-extended mouth, showing its fiery tongue and rows of sharp teeth. 'Tho movetnents of the serpent were wel! rumaged, and its gyrationt, twistungk, and windings over the people's heads, grave it a formidalfo look. It appeared as if in seareli of at: illmminated glolse, representing the old year, as the serpent is supposed to typify the new one. It was, from time to time, permitied almost to seize the globe, which was thell hurried away, upon wlyich the ponderous jaws would come together with $\Omega$ cmuli, and then the serpent would liurry onward again in hot pursuit. I was told that it swallowed the globe at the expirntion of the year, but I tid uot speak to any one who saw the finalo. The figure of this servent was from eiglity to one hun. dreal feet in length, and two feet in diameter.

During this clusing scenc of the festival, all the Chinese houres were open, and the josit-liouses and idols illumintated with wax เondlos, and decked with thowers and lijssel.

'Pheatrical exhibitions were at tho aame time going forward in many places; open slieds are erected for this purpose, where the exhibition was entiruly gratuitous. 'The setors, I was told, are pait by a seneral subecrition, which also provides for the other expenses of the spectucle. Trese slyeds are closed on three sides, hut open on that which faces the street. The strige is mised alsout bix feet above the street; the whole is richly deco. rated with silk hangings, and banuers with many irrseriptions, sum illuminated with colutured lamps. "Flo otnge, which was by no menes of larye sizc, was oceupiel by a table and two chirs. The dialogue was in a kind of recitative, with an acconpatriment performed by beating with two small stieks on the hottom of a copper kettle of the shnpe of a coffec-pot. The person wlia performed this duty appeared to direct all the spectacle, as prompter and leader of the oreliestra. The other musienl intrumetsts were the gong, cyubuls, and a kind of hautboy', the holes of which are not alpunged with any view to produce harmonions souuds, The dresses of the actors were very rich, and the fentales were repuresented by youm men or boys. The male claractors were for the most part mastiod, but not the female; the former generully had long black aud white beards, The prineiphal part of the performaneo seemed to consist in attitudinizing, and appeared to interest the nudience, as it did ws, aleliough accorting to our jcleas it was not suited to the words or sentiment; for instance, during a pathetic purt, whilsk the actor was shedding tears, he would suddenly throw up one leg, and almost kick bimself on the nose! The acting, upon the whole, was, to our notions, in a muck-heroic style; but this might have arisen from our not being able to comprehend the meaning, for the ofler spectstors seemed greatly inrerested. Thuro was sonething, however, which there was no diffienlty in onr understanding, and this was the figlolisg. The two combatants draw their swords or handle their speurs, and begin turuing round poking at each other withour closing, when sudduly atse runs off; the other, after having evidenty infurmed the atwience that lhe is the vietor, then makes his exit, aceompanied with a mogt tremendong noise from troth the musie and audience. After the performanee lond clused, it whs with diffeulty that I could detemine whetior it lind been contedy or tragedy: whielyever it was, it was mingled with still vaulting sonsersets, cart-wheel motions, and ensting themselveg about, judifferent as to what purt they fell on, in modes which I may truly say, I had never seen surpassed, either in muscular actiun or agility.

The convicts sent to Singepore are employed upon the public works; and a large prison in the suburbs of Singapore is provided for their safekeeping at vight, or when not at work. I was not able to arcurtain thoir exact number, but I believe it smunts to sorne tifteen bundred.

'The market was well filled witl venders, so much so, indeed, that the passnges through it are rendered nartow and tortwons; tho principal article for sale was fisl, fresh and driect, nud prawn. 'This kizd of fish is numerous aud sumudant. The part of the market where they are suld is built over the water, and being furnisled with a loose Hooring, the filth is easily got rid of. The butcherments cousisted for the most fart of pork, which is rnised in latge guantities. Fowls and ducks were alsn very numeruts, $A$ number of eggs were nees with the slsell broken, to exhibit the clend clvicken, and others that were rotten, in which state they were favourite food of the Chincse. Vegutables and dried fruits were also in great aluurdance; these lntter were imported from China. Of vegetables, tler'o were lettueus, onions, garlic, sweet jotatoes, and large quantities of germinating rice, which is sold for planting. Of the quantities of fresh fruit it is almost jnpossible to give an adequate idea, and they are all of fine kinds, many of which I lund nover before seen.

The bazars form the general resort of those who frequent the market. Every avenue, areade, or veranda approaching it is filled with money. chnngers, and small-ware dealers, eager for selling European govds, Cluinese toys, and many other attractive curiosilies. It is necessury to be enteful in making cven the smallegt offerw, for although it may be but half or a fonrth of what is asked, it is iniataully neepted. The money-clungers seem to be a preculisar class; they nro tminh darker in eolour than the rest of this singular throng, and are seen sitting cross-legged on their tahles, with extensive rouleaux of cupper coin, heapgs of cowricshells, and some silver.

The Malay population dwell chiefly in the suburbs, or what nre termed the Malay villages. The Malays seem to bent the palm for idlenesa arnong the common people, and are rarely found engnged in any steady employment, jreferring thuse that are cither light or of a roving ebracter. They engrose the aceupation of the drivers of palanguins, are strong and retive, and will run ॥ great length of time and distance, in a hot and oppressive day, seemingly without ineonvenience. 'llusas of the latter sort who aro more wealthy, inclulge in many Joxuries, porticularly in dress. Tllny ustualfy wenr mustucheg, which are always nenty kept, and oceupy no suald grortion of doerr attencion and tisne; and, controsted with the white turbau, witle its bant of searlet and gold, has a particularly pleusing effect, witl their swartliy skins. On holidays they are to bo met with it 
their snow white rainent, thrown over a richlyembroidered coloured vest, fitting tight to the body, with loose trousers, tied just to meet their embrotdered slippers at the snkle.

The most distinguished men as to looks are the Armenians. Although few in number, yet they hrse much influence from their wealth; they are aIs exceedingly handsome race, dress after lise English fashion, aud generally speak Linglish or the Portuguese fluently. Some of them, thint I bad occasion to visit, were extremely cunrteous, but spoke of the inlabitants of Singapore generally as of a low class. The Amenian clsurch is one of the finest bujldings in the place.

Parsece are not numervis nt Singapore, but they mak nmong the most wealthy of its inhabiturts. 'L'hey are dressed partly after' the Eastern and parily after the Europens fastion. They excited our attention as being worshippers of fire, which they venerate as emblematical of the Dojty. They are of various flades of colour, and generally more robust and portly than the other mices. MIany of then spenk the English language.

Some persons, who were snid to he Arubs from the east const of Arica, were also printed out to me, who were quite diffurent from all the other races. They had what would be terned woolly lair, with large whiskers, and one of them was remarkable for his large blubber lips. Their com. plexion did not strike any of us as being much darker than that of the Hindous or Malays. Their face was long, and the nose by nn means prominest: one of these had a strange apnearance about his hend, and it was some time before it was discovered that it whs owing to his beard and whiskers, which were long, being in grny and black stripes. Although it wo undonbtedly done by some atifieial process, yet it scemed quite naturnl.

Individurls of the Caffre tribe, from the east coast of Alrict, were slog met with; and it is anid that there are many of them in Hindoustan, whither they lave been earried by the kinglish from Mozanbique; but they are rarely met with so far east as Singapore. They resemibled those seen by I\% at Rio, though we had no opporlunity of identifying them by their tattooing.

One of the most nmusing ineidents that ocetired dnring our stay at Singapore, was a visit to a slip of the king of Cochin-China, which we marle by exprese invitation. The whole trude of Cochin. China is a monopoly in the hands of the king who owns the ships, which likewise comnoge part of his unvy. They are built after the European model of some half a cotury back. T'le veasel that furnislied it belonged to Frrutee, and was wrecked on their coust many years ago, after whicl missionaries and artisans were sent out by Lonis XVI, who taught them many of the arts of Europie. The outward form of the old French sllip appears to have been pretty well imitated, but the stern is more elaborately earved and umamented with gilding. The internal arrangements slso show a great variation from the model, and in them tho tustions of the Cochin-Clanese prevail, uamixed with those of Europears. This two khips were about five hundred tons burden; they guro very rouglily built, linte buge aterns, and exeeedingly thick sides. Indeed, every thing on honed is unsightly, and all the work is of the rudest deserip- tion, giving no very high idea of the proficiency of the mechnnies of Cochill-Chins.

These resscls have a middle-deck, which is pierced for guns. The cabin, into which we were atsown, had a josh-temple, and with josh-stieks burning. There were two cabins; that under the poop had small roons, and was rery low between decks. There were no fixturey, but simply a mat to lie on. The binnnele is a bed of sand, in which the compuss-box is set for security; and a number of small, coloured sticky were stuck into the sand, which were reprosented to be markers, by which the way of the ressel was noted. A manuseript elart, which the enptain took great pride in exhibiting, was slown tus. This was evidently a eopy of an English one, but all the narnes were in Chinese. The erew bad a decided Malay look, and were smalt men; they are in form stont, but are not athletic. Thero did not appenr to be any mix. ture of races among them. As we jassed around the deck, we observed a prurty of five or six of the men engaged in gambling with eards, in which they were so much engrassed, that they heeded not the command of their oftieers to desist and make room for us. This vessel was furnished with rattan-eables, which wers exceedingly well male. The wheel for steering sppeared odd, on account of its small size, and the leelntsman sits when he tnkes his trick. On cither side of the deck, just abaft the foremast, there is a cook-house, formed of a liuge box of eartli, mout three feet above the dech, in which a few large stones are set to bupport their earthen cooking vessels.

'The ofticers and men liave but a small pittance of pay. The captaill, for instanee, I was told, received only three dulars a month. A supercargo or faetor is sppointed for ench voyage, and is obligated to do all the business for his nuster, and take charge of the whole commercial enterprise without receiving any of the profita for the sucess of the undertaking; he is also held to be responsible, and bis property is accountable likewise for any depreciation in the foreign market; and if any suspicious fall upon bim of mismanagement, he is sure of the bastinado on his return. The consequente is, that tho king of Cochin-Chins is a suecessful merchant, grows rich onl his commercial speulations, and is always well served. The recompense of the factor is but a small quantity of rice.

Four or five of his shipe resort inmualy to Singapore, loaded witlı sugar, coffee, ivory, and mnny other articles of less inmortance, in return for which they take Britisls and India goots, fire. arms, iron, glassware, kc. 1 have been informed that his suceess in trade has been such that out of ita profits within a year he has added a stoamer of six hundred tons to his navy.

$A$ tmust every one has sonse idea of the external form of a Chinese junk; but the arrangement of the interior, although of grent antiquity, was new to us all. From the appearance of every thing on board, the arrangements camuot have clianged much in the inpse of many centuries. The junks are of varions sizes: the three that were visited were from serenty-five to cighty feet in length, nbunt twenty-two feet bean, aud nbout eighteen feet high forward, rescendiug in a ctrve to withirs three or four fect of the water smidsthips, and then again rising in a like curve to the height of twenty- 
five feet. At the top of the stern is the poop-enbin, with acenmodations for the master, his clerk, and the trader, in four stmall sleeping-rooms; under these are other cabins, with ats ening spartnent, and before this is a platform or small deck, from which the vessel is stuered. The rulder is an extrarilinary pieco of woorl, fully equal, in poinc of size, to that of a line-of-inttle ahip. While in port it is always unshipped, and drawn in to the vessed on a smail inclined slip or way. The junks lave ustally two large masts, with a jigger, and there are nn less than three wiadlasses, which are used upou every aecasion; without these the junkm sould really be almont unnangenble. In order to preserve the vessel di'y, they have watstiontuls of solid thick plank, which are urshipped is port; there ruacl from the plask-pheer to the rail, and from appearances effectually answer the zumpose for which they ret intended. The cargo, however, was more interesting to us than the vessed: Whis consisted chictly of teas and chimn-ware; the hatter, to ous strprise, wo found neatly mud efrefully stowed in bulk is the bold. The lighter articles of Chinese ninnulincturo are atranged about the vessel, and even hang over the poup arr sides. The wooden anehors, eables, grass mpes, ofld and curious paintings, the grotes(pue mode of extormal oruament, with the large eye on either bow in the culours of the rainbow, did not fril to attrnct our attention. We were alsa amused will the junk-like form of the tiay boat, but thess, as woll as the Chinamen themigelves, are so well represented in Chinege pietures, that no rise ean be at a loss to conceivo their peeslisu form. Worda fail to express the content and prisle with which the Chimuman sits and enjuys his aymatic excursions ; and thongh ridiculous in appearanee, and ill fisted in every way to contend with the elements, yet there is sunseitsing nbont the junks that communds a certaiu degree of resquect.

The tracle of Singapore, although it thas but lately grown up, has nevertheless renched the large aggregate of $24,500,000$ dollars. Abont one-sixth of this amount goes to Grent. Britain, and $600,0(0)$ dollars to eontinental Furvere. Thene are no ilities on imports or experts, und every veses! in left free to come and go ns they plonse; all that fo askerl is of what the cargo consista, its value, ass the gize uf tho vessol. T'hese particulars are publislied wechly in the only paper. Every laug is sold for esah, or un a very shore credit, and all secounts are kept ist dollars and cents. Perlings in no other port is lousintss tundueted in so prompit $n$ manke as at Singagiore, and this las probably grown out of the transient churacter of thas risifers of nll Hations, who cotne and go an they plense, which malies it necessary to receive paymetih fur the grods als soan as they are delivered.

From what lans been already suid, it will appear that very fittle of the importanee of Singnpore is owing te its Dwh proditetions; yet there are many things shipped here that are the produet of the Strnits, or of the territory under the Strait Government, as it is exiled. Aimeng these are pepper, cloves, sugar, nutmegss, coffee, and gamieer, to which may bo added the leted-nut. These products are prucured from Pinang and Prince of Wales Islsul, and reach a large minount. Tortoiso-sliell may also twe iucluded in this trade, for almost alt that is taken in tho Easterts acas is now brought to Sirgapore for Eale; and it may indeal be said to be the clisef mart of that article. Any attemnt to give a catalogne of the trade of Singapore would fall ghort of the truth, for it may lie eonsidered as at entrepot where all artieles arrive and are distributed. Tha expenes of doing businesy are estnblished and publistred in the gazeltes, so that any one may inform hinaself of the charges lie is liabite to incur, and of the adsantages it has in that respect over the other ports in the Eastern seas. What renders the truffic at Singapure atill more compenient is, that almost exery thing is sold by weight, jutabuly because so large a proportion if the population is from Chinn, in which country this method is labitual. In employiug it, however, the articles from different sumatries are sold by the weight of tho coustry whence they come, Fur instauce, gold-dust being for the most part brought by the Mialays, is sold by their weight, ealled a "bunglial," which is nbout equal to two ounces rice, se., the produce of Bengal, is sold by the bag, containing one hundred aud sixty pounds, which is termed a "umund." The foreign business is genemlly in the hands of a fow Euglishl houses, but the greater lart of the mercuntile clases at Singapore are enghged as agents, or do a corsulission business, for various houses in Furope, Calcuta, sc. There is a branch of the India Batk at Singapore, which, however, is limited in its discounts and husiress ; and there are besides n Jarge number of insuranev attices, in which polieicss may be effected on almost any risk. T'he espital of these companieg is for the inust part uwned in Caleutta.

Although Singapore tar fewer real advantages for trade than numy of the ports nround, yet it lias now acquised the suporiority, and holds intereourse with the surrutnding eumtries.

Its trndo with Chus hus of late much increased, in consequente of the diftienflies between that country and Bugland, duriug whicl it was the only port where the junlis were allowed to trade free of inolestation. It in conseguence liecame for the time a place of transhipment for teas and otlier Chinese articles to English vesects. For this reason, Singnpore may lawe appeared to us a more active place of lasiness than it wonld have lune last the tracle will, Cliua been no more thun urdinnry. No large connneree call well exist betweon Chisa and Singaprre alone, fur the supplies the Iatter furuishes tu tha: empire sre confined to thirds'-neste, biche-dit. mar, tortoise-uhell, \&c.

Borme probably furnishes the most valunble produets thint are brought to Singuport, and there: are mure than one londred probus enguged in tles trade 'Tlitse are for the most jant. nityignted by Bugis fiom the istand of Cielebes, who inay be termed the carriess of this arehipelngo. This preaphe frequent all the ports on the south sad southwest side of that grent twiand, and are frequently eaployed by the rajoins or chiefo to cunduct their trade with the other prorta. The restrictiolus they are under in visiting the Buteh possessions, ani] the restrictive poliey of the later, whicl simits them to but one or two ports, has driven them to seek that of Singapore, theugh nore distnnt. These pratus ne suid wher trate or tujploy. went fails, to turn their attention to piracy, if a 
favonrable opportunity should offer ; though no ane secmed diaposed to class them as pirates of tho sutne chumeter as the Matays, but rather to lowk upon then as generally inclined to be peaceable.

The ialand of Celebes serds to Singapore nearly a foudred panhus anmually, and they also eume from Flores, Timor, Amboyza, Sutnlywa, Lubok, and ovell from Papua and $\Lambda$ roo. From the latter countries they bring the bird of paradise, so abundast in the natket of Singapore. The prataus that conre annually from these distant ports nre not mun'c than bifty in number.

With the porta of Sumatra and Java there is a great dea! of intereourse, nud I was fold that the native vessels engaged in it, independently of those betouging to Luroptasts, anกunt now to kome six liundred. These are of various sizes, and keep up as constat intercourse, solne of them visiting the ports scveral times during the year. These nrrive from both cotsts of Sutnatrit, and fielong to the rajals or clviefs of small plices, of which even the names are bittle knuwn, and whose suljects are mostly engaged in piracy. Tho islant of Bali likewise engages in this troule, through the agency of the Bugis. The prodicts of the Madayan pentisula, and of all the ports of the Malicea Struits, aro also buought to Singapore; but these may be sermed incidental supplics, for they fluctuate muck, both in guantity and sulue,

The most regular of all the trude is that with the islands of Rhio and Lingin, in the neighbourhood of which the Duteh have a facury. 'This trade is carried on in the sampan bouts, and the people of these plines prefur resorting to this free port to dispose of their produes, rather than sell it to the Dutel. 'Tho number of the vessels employer in this traffic was represented to me to be somewhere nbont five hundred. The articles brovght from all theso places are very mush the mane, and comsist of pruper, riee, camplus, sago, eoffer, nutmegs, oil, tohnced, wax, betrzoir, seaweed, dragon'y-blood, biche-de-nar, birds'-nests, tortuise-stiell, dinmothds, gold-dust, presuls, the pent-oyster-shell, samdalwood, ratıns, ivory, some hides, und articles of native manufacture, such as saromigs (wort as a wrapper, which cons prineipally from Celebes), snlendungs, and thequerod ware.

I'he foregoing detnil exhibits a rast variety of articles of commeree, and nccounts for the employnuent of the hifteen hundred, or two thowsand reg. sels of varions sizes, that are continually pouring into this mart. It ruay readily be imagined what s stir and life this comneree must creste; und when it is considered that nearly all the various mations of the Einst resort here fur the purpose of tmode, it will jot exeite much astonislinent that Singapore has grown up so rapidly in the face of older and lunger-established marts, which it bids fair to surpuss, both in wealth and importance.

The opitm shops are anoug the wost extranrdinury sights in Singapore; it is ineoneeivable with what avidity tho smokers seek this noxious drag at tlee shop windows. They then retire to the interior, where a number of sicklydookiag persons, in the last stage of consumption, haggard, fand worn dow's with cau'c, are seen smoking. The drug it snlt in very small pieces, aud for ten cents enough to lill a pipe once is olstaiued. With it are furvisherl a pipe, a lamp, and a coucls to lie on, if such it may tho outhed. The jipe is of a peculiar construetion, and is in part of metal, lasving an interior or eur just large enough to contuin a piece of the size of a pea. The opium is diflicult to junite, and it re. quites much management in the smoker to obtain the necessary number of whiffs to protuce intoxication in one labitunted to its use. The couel is sometimes a rude bench, but mere often a mat on the floor, with a smail mised bench, Each of these mats in the frequented shops is generally oceupied by a pair of smokers, who have a lamp between thetil.

These shops with their jumntes formed one of the mast diegusting spectacles I saw during our extended ertise; although, to the who could be anused with linman degtadation, this sight could not have failed to ufford pastime.

It was not difteult even for a strunger to distinguish those who lnwe lung indulged in this jer. nicious practice, from those to whom it is yet new. The engersess with which the former sought the mat, seized the pipe, and islualed the smoke, showed a nervous ansiety to rench that point where forgetfulness should come. This in the thovitiate way but the work of a few misutes, while those whose organs had becone aceustoncel would draw long whiff's and puff away until the wentiened state of their lungs would betray them, and cause then to sanp to renew their breath before they were cuabled to accomplish their wishes. I jearned that many of the old smokiers found so grent a diffieulty in inducing the netion of tho smolie, that they wete aceustomed to lave recourse to swallowing the drug itself. The Clinese only aro addicted to this practice: the Gentuos and those of the Moslem faith look upon it with great horror and dibgust.

The individuals whom I have deseribed shove are the wealthy, who can aflurd to stuoke the drug as it is found in commerce, From the difficulty with which it lurtis there is a large residnum lefi, which is carefully taken out of the pipes, and sold to the less opulent, who in like manter smuke it, though withunt the luxury of mats and lampe. I was told that there is stilt a poorer class of Chinesce, that again use the residuun of this second suoking.

The Chinese at Sitgaprore possess every facility for full gratification in the smoking of this deleterious drug; for there is no interdiction to its introduction, and most, if not als the vessels engaged in sanuggliug it, resurt there in their passnges to and from Bengal, and many of them are owned or under the arency of the merchnnts of this place. It is not a litule remarkable that even those who are engaged in the trade, eutidemn its imnural and hurtini results, while others at a distance offer towny reasons in its defenet. I must say that it appears to me truly strunge that with the secness that daily uffer thenselves in Singaprore, before the eyes and under the engnizance of the governor aut officers of the place, sume sheps should not be cakess to put a stoji to tlue practice sltogether, instead of making it a souree of revetune.

The population, from the most authentic returis, is in all about sixty thousand souls: of these forty-five thousand are Chinese, eigliz thousand Mninys, seven thousand nativey of Iudin, and about oue limindred and fifty foreigners; aud unly oneteath of the whole are females. 
On my arrival at Singapore, various reports were made to me of flefeets exisling in the terkle: Flying-Fish. It was to he expected, after the arduous sersice slie laad periormed; yet, having brought her safely thus far, 1 folt a matural desire to carry leer home with us; nnul in this all the ofticers seemed to partake. But the iden of risking the lives of her officers and erew, after tho disaster that had already befallen her sister cruft, was not to be endured; and I saw that it was neceseary to have a thorough examiustion of her beforo I ventured her in the homeward voyage. I therefore ordered a survey by the most experienced persons in the squadron, who, although they could not point out any conspicuous defeet, were satisfied that from lume and hard service she liad become weakened in lher fmue, and that she would not only need much tirne, but a lange expense, to plaee her in a fit condition to make the voyage home. I muat say that even after I had reeeived the report I still felt a strong inclimation to persist in bringing her back to the United Strtes; but my final decision was against it. The eonsul was therefore desired to advertise her for sale, and in the mean time all her stores and armament were removed.
She was, agreeably to the notice, sold at public sale fis three theusand seven hundred donllırs. To part with this vessel was unplousant on many accounts; for she lad been dnily, for nearly fois years, my first and last thouglit. The atinchmeut I had felt for ber was great; the efticiont ait slle had occusionally aftorded in the prerformance of my dutica, esused the to value her highly; and ns a ressel of her class, she was almost faultices.

By the 25th of February, wo had completed fill. ing onr water, which is hero enveniently supplied by tank-boats; and having obtained for the pasage home all the stores wo nedded, rexeept bread, we made every preparation for sailing.

In eonseguence of the short supply of the latter article, I duermined to touch witl, the Vincennes at the Cape of Good Hope; while the two lrigs were ardered to stop at Rio Janciro, for the same purpose, as well as to obtain some further observations, and sddilional squeimens of natural histury.

At five o'clock on the morning of the $26 \mathrm{th}$, I took advantage of the land-breeze, and mado signal to the Purpoise and Oregon to get under way.

\section{CHAPTER XXXIX.}

\section{CAPE OF GOOD HOPE.}

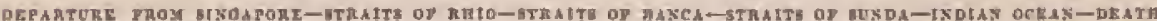

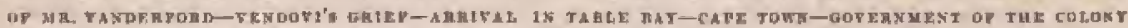

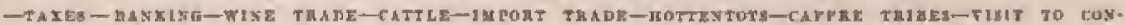

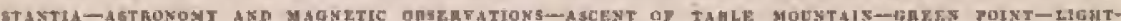

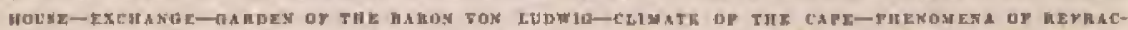

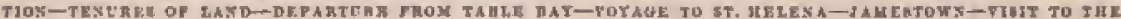

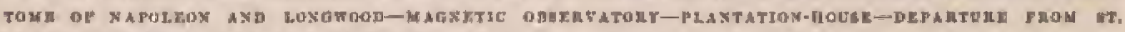

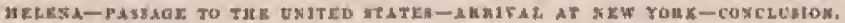

Afrer leaving Singapore, I determined to pass through the Strats of Rhio, a rute which J deemed the shiortest and beat. for ressels bunul through the Straits of Sunda. We had light winds and rain-sijualis at the entrance of the struit; but towards the afterzom we were fnvoured witla the nurth-enat breezo, which carried us rapidly onwaril. At night I atuelored, wishing to exanine note particularly the churts extant, und to make what curreetions I uight deen necestary.

The next moming ut daylight wo again resumed nur route, but in conseguence of fog were obliged to anchor off the Dutrh factory at Rhio, where a furt is established. This war first occupied in 1824, niter the cession of Malacen.

The island comains but fow inhabitants, and those fow are not intlinsd to uno under the Dutch authority. From all I condl lenth, there is very little inducement fur a ressel to resurt lieto for urade, The ieland is considered extremely' unliealtyy for foreigncts during sereral montlis of the year.

When the wenther elenred off, we nimin passed down the strnit, and on onr arrival off the southern point of the islands, we steered for the east proint of Lintin, which island we passel on the agth, on atur way to the Straits of Banca.
On the morning of the 1st of March, we ipproached the northern entrance of the Straits of Banca, nnil got $n$ view of these low and uninterestfing consts.

The enme afternoon, we fell in with a barque, under Dutcly coluure, which refused to answer our hnil as we passed; wo imuedistely wore olip, ath fired a shut; thon which they let thy all their batyards and wheets. A buat was aeut on board with an oftieer, who discovered that hie was manued by Malays, fund that no one on bond conlel speak English; lowever, ho managed to umilerstand that they were from Palamban, Sumatra, and bound to Singapore. Soon afterwards, we saw the lutch establishment of Mintuw; it is situnted on a knoll, at the northers end of Banca, and liat the Dutel fling fiyjug oster it. 'l'he ureater part of Banen is low land; the northern end particulnuly so. 'There are, however, a few detached lills, of considernble altitude, which serve as eniling-narlis dutring the passuge through the struits. The southern end of the island rises, and appears to be of $n$ different furnution from the other parts, as its suil is thiekly wooded. In the furest weje seen mumerous clearings, where people had been and were then buraing charcoal, to obtsin fitel for smeiling the tin ores. 'l'he principal mining distriet lies towards 
the southern end of the island, in the swampy flat land at the foot of the isolated hilla before inen. tioned. Tho ore is usually found at the depth of from six to twenty feet from the surface, in layers that rus borizostilly for two or three miles; these vary in thickness from six to twenty inches, and eonsist of henry granulated particles, of a dark metallic lustre, mixed with white sand. The strata abuve the vein consists of vegetahle mouls, red and white elay, intermixed with pebbles of white quartz, and white sand, like that which is fonnd with the motal. A stratum of stentile is said to be found underiying these ores of tin.

The process of working these mines is exceedingly rude; both MIaluse and Chinese are employed in them, but the latter are preferred on account of their greater fyerseverance and industry. I was told at Singapore that the anount of tis derived frum Ihases by the Dutch was not balf so great as that obtained while it was under British managetnent, or that it is stitl capablo of yielding. The ore is waslied ifter its remuval from the veins, which separates the earth, and leswes only the metal and stones; the last are separated by hand, ant the metal is then smeltod; to effect this, luge piles of alternate layers of ore and ehareonl are formed; the fused metal escapes into s hole dug in the ground, from which it is dipped and poures into moulds, forming, when cool, the tin of commerce. Tin ore is fursud at Banca in grcat gunntities, but its quality is inferior to that obtained from other plnees; sind st ruvely yields more than sixty per cent. of pure metal. The proeess of sumeliting is but seldom performed, generally not. ofener than once or iwice a yenr. liude hellows of various forns are used in kindling the smelting fires; some of theso are composed of large wooden cylinders will movits pistons, which give $n$ strong continuous lilnst; others are nothing more than a bamboo tube, through which the breath is forced upon the flame. The process for working the nines and extracting the metal from the ore, are similar in all the mining districts, and differ but littlo from those employed when the mines were first openel.

The Sumatra shore of the Straits of Dunen is low, and appears to be covered with a dense forest. During the niglı wo were visited by a beavy storm of thunder nud lightning, with much rain. The next morning being pleasant, wo got under why again, and passed rupilly through the straits; tho gunthers outlet, however, enlled the Luceparn Parsage, was not attained until nenrly dark, and before reacling it we crossed many shoals, so near the surface as to leave but little water under our keels. An Engliah vessel in adrance of us looisted n liglıt after dark, and by taling it for our guide, we suceceded in passing through safely. This vessel was goon overtaken by us, and proved to be the bartiue Java, Lewis master, thirty-ejght days from Batavia, and boumd to Singapore. Havich lost twelve of her erew by dysentery, and but few of the surviruts being able to perforn their duty ill consenuence, she was returning to Batavin. The surgeon was bert on toard, sul the necessary medisines, kc., of which they were in greal want, were aippliticd,

On the sth of March we arrived off Itotst's Island, at the entranee of the Straits of Sunda. Tho wind dying away, wo were left at the tuercy if a stroug current setting in towmords the island. We anclored to avoid dnnger, and lay until the turs of the tide; we afterwards pased round Zutptien's Island and Hog Point, anchoring for the night off Rajah Hassa.

$\Lambda$ a far as my experience goes, I can testify that Horsburgh't directions for the Straits of Sunda are safe and good, although perhaps not the most suitable for our navigatora, for he makes the safety of the strip his principal nim, and gives directions so to navigato a large class vessel as to insure it; whilst my eountrymen, although they always read him, are unt disposed to pursuce his directions exactly, believing that in following his advice more time is lost than a regurd to stuflicient safoty domands. Although such may be the ense, it ought must to lessen the gratitude that navigators owo bim for his Fast India Directory, a contribution to nautical information that cannus well be surpassed, either for general accuincy, or as regards the grent number of antisfactury directions that it eortains.

On the morzing of the Gth, we again got under way, the men oxhibiting their joy in taking this first real step on their homeward coune, by running up the ancluor quickly to the bows, and by the alscrity witl which they performed their other duties. With a light wind forn the eastward, we stood into the Indian Ocean, between the ishards of Pulo Bessy and Crockstos; the dry was a delightiful one, and being Sumday, when no unessential duty was performed, there was leisure to enjoy it. After divine service, the wind slifted to the northward and westwaril, and towards uight we expericneed severe squalls from that quarter, necompanied by lightring and torrents of rain. In the incervals between the gusts, the wind blew freslily, and on the morning of the 7 th we found aurselves fairly lnunched on the blue waters of the ocean, pursuing rajidly our lomeward course.

We were now truly on our route for home, and finding that the brigs detained us by their slower rute of sailing, I determined to part company with then, lisving some ilays prevously given them hirections what course to pursue in such an event. We necordingly made all the sait lunt could be carried, and goon left them behind us.

On the 23rd, Benjumin Vanderford, nuster's mate, died. During the cruise, I had often experienced his ugefulness, and now regretted his loys. He hud formerly been in command of various ships eailing from Salem, and had made masy voyages to the Feejee Islands. During our stay there he was particularly useful in superintendiug all tmdo carried on to supply the slipps; lae always proved lisuself a good ofteer, and wha one for whom I fole a great regard. He haud a presentiment of lis own leath, and hat long heen impressed with the opinion that he would not survive to return to his country. His ilenth produced a great impression upor Vendovi, for Mr. Vauderfort was the only person witl whom that ohief could covverse, atsd a sort of attachment had sprung up between thers, arising from the officer's long residence with Tanon at Ambath, and lia familiurity with the manners and eustons of the Fecjee Isinnds. Besides, Vendovi looked forward to lis becoming a protectur on their arrival in the United Stntes. While conversing with Mr. Vinderford, some time before his death, ho expressed lis willingness to tako clasge of $V$ endovi, and tu befriend bin on our 
arrival at home; for, although the Feejeeans lad despoiled him of all his property, they thal nevertheless saved his life, ntud for thint, or ratlec for refraining from develuring him, he felt some gratitude, and would trave shown it to Vendovi.

Ponr Vendovi could not be persmarled to besk at his friend's eorpse; his spirits evidently flagged; a marked change came over him; asu lie no doubt felt as thought he had lost his otsly friend. His own diserse, henteforwaril, made mpid strides towards it fatal terunination, and he slowed that such wa the case by his total diaregard of every thing that passed speund hisu, as well as by lis troping, melunelioly look. Ou the 24th, the remains of Mr. Fanderford were cummitted to the deeg, with the usual gervice and honours. The eamo dny wo experienced is currest so the north-west; and the crew, after liswing heen for ten days atllicted with colds and inftitnza, betgan rapidly to recover.

On the 12th of April, we arrived of Falso Bay. The temperalure of the surfnce water was reduced en $64^{\circ}$, and the enrrent was betting us rapilly to the northi-nort 1 -west. The fog and mist that now jrevailed, prevented my observations for ascertaining the rate of the cturrent from heing as aecurate as I desired; the rosuits, wnch as they were, gave it a velocity of more than a mile per hour.

On the 13th, no observations coult be obtained on acownt of the fog and nist; asul our situstion became rather a perplexing one. On making trial of tho cirrent, we found that it was drifting us to the morth at the rate of eighteen miles in twentyfour hours. Soundings wero obtained in eightyfive fathrons, 'l'he temperature of the surface water fell to $54^{\circ}$. 'Towards evening it cleared up, and our situation was obtained by bearings, which plueed us off Snake's Head, about twelve miles to the southward and westward of the Lion's Head. Believing that my only chanee of making Tuble Hay was by keeping ns close to the showe as possible, 1 kept the ship on soundiugs during the night, and at daylight sumed in through $n$ thick fog for what I fell sure must bo the prisition of Green Point. While under way, we fell in with a flect of small ftshing-boats lying at atschor. 'I'leir

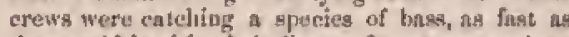
they could haul in their liues. Imunense numbers of birds, fuch ns albatrusses, petrels, and gulls, surrounded the brats, and were feeling on the sinall tisht and offal thrown overboard frum them. The fislı eaught: here are salted, snd being nfter. wate dried, furnish no ineonsiderable portion of the foes of the lowner orders of the colony. One of the fisbertusu was desired to cone on lontrl, and after live lad salisfied me that some reliante might be jlaced in hin as a pilot, loe whs retained with us. Uuder his guidnnee we stood nu, and as slie fog bogin to break away renched our anchornge, Javing passed elowe to the lighthouse and Green Puint, the western point of Table Bay. The enptain of the pust, Commander Bunee, R.N., hoarted us soon after we lind anchored. I was ghal to see this gemeleran, to whom I felt under obligations, for civilities and kindness shown me some eighterell years previonsly, duriug a eruise of the ecount of P'erit.

An officer was despateliel by me to call upon, and report our arrival to Sir Genrgo Thoms Napier, govertior of the colony.

The falling of the ball at the Royal Observatory afforded us an opportunity for comparing tho time as shown hy our chronurueters with that of the Cape. Of this we took alvantage, and found that our timekeepers had perforwed well.

The view of Cape Town and its vicinity from the anchurage, is remarkable, and the whole seems novel. Direetly in its rear rise the grerpen. dicular sides of Tulhle Mountain, while on either hnud are scen the erags of the Lion's Head and Deril's Penk; the former usunlly overhusg by a large eloud, which often eovery the whole town witl its broud shudow. These monntrins are composed of a dark ruddish -gmy sandstone, and excreting inmediately at their base, and close to the rear of the town, show but little signs of vegetation. Here anil there pretty straw-coloured cottages are senttered anong the folinge.

The nnehurage, which is at some distance from the theach, was, at the time of our arrival, oecupied by a large number of vessels, which somewhat surprised ne, for at this stason of the year the bay is often vieited by nurthers, which have in former years doue muel damage, and caured the loss of many lives. I was infurned, hwwever, that but little apprehension is now felt on their account, for ships are at the present time well provided with chain eables, and enn loold their ground. "Two quays extend from the beach into the bay, affording facility to lighters to discharge and take in their eargoes at all times of the tide.

The town jtself shows many traces of its original oceujnuts. The houses, with their prim little stoops, porches, and gables to the street, reninding ne strongly of those built by the early settlers of New York and Albany, But few of the etreets have any" sidewalks, aud many of them are not paver at all, causing them, in consequenee of the arid climate, to be ankle deep in dust. Ninc-tentus of the inbabitants still retain a Duteh look, and many of them are unable to gpenk any other than their original language, while to a large number of them the epithet "boors," so cummonly bestowed, is quite spplicatio. The town is Isid out with reguhrity, many of the surects crossing each other at riglit augles, and some are of respecinble widith. Rows of oak, poplar, and pine trees line the sides of the prineipal aveutes. Many contain shops, which are well supplied with the usual varieties of European goods. Roses and vines are cultirnted in front of the honses, and their blossons and fruit, although within reach of all, are respeeted. The louses are painted of various culours, without any regard to taste, and aro of a clenn though autiquated appearmee. No two of them are alike, yet their styles are so marked, that the country whence theit builders cane may be julged with tolerable certainty from each. Baily-prituted signs ure as mumerous at in our own country, and vanes pointing in every direction surtnount the gables. The Dutch eostume still prevails amortg the inlsaLiesuts, and aftorded uy nuch amugement. In the schools the Dutch language is still taught; though in many the English is a brunch of eduention. Consilering the number of years that this colony has been under tho British duminion, it surprised me to find that a linowledge of tho Duteh who much more necessury than that of English, while dealing with the irlıabitunts.

There are two hotels in Cape Town, the Royal George and the Victoria, both kept on the Finglish 
plan. The former we freguented duriug our slogrt stay, and found it comfurtuble, althougl far inferior to wlart might have been expected from tho size of the towis.

The Cape of Gond Hope was originally settled by the Dutch in 1652; enptured by slec British in $1795 ;$ restored again after the pones of $A$ miens in 1802; ngain taken possession of it Vfont; and finslly ceded to Great. Britain in 1815. Durivg its oceu[ration as is Duteh eolony, it had twenty-ciglıt goo vernors, and since it has been under Britisls rule it has had eighteell. By this it will he perceived that the chatnger in its administration lave been freyuent, und what might naturally bo expected to follow, the policy and character of its governors have been vacillating. It tins been generally ruled very much after the ideas of those who presided for the time leing. The govertment is nominally vested in the governor, and an executive and legislative council, who are all appointed by the crown, or with its approlintion and cunsezt.

Undes this system of government $i$ lias been the misfortune of the Cape exlony to be placed; and the advantages it has jossegsed under sume, have been comanterbalanced by others, and not unfreiguently the salutary regulations made by one, have, without any apparent reason, in the minds of the colonists, been annulled or set aside lyy others; which, of course, las tended to foment diseord and produee a foeling of opmosition to British rule: this has prevented the advancenent of tho colony, and retarded its usefulues by giving license to erime that otherwise would not have existed.

Of late years, however, although the goverument still remaing the same, yet they have been more fortunate is the individuals who linve presided over it. In regarding the British colotial sygtem, it appears remarkable that the British nation, generally so miniful of political rights, should place it in the power of distant governurs to rule their colonists with almost despotic swny, and their Frowth and rise to be at the option of any une individual, who may urbitrarily erush or paralyse the efforts of industry and the development of resources. Many of the inhabitants of the Capre complain of this polity, bue look forward to the adoptinn, in the course of time, of an elective legislative borly, which will give them gome share is the government, and prevent not only inisrule, bua tudude taxation and a misapplieation of its funds in the various improvenents which government may authorize.

The executive council consists of Reven menhers, including the governor, who is the presiding officer; and the legislative comeil of thirtect, composed of the methlers of the executive council and tive additional unofficinla, who are dienselves residents of the eolony, named by the governor, and appointed by the erowil.

The eame kind of government may be said to exist now as in New South Wales, of which I have had oceasion to speak when treating of that colony; and it is thought to be equally inefficiont, and to require reform.

One of the circumstunces that had agitated the respectable portion of this colony, has been the publication of the authentic Caje records. Many entered warmly into the scheme at first, lut it was ston perceiverl what the derclopments were likely to be, and that many who bat played a conspienous part is the history of the colony, were about to have all their public as well as private acts brought to light; and this has rajsed as strong opposition to the continnance of the publication. The editor, Dunal Mondie, Esr., in the year previous to our visit, ande all appresh, stating the difficulties that he lad encountered, and adding, that he would in consequener he obliged to give up the tnsk. Some of the umbers were sent me by a friend, which I took the more interest in perusing, as exluthiting the history of the tribe of Hottentuts, which msy he now deemed nimost extinct, so far as the civilized and settled prortions of the colony extend. Mamy disreputalile actions on the part of all those who have been engnged were here exposed, thil I am not at atl surprised that the ofticial incumbent, ns well hs uthers, should exert all their interest to effect its suppression; however, as many of theso statements are now before the public, it would be desirnble that they should be gone through with, that there may bo a full understandiug of the trussactions that Jnve now come to light, in order to have a full knowkenge of the state of the affairs of the colony, as well in relation to the governor as to those who have been employed under the gevernmental suthority, whether missionaries or oftheials. Like the secret detnils of ail colonies, they will show a grent deal of mistule, inhumanity, aut wunt of system, in the conduet of nffairs. The opposing interests are such that the whole will prodmably be exposed. The colnnists, on the one side, feoling themselves anjustly charged with cruelty and persecution of the unfortumate natives, desire that a!l the investigations that lave taken place may bo brought before the public; while, on the other hand, those who are or hrve been in any way connected with the goverument, are, from all aceounts, disposed to the suppression of this documentary evidenee. Were I desironts of showing the dark side of the picture, I mighit insert here a few extracts that wisuld startle the many who now botsi of their plilanthropic actions, and sre disposed to condemn the actions of others in regard to slavery, who are, in comparison, far less guilty of wrong to the interests of humanity. These who are disposed to look further into these snbjects, may econsult "Specisnens of the Anthentic lkecords of the Culony of the Cape of Goud Hape, relative to the Aboriginal Tribe; together with an Impuiry into the Justice and Expediency of pablishing the re. mainiug Portion of those Reenrds, by Donnld Mondie: Cape of Good Hope, 1841."

On live morning after my arrival I called on his excellency the governor, at the government-hutse, where I hat die hounur of an introduction to Sir George Napier, Ilis reeeption was kind and frank. With him I pasced n pleasait hall hour. Sir George is one of the heroes of the Peninsular War, and bears the marks of lis setivity in those well-eontested conflicts, in che lass of an mrm. He showed the over the spartments, which, however, ure not now occupied, as he was living at his country-sent. They appear conrenient, and afford from the windows a view of the goverument demesne, which is quite pretty, planted as it is with fine old onks; part of it is kept as a public walk, which the citizens Irequent on holidays in large numbers. The Cape station las never been a popular one, from the waut of socinty; but of late yearg very many persons from India have made it a resort for the reco- 
very of their health, and in a ineasure supplied the deficiency its this respect. The offices for the Imnsaction of guverumeut business are in the im. mediate neighbourbnod of the government-house, and within the precirets is alsu a college for the eduention of the youths of the colony; it has severnl profegsurs, but 1 understood all throe who desise to hitve their children well eftucated send theu to England.

The barracks are extensire, aud well buils, and have a large area in front as a parade-ground. There are several other buildinge going up, for the accommodation of the troops, and hospitals for the sick, all haudsome and well siturted. I regret to sny that an nuch ennnot be said for the town prison, nor for the buildiugs approprinted to the puliee department, custom-louse, and harbour-master's department: all tliese bear the marks of what Cape Town was, and stand in strong contrast to the modern improvements.

Formerly the muricipal government of Cape Tuwn consisted of a president, four members, the towa treasurer, and a secretary. The president was elected for two yeass, and was streceeded by the senior member of the bonrl. This board was dissolved, apparuntly for no sufficient reason, for every one was astisfited with jts usefulness in controlling the various datics appertaining to a cor. porate body.

The town is now divided into twelve districts, and each district into four whrds, over each of which there is a commiseinner, and four ward. masters, elosen by the people. The first form the upper board, aral the last the lower, aud each have a duirman and deputy clasirman, who, ameng other duties, aet as apprajsers of property, an which the taxes are assessed equal to threc-quarter pence in the pound. By the itatistical tahles pub. lished, it apgeas that the valuation of property of Cape Town reaches the sum of one milion six hutidred and thirty-six thousant pounds.

The municipal regulations now meem to be excellent, and are more or less tuder military control. The police has been orgavized on the plars of the police of Lmidon, nul jts effieiency is highly sproken of. From all the information I could gablier, crime has very nuch decreased in hoth the Cape distrint anil endony". The statiaties of crinse show bue fow cases. The quarterly sitting o the grand jury touk place durizg our visit, and there were but six presentments, viz, one for eulpable homicide, two assaults with intenc to farm, ane rolsberz, ono theft, or receiving stolen guork, and one truudulent insolveney; and this within a district containing fifty thousail intrabitants.

There are great eomplaints alout the ndiniristration of the laws of the colony; the English system now prevails so far as to allow courisel to the criminal. The trial by jury is established; seven of the twelve must be presect, asrd it roquires a majority of these only to conviet; if more than seven are present, and the jury are divited equally, the prisoner is acipitted. The Dutch crimial cote formerly in foree las ben melified by the English, so far as respects sonie punish. ments; torture, for instance, hus been done awny witl. The crines of murder, ligh trechann, coun. terfeiting, and rape, are ptrished with death; thefts of large amount, nssall, robbery, and the like, are punighed by transportation; while, for uther and utiant erimes, the prisoners are employed as ennviets mu Robben's Island, working in the quarries; for less offences, flugging and imprisonment aro inflieterd.

On the other luand, the English eivil law ham beer modified by that of the Jutch: this has increusul litigation, in eonsequence of the absurd manuer in which beundaries were fomnerly lnid off; such, for instance, as estimating by the slis. tauce a man could walk in an hour, or ennter witl: lis loorse.

Another source of complaint, which amused no not is little, was the administration of justico by a supreme court, over which a chief justice and two puisne juriges pregide; two of these are Euglish, while the third is a Scotchman; the consequenco is, the Engliah judges administer the law after tho Einglish code, while the Seoteh judge follows that of Scothnu, which often renders the decision dinmetrically opposite: and it is impossible for tho advoeste or elient to know by what judge or law bis case is to bo tried. It was said, I hrow not with wluat truth, that ligh connexions have becn cunsidered more suitable qualifieations fur the oflice than begal tnowledge. The alaries do not exceod fiftecs hundred and two thotsand pounds anmually.

There are in the Cape culony eight districts. Facl! of these is goverued by a comanissioner or eivil magistrate, who is assisted by justices of the pence. These districts are again fuldivided into vejd cornetcies, The cornetcies are governed ty a petty magistrate, who is called ${ }^{2}$ veld cornet. Tlese exterd over a distance of atrout twenty miles, and under him is orgatrized the militis foree, in ease it should be ealled out. It is the duty of the latter to meet the requisitions of the higher govertument officers for suppilies, \&c. "There is little liberty allowed the inlabilnus of the districts, who are reatricted from oll acts that might in any way tend to give expression to their senciments; not even are they allowed to hold a publie meeting, and all kinds of prosecutiuns are referred to the enpital for firml decision. At the Cape they liswe a rice-admirnlty court for the trial of offenees on the high seas. The commiarsioner of the alistrich, and others holding office, ate appointed under the great seal, who sre each empowered to grant liennses of marriage, and th other civil acts, and have associated with them the justices of peace, as well as the veli cornets.

The taxes are represented as leing onenuss; there is, for instance, a capitation tax of six sliti. lings anumally, on all free males and females, nhore the age of sixteen. Those in the employ of the goverument are exempt, rs well as the serrants atterndant on them. Inrses and carringes of alt kinds are taxed from two to four pounula. Thery is a tax on all incomes execenling thirty noutuds, of two per cent.; in aldition to these are the stamp dutics, water taxes, louse taxus, nuction duties, market duties, titlies on wine and grain, in short, on every thing that is solil; all papers execnted, trmnsfurs of property, promissory notes, bonds, and licenses of atl kinuls; indeed, it would be diff:eult to mention any thing exempted from the allo persading taxation whiwh bere prevails. On inquiring the cost of articles, it is itsariablo to aceount for the price, lyy nduling that the article is tnxed. The peuple are even taxed for permission 
to leave the colony; and I was told it was necessary to pay a tax to take a bath,

The whole revenue raised nmounts to $130,000 \%$, and the expenditures do not exeeed $125,000 \%$.

In order to lessen the weight of the taxation, it was in agitation at the time of otr visit to incrense the duties on imports, which are about three per eent. ad ralorem, on Euglish articles, and ten per cent, on foreign gonds,

Thu circulation is a paper one of the denominntiou of rix-dollas, valued at one shilling and sixpence. There are no notes less than twelve rixdowlurs, equal to a pound. Tho monetary concerns of the colony have undergone many vicissitudes, and numerons experiments lave been made, alf tending to produce a want of confillence, Government, uratil wjtlin a few years, lad the entire contrul of the rliseount hanks, and through them possessed a full knowledge of the affairs of men in business, and it is said did not fnil to use it in an arbitrary manner, producing revulsions in the monetary affairs of the colony that were lighly prejudicial to the comncreial comuunity, causing much distrese, and in some cases ruin, of whieh many fect the effects to this day.

This state of things gave rise to the establishment of haulis exclusively under the control of private individuala: there are two of these corpoIations, bearing the title of the "Cape of Gond Hope Bank," with a capital of $50,000 \%$, and the "South African Bnuk," whose capital amounts to $100,000 \mathrm{l}$; the eapitnl of each is all paid in, and no part of it can be withdrawil. The latter is not $\Omega$ bauk of issue. A genernl statement of their affairs is aumually made to the proprietors. Interest is paid on deposits remining longer tlan a certain specified time. Inviolatłle secresy is observed with regard to individual accuunts, and each person comected with the institution signs a fromise to that effect. These bunks afford every facility within the bounds of prudence to those dealing with them, even carrying the epirit of accommodation sa far as to keep early hours for the benelit of the agrieulturists who frequent the market.

This new aystem is found to work admirably, and pays handsome dividends to the proprietors. It gratified me to learn that the public of Cape Town is ehiefly indebted to Isare Cliase, Esin the United States consul, for the adoption of this bank. ing system. 1 had many interesting conversations with him on the subject, and also conversed with others, ithatitants of the colony, who expressed themselves highly plensed with the suecess of these inatitutions, while at the same timo they acknowledged their obligations to our commercial agent.

Wine is the great staplo of the culony"; but many of the vine-growers have heen ruiner, in consequence of the racilating policy mrsued by the home government, with regard to this branch of iqdustry. T'rusting to the promises made by the goversment, a vast amount of enpital was invested in the business, and tho anums production was in a short time tripled. This state of things continued for about ten yenrs; but in the year 1825 a change of policy took place, and the prutection was dininished more than one-lialf; and at the sarue time a further reduction was proposed in the bounty, $\Lambda \mathrm{s}$ a natural consequence, a depreciation in all the wine estates tirok place, and the loss of much property ensued. This was madet more unpleassnt to the Cape colosists by a propon sition to put a ducy on Cape wives, that would have the effect of placing them at a higher duty than those of foreign wines. The colonists are stifl very sensitive upon the nubject of wine, and the treatment they have received; not only have they to cotuplain of bad faitl on the part of the goverument, but the combtant efforts of others to deery their wines, some of which are produced of sas fine a dinality as those in any other part of the world; bue there is some foundation for the disparaging reports that have been circulated, for quantities have certainly been sent abroad that had been very much aluiterated.

The Cape colony, both as to soil and clisante, is well adajted to the raising of all descriptions of wines, from the light Gernan nnd French, to those of Mndeira and Sherry.

In consequence of the reverses the colonists have met with in the wine trade, they have lyegun to turn their attention to the rising of sheep; the colony has been found to be well adapted to those producing fiwe wool, and the investments that have been mado in then bid fair to be profitable.

Whent and maize are also cultivated, partieu. larly on the mouncaing near the Cape, where these grains grow in great perfection, and are raised in suffieient quantities to meet the consumption of the colony, and to be exported in considerable quantity to the Mauritius. The wheat now used is of a hard and flinty kisd, and effeetually resists the ntthelis of insects, as woll as the rust, which were formerly troublesome,

The other chice productions are fruit, oil, and phrisions.

One great obstacle is opposed to this eolony ever becuming $n$ grent producer of wool, and that is the immense distances and thto almost total want of communications, So bas are the ronds and so great the hindrances, that the wonler is, not that there is a little internal tmale, but how tmneportation is effected at all. Were it not for the energy and perseverance of the early colonists, and the bardy breed of cattle that they possess, communication hetween distnnt parts of the colony would be nearly impossible. Some opinion may be formed of the state of the roads and the difficultieg to surmount, by the fact that fourteen pair of oxen are frequeutly attached to a small wagun.

The ox used in Africa seems to me to be of an entirely different breed from the animal we are aceustomed to see in our country. Their legs are much longer in proportion to their bulies, lank and bare bones, with imtneuse horns; and aheig gait, instead of a slow walk, is often a trot.

The whole of the foreign trade of the colony panses through Cape Town. The value of imports is estimnted at one and a lakif ruilion sterling, and that of exporis anıouta to upwards of a million. The ressels engaged in this trade number about six hundred, whoke tonnage amourts to one hundred and eighty thousand tons. The total revenue from customs, in the year 1840 , was forty-two thouand eight hundred and seventy-seven pounds. The exports consist of wine, woot, ivory, whale-ail, hides, tallow, and aloes. Tluese are either brought to Cape Town from the interior in wagons, or in small vessels 
from Algna Bay. They are sold by anction, in the market-place, every Saturday. This mode of offecting sales is almost universal. The services of auctioneers are of courso in request, aud in addition to their legitimste trade they receive doposits and rake adranees on merchiandize committed to their charge. The gowernment taxes on sales by suction amount to a large sum, and no article can be solil unless a tax is paid; for sty infraction of this ia w there is a heavy penalty, to be collected by the markot-master, who is appointed by tho goverument, and who superintends the collection of the dues aceording to a tarift wlich is pulblistied.

There is a great want of Jalsourers in the colony; and sicuee tho abolition of slavery, this keareity hins rery mueh itsereased, for it is found that those who hitvo been munumilted aro nut disposed to work more than is necessary to provilo thenwelves with food. The attompt hins boer made, and arrangetnents I believe were in progress, or contemphated, to bind as apprentices the captured slaves brought into the island of St. Helenn, to thesse who were willing to receive them, at the Cane of Good Hope. The governor of St. Hefena, Culnuel H. Trelnwny, wrs well disposed to this plan, and it was understorl was co-operating with the autho. rities of the Cape to earry it fully into elftect. Five years is to be the term of anprenticeshipg. However much the autlaritics incline to this plan, the wistom of $\mathrm{it}$ is much doubted by a large number of the luhnbitants of the colony, who allege, that ulthuugh it may answer tho purpase of giving relief, yet this benefic will not be permanent, nind in a few yeara they may be overlurdened with a mppulation of blachs, who wilt be little inclined to Inbots, and may be a grent inprediment to the introduction of a class of free lithourem, who might be permanently beneficial to the tosns as well na to the interior.

In the inhabitants of Cape 'T"own, although one sees $\mathbf{n}$ great varicty of costume and figure, yet a true Hottentot of full blood is said to be but rarely met witl. Some, indeed, were pointed out as such; bnt, nlthougl they seemed to lave the distinguishing marks that are generally inpressed apen us as characteristic, yet on furlier inquiry they did not prove on be really so.

The men are representer as being very much attached tu their slieep-skin elorli or caross. Thoss that we saw were remarkiable for very ligh and prominent eheek-bones and a sharp chin; they are not much inclined to stendy employment: tho attending of eattle, and the indolent and wandering lifo in which they pass their time, suit their diepnsition, They at times hire themselveg our to tho farmers, receiving enttlo as wages. In the colony they do not bear a very high elameter for honesty and faithfuiness. They are expert drivers of wagons, but are otherwise careless and inattentive. They are decmed an improvident race, though there are sumo instances of their showing grent attachinent to individuals who have trented them well. Their numbers now are varioushly stated; but little dependence is to be placed on tho accounts given, as is evident by their ranging from ten to thirty thonsanil,

Upwards of thirty thotasoul slaves in the colony have been mnnumitted; but the success of these as ree labourers is by 1 io menus encournging. The covleys or bearers have regular employment, but the grent snajority of thest are Malays or people from Indic.

1 had the pleasure of becoming acquainterl with Mr. 'T'ıoungou, the intelligent Afrien traveller, to whom the world is indebted for his jneresting accounts of the Buslunen, and the chicf kuowledge we have of the interior of the colony. We nre indebted to his excrtions, through the liberatity and joint action of sone gentlemen of the Cape, for the many attompts that have been mado to penerrate into the interior of Africa. When the diflicultics aul jerils of such efforts are duly considered, it is uot surprising that so little suceess las leen met witl in the various expeditiuns underthken with this viow. To thoso who would? wislı to seek adventure, the exploration of Africa offere nt present o widel and more novel field tlun asy other portion of the world.

The colnnial goverument has of late years had much trunble with the Caffre tribes on the eastern limits of the colony. These have fremuently made ineursions, and driven off the enttle of the setelers, in revenge for the injuries they hnve sustniued from the whites. The ustral result is taking plneo; here, as elsewliere, civilized man is driving the satve before lim, and occupying their buntinggrounds for permanent agriculture. The missionaries linve in onme cases pushed their establishments amnng these savage mees, and from them the nceourta of the Cuffres have heen mostly derived. 'their applearulee as well as eliaracter seem to indieate a totally rlifferent origin ftom the negro and Hottentot uribes. One of the marked peculiaritics absut thom is than they nvoit marrying the wanen of their own trilse, preferring to purchase wives from their neighlonurs, for whom they barter their eattle. Tanboukie women are preforred, althongl they are described as very ugly, being short, stout in the bouly, and having strong muscular limbs.

Those who have visited the country of the Caffres, describe them as extremely lrospitable, and very cheerful in their dispositions. They mostly go natied, particularly during the beat of summer, thougl they went the carness of shin in the wister. Their auns eonsiat of the spear and elab, with a shietil of bull's-hislo to protect the prerson. T'heir principal foorl is the milk of their herds, which they value beyond any thing olse: they are a prostorat penple, and the catte-foid is considered the grest place of honour, so much so that their chices are always found to occupy it. They have of late years olutained many horses; fornerly they used the ox for riding, and this animal is said to have been even trained by them for the race.

The part of South $A$ frica oceupied by the Caffres enjoys a delightful clinate, and they, consequeraly; need but little protection from the weather; and their buta are midely constructed.

of late years tho settlers at P'ort Natal, on the eastern const, who are surrounded by the Caflte trilses, set themselves ùp as a sort of indepentent community, believing they were beyond the limits of the colony ; they emacted laws aud regulations, issued their declaration of independence, invited setters, and for a time cotnmitted mnny atrocities on the Caffres. The Cape government, deeming it was atvisable to check this disorderly spirit, sent 
an expedition to nssert their proper supromacy. Troops wero proceding to Port Natal at the tine of our visit.

During our stay we visited, as all strurgers do, the estate of Constantin; it is situated about thirteen miles from Cnpe Town, There are three small estates that bear this name, viz. High, Grent, and Littlo Constantia, The country we pased through, although barren and sandy, was supurently well settled: the villnge of Wyuberg is the residence of many persons who come here to enjoy the delightiful air that generally blows from the eastwaril; most of the resideneeg are pretty cottages, and some have the appearance of hant. somo villas ; they all have an sir of nentness snd comfort about them. Oaks and the pince are almust the only trees met witl, and one is somewhat surprised that even these should be foumd ; for the cuantry is, to aptrearance, in barren waste, and many mijles of it are quite unproduclive for acriculture. I'se scatlet hentli, blue oxalis, and the yellow compositze, not on'y enliven this waste, lsut give it sorsewhat the chnracter of the flowery prniries of Grogon. The santy soil Inoked like the sea-shore, and bears indulitable matks of having been once eoverel by the ocenu.

The estates of Conctantia lie east of the Thable Munntrin, on False Bay, and from their peculiar situstion are adequately wntered by the mists condensed by that lofty mountain. Thio soil of these estates is far from being rich, lut is rather a light and in some places a gravelly soil. The graperies Jie for the most part on the slope to the south-esst, while some are situated on the low lande, which aro carefully ditelsed to preserve them dry. 'They are divided into fields of sonse four or five acres ench; the genpe-vines are planted in rows four feet mpart, they aro nerer permilted to grow higher than three feet, and the whole is kept free from grass and weeds. In the spring, the vines are pruned; the grapes come to maturity in April ; while they nro growing, all untecessary leaves and sprouts are removed, to give free aceess to the sus and air, and full Bdvantage of tho growth of the yarent atock.

The gropes aro nllowed to remain on the vines until almost eanverted into raisius: they are then carefully examined, and ald the deeayed and bruised ones retuoved, before being gathered. "The sme urocess is used for expressing the grape here on at Madeira; but they lave in some ghees advarseed a step, and use the gerew-press. The buildings for the storage of the wines are of one story, aud arranged into three apartments ; two of these nre mppropriated to the mintufacture of the wine, and the third to that which is kept ribsenirg for sate. 'The wines are of four kiryds, Poncace, Frontignas, and tle white and red Constantia. Tlueses are named in the erder of their celobrity and price, which is tsoually a fixod one: the wine here is sold by the arm and balf nan, equivalent to a barrel and lualf lnrrel; the cost for the last quantity is one hundret dollars for the first kind, eighty-five for the second, seventy-five for the third, and sixty for the fourtl. To L. V. Renen, Eson., the proprietor of tho High Constantia, we are indebted for many attentions. Tho grounds of Constantin were ornamented with some plaster stntues of Hottentots and Caffres, which were said to represent the true type of these uatives.
I prid a visit to tho Cape obrerwatory, famons fron the Jabours of Sir Joln Herschell, on thr southern constelJstions. It is now it clarge of T. Maclear, Ean, who was at the time of our visit. absent, being enginged in the measuroment of an are of the merilinn. His assistant Mr. Smyth, fund Lieutenant Wilmot, of the magnetie observatriry, showed wo the instrutuents. Lieutenant Wilmot has four non-eomnissioned artillery ofticens for his assistauts. 'The day of our visit liappened to be term-day, when an almost uninterrupted serieg of observations are taken; our stny was therefure but slort, as I was disinelined to interrupt the constrnt duties of the observers. During our visit at the olservatory, the weather was bestlifully elear; no elouds were to be seen exeept over the Table Hountajn, and oljects viewed acrogs the sandy plain were much distorted by refraction.

The botanista altuched to the expedition attempted, during our stay, to ascend to the top of Talile Mowntnin; but laving takes a path different from thant usunliy purstsed, they were arrested by the perpendicular wall when about six lumired feet below the top. A great collection of botanical specimens amply repaid them for their disappointment. They visited the valley between I'able Mountain and the Devil's Penk, and found it to consist of a dry spangy soil, densely covered witly rutrcese, internixed with low lushes of lienth, thymelacere, diosmas, and compositro, having in clnse resemblance and analogy to the uphand bogs of New Zealand.

The drives around Cape Town are pleasant; the one to Green Print is the most agreeable: this is $\mathrm{A}$ straggling village, with the louses having pretty gardens in front, laid out in the Linglish style: the distant riew of the ocenn, with tho heary sur breaking upon the rocky coast, are fine objects tn seaward. Tho sides and tous of the hills in the rear sre bare of trees, but the roads are lined witlı cneti of large growth, giving to the seenery a de. cidedly tropical charzeter. Green Poust has a municipal government, and elects its commissiner and ward-snasters in the samo manuer as Cape 'Town. The light-touse is within this district: it is quite unworthy of the name, being decidedly the most inferior Britislı establishnent I have Beell, This surprised me the more, beense there is here a great necessity for a lyrilliant light.

There is a conmercial exclange at Cape Iown, possessing a public library, consisting of abont thisty thousand vulumes, and containing a readingrom, as well as a Jarge hall, which is used for the public meetings and festivities of the inhahitants.

Different seets of Christians are vying with ench other, to earry civilization and the Gospel to the tribes in the interior; but, as uswn?, there are many who deny the pusity of their prisciples, nnit sprend scindalous reports concerning their operatinns.

The walks nenr the town are pretty, and kopt in neat order. One that lends along the brows ir the renr of the town, whose banks are ocenpied by hosta of washcrwomen, is peculiarly picturesijue; hs soont as you ascend to tho top of the bill, you overlook the town, bay, and shipping, and gain a riew of the Eandy jolnin nol distaut motntains, with Robben"s lalasid and Green Point iz tho diatance.

Anong the objects of juterest nt tha Cnģe, is the 
Botarical Crarden of the Barna von Judwig. To his liberstity we are much indebted for plants and seeds; and in fact every thing that our botnuists flesired was placed at their disposition. The garden is surrounded by a briek wail, and situated near the foot of the Lion's Rump; itg smil way originally poor, but it lias been mush enriched by manure. The collection of plante, both native and exotic, is good, but the seasun of flawers whs over. The native bulbs, which form the grcat beauty of the cullections here, had passed, and but a few manryllide, and some varietics of the oxnlia, re. mained in bloom. Many eurisus specimens of Afriean plants were noticed, particularly some zamins, strelitzias, aloes, and testudinnrias, of the furmer we brought home a fine upecimen, whose fruit, which resembles in shape a large pine-apple, is eaten ly the bushmen, and is said to be palntalle when properly prepared. The collection of Estst Indian planta wrs in fine ordes, and numerous specimens of the cacti nttmeted our notice.

The portion of ground allotted us $\mathrm{n}$ flower-garjen contains a fine cullestion of reses and dalifias, of ormamental slirubs and axmunls. "I'here is also s vegetable-garder, while fruit-trees are interspersed here atud there throughout the whole. Thlie proprietor furtishes tiekets of admisgion to all who desire them; but his rttles and regulations as to tho huur of entrance, and respectirg the poliee of the gardelt, muat be strictly observed.

The phasts furnished us by the baron lave flourished ndmirnbiy sisce our return.

If one were to place full reliance ou the assortiong of its imhabitants, Caje 'Fowu aud the surrounding country posseas a perfectiun of elimnte to be met with in no other part of stre world; but this, it is to be regretted, is not fully corruborted by the testimony of the meteorological registers that have been kept, as well as tho experience of thoso who have writter upon the subject. It has many peeuliarities, ond may be terned rather a cold elimate for its latitude. The mean tompernture throughout the year is $674^{\circ}$. The extremes vary $10^{\circ}$ above and as ruch below the mean, It is classed by its inhabitants under the warm and equable climates; yet, notwitlsatanding, in many situations, it is extremely variable: the thermometer will fluctuate ten degrees in as many minutes, producing an unplenbatnt sensation of cold; this is owing to the elilly winds that sweep down from the Table Mountain in blusts, to equalize the density of the atmosptrere rarefied by being in contact with the lented soil benenth. Liut littlo difference is observed between the temperature of sunshine and slude in free ass open situations.

This vartation of elimate is nseribed to the winds: the south-east winds prevail for the most part of the year, nud are warm; these are suceceled by the cold winterly winds, wlich invariably bring fog and misty wenther; but in viewing the situntion of the Cape with respect to the large bodies of water flowing pust it, it would seem more rensonable to impute it to the warm tropical and cold pular cur. rents of water, of whose existence we have given ample proof in the preceding pages; for if the winds were alone to be taken iuto account, that which cones from the south-cast, in the sunthern hemisplinere, ought to produce the cold, while the west and north-westerly wiuds should be warm. The studen ehanges of temperaturo mentioned sbore are merely loeal, snd oftell confined within narrow timits.

At our anchornge in tho bay this occurrence was strikingly percentible, not only by the themanmeter but from the effect produced on our own feelings; while in the town, although the change couk be folt, atill it was not so remarksble. Tho indrabitnnts nssert that these changee oceur oftenest during the prevalenee of a strung south.east wind; but my own experience lends me to believe that they take place during the night, nul particularly when a calm provails, or but a sightu breeze is blowing, not indeed all the facts connected with it would lead me to the opinion that such must be the erse. Althouglt all seem to be aware of these variations of iemperature, I did not learn of wy observations that have been taken that cunld bo relied on for securncy.

Thermnmeterg in different parts of the rown, of course, give very discordant results, and all metenrological olsservations ouglat to be taken in situa. tious as far as possible removel from the inflesese of these clianges. The soutli-cast wiuds nre often 50 violent as to prevent cummunicalim between the ofiiping ast the shore during swme parts if the day, and often cause damage to the small bonts, or to the vessels themselves. Cargoes call only lie takes in or disclarged with safety in the murning, previons to the occurrence of these winds.

Before concluding my remarks on the climate of the Cape, it is necessnry to advert to the eurions effects of refraction that are often observed. A struige distortion of oljects is frequently seen, and evea at a sliont distance from Robben's Jaland the gurf sonutines appears to be chrown up into lofty jets of fonm, or a wave is so dintorted that it seenis. rolling in ligh enouglı to subuserge the whole island, These distortions oecur not only in the sea, but irs the land view. I noticed them during our visit to the observatory, and now call attention to the'us again, because the srme effect seens to be produced on sea or on land by contraty causes. When at sea, refractions litre been oliserved by us, whenever the thermoneter at the masthend showed a ligher degree of temperature than that at the surfince of the water; but at the Cape the current of ain in contact with tho heated and sandy soil must bo of a ligher tenypernture than that immedintely above it, and thus causes the distortion of distaut objects; or the fact may be accounted for on the supposition of two parallel eurrents of diffirent tempetutures, moving in opposite dinections, and beyoud any inumediate influence of the earth. I know of no place so favourable to the observation of this deseription of atmospheric phenonema as the Cape and its vicinity.

The population of the Cape colony, by the returns in 1841, was one bundred and fifty-tluree tlsousand, on an surea of one lumdred and uine thousand eiglit Hundred and sixty-four squnre miles. The deatlos amount anmally to about one in forty. The coloured population exceeds the white by about ten thousand. Latuded estates in the colony are gene. rally held by those cultirnting them, under a lease, atsi not in fee. The early settlers had not sufficient funds to etiable them to purchase as large farms as were necessary, and the prese'ut syateur was in consequence resorted to. The leases, however, were nade perpetual, and the farms held under this tenure nre known in the colony as "Loun 
Farns;" they contain about three square miles, and there are many of thia descrjption still existing: these ars considered as desirable tenures, bcing good as long as the rent is regularly paid, wlich is generally at the low rate of ten dollars for the tract. The lands, however, about the Cape, aud in the Cape district, were obtained by grancs, and are now knowis as "Gratuity Farms,"

Thero aro likewise frechold eatates, which con. sist of a small farm, not much exceding ono lsundred acres. These, I was told, were in the immediate vicinity of Cape Town. I'hey were usually abtained by purchase of the first settlers.

The system of quit-rents is in perpetuity, and the rent is made to depend upon the quality and cil. cumstatsoes of the crop. I'hene are the largest kirnd of estatea, arhs seldom include less than five to viglat thoueand acres.

The sale or transfer of land was also novel to us. No land can be solt, unless the persuns tuake application st the Cope, to aflicurs appointed, ealled commissioners, whose duty it is to see llast all liens on the land, sueth as bouds and mortgages, are all paid up; and tho liabilities are fully protected; and the person wishing to sell must hive permission of the one who may hold siy chitur on the estate, hefure he ean legally dispose of his property; and the consent of the mortgagee must bo oblained in writing befure the debt cats tre transferred with the property.

Supplies of all teinde can be obthined at the Cajec, and usually at reasonable prices; the bread we purehased, male from native flour, was of excelleut quality; fruit also, though considered out of senson by the ishabitants, could be purehased in any quantity, either in the tuarkets or from the bumborts alungside of the ressels. The usual facilities for watering are rather defietent: there are no ffonting tanks, and some imeonveujence results from the use of casks.

On the 17 h, we got under way with a light and bafliug wind. The air was frotn the eastward alot, while a westerly breezc bluwing below it, often took our lower sails abatk; still tho upper ones woro full. By constant attention aud frequent swinging of the yards, we effected a pasatge through the nombern clanmel, paesing at a short distance irum Roblsen's Island, on whose shore wo at w, as thual, the breaking surf curiotsly refraeted.

Rabben's Island is now used as a place of confinesuent for criminals, who aro employed in the qtrarries to furtigh stone for paving and building. The stone is a sehistus, and commonly known at the Cape as blue flig.

As we cleared the island, objects to seawarl were secn refmeted in a manner that I had never before observed so distiuetly. As before stated, there was an upper and an under current in the atmosphere, and these strath were of different temperature, The thermotneter at the masthead marking $75^{\circ}$, white that on the deok stood at no more than $59^{\circ}$. $\Lambda$ ship ntont three miles distant in the offing, was ween vertieally and hurizontally refmeted at the same time.- Iler courses and topsails appeared ill-defined, shapeless, and quivering; frer bowsprit and lienil-spars formed curves, while her jib and flying-jib were drawn cut in nearly horizontal lines, Above, her topgallant-sails and royals were seen perfectly well detiuel; a distinct line of bluish hazo divided them from the lower sxils, and could be traced to alsout sixty degrees un ench side, until it joined with the hingizon.

We now slaped our course for St. Hedratu, which I whs desiruns of reaching at the earliest day, in order to intereept the two brigs, and if a further supply of bresd could be obtaized there, to proced with them directly for the L'nited States.

Our prasage to St. Helena was of the ordinary length, thirtece dnys; we had very light winds aud a smooth sen, indicating that a long cain had ex. isted. Northerly currents generally purvailed, though at tirues setling to the eastward and westward of that point. On the 3oth of $A$ pril, in tho latitude of $23^{\circ} S_{\text {. }}$ atad longitude $2^{\circ} 40^{\circ}$ E., we enterced the trades, frou which lime unlil our arriwal al St. Helena un the lst of Hay, we expericued no currents.

The anprearance of the island disappointed us: ito height and size were much less than wo suticipated. It is but a bare and barren rock, rising alimptly from the sea; and tlwe only thing remarliable is the euccessiou of untterieb, which aro eeen oceupying every nuok and corner where cannon could be placed, from the water-line to the higlhest peak. Alt now serve but to reenll to mind the extraordiunry juan for whose safe-liceping so much cost and eare lasd been beslowed. From the outward view of St. Helena, it seens seareely necessary to have incurred so much expense and provided such means for the safe-keeping of Napoleou; for the island itself is almost inaccessible on all sides; its bare rock rising вevensl butdred ftet perpendicularly from the water. To reach the roadstead it is recessary to pass within a sliort distanco of the rocks, and elose ulkur them unit the valley of Jumestown is reteled, which offers the ouly anchorage, Here it is often diflicult to procure a good berth, as the rondstead is frequently crowded with ressels.

On our arrival we were informed that the Porpoise and Oregon had sailed but a strort time previously; all were well, and their stay at the islntul had been sturt. Six Amorican ships were at anchor in the rondstead when we arrived, and three more carne in the day after, miking in alt ten ships and a sehooner bearing the flag of our own country.

The interior of the jshnd of St. Helenn is unitr. teresting, and when compared with those we had recently" risited, may be stid to be devoid of benuty. It possesses notlung to recoinmend it in the notice of a stranger, except jts consexiou with Nappoleon's exile. It is said this island was first suggested as a place of confinetnent for the great prisoner by the Duke of Wellington, who bad ham. self been kletainet there for Bome montlis, while on litis way from India, and was forcibly inpressed wils jts natural strength and adaptaion for his confinement.

To the circumstance of the residence of Napoleen this island owes nut only its chict celebrity; hut an a consenuence, its temporary growth and prosperity: and with the removal of lis remains, St. Heleus will revert to what it was formerly.

On his first landing, the ex-etnperor oceupied the very apartinents formerly used by the Dulie of Wellington; but was, the jext day, at his own request, removed to the "i Briars," a retired country cuttige, situated in the small "bosom" at the head of the guily of Jamestown. 
The unty collection of houser is Junestown; and although situnted in a lneality on tho island for a town, The equace ocenpied by il has licen as tench jmproved as was possithe, und the place lias rather a cheerful appuneance; mure, lowever, from tho divetsified clstace ter uf its inhabitants, thas from the nentmeas stu

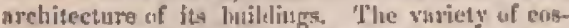
tune is greater timn one woult expect, ranging from the well-dnosked Einglimll suldier to the Orien. inl costusnes of India aut China. I'lacre are stany quadrous who aro astil to the desecendants of the batives of Mindagusens, Lrughtht here ariginaly by the Duteh. Thoy were pointed ont to me sa rematkablo for their beaty, nul many of them lave certainly, it must be ackinuwledged, well-developed sml even liandsone furme; which, from surnestrances, they are font of exlaibitus, and to which their style of dress is well adirpted.

bixtortion is here curried to jts lueight, and nlthough the stay of the stranger is ouly for a few hours, the time is sufficient to make him nware that he has submitted to some exorbitant demand, if his curiosity hare led him to visit Longwood and the umb of Naphlen.

Our consul, Mr. CarTol, was hind enotgh to muke arrangements for our risitung Longwood and the tomb, and it was decided thut we should set out at nn esrly hour the next morning.

Captain Hudson, Mr. WaldroH, sul myself, ac. cordingly lamled at lie jotty early tho sext dny, and found waiting for us a srogll wagen with two stunt horses, in which wo seated ourelves, atw were driven to the Aumericnil consulate. We were there joined lyy Mr. Carrot, snd tnking the eastern road, cummenced ascending the narrow track leading up the sille of the clift. The road seemed to have been curried over anme places with great difficulty; heavy wails were built in sonte places to form the roal, while in others the path was blasted out of the ruck. $\Lambda \mathrm{s}$ we nscended, we had s bird's. cye vicw of the town and the gurge in which it lies. Tho hovees and their inhabitats were nlike reduced in sire, and wo experionced the necuracy of the puetical assertion, "that distance lends en. chantment to the view," for frum onr elevawd ровіtion all appeared meat and clean. The hosjptals for the troups are situated in the upper end of the valley, in in space ton contracted for coufort. Their nppenranee is strungly in contrast with that of those nsunlly attached to British gurrisons, and led to gome intiuizic on my part as to the necessity for their confined pusition. The inland beimg usแally lealthy, and infectious disenses lut welefom pre. Yailing, quarathe is performed at Lemon Valley, or ratlier it was used for that purpose during our visit; a number of reaptured slaves, nurong whotn tho emali-jox bad mado its appearance, being detained shere.

"I'lue first object of iutereat llat presents itself sh crunsecterl with the residence of Napoleon, is the cuthge at the Brings, to which de was removed soon after bis swrivnl. Is is situated is a strinlt dell at the head of the gully, and liss attated $t o$ it some ten ucres of ground, laid ouk in walks and

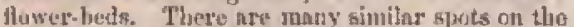
island, which are known liy the uame of "boBoms ;" nosse of them, loweror, so striking, nor having such na nir of quiet and enmfort as that just tmentiened. Its beatuties are niore strungly improsed by the markerl contrast they affurd to the arid ark barren rocks of the gully sidde, up wlsich we had been making our ascest tuider a lurning sun. The only vegetation on the surroumuling hills waล ล few cacti and wild vines, and Bome firy that were itmported from Scotland about fifty yenry aga. The hights ground of the islased was of equal altitude, there being but few prints above the general level.

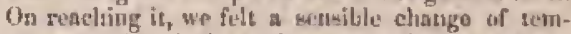
perature, the nir beconning rnw and disagrceable I'urning to the castward, we proceeded three miles aloug the road, and then turned into the path which dends th the quiet dell in which the tomly is siotsater. Tlie rond soon becnme on steep that we were oliliged to alight from the carringe, and descend ou foot to the ecottage oecupied by the widuw 'llulbat, who furnishes refreshmenls to sisibers, and who takes eare to let it be known that it is eustomary to pay for tirem, whether you partake or not Het contilutued whinings alout her poverts, the injustice of the Britisl guverument, and the unfultilled fronisus of the Prince tle Juinville, are singulaviy out of place, and at vatinnee with the thoughts with wlich stre's mind is creeupied when visiting such a spout. In the renr of the cottage, at the end of the dell, anil about thirty yards distant, is the tomb.

On the banks of the dell, a few yews, cedars, ant] พeeping-willows, nre growing; while in its eentre stands the old and now leafless willuw, which seens, like the empreror, to have been killed by the treatment it has received. A spring of pure and delicions water buthbleg from the rock near by; to is we retrented to avbid the annoyance ocensicued by the monotonous whinings of an old sergeant. He talked continually of the length, breadeh, ank deptis of the raut, told us of how many shabs it was formed, low they were comented tugethur, how opened, aud many other particulars of su liule importance, that I elsall nut trouble my readers by repenting ilrem. Wo at last put an clld to tli garrulity by paying him the expecterl shilling, and waking of ont of henting. This is an annoyane to which all who linve visited lise tomb have been gubject, sud which does away with half the antisfaction of the pilgrimnge. We drank some water from the spring, received a botsquet of the Napmlen gerunium from the little girls, and returmest of the eothage, which we found erowded with Duted cllieces, who ware devouring the widow's entablits as if deterntued to have the worth of their noney from their great appetites sho tuld us she anticipated but fittle protit. Setrecly lial they fintsised eating, when their pripes were put in requikition, and a clund of smokt wot only filled the apartment, but issued in all directions from its door nud win. ulows. I have seldom seen so litale regard paid ta the comfort of others, or so lible resplect showil ta the resting-phise of the mighty dead, na by thest officens.

After satisfying the elaims of the vidow, and disposiug of ectrain relics obtrined through lier a marky of speecial favon:, we departed for Longwond, nbout two unileg further an. The rond is good and nearly level, rumning along the top of is harren ridge; on var wny we phased the "Thpr-rom," imInediately opposite to which was the dwelling of the Cuust lhotrand. The horizon is visible finen the rosd, both w the north and east; and on either bidle the eye wanders henenth into the deep ant inaccessible gullice, from which their gloomy and 
uninviting elaracter lnve obtained the appropriato name of the Devil's Gorge, \&e.

The day on which we paid this risit whe ealled by the inhubitants a tine one, lut wo thought the air damp snil chilly, and were glad to draw our cloaks elosely around us. We swon reached the eate, and were stupped until we poind tho usual for if two shillings bterling for ench persoll. The liouye is at present lensid ty the governonent in a Capunin Mason, a retited anny olficer, for one liandrod and fify pounds per annum, and by his order the entratec foe is demnnlod hefore the gate is opened. MIr. Carrol pointed ont to us the sites of the enmis of observation, and ollue spots in the neighbourluoor, interesting from nsancintions eounected with the resideneo of Napoleon. $A \mathrm{~s}$ we drove towards the house, every thisig wore a neglected look, to all appentance intentional.

Long woul is now but litslo hetter than a baru the glass of Ute wituows is broken, and the outwatd walls much disfigured. The diror at which visiters are aldmitted is corered with a stnall lattiecd vemundit, sud lends into what is eallevd the liilliard-room, altiknegh it scems much too smalt ever to have lieen nsed for that purpose; its walls are covered with seribbling, athd its getsenal appearance is dirty and wuplected. The vext npartment is about fourteers by suventeen feet, said to larve been used as a disiug-room, ard in which Nrpoleon aied; it is now ocentived by a patent thrnsling and winnowing madhine, and was strewerl with chuff and stmw. The adjoining tomm lase been used as n library; its present state wus dismusting, nud it seemed as if appropristed to the lintehing of clickens. The luath, hed, and dressing. rnouss, whiels he ocetupierl at the eonnenement of his illaess, ure now in part used as a stable. Thie plice in which his bouly lay in state, coutains eight stalle, fire of which were eocupited by horses aud eatzle.

If the design had been to deseernte as much as rassible the babitation that hat been oceupied by the fallen cupperor, it could nut have been more effectually accumplished; but wlrntever tnay be the notive, whether intentional or otherwise, it eertsinily rediunds litto to the eredit of the Hritish nation. T'he miserable conulition of Longwond when we visited it was a subject of general animad version. The money derived from the lense of the froperty is paid into the queen's trensury, no purt of this small sum being retained to keep the building in repair; nor are there any conditions in the leuse thut coinicl the lessee to to it. It is with regret I am compelled to state that the lessee is a military man, and na officer in the British army

Longwoond is bleak nud exposed; the dnmp trade-winds sweep past it eotatinually, and but few tass in the senr are without either mist or raill. The valley of Jumestown is kuown to be dry and healthy: there are' goune other spots Mlso on tho island thut enjoy a climate ns fine nas any on the globe. One of theso might lare been clween as a resilenee, whiels would have proved much more congenir! to the taste, and botter suited to the constitution of the emperor. I'lantation House, for instance, the country geat of the governor, enjoys, by al! necounts, a delightful climate.

Tile yrounds of Longwood cannot be callert prety, but from the constant moisture the luerb. age is groener than in other parts of the ialand. There are to trees, but the shrublicry is denke nround the garrilens. The new louse at Longwool is Inilt of yellow sanclatone, one story in height, and is situated some lundred yards on the westprn declivity, and is in some measture slielured frin the ensterly winds. It contsins a

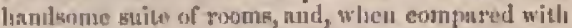
the uhl honso, stemin quite a paince. At the time of nur visit it was necuphed by Lientenant Sulth, of the arillery, and his nseistants, who have clange of tine magnetic obsorvatory. 'The lionse lan never bees finished; the dentil of the enuperur of coursts remfering its completion tunceessary. It is saitl that during lis life lie never visited it, tor wruldd he allow any ono to ennsult hitm about its plat, declaring that he would not jemove to it.

Napoleon seens to have engrafted himself on the memory of the islunders; nnd all the erents and litle incidents ocenrring to lim during lis re. sidenee, are remembered and cherished ly them with plensure. Hia elitef enrnplaint regarted the syetem of espionnen umler which he way placed, from the lour in which he gave himself up to the English to that of his death. It lins been nsserted, and up to this time witlout eontsaliction, that Sir Geore Cuckburn, who commandud the Beflecophon, in which ressel Bonaparte was transported to St. Helern, was orlered to makio mimuscy of every ennvelsation that took place during the roy. age, These meanotumla have heen alresdy published in Boston, amd their authenticity, althungt

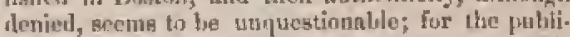
cation enzannted from tho private secretnry of Sir George; whos, while making out one frir cojy of the uinutes, made nrother for Limself. Altharshl the ministry may have thought themselves jugtified in taking this churse ot llic time, yot it seenis, at this tinıe, seareely reconcilable with $\mathrm{n}$ high seuse of hurlour; and uotwithatanding Sir George may have considered it theessary wobey inzplicitfy his orders, still the fact that he lent himself to etsch a serrico must injuxe his reputation.

In justice to Sir If udson lowe, it must be stated, aceorting to what I heard at the island, that his treatment of lis royal caplive was in etriet eor formity to lis instructions, and that, as far as lif orvlery were concorned, he was sllowed no discretion. Many of the inlabitants know llant lie tricd in severn! ways to anclionte the condition of his prisonce, but he was 1ut permitted to do so.

I trust that what I lave sail unon this stabject will not be construed as disrespectful to a highminded and friendly goverutment, or the costing any odium on the many lonoumalule and cumrteous Btitisl officers it lins been my groul furture to meet in many parts of tho globe, ind who linve extended to no and ny oftieers the most grutefinl civilities; but I cound not forthent the exprassion of iny sentimanta when I contemplate the prison-lumuse of Napuleon, and the iguoble condition and uses to which it is put.

The officer in charge of the magnetic oliservatory complatined that it was hadly plucel, atad that both lig jnstruments and olservations suffersel from the coustant changa of temperature, snol the danzmes of the situation. He politely showed us she instruments, which were in a detrehed buill. ing; after whicl we returned w Longwood, and 
gonn after left it, glad to eseape from the mist and driving wind that enveloped it.

From Inngwood we took the ronal to Plantation House, which leads across the island, making mufnerous turns as it ascends mal descends the gullies. Many protty dells were ocempied by neat cottages, in whose gardens were cultivated potatoes and other regetables. Of the former, two crops are abtained within the year, and a ready sale is found for them to the vessels that visit the island. On our arrival at the porter's lodge of Plantation House, we were informed that the guvernor, Colonol Trelawny, hnd gone to Jamestown, and that the ladieg of the family were not visille. We therefore, ou far as time permitted, examined the grounds, which are laid out with taste, ntud contained a good collection of foreigu trees. Sone of these were very flourishing, and it was curious to see many trees of Europenn species growing side by side with those of Australia.

Our botarists were of opinion that the tradition which prevails, of the island, at the time of jta discovery, lating been covered with wood, is crroneous; and that the story of the destruction of this forest by gonts, is equally so. The harrenness of this ishind is well Illastrated by the difficulty with which roung trees aro preserved from the ravages of sheep or goats, I'nsture is so searce, that but few cattle are kept, and there are chiedty imporia. thuns from the Cape of Grod Hope, Their seareity may bo judged of from the price of becf, which sells for twenty-five cents a pound; and it may be as well to state, that to strangers the prices of all other eatulies ate equally exorbitath.

From the roald near Plantation House, we lad a good view of the gully in which Jamestown is simuterl, sogether with the mrineg extending into it frum the interior of the island. Descending, we prosed over a portion of the island which is little iretter than s barren ruck. Yet in some places comfortsble-froking houses were seen, and here nnd lhere a heer-house, or tap-ronm, guite in the Eng. lish style, and, from nl! nceounts, as great nuisances as low taverna nre in any country. We fiunlly reached the fortifieation osi Ladder Hill, and made the desernt of the zigarg rond on the side of the eliff, passing a place called Colenel Pearce's Revenge, whore the rond is completaly overtiung by large masses of rock, which seen ready to fall. The rapid pace of the horacs, the frequent shasp turns, and the overthanging cliff, excite Borne alarm in thuse not aceustomed to them; and I must confess that I was quite satisfed wlien we passed the Inst turn, nod were saiely landed at the enn= sulate.

The population of the island is abont four thousatud. It consists of whites, who, if the garrison be deducted fion their numbers, form the smallest portion of the inhabitants ; of negroes and their descemiants of the mixed blool, and some few Chinese. The negroes were brouglit by the East India Company from Madagasear, nnd, with their degcendants, now form the largest portion of the population. The number of resgeis that touch. mnually at the island is now about cight hun dred.

We embarked in the aftermbon, regretling that our time was no limited, and that no opportunity was afforded us to return the kind attentions bestowed upon us by the eonsul and his family.
As we wero getting under way, it hecame evident that many of the seames land obtained supjlices of grog from the shore, in epile of all the precautionary measures that liad been taken. One, is eorssequence, fell from the mnin-top, but, fortunatedy for lim, while falting, struck at portion of the rigging, and was thus canted into the sen, from which he was picked up tuninjured. When the anchor was up we bore away to the northward, under all Rail, with a favourabla breeze.

As we passed through the tropics, many opportunities were afforded no for viewing the zodineal light, both in the norruing and the erening. Its general appearance was that of a well-defined cone, whose height, as marked by the stars, remained nearly constant at $40^{\circ}$ elevation, and at the base $15^{\circ}$. I ts first appenrance sfter zunset wns like a brond semicircala band of ligfit, the brightness of which jucreased as the evening closed in, when its shape became that of $\mathrm{a}$ well.ulefined cone. The light was sometimes equally diffused, and at others appenred as if radiating througl the cone. Its intersisy raried from a light equal to that given by a bright antora to that of $n$ comet, the centre of the cone being often the least lrilliant; sad during a partially cloudy evening it was oometimes so bright as to obscure stars of the second innguitude. It appenrance in the morning was better ilefined than in the evening, and the light was more of a blue than a yellow tint; the altitule of the cone was greater, and its bage of less extent. $\Lambda$ s we cliniged our latitute, the prosition of the apex of the cone remained atationary, but its juchination raried. For further itsformation on these phenonem, I must refer the render to the volume on Physics.

On the ath of Mny, we erossed the magnetic equator in latitude $9^{\circ} 20^{\prime} \mathrm{S}$, and in longitude $16^{\circ}$ $40^{\prime} \mathrm{W}$.

On the ?nd of June, wo lad rencher latitude $29^{\circ} \mathrm{N}_{\text {, }}$ and longitude $68^{\circ} \mathrm{W}$; and the wind, which Jud been gradually hauling from the mortisward and enstward round to the south-suluth-west, began to fail us. We lad light and variable breezea from this dny until the Bth, when we renclied the neightrourhond of the Gulf Strenm, and experienced the wenther that is peculins to it The lightning was very virid, and the suin foll in torreits; its tempeinture was $63^{\circ}$. In the latter part of the day it blew a stmong gale from the eastward. I regretted this much, os it was my intention to make full experiments on the deep tempersture and the velocity of the current in the stream; but the roughness of the sen and violence of the wind prevented it. The elose proximity to our port slso, and the increasing inupatienco of all on binard to reach their liomes, forbade all unta. cessary delay. The experiments we did matre gave a difference of three degrees of temperature, between tho surface and one hundred fathoms deptl. The highest temperature of the surface experienced while erossing the strean who $79^{\circ}$ wheu we entered, it was $77^{\circ}$. We were seren hours in crossing it, and found, as in our first pasBage, that the ivner edge was the wartuest. During the next haif hour after loting the Galf Stream, the surface tomperature fell twelve degrees, and so continued until we got on soundings, when it roso again some three or four degrees. The morning of the atb was foggy, which ratter tried our pationce, but by firing guus we attrncted the atteution of the 
pilot boats, and on the for cletring awny a little, discovered one elose to $11 \%$. A pilut now buarled and tonk eharge of the ship, ntod at noon on the I0th of June, 1812, suchured us of Sandy Hook, where a stenner came alougside soon afterwards, and took us in uw. After stopping late an hour at the quarantine ground, to receive the visit of the liealith ofticer, we held our course towarls the eily of New lork.

Bofore I luft tho Vincennes off the Battery, the crew were ealled to muster, when I expressed to them my thanks for the manmer in which they laad conducted thenselves during the cruige, and stated tho cunfitent belief entertained by me, that they woutd receive from the government such rewats as the guccesstul perfurmance of the cruise, nud their long and periluus services, entitled them to. A national salute was then fired, and ny pennant hauled duwn, the conmand of the ship being given to Captain Iludsum, who proeeded with her to the navy-yard. As soon as glie was safely monred, all the inen who could be epared wero allowed to go on shore, with their tags and lammucks, it lappier set of folluws thau they were is not often tu be net with; boing relieved frum their Jung confine- ment on shipboard, and the severe discipline of a nutiof - war.

Those who have peruged this fitl narntive of the events of the experlition, I confidently believe, will absulve me from all the charges so industriously citculated against me, relative to the manner in which 1 had conducted the expedition; at tho same time they will see what meel of honour or reward is justly due to the oflicers and crews who faithfully serval out the cruise. All of the former, and many of the fatter, are still to be found on the rolls of the mavy, mad to them, I trust tlast tho applause of a grateful cowitry has beeu only delayed, not wholly lost.

On atir nrrival lome, the health of the prisoner Fendovi had so far deelined, that it was mecessary to place him in the Naval Hospital at New York. Every attention was paid him there, but very sown afterwarl he expired.

The Porpoise and Oregon lad, in the mean tine, proceeded to Rio Janeir*, where they executed their instructions, and having obtained the neces. sary supplies, sailed for the United Stateg. After leaving the equator, thicir rotate differed but little from that pursued by the Yincenues. 


\section{A P P E N D I X.}

A.

\section{INSTRUCTIONS.}

Navy Department, August It th, 1838.

Sin,-The Congress of the Uuited States, having in view the imfrortant interests of our commerce embarked in tho whnle fisheries, and other adventures in the great Southern Oeenn, by an act of the 18th of May, 1836, authorized an Expedition to be fitted out for the purpose of exploring and surveying tint sch, is well to deternine the existence of all doublfisl islands and slionla, as to dis orer and aceuntely fix the position of those which lie in or near the track of our vessele in that quarter, and may lave escaped the observation of scientific uavigators, Liberal appropriations have been made for the attainment of these olyeets, nud the President, reposing grent confjdence in your eourage, enpacity, and zeal, has appointed you to the command of the Expedition, requiring you to proceed to the performance of the duties of that station with the vessels pluced under your onders, consisting of the sloops of war Vincentes and Peneock, the ship Relief, the brig Poryoise, 'and tenders Sen-Gull and Flying-Fish.

As soon as theso vessels are in every respect rendy, you will aceordingly take your departure frum Norfolk, and shape your course to Kio Janeito, arossing the line between longitude $1 \mathrm{H}^{3}$ and $22^{\circ} \mathrm{W}$., and liceping within those meridians to about latitnde $10^{3} \mathrm{~S}$, with a view to daterunine the existence of certain rigios or shonls lajd down in the eharty as doubthil, and wliose purition, should they be found to exist, it is disemed ugeful to the interests of our commerce to ssecrtain.

At Kio Jnneiro you will roplenish your supplie日, taking apecial care to furnish yutrecif with a sulticiency of all those artieles which aro considered the best preventives and remedies for the scurry. You will determine the longitude of that place, is well as of Cape Frio; after which, yon will cillier detach a vessel, or proeed with your whole squadron, to make a particular examination of Rio Negro, which falls into the Soutla Allantic about Iatitule $41^{\circ} \mathrm{S}$., with a view to ascertain its resources and lacilities for triule.

Having completed this survey, you will proneed to a affe port or ports in Terra del Fuego, where the members of the scientilie evrps may have favourable opportunities of prosecuting their researches. lienving the larger vesiels yecurely moorel, and the officers and evews occupied in their reapective datics, yoll will proced with the brig Porpoise, and the tendem, to explore the southern
Antaretic, to the southward of Powell's Gronp, and between it and Sandwiel Land, following the trnek of Woddell as elosely as practicable, and endeavouring to reach a high eouthern latitude; taking care, however, not to be obliged to pnsa the winter there, and to rejoin the other ressels between the niddle of liebruary and begiming of Mnreh. The sttention of the oflicers left $\pi$ t'Term del Fuego, will, in the mean time, be specialiy directed to making such accurate and particular examinations and surveys of the bays, ports, inlets, nud sounds, in thut reginn, as may verify or extenut those of Captain Kzing, and be servieenlile in future to ressels engaged in whale-fisheriog, in their outwrrd and lomeward-bound passages,

Yot: will then, on rejoining the vesscls at 'Terra del Fuego, with all your aquidron, stretch townrda the southward and westwatd as far as the Ne Plus Litn of Cook, or longitude $105^{\circ} W_{\text {.g }}$ and return nortluward to Valparaiso, where a store slip will neet you in the month of March, 1839. Proteding once more from that port, you will direct your course to the Ninigator's Group, keeping to the soutlward of the place of departure, in order to verify, if possible, the existence of certain islnnis and shoals, laid down in the ebarts as doultful, and if they exist, to determine their mecise josition, as well as that of all otherg which may bo diservened in this unfrequented track. When you arrive in those latitudes where discoveries may bo reasonably nnticipated, you will so dispuse your vesecls as that they slaill sweep the broadest ex. panse of the ocean that may be proctionble, with. out danger of parting company, lyimg-to at diglıt in orler to nvold the elanece of phssing nny smalt island or shonl without deteetion.

It is presumed you will zeach the Navigator's Group some time in June, 1830. Y'ou will survey this group and jts larbours, witlı alt itno enrẹ and attention, If time will permit, it will le well to visic the Society Islands, aud exnmine Himeo, which, it is atated, possusses a convenient harbots.

From the Nawigntor's Gromp, you will proceed to the Feejec Islands, which you will examine with particular attention, with a view to the selection of a safe harbour, easy of accesa, and in every reapect adapted to the reception of vessels of the Uniter States engaged in the whale-fishery, and the general commerce of these geas; it being the intention of the government to keep one of the squadron of the Pacilic cruising menr these islands in future. 
Aftor selecting the island and liarbour best adrpted to the purposes in view, you will uso your endeavours to make such arrangements as will insure a supply of fruits, vegetables, and freah provisiuns, to vessela visiting it lorenfer, teaching the natives the modes of cultivation, and encous. raging them to raise logs in grenter abundance.

These objects will, ji is presumed, oceupy you until the latter end of Oetober; nnd when nttained as far as mny be possible, you will proceed to the port of Sydney, where adequnte supplies may be obtained. From thence you will malie a second attemp't to penetrate witkin the $\Lambda$ ntaretic region, soutl of Van Diemen's Land, and as far west as longitude $45^{\circ} \mathrm{E}_{\text {, }}$ or to Enderby's I,and, mahing your rendezvous on your return at herguelen's Land, or the fole of Desolation, as it is now usually denominated, nad where you will probably arrive by the Jatter end of March, 1840.

From the Isle of Desolation you will proceed to the Sandwich Islands, by such route as you may judge best, from the information you may acquire from such sourecs as fall in your way.

A sture-ship from the United States will meet yol there, with a supply of provisions, in the month of A pril, inso.

Thence you will direct your course to the northwest eoust of America, making streh surveys and examinations, first of tho territory of the United Stuten on the seaboard, and of the Columbia river, and afterwaris uluog the const of California, with special roference te the Bay of St. Frusciseo, as you can aceomplish by the munth of October fol. Jowing your arriwal.

You will then proceet to the earst of Japan, taking in your route as many doubtrul islands as pose gible; and you have permingion to pass througl the Struits of Sangar inta tho Soa of Japan, where you may spend us much time as is cumptible with your arrival at the proper seasun in the sen of Sunloo or Mindoro.

Of this вea you will nuke a particular examination, with a view lo nscertain whether there is any safo route through its, which will shorten the passage of our vessels to and frum Cluina.

It is enjoined on you to pay very particular attention to shis object, in order that you may be enabled to furnish aniling instrutions to navigators. It may be also advibable to ascertain the dispmesition of the inlatitants of the islauds of this archipelago for commeree, their proútuetions and resurces.

Having completed this survey, you will proceed to the Straits of Sunda, pass throngh the Straits of Bilfitron, whieh you will examine, and thence to the purt of Singapore, where it is prubable youl uny arrive about the beginuting of April, 184l, and whete you will meet a store-ship from the United Strles.

Having completed this service, it is presumed the olyjects of yots enterprise will be aeconplished, and you will, accordingly, after receivisg your supplies at Singapore, return to the United States by the Cape of Good Hone, taking such a course is may be most likely to further the great purposes of the expedition.

During your stay in the Bouthem latitules, shoruld the dysentery or any other fatal epidensic make its appearance among your crews, you have leave to pruceed tu the northwrerd, until the disense sluall eitliev dissppent, or be so mitigated, as to admit of the resumption of your surveys.

The department does not feel the necessity of giving any apecial directions for preserving the heahti of those under your cosumant, confiding in youtr owa experience, the caro and precautions of the able surgeons with whon you tro proviled, sud in the convietion you must feel, that on the health of your erews must depend the suecess of the enterprise.

In thu prosecution of these long and devious royiges, you will necessarily be fluced is situations which cannot be anticipated, and in which, aometimes your orw jurgment and discretion, at others, лecessity, must bs your guide. Amoug savagc nations, unacyuniuted with, or possessing but vague ideas of the rights of juroperty, the most commons entuge of collision with civilized visiters, is the offeneo and the puntament of theft. You will therefore Adopt every possible precation against this practice, and is the recuvery of the stolen property, as well as in purisling the offeuder, uso all due modemtion and furbearuice.

You will permit no trade to be earried on by the erjuadron with tho ertutries you suay visit, either civilized or savnge, excegh for mecessarites or curionities, aud that under exjtress regulations established by yourself, jn which the rights of the thatives tmust bo serupulously respected nud earefully guisriled.

You will neither interfere, nor vermit any wanton interference witls the custous, lintits, manners, or prejudices of the natives of such countrics or islands as you may wisit; nor take part in their disputes, except as a moliator ; лor eormit assy nct of hostility, unless in seff-ilefence, or to protect or secure the property of hlose under your cummand, or whom circumstanes's may hive plaeed witinin rencli of your prutection.

You will enrefully inculente on all the oftieers nitd men under your command, that courtesy and lindness towards the natives, which is understool and fult by all classes of mankind; to display neitler arrogance nor eantempt, and to agpenl to their goud-will rather than their feary, unti] it stsall becone ajparent that they can only be restrmitred from viulenee by fear ol force.

lou will, on all occasions, arojd risking the ofticers and men unnecessarily on shore at the mercy of the untives. 'l'reaclstry is cono of the in. varinble characteristics of savages and barbarinns; and very many of the fatal disasters which have befaller preceding navigators, hnve arisen from 109 great a reliance on anvage professions of friendship, or overweening confudence in themselves.

Much of the character of our future istercourge with the natives of the lnmds you may visit, witl depend on the impressions nade on their minds ly their first intercourse with yuur ressels.

It is the nature of the savage long to remember benctits, nud bever to forget injuries; nad you will use your best eudenvuurs wheruver you may go, to leave bebind a tavoutuble impression of your country snd eurntrymen. The expedition is not for contquest, but discovery. Its objects are all preaceful; they are to extend the empire of commeree and seieses ; to diminish the hozards of the oceall, and ponat out to future uavigatora a courso by which tlicy naty avoid dangers and find safety. An expelition so constituted, and for such 
purposes, armed for defence, not conquest, and entaged in pursults in which all colightened nation are equally interested, has a right to expect the gaod-will and gond oflices of the whole civilized world. Should our country, therefore, be unhapjitly involved is war during your absenee, you will refrain from all acts of hostility whatever, as it is confidently believed none will be enmmitted agrainst you. So far frura this being the case, it is not to be doubted that even hostile nations will respect vour purposes, and afford every facility to their accorulishment.

Finally, you will recolleet, that though you may frequenty be earried beyond the sphere of social life, and the restraints of law, yet that the obligntions of justice and humuly are alwnys and every where equally imperntive in our intereourse with men, and most especially savages; that we seek them, not they us; and that if we expect w de. rivo ndvantages from the intereourse, wo should endenvour to confer benefits in return.

Although the primary object of the expedition is the promotion of the grent interests of comuneree and marigation, yet you will take alt ocessions, not incumpatible with the great purposes of your un. dertaking, to extend the bounds of science, and pronoto the acquisition of knowledge. For the more sucecssful attrinment of these, a corps of scientifie gentlemen, consisting of the following persons, will accompany the expedition, and are placed under your direction.

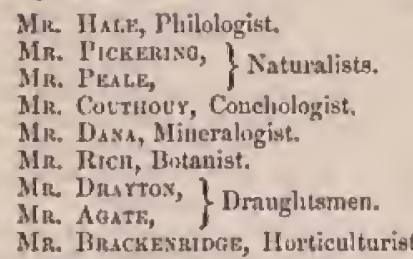

The hydrograply and geograply of the various seas and countries you may visit in the route pointed out to you in the precelling instructions, will occupy your special attention; and all the resenrches connected with them, as well as with astronomy, terrestrial magnetism, and metenrology, nre confided exclusively to the ofticers of the navy, on whose zoal and tulents the department eonfidently relies for such results as will enable futuro wavigators to pass over the trnek traversed by your vessels, witlout foar and wishout danger.

No special directions are thuoght necessary in segard to the mode of conducting the sciestific researehes and experiments which you aro enjoined to prosecute, nor is it intended to limit the menbers of the corps each to his owa partieular serviee. All are expected to eo-operate harmoni. noraly in those kinilred pursuits, whose equal dignity and usefulness should ensure eigual arilour and industry in extending their buunds and verifying their prineiples.

As guides to yourself and to the seicutific corpe, the department would, huwever, direct your partieular attention to the lestred and compreliensive reparts of a committee of the American Philosophical Society of I'hiladelphia, the repart of a conmittee of the East Indin Marino Sneiety, of Salem, Massachusetts ; and to a communication from the Naval Lyceum of New York, which ac- company, and are to be regarded as formirg a part of these instructions, so far as bliey mny nccond with the primary objects of the expedition, and its present organization. Yon will, therefore, allow the gentlemen of the scientific corps the ree perusid of these valuable docnments, and permit them to eopy such portious as they may thisk proper.

The IRnsian Vice-Admiral kirugensteru bag tranemitted to the department memorandums reInting to the objects of this experlitions, together with the most improved charts of his atlas of the Pacifie Ocentr, with explanations, in three volumes. Theee are also confided to your enre; and it is not dumbled that the friendly contributions of this distiuguislied uavigator will essentially contribute to the suceess of an enterprise in which he takes so deep an interest.

Yous will prohibit all thoso under your commant from furnishing any pereons not belouging to the expelition with copies of any jourual, elarts, plan, memorandusn, specimen, drawing, painting, nT information of any kind, which has reference to the objects or proceedings of the expedition.

It being considered Jighlily important that on journal of these voynges, either partial or complete, should be published withont the anthority and under the supervision of the government of the United Strtes, at whose expense this expedition is undertaken, you will, before you reach the waters of the United States, require from every person under your command the surrender of all journals, merworatulums, remnrks, writings, drawings, skctehes, and printings, as well as all specimerts of every kind, collected or prepared during your absence from the United Stntes.

Afrer causing correct inventories of these to be made and signed by two eommissioned officers, and by the parties by whon they were collected or prepared, you will cause them to be carefully senled by the said ofticers, and reserved for such disposition as the department may direct.

You will adopt the mosteffectual mensures to pre. pare and preservo all eqpecimens of natural bistory that may be collected, and stionk any opportunities ocenr for sending home by a ressel of war of the United States, copies of irformation, ot dupli. entes of specimens, or any other material you may deern it important to preserve from the reach if fiture accident, you will arnil yourself of the oc. cusion, forwarding as frequently ns mny be done with Bafety, details of your vaynge snd its most raterial events, at the same time strictly prohibiting all communications except to this department, frim any person attached to the expedition, referring to discoveries, or any circumstaneeg connecterl with the progress of your enterprise.

It is belioved that the ofteers under your command regnire no specia! advice or lirection frum this department. Bearing in mind, as they no dotabt will, that the undertaking which they are ntrout assisting to accomplish, is one that neeessarily attracts the attention of the civilized worid, and that the honour and interests of their country are equally involred in its results, it is not for a moment doulsted that in this, as on all other vecasions, they will so conduct themselves, as to neld to the reputation our navy las so justly acquired at home sind abrond.

With the best wislies for the sucecsu of the ex- 
pedition, and the safe return of yourself und your companions,

$$
\text { I am, wery respectfully, }
$$$$
\text { (Signed) J.K. Pact.ptso. }
$$

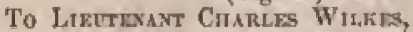
Commanding tho explorimg and surveying expedition, \&c.

P. S. The accompanying printod list of English worde, drawa up by Mr. Gallatin, and received from the war departusent since these instructions were prepured, aro intested for Indian vocabuhates, which eur be filled up as cireumstances pertmit, taking eate that the same words be used in all of them.

(Signed) J. k. Pautorso.

\section{B.}

\section{MEMORANDUM BY ADMIRAL KRUSENSTERN •}

I. I нау pointed out, in the eupplementary volume of my Hydrograplical Memoirs, (pages 19,96 , and 1 i 3, siveral islands, the existetice of which dnes not appenr to be subject to any doubt, but of which the positing is not determined with the best precision. It is much to be wished that all such islauds were to he visited, and their prisition verilied. With respect to the islande of rnther doubtful existence, the names of which I have given, (pages 156-165, oupplement,) there is cer. ixinly 10 uther method of nsecrtsining their existence than to eesrels for them, and to determine, with the greatest precisiun, the Latitudes and longitudes of such as are fouml. $A$ great number of these inaginary islauds will then, of course, vanish from the clants,

1J. Captain Hligh disenvered, in the year 1789 , to the torthward of the New Hebrides, a group of islands, which he namert Bankats lalasds; nnd Captrin Wilsum, noother cluster of islands, to the northward of the Santa Cruz Islands, uanted by him Duf"s Group. Neither these nor the Banks's Islands have been since aeen, it would be well to make a new survey of them.

III. I slands of Samta Crwz.-In my memoir, belonging to the chart of these islands, I have discussed the situntion of Carteret's Strullow Idand, and expressed my belief that the jolinds seen by Caytair Wilson in 1797 are the eame as Swallow leland. Captain Freycinet is of the same onizion, nul, by a new survey of Wilkon's 1 shand, cotstirned this liypothesis. There remaink, then, no douts that Byron's Swallow Istand toes not exist; but, as it still continues to tre delineated on some of the Intest charts, it would be well that its non-existence showld be expanly pitoved ly the Ameriens expedition.

15. The Solomon Tdands,-These islands have party heen visited by D'Ursilte and Shortand, jartly by D'Lintrecustenux; and severnl Einglish ships have at different times sniled tlurough them ; but a complete survey of all the jelands cumposing this great archipelago is still wanting. It is indeed very singular that, of all the navigators who hove lately visiled the Pacific Ocean, none have ever atterupted nny thing like a ststematic survey of these isin nds, with the exception of D'Listrecasteaux, who, at least, stỉlel alung the southern islands, from enst to west, and thuy greatly inproved the

- The asterlak aner the number of some of these articlen, denotes that the fulands, \&c., have bees cxantined by the expedilion. hydrograply of them. I have mablished, in the year IR27, a ehurt of these islands (Curte Sys. tematique de l'Arehipel des I les Salomon). Having collected all the materials that were to be had at that time, many of them in apparent contradietion to each other, I endeavoured to reconeslo them, and to delineate the islards belonging to this arehipelago, to tho hest of nyy judgrnent. (An account of my proceedings will be found in the mernoir accompanying my chart.) By the first survey of these islands, it will be seen whether some of my eombinations lave been well founded or not. Tlie Solomon lslands being the greatest archipelago in the Pacifie Ueesun, and the least known, deserve, tho doubt, to be $\pi \mathrm{s}$ completely surveyed as the Society, Friestly, or other grouph, Althought ten! years have elajoed since ny clart was published, iwtlung las been done since that time for the lydrograply of these islands, to enable me to improve the second edition of that cinart, (1836, except in the situstionn of a gromp of islands, discovered lately, to the northwarl of the Solomun Islinde,

V. Nen Calcedonica. A dangerous reef had lately heen discovered by the oluip Petrie to the north. ward of New Caledursia; the precise position of this danger ought to the determined.

VI. Loyalty Idudo-Capuiu D'Urville lus been the first to eurvey the Loyalty lsinnds; but having aniled only along the northern gide of them, it is to be wislied that the southern shore might also be surveyod.

VIJ. The Fejic Islands.-Captain D'Urville las dome $\mathrm{x}$ great deal to give us a tnore correct chart of thete islands, laving surveyed a great phirt of them; lout atill ho has lefi unexplured many islands belonging to this ardnipelago. In my suppletnentary juetnoir to the chart of these islands, I have endeavoured to combine Captain D'Urvillo's survey with anch surveys as had been mnde previous to bis voyage; and have constructed, according to all the datn that have come to my knnwledge, a new chart of the Feejeo lslands (uamed by Captain $D^{9}$ Urville, Viti Islands). Of course the chart enunot be very correct, but it may perlonps serve till a new complete survey is made of them.

VIII. New Ireland,-It is nstonishing that nearly two centuries lave ulapsed without the inlands situated to the north of New Irelandfirst seen by Tasman, and sinee by lonnpier and Bougainville- hnving been exnnined, no that we know as litule of them as was known une hundred 
and fifty yenry ago. There detusist, thell, to be made a complete survey of all these islands. As to the islands near them, sech by Maurelt, it is uot likely that they are the same, as some have supposed. This is another rensun why they thuth bo all exploted with the grontest precision.

1X. Admiruly /siands. It is mucl to be wished that the islamds seen by Maurell, to the enstward of the Grent Admiralty Islnnd, should be explored, since we know that Minurell's aceomat of lis discoveries does not satisfy the lydrogrupher.

X. Nev britain,-Aumiral D'Entuechsteax has seen and determined, with his usual exactness, the islands situated along the north const of New Britain; but he has not been able to lay duwn the pocul iterlf, which he has seen only at a distance, and some parts trot all.

XI. Lov Jalands-Captain Hagenuster, of the Rusaian nary, discovered, in tho yeac 1830 , su islnnd to the westward of King George's latumds. This island earnot be any oller tlats Seltouten's Wateriandt. Captaiu Wilsou sailed between two islatuls, which lic took to be liing feorge's Islands. Most navigators Jave beers of the same ogninion; althmglt there is a diffurence of lougitude of more than a degree between the islands sets by Wism and king George"s Jalands. Captain Duperrey (au excellent suthority, as every hydngripher will readily admit, is of a different ophiniun; he maintaixs that the two islatuls between which Wilson sailed are Int King Ceorge's Islands, but are siluated to the westward of them. He thinks that the ishand seen by Captrin Hage. tmuster, which I take to be Wisterlandt, is one of the two islands; and that Captain Ilagentuster has not seeu the other. In order to refute Captain Dujurrey ${ }^{4}$ lyypothesis, the second island, which, ac. cording to him, Captain Hagemuster might not linvo perceived, ouglat to be searched for, to the westward of Captnin Hagetnuster's island; if it really does exist, it ennnot be at a greater distance chan nbout fifleen or twenty miles.

XII. Conmodure Byrour's Isles of Disappointment linve tot been visited sinee their first discuvery in 1765 . I have endeavoured to settle their longitude at $140^{\circ}+42^{\circ} \mathrm{W}$. (pago 87 of my supplement); but this being only si spproximation, they ought to be surveyed-at least visited anew.

X111. 13y my memoiss, pnge 281 , and supplemeut, page go, you will perceive that there is differenee of 27 between Captain Bellinghaugen's und Captain Kotzebue's longitude of the west poist of Prines of Wates's Salawd and the jelnud situnted to the westward of it $t$. What may be the cuuse of this difference I sinee the two havi. paturs do trot differ, eiller before or after, more than three minutes, Fither the length of Vlighen Islaud has beon overrated by Captain Kotzelue, or sone ather error has orept into the longitude of either the are or the other. As both are excellent ubsirvers, it would be very sleairable to settie this point, by exsuning and surreying earefulty all the islands lying to the westward and eastward of Vlighen Isluad, and determine with the grentest prccision the width of the clannels separating the differest islands, as weil as the exact length of

- On nome cliars this island ha namel Deau'a Isie; on my chars. VIighen isle.

+ Fy Captain Porter eniled Gamble; ty Captain Kotzebue, Krusenstern Loland.
Vliglien or l'rince of Waltes b laland: the error will, most likely, be detecterl in the lengll of that isle.

XIV. There is a difference of 17 in the lnngitude of the isle Clermont de Tomnerre between Cantain Buperrey and Captaill Brechey. At Serle Islaud, close to it, there is lurdly any differenee at all. The same difloronce of 17 ' exists in the longitule of Prince William Jenry, which Captnin Beeclicy has proved to be the same with Captain Duperrey's isle Lortingo; wherens at Mallu Istand, buth Captaius Beectiey and Duperrey agroe perfectly well. It would he worth while to search for the cuuse of sucls anomalies.

XV. Captain Beedacy is of opinion that Captrin Duperrey's isle Clemont de Tonnerro is oue and the same with the islaud of Minerva. Ciptain Dugrerrey, on llie cuntrary, maintulns that tho fsland Minerya is the same as Serte Island. I am of this latter opinion; Although the salution of this problem will much dejend upon the distance of the island Clermont ile Tonnerre fuvtu Serte Island, which is much lese on Duperrey's clant than on Captain Beechey's,

XYJ.- "liere lias been lately dikcovered an island of considernble extent, of the name of Rarala. It would be well to exanuine it, sinee the nceount given of it is not quite satisfaetory. It is stated to be situated in $16,3^{\prime} \mathrm{S}$, and $145^{\circ} \mathrm{W}$.

XVI1.- I lawe placed on nyy ehat of the low Islands, several sistands, the jositim of which is rather doubtful ; for intanee, the Jisnyer's Grony of 'Turnbull, the island of Lritomart, the istarnds discovered by Quiros, and sereral thers. II order to have any certainty about their existence and preciso position, it is necessary to search for and make a suryey of them.

XVIII." The Islands of Sin Bermondo and the

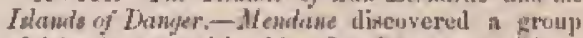
of islunds, named by hiut San bernardo. "I"lese ialonda thave been seen by Captains Freyeinet and Bellitghausen. Not far from tleent Byrots ditscuvered a small group, which he unmed islands of Danger. Notwithstanling a difTerence of latitude of hinlf a degreo, the two gromps lave been considered as one and the samo. It las not bees thought inpinossible that in Byron's datitutes there might have been a typograpirical crror: besides, none, of alt the navigatorg who bave passed liere, have ever fuut a becond gruup, which they could nut bave missed if it really existed. Cap. tain Duperrey, however, who is, as I linve said above, a high authority is whatever relates to the hydrugrapily of the Suuth Sens, is of a different opintion: he masitains that Byron's ishunts of langer do exist, In order to settle that question, it is neeessary to senth under the neridian of the islandy Sar Berunrdo, as determined by Captain Bellinghausen, for these Islanils of Dunger in the Jutude assigned to them by Byton, as well as for the chnin of roeks of which he spenks, snd which are situated, according to him, to the eustwatrd. This las not been dome yot, and it would be very desiruble if it was done, in order not to lenve tive least doubt on the subject.

XIX. Marianne Jneands.-On Captain Freycinet's chart there is to be seen, to the south-west of the Island of Assumption, rucks, by the namo of Mary's. Rocks of the sane name lave been seon by La Percuse, to tho northward of Assump- 
tiun Islaru. In case tho expetition slinuld extend itg explaratory researches to the northers hemisphere, thin doubiful pohist sliould tre settled.

$\mathrm{XX}$ * Cardine /s/unds. T'hẹge islanda lasve been an weil surverol ly Captain Duperery nnd Cajtrin Llitke, that there is very little now left to be done concerniag thein. I slatl, Jowever, point out here same islands that require to be deterninel with great precision: I. T'ho island nater! by Captsin Murell, Fraelia, in most Jikely llae same witls Captnin Litke's, Farroilep; but a difference of $2 I^{\prime}$ in latikude, makes this dotzbtful. 2. Island $L y d i a_{\text {, on }}$ Captain's Dhperrey's ehart. We do not know lyy whom it Jaas been discovered, nor who las deterrsined its siluntion. 3. I lase condeavoured to prove, in my Supplementary Memoir of the Caroline Jslands, that tho islands Burdelaire, Fame, Camploell, and the island St. Augustine, are one and the same. This liypothesis requires to be verifted. 4. The Monteverile Islands ought to be surveged; what Captsins Bonteverde and Mirell, the only marigntors who have been them, have said of them, is not sufticiently satisfactory, 7. We see on Captain Duperrey's chart of the Caruline Islands, several islnuls, of which we know nothing more than the name, riz.: Bunzkny"z, Quekin'a, \&c., and their existence and pusitivit remain to be ascertained. 6. The island of Arrecifus luss, so fur as my lnowledge extends, becn seen only by the Bhip Providence, in the year 1811. Not knowing much respecting it, it is to Lo wished that it slould the surveyed.

XXI. The Iriand of Gilkert-At the end of my smplementay volume, I have pointed out wisat remnins to biy done in order to have a perfect linowledise of all the jalands belonging to this areliprelago.

Rewark.-Independent of the American exploratory expotition, there are to be at the same time three others in the South Seas : two English and one French expedition, Many of the islands will of cuurse be visited by all the expeditions; and it is to be apprelsemded that their Jongitudes, deternined by the different astronomers of the expeditions, will, perhajs, not agree so well as might be wistred. This difficulty will of course be obviated, by referring their astronomical obserrations to the longitudes of such places as are determined by absolute astronomicul observations with the greatest precision, and those most likely (1) be visited by the slipis of the expeditions. The positions we have in the South Scas, are I'vint Vemu, in longitude $149^{\circ} 29^{\prime} 17^{\prime \prime} \mathrm{W}_{\text {. }}$ determineil by the passage of Venus over the disk of the eun ; Fort Honolidu, in the island of Oalıo, by occultation of several stars, in $202^{\circ} 10^{\prime} \mathrm{L}$; and $P^{2}$ ort Jochson, Syiney Coce, in $151^{\circ} 17^{\circ} \mathrm{E}$, by an eclipse of the suss. In the northern part of the Pacifie, Erust Cuse, $100^{\circ} 16^{\prime \prime} 10^{\prime \prime}$ E., may be adopted as a well-fixed point, although not determined by absolute astromunient olservations. With regpeet th the const of South $A$ merien, Talcahusm, the longi. tude of nhich was deterulined by Captaits Becchey, to bo in $72^{\circ} 56^{\prime} 59^{\prime \prime}$ W., seoms to mo a weld diotermined point. Captain Duperrey is not of that opinion; and it rennins to lie settled whether the lougitude of "Talcnhuasin, or Valparaiso, in $71^{\circ} 34^{\circ}$ $34^{\prime \prime} \mathrm{W}$, deserves the preferenec.

St, Petersburg, Junuary 26, 1 B37.
KITUSENSTER:

C.

TO CAPTAIN JAMES C. ROSS, COMMANDING H. B. M. SHIPS EIEBLS AND TERROR.

\section{U.S. Flag-Ship Vineennes,}

New Zealand, Bay of Islands,

Mr Dear Str, A pril 5 เl, 1 ato.

1 need not teil you how much I fecl interested in your ernise. From the interest you took in the outfit of nur expedition, 1 an sure you well know the intercst it exeites, snd how much this fecting is heiglitened by a trmowledge on my part of wist you have undertaken, and have to go through, This prompts me to a desire to be useful to your if pessible, and to give you my experience of the last senson among the ice, whither you are hound.

Your cruise will be an arduous one, no natter low you may bo enlightened on your coure; but you have so mueli knowledge of the jee, and the maumer of trestiug it, that it aypears alumst presamplunus in me to sit dowi to give you uny hitits relative to it. But, believing as $[$ do, thas the ice of the Antaretic is of a totally different slnaracter from that of the Aretic, 1 venture to offer you a few lints that may be useful to you in your undertaking; and although my instructions are binding upon me relative to discoveries, I an neverthelesa aware tlint I am reting ss my government would order, if they coust have natieipated the ease, knowing how deeply it feels the liberal assiktanco und great interest evinced by all tha societies and distinguished men of (ireat Britain, to promote and ain? this, our fist undertaking, in the great eause of seience and usefulnesa; and I most add the pleaEuro it gives to me personaily, to be alle to return, thwugh in a sisall degree, the great obligation i snyelf feel undter to you, and inasyy others, the promoters of your undertaking.

Wisns,-The winds for the first fortnight of our time, 10 the eastward of longitude $140^{2} \mathrm{E}_{\text {, }}$, were frum the northward and westward, light generally, aceompanied acensiumally with clear weather for hours, and ngain with denso fongs of short durntion, with a long swell from the same quarter.

AfRer passing longitude $140^{\circ} \mathrm{E}$, or to the westwars of it, we experienced fine weather, with sunth-esst winds and oecasional Bnow-squalls, last. ing thit ten or fifteen minutes, and a dry healthy atmosphere.

The barometor, duriug our stay on the const, wns alwayg indicative of wind by its depression, and was a true guide. Its menn stauding whs 2H1-in. The temperature furprised me: we eel- 
dum, if ever, Juml it ntrove : midl-day, and I do not think that three times it was found above $35^{\circ}$.

Gales come on very suddenly, and are always attended with snow, sleet, and thick fogs, rendering it extremely hazardous; for one must be found, when they do come, more or less surrounded with ice-islnnds, They sometines last for thirty-six lrourg. After they set in, you may calculate that they will blow strong for at lenat half that time. The nearer you are to the land, the more fiolent they are, though not of such long duration. Fine weather usually precedes then, and we found them to happen, and the wenther to be more change. able, uear the full and change, alchough 1 am no believer in the lunn influenoes upon the weather.

Curnexts-During the whole of our stay along the icy const, we fouth no perceptible current by the reekning and current log. During a gale of wind 1 was induced tomelieve that some existed, from the short sea that wns formed, thinking there was more than was to be expocted. Tides on snch nn extent of coast there unilonbtedly unst be, but of tittle strength, or we strould have perceived them.

In many of the icy lays we were stationary for a sufficient time to perceive then if they hat been of any ningnitude, and where the eurrent was repertedly tried.

The winus have their effect upm the loose driftice, or that which is detached from the icy barrier. Owing to a clinuge of wind from south-east to north, with a fresh breez, the Peacock beeame cmbayed, and the ice forced in upon her, which brought alout the accident. The northerly winds are always accompanied with a heavy swell, and lier escape is atcributable to a mare exereise of good senmanship and persevernnce. If Captain Hodson's ship had been as strong as adumant itself, he is of opinion she would have been ground to atoms by $n$ longer exposure; her stem was abraded to within an inch and a half of the wood. enis.

There are places in which the barrier is within the floe-ice several mileg. I enclose you the mens temperature during the summer months,

You will see there is but little chanee of the ice melting or disappearing, sts from neeounts frequently takes place in the Aretic Ocenn. Yonr cime, being unlimited, will allow you to wat some days in a situntion to make expreriments.

1 frequently found nyself so elosely besct that I thought it next to improssible to esenpe, and if the wind had not been extremely constant in its direction, I should have been shut up or much injured; as it was, I escaped with searcely a sersitch, al. thingh we took some heavy thumps.

The charts will show you the tracks and state of the ice. It was constructed as I went on, and the ice-islands lail down by carefully-kept dingrams by the officer of the deek during his watch. This 1 fonnd gave me more confudence in proeeding, and facilities in ease of having to returi.

Magneric Pose, - I consider we have approached very near to the polo. Our dip was $87^{\circ}$

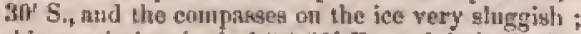
this was is longitude $147^{\circ} 30^{\circ} \mathrm{E}$., and latitude $67^{\circ}$ 4" S. Our variation, ns accurately na it eould bo olserved on the ice, we made $12^{\circ} 30^{\prime} \mathrm{E}$. It
Whe diffieult to get a gool obsersatiwll, on accotsat. of the sluggisluese of our compnoses. About one hutudred triles to tho westwnrd, wo crossed the uraghetic meridinn.

The pole, without giving you nccurate derluetions, I think ny observations will place iu about Iatitule $70^{\circ} \mathrm{S}$, and longitude $1+0^{\circ} \mathrm{E}$.

On the meridian of $140^{\circ} \mathrm{E}$, you will find $\mathrm{a}$ smal bay, partly formed by ice-islauils and meks, which I have unmed Piner's Hay, and I think among the rocks you may find $\mathrm{n}$ enug little lanrtour. I was driven nut of the bay by $\mathrm{n}$ gale of wind; sounding about one and a lialf nije from the shore in thitty fathotns. The icehergs being aground, furm good ghelters; but I was tno mucl exposed to venturo to remain, ami nuy object was to traco the land and the icy barrier, which ] have done, as you will see it laid down on my chart.

We had delightulu and clear weather ten days or a fortnight along the const, witli the wind at from sonth-enst to south-gouth-west; the two latter points particularly. The drift-ieo is in large pieces, so large as to give a ship an awkward thump; but when I found it tolembly open. I lave run through it to get to clear water, and in hopes of making the laud, but onr progress was enon stmped by the firm barter, inpenetrable, through which there is no passing.

I am of opinions that there is little movement of the jee during the scason. Strong gales may change its position a trifle, but I think not materially.

The only prospect of nearing the land is through n sea well stndled with large iceberge, nenrly thirty or forty miles in widtla; and I generally found that we got nearer to the shore in these places than elsewhere. One thing I mast tell you, as respects filling your water: you will sometimes find a prond of dolicious water un the top of an old ictberg, frozen over, but on eutting through it you will seo a supply sufficient for a navy. It will save you fuel, and discomfort and cold to you, your vessels, and their erews.

I was very fortunate in the wenthice the Intter part of the tine; and indeed altogether I was seareely s day withont some observation, (except during the gales, of which we had three, occupying nbout eight days,) and generally half a dozen.

My time fur six weeks wns pased on deck, and having all dnylight, I of course had constant employment, and with the many assiatants, I could mako mipid progress; and you will tind that no opportunity ought to be lose in this mavigation, if one is to ifo any thing. One's ship is in constant danger, and the Fincennes, a first-class lowon of seven hundred and eighty tous, it requires all the foresight and activity one is possegsed of to loukout for her.

I consider that I have had a moat prowidential escape; and if this ship had not been emabled to "do every thing hut talk," I should not lave been where I now am; tut she had insjired me with so much confidence, among the curnl reefs last summer, that I could jut full faith in her doing her duty. I must refer you to the claart, on which I have noted remarks, variations, \&c.

$\checkmark$ should Iave mentioned, slant in 1838 and 1839 , I went south in the brig Porpuige, in order to trace 
latmer's Land on its enstern side, (but tono late for any trial to reach high latitudes, and hoping that the lateness of the seagon would enable me tu rut some distance alung it. I got within three miles of the const, and snw it tretuliug to the soutlsoutl-enst aliout thirty miles; but it was so blocked up with jue ns to retader it imposeible to get through. I have little soubt inyedr, in favourable seasous, Weddell's track may be fillowed, notwithstanding what the Frucheliman may asy, them being no lassd to which the ice is altached; and that the ice in those pouts ehanges very much, tho eurrents being exceedingly strong, af 1 inyself witnessed. 1 could not affurd the time to be frozen up, ак my other duties were and are parnmount to pasing the winter in such a siluation. But you are differently situated, and I stould alvise you, by all mests, to $t^{2} y$ to penetrate between lung:tude $35^{\circ}$ and $45^{\circ} \mathrm{W}$.

$$
\text { I am, אe., }
$$

CHARLFS WILESS,

Comnanding Exploring Expedition.

D.

YALUE OF EXCHAXGE ON LONDON AND TIE UNITED STATES AT DIFEETENT PORTS YISLTED BY 'HU YXILORING SQUADRON, MADE UH TO 1812.

\begin{tabular}{|c|c|c|c|c|c|}
\hline 10 Its. & \multicolumn{3}{|c|}{$\begin{array}{l}\text { Amount realized in dol- } \\
\text { lars per ElHo sterling } \\
\text { exelunge on Lorulua. }\end{array}$} & $\begin{array}{c}\text { Rate of Exchange on the } \\
\text { Lniftul States. }\end{array}$ & $\begin{array}{c}\text { Vulue of Silver } \\
\text { Dollins. }\end{array}$ \\
\hline Marleiris . .... & \multicolumn{3}{|c|}{ Elon mella fors 8 t60 } & Io to 12 per ecent. disc. & Par. \\
\hline Rin de Janeiro . & $1+10$ & & 440 & 12 to 14 a & " \\
\hline Valpatraiss.... & 100 & $"$ & 520 & linr. & "4 \\
\hline Lima ........ & jon & "6 & 510 & & " \\
\hline Sydney, N. S.W. & 100 & “ & 4tit! & 10 per eent, diac. & a \\
\hline Cutiformia .... & 100 & « & 450 & 12 of 6 & " \\
\hline Sandwich Islands & 100 & " & $4: 30$ & 12 to 15 uev cent. disc. & 4 \\
\hline Manilla...... & 100 & at & 450 & 10 & " \\
\hline Siugapore .... & 100 & sf & 450 & 10 & " \\
\hline Cape Town .... & 100 & $"$ & 144 & 10 & uf \\
\hline St. Helena. .... I & 100 & " & 44 & 10 & $\pi$ \\
\hline
\end{tabular}





\section{N D E X.}

\section{A.}

Ansuos Shonl, 312.

Admiralty Inlet, 281.

Adventure Islets, 27.

Ahii or Pencock Island, 71.

Aiva Islands, 233.

Alpataraca, 04.

Ambutiki Island, 237.

Ambau, 196. 16 .

Anar or Chain Island, 72.

Andulung Penk, I!is.

Anganga Jaland, 243 .

Augasa Tslsad, 233.

Angau Rouf, $23 \%$.

Antarctie Cruise, 129-150.

Antigute, Bity of, 329 .

Aorni Pent, 84.

A prumana Island, 2ns.

Apia or Charlotte fsland, 102. 294.

Anolina Island, 100.

Apple Tiree Cove, $28 \mathrm{r}$.

Arvitica or Carlshoff Istand, 70. 277.

Arelinngel Island, $27 \%$.

Argo IReef, 203 .

Aru Island, 934

Arro, Town of, 248

Aritua Island, 71.

Astu Inlet, I0I.

Aspland's Istand, 26.

Astoria, 283.

Auckland Isfinds, 154.

Anrora Islos, 27.

Aurora Island, 71 .

Avia lsland, 295.

B.

Baily Islaud, 29.

Balabac Straits, 387.

Balambatugan Island, 336.

Ball's Pyтutd, 117 .

Banca Straita, 346 .

Banks Peurinsula, 174.

Hatros, 55, 56. 59 .

Bapliam's island, 313.

Bella Vista, 47.

Bellingham Bay, 287.

Bird Island, 241.

Birnic's Island, 202. 292.

Bishop's Isinnd, 297.

Bom Felix Shosl, 7.

Bonetta loocks, 7 .

Botuqueron Passage, 45.

Bouret's Sandy Iste, $y$.

Bowditch Island, 293 .

Brazils (The), 15 .

Bridgerman's Island, 26. c.

Caballeros, 52. 60.

Caldera Fort, 329.

Callifornia, 441 .

Callan, 46, 47. 63.

Camboy's Istind, 277.

Canta, Thon of, 52

Cape Beไslısn, 27.

Cape Irett, 178.

Cape Carpubell, I75.

Cape Carr, 143.

Cape Dissppoiztment, 208.

Crupe of Guorl Hupe, 316 .

Crje Horn, 33. 149

Cape Howe, 158.

Cape Jervis, 158.

Cape Melville, 20 .

Cape Town, 34d.

Cape de Yerdes, 6.

Carr's Harbuur, 2088.

Casa Canca, $53,54,56.58$.

Chain Island, 72. 93.

Chatham Islatud, 173.

Chichia Island, 24.

Chief's or Chioftain't Leap, 238.

Chili, $34-44$.

Classet Indians, gut.

Clermont de Fonkerse or Minerva Island, 64.

Cloudy Bay, 175 .

Cobut knek, 287 .

Columbia River, 279. 282. 289.

Commencenent Bay, 285.

Copper's Isisnd, 312.

Corcovado Mountaiu, I5.

Cordilleras, 34. 5 ?.

Corzwallis Jsland, 27. 31 1. 313.

Corolib or Gont Istawl, 311. 313.

Cotongangin, 221.

Corregidor Island, 313.

Cowlitz River, 282.

Culnai, 53, 5it).

Cunninghnm (Allan), the Botanist, 119.

Curral (The), 4.

I).

Dalles (The), 2 is.

Deception Island, 29.

De Fuea"s Pillar, 208.

De Fuea's Straits, 280. 295.

De Peyster'y Group, 295.

Diego Ramieres" Island, 34.

Diretion Island, 230.

Disappointment Bay, 139.

Disappointment Harbour, 235.

Disnppointment lsland, 66.

Diseovery Harbour, 235. 
Dog Island, 66 .

Irummond's Islath, 296.

Duke of Clarence's 1sland, 202.

Duke of York's Island, 202.

$$
\text { E. }
$$

Eimeo Istand, $8 \overline{5}$.

Flephant Isiand, 27.

Eliza Reci, 237 .

Eilice's Group, 295.

Emerald Isle, 130.

Endarbury's Island, 252.

Enderbury's Land, 148.

Enkaba Island, 232.

Eooa Island, 179,

Evout's Islauil, 29.

Exploriug Isles, 235.

\section{F.}

False Bay, 348 .

Farm Cove, 158.

Faroilip Island, 313.

Fawn Harbour, 236 .

Feather River, 302. 304.

Feejee Group, $192-240$.

Feis Island, 313.

Fletcher's falsund, 202.

Flying-Fisis Harbour, 220.

Fort Macquarie, 158.

Fraser's River, 287.

Frencl! Slioal, 9.

Friendly Isles, 179 .

Fulanga Island, 232

Funchal, 2.

Gaspar Island, 311.

Goat I land, 23t. 236.

Good Success Bay, 27.

Goro Island, 23:

Gulf Stream, 337.

H.

Halcyon Islani, 312

Hall's Island, 298.

Hetderville Island, 298.

Henuake, Honden, of Dog Island, 66.

Herotua Island; 277.

Heruit's Isinud, 29.

Hilo $\mathrm{B} s y, 260$.

Hokennga, 161. 172.

Honden Island, 66.

Honga Hapai, 192.

Honga Torga, 192.

Honolulu, 252. 308.

Hoorn Island, 117.

Horse Shoc Reef, 193. 239.

Hout's Islani, 347.

Hudson's 1s]and, 296.

Hull's Island, 252. 292.

Hunter's Island, 313.

\section{I.}

Illwarra, 120.123.

\section{J.}

Jane's Istand, 311.

K.

Kahoolawe Island, 272, 275 .

Kambara Island, 232.
Ḱapuauli, 261.

Katafunga I tand, 2955

Katia or Sacken Istand, 71.

Kawn-Kawa River, 155. 160.

Kealakonkun Bay, 258.

Kemin's or Gardner's Islagd, 252.

Kilawea (crater) 261.

King Goorgo's Group, 72.

hing George't Island, 26.

King Geurge Town, 182.

King's Island, 60.

Kingsmill Growp, 296-300.

Kinox Island, $20 \%$ 。

Komo-Levu Island, 233.

Kono-Riki Jeland, 233.

Koromrika, 165. 172.

Krusenstern, Adnuiral, 303.

Krrusenstern's Island, 70 .

lirusensterri's Shosl, 10.

Kula or Fast Maui, 273.

líuria Island, 298.

\section{L.}

Ladrone Islatuds, 3I2.

Lathaina, Town of, 270.273.

Lahairaluna, Roadstend of, 273

Lahaimatum, Seminary of, 270 ,

Lakemtin, 228. 234.

Lanai Ishand, 275.

Leluria Islnnd, 220.

Levuka, Totwu of, 194, 198.

Lima, 47.

M.

Macquario Fort, 158 .

Macquarie Island, 131. 155.

Madeira, 1-6.

Malaki Islatsd, 225.

Malaki Passage, 24I.

Malatia lsland, 235.

Malevuvu Tuef, 233 .

Malolo Island, 240. 244.

Mamouko Reefs, 534 .

Mango Islund, 245.

Mangsee Islanda, 336 .

Manhiit Joland, 71. 276.

Mañilia, 314 .

Matsus Ioland, 87.

Manuel Rodrigtez Shon, 276 .

Maraki or Matthews" Islnud, 299.

Margaret's Ishand, 277.

Maria Rock, 6.

Maro Reef, 337.

Matafon Pesk, 89.

Matainote, 241 .

Matarai Bay, 71.

Matthows' Rinek, 117.

Matulu Island, 229.

Mati Island, 260-271.

Mzui (East), 274.

Mruma Haleakila, t75.

Mauna Kiea, 268 .

Млแпа Lou, 260-208.

Mayew's Puint, 16.5.

Maypo, Plsin of, 37

Maypoeho IRiver, 38.

Mbuia or Sandalurood Bay, 221, 239, 240.

Mbeuga Island, 241.

Mellneen Hill, 41 . 
Merril's Istand, 277.

Metia of Auronu Island, 71.

Miudano Island, 329 , 330.

Mindoro, 328.

M'Kenn's Islaud, 252.

M'Kenzie" E Group, 313.

Mokmingat Ialand, 198. 238.

Moloksi Istand, 275.

Mormba 1stun, 232.

Motlin Island, 2933.

Mothes Ref, 237.

Motugee, 164.

Moturiki Island, 229.

Mount Egmont, 173.

Mulgrawe's Istrands, 317 .

MLtria Islavd, 235.

Siutliunta, Tow of of, 241.

\section{N.}

Nacundi, 221

Nainu ]sland, 234.

Nairai Isโand, 237.

Nairsin or Dean'a Jistand, $7 \mathrm{l}$.

Naitnmba, 236.

Naitssiri, 221.

Niamukit Islatud, 232.

Nanouti Island, 297.

Napolo, 259.

Nassau Biy, 28.

Nealy Harbour, 288.

Neclier's Island, 337.

Nemena ar Direction Island, 230.

Ne Plus Ulim of Gook, 31. 145.

Nova Isle, 337.

New Dungeness, 280.

New Helvetis, 304.

New Island, 27.

New Suth Wales, 114-129.

New York [s]and, 20 ?

New Zaalaut, $1100-178$.

Nisqually, 201.

Noir Istand, 32.

Nou Souri, 221.

Nugu-Ongea Reef, 932.

Nukalau Island, 237.

Nukualoria, 179, 180. 187.

Nukutipipi or Blargaret's Island, 277.

\section{O.}

Oahu, 252 .

Oak Point, Oregon, 283.

Obmijlo, 52,53 . 5 .

O'Brien's lsland, 206.

Observatory lstand, 235.

Ofoo, 87. Rit.

Okimbs Isinud, 236.

Oloosinga, 87, 88 .

Oneuta Islaul, 233.

Omgen lsland, 232 .

Oruitge Harbour, 21, 22. 33 .

Oregon, 279.

Otuku Island, 235.

Otoolno Island, 68.

Orolat, 193, 195.

$$
\text { r. }
$$

Pachacamac, 64k.

Pago-Pago Harbour, 86.

Pahia, 162. 165.
Pnlangan Passage, 337.

Pahner's Land, 26 .

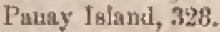

Pangai-Moutu, L20. 182.

Papueti, 81, 82.

Papoa or Cook's Harlyour, 80.

Pasen, 58.

Polty's Overfalls, 9

Panotu Gтuн, f2. 276.

Pencoele Istand, 71.

Peale's River, 216 , 922.

Pendulum Cove, 29.

Pendulum Peak, 269.

Penn"s Cove, 266.

Yeru, 45-62.

Philippines (The), 315.

Pico-Ruivo, 5.

Pigenn Bay, 174.

Pilot's Cove, 281.

Piner's 13ay, 199. 142, 143.

Pitt's Rock, sy9.

Point Gardner, 2m6.

Point Greuville, 286.

Point Roborts, 287.

Ponchorua, 52 .

Port Cooper, 174.

Port Discotery, 280.

Port Jackson, 117.

Port Laurence, 281.

Port Levy, 174.

Port Oreluard, m86.

Port Refuge, 232.

Port Tlowhisend, 281 .

Porto Praya, 7.

Possersion Sound, 287.

Protection Island, 280.

Puget Sound, 281 .

Puyallup River, a85.

$\mathrm{R}$.

Rabe-Rabe Island, 240.

Rarika 1slund, 68, 69 .

Raruis Island, 277.

Retiva Island, 236.

Reid Island, 276.

Rewa, 215, 219.

Rimne kiver, 50.

Ringgold's knoli, I48.

Rio de Caxavilu, st.

Rio do Janeiro, 10.

Rio Negro, 15 .

Rose Islanit, 87 .

Rotuma 1skud, 186.

Round Island, 201.

Royal George Stoal, 87.

S.

Sacramento River, 302.

Saluafuta Hnrbour, 294.

Saluafots Town, 294.

Samoan Grous, $87-116$.

San Autonio Fort, 45.

Sun Felipe, $40-43$.

San Francisco, 49. 307 .

San Jose, 328.

San Juan, 56.

San Lorenzo, 45, 46 .

San Miguel, 52.

San Pablo Island, 277. 
Sun Hedro Jstand, 313.

Snn Salvador, 10.

Sandwich Islands, 251.

Sangbov's Istand, "\$31.

Santiago, 34.

Sartit's Busom, 154, 155 .

Sastiit, 94. 100. 102.

Savu-Bavu, 239.

Seapenham Bay, 33.

Semarara Islanit, 328.

Sutters Islank, tis.

Shute's River, 240.

Sierra, an?.

Simpin's Foland, 298.

Siugitpore, 338.

Somu-Soml, 230.

Sooloo, 3:7.

Sotug, 235.

Southern Cruise, 22-30.

St. Anne Shoal, 1.

St. Helena, 355 .

St. Helen'a Resch, 283 .

Sth Jago, 7.

Starer's Ielands, 278.

Straits of Bamo, 346 .

Strails of Le Maire, 21.27.

Strints of Thlin, 340 .

Sualib Bay, 242.

Sugar Lonf Islands, 172.

Susti Island, 233.

Sydenham Island, 207.

Sydaey, New South Wales. 117, 118. 159.

Syduey Island, 252.

T.

Tabanielli Island, 232.

Table Bity, 348.

Tsibutha Island, 234.

Taluiti, 73-87.

Trüini, 16!.

Takurea Island, 277.

Tлта wa Islund, 299.

Tavt-Taพu, 221 .

Taweren or Resolution Island, 277.

Teinhoven Islaud, 278 .

Teku Island, $27 \%$.

Terra del F'uego, 15. 21, 22.

Thargala [aland, 229.

'I'icumbir Isiund, 235.

Tongataboo, $178-192$.

Totoin Island, 193. 228.

Tova Reef, 228.

Tower Rncks, 33.

'Truey's Ishud, 2015.

Tríton Bank, 9.

T'upongati Peak, 37. 39. 41.

Turnbull Island, 277 .

Turtle Island, 192. 253.
"Tutuila, 89-93.

Tye, 242.

U.

Uea or Wallis Island, 116.

Upolu, 94. 294.

Utiroa, 290 .

$$
\text { V. }
$$

Talparaiso, 30, 34.

Vancoufer, 284.

Vanua-Valaro Island, 24h.

Fantu-Yatu, 228.

Vashon's Istanel, 281.

Vasquez Isliund, 17\%.

Vatia, 220 .

Vatos or T'urtle Island, 253,

Vatura, Town of, 241 .

Vekai Island, 2m5.

Venemole Hartomr, 237.

Vernta, 216 .

Victoria, City of, 165.

Vincenires Island, 70 .

Vione, 238 .

Viper Shon!, 337.

Viti, 221.

Viwa, 216.

Vun Island, 230 .

W.

Wainkea Bay, 269.

Waicaddio Fiver, 1fa.

Wailaku Seminnry, 270 .

Wrilevu or Peale's Kiver, 246. 222.

Wailuku District, a73.

Waimati, 16 .

Waibea Fort, 257.

Waitanga River, 161.

Wakaia Istand, 1013. 238.

Wake Island, 31I.

Wallis's Island, 116.

Wangarara Bay, 170,

Wangatra Town, 169.

Washington Island, 292.

Waterlandt Island, 70 .

Whidhy's Islaud, 280 .

Willamette Rivet, 284.

Williams (Rer. Mr.), the Misionary, 96 .

Wolconsky Istand, 277.

Wollaston's Island, 26 .

Woodle's Ishaud, '208?.

Wytoohee Island, 67.

Y.

Yanga, 59.

Yerba Buent, 301.

$Z$.

Zonoma, City of, 906 .

THE END. 


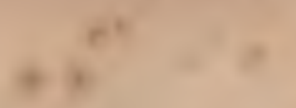

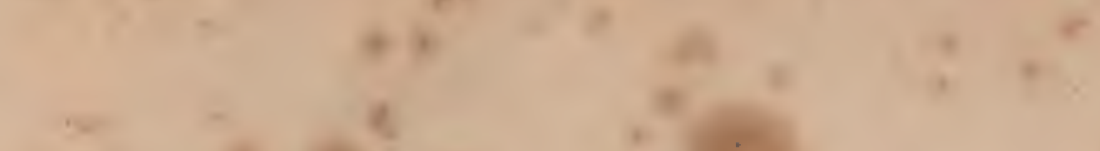

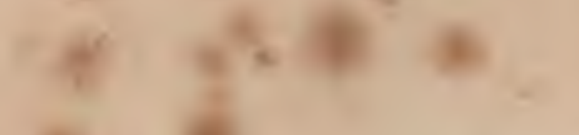

)

the

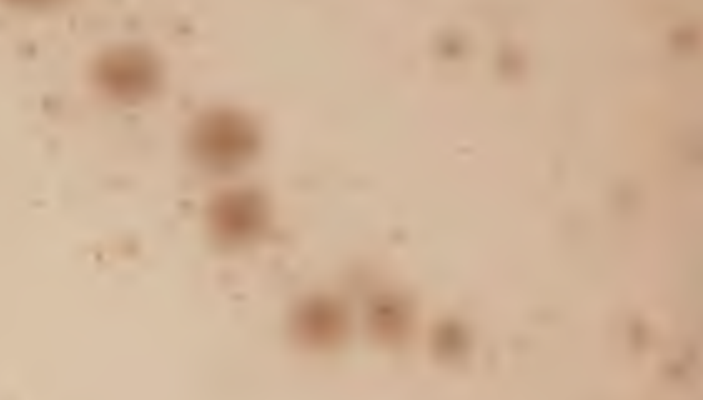

1

Y

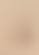

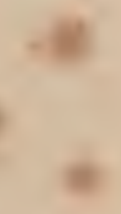

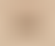

e

$\sqrt{2}$

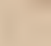

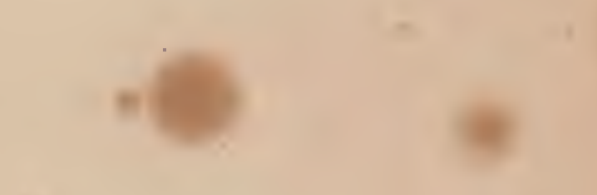

4

$+$

$+$

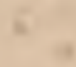

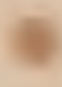





61 .

$\log \left(\begin{array}{l}1 \\ 1\end{array}\right.$

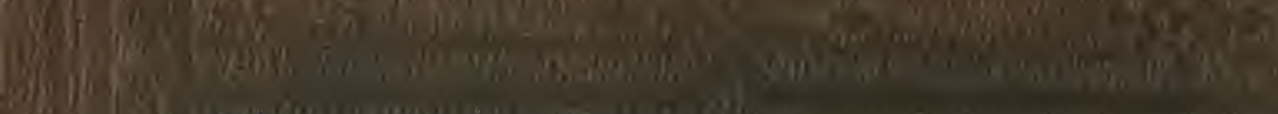

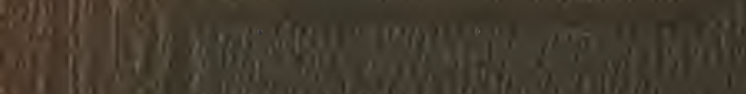

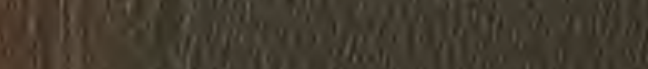

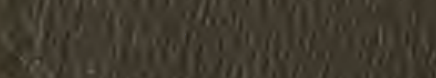

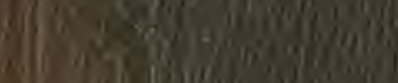

(2) $\mid(2)$

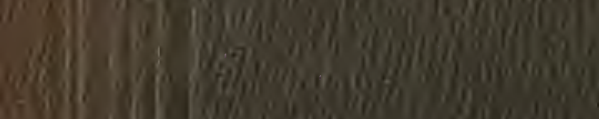

(7)

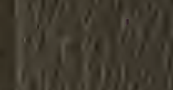

(1)

(1)

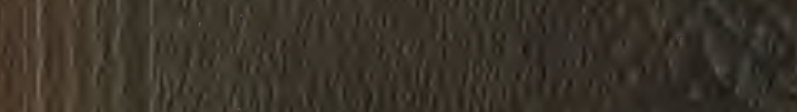

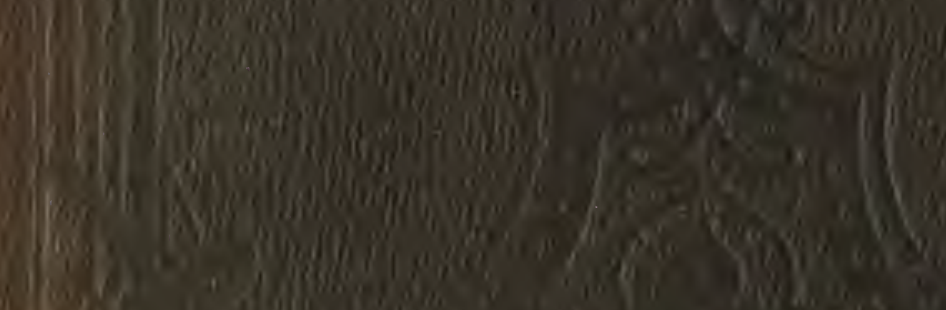

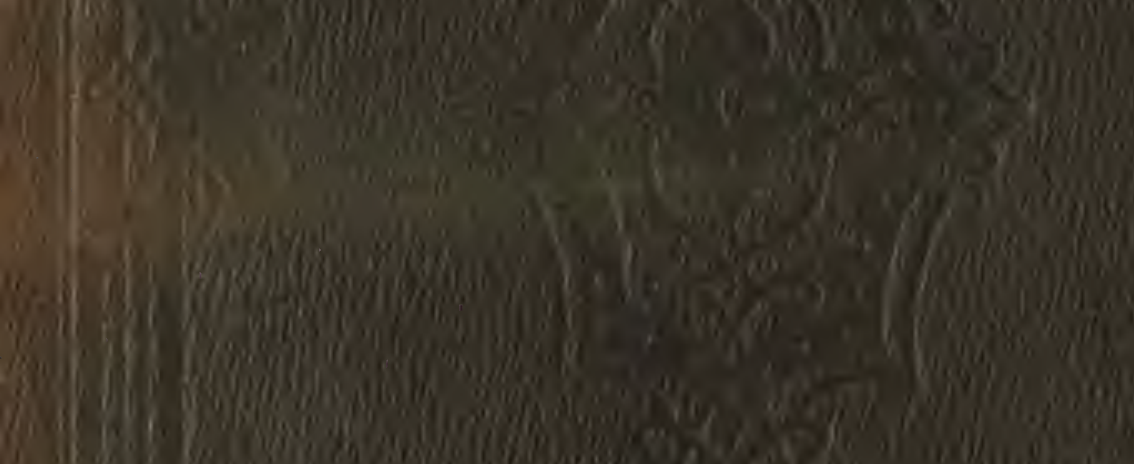

18 